\title{
Gray's Manual of Botany
} REVISED EDITION 


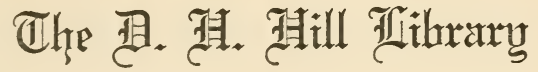

Worth Taralina State Trallege

$$
\begin{aligned}
& \text { QK } 117 \\
& \text { G75 }
\end{aligned}
$$

1889 
* Date Due

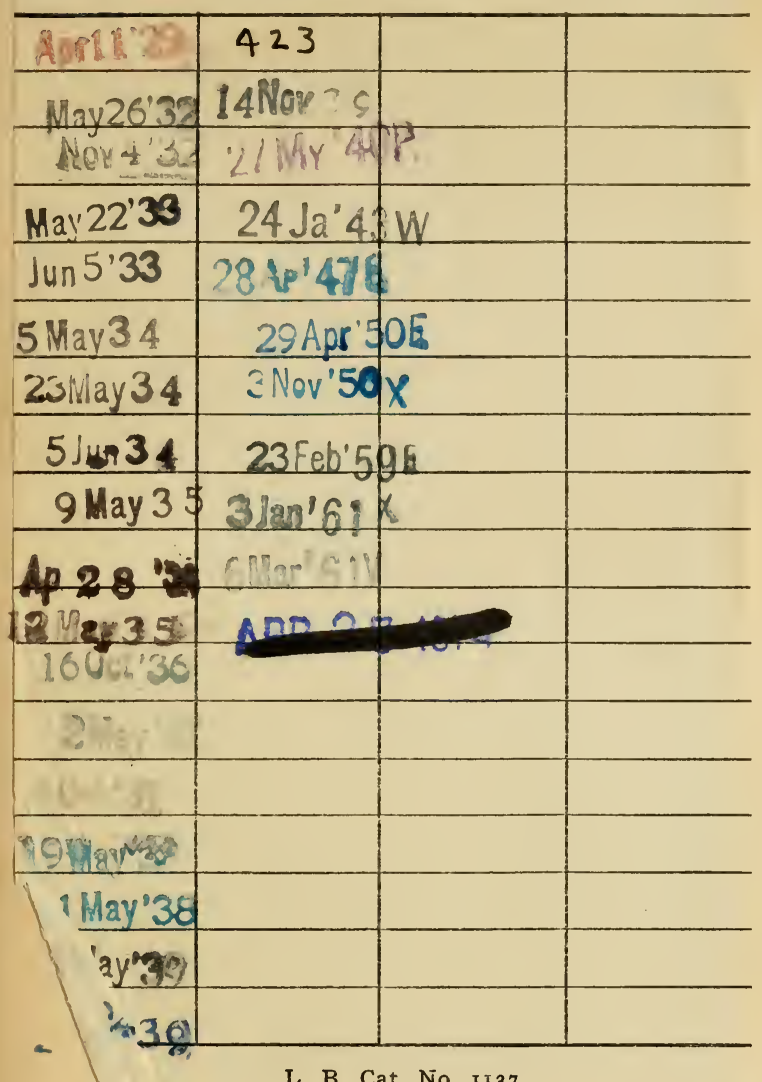

L. B. Cat. No. II 37 


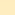





\section{B O T A N Y \\ OF}

THE NORTHERN UNITED STATES. 



\section{MA N UA L}

\section{OF \\ THE B OTANY \\ ов मив \\ NORTHERN UNITED STATES,}

INCLUDING THE DISTRICT EAST OF THE MISSISSIPPI AND NORTH OF NORTH CAROLINA AND TENNESSEE.

\section{By ASA GRAY,}

LATE FISHER PROFESSOR OF NATURAL HISTORY IN HARVARD UNIVERSITY.

\section{Sixth Edition.}

REVISED AND EXTENDED WESTWARD TO THE IOOth MERIDIAN, BY

SERENO WATSON, CURATOR OF THE GRAY HERBARIUM, HARVARD UNIVERSTY.

AND

JOHN M. COULTER, PROFESSOR OF BOTANY IN WABASH COLLEGE,

ASSISTED BY SPECIALISTS IN CERTAIN GROUPS.

WITH TWENTY-FIVE PLATES, ILLUSTRATING THE SEDGES, GRASSES, FERNS, ETC.

NEW YORK · : CINCINNATI $\cdot: \cdot$ CHICAGO

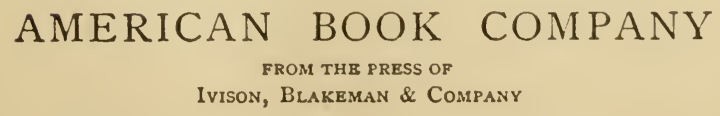


Copyright, 1889,

By the President and Fellows of Harvard Coliege. 


\section{O N T E N T S.}

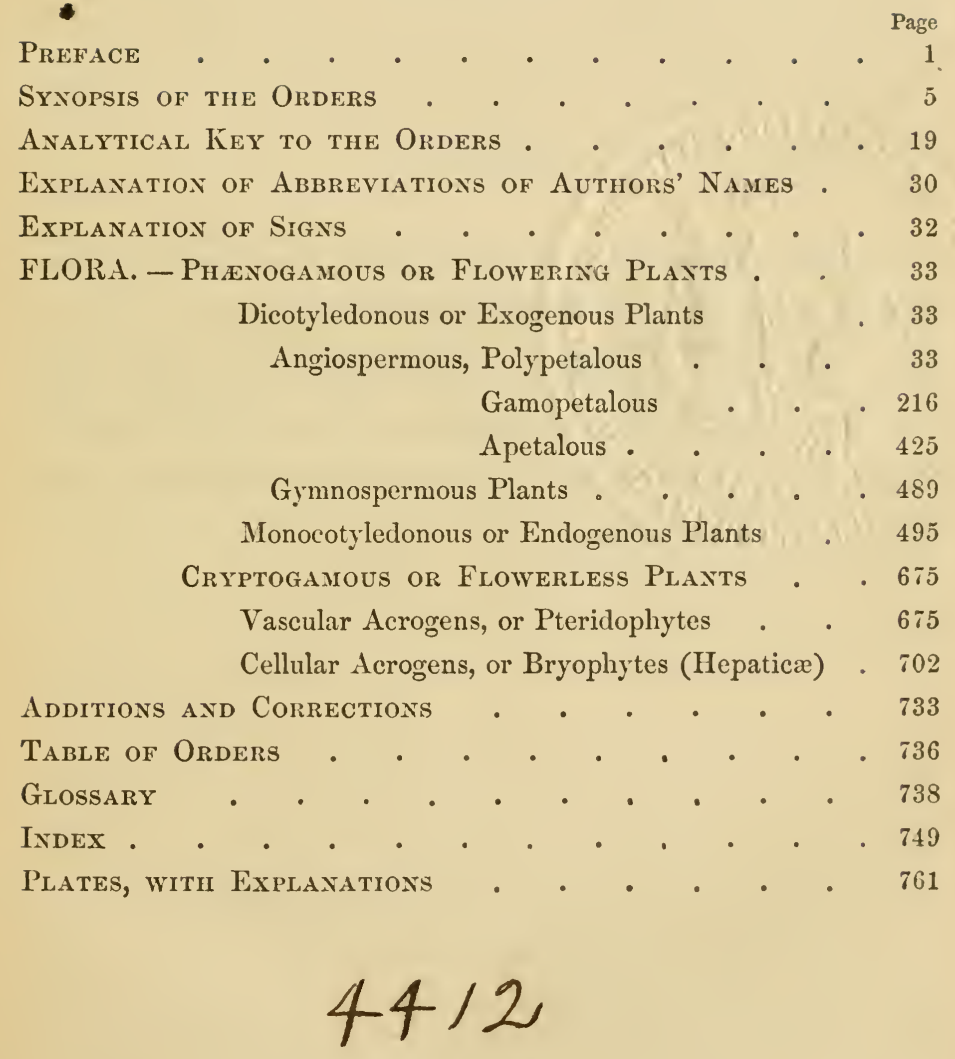




\section{NOT E.}

Ix this second issue of the Maxual are given all such needed emendations of every kind as have come to our notice. Wherever it could be conveniently done, these alterations have been made in the plates. The remainder will be found in supplementary "Additions and Corrections" near the end of the volume. 


\section{P R E F A C E.}

THE first edition of Gray's Manual was published in 1848 . It was to a great extent rewritten and its range extended in 1856 , and it was again largely rewritten in 1867. The great advances that have since been made in systematic botany and in the knowledge of our flora have for several years past made another revision desirable, which Dr. Gray before his death was purposing to undertake.

The present editors, acting to the best of their ability in his stead, have endeavored throughout to follow his methods and views. The original plan, so long retained by Dr. Gray and so generally approved, has been closely adhered to, the characters and descriptions of the last edition have been left essentially unchanged so far as possible, and in the numerous alterations and additions that have been considered necessary or advisable, his conclusions and principles have governed in every matter of importance, so far as they could be known. The effort especially has been to maintain that high standard of excellence which has always made the Manual an authority among botanists.

In the treatment of the genera and species, Gray's Synoptical Flora has been made the basis in the revision of the Gamopetalous Orders, and his manuscript in continuation of that work, so far as prepared, for the Polypetalous Orders which precede Leguminosa (excepting Nuphar, the Cruciferce, Caryophyllacea, Vitis, and the small Orders numbered 18, 22, 23, 25-27, and 29). The genus Salix has been rewritten for this edition by M. S. Bebs, Esq., the genus Carex by Prof. L. H. Bailex, and the Ferns and allied orders by Prof. D. C. Eatox. For the rest, all known available sources of information have been made use of, and much willing help has been received from botanists in all parts of our territory. 
The increasing interest that is taken in the study of the Cellular Cryptogams, and the desire to encourage it, have led to the inclusion again of the Hepaticæ, which were omitted in the last edition. These have been prepared through the kindness of Prof. L. M. UNDERwood, though the limits of the volume have necessitated somewhat briefer descriptions than he considered desirable. The three fine plates illustrating the genera of these Orders, which were used in the early editions, are also added, with a supplementary one, as well as an additional one in illustration of the Grasses, thus increasing the number of plates to twenty-five. A Glossary of botanical terms is appended, to meet an expressed need of those who nse the Manual alone, and a Synopsis of the Orders in their sequence is given, to contrast more clearly their characters, and to show the general principles which have determined their present arrangement. This should be a useful adjunct to the more artificially arranged Analytical Key.

Geographical Lmits, and Distrimution. - The southern limit of the territory covered by the present work is the same as in the later previous editions, viz. the southern boundary of Virginia and Kentucky. This coincides better than any other geographical line with the natural division between the coolertemperate and the warm-temperate regetation of the Atlantic States. The rapid increase of population west of the Mississippi River, and the growing need of a Manual covering the flora of that section, have seemed a sufficient reason for the extension of the limits of the work westward to the 100th meridian, thus connecting with the Manual of the Flora of the Rocky Mountain Region by Prof. Coulter. These limits, as well as that upon the north, have been in general strictly observeit, very few species being admitted that are not known witl some degree of certainty to occur within them. The extreme western flora is no doubt imperfectly represented.

The distribution of the individual species is indicated somewhat more definitely than heretofore in many cases, so far as it could be satisfactorily ascertained. The extralimital range is also sometimes given, but the terms "northward," "southward," and "westward" are more frequently employed, signifying an indefinite range in those directions beyond the limits of the Manual. Where no definite habitat is specified, the spe- 
cies may be understood as found more or less generally throughout the whole area, or at least to near the western limits.

Nomenclature, Accentuation of Names, etc. - In case of question respecting the proper name to be adopted for any species, Dr. Gray's known and expressed views have been followed, it is believed, throughout the work. While reasonable regard has been paid to the claims of priority, the purpose has been to avoid unnecessary changes, in the belief that such changes are in most cases an unmitigated evil. Synonyms are rarely given except where changes have been made. As a guide to correct pronunciation, the long sound of the accented vowel (modified often in personal names) is indieated, as lieretofore, by the grave accent ('), and the short sound by the acute ('). In regard to the derivations of generic names, many valuable suggestions have been due to W. R. Gerard, Esq., of New York.

Prominent Characters are indicated by the use of Italic type for the leading distinctions of the Orders, and generally in the specific descriptions for those points by which two or more nearly allied species may be most readily distinguished. The ready discrimination of the genera is provided for by a Synopsis of their leading characters under each order. Whenever a genus comprises several speeies, pains have been taken to render important differences conspicuous by proper grouping, and when needed by a series of subordinate divisions and subdivisions. The headings of these various groups are to be considered as belonging to and forming a part of the specific characters of the several species under them, - a fact which the student should always bear in mind.

Arrangement of the Orders. - The Natural Orders are disposed in very close accordance with the method followed by Bentham and Hooker in the Genera Plantamem, the principles of which are concisely shown in the Synopsis of Orders which precedes the Analytical Key. The Gymnospermce are retained as a Subclass following the Angiospermous Dicotyledons, with which they have an obvious relationship, in preference to placing them, as some authorities would do, next before the Pteridophytes, to which their affinity, if no less certain, is nevertheless obscure. A more natural arrangement than either would be the withdrawal of the Endogens, placing them at the beginning, in perhaps an inverse order. 
Avalytical Key to the Orders. - As stated in Dr. Gray's Preface to the last edition, this is designed to enable the student to refer readily to its proper Order any of our plants, upon taking the pains to ascertain the structure of its flowers, and sometimes of the fruit, and by following out a series of easy steps in the analysis. It is founded upon the most obvious distinctions which will answer the purpose, and is so contrived as to provide for all or nearly all exceptional instances and variant cases. Referring to the Order which the Key leads him to, the student will find its most distinctive points brought together and printed in Italics in the first sentence of the ordinal lescription, and thus can verify his results. The Synopsis which fo. ows will then lead him to the genus, to be verified in tur'l by the full generic description in its place; and the progress thence to the species is facilitated, when there are several to choose from, by the arrangement under divisions and subdivisions, as already explained.

It will be seen that the Key directs the inquirer to ascertain, first, the Class of the plant under consideration, - which, even without the seerls, is revealed at once by the plan of the stem, as seen in a cross-section, and usually by the veining of the leaves, and is commonly confirmed by the numerical plan of the flower; - then, if of the first Class, the Subclass is at once determined by the pistil, whether of the ordinary kind, or an open scale bearing naked ovules. If the former, then the choice between the three Divisions is determined by the presence or absence of the petals, and whether separate or united. Each Division is subdivided by equally obvious characters, and, finally, a series of successively subordinated propositions, - each set more indented upon the page than the preceding, - leads to the name of the Order sought for, followed by the number of the page upon which it is described in the body of the work.

The book is now submitted to those for whose benefit it has been prepared, in the trust that its shortcomings will meet with friendly indulgence, and with the earnest request that information be kindly given of any corrections or additions that may appear to be necessary.

Cambridge, Mass., Dec. 26, 1889.

SERENO WATSON. 


\title{
SYNOPSIS OF THE ORDERS OF PLANTS
}

\author{
DESCRIBED IN THIS WORK.
}

Series I. PHANOGAMUUS or FLOIVERING PLANTS : those producing real flowers and seeds.

\section{Class I. DICOTYLEDONOUS or EXOGENOUS PLANTS.}

Siems formed of bark, wood, and pith; the wood forming a zone between the other two, and increasing, when the stem continues from year to year, by the annual addition of a new layer to the outside, next the bark. Leares netted-veined. Embryo with a pair of opposite cotyledons, or in Subclass II. often three or more in a whorl. Parts of the flower mostly in fours or fives.

Subclass I. ANGIOSPERM which contains the ovules and becomes the fruit. Cotyledons only two.

Drvision I. POLYPETALOUS : the calyx and corolla both present; the latter of separate petals. (Apetalous flowers occur in various Orders, as noted under the subdivisions.)

A. THALAMIFLOR E. Stamens and petals hypogynous (free both from the calyx and from the superior ovary), upon a usually narrow receptacle (not glandular nor discoid, except in Reseda, sometimes stipe-like). (Stamens and petals upon the partly inferior ovary in some Nymphæaceæ.) Apetalous flowers occur in the Ranunculace and Caryophyllaceæ.

* 1. Carpels solitary or distinct (or coherent in Magnoliaceæ); sepals and petals deciduous (except in Nymphæacex); leaves alternate or without stipules (sometimes opposite or whorled and rarely stipular in Rauunculaceæ) ; embryo (except in Nelumbo) small, in fleshy albumen.

1. Ranunculaceæ (p. 34). Sepals (3 or more), petals (as many, in regular flowers, or none), stamens (usually many), and carpels (1 - many) all distinct. Fruit acheues, follicles, or berries. Mostly herls.

2. Magnoliaceæ (p. 49). Sepals and petals colored alike, in three or more rows of three, imbricate. Fruit cone-like, formed of the numerous cohering pistils. Trees.

3. Anonaceæ (p. 50). Sepals (3) and petals (6, in two rows) ralvate. Fruit pulpy. Shrubs or small trees.

4. Menispermacere (p. 51). Sepals and petals in twos or threes, imbricate. Pistils becoming l-seeded drupes. Diocious woody climbers, with palmate or peltate leaves. 
5. Berberidaceæ (p. 52). Sepals and petals imbricate, each in two rows of three (rarely in twos or fours). Stamens opposite the petals. Pistil solitary, becoming a berry or pod. Shrubs or low herbs.

6. Nymphæaceæ, in part (p. 54). Sepals and petals each 3, or many in several rows. Vistils becoming coriaceous and indehiscent. Aquatics; floating leaves peltate.

* 2. Carpels (2 or more) united into a compound ovary with parietal, often nerve-like placentæ (or the seeds corering the inner surface in Nymphæaceæ, and the placentix axile in Sarraceniaceæ). Herbs (some Cistaceæ somewhat shrubby).

+ Fruit 5-many-celled; calyx or whole perianth persistent; embryo small, at the base of fleshy albumen.

6. Nymphæaceæ proper (p. 54). Sepals 2-6. Petals and stamens numerons, on a thick liypogynous receptacle or inserted upon the ovary. Capsule 8-30-celled. Aquatics, with peltate or cordate leaves.

7. Sarraceniaceæ (p. 57). Sepals and petals 5. Capsule 5-celled. Marsh plants, with pitcher-shaped leaves.

+ + Fruit 1-celled, or spuriously 2 -more-celled by partitions connecting the placentie.

+ Embryo minute at the base of fleshy alburnen; perianth deciduons; sepals 2.

8. Papaveraceæ (p. 57.) Hlowers regular. Sepals fugacious. Petals 412. Stamens and seeds numerous. Capsule 2 -several-valved. Juice milky or colored.

9. Fumariaceæ (p. 59.) Flowers irregular. Petals 4, in dissimilar pairs. Stamens 6, diadelphous. Fruit 2-valved (indehiscent and 1-seeded in Fumaria). Juice watery; leares dissected.

++ Albumen none; embryo curved or folded; perianth deciduous (sepals persistent in Resedacer).

10. Cruciferæ (p. 61). Sepals and petals 4. Stamens mostly 6, tetradynamons (two inserted lower and shorter). Pod 2-celled by a transverse partition, 2-valved, or sometimes indehiscent or transrersely jointed. Bracts and stipules none.

11. Capparidaceæ (p. 74). Sepals and petals 4. Stamens 6 or more, nearly equal. Pod 1-celled, 2-valved. Embryo coiled. Leaves often palnately divided; bracts and stipnles often present.

12. Resedaceæ (p. 75 ). Sepals and petals $4-7$, irregular. Stamens indefinite on an lypogynons disk, not covered in the bud. Pod 1-celled, 3-6lobed, opening at the top.

++ + Enbryo rather large in fleshy allumen; placentæ on the middle of the valves; calyx persistent.

13. Cistacez (p. 76). Flowers regular; sepals and petals 5, the two onter sepals'minute. Stamens indefinite. Pod 1-celled, 3-5-ralved. Ovules orthotropous. Embryo curved. Leaves entire, the lower often opposite.

14. Violaceæ (p. 78). Flowers irregular; sepals and petals 5 . Stamens 5 , with connivent introrse anthers. Style clavate. Pod 1-celled, 3-valved. Ovules auatropous. Embryo straight. Stipules present. 
* 3. Ovary compound, l-celled, with central placenta ; embryo curved around mealy albumen (except in I)iauthus); leaves entire; stipules mostly none.

15. Caryophyllaceze (p. 82). Sipals (5, rarcly 4) distinct or uniterl, persistent. I'etals as many, rarely none. Stamens as many or twice as many, rarely fewer. Styles 2-5. Leaves opposite.

16. Portulacaceæ (p. 90). Sepals 2. l'etals 5. Stamens 5-20. Capsule 3-valved or circumscissile. Fleshy herbs; leaves mostly alternate.

* 4. Calyx imbricate; stamens as many or twice as many as the petals or often indefinite; ovary compound, l-cclled with parietal placenta or several-celled with the placenta united in the axis; embryo straight or slightly curved; albumen none or scanty.

17. Elatinaceæ (p.91). Small marsh annuals, with opposite leaves, membranous stipules, minute axillary flowers, few stamens, and pod 2-5-celled.

18. Hypericaceæ (p. 92). Herbs or shrubs, with opposite entire dotted leaves and no stipules. Flowers cymose or panicled. Stamens few or many, usually in 3 or more clusters. Pod 1-celled or 3-5-celled.

19. Ternstrœmiaceæ (p. 95). 'Trees or shrubs, with alternate leaves and no stipules. Flowers large, axillary, solitary. Stamens numerous, more or less united together and with the base of the petals. l'od 3-5-celled.

* 5. Calyx valvate; stamens numerous, usually more or less united together and with the base of the petals; orary 3 -many-cellerl with the placentic united in the axis (becoming 1-celled and 1-seeded in Tilia).

20. Malvaceæ (p. 96). Stameus monadelphous; anthers 1-celled. Calyx persistent. Seeds kidney-shaped, with curved embryo and little albumen. Herbs or shrubs, with alteruate palmately veined stipular leaves.

21. Tiliaceæ (p. 101). Stamens polyadelphous or nearly distinct; anthers 2-celled. Calyx deciduous. Embryo nearly straight. Trees, with alternate leaves and decidnous stipules.

B. DISCIFIORE. Stamens as many as the petals or twice as many or fewer, inserted upon or at the outer or inner base of a more or less tumid hypogynous or perigynous disk, which is cushion-like or annular or divided into glands, sometimes obscure or minute (or none in Linum, Ilex, some Geraniacex and Polygala); orary superior (or half-inferior in some Rhamnacex); sepals more usually distinct. l'etals wanting in some Rutacea, Rhamnacex, and Sapindacex.

* 1. Orules (mostly 1 or 2 in each cell) pendulous, with the rhaphe toward the axis of the ovary; disk often reduced to glands alternate with the petals or none; ovary often lobed or the carpels nearly distinct.

22. Linaceæ (p. 101). Flowers regular, usually 5-merous. Capsule not lobed, mostly 5-valved, spuriously 10-celled, 10-seeded. Stamens united at lase. I)isk none or 5 mimute glands. llerbs, with entire alternate or opposite leaves; stipules gland-like or none.

23. Geraniaceæ (p. 102). Fluwers regular or irregular, 5-merous or 3 merous as to the stamens and pistils. Ovary $3-5$-lobed, the cells $1-$ few. ovuled, and axis persistent. I)isk of 5 glands or none. Ilerls, with often lobed or divided mostly alternate leaves, with or without stipules. 
24. Rutaceæ ( $\rho .106)$. Flowers mostly regular, 3-5-merous, diœcious or polygamous in our genera. Ovary 2-5-lobed or the carpels nearly distinct, upon a glandular disk; cells 2-ovuled. Mostly shrubs or trees, with glandular-punctate compound leaves, without stipules.

* 2. Ovules ( 1 or 2 ) pendulous, the rhaphe away from the axis; disk none and ovary not lobed.

25. Ilicineæ (p. 107). Flowers small, diœciously polygamous, axillary, 48-meruus. Fruit a 4-8-seeded berry-like drupe. Shrubs or trees, with simple alteruate leares and no stipules.

* 3. Ovules ( 1 or 2 in each cell) erect, the rhaphe toward the axis ; disk fleshy, covering the base of the calyx; stamens as many as the petals, at the margin of the disk ; flowers perfect or polygamo-diøcious ; albumen fleshy; shrubs or trees, with simple leaves (compound in soine Vitaceæ).

26. Celastraceæ (p. 109). Sepals and petals imbricated, the stamens alternate with the petals. Fruit 2-5-celled; seeds arilled.

27. Rhamnaceæ (p. 111). Calyx valvate. Petals small or none. Stamens alternate with the sepals. Fruit 2-5-celled; seeds solitary, not arilled.

28. Vitacere (p. 112). Calyx minute. Stamens opposite the valvate caducous petals. Climbing by tendrils opposite the alternate leaves.

* 4. Ovules ( 1 or 2 ) ascending or horizontal, or pendulous from a basal funicle; fleshy disk entire or lobed; stamens $5-10$; shrubs or trees, with compound leares (simple in Acer) and mostly polygamo-dicecious and often irregular flowers; petals imbricate (sometimes none in Sapindacex).

29. Sapindaceæ (p. 115). Flowers mostly unsymmetrical or irregular. Ovary 2-3-celled and -lobed.

30. Anacardiacea (p. 118). Flowers regular, 5-androus. Ovary 1-celled, becoming a small dry drupe. Leaves alternate; juice milky or resinous.

* 5. Orules solitary, pendulous from the summit of the 2-celled ovary; disk none; flowers irregular (subpapilionaceous), hypogynous; stamens monadelphous or diadelphous; anthers l-celled, opening by an apical pore.

31. Polygalaceæ (p. 120). Herbs, with perfect flowers and alternate or opposite or whorled entire leares. Stamens 6-8. Seed carunculate.

C. CALYCIFLORA. Sepals rarely distinct; disk adnate to the base of the calyx, rarely tumid or couspicuous; petals and stamens on the calyx, perigynous or epigynous, the ovary being often inferior (hypogynous in Drosera and Parnassia, nearly so in some Leguminosæ and Crassılaceæ). Apetalous flowers in Orders 33, 35, 36, 38, 39, 41, 42, 47, and 50.

* 1. Ovary usually superior, the pistils solitary, or several and distinct (sometimes more or less united but at least the styles distinct except in some Saxifragaceæ).

32. Leguminosæ (p. 122). Flowers papilionaceous or regular. Stamens usually 10, and mostly monadelphous or diadelphous. Pistil one, free, becoming a legume; style terminal. Albumen none. Leaves mostly compound, alteruate, stipular.

33. Rosaceæ (p. 150). Flowers regular, with usually numerous distinct stamens, and 1 - many pistils, distinct or (in Pomeæ) united and combilied 
with the ealyx-tube; style often lateral or hasal. Calyx-lobes and petals mostly 5. Ovules mostly 1 or 2. Albumen mostly none. Trees, shrubs, or herbs; leaves usually alternate and stipulate, simple or compound.

34. Calycanthaceæ (p. 167). Calyx-lobes, petals, and stamens indefinite. Pistils numerons, becoming achenes in a hollow receptacle. Albumen none. Aromatic shrubs, with opposite entire leaves and no stipules.

35. Saxifragaceæ (p. 168). Flowers regular, with 5-10 stamens (numerous in Philadelphus), few (mostly 2) more or less united, free or partially adnate carpels, and few - many ovules on axile or sometimes parietal placentx. Seeds albuminous. Herbs or shrubs, with opposite or alternate leaves, with or without stipules.

36. Crassulaceæ (p. 170). Mostly fleshy herbs, with symmetrical flowers, the usually distinet many-seeded carpels as many as the sepals. Seeds albuminous. Leaves alternate or opposite or whorled; stipules none.

37. Droseraceæ (p. 178). Glandular-haired scapose marsh herbs, with regular 5-merous hypogynous flowers. Capsule 1-celled, with $3-5$ manyseeded parietal placentax. Anthers extrorse. Leaves circinate iu vernation.

38. Hamamelideæ (p. 179). Shrubs or trees; flowers often polygamomonœcious, in clusters, heads, or spikes; petals often none. Seeds 2 or more, bony, in a 2-beaked woody pod opening above, the base adnate to the calyx-tube. Stamens few or many. Leaves alternate, simple.

39. Halorageæ (p. 180). Aquatic or marsh herbs; flowers perfect or poJygamo-diccious, small, axillary or spicate; petals often none. Stamens 1-8. Ovary inferior, the calyx-limb obsolete or very short. Fruit small, indehiscent, 1-4-celled, 1-4-seeded. Leaves alternate or opposite, the submersed often dissected.

* 2. Ovary inferior (except in Lythracex), 1-sereral-celled; style entire; flowers perfect, regular or nearly so, mostly 4-merous; herbs, with simple and mostly entire leaves without stipules.

40. Melastomaceæ (p. 183). Calyx open. Stamens definite; anthers opening by an apical pore. Leaves opposite, 3-7-nerved; flowers cymose.

41. Lythracer (p. 184). Calyx-lobes valvate. Pod free, but enclosed in the calyx, membranous, 1-4-celled, many-seeded with axile placentx. Leaves mostly opposite; flowers axillary or whorled; petals crumpled, or none.

42. Onagraceæ (p. 186). Calyx-lobes valvate. Ovary 1-4-celled, the cells 1 -many-ovuled. Stamens 2, 4, or 8 . Petals 2 or 4 , convolute, or nowe. Leaves opposite or alternate.

* 3. Ovary inferior (except in Passifloraceæ and Ficoideæ), 1-celled with parietal placenta or several-celled by the intrusion of the placenta; flowers regular, perfect or unisexual; styles free or united; herbs.

- Embryo straight; cotyledons foliaceous; leares alternate, often lobed.

43. Loasaceæ (p. 193). Flowers perfect. Stamens indefinite. Style entire or 2-3-cleft. Capsule 1-celled, with 2 or 3 many-seeded placentæ. Pubescence of hooked hairs.

44. Passifloraceæ (p. 194). Climbing by tendrils. Flowers perfect. Stamens 5, monadelphous. Ovary stalked, superior, becoming a 1-celled many-seeded berry with 3 or 4 placenta. Styles 3 , clavate. 
45. Cucurbitaceæ (p. 194). Tendril-bearing vines, with diœcious or monœcious flowers. Corolla 5-lobed, often confluent with the calyx. Stamens 3 or 5 , usually more or less united and the anthers often tortuous. Fruit fleshy or membranous, 1-5-celled, the placenta often produced to the axis and revolute. Seeds exalbuminous.

+ + Embryo curved or coiled about central albumen; leaves entire.

46. Cactaceæ (p. 196). Fleshy and mostly leafless prickly plants, with solitary sessile perfect flowers. Calyx-lobes and petals indefinite, imbricated, the numerous stamens on the tube. Fruit a l-celled many-seerled berry.

47. Ficoidez (p. 198). Calyx-lobes or sepals 5 and petals none in our genera. Capsule 3-5-celled with axile placentæ, loculicidal or circumscissile, many-seeded. Often fleshy; leaves mostly opposite or verticillate.

* 4. Flowers small, regular, perfect or polygamous; calyx-limb minute or obsolete; ovary inferior, 2-sereral-celled, with solitary penclulous orules; petals and stamens mostly 4 or 5 , on the margin of an epigynous disk surrounding the styles; albumen copious.

48. Umbelliferæ (p. 198). Flowers in umbels or heads. Petals (inflexed) and stamens 5. Styles 2. Fruit of 2 dry seed-like carpels, the pericarp usually with oil-tubes. Herbs, with alternate mostly compound leaves.

49. Araliaceæ (p. 212). Flowers mostly in umbels and nearly as in Umbelliferæ; petals not inflexed and styles 2 or more. Fruit a 2 -several-celled drupe. Herbs or shrubs, with alternate mostly compound leaves.

50. Cornaceæ (p. 213). Flowers not in umbels; petals (valvate, or none) and stamens 4 or 5 . Style 1. Fruit a 1-2-seeded drupe. Trees, shrubs, or rarely herbs, with opposite or alternate simple and mostly entire leares.

Division II. GAMOPETALOUS: calyx and corolla both present, the latter of united petals (excepting some Ericaceæ, Styracaceæ, and Oleaceæ, Galax, Statice, and Lysimachia). Apetalous flowers occur in Glaux and some Oleacer. Stipules present only in Rubiaceæ and Loganiaceæ, or rarely in Caprifoliaceæ.

* 1. Ovary inferior; stamens borne upon the corolla, alternate with its lobes.

- Stamens distinct; leares opposite or whorled; seed albuminous except in Valerianaceæ.

51. Caprifoliaceæ (p. 216). Corolla mostly 5-lobed, regular or irregular, the stamens as many (one fewer in Limnæa, doubled in Adoxa). Ovary 1 several-celled; fruit a berry, drupe, or pod, 1-several-seeded. Shrubs or herbs; leares opposite, rarely stipular, not turning black in drying.

52. Rubiacez (p. 222). Flowers regular, 4-5-merous, the corolla mostly valvate. Ovary 2 -4-celled. Herbs or slurubs; ]eares simple, entire, opposite with stipules, or verticillate, usually turning black in drying.

53. Valerianacea (p. 228). Stamens $(1-4)$ fewer than the lobes of the somewhat irregular corolla. Orary with two abortive or empty cells and one containing a suspended orule. Fruit dry and indehiscent. Herbs.

54. Dipsaceæ (p. 229). Flowers mostly 4-merous and with 4 (rarely 2) stamens, involucellate in involncrate heads; corolla-lobes imbricate. Ovary simple, 1-celled, with a suspended ovule. Herbs. 
++ Anthers connate into a tube.

55. Compositæ (p. 230). Stamens as many as the valvate corolla-lobes. Ovary with a solitary erect ovule, becoming an achene. Albumen nonc. Calyx-limb reduced to a pappus or none. Flowers in involucrate heads.

* 2. Ovary inferior (or superior in most Ericaceæ and in Diapensiacea); stamens free from the corolla or nearly so (adnate in some Diapensiacex), as many as the lobes and alteruate with them, or twice as nany ; leaves alternate (opposite in some Ericaceæ); style 1.

- Juice milky ; capsule 2-5-celled, many-seeded; herbs.

56. Lobeliaceæ (p. 305). Corolla irregular, 5-lobed. Stamens united, at least by the anthers. Capsule 2-celled or with two placentx.

57. Campanulaceæ (p. 307). Corolla regular, 5-lobed, valvate. Stamens usually distinct. Capsule 2-several-celled.

+ + Juice not milky nor acrid ; capsule 3-10-celled.

58. Ericaceæ (p. 309). Flowers mostly regular, 4-5-merous. Stamens distinct, more usually twice as many as the corolla-lobes or petals. Uvary inferior or superior. Herbs or shrubs.

59. Diapensiacere (p. 326). Flowers regular. Stamens 5, on the corolla, or monadelphous with 5 petaloid staminodia. Ovary superior, 3-celled.

* 3. Ovary superior; stamens as many as the corolla-lobes and opposite them.

60. Plumbaginaceæ (p. 327). Stamens 5, on the base of the petals. Styles 5. Fruit an achene or 1-sceded utricle. Herbs; leaves radical.

61. Primulaceæ (p. 328). Stamens 4-8, perigynous. Style 1. Fruit a capsule with several seeds on a central placenta. Herbs; leaves radical or opposite or alternate.

62. Sapotaceæ (p. 332). Flowers small, 4-5-merous. Style 1. Ovary few-several-celled; fruit fleshy, bearing a siugle bony-coated seed. Shrubs or trees, with milky juice and alternate entire leaves.

* 4. Ovary superior or more or less adnate to the calyx, few-several-celled, the cells 1-oruled; stamens twice as many as the corolla-lobes or more; trees or shrubs, with alternate leares.

63. Ebenacez (p. 333). Flowers diccions or polygamous Stamens on the corolla. Uvary superior. Styles distinct. Fruit fleshy, few-seeded.

64. Styracaceæ (p. 333). Flowers perfect. Stamens subhypogynous. Ovary more or less inferior. Style 1. Fruit dry or nearly so, 1-4-seeded.

* 5. Ovary superior, of two carpels (sometimes by division apparently 4-carpellary, sometimes of $3-5$ in l'olemoniacex, Convolvulacex, and Solanacex); stamens on the corolla (except in apetalous Oleacea), alternate with its lobes, as many or fewer.

- Corolla not scarious and nerveless.

+ Corolla none, or regular and 4-cleft or -parterl, the stamens fewer than its lobes; style 1 ; seeds $1-3$.

65. Oleaceæ (p. 335). Trees or shrubs, with opposite and pinnate or simple leaves. Flowers perfect or polygamo-dicecious. Stamens mostly 2, alternate with the usually 2-ovuled carpels. 
+ Corolla regular, its lobes 4-5 or rarely more; stamens as many.

$=$ Ovaries 2, becoming follicles; stigmas and sometimes the styles united; herbs with milky juice, perfect 5-merous flowers, and simple entire leaves.

66. Apocynaceæ (p. 337). Stamens distinct or the anthers merely connivent, with ordinary pollen. Style 1.

67. Asclepiadaceæ (p. 338). Stamens monadelphous, the anthers permanently attached to a large stigmatic body; pollen mostly in waxy masses. Styles distinct below the stigma.

$==$ Ovary compound (ovaries two in Dichondra), with 2 or 3 (rarely 4 or 5) cells or placeutæ; stamens distinct; mostly herbs.

a. Leaves opposite; corolla-lobes 4 or 5 or more.

68. Loganiaceæ (p. 345). Leaves entire, with stipules or a stipnlar line joining their bases. Capsule 2-celled, few-many-seeded. Herbs or woody twiners (our species).

69. Gentianaceæ (p. 346). Glabrous herbs; leaves entire, sessile and simple (except in Menyanthes). Capsule l-celled with 2 parietal placentæ or the whole inner surface ovuliferous, many-seeded.

b. Leaves alternate (sometimes opposite in Polemoniacex and Hydrophyllaceæ); corolla-lobes always 5 in our species.

70. Polemoniaceæ (p. 354). Capsule usually 3-celled, loculicidal; seeds 1 - many in each cell on the stout placental axis. Style 3-cleft or -lobed. Leaves opposite or alternate, simple or compound.

71. Hydrophyllaceæ (p. 357). Leaves often lobed or divided, and the inflorescence frequently scorpioid. Style 2-parted or 2-lobed. Capsule 1-celled, 2-valved with two parietal or introflexed placentæ, or sometimes 2-celled. Seeds 2 or more on each placenta.

72. Borraginaceæ (p. 360). Leaves mostly entire and plants often roughhispid; inflorescence commonly scorpioid. Style 1. Ovary 4-ovulate, usually 4-lobed and maturing as 4 separate or separable nutlets, or not lobed, 2-4-celled and separating when ripe into 2 or 4 nutlets.

73. Convolvulaceæ (p. 367). Usually twining or trailing; flowers on axillary peduncles or cymose-glomerate. Corolla 5-lobed or 5-plaited, twisted in the bud. Styles 1 or 2. Ovary 2- (sometimes 3- or spuriously 4-) celled, becoming a globular 4-6-seeded capsule (or ovaries two and distinct in Dichondra). Cotyledons broad-foliaceous.

74. Solanacez (p. 373). Style 1. Ovary 2-celled (rarely 3-5-celled), with numerous ovules on axillary placentæ, becoming a pod or berry. Cotyledons narrow.

++++ Corolla more or less bilabiately irregular (sometimes nearly regular), 5-lobed. Fertile stamens 4 and didynamous, or 2. Style 1. Ovary always of two carpels.

a. Ovules several or many.

75. Scrophulariaceæ (p. 377). Capsule 2-celled, with central placentæ. Seeds small, usually numerous. Herbs; leaves alternate or opposite.

76. Orobanchaceæ (p. 393). Root-parasites with no green foliage. Capsule 1-celled, with 2 simple or double parietal placentæ. Seeds many. 
77. Lentibulariaceæ (p. 395). Aquatic or marsh herbs, witl scapes or scape-like peduncles, sometimes nearly leafless. Corolla personate and spurred. Capsule globular, 1-celled; placentæcentral, free, many-seederl.

78. Bignoniaceæ (p. 398). Large-flowered trees or often climbing shrubs, with usually opposite simple or compound leaves. Capsule 2-celled by a partition between the 2 parietal placentx. Seeds numerous, large, mostly winged.

79. Pedaliaccæ (p. 399). Herbs, with opposite simple leaves. Ovary lcelled with two bilamellar parietal placentæ, or 2-4-celled by their union, becoming drupaceous or capsular. Seeds few or many, wingless.

80. Acanthaceæ (p. 399). Herbs, with opposite simple leaves. Capsule 2-celled, loculicidal, with each axile placenta bearing $2-10$ flattish seeds.

b. Cells of the ovary 1-2-ovuled; herbs or low slirubs, with opposite leares.

81. Verbenaceæ (p. 401). Ovary 2-4-celled, not lobed, the dry or drupaceous fruit separating into 2 or 4 1-seeded nutlets (fruit 1-celled and 1seeded in Phryma). Style terminal.

82. Labiatæ (p. 403). Ovary dceply 4-lobed around the style, the lobes becoming dry seed-like nutlets. Stems square; aromatic.

+ + Curolla scarious and nerveless; flowers regular, 4-merous; style 1 .

83. Plantaginaceæ (p. 422). Scapose herbs, with perfect or polygamodiœcious or monœcious flowers in 1 -many-flowered spikes. Fruit a circumscissile 2-celled capsule, with one or more peltate seeds in each cell, or an achene.

Drvision III. APETALOUS FXOGENS. The corolla wanting (except in some Euphorbiacex), and sometimes also the calyx.

* 1. Ovary superior (though sometimes enclosed within the calyx), 1-celled with a solitary basal ovule (several-celled in Phytolaccacex); embryo coiled or curved (nearly straight in Polygonacex) in or about mealy albumen (albumen none in some Chenopodiacex); herbs.

a- Fruit the hardened or membranous closed base of the corolla-like perianth enclosing a utricle.

84. Nyctaginaceæ (p. 425). Perianth tubular or funnelform. Stamens hypogynous. Fruit ribbed or winged. Leaves opposite; stipules none.

+ + Fruit a utricle; perianth mostly persistent, small, 4-5-lobed or -parted, or none.

85. Mlecebraceæ (p. 426). Perianth herbaceous. Stamens perigynous. Leaves opposite; stipules scarious (none in Scleranthus).

86. Amarantaceæ (p. 427). Flowers sessile, bracteate, the bracts (usually 3) more or less rlry and scarious, as well as the $3-5$ distinct sepals. Stamens 1-5, hypogynous. Ltricle indehiscent or circumscissile. Embryo annnlar. Leaves mostly alternate, entire; stipules none.

87. Chenopodiaceæ (p. 430). Flowers sessile, not scarious-bracteate. Sepals greenish or succulent, 5 or fewer, or none. Stamens 5 or fewer, perigynous or hypogynous. Embryo annular or spiral or conduplicate. Leaves alternate; stipules none. 
+++ Ovary of several 1-ovuled carpels, in fruit a berry (in our genera).

88. Phytolaccaceæ (p. 435). Sepals $4-5$, petaloid or herbaceous. Stamens 5-30, hypogynous. Carpels 5-12. Embryo annular. Leaves alternate, entire; stipules none.

++++ Fruit a triangular or lenticular achene.

89. Polygonaceæ (p. 436). Flowers on jointed pedicels. Calyx 3-6-lobed or -parted, more or less corolla-like. Stamens 4-12, on the calyx. Embryo nearly straight. Leaves alternate, with sheathing stipules or none.

* 2. Ovary componnd, the cells many-ovuled (or 1-ovuled in Piperaceæ); embryo minute in copions albumen; flowers perfect.

90. Podostemaceæ (p. 444). Aquatic, with the aspect of sea-weeds or mosses, with minute naked flowers from a spathe-like involucre. Uvary superior; pod 2-3-celled.

91. Aristolochiaceæ (p. 444). Terrestrial herbs or climbing shrubs. Calyx valvate, adnate at least at base to the 6-celled many-seeded ovary. Stamens 6-12, more or less mited with the style. Leares alternate, mostly cordate; stipules none.

92. Piperaceæ (\$ Saurureæ), (p. 446). Marsh herb (our species). Perianth none. Carpels $3-4$, distinct, with usually a single ascending seed. Leaves alternate, entire.

* 3. Uvary superior, simple, 1-celled, 1-ovuled, forming a berry or drupe; trees or shrubs, with mostly entire leares and no stipules.

93. Lauraceæ (p. 446). Flowers perfect or diœcious. Sepals 4 or 6 , in 2 rows. Stamens 9-12; anthers opening by 2 or 4 uplifted valves. Seed suspended; albumen none. Aromatic; leaves alternate.

94. Thymelæaceæ (p. 448). Flowers perfect. Calyx corolla-like, 4-5cleft. Stamens twice as many. Seed suspended, with little or no albumen. Acrid shrubs with very tough bark; leaves alternate.

95. Elæagnaceæ (p.448). Flowers mostly diœcious. Calyx-tube becoming berry-like and enclosing the achene. Seed erect, albuminous. Leaves silvery-scurfy, opposite.

* 4. Ovary inferior, 1-celled, 1-3-ovuled (but 1-seeded); albumen without testa, bearing the embryo in a cavity at the apex; calyx-lobes valvate.

96. Loranthaceæ (p. 449). Parasitic on trees, with jointed stems and opposite leaves. Flowers diccious. Ovule solitary, erect. Fruit a berry.

97. Santalaceæ (p. 450). Flowers perfect. Orules 2-4, suspended from the apex of a central placenta. Fruit dry, indehiscent. Leaves alternate.

* 5. Hlowers all unisexual (polygamous in some Urticaceæ and Empetraceæ, apparently perfect in Euphorbia); cells 1-2-ovuled; embryo nearly as long as the albumen or filling the seed; calyx often wanting, corolla-like only in some Euphorbiaceæ and Empetracer; stipules often present.

- 1. Ovary superior, 3-celled (1-celled in Crotonopsis) with 1 or 2 pendulous ovules in each cell; herbs.

98. Euphorbiaceæ (p. 451). Flowers monœcious or diœcions (involucrate and apparently perfect in Euphorbia). Mostly with milky juice, and usually alternate often stipulate leaves. 
+ 2. Ovary 1-celled, 1-seeded; trees or shrubs (except some Urticacex).

+ Calyx regular, the stamens as many as the lobes and opposite them or fewer; ovary superior.

99. Urticaceæ (p. 461). Flowers monœcious, divecious, or (in Clmeæ) perfeet. Seeds exalbuminous or nearly so. Inflorescence very various.

\#+ Perianth mostly none; at least the staminate flowers in aments or spikes or dense heads; albumen none.

100. Platanaceæ (p. 466). Trees, with alternate palmately lobed leaves, sheathing stipules, and monoeious flowers in separate globose lieacis. Ovary superior; fruit a club-shaped nutlet.

101. Juglandaceæ (p. 467). Trees, with alteruate pinnate leaves, no stipules, and monocious flowers, the staminate in aments. Ovary inferior; fruit a uut.

102. Myricaceæ (p. 469). Shrubs, with resinous-dotted leaves, with or without stipules, and monoecious or dicecious flower's, botlı kinds in short scaly aments. Ovary superior, becoming a small drupe-like nut.

-3. Ovary 2-7-celled, with 1 or 2 suspended ovules in each cell, becoming 1-celled and 1-seeded; calyx mostly noue or adherent to the ovary; trees or shrubs with simple leaves.

103. Cupuliferæ (p. 470). Flowers monœcious. Fruit a nut surrounded by an involucre, or (in Betuleæ) a small winged or angled uaked nutlet in the axils of the scales of an ament.

- 4. Ovary 1-celled, becoming a 2-valred pod with two parietal or basal placentæ bearing numerous small comose seeds; perianth none.

104. Salicaceæ (p. 480). Diœcious trees or shrubs, with botlı kinds of flowers in aments, and simple alteruate stipulate leaves.

- 5. Orary several-celled, becoming a drupe containing 3-9 1-seeded nutlets ; seed erect; low slirubby heath-like evergreens.

105. Empetraceæ (p. 487). Flowers polygamous or diecious, scaly-bracted. Sepals somewhat petaloid or none. Embryo axile in copious albumen.

- 6. Ovary 1-celled with a suspended ovule, becoming an achene; calyx uone; aquatic herbs, with finely dissected whorled leaves.

106. Ceratophyllaceæ (p. 488). Flowers monœcious, minute, axillary and sessile. Albumen none; the seed filled with a highly developed embryo.

Subclass II. GYMNOSPERMIOUS EXOGENS. Ovules naked upon a scale, bract, or disk. Cotyledons two or more.

107. Coniferæ (p. 489). Resiniferons trees or shrubs, with mostly awlshaped or needle-shaped and evergreen leaves, and monocions or diacious flowers.

\section{Class II. MONOCOTYLEDONOUS PLANTS.}

Stems withuut ecntral pith or annular layers, but having the woody fibres distributed irregularly through them (a transverse slice showing the fibres as dots scattered through the cellular tissue). Fmbryo with a single cotyledon and the early leaves always alternate. Parts of the 
flower usually in threes (never in fives), and the leaves mostly parallelveined. Our species herbaceous, excepting Smilax.

* Ovary inferior (superior in Bromeliaceæ, nearly so in some Hemodoracex); at least the inner lobes of the perianth petal-like.

+ 1 . Seeds without albumen, very numerous and minute.

108. Hydrocharidaceæ (p. 495). Aquatics, with diœcious or polygamous flowers from a spathe; outer perianth calyx-like, the inner sometimes wanting. Stamens 3-12. Ovary 1-celled with 3 parietal placentæ or 6 -9-celled with axile placentæ.

109. Burmanniaceæ (p.496). Terrestrial, with scale-like canline leares and regular perfect triandrous flowers. Perianth corolla-like.

110. Orchidaceæ (p. 497). Terrestrial, with very irregular perfect flowers. Stamens and style connate; anthers 1 or 2. Capsule 1-celled; placentæ 3, parietal. Perianth corolla-like.

- 2. Seeds albuminous. (Ovary 3-celled and flowers regular in our genera.)

111. Bromeliaceæ (p. 511). Mostly epiphytes, with dry persistent scurfy leaves. Flowers 6-androus; outer perianth calyx-like.

112. Hemodoraceæ (p. 512). Fibrous-rooted, with equitant leaves and perfect 3- or 6-androus flowers. Perianth persistent, woolly or scurfy outside. (Ovary sometimes nearly free; leares flat in Aletris.)

113. Iridaceæ (p. 513). Root not bulbous; leaves equitant in two ranks. Flowers from a spathe. Stamens 3, opposite the outer lobes of the corolla-like perianth; anthers extrorse.

114. Amaryllidaceæ (p. 515). Often bulbous-rooted and scapose. Perianth corolla-like. Stamens 6; anthers introrse.

115. Dioscoreaceæ (p. 517). Climbing, with net-reined leaves. Flowers diœeious, small, 6-androus; perianth calyx-like. Ovules 1 or 2 in each cell.

* * Ovary superior (very rarely partially adnate to the calyx in Liliaceæ).

+1. At least the inner perianth corolla-like; ovary compound; seeds with copious albumen.

116. Liliaceæ (p. 517). Flowers perfect, 6-androus, the regular perianth corolla-like (diocious in Smilnx, dimerous in Maianthemum, the outer divisions herbaceous in Trillium). Fruit a 3-celled capsule or berry.

117. Pontederiaceæ (p. 535). Aquatic, with more or less irregular perfect flowers from a spathe; perianth corolla-like. Stamens 3 or 6 , mostly unequal or dissimilar. Capsule 1-celled or imperfectly 3-celled.

118. Xyridaceæ (p. 536). Rush-like, scapose. Flowers capitate, perfect, 3-androus, the calyx glumaceous. Capsule 1-celled.

119. Mayaceæ (p. 537). Moss-like aquatic. Flowers perfect, axillary, solitary, 3-androns; calyx herbaceous. Capsule 1-celled.

120. Commelinaceæ (p. 538). Flowers perfect, regular or somewhat irregular, with 3 more or less herbaceous persistent sepals and 3 fugacious petals. Stamens 6 or some sterile. Capsule 2-3-celled.

127. Eriocaulez (p. 566). Scapose aquatic or marsh plants, with linear leaves and dense heads of monœcious (rarely diœcious) minute flowers. Corolla tubular or none. Capsule 2-3-celled, 2 -3-seeded. 
- 2. Perianth small, of 6 equal persistent glumaceous segments; flowers perfect; ovary compound.

121. Juncaceæ (p. 539). Rush-like. Stamens 3 or 6. Capsule 1- or 3celled, 3-valved.

- 3. Flowers without chaffy glumes, the perianth none or reduced to bristles or sepal-like scales; flowers often monœcious or diceious; carpels solitary or united.

- Flowers capitate or upon a spike or spadix, with or without a spathe.

122. Typhaceæ (p. 547). Marsh or aquatic plants, with linear leares, and monœcious flowers without proper perianth, in heads or a naked spike.

123. Araceæ (p. 548). Flowers perfect or monœcious upon the same spadix, rarely diccious, with 4 or 6 scale-like sepals or none.

\# Flowers very minute, one or few from the margin of a floating disk. like froud.

124. Lemnaceæ (p. 551). Plants very small, green, mostly lenticular or globose.

-4. Perianth of 4 or 6 segments, the inner often petaloid, or none; carpels solitary or distinct (coherent in Triglochin); seeds without albumen; aquatic or marsh plants, often monœcious or diœcious.

125. Alismaceæ (p. 553). Perianth of 6 segments, the inner petal-like.

126. Naiadaceæ (p. 557). Periauth-segments herbaceous or none.

- 5. Flowers in the axils of chaffy scales or glumes arranged in spikes or spikelets, without evident perianth; stamens $1-3$; ovary l-celled, I-seeded; seed albuminous.

128. Cyperaceæ (p. 567). Scales single. Perianth none or replaced by bristles. Anthers basifixed. Fruit a triangular or lenticular achene. Stem solid, often triangular, with closed sheaths.

129. Gramineæ (p. 623). Glumes in pairs. Perianth replaced by minute scales. Anthers versatile. Fruit a caryopsis. Culm usually hollow, terete; sheaths split to the base.

Series II. CRYPTOGAMOUS or FLOWERLESS PLANTS; destitute of stamens and pistils, in fructification producing spores instead of seeds.

\section{Class III. ACROGENOUS PLANTS.}

Cryptogamous plants with a distinct axis (stem and branches), growing from the apex only, and furnished for the most part with distinct leaves (sometimes taking the form of an expanded leaf-like usually prostrate thallus); reproduction by means of antheridia and archegonia, sometimes also by gemmation.

SubClass I. VÁSCULAR ACROGENS, or PTERIDOPHYTES. Stems (and foliage when present) containing both woody fibre and vessels; antheridia or archegonia, or both, borne on a minute prothallus, which is developed from the spore on germination. 
* Spores of only one kind; prothallus bearing antheridia and archegonia.

130. Equisetaceæ (p. 675). Cylindric jointed hollow-stemmed plants, with toothed sheaths. Fructification in a terminal spike.

131. Filices (p. 678). Ferns, with fronds circinate in vernation, bearing the fructification on the under surface or beneath the margin.

132. Ophioglossaceæ (p. 693). Fronds often fern-like, erect in vernation. Sporangia globose, coriaceous, 2-valved, in special spikes or panicles.

133. Lycopodiaceæ (p. 695). Low moss-like plants with elongated stems and small persistent entire several-ranked leaves. Sporangia solitary, axillary, 1-3-celled, 2-3-valved.

* Spores of two kinds, the macrospore producing a prothallus with archegonia, the microspore smaller and developing antheridia.

134. Selaginellaceæ (p. 697). Low leafy moss-like or marsh plants, with branching stems, and small 4-6-ranked leaves, or with a corm-like stem and basal linear-subulate leaves, the two kinds of spores in distinct solitary axillary 1-celled sporangia.

135. Marsiliacea (p. 700). The two kinds of spores in the same or different sporangia which are borne in a coriaceous peduncled sporocarp arising from a slender creeping rhizome. Fronds digitately 4 -foliolate or filiform.

136. Salviniaceæ (p. 701). The two kinds of spores in separate thin-walled 1-celled sporocarps or conceptacles clustered beneath the small floating fronds; macrospores solitary.

Subclass II. CELLULAR ACROGENS, or BRYOPHYTES. Plants with cellular tissue only; both antheridia and archegonia borne upon the plant itself. - Including the Musci, or Mosses (which are not treated of here), never thallose, and bearing capsules which usually dehisce by a lid and contain spores only, and the HEPATIC.E, which bear capsules which dehisce by valves or irregularly and usually have elaters mingled with the spores. The latter division comprises the following Orders.

* Capsule 4-valved; plant a leafy axis or sometimes a branching thallus.

137. Jungermanniaceæ (p. 702). Leaves, when present, without a midrib, 2-ranked, with often a third row beneath; pedicels slender.

* * Capsule 2-ralved, or dehiscing irregularly, or indehiscent; plant a thallus or thalloid stem.

138. Anthocerotaceæ (p. 726). Thallus without epidermis, irregularly branching; pedicels stout or none. Capsule with a columella. Elaters mostly without fibres.

139. Marchantiaceæ (p. 727). Thallus radiate or dichotomous, the epidermis usually porose. Capsules borne on the under side of a pedunculate receptacle, irregularly dehiscent. Elaters 2-spiral.

140. Ricciaceæ (p. 730). Thallus radiate or dichotomous, the epidermis eporose. Capsules immersed in the thallus or sessile upon it, indehiscent. Elaters none. 


\section{ANALYTICAL KEY TO THE ORDERS.}

\section{Class I. DICO'TYledonOUS PLAN'TS. (See p. 5.)}

Subclass I. ANGIOSPERMLE. Pistil consisting of a closed ovary. Cotyledons only two.

Division I. POLYPETALOUS : the calyx and corolla both present; the latter of separate petals.

A. Stamens numerous, at least more than 10, and more than twice the sepals or lobes of the calyx.

1. Calyx entirely free and separate from the pistil or pistils.

Pistils numerous but cohering over each other in a solid mass on PAGE an elongated receptacle. . . . . . Magnoliace.; 49

Pistils numerons, separate, but concealed in a hollow receptacle.

Leaves opposite, entire; no stipules. . . . Calycantiacras, 167

Leaves alternate, with stipules. . . . . Rosa, in RosACEx, 162

Pistils several, immersed in hollows of the upper surface of a

large top-shaped receptacle. . Nelumbo, in Nrminzaces, 55

Pistils more than one, separate, not enclosed in the receptacle.

Stamens inserted on the calyx, distinct. . . . . Rosace.x, 150

Stamens united with the base of the petals, monadelphous. MaLvices, 96

Stamens inserted on the receptacle.

Filaments much shorter than the anther; trees. . . ANONACE.E, 50

Filaments longer than the anther.

Flowers diocious; twiners with alternate leaves. Menispermace.e, 51

Flowers perfect; if climbers, the leaves opposite.

Leaves not peltate; petals deciluous. - Ranunculaces, 34

Leaves peltate; petals persistent. Brasenia, in Nrmpiledce., 55

Pistils several-lobed, the ovaries united below the middle. Resedace. i5

Pistils several, their oraries cohering in a ring around an axis. Matvace.e, 96 Pistils strictly one as to the ovary; the styles or stigmas may be several.

Leaves punctate under a lens with transparent dots. HYpenicice.e, 92

Leaves not punctate with transparent dots.

Ovary simple, 1-celled, 2-ovuled.

ROSACE.X, 150

Ovary simple, l-celled, with one parietal many-oruled placenta.

Leaves 2-3-ternately compound or dissected. Raxuxculacex, 34

Leaves peltate, sinply lobed. Podophyllum, in Berberidace.e, 52

Ovary compound, 1-celled, with a central placenta. I'ontulacace.s, 90 
Ovary compound, 1-celled, with two or more parietal placentæ.

Calyx caducous ; juice milky or colored.

Papayeracese, 57

Calyx deciduous, of 4 sepals. . . . . Capparidace 74

Calyx persistent, of 3 or 5 sepals. . . . . Cistace 2,76

Ovary compound, several-celled.

Calyx valvate in the bud, and

Persistent ; stamens monadelphous ; anthers 1-celled. MaLvace£, 96

Deciduous; anthers 2-celled

Tiliaceie, 101

Calyx imbricated in the bud, persistent.

Shrubs; stamens on the base of the petals. Ternstramiaces, 95 Aquatic or marsh herbs; ovaries many,

On 5 placentæ in the axis.

Sarraceniacea, 57

On the 8-30 partitions.

NYMPHÆACE., 54

2. Calyx more or less coherent with the suiface of the (compound) ovary.

Ovary 8-30-celled; ovules many, on the partitions ; aquatic. NrмpHжACE Ovary 10-celled; cells 1-ovuled. . . . Amelanchier, in Rosacex, 166 Ovary 2-5-celled.

Leaves alternate, with stipules. ․ . . Pomex, in RosACE£, 151

Leaves opposite, without stipules. . . Some SAXIFRAGACE 163

Leaves alternate, without stipules. . . . . STrRACACE 333

Ovary 1-celled, with the orules parietal.

Fleshy plants with no true foliage; petals many. - CACTACE 186

Rough-leaved plants; petals 5 or 10 . . . . . LOASACEE, 193

Ovary one-celled, with the ovules rising from the base. PORTULACACEe, 90

B. Stamens of the same number as the petals and opposite them.

Pistils $3-6$, separate; flowers diœecious; woody vines. Mexispermack 51 P'istil ouly one.

Orary one-celled; anthers opening by uplifted valves. BErberidace, 52

Orary one-celled; anthers not opening by uplifted valves.

Style and stigma one; ovules more than one. - Primelacex, 328

Stỵle 1 ; stigmas 3 ; sepals 2 ; ovules several. Portulacace.e, 90

Style twice.or thrice forked; flowers monœcious.

Crotonopsis, in Euphorbiaces, 458

Styles 5 ; ovule and seed only one. . . . Plumbaginacex, 327 Ovary 2-4-celled.

Calyx-lobes minute or obsolete; petals valvate. _ . Vitace., 112

Calyx 4-5-cleft, valvate in the bud; petals inrolute. RHAmnace 111

C. Stamens not more than twice as many as the petals, when of just the number of the petals then alternate with them.

1. Calyx free from the ovary, i. e. the ovary wholly superior.

* Ovaries 2 or more, separate.

Stamens united with each other and with a large and thick

stigma common to the two ovaries. - . AsCLEPIADACE 2,338

Stamens unconnected, on the receptacle, free from the calyx.

Leaves punctate with pellucid dots.

- Rutaces, 106 
Leares not pellucid-punctate.

Tree, with pinnate leaves.

Low shrub, with pinnate leares.

Herbs, not fleshy.

Ailanthus, in Simarcbaces, 107 Tanthorrhiza, in liaxexcelaces, 48

Herbs, with thick fleshy leares.

Stamens unconnected, inserted on the calyx.

Just twice as many as the pistils (flower symmetrical). CRASsclacke, 176 Not just the number or twice the number of the pistils.

Leaves without stipules.

SAXIfragaCe.e, 168

Leares with stipules.

Rosace.e, 150

* *varies 2-5, someuhat united at the base, separate above.

Leaves punctate with pellucid dots. Raxunculace.e, 34

Crassulace.e, 176

Leares not pellucid-punctate.

Shrubs or trees with opposite leaves.

Rutaces, 106

Thrubs or trees with opposite leaves.

SAPINDACE.e, 115

Terrestrial herbs; the carpels fewer than the petals. SAxifragacede, 168

* * * Ovaries or lobes of ovary 3 to 5, with a common style. GeraviaCE

* * * Orary only one, and

- Simple, with one parietal placenta. LEguminosæ, 122

+ + Compound, as shown by the number of cells, placenter, styles, or stigmas.

Ovary one-celled.

Corolla irregular; petals 4 ; stamens 6 .

Fumariaces, 59

Corolla irregular; petals and stamens 5.

Corolla regular or nearly so.

- VIOLACE.E, 78

Ovule solitary; shrubs or trees; stigmas 3.

Avacardicen, 118

Ovules solitary or few; herbs. . . Some anomaluus Cruciferf, 61

Ovules more than one, in the centre or bottom of the cell.

Petals not inserted on the calyx. . . . CARYOPUXLLACEA, 82

Petals on the throat of a bell-shaped or tnbular calyx. LrTHRACEA, 184 Ovules several or many, on two or more parietal placentæ.

Leaves punctate with pellucid and dark dots.

HYPERICACE.E, 92

Leaves beset with reddish gland-tipped bristles.

Droseraceis, 178

Leaves neither punctate nor bristly-glandular.

- Sepals 5, very unequal or only 3. . . . Crstace.e, 76

Sepals and petals 4 ; stamens 6. . . Anomalous Crucifer.e, 61

Sepals and petals 5 ; stamens 5 or 10.

Ovary and stamens raised on a stalk.

Orary sessile. . . . . . . SAXIFRAGACE 168

Ovary 2-several-celled.

Flowers irregular.

Anthers opening at the top,

Six or eight and 1-celled; ovary 2-celled, 2-ovuled. Polrgalacex, 120

Ten and 2-celled; ovary 5-celled. Rhododendron, in ERICACE.z, 286 Anthers opening lengthwise.

Stamens 12 and petals 6 on the throat of a tubular inflated or gibbous calyx. - . . Cuphea, in Lrturace.e, 186 
Stamens $5-8$ or 10, and petals hypogyuous, or nearly so.

Ovary 3-celled. . . . . . . . SAPINDACE 2,115

Ovary 5 celled. . . . Impatiens, \&c., in Geraxiacez, 105

Flowers regular or nearly so.

Stamens neither just as many nor twice as many as the petals,

Triadelphous; petals 5. . . . . . HYPERICACEA, 92

Tetradyuamous (or rarely only 2 or 4 ) ; petals 4 ; pun-

gent herbs. $\quad . \quad . \quad . \quad . \quad . \quad$ Crucifere, 61

Distinct and fewer than the 4 petals. . . . OLeAcex, 335

Distiuct and more numerous than the petals. . SAPINDACEA, 115

Stameus just as many or twice as many as the petals.

Ovules and seeds only 1 or 2 in each cell.

Herbs; flowers monœcious or diceious.

Herbs; flowers perfect and symmetrical.

EupHorbLACEA, 451

Cells of the ovary as many as the sepals, \&c. Geraxuacex, 02

Cells of the (divided) orary twice as many as

the styles, sepals, \&e. . . . . Lricace, 101

Shrubs or trees.

Leaves 3-foliolate, pellucid-punctate. Ptelea, in Rctaces, 107

Leares palmately reined and fruit 2-winged, or

pinnate and fruit a berry. . . . SAPINDACE 115

Leaves pinnately veined, simple, not punctate.

Calyx not minute; pod colored, dehiscent;

seeds euclosed in a pulpy aril.

Celastracex, 109

Calyx minute; fruit a berry-like drupe.

ILICINEA, 107

Ovules (and usually see(ls) several or mauy in each cell.

Stipules between the opposite and simple leaves. Elativacex, 91

Stipules between the opposite and compound leaves

(but they are caducous). Staphylea, in SAPINDACEA, 118

Stipules none when the leaves are opposite.

Stamens 5, monadelphous in a 10-toothed tube or cup ;

leaves simple, all radical. Galax, in Dia pexsiacex, 326

Stamens 10, monadelphous at the base. Leaflets 3,

inversely heart-shaped. Oxalis, in GeraxiaCE.z, 105

Stamens distinct, free from the calyx.

Style 1, undivided. . . . . . ERICACEA, 309

Styles 2-5, separate. - . - CARYOPHYLLACEæ, 82

Stamens distinct, inserted on the calyx.

Styles 2 (or 3), or splitting into 2 in fruit. SAxifragaCEe, 168

Style 1; pod in the calyx, 1-celled. Lxturace., 184

2. Calyx-tube adherent to the ovary, at least to its lower half.

Tendril-bearing and often succulent herbs.

- Cucurbitacese, 194

Not tendril-bearing.

Orules and seeds more than one in each cell.

Ovary 1-celled, many-ovuled from the base. - . Portclacacex, 90

Ovary 1-celled, with 2 or 3 parietal placentæ. - SAxifraGace 2,168

Ovary 2-several-celled.

Anthers opening by pores at the apex; style 1. Melastomace 183 
Anthers not opening by pores.

Stamens on a flat disk which covers the ovary. Celastrace. 109 Stamens inserted on the calyx.

Eight or four (rarely five); style 1. - . OxagraCEs, 186 Five or ten; styles 2-3, distinct. . . SAxImRAGACE.z, 168 Ovules and seerls only one in each cell.

Stamens 10 or 5 (instead of many), - rarely in Cratxgus, in Rosict:s, 165 Stamens 2 or 8 ; style 1; stigma 2-4-lobed; herbs. OxaGracke, 186 Stamens 4 or 8 ; aquatics; styles or sessile stigmas 4 . HA LORAGEA, 180 Perfect stamens 4 ; styles 2 ; shrub. . . HaMamelinede, 179 Stamens 4 ; stỵle and stigma 1 ; chiefly shrubs. . . Cornace e, 213 Stamens 5 ; flowers in umbels, or rarely in heads.

Fruit dry, splitting in two at maturity; styles 2. Fruit berry-like ; styles $2-5$, separate or united.

UMBELLIFER

ARALACEA, 212

Division II. GAMOPETALOUS calyx and corolla both present; the latter with its petals united more or less into one piece.

A. Stamens more numerous than the lobes of the corolla.

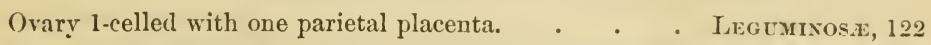
Ovary l-celled with two parietal placentæ. Adlumia, \&c., in Fumariace $E, 60$ Orary l-celled with the orules at the centre or base. . STrRACACE. 333 Ovary 2-celled with a single ovule in each cell. . . POLYGALACE 120 Ovary 3-many-celled.

Stamens free or nearly free from the corolla; style single. Ericace Stamens free from the corolla; styles 5. Oxalis, in Geraxiacese, 105 Stamens inserted on the base or tube of the corolla.

Filaments monadelphous; anthers l-celled, kidney-shaped. MALVACEE, 96 Filaments 1-5-adelphous at base; anthers 2-celled.

Calyx free from the ovary. . . . . Tersstramace, 95

Calyx coherent with the ovary or with its base. STrRACACEE, 333

Filaments wholly distinct; calyx free, persistent. Enexices, 333

Filaments in pairs at each sinus; anthers 1-celled. CAPrIfolide.e, 216

B. Stamens (fertile ones) as many as the lobes of the corolla and opposite them.

Ovary 5-celled; corolla appendaged with scales inside.

SAPOTACE. 332

Ovary 1-celled; pod several-many-seeded; style 1.

Ovary 1-celled; utricle 1-seeded; styles 5. . . Plumbaginaceж, 327

C. Stamens as many as the lobes of the corolla and alternate with them, or fewer.

1. Ovary adherent to the calyx-tube (inferior).

Tendril-bearing herbs ; anthers often united. $\because . \quad$ Cucurbitaces, 194

Tendrils none.

Stamens united by their anthers into a ring or tube.

Flowers in an involucrate head.

Composite, 230

Flowers separate, not involucrate; corolla irregular. LoBELracex, 305

Stamens separate, free from the corolla or nearly so, as many as its lobes: stipules none: juice milky.

Campanulace 307 
Stamens separate, inserted on the corolla,

One to three, always fewer than the corolla-lobes. VAlerianaceÆ, 228

Four or five; leaves opposite or whorled.

Ovary 1-celled; flowers in a dense involucrate head. Dipsaces, 229

Ovary 2-5-celled.

Leaves whorled and without stipules.

Leaves opposite or whorled, and with stipules.

RUBIACEN, 222

Leaves opposite without stipules (petioles sometimes with stipule-like appendages).

Caprtfoliacee, 216

2. Ovary free from the calyx (superior).

* Corolla irregular: stamens (with anthers) 4 and didynamous, or only 2.

Ovules and seeds solitary in the $(1-4)$ cells.

Ovary 4-lobed, the style rising from between the lobes.

Ovary not lobed, the style from its apex.

I.ABIATE, 403

VERBENACEE, 401

Ovules numerous or at least as many as 2 in each cell.

Ovary and pod 1-celled,

With a free central placenta; stamens 2. - Lextibclace 2395

With 2 or more parietal very many-seeded placentæ ;

stamens 4. . . . . . . . ORobarchace无, 393

Ovary and fruit more or less 4-5-celled. . . . Pedalices, 399

Ovary and pod 2-celled, but the 2 placentæ parietal. Brgxoniace 2,398

Orary and pod 2-celled; placentæ in the axis.

Seeds rarely few, not on hooks, with albumen. Scrophulariaces, 377

Seeds few, borne on hook-like or other projections

of the placentæ : no albumen. . . . ACANthaCeæ, 399

* Corolla somerchat irregular: stamens (with anthers) 5.

Stamens free from the corolla; anthers with their cells opening by

a hole or chink at the top. Rhododendron, in ERICACE 2,320

Stamens inserted on the corolla.

Ovary deeply 4-lobed around the style. Echium, in Borragivacew, 367

Ovary not lobed; pod many-seeded.

Filaments or some of them woolly. Verbascum, Scrophd Lariaceæ, 379

Filaments not woolly. . . . Hyoscyamus, Solanace 376

* * Corolla regular.

- Stamens as many as the lobes of the corolla.

Oraries 2, separate; their

Styles and stigmas also wholly separate. Dichondra, CoxvolvulaCE $\mathbb{E}, 368$

Stigmas and sometimes styles united into one.

Filaments distinct; pollen in ordinary grains.

Filaments monadelphous; pollen in masses. .

- Apocynacese, 337

Ovary one, but deeply 4-lobed around the style (or 2-lobed in Heliotropium).

Leaves alternate.

- Borraginace 2360

Leaves opposite. . . . . . . Mentha, in Labiate, 407

Ovary one; pod 2-lobed or 2-horned at the summit. IOGANIACE

Ovary one; not deeply lobed,

One-celled, one-ovuled, becoming an achene.

Plantaginacee, 422

\section{PROPERT LIBRARY}

N. C. State College 
One-celled, with ovules parietal or on 2 parietal placentx.

Leaves (or in Menyanthes three leaflets) entire.

Gextiayace.e, 346

Leaves toothed, lobed, or pinnately compound. IIYIROPII LLACEA, 357 Two- to ten-celled.

Leafless parasitic twining plants. Cuscuta, in Coxvolvulacex, 370 Leaves opposite, their bases or petioles connected

by stipules or a stipular line.

LOGANIAEX, 345

Leaves when opposite witlout stipules.

Stamens free from the corolla or nearly so; style 1. EnICACE $A, 309$

Stamens almost free from the corolla; style none. Ilicixex, 107

Stamens in the sinuses of the corolla; style 1. Drapexiacex, 326

Stamens inserted on the tube of the corolla,

Four; pod 2-celled, circumscissile. . . P'Lantagrnaces, 422

Four; ovary 2-4-celled; ovules solitary. . Verbexacex, 401

Five or rarely more.

Fruit of two or four seed-like uutlets. - IBORnagrNace 2,360

Fruit a few-seeded pod.

Calyx 5-cleft; style 3-lobel or -cleft. . Polemoviace $x, 354$

Sepals 5; styles 1 or 2, entire or 2-cleft; scels

large, only one or two in a cell. Convolvulaces, 367

Fruit a many-seeded pod or berry.

Styles 2. . . - Hydrolea, in Hydropityllacex, 360

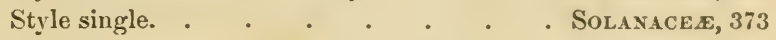

++ Stamens feuer than the lobes of the corolla.

Stamens 4, didynamous.

Ovary 2-celled; the cells several-seeded. . . . ACANTIACE£, 393

Ovary 2-4-celled; the cells 1-seeded. . . . VERBENACEx, 401

Stamens only 2 with anthers; ovary 4-lobed. . Iycopus, in LABIATæ, 408

Stamens 2, rarely 3 ; ovary 2 -celled.

Low herbs ; corolla scarious, withering on the pod. Plantagrnacex, 422

IIerbs; corolla rotate, or somewhat funnelform, and

slightly irregular. . . . Yeronica, in Scrophulariceæ, 386

Shrubs or trees: corolla perfectly regular. . . . . OLEACEA, 335

Drvisiox III. APETALOUS : corolla (and sometimes calyx) wanting.

\section{A. Flowers not in cathins.}

1. Ovary or its cells containing many ovules.

Ovary and pod inferior (i. e. calyx-tube adherent to the ovary),

Six-celled; stamens 6-12. . . . . . Aristolochice e, 444

Four-celled; stamens 4. . . . . Ludwigia, in Ovagraces, 187

One-celled, with parietal placenta. Chrysosplenium, in SAxrfragaced, 172

Ovary and pod wholly naked (there being no calyx),

Two-celled, 2-beaked; flowers capitate; tree. . HAMAMELInEx, 179

Two-celled, many-ribbed; aquatic herb. . . . Podostemaces, 444 
Ovary and pod superior, i. e. free from the calyx.

Five-celled and 5-beaked, opening across the beaks, which

fall off at maturity ; stamens 10. Penthorum, in Crassclacese, 176 Three-celled and 3-valved, or 3-5-celled and circumscissile. FicoIdEx, 198 Two-celled or one-celled; placentæ central.

Stamens inserted on the throat or tube of the calyx. LrTHrace $\mathbb{2}, 184$ Stamens inserted o: the receptacle or the base of the calyx,

Alternate with the 5 sepals. . . . Glaax, in Primelace 331

Opposite the sepals when of the samenumber. Caryophyllace 2,82

One-celled, with one parietal placenta. $\}$. . IRANuxcclace $\mathbf{3}, 34$ Draries 2 or more, separate, simple.

2. Ovary or its cells containing only 1 or 2, rarely 3 or 4 , ovules.

* Pistils more than one, and distinct or nearly so.

Stamens inserted on the calyx; leares with stipules.

ROSACEE, 150

Stamens inserted on the receptacle.

Leaves punctate with pellucid dots. . Xanthoxylum, in Rutaces, 106 Leaves not dotted.

Calyx present, and usually colored or petal-like. RAxunculace 2,34

Calyx absent; flowers entirely naked, perfect, spiked. PiPeracex, 446 * Pistil one, either simple or compound.

Ovary partly inferior, the calyx colierent to its lower half,

2-celled; styles 2 ; stamens many.

HAMAMELIDEA, 179

Ovary wholly inferior (in perfect or pistillate flowers).

Aquatic herbs; ovary 3-4-celled, or (Ilippuris) 1-celled. Ha lorage $x, 180$ Mostly woody plants; style or stigma one, entire; ovary l-celled.

Stigma running down one side of the style. Nyssa, in Corracex, 215

Stigma terminal, with or without a style.

Parasitic on the branches of trees ; anthers sessile. Loraxthacez, 449

Not parasitic above ground; anthers on filaments. SAXTALACE $Æ, 450$

Ovary really free from the calyx, but permanently invested by its

tube, or the basé of it, so as to seem inferior.

Shrubs, with scurfy leaves; flowers mostly diœcious. Elananacem, 448

Herbs, with the calyx colored like a corolla.

Leaves opposite, simple.

NrCtaginace 2,425

Leaves alternate, pinnate. . . . Poterium, in RosAcE 2,161

Ovary plainly free from the calyx, which is sometimes wanting.

Stipules (ocrex) sheathing the stem at the nodes.

Tree; calyx none; flowers monœcious, in heads.

Platanacee, 466

Herbs; calyx present and commonly petal-like.

Polygonacex, 436

Stipules not sheathing the stem, or none.

Aquatic herbs, submerged or nearly so.

Leaves whorled and dissected; style single. CeratopHrllace $\$$, 488

Leares opposite, entire; styles 2; ovary 4-celled. Haloragex, 180

Not aquatics, herbs.

Ovary 10-celled; berry 10-seeded. . . Purtolaccacex, 435

Ovary 3- (rarely 1-2-) celled; juice usually milky. Euphorbiaceæ, 451 
Ovary 1-celled; juice not milky.

Style, if any, and stigma only one; leares simple; no scarious bracts around the flowers. .

Urticaces, 461

Styles 3 ; embryo straight; flowers involucrate.

Eriogonum, in Polygoxaces, 436

Style or stigmas 2 or 3 ; embryo coiled or curved.

Stipules not scarious, leaves palmately cleft or palmately compound. . - Cannabinex, in Urticace $£, 461$

Stipules scarious (or none) ; leares opposite. Illecebracex, 426

Stipules none; but flowers with scarious bracts. AмA RAxтACE $\mathbb{E}, 427$

Stipules and scarious bracts none . . Chexopodiacex, 430 Shrubs or trees.

Ovules a pair in each cell of the ovary.

Fruit 2-celled, a double samara. Acerineæ, in SAPINdaces, 115

Fruit a 1-celled and 1-seeded samara or a drupe. OLEACEA, 335

Ovules single in each cell of the

Three-nine-celled ovary; leaves heath-like. . Eupetraceæ, 487

Three-celled ovary; leaves broad. . . . RHAMxaces, 111

One-two-celled ovary; styles or stigmas 2-cleft. UnTICACEx, 461 One-celled ovary; style and stigma single and entire.

Anthers opening longitudinally. . . Thrmeleacez, 448

Anthers opening by uplifted valves. . . . Lauracex, 446

B. Flowers monœcious or diceious, one or both sorts in catkins.

1. Only one sort of flowers in catkins or catkin-like heads.

Fertile flowers in a short catkin, head, or strobile. . . URTICACE. 461

Fertile flowers single or clustered; sterile in slender catkins (except in Fagus).

Leares pinnate; fertile flowers and fruit naked. JLGLANDACE. 467

Leaves simple; fertile flowers 1-3 in an involucre or cup. Cupclifere, 470

2. Both sterile and fertile flowers in catkins or catkin-like heads.

Ovary and pod 2-celled, many-seeded. Iiquidambar, in HamaneldDex, 180

Ovary and pod 1-celled, many-seeded; seeds furnished with

a downy tuft at one end. . . . . . SALICACEA, 480

Ovary 1-2-celled, only one ovule in each cell; fruit 1-sceded.

Parasitic on trees; fruit a berry. . . . . I.oRAxtIACE

Trees or shrubs, not parasitic.

Calyx regular, in the fertile flower succulent in fruit. URTICACEx, 461

Calyx none, or rudimentary and scale-like.

Style and stigma one, simple; the flowers in heads. Plataxaces, 466

Styles or long stigmas 2.

Fertile flowers 2 or 3 at each scale of the catkin. Curulifers, 470

Fertile flowers single under each scale; nutlets

naked, waxy-coated or drupe-like. . . . Mrricnce., 469

Subclass II. GYMNOSPFRMA. Pistil an open seale or altered leaf, bearing naked ovules on its margin or its upper surface, or in Taxus entirely wanting. Flowers monøecious or dicecious. Coxifera, 459 


\section{Class II. MONOCOTYLEDONOUS PLANTS. (See p.15.)}

A. Spadiceous Drvision. Flowers aggregated on a spadix or fleshy axis, or sometimes scattered, destitute of calyx and corolla (excepting some Araceæ and Naiadaceæ, where, however, they are on a spadix), and also without glumes (hust.y scales). Leaves sometimes with netted veins.

Little floating aquatics, with no distinction of stem and foliage. LEMNACE $E, 551$ Immersed aquatics, branching and leafy. . . . NAIADACE $£, 557$ Reed-like or Flag-like marsh herbs, with linear and sessile nerved leaves; flowers in spikes or liearls.

Flowers monœcious, and quite destitute of floral envelopes. TrpHace.e, 547 Flowers perfect, on a lateral spadix; sepals 6. Acorus, in Araces, 550 Terrestrial or marsh plants; leaves mostly with a distinct netted-reined blade, petioled. . . . . . Arace E, 548

B. Petaloideous Division. Flovers not collected on a spadix, furnished with floral envelopes (periunth) answering to calyx or to both calyx and corolla, either herbaceous or colored and petal-like (wholly glumaceous in Juncaceæ).

1. Perianth adherent to the whole surface of the ovary.

Flowers diœecious (or rarely perfect), regular.

Aquatics; orules and seeds several or numerous. Hydrocharidacex, 495

Twiners; orules and seeds one or two in each cell. Drosconedces, 517

Flowers perfect; ovules and seeds usually numerous.

Stamens only one or two; flower irregular, gynandrous. Orchidace 2,497 Stamens three.

Anthers introrse, opening transversely. - . Burmaxiaceæ, 496

Anthers introrse or versatile, opening lengthwise. HжModorace£, 512

Anthers extrorse, opening lengthwise. . . . IRIDACE E, 513

Stamens 6; flowers usually on a scape from a bulb. Amaryllidaceæ, 515

2. Perianth adherent only to the base or lower half of the ovary.

Perianth woolly or roughish-mealy; leaves often equitant. HæModoracEæ, 512 Perianth smooth; the leaves grass-like. Stenanthium, etc., in Liliacex, 517

3. Perianth wholly free from the ovary.

Pistils numerous or few in a head or ring. . . . . Alismaceæ, 553

Pistil one, compound (cells or placent:e mostly 3 ).

Perianth not glumaceous or chaffy ; flowers not in dense heads.

Stamens 6 (in Maianthemum 4), similar and perfect.

Scurfy-leaved epiphyte; seeds hairy-tufted. . Broneliaceæ, 511

Marsh herbs ; carpels nearly distinct or separating closed from

the axis ; seed without albumen. Juncagineæ, in NAIA DACE \&, 557

Terrestrial, not rush-like; seeds with albumen.

Perianth of similar divisions or lobes, mostly colored. )

Perianth of 3 foliaceous and green sepals and 3 col- $\}$ Liliace $\approx, 517$ ored withering-persistent petals. Trillium in

Perianth of 3 persistent green sepals, and 3 ephemeral deliquescent petals. 
Stamens 6, dissimilar, or only three with perfect anthers.

Sepals 3, herbaceous; ephemeral petals 3 , unequal.

Periantl tubular, 6-lobed. . . . . P'ONTEDERIACEe, 535

Stamens 3, similar. Moss-like aquatic. . . . Maraced, 537

Perianth wholly glumaceous, of 6 similar divisions. . JuxcaCEE, 539

Perianth partly glumaceous or chaff-like; flowers in very

dense heads. Rush-like or aquatic.

Flowers perfect; inner perianth of three yellow petals;

perfect stamens and plumose sterile filaments each

3 ; pod 1-celled, many-seeded on 3 parietal placenta. I Y RIDACE E, 536

Flowers monœcious or diœcious, whitish-bearded; sta-

mens 4 or 3; pod 2-3-celled, 2-3-seeded. . Eriocaulex, 566

C. Glumaceous Division. Flowers destitute of proper perianth, except sometimes small scalcs or bristles, but covered by scale-like bracts or glumes.

Glume a single scale-like bract with a flower in its axil. . Crreracex, 567 Glumes in pairs, of two sorts.

GraMisex, 623

\section{Class III. CRYPTOGAMIOUS ACROGENS. (See p. 17.)}

Subclass I. PTERIDOPHYTES: with woody fibres and ressels.

Spores of only one kind; spore-cases

Borne beneath shield-shaped scales in a terminal spike; stems naked, sheathed at the nodes. .

- Equisetacem, 675

On the back or margin of fronds circinate in veruation. FillCEs, 678

Bivalvular, in special spikes or panicles ; fronds erect in rernation,

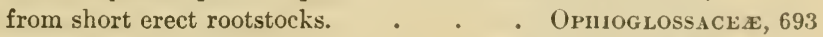

Solitarv in the axils of leaves, 2 - 3-ralved; low long-stemmed moss-

like evergreens; leaves small, in 4-16 rauks. LxCOPODIACE 2,695

Spores of two kinds, large and small; spore-cases

Solitary in the axils of small 4-ranked leaves, or in the bases of

linear radical leaves. - o . - Selaginellacex, 697

Enclosed in peduncled sporocarps; leaves 4-foliolate. MARsiliaces, 700

Sporocarps sessile beneath the stem; small, floating, pinnately

branched, with minute imbricate leaves. . SALVINiACEA, 701

Subclass II. BRYOPHY'TES: with cellular tissue only. [Capsules not operculate, containing spores and usually elaters, in the following Orders.]

Capsule 4-valved, pedicellate; plants leafy-stemmed, rarely thallose.

JUNG ERMANIACE.E, 702

Capsule 2-valved or valveless; plants tliallose.

Thallus without epidermis; capsule with a columella, short-pedicelled or sessile on the thallus.

ANTHOCERotACEN, 726

Capsules borne beneath a pelunculate receptacle. Marchaxticex, 727

Capsules immersed in the thallus or sessile upon it, indehiscent. 


\section{$\triangle B$ BREVIATIONS}

\section{OF THE NAMES OF AUTHORS CITED IN THIS VOLUME.}

Adans. - Adanson, Michel.

Ait.-Aiton, William.

Ait.f.-Aiton, William Townsend.

All. - Allioni, Carlo.

Anders. - Andersson, Nils Johan.

Arn. - Arnott, George A. Walker.

Aust. - Austin, Coe Finch.

Baldw. - Baldwin, William.

Bart. - Barton, William P. C.

Beauv.-Palisot de Beauvois, A. M. F. J.

Benth.-Bentham, George.

Benth. \& Hook. - G. Bentham and J. D. Hooker.

Bernh. - Bernhardi, Johann Jacob.

Bess. - Besser, Wilhelm S. J. G. von.

Bieb. - Bieberstein, F. A. MI. von.

Bigel. - Bigelow, Jacob.

Bisch. - Bischoff, Gottlieb Wilhelm.

Boeckl. - Boeckeler, Otto.

Boiss. - Boissier, Edmond.

Borkh.-Borkhausen, M. B.

Br., R. Br.-Brown, Robert.

Britt. - Britton, Nathaniel Lord.

Carr. - Carrière, Élie Abel.

Carring. - Carrington, Benjamin.

Cass. - Cassini, Henri.

Cav. - Cavanilles, Antonio Jose.

Cerv. - Cervantes, Vicente.

Cham. - Chamisso, Adalbert ron.

Chapm. - Chapman, Alran Wentworth.

Chois. - Choisy, Jacques Denis.

Clayt. - Clayton, John.

Cogn.-Cogniaux, Alfred.

Coult. - Coulter, John Merle.

Darl., Darling. - Darlington, William.

$D C$. - DeCandolle, Augustin Pyramus.

A. DC.-DeCandolle, Alphonse.

Decsne. - Decaisne, Joseph.

Desf.-Desfontaines, Réné Louiche.

Desv. - Desvaux, Nicaise Augustin.
Dicks. - Dickson, James.

Dill. - Dillenius, Johan Jacob.

Dougl. - Douglas, David.

Dufr. - Dufresne, Pierre.

Dumort. - Dumortier, Barthélemy C.

Eat.-Eaton, Amos.

Ehrh. - Ehrhart, Friedrich.

Ell. - Elliott, Stephen.

Endl. - Endlicher, Stephan L.

Esch.-Eschscholtz, J. F.

Fisch. - Fischer, F. E. Ludwig ron.

Foug. - Fougeroux, Auguste Denis.

Forst. - Forster, J. R. and George.

Froel. - Froelich, Joseph Aloys.

Gaertn. - Gaertner, Joseph.

Gaertn.f. - Gaertner, Carl Friedrich.

Gal.-Galeotti, Henri.

Gaud.-Gaudichaud-Beaupre, Charles.

Gey. - Geyer, Charles (Carl Andreas).

Ging. - Gingins de Lassaraz, F. C. J.

Glox.-Gloxin, Benjamin Peter.

Gmel._Gmelin, Samuel Gottlieb.

Gooden.-Goodenough, Samuel.

Grev. - Greville, Robert Kaye.

Griseb._Grisebach, Heinrich R. A.

Gronov. - Gronovius, Jan Fredrik.

Guss. - Gussone, Giovanni.

Hack. - Hackel, Eduard.

Hartm. - Hartman, Carl Johann.

Hassk. - Hasskarl, Justus Carl.

Hausskn. - Haussknecht, Carl.

Haw. - Haworth, Adrian Hardy.

$\Pi B K$. - Humboldt, F. Alexander von,

Aimé Bonpland, and C. S. Kunth.

Hegelm. - Hegelmaier, Friedrich.

Herb. - Herbert, William.

Hochst. - Hochstetter, Christian F.

Hoffm. - Hoffman, Georg Franz.

Holl.-Hollick, Arthur. 
Mook. - Hooker, William Jackson.

Hook.f. - Hooker, Joseph Dalton.

Hornem. - Hornemann, Jens Wilken.

IIuds. - Hudson, William.

Huebn. - Huebener, J. W. P.

Jacq. - Jacquin, Nicolaus Joseph.

Juss. - Jussieu, Antoine Laurent.

A. Juss. - Jussieu, Adrien de.

L., Linn. - Linnæus, Carolus, or Carl von Linné.

L. $f$. - Linné, Carl von (the son).

L'Her. - L'Heritier de Brutelle, C. L.

Lag. - Lagasca, Mariano.

Lam. - Lamarck, J. B. A. P. Monnet.

Ledeb. - Ledebour, Carl F. von.

Lehm. - Lehmann, J. G. C.

Less. - Lessing, Christian Friedrich.

Light. — Lightfoot, John.

Lindb. - Lindberg, Sextus Otto.

Lindenb. - Lindenberg, Johann B. W.

Lindl. - Lindley, John.

Loisel. - Loiseleur-Deslongchamps, J.

Lour. - Loureiro, Juan.

[L. A.

Marsh. - Marshall, Humphrey.

Mart. - Martens, Martin.

Maxim. - Maximowicz, Carl Johann.

Medic. - Medicus, Friedrich Casimir.

Meisn. - Meisner, Carl Friedrich.

Mey. - Meyer, Ernst (Heinrich F.).

Mich. - Micheli, Pier' Autouio.

Michx. - Michaux, André.

Mich.x. f. - Michaux, François André.

Mill. - Miller, Philip.

Mitch. - Mitchell, J.

Mrtt. - Mitten, William.

Mont. - Montagne, (J. F.) Camille.

Moq. - Moquin-Tandon, Alfred.

Nuell. - Mueller, Jean (of Aargau).

Muhl. - Muhlenberg, IIenry (H. Ernst).

Murr. - Murray, Johann Andreas.

Neck. - Necker, Noel Joseph de.

Nutt. - Nuttall, Thomas.

Pall. - Pallas, Peter Simon.

Pers. - Persoon, Christian Hendrik.

Planch.-Planchon, Jules Émile.

Poir. - Poiret, Jean Louis Marie.

Poll. - Pollich, Johann Adain.

R. \& S. - Roemer, J. J., and Joseph August Schultes.

Raf.-Rafinesque-Schmaltz, C. S.

Reichenb. - Reichenbach, II. G. L.

Richards. - Richardson, Johur.
Roem. - Roemer, Johann Jacob.

Rostk. - Rostkovius, F. W. G.

Rottb. - Rottboell, C'hristen Fries.

St. Ilil. - St. Hilaire, Auguste de.

Salisb. - Salisbury, Richard Anthony.

Sartw. - Sartwell, llenry I'.

Sav. - Savi, Gaetano.

Schlecht. - Schlechtendal, D. F. L. von.

Schleich.-Schleicher, J. C.

Schleid. - Schleiden, Matthias Jacob.

Schrad. - Schrader, Heinrich A.

Schreb. - Schreber, Johann C. D.

Schum. - Schumacher, Christian F.

Schwein. - Schweinitz, Lewis David de.

Scop. - Scopoli, Johann Anton.

Scribn. - Scribner, F. Lamson.

Shuttlw. - Shuttleworth, Robert.

Sibth. - Sibthorp, John.

Sieb. \&. Zucc. - Siebold, P. F, von, and

$$
\text { J. G. Zuccarini. }
$$

Spreng. - Sprengel, Kurt.

Steph. - Stephani, F.

Steud. - Steudel, Einst Gottlieb.

Sulliv. - Sullivant, William Starling.

Tayl. - Taylor, Thomas.

Thuill. - Thuillier, Jean Louis.

Thunb. - Thunberg, Carl Peter.

Thurb. - Thurber, George.

Torr. - Torrey, John.

Tourn. - Tournefort, Joseph Pitton de.

Tratt. - Trattenick, Leopold.

Tuckerm. - Tuckerman, Edward.

Turcz. - Turczaninow, Nicolaus.

Underw. - Underwood, Lucien MI.

Vaill. - Vaillant, Sébastien.

Vent. - Ventenat, Etienne Pierre.

Vill. - Villars, Dominique.

Wahl. - Wahlenberg, George.

Wahlb. - Wahlberg, Pelır Fredrik.

Walp. - Walpers, Wilhelm Gerhard.

Walt. - Walter, Thomas.

Wang. - Wangenheim, F. A. J. von.

IVeb. - Weber, Friellich.

Wigg. - Wiggers, F. H.

Willd. - Willdenow, Carl Ludwig.

Wils. - Wilson, William.

Wimm. - Wimmer, Friedrich.

With. - Withering, William.

Wormsk, - Wormskiold, M. von.

Wr. (Eat. \& Wr.) - Wright, John.

Wulf. - Wulfen, Franz Xaver. 


\section{SIGNS USED IN THIS WORK.}

', ," . The sign of degrees $\left({ }^{\circ}\right)$ is used for feet; of minutes ('), for inches; of seconds ("), for lines, - the line being the twelfth part of an inch, and very nearly equivalent to two millimetres.

$\mu$. In microscopic measurements, the conventional sign for the micromillimetre or the one-thousandth part of a millimetre = one two-thousandth part of a line.

\& Bearing only stamens or antheridia.

Pistillate or bearing archegonia.

? A mark of doubt.

! A mark of affirmation or authentication.

Figures or words separated by a short dash $(-)$ indicate the extremes of variation, as “ $5-10$ " long, few-many-flowered," i. e. varying from 5 to 10 lines in length, and with from few to many flowers. 


\section{B O T A N Y}

OF THE

\section{NOR'THERN UNITED STATES.}

\section{SERIES I.}

\section{PHÆNOGAMOUS OR FLOWERING PLANTS.}

VEgETABLES bearing proper flowers, that is, having stamens and pistils, and producing seeds, which contain an embryo.

\section{Class I. DICOTYledonOUS or EXOGENOUS PLANTS.}

Stems formed of bark, wood, and pith; the wood forming a layer between the other two, increasing, when the stem continues from year to year, by the annual addition of a new layer to the outside, next the bark. Leaves nettedveined. Embryo with a pair of opposite cotyledons, or rarely several in a whorl. Flowers having their parts usually in fives or fours.

\section{Subclass I. ANGIOSPÉRME.}

Pistil consisting of a closed ovary, which contains the ovules and forms the fruit. Cotyledons only two. 


\section{Division I. POLYPETALOUS EXOGENOUS PLANTS.}

Floral envelopes consisting of both calyx and corolla; the petals not united with each other. (Several genera or species belonging to Polypetalous Orders are destitute of petals, or have them more or less united.)

\section{Order 1. RANUNCULÀCEA. (Crowfoot Family.)}

Herbs or some woody plants, with a colorless and usually acrid juice, polypetalous, or apetalous with the calyx often colored like a corolla, hypogynous; the sepals, petals, numerous stamens, and many or few (rarely single) pistils all distinct and unconnected. - Flowers regular or irregular. Sepals $3-15$. Petals $3-15$, or wanting. Stamens indefinite, rarely few. Fruits either dry pods, or seed-like (achenes), or berries. Seeds anatropous (when solitary and suspended the rhaphe dorsal), with hard albumen and a ninute embryo. - Leaves often dissected, their stalks dilated at the base, sometimes with stipule-like appendages. (A large family, including some acrid-narcotic poisons.)

\section{Synopsis of the Genera.}

Tribe I. CLEMATIDEAE. Sepals normally 4, petal-like, valvate in the bud, or with the edges bent inward. Petals none, or small. Achenes numerous, tailed with the feathery or hairy styles. Seed suspended. - Leaves all opposite.

1. Clematis. Climbing hy the leafstalks, or erect herbs.

Tribe II. ANEMONEA. Sepals 3-20, often petal-like, imbricated in the bud. Stamens mostly numerous. Achenes numerous or several, in a head or spike.-Herbs, never climbing; leaves alternate, or radical, the upper sometimes opposite or whorler.

* Petals none (rarely some staminodia). Seed suspended.

- All but the lower leaves opposite or whorled Peduncles 1-flowered.

2. Anemone. Involucre leaf-like, remote from the flower. Leaves compound or dissected. Pistils very many.

3. Hepatica. Involucre close to the flower, of 3 oval bracts, calyx-like. Leaves radical, simple and lobed. Pistils several.

4. Anemonella. Stigma termiual, broad and flat. Radical leaves and involucre compound. Peduncles umbellate. Achenes $4-15$, many-ribbed.

++ Leaves alternate, compound. Flowers panicled, often diœcious.

5. Thalictrum. Sepals usually 4, petal-like or greenish. Achenes few.

** Petals none. Sepals $3-5$, caducous. Seed erert. Leaves alternate.

6. Trautvetteria. Achenes numerous, inflated, 4-angled. Flowers corymbose. Filaments white, clavate.

*** Petals evident. Sepals usually 5. Achenes many.

7. Adonis. Sepals and petals $(5-16$, crimson or scarlet) flat, unappendaged. Seed suspendled.

8. Myosurus. Sepals spurred. Petals 5, white. Achenes in a long spike. Scapes 1-flowered. Seed suspended.

9. Ranumculus. Petals 5, yellow or white, with a scale or gland at base. Achenes capitate. Seed erect. 
Tribe III. HELLE BOREA. Sepals inbrieated in the bud, rarcly persistent, petallike. l'etals often neetariferous or reduced to staminolia or none. Pouls (follieles) or berries (in n. 20,21) few, rarely single, few - many-seeded. - Leaves alternate.

* Ovules and commonly seels more than one pair. Ilerbs.

- Flowers regular, not racemose. P'etals inconsujucuous nectaries or slender or none. Sepals tarlily deciduons.

10. Isopyrum. Petals none. Sepals broad, white. Pods few. Leaves compound.

11. Caltha. Petals none. Sepals broad, yellow. Leaves kidney-shapred, undiviled.

12. Trollius. Petals 5-20, narrow, pitted above the base. Pods sessile. Leaves palmately lobed.

13. Coptis. Petals 5-6, small, hollowed at apex, white. Porls long-stalked. Leaves radical, trifoliolate.

14. Helleborus. Petals small, tubular, 2-lipped. Sepals 5, broad, persistent and turning green. Pods sessile.

15. Eranthis. Petals small 2-lipped nectarics. Sepals 5-8, narrow, decidnous. Flower solitary, involucrate.

$$
\text { + + Sepals and large spur-shaped petals regular, euch } 5 \text {. }
$$

16. Aquilegia. Pistils 5 , with slender styles. Leaves teruately compound.

$$
+++ \text { Flowers unsymmetrical and irregrular. Sepals } 5 .
$$

17. Delphinium. Ulper sepal spurred. Petals 4, of two forms; the upper pair with long spurs, enclosed in the spur of the ealyx.

18. Aconitum. Upper sepal hooded, covering the two long-clawed small petals.

++++ Flowers regular, racemose. Sepals caducous. Petals very small, stamen-like, or none. Leares decompound.

19. Cimicifuga. Fluwers in long often paniculate racemes. Pistils $1-8$, becoming many-seeded pods.

20. Actaea. Flowers in a single short raceme. Pistil single, forming a many-seeded berry.

* Ovules a single pair. Flowers regular. Ronts yellow and bitter.

21. Hydrastis. Flowers solitary. Sepals 3, petal-like, eaducous. Petals none. Stamens numerous. Pistils several, becoming 2-seeded herries. Leaves simple, lobed.

22. Xanthorrhiza. Flowers in compound ricemes. Sepals 5. Petals 5, small, 2-lobed, with claws. Stamens 5-10. Pods 1-seeded. Shrub with pinnate leaves.

\section{CLÉMATIS, L. Virgix's-Bower.}

Sepals 4 , or rarely more, colored, the valvate margins turned inward in the bud. Petals none or small. Achenes numerous in a head, hearing the persistent styles as naked, hairy, or plumose tails. - I'erenuial herbs or vines, mostly a little woody, and climbing hy the bending or clasping of the leafstalks, rarely low and ereet. Leaves opposite. (K゙ $\lambda \mu \alpha \tau i$ s, a name of Dioscoriles for a climbing plant with long and lithe branches.)

§ 1. FLÁMMULA. Flouers eymose-paniculate, rather small, in our species dixcious. Sepals petaloid, whitish, spreading, thin. P'ctals none. Anthers short, blunt.

1. C. Virginiana, I. (Commox Virgis's-Bower.) Smooth; leaves bearing 3 orate acute leaflets, which are cut or lobed, and somewhat heartshaped at the base; tails of the fruit plumose. - River-banks, etc., common , climbing over slirubs. July, August.

2. C. ligusticifolia, Nutt. Very similar, hụt the leaves 5-foliolate or qninate-ternate. - Long l'ine, Neb., and west to the Pacifie. 
§ 2. VIÓRNA. Flowers large, solitary on long peduncles, usually nodding. Sepals thick, erect and connivent at base, mostly dull purple. Petals none. Anthers linear.

- Stens climbing; leaves pinnate; calyx (and foliage) glabrous or puberulent.

3. C. Viórna, L. (Leather-Flower.) Calyx ovate aud at length bellshaped; the purplish sepals ( $\mathrm{I}^{\prime}$ long) very thick and leathery, wholly connivent or only the tips recurved; long tails of the fruit very plumose; leaflets $3-7$, ovate or oblong, sometimes slightly cordate, $2-3$-lobed or entire; uppermost leaves often simple. - Rich soil, Penn. to Mo., and southward. May-Aug.

4. C. Pitcheri, Torr. \& Gray. Calyx bell-shaped; the dull purplish sepals with narrow and slightly margined recurved points; tails of the fruit filiform and naked or shortly villous; leaflets 3-9, ovate or somewhat cordate, entire or 3-lobed, much reticulated; uppermost leaves often simple. - S. Ind. to Kan., and Tex. June.

5. C. críspa, L. Calyx cylindraceous below, the upper half of the bluishpurple sepals ( $1-2^{\prime}$ long) dilated and widely spreading, with broad and wavy thin margins; tails of the fruit silky or glabrate; leaflets 5-9, thin, varying from ovate or cordate to lanceolate, entire or 3-5-parted. (C. cylindrica, Sims.) - Va. near Norfolk, and southward. May-Aug.

+ + Low and erect, mostly simple; flowers solitary, terminal; leaves sessile or nearly so, undivided, strongly reticulated.

6. C. ochroleùca, Ait. Leaves ovate, entire or sometimes 3-lobed, silky beneath; perluncles long; tails of the fruit very plumose.-Copses, Long Island to Penn. and Ga.; rare. May.

7. C. Fremónti, Watson. Leaves crowded, thick, often coarsely toothed, sparingly villous-tomentose; peduncles very short; tails villous or glabrate, not plumose. - Mo. and Kan.

§3. A'TRAGENE. Some of the outer filaments enlarged and more or less petaloid; peduncles bearing single large flowers; the thin sepals widely spreading.

8. C. verticillàris, DC. Woody-stemmed climber, almost glabrous; leaves trifoliolate, with slender common and partial petioles; leaflets ovate or slightly heart-shaped, pointed, entire, or sparingly toothed or lobed; flower bluish-purple, 2-3' across; tails of the fruit plumose- - Rocky places in mountainous districts, Maine and W. New Eng. to Va., Minn., and northwestward; rare. May. - A pair of leares with a peduncle between them, developed in spring from each of the opposite buds, gives the appearance of a whorl, whence the specific name.

\section{A NEMÒNE, Tourn. ANÉmone. Wixd-Flower.}

Sepals few or many, petal-like. Petals none, or in n. 1 resembling abortive stamens. Achenes pointed or tailed, flattened, not ribbed. Seed suspended. - Perennial herbs with radical leaves; those of the stem 2 or 3 together, opposite or whorled, and forming an involucre remote from the flower; peduncles 1-flowered, solitary or umbellate. (The ancient Greek and Latin name, from á $\nu \in \mu$ ó $\omega$, to be shaken by the wind.) 
§ 1. PULSATILLA. Carpels numerous in a head, with long hairy styles which in fiuit form feathery tails, as in Clematis; flouer large, usually with some minute or indistinct gland-like abortive stamens ansuering to petals.

1. A. pàtens, L., var. Nuttalliàna, Gray. (I'ASQLE-F Lower.) Villous with long silky hairs; peduncle solitary; flower erect, developed hefore the leaves, which are ternately divided, the lateral divisions 2-jarted, the middle one stalked and 3-parted, the segments deeply once or twice cleft into narrowly linear and acute lohes; lobes of the sessile involucre like those of the leaves, at the base all united into a shallow cup; sepals 5-7, purplish or whitish ( $1-1 \frac{1}{2}$ ' long), sprearling when in full anthesis. - I'rairies, Ill. and Mo., thence northward and westward. March $-\Lambda$ pril. $-\Lambda$ span high. Tail of carpels $2^{\prime}$ long. (Eu., Siberia.)

5. ANEMONE proper. Styles short, not plumose. Staminodia none.

* Achenes densely long-uoolly, compressed; involucre far below the flower. - Stem single, from a small tuber; sepals 10-20; style filiform.

2. A. Caroliniana, Walt. Stem $3-6^{\prime}$ high; root-leaves once or twice 3-parted or cleft; involucre 3-parted, its wedge-shaped divisions 3-cleft; sepals 10-20, oblong-linear, purple or whitish; head of fruit oblong. - Ill. to Neb. and southward. May.

+ + Stems several; sepals 5-8; style filiform.

3. A. parviflora, Michx. Stem 3-12' high from a slender rootstock, 1-flowered; root-leaves 3-parted, their broadly wedge-shaped divisions crenateincised or lobed; involucre 2-3-leaved; sepals 5 or 6, oval, white; head of fruit globular. - Lake Superior, northwarl and westward. May, June.

4. A. multífida, Poir. Stems from a branching caudex, silky-hairy (6-12' high); principal involucre 2-3-leaved, bearing one naked and one or two 2-leaved peduncles; leaves of the involucre short-petioled, similar to the root-leaves, twice or thrice 3-parted and cleft, their divisions linear; sepals obtuse, red, sometimes greenish-yellow or whitish; head of fruit spherical or oval. - Rocks, etc., N. E. Maine to Lake Superior, north and westward; rare. June.

+ + + Taller, commonly branching above or producing tuo or more peduncles; involucral leaves long-petioled; sepals $5-8$, silky or douny beneath ( $4-6$ "long), oval or oblong; style subulate.

5. A. cylíndrica, Gray. (Loxg-freiten A.) Slender $\left(2^{\circ}\right.$ high), silkypubescent; flowers 2-6, on very long upright naked peduncles; involucral leaves twice or thrice as many as the perluncles, 3-divided; their divisions wedge-lanceolute, the lateral 2-parted, the middle 3-cleft; lobes cut and toothed at the apex; sepals 5, rather oltuse, greenish-white; head of fruit cylindrical (1' long). - Dry woods, N. Eng. to Mo., and northwestward. May. - Peduncles $7-12^{\prime}$ long, all from the same iurolucre and naked throughout, or one involucellate in the middle.

6. A. Virginiàna, I. More loosely pubescent or glabrate; involucral leaves 3, 3-parted; their divisions orate-lanceolate, pointed, mot-serrate, the lateral 2-parted, the middle 3-cleft; peduncles elongated, the earliest naked, the others with a 2-leaved involucel at the middle, repeatedly proliferous; sepals 5 , 
acute, greenish (in one variety white and obtuse); head of fruit oval or oblong. - Woods and meadows; common. June-August. - Plant 2-3 $3^{\circ}$ high; the upright peduncles $6-12^{\prime}$ long.

* Achenes naked, orbicular, compressed, wing-margined; sepals 5, obovate; incolucre sessile.

7. A. Pennsylvánica, L. Hairy, rather low; primary involucre 3leaved, bearing a naked peduncle, and soon a pair of branches or peduncles with a 2-leaved involucre at the middle, which branch similarly in turn; their leaves broally wedge-shaped, 3-cleft, cut and toothed; radical leaves 5-7. parted or cleft; sepals white $\left(6-9^{\prime \prime}\right.$ long) ; head of fruit spherical. - W. New Eng. to Penn., Ill., and northwestward. June-Aug.

* * * Achenes rather few, nearly naked, ovate-oblong; stems slender, 1-flowered; leares radical.

8. A. nemorósa, L. (Wixn-flower. Woon A.) Low, smootlish; stem perfectly simple, from a filiform rootstock ; involucre of 3 long-petiolerl trifoliolate leaves, their leaflets wedge-shaped or oblong, and toothed or cut, or the lateral ones (var. QuiNQUEFOLiA) 2-parted; a similar radical leaf in sterile plants solitary from the rootstock; peduncle not longer than the involucre; sepals $4-7$, oval, white, sometimes blue, or tinged with purple outside; carpels only 15-20, ollong, with a hooked beak. - Margin of woods. April, May.A delicate vernal species; the flower $l^{\prime}$ broad. (Eu.)

9. A. nudicaùlis, Gray. Glabrous, rootstock filiform; radical leares reniform, 3-parted, the divisions broadly cuneate with rounded crenate-incised or -lobed summit; involucre of a single similar petiolate leaf or wanting; achenes glabrous, tipped with a slender-subulate hooked style. - North shore of Lake Superior near Sand Bay, Minn., in bogs. (Joseph C.Jones.) Imperfectly known.

\section{H E P Á T I A, I)ill. Liver-leaf. Hepatica.}

Involucre simple and 3-leaved, very close to the flower, so as to resemble a calyx; otherwise as in Anemone. - Leares all radical, heart-shaped and 3-lobed, thickish and persistent through the winter, the new ones appearing later than the flowers, which hre single, on hairy scapes. (Name from a fancied resemblance to the liver in the shape of the leaves.)

1. H. tríloba, Chaix. Leaves with 3 ovate obtuse or rounded lobes; those of the involucre also obtuse ; sepals 6-12, blue, purplish, or nearly white; achenes several, in a small loose head, ovate-oblong, pointed, hairy. - Woods; common from the Atlantic to Mo., Minn., and northward, flowering soon after the snow leaves the ground in spring. (Eu.)

2. H. acutíloba, I)C. Leares with 3 ovate and pointed lobes, or sometimes 5-lobed; those of the involucre acute or acutish. - Passes into the other and has the same range.

\section{ANEMONÉLA, Spach.}

Involucre compound, at the base of an umbel of flowers. Sepals 5-10, white and conspicuous. Petals none. Achenes 4-15, ovoid, terete, strongly 8-10-ribbed, sessile. Stigma terminal, broad and depressed. - Low glabrous perennial; leaves all radical, compound. 
1. A. thalictroldes, Spach. (RUE-Asesose.) Stem and slender petiole of radical leaf (a span high) rising from a cluster of thickened tuberous roots; leaves 2-3-ternately compound; leaflets roundish, somewhat 3-lobed at the end, eordate at the base, long-petiolulate, those of the 2-3-leaved 1-2ternate involuce similar; flowers several in au umbel; sepals oval ( $\frac{1}{2}$ long, rarely pinkish), not early deciduous. (Thalictrum anemonoides, Michx.) Woods, common, flowering in early spring with Anemone nemorosit, and considerably resembling it. Rarely the sepals are 3-lubed like the leaflets.

\section{THALÍCTRUM, Tourn. Meadow-Rue.}

Sepals $4-5$, petal-like or greenish, usually caducous. l'etals none. Achenes 4-15, grooved or ribbed, or else inflated. Stigma unilateral. Seed suspended. - Perennials, with alternate 2-3-ternately compound leares, the divisions and the leaflets stalked; petioles dilated at base. Flowers in corymbs or panicles, often polygamous or diøecious. (Derivation obscure.)

* Flowers diccious or sometimes polygamous, in ample panicles; filaments slender; stigmas elongated, linear or subulate; achenes sessile or short-stipilate, ovoid, pointed, strongly several-angled and grooved.

1. T. diòicum, L. (EArLy Mkinow-Rev.) Smooth and pale or glaucous, $1-2^{\circ}$ high; leaves $(2-3)$ all with general petioles; leaflets drooping, rounded and 3-7-lobed; flowers purplish and greenish, dicecious; the yellowish anthers linear, mucronate, clrooping on fine capillary tilanents. Rocky woods, etc.; common. A pril, May.

2. T. polýgamum, Muhl. (T.ıL M.) Smooth, wot glandular, $4-80$ high; stem-leaves sessile; leaflets rather firm, roundish to oblong, commonly with mucronate lobes or tips, sometimes puberulent beneath; panicles very compound; flowers white, the fertile ones with some stamens; anthers not drooping, small, obloug, blunt, the mostly white filaments decidedly thickened upwards. (T. Cornuti, Man., not L.) - Wet meadows and along rivulets, $N$. Eng. to Ohio and southward; common. July -Sept.

3. T. purpuráscens, I. (Perplisi M.) Stem $\left(2-4^{\circ}\right.$ high) usually purplish; stem-leaves sessile or nearly so; leaflets more veiny and reticulated beneath, with or without gland-tipped or glandless hairs or waxy atoms; panieles compound; flowers (sepals, filaments, etc.) greenish and purplish, dicecious; anthers liuear or oblong-linear, mucronulate, drooping on capillary filaments occasionally broadened at the summit. - Dry uplands and rocky hills, S. New Eng. to Minn., and southward. May, June.

* * Flowers all perfect, corymbed; the filaments strongly club-shaped or inflated under the small and short anther; stigma short; achenes gibbons, long-stipitate.

4. T. clavàtum, DC. Size and appearance of 11.1 ; leaves unly twice ternate; flowers white, fewer; achenes 5-10, flat, somewhat erescent-shaped, tapering into the slender stipe. - Mountains of Va. and southward. Jume.

\section{TRAUTVETTERIA, Fiscls. Mey. False Bugane.}

Sepals $3-5$, usually 4 , concave, petal-like, very caducous. Petals none. Achenes numerous, eapitate, membranaceous, compressed-4-angled and inflated. Seed erect. $-\Lambda$ perennial herb, with alternate palmately-luhed leaves, aud corymbose white flowers. (For Prof. Trantictter, a Russian botauist.) 
1. T. palmàta, Fisch. \& Mey. Stems $2-3^{\circ}$ high; root-leaves large, 5-11-lobed, the lobes toothed and cut. - Moist ground along streamlets, Mu. to S. Ind., and south to Ga.

\section{A D ÒNIS, Dill.}

Sepals and petals $(5-16)$ flat, unappendaged, deciduous. Achenes numerous, in a head, rugose-reticulated. Seed suspended. - Herbs with finely dissected alternate leaves and showy flowers. ("A $\delta \omega \nu$ เs, a favorite of Venus, after his death changed into a flower.)

A. autuminals, L. A low leafy annual, with scarlet or crimson flowers, darker in the centre. - Sparingly naturalized from Europe.

\section{IM Y O S Ù U S, Dill. Mouse-tail.}

Sepals 5, spurred at the base. Petals 5, small and narrow, raised on a slender claw, at the summit of which is a nectariferous hollow. Stamens 5-20. Achenes numerous, somewhat 3-sided, crowded on a very long and slender spike-like receptacle (whence the name, from $\mu \hat{v} s$, a mouse, and oùpá, a tail), the seed suspended. - Little annuals, with tufted narrowly linear-spatulate root-leaves, and naked l-flowered scapes. Flowers small, greenish.

1. I. mínimus, L. Fruiting spike 1-2' long; achenes quadrate, blunt. - Alluvial ground, 1ll. and Ky., thence south and west. (Eu.)

\section{RANÚ N CULUS, Tourn. Crowfoot. Buttercup.}

Sepals 5. I'etals 5, flat, with a little pit or scale at the base inside. Achenes numerous, in a head, mostly flattened, pointed; the seed erect. - Annuals or perennials; stem-leaves alternate. Flowers solitary or somewhat corymbed, yellow, rarely white. (Sepals and petals rarely only 3, the latter often more than 5. Stamens occasionally few.) - (A Latin name for a little frog; applied by Pliny to these plants, the aquatic species growing where frogs abound.)

R. Ficaria, L. (representing the $\S$ Ficaria), which has tuberous-thickened roots, Caltha-like leaves, and scape-like peduncles bearing a 3 -sepalous and 8-9-petalous yellow flower, has been found as an escape from gardens about New York and Ihiladelphia.

§ 1. BATRÁCHIUM. Petals with a spot or naked pit at base, white, or only the claw yellow; achenes marginless, transversely urinkled; aquatic or subaquatic perennials, with the immersed foliage repeatedly dissected (mostly by threes) into capillary divisions; peduncles 1-flowered, opposite the leaves.

$$
\text { * Receptacle hairy. }
$$

1. R. circinàtus, Sibth. (Stiff WAter-Crowfoot.) Leaves all under water and sessile, with broad conspicuous stipules, the divisions and subdivisions short, spreadiug in one roundish plane, rigid, not collapsing when withdraun from the water. (R. divaricatus, Man., not Schrank.) - Ponds and slow streams, Maine and Vt., to Iowa, north and westward, much rarer than the next. June-Aug. (Eu.)

2. R. aquátilis, L., var. trichophýllus, Gray. (Common White WATER-CROWFoot.) Leaves all under water and mostly petioled, their capillary divisions and subdivisions rather long and soft, usually collapsing more or less when withdrawn from the water; petiole rather narrowly dilated. - Com- 
mon, especially in slow-flowing waters, the eastern form with more soft and flaccid leaves. June-Aug. (Eu.)

Var. cæspitosus, I)C. $\Lambda$ dwarf terrestrial form, rooting at the nodes, the small leaves somewhat fleshy, with broader rigid divisious. - S. 111 . (Schneck), and westward.

* * Receptacle glabrous; no submersed leaves.

R. HEDERACELs, L. Rooting freely in shallow water; leaves all reniform, angulate-lobed. - Fresh-water marshes at Norfolk, Va. (Nat. from Eu.)

§2. HALÒDES. Petals yellow, with nectariferous pit and scale; carpels thin-walled, striate, in an oblong head; scapose, spreading by runners.

3. R. Cymbalària, Pursh. (Sea-sine Crowfoot.) Glabrous; scapes 1-6' high, 1-7-flowered; leaves clustered at the root and on the juints of the long rooting rumners, roundish-heart-shaped or kidney-shaped, crenate, rather fleshy, long-petioled; petals 5-8. - Sandy shores, from New Jersey northward, and along the Great Lakes to Ill., Kan. and westward; also at salt springs. June - Aug.

§3. RANUNCULUS proper. Petals with a little scale at the base, yellow; achenes nerveless.

* Achenes smooth; mostly perennial.

- Aquatic; immersed leaves filiformly dissected, as in § Batrachium.

4. R. multífidus, Pursh. (Yellow Water-Crowfoot.) Stems floating or inmersed, with the leaves all repeatedly 3 -forked into long filiform divisions, or sometimes creeping in the mud (perennial by rooting from the nodes, if at all); emersed leaves with shorter and linear or wedge-shaped divisions, or else kidney-shaped and sparingly lobed or toothed; petals 5-8, deep bright yellow, 4-6" long, much larger than the calyx; carpels in a round head, pointed with a straight beak. - E. New Eng. to S. Penn., Mo., and northward. May -July. - Out of water it is often pubescent, especially in

Var. terréstris, Gray. Stem rooting in the mud or ascending from the base; leaves all smaller, coarsely dissected, round-reniform in outline; flowers and fruit twice or thrice smaller. $-\mathrm{N}$. Olio to N. Ill., Minn., and westward.

+ + Terrestrial but grouing in very wet places, glabrous or nearly so; leaves entire or barely toothed, all or else all but the lowest lanceolate or linear; carpels forming a globular head. (SPEARWORT.)

5. R. ámbigens, Watson. (Water Pluntaix Spearwort.) Stems ascending $\left(1-2^{\circ}\right.$ high), often rooting from the lower joints; leaves lanceolate or the lowest oblong, mostly denticulate $\left(3-5^{\prime}\right.$ long), contracted into a margined half-clasping petiole; petals $5-7$, bright yellow, oblong $\left(2-3^{\prime \prime}\right.$ long); carpels flattened, large ( $1^{\prime \prime}$ long), pointed with a long narrow-subulate beak. (R. alismafolius, Man., not Gey.) - N. Eng. to Ont., Minu. and southwarl ; common, especially at the north. June-Aug.

6. R. Flámmula, L. (Smallkr SPearwort.) Stem reclining or ascending, rooting below, leaves lanceolate or linear, or the lowest ovateoblong to lanceolate, entire or nearly so, mostly petioled $\left(1-2^{\prime}\right.$ long $)$, petals 5-7, much longer than the calyx, bright yellow, carpels small, flattish but turgid, mucronate with a short abrupt point. - Only a small form (var. IxTER- 
MÈDILs) met with in this country (shore of L. Ontario, and northward), a span high, with flowers $3-5^{\prime \prime}$ in diameter, passing into

Var. réptans, E. Meyer. (CReEPixg S.) Small, slender, the filiform creeping stems rooting at all the joints; leaves linear, spatulate, or oblong $\left(\frac{1}{4}-1\right.$ ' long); flowers small. — Gravelly or sandy banks; Newf. to Penn., north and westward. June-Sept. (Eu.)

7. R. oblongifòlius, Ell. Lsually annual; stem erect or ascending, often pubescent below, slender $\left(1-2^{\circ}\right.$ high), diffustly branched above and many-flowered; leates serrate or denticulate, lower long-petioled, ovate or oblong ( $\frac{1}{2}-1 \frac{1^{\prime}}{2}$ long), uppermost linear; flowers $3-5^{\prime \prime}$ broad ; petals 5 , bright yellow, $1-3^{\prime \prime}$ long; carpels minute, almost globular, the small style deciduous. - Wet prairies, Ill., Mo., and in S. States. June.

8. R. pusíllus, Poir. Stem ascending, weak, loosely branching $\left(6-18^{\prime}\right.$ long) ; leares entire or obscurely denticulate, the lowest round-ovate or heartshaped ( $\frac{1}{2}^{\prime}$ long), long-petioled, the upper oblong or lanceolate (1-1 $\frac{1}{2}^{\prime}$ long); flowers very small; petals $1-5$, yellowish; stamens $3-10$; carpels very turgid, smooth or slightly papillose, tipped with a minute sessile stigma. - Wet places, S. New York, and southward along the coast. June- $\mathrm{Aug}$.

+++ Terrestrial, but often in uet places; leaves mostly cleft or divided. + Root-leaves not divided to the very base; achenes maryinless.

9. R. affinis, R. Br. Somewhat hairy or glabrous; low or slender, $1^{\circ}$ high or less; leares pedately cleft, the cauline with linear or narrow oblanceolate divisions; petals light yellow, $3-4^{\prime \prime}$ long or smaller; heads oblong; achenes turgid, with small and mostly recurved style, pubescent or glabrous. - And var. validus, Gray, stouter and with more fleshy leaves, the lower mostly undivided and roundish, cordate, truncate or cuneate at base, coarsely crenate or more or less cleft. - Minn., Iowa, north and westward.

10. R. rhomboídeus, Goldie. Low $\left(3-8^{\prime}\right.$ high), hairy; root-leares roundish or rhombic-orate, rarely subcordate, toothed or crenate; lowest stemleaves similar or 3-5-lobed, the upper 3-5-parted, almost sessile, the lobes linear; carpels orbicular with a minute beak, in a globose heal; petals large, deep yellow. - Prairies, Mich. to N. Ill., Minn., and northward. A pril, May.

11. R. abortivus, L. (Srall-flowered C.) Biennial, glabrous, branching, $6^{\prime}-2^{\circ}$ higll; primary root-leaves round heart-shaped or kidney-form, barely crenate, the succeeding often 3-lobed or 3-parted; those of the stem and branches 3-5-parted or divided, subsessile, the divisions oblong or narrowly wedge-form, mostly toothed; head globose; carpels mucronate, with a minute curred beak; petals pale yellow, shorter than the small reflexed calyx. - Shady hillsides and along brooks, common. April-June.

Var. micránthus, Gray. Pubescent, roots often fusiform-thickened; root-leares seldom at all heart-shaped, some 3-parted or 3-divided; peduncles more slender and carpels fewer. - E. Mass. to 1ll., Minn., and westward.

12. R. sceleràtus, L. (Cursed C.) Annual, glabrous; root-leaves 3-lobed, rounded; lower stem-leaves 3-parted, the lobes obtusely cut and toothed, the uppermost almost sessile, with the lobes oblong-linear and nearly entire; carpels barely mucronulate, very numerous, in oblong or cylindrical 
heads; petals scarcely exceeding the calyx. - Wet ditches; appearing as if introduced. June-Aug. - Stem thick and hollow, $1^{\circ}$ high; juice acrid and blistering; leares thickish; flowers small, pale yelluw. (ku.)

+ + Leares variously cleft or diviled; achenes in globular heads (exe pt n. 17), compressed, with an evident firm margin; hirsute or pubescent.

$=A$ chenes with long recurved beak; root-leaves rarely divided.

13. R. recurvàtus, Poir. (1оокг C.) Hirsute, $1-2^{\circ}$ high ; leares of the root and stem nearly alike, long-petioled, deeply 3 -cleft, large; the lohes broadly wedge-shaped, 2-3-cleft, cut and toothed toward the apex; petals shorter than the reflexed calyx, pale. - Woods, common. May, June.

$==$ Style long and attenuate, stigmatose at the tip, persistent or the upper part usually deciduous; early root-leures only 3-parted, the luter 3-5-foliolute; petals bright yellow.

14. R. fasciculàris, Mulll. (E.ırLy C.) Low, ascendiug, 5-9' high, pubescent with close-pressed silky hairs; root a cluster of thickened fleshy fibres; radical leaves appearing pinnate, the long-stalked terminal division remote from the sessile lateral ones, itself 3 -5-clivided or parted and 3-5-cleft, the lobes oblong or linear; petals often 6 or 7 , spatulate-ollong, twice the leugth of the spreading calyx; carpels scurcely margined, tipped with a slender straight or rather curved beak. - Iry or moist hills. April, May.

15. R. septentrionàlis, P'oir. Low, hairy or nearly glal,rous; stems ascending, or in wet ground some of them procumbent or forming long rumers; leaves 3-divided, the divisions all stalked (or at least the terminal one), broadly wedge-shaped or ovate, unequally 3-cleft or parted and variously cut, never pinuately compound; petals obovate, much larger than the sprearling calyx; carpels strongl!y margined, pointed by a stout straightish beak. (R. repeus, of Manual, mainly.) - Moist or shady places, ete., May-Aug. - Extremely variable in size and foliage, conmencing to flower ly upright stems in spring before any long runners are formed.

$===$ Style subulate, stigmatose along the inner margin, mostly persistent.

16. R. rèpens, L. In habit and foliage clusely similar to the last species; leaves frequently white-variegated or spotted; commeucing to flower somewhat later. - In low grounds; generally in waste grounds near the coast and probably introduced from liurope, lut indigenous westwarl.

17. R. Pennsylvánicus, L.f. (Buistry C.) Sitout and erect from a usually annual root, hirsute with widely spreading bristly hairs, leafy to the top, $1-2^{\circ}$ high ; leaves all ternately diviled or compound, the stalked leaflets unequally 3-cleft, sharply cut and toothed, acute; flowers inconspicnous; calyx reflexed; head of carpels ol,long. - Wet places, common. JuueAug.

18. R. hispidus, Hook. (not Michx, or 1)C.). liesembling the last, but the ascending or reclining stems few-leaved, rarely if ever rooting, not always hirsute; petals (about $3^{\prime \prime}$ long) surpassing the liaidly reflexed and soon deciduous ealyx; achenes with a stout straight beak, in a globose or oval heal. On the northern shore of Lake Superior, and north and westward; Inobably in N. Minn. 
R. Bulbòsus, L. (Brlboys C. or Buttercups.) Hairy ; stem erect from a bulb-like base, $1^{\circ}$ high; radical leaves 3-divided; the laterul divisions sessile, the terminal stalked and 3-parted, all wedge-shaped, cleft and toothed; peduncles furrowed; petals round, wedge-shaped at base; calyx reflexed; carpels tipped with a very short beak. - Fields; very abundant only in E. New England; rare westward. May - July - Leaves appearing as if pinnate. Petals often 6 or 7 , deep glossy yellow, the corolla more than an inch broad. (Nat. from Eu.)

R. ACris, L. (TAll C. or Bettercles.) Hairy ; stem erect $\left(2-3^{\circ}\right.$ high) ; leaves 3-divided; the divisions all sessile and 3-cleft or parted, their segments cut into lanceolate or linear crowded lobes; peduncles not furrowed; petals obovate, much longer than the spreading calyx. - Fields ; common, especially eastward. June-Aug. - Flower nearly as large as the last, but not so deep yellow. - The Buttercups are avoided by cattle, on account of their very acrid or even blistering juice, which property, howerer, is dissipated in drying when these plants are cut with hay. (Nat. from Eu.)

* * Achenes beset with rough points or small prickles; annuals.

R. Municàtus, L. Nearly glabrous; lower leaves roundish or reniform, 3-lobed, coarsely crenate; the upper 3-cleft, wedge-form at the hase; petals longer thun the caly $x$; carpels flat, spiny-tuberculate on the sides, strongly beaked, surrounded with a wide and sharp smooth margin. - Eastern Virginia and southwark. (Nat. from Eu.)

R. PARViflòrts, L. Hairy, slender and diffuse; lower leaves roundishcorclate, 3-cleft, coarsely toothed or cut; the upper 3-5-parted; petals not longer than the culyx; carpels minutely hispid and rough, beaked, narrowly wargined. - Norfolk, Va., and southward. (Nat. from Eu.)

\section{I S O P Ỳ R U M, L.}

Sepals 5, petal-like, decirluons. Tetals 5, minute, wanting in the American species. Stamens 10-40. Pistils $3-6$ or more, pointed witl the styles. Pods ovate or oblong, 2-several seeded. - Slender smooth perennial herls, with 2-3-ternately compound leaves; the leaflets 2-3-lobed. Flowers axillary and terninal, white. (From iбór

1. I. biternàtum, Torr. \& Gray. Petals none; filaments white, clubshaperl; pistils 3-6 (commonly 4), diraricate in fruit, 2-3-seeded; seeds smooth. - Moist shady places, (jhio to Ninn. and sonthward. May. - Fibres of the root thickened here and there into little tubers. Aspect and size of the plant much as in Anemonella.

\section{C ÁtThA, L. Marsh Marigold.}

Sepals 5-9, petal-like. Petals none. Pistils 5-10, with scarcely any styles. Pols (follicles) compresserl, spreading, many-seeded. - Glabrous perennials, with round and heart-shaped or kilney-form, large, undivided leares. (Au ancient Latin name for the common Marigoll.)

1. C. palústris, I. Stem hollow, furrowed; leaves round or kidneyshaped, either crenate or dentate or nearly entire; sepals broadly oval (bright yellow). - Swamps and wet meadows, common northward. April, May. ()ften called incorrectly Cowslips; used as a pot-herb in spring, when coming into flower. C. Flabellifolia, Pursh, is a weak slender form, with openreniform leaves and smaller flowers ( $l^{\prime}$ broad or less), occurring in cold mountain springs, N. Y. to Md. (En.) 


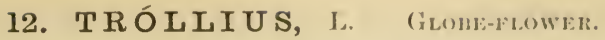

Sepals 5-15, petal-like. Petals numerous, small, 1-lipped, the concarity near the base. Nitamens and pistils numerus. Pods 9 ur more, sexsile, manyseeded. - smoutl perennials with palmately parted and cut leaves, like Ranunculus, and large solitary terminal flowers. (Name thought to be derived from the olıl (ierman word troll, a globe, or something rouml.)

1. T. láxus, Salisb. (Npreanxg Glonk-Flower.) Leaves 5-7-parted; sepals 5-6, spreading; petals $15-25$, inconspicnons, unch shorter than the 5.amens. - Deep swamps, X. H. to Del. and Mich. May.-Flowers twice the size of the common Buttereup; the sepals sprealing, so that the name is not appropriate, as it is to the Europeun Gilobe-flouer of the gardens, nor is the blossom showy, being pale greenish-yellow, or neasly white.

\section{Có PTIS, Salisb. Golnturean.}

Sepals 5-7, petal-like, ilecilluous. Petals 5-7, small, club-shaped, holluw at the apex. Stamens 15-25. I'istils $3-7$, on slencler stallis. l'ods divergent, mombranaceous, pointerl with the style, 4-8-seeded.-Low smootl perennials, with ternately divided root-leaves, and small white flowers on scapes. (Name from кó $\tau \omega$, to cut, alluding to the dividerl leaves.)

1 C. trufolia, Salisb (Three-leaved Golnturean.) Leaflets 3, obovate-wedge-form, sharply toothed, obscurely 3-lobed, scape 1-flowered.Bogs, abundant northward; extending sonth to Maryland aloug the mountains, and west to Iowa. May. - Root of long, bright yellow, bitter fibres. Leaves evergreen, shining. Scape naked, slender, 3-5' high. (Lu.)

\section{HELLÉ B O R U S, Tourn. Helleibone.}

Sepals 5, petal-like or greenish, persistent. Petals 8-10, very small, tubular, 2-lipped. l'istils $3-10$, sessile, forming coriaceous many-seeded pucls. Pereunial herbs, with ample palmate or perlate leaves, anil large, solitary, nodding, early vernal Howers. (An ancient name of unknown meaning.)

H. vfribis, L. (Grees Hemliborli.) lioot-leaves glabrous, pedate; calyx spreading, greenish. - Ilas been found wild on Long Island, in Penn., and WV Va. ( $\Lambda$ dr. from Eu.)

\section{ERÁ N THIS, Salish. Wixter Acoxite.}

Sepals 5-8, petal-like, deciduous. Petals small 2-lipped nectaries. Carpels few, stipitate, several-seeded. - P'erennial herbs, witl jalmatcly unltificl radical leaves, the scape bearing a single large yellow flower surrounded by an involucre of a single leaf. (Name from $\hat{\eta} \rho$, spring, and $\alpha_{\nu} \theta 0 s$, flouer.)

E. IrYend Ls, Salish. I)warf; flowers ''up-shapel, $1 \frac{1}{2}$ ' in ilianeter; petals shorter than the stamens. - Near I'hiladelphia. ( $\Lambda$ (lv. from Eu.)

\section{A Q UILEG I A, Tuurn. Columme.}

Sepals 5, regular, colored like the petals. Petals 5, all alike, with a short spreading lip, producer backward into large lollow spurs, much longer tlan the calyx. I'istils 5, witl slender styles. l'ods erect, many-seeded. - J'erennials, with 2-3-ternately compound leaves, the leatlets lubed. Flowers large and showy terminating the branches. (Name from aquilegus, waterdrawing.) 
1. A. Canadénsis, L. (Wild Columbive.) Spurs nearly straight; stamens and styles longer than the ovate sepals. - Rocks, common. AprilJune. - Flowers 2' long, scarlet, yellow inside (or rarely all over), nodding, 6o that the spurs turn upward, but the stalk becomes upright in fruit.

2. A. brevístyla, Hook. Flowers small, blue or purplish or nearly white; spurs incurved. - Red River valley, Dak.; Rocky Mts., northward.

A. velgaris, L., the common Gardex Colcubise, of Europe, with hooked spurs, is beginning to escape from cultivation in some places.

\section{DELPHÍNIUM, Tourn. Larksper.}

Sepals 5, irregnlar, petal-like; the upper one prolonged into a spur at the base. Petals 4, irregular, the upper pair continued backward into long spurs which are enclosed in the spur of the calyx, the lower pair with short claws; rarely only 2 , united into one. P'istils $1-5$, forming many-seeded pods in fruit. - Leares palmately divided or cut. Flowers in terminal racemes. (Name from Delphin, in allusion to the shape of the flower, which is sometimes not unlike the classical figures of the dolphin.)

$$
\text { * Perennials, indigenous; pistils } 3 \text {. }
$$

1. D. exaltàtum, Ait. (Tall LARKspk.) Stem slender, $2-5^{\circ}$ high ; leares deeply $3-5$-cleft, the divisions narrow wedge-form, diverging, 3-cleft at the apex, acute; racemes uand-like, panicled, many-flowered; flowers purplish-blue, downy; spur straight; pods erect. - Rich soil, Penn. to Minn. and southward. July

2. D. tricórne, Michx. (Dwarf L.) Leaves deeply 5-parted, their divisions unequally 3 -5-cleft; the lobes linear, acutish; raceme few-flowered, loose; spur straightish, ascending; pods strongly diverging. - W. Penn. to Minn. and southward. April, May. - Root a tuberous cluster. Stem simple, $6^{\prime}-3^{\circ}$ high. Flowers bright blue, sometimes white, occasionally numerous.

3. D. azùreum, Michx. Leaves deeply 3-5-parted, the divisions $2-3$ times cleft; the lobes all narrowly linear; raceme strict: spur ascending, usually curved upward; pods erect. - Wisc. to Dak. and southward. May, June. - Stem 1-2 ${ }^{\circ}$ high, sleuder, often softly pubescent. Flowers sky-blue or whitish.

* * Annual, introduced; petals 2, united into one body; pistil single.

D. CoxsólidA, L. (FIELD L.) Leaves dissected into narrow linear lobes ; inflorescence loosely paniculate; pedicels shorter than the bracts; pod glabrons. - Old grain-fields, Pem. and Va.; also sparingly along roadsides farther north. (Nat. from Eu.)

D. AJAcrs, L. Flowers more numerous and spicately racemose; pods pubescent. - Sparingly escaped from gardens in E. Atlantic States. (Nat. from Eur.)

\section{A CONitidim, Tourn. Aconite. Monkshood. Wolfsbane.}

Sepals 5, petal-like, very irregular; the upper one (helmet) looded or helmet-shaped, larger than the others. Petals 2 (the 3 lower wanting entirely, or very minute rudiments among the stamens), consisting of small spur-shaped bodies raised on long claws and concealed under the helmet. I'istils 3-5. Pods several-seeded. Seed-coat usually wrinkled or scaly.-Perennials, with 
palmately cleft or dissected leaves, and showy flowers in racemes or panicles. (The ancient Greek and Latin name, of uncertain origin.)

1. A. Noveboracénse, (iray. Erect from tulerous-thickened roots, $2^{\circ}$ high, leafy, the summit and strict loosely flowered ruceme puluescent; leaves rather deeply parted, the broally cuneate divisions 3-cleft and incised ; fluwers blue, the helmet gibbous-oborate with broad rounded summit and short descending beak. - Chenango and Orange Cos., N. Y.

2. A. uncinatum, L. (WiL1) MoxksnonI.) Glabrous; stem slender, from tuberous-thickened roots, erert, but weak ancl (lisposed to climb ; leaves firm, deeply 3-5-lobed, petioled, the lobes ovate-lanceolate, coarsely toothed; flow'rs blue; helmet erect, obtusely conicul, compresserl, slightly beaked in front. - Rich shady soil along streams, l'enn., and southwarl in the monntains; Wisc. June-Aug.

3. A. reclinàtum, Gray. ('Trunixg Wotfsmane) Gilabrous; stems trailing $\left(3-8^{\circ} \mathrm{long}\right)$; leaves deeply $3-7$-rleft, petioled, the lower orbicular in outline; the divisions werlge-form, incised, often 2-3-lobed; flourers v/lite, in very loose panicles; helmet soon horizontal, elongated-conical, with a straight beak in frout. - Cheat Mountain, Ya., and southward in the Alleghanies. Aug. - Lower leaves 5-6' wide. Flowers $9^{\prime \prime}$ long, nearly glabrous.

\section{Cimííf}

Sepals 4 or 5, falling off soon after the flower expands. Petals, or rather transformed stamens, $1-8$, small, on claws, 2 -horned at the apex. Stamens as in Actaa. P'istils $1-8$, forming dry dehiscent porls in fruit.- Perennials, with 2-3-ternately-divided leaves, the leaflets cut-serrate, and white flowers in elongated waud-like racemes. (Name from cimex, a bug, and fugo, to drive away.)

§ 1. CIMICIFLGA proper. Pistils 3-8, stipitate; seeds flattened laterally, corered with chaffy scales, in one row in the membranaceous pods; style aul-shaped; stigma minute.

1. C. Americàna, Michx. (Americax Brgbaxe.) Stem 2-40 high; racemes slender, panicled, ovaries mostly 5, glalırous; pols flattened, veiny, 6-8-scerled. - Mountains of S. Y'enn. and sonthwarl. Ang- - Sept.

\$2. MACRÒTYS. Pistil solitary, sometimes 2-3, sessile; seeds smooth, flattened and packed horizontally in the pod in tuo rous, as in Actan; stigma broad and flut.

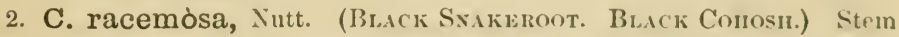
$3-8^{\circ}$ high, from a thick knotter rontstock; racemes in fruit hecoming $1-3^{\circ}$ long; pods ovoil. - Rich woods, Maine to Wisc, and southward. July.Var. nisścta, Gray. Leares irregnlarly pinnately decompound, the rather small leaflets incised. - Centreville, Del. (Commons.)

\section{A C T 㐫 A, L. LiNemerry. Comosir.}

Sepals 4 or 5 , falling off when the flower expands. P'etals $4-10$, small, flat, spatulate, on slender claws. Stamens ummerous, with slender white filaments. l'istil single; stigma sessile, depressed, 2-lobed. Fruit a many-seeded berry. 
Seeds smooth, flattened, and packed horizontally in 2 rows. - Perennials, with ample 2-3-teruately compound leaves, the ovate leaflets sharply cleft and toothed, and a short and thick terminal raceme of white flowers. (From áktéa, actca, ancient names of the elder, transferred by Linnæus.)

1. A. spicàta, L., var. rùbra, Ait. (Red Baneberry.) Raceme ovate; petals rhombic-spatulate, much shorter than the stamens; pedicels slender; berries cherry-red, or sometimes white, oval. - Rich woods, common, especially northward. April, May - Plant $2^{\circ}$ high. (Eur.)

2. A. álba, Bigel. (White Baxeberry.) Leaflets more incised and sharply toothed; raceme oblong; petals slender, mostly truncate at the end, appearing to be transformed stamens; pedicels thickcned in fruit, as large as the peduncle and red, the globular-oval berries white. - Rich woods, flowering a week or two later than the other, and more common westward and southward. - White berries rarely occur with slencler pedicels, also red berries with thick pedicels; but these are perhaps the result of ('rossing.

\section{HYDRástis, Ellis. Orange-root. Yellow Prccoos.}

Sepals 3, petal-like, falling away when the flower opens. Petals none. Pistils 12 or more in a hear, 2-ornled; stigma flat, 2 lipped. Oraries becoming a head of crimson $1-2$-seeded herries in fruit. $-A$ low peremial herb, sending up in early spring, from a thick and knotted rellow rootstock, a single radical leaf and a simple hairy stem, which is 2-leared near the summit and terminated by a single greenish-white flower. (Nane unmeaning.)

1. H. Canadénsis, I. (Golnex SEAL, etc.) Leaves rounded, heartshaped at the base, $5-7$-lohed, doubly serrate, reiny, when full grown in summer $4-9^{\prime}$ widle. - Rich woods, N. Y. to Minn., and southward.

\section{X A N THORRHi Z A, Marshall. Snrt Yellow-Root.}

Sepals 5, regular, spreading, decidnous. Petals 5, much smaller than the sepals, concave and obscurely 2-lobed, raised on a claw. Stamens 5 to 10. Pistils 5-15, with 2 pendulous ovules. Pods 1 -seeded, ollong, the short style becoming dorsal. $-A$ low shrubby plant; the bark and long roots deep yellow and bitter. Flowers polygamous, brown purple, in compound drooping racemes, appearing along with the 1-2-pinnate leaves from large terminal buds in early spring. (Name compounded of $\xi a \nu \theta o ́ s$, yellow, and pís $\alpha$, root.)

1. X. apinfòlia, L'Her. Stems clustered, $1-2^{\circ}$ high; leaflets cleft and toothed. - Sharly hanks of streams, Penn. to S W. New York and Ky., and south in the mountains. The rootstocks of this, and also of the last plant, were used as a yellow dye by the aborigines.

Nigélla DauascèxA, L., the Fexvel-flower, which offers a remarkable exception in having the pistils partly united into a compound ovary, so as to form a several-celled capsule, grows nearly spontaneously around gardens. 


\section{Order :. magnoliticede. (Magnolia Famity.)}

Trees or shruls, with the leaf-buds covered by membrunous stipules, polypetalous, hypogynous, polyandrous, polygynous; the culys amel surrolla colored alike, in three or more rons of there, and imbricated (morcly crmrolute) in the bud. - Sepals and petals decidnous. Anthers adnate. Pistils many, mostly packed together and covering the prolonged receptacle, cohering with each other, and in fruit forming a sort of fleshy or dry cone. Seeds 1 or 2 in cach carpel, anatropous; albumen flexhy; embryo minute. - Leaves alternate, not toothel, marked with minute transparent dots, feather-veined. Flowers single, large. Bark aromat ic and bitter.

\section{M A G N Ò L I A, I.}

Sepals 3. Petals 6-9. Stamens imbricated, with very short filiunents, and long anthers opening inward. l'istils colcerent, forming a fleshy and rather wooly cone-like red fruit; each carpel at maturity opening on the hack, from which the 1 or 2 berry-like seeds hang by an extensile thread composed of unrolled spiral vessels. Inner seed-cont bony. - Buds conical, the coverings formed of the successive pairs of stipules, each pair enveloping the leaf next above, which is folded lengthwise and applied straight against the side of the next stipular sheath, and so on. (Named after Magnol, Professor of Botany at Montpellier in the 17th century.)

* Leaves all scattered along the branches, leaf-buds silk:y.

1. M. glaùca, L. (Simli or Latier Mragiolia. Sweet Bar.) Leares oral to broadly lanceolate, $3-6^{\prime}$ long, obtuse, glaucous beneath; flower glolular, white, 2' long, very fragrent; petals loroad; cone of fruit small, oblong. - Swamps, from near Cape $A$ m and N. Y. southward, near the coast; in P'enu. as far west as Cumberland Co. June-Aug. - Shrub $4-20^{\circ}$ high, with thickish leares, which farther south are evergreen.

2. M. acuminàta, L. (CrCrмBer-Tree.) Leaves thin, obloug, pointed, green and a little pulessent heneath, 5-10' long; flover oblong hell-shinju-d, ylaucous-yreen tinged with yellow, $2^{\prime}$ long; cone of fruit 2-3' long, cylindrical. - Rich woods, western N. Y. to Ill, and southwarl. May, June. - Tree $60-90^{\circ}$ high. Frnit when young slightly resmbling a small cueumber, whence the common name.

3. M. macrophýlla, Michx (Great-ienven Magomia.) Lemers oborate-oblong, cordute at the narrowed lase, pulieseent and uhle beneath; flower open bell-shuped, white, with a purple spot at buse; petals ovate, $\sigma^{\prime}$ long: cone of fruit ovoil. - S. K. Ky. and southward. May, June. - Tree 20-40 high. Leares $\mathbf{I}-3^{\circ}$ long, somewhat clustered on the flowaring branches. * * Leaves croncded on the sumnit of the floxcering branches in an umbrellatike cirrle; leaf-luds glabrous: flowers white, sliglhtly scented.

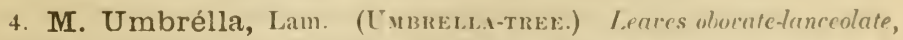
pointed at both ends, soon glalirous, $1-2^{\circ}$ long; petals ohorate-ohlong, 4-5' long. - S. l'enn. to Ky and southward. May. $-\Lambda$ small tree. Fruit rose color, 4-5' long, ovoid-oblong 
5. M. Fràseri, Walt. (FAr-Leaved Umbrella-tree.) Leaves oblongnlioute or spatulate, auriculate at the base, glabrous, 8-20' long ; petals obovatespatulate, with narrow claws, $4^{\prime}$ long. - Va. and Ky., along the Alleghanies, and southward. April, May. $-A$ slender tree $30-50^{\circ}$ high. Flower more graceful and cone of fruit smaller than in the preceding.

\section{IIRIODÉNDRON, L. Triptree.}

Sepals 3, reflexed. l'etals 6 , in two rows, making a bell-shaped corolla. Anthers linear, opening ontward. Pistils flat and siale-form, long and narrow, imbricating and cohering together in an elongated cone, dry, separating from each otler and from the long and slender axis in fruit, and falling away whole, like a samara or key, iuclehiscent, 1-2-seeded in the small cavity at the base. Buds flat, sheathed by the successive pairs of flat and broal stipules joined. at their edges, the folled leaves bent down on the jetiole so that the apex points

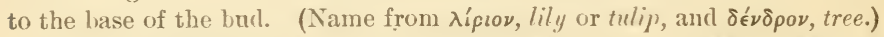

1. L. Tulipifera, L. - Rich soil, s. New Eng. to Mich., Wisc., and southwarl. May, June. $-\Lambda$ most beantifnl tree, sometimes $140^{\circ}$ high and $8-9^{\circ}$ in diameter in the Western States, where it is wrongly called Wurte Poplar. Leaves very smooth, with 2 lateral lohes near the base, and 2 at the apex, which appears as if ent off abruptly by a droal shallow notch. P'etals $2^{\prime}$ long, greenish-yellow marked with orange. Cone of fruit $3^{\prime}$ long.

\section{Orner 3. A NonACEAE. (C'ustard-Apple Family.)}

Trees or shrubs, with nakerl buds and no stipules. a culyx of 3 sepals, and a corolla of 6 petals in two rous, valcate in the burl, hypogynous, polyandrous. - Petals thickish. Anthers adnate, ojening outward; filaments rery short. Pistils several or many, separate or cohering in a mass, fleshy or pulpy in fruit. Seeds anatropous, large, with a crustaceous seed-coat, and a minute embryo at the base of the ruminated allumen. - Leaves alternate, entire, feather-reined. Flowers axillary, solitary. $-\Lambda$ tropical family, excepting the following genus :-

\section{ASÍmIN A, Aclans. Nonth Anerican Papaw.}

Petals 6, increasing after the bud opens; the onter set larger than the inner. Stamens numerous in a globular mass. l'istils few, ripening 1-4 large and oblong pulpy several seeded fruits. Seeds horizontal, flat, enclosed in a fleshy aril. - Shruhs or small trees with unpleasant odlor when bruised; the lurid flowers solitary from the axils of last year's leaves. (Name from Asiminier, of the French colonists, from the Indian name assimin.)

1. A. tríloba, Dunal. (Соммох PApaw.) Leaves thin, obovate lanceolate, pointed; petals dull-purple, veiny, round-ovate, the onter ones $3-4$ times as long as the calyx. - Bauks of streams in rich soil, western N. Y. and Penu. to 111., S. E. Neb., and southwark. A pril, May. - Tree 10-20 high; the young shoots and expanding leaves clotherl with a rusty down, soon glabrons. Flowers appearing with the leares, $1 \frac{1^{\prime}}{2}$ wicle. Fruits $3-4^{\prime}$ long, yellowish, sweet and edible in antumn. 


\section{Order 4. MENispermàCEA. (Moonsend Family.)}

Woody climbers, with palmate or peltate alternate leaves, no stipules, the sepals and petals similar, in three or more rows, imbricated in the bud; hypogynous, dicecious, 3-6-gynous ; fruit a 1-seeded drupe, with a large or long curved embryo in scanty albumen. - Flowers small. Stamens several. Ovaries nearly straight, with the stigma at the apex, but often incurved in fruitinr, so that the seed and embryo are bent into a crescent or ring. - Chiefly a tropical family.

* Sepals and petals present. Anthers 4-celled. Seed incurved.

1. Cocculus. Stamens, petals, and sepals each 6 .

2. Menispermum. Stamens $12-24$, slender. Petals $6-8$.

** Petals none. Inthers 2-celled. Seed saucer-shaperl.

3. Calycocarpum. Stamens in the sterile flowers 12 ; in the fertile flowers 6 , abortive.

\section{CóCCULUS, DC.}

Sepals, petals, and stamens 6 , alternating in threes, the two latter short. Anthers 4-celled. I'istils $3-6$ in the fertile flowers; style pointerl. Drupe and seed as in Menispermum. - Flowers in axillary racemes or panicles. ( $\mathrm{n}$ old name, a diminutive of соссиs, ко́ккоs, a berry.)

1. C. Caıolinus, DC. Minutely pubescent; leaves downy beneath, ovate or cordate, entire or sinuately or hastately lobed, variable in sliaje; flowers greenish, the petals in the sterile ones auriculate-inflexed below around the filaments; drupe red (as large as a small pea). - River-banks, Va. to S. Ill., Kan., and southward. July, Aug.

\section{MENISPÉRMUM, L. MOoNSEED.}

Sepals 4-8. Petals 6-8, short. Stamens $12-24$ in the sterile flowers, as long as the sepals; anthers 4 -celled. Pistils $2-4$ in the fertile flowers, raised on a short common receptacle; stigma broad and flat. Drupe globular, the mark of the stigma near the base, the ovary in its growth after flowering being strongly incurved, so that the (wrinkled and grooved) laterally flattened stone takes the form of a large crescent or ring. The slender embryo therefore is horseshoe-shaped; cotyledons filiform. - Flowers white, in small and loose axillary panicles. (Name from $\mu \hat{\eta} \nu \eta$, moon, and $\sigma \pi \epsilon ́ \rho \mu \alpha$, seed.)

1. M. Canadénse, L. Leares peltate near the edge, 3-7-angled or loberl.-Banks of streams; common. June, July.-Drupes black with a bloom, ripe in September, looking like frost grapes.

\section{CALYCoCÁRPUM, Nutt. Cupseen.}

Sepals 6, petaloid. Petals none. Stamens 12 in the sterile flowers, short; anthers 2-celled. Pistils 3, spindle-shaped, tipped with a radiate many-cleft stigma. Drupe globular; the thin crustaceons putamen hollowerl ont like a cup on one side. Enhryo foliaceous, heart-shaperl. - Flowers greenish-white,

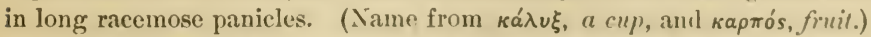

1. C. Lyoni, Nutt. Leaves large, thin, deeply 3-5-lohed, cordate at the base; the lobes acuminate; drupe an inch long, black when ripe; the shell 
crested-toothed on the edge of the cavity. - Rich soil, Ky. to S. Ill. and Kan., and southward. May. - Stems climbing to the tops of trees.

\section{Order 5. BERBERIdìceze. (Barberry Family.)}

Shrubs or herbs, with the sepals and petals both imbricated in the bud, usually in two rows of 3 (rarely 2 or 4 ) each ; the hypogynous stamens as many as the petals and opposite to them; anthers opening by 2 valves or lids hinged at the top. (Podophyllum is an exception, and Jeffersonia as respects the sepals in one row.) Pistil single. Filaments short. Style short or none. Fruit a berry or a pod. Seeds few or several, anatropous, with albumen. Embryo small, except in Berberis. Leaves alternate, with dilated bases or stipulate.

* Petals and stamens 6. Fruit few-seeded.

1. Berberis. Shrubs, wit'.1 yelluw Howers and wood; a pair of glandular spots on the base of each petal. Fruit a berry.

2. Caulophyllum. Herb, with greenish flowers; petals thick, much shorter than the sepals. Ovary soon bursting; the two seeds left naked.

3. Diphylleia. Herb with white flowers; petals much longer than the sepals. Berry 24 -seeded.

* * Petals 6-9. Stamens $8-18$. Fruit many-secded. Herbs.

4. Jeffersonia. Petals and stamens usually 8 ; anthers opening by uplifted valves. Pod opening by a lid.

5. Podophyllum. Petals $6-9$. Stamens $12-18$; anthers not opening by uplifted valves. Fruit a large berry.

\section{BÉRBERIS, L. Barberry.}

Sepals 6, roundish, with 2-6 bractlets ontside. Petals 6 , obovate, concave, with two glandular spots inside above the short claw. Stamens 6. Stigma circular, depressed. Fruit a 1 -few-seeded berry. Seeds erect, with a crustaceous integument. - Shrubs, with yellow woor and inner bark, yellow flowers in drooping racemes, sour berries, and $1-9$-foliolate leares. Stamens irritable. (Derived from Berberys, the Arabic name of the fruit.)

1. B. Canadénsis, Pursh. (Americay Barberry.) Leaves repandly toothed, the teeth less bristly-pointed; racenes fer-flowered; petals notched at the apex; berries oral; otherwise as in the next. - Alleghanies of Va. and southward; not in Canada. June. - Shrub $1-3^{\circ}$ high.

B. vilgaris, I. (Common Barberry.) Leaves scattered on the fresh shoots of the season, mostly reduced to sharp triple or branched spines, from the axils of which the next season proceed rosettes or fascicles of oborateoblong closely bristly-toothed leaves (the short petiole jointed!), and drooping many-flowered racenes; petals entire; berries oblong, scarlet. - Thickets and waste grounds in E. New Eng., where it has become thoronghly wild; elsewhere occasionally spontaneous. May, June. (Nat. from Eu.)

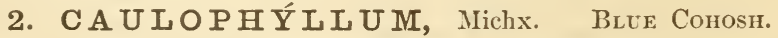

Sepals 6, with 3 or 4 small bractlets at the base, orate-oblong. Petals 6 thick and gland-like somewhat kidney-shaped or hooded bodies, with short claws, much smaller than the sepals, one at the base of each of them. Stamens 6; anthers oblong. Pistil gibbous; style short; stigma minute and unilateral; 
ovary bursting soon after flowering by the pressule of the 2 erect, enlargind seeds, and withering away; the splierical seeds naked on their thick seed-stalhs, looking like drupes, the fleshy integument turning blue; allomen horny.A perennial glabrous herb, with matted knotty rootstocks, scouling up in carty spring a simple and naked stem, terminated by a small raceme or panicle of yellowish-green flowers, and a little below beariug a large triturnately cont-

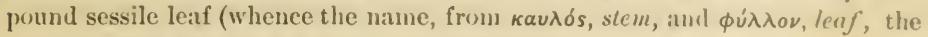
stem seeming to form a stalk for the great leaf.)

1. C. thalictroides, Michx. (Also called P'xpons:-kont.) Stems $1-2 \frac{1}{2}^{\circ}$ high; leaflets olovate werlge-form, 2-3-loberl, a sinaller biteruate leaf often at the base of the panicle; flowers appearing while the lat is yet sunall. - Jeep rich woods; common westward. A pril, May. - Whole plant glaucous when young, as also the seels, which are as'liurge as peas.

\section{DIPH YLLEIA, Michx. TMBRELlA-LEN.}

Sepals 6, fugacious. Pet:ls 6, oval, flat, larger than the sepals Stamens 6; enthers oblong. Orary obloug; style hardly any ; stigma depressed. Ovules 5 or 6 , attached to one side of the cell below the middle. Berry globose, fewseeded. Seeds oblong, with no aril. - A peremuial glabrous herb, with thick horizontal rootstocks, sending up each year either a huge centrally peltate and cut-lobed, rounded, umhrella-like radical leaf, on a stout stalk, or a flowering stem bearing two similar (but smaller and more 2-cleft) alt wnate leaves which are peltate near one margin, and terminated by a cyme of white flowers.

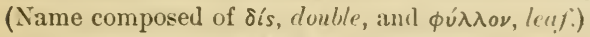

1. D. cymòsa, Michx. Loot-leaves $1-20$ in cliameter, 2-cleft, each division 5-7-lobed; lobes touthed; berries blue. - Wret or springy places, mountains of Va. and sonthward. May.

\section{JEFFERSÒ I A, Barton. TWIN-LEAF.}

Sepals 4, fugacious. l'etals 8, oblong, flat. Stamens 8 , anthers olılonglinear, on slender filaments. Ovary ovoid, soon gibbous, pointed, stigma 2 lobed. Pod pear-shaped, opening half-way round horizontally, the upper part making a lid. Seeds many in several rows on the lateral placental, with a fleshy lacerate aril on one side. $-A$ perennial glabrous herl, with matted fibrous roots, long-petioled root-leaves, parted into 2 half-uvate leaflets, and simple naked 1-flowered scapes. (Namerl in honor of Thomes Jefii ism

1. J. diphýlla, Pers. Low; flower white, $\mathrm{l}^{\prime}$ broml, the parts rarely in threes or fives. - Wookls, western N. Y. to Wise. and southward. April, May. - Called R'heumatisu-root in some places.

\section{PODOPHÝLLUM, I. MIY-APRLE. M.NnR.ME.}

Flower-bul with three green bratlets, which early fall away Sepals 6, fugacious. Petals 6 or 9 , olorate. Stamens twice as many as the petals in our species; anthers linear-oblong, not opening by uplifted ralves Ovary oroid; stigma sessile, large, thick and undulate. Frnit a large tleshy berry. Seeds corering the very large lateral placenta, in many rows, each seed enclosed in a pulpy aril, all forming a maks which fills the cavity of the fruit. l'erenuial herbs, with creeping rootstocks and thick filsous roots. Stems 


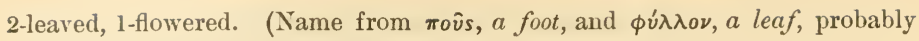
referring to the stout petioles.)

1. P. peltàtum, L. Stamens 12-18; leaves 5-9-parted, the lobes oblong, rather wedge-shaped, somewhat lobed and toothed at the apex. - Rich woods, common. May.-Flowerless stems terminated by a large round 7 -9lobed leaf, peltate in the middle like an umbrella. Flowering stems bearing two one-sided leares, with the stalk fixed near their inner edge; the nodding white flower from the fork nearly $2^{\prime}$ broad. Fruit ovoid, 1-2' long, ripe in July, sweet and slightly acid, edible. The leaves and roots are drastic and poisonous! - Found occasionally with from 2 to 6 carpels!

\section{Order 6. NYMPHAàceas. (Water-Lily Family.)}

Aquatic perennial herbs, with horizontal rootstocks and peltate or sometimes only cordate leaves floating or emersed; the ovules borne on the sides or back (or when solitary hanging from the summit) of the cells, not on the ventral suture; the embryo enclosed in a little bag at the end of the albumen next the hilum, except in Nelumbium, which has no albumen. Radicle hardly any; cotyledons thick and fleshy, enclosing a well-developed plumule. - Flowers axillary, solitary. Vernation involute. Rootstocks apparently endogenous. - The few genera differ so much in the flower and fruit that they are separated into the three following suborders.

Suborder I. Cabombere. Sepals and petals each 3 or sometimes 4, hypogynous and persistent. Stamens definite $(3-18)$. Pistils 2-18, free and distinct, coriaceous and indehiscent, 1 -3-seeded on the dorsal suture. - Stems slender, leafy, coated with mucilage. Flowers small.

1. Cabomba. Stamens 3-4. Carpels $2-3$. Submersed leaves eapillary-muitifid.

2. Brasenia. Stamens $12-18$. Carpels $4-18$. Leaves all peltate.

Scborder II. Nelumbonere. Sepals and petals numerous in several rows, passing gradually into each other, and with the indefinitely numerous stamens hypogynous and deciduous. Pistils several, 1-oruled, separately immersed in the obconical receptacle, which is much enlarged and broadly top-shaped at maturity, the imbedded nut-like fruits resembling small acorns. Embryo large; no albumen.- Petioles and peduncles all from the tuberous rootstock, the centrally peltate leares and the flowers large.

3. Nelumbo. Character of the Suborder.

Suborder III. Nymphaeacea proper. Sepals 4-6, and petals numerous in many rows, persistent or decaying away, either hypogynous or variously adnate to the surface of the compound 8-30-celled ovary, which is formed by the union of as many carpels; the numerous ovules inserted over the whole inner face of the cells, except at the ventral suture. Stigmas radiate as in Poppy. Fruit baccate, with a firm rind. Petioles and perluncles from a thick rootstock.

4. Nymphaea. Petals adnate to the ovary, large; the stamens on its summit.

5. Nuphar. Petals (very small and stamen-like) and stamens inserted under the ovary. 


\section{C A B Ó M B A, Aublet.}

Sepals 3 . Petals 3 , oval, bi-auriculate above the very short claw. Stamens 3-6; anthers short, extrorse. l'istils $2-4$, with small terminal stigmas. Seeds 3 , pendulous. - Slender, mainly submorsed, with opposite or verticillate capillary-dissected leaves, a few floating, alternate and centrally peltate. Flowers single on long axillary peduncles. (P'robably an aboriginal nane.)

1. C. Caroliniàna, Gray. Fluating leaves linear-oblong or -obuvate, often with a basal notch; flowers $6-8^{\prime \prime}$ broal, white with yellow spots at base; stamens 6. - Ponls, S. Ill. (May - Sept., Schneck) to Fla. and 'Tex.

\section{BRA S E $\mathbf{E}$ A, Schreher. Water-SHel.}

Sepals 3 or 4 . Petals 3 or 4 , linear, sessile. Stamens 12-18; filaments filiform; anthers innate. Pistils 4-18, forming littlo club-shapel indehiscent pods; stigmas linear. Seeds 1-2, pendulous on the dorsal suture!-Rootstock creoping. Leaves alternate, long-petioled, centrally peltate, oval, fluating. Flowers axillary, small, dnll-purple. (Name of uncertain origin.)

1. B. peltàta, I'ursh. Leaves entire, 1-4' across. - I'onds and slow streams. June-Aug. (Asia, $\Lambda$ frica and Australia.)

\section{N ELÚ M B O, Tourn. SiCreI BEAx.}

The only genus of the suborder. (Nelumbo is the Ceylonese name of the East Indian species, the pink-flowered N. speciosa.)

1. N. lùtea, Pers. (Yellow Neltumo, or Water Chisquapin.) Leaves usually raised high out of the water, circular, with the centre depressed or cupped, $1-2^{\circ}$ in diameter; flower pale yellow, $5-10^{\prime}$ broal ; anthers tipped with a slender hooked appendage. (Nelumbium luteum, Willd.) - S. Conn. (probalsly of Indian introduction) to Lake Ontario, Mich., Minn., F. Neb., and southwarl; rare in the Middle States. - Tubers fariuaceous and edible. Sieeds also catable. Embryo like that of Nymphaa on a large scale; cotyledons thick and fleshy, enclosing a plumule of 1 or 2 well-formed young leaves, enclosed in a delicate stipule-like sheath.

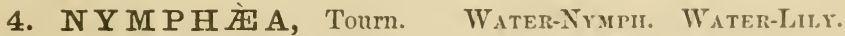

Sepals 4, green ontside, nearly free. Petals numerous, in many rows, the innermost gradually passing into stamens, imbricately insertel all over the ovary. Stamens indefinite, inserted on the ovary, the vuter with dilated filaments. Ovary 12-35-(elled, the coneave summit tipped with a glohular projection at the centre, around which are the radiate stigmas; these project at the margin, and are extended into linear and incurved sterile appendages. Fruit depressed-globular, covered with the bases of the decayed petals, maturing under water. Seeds enveloped by a sac-like aril. - Flowers white, pink, yellow, or blue, very showy. (1)edicated by the Greeks to the Water-Nymphs.)

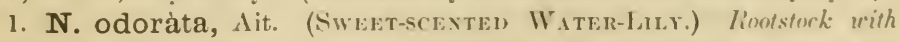
few and persistent lirunches; leaves orbicular, cordate-cleft at the base to the petiole $\left(5-9^{\prime}\right.$ wille), the margin entire; stipules broadly triangular or almost kidney-shaped, notehed at the apex, appressed to the rootstock: flurer white, very sueet scented (often as much as $5 \mathrm{~h}^{\prime}$ in diameter when fully expanderl, opening early in the morniug, (losing in the afteruoon); petals ohtuse ; anthers 
blunt; aril much longer than the distinctly stipitate oblong seeds (these about $1 \frac{1}{2}$ " long). - Ponds and still or slow-flowing water; common. June-Sept. Varies with pinkish-tinged and rarely with bright pink-red flowers (especially at Barnstable, Mass.), the leaves often crimson underueath, - and in size by gradations into

Var. minor, Sims, with leaves only $2-5^{\prime}$ and flowers $2-3^{\prime}$ broad. - Shallow water, in cold bogs and in sandy soil.

2. N. renifórmis, I)C. ('Ttber-bearivg W.) Leaves reniform-orbicular, mostly larger $\left(8-15^{\prime}\right.$ wide) and more prominently ribbed than the last, rarely purplish beneath; rootstock bearing numerous spontaneously detachng often compound tubers; flower scentless (or with a slight odor as of apples), white, never pinkish, $4 \frac{1}{2}-9^{\prime}$ in diameter, the petals proportionally broader and blunter than in n. 1; the fruit more depresserl, and with fewer but much larger (i. e. twice as broad) globular-ovoid seeds, which when mature are barely enclosed by the aril and not stipitate. (N. tuberosa, Paine.) - Lakes, slow rivers, etc., western N. Y. (from Oneida Lake, Paine) and near Meadrille, Penn., to Mich., E. Neb., and probably in the Southern States. July-Sept.

\section{N Ù PHA R, Smith. Yellow I'oxd-Lily. SPatter-Dock.}

Sepals 5, 6, or sometimes more, colored, or partly green outside, roundish, concave. l'etals numerous, small and thickish, stamen-like or scale-like, inserted with the very mumerous short stamens on the receptacle under the ovary, not surpassing the disk-like 8-24-rayed sessile stigma, persistent and at length recurved. Fruit ovoid, naked, usually ripening above water. Aril none. - Rootstock crecping, cylindrical. Leaves with a deep sinus at the hase. Flowers yellow or sometimes tinged with purple, produced all summer (Name sail to be of Arabic origin.)

1. N. ádvena, Ait.f. Sepals 6, unequal; petals shorter than the stamens and resembling them, thick and Heshy, truncate; stiginat nearly entire, 12-24rayed, pale red; ovary and fruit ( $1 \frac{1}{2}^{\prime}$ long) ovate, not contracted above into a narrow neck; thin snbmersed leares seldom present; floating or emersed and erect leares thick $\left(6-12^{\prime}\right.$ long), from roundish to orate or almost oblong, the sinus open, or closed or narrow. - Very common, in still or stagnant water; stunt and course; flower often partly purplish (var. vanígìtis, Engelm.).

Var. minus, Morong. Nure slender; leaves sumewhat smaller (3-8' long) ; flowers usually smaller (sepals $12-15^{\prime \prime}$ long) ; petals spatulate; stigmes 9 -13-rayed, crenately touthed, bright red or crimson ; fruit l' long, contracted above. (N. rubrodiscum, IForong. N. luteum, Man.; not Smith.) - N. Vt. to Mich. and Penn. Probably a lybrid between this and the next species.

2. N. Kalmiànum, Ait. Very slender and with slender rootstock; submersed leares thin, round-reniform, the floating broadly elliptical with a deep narrow sinus, $2-4^{\prime}$ long; sepals usually 5 , the flowers an inch broad or less; petals spatulate or obovate; stigmas 7-10-rayed, dark red ; fruit globular with a short neck $\left(6-9^{\prime \prime}\right.$ in diameter). ( $($. luteum, var. pumilum, Man.) - Maine to Pem and Minn., and northward.

3. N. sagittifolium, Pursh. Routstuck stout; leaves narrowly oblong to oblong-lauceulate with a short sinus, $6-15^{\prime}$ long; flowers small ( $1^{\prime}$ broad). - S. Ind. and 11l. (Schneck), and southward. 


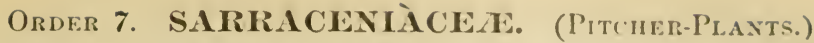

Polyandrous and hypogynous bog-plants, with hollow pitcher-form or trumpet-shaped leares, - comprising one plant in the mountains of Guiana, another (Darlingtonia, Torr.) in California, and the fullowing genus in the Atlantic United States.

\section{SARRACENIA, Tourn. SIDE-SAddLE Flower.}

Sepals 5, with 3 liractlets at the base, colored, persistent. I'ctals 5, oblong or obovate, incurved, deciduous. Stamens numerous, hypogrnous. Ovary compound, 5-celled, glohose, crowned with a short style, which is expanded at the summit into a very broad and petal-like, 5-angled, 5-rayed, umbrella-shaped body, the 5 delicate rays terminating under the angles in as many little hooked stigmas. Capsule with a granular surface, 5-celled, with many-seeded placentæ in the axis, loculicidally 5-ralved. Sceds anatropous, with a small embryo at the base of fleshy albumen. - Perennials, yellowish-green and purplish; the hollow leaves all radical, with a wing on one side, and a rounded arching hood at the apex. Scape naked, l-flowered ; flower nodding. (Named by 'Tournefort in honor of Dr. Sarrasin of (quelec, who first seut our Northern species, and a botanical account of it, to Europe.)

1. S. purpurea, L. (Side-Saidle Flower. Pitciner-Plant. Iuntssax's CUP.) Leares pitcher-shaped, ascending, (urved, broally winged; tho hood erect, open, round heart-shaped; flouer deep purple; the fiddle-shaped petals arched over the greenish-yellow style. - Varies rarely with greenishyellow flowers, and without purple veins in the foliage. - P'eat-bogs; common from N Eng. to Minn., N. E. Iowa, and southward east of the Alleghanies. June. - The curious leares are usually lialf filled with water and drowned insects. The inner face of the hood is clothed with stiff bristles pointing downward. Flower globose, nodling on a scape a foot high; it is difficult to fancy any resemblance between its shape and a side-saddle, but it is not very unlike a pillion.

2. S. flàva, I. (Trumpets.) Leares long $\left(1-3^{\circ}\right)$ and trumpet-shriperi, erect, with au open mouth, the erect hood rounded, narrow at the base; wing alınost none; flower yellow, the petals becoming long and drooping. - Bugs, Va and southward. April.

\section{Order 8. PAPAVERACEA. (Poppy Famu.)}

Herbs with milky or colored juice, regulur flowers with the parts in twos or fours, fugacious sepals, polyandrous, hypogynous, the orary 1-celled with two or more parietal placenta. - Sepals 2, rarely 3, falling when the flower expands. Petals 4-12, spreading, imbricated and often crumpled in the bud, early deciduous. Stamens rarely as few as 16, distinct. Fruit a dry 1-celled pod (in the Poppy imperfeetly many-celled, in (ilaucium 2-celled). Seeds numerous, anatropous, often crested, with a minute embryo at the base of fleshy and oily albumen. - Leaves alternate, without stipules. Peduncles mostly 1-tlowered. Juice narcotic or acrid. 
* Petals 8-12, not crumpled in the bud, white. Pod 1-celled, 2-valver.

1. Sanguinaria. Petals white. Leares and 1-flowered scape from a short rootstock.

* Petals 4, crumpled in the bud. Pod 2-valved or more.

- Pod 2-4-valved, the valves separating to the base from the placentas. Leaves pinnately parted. Flowers yellow.

2. Stylophorum. Pod bristly; style distinet; stigmas and placentas 3-4.

3. Chelidonium. Porl linear, smooth; style almost none; stigmas and placentas 2.

4. Glaucium. Porl rough, long-linear, 2-celled by a spongy partition; style none.

+ + Pod 4-20-valved, dehiscent only at the top or to the middle.

5. Papaver. Ovary inconıpletely many-celled; stigmas united into a radiate sessile crown.

6. Argemone. Stigmas (sessile) and placer.tas 4-6. Pod and leaves prickly.

\section{SA NGUINÁRIA, Dill. Blood-Root.}

Scpals 2. Petals 8-12, spatulate-oblong, the inner narrower. Stamens about 24. Style short; stigma 2-grooved. I'od oblong, turgid, 1-celled, 2valved. Seeds with a large crest. - A low perennial, with thick prostrate premorse rootstocks, surcharged with red-orange acrid juice, sending up in earliest spring a rounded palmate-lobed leaf, and a 1-flowered naked scape. Flower white, handsome, the bud erect, the petals not crumpled. (Name from the color of the juice.)

1. S. Canadénsis, L. - Open rich woods; common. April, May.

\section{STyLóphoRUM, Nutt. Celaxdive Poprt.}

Sepals 2, hairy. Petals 4. Style distinct, columnar; stigma 2-4-lobed. Pods bristly, 2-4-valved to the base. Seeds conspicuously crested. - Perennial low herbs, with stems naked below and oppositely 2-leaved, or sometimes 1-3-leaved, and umbellately 1 -few-flowered at the summit; the flower-buds and the pods nodding. Leaves pinnately parted or divided. Juice yellow.

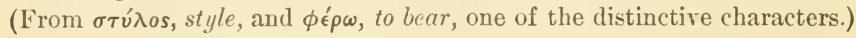

1. S. diphýllum, Nutt. Leaves pale or glancous beneath, smoothish, deeply pinnatifid into 5 or 7 oblong sinuate-lobed divisions, and the root-leaves often with a pair of smaller and distinct leaflets; peduncles equalling the petioles; flower deep yellow ( $2^{\prime}$ broad); stigmas 3 or 4 ; pod oval. - Damp woods, W. Penn. to Wisc. and Tenu. May. - Foliage and flower resembling Celandine.

\section{C H E L I D Ò N I U M, L. Celandine.}

Sepals 2. Petals 4. Stamens 16-24. Style nearly none; stigma 2-lobed. Pod linear, slender, smooth, 2-ralved, the valves opening from the bottom upward. Seeds crested. - Biennial herb with brittle stems, saffron-colored acrid juice, pinnately divided or 2-pinnatifid and toothed or cut leaves, and small yellow flowers in a pedunculate umbel; buds nodding. (Ancient Greek name from $\chi \in \lambda \iota \delta \omega \nu$, the swallow, because its flowers appear with the swallows.)

C. MAJus, L. (Celandine.) Waste grounds near dwellings. May-Aug. (Adv. from Eu.)

\section{G L A Ù C I U M, Tourn. Horx-Poppr.}

Sepals 2. Petals 4. Style none; stigma 2-lobed or 2-horned. Pod very long and linear, completely 2-celled by a spongy false partition; seeds crest- 
less. - Annuals or biennials, with saffron-colored juice, clasping leaves, and

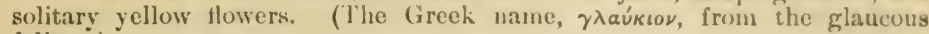
foliage.)

G. LÙter $\mathbf{x}$ Senp. Lower leaves pinnatifid; upper ones sintate-lobed anc: toothed, cordate-clasping; pods rough $\left(6-100^{\prime}\right.$ long $)$. - Waste places S. L. New Eng., Md., and Va.; not common. (Adv. from Eu.)

\section{PAPÁ VER, Tourn. Lorry.}

Sepals mostly 2. l'etals mostly 4. Stigmas nuited in a flat 4 -20-raved crown, resting on the summit of the ovary and capsuld; the latter sliort and turgid, with 4-20 mamy-sected placentie projecting like imperfect partitions, opening ly as many pores or chinks nucler the eilge of the stigma. Herhs with a white juice; the flower-buds nolding. (Derivation olscure.) Three annual species of the Uld World are sparingly adventive; viz.:

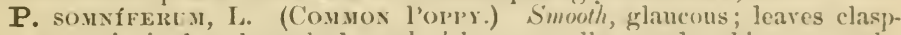
ing, wavy, incised and toothed; pod globose; corolla mostly white or purple. - Near dwellings in some places. ( $\Lambda$ dv. from Eu.)

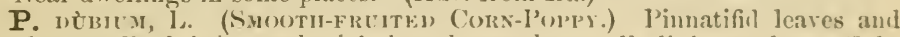
the long stalks bristly; pods club-shuped, smooth; corolla lighth scarlet. - Cult. grounds, Westchester, l'enn., and southward; rare. ( $\Lambda d v$, from Fu.)

P. Argenòne, I. (Rocgh-fruten C.) simaller, with finer-ut leaves and paler flowers than the last; pods club-shaped and bristly. - Waste grounds, near l'hiladelphia. ( $\Lambda \mathrm{dv}$. from Eu.)

\section{ARGEMÒNE, L. Prickly Porry.}

Sepals 2 or 3 , often prickly. Petals $4-6$. Style almost none; stigmas 3-6, radiate. Pod oblong, prickly, opening by $3-6$ valves at the top. Sicerls crested. - Annuals or biennials, with prickly bristles and yellow juice. I.eaves sessile, sinuate-lobed, and with prickly teeth, often blotched with white. Flower-buds erect, short-peduncled. (Name from $a \rho \gamma \in \mu a$, a clisease of the eye, for which the juice of a plant so called by the Greeks was a supposed remedy.)

1. A. platýceras, Link \& Otto. Setose-hispicl all over; petils white, $1 \frac{1}{2}-2^{\prime} \operatorname{long}$; capsule armed with stout spines. - Central Kan. and Neb., south and westward.

A. Mexicdsa, L. (Mexican P.) Flowers yellow, rarely white. - Waste

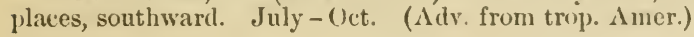

\section{Order 9. Fumariácene. (Fumtory Famly.)}

Delicate smooth herbs, with watery juice, compound dissected leates, irregular flowers, with 4 somewhat united pelals, 6 diadelphous stamens, and 2-merous porls and sects like those of the Poppy Family. - Sepals 2, small and scale-like. Corolla flattened, elosed : the 4 jetals in two pairs; the outer with spreading tips, aud one or both of them spurred or salecate at the base; inner pair narrower, and their callous crested tips united over the stigma. Stamens in two sets of 3 each, placed opposite the larger petals, hypogynous; their filaments often united; middle anther of each set 2-celled, the lateral ones 1-celled. Pod 1-cellerl, either 1-seeded and indehiscent, or several-seederl with 2 parietal placentre and deciduous valves. - Leaves delieate, usually alternate, without stipules. Slightly bitter, innocent plants. 
* Corolla bigibbous or 2 -spurred, the 2 outer petals alike. Pod several-seeded.

I Adlumia. Petals united into a spongy persistent subcordate corolla. Seeds crestless.

2. Dicentra. Corolla cordate or 2-spurred at base, less united. Seeds crested.

* Corolla with but one petal spurred at base, deciduous.

3. Corydalis. Pod with few to many crested or arilled seeds.

4 Fumaria. Fruit a globular 1-seeded uutlet. Seed crestless.

\section{A D L Ù mi A, Raf. Chimbing Fumitory.}

Petals all permanently united in a cordate-ovate corolla, becoming spongycellular and persistent, enclosing the small, few-seeded pod. Seeds not crested. Stigma 2-crested. Filaments monadelphous below in a tuhe which is adherent to the corolla, diadelphous at the summit. $-\Lambda$ climbing biennial, with thricepinnate leares, cut-lobed delicate leaflets, and ample panicles of drooping white or purplish flowers. (I)edicated by Rafinesque to Major Adlum.)

1. A. cirrhosa, Raf. - Wet woods ; N. Eng. to Wisc., E. Kan., and southward. June-Oct. - $\Lambda$ handsome vine, with delicate foliage, climbing by the slender young leaf-stalks over high bushes; often cultivated.

\section{D I CÉ N T RA, Borkh. Dutchmax's Breeches.}

Petals slightly cohering into a heart-shaped or 2-spurred corolla, either deciduous or withering-persistent. Stigma 2-crested and sometimes 2-horned. Filaments slightly united m two sets. Pod 10-20-seeded. Seeds crested. Low, stemless perennials (as to our wild species) with teruately compound and dissected leaves, and racemose nodding flowers. Pedicels 2-bracted. (Name

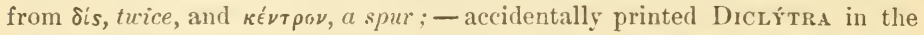
first instance, which by an erroneous conjecture was afterwards changerl into Diélytra.)

* Raceme simple, few-flowered.

1. D. Cucullària, DC. (Derchuax's Breeches.) Scape and slender-petioled leaves from a sort of granulate bulb; lobes of leaves linear; corolla with 2 divergent spurs longer than the pedicel; crest of the inner petals minute. - Rich woods, especially westward. $-A$ very delicate plant, sending up in early spring, from the cluster of grain-like tubers crowded together in the form of a scaly bulb, the finely cut leaves and the slender scape, bearing $4-10$ pretty, but odd, white flowers tipped with cream-color.

2. D. Canadénsis, DC. (Secirrex Corx.) Subterranean shoots bearing scattered grain-like tubers (resembling peas or grains of Indian corn, yellow); leaves as in $\mathrm{n} .1$; corolla merely heart-shaped, the spurs very short and rounded; crest of the inner petals conspicuous, projectin. - Rich woods, especially northward. April, May. - Flowers greenish-white tinged with rose, with the fragrance of Ilyacinths.

* * Racemes compound, clustered.

3. D. eximia, DC. Subterranean shoots scaly; divisions and lobes of the leaves broadly oblong: corolla oblong, 2-saceate at the base; crest of the inner petals projecting. - Rocks, western N. Y., rare, and Alleghanies of Va. May * Aug - Coarser-leared than the others; scapes 6-10' high. 


\section{CORÝDALIS, Vent.}

Corolla 1-spurred at the base (on the upper side), deciduous. Sityle persistent. l'orl many-seeded. Feeds crested or arilled. Flowers in racemes. Our species are hiennial, leafy-stemmed, and pale or glaucous. (The ancient Greek name for the (rested lark.)

* Stem strirt; floners purplish or rose-rolor with yellou tipls.

1. C. glaùca, I’ursh. (I’uz ('onvmuss.) liacemes panicled; spur of tise corulla very short and romiled; pols erect, slender, elongated. - liocky places; common; $6^{\prime}-2^{\circ}$ high. May-Aug.

$$
\begin{aligned}
& \text { * * Lou, ascendung; flowers yellowe. } \\
& \text { + Outer petuls uing-crested on the burk. }
\end{aligned}
$$

2. C. flávula, DC. Pelicels slemler, conspicunusly liracted : coro'la pale yellow, :3-4" long, spur very short; tijs of the onter petals pointerl, longer than the imner; crest $3-4$-tuntlesl; poils torulose, penlulous or spreading; seeds acutely margined, rugose-reticulated; aril loose. - l'enn. to Minu., and sonthward.

3. C. micrántha, Gray. I'elicels short aul bracts small; corolla pale yellow, $4^{\prime \prime}$ long, with short spur and entire erest, or Howers often cleistogamous and much smaller, without spur or crest, pods ascenling, torulose; seeds obtuse-margined, smooth and shining. - N. Car., Ill., Minn., and sontlıward.

4. C. crystállina, Engelm. P'elicels short, erect; corolla bright yellow, $8^{\prime \prime}$ long, the spur nearly as long as the body; (crest very broad, usually" toothed; pods tercte, erect, densely covered with transparent vesicles, seeds acutely margined, tuberculate. - s. W. Mo. and sonthward.

$$
\text { + +- Outer petals merely carinate on the back, not crested. }
$$

5. C. aùrea, Willd. (Golnex C.) Corolla gollen-yellow, $\frac{1}{2}$ long, tho slightly decurved spur about half as long, shorter than the pedicel; pods sprearling or pendulons, hecoming torulose; seeds obtuse-margined. - liocky banks, Vt. to Peun., Mo., Minn., and westwarl.

Var. occidentàlis, Engelm. Flowers rather larger, the spur nearly as long as the body: polls less torulose, on short perlicels; seeds acutish on the margin. - Neb. and Kan. to $\mathrm{W}^{r}$. Tex. and westwarl.

\section{Fu M À R I A, Tourn. Fumitory.}

Corolla 1-spurred at the hase. Style decilunus. Fruit indehiscent, small, globular, l-seeded. Seeds crestless. - Brancherl and leafy-stemmed annuals, with finely dissected compound leaves, and small ftowrs in dense racemes or spikes. (Name from jumus, smoke.)

F. ofricisals, I. (Commox Fumtory.) Sephls ovate-lanceolate, acute, sharply toothed, narrower and shorter than the enrolla (which is flesherolor tipped with crimson); fruit slightly notchel. - Waste places, about dwellings. (Adv. from Eu.)

\section{Order 10. CRUCífiste. (Mustame Famlo.)}

Herbs, with a pungent watery juice aud cruciform tetralynamous flowers; fruit a silique or silicle. - Sepals 4, deciduons. Petals 4, hypogynous, regular, placed opposite each other in pairs, their sprearling limbs form- 
ing a cross. Stamens 6, two of them inserted lower down and shorter (rarely only $t$ or 2). Pod usually 2-celled by a thin partition stretched between the two marginal placentr, from which when ripe the valves separate, either much longer than broad (a silique), or short (a silicle), sometimes indehiscent and nut-like (nucumentaceous), or separating across into 1-seeded joints (lomentaceous:). Seeds campylotropous, withont albumen, filled by the large embryo, which is curved or folded in various ways : i. e. the cotyledons accumbent, viz., their margins on one side applied to the radicle, so that the cross-section of the seed appears thus $0=$; or else incumbent, riz., the back of one cotyledon applied to the radicle, thus o\|. In these cases the cotyledons are plane; but they may be folled upon themselves and round the radicle, as in Mustard, where they are conduplicate, thus $0 \gg>$. In Leavenworthia alone the whole embryo is straight. - Leaves alternate, no stipules. Flowers in terninal racemes or corymbs; pedicels rarely bracted. - A large and very natural family, of pungent or acrid, but not poisonous plants. (The cliaracters of the genera are taken almost wholly from the pods and seeds; the flowers being nearly alike in all.)

SERIES I. Pod 2-celled, regularly dehiscent by 2 valves.

* Pod eompressed parallel to the broad partition. Seeds flat or flattish, orbieular or oval ; cotyledons accumbent or nearly so.

- Pod large, oblong-elliptical, valves nerveless. Seeds in 2 rows. Flowers yellow.

1. Selenia. Leaves pinnatisect. Raceme leafy-braeteate. Seeds winged.

++ Pod linear; valves nerveless. Seeds in one row. Flowers yellow only in n. 2.

2. Leavenworthia. Seed winged; embryo straight or nearly so. Aunual; stem often scapose, 1-few-flowered.

3. Dentaria. Stem naked belnw, 2-3-leaved. Pori eoriacenus, with thick placentas, long-stỵlerl. Seeds wingless; cotylerlons thick, very unequal.

4. Cardamine. Stem leafy. Pod coriaceons, with thick placentas. Seeds wingless; cotylerlons flattened, equal.

+++ Pod linear, or oblong, or orbicular; valves 1-nerved or nerveless. Seeds in 2 rows (except in species of n. 5).

5. Arabis. Pod long-linear, the flat or flattish valves more or less 1-nerved. Seeds winged or wingless. Flowers white to purple. Stems leafy, at least below.

6. Draba. Pod oval to narrowly oblong or lanceolate; valves flat or flattish, faintly nerved or veined. Serds wingless, numerous.

7. Alyssum. Pod nrbicular: valves veinless, somewhat eonvex with flattened margin. Seerls wingless, $2-4$.

* Pod terete or turgid, or 4-angled by the prominent midnerves. Seeds wingless, more or less turgid.

+ Pods short. (See also n. 11.)

8. Lesquerella. Pod globular-inflated, about 4-seeded; valves nerveless. Cotyledons accumbent. Flowers yellow.

9. Camelina. Pod obovoid, many-seeded, valves 1-nerved; style slender. Cotyledons ineumbent. Flowers yellow.

10 Subularia. Pod ovoid or globular, few-seederl, valves 1-nerved; style none. Cotyledons long, folded transversely. Flowers white. Dwarf stemless aquatic. 
++ Pod linear (or oblong or even globular in n. 11).

* Cotyledons accurnbent.

11. Nasturtium. Pod often short; valves strongly convex, nerveless. Seeds small, in 2 rows in each cell. Flowers yellow or white.

12. Barbarea. Pod somewhat 4-sided; valves strongly 1-nerved. Seeds in 1 row. Flowers yellow.

\#+ Cotyledons incumbent or partially so.

13. Hesperis. Pod terete, elongated; stigma-lobes narrow, ereet. Flowers large, purple.

14. Erysimum. I'od 4-sided; valves strongly 1-nerved; stigma broadly 2-lubed. P'ubescence of appressed 2-3-parted hairs. F'lowers yellow.

15. Sisymbrium. Pod angled or teretish; valves 1-3-nerved; stigna suall. Flowers yellow or white, small.

16. Thelypodium. Pod teretish; valves 1-nerved; stigma entire. Cotyledons obliquely incumbent. Flowers rose-eolor. Leaves auricled.

$$
\text { +*+ + Cotyledons conduplicate. }
$$

17. Brassica. Pod beaked or pointed beyond the end of the valves, or tipped with a rigid style, nearly terete, or 4 -sided. Flowers yellow or whitish.

- * Pod short; the boat-shaped valves conduplieate or uuch flattened contrary to the narrow partition. Flowers white.

18. Capsella. Pod many-seeded, obcordate-triangular, wingless. Cotyledons incumbent.

19. Thlaspi. Pod several-seederl, obovate or obcordate, winged. Cotyledons accumbent.

20. Lepidium. Pod 2-seeded, flit, scale-shaped. Cotyleduns incumbent or accumbent.

21. Senebiera. Pod 2-seeded, didymous; the valves rugose, separating at maturity from the little partition as 2 closed 1 -seeded nutlels. Cotyledons incumbent, narruw.

SERIES II. Pods indehiscent, continuous or transversely jointed; joints 1-celled.

22. Cakile. Pod short, 2-jointed; joints 1-seeled. Cotyledons plane, accumbent.

23. Raphanus. Pod elongated, several-seeded, continuous, or constricted between the seeds and moniliform. Cutyledons conduplicate.

\section{SELE N I A, Nutt.}

Pod large, oblong-elliptical, flat; the valves nerveless. Seeds in 2 rows in each cell, rounded, broadly winged; cotyledons accumbent; radicle short. A low annul, with once or twice pimnatifid leaves and leafy-bracteate racemes of yellow flowers. (Name from $\sigma \in \lambda \eta \nu \eta$, the moon, with allusion to Lunaria, which it sornewhat resembles in its pods.)

1. S. aurea, Nutt. Lobes of the simply pinnatifid leaves entire or toothel ; porl $\frac{1}{2}$ long, on elongated spreading pedicels, beaked by the long slender stỵle. - Mo. and lían. to 'Tex.

\section{LEA VEN W ÓRTHIA, Torr.}

Pod broally linear or oblong, flat; the valves nerveless, hut minutely reticulate-veined. Seeds in a single row in each cell, flat, surrounded ly a thick wing. Embryo straight! or the slourt radicle only slightly hent in the direetion which if continued would make the orbicular cotyleclons acmunbent. Little winter anmuals, glabrous and often stemless, with ly rate leaves and short 1-few-flowered scape-like peduncles. (Named in honor of the late M. C. Leavenworth.)

1. L. Michaùxii, Torr. Seapes 2-6' high; leaf-lohes usually numerous $(7-15)$; petals purplish or nearly white with a yellowish base, obtuse: 
pods not torulose, oblong to linear $\left(6-15^{\prime \prime}\right.$ long); style short. $-\mathrm{S}$. Ind. to Tenn. and Mo.

2. I. torulosa, Gray. Similar, but pods torulose even when young, linear; style $1-2^{\prime \prime}$ long; seeds acutely margined rather than winged; petals emarginate. - Barrens of ky. and Tenn.

\section{DENTÁ I A, Tourn. Toотhwort. Pepper-root.}

Pod lanceolate, flat, as in Cardamine. Style elongated. Seeds in one row, wingless, the stalks broad and flat. Cotyledons petioled, thick and very unequal, their margins somewhat infolding each other.-Perennials, of damp woodlands, with long, horizontal, fleshy, sometimes interrupted, scaly or toothed rootstocks, of a pleasant pungent taste; the simple stems leafless below, bearing 2 or 3 petioled componud leares about or above the middle, and terminated by a single corymb or short raceme of large white or purple flowers. Flowers larger, pods broader, and seeds larger than is usual in Cardamine. (Name from dens, a tooth.)

\section{* Rootstock elongated; leaves 3-foliolate.}

1. D. diphýlla, L. Rootstock long and continnous, often branched, toothed; stem-leaves 2, similar to the radical ones, close togetlier; leaflets rhombic-ovate or oblong-ovate, shortly petiolate, coarsely crenate, the teeth abruptly acute; petals white. - Rich woods, Maine to Minn. and Ky. May. - Rootstocks 5-10' long, crisp, tasting like Water-Cress.

* * Rootstock tuberous, more or less moniliform; leaves 3-foliolate or 3-parted.

2. D. laciniàta, Muhl. Tubers deep-seated, usually not jointed nor prominently tubercled; root-leaves often none; stem-leaves 3-parted, the lateral segments often 2-lobed, all broadly oblong to linear, more or less gashtoothed ; flowers white or rose-color. - N. Eng. to Minn., Kan., and southward. A pril, May. - Var. MuLffFIDA, a slender form with the narrowly linear segments usually more or less divided into linear lobes. (D. multifida, Muhl.) Southward, scarcely if at all within our limits.

3. D. heterophýlla, Nutt. Tubers near the surface, jointed, narrowly oblong or thick-clavate, prominently tubercled; leaves 3 -foliolate, the leaflets distinctly petiolate, oblong-lanceolate to linear, entire to rather deeply crenate, rarely laciniate or lobed; root-leaves with ovate or lanceolate and usually lobed leaflets. - Penn. to Ky. and southward. Blooming a little later than the last.

4. D. máxima, Nutt. Tubers jointed, strongly tubercled; stem-leares usually alternate, 3-foliolate; leaflets ovate or oblong-ovate, coarsely toothed and somewhat cleft or lobed. - Vt. to western N. Y. and Peun. May.

\section{C A R D A M İ N E, Tourn. Bitter Cress.}

Pod linear, flattened, usually opening elastically from the base; the valves nerveless and reinless, or nearly so; placentas and partition thick. Seeds in a single row in each cell, wingless; their stalks slender. Cotyledons accumbent, flattened, equal or nearly so, petiolate. - Mostly glabrous perennials, ieafy-stemmed, growing along watercourses and in wet places. Flowers white or purple. (A Greek name, in Dioscorides, for some cress, from its cordial or cardiacal qualities.) 
* liont perennial; leares simple.

1. C. rhomboídea, 1)C. (Sirus:; (Nisss) , tems upright from a tuberous base and slender rootstock bearing small enbers, simple; root-leaves lound and often heart-shaped; lower stem-leaves ovate or rhumbicublung, sunewhat petioled, the upper almost lanceolate, sessile, all often sparingly tootled ; pods linear-lanceolate, pointed with a slender style tipped with a conspicuous stigma; seeds round-ocal. - Wet meadows and springs; common. April-June. Flowers large, white.

Var. purpùrea, Torr. Lower $\left(4-6^{\prime}\right.$ high), and usually slightly pules- ant; flowers rose-purple, appearing earlier. - $\Lambda$ long streams in ricli soil. Western N. Y. to Md, and Wise.

2. C. rotundifolia, Michx. (Mouxtar Water-Cress.) Stems branching, weuk or decumbent, muking long runners, root fibrous: leaves all much alike, roundish, somewhat angled, often heart-shajed at the hase, petioled: pods small, linear-awl-shaped, pointed with the slender style; stigma minute; seeds ocal-oblong. - Cool shaded springs, N. J. (Middletown, Willıs) to ky., and southward along the mountains. May, June. - Flowers white, smaller than in $\mathrm{n} .1$.

3. C. bellidifolia, I. Duarf $\left(2-3^{\prime}\right.$ high), alpine, tufted; leaves ovate, entire, or sometimes with a blunt lateral tooth ( $t^{\prime \prime}$ long), on loug petioles; pods $\mathrm{I}^{\prime}$ long, upright, linear; style nearly none, stout. - Summits of the White Mountains and Katahdiu, Maine. July. - Flowers 1-5, white. (Eu.)

\section{* Root perennial; leares pinnate; flowers showy.}

4. C. praténsis, L. (Cuckoo Flower.) Stem ascending from a short rootstock, simple; leaflets $7-13$, those of the lower leaves rounded and stalked, of the upper oblong or linear, entire, or slightly augled-toothed; petals (white or rose-color) thrice tlie length of the ealyx; porl $9-15^{\prime \prime}$ long, $I^{\prime \prime}$ hroad; style short. - Wet places and bogs, Vt. to $\mathrm{N}$. J., Wisc., and northward; rare. May. (Eu.)

* * * Root mostly biennial or annual; leares pinnate; flouers small, white.

5. C. hirsùta, L. (Syall Bitter Cress.) Glabrous or beset with seattered hair's; stems $\left(3^{\prime}-2^{\circ}\right.$ high) erect or ascending from the spreading cluster of root-leaves; their leaflets rounded, those of the upper leaves ohlong or linear and often confluent, all either toothed, angled, or eutire ; pods line:ir, very narrow, erect or ascending; style variable. - Wet places; commun. May-July. The ordinary form corresponds closely to the European var. sYlvatica, Gaud. 'The typical imperfectly developed annual form, with only 4 stameus and rather strict pods, occurs very rarely. A form answeriug to $C$. parviflora of Europe, with mostly linear leaflets and pods often erect on spreading pedicels, is oceasionally found in (lrier localities. (Eu., Asia.)

\section{5. ÁRABIS, I. Rock Cress.}

Pod linear, flattened; placentas not thickened; the valves plane or convex, more or less 1-nerved in the midulle, or longitudinally veiny. Seeds usually margined or winged. Cotyledons acenmhent or a little ollique. - Leaves seldom divided. Flowers white or purple. (Name from the country, Arubia. See Linn. Phil. Bot. § 235.) 
§ 1. ARABIS proper. Seeds in one row in each cell, orbicular or nearly so, more or less wing-margined; cotyledons strictly accumbent.

* Low, chicfly biennials, diffuse or spreading from the base.

1. A. Ludoviciàna, Meyer. Nearly glabrous, often annual; leaves all pinnately parted into oblong or linear few-toothed or entire divisions, those of the lower leaves numerous; pedicels very short; flowers small, white; pods rather broadly linear, spreading, flat; seeds winged. - Open grounds, Va. to Mo., and southward.

* Erect and simple leafy-stemmed biennials, with simple leaves, white or whitish flowers, narrow but flattened ascending or erect pods, and nearly wingless seeds.

2. A. pàtens, Sulliv. Downy with spreading hairs, erect $\left(1-2^{\circ}\right.$ high $)$; stem-leaves oblong-ovate, acutish, coarsely toothed or the uppermost entire, partly clasping by the heart-shaped base; petals (bright white, $4^{\prime \prime}$ long) twice the length of the calyx ; pedicels slender, spreading; pods spreading or ascending, tipped with a distinct style. - Penn. to central Ohio and southward; Miun. April, May.

3. A. hirsùta, Scop. Rough-hairy, sometimes smoothish, strictly erect (1-2 $2^{\circ}$ high $)$; stem-leaves oblong or lanceolate, entire or toothed, partly clasping by a somewhat arrow-shapel or heart-shaped base; petals (greenish-white) small, but longer than the calyx; pedicels and pods strictly upright; style scarcely any; immature seeds somewhat 2-rowed. - Rocks, common, especially northward. May, June. (Eu.)

* * * Erect and simple leafy-stemmed biennials ( $1-3^{\circ}$ high), with small whitish flowers, recurved-spreading or pendulous flat pods $\left(3-4^{\prime}\right.$ long), and broadly winged seeds, their stalks adherent to the partition; root-leaves rarely lyrate.

4. A. Iævigàta, Poir. Smooth and glaucous, upright; stem-leaves partly clasping by the arrow-shaped base, lanceolate or linear, sparingly cut-toothed or entire; petals scarcely longer than the calyx; pods long and narrow, recurvedspreading on ascending or merely spreading pedicels. - Rocky places, Maine to Minn. and southward. May.

5. A. Canadénsis, L. (Sickle-Pod.) Stem upright, smooth above; stem-leares pubescent, pointed at both ends, oblong-lanceolate, sessile, the lower toothed; petals twice the length of the calyx, oblong-linear; pods very flat, scythe-shaped, hanging on rough-hairy pedicels ( $2^{\prime \prime}$ wide). - Woods and ravines; not rare, especially westward. June-Aug.

§ 2. TURRÌTIS. Seeds not so broad as the partition, in two more or less distinct rows in each cell, at least when young; strict and very leafystemmed biennials; cauline leav' es partly clasping by a sagittate base. (Our species very glabrous, except the mostly hirsute base of the stem and the lower leaves.)

6. A. perfoliàta, Lam. (Tower Mustard.) Tall $\left(2-4^{\circ}\right.$ high), glaucous; stem-leaves oblong or ovate-lanceolate, entire; petals yellowishwhite, little longer than the caly $x$; pods very narrow (3'long) and pedicels strictly erect; seeds marginless; cotyledons often oblique. - Rocks and fields, N. Eng. to Minn. (rare), north and westward. (Eu.) 
7. A. confinis, Watson. Scarcely glaucous, $1-3^{\circ}$ high; pubescence below finely stellate; stem-teaves lanceolute or oblong-lineur, entire (1-2' long), with narrow auricles, or the lowest spatulate and toothed; petuls white or rose-color, fully twice the length of the culyx; pedicels and flat pods loosely ereet, or ascenling, or even spreading; sceds wing-margined, when nature little narrower than the partition. ( $\Lambda$. Drummondii, 1/an.) - From the lower Sit. Lawrence to Minu., south to Conn., N. Y., and Ill. - Pods $2 \frac{1}{2}-3 \frac{1}{2}$ long, or in a var. ('I. brachycarpa, Torr. \&. Gray) only $1-2$ ' long.

§3. PSEUIARAIBS. Sceds oblong or elliptical, very small, wingless, in one row; cotyledons often more or less oblique. Biennial or perennial, branching from the base.

8. A. lyràta, L. Mostly glabrous, except the lyrate-pinnatifid root-leares; stem-leares seattered, spatulate or linear with a tapering base, sparingly toothed or entire; petals white, nuch longer than the vellowish ealyx; pods long and slengler, flat, ascending or spreading. - On rocks or sandy shores,

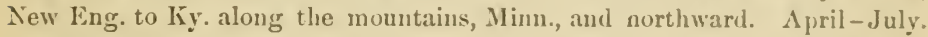
- Usually biennial, but southward in the mountains decidedly peremnial.

9. A. dentàta, Torr. \& Gray. Roughish-pubescent, slender $\left(1-2^{\circ}\right.$ high $)$; leaves oblong, very obtuse, unequally and sharply toothed; those of the stem numerous, lalf-clasping and eared at the base, of the root broaler and tapering into a short petiole; petals (whitish) scarcely exceeding the calyx; pods widely spreading, very slender, short-stalked; style scarcely any.-N. Y. to Mich., Minn., aud southward. May, June.

\section{DR A B A, Dill. Whitlow-Grass.}

Pod oval, oblong, or even linear, flat; the valves plane or slightly convex; the partition broad. Seeds several or numerous, in 2 rows in each cell, marginless. Cotyledons accumbent. Filaments not toothed.- Low herbs with entire or toothed leaves, and white or yelluw flowers; pubescence often stellate. (Nane from $\delta \rho \alpha \dot{\beta} \eta$, applied by Dioscorides to some cress; meaning unknown.)

§1. DRABÀA. Pelals not notrlied or sleft; peremial or biennial, lenfystemmed, flowers white; pods twisted whan ripe.

1. D. ramosíssima, Desv. Diffisely much branched and forming many radical tufts, perennial (5-8' high), puhescent; leaves laciniufc-toothed, linearlanceolate, the lower ollanceolate ; racemes corymhosely-branched ; pods hairy, oval-oblong or lanceolate $(2-5$ " long), on slender spreading perlicels, tippesl with a long style. - Cliffs, Harper's Ferry, Natural Bridge, ete., Va., to Kentucky River, and soutlward. $\Lambda_{\text {p }}$ ril, May.

2. D. incána, L. Hoary-pubesent, biennial or somewhat perennial, the radical tuft seldom branching; leares oblanceolate or the cauline lanceolate to ovate, few-toothed or entire; pods oblong to lanmolate, usnally arute and straight, often pubescent, ou short erect pedicels; style very short or none. - I)ry rocks, Willoughby Mountain, Vt.; also northward and far westward. (Eu.)

Var. arábisans, Watson. Cauclex much branched; pod glahrous, an'uminate or acute, twisterl, beaked with a longer distinct style. (I). arabisans, Michx.) - N. V't. to western N. Y. and the shores of the npuer lakes. 
§ 2. DRABELLA. Winter annuals; leafy stems short; flowers white (yellow in $\mathrm{n.} .5)$; style none. (Leaves oblong or oborate, hairy, sessile.)

3. D. Caroliniàna, Walt. Small (1-5' high); leaves oborate, entire; peduncles scape-like; petals usually twice the length of the calyx; raceme short or corymbose in fruit ( $\frac{1}{2}-1^{\prime}$ long); pods broadly linear, smooth, much longer than the ascending pedicels. - Sandy and waste fields, E. Mass. to Minn., and southward. March-May.-Petals often wanting in the later racemes, especially in the var. uicrixtin, Gray, with minutely rough-hairy pods, which is found with the other, westward.

4. D. cuneifolia, Nutt. Leaves obovate, wedge-shaped, or the lowest spatulate, toothed; raceme somewhat elongated in fruit $\left(1-3^{\prime}\right)$, at length equalling the naked peduncle; petals emarginate, much longer than the calyx; pods oblong-linear, minutely hairy, longer than the horizontal pedicels. - Grassy places, Ill. to E. Kan., and southward. March, April.

5. D. brachycárpa, Nutt. Low $\left(2-4^{\prime}\right.$ higl $)$, minutely pubescent; stems leafy to the base of the dense at length elongated raceme; leares narrowly oblong or the lowest ovate $\left(2-4^{\prime \prime}\right.$ long), few toothed or entire; flowers small; pods smooth, narrowly oblong, acutish (2" long), about the length of the ascending or spreading pedicels. - Dry hills, Ill., Ky., Va. (A. I. Curtiss), and southward. April. - Petals sometimes minute, sometimes none.

6. D. nemorosa, L. Leaves oblong or somewhat lanceolate, more or less toothed; racemes elongated (4-8' long in fruit); petals emarginate, small; pods elliptical-oblong, half the length of the horizontal or widely-spreading pedi. cels, pubescent or smooth. - Fort Gratiot, Mich., N. Minn., and westward. (Eu.)

§3. ERÓPHILA. Petals 2-cleft. (Annual or biennial; flowers white.)

D. vérna, L. (Whitlow-Grass.) Small (scapes $1-3^{\prime}$ high); leaves all radical, oblong or lanceolate; racemes elongated in fruit: pods varying from round-oval to oblong-lanceolate, smooth, shorter than the pedicels. - Sandy waste places and roadsides. A pril, May. (Nat. from Eu.)

\section{A L Ý S S U M, Tourn.}

Pod small, orbicular, with only one or two wingless seeds in a cell; valves nerveless, somewhat convex, the margin flattened. Flowers yellow or white. Filaments often toothed. Cotyledons accumbent. (Greek name of a plant reputed to check the hiccup, as the etymology denotes.)

A. marítimum, L. (Sweet Alrsscr), with green or slightly hoary linear leares, honey-scented small white flowers, and 2-seeded pods, commonly cult., begins to be spontaneous southward. (Adv. from Eu.)

A. CAlycìum, L., a dwarf hoary annual, with linear-spatulate leaves, pale yellow or whitish petals little exceeding the persistent calyx, and orbicular sharp margined 4-seeded pod, the style minute, occurs occasionally in grassland. (Adv. from Eu.)

\section{LESQUERÉLIA, Watson.}

Pod mostly globular or inflated, with a broad orbicular to orate hyaline partition nerred to the middle, the hemispherical or convex thin valves nerveJess. Seeds few or sereral, in 2 rows, flat. Cotyledons accumbent. Filaments toothless. - Low herbs, hoary with stellate hairs or lepidote. Flowers mostly yellow. (Named for Leo Lesquereux.) 
1. L. glıbosa, Watson. Minutely hoary all orer; stems spreading or decumbent from an annual or bienuial root; leaves oblong or lanceslate with a tapering base, repaul-toothel or nearly entire; raceme at length elongated, with filiform diverging pedicels; petals light yellow; style tiliform, much longer than the small glohose, acutish, about 4 -seeded pod; secels marginless. (Vesicaria Shortii, Torr.) - liocky hanks, Ky. to 'Tenn. and Mo. May, June.

2. L. grácilis, Watsun. Annual, slender; pubescence very fine; leaves narrowly oblanceolate; pods glahrous, suberect on ascending or curved pecticels, stipitate; style long. (Vesicaria gracilis, Hook.) - \$. Kau. to 'Tex.

3. L. Ludoviciàna, Watson. Biennial or perennial; pubencence compact; leaves linear-oblanceolate, mostly entire; pouls pulescent, penclulous on recurved pelicels; style long. (Vesicaria Lurl:viciana, $D C^{\prime}$ ) - Minu. to Neb. and southwestward.

\section{C A M ÉLIN A, Crantz. Filse Fi.lx.}

Pod obovid or pear-shaped, pointed, flattish parallel to the broad partition; valves l-nerven. Seels numerous, oblong. ('otyledons incumbent. Style slender. Flowers small, yellow. (Name from $\chi \alpha \mu \alpha \dot{i}$, duarf, and $\lambda l \nu o \nu$, flax.)

C. satìva, Crantz. Annual; leaves lanceolate and arrow-shaped; jouls margined, large. A weed in flax-fields, etc. ( $\Lambda d v$. from Eu.)

\section{SU BULÀ R I A, J. AwLwont.}

Pod ovoid or globular, with a broal partition; the turgid valves 1-nerved. Seeds several. Cotyledons long and narrow, incumbently folded transversely, i. e., the cleft extending to the radicular side of the curvature. Style none.A dwarf stemless perennial, aquatic; the tufted leares awl-shaped (whence the name). Scape naked, few-flowered, 1-3' high. Flowers minute, white.

1. S. aquática, L. Margin of lakes in Maine; Echo Lake, Franconia, N. H. ; also in alpine regions of the western mountains. June, July. (Eu.)

\section{N A S T Ú RT U M, R. Br. WATER-Cress.}

Pod a short silıque or a silicle, varying from oblong-linear to globular, terete or nearly so; valves strongly convex, nerveless. Seeds usually numerous, small, turgid, marginless, in 2 irregular rows in each cell (except in $\mathrm{N}$. sylvestre). Cotyledons accumbent. - Aquatic or marsh plants, with yellow or white flowers, and commonly pinnate or pimatifid leaves, usually glabrous. (Name from Nosus tortus, a couvulsed uose, allucling to the effect of its pungent (qualities.)

$\$ 1$. Petals white, tuice the length of the calyx; pouls linear; leaves pinnate.

N. officisdte, R. Br. ('Tnte Water-Criss.) Perennial; stems spreading and rooting; leatlets $3-11$, roundish or oblong, nearly entire ; pouls $\left(6-8^{\prime \prime}\right.$ long) ascending on slender widely spreading pedicels. - Hrooks and ditehes; escaped from cultivation. (Nat. from ku.)

$\S 2$. Petals yellow or yellowish, seldom much exceeding the calyx; pods linear, oblong, or even ovoid or globular; leaves mostly pinuntifid.

* Perennial from creeping or subterrancan shoots; flouers ruther large, yellow.

N. SYlvéstre, R. Br. (Yirlow Curss.) Stems ascending; leares pinnately parted, the divisions toothed or cut, lanceolate or linear; pods ( $\frac{t^{\prime}}{2}$ loug) 
on slender pedicels, linear and narrow; bringing the seeds into one row; style very short. - Wet meadows, Mass. to Va.; rare. (Nat. from Eu.)

1. N. sinuàtum, Nutt. Stems low, diffuse; leartes pimately cleft, the short lobes nearly entire, linear-oblong; pods linear-oblong $\left(4-6^{\prime \prime}\right.$ long), on slender pedicels; style slender. - Banks of the Mississippi and westward. June.

* Annual or biennial, rarely perennial (?), with simple fibrous roots; flowers small or minute, greenish or yellowish; leaves someuhat lyrate.

2. N. sessiliflòrum, Nutt. Stems erect, rather simple; leares obtusely incised or toothed, obovate ur oblong; flowers minute, nearly sessile; pods elongated-oblong $\left(5-6^{\prime \prime}\right.$ long), thick; style very short. - W. Ill. to E. Kian., Tenn., and southward. April-June.

3. $\mathbf{N}$. obtùsum, Nutt. Stems much branched, diffnsely spreading; leaves pimately parted or dirided, the divisions roundish and obtusely toothed or repand; flower's mmute, short-pedicelled; pods longer than the pedicels, varying from linear-oblong to short-oval; style short. - With n. 1 and 2.

4. N. palústre, DC. (MARsh Cress.) Stem erect; leares pinnately cleft or parted, or the upper laciniate; the lobes oblong, cut-toothed; pedicels about as long as the small flowers and mostly longer then the oblong, ellipsoid, or ovoid pods; style short. - Wet places or in shallow water; common. June-Sept. - Flowers only $1-1 \frac{1}{2}{ }^{\prime \prime}$ long. Stems $1-3^{\circ}$ high. - The typical form with oblong pods is rare. Short pods and hirsute stems and leaves are common. Var. Híspincy is a form with oroid or globular pods. (Eu.)

§ 3. Petals white, much longer than the calyx; pods ovoid or globular; leaves undivided, or the louer ones pmnatifid; root perennial.

5. N. lacústre, Gray. (Line Cress.) Aquatic; immersed leaves 1-3pinnately dissected into numerous cajillary divisions; emersed leaves oblong, entire, serrate, or pinuatifid; pedicels widely spreading; pods ovoid, 1-celled, a little longer than the style. - Lakes and rivers, N. F. New York to N. J., Minn., and southwestwarl. July - Aug. - Near N. amplibinm.

N. Aruoracri, Fries. (Hormeranisir.) Root-leaves very large, oblong, crenate, rarely pinnatificl, those of the stem lanceolate; fruiting pedicels ascending; podis ylobnlar (seldom formed); style very short. (Cochlearia Armoracia, L.) - Roots large and long; a well-known condiment. Escaped from cultivation into moist ground. (Adv. from Eu.)

\section{B A R B A R A, R. Br. Winter Cress.}

Pod linear, terete or somewhat 4-sided, the valves being keeled by a midnerve. Seeds in a single row in each cell, marginless. Cotyledons accumbent.-Mostly biennials, resembling Nasturtium; flowers yellow. (Anciently called the Herb of St. Barbara.)

1. B. vulgàris, R. Br. (Comyox Winter Cress. Yellow Rocket.) Smooth; lower leaves lyrate, the terminal division round and usually large, the lateral $1-4$ pairs or rarely wanting; upper leaves obovate, cut-toothed, or pixnatifid at the base; pods erect or slightly spreading; or in var. STRICTA, appressed; in var. ARCcÀTA, ascending on spreading pedicels. - Low grounds and roadsides; apparently introduced, but indigenous from L. Superior northward and westward. (Eu.) 
B. I'Rlatox, R. 13r. (EAkLy Wixten C.), with 5-8 pairs of lateral lobes to the leaves, and longer pouls on very thick perlicels, - yet probalily only a variety of the other, - somewhat cultivated from $\mathrm{N}$. Y. southwarel as is winter salad, under the name of Sctrry-Grass, - is beginuing to run wild. (Eu.)

\section{HésPERIS, Tourn. Rocket.}

Pod linear, nearly cylindrical; stigma lobed, erect. Sceels in 1 row in each coll, oblong, marginless. Cotyledons incmubent. - Biennial or peremial, with serrate sessile or petiolate leaves, and large purple flowers. (Name from $\dot{\epsilon} \sigma \pi \epsilon^{\rho} \alpha$, evening, from the evening fragrance of the flowers.)

H. мatвoxalis, I. (1)inL's V́rolit.) 'Tall; leaves lanceolate, acuminate, mostly petiolate; pods $2-4^{\prime}$ long, spreading. - Sparingly naturalized. (Nat. from Eu.)

\section{ERÝ S I M U M, Tourn. Treacle Mustard.}

Pod linear, 4-sirled, the valves keeled with a strong mirlrib; stigma broally lobed. Seeds in 1 row in each cell, ollong, marginless. Cotylectons (often obliquely) in(nmbent. - Chiefly biennials, with yellow flowers; the leaves not clasping. P'nbescence of appressed 2-3-parted hairs. (Name from épúw, to draw blisters.)

1. E. ásperum, DC. (Western WaLl-Flower.) Minutely roughishhoary; stem simple, leaves lanceolate to linear, entire or somewhat toothed; pods nearly erect or widely spreading on short pedicels, elongated ( $3-4^{\prime}$ long), exactly 4-sided; stigma 2-lobed.-Ohio (on limestone cliffs) to Ill., Ark., Dak., and common westward. June, July. - Plant stout, $1-2^{\circ}$ high; the crowded bright orange-yellow flowers as large as those of the Wall-flower. P'etals orbicular, on very slender claws.

2. E. cheiranthoides, L. (Worm-seen Mrstard.) Minutely rough. ish, branching, slender; leaves lanceolate, scarcely toothed; flowers small; pods small and short ( $7-12^{\prime \prime}$ long), very obtusely angled, ascending on slender divergent pedicels. - Banks of streams, Mass. to I'enn., Minu., and northward. July. (Eu.)

3. E. parviflorum, Nutt. Stem erect, often simple; leaves lincaroblanceolate, entire or the lowest coarsely toothed; flowers small ( $3^{\prime \prime}$ long); pods narrow, $1-2 \frac{1}{2}^{\prime}$ long, ascending on short pedicels. - Minn. to Kan. and westward.

\section{S I S ÝM B R I U M, Tourn. Hedge Mustard.}

Pod terete, flattish or 4-6-sided, the valves 1-3-nerved; stigma small, entire. Seeds ol,long, marginless, in 1 or 2 rows in each cell. Cotyledons incumbent. Calyx open. - Flowers small, white or yellow. P'ubescence sprealing. ( $\mathrm{An}$ ancient Greek name for some plant of this family.) Ours are mostly annuals or biemnials.

1. S. hùmile, Meyer. P'erennial, branching from the base, sparingly pubescent, 6' ligh or less; leaves narrowly oblanceolate, mostly coarsely and sharply toothed; flowers white or rose-color: pods very narrow, subterete, 4-9" long, ascending on short pedicels, beaked with a short style, seeds 1-ranked. (Arabis petrea, M/an., not L(um.) - Willoughby Mountain, Vt.: Canada and westward. (X. Asia.) 
2. S. canéscens, Nutt. (Taxsy Mrstard.) Leaves 2-pinnatifid, often hoary or downy, the divisions small and toothed; flowers yellowish, very small; pods in long racemes, oblong-clul-shaped or oblong-linear, shorter than their mostly horizontal perlicels; seeds 2-ranked in each cell. - Penn. and N. Y. to Lake Superior, thence southward and westward. June-Aug.

S. Sóprix, L. A similar hoary species, with decompound leaves; pods slender, 6-15" long, ascending; seeds 1-ranked. - Sparingly naturalized from Europe.

S. officivale, Scop. (Hedge Mustard.) Leares runcinate; flowers verv small, pale yellow; pods awl-shaped, close pressed to the stem, scarcely stalked. - Waste places. May - Sept. - An unsightly branched weed, 2-3 high. (Nat. from Eu.)

S. Thaliava, Gaud. (Movse-ear Cress.) Leaves obovate or oblong, entire or barely toothel; flowers white; pods linear, somewhat 4-sided, longer than the slender spreading perlicels. - Old fields and rocks, Mass. to Kan. April, May. - A span high, slender, branched, hairy at the base. (Nat. from Eu.)

S. Allidria, icop. Stout, erect; leaves reniform to ovate-cordate, coarsely repand-dentate; flowers white; pods tapering, 1-2' long, ascending on very stout spreading pedicels. - Near Georgetown, D. C. (Nat from Eu.)

\section{TH ELY P Ò I U M, Endl.}

Pod terete or teretish; ralves 1-nerved; stigma mostly entire. Seeds in 1 row in each cell, oblong, marginless. Cotyledons obliquely incumbent. Stout biennials or perennials, with mostly large purplish or white flowers. Leaves or petioles often auricled at base. (Name from $\theta \hat{\eta} \lambda u s$, female, and rov́s, foot, the ovary in some species being stipitate.)

1. T. pinnatífidum, Watson. Glabrons $\left(1-3^{\circ}\right.$ high $)$, often branched above; root-leaves rounl or heart-shaped, on slender petioles; stem-leaves auricled, ovate-oblong and ovate-lanceolate $\left(2-6^{\prime}\right.$ long), sharply and often doubly toothed, tapering to each end, the lower into a winged petiole, rarely bearing a pair or two of small lateral lohes; flowers purplish; pods $1-1 \frac{1^{\prime}}{}{ }^{\prime}$ long, on short diverging pedicels, pointed by a short style. (Arabis hesperidoides, Gray.) Alluvial river-banks, W.Pa. to Minn., Mo., and southwestward. May, June.

\section{B R Á S S I C A (Brassica and Sinàpis), Tourn.}

Pod linear or oblong, nearly terete or 4-sided, with a stout 1-seeded beak or a rigid style; ralves $1-5$-nerved. Seeds globose, 1-rowed. Cotyledons incumbent, folded around the radicle. - Annuals or biennials, with yellow flowers. Lower leaves mostly lyrate, incised, or pinnatifid. (The Latin name of the Cabbage. Sinapis is the Greek $\sigma^{\prime} \nu a \pi \imath$, which is said to come from the Celtic nap, a turnip.)

B. Sivapfstrin, Boiss. (or Sixapis arvéxsis, L., the English Ch.irlock), with knotty pods, fully one third ocenpied by a stout 2-erlged beak (which is either empty or l-seeded), the upper leaves barely toothed, is a noxious weed in grain-fields, from $\mathrm{N}$. Eng. to Penn. and $\mathrm{N}$. Y. westward. (Adv. from Eu.)

B. (or Sindpis) Ába. (White Mrstario.) Pods bristly, ascending on spreading pedicels, more than half its length occnpied by the sword-shaped 1seeded beak; leaves all pinnatifid; seeds pale. (Cult. and adv. from Eu.)

B. (or Sixipis) xìgra, Koch. (Black Mustard.) Podls smooth ( $\frac{1}{2}$ long), 4-cornered (the valves only l-nerved), erect on appressed pedicels forming a slender raceme, tipped with a stout persistent style; seeds dark brown, smaller 
and more pungent than in the last; lower leaves with a large terminal lobe and a few small lateral ones. - Tields and waste places. (Adv. from liu.)

B. CAMPÉstris, L., in the form of the RITABAGA and the 'I'LnNir', sometimes persists a year or two in neglected grounds.

\section{CA P SÉLLA, Medic. Shepreris's Purse.}

Pod obcordate-triangular, flattened contrary to the narrow partition; the valves boat-shaped, wingless. Seeds numerous. Cotyledons incurubent. Annuals ; flowers small, white. (Name a diminutive of cripso, a box.)

C. Bursa-Pastòris, Moench. Root-leaves clustered, pinnatifill or touthed; stem-leaves arrow-shaped, sessile. - Waste places; the commonest of weeds. April-Sept. (Nat. from Eu.)

\section{THLÁS PI, Tourn. P'exyicress.}

Pod orbicular, obovate, or ohcordate, flattened contrary to the narrow partition, the midrib or keel of the boat-shaped valves extenderl into a wing. seeds $2-8$ in each cell. Cotylerlons arcumbent. Petals equal. - Low plauts, with root-leares mndivided, stem-leaves arrow-shaped and clasping, and small white or purplish flowers. (Ancient Grcek name, from $\theta \lambda a \dot{\omega}$, to crush, from the flattened pod.)

T. Arvénse, L. (Finild P. or Mithidite Mestard.) A smooth annual, with broadly winged porl $\frac{1^{\prime}}{2}$ in diameter, several sceded, deeply notched at top; style minute. - Waste places; rarely naturalized. (Nat. from Lu.)

\section{LEPÍdI M, Tourn. Peppenwort. Peppergrass.}

Pod roundish, much flattened contrary to the narrow partition; the valves boat-shaped and keeled. Seeds solitary in each cell, pendulous. Cutylerlons incumbent, or in $\mathrm{n} .1$ accumbent! Flowers small, white or greenish. (Name from $\lambda \in \pi i \delta เ \nu$, a little scale, alluding to the small flat poils.)-Ours are annuals or biennials, except the last.

* Leaves all with a tapering base, the upper linear or lanccolate and entire, the lower and often the middle ones incised or pinnatifid; pods orbicular or oval, with a small notch at the top; the style minnte or none; stamens orly 2.

1. L. Virgínicum, L. (Wild Peppergrass.) Cotyledons accumbent and seed minutely margined; pod marginless or obscurely margined at the top; petals present, except in some of the later flowers.-June-Sept. A common roadside weed, which has immigrated from farther south.

2. L. intermèdium, Gray. Cotyledons incumbent as in the following; pod minutely wing-margined at the top; petals usually minute or wanting; otherwise nearly as in n. 1.- Dry places, from western N. Y. and N. 111., north and westward.

L. RLDERALE, I. More diffuse, the smaller and oval pods and the seeds marginless; petals always ranting. - Roadsides, near Boston, Philadelphia, etc.; not common. (Adv. from Eur.)

* * Stem-leaves with a sagittate partly claspmig buse, rather crowded.

L. CAMPÉstre, Br. Minutely soft dou'ny; leaves arrow-shaped, somewhat toothed: pods orute, winged, rongh, the style longer than the narrow notch. Old fields, Mass. and N. Y. to Va.; rare. (Nat. from lin.)

L. DnABA, L. Peremnial, obscurely hoary; leaves oval or oblong, the upper with broad clasping auricles; flowers corymbose; pods hrurt-shaped, wingless, thickish, entire, tipperl with a conspicuous style. - Astoria, near New York, D.C.Eaton. (Adv. from Eu.) - 


\section{SENEBItira, IC. Wart-Cress. Swine-Cress.}

Pod flattened contrary to the narrow partition; the two cells indeliscent and falling away at maturity from the partition as closed nutlets, strongly wriukled or tuberculate, 1-seeded. Cotvledous narrow and incumbently folded transversely. Low and diffuse or prostrate amnuals or bienuials, with minnte whitish flowers. Stamens often only 2. (Dedicated to $J$. Senebier, a distinguished vegetable physiologist.)

S. DfDyma, Pers. Leaves 1-2-pinnately parted; pods notched at the apex, rough-urinkled. - Waste places, at ports, L. Mass. to Va., etc.; an immigrant from farther south.

S. Coroxopis, I) '. Leaves less divided, with narrower lobes; pods not notched at the "ipex, tubercied. - It ports, R. I. to Va., ete. (Adv. from Eu.)

\section{CAKII E, Tourn. SEA-Rocket.}

Pod short, - -jointed across, fleshy, the npper joint separating at maturity ; each indehiscent, 1-celled and 1-seeled, or the lower sometimes scedless. Seed erect in the upper, suspeniled in the lower joint. ('otyledons obliquely accumbent. - Seaside fleshy annuals. Flowers jurplish. (An oll Aralic name.)

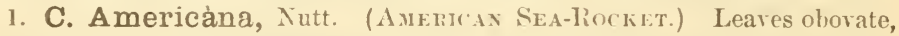
sinuate and tootherl; lower joint of the fruit obovoid, emarginate; the upper ovate, flattish at the apex. - Coast of the Northern Sitates and of the Great lakes. July-sept. - Joints nearly even and fleshy when fresh; the upper one 4 -angled and appearing more beaked when dry.

\section{RÁ P H A N U S, Tourn. Radisr.}

Pods linear or oblong, tapering wjward, indehiscent, several-seeded, continnous and spongy within letween the seerls, or necklace-form ly constriction hetween the sceds, with no proper partition. Style long. Seeds spherical and cotyledons conduplicate, as in Brassica. - Annuals or biennials. (The ancient Greek name from $\rho a$, quickly, and $\phi a i \nu \omega$, to appear, alluding to the rapid germination.)

R. Raphanístrim, L. (Wiln Ranish. Joixten Charlock.) Pods necklace-form, long-beaked; leaves lyre-shaped, rough ; petals yellow, turning whitish or purplish, veiny. - A troublesome weed in fields, E. New Eng. to Penn. (Adv: from Eu.)

\section{Order 11. Capparidacede. (Caper Famiry.)}

Herbs (when in northern regions), with cruriform flowers, but 6 or more not tetradynamous stamens, a 1-celled porl with 2 parietal placenta, and kidney-shaped seeds. - Pod as in C'ruciferre, but with no partition ; seeds similar, but the embryo coiled rather than folded. Leaves alternate, mostly palmately compound. - Often with the acrid or pungent qualities of Cruciferæ (as in capers, the flower-buds of Cápparis spinòsa).

1 Polanisia. Stamens 8 or more Pod many-seeded, not or scarcely stipitate.

2. Cleome. Stamens 6 . Pod linear, many-seeded, long-stipitate.

3. Cleomella. Stamens 6 . Pod rery short, rhomboidal, few-seeded, long-stipitate.

\section{POLA ÍSIA, Raf.}

Petals with claws, notched at the apex. Stamens 8-32, unequal. Receptacle not elongated, bearing a gland behind the base of the ovary. Pod linear 
or oblong, veiny, turgid, many-seeded. - Fetid annuals, with glandular or clammy hairs. Flowers in leafy racemes. (Name from moגús, many, and ăvoos, unequal, points in which the genus differs in its stamens from Cleome.)

1. P. gravèolens, Raf. Leaves with 3 oblong leaflets; stamens about 11 , searcely exceeding the petals; style short; pod slightly stipitate. - Gravelly shores, from Conn. and W. Vt. to Minn. and Kan. June-Aug. - Flowers small (2-3"long); ealyx and filaments purplish; petals yellowish-white.

2. P. trachyspérma, Torr. \& Gray. Flowers larger $\left(4-5^{\prime \prime}\right.$ long), the stamens (12-16) long-exserted; stỵle 2-3" long; pod sessile; seeds usually rough. - Iowa to Kan. and westward.

\section{CLEÒME, L.}

Petals entire, with claws. Stamens 6. Receptacle somewhat produced totween the petals and stamens, and bearing a gland behind the stipitate orary. Pod linear to oblong, many-seeded. - Our species a glabrous annual, with 3 -foliolate leaves, leafy-bracteate racemes, and rose-colored or white flowers. (Name of uncertain derivation, early applied to some mustard-like plant.)

i. C. integrifolia, Torr. \& Gray. Calyx 4-cleft; petals with very short claws, leaflets narrowly laneeolate to oblong; bracts simple; pod oblong to linear, 1-2' long, the stipe as long as the pedicel. - Minn. to Kan. and west. ward; N. Ill. Flowers showy; $2-3^{\circ}$ high.

\section{CLEOMELLA, DC.}

Differing from Cleome in the clawless petals, glandless receptacle, and the short few-seeded pod with more or less distended or even conical valves. Flowers small, yellow. (Name a diminutive of Cleome.)

I. C. angustifolia, Torr. Glabrous, $1-2^{\circ}$ high ; leaflets (3) and simple bracts linear to linear-lanceolate, acute; pod rhomboidal, the valves very bluntly conical; stipe shorter than the pedicel. - Kan. to Tex, and westward.

\section{Order 12. RESEdícede. (Mignonette Family.)}

Herbs, with unsymmetrical 4-7-merous small flowers, a fleshy 1-sided hypogynous disk between the petals and the $(3-40)$ stamens, bearing the latter. Calyx not closed in the bud. Capsule 3-6-lobed, 3-6-horned, 1celled with 3-6-parietal placentce, opening at the top before the seeds (which are as in Order 11) are full yrown. - Leaves alternate, with only glands for stipules. Flowers in terminal spikes or racemes. - A small and unimportant family, of the Old World, represented by the Mignonette (Reseda orlorata) and the Dyer's Weed.

\section{RESE D A, Tourn. Mignonette. Dren's Rocket.}

Petals 4-7, cleft, mequal. Stamens 12-40, on one sile of the flower. (Name from resedo, to calm, in allusion to supposed sedative properties.)

R. Lutèol, L. (DYer's Wren or Welr.) Leaves lanceolate; ealyx 4-parted; petals 4, greenish-yellow; the upper one 3-5-cleft, the two lateral 3-cleft, the lower one linear aind entire; capsule depressed. - Roadsides, N. Y., etc. - Plant $2^{\circ}$ high. Ised for dyeing yellow. (Adv. from Eu.)

R. LÙTEA, L. Leaves irregularly pinuately parted or hipinnatifid; sepals and petals 6, stamens 15-20.-Nantucket, Mass., and ballast-grounds. 


\section{Order 13. CISTÀCEAE. (Rock-rose Family.)}

Low shrubs or herbs, with regular flowers, distinct and hypogynous mostly indefinite stamens, a persistent calyx, a 1-celled $3-5$-valved capsule with as many parietal placenta borne on the middle of the valves, and orthotropous albuminous seeds. - Sepals 5; the two external much smaller, bract-like, or sometimes wanting; the three others a little twisted in the bud. Petals 3 or 5 , convolute in the opposite direction from the calyx in the bud. Anthers short, innate, on slender filaments. Style single or none. Ovules few or many, on slender stalks, with the orifice at the apex. Embryo long and slender, straightish or curved, in mealy albumen; cotyledons narrow. - Leaves simple and mostly entire, the lower usually opposite; and the upper alternate. Inert plants.

1. Helianthemum. Petals 5 , ('wumpled in the bud, fugacions (or none). Stigma nearly sessile. Stamens and ovn'es numerous in the petal-bearing flowers.

2. Hudsonia. Petals 5, fugaciots. Stamens 9-30. Style long and slender. Pod strictly 1-celled, 2-6-seeded. Heath-like.

3. Lechea. Petals 3, persistent. Stamens 3-12. Style none. Pod partly 3-celled, the imperfect partitions bearing broad 2 -seeded placentie.

\section{HEIIÁNTHEMUM, Tourn. Rock-Rose.}

Petals 5, crumpled in the bud, fugacious. Styles short or none in our species; stigma 3-lobed. Capsule strictly l-celled. Embryo curred in the form of a hook or ring. - Flowers in most N. American species of two sorts, viz., primary or earlier ones, with large petals, indefinitely numerous stamens, and many-seeded pods; and secondary, or later ones, which are much smaller and in clusters, with small petals or none, 3-10 stamens, and much smaller 3few-seeded pods. The yellow flowers open only once, in sunshine, and cast their petals by the next day. (Name from $\ddot{\eta} \lambda \iota s$, the sun, and $a \nu \theta \epsilon \mu \nu \nu$, flouer.)

1. H. Canadénse, Michx. (Frost-Weev.) Petal-bearing flowers solitary; the small secondary fluwers clustered in the axils of the leaves, nearly sessile; calyx of the large flowers hairy-pubescent, of the small ones hoary, like the stem and lower side of the lanceolate-oblong leares. - Sandy or gravelly dry soil, Maine to Minu. and southward. June-Aug. - Stems at first simple. Corolla of the large flowers $\mathrm{l}^{\prime}$ wide, producing pods $3^{\prime \prime}$ long; pods of the smaller flowers not larger than a pin's head. A variety is more hoary, and with a stronger tendency to multiply the minute clustered flowers. Late in autumn crystals of ice shoot from the cracked bark at the root, whence the popular name.

2. H. corymbosum, Michx. Flowers all clustered at the summit of the stem or branches, the petal-bearing ones at length on slender stalks; calyx woolly. - Pine barrens, N. J. and southward along the coast.

\section{HU D S Ò I A, L.}

Petals 5, fugacions (lasting but a day), much larger than the calyx. Stamens 9-30. Style long and slender; stigma minute. Pod oblong, enclosed in the calyx, strictly 1-celled, with 1 or 2 seeds attached near the base of each nerve-like placenta. Embryo coiled into the form of a closed hook. - Bushy 
heath-like little shrubs (seldom a foot high), covered all over with the smail awl-shaped or scale-like alternate persistent downy leaves, producing numerous (small but showy) bright yellow flowers crowded along the upper part of the branches. (Named in honor of $\mathrm{H}^{\prime} \mathrm{m}$. Hudson, an early English botanist.)

1. H. ericoides, L. Downy hut greenish; leaves slculcr, awl-shaped, loose; flowers on slender naked stalks; ovary hairy. - Dry sandy suil wear the coast, E. Maine to Va.; N. Conway, N. II. (Miss Minns.) May.

2. H. tomentòsa, Nutt. Iloary witl dowu; leaves oval or narrowly oblong, $I^{\prime \prime}$ long, close-pressed and imbricated; flowers sessile or some shortpeduncled. - Sandy shores, Maine to Md., and along the Great Lakes to Minn.; rarely on banks of streams inland. May, June.

\section{LÉCHEA, Kalm. P'ixwed.}

Petals 3, narrow, flat in the bud, not longer than the calyx, withering-persistent. Stamens 3-12. Style scarcely any; stigmas 3, plumose. I'od globular, partly 3-celled; the 3 broad and thin placenta bone on imperfect partitions, each bearing 2 seeds on the face toward the valve; in our species the placenta curve backward and partly enclose the seeds. Embryo straightish. - Homely perennial herbs, with rery small greenish or purplish flowers, in summer. (Named in honor of John Leche, a Swedish botanist.)

* Pubescence villous, spreading; leaves oblong; flowers very short-pedicelled in cymulose clusters.

1. I. màjor, Michx. Stem upright $\left(1-2^{\circ}\right.$ high $)$, stout, simple, very leafy, producing slender prostrate branches from the base; leaves elliptical, mucronate-pointed, alternate and opposite or sometimes whorled; fluwers densely crowded; pedicels shorter than the very small depressed-globose pod; sepals narrower than its valves. - Sterile grounds ; common, especially southward.

* * Pubescence appressed, leaves narrower; flowers paniculate.

- Leaves comparatively short, broad, and thin; panicles leafy.

2. L. thymifolia, Michx. Erect, abont $2^{\circ}$ high; stem-leaves oval or oblong $\left(3-6^{\prime \prime}\right.$ long), commonly somewhat hairy, some whorled or opposite, those of the rather crowded panicles more linear; pod olovate-globose, one of the narrow outer sejals often longer. (L. Novi-Casarex, Austin.) - Dry grounds near the coast, E. Mass. to Fla.

+ + Leares firmer, narrow, the cauline linear 10 slender-subulate; panicles more naked and racemiform.

* Fruiting calyx globular or broadly ovoud: pod rather large, nearly globose.

3. L. minor, L. Rather strict, $1^{\circ}$ high or more, usually glabrate in age; leaves of radical shoots lanceolate, rigid, $2-3^{\prime \prime}$ long, the cauline linear, 6-9" long; pod about $\mathrm{I}^{\prime \prime}$ high. - Dry and sterile ground; common.

Var. marítima, Gray in herb. Stouter and more rigid; leaves of radical shoots thicker, linear, loary, the cauline puberulent or glabrous ; calyx canescent. (L. thymifolia, Pursh.: L. maritima, Leggett.) - Sandy soil near the coast, Mass. to Ga.

4. L. tenuifolia, Michx. Low, slender and diffuse, minutely pubescent or glabrous; leaves all small and very narrow; tlowers mostly ou very shork 
pedicels, diffusely racemose-paniculate; sepals without lateral ribs; pod ovoidglobose. - Dry, sterile soil, E. Mass. to Mo., and sonthward.

+- Smaller-flowered; fruiting calyx narrower; pod ellipsoidal.

5. L. racemulòsa, Lam. Erect, soft-pubescent when young, soon nearly glabrous; leaves of radical shoots narrowly oblong, the cauline oblong-linear, 4-6" long; inflorescence loose and diffuse; fruiting calyx glabrous. - Dry and rocky soil, Long Island to Ky., and southward.

\section{Order 14. VIOLACEAE. (Violet FAmily.)}

Herbs, with a somewhat irregular 1-spurred corolla of 5 petals, 5 hypogynous stamens with adnate introrse anthers conniving over the pistil, and a 1-celled 3-valved pod with 3 parietal placentce. - Sepals 5, persistent. Petals imbricated in the bud. Stamens with their short and broad filaments continued beyond the anther-cells, and often coherent with each other. Style usually club-shaped, with the simple stigma turned to one side. Valves of the capsule bearing the several-seeded placentæ on their middle; after opening, each valve as it dries folds together lengthwise firmly, projecting the seeds. Seeds anatropous, rather large, with a hard seed-coat, and a large and straight embryo nearly as long as the albumen; cotyledons flat. - Leares alternate, with stipules. Flowers axil. lary, nodding. (Roots slightly acrid or emetic.)

1. Viola. Sepals auricled. Lower petal spurred. Stamens distinet, the 2 lower spurred.

2. Solea. Sepals not auricled. Petals equal in length. Stamens united into a sheath.

3. Ionidium. Sepals not aurieled. Petals very unequal. Filaments distiuct, the anthers merely comnivent.

\section{VIOLA, Tourn. VIOLEt. IIEART'S-EASE.}

Sepals extended into ears at the base. Petals somewhat unequal, the lower one spurred at the base. Nitamens closely surrounding the ovary, often slightly cohering with each other; the two lower bearing spurs which project into the spur of the corolla. Besiles these conspicuous blossoms, which appear in spring, others are produced later (especially in the stemless species), on shorter peduncles or on rumers, usually concealed under the leares; these never open nor develop petals, but are fertilized in the bud, and are far more fruitful than the ordinary blossoms. (The ancient Latin name of the genus.)

$\S 1$. Peremials; stipules never leaf-lite, the lower more or less scarious.

* Stemless, the leares and scapes directly fiom a rootstock or from runners.

+ Stigma large, naked, not beaked; stolons none; rootstock short and thick.

1. V. pedàta, I. (Bın-Foot V.) Nearly smooth; rootstock erect, not scaly; leaves all 3-5-divided, or the earliest only parted, the lateral clivisions 2-3-parted, all linear or narrowly spatulate, sometimes 2-3-toothed or cut at the apex; flower large, $l^{\prime}$ broad, pale or deep lilac-purple or blue. - Sandy or gravelly soil, New Eng. to Minn., and southward. - Var. BfColor, Pursh, a very handsome variety, with the two npper petals deep violet, and as it were velvety, occurs sparingly from Mass. to Md.; most common in Md., on shale. 
+ + Stigma small, naked, often beaked or pointed.

- Rootstock fleshy and thickencd, never filiform nor produring runners; flowers violet or purple (rarely uhite); lateral petals beneded.

2. V. pedatífida, G. 1)on. Leaves all palmately or pedately 5-i-parted; divisions 2-3-cleft; luhes linear; otherwise like n. 3. (V. Iclplinifolia, Natt.) - Rich prairies, or more often in dry poor land, Ill. to Kan. and Minn.

3. V. palmàta, L. (Commox Iheve V.) Gilabrons to villons-julessent; early leaves rommlish-cordate or reniform and merely crenate, the sides rolled inward when young, the later very various, palmately or pedately or hastately lobed or parted, the segments olovate to linear. (V. ('ncullata, var. palmata, Gray.) - Moist or dryish, especially sterile, ground ; very common.

Var. cucullàta, Gray. Later leaves merely crenate, not luberl. (V.cucullata, Ait.) - Low grounds; common everywhere. Both forms are very variable in the size and shape of the leaves and sejals, and in the size and color of the flowers, which are deep or pale violet-blue or purple, sometimes white or variegated with white.

4. V. sagittata, Ait. (Akrow-LEAven V.) Sinoothish or hairy; leaves on short and margined, or the later often on long and naked petioles, varying from oblong-heart-shaped to halberd-shajed, arrow-shaped, oblong-lanceolate or ovate, denticulate, sometimes eut-toothed near the base, the lateral or occasionally all the (rather large purple-blue) petals bearded; spur short and thick ; stigma heaked. - Dry or moist sandy places, New Eng. to Minn., aud southward. Some forms pass into the last.

\section{+ Rootstocks long and filiform, extensively creeping. $=$ Flowers blue or purple.}

5. V. Selkirkii, Pursh. (Great-spurred V.) Small and delicate; the filiform rootstock fibrose-rooted, no runners above ground; smooth, except the round-heart-shaped crenate leaves, which are minutely hairy on the upper surface and have a deep narrowed sinus; spur very large, thickened at the end, almost as long as the beardless pale violet petals. - Damp and shady soil, N. Maine to IV. Mass., central N. Y., I. Superior (Rolbins), and northward ; rare. - Scapes and petioles $1-2^{\prime}$, the leaf $\frac{1}{2}-1 \frac{1}{4}^{\prime}$ long, thin; the s.ur $3^{\prime \prime}$ long. (Eu.)

6. V. palústris, L. (M.ısu V.) Sinouth; leaves rouncl-heart-shaperl and kidney-form, slightly erenate; flowers (small) pale lilac with purple streaks, nearly beardless; spur ver!y short and obtuse. - Alpine summits of the White Mountains, N. II., and high northwari. June. (Гu.)

V. odorAta, L. (Sweet Violet), cultivatel in gardons, from liurope, belongs near this group, and is sparingly spontanens in some places.

$==$ Flowers white (small, short-spurred), mostly with brown-purple veins; lateral petals bearded or beardless. Species apparently confluent.

7. V.blánda, Willd. (Niwet Wut: V.) Commonly glabrous: leaves round-heart-shaped or kiduey-form ; jetals mostly bearlless, the lower st rungly veined. - Damp places, everywhere. Flowers faintly sweet-scentesl.

Var. palustrifórmis, Gray. 'The larger form; upper surface of the leaves sparsely and finely hairy; petals $5 "$ long, oftener bearded, less distinctly veined. - Shaded mossy ground, N. Eng. to Del., and westward. 
Var. renifolia, Gray. Slightly or strongly pubescent with soft spread. ing hairs; leaves round-reniform; petals usually beardless. (V. renifolia, Gray.) - Maine to Mass., western N. Y., Lake Superior, etc.

8. V. primulæfòlia, L. (Primrose-leaved V.) Smooth or a little pubescent; leaves oblong or ovate, abrupt or somewhat heart-shaped at the base; petals often acute, the lateral ones usually sparingly bearded. - Damp or dry soil, N. Eng. to Fla., toward the coast.

9. V. lanceolàta, L. (LAice-leaved Vrolet.) Smooth; leaves lanceolate, erect, blunt, tapering into a long-margined petiole, almost entire; petals beardless. - Damp soil ; common, especially eastward.

$$
===\text { Flowers yellow. }
$$

10. V.rotundifólia, Michx. (Round-Leaved Violet.) Leaves roundovate, heart-sliaped, slightly crenate; lateral petals bearded and marked with brown lines; spur very short. - Cold woods, Maine to Minn., and south along the Alleghanies. - Smoothish; leaves $l^{\prime}$ broad at flowering, increasing to 3 or $4^{\prime}$ in the summer, then lying flat on the ground, shining above.

* * Leafy-stemmed; all perennial with short rootstocks.

+ Low, at first nearly stemless; flowers yellow; stigma concave, bearded.

11. V. Nuttàllii, Pursh. Pubescent or nearly glabrous; leaves ovate to oblong-lanceolate, obtuse, entire or slightly crenate, decurrent on the petiole. - Central Kiansas and westward.

+ + Stems erect, without root-lcaves; stipules entire; spur very short; stigma beakless, pubescent.

+ Stems naked below; flowers yellow.

12. V. pubéscens, Ait. (Dowxy Yellow V.) Softly pubescent (6$12^{\prime}$ high); leaves very broadly heart-shaped, toothed, somewhat pointed; stipules ovate or ovate-lanceolate, large; lower petals reined with purple, capsule oblong to globular, glabrous or tomentose. - Woods, common. - Var. sci. BRísccla, 'Torr. \& Gray, smaller and greener, slightly pubescent $\left(4-10^{\prime}\right.$ high). - R. I. to Ky., and southwestward.

13. V. hastàta, Michx. (Halberd-Leaved V.) Nearly glabrous, slen. der (4-10' high); stem-leaves halberd-shaped or oblong-heart-shaped, slightly serrate, acute; stipules orate, small. - Woods, N. Ohio (near Painesville, Miss shattuck), mountains of Peun., and southward; rare.

+ Stems more leafy and prolonged; flowers white or purplish

14. V. Canadénsis, L. (CAxadi V.) Upright (1-2 high); leares heart-shaped, pointed, serrate; stipules ovate-lanceolate, entire; petals white or whitish inside, the upper ones mostly tinged with violet beneath, the lateral bearded. - Rich woods; common northward and along the Alleghanies. May-Aug.

+++ Stems erect or spreading (at first nearly acaulescent) : stipules fringe. toothed; spur oblong to cylindrical; stigma naked.

15. V.striàta, Ait. (PALE V.) Stems angular, ascending $\left(6-10^{\prime}\right.$ high); leaves heart-shaped, finely serrate, often acute; stipules oblong-lanceolate, large; spur thickish, much shorter than the cream-colored or white petals, the 
lateral ones bearded, the lower striped with purplish lines; stigma beaked. Low grounds, W. New Eng. to Minu. and Mo., and southward in the mountains. April-Oet.

16. V. rostràta, Pursh. (Loxg-spurme I.) Stems ascending (3-6, high); leaves roundish-heart-slaped, serrate, the uppcr acute; stipules lanceolate, large; spur slender ( $\frac{1}{2}$ long), longer thun the pale violet hentelless petals; style straight and slender; stigma terminal, beakless. _ Shaded hillsides, N. New Eng. to Mich., and southward in the Alleghanies; rather rare. June, July.

17. V. canina, L., var. Mublenbérgii, Gray. (Dog $V^{\prime}$.) Low (3-8' high), mostly glabrous; stems ascending, mostly simple, from the lase at length producing creeping branches; leaves heart-shaped, or the lowest killney-form, crenate, th un mprmost slightly pointed; stipules lanceulate; spur cylindrical, half the length of the light violet petals, the lateral ones slightly bearded; stigma beaked. - Damp or wet shady places; common. MayJuly. (Eu.) - Var. púb́́rula, Wratson in herb. Finely puberulent; leaves mostly ovate and acutish with a cordate base, often small; flowers small and mostly cleistogamous. - Sandy or stony slores and islands of Lakes Huron and Superior. (Robbuns, Eugelmann, etc.) - Var. sucticat̀ls, Gray. Depressed and stoloniferous; flowers mostly cleistogamous; leaves small, suborbicular to reniform. - Ky. to Fla. and 'Tex.

\$2. Leaf-bearny thronghout from an annual, biennial, or sometimes short-lived perennal root; the stipules large, leaf-like and lyrate-pinnatifid.

V. tuf́olor, L. (PAxsy. Heart's-ease.) Stem angled and branched; leaves roundish, or the upper oval and the lowest heart-shaped, crenate or entire; petals variable in color or variegated (yellow, whitish, violet-blue and purple); -in var. ARvéxss shorter or little longer than the ealyx. - Dry or sandy soil, N. Y. to Iowa, Kan., and southward; the variety sometimes seeming like a native plant. A pril-sept. (Nat. from Eu.)

\section{S Ò L E A, Spreng., in part. Greex Violet.}

Sepals not prolonged at the base. Petals nearly equal in length, but the lower one larger and gibbous or saceate at the base, more notched than the others at the apex. Stamens completely united into a sheath enclosing the ovary, and bearing a broad gland on the lower side. Sityle hooked at the cummit. - A homely perennial herb, with stems leafy to the top, and 1-3 small greenish-white flowers in the axils, on short recurved pedicels. (Naned in honor of $W$. Sole, author of an essay on the British Mints.)

1. S. cóncolor, Ging. Plant $1-2^{\circ}$ high; leaves oblong, pointed at both ends, entire; pod 1'long. - Woods, N. Y. to Kan., and southward. June.

\section{I O IÍDIU M, Veut.}

Sepals not prolonged at base. I'etals very unequal, the two upper shorter, the lower longest and largest, coneave at hase, contracted in the middle. Filaments distinet, the two lower with a sule-like gland or spur at base; anthers merely connivent. - Pereunials, branching and leafy, with alternate and opposite leaves, and small axillary flowers. (Name from tov, violet, and $\epsilon$ İos, appearance.) 
1. I. polygalæfolium, Vent. Stems low, from a woody base; leaves linear to oblanceolate, or the lower obovate, entire, the stipules leaf-like or small or none; flowers solitary, modding, $2^{\prime \prime}$ long, white. (I. lineare, Torr.) - Kan. and southwestward.

\section{Order 15. CARYOPHyLLACEA. (Pink Family.)}

Herbs, with opposite entire leares, symmetrical 4-5-merous flowers, with or without petals; the distinct stamens no more than twice the number of the sepals, either hypogynous or prerigynous; styles 2-5 (or rarely united into one); secds several or usually mainiy, attached to the base or to the central column of the 1-celled (rarely 3 -5-celled) ind, with a slender embryo coiled or curved around the outside of mealy albumen, in siantitus nearly straight. - Bland herbs; the stems usually swollen at the joints; uppermost leaves rarely alternate. Leaves often united at the base. Calyx persistent. Styles stigmatic along the inside. Seeds amphitropous or campylotropous.

Tribe I. SILENEAE. Sepals united into a tube or cup. Petals (mostly convolute in the bud) and stamens (10) borne on the stipe or stalk of the ovary, the former with slender claws, to the base of which the corresponding tilaments often adhere, included in the calyx-tube. Seeds numerous. - Stipules none. Flowers often large and showy.

* Calyx with scaly bractlets or suall leaves at the base. Seeds flattened on the back, attached by their face; embryo nearly straight.

1. Diantluss. Calyx terete, mostly cylindrical. Styles 2.

* * Calyx naked. Seeds globular or kidney-shaped; embryo curved or coiled.

2. Gypsophila. Calyx top-shaped or campanulate. Pod deeply 4-valved Styles 2.

3. Saponaria. Calyx oblong-cylindrical, obscurely nerved, terete or 5-angled. Pod shortly 4-valved. Styles 2.

4. Silene. Calyx 5-toothed, 10-nerved. Styles 3.

5. Lychnis. Calyx 5-toothed, 10-nerved. Styles 5, rarely 4.

Tribe II. ALSINEAE. Sepals distinct or nearly so, imbricated in the bud. Petals when present without claws, mostly imbricated, and with the stamens inserted at the base of the sessile ovary, or into a little disk. Pod splitting into valves or teeth, several many-seeded. Stamens opposite the sepals, when not nore in number, - Low herbs.

* Stipules none.

- Styles opposite the sepals, or, when fewer, opposite those which are exterior in the bud. 廿 Pod short, splitting into as many valyes as styles; valves often bifid or 2-parted.

6. Arenaria. Petals entire. Styles usually 3. Valves of the pod entire, bifid, or 2-parted.

7. Stellaria. Petals 2-cleft or none. Styles usually 3. Valves bifid or 2-parted.

+ Pod cylindrical, dehiscent by twice as many equal teeth as styles.

8. Holosteum. Petals denticulate or notched. Styles usually 3 . Seeds fixed by the face.

9. Cerastium. Petals notched or 2-cleft. Styles 5 or 4 . Seeds fixed edgewise. + + Styles alternate with the sepals. Stamens as many, or twice as many.

10. Sagina. Petals 4 or 5, entire, or none. Styles 4 or 5. Porl short, 4-5-valved. * Stipules present. Pod short.

11. Buda. Styles 3. Pod 3-valved. Leaves opposite.

12. Spergula. Styles 5. Valves of the pod opposite the sepals. Leaves whorled. 


\section{DIÁNTH U S, I. Pıк. Carsation.}

Calyx crlindrical, nerved or striate, j-toothed, sultended by 2 wr more imbricated liractlets. Stamens 10 . Sityles 2 . I'orl 1-celled, 4-valied alt the apex. Seeds flattish on the back; embryo scarcely ('urvecl. - () ruamental plants, of well-known aspect and value in cultivation. (Name from $\Delta$ ós, of Jujpiter, and ăveos, floucer, i. e., Jove's own flower.)

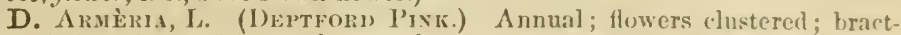
lets of the calyx and lracts lance-aul-form, lierbaceons, downy, as long as the tube ; leaves linear, hairy; petals small, rose-rolor with white dots, erenate. Fields, etc., eastward. July. ( \dv. from En.)

D. PIÓlifes, I. Annial, smooth, slender; flowers clustered; bractlets ovate, dry, concealing the calyx; leaves few, narrow, linear, erect; petals small, pink. - N. J. and E. Penn. (Adv. from Eu.)

D. neltoìns, L. (Maniex P’ixk.) l'erennial; leares slort, narrowly lanceolate, downy and romghish; flowers solitary; bracts ovate, half as long as the tube; petals rose-color or white, toothed. - Mich., L. II. Bailey. (Nat. from Eu.)

D. Barbàtes, I. (SWeet Willan.) I'eremial; flowers fascicled; leaves large, lanceolate; bracts filiform-attenuate, equalling the calyx. - Sparingly spontaneous. (Adv. from Eu.)

\section{GYPSÓPHILA, L.}

Calyx narrowly top-shaped or campanulate, 5-nerved, 5-toothed, naked at hase. Petals not crowned. Stamens 10. Styles 2. Pool 1-celled, 4-valved at the apex, sessile. - Slender glaucons annuls or perennials, with numerous

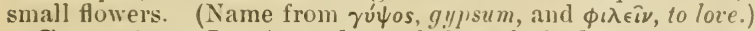

G. munÀis, L. Annual, much liranched; leares very narrowly linear; flowers on slender pedicels, solitary in the forks; calyx turbinate, the teetli short, obtuse; petals purplish, crenate or emarginate. - Sparingly naturalized. (Nat. from Eu.)

\section{S A P O N À R I A, L.}

Calyx narrowly oroid or ollong, 5-toothed, obscurely nerved, naked. Stamens 10. Styles 2. I'od 1-celled, or incompletely 2-4-celled at base, 4-toothed at the apex.-Coarse annuals or peremial, with large flowers. (Name from sapo, soap, the mucilaginons juice forming a lather with water.)

S. OfFICINAlis, I. (SoApwont. BolNciNg Bet.) Fluwers in corymbel clusters; calyx terete; petals crownerl with an appendage at the top of the claw; leaves oval-lanceolate. - Roadsiles, etc. July-Sept. - A stout perennial, with large rose-colored flowers, commonly double. (A dv. from Lu.)

S. Vaccaria, I. Annual, glabrons; flowers in corymbed eymes; calyx 5-angled, enlarged and wing-angled in frnit; petals pile red, not crowneil; leaves ovate-lancerlate. (Vaccaria vulgaris, Host.) - Uceasioually spontaneous. (Adv. from Eu.)

\section{S I L E N E, I. Catchifr. Canion.}

Calyx 5-toothed, 10-many-nerved, naked at the base. Stamens 10 . Styles 3 , rarely 4. I'od 1-celled, sometimes 3-celled at least at the hase, opening ly 3 or 6 teeth at the apex.-Flowers solitary or in cymes. P'etals mostly erowned with a seale at the hase of the blacle. (Name from ola from the viscid exudation on the stems and ralyx of many species. The English name Catchfly alludes to the same peculiarity.)

* Durarf, ulpine, tufled, smooth, percnnial; flowering shoots 1-floucred.

1. S. acaùlio, I. (Moss CAmprox.) 'l'ufted like a moss (1-2' high); leaves linear, crowded ; flower's almost sessile, or rarely on a naked peduncle; 
petals purple or rarely white, notched or entire, crowned. - Alpine summits of the White Mountains, N. H. July. (Eu.)

* Calyx bladdery-inflated; perennial; flowers panicled, white, in summer.

2. S. stellàta, Ait. (Starry CAmpios.) Leaves in whorls of 4 , oratelanreolate, taper-pointed; calyx bell shaped; petals cut into a fringe, rrounless. - Wooded banks, R. I. to Minn., and southward. - Stem $3^{\circ}$ high, with a large and open pyramidal panicle. Corolla $\frac{s^{\prime}}{4}$ broad.

3. S. nivea, Otth. Leaves opposite, lanceolate or oblong, taper-pointed; calyx oblong; petals uedge-form, 2-cleft, minutely crouned. - Penn. to Iowa and Minn.; rare. - Stem $1-2^{\circ}$ high, almost smooth. Flowers few, larger than in the last.

S. Cucubalus, Wibel. (Bladder Campiox.) Glancous; leaves oprosite, orate-lanceolate; calyx globular, much inflated, elegantly veined; petals 2-cleft, nearly crownless. (S. inflata, Smith.) - Fields and roadsides, E. New Eng. to Ill. - A foot high. Flowers loosely cymose. (Nat. from Eu.)

* * Calyx elongated or club-shaped, not inflated except by the enlarging pod; flowers cymose or clustered; perennial, pubescent with viscid hairs, especially the calyx; petals crouned, red or rose-rolor.

4. S. Pennsylvánica, Michx. (Wild Pixk.) Stems low $\left(4-8^{\prime}\right)$; root-leaves uarrowly spatulate, nearly glabrous, tapering into hairy petioles; stem-leaves (2 or 3 pairs) lanceolate; flowers clustered, shortstalked; calyx club-shaped; petals wedge-form, slightly notched and eroded, pink. - Gravelly places, E. New Eng. to N. Y., Ky., and southward. April-June.

5. S. Virgínica, L. (Fire Pixk. Cıтснғцy.) Stems slender $\left(1-2^{\circ}\right.$ high); leaves thin, spatulate, or the upper oblong-lanceolate; flowers few and loosely cymose, peduncled; calyx oblong-cylindrical, soon obconical ; petals oblong, 2-cleft, deep crimson; the limb 1' long. - Open woods, western N. Y. to Minn., and southward. June-Aug.

6. S. règia, Sims. (Roral Catchfly.) Stem roughish, erect $\left(3-4^{\circ}\right.$ high); leaves thickish, ovate-lanceolate, acute; flowers numerous, short-stalked, in clusters, forming a strict panicle; calyx oroid-club-shaped in fruit; petals spatulate-lanceolate, mostly undivided, deep scarlet. - Prairies, Ohio to Mo., and southward. July.

7. S. rotundifolia, Nutt. (Rocrd-Leared Catchflr.) Viscid-hairy ; stems weak, branched, decumbent ( $\left.2^{\circ} \mathrm{long}\right)$; leares thin, round, abruptly pointed, the lower oborate; flowers few, loosely crmose, stalked; calyx elongated; petals 2-cleft and cut-toothed, deep scarlet. - Shaded banks of the Ohio, and in $\mathrm{Ky}$. June-Aug. - Leaves and flowers large.

* * * Caly $x$ not inflated, except by the enlarging pod; annuals.

- Glabrous, a portion of each joint of the stem glutinous; flowers pink.

8. S. antirrhina, L. (SieEry C.) Stem slender $\left(8-30^{\prime}\right.$ high); leaves lanceolate or lincar; flowers small, paniculate; calyx ovoid; petals obcordate, crowned, opening transiently in sunshine.-1) soil; common in waste places. June-Sept.

S. Arvèria, L. (Sweet-Willay Catchfly.) Glaucous; lcaves ovatelanceolate; flowers in flat cymes, open in sunshine; calyx club-shaped; petals notched, crowned with awl-shaped scales. - Escaped from gardens; rare. (Adr, from Eu.) 
+- Viscid-pubescent: flouers white or nearly so, opening at night, sueet-scented.

S. voctúns, L. (Nignt C.) Leaves sliort, the lower spratulate, the upper linear; flowers small, altemate in a 1 -sided spike; petals 2-parted. Introulnced sparingly in l'a., according to schueinitz. (Adr. from lin.)

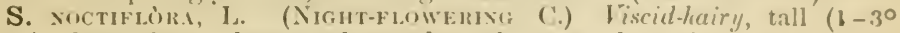
high); lower leaves large and spatulate, the upper lancenlatc: ftonters fer, peduncled; calyx-tube elongaterl (over l' long), soon ovoid, with awl-shajed teeth; petals rather large, 2-parted, crowned. - Cultivated gromuls.

\section{L Ý C H I S, Touru. Cockle.}

Styles 5, rarely 4, and pol opening by as many or twice as many tecth; ctherwise nearly as in silene. ('alyx in one sjecies with leaf-like luhes. (Aneient Greek name for a searlet or flame-colored species, from $\lambda u ́ \chi v o s, a$ light or lamp.)

L. Vespentìn, Sibth. (Eviswo L.) Biennial, usually dicecious, riscidpulsescent, in foliage, ete., like silene nuctiftora; but 5 styles, caly $\mathrm{x}$ unch shorter ( $7-9^{\prime \prime}$ long), with lance-linear teeth, and floners white or pinkish, opening at evening. - ('ult. or waste gromals; scarce. (Adv. from Lin.)

L. nćnxi, Silsth. (RE1, Licusis.) Resembling I. vespertina, lut less viscid, the calyx usually shorter $\left(t-6^{\prime \prime}\right.$ long), and the flowers red, opening in the morning. - harely spontaneons. ( $\Lambda \mathrm{d} v$, from Eu.)

L. Gitñag, Lam: (Com Cockle.) Anmul, (lutled with long soft appressed hair's; Howers long-peduncled; calyx-lobes similar to the long und linear leaves, surpassing the broad and crownless murple-red petuls, falling off in fruit. ( $\Lambda$ grostémma Githago, L.) - In wheat-fields. ( $\Lambda \mathrm{d} v$, from Ku.)

L. Flos-cúceli, L. (RAGGen Robix.) l'erennial, erect, slightly dluwny below, viscid above; leaves narrowly lanceolate; flowers in loose panicles; calyx short, glabrous; petals red, 4-lobed, lobes linear. - Moist or marshy places; New Eng. and N. X. (Adv. from Eu.)

\section{A REN A RIA, I. SiNDwort.}

Sepals 5. Petals 5, entire, sometimes barely notehed, rarely wanting. Stamens 10. Styles 3, rarely more or fewer, opposite as many sepals. Pod short, 8plitting into as many or twice as many valves as there are styles, few - manyseeded. - Low, usually tufted herbs, with sessile exstipulate leaves and small white flowers. (Name from arena, sand, in which many of the species grow.) - The following sections are by many botanists taken for genera.

§ 1. ARENARIA proper. Pod splitting wholly or part-uay down into 3 or at length into 6 ralves; seeds many, naked at the hilum.

A. Serpyllifolda, L. (Thyme-Leaveid SANnwort.) Diffusely branched, roughish $\left(2-6^{\prime}\right.$ high); leares ovate, ac'ute, small; cymes leafy; sepals lanceolate, pointed, 3-5-nerved, about equalling the petals and 6 -tonthed pod. $-\Lambda$ low annual; santy waste places. June-Ang. (Nat. from Eu.)

§ 2. ALsive. Pod splitting to the base into 3 entire valves; sceds many, usually rough, naked at the hilum; flowers solitary und terminal or cymose; root in our species perennial, except in n. 4.

$$
\text { * Leaves small, rigid, aucl-shaped or bristle-shaped. }
$$

1. A. Caroliniàna, Walt. (1'rise-1заликx S.) Densely tufted from a deep perpendicular root; leaves closely imbricated, hut sprealing, aul-shaped, short, channelled; branches naked and minutely glauchlar above, several-flowered; sepals obtuse, ovate, shorter than the pod. (A. squarrosa, M/ichx.) - In pure sand, S. New York, X. J., and southward along the coast. May-July:

2. A. Michaùxii, Hook. f. Erect, or usually diffusely sprealing from a small root, smooth; leaves slender, lietucen aul-shaped and bristle-form, with 
many others clustered in the axils ; cyme diffuse, naked, many-flowered; sepals pointed, 3-ribbed, ovate, as long as the pod. (A. stricta, Mich x.) - Rocks and dry wooded banks, Vt. and Penu. to Minn., Mo., and southwestward. July.

3. A. vérna, L. Dwarf, alpine, densely matted, glabrous or (var. innta) somewhat pubescent, 1-3' high; leaves narrowly linear or awl-shaped; flowers loosely cymose; sepals lanceolate, pointed, 3-nerved, shorter than the pod. - Smuggler's Notch, Vt. (Pringle); north and westward. (Eu.)

* * Leares soft and herbaceons, filiform-linear; petals retuse or notched.

4. A. pátula, Michx. Diffusely branched from the slender root; stems filiform (6-10' long); brauches of the cyme diverging; peduncles long; sepals lanceolate, acuminate, 3-5-nerved. (A. Pitcheri, Nutt.)-S. W. Va. to Ky., Ill., Kan., and sonthward.

5. A. Grœnlándica, Spreng. (Mountais S.) Densely tufted from slender roots, smooth; flowering stems filiform, erect $\left(2-4^{\prime}\right.$ high), few-flowered; sepals oblong, obtuse, neveless. - Summit of the Shawangunk, Catskill, and Adirondack Mountains, N. Y., of the higher mountains of New Eng., and northward; alpine or subalpine. At Bath, Maine, on river-banks near the sea, and near Middletown, Ct. June-Aug. - Leares and peduncles 3-6" long; flowers large in proportion.

§ 3. M(EHRíngIA. Parts of the flouer sometimes in fours; pod as in $\$ 1$, but the young ovary 3-celled; secds rather fex, smooth, with a thickish appendage (strophiole) at the lilum; perennials, with flaccid broadish leaves.

6. A. laterifiora, L. Sparingly branched, erect, minutely pubescent; leaves oval or oblong, obtuse ( $\frac{1}{2}-1^{\prime}$ long) ; peduncles 2-(rarely $3-4-$ ) Howered, soon becoming lateral; sepals oblong, obtuse. - Gravelly shores, etc., New Eng. to Penn., Mlo., Minn., and northward. May, June. (Eu.)

§4. AMMADENIA. Styles, cells of the ovary, and valves of the fleshy pod 3 , rarely 4 or 5 ; seeds feu, smooth, short-beaked at the naked hilum; disk under the ovary more prominent than usual, glandular, 10-lobed; flowers almost sessile in the axils, sometimes diocious or polygamous; root perennial.

7. A. peploides, L. Stems (simple or forking from long rootstocks, $6-10^{\prime}$ high) and ovate partly-clasping leaves ( $8-10^{\prime \prime}$ long) very fieshy. (Honkenya peploides, Ehrh.) - Sands of the sea-shore, N. J. to Maine and northward. June. (Eu.)

\section{STELLARIA, L. Chickweed. Starwort.}

Sepals 4-5. Petals 4-5, deeply 2-cleft, sometimes none. Stamens 8, 10, or fewer. Styles 3, rarely 4 or 5, opposite as many sepals. Pod ovoid, 1-celled, opening by twice as many valves as there are styles, several-many-seeded. Seeds naked. - Flowers (white) solitary or cymose, terminal, or appearing lateral by the prolongation of the stem from the upper axils. (Name from stella, a star, in allusion to the star-shaped flowers.)

* Stems spreading, flaccid, marked longitudinally with one or two pubescent lines; leaves ovate or oblong, $\frac{1}{2}-2 \frac{1}{2}$ long.

S. mèdia, Smith. (Comsox Chickweed.) Annual or nearly so; lower leaves on hairy petioles, petals shorter than the calyx, 2-parted, stamens 3-10. - Everywhere in damp grounds. (Nat. from Eu.) 
1. S. pùbera, Michx. (Great Chickwevd.) Root perennial; leaves all sessile; petals lonyer than the calyx, deeply 2-cleft; stamens 10. - Shaded rocks, Penn. to Ind., and southward. May.

* * Stems erect or spreading; wholly glabrous perennials, with sessile and nar. row or small leares; stamens usually 10, periyynous.

+ Scaly-bracted; petals 2-parted, equalling or surpassing the calyx.

2. S. longifolia, Muhl. (Loxi-LeAven Sitrinwont.) Stem erect, weak, often with rough angles $\left(8-18^{\prime}\right.$ high) ; leaves linear, acntish at both onds, spreading; cymes naked and at length lateral, peduncled, many-flowered, tha slender pedicels spreading; petals 2-parted, longer than the calyx; seeds smooth. - Grassy places; common, especially northward. June, July. (Eu.)

3. S. lóngipes, Goldie. (Loxg-Stakkey S.) Shining or somewhat glancous, very smooth; leares ascending, lanceolate or linear-funceolute, acute, Lroudest at the base, rather rigid; cyme terminal, few-flowered, tho long pedicels strictly erect; petals longer than the calyx; seeds smouth. - Maiue to Minn., rare; common farther north. (Eu.)

S. GRumínA, L. Resembling the last; leaves linear-lanceolate, broadest abore the base; pedicels widely spreading; seeds strongly but minutely rugose. - Becoming rather frequent. (Int. from ku.)

4: S. uliginósa, Murr. (Swamp S.) Stems weak, decumbent or diffuse, at length prolonged, leaving the naked and usually sessile cymes lateral; leaves lanceolute or oblong, veiny; petals and ripe pods as long as the calyx; seeds roughened. - Swainps and rills, MA. to N. Eng., and northward; rare. (Eu.)

+ + Flowers terninal or in the forks of the stem or of leafy branches; bracts foliaceous; petals 2-purted, small or often none; styles 3-4; pod longer than the calyx.

5. S. crassifolia, Ehrh. Stems diffuse or erect, flaccid; leares rather fleshy, varying from linear-lanceolate to oblong; petals longer than the calyx, or wanting; seeds rugose-roughened. - Springy places, eastern Ky. (Short), Ringwood, Ill. (Tasey), and northward. A pril-June. (Eu.)

6. S. borealis, Bigel. (Nontwinx S.) Stems erect or spreading, flaccid, many times forked, at length resolved into a leafy cyme; leaves varying from broadly lanceolate to ovate-oblong; petals $2-5$, shorter thun the calyx, or oftener none: sepals acute; styles usually 4 ; seeds smonth. - Shaded or wet places, R. I. to Minn., and northward. June-Aug. - Var. All'ssrris has the later flowers more eymose, and their bracts small and partly scarious, also the seeds obscurely reticulated or roughish. - Lake Superior, Dr. Robbins. (Eu.)

7. S. humifùsa, Rottb. Spreading or crecping; stems or branches (2' high) 1-3.flowered; leares fleshy, orate or oblon! (2-3"long); petals a little longer than the calyx: seeds smooth. - Northern border of Maine on the St. John's (G.L. Goodale), and high northward. June. (Li.)

\section{HOLÓSTEU M, L. JAGGen CHICKWED.}

Sepals 5. Petals 5, usually jagged or denticulate at the point. Stamens 3-5, rarely 10. Sityles mostly 3. I'od ovoid, 1-celled, many-seeded, opening at the top by 6 teeth. Seeds rongh, flattened on the back, attached by tho inner face. - Anuuals or biennials, with several (white) flowers in an umbel. 


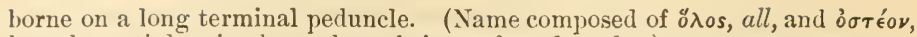
bone, by antiphrasis, these plants being soft and tender.)

H. VMBELLATUM, L. Leaves oblong; peduncle and upper part of the stem glandular-pnbescent; pedicels reflexed after flowering. - Hills around Lancaster, Penn., Prof. Porter, and Morris Co., N.J., C. F. Austin. (Nat. from Eu.)

\section{CER Ás T i U M, L. Mouse-ear Chickweed.}

Sepals 5, rarely 4. Petals as many, 2-lobed or cleft, rarely entire. Stamens twice as many, or fewer. Styles equal in number to the sepals and opposite them. Pod 1-celled, usually elongated, membranaceous, opening at the apex by twice as many teeth as there were styles, many-seeded. Seeds rough. Flowers white, in terminal cymes. Our species liave the petals 2-cleft or obcordate, the parts of the flower always in fives, and the exserted pods more or less curved. (Name from $\kappa$ épas, a horn, alluding to the shape of the pod in many species.)

C. viscossm, L. (Morse-ear Chickweed.) Annual, hairy and rather clammy, nearly erect $\left(4-9^{\prime}\right.$ high) ; leaves orate or obotate to oblong-spatulate; bracts herbaceous; flowers small in close clusters at first; pedicels even in fiuit not longer than the acute sepals; petals shorter than the calyx. (C. vul. gatum, L. Merb., and Man. The names of this and the next were transposed in the Linnaan herbarium, which has caused much confusion. 'They are here applied as originally by Limmeus, and by many recent botanists. Others substitute for this the later name, C. glomeràtum, Thuill.) - Grassy places, eastward and southward; not common. May-July. - Stamens often 5. (Nat. from Eu.)

C. Vulgàtur, L. (LARger M.) Peremial; stems clammy-hairy, spreading $\left(6-15^{\prime}\right.$ long); leaves oblong; upper bracts scarious-margined; flocers larger (sepals $2-3$ " long), at first clustered, the fruiting pedicels longer, the earlier ones mostly much longer than the obtuse sepals; petals equalling the calyx. (C. viscosum, L. Herb., and Man. C. triviàle, Link.)-Fields and copises; common, perhaps indigenous. May-July. (Nat. from Eu.)

1. C. nùtans, Raf. Annual, very clammy-pubescent; stems erect, slender, grooved, diffusely branched $\left(6-20^{\prime}\right.$ high) ; cyme loose and open, manyflowered: lectes oblong-lanceolate, acute, the lowest spatulate; peduncles mostly elongated; petals longer than the calyx; pods nodding on the stalks, curved upward, thrice the length of the calyx. - Moist places, Vt. to Miun., and southward. May-July.

2. C. arvénse, L. (Field Chiскweed.) Perennial; stems ascending or erect, tufted, downy or nearly smooth, slender $\left(4-8^{\prime}\right.$ high), naked and few several-flowered at the summit; leaves linear or narrowly lanceolate; petals obcordate, more than twice the length of the calyx; pods scarcely longer than the calyx. - Dry or rocky places. May -July. (Eu.)

Var. oblongifolium, Holl. \& Britt. Usually taller, pubescent; leaves narrowly or broatly oblong or oblong-lanceolate; pod about twice longer than the calyx. (C. oblongifolium, Torr.) - Rocky places, N. Y. to Minn., and southward. - Var. vılıoscu, Holl. \& Britt. Similar bnt densely villous-pubescent, and the leares lanceolate to ovate-lanceolate. - E. Penn.

\section{SA GIN A, L. Pearlwort.}

Sepals 4 or 5 . Petals 4 or 5 , undivided, or often none. Stamens as many as the sepals, rarely twice as many. Styles as many as the sepals and alternate with them. Pod many-seeded, 4-5-valved to the base; valves opposite 
the sepals. - Little, matted herbs, with threal-like or awl-shaped leaves, no stipules, and small flowers terminating the stems or branches; in summer. (Name from sayma, fattening; previously applied to the spurry.)

* I'arts of the flower in fuurs, rarely with some few in fires.

1. S. procúmbens, L. Annual or pereunial, depressed or spreading on the ground, gliabrous; leaves linear-thread-shajed; aper of the juduncle ofien hooked soon after Howering; petuls shorter than the broadly ovate uhtuse sepuls, sometimes none. - S 'pringy places and clamp rocks, coast of Maine to l'enn. (1ui.)

2. S. apétala, L. Anmual, erect or ascending; leaves ciliate at base or glabruus; petals none or very small ; peduncles aluays erect.-Iry soil, Mass. to P'eun.; scarce, seemingly native? (Eu.)

* * P'urts of the flower in fices, the stumens not rarely 10.

3. S. decúmbens, Torr. \& Gray. Annual, ascending; the peduncles and calyx with the margins of the upper leaves at first glandulur-pulescent; leaves short, often bristly-tipped, not fascicled in the axils; pechncles slencler; petals equalling or shorter than the calyx; pod oblong-ovate, nearly twice lunger than the acutish sepals. (S. subulata, Man., not П imm.) - E. Mass., to 111., Mo., and southward. - Var. Suítun, a sleuder form, apetalons, at least in the later flowers. - Near Philadelphia, in waste ground, and in saudy ficlds at Somers' Point, N. J., C. E. Simith. Seeds minutely roughened.

4. S. nodòsa, Fenzl. P'eremial, tufted, glahrous, or glandular above; stems ascending $\left(3-5^{\prime}\right.$ high $)$; lower leaves thread-form, the upper short and awl-shaped, with minute ones fascicled in their axils so that the branchlets appear knotty, petals much longer than the calyx. - Wet sandy soil, along the coast of Maine and N. H., also Lake Superior, aud northward. (Eu.)

\section{B Ù D A, Adaus. Saxd-Spuriex.}

Sepals 5. Petals 5, entire. Stanens 2-10. Styles and valves of the manyseeded pod 3, very rarely 5 , when the valves alternate with the sepals! Linbryo not coiled into a complete ring. - Low herbs, mostly on or near the sca. coast, with filiform or linear somewhat fleshy opposite leaves, and smaller owes often clustered in the axils; stipules scaly-membranaceous ; fluwering all smmmer. (Named probably for the city so called.) - Genus also known as Tissa, Adins., Shergularia, Presl, and Lepigoxum, Wahlb. The species are very variously understood by European botanists, and are much confused, as well as the synonymy. Our forms are annual, or at the most biennial.

1. B. rubra, Dumort. Nearly glabrous, the summit of the prostrate or ascending slender stems, peduncles, and sepals nsually glandular-pubescent; leaves linear, flat, scarcely fleshy; stipules lanceolate, entire or cleft ; pedicels longer than the bracts; pods and pink-red corolla small ( $\left.1 \frac{1}{2}{ }^{\prime \prime}\right)$, hardly equalling or exceeding the calyx; seeds rough with projecting jwints, semi-ubotate or gibbous-uedge-shaped, uingless. (Spergularia rubra, Presl.) - 1)ry saudy suil, New Eug. to Va., along aud near the const, but rarely marime. (Ku.)

2. B. marina, Dumort. More decidedly fleshy than the preceding, erect or ascending, usually pubescent, with ovate stipules, terete leaves, and pedirels $2-4^{\prime \prime}$ long; sepals usually becoming $2-2 \frac{1}{2}$ " long, little shorter than the 
pod; petals pale; secds obovate-rounded and roughened with points, wingless or narrow-winged. (Spergularia salina, Presl. Tissa marina, Britt.) - Brackish sands, etc., coast of N. Eng. to Va., and southward. A form with smooth seeds is var. leiospérua, N. E. Brown. (S. media, Presl.) (Eu.)

Var. (?) minor, Watson. Small, ascending or decumbent; flowers smaller, on shorter pedicels (rarely $2^{\prime \prime}$ long), the sepals and pod 1-1 $\frac{1}{2}$ "long; seeds wingless, usually papillose. - Coast of N. H. and Mass.

3. B. boreàlis, Watson. Diffusely branched, glabrous; pedicels usually $2-4^{\prime \prime}$ long; petals white; pod ovate, $2^{\prime \prime}$ long, about twice longer than the sepals; seeds usually wingless, smooth or nearly so. (Tissa salina, Britt.) On the coast, E. Maine to Labrador.

\section{SPÉRGULA, L. SpUrRey.}

Stameus 5 or 10 . Styles 5. The 5 valves of the pod opposite the sepals. Embryo spirally annular. Leares in whorls. Otherwise as in Buda. (Name from spargo, to scatter, from the seeds.)

S. Arvéxsis, L. (Corn Sptrrey.) Annual; leaves numerous in the whorls, threarl-shaped ( $1-2^{\prime}$ long); stipules minute; flowers white, in a stalked panicled cyme; seeds rough. - Grain-fields. (Adr. from Eu.)

\section{Order 16. Portulacàceze. (Purslane Family.)}

Herbs, with succulent leaves, and regular but unsymmetrical flowers; viz., sepals fewer than the petals; the stamens opposite the petals when of the same number, but often indefinite; otherwise nearly as Chickweeds.Sepals 2. Petals 5, or sometimes none. Stamens mostly 5-20. Styles $2-8$, united below, or distinct, stigmatic along the inside. Pod 1-celled, with few or many campylotropous seeds rising on stalks from the base. Embryo curved around mealy albumen. - Insipid and innocent herbs, with entire leaves. Corolla opening only in sunshine, mostly ephemeral, then shrivelling.

1. Portulaca. Stamens $7-20$, on the partly adherent calyx Pod opening by a lid.

2. Talinum. Stanens more numerous than the petals, hypogynons Calyx deciduous. Pod many-seedled.

3. Claytonia. Stamens as many as the hypogynous petals, and attached to their base. Calyx persistent. Pod 3-6-seeded.

\section{Por $\mathbf{T}$ u $\mathbf{A} \mathbf{A} \mathbf{A}$, Tourn. Purslane.}

Calyx 2-cleft; the tube cohering with the ovary below. Petals 5, rarely 6 , inserted on the ealyx with the $7-20$ stamens, fugacious. Style mostly 3-8parted. Pod 1-celled, globular, many-seeded, opening transversely, the upper part (with the upper part of the calyx) separating as a lid. - Fleshy annuals, with mostly scattered leaves. (An old Latin name, of unknown meaning.)

P oleracea, L. (Common Ptrslane.) Prostrate, very smooth; leaves obovate or wedge-form; flowers sessile (opening only in sunny mornings); sepals keeled; petals pale yellow; stamens $7-12$; style deeply 5-6-parted; flower-bud flat and acute. - Cultivated and waste grounds; common. Seemingly indigenous west and southwestward. (Nat. from Eu.)

1. P. retùsa, Engelm. Leaves often retuse; calyx-lobes obtuse in the bud; petals small or minute; style shorter, 3-4-cleft; seeds larger, sharply 
tuberculate; otherwise like the last. $-\Lambda$ rk. to Tex. and westward; reported from Kan., Iowa, and Minn.

2. P. pilosa, L. Ascending or spreading, copiously hairy in the axils; leaves linear-subulate, nearly terete, $3-6^{\prime \prime}$ long; petals red or purple. - Kan. to Tex., etc.

\section{TALI N U M, Adans.}

Sepals 2, distinct and free, deciluous Petals 5, ephemeral. Stamens $10-$ 30. Style 3-lobed at the apex. Pod 3-celled at the base when young, 3-valved, with many seeds on a globular stalked placenta. (1)erivation obscure.)

1. T. teretifolium, l'ursh. Perennial; leafy stems luw, tuberous at base; leaves linear, cylindrical; peduncle long (3-6) and naked, bearing an open cyme of pink flowers (2, broad); stannens 15-20. - Serpentine rocks, Penn., to Ind., Minn., and southward. June-Aug.

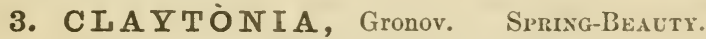

Sepals 2, ovate, free, persistent. Stamens 5, adhering to the short claws of the petals. Style 3-cleft at the apex. Pod 1-celled, 3-valved, 3-6-seeded. Our two species are perennials, sending up simple stems in early spring from a small deep tuber, bearing a pair of opposite leaves, and a loose raceme of pretty flowers. Corolla rose-color with deejer veins, opening for more than one day! (Named in honor of Dr John Clayton, one of our earliest botanists, who contributed to Gronovius the materials for the Flora Virginica.)

1. C. Virgínica, L. Leaves linear-lanceolate, elongated (3-6' long). Moist open woods ; common, especially westward and southward.

2. C. Caroliniàna, Michx. Flowers rather smaller and fewer; leaves spatulate-oblong or oral-lanceolate (1-2' loug). - Maine to Minn., and sonthward along the Alleghanies.

\section{Order 17. ELATINACEAE. (Water-wort Family.)}

Little marsh annuals, with membranacenus stipules betueen the opposite dotless lectes, minute axillary flowers like those of the Chickwcels, but the pod 2-5-celled, and the seeds as in St. Jolnn's-wort. 'The principal genus is

\section{ELATİNE, L. WATER-Wort.}

Sepals 2-4, persistent. Petals $2-4$, hypogynous. Stameus as many, rarely twice as many, as the petals. Styles, or sessile capitate stigmas, 2-4. I'od membranaceous, glohose, 2-4-celled, several-many-seeded, 2-4-valved; the partitions left attached to the axis, or evanescent. Seeds cylindrical, straightish or curved, marked by both longitudinal and transverse lines. - Dwarf glitbrous plants, usually rooting at the nodes, apuatic or terrestrial. (A Greek name for some obscure herb.)

1. E. Americàna, Aru. Tufted, l' high ; leaves obovate, obtuse, 1-3" long; flowers sessile, rarely opening in the aquatic form; sepals, petals, stamens, and stigmas 2, rarely 3 ; seeds 5 or 6 in each cell, rising from the base, marked by 9 or 10 longitudinal lines and 20-30 crossbars. - Margin of ponds, 
etc., N. H. to Ill., Va., and southwestward. Pod very thin and delicate; the seeds large in proportion, straightish.

2. E. triándra, Schkuhr. Leaves oblanceolate or nearly lanceolate; petals and stamens commonly 3 ; seeds more slender, covering the axis Ponds, Ill., Neb., and westward. (Eu.)

3. E. brachyspérma, Gray. Leaves oblong or oval with narrowed base; flowers mostly dimerous; seeds short-oblong, with 6 or 7 longitudinal lines and 10-12 crossbars. - Ill. and southwestward.

\section{Order 18. HYPERICÀCEAE. (St. John's-wort Family.)}

Herbs or shrubs, with opposite entire dotted leaves and no stipules, regular hypogynous flowers, the petals mostly oblique and convolute in the bud, and many or few stamens commonly collected in 3 or more clusters or bundles. Pod 1-celled with 2-5 parietal piacenta, and as many styles, or 3-7-ceiled by the union of the placento in the centre; dehiscence mostly septicidal. Sepals 4 or 5 , imbricated in the bud, herbaceous, persistent. Petals 4 or 5 , mostly deciduous. Styles persistent, at first sometimes united. Seeds numerous, small, anatropous, with no albumen. Embryo cylindrical. Plants with a resinous juice, dotted with pellucid or dark glands, usually smooth. Leaves mostly sessile. Flowers solitary or cymose.

* Petals oblique, convolute, yellow; hypogynous glands none.

1. Ascyrum. Sepals 4 , in 2 very unequal pairs. Petals 4 . Stamens many, distinct.

2. Hypericum. Sepals 5, alike. Petals 5. Stamens usually many and in 3 or 5 clusters. * Petals equal, inibricate, purplish; glands alternating with the 3 stamen-clusters.

๘. Elodes. Sepals and petals 5. Stamens usually 9. Ovary 3-celled.

\section{1. Á SCY R U M, L. St. Peter's-wort.}

Sepals 4 ; the two onter very broad and leaf-like; the inner much smaller. Petals 4, oblique, very deciduous, convolute in the bud. Stamens numerous; the filaments distinct and scarcely in clusters. Pod strictly 1-celled, 2-4valved. - Low, rather shrubby, smooth plants, with pale black-dotted leaves, and uearly solitary light yellow flowers. (An ancient Greek name of some plant, from $\alpha$-, without, and $\sigma$ kípos, roughness.)

1. A. stáns, Michx. (Sт. P'eter's-wont.) Stem rather simple, 2-edged, 1-2 $2^{\circ}$ high, stout; leares oval or ol,ong, someuhat clasping, thickish; flowers showy; outer sepals round-cordate, inner lanceolate; petuls obovate; styles 3 or 4. - Pine barrens, Long Island to Penn., and southward. July, Aug.

2. A. Crux-Ándreæ, L. (St. Avinew's Cross.) Low, much branched and decumbent; leaves narrouly oborate-oblong, contracted at the base, thin; petals linear-oblong: styles 2, very short; pod flat. - Nantucket; pine barrens of N.J. to S. Ill., Neb., and southward. July - Sept. - Petals scarcely exceeding the outer sepals, approaching each other in pairs over them, in the form of a St. Andrew's cross.

\section{H Y PÉRICUM, Tourn. ST. John's-wort.}

Sepals 5, somewhat equal. Petals 5, oblique, convolute in the bud. Stamens commonly united or clustered in 3-5 parcels; no interposed glands. 
Pod 1-celled or 3-5-celled. Seeds usually cylinirical. - Herbs or shruts, with cymose yelluw fluwers. (An ancient Greek name, of ubseure meaning.)

§1. Stumens ver!y mumerous, 5-adelphous; styles 5, united below, the stigmas capitate; poil 5-celled, the placentw turned fur back into the cells; perennial herb; flowers very larye.

1. H. Áscyron, L. (Great St. Jonx's-wort.) Stems $2-5^{\circ}$ high; branches $2-4$-angled; leaves $\left(2-5^{\prime}\right.$ long) ovate-oblong, partly clasping; petals narrowly ohovate ( $1^{\prime}$ long), not deciluous until after they wither; pod g g'long, conical. (II. pyramidatum, Ait.) - Banks of rivers, New Ling. and Penu. to Iowa and Minn. July.

§ 2. Stamens very numernus, obscurely if at all clustered; styles 3 (n. 2 excepted), more or less united into one, the stigmas not capitate except in $\mathrm{n} .10$; sepals mostly foliaceous.

\section{* Bushy shrubs, $1-6^{\circ}$ high, leafy to the top. \\ + Styles 5 ; pod completely 5 -celled.}

2. H. Kalmiànum, L. (Kaly's St. Jonn's-wort.) Branches 4angled; branchlets 2-edged; leaves crowded, glaucous, linear to oblanceolate $\left(1-2^{\prime}\right.$ long); flowers few in a cluster $\left(1^{\prime}\right.$ wide $)$; pocls orate. - Wet rocks, Niagara Falls and northern lakes. Aug.

+ - Styles 3 ; pod completely 3-celled.

3. H. prolíficum, L. (Snвсвиу S'т. Jonx's-wont.) Branchlets 2edged; leaves narrowly oblong ( $1-2^{\prime}$ long), mostly obtuse, narrowed at the base; flowers numerous, in single or compound clusters; pods lanceolate to ovate, 4-6" long. - N. J. to Mich., Minn., and southwarl. July-Sept. Varies greatly in size, etc.

4. H. densiflorum, Pursh. Exceedingly branched above, $1-6^{\circ}$ high, the branches slender and crowled with smaller leaves; flowers smaller $\left(\frac{1}{2}-\frac{2}{3}\right.$ ' in diameter) and more numerous, in crowded compound cymes; pod 2-3" long. (H. prolificum, var. densiflorum, Gray.) - P'ine barreus of N. J. to glades of Ky., Ark., and southward.

* * Perennial herbs or a little uoody at the base.

- Pod incompletely 3-4-celled.

5. H. galioides, Lam. Slender, branching, woody helow; leaves linearollanceolate, narrowerl downward, $\frac{1}{2}-3^{\prime} \operatorname{long}$, mostly acute; flowers small in terminal and axillary eymes; sepals very narrow, $1 \frac{1}{2}-3^{\prime \prime}$ long; pod as lung, ovate. - Del. to Gat. and F. Tenn.

6. H. adpréssum, Barton. Stem simple, herbaceous, from a slightly woody creeping base $(1-20$ high $)$, obseurely 4 -angled below and 2-ailged above ; leaces ascendiny, lanceolate or linear-oblong, often acute, thin; cyme terminal, leafy at the base, few-flowered; sepals linear-lanceolate, pods ovoid-olblong. Moist places, Nantucket and R. I. to Penn., and suthliwestward. July-Aug. - Leaves $1 \frac{1^{\prime}}{2}$ long. Petals bright yellow, $3-5{ }^{\prime \prime}$ long.

$$
\text { + + Pod 1-celled uith } 3 \text { parietal placenta. }
$$

7. H. dolabrifórme, Vent. Stems l,ranched from the decumbent base, woody below $\left(6-20^{\prime}\right.$ high), terete; lcaves lincar-lanceolate, widlely spreading, 
veinless; cyme leafy, few-flowered; sepals oblong or ovate-lanceolate, about the length of the very oblique petals (5-6" long); pods ovate-conical, pointed, the walls very thick and hard. - Dry hills and rocks, barrens of Ky. and Tenn. June-Aug.

8. H. cistifolium, Lam.! Stems mostly simple, herbaceous, with a somewhat woody base, angled with 4 very narrow salient lines $\left(1-2^{\circ}\right.$ high $)$; leaves narrowly oblong to nearly linear $\left(1-3^{\prime}\right.$ long), sessile with a somewhat clasping base; the cyme naked, compound, usually many-flowered; sepals ovate; pods depressed-globular or oroid-conical; seeds large, oblong, very rough-pitted. (H. sphærocarpon, Michx.) - Rocky river-banks, S. W. Ohio, to Iowa and southward. July - Sept. - Flowers small.

9. H. ellípticum, Hook. Stem simple, herbaceous $\left(10-20^{\prime}\right.$ high $)$, obscurely 4-angled; leaves spreading, elliptical-oblong, obtuse, usually narrower toward the subclasping base, thin; cyme nearly naked, rather few-flowered; sepals oblong; pods ovoid, very obtuse; seeds minutely striate. - Wet places, New Eng. and Penn. to Minn., and northward. July, Aug. - Petals light yellow, $3^{\prime \prime}$ long.

10. H. virgàtum, Lam. Stem slender, strict, simple, sharply 4-angled, herbaceous $\left(1-2^{\circ}\right.$ high); leares ascending, opaque, ovate or oblong-lanceolate, acute ( $\frac{1}{2}-1^{\prime}$ long), closely sessile by a broad base; cyme compound, naked, the scattered flowers racemose on its ascending branches; sepals herbaceous, erect, enclosing the oroid pod; styles 3 , separate, with capitate stigmas. (H. angulosum, Michx.) - Wet pine barrens of N.J. and southward; Ky. July - Sept. - Petals copper-yellow, 4-5" long.

§ 3. Stamens very many, in 3 or 5 clusters; styles 3 , separate and usually diverging; pod 3-celled; calyx erect; petals and anthers with black dots; perennials.

H. Perforàtum, L. (Commox St. Jonn's-wort.) Stem much branched and corrmbed, somewhat 2-edged (producing runners from the base); leaves elliptical-oblong or linear-oblong, with pellucid dots; petals (deep yellow) twice the length of the lanceolate acute sepals; flowers numerous, in open leafy cymes. - Fields, etc. June-Sept. - Too well known as a pernicious weed, which it is difficult to extirpate. Juice very acrid. (Nat. from Eu.)

11. H. maculàtum, Walt. Conspicuously marked with both black and pellucid dots; stem terete, sparingly branched; leaves oblong or lance-ovate, the base either obtuse or somewhat clasping; flowers crowded (small); petals pale yellow, much longer than the oblong sepals, styles mostly not longer than the pod. (H. corymbosum, MIuhl.) - Damp places; common. July-Sept. - Leaves larger and flowers much smaller than in the last; petals $2-3^{\prime \prime}$ long, marked with black lines as well as dots. The ordinary northern form differs from the typical southern one in the shorter style and the more oblong less clasping leares.

§4. Stamens 5-12, distinct or in 3 clusters; pod 1-celled, with 3 strictly parietal placentce; styles short, distinct, with capitate stigmas; petals oblong or linear; sepals narrow, erect; slender annuals, with 4-angular branches; flowering all summer.

* Stem simple or loosely branched; leaves linear to ovate, spreading.

12. H. mùtilum, L. Stem flaccid, widely branching $\left(6-20^{\prime}\right.$ high); leaves ovate to narrowly oblong, obtuse, partly clasping, 5-nerved; cymes leafy; 
flowers $2^{\prime \prime}$ broad; pods ovate-conical, rather longer than the calyx. - Low grounds, everywhere.

13. H. gymnánthum, Engelm. \& Gray. Almost simple, with strict stem and branches ( $1-3^{\circ}$ high) ; leaves clasping, heart-shaped, a(ute or obtuse ; cyme naked, the floral leaves rednced to small awl-shaped bracts; in aspect approaching the next. (II. mutilum, var. gymmanthum, (iruy.) - I)el. and Penn. to Minn., and southward.

14. H. Canadénse, L. Stem strict $\left(6-15^{\prime}\right.$ high), with the branches erect; leaves linear, 3-nerved at the base, obtuse; cymes naked; flowers deep yellow, $2-3^{\prime \prime}$ broad when expanded; pods conical-oblong, usually murh longer than the calyx. - Wet, sandy soil ; common. June - ()et. - Var. MAJ's, Gray, is a large form, $1-2^{\circ}$ high, with lanceolate leaves $1 \frac{1^{\prime}}{2}$ long, $3^{\prime \prime}$ wide, the upper acute. L. Superior, Robbins; S. New York and sonthward. - Var. Mмrмuм, Chois., a simple few-flowered form, 1-3' high, with oblong obtuse leaves. On wet rocks, Wisc., and northward.

* Stems fastigiately branched; leaves linear or bract-like, ascending or appressed.

15. H. Drummóndii, Torr. \& Gray. Stem and the mostly alternate bushy branches rigid, erect $\left(10-18^{\prime}\right.$ high) ; leaves linear-subulate, nearly erect, 1-nered (3-9" long); flowers scattered along the upper part of the leafy branches, short-pedicelled; pods ovoid, not longer than the calyx. - W. Ill., lowa, Kan., and southward, in dry soil.

16. H. nudicaùle, Walt. (Uraxge-grass. Pixe-ween.) Stem and bushy branches thread-like, wiry $\left(4-9^{\prime}\right.$ high) ; leaves minute aul-shaped scales, appressed ; flowers minute, mostly sessile and scattered along the erect branches; pods ovate-lanceolate, acute, much longer than the calyx. (II. Sarothra, Michx.) - Sandy fields, N. Eng. to Ill., Mo., and southward; common. June-Oct.

\section{EL Ò D E, Adans. Marsi St. Jonx's-wort.}

Sepals 5, equal, erect. Petals 5, equal-sided, oblong, naked, imbricated in the bud. Stamens 9 (rarely more), united in 3 sets; the sets separated by as many large orange-colored glands. Pod 3-celled, oblong; styles distinct. Perennial herbs, in marshes or shallow water, with small close clusters of flesh-colored flowers in the axils of the leares and at the summit of the stem.

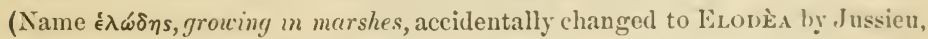
who was followed by I'ursh, etc.)

1. E. campanulàta, Pursh. Leaves closely sessile or clasping by a broad brase, oblong or ovate, very olituse; filaments united below the middle. (L). Virginica, $N^{\prime} u t t$.) - Common in swamps; $1-2^{\circ}$ high. July, Aug.

2. E. petiolàta, I'ursh. Taller, more branching; leates tapering into a short petiole, oblong: filaments united beyond the middle. - From Va. south and westward.

\section{Order 19. TERNSTRQLiIA CEAE. (Tea or Camellia}

\section{FAMIIY.)}

Trees or shrubs, with alternate simple feather-veined leaves, and no stipules, the regular flowers hypogynous and polyandrous, the sepals and petals 
both imbricated in astivation, the stamens more or less united at the base with each other (monadelphous or 3-5-adelphous) and with the base of the petals. - Anthers 2-celled, introrse. Fruit a woody 3-5-celled loculicidal pod. Seeds few, with little or no albumen. Embryo large, with broad cotyledons. - A family with showy flowers, the types of which are the well-known Camellia and the more important Tea Plaxt, - represented in this country by the two following genera.

\section{STUÁRTIA, L.}

Sepals 5, rarely 6, ovate or lanceolate. Petals 5, rarely 6, obovate, crenulate. Stamens monadelphous below. Pod 5-celled. Seeds 1 or 2 in each cell, crustaceous, anatropons, ascending. Embryo straight, nearly as long as the albumen ; radicle longer than the cotyledons. - Shrubs with membranaceous deciduous oblong-ovate serrulate leaves, soft-downy beneath, and large short-peduncled flowers solitary in their axils. (Named for Joln Stuart, Marquis of Bute.)

1. S. Virgínica, Cav. Petals 5, white ( $1^{\prime}$ long); sepals orate; style 1 ; stigma 5-toothed; pod globular, blunt; seeds not margined. - Woods, Va., and southward.

2. S. pentágyna, L'Her. Leaves larger, 5-6' long; sepals acute ; petals often 6 ; styles 5, distinct ; pod angled, pointed ; seeds wing-margined. - Mountains of Ky., Car., and southward.

\section{GORD O N I A, Ellis. Loblolly Bay.}

Sepals 5, rounded, concave. Petals 5, obovate. Stamens 5-adelphous, one cluster adhering to the base of each petal. Style 1. Pod ovoid, 5-valved; the valves separating from the persistent axis; cells $2-8$-seeded. Seeds pendulous. Embryo straightish, with a short radicle, and thin longitudinally plaited cotyledons. - Shrubs or small trees, with large and showy white flowers on axillary perduncles. (Dedicated by Dr. Garden to his "old master, Dr. James Gordon of Aberdeen," and by Ellis to a London nurseryman of the same name.)

1. G. Lasiánthus, L. (Loblolly BAY.) Leaves coriaceous and persistent, lanceolate-oblong, narrowed at the base, minutely serrate, smooth and shining; pod pointed; seeds winged above. - Swamps near the coast, Va. and southward. May-July. - Petals $1 \frac{1}{2}^{\prime}$ long.

\section{Order 20. MALVACEAE. (Mallow Family.)}

Herbs or shrubs, with alternate stipulate leaves and regular flower's, the calyx valvate and the corolla convolute in the bud, numerous stamens monadelphous in a column, and united at base with the short claws of the petals, 1-celled anthers, and kidney-shaped seerls. - Sepals 5, united at base, persistent, often involucellate with a whorl of bractlets forming a sort of exterior calyx. Petals 5. Anthers kidney-shaped, opening along the top. Pistils several, the ovaries united in a ring or forming a severalcelled pod. Seeds with little albumen; embryo curved, the leafy cotyledons variously doubled up. - Mucilaginous, innocent plants, with tough bark and palmately-veined leares. Flower-stalks with a joint, axillary. 
Tribe I. MA I.VEF. Columns of stamens anther-hearing at the top. Ovaries and carpels $5-211$ or more, clusely united in a ring arouma a central axis, from which they separate after ripening.

* Stigmas occupying the inner face of the styles; carpels l-seeded, falling away separately.

1. Athaea. Involucel of 6 to 9 bractlets.

2. Malva. Involucel of 3 bractlets. Petals obcordate. Carpcls rounded, lroakless.

3. Callirrhoe. Involucel of $1-3$ bractlets or none. Petals truncate. Carpels beaked.

4. Napaea. Involucel none Flowers diocious. Stamens few $(15-20)$. Carpels beakless.

* Stignas terminal, capitate; carpels 1 - few-seeded, usually deliscent.

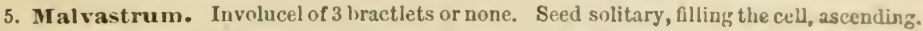

6. Sida. Involucel none. Seed solitary in the cells, pendulous.

7. Sphaeralcea. Bractlets 3 . Seeds 2 or 3 in each cell.

8. Abution. Involucel none. Seeds $3-9$ in each cell.

9. Modiola. Bractlets 3 . Seeds 2 in each cell, with a transverse partition between them.

Tribe II. HIBISCEA. Column of stamens anther-bearing for a considerablo part of its leugth, naked and 5-toothed at the very apex. Pod mostly 5-celled, loculicidal, leaving scarcely any axis in the centre after opening.

10. Kosteletzkya. Involucel of several bractlets. Pod 5-celled, 5-seeded.

11. Hibiscus. Involucel of many bractlets. Pod 5-celled, many-seeded.

\section{A LTH安A, L. Marsh-Mallow.}

Calyx surrounded by a 6-9-cleft involucel. Otherwise as in Malva. (Old Greek and Latin name, from $a \alpha \theta \omega$, to cure, in allusion to its healing properties.)

A. Officinalis, L. (Marsi-Mallow.) Stem erect, $2-4^{\circ}$ high; leaves ovate or slightly heart-shaped, toothed, sometimes 3-lobed, velvety-downy; peduncles axillary, many-flowered; flowers pale rose-color - Salt marshes, coast of N. Eng. and N. Y. Aug., Sept. - Perennial root thick, abounding in mucilage, the basis of the Pâtes de Giuimauve. (Nat. from Eu.)

\section{Má L V A, I. Mallow.}

Calyx with a 3 -leaved involucel at the base, like an outer calrx. Petals obcorlate. Styles numerous, stigmatic down the inner side. Fruit depressed, separating at maturity into as many 1 -seeded and indehiscent round kidneyshaped blunt carpels as there are styles. Radicle pointing downward. ( $\mathrm{An}$ old Latin name, from the Greek name, $\mu \alpha \lambda \alpha \chi_{\chi} \eta$, liaving allusion to the enollient leaves.)

\section{* Flovers fascicled in the axils.}

M. Rotundifólia, L. (Common Mallow.) Stems procumbent from a deep biennial root; leaves round-heart-shaped, on very long petioles, crenate, obscurely-lobed; petals twice the length of the calyx, whitish; carpels pubescent, even. - Waysides and cultivated grounds; common. (Nat. from Eu.)

M. sylvéstris, L. (IItiII M.) Biennial; stem erect, branched $\left(2-3^{\circ}\right.$ high); leaves sharply 5-7-lobed; petals thrice the length of the calyx, large, purple and rose-color; carpels wrinkled-veiny. - Waysides. (Adv. from Eu.)

M. crifsa, L. (Curcen M.) A tull, erect annual, with round and angled toothed and crisped leaves, and small sessile flowers crowded in the axils. Sparingly escaped from old gardens. ( $\Lambda d v$. from liu.)

* *louers only in the upper axils, someuhat racemose or panicalate.

M. Moschita, L. (Misk M.) A low perennial, with the stem-fenves 5-parted, and the divisions once or twice parted or cle $f$ into linear lobes, faintly musky-scented, the flowers rose-color or white ( $1 \frac{1}{2}$ in diameter) on short po duncles crowded on the stem and branches, the fruit downy. - Eseapod from gardens to waysides. ( $(\mathrm{d} \mathrm{r}$. from Eu.) 
M. Alcea, L., with the stem-leaves only once 5-parted or cleft, the lobes incised, large flowers like the last, but the fruit smooth, and bractlets of the involueel ovate, has escaped from gardens. (Adv. from Eu.)

\section{CALLÍRRHOت̈, Nutt.}

Calyx either naked or with a 3-leaved involneel at its base. Petals werlgeshaped and truncate (usually rerl-purple). Styles, ete., as in Malva. Carpels 10-20, straightish, with a short empty beak, separated within from the 1 seeded cell by a narrow projection, indehiscent or partly 2-valved. Radicle pointing downward. (Name drawn from Greek mythology.)

\section{* Involucel 3-leaved.}

1. C. triangulàta, Gray. Hairy-pubescent; stems nearly ereet $\left(2^{\circ}\right.$ high) from a fusiform root; leaves triangular or halberd-sliaped, or the lowest rather heart-shaped, coarsely erenate; the upper incised or 3-5-cleft; flowers panicled, short-pedicelled (purple); involucel as long as the 5-cleft 5-nerved calyx ; carpels not rugose. - Dry prairies, Ind. to Minn., and southward.

2. C. involucràta, Gray. Hirsute or lispid, procumbent; leaves rounded, 5-7-parted or -cleft, the segments ineisely lobed: peduncles elongated, 1-flowered; calyx 5-parted, the lanceolate 3-5-nerved sepals twice as long as the involucel; petals red or purplish, earpels indehiseent, rugosereticulated. - Minn. to Tex.

* Involucel none; calyx 5-parted; carpels strongly rugose.

3. C. alcæoides, Gray. Strigose-pubescent; stems slender (10 high), ereet from a perennial root; lower leaves triangular-heart-shaped, incised, the upper 5-i-parted, laciniate, the uppermost divided into linear segments; flowers (rose-color or white) eorymbose, on slender peduneles. - Barren oaklands, S. Ky. to Kan. and Neb.

4. C. digitàta, Nutt. Sparsely hirsute or glabrous, erect; leaves few, round-cordate, 5-7-parted, the cauline commonly with linear divisions; peduncles subracemose, long, filiform; flowers red-purple to white. - Kan. to Tex.

\section{NA P 㐫 A, Clayt. Glade Mallow}

Calyx naked at the base, 5-toothed. Petals entire. Flouers dixcious; the staminate flowers destitute of pistils, with 15-20 anthers; the fertile with a short column of filaments but usually no anthers. Styles 8-10, stigmatic along the inside. Fruit depressed-globular, separating when ripe into as many kilney-shaped 1-seeded beakless and scarcely dehiscent carpels as there are styles. Radicle pointing downward. $-\Lambda$ tall roughish perennial herb, with very large 9-11-parted lower leaves, the pointed lobes pinnatifid-cnt and toothed, and with small white flowers in panicled clustered corymbs. (Named from $\nu a ́ \pi \eta$, a glade or dell, or, poetically, a nymph of the glades.)

1. N. diòica, L. Stems nearly simple, 5-9 ${ }^{\circ}$ high. - Penn. to Va., and west to Iowa and Minn.; rare. July.

\section{MaLVÁstrum, Gray. False Mallow.}

Calyx with an involucel of 2 or 3 bractlets, or none. Petals notehed at the end or entire. Styles 5 or more; stigmas eapitate. Carpels as in Malva, or 
else as in Sida, but the solitary kidney-shaped seed ascending and the radicle pointing downward, as in the former. (Nitme altered from Malva.)

1. M. angústum, Griy. Annual, slightly hairy, erect $\left(6^{\prime}-10\right.$ high) ; leaves lance-oblong or linear, with seattered fine eallous teeth; flowers in the upper axils, on peduncles shorter than the lroadly ovate-triangular sepals; bractlets and stipules setaceous; petals yellow, searcely exceeding the calyx; carpels 5, kidney-shaped, smooth, at length 2-valved.- W. Teun. to Iowa and lian. Aug.

2 M. coccíneum, Gray. Perenuial, low and hoary; leaves 5-parted or pedate, flowers in short spikes or racemes, the pink-red petals rery much longer than the ealyx; carpels 10 or more, reticulated on the sides and indehiscent. - Miun to IV. Tex., and westward.

\section{S I D A, L.}

Calyx nakerl at the base, 5-cleft. Petals entire, usually oblique. Styles 5 or more, tipperl with capitate stigmas; the ripe fruit separating into as many 1-seeded earpels, which are closed, or commonly 2-ralved at the top, and tardily separate from the axis. Seed pendulons. Embryo abruptly bent; the radicle pointing upward. (A name used by Theophrastus.)

1. S. Napæa, Cav. A smooth, tall ( $4-10^{\circ}$ high) perennial; leaves $3-7$ cleft, the lobes oblong and pointed, toothed; flowers (uhite) umbellate-corymbed, 1 'wide; carpels 10, pointed. - Rocky river-banks, along the Alleghanies, Penn. to Va.; rare. (Cultivated in old gardens.)

2. S. Ellióttii, Torr. \& Gray. A smooth, erect perennial $\left(1-4^{\circ}\right.$ higl $l_{1}$; leaves linear, serrate, short-petioled; peduncles axillary, 1-flowered, short; flowers (yellow) rather large; carpels 9-10, slightly and abruptly pointed, forming a depressed fruit. - Sandy soil, S. Va. and southward. May-Aug.

S. spixòsA, I. Annual weed, minutely and softly pubescent, low $\left(10-20^{\prime}\right.$ high), much branched; leares oicate-lanceolate or oblong, serrate, rather longpetioled; perluncles axillary, 1-flowered, shorter than the petiole; flou irs (yellow) snall; carpels 5, combined into an orate fruit, each splitting at the top into 2 beaks. - $A$ little tuberele at the hase of the leaves on the stronger plants gives the specific name, but it cannot be called a spine. - Waste places, S. New York to lowa, and common southward. (Nat. from the tropics.)

\section{SPH Á RÁ L C E A, St. Ilil.}

Orules anit seeds usually 2 or 3 in each cell. Characters otherwise as in Malvastrum. (Name from $\sigma \phi \alpha \hat{i} p \alpha$, a sphere, aud ảkéa, a mallow-from the commonly spherical fruit.)

1. S. acerifolia, Nutt. Perennial, erect, $2-6^{\circ}$ high, stellately pubescent or glabrate; leaves maple-shaped, 3-7-cleft; flowers clustered in the upper axils aud subspicate, rose-color to white. - Kankakee Co., 11l., E.J. Hill; 1)ak. and westward.

\section{A B ÙT ILON, Tourn. Innux Marlow.}

Carpels 2-9-seeded, at length 2-valved. Radicle ascending or pointing inward. Otherwise as in Silda. (Name of unknuwn origin.)

A. Avicéxxa, Gaertn. (Vervet-Ifiaf.) Tall amual (to high); leaves roundish-heart-shaperl, taper-pointed, velvety; perluncles shorter than the leafstalks; corolla yellow; carpels $12-15$, hairy, beaked. - Wasto places, escaped from gardens. (Adv. from India.) 


\section{MODİ L A, Moench.}

Calyx with a 3-leaved involucel. Petals obovate. Stamens 10-20. Stigmas capitate. Carpels 14-20, kidney-shaped, pointed, and at length 2-valved at the top; the cavity divided into two by a cross partition, with a single seed in each cell. - Humble, procumbent or creeping annuals or biennials, with cut leaves and small purplish flowers solitary in the axils. (Name from modiolus, the broad and depressed fruit resembling in shape the Roman measure of that name.)

1. M. multífida, Moench. Hairy ; leaves 3-5-cleft and incised; stamens 15-20; fruit hispid at the top. - Low grounds, Va. and southward,

\section{KOSTELÉTZKYA, Presl.}

Pod depressed, with a single seed in each cell. Otherwise as Hibiscus. (Named after I: F. Kosteletzky, a Bohemian botanist.)

1. K. Virgínica, Gray. Ronghish-hairy perennial $\left(2-4^{\circ}\right.$ high); leaves halberd-shaped and heart s! t: ped, the lower 3-lobed; corolla 2 ' wide, rosecolor; column slender. - I,wishes on the coast, X. Y. and southward. Aug.

\section{H I B Í S C U S, L. Rose-Mallow.}

Calyx involucellate at the base by a row of numerous bractlets, 5-cleft. Column of stainens long, bearing anthers for much of its length. Styles nuited, stigmas 5, capitate. Fruit a 5-celled loculicidal pod. Seeds several or many in each cell. - Herbs or shrubs, usually with large and showy flowers. ( $\mathrm{An}$ old Greek and Latin name of unknown meaning.)

* Indigenous tall perennials $\left(4-8^{\circ}\right.$ high $)$, flowering late in summer.

1. H. Moscheùtos, L. (Swamp Rose-Mallow.) Leaves ovate, pointed, toothed, the lower 3-lobed, the uppermost oblong-lanceolate, all whitened underneath with a fine soft down, glabrous or slightly downy above; the 1-flowered peduncles sometimes united at the base with the petioles; bractlets not hairy; calyx not inflated; pod and seeds smooth or nearly so. - Brackish marshes along the coast, from E. Mass. southward, and lake shores and swamps westward to Ill. and Mo., especially within the influence of salt springs. - Corolla $5-6^{\prime}$ in diameter, light rose-color or white, with or without a crimson eye.

2. H. lasiocárpus, Cav. Leaves soft-downy both sides, the lower broadly ovate and heart-shaped ; bractlets ciliate; pod hirsute ; - otherwise resembling the last. (H. grandiflorus, Michx.) - Ind. to Mo., and southward.

3. H. militàris, Cav. (Halberd-Leaved R.) Smooth throughout; lower leaves ovate-heart-shaped, toothed, 3-lobed ; upper leaves halberd-form, the short lateral lobes spreading at the base, the middle one prolonged and taper-pointed; peduncles slender; fruiting calyx inflated; seeds hairy. - River-banks, Penn. to Minn., and southward. - Corolla 2-3' long, flesh-color with purple base.

$$
\text { * Escaped from gardens or grounds. }
$$

H. Triònum, L. (Bladner Ketuia.) A low, rather hairy annual; upper leaves 3-parted, with lanceolate divisions, the middle one much the longest; fruiting calyx inflated, membranaceous, 5-winged; corolla sulphur-yellow with a blackish eye, ephemeral; hence the name flower-of-an-hour. (Adv. from Eu.)

H. Syritacus, L. (Shrubbr Alth.eA of gardeners.) Tall shrub, smooth; leaves welge-ovate, pointerl, cut-toothed or lobed; corolla usually rose-color. - Escaped rarely from cultivation, Penn., etc. Sept. (Adv. from Eu.) 


\section{Order 21. TILIACEA. (LMnex Fanily.)}

Trees (rarely herbs), with the mucilaginous properties, fibrous bark; valvate calyx, etc., of the Mallow Eamily; but the sepals deciduous, petals imbricated in the liud, the stamens usually polyalelplons, and the anthers 2-celled. Represented in Northern rerions only by the genus,

\section{Tíli A, Tourn. Iindex. Basswoon.}

Sepals 5. Petals 5, spatulate-oblong. Stamens numerous; filaments coliering in 5 clusters with each other (in European species), or with the base of a spatulate petal-like body placed opposite each of the real petals. I'istil with a 5-celled ovary, and 2 half-anatropous ovules in each cell, a single style, and a 5-toothed stigma. Fruit dry and woody, indehiscent-glohular, becoming 1celled and 1-2-seeded. Embryo in hard albumen; cotyledons broad and thin, 5-luhed, crumpled. - Fine trees, with soft and white wood, very fibrons and tough inner bark, more or less heart-shaped and serrate alternate leaves (ublique and often truncate at the base), deciduous stipules, and small cymes of flowers, hanging on an axillary peduncle which is united to a ligulate membranaceous bract. Flowers cream-color, honey-bearing, fragrant. ('The classical Latin name.)

1. T. Americàna, L. (Basswoon.) Leares large, green and glabrous or nearly so, thickish; floral bract usually tapering at base; fruit oroid. Rich woods. May, June. - Here rarely called Lıme-tree, oftener White-uood, commonly Bassucood; the latter name now obsolete in England.

2. T. pubéscens, $A$ it. Leaves snaller $\left(2-3^{\prime}\right.$ long $)$, thinner, and rather pubescent beneath ; floral bract usually rounded at base; fruit globose, smaller (3" broad). (T. Americana, var. pubescens, Man.) - N. Y. to Fla., and west ward.

3. T. heterophýlla, Vent. (Wuite Basswood.) Leaves larger, smooth and bright green above, silvery-whitened with a fine down underneath. - Mountains of Penn. to S. Inl., and southward.

T. Europies, the Er ropean LiNDEx, several varieties of which are planted in and near our cities for shade, is at once distinguished from any native species by the ahsence of the petal-like scales annong the stamens. This tree (the Lin) gave the family name to Linnerus.

\section{Order 22. LINÁCEAE, (Flax Famir.)}

Herbs (rarely shrubs) with the regular and symmetrical hypngynous flowers 4-6-merous throughout, strongly imbricated calyx and connolute petals, 5 stamens monadelphous at base, and an 8-10-seeded pod, having twice as many cells as there are styles. Representel by the genus,

\section{LI N UM, Tourn. FLAx.}

Sepals (persistent), petals, stamens, and styles 5, regularly alteruate with each other. Pod of 5 united carpels (into which it splits in dehiscence) and 5 -celled, with 2 seeds hanging from the summit of each cell, which is partly or completely divided into two by a false partition projecting from the back of the carpel, the pod thus becoming 10-celled. Seeds anatropons, mucilaginous, flattened, 
containing a large embryo with plano-convex cotyledons. - Herbs, with tough fibrous bark, simple and sessile entire leaves (alternate or often opposite), without stipules, but often with glands in their place, and with corymbose or panicled flowers. Corolla usually ephemeral. (The classical name of the Flax.)

* Flowers rather small, yellow; glabrous, $1-2^{\circ}$ high.

1. I. Virginianum, L. Stem erect from the base and with the corymbose spreading or recurving branches terete and even; no stipular glands; leaves oblong or lanceolate, or the lower spatulate and often opposite; flowers scattered, small (barely $3^{\prime \prime}$ long); sepals ovate, pointed, smooth-edged or nearly so, equalling the depressed 10-celled pod; styles distinct. - Dry woods; common. - Root apparently annual; but the plant propagates by suckers from the base of the stem.

I. Floridixum, Trelease, of rather stricter habit and the pods broadly ovate and obtuse, appears to have been found in S. Ill.

2. L. striàtum, Walt. Stems gregarious, erect or ascending from a creeping or decumbent base, slightly viscid, and with the mostly racemose short branches striate with about 4 sharp wing-like angles decurrent from the leaves; these broader than in the last, and mostly oblong, usually with all the lower ones opposite; flowers more crowded; sepals scarcely equalling the very small subglobose brownish pod; otherwise nearly as n. i. - Wet or boggy grounds, E. Mass. to Lakes Ontario and Huron, Ill., and southward.

3. L. sulcàtum, Riddell. Stem strictly erect from an annual root, and with the upright or ascending branches wing-angled or grooved; leares alternate, linear, acute, the upper subulate and glandular-serrulate; a pair of dark glands in place of stipules; sepals orate-lanceolate and sharp-pointed, strongly 3-nerved and with rough-bristly-glandular margins, scarcely longer than the oroid-globose incompletely 10-celled pod; styles united almost to the middle.-Dry soils, E. Mass. to Minn., and southwestward. - Flowers and pods twice as large as in the preceding.

4. L. rigidum, Pursh. Glaucous, sometimes slightly puberulent, often low and cespitose, the rigid branches angled; leaves narrow, erect, usually with stipular glands; flowers large; sepals lanceolate, glandular-serrulate; styles united; capsule ovoid, 5-ralved. - Minn. to Kan., and southward.

$$
\text { * Flowers large, blue. }
$$

5. L. perénne, I., var. Lewísii, Eat. \& Wright. Perennial, glabrous and glaucous, $1-3^{\circ}$ high; leaves linear, acute; flowers rather few on long peduncles; sepals obtuse or acutish, not glandular-serrulate; styles distinct; ipod orate. - Minn. to Neb., and westward. (Eu., Asia.)

L. esitatfssimum, L. (Common Flax.) Annual; stem corymbosely branched at top; sepals acute, ciliate. - Occasionally spontaneous in fields. (Adv. from Eu.)

\section{Order 23. GeraniàceAe. (Geraxium Famim.)}

Plants (chiefly herbs) with perfect and generally symmetrical hypogynous flowers; the stamens, counting sterile filaments, as many or commonly twice as many, and the lobes or cells (1-few-ovuled) of the orary as many, as the sepals, the axis of the dry fruit persisting. - Seeds without albumen 
except in Oxalis. Flowers mostly 5-merons and the sepals usually distinct. Leaves never punctate. An order not easily defined, and including several strongly marked tribes or suborders which have been regarded by many botanists as distinet.

Tribe I. GERANíc. (Geranium Family pmper.) Flowers regular, 5-memns, the sepals inbricate in the bud, persistent. Glamls of the disk 5, alternate with the petals. Stamens somewhat united. Ovary deeply lobed; carpels 5, 2-ovuled, 1-seeded, separating clastically with their long styles, when mature, fronı the elongated axis. Cotyledons plicate, incumbent on the radiele. - Herbs (our specios) with more or less lobed or divided leaves, stipules, and astringent roots.

1. Geranium. Stamens with anthers 10, rarely 5. The recurving bases of the styles or tails of the carpels in fruit naked inside.

2. Erodium. Stamens with anthers only 5. Tails of the carpels in fruit bearded inside, often spirally twisted.

Tribe II. LIMNÁNTHEzE. Flowers regular, 3-merous (in Florkea), the persistent sepals valvate. Glands alternate with the petals. Stamens distinct. Carpels nearly distinct, with a cominon style, 1-ovuled, 1-seeder, at length fleshy and indehiscent, not beaked, separating from the very short axis. Emhryo straight; cotyledons very thick ; radicle very short. - Low tender annuals, with alternate pinnate leaves and no stipules.

3. Fløerkea. Sepals, minute pistils, and lobes of the ovary 3 ; stamens 6 .

Tribe III. OXALÍIERE. (Sorrel FAmily) Flowers regular, 5-merous, the persistent sepals imbricate. Glands none. Stamens 10, often united at base. Stigmas capitate. Fruit a 5-celled loculieidal pod (in Oxalis); cells 2-several-seeded. Embryo straight, in a little fleshy albumen.-Leaves compound (3-foliolate in our species): juice sour.

4. Oxalis. Styles 5, separate. Pod oblong; the valves not falling away. Leaflets usually obcordate.

Tribe IV. BALSAMÍnEAE. (BALSAM FAmily.) Flowers irregular (5-metous as to the stamens and pistil), the petals and colored sepals fewer in number, deciduous, the larger sepal with a large sac or spur. Glands none. Stamens 5, distinct, short. Fruit a fleshy 5-celled pod (in Impatiens); cells several-seeded. Embryo straight. - Tender and very succulent herbs, with simple leaves and no stipules.

5. Impatiens. Lateral petals unequally 2-lobed. Pod bursting elastically into 5 valves.

\section{G E R À N I U M, Tourn. Craxesille.}

Stamens 10 (sometimes only 5 in n. 3), all with perfect anthers, the 5 longer with glands at their base (alternate with the petals). Styles smooth insille in fruit when they separate from the axis. - Stems forking. Peduncles $1-3$ flowered. (An old Greek name, from $\gamma$ épavos, a crane; the long fruit-bearing beak thought to resemble the bill of that biril.)

$$
\text { * Rootstock perennial. }
$$

1. G. maculàtum, I. (Wiln Craxesbill.) Stem erect, hairy; leaves about 5-parted, the werlge-shaped divisions lobed and ent at the end; sepals slender-pointed; petals entire, light purple, bearled on the claw ( $\frac{\frac{1}{}^{\prime}}{}$ long). Open woods and fields. April-July.-Leaves somewhat blotehed with whitish as they grow old.

$$
\text { * Root biennial or annual; flowers small. }
$$

- Leaves ternately much-dissected; heavy scented.

2. G. Robertiànum, L. (Herr Rojert.) Sparsely hairy, diffuse, strong-scented; leaves 3-divided or pedately 5-divided, the divisions twice pin- 
natifid; sepals awned, shorter than the (red-purple) petals; carpels wrinkled; seeds smooth. - Moist woods and shaded ravines; N. Eng. to Mo., and northward. June-Oct. (Eu.)

$$
\text { +- Leaves palmately lobed or dissected. }
$$

3. G. Caroliniànum, L. Stems at first erect, diffusely branched from the base, hairy ; leaves about 5-parted, the divisions cleft and cut into numerous oblong-linear lobes; peduncles and pedicels short; sepals awn-pointed, as long as the emarginate (pale rose-colored) petals ; carpels hairy ; seeds ovoid-oblong, very minutely reticulated. - Barren soil and waste places; common. May Aug. - Depauperate forms, except by the seeds, are hardly distinguishable from

G. DisséctuM, L. More slender and spreading, with narrower lobes to the crowded leaves, and smaller red-purple petals notched at the end; seeds shoit-ovoid or globular, finely and deeply pitted. - Waste grounds, rare. (Nat. from Eu.)

G. rotusifólum, L. With the habit of the next but the fruit and seed of the last; villous with long white hairs tipped with purple glands; leares short-lobed. - Rare. (Nat. from Eu.)

G. Pesíllcy, L. Stems procumbent, slender, minutely pubescent; leaves rounded kidney-form, 5-7-parted, the divisions wedge-shaped, mostly 3-lobed; sepals awnless, about as long as the (purplish) petals; stamens 5 ; fruit pubescent; seeds smooth. - Waste places, Mass. to Penn.; rare. (Nat. from Eu.)

G. мólLE, L. Like the last; more pubescent; flowers dark purple; sta. mens 10 ; carpels transversely wrinkled; seed slightly striate._Occasionally spontaneous. (Nat. from Eu.)

G. Columbixum. (Loxg-Stalked C.) Minutely hairy, with yery slender decumbent stems; leares 5-7-parted and cut into narrow linear lobes; peduncles and pedirels filiform and elongated; sepals awned, about equalling the purple petals, enlarging after flowering; carpels glabrous; seeds nearly as in G. dissectum. - Rarcly introduced; Penn. and southward. June, July. (Nat. from Eu.)

G. Sibfricrm, I. Slender, repeatedly forked, short-villons; leaves 3-cleft with serrate divisions; flowers inll-white, mostly solitary ; sepals awned; seeds minutely reticulate. - Rare. (Nat. from Eu.)

\section{ER Ò I U M, L’Her. Storksbill.}

The 5 shorter stamens sterile or wanting. Styles in fruit twisting spirally, bearded inside. Otherwise as Geranium. (Name from é $\rho \omega \delta$ เós, a heron.)

E. cictótariur, L'Her. Annual, hairy; stems low, spreading; stipules acute; leares pinnate, the leaflets sessile, 1-2-pinnatifid; peduncles sereralflowered. - N. Y., Penn., ete. ; scarce. (Adr. from Eu.)

\section{FLof́kEA, Willd. False Mermaid.}

Sepals 3. Petals 3, shorter than the calyx, oblong. Stamens 6. Ovaries 3, opposite the sepals, united only at the base; the style rising in the centre; stigmas 3. Fruit of 3 (or $1-2$ ) roughish fleshy achenes. Seed anatropous, erect, filled by the large embryo with its hemispherical fleshy cotyledons. A small and inconspicuous annual, with minute solitary flowers on axillary peduncles. (Named after Floerke, a German botanist.)

1. F. proserpinacoides, Willd. Leaflets 3-5, lanceolate, sometimes 2-3-cleft. - Marshes and river-banks, W. New Eng. to Penn., Ky., Wisc., and westward. April-June. Taste slightly pungent. 


\section{4. ÓXALIS, I. Wonthiorrel.}

Sepals 5, persistent. Petals 5, sometimes united at base, withering after expansion. Stamens 10, usually monadelphous at base, alternately shorter. Styles 5, distinct. l'od oblong, membranaceous, 5-celled, more or less 5-lobed, each cell opening on the back; valves persistent, being fixed to the axis by the partitions. Seeds 2 or more in each cell, penduluns from the axis, anatropons, their outer coat loose and separating. Embryo large and straight in fleshy albumen; cotyleslons flat. - Herls, with sour watery juice, alternate or radical leaves, mostly of 3 obcordate leaflets, which close and droop at nightfall. Several species produce small peculiar flowers, precociously fertilized in the bud and particularly fruitful; and the ordinary flowers are often dimorphous or even trimorphous in the relative length of the stamens and styles. (Name from ỏ ús, sour.)

* Stemless perennials; leaves and scapes arising from a rootstock or bulb; leaflets broadly obcordate; flowers nearly l' broad; cells of the pod fcw-seeded.

1. O. Acetosélla, L. (Соммon Woon-Sorrex.) Rootstock creeping and scaly-toothed; scape 1-flowered $\left(2-5^{\prime}\right.$ high); petals white with redllish veins, often notched. - Deep cold woods, Mass. to l'enn., L. Superior, and northward; also southward in the Alleghanies. June. (Eu.)

2. O. violàcea, L. (Violet W.) Nearly smooth; bulb scaly; scapes umbellately several-flowered (5-9' high), longer than the leaves; petals viulet. - Rocky places and open woods; most common southward. May, June.

* * Stems leafy, branching; peduncles axillary; flowers yellow; cells several. secded.

3. O. corniculàta, L. (Yellow WV.) Annual or perennial by running subterranean shoots, erect or procumbent, strigose-pubescent; stipules round or truncate, ciliate; peduncles 2-6-flowered, longer than the leaves; porls elongated, erect in fruit. - Rare; on ballast, etc.; indigenous in Mo. (Bush), and southwestward. (Cosmopolitan.)

Var. strícta, Sav. Stem erect, somewhat glabrous to very villous; stipules none. (O. stricta, L.) - Common. May - Sept. Varies greatly.

4. O. recúrva, Ell. Like var. stricta of n. 3 ; leaflets larger $\left(\frac{1}{2}-1 \frac{1}{2}^{\prime}\right.$ broad), usually with a brownish margin; flowers larger $\left(6-8^{\prime \prime}\right.$ long). - Peun. to S. Ill., and sonthward.

\section{IMPÀTIENS, L. BALSAM. JEWEL-WEED.}

Calyx and corolla colored alike and not clearly distinguishahle. Sepals apparently only 4 ; the anterior one notehed at the apex and probahly consisting of two combined; the posterior one (appearing anterior as the flower hangs on its stalk) largest, and forming a spurred sac. l'etals 2, nnequalsided and 2-lobed (each consisting of a pair united). Stamens 5, short; filaments appendaged with a scale on the inner side, the 5 scales connivent and uniter over the stigma; anthers opening on the inner face. Ovary 5-celled; stigma sessile. Pod with evanescent partitions, and a thick axis hearing several anatropous seeds, 5-valved, the valves coiling elastically and projecting the seeds in bursting. Embryo straight; albumen nowe. - Leaves simple, alternate, without stipules, in our species ovate or oval, coarsely toothed, peti- 
oled. Flowers axillary or panicled, often of two sorts, viz., - the larger ones, which seldom ripen seeds; - and very small ones, which are fertilized early in the bud; their floral envelopes never expand, but are forced off by the growing pod and carried upward on its apex. (Name from the sudden bursting of the pods when touched, whence also the popular appellation, Touch me-not, or Snap-weed.)

1. I. pállida, Nutt. (PALE Tozch-мe-хот.) Flowers pale-żellow, sparingly dotted with brownish-red; sac dilated and very obtuse, broader than long, tipped with a short incurved spur. - Moist shady places and along rills, in rich soil; most common northward. July-Sept. - Larger and greener than the next, with larger flowers, and less frequent.

2. I. fúlva, Nutt. (Spotted Tovch-мe-xot.) Flowers orange-color, thickly spotted with reddish-brown; sac longer than broad, acutely conical, tapering into a strongly inflexed spur half as long as the sac. - Rills and shady moist places ; common, especially southward. June - Sept. - Plant $2-4^{\circ}$ high; the flowers loosely panicled, hanging gracefully on their slender nodding stalks, the open mouth of the cornucopiæ-shaped sepal upward. Spur rarely wanting. Spotless forms of both species occur.

\section{Order 24. rutaceAe. (Rue Family.)}

Plants with simple or compound leaves, dotted with pellucid glands and abounding with a pungent or bitter-aromatic acrid volatile oil, producing hypogynous almost always regular 3-5-merous flowers, the stamens as many or twice as many as the sepals (rarely more numerous); the 2-5 pistils separate or combined into a compound ovary of as many cells, raised on a prolongation of the receptacle (gynophore) or glandular disk. - Embryo large, curved or straight, usually in fleshy albumen. Styles commonly united or cohering, even when the ovaries are distinct. Fruit usually capsular. Leaves alternate or opposite. Stipules none. - A large family, chiefly of the Old World and the southern hemisphere; our two indigenous genera are

1. Xanthoxylum. Flowers diœcious; ovaries $3-5$, separate, forming fleshy pods.

2. Ptelea. Flowers polygamous; ovary 2-celled, forming a samara, like that of Elm.

\section{XANTHÓ XYUUM, L. Prickly Ash.}

Flowers diœcious. Sepals 4 or 5, obsolete in one species. Petals 4 or 5, imbricated in the bud. Stamens 4 or 5 in the sterile flowers, alternate with the petals. Pistils 2-5, separate, but their styles conniving or slightly united. Pods thick and fleshy, 2-ralred, 1-2-seeded. Seed-coat crustaceons, black, smooth and shining. Embryo straight, with broad cotyledons. - Shrubs or trees, with mostly pinnate leares, the stems and often the leafstalks prickly.

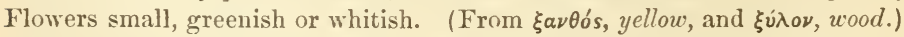

1. X. Americànum, Mill. (Northery Prickly Ash. TootincheTREE.) Leaves and flowers in sessile axillary umbellate clusters; leaflets 2-4 pairs and an odd one, orate-oblong, downy when young; calyx none; petals 4-5; pistils $3-5$, with slender styles; pods short-stalked. - Rocky woods and river-banks; common, especially northward. April, May.-A shrub, with 
yellowish-green flowers appearing before the leaves. Bark, leaves, and pods very pungent and aromatic.

2. X. Clàva-Hérculis, I. (Sovtuenx I'.) Glahrous; leaflets 3-8 pairs and an odd one, ovate or ovate-lanceolate, oblique, shining aluve; flowers in an ample terminal cyme, appearing after the leaves; sepals aud petals 5 ; pistils 2-3, with short styles; pods sessile. (X. Carolinianmn, I am.) Sandy coast of Virginia, and southward. June. $-\Lambda$ small tree with very sharp prickles.

\section{PtèteA, T. Survbir Trefoll. Hop-tree.}

Flowers polygamons. Sepals 3-5. Petals 3-5, imbricaterl in the bud. Stamens as many. Ovary 2-celled; style short; stigmas 2. Fruit a 2-celled and 2-seeded samara, winged all round, nearly orbicular. - Shrubs, with 3-foliolate leaves, and greenish-white small flowers in compound terminal cymes. (The Greek name of the Elm, here applied to a genus with similar fruit.)

1. P. trifoliàta, L. Leaflets uvate, pointed, downy when young. Rocky places, Long Island to Minn., and sonthward. June. - A tall slirub. Fruit bitter, used as a substitute for hops. Odor of the flowers disagreealle.

Ailánthus glandulósus, Desf., called Tree of Heavex, - but whose blossoms, especially the staminate ones, are redolent of anything but "airs from hearen," - is much planted as a shade-tree, especially in towns, and is inclined to spread from seed. It belongs to the order Simarubaces, wlich differs from Rutacex in the absence of dots in the leaves. The tree is known by its very long pinnate leaves of many leaflets, and small polygamous grecnish flowers in panicles, the female producing 2-5 thin, linear-oblong, reiny samaras. (Adv. from China.)

\section{Order 25. ILICINEAE. (Holly Family.)}

Trees or shrubs, with small axillary 4-8-merous flou'ers, a minute calyx free from the 4-8-celled ovary and the 4-8-seeded berry-like ilrupe: the stamens as many as the divisions of the almost or quite 4-8-petallal corolla and alternate with them, athacherl to their very base. - Corolla imbriented in the bud. Anthers opening lengthwisc. Stigmas 4-8, or united into one, nearly sessile. Seeds suspended and solitary in each cell, anatropous, with a minute embryo in fleshy allumen. Leaves simple, mostly alternate. Flowers white or greenish. $-\Lambda$ small family, nearly related to the Gamopetalous order Ebenacece.

1. Ilex. Petals or corolla-lobes oval or obovate. Pedicels mostly clustered.

2. Nemopanthes. Petals linear. l'erlicels solitary.

\section{1. İLEX, L. Holly.}

Flowers more or less diøeciously polygamous. Calyx 4-6-toothed. l'etals 4-6, separate, or united only at the base, oval or obovate, obtuse, spreading. Stamens 4-6. The berry-like drupe containing $4-6$ little nutlets. - Leaves alternate. Fertile flowers inclined to be solitary, and the sterile ur partly 
sterile flowers to be clustered in the axils. (The ancient Latin name of the Holly-Oak, rather than of the Holly.)

$\S 1$. AQUIFÒLIUII. Parts of the flower commonly in fours, sometimes in fives or sixes; drupe red, its nutlets ribbed, veiny, or 1-grooved on the back; leaves (mostly smooth) coriaceous and evergreen.

\section{* Leaves armed with spiny teeth; trees.}

1. I. opàca, Ait. (American Holly.) Leaves oral, flat, the wary margins with scattered spiny teeth; flowers in loose clusters along the base of the young branches and in the axils; calyx-teeth acute. - Moist woodlands, Maine to N. J., near the coast, west to S. Mo., and southward. June. - Tree $20-40^{\circ}$ high; the deep green foliage less glossy than in the European Holly (I. Aquifoliu M, $L$.), the berries not so bright red, and nutlets not so veiny.

* * Leaves serrate or entire, not spiny; shrubs.

2. I. Cassine, L. (Cassexa. Yaupox.) Leaves lance-ovate or elliptical, crenate (1-1 $\frac{1}{2}$ long); flower-clusters nearly sessile, smooth; calyx-teeth obtuse. - Virginia and southward along the coast. Nay. - Leares used for tea by the people along the coast, as they were to make the celebrated black drink of the North Carulina Indians.

3. I. Dahòon, Walt. (1) Anoox Holcy.) Leaves oblanceolate or oblong, entire, or sharply serrate toward the apex, with revolute margins $\left(2-3^{\prime}\right.$ long), the midrib and peduncles pubescent; calyx-teeth acute. - Swamps, coast of Va. and southward. May, June.

Var. myrtifòlia, Chapm. Leaves smaller ( $1^{\prime}$ long or less) and narrower. (I. myrtifolia, Walt.) - Same habitat. May.

§ 2. PRINOIDES. Parts of the (polygamons or diacious) flowers in fours or fives (rarely in sixes); drupe red or purple, the nutlets striate-many-ribbed on the back; leaves deciduous; shrubs.

4. I. decídua, Walt. Leaves wedge-oblong or lance-obovate, obtusely serrate, downy on the midrib beneath, shining above, becoming thickish; peduncles of the sterile flowers longer than the petioles, of the fertile short; calyx-teeth smooth, acute. - Wet grounds, Va. to Mo., Kan., and southward. May.

5. I. montícola, Gray. Leaves ovate or lance-oblong, ample (3-5' long), taper-pointed, thin-membranaceous, smooth, sharply serrate; fertile flowers very short-peduncled; calyx ciliate. - Damp woods, Taconic and Catskill Mountains, and Cattaraugus Co., N. Y., through Penn. (east to Northampton Co.), and southward along the Alleghanies. May.

6. I. móllis, Gray. Leaves soft douny beneath, oval, ovate, or oblong, taper-pointed at both ends, especially at the apex, thin-membranaceous, sharply serrulate; sterile flowers very numerous in umbel-like clusters, the pedicels shorter than the petiole and (with the calyx) soft-downy, the fertile peduncles very short. - Burgoon's Gap, Alleghanies of Penn. (J.R. Lourie, Porter), and along the mountains in the Southern States. - Resembles the last.

§3. PRiNOS. Parts of the sterile flower's commonly in fours, fives, or sixes, those of the fertile flowers commonly in sixes (rarely in fives, sevens, or eights); nutlets smooth and even; shrubs. 
* Leaves deciduous; flowers in sessile clusters, or the jertile solitury; fruit bright red.

7. I. verticillàta, Gray. (Black Almfr. Wintrermerry.) Leaves oval, obovate, or werlge-lauceolate, pointed, acute at hasse, scrrate, dou'ny on the veins beneath; flowers all very short-peduncled. - Low grounds; common. May, June.

8. I. lævigàta, Gray. (Swooti Wixternerry.) Leaves lanceolate or oblong-lanceolate, pointed at both ends, appressed-serrulate, shining above, beneath mostly glabrous; sterile flouers long-peduncled. - Wet grounds, Mtaine' to the mountains of Va. June. - Fruit larger than in the last, ripening earlier in the autumn.

* * Leaves coriaceous, evergreen and shining, often black-dotted beneath; fruit black.

9. I. glàbra, Gray. (Iмkвerrr.) Leaves welge-lanceolate or oblong, sparingly toothed toward the apex, smooth; peduncles ( $\frac{1}{2}$ long) of the sterile flowers 3-6-flowered, of the fertile 1-flowered; calyx-teeth rather blunt. Sandy grounds, Cape Ann, Mass., to Va., and southward near the coast. June. - Shrub $2-3^{\circ}$ high.

\section{NEMOPÁNTHES, Raf. Mountain Holly.}

Flowers polygamo-diœcious. Calyx in the sterile flowers of 4-5 minute dociduous teeth, in the fertile ones obsolete. Petals 4-5, oblong-linear, spreading, distinct. Stamens 4-5; filaments slender. Drupe with $4-5$ bony nutlets, light red. $-\Lambda$ much-branched shrub, with ash-gray bark, alternate and oblong deciduous leaves on slender petioles, entire or slightly toothed, smooth. Flow: ers on long slender axillary peduncles, solitary or sparingly clustered. (Name said by the author to mean "flower with a filiform peduncle," therefore prob-

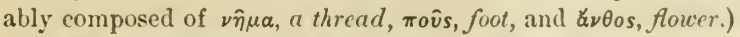

1. N. fasciculàris, Raf. (N. Canadensis, DC.) - Damp cold woods, from the mountains of Va. to Maine, Ind., Wise., and northward. May.

\section{Order 26. CELAstràCeAe. (Staff-tref Family.)}

Shrubs with simple leaves, and small regular flowers, the sepals and the petals both imbricated in the bull, the 4 or 5 perigynous stamens as many as the petals and alternate with them, inserted on a disk which fills the bottom of the calyx and sometimes covers the orary. Seeds arilled.-Ovules one or few (erect or pendulous) in each cell, anatropous; styles united into one. Fruit 2-5-celled, free from the calyx. Embryo large, in fleshy albumen; cotyledons broad and thin. Stipules minute and fugacious. Pedicels jointed.

* Leaves alternate. Flowers in terminal racemes.

1. Celastrus. A shrubby climber. Fruit globose, orange, 3-valved. Aril scarlet.

* Leaves opposite. Flowers in axillary ('ymes or solitary.

2. Euonymus. Erect shrubs. Leavesdecidnous. Fruit 3-5-lohed,3-5-valved. Aril red.

3. Pachystima. Dwarf evergreen shrub. Flowers very small. Frnit oblong, 2-valved. Aril white. 


\section{Cetústru S, L. Staff-tree. Shrubby Bitter-Sweet.}

Flowers polygamo-dioecious. Petals (crenulate) and stamens 5, inserted on the margin of a cup-shaped disk which lines the base of the calyx. Pod globose (orange-color and berry-like), 3-celled, 3-valved, loculicidal. Seeds 1 or 2 in each cell, erect, enclosed in a pulpy scarlet aril. - Leaves alternate. Flowers small, greenish, in raceme-like clusters terminating the brauches. (An ancient Greek name for some evergreen, which our plant is not.)

1. C. scándens, L. (Wax-work. Climbixg Bitter-sweet.) Twining shrub; leares ovate-oblong, finely serrate, pointed. - Along streams and thickets. June. - The opening orange-colored pods, displaying the scarlet covering of the seeds, are very ornamental in autumn.

\section{EU Ó N Y M US, Tourn. SPINdle-tree.}

Flowers perfect. Sepals 4 or 5 , united at the base, forming a short and flat calyx. Petals 4-5, rounded, spreading. Stamens very short, inserted on the edge or face of a broad and flat 4-5-angled disk, which coheres with the ealyx and is stretched over the ovary, adhering to it more or less. Style short or none. Pod 3-5-lobed, 3-5-valved, loculicidal. Seeds 1-4 in each cell, enclosed in a red aril. - Shrubs, with 4-sirled branchlets, opposite serrate leares, and loose cymes of small flowers on axillary peduncles. (Derivation from $\epsilon \bar{v}$, good, and óvopa, name, beeause it has the bad reputation of poisoning cattle. Tourn.)

1. E. atropurpùreus, Jacq. (Bursixg-Besir. WAanon.) Shrub tall $\left(6-14^{\circ}\right.$ high $)$ and upright; leaves petioled, oval-ol,long, pointed; parts of the (dark-purple) flower commonly in fours; pods smooth, deeply lobed. - N. Y. to Wisc., Neb., and south ward; also cultivated. June.-Ornamental in autumn, by its copious erimson fruit, drooping on long peduncles.

2. E. Americànus, L. (STrawberRY Busn.) Shrub low, upright or straggling $\left(2-5^{\circ}\right.$ high); leaves almost sessile, thickish, bright green, varying from ovate to oblong-lanceolate, acute or pointed; parts of the greenish-purple flowers mostly in fires; pods rough-urarty, depressed, crimson when ripe; the aril and dissepiments scarlet. - Wooded river-banks, N. Y. to Ill., and southward. June.

Var. obovàtus, Torr. \& Gray. Trailing, with rooting branches; flowering stems $1-2^{\circ}$ high; leaves thin and dull, oborate or oblong. - Low or wet places; the commoner form.

\section{PACHÝ STIMA, Raf.}

Flowers perfect. Sepals and petals 4. Stamens 4, on the edge of the broad disk lining the calyx-tube. Ovary free; style very short. Pod small, oblong, 2-celled, loculicidally 2-valved. Seeds 1 or 2, enclosed in a white membranaceous many-cleft aril. - Low evergreen shrubs, with smooth serrulate coriaceous opposite leaves and very small green flowers solitary or fascicled in the axils. (Derivation obscure.)

1. P. Cánbyi, Gray. Leares linear to linear-oblong or oblong-obovate, obtuse, $3^{\prime \prime}-1^{\prime}$ long; pedicels very slender, often solitary, shorter than the leaves; fruit $2^{\prime \prime}$ long. - Mountaius of S. W. Va. 


\section{Order 27. RHAMNÁCEA. (Beckthorn Family.)}

Shrubs or small trees, with simple leaves, small and regular flowers (sometimes apetalous), with the 4 or 5 perigynous stamens as many as the valvate sepals and alternate with them, accordingly opposite the petals! Drupe or pod with only one erect seed in each cell, not arilled. - Petals folded inwards in the bud, hooded or concave, inserted along with the stamens into the edge of the fleshy disk which lines the short tube of the calyx and sometimes unites it to the lower part of the 2-5-celled ovary. Ovules solitary, anatropous. Stigmas 2-5. Embryo large, with broad cotyledons, in sparing fleshy albumen. - Flowers often polygamous, somètimes diœcions. Leaves mostly alternate; stipules small or obsolete. Branches often thorny. (Slightly bitter and astringent; the fruit often mueilaginous, commonly rather nauseous or drastic.)

* Calyx and disk free from the ovary.

1. Berchemia. Petals sessile, entire, as long as the calyx. Drupe with thin flesh and a 2-celled bony putamen.

2. Rhamnus. Petals small, short-clawed, notched, or none. Drupe berry-like, with 2-4 separate seed-like nutlets.

* Calyx with the disk adherent to the base of the ovary.

3. Ceanothus. Petals long-clawed, hooded. Fruit dry, at length deliscent.

\section{BERCHËIA, Necker. SuPPLEJACK.}

Calyx with a rery short and roundish tube; its lobes equalling the 5 oblong sessile acute petals, longer than the stamens. 1)isk very thick and flat, filling the calyx-tube and covering the ovary. Drupe oblong, with thin flesh and a bony 2 -celled putamen. - Woody high-climbing twiners, with the pinnate veins of the leaves straight and parallel, the small greenish-white flowers in small panicles. (Name unexplained, probably personal.)

1. B. volùbilis, DC. Glabrous; leaves oblong-ovate, acute, scarcely serrulate; style short. - Damp soils, Va. to Ky. and Mo., and southward. June. - Ascending tall trees. Stems tough and very lithe, whence the pup)ular name.

\section{RHá MNUS, Tourn. Bıсктиок.}

Calyx 4-5-cleft; the tube campanulate, linel with the disk. Petals small, short-clawed, notched at the end, wrapped around the short stamens, or sometimes none. Ovary free, 2-4-celled. Drupe berry-like (black), contining 2-4 separate secl-like nutlets, of cartilaginous texture. - Shrubs or small trees, with loosely pinnately veined leaves, and greenish polygamous or diœcious flowers, in axillary clusters. (The ancient Greek name.)

§ 1. RHAMNUS proper. Flowers usually diacious; nutlets and seeds deeply groored on the back; rhaphe dorsal; cotyledons foliaceuns, the margins revolute.

* Calyx-lobes and stamens 5 ; petals wanting.

1. R. alnifolia, L'Her. A low shrub; leaves oval, acute, serrate, nearly straight-veined; fruit 3-seeded. - Swainps, Maine to Y'eun., Neb., and northward. June. 
* Calyx-lobes, petals, and stamens 4.

R. сатиírtica, I. (Соммом весктноrx.) Leaves ovate, miuutely serrate; fruit 3-4-seeded; branchlets thorny. - Cultivated for hedges ; spariugly naturalized eastward. May, June. (Nat. from Eu.)

2. R. lanceolàta, Pursh. Leaves oblong-lanceolate and acute, or on flowering shoots oblong and obtuse, finely serrulate, smooth or minutely downy beneath; petals deeply notched ; fruit 2-seeded.- Hills and river-banks, Penn. (Mercersburg, Green) to Ill., Tenn., and westward. May. - Shrub tall, not thorny ; the yellowish-green flowers of two forms on distinct plants, both perfect; one with short pedicels clustered in the axils and with a short included style; the other with pedicels oftener solitary, the style longer and exserted.

§ 2. FRÁxGULA. Flowers perfect; nutlets and seeds not furrowed; cotyledons flat, thick; rhaphe lateral.

3. R. Caroliniàna, Walt. Thornless shrub or small tree; leaves $\left(3-5^{\prime}\right.$ long) oblong, obscurely serrulate, nearly glabrous, deciduous ; flowers 5-merous, in one form umbelled, in another solitary in the axils, short-peduncled; drupe globose, 3-seeded. (Frangula Caroliniana, Gircly.) - Swamps and river-banks, N. J., Va. to Ky., and southward. June.

\section{CEA N ÒTH U S, L. New Jersey Tea. Red-root.}

Calyx 5-lobed, incurved; the lower part cohering with the thick disk to the ovary, the upper separating across in fruit. Petals hooded, spreading, on slender claws longer than the calyx. Filaments elongated. Fruit 3-lobed, dry and splitting into its 3 carpels when ripe. Seed as in § Frangula. - Shrubby plants; flowers in little umbel-like clusters, forming deuse panicles or corymbs at the summit of naked flower-branches; calyx and pedicels colored like the petals. (An obscure name in Theophrastus, probably misspelled.)

1. C. Americànus, L. (New Jerser TeA.) Leaves ovate or oblongovate, 3-ribbed, serrate, more or less pubescent, often slightly heart-shaped at base; common peduncles elongated. - Dry woodlands. July. - Stems $1-3^{\circ}$ high from a dark red root; branches downy. Flowers in pretty white clusters, on leafy shoots of the same year. The leares were used for tea cluring the American Revolution.

2. C. ovàtus, Desf. Leaves narrowly oval or elliptical-lanceolate, finely glaudular-serrate, glabrous or nearly so, as well as the short common peduncles. (C. ovalis, Bigel.) - Dry rocks, W. Vt. and Mass. to Minn., Ill., and southwestward; rare eastward. May.

\section{Order 28. VITACEAE. (Vixe Fanily.)}

Shrubs with watery juice, usually climbing by tendrils, with small regular flowers, a minute or truncated calyx, its limb mostly obsolete, and the stamens as many as the valvate petals and opposite them! Berry 2-celled, usually 4-seeded. - Petals 4-5, very deciduous, hypogynous or perigynous. Filaments slender; anthers introrse. Pistil with a short style or none, and a slightly 2-lobed stigma; ovary 2-celled, with 2 erect anatropous ovules from the base of each cell. Seeds bony, with a minute 
embryo at the base of the liard albumen, which is grooved on one side. - Stipules deciduous. Leaves alternate, palmately veined or compound; tendrils and flower-clusters opposite the leaves. Flowers small, greenish, commonly polygamous. (Young shoots, foliacre, etc., acil.)

* Ovary surrounded by a nectariferous or glanduliferous disk ; plants climbing by the coiling of naked-tipled tendrils.

1. Vitis. Corolla calucous without expanding. Ifypogynous glands 5 , alternate witl the stameus. Fruit pulpy Leaves simple.

2. Cissus. Corolla expanding. Disk cupular. Berry witlı scanty pulp, inedible. Luaves simple or pinnately compound.

* * No distinct hypogyuous disk ; plants climbing by the adhesion of the dilated tips of the tendril-branches.

3. Ampelopsis. Corolla expanding. Leaves digitate.

\section{Vİtis, Tourn. Grape.}

Flowers polygamo-diceious (some plants with perfect flowers, others staminate with at most a rudimentary ovary), 5-merous. Calyx very short, usually with a nearly entire border or none at all. P'etals separating only at base and falling off without expanding. Hypogynous disk of 5 nectariferous glands alteruate with the stamens. Berry pulpy. Seeds pyriform, with beak-like base. - Plants climbing by the coiling of naked-tipped tendrils. Flowers in a compound thyrse, very fragrant; pedicels mostly umbellate-clustered. Leares simple, rounded and heart-shaped. (The classical Latin name.)

$\S 1$. VITIS proper. Bark loose and shreddy; tendrils forked; nodes solid. - A tendril (or inflorescence) opposite each leaf.

1. V. Labrúsca, L. (Northern Fox-Grape.) Branchlets and roung leaves very woolly; leaves large, entire or deeply lobed, slightly dentate, continuing rusty-woolly beneath ; fertile panicles compact; berries large. - Moist thickets, N. Eng. to the Alleghany Mountains, and south to S. Car. June. Fruit ripe in Sept. or Oct., dark purple or amber-color, with a tough musky pulp. Improved by cultivation, it has given rise to the Isabella, Catawba, Concord and other varieties.

+ + Tendrils intermittent (none opposite each third leaf).

+ Leares pubescent and floccose, especially beneath and when young.

2. V. æstivàlis, Miebx. (Sum mer Grape.) Branchlets terete; leaves large, entire or more or less deeply and obtusely 3-5-lobed, with short broal teeth, very woolly and mostly red or rusty when young; berries middle-sized, l,ack with a bloom, in compact bunches. - Thickets; common. May, June. l3erries pleasant, ripe in Sept. - V. isico Lor, LeConte, has its leaves smoothish when old and pale or glaucous beneath; common north and westward.

3. V. cinerea, Engelm. (Dowry Grapk.) Branchlets angular; pubescence whitish or grayish, persistent; leaves entire or slightly 3-lobel; inflorescence large and loose; berries small, black without bluom.-Central IIl. to Kan. and 'Tex.

+ Leaves glabrous and mostly shining, or short-hairy especially on the rils beneath, incisely lobed or undivided

4. V. cordifolia, Michx. (Frost or Cuicken Grape.) Leares 3-4' wide, not lobed or slightly 3 lubed, cordate with a deep acute sinus, acuminate, 
coarsely and sharply toothed; stipules small; inflorescence ample, loose; berries small, black and shining, very acerb, ripening after frosts; seeds $\mathbf{I}$ or 2 , rather large, with a prominent rhaphe. - Thickets and stream-banks, New Eng. to central Ill., Mo., Neb., and southward. May, June.

5. V. ripària, Michx. Differing from the last in the larger and more persistent stipules $\left(2-3^{\prime \prime}\right.$ long), more shining and more usually 3 -lobed leaves with a broad rounded or truncate sinus and large acute or acuminate teeth, smaller compact inflorescence, and berries $\left(4-5^{\prime \prime}\right.$ broad) with a bloom, sweet and very juicy, ripening from July to Sept.; seeds very small; rhaphe indistinct. (V. cordifolia, var. riparia, Gray.) - Stream-banks or near water, W. New Eng. to Penn., west to Minn. and Kan. Eastward the berries are sour and ripen late.

6. V.palmàta, Vahl. Branches bright red; leaves dark green and dull, 3-5-lobed, with a broad sinus, the lobes usually long-acuminate; inflorescence large and loose; berries black, without bloom, ripening late; seeds very large and rounded; otherwise like n. 5. (V. rubra, Michx.) - Ill. and Mo.

7. V. rupéstris, Scheele. (SAxd or Sugar Grape.) Usually low and bushy, often without tendrils; leaves rather small, shining, broadly cordate, abruptly pointed, with broad coarse teeth, rarely slightly lobed; berries rather small, sweet, in very small close bunches, ripe in Aug. - Mo. to Tex. ; also found in Tenn., and reported from banks of the Potomac, near Washington.

§ 2. MUSCADfNIA. Bark closely adherent on the branches; pith continuous through the nodes; tendrils simple, intermittent; seeds with transverse wrinkles on both sides.

8. V. rotundifólia, Michx. (Mrscanine, Bullacf, or Southern Fox-Grape.) Leaves shining both sides, small, rounded with a lieart-shaped base, very coarsely toothed with broad and bluntish teeth, seldom lobed; panicles small, densely flowered; berries large $\left(\frac{1}{2}-\frac{8^{\prime}}{4}\right.$ in diameter), musky, purplish withont a bloom, with a thick and tough skin, ripe early in antumn. (V. vulpina, Man., not L.?) - River-banks, Md. to Ky., Mo., Kan., and sonthward. May - Branchlets minutely warty. This is the original of the Scupperuong Grape, etc.

\section{CÍS U U S, L.}

Flowers perfect or sometimes polygamous, 4-merous or (in ours) 5-merous. Petals expanding. 1)isk cup-sliaped, surrounding the base of the ovary. Berry inedible, with scanty pulp. Seeds usually triangular-oborate- - Tendrils in our species few and mostly in the inflorescence. A rast genus, mainly tropical. (Greek name of the Ivy.)

1. C. Ampelópsis, Pers. Nearly glahrous; ieaves heart-shaped or truncate at the base, coarsely and sharply toothed, acuminate, not lobed; panicle small and loose; style slender; berries of the size of a pea, 1-3-seeded, bluish -or greenish. (Vitis indivisa, Willd.) - River-banks, Va. to Ill., and southward. June.

2. C. stans, Pers. Nearly glabrous, bushy and rather upright; leaves twrce pinnate or ternate, the leaflets cut-toothed; flowers cymose; calyx 5toothed; disk very thick, adherent to the ovary; berries black, obovate. (Vitis bipinnata, Torr. \& Gray.) - Rich soils, Va. to Mo., and southward. 


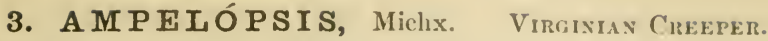

Calyx slightly 5 -toothed. Petals coneave, thick, expanding before they fall. Disk none. - Leaves digitate, with $5(3-7)$ oblong-lanceolate sparingly serrate leaflets. Flower-clusters cymose. Tendrils fixing themselves to trunks or

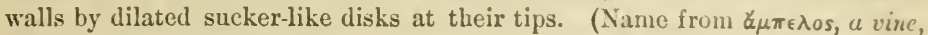
and $\check{\psi} \psi \mathrm{is}$, appearance.)

1. A. quinquefolia, Michx. A common woody vine, in low or rich grounds, climbing extensively, sometimes by rootlets as well as by its diskbearing tendrils, blossoming in July, ripening its small blackish berries in October. Also called American Ivy, and still less appropriately, Woodbine. Leaves turning bright crimson in autumn.

\section{Order 29. SAPINDACEAE. (Soapberry Famlly.)}

Trees or shrubs, with simple or compound leaves, mostly unsymmetrical and often irregular flowers; the 4-5 sepals and petals imbricated in cestivation; the 5-10 stamens inserted on a fleshy (perigynous or hypogynous) disk; a 2-3-celled and -lobed ovary, with 1-2 (rarely more) ovules in each cell; and the embryo (except Staphylea) curved or convolute, without allumen. - A large and diverse order.

Subordm I. Sapindea. Flowers (often polygamous) mostly unsymmetrical and irregular. Stamens commonly more numerous than the petals, rarely twice as many. Ovules 1 or 2 in each cell. Embryo curved or convolute, rarely straight; cotyledons thick and fleshy. - Leaves alternate or sometimes opposite, without stipules, mostly compound.

1. AEsculus. Flowers irregular. Calyx 5-lobed. Petals 4 or 5 . Stamens commonly 7 . Fruit a leathery 3-valved poil Leaves opposite, digitate.

2. Sapindus. Flowers regular. Sepals $4-5$, in two rows. Petals $4-5$. Stamens $8-10$. Fruit a globose or 2-3-lobed berry Leaves alternate, pinnate.

Suborder II. Acerineae. (Maple Famix.) Flowers (polygamous or dioceious) small, regular, but usually unsymmetrical. Petals often wanting. Ovary 2-lobed and 2-celled, with a pair of ovules in each cell. Fruits winged, 1-seeded. Embryo coiled or folded; the cotyledons long and thin. - Leaves opposite, simple or compound.

3. Acer. Flowers polyganons. Leaves simple.

4. Negundo. Flowers diœeious. Leaves pinnate, with $3-5$ leaflets.

Suborder III. Staphyleae. (Bladner-Nut Family.) Flowers (perfect) regular; stamens as many as the petals. Ovules $1-8$ in each cell. Seeds bony, with a straight embryo in scanty albumen. - Shruls with opposite pinnately compound leaves, both stipulate and stipellate.

5. Staphylea. Lobes of the colored calyx and jetils 5, erect. Stamens 5. Fruit a 3 celled blatdery-inflated pod.

\section{1. 舟 SCULUS, L. IIorse-chestnut. Buckete.}

Calyx tubular, 5-lobed, often oblique or gibbous at base. P'etals 4-5, more or less unequal, with claws, nearly hypogynous. Stamens 7 (rarely 6 or 8 ); 
filaments long, slender, often unequal. Style 1; ovary 3-celled, with 2 ovules in each cell. Fruit a leathery pod, 3-celled and 3-seeded, or usually by abortion 1-celled and 1-seeded, loculicidally 3-ralved. Seed very large, with thick shining coat, and a large round pale scar. Cotyledons very thick and fleshy, their contiguous faces coherent, remaining under ground in germination; plumule 2-leaved; radicle curved. - Trees or shrubs. Leaves opposite, digitate; leaflets serrate, straight-veined, like a Chestnut-leaf. Flowers in a terminal thyrse or dense panicle, often polygamous, most of them with imperfect pistils and sterile; pedicels jointed. Seeds farinaceous, but imbued with a bitter and narcotic principle. (The ancient name of some Oak or other mast-bearing tree.)

\section{§1. ASCULL'S proper. Fruit covered with prickles when young.}

妮. Hippocastaxum, L. (Comon Honse-chestret.) Corolla spreading, white spotted with purple and yellow, of 5 petals; stamens declined; leaflets 7.-Commonly planted. (Adv. from Asia via Eu.)

1. 开. glàbra, Willd. (Fetid or Oнio Bсскеге.) Stamens curved, longer than the pale yellow corolla of 4 upright petals; leaflets usually 5. River-banks, IV. Penn. to Mich., Mo., Kan., and southward. June.-A large tree; the lark exhaling an unpleasant odor, as in the rest of the genus. Flowers small, not showy.

§ 2. PAVIA. Fruit smooth; petals 4, connwing; the 2 upper smaller and longer than the others, with a small rounded blade on a very long cluw.

2. 王. flàva, Ait. (Swеet Buckere.) Stamens included in the yellow corolla; calyx oblong-campanulate; leaflets 5 , sometimes 7 , glabrous, or often minutely downy uuderueath. - Rich woods, Va. to Ohio, Mo., and southward. May. A large tree or a shrub.

Var. purpuráscens, Gray. Calyx and corolla tinged with flesh-color or dull purple; leaflets commonly downy beneath. - From IV. Va., south and westward.

3. 即. Pavia, L. (Red Brckeye.) Stamens not longer than the corolla, which is bright red, as well as the tubular calyx; leaflets glabrous or soft-downy beneath. - Fertile valleys, Va., Ky., Mo., and southward. May. A shrub or snall tree.

\section{SA Pİ D U S, L. SOAP-BERrY.}

Flowers regular, polygamous. Sepals $4-5$, imbricated in 2 rows. Petals $4-5$, with a scale at the base. Stamens 8-10, upon the hypogynous disk. Ovary 3-celled, with an ascending ovule in each cell. Fruit a globose or 2-3lobed berry, $1-3$-seeded. Seed crustaceous, globose. - Trees or shrubs, with alternate abruptly pinnate leaves, and small flowers in terminal or axillary racemes or pauicles. (Name a contraction of Sapo Indicus, Indian soap, having reference to the saponaceous character of the berries.)

1. S. acuminàtus, Raf. $A$ tree $20-60^{\circ}$ high; leaflets $4-9$ pairs, obliquely lanceolate, sharply acuminate, entire, $1 \frac{1}{2}-3^{\prime}$ long; the rhachis of the leaf not winged; flowers white, in a large panicle; fruit mostly globose, 6" broad. (S. marginatus of authors, not Willd.) - S. Kan. to La., Fla., and Mex. 


\section{3. À CER, Tourn. Mirti:}

Flowers polygamo-diccious. Calyx colored, 5- (rarely 4-12-) lubed or parted. I'etals either none or as many as the lobes of the calyx, equal, with short claws if any, inserted on the margin of the lothed disk, which is either perigynous or hypogynous. Stamens 3-12. (Nary 2-celled, with a pair of orules in each cell; styles 2, long and slender, united only beluw, stigmatic down the inside. From the back of each carpel grows a wing, converting the fruit into two 1-seeded, at length separable samaras or keys. Embryu varionsly coiled or folded, with large and thin cotyledons. - Trees, or somctimes shrubs, with opposite palmately-lobed leaves, and small flowers. P'edicels not jointed. (The classical name, from the Celtic ar, hard.)

* Flou'ers in terminal racemes, greenish, appearin! " ier the leares ; stamens 6-8.

1. A. Pennsylvánicum, L. (Strupe1, .laple.) Leaves 3-lobed at the apex, finely and sharply doubly serrate, the short lobes taper-pointed and also serrate; racemes drooping, loose: petals obocate; fruit with large diverging wings. - Rieh woods, Maine to Minn., and southward to Va., Ky., and Mo. June.-A small and slender tree, with light-green bark striped with dark lines, and greenish flowers and fruit. Also called Striped Doywood and Moose-Wood.

2. A. spicàtum, Lam. (Movxtaix MI.) Leaves downy beneath, 3- (or slightly 5-) lobed, coarsely serrate, the lobes taper-pointed; racemes upright, dense, somewhat compound; petals linear-spratulate; fruit with small erect or divergent wings. - Moist woods, with the same range as n. l. June. $-\mathbf{A}$ tall shrub, forming clumps.

* * Flowers in nearly sessile terminal and lateral umbellatc-corymbs, greenishyellow, ajpearing with the leaves.

3. A. saccharinum, Wang. (SıGAR or Rock M.) Ieaves 3-5-lobed, with rounled sinuses and pointerl sparingly sinuate-toothed lobes, either heartshaped or nearly truncate at the base, whitish and smooth or a little downy on the veins beneath; flowers from terminal leaf-bearing and lateral leafless buds, drooping on very slender hairy pedicels; calyx hairy at the apex; petals none; wings of the fruit broad, usually slightly diverging. - Rich woods, especially northward and along the mountains southward. A pril, May. - A large and handsome tree.

Var. nigrum, Torr. \& Gray. (BLAck Sugali-M.) Leaves searcely paler beneath, but often minutely downy, the lobes wider, often shorter and entire, the sinus at the base often closed. - With the ordinary form; quite variable, sometimes appearing distinet.

*** Flouers in umbel-like clusters arising from separate lateral buds, and much preceding the leures; stumens $3-6$.

4. A. dasycárpum, Ehrh. (White or Silven M.) Leuves very deeply 5-lobed with the sinuses rather acute, silvery-white (and when young downy) underneath, the divisions narrow, cut-lobed and toothed; flowers (greenishyellow) on short pedicels; petals none; fruit woolly when young, with large divergent wings. - River-banks; most common southward and westward. March-April. - A fine ornamental tree. 
5. A. rủbrum, L. (Red or Swamp M.) Lenves $3-5$ lobed, with acute sinuses, whitish underneath; the lobes irregularly serrate and notched, acute, the middle one usually longest; petals linear-ablong; flower's (scarlet, crimson, or sometimes yellowish) on very short pedicels; but the smooth fiuit on prolonged'drooping perlicels. - Swamps and wet woods. April. - A small tree, with reddish twigs; the leaves varying greatly in shape, turning bright crimson in early autumn.

\section{NEGÚ NDO, Moench. Ash-ledieg Maple. Box-Elder.}

Flowers dicecious. Calyx minute, 4-5-cleft. Petals none. Stamens 4-5. 1)isk none. - Sterile flowers in clusters on capillary pedicels, the fertile in drooping racemes, from lateral buds. Leares pinnate, with 3 or 5 leaflets. Fruit as in Acer. (Naine numeaning.)

1. N. aceroides, Moench. Leaflets smoothish when old, very veiny, ovate, pointed, toothed; fruit smooth, with large rather incurved wings. River-banks, W. New Eng. to Dak., south and westward. April. - A small but handsome tree, with light-green twigs, and very delicate drooping clusters of small greenish flowers, rather earlier than the leaves.

\section{STAPHYLEA, I. BLADDER-Nút.}

Calyx deeply 5-parterl, the lobes erect, whitish. Petals 5, erect, spatulate, inserted on the margin of the thick perigymons disk which lines the base of the calyx. Stamens 5, alternate with the petals. I'istil of .3 sereral-ovuled carpels, united in the axis, their long styles lightly cohering. Pod large, membranaceous, inflated, 3-lobed, 3-celled, at length bursting at the summit ; the cells containing $1-4$ bony anatropons seeds. Aril none. Embryo large and straight, in scanty albumen, cotyledons broad and thin. - Upright shrubs, with opposite pinnate leaves of 3 or 5 serrate leaflets, and white flowers in drooping raceme-like clusters, terminating the branchlets. Stipules and stipels deciduons. (Name from $\sigma \tau a \phi u \lambda \eta ́$, a cluster.)

1. S. trifòlia, L. (Amiricax BLADner-xct.) Leaflets 3, ovate, pointerl. - Thickets, in moist soil. May. - Shrub $10^{\circ}$ high, with greenish striped branches.

\section{Order 30. ANACARDIACEAE. (CASHEW FAMILY.)}

Trees or shrubs, with resinous or milky acrid juice, clotless alternate leaves, and small, often polygamous, regular, 5-merous flowers, but the ovary 1-celled and 1-orulerl, with 3 styles or stigmas. - Petals imbricated in the bud. Fruit mostly drupaceous. Seed without albumen, borne on a curved stalk that rises from the base of the cell. Stipules none. Juice or exhalations often poisonous.

\section{RHÚ S, L. Sumach.}

Calyx small, 5-parted. Petals 5. Stamens 5, inserted under the edge or between the lobes of a flattened disk in the bottom of the calyx. Fruit small and indehiscent, a sort of dry drupe:-Leaves usually compound. Flowers greenish-white or yellowish. (The old Greek and Latiu name.) 
§ 1. RHUS proper. Fruit symmetrical, with the styles terminal.

* Flowers polygamons, in a terminal thyrsoid panicle; fruit glolular, clotherl with acid crimson hairs; stone smooth ; leaves gdld-pinnate. (Not poisonous.) - (§ SuMAC, I)C.)

1. R. týphina, L. (Stagnors Sumacu.) Brunches and stulks densely velvety-hairy: leaflets $11-31$, pale beneath, oblong-laneeolate, pointed, serrate, rarely laciniate - Ilillsides. 'June. - Shrub or tree $10-30^{\circ}$ high, with orangecolored wood. A pparently hybridizes with the next.

2. R. glàbra, L. (Sмоoтu S.) Smooth, someuhat gluirous; leaflets 11 31, whitened beneath, lanceolate-oblong, pointed, serrate. - Rocky or barren soil. Juue, July..-Shrub $2-12^{\circ}$ high. $\Lambda$ rar. has laciniate leaflets.

3. R. copallina, L. (1)W.aRF S.) Branches and stulks doun!l protioles. uing-margined between the 9-2l oblong or orate-lanceolate (often entire) leaflets, which are oblique or unequal at the base, smooth and shiniug above. Rocky hills. July. - Slurub $1-7^{\circ}$ high, with running roots.

* * Flourers polygamous, in loose and slender axillary panicles; fruit globular, glabrous, whitish or dun-colored; the stone striate; leares odd-pinnate or 3 foliolute, thin. (Poisonous.) - (§ Toxiconexnros, DC.)

4. R. venenàta, DC. (Porson S. or Dogwoow.) Smooth, or nearly so; leaflets 7-13, aborate-oblong, entire.-Swamps. June.-Shrub 6-18 high. The most poisonous species; also called Poison Elder. ๑)

5. R. Toxicodéndron, L. (Porsox Iry. Porsos OAk.) Climbing by rootlets over rocks, etc., or ascending trees, or sometimes low and erect; leaflets 3 , rhombec-ovate, mostly pointed, and rather downy beneath, variously notched, sinuate, or cut-lobed, - high-climbing plants (R. radicans, L.) having usually more entire leaves. - Thickets, low grounds, ete. June.

* * Flowers polygamo-dixecious, in sina!l solitary or clustered spikes or heads which develop in spring before the leaces: leares 3-foliolate; finit as in first group. (Not poisonons). - (\$ Lomadiu, Turr. \& Gray.)

6. R. Canadénsis, Marsh. Leaves soft-pnbescent when young, becoming glabrate; leaflets rhombic-obovate or orate, unequally cut-toothed, 1 - 3' long, the terminal one cuneate at base and sometimes 3-cleft; Howers pale yellow. (R. aromatica, Ait.) - Dry rocky banks, Wr. Vt. to Mimn., and sonthward. - A straggling bush, 3-70 high; the crushed leaves nut unpleasantly scented.

Var. trilobata, Gray, With smaller leaflets $\left(\frac{1}{2}-1^{*}\right.$ long), crenately fewlobed or incised towarl the summit. - Loug Pine, Neb., and common westward. Unpleasantly scented.

§ 2. CÒTINUS. Orary becoming rery gibbous in fruit, with the remains of the styles lateral; flowers in loose ample panicles, the pedicels elongating and becoming pluniose; leaves simple, cutire.

7. R. cotinoldes, Nutt. 'Glabrous or nearly so; leaves thin, oval, $3-6$ ' long; flowers and fruit as in the cultivated Sinoke-trce (R. Cotiuus) - Mo. to Tenn., and southward. $-\Lambda$ tree, $25-40^{\circ}$ high. 


\section{Order 31. POLYGALÁCEA. (Milkwort Family.)}

Plants with irregular hypogynous flouers, 4-8 diadelphous or monadelphous stumens, their 1-celled anthers opening at the top by a pore or chink; the fruit a 2-celled and 2-seeded pod.

\section{POLÝGALA, Tourn. Milkwort.}

Flower very irregular. Calyx persistent, of 5 sepals, of which 3 (the upper and the 2 lower) are small and often greenish, while the two lateral or inner (called ungs) are much larger, and colored like the petals. Petals 3, hypogynous, connected with each other and with the stamen-tube, the middle (lower) one keel-shaped and often crested on the back. Stamens 6 or 8 ; their filaments united below into a split sheath, or into 2 sets, cohering more or less with the petals, free above; anthers 1-celled, often cup-shaped, opening by a hole or broad chink at the apex. Ovary 2-celled, with a single anatropous ovnle pendulous in each cell; style prolonged and curved; stigma various. Fruit a sniall, loculiculal 2-seeded pod, usually rounded and notched at the apex, much flattened contrary to the very narrow partition. Seeds carunculate. Embryo large, straight, with flat and broad cotyledons, in scanty albumen. - Bitter plants (low herbs in temperate regions), with simple entire often dotted leares, and no stipules; sometimes (as in the first two species) bearing cleistogamous flowers next the gromud. (An old name composed of roגús, much, and $\gamma a ́ \lambda \alpha$, milk, from a fancied property of its increasing this secretion.)

* Perennial or biennial; flouers purple or white; leaves alternate.

- Flowers showy, rose-purple, conspicuously crested; also bearing inconspicuous colorléss cleistogamous flowers on subterranean branches.

1. P. paucifolia, Willd. Perennial; flowering stems short (3-4' high), from long slender prostrate or subterranean shoots, which also bear concealed fertile flowers; lower leaves small and scale-like, scattered, the upper ovate, petioled, rrowded at the summit; flowers 1-3, large, peduncled; wings obovate, rather shorter than the fringe-crested keel; stamens 6 ; caruncle of 2 or 3 awlshaped lobes longer than the seed. - Woods, in light soil, N. Eng. to Minn., Ill., and southward along the Alleghanies. May. - A delicate plant, with very handsome flowers, $9^{\prime \prime}$ long, rose-purple, or rarely pure white. Sometimes called Flowering Wintergreen, but more appropriately Frixged Polygala.

2. P. polýgama, Walt. Stems numerous from the biennial root, mostly simple, ascending, very leafy $\left(6-9^{\prime}\right.$ high $)$; leaves oblanceolate or oblong: terminal raceme loosely many-flowered, the broadly obovate wings longer than the keel; stamens 8 ; radical flowers racemed on short subterranean runners; lobes of the caruncle 2, scale-like, shorter than the seed.-Dry sandy soil; common. July.

+ + Flowers uhite, in a solitary close spike; none cleistogamous.

3. P. Sénega, L. (SExkca Sxakeroot.) Stems several from thick and hard knotty rootstocks, simple $\left(6-12^{\prime}\right.$ high) ; leares lanceolate or oblonglanceolate, with rough margins; wings round-oborate, concave; crest short; caruncle nearly as long as the seed. - Rocky soil, W. New Eng. to Minn., and southward. May, June. 
Var. latifolia, Torr. \& Gray. Taller, sometimes hranched; leaves ovato or ovate-lanceulate, $2-t^{\prime}$ long, tapering to each end. - Mu. to Mich. and Ky.

4. P. álba, Nutt. Stems several from a larrl rootsterk, $1^{\circ}$ high; leaves narrowly linear, 3-12" long, acute; wings oblong-obovate ; crest small ; lobes of the caruncle half the length of the appressed-silky seed. - Neb. and Kan. to 'l'ex.

Annuals, with all the leaves alternate; flowers in terminal spikes, heads or racemes, purple or rose-color, in summer; none subterranean.

- Keel conspicuously crested; claus of the true petals united into a long and slender cleft tube much surpassing the wings.

5. P. incarnàta, L. Glaucous; stem slender, sparingly branched; leaves minute and linear-awl-shaped; spike cylindrical; Howers flesh-color; caruncle longer than the narrow stalk of the liairy seed. - I)ry soil, J'enn. to Wisc, Iowa, Neb., and southward; rather rare.

+ + Keel minutely or inconspicuously crested: the true petals not longer but mostly shorter than the wings; seed perer-shaped.

6. P. sanguinea, L. Stem sparingly branched above, leafy to the top; leares oblong-linear; heads globular, at length oblong, very dense ( $4-5$ " thick), bright red-purple (rarely paler or even white); pedicels scarcely any; wings broadly ovate, closely sessile, longer than the pod; the 2-parted caruncle almost equalling the seed. - Sandy and moist ground; common.

7. P. fastigiàta, Nutt. Stem slender, at length corymbosely branched; leaves narrowly linear, acute, $3-8^{\prime \prime}$ long; spikes short and dense ( $3^{\prime \prime}$ in dianeter); the small rose-purple flowers on pedicels of about the length of the pod; wings obovate- or oval-oblong, narrowed at the base, scarcely exceeding the pod; bracts deciduous with the flowers or fruits; caruncle as long as and nearly enveloping the stalk-like base of the minutely hairy seed. - P'ine barrens of N. J. and Del. to Ky., and southward.

8. P. Nuttàllii, Torr. \& Gray. Resenbles the last, but usually lower; spikes cylindrical, narrow; flowers duller or greenish purple, on very short pedicels; the awl-shaped scaly bracts persistent on the axis after the flowers or fruits fall; seed very hairy, the caruncle smaller. - I)ry sandy soil, coast of Mass. to Mo., and southwarl. - Spike sometimes rather loose.

9. P. Curtíssii, Gray. Slender ( $9^{\prime}$ high $)$; leaves, etc., as in the two preceding, flowers rose-purple, in usually short racemes; pedicels ahout equalling or exceeding the persistent bracts; the narrow oblony erect wings fully twice the length of the pod: : caruncle small, on one side of the stalk-like base of the very hairy seed, which is conspicuously apiculate at the broader end. - Md. to Ga. The species was founded upon an abnormal form witl elongated racemes aud pedicels.

* * Annuals with at least the lower stem-tenves whorled in fours, sometimes in fives: spities terminating the stem and brunches; Jl. summer and uutumn.

- Spikes short and thick (4-9" in diameter); bracts persisting afier the fall of the (middle-sized) rose or greenish purple flourers; crest small.

10. P. cruciata, L. Stens $\left(3-10^{\prime}\right.$ high) almost winged at the angles, with spreading opposite hranches; leaves nearly all in fours, linear and somewhat spatulate or oblanceolate; spikes sessile or neurly so; wings brondiy 
deltoid-orate, slightly leart-shaped, tapering to a bristly point or rarely pointless; caruncle nearly as long as the seed. - Margin of swamps, Maine to Va. and southward near the coast, and west to Minn. and Neb.

11. P. brevifolia, Nutt. Rather slender, branched above; leaves scattered on the branches, narrower; spikes peduncled; wings lanceolate-orate, pointless or barely mucronate. - Margin of sandy bogs, R. I., N. J., and southward.

+ - Spikes slender (alout 2" thich), the bracts falling with the flowers, which are small, greenish-white or barely tinged with purple, the crest of the keel laryer.

12. P. verticillàta, L. Slender $\left(6-10^{\prime}\right.$ high), much branched; stemleaves all whorled, those of the (mostly opposite) branches scattered, linear, acute; spikes peduncled, usually short and dense, acute; wings round, clawed; the 2-lobed caruncle half the length of the seed.-1)ry soil; common.

Var. ambígua. Leares (and branches) all scattered or the lowest in fours ; spikes long-perluncled, more slender, the flowers often purplish and scattered. (l'. ambigua, Nutt.) - N. Y. to Mo., and soutliward.

* * * Biennials or annuals, with alternate leaves, and yellow flowers, which ure disposed to turn greenish in drying; crest small; flowering all summer.

13. P. lutea, L. Low ; flowers (briglit orange-yellow) in solitary ovate or ollong heads ( ${ }^{\prime}{ }^{\prime}$ thick) terminating the stem or simple branches; leaves $\left(1-2^{\prime}\right.$ long) obovate or spatulate; lobes of the caruncle nearly as long as the secd. Santly swamps, $\mathrm{N}$ J and southward, near the coast.

14. P. ramòsa, Eill. Flouers (citron-yellou) in numerous short and dense spike-tike racemes collected in a flat-topped compound cyme: leaves oblonglinear, the lowest spatulate or oborate; seeds ovoid, minntely hairy, twice the lenyth of the curumcle. - Damp pine-barrens, Del. and sonthward.

15. P. cymòsa, Walt. Stem short, naked above, the numerons racemes in a usually nearly simple cyme, leares narrow, acuminate; seeds globose, without caruncle. - Del. and southward.

\section{Order 32. lieguminòs ae. (Ptlase family.)}

Plants with papilionaceous or sometimes regular flowers, 10 (rarely 5 and sometimes many) monadelphous, diadelphous, or rarely distinct stamens, and a single simple free pistil, lecoming a legume in fruit. S'seds mostly uithout albumen. Leaves alternate, urith stipules, usually compound. One of the sepals inferior (i. e. next the bract); one of the petals superior (i.e. next the axis of the inflorescence). - A very large order (nearly free from noxious qualities), of which the principal representatives in northern temperate regions belong to the first of the three suborders it comprises.

Suborder I. Papilionacere. Calyx of 5 sepals, more or less united, often unequally so. Corolla inserted into the base of the calyx, of 5 irregular petals (or very rarely fewer), more or less distinetly papilionaccous, i. e. with the upper or odd petal (vexillum or standard) larger than the others and enclosing them in the bud, usually turned backward 
or sprearling; the two lateral ones (wings) oblique and exterior to the two lower, which last are connivent and commonly more or less colierent by their anterior edges, forming the carina or keel, which usually encloses the stamens and pistil. Stamens 10 , very rarely 5 , insurted with the corolla, monadelphous, diadelphous (mostly with 9 united into a tule which is cleft on the upper side, and the tenth or upper one separate), or occasionally distinet. Ovary 1-celled, sometimes 2-celled by an intrusion of one of the sutures, or transversely 2-many-celled by cross-division into joints; style simple; ovules amphitropous, rarely anatropous. Cotyledons large, thick or thickish; radicle ineurved. - Leaves simple or simply compound, the earliest ones in germination usually opposite, the rest alternate; leaflets almost always quite entire. Flowers perfect, solitary and axillary, or in spikes, racemes, or panieles.

\section{Stamens (10) distinct.}

* Leaves palmately 3 -foliolate or simple; calyx 4-5-lobed; herbs. (Ponalyrie.e.)

I Baptisia. Pod inflated.

2. Thermopsis. Pod flat, linear.

* * Leaves pinnate; ealyx-teeth short. (SOPHOREe.)

3. Cladrastis. Flowers panicled, white. Pod flat. A tree.

4. Sophora. Flowers racemose, white. Pod terete, moniliform. Herbacenus.

II. Stamens monadelphous, or diadelphous (9 and 1 , rarely 5 and 5); nearly distinct in n. 14.

- Anthers of two forms; stamens monadelphous; leaves digitate or simple; leaflets entire. (GENiSTEA.)

5 Crotalaria. Calyx 5-lobed. Pod inflated. Leaves simple.

6. Genista. Calyx 2-lipped. Por flat. Seed estrophiolate. Leaves simple. Shrubby.

7. Cy1isus. Calyx 2-lipped. Pod flat. Seed strophiolate. Leaves $1-3$-foliolate. Shrubby.

8. Lupinus. Calyx deeply 2-lipped. Porl flat. Leaves 7 -11-foliolate.

* Anthers uniform (except in n. 13 and 29).

- Leaves digitately (rarely pinnately) 3-foliolate ; leaflets denticulate or serrulate ; stamens diadelphous; porls small, 1 - few-seeded, often enclosed in the calyx or curved or colled. (TRIFOLIE.A.)

9. Trifolium. Flowers capitate. Pods membranaceous, 1-6-seeded. Petals adlerent to tre stamen-tube

10. Melilotus. Flowers racemed. Pod coriaceous, wrinkled, 1-2-secled.

11. Medicago. Flowers racemed or spiked. Pods curved or coiled, 1 -few-seeded.

- + Leaves unequally pinmate. (or digitate in n. 13); pod not jointed; not twining nor climbing (except n. 20).

++ Flowers umbellate (solitary in nurs) on axillary peduncles. (LOTE..)

12. Hosackia. Leaves 1 -3-foliolate. Peduncle leafy-bracteate. Pod linear. ++ Flowers in spikes, racemes, or heads. (GALEGE...)

= Herbage glandular-dotted: stamens mostly monadelphous: pod small, indehiscent, mostly 1-seeded; leaves pinnate (excejt in $\mathrm{n} .13$.

13. Psoralea. Corolla truly papilionaceous. Stamens 10 , half of the anthers often smaller or less perfect. Leaves mostly palmately 3 -5-foliolate.

14. A morpha. Corolla of one petal! Stamens 10, monadelphous at hase.

15. Dalea. Corolla imperfectly papilionaceous. Staniens 9 or 10 ; the cleft tube of filaments bearing 4 of the petals about its niddle.

16. Petalostemon. Corolla scarcely at all papilionaceous. Stamens 5 ; the cleft tube of flaments bearing 4 of the petals on its summit. 
$==$ Herbage not glandular-dotted (except in n. 23) ; stamens mostly diadelphous; pod 2-valved, several-seeded; leaves pinnately several-foliolate; flowers racemose.

a. Wings cohering with the keel; pod flat or 4-angled; loary perennial herbs.

17. Tephrosia. Standard broad. Pod flat. Leaflets pinnately veined.

1S. Indigofera. Calyx and standard small. Pod 4-angled. Leaflets obscurely veined.

b. Flowers large and showy; standard broad; wings free; woody; leaflets stipellate.

19. Robinia. Pod flat, thin, margined on one edge. Trees or shrubs.

20. Wistaria. Pod tumid, marginless. Woody twiners ; leaflets obscurely stipellate.

c. Standard narrow, erect; pod turgid or inflated; perennial herbs.

21. Astragalus. Keel not tipped with a point or sharp appendage. Pod with one or both the sutures turned in, sometimes dividing the cell lengthwise into two.

22. Oxytropis. Keel tipped with an ereet point; otherwise as Astragalus.

23. Glycyrrhiza. Flowers, ete., of Astragalus. Anther-cells confluent. Pod prickly or muricate, short, nearly indehiscent.

+ + - Herbs with pinnate or pinnately 1-3-foliolate leaves; no tendrils ; pod transversely

2-several-jointed, the reticulateil 1-seeded joints indehiscent, or sometimes reduced to one such joint. (HEDYSARi ...)

$=$ Leares pinnate, with several leaflets, not stipellate.

24 Aschynomene. Stamens equally diadelphous (5 and 5). Calyx 2-lipped. Pod severaljointed; joints square.

25. Coronilla. Stamens unequally diadelphous (9 and 1). Calyx 5-tootlied. Joints oblong, 4-angled. Flowers umbellate

26. Hedysarum. Stamens unequally diadelphous (9 and 1). Calyx 5-cleft. Pod severaljointed ; joints roundish.

$==$ Leaves pinnately 3 -foliolate, rarely 1-foliolate.

27. Desmodium. Stamens diadelphous (9 and 1) or monadelphous below. Calyx 2-lipped. Pod several-jointed. Flowers all of one sort and complete. Leaflets stipellate.

28. Lespedeza. Stamens diadelphous (9 and 1); anthers uniform. Pod 1-2-jointed. Flowers often of 2 sorts, the more fertile ones apetalous. Leaflets not stipellate.

29. Stylosanthes. Stamens monalelphous; anthers of 2 sorts. Pod 1-2-jointed. Calyx deciduous, the tube narrow and stalk-like. Leaflets not stipellate.

+++ Herbs with abruptly pinnate leaves, terminated by a tendril or bristle ; stamens diadelphous ; pod continuous, 2-valved, few-several-seeded. (VICIEF.)

30. Vicia. Wings adherent to the keel. Style filiform, bearded with a tuft or ring of hairs at the apex.

31. Lathyrus. Wings nearly free. Style somewhat dilated and flattened upwards, bearded down the inner face.

+++++ Twining (sometimes only trailing) herbs; leaves pinnately 3 - (rarely 1- or 5-7-) foliolate; no tendrils; peduncles or flowers axillary pod not jointed, 2-valved. (PHASEOLE.⿻.

$$
=\text { Leaves pinnate. }
$$

32. A pios. Herbaceous twiner; leaflets 5- 7 . Keel slender and much incurved or coiled. $==$ Leaves 3 -foliolate. Ovules and seeds several. Flowers not jellow.

33. Phaseolus. Keel spirally coiled; standard recurved-spreading. Style bearded lengthwise. Flowers racemose. Seeds round-reniform.

34. Strophostyles. Keel long, strongly incurved. Style bearded lengthwise. Flowers sessile, capitate, few. Seeds oblong, mostly pubescent.

35. Centrosema. Calyx short, 5-cleft. Standard with a spur at the base; keel broad, merely incurved. Style minutely bearded next the stigma.

36. Clitoria. Calyx tubular, 5-lobed. Standard erect, spurless; keel scythe-shaped. Style bearded down the inner face.

37. Amphicarpæa. Calyx tubular, 4-5-toothed. Standard erect; keel almost straight. Style beardless. Some nearly apetalous fertile flowers next the ground. 
88. Galactia. Calyx 4-cleft, the upper lobe broadest aud entire. Style beardless. Bract and bractlets minutc, uostly deciduous.

$===$ Leaves 1 -3-foliolate. Ovules and seeds only one or two. Fluwers yullow.

39. Rhynchosia. heel scythe-shaped. Calyx 4-5-partul. Poil short.

Suborner II. Caesalpiniece. (Brasilhtto Family.) Corolla imperfectly or not at all papilionaceous, sometimes nearly regular, imbricated in the bud, the upper or odd petal inside and enclosed by the othere, Stamens 10 or fewer, commonly distinet, inserted on the calyx. Seeds anatropous, often with albumen. Embryo straight.

* Flowers imperfectly papilionaceous, perfect. Trees.

40. Cercis. Calyx campanulate, 5-toothed. Pod flat, wing-marginerl. Leaves simple.

* Flowers not at all papilionaceous, perfect. Calyx 5-parted. Ilerbs.

41. Cassia. Leaves simply and abruptly pinnate, not glandular-purctate.

42. Hoffmanseggia. Leaves bipinnate, glandnlar-punctate.

*** Flowers not at all papilionaceous, polygamous or diøcions. Trees.

43. Gymnocladus. Leaves all doubly pinuate. Calyx-tube elongated, at its sumnit bearing 5 petals resembling the calyx-lobes. Stamens 10.

44. Gleditschia. Thorny ; leaves simply and doubly pinnate. Calyx-tubeshort; its lobes, petals, and the stamens $3-5$.

Suborder III. Mimosea. (Mimosa Family.) Flower regular, small. Corolla valvate in æstivation, often united into a 4-5-loberl cup, hypogynous, as are the (often very numerous) exserted stamens. Embryo straight. Leaves twice pinnate.

45. Desmanthus. Petals distinct. Stamens 5 or 10. Por smooth.

46. Schrankia. Petals united below into a cup. Stamens 8 or 10 . Pod covered with small prickles or rough projectious.

\section{Baptísia, Vent. False Indigo.}

Calyx 4-5-toothed. Standard not longer than the wings, its sides reflexed; keel-petals nearly separate, and, like the wings, straight. Stamens 10, distinct. Pod stalked in the persistent calyx, roundish or oblong, inflated, pointed, many-seeded. - Perennial herls, with palmately 3-foliolate (rarely simple) leaves, which generally blacken in drying, and racemerl flowers. (Named from $\beta a \pi \tau l \zeta \omega$, to $d y e$, from the economical use of some species, which yield a poor indigo.)

* Racemes many, short and loose, terminal, often leaf.y at base, flouers yellow.

1. B. tinctoria, R. Br. (Wrild Irmigo.) Smooth and slender $\left(2-3^{\circ}\right.$ high), rather glaucous; leares almost sessile, leaflets rounded wedge-oborate $\left(\frac{1}{2}-1 \frac{1^{\prime}}{2}\right.$ long); stipules and bracts minnte and deciduous; porls oval-globose, on a stalk longer than the calyx. _ Sandy dry soil, N. Eng. to Fla., west to Minn. and La.

* * Racemes fewer, npposite the leaves.

- Flowers yellow.

2. B. villosa, Ell. Sometimes soft-liairy, usually minutely pubescent when young, erect $\left(2-3^{\circ}\right.$ high) with divergent branches; leares amost ses- 
sile; leaflets wedge-lanceolate or obovate; lower stipules lanceolate and persistent, on the branchlets often small and subulate; racemes many-flowered; pedicels short; bracts subulate, mostly deciduous; pods ovoid-oblong and taper-pointed, minutely pubescent. - Va. to N. C. and Ark.

+ + Flowers white or cream-color.

3. B. leucophæa, Nutt. Hairy, low $\left(1^{\circ}\right.$ high), with divergent branches; leaves almost sessile, leaflets narrowly oblong-obovate or spatulate; stipules and bracts large and leafy, persistent; racemes long (often $1^{\circ}$ ), reclined; flowers on elongated pedicels, cream-color; pods pointed at both ends, hoary. - Mich. to Minn., south to Tex. April, May.

4. B. leucántha, Torr. \& Gray. Smooth; stems, leaves, and racemes as in n. 6; stipules early deciduous; flowers white; pods oval-oblong, raised on a stalk fully twice the length of the calyx. - Alluvial soil, Ont. and Ohio to Minn., south to Fla. and La.

5. B. álba, R. Br. Smooth $\left(1-3^{\circ}\right.$ high), the branches slender and widely spreading; petioles slender; stipules and bracts minute and deciduous; leaflets oblong or oblanceolate; racemes slender on a long naked peduncle; pods

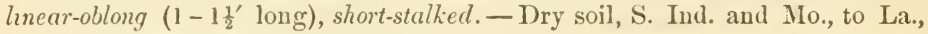
N. C., and Fla. July.

\section{+ + Flowers indigo-blue.}

6. B. austràlis, R. Br. (Bure False-Ivdigo.) Smooth, tall and stout $\left(t-5^{c}\right)$; leaflets ol,long-werlge-form, obtuse; stipules lanceolate, as long as the petioles, rather persistent; raceme elongated $\left(1-2^{\circ}\right)$ and many-flowered, erect; bracts deciduous; stalk of the oval-oblong pods about the length of the calyx. - Alluvial soil, P'enn. to Ga., west to S. Ind., Mo., and Ark.

\section{THERMÓPSIS, R. Br.}

Pod sessile or shortly stıpitate in the calyx, flat, linear, straight or curred. Otherwise ncarly as Baptisia. - Perennial herhs, with palmately 3-foliolate leaves and foliaceous stıpules, not blackening in drying, and yellow flowers in

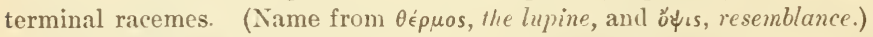

ı. T. móllis, M. A. Curtis. Finely appressed-pubescent, $2-3^{\circ}$ high ; leaflets rhombic-lanceolate, $1-3^{\prime}$ long; stipules narrow, mostly shorter than the petiole, raceme elongated; pocls narrow, short-stipitate, somewhat curved, 2-4 long. - Mountains of $\mathrm{S}$. Va. and N. C.

2. T. rhombifolia, Nutt. Low, with smaller leares and broad conspicuous stıpules; racemes short, few-flowered; pods broadly linear, spreading, usually strongly curred. - Sask. to E. Col, near or in the mountains, reported from central Kan.

\section{CLADRÁSTIS, Raf. Yellow-Wood.}

Calyx 5-toothed. Standlard large, roundish, reflexed; the distinct keel-petals and wings straight, oblong. Stamens 10, distinct; filaments slender, incurved above. Pod short-stalked above the calyx, linear, flat, thin, marginless, 4-6seerled, at length 2 valved $-\Lambda$ handsome tree, with yellow wood, smooth bark, nearly smooth pinnate leaves of 7-11 oval or ovate leaflets, and ample panicled racemes $\left(10-20^{\prime}\right.$ long) of showy white flowers drooping from the ends of 
the branches. Stipules obsolete. Base of the petioles hollow, enclosing the

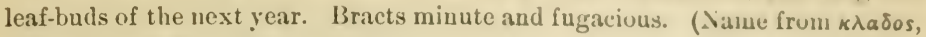
a branch, and $\theta$ pavorós, brittle.)

1. C. tinctòria, Raf. Sometimes $50^{\circ}$ high ; pols $3-4^{\prime}$ lung. - Rich hillsides, central Ky. and 'Tenn. to N. C. Mlso in cultivation. 'The wood yiclds a yellow dye.

\section{SOPH Ò $\mathbf{A}$, L.}

Calyx bell-shaped, shortly 5-toothed. Standard rounded; keel nearly straight. Stamens distinct or nearly so. Pol coriaceous, stipitate, terute, more or less constricted between the seeds, indehiscent. Siceds subglobose. Shrubby or ours an herbaceous perennial, the leares pinnate with numerous leaflets, and flowers white or yellow in terminal racemes. (Said by Linnæus to be the ancient name of an allied plant.)

1. S. serícea, Nutt. Silky-canescent, erect, $1^{\circ}$ high or less; leaflets oblong-obovate, 3-6" loug; flowers white; pods few-seeded. - Central Kan. to Col., Tex., and Ariz.

\section{CROTALÀ RIA, I. Rattle-вox.}

Calyx 5-cleft, scarcely 2-lipped. Standard large, heart-shaped; keel scrtheshaped. Sheath of the monarlelphous stamens cleft on the upper side; 5 of the anthers smaller and roundish. l'od inflated, oblong, many-seeded. - Herls

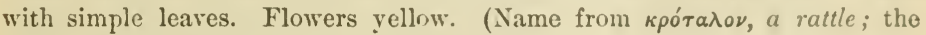
loose seeds rattling in the coriaceous inflated pods.)

1. C. sagittàlis, L. Annual, hairy $\left(3-6^{\prime}\right.$ high) ; leaves oral or oblonglanceolate, scarcely petioled; stipules united and decurrent on the stem, so as to be inversely arrow-shaped; peduncles few-flowered; corolla not longer than the calyx; pod blackish. - Sandy soil ; Maine to Ill., Minn., Kan., and southward.

\section{GEIÍTA, L. WолD-WAXex. Wuis.}

Calyx 2-lipped. Standard oblong-oval, spreading, keel ohlong, straight, deflexed. Stamens monadelphous, the sheath entire; 5 alteruate anthers shorter. Pod mostly flat and several-seeded. - Shrubby plants, with simple leaves, and yellow flowers. (Nane from the Celtic gen, a lush.)

G. Tixctória, L. (Dren's Griex-Weris.) Low, not thorny, with striateangled erect branches; leaves lanceolate; flowers in spiked racemes. - Lstablished on sterile hills, eastern N. Y. and Mass. ( Idl. from liu.)

\section{CÝTIS U S, Tourn. Broos.}

Calyx campanulate, with 2 short broarl lips. l'etals hroal, the keel olituse and slightly incurved. Stamens monadelphous. l'od that, much longer than the calyx. Seeds several, with a strophiole at the hilum. _ shrubs, with stiff green branches, leaves mostly digitatcly 3-foliolate, ancl large bright yellow flowers. ('The ancient Roman name of a plant, probably" a Melieago.)

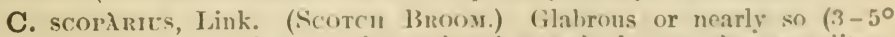
high); leaflets small, oborate, often reluced to a single one; fluwers solitary or in pairs, on slender pedicels, in the axils of the old leaves, forming leafy racemes along the upper branches; style very loug and spirally incurved. Va. and southward. (Nat. from Eu.) 


\section{L U PIN U S, Tourn. LrPINE.}

Calyx very deeply 2-lipped. Sides of the standard reflexed; keel scytheshaped, pointed. Sheath of the monadelphous stamens entire; anthers alternately oblong and roundish. Pod oblong, flattened, often knotty by constrictions between the seeds. Cotyledons thick and fleshy.-Herbs, with palmately 1-15-foliolate leaves, stipules atnate to base of the petiole, and showy flowers in terminal racemes or spikes. (Name from Lupus, a wolf, because these plants were thought to derour the fertility of the soil.)

1. L. perénnis, L. (Wild Lupixe.) T'erenuial, somewhat hairy; stem erect $\left(1-2^{\circ}\right)$; leaflets $7-11$, oblanceolate; flowers in a long raceme, showy, purplish-blue (rarely pale); pods broad, very hairy, 5-6-seeded. - Sandy soil, N. Eng. to Minn., Mo., and south to the Gulf. - Var. occidentalis, Watson, has stems and petioles more villous. - Mich. and Wisc.

2. L. pusíllus, Pursh. Annual, low, villous; leaflets usually 5 ; racemes short, sessile; flowers purple or rose-color; pods oval, hirsute, 2-seeded. Central Dak. and Kan., and westward.

\section{TRI F Ò I I M, Tourn. Clover. Trefoll.}

Calyx persistent, 5-cleft, the teeth bristle-form. Corolla mostly withering or persistent; the claws of all the petals, or of all except the oblong or ovate standard, more or less united below with the stamen-tube; keel short and obtuse. Tenth stamen more or less separate. Pods small and membranous, often included in the calyx, 1-6-seeded, indehiscent, or opening by one of the sutures. - Tufted or diffuse herbs. Leaves mostly palmately, sometimes pinnately 3 -foliolate; leaflets usually toothed. Stipules united with the petiole. Flowers in heads or spikes. (Name from tres, three, and folium, a leaf.)

* Flowers sessile in denso heads ; corolla purple or purplish, withering away after flowering, tubular below, the petals more or less coherent with each other.

+ Calyx-teeth silky-plumose, longer than the whitish corolla; root annual.

T. ARvéxse, L. (RABrit-foot or Stone Clover.) Silky, branching (5-10' high); leaflets ohlanceolate; heads becoming very soft-silky and grayish, oblong or cylindrical. - Old fields, etc. (Nat. from Eu.)

+ + Calyx scarcely hairy except a bearded ring in the throat, shorter than the rosepurple elongated-tubular corolla. (Short-lived perennials; flowers sweet-scented.)

T. pratésse, I. (Red C.) Stems ascending, somewhat hairy; leaflets oval or obovate, often notched at the end and marked on the upper side with a pale spot; stipules broad, bristle-pointed; heads ovate, sessile. - Fields and meadows; largely cultivated. (Adv. from Eu.)

T. uغ̀dIu i, L. (ZigZAG C.) Stems zigzag, smoothish; leaflets oblong, entire, and spotless; heads mostly stalked; flowers deeper purple, otherwise too like the last. - Dry hills, N. Scotia to E. Mass. (Adr. from Eu.)

* * Flou'ers pedicelled in umbel-like round heads on a naked peduncle, their short pedicels reflexed when old; corolla white or rose-color, withering-persistent and turning brownish in fading; the tubular portion short.

1. T. refléxum, L. (Brffalo C.) Annual or biennial; stems ascending, downy; leaflets oborate-oblong, finely toothed; stipules thin, ovate; standard rose-red, wings and keel whitish; calyx-teeth hairy; pods 3-5-seeded. Western N. Y. and Ont. to Iowa, Kan., and southward. 
2. T. stoloniferum, Muhl. (Rrxwixa Brifalo-C.) Sinnoth, peresnial; stems with long runners from the base; leaflets broully olwocate or whendule, minutely toothel; heads loose; flowers white, tinged with purple; pouls 2 seeded. - Open woodlands and prairies, Ohio and liy., west to luwa and Kan.

3. T. repens, I. (Wunte C.) Smooth, perenuial; the slender stems spreating and creeping; leaflets inversely heart-shaped or merely notched, whscurely toothed; stipules scale-like, narrow ; petioles and esperially the produncles very long; heads small and loose; calyx much shorter thun the white corollu; porls about 4-sceded. - Fields and copses, everywhere. Indigenuus only in the northern part of our range, if at all.

4. T. Caroliniànum, Michx. Somewhat pubescent small perennial, procumbent, in tufts; leatlets werge-ohovate and slightly notcherl; stipules ovate, foliaceous; heads small on slender peduncles; calyx-terth lanceolate, nearly equalling the purplish corolla; standard pointed; pods 4-secded. - Waste ground near Philadelphia, south to Va., Fla., and 'Tex.

T. Hýbidu, L. (Alsike C.) Resembling 'T. repens, but the stems erect or ascending, not rooting at the nodes; flowers rose-tinted. - Becoming common. (Nat. from Eu.)

* * Flowers short-pedicelled in close heads, reflexed when old; corolla yellow, persistent, turning dry and chestnut-broun with age, the standard becoming hood-shaped; annuals, $f$. in summer.

T. AgRARIU. L. (Yellow or Hop-C.) Smoothish, somewhat upright (6-12' high); leuflets obovate-oblong, all three from the same point (palmate) and nearly sessile; stipules narrow, cohering with the petiole for more thun hulf its length. - Sandy fields and roadsides; N. Scotia to Va.; also in western $\mathbf{X}$. . (Nat. from Eu.)

T. Procúsunexs, L. (Low Hop-C.) Stems sprealing or ascending, pubescent ( $3-6^{\prime}$ high); leaflets wedge-oborate, notched at the end, the lateral at a small distance from the other (pinnately 3 -foliolate); stipules ovate, short.Sandy fields and roadsides, common. - Var. uixı's, Gray, has smaller heads, the standard not much striate with age. (Nat. from Eu.)

\section{MELILOTUS, Tourn. Melilot. Sweet Clover.}

Flowers much as in Trifolium, but in spike-like racemes, small; corolla deciduous, free from the stamen-tube. Por ovoid, coriaceous, wrinkled, longer than the calyx, scarcely dehiscent, 1-2-seeded. - Annual or biennial herls, fragrant in drying, with pinnately 3 -foliolate leares, leatlets touthed. (Name from $\mu \in \lambda_{\lambda}$, honey, and $\lambda \omega \tau o ́ s$, some leguminous plant.)

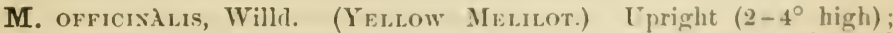
leaflets ohovate-oblong, olituse; corolla yellow; the petals nearly of equal length. - IVaste or cultivated grounds. (Adv. from liu.)

M. ÁBA, Lam. (Wnite M.) Leatlets truneate; corolla whe; the standard longer than the other petals. - In similar places. ( $\mathrm{Adv}$. from Eu.)

\section{MEDICÁG O, Tourn. MEnIok.}

Flowers nearly as in Melilotus. Porl 1-several-secled, scythe-shaped, incurved, or variously coiled. - Leaves pinnately 3-foliolite; leathets tootherl; stipules often ent. (M $\eta \delta\left\llcorner\eta^{\prime}\right.$, the name of Lucerne, because it came to the Greeks from Media.)

M. sativa, L. (Iucerse. Alfarfa.) Upright, smooth, perennial; leaflets obovate-oblong, toothed; flowers (purple) racemed; pods spirally twisted. - Cultivated for green fodder; spontaneous from Mass. to Minn. and lian. (Adv. from Eu.) 
M. lupulìa, L. (Black Medick. Noxescri.) Procumbent, pubescent, annual; leaflets wedge-obovate, toothed at the apex; flowers in short spikes (yellow); pods kidney-form, 1-seeded. - Waste places, N. Eng. to Fla., west to Mich., Iowa, and Mo. (Adv. from Eu.)

M. Maculatta, Willd. (Spotted Medick.) Spreading or procumbent annual, somewhat pubescent; leaflets obcordate, with a purple spot, minutely toothed; peduncles 3-5-flowered; flowers yellow; pods compactly spiral, of 2 or 3 turns, compressed, furrowed on the thick edge, and fringed with a double row of curved prickles. - N. Brunswick to Mass. (Adv. from Eu.)

M. Dexticulatia, Willd. Nearly glabrous; pods loosely spiral, deeply reticulated, and with a thin keeled edge; otherwise like the last, and with the same range. (Adv. from Eu.)

\section{HOSÁ CKI A, Donglas.}

Calyx-teeth nearly equal. Petals free from the diadelphous stamens ; standard ovate or roundish, its claw often remote from the others; wings obovate or oblong; keel incurved. Pod linear, compressed or somewhat terete, sessile, several-seeded. - Herbs, with pinnate leaves (in ours 1-3-foliolate, with glandlike stipules), and small yellow or reddish flowers in umbels (ours solitary) upon axillary leafy-bracteate peduncles. (Named for Dr. David Hosack, of New York.)

1. H. Purshiàna, Benth. Annual, more or less silky-villous or glabrous, often $1^{\circ}$ high or more; leaves nearly sessile, the $1-3$ leaflets ovate to lanceolate $\left(3-9^{\prime \prime}\right.$ long); peduncles often short, bracteate with a single leaflet. - N. C. ; S. W. Minn. to Ark., and west to the Pacific. Very variable.

\section{PSORÀ LA, L.}

Calyx 5-cleft, persistent, the lower lobe longest. Stamens diadelphous or sometimes monadelphous. Pod seldom longer than the calyx, thick, often wrinkled, indehiscent, 1-seeded. - Perennial herbs, usually sprinkled all over or roughened (especially the calyx, pods, etc.) with glandular dots or points. Leaves mostly 3-5-foliolate. Flowers spiked or racemed, white or mostly blue-purplish. Root sometimes tuberous and farinaceous. (Name, $\psi \omega \rho a \lambda \epsilon ́$ s, scurfy, from the glands or dots.)

\section{* Leaves pinnately 3-foliolate.}

1. P. Onóbrychis, Nutt. Nearly smooth and free from glands, erect (3-5० high); leaflets lanceolate-ovate, taper-pointed ( $\left.3^{\prime} \mathrm{long}\right)$; stipules and bracts axl-shaped; racemes elongated; peduncle shorter than the leaves; pods roughened and wrinkled. - River-banks, Ohio to Ill. and Mo.; also south and east to S. C. July.

2. P. stipulàta, Torr.\& Gray. Nearly smooth and glandless ; stems diffuse; leaflets ovate-elliptical, reticulated; stipules ovate; flowers in heads on rather short peduncles; bracts broadly ovate, sharp-pointed. - Rocks, S. Ind. and Ky. June, July.

3. P. melilotoides, Michx. Somewhat pubescent, more or less glandular; stems erect $\left(1-2^{\circ}\right.$ high), slender; leaflets lanceolate or narrowly oblong ; spikes oblong, long-peduncled; stipules awl-shaped; bracts ovate or lanceolate, taper-pointed; pods strongly wrinkled transrersely. - Dry soil, Fla. to Tenn., S. Ind. and Kan. June. 
* Leares palmately 3-5-foliolate; roots not tuberous.

4. P. tenuiflora, Jursh. Slender, erect, much branched and bushy $\left(2-4^{\circ}\right.$ high), minutely houry-pubscent when young; laflets varying from linear to obovate-oblong $\left(\frac{1}{2}-1 \frac{1^{\prime}}{2}\right.$ long), glandular-fotted ; flowers (2-3" long) in loose racemes: lobes of the calyx and bracts ovate, acute; porl glandular. (l’. floribunda, Null.) - P'rairies, Minn. to Ill., 'Tex., and westward. JuneSept.

5. P. argophýlla, Pursh. Sileery silky-uhile all over, erect, livergently branched $\left(1-3^{c}\right.$ high); leaflets ellipticaltunceolate; spikes interrupted: lubes of the ealyx and bracts lanceolute. - High plains, N. Wisc. to lowa, Kan,, and westward. June. - Flowers $4-5^{\prime \prime}$ long.

6. P. digitàta, Nutt. More slender and less hoary, $1-2^{\circ}$ high; leaflets linear-oblanceolate; bracts of the interrupted spike olscordate; calyx-lules oblong, acute. - Central Kan. to Col. and 'T'ex.

7. P. lanceolata, l'ursh. Glahrous or nearly so, yellowish green, denscly: punctate; leaflets 3 , linear to oblanceolate; flowers small, in very slust spike's;

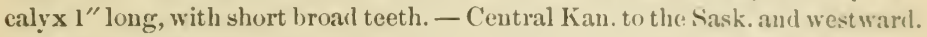

* * Leaves palmately 5-foliolate; root tuberous; spike-tike racemes dense.

8. P. esculénta, Pursh. Roughish hairy all over; stem stont $\left(5-15^{\prime}\right.$ high) and erect from a tuherous or turnip-shaped farinacenus root; leaflets obovate- or lanceolate-oblong; spikes oblong, long-peduncled; lobes of tho calyx and bracts lanceolate, nearly equalling the corolla ( $\frac{1}{2}$ ' long). - High plains, Sask. to Wisc, Iowa, and T'ex. June. The I'oume BLAxcue, or l'omue de Prarie, of the voygeurs.

9. P. hypogæ̀a, Nutt. 'Tuber small; nearly acaulescent, hoary with appressed hairs; leaflets linear; spikes short-eapitate, on peluncles $\frac{1}{2}-2^{\prime}$ long: calyx narrow, 3-6" long. - Central Kan. to Col. and Tex.

10. P. cuspidàta, Pursh. Stout, tall, from a leep-seaterl tuber, hoary with appressed hairs; leaflets usually broadly oblanceslate, obtuse; flowcrs large, the petals $\left(6-8^{\prime \prime}\right.$ long) exceeding the lauceolate-lobed calyx - Central Kan. to Col. and Tex.

\section{A M ÓRPHA, I. False INingo.}

Calyx inversely conical, 5-toothed, persistent. Standarl (the other petals entirely wanting!) wrapped arouml the stamens and style. Stamens 10, monadelphous at the very hase, otherwise distinct. l'ol ohlong, longer than the ealyx, 1-2-seeded, ronghened, tardily dehiscent. - Shruls, with oxlipinnate leaves: the leaflets marked with minute duts, usnally stipellate, the midvein excurrent. Flowere violet or purple, crowled in clustered torminal spikes. (Naune, ămopфos, de formed, from the alssence of four of the petals.)

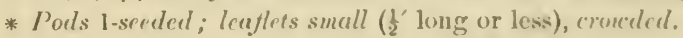

1. A. canéscens, Nutt. (LAism-Plaxt) Whutened with houry doun $\left(1-3^{\circ}\right.$ high $)$; leaflets $15-25$ pairs, olibugg-ellijtical, becoming smeothish above; spikes usually chustered at the sumunit. - Sask. to Ind. and 'T'ex., west to the Rocky Mits. ; also eastward to (ia.

2. A. microphýlla, l'ursh. Neurly glabrous throughont, 10 high or less; leaflets rather rigid; spikes usually solitary. - Sask. to Minu. and lowa, west to the Rocky Mts. 


\section{* Pods 2-seeded; leaflets larger, scattered.}

3. A. fruticosa, L. (FAlse INdigo.) A tall shrub, rather pubescent or smoothish, leaflets 8-12 pairs, oblong to broadly elliptical. - River-banks, S Penn to Fla., west to Sask., Tex., and the Rocky Mts. Very variable.

\section{D Á L A, L.}

Calyx 5-cleft or toothed. Corolla imperfectly papilionaceous; petals all on claws; the standard heart-shaped, inserted in the bottom of the calyx; the keel and wings borne on the middle of the monadelphous sheath of filaments, which is cleft down one side. Stamens 10, rarely 9. Pod membranaceous, I-seeded, indehiscent, enclosed in the persistent calyx. - Mostly herbs, more or less glandular-dotted, with minute stipules; the small flowers in terminal spikes or heads (Named for Samuel Dale, an English botanist.)

* Gilabrous; flowers white or rose-color; leaflets $4-20$ pairs; annuals.

1. D. alopecuroides, Willd. Erect $\left(1-2^{\circ}\right.$ high $)$; leaflets $10-20$ pairs, linear-oblong; flowers light rose-color or whitish, in cylindrical spikes; bracts ovate-lanceolate, acuminate, decicluous; calyx very villous, with long slender teeth. - Alluvial soil, Minn. to Ill. and Ala., west to the Rocky Mts.

2. D. laxiflòra, Pursh. Erect $\left(1-4^{\circ}\right.$ high), branching; leaflets $3-5$ pairs, linear, 2 - 3" long; spikes loosely-flowererl; hracts conspicuous, persistent, almost orbıcular and very obtuse; petals white; calyx densely villous, the long teeth beautifully plumose. - Iowa and Mo. to Tex., west to Col.

* * Pulescent : leaflets $3-4$ pairs; perennial herbs.

3. D. aùrea, Nutt. Stems erect and simple, $\mathrm{l}-3^{\circ}$ high; leaflets oblong, obovate to linear-oblong, more or less silky-pubescent; spikes solitary, oblongovate, very compact and densely silky; bracts short, rhombic-orate; petals yellow. - (On the plains, Mo. to Tex., and westward.

4. D. lanàta, Spreng. Very pubescent throughout, $1-2^{\circ}$ high, branching; leaflets obovate to oblong-oborate, 2-3" long; spikes slender, rather loose, the obovate acute bracts equalling the small short-toothed calyx; petals short, purple. - Central Kan. to Tex., and westward.

\section{PETALOSTEMON, Michx. Prarrie Clover.}

Calyx 5-toothed. Corolla indistinctly papilionaceous; petals all on threadshaped claws, 4 of them nearly similar and spreading, borne on the top of the monadelphous and cleft sheath of filaments, alternate with the 5 anthers; the fifth (standard) inserted in the bottom of the calyx, heart-shaped or oblong. Pod membranaceous, enclosed in the calyx, indehiscent, 1 - 2-seeded. - Chiefly perennial herbs, upright, glandular-dotted, with crowded odd-pinnate leaves, minute stipules, and small flowers in very dense terminal and peduncled heads or spikes. (Name combined of the two Greek words for petal and stamen, alluding to the peculiar union of these organs in this genus.)

1. P. violàceus, Michx. Smoothish; leaflets 5, narrouly linear; heads globose-orate, or oblong-cylindrical when old; bracts pointed, not longer than the silky-hoary calyx; corolla rose-purple. - Dry prairies, Minn. to Ind. and Tex., west to the Rocky Mts July. 
2. P. cándidus, Michx. Simooth; lenflets 7-9, luncrulute or linear-ohlong; heads oblung, when old cylindrical ; hracts awned, longer than the nearly glabrous calyx; corollı white. - With n. 1.

3. P. villosus, Nutt. suji-douny or silky all over; leaflets $13-17$, linear or oblong, small ( $4-5^{\prime \prime}$ long); spikes cylindrical ( $1-5^{\prime}$ long), short-peduncled, soft-villous; corolla rose-color. - Wisc. to Mo., west to the liocky Mt.s.

4. P. foliosus, Giray. Smooth, very leafy ; leaflets 15-29, lineuroblong; spikes cylindroul, short-peduncled; bracts slender-awned from a lanceolato base, exceeding the glabrous calyx; petals rose-color. - liver-banks, 111. and Tenn.

5. P. multiflorus, Nutt. Glabrous throughout, erect, branching; leaflets $3-9$, linear to oblong; spikes ylubose, the subulate-setaceons bracts much shorter than the acutely toothel calyx; petals white. - Kan. to Tex.

\section{TEPHRÒSIA, Pers. Honk PEA.}

Calyx about equally 5-cleft. Standard roumlish, usually silky outside, turned back, scarcely longer than the coherent wings and keel. Stamens monalelphous or diadelphous. l'od linear, flat, several-seeded, 2-valverl. - Huary perennial herbs, with odd-pinnate leaves, and white or purplish racemed flowers. Leaflets mucronate, veiny. (Name from $\tau \epsilon \phi \rho o ́ s, ~ u s h$-colured or hoary.)

1. T. Virginiana, Pers. (Goat's Rce. C.тист.) Silky-villous with whitish hairs when young; stem erect and simple $\left(1-2^{\circ}\right.$ high $)$, leafy to the top; leaflets 17-29, linear-oblong; flowers large and numerous, clustered in a terminal oblong dense raceme or panicle, yellowish-white marked with purple. Dry sandy soil. June, July. - Roots long and slender, very tough.

2. T. spicàta, Torr. \& Gray. Tillous with rusty hairs; stems branched below, straggling or ascending ( $\left.2^{\circ} \mathrm{long}\right)$, fex-lecued: leaflets $9-15$, ohovate or oblong-wedge-shaped, often notched; flowers feu, in a loose and interrupted very long-peduncled spitie, reddish. - Dry soil, from Del. and Va. to Fla. and Miss. July.

3. T. hispídula, Pers. Hairy with some long and rusty or only miunte and appressed pubescence; stems slender $\left(9-24^{\prime}\right.$ long), divergently branehed, straggling; leaflets 5-15, oblong, varying to obovate-wedge-shaped and oblanceolate; peduncles longer than the leures, 2-4-flowered, fluwers reddishpurple.-Dry sandy soil, Va. to Flia. and Ala.

\section{INDIGÖERA, I. INmGo.}

Calyx small, equally 5-cleft. Standard roundish, silky ontside, wings coherent; keel erect, gibbous or spurred at base. Stamens diadelphous; connective gland-like. Pod 1-several-seeded, septate within hetween the seeds. - Herbs or shrubs, mostly canescent with appressed hairs fixed by the middle, with odd-pinnate faintly-nerved leaves, and pink or purplish flowers in naked axillary spikes. (So named because some of the species yield the indigo of commerce.)

1. I. leptosépala, Nutt. A perennial herb, $\frac{1}{2}-2^{\circ}$ high ; leaflets $5-9$, oblanceulate; spikes very loose; pods linear, 6-9 seeded, obtusely 4-angled, reflexed, $l^{\prime}$ long. - Kan. to Tex. and Fla. 


\section{ROBÍNIA, L. Locest-tree.}

Calyx short, 5-toothed, slightly 2-lipped. Standard large and rounded, turned back, scarcely longer than the wings and keel. Stamens diadelphous. Pod linear, flat, several-seeded, margined on the seed-bearing edge, at length 2-valred. - Trees or shrubs, often with prickly spines for stipules. Leaves oddi-pinnate, the ovate or oblong leaflets stipellate. Flowers showy, in hanging axillary racemes. Base of the leaf-stalks covering the buds of the next year. (Named iu honor of Joln liobin, herbalist to Henry IV. of France, and his son Vespasian Robin, who first cultivated the Locust-tree in Europe.)

1. R. Pseudacàcia, L. (Commox Locest or False Acacia.) Branches naked; racemes slender, loose; flowers white, fragrant; pod smooth. - S. Penn. to Ind., Iowa, and southward. Commonly cultivated as an ornamental tree, and for its valuable timber; naturalized in many places. June.

2. R. viscosa, Vent. (CLAmy L.) Branchlets and leaf-stalks clammy; flowers crouded in oblong racemes, tinged with rose-color, nearly inodorous; pod glandular-hispid. - Va. to N. C. and Ga., in the mountains. Cultivated, like the last, and often escaped. Jume.

3. R. híspida, L. (Bristly L. or Rose Acacia.) Shrub 3-8 $8^{\circ}$ high; branchlets and stalks bristly; flowers large and deep rose-color, inodorous; porls glandular-hispid. - Varies with less bristly or nearly naked branchlets; also with smaller flowers, etc. - Mts. of Va. to N. C. and Ga. May, June.

\section{W I S T A I A, Nutt.}

Calyx campanulate, somewhat 2-lipped; upper lip of 2 short teeth, the lower of 3 longer ones. Standard roundish, large, turned back, with 2 callosities at its base; keel scythe-shaped; wings doubly auricled at the base. Stamens diadelphous. I'ods elongated, thickish, knobby, stipitate, many-seeded, at length 2-ralved. Seeds large. - Woody twiners, climbing high, with minute stipules, pinnate leaves of $9-13$ ovate-lanceolate leaflets, with or without minute stipels, and dense racemes of large and showy lilac-purple flowers. (Dedicated to the late Professor ITistar, of Philadelphia.)

1. W. frutéscens, Poir. Downy or smoothish when old; wings of the corolla with one short auricle and an awl-shaped one as long as the claw. Alluvial grounds, Va. to Fla., west to S. Ind., Kan. and La. May. - Sometimes cultivated for ornament, as is the still handsomer Chinese species.

\section{A S T RÁGA I US, Tourn. Milk-Vetch.}

Calyx 5-toothed. Corolla usually long and narrow; standard narrow, equalling or exceeding the wings and blunt keel, its sides reflexed or spreading. Stanens diadelphous. Pod sereral-many-seeded, various, mostly turgid, one or both sutures usually projecting into the cell, either slightly or so as to divile the carity lengthwise into two. - Chiefly herbs (ours perennials), with odd-pinnate leaves and spiked or racemed flowers. Mature pods are usually necessary for certain identification of the species. (The ancient Greek name of a leguminous plant, as also of the ankle-bone; but the connection between the two is past all guess.) 
I. Pod turgid, completely or imperfectly 2-celled by the intrusion of the dorsal suture, the ventral suture being not at ull or less deeply inflexed. - AstraGAL's proper.

* Pod plum-shaped, succulent, becoming thick and fleshy, indehiscent, not stipitate, completely 2-celled.

1. A. caryocárpus, Ker. (Gisoexi) Pium.) Pale and minutely appressecl-pubescent; leaflets narrowly oblong; flowers in a short spike-like raceme; corolla violet-purple; fruit glabrous, ovate-glubular, more or less prointed, abont $\frac{2}{3}$ in diameter, very thick-walled, cellular or corky when dry. - Sask. and Minn. to Mo., Col., and Tex. May.

2. A. Mexicànus, A. I) . Smoother, or pubescent with looser hairs, larger; leaflets rounlish, obovate, or oblong; flowers larger (10-12" long); calyx softly hairy ; corolla cream-color, bluish only at the tip: fruit glolulur, very obtuse and pointless, l' or more in cliameter; otherwise like the last. - l'rajries and open plains, Ill. to Kan., sonth to Tex. The unripe fruits of both resemble green plums - whence the popular name - and are eaten, raw or cooked, by travellers.

3. A. Platténsis, Nutt. Loosely villons; stipnles conspicunns; leaflets oblong, often glabrous above; flowers crowded in a short spike or oblong he:ul, cream-color often tinged or tipped with purple; fruit orate, pointed, and with the calyx villous. - Gravelly or sandy banks, Minn. to Iud. and Ala., west tu Col. and 'Tex. - Var. Texxessenxsis, Gray, has the pod oblong and slightly curved, and much less fleshy. May.

* * Pod dry, coriaceous, cartilaginous or membranous, dehiscent.

$$
\text { + Pod completely 2-celled, sessile. }
$$

4. A. mollíssimus, Torr. Stout, decumlient, densely silky-villous throughout and tomentose; leaflets 19-29, ovate-oblong; peluncles elongated; spikes dense, with rather large violet flowers (6-12" long); pod narrow-oblung (59 "long), glabrous, somewhat obcompressed and sulcate at loth sutures, at length incurved. - Neb. to Kan. and Tex., west to Col. The most common "lucu". plant, and said to be very poisonous to eattle.

5. A. Canadénsis, L. Tull and erect $\left(1-4^{\circ}\right.$ high), someuhat pubescent or glabrute; leatlets 21-27, oblong; flowers greenish cream-color, very numerous, in long dense spikes; pods trowded, ohlong (6" loug), glahrous, terte, scarcely sulcate and only on the back, nearly straiglit. - River-bauks, western N. Y. to N. Ga., and far westward.

6. A. adsúrgens, P’all. Ascending or decumbent (4-1s' high), (inerenus with minute appressecl pubescence or glabrate; leaflets about 21, narrowly or linear-oblong; spike dense, with melium-sized pale or purplish tlowers; pubescence of calyx appressed; pod oblong ( $4-5$ " long), finely pubescent, triangular-compressed, with a deep dorsal furrow, struight. - Red River valley, Minn., to W. Kan., and westwaril. (Asiiı.)

7. A. hypoglóttis, I. silender $\left(6^{\prime}-2^{\circ}\right.$ long), diffusely procumbent or ascending, with a rather loose pubescence or nearly glahrous; leaflets 15-21, oblong, obtuse or retuse; flourers violet, capitute: culyx loosely pulvescent; pod as in the last, but ovate and silky-villous. - Red River valley, Miun., to central Kian. and westward. 
+ - Pod not completely 2-celled.

+ Pod stipitate, pendent.

8. A. alpinus, L. Diffuse $\left(6-12^{\prime}\right.$ high $)$, smooth or slightly hairy; leaflets 13-25; flowers violet-purple, or at least the keel tipped with violet or blue; calyx campanulate; pod narrowly oblong, short-acuminate, black-pubescent, triangular-turgid, deeply grooved on the back, straight or curved, its stipe usually rather exceeding the calyx. - Rocky banks, Lab. to Maine and $\mathrm{N}$. Vt.

9. A. Robbinsii, Gray. Nearly smooth and erect ( $1^{\circ}$ high), slender; leaflets 7-11; calyx more oblong; flowers white; pod oblong (6" long), obtuse or acutish, minutely darkish-pulescent, somewhat laterally compressed, not dorsally sulcate or obsoletely so, straight or somewhat iriurved, rather abruptly narrowed at base into the often included stipe. - Kocky ledges, Vt.

10. A. racemòsus, Pursh. Stout $\left(1-2^{\circ}\right.$ high $)$, erect or ascending, appressed-pubescent or glabrate; leaflets 13-25; flowers numerous, white, pendent; calyx campanulate, gibbous, white-pubescent; pod straight, narrow, $\mathbf{l}^{\prime}$ long, acute at both ends, triangular-compressed, deeply grooved on the back, the ventral edge acute. - Neb. to Mo., and westward.

+ Pod sessile.

11. A. grácilis, Nutt. Subcinereous, slender ( $1^{\circ}$ high or more); leaflets $11-17$, linear, obtuse or retuse ; racemes loose ; flowers small ( $3^{\prime \prime}$ long); pods pendent, $2-3^{\prime \prime}$ long, coriaceous, elliptic-ovate, concave on the back, the ventral suture prominent, white-hairy, at length glabrous, transversely veined. - Minn. to Neb. and Mo., and westward.

12. A. distórtus, Torr. \& Gray. Low, diffuse, many-stemmed, subglabrous ; leaflets $17-25$, oblong, emarginate ; flowers in a short spike, pale-purple; pod ovate- or lance-oblong, curved, 6-9' long, glabrous, thick-coriaceous, somewhat grooved on the back, the ventral suture nearly flat. - Ill. to Iowa, Mo., Ark. and Tex.

13. A. lotiflorus, Hook. Hoary or cinereous with appressed hairs ; stems very short; leaflets $7-13$, lance-oblong; flowers yellowish, in few-flowered heads, with peduncles exceeding the leares or very short; calyx campanulate, the subulate teeth exceeding the tube; pod oblong-ovate, 9-12" long, acuminate, acute at base, canescent, the back more or less impressed, the acute ventral suture nearly straight. - Sask. to Neb. and Tex., west to the mountains.

14. A. Missouriénsis, Nutt. Short-canlescent, hoary with a closely appressed silky pubescence; leaflets 5-15, oblong, elliptic or obovate; flowers few, capitate or spicate, $5-8^{\prime \prime}$ long, violet; caly $x$ oblong, the teeth very slender ; pod oblong ( $1^{\prime}$ long), acute, obtuse at base, pubescent, nearly straight, obcompressed or obcompressed-triangular, depressed on the back and the ventral suture more or less prominent, transversely rugulose. - Sask. to Neb. and N. Mex.

II. Pod 1-celled, neither suture being inflexed or the ventral more intruded than the dorsal. - PHACA.

15. A. Coòperi, Gray. Nearly smooth, erect (1-2 ${ }^{\circ}$ high $)$; leaflets $11-21$, elliptical or oblong, somewhat retuse, minutely hoary beneath; flowers white, rather numerous in a short spike; calyx dark-pubescent; pod coriaceous, inflated, ovate-globose (6-9" long), acute, glabrous, slightly sulcate on both sides, cavity webby. - Ont. and western N. Y. to Minn. and Iowa. 
16. A. flexuósus, Dongl. Ashy-puberulent, ascending $\left(1-2^{\circ}\right.$ highs ; leaflets 11-21, mustly narrow; flowers small, in lowse racmes; jul thin-coriaceous, cylindric (8-11" long, 2" broal), pointed, straight or curved, puberulent, very shortly stipitate. - lied River Valley, Minn., to (ul.

\section{OXÝTROPIS, IC.}

Keel tipped with a sharp projecting point or appendage; otherwise as in $\Lambda$ stragalus. l'od often more or less 2xelled by the intrusion of the ventral suture.-Our species are low, nearly acaulescent perennials, with tufts of numerous very short stems from a hard and thick root or rootstock, corered with scaly adnate stipules; pinnate leaves of many leaflets; pecluncles scapelike, bearing a head or short spike of flowers. (Name from ókis, sharp, and $\tau \rho \dot{\pi} \pi$ s, lieel.)

* Leaves simply pinnate.

1. O. campéstris, DC., var. cærùlea, Koch. I'uliescent or smoothish ; leaflets lanceolate or oblong; flowers violet or blne, sometimes pure white; pods ovate or oblong-lanceolate, of a thin or papery texture.- N. Maine to Labrador.

2. O. Lambérti, Pursh. Silky with fine appressed hairs; leaflets mustly linear; flowers larger, purple, violet, or sometimes white; porls cartilayinous or firm-coriaceous in texture, silky-pubescent, strictly erect, cylindraceous-lanceolate and long-pointed, almost 2-celled by intrusion of the ventral suture. Dry plains, Sask. and Minn. to Mo. and Tex., west to the mountains.

* Leaflets numerous, mostly in fascicles of 3 or 4 or more along the rhachis.

3. O. spléndens, Mougl. Silvery silky-rillous $\left(6-12^{\prime}\right.$ high); scape sjicately several to many-flowered; flowers erect-spreading; pod ovate, erect, 2 celled, hardly surpassing the very villous calyx - P'lains of Sask. and W. Minn., to N. Mex. and the Rocky Mts.

\section{GL Y C Y R R H İZ A, Tourn. Lrqvonice.}

Calyx with the two upper lobes shorter or partly mited Anther-cells confluent at the apex, the alteruate ones smaller. l'od ovate or ohlong-linear. compressed, often curved, clothed with rough glands or short prickles, scarcely dehiscent, few-seeded. The fluwer, etc., otherwise as in Astragalus - Long perennial root sweet (whence the name, from $\gamma \lambda$ voús, sucet, aud pija, ruol); herbage glandular-viscid; leaves odd-pinnate, with minute stipules; flowers in axillary spikes, white or bluish.

1. G. lepidota, Nutt. (WIL1 Liovorice.) Tall $\left(2-3^{\circ}\right.$ high); leaflets 15-19, oblong-lanceolate, mucronate-puinted, sprinkled witl little scales when young, and with corresponding dots when old; spikes peduncled, short ; flowers whitish; pods oblong, heset with hooked prickles, so as to resemble the fruit of Xinthium on a smaller scale. - Minn. to Iowa and Mo., and west warl; Ft. Erie, Ont.

\section{E SCH Y N Ó M E N E, I. SExitre JorNT-Vetch.}

Calyx 2-lipped; the upper lip 2-, the lower 3-cleft. Standard roundish; keel boat-shaped. Stamens diadelphous in two sets of 5 each. I'(rd flattened, 
composed of sereral easily separable joints. - Leares odd-pinnate, with several pairs of leaflets, sometimes sensitive, as if shrinking from the touch (whence

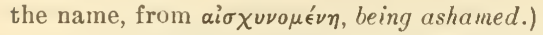

1. 屍. híspida, Willd. Erect, rough-bristly annual ; leaflets $37-51$, linear; racemes few-flowered; flowers yellow, reddish externally; pod stalked, 6-10-jointed. - Along rivers, S. Penn. to Fla. and Miss. Aug.

\section{CORONÍLLA, I.}

Calyx 5-toothed. Stanclard orbicular; keel incurved. Stamens diadelphous, 9 and 1 . Pod terete or 4-angled, jointed ; the joints oblong. - Glabrous herbs or shrubs, with pinuate leaves, and the flowers in umbels terminating axillary peduncles (Diminutive of corona, $a$ croun, alluding to the inflorescence.)

C. VAria, I. A perennial herb with ascending stems; leares sessile; leaflets $15-25$, oblong; flowers rose-color; pods coriaceous, $3-7$-jointed, the 4 -angled joints $3-4^{\prime \prime}$ long. - Conn. to N. J. (Nat. from Eu.)

\section{HEDÝSARUM, Tourn.}

Calyx 5-cleft, the lobes awl-shaped and nearly equal. Keel nearly straight, obliquely truncate, not appendaged, louger than the wings. Stamens diadelphous, 5 and 1. Pod Hattened, composed of several equal-sided separable roundish joints connected in the middle. - Perenuial herls; leaves odd-pinnate. (Name composed of ìjús, sueet, and ă $\rho \omega \mu \alpha$, smell.)

1. H. boreàle, Nutt. Leaflets 13-21, oblong or lanceolate, nearly glabrons; stipules scaly, united opposite the petiole; raceme of many deflexed purple flowers; standard shorter than the keel ; joints of the pod 3 or 4 , smooth, reticulated. - Lah. to northern Maine and Vt.; north shore of L. Superior, and north and westward.

\section{DES M ÒDIUM, Desv. Tick-Trefoil.}

Calyx usually more or less 2-lipped. Standard obovate; wings adherent to the straight or straightish and usually truncate keel, by means of a little transverse appendage on each side of the latter. Stamens diadelphous, 9 and 1, or monadelphous below. Pod flat, deeply lobed on the lower margin, separating mto few or many flat reticulated joints (mostly roughened with minute hooked hairs, by which they adhere to the fleece of animals or to clothing). - Perennial herbs, with pinnately 3 -foliolate (rarely 1 -foliolafe) leaves, stipellate. Flowers (in summer) in axillary or terminal racemes, often panicled, and 2 or 3 from each bract, purple or purplish, often turning green in withering. Stipules and bracts scale-like, often striate (Name from $\delta \epsilon \sigma \mu o ́ s, a$ bond or chain, from the connected joints of the pods.)

\$1. Pod raised on a stalk (stipe) many times longer than the slightly toothed caly $x$ and nearly as long as the pedicel, straightish on the upper margin, deeply sinuate on the lower; the $1-4$ joints mostly half-abovate and concave on the back; stamens monadelphous below; plants nearly glabrons; stems erect or ascending; raceme terminal, panicled; stipules bristle-form, deciduous.

1. D. nudiflòrum, DC Leaves ali crowded at the summit of sterile stems; leaflets broadly ovate, bluntish, whitish beneath; raceme elongated on an ascending mostly leafless stalk or scape from the root, $2^{\circ}$ long. - Dry woods, common. 
2. D. acuminatum, DC. Leaves all crouded at the sumnit of the stem from uhirh arises the elongaled naked ruirme or punirle; leaflets ronnd-avate, taper-pointed, green both sides, the end one round ( $4-5^{\prime}$ long). - Kich woods, from Canala to the Gulf.

3. D. pauciflorum, I)C. Leaces seattered along the low $\left(4-15^{\prime}\right.$ high) ascending stems; leaflets rhombic-ovate, bluntish, pale bencath; raceme fiwflowered, terninal. - Woods, Ont. to P'enn., Mich., Kan., and southward.

\$2. Pod raised on a stalk (stipe) little if at all surpassing the dieply cle $f$ caly $x$; stems long and prostrate or decumbent; racemes axillary und terminal.

* Stipules conspicuous, orate, attcmute, striate, persistent; rucemes mostly simple.

4. D. rotundifòlium, 1)C. Softhairy all over, truly prostrate; leaflets orlicular, or the odd one slightly rhomboid ; flowers purple ; pods almost equally sinuate on both elges, 3-5-jointed; the joints rhomboid-oval. - I)ry rocky woods, N. Eng. to Fla., west to Minn., Mo., and La.

Var. glabràtum, Gray, is almost glabrous, otherwise nearly as the ordinary form. - Mass. and N. Y.

5. D. ochroleùcum, M. A. Curtis. Stems sparsely hairy, decumbent; leaflets nearly glabrous, ovate, acute or obtuse, transversely reticulated beneath, the lateral ones smaller or sometimes wanting; racemes inuch elongated ; corvlla whitish ; pods twisted, $2-4$-jointed, the large rhomboid joints smonth and reticulated but the margins downy. - IVoodlands, MId. and Va.

* * stipules smaller, lanceolate and aucl-shaped, less persistent; racemes panicled.

6. D. humifùsum, Beck. Cilabrous or neurly so, procumbent; leaflets ovate or ovate-oblong, rather obtuse, much smaller than in the two preceling (1 $\frac{1}{4}-2^{\prime}$ long) ; corolla purple ; pods $2-4$-jointed, flat, the oval-rhombuid joints minutely scabrous throughout. - Dry sandy soil, S. Penn. to Md.

$\S 3$. Pod slightly if at all stalked in the calyx; racemes panicled.

* Stems tall $\left(3-5^{\circ}\right)$ and erect; the persistent stipules and deciduous bracts large and conspicuous, ovate or ovate-lanceolate, taper-pointed; flovers rather large.

- Pods of 4-7 unequal-sided rhombic joints, which are considerubly longer than broad (about 6" long).

7. D. canéscens, DC. Stem loosely branched, hairy; leaflets orate, bluntish, about the length of the petioles, whitish and reticulated beneath, both sides roughish with a close fine pubescence; joints of the poul very adhesive. Moist grouuds, Mass. and Vt. to Minn. and southward, chiefly westwarl. Branches clothed with both minute and hooked, and longer, sprealing, rather glutinous hairs. - Var. villosíssimus, Torr. \& Gray, has the panicle aud upper part of the stem very villous, and leaflets ohlung-ovate. - Mo.

8. D. cuspidàtum, Torr. \& Gray. Very smooth except the panicle; stem straight; leaflets lanceolate-ovale und taper-pointal, green loth sides, longer than the petiole $\left(3-5^{\prime}\right)$; joints of the pol rhomboid-olblong, smouthish. Thickets, common. 'The conspicuons bracts and stipules gु' long.

$$
\text { + + Pods of 3-5 oral joints (not over } 3^{\prime \prime} \text { long). }
$$

9. D. Illinoénse, Gray. Erect ( $3-5^{\circ}$ high); stem aul leares with short rough pubescence; leaflets ovate-ol,long or ovate-lauceulate $\left(2-4^{\prime}\right.$ long), ubtuse, subcoriaceous, cinereous beneath, veins and veinlets proninent, strongly retic- 
ulated, the lower leaflets nearly equalling the petiole; pods scarcely over $\mathbf{1}^{\prime}$ long. sinuate on both margins (deeper below). - Dry ground, Ill. to Iowa and Kan. * * Stems $\left(2-5^{\circ}\right.$ high $)$ erect; stipules and lracts mostly deciduous, small and inconspicuous; joints of the pod 3-5, triangular or half-rhombic or very unequal-sided rhomboidal, longer than broad, 3 " or less in length; flowers middle-sized.

10. D. lævigàtum, 1)C. Sinooth or nearly so throughout; stem straight; leafets ovate, bluntish, pale beneath (2-3' long); panicles minutely roughpubescent. - l'ine woods, N. J. to Fla., west to NLo. and 'Tex.

11. D. viridiflorum, Beck. Stem very downy, rough at the summit; leaflets broudly ovate, very ol,tnse, rough above, whitened with a soft velvety down underneuth $\left(2-3^{\prime}\right.$ long). - Southern N. Y. to N. J. and Fla., west to Mich., Mo., and Tex.

12. D. Dillènii, Darlingt. Stem pubescent; leaflets ollong or oblong-or'ate, commonly bluntish, pale beneath, softly and finely pulescent, mostly thin $\left(2-3^{\prime}\right.$ long). - Open woodlands, common.

13. D. paniculàtum, DC. Nearly smooth throughout; stem slender, tall; leaflets oblong-lanceolate, or narrouly lanceolate, tapering to a blunt point, thin (3-5' long); racemes much panicled. - Copses, common.

14. D. stríctum, I)C. Stem very straight and slender, simple $\left(2-3^{\circ}\right.$ high), the upper part and narrow panicle rough-glandular; leaflets linear, blunt, strongly reticuluted, thickish, very smooth (1-2' long, $\frac{1}{4}{ }^{\prime}$ wide); joints of the pod $1-3$, semi-oborate or very gibbous (only $2^{\prime \prime}$ long). - l'ine woods, N. J. to Fla. and La.

** * Stipules small and inconspicuous, mostly deciduous; pods of few roundish or abliquely oval or sometimes roundish-rhomboidal joints, $1 \frac{1}{2}-2 \frac{1}{2}$ "long.

- Stems erect; bracts before flowering conspicuous; racemes densely flowered.

15. D. Canadénse, I)C. Stem hairy $\left(3-6^{\circ}\right.$ high $)$; leaflets oblong-lanceolate or ovate-lanceolate, obtuse, with numerous straightish veins, much longer than the petiole $\left(1 \frac{1}{2}-3^{\prime}\right.$ long); flowers show'y, larger than in any other species $\left(\frac{1}{2}-\frac{1^{\prime}}{3}\right.$ long) $)-$ Dry rich woods, N. Brunswick to N. C., Minn., and Kan.

16. D. sessilifòlium, Torr. \& Gray. Stem pubescent $\left(2-4^{\circ}\right.$ high $)$; leares nearly sessile; leuflets lineur or linear-oblong, blunt, thickish, reticulated, rough above, downy beneath; branches of the panicle long; flowers small.Copses, P'enn. and Ky., west to Mich., Iowa, Mo., and Tex.

+ + Stems ascending $\left(1-3^{\circ}\right.$ high $)$; bracts small ; racemes or panicles elongated and loosely flocered; flouers small.

17. D. rigidum, 1)C. Stem branching, somewhat hoary, like the lower surface of the leaves, with a close roughish pubescence; leaflets ovate-oblong, blunt, thickish, reticulated-veiny, rather rough above, the lateral ones longer than the petiole. - Dry hillsides, Mass. to Fla., west to Mich., Mo., and La.

18. D. ciliàre, DC. Stem slender, hairy or rough-pubescent; leares crowded, on rery short hairy petioles; leaflets round-orate or ocal, thickish, more or less hairy on the margins and underneath $\left(\frac{1}{2}-1^{\prime}\right.$ long $\left.) .-1\right) r y$ hills and sandy fields, N. Eng. to Fla., west to Mich., Mo., and Tex.

19. D. Marilándicum, F. Boott. Nearly smooth throughout, slender; leaflets orate or roundish, very obtuse, thin, the lateral ones about the length of 
the slender petiole; otherwise resembling the preceding. - Copses, N. Eng. to Fla., west to Mich., Mo., and Ia.

t- +- + Stems redining or prostrate; rusemes lonsely flucered.

20. D. lineàtum, 1)C. Stem minntely julescent, striate-inglenl; leaflets orbicular, smoothish ( $\frac{1}{2}-l^{\prime}$ long), much longer than the petiole; perl scarcely stalked in the calyx. - Dry soil, Md. and Va. to Fla. and La.

\section{LES PED EZA, Michx. Jush-Clover.}

Calyx 5-eleft; the lobes nearly equal, slender. Stamens clialclphous (9 and 1); anthers all alike. Pools of a single 1-seeded joint (sometimes 2-jointerl, with the lower joint empty and stalk-like), oval or romulish, flat, reticulaterl. - Herhs with pinnately 3-foliolate leaves, not stipellate. Flowers often polyganous, in summer and autumu. (1)edi.atced to Lespedez, the Sipanish governor of Florida in the time of Michaux.)

$\S 1$. Stipules subulate-setaceous; bracts minute; caly.x-lolies attenuute; peremial.

* Flouers of two sorts, the larger (violet-purple) perfert, lut seldom fruitful, panicled or clustered; with smaller pistillate and fertile but mosily apretaluus ones intermixed or in small subsessile clusters; calyx 1-2" long; pod exstrted.

1. L. procúmbens, Michx. Slender, trailing and prostrate, minutely appressed-hairy to soft-downy; leaflets oval or obovate-elliptical, $3-9^{\prime \prime}$ long ; peduncles very slender, few-flowered; keel equalling the wings; pod sinall, roundish, ohtuse or acute. (Incl. L. repens, Burl.) - Dry sandy soil ; common.

2. L. violàcea, Pers. Stems upright or spreatling, slender, branched, rather sparsely leafiy and sparingly pubescent; leaflets thin, broudly oful or oblong, finely appressed-pubescent beneath; peduncles rery slender, loosely fewflowered, mostly longer than the leaves; flowers $3-4^{\prime \prime}$ long, the kcel often the longest; pod oicule, 2-3" long, nearly glabrous. - Lry colses, N. Eng. to Minn. and E. Kan., south to Fla. and La.

3. L. reticulàta, Pers. Stouter, ere⿰t, veryleafy; leaflets thickish, linear to lineur-oblony, 6-15" long, finely appressed-pubescent; flowers (scarcely 3" long) clustered on peduncles much shorter than the leures, the keel shorter than the standard; pods ovate, acute, $2^{\prime \prime}$ long, appressed-sul,pulescent. (L. viulacea, var, angustifolia, Torr. \& Gray.) - Mass. to Miun., aul sunthward.

4. L. Stùvei, Nutt. Stems upright-sprealing, very leufy, simple or somewhat branched, doun!y with spreading pubescence; lectlets ocal or mudish varying to oblong or rarely linear-oblong, silky or white-uvolly beneuth and sumetimes above; flowers as in the last, often numerous and crowded; pouls orute, acuminate, mostly $3^{\prime \prime}$ long, dor'ny. - Mass. to Mich., and sonth to Va. and 'Tex.

Var. intermèdia, Watson. l'ulescence nure scanty and ustally fine and appressed as in 11.3 , but the leaflets oral to oblung; inflorescence often more open; pod of $\mathrm{n} .4$ or of n. 3. (I. violacea, var. sessiliffura, of I/an., mainly.) - Mass. to Fla., and west to Mich., Ill., k. Kian., aud $\mathrm{A}$ rk.

* *lowers all alike and perfect, in close spikes or heads; corvlla whitish or cream-color with a purple spot on the standard, about the length of the douny 5-parted calyx; pod included; stems upright, wand tike $\left(2-4^{\circ}\right.$ high).

5. L. polystàchya, Michx. Stem with mostly spreading jubescence; petioles 2-6" long; leaflets from orbicular to oblong-ovate, hairy; spikes oblong, 
on elongated peduncles; pod (at maturity) oblong-ovate, pubescent, nearly 3 " long, hardly shorter than the calyx. (L. hirta, Ell.) - Dry hills, common.

6. L. capitàta, Michx. Stems rigid, woolly; petioles very short; leaflets oblong to narrowly oblong, thickish, reticulated and mostly smooth above, silky or sometimes downy beneath; heads of flouers globular, on peduncles shorter than the leares; pod oblong-ovute, pubescent, much shorter than the calyx. - Dry and sandy soil, N. Eng. to Fla., west to Minn., Mo., and La.

7. L. angustifòlia, Ell. Iike the last, but mostly appressed-silky, the leaflets linear, the smaller often oblong heads on distinct and sometimes. slender peduncles, the pod round-ovate, acutish, $1 \frac{1}{2}-2^{\prime \prime}$ long, hardly shorter than the culyx. (L. capitata, var. angustifolia, Pursh.) - N. J. to Fla., west to Mich., Iowa, and Iia.

8. L. leptostàchya, Gray. Clothed with appressed silky pubescence; stems often branched, sleuder; leaftcts linear to uarrowly oblong; spikes slender, somewhat loosely-flowered, on peduncles as long as the leaves; pod ovate, small (1 $\frac{1}{2}$ " long), about equalling the calyx, densely pubescent. - Ill., Iowa, and Minn.

\section{§2. Stipules and bracts lroad and scarious; calyx-loles broad; annual.}

L. sтrì̀ta, Hook. \& Arı. Diffusely i ranched, decumbent, subpubescent; petioles very short; leaflets oblong-obovate, $6^{\prime \prime}$ long or less; peduncles very short, 1-5-flowered; pod small, little exceeding the calyx. - Common in the Southern States, extenling into Mo. (Nat. from E. Asia.)

\section{STYLOSÁNTHES, Swartz.}

Calyx early deciduous; tube slender and stalk-like; limb unequally 4-5cleft, the lower lobe more distinct. Corolla and monadelphous stamens inserted at the summit of the calyx-tube; standard orbicular; keel incurved. Anthers 10, the 5 longer ones fixed near their base, and the 5 alternate shorter ones fixed by the middle. Style filiform, its upper part falling off after flowering, the lower part incurved or hooked, persistent on the 1-2-jointed small and short reticulated pod; the lower joint when present empty and stalk-like. Low perennials, branclied from the base, with wiry stems, piunately 3 -foliolate leaves, the sheathing stipules united to the petiole, no stipels, and small, yellow flowers in terminal healls or short spikes. (Name composed of $\sigma \tau u$ inos, a col$u m n$, and á $\nu$ os, a flower, from the stalk-like calyx-tube.)

1. S. elàtior, Swartz. Tufted; leaflets lanceulate, strongly straightveined; heads or clusters small and few-flowered. - Pine barrens, Long Island and N. J. to Fla., west to S. Ind., Kan., and Ark.

\section{Vícia, Tourn. Vetchi. Tare.}

Calyx 5-cleft or 5-toothed, the 2 upper teeth often shorter, or the lowest longer. Wings of the corolla adhering to the middle of the keel. Stamens more or less diadelphous (9 and 1); the orifice of the tube oblique. Style filiform, hairy all round or only on the back at the apex. Pod flat, 2-valved, 2several-seeded. Seeds globular. Cotyledons very thick, remaining under ground in germination. - Herus, mostly climbing more or less by the tendril at the end of the pinnate leaves. Stipules half-sagittate. Flowers or peduncles axillary. (The classical Latin name.) 
* Annual; flowers 1 or 2 in the axils, nearly sessile, large, riolet-purple.

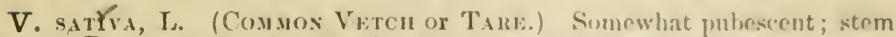
simple; Teaflets 5- 7 pairs, varying from obovate-olulong to linear, notcherl and mucronate at the apex; pod linear, several-seeded. - ('ultivated fielils and waste places, N. Eng. to N.J. and southward, West to Mich. and Minn. Var. A.velstifóla, seringe, has longer and narrow leatlets. ( $\Lambda$ dv. from L.u.)

* Annual, slender; peduncles elongnted: floucers smull.

V. тетваspénua, L. Peduncles 1-2-flowered: leaflets $4-6$ pairs, linearoblong, obtuse; calyx-teeth unequal; corolla whitish; porls nurrou; 4-serleci, smooth. - Waste places, near the coast, $\mathrm{N}$. Scotia to N. J. (Nat. from Fiu.)

V. IIrsùt., Koch. Peduncles 3-6-flowered; leaflets 6-8 pairs, truncate ; calyx-teeth equal; corolla bluish; pods oblong, 2-seeded, hairy. - N. Brunswick to Mass. and Va. (Nat. from Lu.)

*** Perennial; peduncles clongated; calyx-tceth unequal ; poul spreral-seeded.

1. V. Crácca, I. Jowny-pubescent; leaflels 20-24, ollong-lanireolate, strong!y mucronate; sprikes densely many-flowered, I-sided; flowers blue, turning purple, 6 "long, reflexed ; calyx-teeth shorter than the tube. - Burlers of thickets, Newf. to N. J., west to liy., Iowa, and Minn. (En.)

2. V. Caroliniàna, Walt. Nearly smooth; leaflets $8-24$, olilong, olinse, scarcely mucronate; peduncles loosely-flowered; flowers small, more scattered than in the preceding, whitish, the keel tipped with blue; calyx-teeth very short. - River-hanks, Ont. and N. Y. to Ga., west to Minn, and Kan.

3. V. Americána, Muhl. Glabrous; leaflets 10-14, elliptical or orateoblong, very obtuse, many-veined; peduncles 4-8-flouered: flowers purplish (8" long). - Moist soil, N. Y. and N. J., to Kan., Minn., aud westward. - Var. LINedris, Watson, a low form with linear leaflets, occurs in Kan. and Neb., and is common westward.

\section{LÁt}

Style flattish, dilated and flattish (not grooved) above, hairy along the inner side (next the free stamen). Sheath of the filaments scarcely oblique at the apex. Otherwise nearly as in Vicia. - Our species are perenuial and mostly smooth plants, the rhachis of the leaves in some not produced into a tendril. ( $\Lambda$ átupos, a leguminous plant of Theophrastus.)

* Tendrils present; stipules large and broad; leaflets 3-5 pairs.

1. L. marítimus, Bigelow. (BEACn $\mathrm{P}^{\mathrm{E}} \mathrm{A}$.) Stout ( $1^{\circ}$ high or more); stipules broadly ovate and hulberd-shaped, nearly us large as the leaflats, the lower lobe larger and usually coarsely tootherl; leaflets thek, orate-obling ( $1-2^{\prime}$ long); peduncles a little shorter than the leaves, 6-10-fluwered, fiureers large ( $9^{\prime \prime}$ long), purple. - Seashore from X.J. and Oregon to the Arctic Sea; also on the Great Lakes. (Eu.)

2. L. ochroleùcus, Ilook. Stem slender $\left(1-3^{\circ}\right.$ high); stipules semicordate, half as large as the thin orate lcuflets; peduncles 7 -10-flowered; fluwers smaller, yellowish-uhite. - Ilillsides, N. Eng. to Minu., Iowa, and westward.

* Tendrils present; stipules narrow, semi-sagittate, acuminate.

- Flouers purple: leaflets several pairs.

3. L. venosus, Muhl. Stoul, climbing, usually somewhat downy; stipules very small and mostly sleuder; leaflets $4-6$ pars, oblongorate, mostly 
obtuse (about 2' long) ; peduncles many-flouered; flowers $6-8^{\prime \prime}$ long. - Shady banks, Yenn. to Ga., west to Kan. and Minn.

4. L. palústris, L. Slender, glabrous or somewhat pubescent; stem often winged; stipules lanceolate, sharp-pointed at both ends; leaflets 2-4 pairs, narrowly oblong to linear, acute (1-2'long); peduncles 2-6-flowered; flowers $6^{\prime \prime}$ long. - Moist places, N. Scotia to N. J., and westward across the continent. (Eu.)

Var. myrtifolius, Gray. Stipules usually broader and larger; leaflets orate to oblong ( $1^{\prime}$ long or less). - Same range, and extending south to N. C. +- - Flouers yellow; leaflets a single pair.

L. PRATÉxsis, L. Low and straggling; leaflets narrowly lanceolate to linear, acnte; peduncles several-flowered. - Spontaneous in Mass., N. Y., and Unt. (Nat. from Eu.)

* * * Tendrils usually uanting; low, mostly erect; stipules semi-sagittate; flowers rery large, purple; pod stipitate in the calyx.

5. L. polymórphus, Nutt. Leaflets 3-6 pairs, narrowly oblong to linear, thick and strongly nerved, $1-2^{\prime}$ long; seeds with a narrow footstalk and short hilum. - No., Kan., and westward.

6. L. ornatus, Nutt. Like the last, but leaflets always narrow, 3-12" long; seeds with a very broad footstalk and long hilum. - Kan. to Col. and Dak. Scarcely $1^{\circ}$ high.

\section{2. Á PIOS, Boerhaave. Grocxd-xut. Wild Beax.}

Calyx somewhat 2-lipped, the 2 lateral teeth being nearly obsolete, the upper very shurt, the lower one longest. Stanclard very broarl, reflexed; the long scythe-shaped keel strongly incurved, at length coiled. Sitamens diadelphous. Pod straight or slightly curved, linear, elongated, thickish, many-seedel. - A perennial herb (with some milky juice!), twining and climbing over bushes, and bearing edible tubers on underground shoots. Leaflets 3-7, ovate-lanceolate, obscurely stipellate. Flowers in lense and short, often branching racemes. (Name from ămıv, a pear, from the shape of the tubers.)

1. A. tuberòsa, Moench. Flowers brown-purple or choculate-color, violetscented. - Low grounds, N. Brunswick to Fla., west to Minn., Kan., and La.

\section{PHA S EOLUS, Tourn. Kinney Bean.}

Calyx 5-toothed or 5-cleft, the two upper teeth often higher united. Keel of the corolla, with the included stamens and style, spirally coiled. Stamens diadelphous. Style bearded along the upper side; stigma oblique or lateral. Pod scythe-shaped, sereral-many-seeded, tipped with the harlened base of the style. Seeds round-reniform, with very short hilum. Cotyledons thick and fleshy, rising out of the ground nearly unchanged in germination. - Twining herbs, with pinnately 3 -foliolate stipellate leaves. Flowers racemose, produced in summer and autumn. (The ancient name of the Kidney Bean.)

1. P. perénnis, Walt. (Wild BEAx.) Stem elimbing high from a perennial root; leaflets roundish-ovate, short-pointed; flowers purple, handsome, but small; pods drooping, strungly curved, 4-5-seeded. - Copses, N. Eng. to Fla., west to Minn. and La. 


\section{STROPHOSTỲLE, Fill.}

Keel of the corolla with the included stamens aud sty le chlongaterl, strongly incurved, not spirally coiled. Pod linear, terete or flattish, straight or nearly so. Seeds quadrate or oblong with truncate ends, mealy-pubescont or glal,rate ; hilum linear. Flowers few, sessile and capitate-chustered on the mustly long peduncles. Otherwise as Phaseolus. - Stems prostrate or climbing, more or less retrorsely hairy. Stipules aud bracts striate. (Nime from $\sigma \tau \rho \circ \phi \eta$, u $u r n$ iny, and $\sigma \tau \hat{v} \lambda o s$, (l style.)

1. S. angulòsa, Ell. Annual; stems branched, $1-6^{\circ}$ long; leaflets ovate to oblong-ovate (rarely linear-oblong), with a more or less prominent roundal lobe touard the buse (the terminal 2-fubed), or some or all often entire, about $\mathbf{l}^{\prime}$ $\left(6-20^{\prime \prime}\right)$ long; corolla greenish-white and purplish ; pod terete, $2-3^{\prime}$ long by $3^{\prime \prime}$ wide, 4-s-sceded, nearly glabrous ; seeds oblong, about $3^{\prime \prime}$ lony, usually very puhescent. (Phaseolus diversifolius, Pers. I'. helvolus, L.) - Sindy shores and river-hanks; eoast of Mass. and southward, along the Great Lakes to Minn., and south to Kan. and 'Yex.

Var. Missouriénsis, Watson in herh. Climbing high $\left(10-30^{\circ}\right)$; leares often $3^{\prime}$ long, rhomlic'-ovate, rarely at all lobed; seeds $3-4^{\prime \prime}$ long. - Riverbottoms near Independence, Mo.; nearly two months later. ( $\%$. Bush.)

2. S. pedunculàris, Ell. Stems more slender, from a perennial rootstock, $2-4^{\circ}$ long; leaflets orate to oblong-linear, rarely at all lobed, $\mathrm{l}^{\prime}$ long or less; pod $1 \frac{1}{2}-2^{\prime}$ long and scarcely $2^{\prime \prime}$ uide; seels much smaller, $1 \frac{1}{2}-2^{\prime \prime} \operatorname{long}$, short-ol,long to quadrate. (Phaseolus helrolus, Man., etc. ; not I.) - Sandy ground, Inug Island and N. J. to Fla., west to S. Ind., liy., and La.

3. S. pauciflorus, Watson in herb. Annual, slender, low-climbing, pubescent ; leaflets oblong-lanceolate or orate-oblong to linear, not lohed, l' long; pod pubescent, $\mathrm{l}^{\prime}$ long, flattish; seeds as in the last, very finely mealy, sorn glabrate. (Phaseolus pauciflorus, Benth.) -- River-banks, Ind. to Minn., sunth to Miss. and 'Tex.

\section{C E N T ROS E M A, 1)C. Spurren Butterfly-I'ed.}

Calyx short, 5-cleft. Corolla, etc., much as in Clitoria, but the sprearling standard with a spur-shaped projection on the back near the base; keel hroad. Style bearded at the apex aroumd the terminal stigna. Pod long and linear, flat, pointed with the awl-shaped style, many-sceder, thickenel at the edgers, the valves marked with a raised line on each sile next the margin. - Twining perennials, with 3-foliolate stipellate leaves, and largeshowy Howers. Stipules, bracts, and bractlets striate, the latter longer than the calyx. (Name from

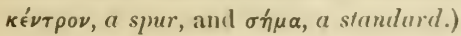

1. C. Virginianum, Benth. Rather rough with minute hairs; leaflets varying from oblong-ovate to lanceslate and linear, very veiny, shining ; peluneles 1-4-flowered; ealyx-teeth linear-awl-shaped; (corulla violet, $1^{\prime}$ long; pods straight, 4-5' long. - Sandy woods, Md. to Fla. and Ark. ('Trop. Am.)

\section{CIITÓRIA, I. ButTenfLY-I'E...}

Calyx tubular, 5-touthed. Standard much larger than the rest of the flower, erect, rounded, notched at the top, not spurred on the back; keel small, shorter 
than the wings, incnrved, acute. Stamens monadelphous below. Style bearded down the inmer face. Pod linear-oblong, flattish, knotty, several-seeded, pointed with the base of the style. - Erect or twining perennials, with mostly pinnately 3-foliolate stipellate leaves, and very large flowers. Peduncles 1-3-flowered; bractlets opposite, striate. (Derivation recondite.)

1. C. Mariàna, L. Low, ascending or twining, smooth; leaflets oblongovate or ovate-lanceolate; stipules and bracts awl-shaped; peduncles short; the showy pale-blue flowers $2^{\prime}$ long. - Dry banks, N. Y. to Va. and Fla., west to Mo. and Tex.

\section{A M P I A R P 髙A, Ell. Hog PeA-Nut.}

Flowers of 2 kinds; those of the racemes from the upper branches perfect, but seldom ripening fruit; those near the base and on filiform creeping branches with the corolla none or rudimentary, and few free stamens, but fruitful. Calyx abont equally 4-(rarely 5-) toothed; bractlets none or minute. Keel and wing-petals similar, almost straight; the standard partly folded round them. Stamens diadelphous. Style beardless. Pods of the upper flowers, when formed, somewhat scymetar-shaped, stipitate, 3-4-seeded; of the lower ones commonly subterranean and fleshy, oborate or pear-shaped, ripening usually but one large seed. - Low and slender perennials; the twining stems clothed with brownish hairs. Leares pinnately 3 -foliolate; leaflets rhombic-ovate, sti. pellate. Flowers in simple or componnd racemes, purplish. Bracts persistent, round, partly clasping, striate, as well as the stipules. (Name from ả $\mu \phi^{i}$, both,

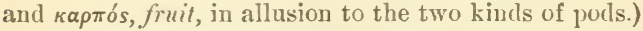

1. A. monòica, Nutt. Leaflets thin, $\frac{1}{2}-2^{\prime}$ long; racemes nodding; calyx of upper flowers 2 " long, the orary glabrous except the hairy margin; pod 1' long; ovary and pod of the rndimentary flowers hairy. - Rich lamp woodlauds, common. Ang., Sept.

2. A. Pítcheri, Torr. \& Gray. Leaflets usually 2-4' long; rhachis of the racemes usually villous; caly $\times 3^{\prime \prime}$ long, the teeth acuminate; ovary hairy. - Western N. Y. to Ill., Mo., La., and Tex. The upper flowers more commonly fertile; apparently producing subterranean fruit but rarely.

\section{GA LÁ CTIA, P. Browne. Milk.PeA.}

Calyx 4.cleft; the lobes acute, the upper one broadest, entire. Keel scarcely incurvel. Stamens diadelphous or nearly so. Style beardless. Pod linear, flat, several-seeded (some few of them rarely partly subterranean and fleshy or deformed). - Low, mostly prostrate or twining perennial herbs. Leaflets usually 3 , stipellate. Flowers in somewhat interrupted or knotty racemes, purplish;

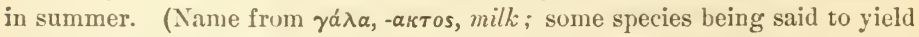
a milky juice, which is unlikely.)

1. G. glabélla, Michx. Stems nearly smonth, prostrate; leaflets elliptical or orate-oblong, sometimes slightly hairy beneath; racemes short,4-8-flowered; jods somewhat hairy. - Sandy woods, sonthern N. Y. to Va., Fla., and Miss.

2. G. pilossa, Ell. Stems (decumbent and somewhat twining) and leaves beneath soft-downy and hoary; leaflets oval ; racemes many-flowered, pods very downy. (G. mollis, Gray, Manual; not Michx.) - Penn. to Fla. and Miss. 


\section{RHY NCHÒSIA, J.}

Calyx somewhat 2-lipped, or deeply 4-5-parterl. Keel seythe-shaped, or incurved at the apex. Stamens diadelphous. (Ovules only 2. I'od 1-2-seeded, short and flat, 2-valved. - Usually twining or trailing perenuial herbs, pinnately 3 -foliolate, or with a single leaflet, not stipellate. Flowers yellow, racemose or clustered. (Name from púrxos, a beak, from the shape of the keel.)

1. R. tomentosa, Hook. \& Arn. Trailing and twining, the stem and leaves more or less pubescent with spreading hairs; leaflets 3 , roundish or roundrhombic, acute or acutish; racemes few-flowered, almost sessile in the axils : calyx about as long as the corolla, 4-parted, the upjer lobe 2-cleft; pod oblong. (R. tomentosa, var. volubilis, Torr. \& Gray.) - Dry soil, Va. to Fla. and 'Tex.

2. R. erécta, I)C. Erect, 1-2 $2^{\circ}$ high; stem and leaves more or less tomen. tose; leaflets 3 , oval to oblong, obtuse or acutish; racemes short and shortly pedunculate. (R. tomentosa, var. erecta, Torr. \& Gray.) - Del. to Fla. and Miss.

3. R. renifórmis, DC. Dwarf and upright, $3-8^{\prime}$ high ; pubescence spreading; leaflets solitary (rarely 3), round-reniform, very obtuse or apiculate; racemes few-flowered, sessile in the axils. (1R. tomentosa, var. monophylla, Torr. \&. Gray.) - Va. to Fla. and Miss.

\section{CÉRCIS, L. RED-Bed. JUDAS-TREe.}

Calyx 5-toothed. Corolla imperfectly papilionaceous; standard smaller than the wings, and enclosed by them in the hud; the keel-petals larger aud not united. Stamens 10, distinct, declined. Pol ollong, Hat, many-seeded, the upper suture with a winged margin. Embryo straight. - Trees, with rounded heart-shaped simple leaves, caducous stipules, and red-purple flowers in unbellike clusters along the branches of the last or preceding years, appearing before the leaves, acid to the taste. (The ancient name of the Oriental Judas-tree.)

1. C. Canadénsis, L. (Ren-Bud.) Leaves pointed; pods nearly sessile above the calyx. - Rich soil, N. Y. and N. J. to Fla., west to S. Minn., Kan., and La. A small ornamental tree, often eultivated.

\section{C Á S SIA, Tourn. Sexxa.}

Sepals 5, scarcely united at base. Petals 5, little unequal, spreading. Stamens 5-10, unequal, and some of them often imperfect, sprealing; anthers opening by 2 pores or chinks at the apex. Pod many-seeded, often with cross partitions. - Herbs (in the United States), with simply and abruptly pinnato leaves, and mostly yellow flowers. (An ancient name of obscure derivation.)

* Leaflets large; stipules deciduous; the three upper anthers deformed and imperfect; flowers in short axillary racemes, the upper ones panicled; herbuge glabrous.

1. C. Marilándica, L. (Wrud Sexwa.) Stem $3-4^{\circ}$ high; leaflets $6-9$ pairs, lanceolute-oblong, obtuse; petiole with a club-shaped gland near the hase; pods linear, slightly curved, flat, at first hairy $\left(2-4^{\prime}\right.$ long); root perennial. Alluvial soil, N. Eng. to Fla., west to Mich., S. F. Neb., Kan., anil La.

2. C. Tora, L. Annual; leaflets 3 or rarely 2 pairs, obovate, obeuse, with an elongated gland between those of the lower pairs or lowest pair ; pods slen- 
der, 6' long, curved. (C. obtusifolia, L.) - River-banks, S. Va. to Fla., west to S. Ind., Mo., and Ark.

C. occidextalis, L. Annual; leaflets 4-6 pairs, orate-lanceolate, acute; an ovate gland at the base of the petiole; pods long-linear ( $5^{\prime}$ long) with a tumid border, glabrous. - Va., S. Ind., and southward. (Adv. from Trop. Amer.)

* Leaflets small, somewhat sensitive to the touch; stipules striate, persistent; a cup-shaped gland beneath the louest pair of leaflets; anthers all perfect; flowers in small clusters above the axils; pods flat; root annual.

3. C. Chamæcrísta, L. (PArtridge PeA.) Stems spreading ( $1^{\circ}$ long); leaflets 10-15 pairs, linear-oblong, oblique at the base; flowers (large) on slender pedicels, 2 or 3 of the showy yellow petals often with a purple spot at base; anthers 10, elongated, unequal ( 4 of them yellow, the others purple); style slender. - Sandy fields; common, especially southward.

4. C. níctitans, L. (WILD Sexsitive-Plant.) Leaflets 10-20 pairs, oblong-linear; flouers (rery small) on very short pedicels; anthers 5 , nearly equal; style short. - Sandy fields, N. Eng. to Fla., west to Ind., Kan., and La.

\section{HOFF M A N SEG I A, Cav.}

Calyx 5-parterl. Petals 5, nearly equal, oblong or oral. Stamens 10, distinct, slightly declined; anthers dehiscing longitudinally. Pod flat, oblong, often falcate, few - sereral-seeded. - Low perennial herbs, or woody at base, punctate with black glands, with bipinnate leaves, and naked racemes of yellow flowers opposite the leaves or terminal. (Named for Count von Hoffinansegg, a German botanist.)

1. H. Jamèsii, Torr. \& Gray. Herbaceous, finely pubescent; pinnæ 2 or 3 pairs with an odd one, the small oblong leaflets 5-9 pairs; pods broad, falcate, 1' long, 2-3-seeded. - Central Kan. to Tex., Ariz., and Mex.

\section{G Y M N Ó CLA D U S, Lam. Kextecky Coffee-tree.}

Flowers diœcious or polygamous, regular. Calyx elongated-tubular below, 5-cleft. Petals 5, oblong, equal, inserted on the summit of the calyx-tube. Stamens 10, distinct, short, inserted with the petals. Pod oblong, fiattened, hard, pulpy inside, several-seeded. Seeds flattish. - A large tall tree, with rough bark, stout branchlets, not thorny, and large unequally twice-pinnate leaves; the leaflets standing rertically. - Flowers whitish, in terminal racernes. (Name from $\gamma u \mu \nu o ́ s, n a k e d$, and $\kappa \lambda a ́ \delta o s ; a$ branch, alluding to the stout branches destitute of spray.)

1. G. Canadénsis, Lam. Leaves $2-3^{\circ}$ long, with several large partial leafstalks bearing $7-13$ ovate stalked leaflets, the lowest pair with single leaflets; stipules wanting; pod $6-10^{\prime}$ long, $2^{\prime}$ broad; the seeds over $\frac{1}{2}^{\prime}$ across. Rich woods, western N. Y. and Penn. to Minn., E. Neb., and Ark.

\section{GLEDÍTSCHIA, L. HoNer-Locest.}

Flowers polygamous. Calyx short, 3-5-cleft, the lobes spreading. Petals as many as the sepals and equalling them, the 2 lower sometimes united. Stamens $3-10$, distinct, inserted with the petals on the base of the calyx. Pod flat, 
I - many-seeded. Seeds Hat. - Thorny trees, with ahruptly once or twice pinnate leaves, aud inconspicnous greenish flowers in small spikes. Thorus aluse the axils. (Named in honor of J. G. Cileditsch, at botanist contemporary wit! Linuaus.)

1. G. triacánthos, L. (Tirze-thornen Acucis, or Iloser-lucist.) Thorus stunt, often triple or compound; leaflets lanrolaterblong, sonewhat serrate; pods linear, elongated ( $1-1 \frac{1}{2}{ }^{\circ}$ long), often twisted, filled with sweet pulp between the seeds. - Rich woorls, western N. Y. and I'enn. to Ga., west to Mich., E. Neb., Kan., and La. A large tree, common in cultivation, with very hard and heary wood.

2. G. aquática, Marsh. (Water-Locust.) Thorns slender, mostly simple; leaflets ovate or oblong; pods oval, 1-seeded, pulpless. (G. monosperma, Walt.) - Deep swamps, Mo. to S. Ind., S. Car., and southward. A smaller trce, $30-40^{\circ}$ ligh.

\section{DES M Á N TH U S, Willd.}

Flowers perfect or polygamous, regular. Calyx campanulate, 5-tootled. Petals 5, distinct. Stamens 5 or 10. I'od flat, membranaceous or somewhat coriaceous, several-seeded, 2-valved, smooth. - Herls, with twice-pinnate leaves of numerous small leaflets, and with one or more glands on the petiole, setaceous stipules, and axillary peduncles bearing a head of small greenish-white flowers. (Name composed of $\delta \epsilon \epsilon \mu \alpha, a$ lond, and ă $\nu \theta 0 s$, flower.)

1. D. brachýlobus, Benth. Nearly glabrous perennial, erect $\left(1-4^{\circ}\right.$ high); pinnæ $6-15$ pairs; leaflets $20-30$ pairs ; peduncles $1-3^{\prime}$ long; stamens 5 ; pods numerous in dense globose heads, oblong or lanceolute, curved, scarcely l' long, 2-6-seeded. - Prairies and alluvial banks, Ind aud Ky. to Miun., Mo., and Tex.; also in Fla.

2. D. leptólobus, Torr. \& Gray. Pinnæ 5-8 pairs; leaflets 10-20 pairs; peduncles $1^{\prime}$ long or less; heads rather loose, stamens 5 ; pods usually few, narrowly linear, erect, 1-2' long. - Central Kan. to 'Tex.

\section{SCHRÁ NKI A, Willd. Sexsitive Brinr.}

Flowers polygamons, regular. Calyx minute, 5 -toothed. Petals united into a funnel-form 5-cleft corolla. Stamens 10-12, distinct, or the filanents united at base. Pods long and narrow, rough-prickly, several-seeded, 4.valved, i. e., the two narrow valves separating on each side from a thickened margin - l'erennial herbs, nearly related to the true Sensitive l'lunts (Mimosa); the procumbent stems and petioles recurvel-prickly, with twice-pinnate sensitive leaves of many small leaflets, and axillary peduncles bearing round heads of small rosecolored flowers. (Named for $F$. P. Sclirank, a Gerinan botanist.)

1. S. uncinàta, Willu. Prickles hooked; pinna 4-6 pairs; leufets ellipw tical, reticulated with strong veius beneath; pols oblong-linear, nearly tereteshort-pointed, densely prickly (2’ long). - Iry sandy soil, Va. to Fla., west to S. Ill., Kan., aud Tex.

2. S. angustàta, Torr. \& Gray. Leafets oblong-tincar, scererly veincel; pods slender, taper-pointed, sparingly prickly (about $4^{\prime}$ long). $-\mathrm{S}$. Va. (!) (1) Fla., Tenu., and T'ex. 


\section{Order 33. ROSÀceAe. (Rose Family.)}

Plants with regular flowers, numerous (rarely few) distinct stamens inserterl on the calyx, and 1 - muny pistils, which are quite distinct, or (in the last tribe) unted and combined with the cályx-tube. Sceds (anatropous) 1 - few in each orary, almost always without albumen. Embryo straight, with large and thick cotyledons. Leaves alternate, with stipules, these sometimes caducous, rarely obsolete or wanting. - Calyx of 5 or rarely $3-4-$ 8 sepals (the odd one superior), united at the base, often appearing double by a row of bractlets outside. Petals as many as the sepals (rarely wanting), mostly imbricated in the bud, and inserted with the stamens on the edge of a disk that lines the calyx-tube. Trees, shrubs, or herbs. - A large and important order, almost destitute of noxious qualities, and producing the most valuable fruits. Very intimately connected with Leguminosæ on one hand, and with Saxifragaceæ on the other.

I. Ovary superior and not enclosed in the calyx-tube at maturity.

- Calyx decidnous, without bractlets ; pistil solitary, becoming a drupe.

Tribe I. PRUNEA. Trees or shrubs, with simple mostly serrate leaves. Ovules 2, penimlons, hut seed almost always solitary. Style terminal.

1. Prumus. Flowers perfect. Lobes of calyx and eorolla 5. Stone of the drupe bony.

* * Calyx mostly persistent; pistils few to many (rarely solitary).

- Callyx without bractlets; ovules 2 - many.

Tribe II. SPIR EEAE. Pistils mostly 5 , hecoming 2 -several-seeded follicles. Shrubs or yerennial herbs.

a. Calyx short, 5-cleft. Petals obovate, equal.

2. Spiraea. Flowers perfect or diœcıus. Pods 1-valved. Herbs or shrubs; leaves sirn. ple or pinnate.

3. Physocarpus. Pods inflated, 2-valved. Shrub: leaves palmately lobed.

b. Calyx elongated, 5-toothed. Petals slender, unequal.

4. Gillenia. Herbs : leares 3-foliolate.

Tribe III. RUBEA. Pistils several or numerous, becoming drupelets in fruit. Ovules 2 and pendulous, but seed solitary. Perennials, herbaceous or with bienuial sofl-woody stems,

5. Rubus. Pistils numerous, fleshy in fruit, crowded upon a spongy receptacle.

6. Dalibarda. Pistils $5-10$, in the bottom of the ealyx, nearly dry in fruit.

- + Calyx-lohes mostly with bractlets; ovule solitary.

Tribe IV. POTExTILLEA. Pistils few - many, 1-ovuled, becoming dry achenes. Herbs

a. Styles persistent and elongated after anthesis, often plumose or jointed.

7. Geum. Calyx-lobes usually with 5 alternating small bractlets. Stamens and carpels numerous, styles becoming plumose or hairy tanls, or naked and straight or jointed.

b. Styles not elongated after anthesis, mostly deciduous.

8. Waldsteinia. Petals and calyx-lobes 5 ; small or no bractlets. Stamens numerous. Achenes 2-6; styles deciduous from the base.

9. Fragaria. Flower as in Potentilla. Receptacle much enlarged and pulpy in fruit.

10. Potentilla. Petals 5 (rarely 4), conspicuous. Calyx.lobes as many, with an alternating set of bractlets. Stamens and achenes numerous; the latter heaped on a dry receptacle. Styles commonly more or less lateral, deciduous or not enlarging in fruit.

11. Siblualdia. Petals minute; stamens and achenes 5-10; otherwise as Putentilla. 
II. Ovaries inferior or enclosed in the ealyx-tube.

Tribe V. POTERIEA. Pistils 1-4, becoming achenes, completely enclosed in the dry and firm calyx-tube, which is constricted or nearly clused at the throat. Herbs with eomponnd or lobed leaves. P'etals often none.

12. Alchemilla. Calyx urceolate, bracteolate. Petals none. Stamens 1-4. Flowers uimute, clustered.

13. Agrimonia. Calyx turbinate, with a margin of hooked prickles. Stanens 5- 12 . Fluwers yellow, in long racemes.

14. Poterium. Calyx-lobes petaloid; tube 4-angled, naked Petals none. Flowers densely (:apitate or spicate.

Tribe VI. ROSEA. Pistils many, beconing bony achenes, enclosed in the globrse or urn-shaped fleshy calyx-tube, which resembles a pome. I'etals conspicuous. Stanens numerous.

15. Rosa. The only genus. Prickly shrubs witl fimnate leaves.

Tribe VII. POMEA. Carpels 2-5, enclosed in and coalescent with the fleshy or herrylike calyx, in fruit becoming a 2 -several-celled pome. Trecs or shrubs, with stipules free from the petiole.

a. Cells of the compound ovary as many as the styles $(2-5)$, each 2-(rarely several-) ovuled.

16. Pyrus. Pome containing $2-5$ papery or cartilaginous carpels.

17. Cratacgus. Pome drupe-like, with $1-5$ bony stones or kernels. Usually thorny.

b. Cells of the eompound ovary becoming twice as many as the styles, each 1-ovuled.

18. Amelanchier. Pome usually of j earpels : each becomes incompletely 2-celled by a projection from its back; otherwise as Pyrus.

\section{PRUNUS, Tourn. Plum, Cherry, etc.}

Calyx 5-cleft; the tube bell-shaped, urn-shaped or tubular-obconical, deciduous after flowering. l'etals 5, spreading. Stamens 15-20. Tistil solitary, with 2 pendulous ovules. Drupe fleshy, with a bony stone. - Sinall trees or shrubs, with mostly edible fruit. (The ancient Latin nane.)

$\S 1$. PRUNUS proper (and CERASCs). Drupe smooth, and the stone smooth or someuhat nugged; flowers (usually white) fiom separate luteral scaly buls in early spring, preceding or coctaneous with the leaves; the pedicels few or several in simple umbel-like clusters.

1. P. Americàna, Marshall. (Wiln Yellow or Ren Prum.) Tree thorny, 8-20 high; leaves ovate or somewhat obovate, conspiruonsly pointed, coarsely or doubly serrate, very veiny, glubrous when mature; fruit nearly ilestitute of lloom, roundish-oval, yellow, orange, or red, $\frac{1}{2}-\frac{2}{3}$ in diameter, with the turgid stone more or less acute on both margins, or in 'ultivated states 1' or more in diameter, the flattened stone with brouler margins; pleasant-tasted, but with a tough and acerb skin. - Woollands and river-banks, common.

2. P. marítima, Wang. (ВE.cI Y'Lcu.) Low and straggling $\left(1-5^{\circ}\right)$; leares ovate or oval, fincly serrate, soflly pubessent underneath; pedicels short, pubescent; fruit globular, purple or crimson with a bloon ( $\frac{1}{2}-1^{\prime}$ in dianeter); the stone very turgid, arute on one edge, rounded and minutely grooved on tho other. - Sea-beaches and the vicinity, N. Brunswick to Va. It varies, when at some distauce from the coast (N. J. and southward), with the leaves smoother and thinner and the fruit smaller.

3. P. Alleghaniénsis, Porter. A low straggling slırnh or small tree

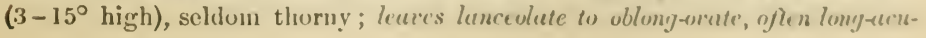


minate, finely and sharply serrate, softly puhescent when young, glabrate with age; fruit globose-aroid, very durk purple with a bloom (less than $\frac{1}{2}$ ' in diameter); stone turgid, a shallow groove on one side and a broad flat ridge on the other. - Bluffs of the Alleghany Mits., Penn.

4. P. Chicàsa, Michx. (Chickasaw Plum.) Stem scarcely thorny $\left(8-15^{\circ}\right.$ high $)$; leaves nearly lanceolate, finely serrulate, glabrous; fruit globular, red, neurily destitute of bloom ( $\frac{1}{2}-\frac{2^{\prime}}{3}$ in diameter); the ovoid stone almost as thick as wide, rounded at both sutures, one of them minutely grooved. Md. to Fla., west to S. Incl., Kan., and Tex.

5. P. grácilis, Engelm. \& Gray. Soft-pubescent, $1-4^{\circ}$ high ; leares oblonglanceolate to orate, acute, sharply serrate, becoming nearly glabrous above, $1-2^{\prime}$ long; pedicels and caly.x pubescent; fruit less than $\frac{1}{2}$ in diameter; stone rather turgid, suborbicular. - P'rairies and sandy places, S. Kan. to Tex. and 'Tenn.

6. P. pùmila, L. (Dwarf Cuerry. Saxd C.) Smooth, depressed and trailing $\left(6^{\prime}-6^{\circ}\right.$ high $)$; leaves oborate-lanceolate, tapering to the base, somewhat toothed near the apex, pule underneath; flowers 2-4 together; fruit oroid, dark red or nearly black when ripe, withont bloom; stone ovoid, marginless, of the size of a large pea. - Rocks or sandy banks, N. Brunswick to Va., west to Miun. and Kan. Fruit usually sour and astringent.

7. P. Pennsylvánica, L. f. (Wild Red Cherry.) Tree $20-30^{\circ}$ ligh, with light red-lorown bark; leaves oblong-lanceulate, pointed, finely and sharply serrate, shining, green and smooth both sides; flowers many in a cluster, on long pedicels; fruit globose, light red, rery small, with thin and sour flesh; stone globular. - Rocky woorls, Newf. to N. C., west to Minu. and Mo.

P. spixósa, L. (SLOE. BLack Thor.) Branches thorny; leares oborateoblong or ovate-lancenlate, sharply serrate, at length glabrous; pedicels glabrous; fruit small, globular, black with a bloom, the stone turgid, acnte on one edge. - Var. insitítio (Bellace-Plexi), is less spiny, the pedicels and lower sile of the leares pubescent. - Roadsides and waste places, N. Eng. to l'enn. and N. J. (Adv, from Eu.)

§ 2. PADUS. Drupe small, globose, without bloom; the stone turgid-orate, marginless; flowers in racemes terminating leafy branches, therefore appearing after the learcs, late in spring.

8. P. Virginiàna, L. (Сноке-Cherrr.) A tall shrub, with grayish bark; leaves oval, oblong, or obovate, abruptly pointed, very sharply (often doubly) serrate with slender teeth, thin ; petals roundish ; fruit red turning to dark crimson; stone smooth. - River-banks, Newf. to Ga., west to Minn., E. Neb., and Tex. - Fruit very austere and astringent. A variety with very short dense racemes and sweeter yellowish fruit has been found at Dedham, Mass.

9. P. serotina, Ehrh. (WIL1) BlACK Cinerri.) A large tree, with reddlish-brown branches; leaves oblong or lanceolate-oblong, taper-pointed, serrate with incurved short and callous teeth, thickish, shining above; racemes elongated; petals obovate; fruit purplish-black. - Woods, N. Scotia to Fla., west to Minn., E. Neb., and La. - Fruit slightly bitter, but with a pleasant vinons flavor.

10. P. demíssa, Walp. Low but tree-like in habit, $3-12^{\circ}$ ligh, resembling $n .8$ in foliage, but the leaves rather thick and the teeth less slender; racemes often elongated; fruit purplish-black, sweet and but slightly astringent. - Central Kan. and Neb. to New Mex., Dak., and westward. 
2. SPI R 良 A, I. Mвлnо-Swert.

Calyx 5-cleft, short, persistent. P'etals 5, olwrate, equal, imhricated in the bud. Stamens $10-50$. Pucls (follieles) 5-8, not intlated, few-scroral-secedrel. Seeds linear, with a thin or loose cuat and uo albumen. - Shruhs or perennial herls, with simple or pinnate leaves, and white or rose-coloned fluwers in corymhs or panicles. (The Greek name, from $\sigma \pi \epsilon \iota \rho \alpha \omega$, to tucist, from the twisting of the pods in the original species.)

§1. SPIRAA proper. Erect shrubs, with simple leaves; stipules obsolete; porls mostly 5, severul-seeded.

1 S. betulæfolia, Pall, var. corymbòsa, Watson. Nearly smonth (1 $2^{\circ}$ high) ; leaves oval or ovate, cut-toothed toward the apex ; corymbs lurge, flut, several times componnd; flowers white. (S. corymbosa, Raf.) - Mountains of l'enn. and N. J. to Ga., west to Ky. and Mo.

2. S. salicifolia, L. (Coumox MEanow-Swevt.) Nearly smooth (2-30 high); leaves werlge-lanceolate, simply or doubly serrate; flowers in a croweded pamrle, white or flesh-color; pods smooth. - Wet or low grounds, Newf to the mountains of Ga., west to Minu. and Mo.; also to the far northwest. (Eu.)

3. S. tomentosa, I. (Hardiack. Steeple-Busir.) Stems and loner surface of the ovate or oblong serrate leaves very woolly; flowers in short racemes crowded in a dense panicle, rose-color, rarely white; porls woolly. - Low grounds, N. Scotia to the mountains of Ga., west to Minn. and Kan.

§ 2. ULMARIA. Perennial herbs, with pinnate leaves and panicled cymose flowers; stipules kidney-form; pods 5-8, 1-2-seeded.

4. S. lobàta, Jacq. (Queen of tue Prairie.) Glabrous ( $2-8^{\circ}$ high); leaves interruptedly pinnate; the terminal leaflet very large, 7 -9-parted, the lobes incised and tootherl; panicle compound-clustered, on a long naked peduncle; flowers deep peach-blossom color, handsome, the petals and sepals often in fours. - Meadows and prairies, Penn. to Ga., west to Mich., Ky., and Iowa.

\$ 3. ARÚNCUS. Perennial herbs, with dixcious whitish flouers in many slender spikes, disposed in a long componnd panicle; leaves thrice pinnate; stipules obsolete; pods 3-5, several-seeded; pedicels reflexed in fruit.

5. S. Arúncus, L. (GoAt's-BEARI).) Smooth, tall; leaflets thin, lanceolate-oblong, or the terminal ones ovate-lanceolate, taper-pointed, sharply cut and serrate. - Rich woods, N. Y. and Penn. to Ga. in the mountains, west to Iowa and Mo.

\section{PHYSOCÁ R U S, Maxim. Nine-bark.}

Carpels 1-5, inflated, 2-valved; ovules 2-4. Seeds roundish, with a smooth and shining crustaceous testa and copious albumen. Stamens 30-40. Otherwise as Spiræa. - Shrubs, with simple palmately-lobed leaves and umbel-like corymbs of white flowers. (Name from $\phi \hat{v} \sigma \alpha, a$ bladder, and kapros, fruit.)

1. P. opulifolius, Maxim. Shruh $4-10^{\circ}$ high, with long recurvel branches, the old bark loose and separating in numerous thin lavers; leaves roundish, somewhat 3-lobed and heart-shinped; the purplish membruareons pods very conspicuous. (Apirxa opulifulia, L. Neillia opulifulia, Lenth. o. 
Hook.) - Rocky banks of streams, N. Eng. to Fla., west to Mo., and the Pacific northward. Often cultivated.

\section{GILLÈ NIA, Moench. Ixdiax Prysic.}

Calyx narrow, somewhat constricted at the throat, 5-toothed; teeth erect. Petals 5, rather unequal, linear-lanceolate, inserted in the throat of the calyx, convolute in the bud. Stamens 10-20, included. Pods 5, included, at first lightly cohering with each other, 2-4-seeded. Seeds ascending, with a close coriaceous coat, and some albumen. - Perennial herbs, with almost sessile 3 -foliolate leaves; the thin leaflets doubly serrate and incised. Flowers loosely paniculate-corymbed, pale rose-color or white. (Dedicated to an obscure German botanist or physician, A. Gille, or Gillenius.)

1. G. trifoliàta, Moench. (Bоwмax's Rоот.) Leaflets ovate-oblong, pointed, cut-serrate; stipules small, awl-shaped, entire.-Rich woods, N. Y. to N. J. and Ga., west to Mich., Ind., and Mo.

2. G. stipulàcea, Nutt. (American Ipecac.) Leaflets lanceolate, deeply incised; stipules large and leaf-like, doubly incised.-Western N. Y. and Penn. to S. Ind. and Kan., south to Ala. and La.

\section{R Ù B U S, Tourn. Bramble.}

Calyx 5-parted, without bractlets. Petals 5, deciduous. Stamens numerous. Achenes usually many, collecterl on a spongy or succulent receptacle, becoming small drupes; styles nearly terminal. - Perennial herbs, or somewhat shrubby plants, with white (rarely reddish) flowers, and edible fruit. (The Roman name, kindred with ruber, red.)

$\S 1$. Fruit, or collective mass of drupes, falling off whole from the dry receptacle when ripe, or of few grains which fall separately. - RASPBERRY.

* Leaves simple; flowers large; prickles none; fruit and receptacle flat and broad.

1. R. odoràtus, L. (Purple Flowerixg-Rasprerry.) Stem shrubby (3-5० high) ; branches, stalks, and calyx bristly with glandular clammy hairs; leaves 3-5-lobed, the lobes pointed and minutely toothed, the middle one prolonged; peduncles many-flowered; flowers showy ( $2^{\prime}$ broad); calyx-lobes tipped with a long narrow appendage; petals rounded, purple rose-color; fruit reddish. - N. Scotia to N. J. and Ga., west to Mich.

2. R. Nutkànus, Moçino. (S.ılıox-Berrx.) Glandular, scarcely bristly; leares almost equally 5-lobed, ccarsely toothed; peduncles few-flowered; petals oval, white. - Upper Mich., Minn., and westward.

3. R. Chamæmorus, L. (Clocd-berry. Baked-Apple Berry.) Herbaceous, low, dixcions; stem simple, 2-3-leaved, 1-flowered; leares roundish-kidney-form, somewhat 5-lobed, serrate, wrinkled; calyx-lobes pointless; petals obovate, white; fruit of few grains, amber-color. - In sphagnous swamps, highest peaks of White Mts., coast of E. Maine, and north and west to the Arctic regions. (Eu.)

* * Leaflets (pinnately or pedately) 3-5; petals small, erect, white.

+ Stems annual, herbaceous, not prickly; fruit of few separate grains.

4. R. triflorus, Richardson. (Dwarf Raspberry.) Stems ascending $\left(6-12^{\prime}\right.$ high) or trailing; leaflets 3 (or pedately 5), rhombic-orate or ovate- 
lanceolate, acute at both ends, coarsely doubly serrate, thin, smonth; pedunclo 1-3-flowered. - Wooded hillsides, Lab. to N. J., West to Minn. and Iowa. Sicpals and petals often 6 or 7 . This appears to be more properly a blackberiy.

+ + Stems biennial and woody, mickly; receptacle oblong; fruit hemispherical.

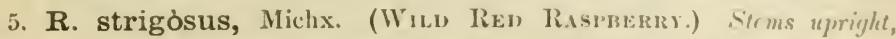
and with the stalks, etc., beset with stiff straight bristles (or a few hecoming weak hooked prickles), glandular when young, somewhat glancous; leaflets $3-5$, oblong-ovate, pointed, cut-serrate, whitish-downy underneath, the lateral ones sessile; petals as long as the sepals; fruit light rerl. - Thickets and hills, Lab. to N. J., and south in the monntains to N. C., west to Minn. and Mo.

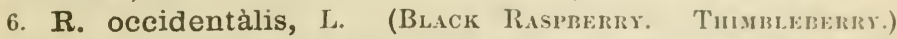
Gluucous all over; stems recurved, armed like the stalks, etc., with hooked prickles, not bristly; leaflets 3 (rarely 5), ovate, pointed, coarscly donbly serrate, whitened-downy underneath, the lateral ones somewhat stalked; petals shorter than the sepals; fruit purple-bluck (rarely a whitish variety), ripe early in Jnly. - Common, especially northward. - An apparent hybrid (R. neglectus, Peck) between this and the last species occurs, with characters intermediate between the two, and growing with them.

\$2. Fruit, or collective drupes, not separating from the juicy prolonged reseptacle, mostly ovate or oblong, blackish; stems prickly and flowers white.BLACKBERR.

7. R. villosus, Ait. (Commox or Hign Blackenrry.) Shrubby ( $1-6^{\circ}$ high), furrowed, upright or reclining, armed with stout curved prickles; branchlets, stalks, and lower surface of the leaves hairy and glandulur; leaflets 3 (or pedately 5), ovate, pointed, unequally serrate, the terminal ones somewhat heart-shaped, conspicuonsly stalked; flouers racemed, numerous; bracts short ; sepals linear-pointerl, much shorter than the obovate-ubloug spreading petals. - Borders of thickets, etc, common, and very variable in size, aspect, and shape of fruit. - Var. Froxioses, Torr., is smoother and much less glandnlar, with flowers more corymbose, leafy bracts and roundish jetals. With the type, more common at the north. - Var. Humitsus, Torr. \& Gray, is smaller and trailing, with peduncles few-flowered. More common southward, and connecting with the next species.

8. R. Canadénsis, L. (Low Blackrerry. Dewnerry.) Shrubhy, extensively truiling, slightly prickly; leaflets 3 (or peclately $5-7$ ), oval or ovatelanceolate, mostly pointed, thin, nearly smooth, sharply cut-serrate; flowers racemed, with leaf-like bracts. - Dry fields, common; Newf. to Va., west to central Minn. and E. Kan.

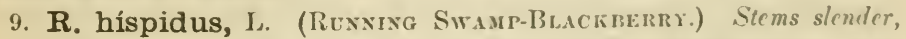
scarcely wood!y, extensively procumbent, leset with smull reflexed prickles; leaflets 3 (or rarely pelately 5), smowh, thickish, mostly persistent, obovate, obtuse, coarsely scrrate, entire toward the base; peduncles leafless, sceral-floucred, often bristly; flowers small; fruit of few grains, black. - In low woods or swampy grassy ground, N. Scotia to Ga., west to Minn. and E. Kan.

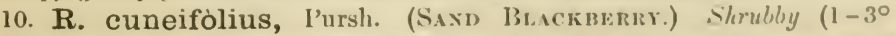
high), upright, armed with stout recurced prickles, branchlets and louer side of the leaves whitish-woolly; leallets 3-5, welgeobovate, thickish, serrate above; 
peduncles 2-4-flowered; petals large. - Saudy woods, southern N. Y. and Penn. to Fla., west to Mo. and La.

11. R. triviàlis, Michx. (Low Bush-Bldckвerrr.) Shrubby, procumbent, bristly and prickly; leaves evergreen, coriaceous, nearly glabrous; leaflets 3 (or pedately 5), orate-oblong or lanceolate, sharply serrate; peduncles 1-3flowered; petals large. - Sandy soil, Va. to Fla., west to Mo. and Tex.

\section{D A LIBÁR D A, L.}

Calyx deeply 5-6-parted, 3 of the divisions larger and toothed. Petals 5, sessile, deciduous. Stamens many. Ovaries 5-10, becoming nearly dry seedlike drupes; styles terminal, deciduous. - Low perennials, with creeping and densely tufted stems or rootstocks, and roundish-heart-shaped crenate leaves on slender petioles. Flowers 1 or 2, white, on scape-like peduncles. (Named in honor of Thomas Dalibard, a French botanist of the time of Linnaus.)

1. D. rèpens, L. Downy; sepals spreading in the flower, converging and enclosing the fruit. - Wooded banks; common northward. June-Aug. - In aspect and foliage resembling a stemless Violet.

\section{G i U M, L. Avexs.}

Calyx bell-shaped or flattish, deeply 5-cleft, usually with 5 small bractlets at the sinuses. Petals 5. Stamens many. Achenes numerous, heaped on a conical or cylindrical dry receptacle, the long persistent styles forming hairy or naked and straight or jointed tails. Seed erect; radicle inferior. - Perennial herbs, with pinnate or lyrate leaves. (A name used by Pliny, of unknown meaning.)

§ 1. GEUM proper. Styles jointed and bent near the middle, the upper part deciduous and mostly hairy, the lower naked and hooked, becoming elongated; head of fruit sessile in the calyx; calyx-lobes reflexed.

* Petals white or pale greenish-yellow, small, spatulate or oblong; stipules small.

1. G. álbum, Gmelin. Smoothish or softly pubescent; stem slender $\left(2^{\circ}\right.$ high); root-leaves of $3-5$ leaflets, or simple and rounded, with a few minute leaflets on the petiole below; those of the stem 3-divided or lobed, or only toothed; hairs upon the long slender peduncles ascending or spreading; receptacle of the fruit densely bristly-hirsute. - Borders of woods, etc.; common. May-Aug.

2. G. Virginiànum, L. Bristly-hairy, especially the stout stem; lower and root-leaves pinnate, very various, the upper mostly 3-parted or divided, incised; petals inconspicuous, shorter than the calyx; heads of fruit larger, on short stout peduncles hirsute with reflexed hairs; receptacle glabrous or nearly so. - Borders of woods and low grounds; common. June-Aug.

* * Petals golden-yellow, conspicuous, broadly-obovate, exceeding the calyx; stipules larger and all deeply cut.

3. G. macrophýllum, Willd. Bristly-hairy, stout $\left(1-3^{\circ}\right.$ high); rootleaves lyrately and interruptedly pinnate, with the terminal leaflet very large and round-heart-shaped; lateral leaflets of the stem-leares 2-4, minute, the terminal roundish, 3-cleft, the lobes wedge-form and rounded; receptacle nearly naked. - N. Scotia and N. Eng. to Minn., Mo., and westward. June. (Eu.) 
4. G. strictum, Ait. Somewhat hairy $\left(3-5^{\circ}\right.$ high) ; root-leaves interruptedly pinnate, the leaflets wedge-otovate; leaflets of the stouderiers 3-5, rlombic-orate or whlong, arute: receptacle douny. - Mnist meadows, Newf. to N. J., west to Minn., Kan, and westward. July, Aug. (Eu.)

§ 2. S'TÝLIJ'TS. Styles smooth; head of fruit conspricuously stalked in the calyx; bractlets of the calyx none; otherwise nearly as $\$ 1$.

5. G. vérnum, Torr. \& Gray. Somewhat pubescent; stems ascencling, few-leaved, slender; root-leaves roundish-heart-shaped, 3-5-lohed, or some of them pinnate, with the lules cut; petals yellow, about the length of the ealyx; receptacle smooth. - Thickets, I'eun. to Ill., south to Kiy. and Tex. A pril-June.

§3. CARYOPHYLLATA. Style jointed and bent in the middle, the upper joint plumose; flowers large; calyx erect or spreading; petals erect.

6. G. rivale, I. (Water, or Perple Avexs.) - Stems nearly simple, several-Howered ( 2 o high) ; root-leaves lyrate and interruptedly pinnate, those of the stem few, 3-foliolate or 3-loberl; petals dilated-obovate, retuse, contracted into a claw, purplish-orange; head of fruit stalked in the brownpurple ealyx. - Bogs and wet meadows, Newf. to N. J., west to Minn. and Mo. - Flowers nodding; pedicels erect in fruit. (Eu.)

§4. SIEVÉRSIA. Style not jointed, wholly persistent and straight; head of fruit sessile; flowers large; calyx erect or spreading. (Flowering stems simple, and bearing only bracts or small leaves.)

7. G. triflorum, Pursh. Low, softly-hairy; root-leares interruptedly pinnate; leaflets very numerous and crowded, oblong-wedge-form, deeply cuttoothed; flowers 3 or more on long peduncles; bractlets linear, longer thun the purple calyx, as long as the oblong purplish erect petals; styles verylong (2'), strongly plumose in fruit. - Rocks, Lab. and northern N. Eng., to Minn. and Mo.; rare. April-June.

8. G. radiàtum, Michx. Ilirsutely hairy or smoothish; root-leaves rounded-kidney-shaped, radiate-reinerl $\left(2-5^{\prime}\right.$ broad), doubly or irregularly cuttoothed and obscurely 5-7-lobed, also a set of minute leaflets down the long petiole; stems $\left(8-18^{\prime}\right.$ high) 1-5-flowered; bractlets mimute: petals yellou, round-obovate and more or less obcorlate, exceeding the caly $\left(\frac{1}{2}^{\prime}\right.$ long), spreading; styles naked except the lase. (High monntains of $\mathbf{N}$. C.)

Var. Péckii, Gray. Nearly glabrous, or the stalks and veins of the leaves sparsely hirsute. - Alpine tops of the White Mts.

DrYas oCtOpeta LA, L., a dwarf matted slightly shrubby plant, with simple toothed leaves and large white solitary flowers, has the characters of this section excepting its 8-9-parted calyx and 8 or 9 petals. It was said by l'ursh to have been found on the White Momntains, N. H., ninety years ago, but it is not known to have been seen there since.

\section{W A L D S E İ I A, Willl.}

Calyx-tube inversely conieal; the limb 5 -cleft, with 5 often minute and deciduous bractlets. Petals 5. Stanens many, inserted into the throat of the calyx. Achenes 2-6, minutely hairy; the terminal slender styles ileciluous from the base by a joint. Seed erect; radicle inferior.-Low perennial herbs, with 
chiefly radical 3-5-lobed or divided leaves, and small yellow flowers on bracted scapes. (Named in honor of Francis von Waldstein, a German botanist.)

1. W. fragarioides, Tratt. (BArren Strawberry.) Low; leaflets 3 , broadly wedge-form, cut-toothed; scapes several-flowered; petals longer than the calyx. - Wooded hillsides, N. Eng. to Ga., west to Ind., Mich., and Minn.

\section{FRA A À r i a, Tourn. Strawberry.}

Flowers nearly as in Potentilla. Styles deeply lateral. Receptacle in fruit much enlarged and conical, becoming pulpy and scarlet, bearing the minute dry achenes scattered over its surface. - Stemless perennials, with runners, and with white cymose flowers on scapes. Leaves radical; leaflets 3 , obovatewedge-form, coarsely serrate; stipules cohering with the base of the petioles, which with the scapes are usually hairy. (Name from the fragrance of the fruit.) - Flowering in spring. (The species are indiscriminately called WILD Strawberry.)

1. F. Virginiàna, Mill. Achenes imbedded in the deeply pitterl fruiting receptacle, which usually has a narrow neck ; calyx becoming erect after flowering and connivent over the hairy receptacle when sterile or unfructified; leaflets of a firm or coriaceous texture; the hairs of the scapes, and especially of the pedicels, silky and appressed. - Moist or rich woodlands, fields, ete.; common.

Var. Illinoénsis, Gray, is a coarser or larger plant, with flowers more inclined to be polygamo-diocious, and the villons hairs of the scape and pedicels widely spreading. - Rich soil, western N. Y. to Minn., and westward.

2. F. vésca, L. Achenes superficial on the glabrous conical or hemispherical fruiting receptacle (not sunk in pits); calyx remaining spreading or reflexed; hairs on the scape mostly widely spreading, on the pedicels appressed; leaflets thin, even the upper face strongly marked by the reins. - Fields and rocky places; less common. (Eu.)

F. INDICA, L., differing from the true strawberries in having leafy runners, a calyx with incised leafy hractlets larger than the sepals, yellow petals, and insipid fruit, has become somewhat established near Philadelphia and in the S. States; an escape from cultiration. Flowers and fruit produced through the summer and autumu. (Adv. from India.)

\section{POTENTÍthA, L. Cixque-forl. Five-fixger.}

Calyx flat, deeply 5-cleft, with as many bractlets at the sinuses, thus appearing 10-cleft. Petals 5, usually roundish. Stamens many. Achenes many, collected in a head on the dry mostly pubescent or hairy receptacle; styles lateral or terminal, decidnous. Radicle superior. - Herbs, or rarely shrubs, with compound leaves, and solitary or cymose flowers; their parts rarely in fours. (Name a diminutive from potens, powerful, originally applied to $\mathrm{P}$. Anserina, from its once reputed medicinal powers.)

$\S 1$. Styles thickened and glandular toward the base; achenes glabrous, numerous : inflorescence cymose.

* Style nearly basal; stamens 25-30: perennial glandular-villous herbs, with pinnate leaves, and rather large white or yellow flowers.

1. P. argùta, Pursh. Stems erect, usually stout $\left(1-4^{\circ}\right.$ high $)$, brownishhairy, clammy above; leaflets $7-11$, oval or ovate, cut-serrate, downy beneath; 
cyme strict and rather close; stamens mostly 30, on a thick glandular disk. liocky hills, N. Brunswick to N. J., Minn., Kinn, and westwatrl.

* * Style terminal; flowers small, yellow; leutes pinnate or ternute.

+ Annual or biennial; leaflets incisely serrate, not white-tomentose ; stamens 5-20.

2. P. Norvégica, I. Stout, erect, hirsute $\left(\frac{1}{2}-2^{\circ}\right.$ high $)$; leaves ternate; leaflets obovate or oblong-lanceolate; cyme rather close, leafy; calyx large; stamens 15 (rarely 20). - Lab. to N. J., west to Minn. and Kan. (Lin.)

3. P. rivàlis, Nutt. More slender and branched, softly villuns; lenves pinnate, with two pairs of closely approximate leaflets, or a single jair and the terminal leaflet 3-parted; leaflets cuneate-obovate or -oblong; cyme loose, often diffiuse, less leafy; calyx small; petals minute; stamens $10-20$ (ararely 5). Neb. to MIo. and N. Mex., and westwart.

Var. millegràna, Watson. Leaves all termate; stems erect, or weak and ascending; achenes often small and light-colored.-Minn. to Mo., N. Mex., and westward.

Var.pentándra, Watson. Leaves teruate, the lateral leaflets of the lower leaves parted nearly to the base; stamens 5, opposite to tlie sepals. - Iowa, Mo., and Ark.

4. P. supina, L. Stems decumbent at base or erect, often stout, leafy, subvillous; leaflets pinnutely 5-11, obovate or oblong; cyme loose, leafy; stamens 20; achenes strongly gibbous on the ventral side. (P. paraduxa, Nutt.) Minn. to Mo., and westward; also eastward along the Great Lakes. - Var. Nicolı́́tir, Watson. Slender; leaflets mostly but 3 ; inflorescence much elongated, leafy, and falsely racemose. - Devil's Lake, Minn.

+ + Herbaceous perennials, more or less white-tomentose; leaflets incisely pinnatifid; bractlets and sepals nearly equal; stamens $20-25$.

5. P. Pennsylvánica, I. Stems erect or decumbent at base $\left(\frac{1}{2}-2^{\circ}\right.$ high); leaflets 5-9, white-tomentose heneath, short-pubescent and greener above, oblorg, obtuse, the linear segments slightly or not at all revolute; cyme fastigiate but rather open. - Coast of Maine, N. H., and the lower st. Lawrence, L. Superior, and westward. July, Aug. - Var. stmigosd, Lehm. Stems 6-12' high; silky-tomentose throughout; leaflets deeply pinnatifict, the margins of the narrow lobes revolute; cyme short and close. - Minn. and westward.

§ 2. Styles filiform, not glandular at base; inflorescence cymose.

* Style terminal; achenes glabrous; stamens 20; herbaceous perennials, with rather large yellow flowers.

- Leares pinnate.

6. P. Hippiana, Lehm. Densely white-tomentose and silky throughout, the upper surface of the leaves a little darker; stems ascending ( $1-1 \frac{1}{2}{ }^{\circ}$ high $)$, slender, branching above into a diffuse cyme; leaflets 5-11, cuneate-oblong. incisely toothed at least toward the apex, diminishing uniformly down the petiole; earpels $10-30 .-\mathrm{N}$. IV. Minn., and westwarl.

7. P. effùsa, Dougl. Tomentose throughout, with seattered villous hairs; stems ascending $\left(4-12^{\prime}\right.$ high $)$, diffusely branched above; leaflets $5-11$, interruptedly pinnate, the alternate ones smaller, cuneate-oblong, coarsely-incised-serrate or dentate; carpels 10. - IV. Minu. to Mont. and Col. 
+- + Leaves palmate, of 3 or 5 leaflets; tomentose or villous.

8. P. argéntea, L. (Silvery Cixque-forl.) Stems ascending, paniculately branched at the summit, many-flowered, white-woolly; leaflets 5, wedgeublong, almost pinnatifid, entire toward the base, with revolute margins, green above, white with silvery wool beneath. - Dry barren fields, etc., N. Scotia to N. J., west to Dak. and E. Kian. June-Sept. (Eu.)

9. P. frígida, Vill. Dwarf $\left(1-3^{\prime}\right.$ ligh $)$, tufted, villous when young; leaflets 3 , broadly cuneate-obovate, deeply $3-5$-toothed at summit, nearly glabrous above; flowers mostly solitary, small, on very slender stems; bractlets and sepals equal. - Alpine summits of the White Mts. (Eu.)

* * Style lateral ; purple petals (shorter than the broad calyx) somewhat persistent; disk thick and hairy; achenes glabrous; hairy receptacle becoming large and spongy.

10. P. palústris, Scop. (Marsh Five-Finger.) Stems stout, ascending from a decumbent rooting perennial base ( $\left.\frac{1}{2}-2^{\circ} \mathrm{long}\right)$, glabrous below; leaves pinnate; leaflets $5-7$, oblong, serrate, lighter colored and more or less pubescent beneath; flowers few in an open cyme; calyx ( $l^{\prime}$ broad) dark purple inside. - Cool bogs, N. J. to N. Ind., Ill., Minn., and northward. (Eu.)

* * Style attached below the middle; achenes and receptacle densely villous; uoody perennials.

11. P. fruticosa, L. (Shrcbir Creqce-forl.) Stem erect, shrubby ( $1-4^{\circ}$ high), much branched; leaves pinnate; leaflets $5-7$, crowded, oblonglanceolate, entire, silky, usually whiter beneath and the margins revolute; jetals yellow, orbicular. - Wet grounds, Lab. to N. J., west to Minn., northern Iowa, and north and westward. June-Sept. (Eu.)

12. P. tridentàta, $\Lambda$ it. (Three-toothed C.) Stems low (1 - 10' high), rather woody at base, tufted, ascending, cymosely several-flowered; leaves palmate; leaflets 3, wedge-oblong, nearly smooth, thick, coarsely 3-toothed at the apex; petals white; achenes and receptacle very hairy. - Coast of N. Eng. from Cape Cod northward, Norfolk, Ct. (Barbour), and mountain-tops of the Alleghanies; also shores of the upper Great Lakes, and N. Iowa, Wisc., and Minu.

§ 3. Styles filform, lateral; peduncles axillary, solitary, 1-flowered; achenes glabrous; receptacle very villous; herbaceous perennials, with yellow flowers.

13. P. Anserina, L. (Silver-Weed.) Spreading by slender manyjointed runners, white-tomentose and silky-villons; leaves all radical, pinnate; leaflets $7-21$, with smaller ones interposed, oblong, sharply serrate, silky tomentose at least beneath; bractlets and stipules often incisely cleft; peduncles elongated. - Brackish marshes, river-banks, etc., New Eng. to N. J., N. Ind., Minn., and northward. (Eu.)

14. P. Canadénsis, L. (Common Cinque-forl or Five-Finger.) Stems slender and decumbent or prostrate, or sometimes erect; pubescence villous, often scanty; leares ternate, but apparently quinate by the parting of the lateral leaflets; leaflets cuneate-oblong or -obovate, incisely serrate, nearly glabrous above; bractlets entire. - Dry soil ; common and variable. A pr.-July. - Often prolucing summer runners. 


\section{SIB B Á L D I A, I。}

Calyx flattish, 5-cleft, with 5 hractlets. l'etals 5, linear-ollong, minute. Sitamens 5, inserted alternate with the petals into the margin of the wimlly alisk which lines the hase of the ealyx. Achenes 5-10; styles lateral. - low and dopresserl mountain perennials; included by some in l'otentilla. (1)erlicated to Dr. livbert sibbuld, professor at Edinburgh at the cluse of the 17th century.)

1. S. procùmbens, I. I.eaflets 3 , wedgre-shapel, 3-toothel at the appex; petals yellow. - $\mathrm{Al}$ pine summits of the White Mts., and northward. (Eu.)

\section{A LCHEMÍLLA, Tourn. IAw's Mixt.e.}

Calyx-tuhe inversely conical, contracted at the throat; limh 4-jarted with as many alternate accessory lubes. l'etals none. Stamens $1-4$. l'istils $1-4$, the slender style arising from near the base; achenes included in the tube of the persistent calyx. - Low herbs, with palmately lobed or componnd leaves, and small corvmbed greenish fowcrs. (From ithemelyeh, the $A$ rabic name, having reference to the silky pubescence of some species.)

A. Arvéxsis, Seop. (Parsley P'inire) Simall amnual $\left(3-8^{\prime}\right.$ ligh), leafy ; leaves 3-parterl, with the werlge-shaped lobes $2-3$-cleft, pubescent; flowers fascicled opposite the axils. - Va. and N. C. (Adv. from Ku.)

\section{A GRIMÒNIA, Tourn. Agrmoxi.}

Calyx-tube top-shaped, contracted at the throat, beset with hooked bristles above, indurated in fruit and enclosing the 2 achenes; the limb 5-cleft, closed after flowering. Petals 5. Stamens 5-15. Styles terminal. Seed suspended - l'erennial herbs, with interruptedly pinnate leaves, and yellow flowers in slender spiked racemes; bracts 3-cleft. (Name a corruption of Argemoniu, of the same derivation as $\mathrm{Argemone,} \mathrm{p.} \mathrm{59.)}$

1. A. Eupatoria, I. (Coumox Agrimoxr.) Leaflets 5- i with minute ones intermixed, oblong-oborate, coarsely toothed; petals twice the length of the calyx. - Borders of woods, common. July-Sept. (Eu.)

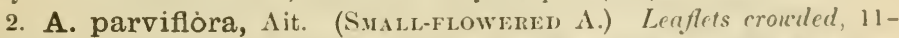
19, with smaller ones intermixed, lanceolate, acute, deeply and regularly cut. serrate, as well as the stipules; petals small. - Woods and glades, N. Y. and N. J. to Ga., west to Mich., Kan., and La.

\section{POTERIU M, I. Birver.}

Calyx with a top-shaped tule, constricted at the throat, persistent; the 4 hroad petal-like spreading lobes imbricated in the lud, decilnous. T'etals none. Stamens 4-12 or more, with flaceil filaments and short anthers. l'istils 1-3: the slencler terminal style tipperl with a tufted or brush-like stigma. Achene (commonly solitary) enclosed in the t-angled iry and thickish clused calyxtube. Seed suspended. - Chiefly perenuial herbs, with mepnally pimate leaves, stipnles coherent with the petiole, and small, often polygamous or diceious flowers crowded in a dense heal or spike at the summit of a long and naked peduncle, each bracteate and 2-bracteolate. (Name norńpıo, a drinking. cup, the foliage of Burnet having been used in the preparation of some medicinal drink.) 
1. P. Canadénse, Benth. \& Hook. (Caxadias Burxet.) Stamens 4, long-exserted, club-shaped, white, as is the whole of the elongated and cylindrical spike; stem $3-6^{\circ}$ high; leaflets numerous, ovate or oblong-lanceolate, coarsely serrate, obtuse, heart-shaped at base, as if stipellate; stipules serrate. - Bogs and wet meadows, Newf. to mountains of Ga., west to Mich.

P. Sanguisórba, L. (Gardex Burnet.) Stamens 12 or more in the lower flowers of the glohular greenish head, with drooping capillary filaments, the upper flowers pistillate only; stems about $1^{\circ}$ high; leaflets numerous, small, ovate, deeply cut. - Fields and rocks, N. Y. to Md. ( $\Lambda$ dv. from Eu.)

\section{ROSA, Tourn. Rose.}

Calyx-tube urn-shaped, contracted at the mouth, becoming fleshy in fruit. Petals 5, obovate or obcordate, inserted with the many stamens into the elge of the hollow thin disk that lines the calyx-tube and within bears the numerous pistils below. Ovaries hairy, becoming bony achenes in frnit. - Shrubby and usually spiny or prickly, with odd-pinnate leaves, and stipules cohering with the petiole; stalks, foliage, etc., often bearing aromatic glands. Many of the species are very variable in their characters, and are often indeterminable upon imperfect specimens. (The ancient Latin name.)

* Styles cohering in a protrudiug colunin, as long as the stamens.

1. R. setígera, Michx. (Cummixg or Pramie Rose.) Stems climbing, armed with stout nearly straight scatterel prickles, not bristly; leaflets $3-5$, ovate, acute, sharply serrate, smooth or downy heneath; stalks and calyx glandular; flowers corymbed; sepals pointed ; petals deep rose-color changing to white; fruit (hip) globular. - Borders of prairies and thickets, Ont. to Ohio, S. C., and Fla., west to Wisc., Neb., and Tex.; also cultivated. July.The only American climbing rose, or with united protruding styles; strong shoots growing $10-20^{\circ}$ in a season.

* Styles distinct; sepals connivent after flowering and persistent; pedicels and receptacles naked.

- Fruit oblong-obovate to oblong; infrastipular spines usually none.

2. R. Engelmánni, Watson. Stems usually $3-4^{\circ}$ high or less; infrastipular spines, when present, straight and slender; prickles often abundant; leaflets $5-7$, often somewhat resinons-puberulent beneath and the teeth serrulate; flowers solitary; sepals entire, naked or hispid; fruit 6-12" long.Whisky Island, L. Huron, shores of L. Superior, and west to the Red River valley, and in the mountains from N. Mont. and N. Idaho to Col.

+ + Fruit globose; infrastipular spines none; acicular prickles often present.

3. R. blánda, Ait. Stems $1-3^{\circ}$ high, uholly unarmed (occasionally with a few or very rarely numerous prickles); stipules dilated, naked and entire, or slightly glandular-toothed; leaflets $5-7$, usually oblong-lanceolate, cuneate at buse and petiolulate, simply serrate, not resinous; flowers usually large, corymbose or solitary; sepals hispid, entire. - On rocks and rocky shores, Newf. to N. Eng., central N. Y., Ill. (La Salle Co.), and the region of the Great Lakes.

4. R. Sàyi, Schwein. Stems usually low (1-2。 high), very prickly; stipules usually diluted, glandular-ciliate and resinous; leaflets $3-7$, broally elliptical to oblong-lanceolate, sessile and obtuse or subcordate at base, resinous- 
puberulent and teeth serrulute; flowers large, solitary (very marely 2 or 3); outer seprals usually with 1 or 2 narrow lateral loluse, not hispicl. - N. Mich. aud Wisc. to Mimn. and ('ol.

5. R. Arkansàna, l'orter. Stems low, very prickly; stijules narrow, more or less glamdular-toothed above (or even glandular-ciliate); leculets $7-11$, broadỵ clliptical to oblongroblanceolate, sulicuneate at base, sessile or petiolulate, simply toothed, not resinous; flowers corymbose; sepuls rarely hispid, the outer lobed. - Minn. to Mo, and W. Tex., west to Col.

+++ Fruit globose: infrastipular spines present.

6. R. Woòdsii, Lincll. Stems usually low $\left(\frac{1}{6}-3^{\circ}\right.$ lighli), with slender straight or recurved spines, sometimes with scattered prickles, or wholly unarmed above ; leaflets 5 - 7, obovate to oblong or lanceolate, more or less toothed; flowers corymbose or solitary ; sepals naked or lispid, the onter usually lubed; fruit globose with a short neck. - Minn. to Mo., west to Col.

* * Styles distinct; sepals spreading after fowering and deciduous; infiustipular spines usually present, often with scattered prickles; sepals, glolose receptacle, and pedicel usually hispid; tceth simple; pubescence not resinous.

\section{+- Leaflets mostly finely many-toothed.}

7. R. Carolina, L. Stems usually tall ( $1-7 \circ$ high), with stont straight or usually more or less eurved spines; stipules long aucl very uilrow; leatlets dull green, 5-9 (usually 7), usually narrowly ollong aul acute at each cul and petiolulate, but often broader, usually pubescent beneath. - Borders of swamps and streams, N. Scotia to Fla., west to Minn. and Miss.

\section{++ Leuflets coursely toothed.}

8. R. lùcida, Ehrh. Stems often táll and stout (a few inches to $6^{\circ}$ high), with at lenyth stout and usually more or less hooked spines; stipules usually naked, more or less dilated; leaflets (mostly i) lark green, rather thick, smooth and often shining alove; flowers corymbose or solitary; onter sepals frequently with 1 or 2 small lobes. - Margins of swamps or moist places, Newf. to N. Fing., N. Y., and F. Penn.

9. R. hùmilis, Marsh. Stems usually low $\left(1-3^{\circ}\right)$ and more slender, less leafy, with straight slender spines, sprealing or sometimes reflexel; stipules narrow, rarely somewhat dilated; leaflets ins in the last, but usually thinner and paler; flowers very often solitary; outer supuls alunys more or less lobed. (R. lucila of most authors.) - Mostly in dry soil or on rocky slopes, Maine to Ga., west to Minn., Mo., Iud. Terr., and la.

10. R. nítida, Willd. Low, nearly or quite gluberses throughont, the straight slender spines often scarcely stouter than the prickles which usually thickly corer the stem and branches; stipules mostly diluted; leaflets bright grcen and shining, usually narrowly oblong and acute at each end ; fluwers solitary (rarely 2 or 3); seprels entire. - Margins of swamps, Newf. to N. Eng.

\section{Nuturalized sperios.}

R. Caxtxa, I. (Dog liosk.) Stems armed with stont recurved spines, without prickles, the branches sumetimes unarmed; leaflets $5-7$, elliptical or ohlong-ovate, glahrous or somewhat pubescont, simply tonther, mot resinumspuberulent; flowers solitary (or 2-4) on usually naked pedicels; sepals pin- 
natifid, deciduous ; fruit oblong-ovate to nearly globular. - Roadsides, E. Penn., 'Ienn., etc. (Int. from Eu.)

R. rubiginosa, I. (Sweetrier. Eglantive.) Resembling the last, but of more compact habit, the leaflets densely resinous beneath and aromatic, and doubly serrate: the short pedicels and pimnatifid sepals hispid. (Inel. R. micrantha, Simith; less aromatic, with oblong fruit and glabrous styles.) - N. Scotia and Ont. to S. C. and Temn. (Int. from Fu.)

\section{PỲ RUS, L. T'Eir. Apple.}

Calyx-tube urn-shaped, the limb 5-cleft. Petals roundish or obovate. Stamens numerous. Styles 2-5. Pome fleshy or berry-like; the $2-5$ carpels or cells of a papery or cartilaginous texture, 2-seeded. - Trees or shrubs, with laudsome flowers in corymbed cymes. (The classical name of the Pear-tree.)

§1. MALLS (APPLE). Leaves simple; cymes simple and umbel-like; pome fleshy, globular, sunk in at the attachment of the stalk.

1. P. coronària, L. (American Crab-Apple.) Leaves ovate, often rather heart-shaped, cut-serrate or lobed, soon glabrous; styles woolly and united at base. - Gladles, Ont. and W. New York to N. C., west to Mimm., Kan., aud La. May. - Tree $20^{\circ}$ ligh, somewhat thorny, with large rose-colored very fragrant blossoms, few in a corymb; fruit fragrant and greenish.

2. P. angustifolia, Ait. Resembling the last, but with leares oblong or lanceolate, often acute at base, mostly toothed, glabrous; styles distinct. Glades, P'enn. to Fla., west to S. Ind., Kian., and La. April.

§ 2. ADENỎRHACHIS. Leures simple, the midilb glandular along the upper side; cymes componnd: styles united at base; fruit berry-like, small.

3. P. arbutifolia, L.f. (Cuoke-Berry.) A shrub usually $1-3^{\circ}$ high; leaves oblong or ohlanceolate, mostly acute or acuminate, finely glandularserrate, tomentose beneath; cyme tomentose; flowers white or redlish ; fruit pear-shaped, or globose when ripe, small, red or purple, astringent. - Swamps and damp thickets; common, from N. Ścotia to Fla., and west to Minu., Ill., Mo., and La.

Var. melanocárpa, Hook. Nearly smooth throughout, with larger black fruit; leaves usually less acute. - Of apparently the same range.

§3. SÓRBUS. Leaves odd-pinnate, with rather numerous leaflets; cymes compound; styles separate: pome berry-like, small.

4. P. Americàna, DC. (Avericax Mocntain-Ash.) Tree or tall shrub, nearly glabrous or soon becoming so; leaflets 13-15, lanccolate, taper. pointed, sharply serrate with pointed teeth, bright green; ' $y$ mes large and flat; berries globose, bright red, not larger than peas; leuf-buds pointed, glabrous and somewhat glutinous. - Swamps and mokntain-woods, Newf. to mountains of N. C., west to N. Mich. and Minn. ()ften eultivated.

5. P. sambucifòlia, Cham. \& Schlecht. Leaflets oblong, oval, or lanceovate, mostly obtuse or abruptly short-pointed, serrate (mostly doubly) with more spreading teeth, often pale beneath; cymes smaller; flowers and berries larger, the latter ( $t^{\prime \prime}$ broad) when young ovoid, at length globose; leaf-lunds sparingly hairy; otherwise nearly as the preceding. - Lab. to northern N. Eng. and Lake Superior, and westward. 


\section{CRAT 妾GUS, L. HАштиок. Wит: Tиок.}

Calyx-tube urn-shaped, the limb 5-cleft. Yetals 5, roundish. Situmens many, or only 10-5. Styles 1-5. l'ome drupe-like, containing 1-5 bony 1-seednd stones. - Thoruy slurubs or small trees, with simple and mostly lobed leaves, and white (rarely rose-colorel) blussoms (Name from крátos, strenyth, un account of the hardness of the wood.)

\section{* Corymbs many-flowered.}

+Fruit small, depressed-globose (not larger than peas), bright red; flowers mostly small; calyx-tecth short and broud (except in 11.3$)$; styles 5 ; glabrous ( $e x$ cept C. Pyracantha) and glandless.

C. Prracíntua, Pers. (Fvergrien Tuonx.) Leaves evergreen, shining (1'long), oblong or spatulate-lanceolate, cremin:; the short petioles and young branclilets pubescent; corymbs sm.ill. - Shrub, spontaneous near Washington and Philadelphia. (Adv. from liu.)

1. C. spathulàta, Michx. Shrub or tree, 10-250 high; lenves thickish, shining, deciduous, spatulate or oblanceolate, with a long tupering base, crenute above, rarely cut-lobed, nearly sessile. - Va. to Fli., west to Mo. and Tex.

2. C. cordàta, Ait. (W Asmixgtox Trokx.) Trunk 15-25० high ; leaves broadly ovate or triangular, mostly truncate or a little heart-shaped at the base, on a slender petiole, variously 3-5-cleft or cut, serrate. - Va. to Git. in the mountains, west to Mo.

3. C. víridis, L. A snall tree, often unarmed; leares orate to orateoblong or lanceolate, or obloug-obovate, mostly acute at botl ends, on slender petioles, acutely serrate, often somewhat lobed, and often downy in the axils: flowers larger, uumerous; fruit bright red or rarely orange. (C. arborescens, Ell.)-Mississippi bottoms from St. Lonis to the Gulf, and from S. Car. to Tex. ++ Fruit small $\left(\frac{1}{5}-\frac{1^{\prime}}{3}\right.$ long), ovoid, deep red; flowers rather large; styles $1-3$.

C. Oxvacáxtha, I. (Exglish Hawthorx.) Sinonth; leques olwerate, cutlobed and toothed, uedge-form at the base; calyx not glandular. More or less spontaneous as well as cultivated. ( $\mathrm{Adr}$. from Eu.)

4. C. apiifòlia, Michx. Softly pubescent when young; leaves roundish, with a broad truneate or slightly heart-shaped base, pinnately 5 - 7 -cleft, the crowded divisions cut-lobed and sharply serrate; petioles slender; calyx-lobes glandular-toothed, slender. - S. Ya. to Fla., west to Mo. and Tex.

+++ Fruit large ( $\frac{1}{2}-1^{\prime}$ long), red; flowers large; styles and stones even in the same speries 1-3 (when the fruit is ovoid or pear-shaped) or 4-5 (in ylobular fruit): stipules, calyx-teeth, bracts, etc., often beset with glands; shrubs or low trees. [Species as characterized by I'rof. C. S. SARGExt.]

5. C. coccínea, I. Branclees reddish; spiues stout, cliestuut-brown; villous-pubescent on the shoots, glandular peduncles, and calyx; leaves on slender petioles, thin, pubescent beneath or often glabrous, round-ovate, cuneate or subcordate at base, acutely glandular-toothed, soinetimes cut-lobed; flowers $\frac{1}{2}$ loroad; fruit coral-red, globose or obovate, $\frac{1}{2}$ broad.- Newf. to Minn. and southward.-Var. MACrıcistu, Dudley ; spiues longer; leaves thicker, cuneate at base, on stout petioles, often deeply incised ; cymes hroader; flowers and fruit rather larger. - From the sit. Lawrence and F. Mass. to Minn.

Var. móllis, Torr. \& Gray. Shoots densely pubescent; leaves large, slender-petioled, cuneate, truncate or corlate at base, usually with acute narrow 
lobes, ofteu subscabrous above, more or less densely pubescent beneath ; flowers $\mathrm{l}^{\prime}$ broad, in broad cymes; fruit bright scarlet with a light bloom, l' broad. (C. tomentosa, var. mollis, Gray. C. subvillosa, Schrad.) - E. Mass. to Mo. and Tex. Sometimes $20-30^{\circ}$ high, blooming two weeks before the type.

6. C. tomentosa, L. Branches gray, rarely with stout gray spines; shoots, peduncles, and calyx villous-pubescent; glands none; leaves large, pale, prominently veined, densely pubescent beneath, ovate or ovate-oblong, sharply serrate, usually incisely lobed, contracted into a margined petiole; flowers small, ill-scented; fruit dull red, obovate, rarely globose ( $\frac{1}{2}{ }^{\prime}$ broad), upright. - Western N. Y. to Mich., Mo., and Ga. In flower 2-3 weeks after n. 5.

7. C. punctàta, Jacq. Branches horizontal; glands none; leaves smaller, mostly wedge-obovate, attenuate and entire below, unequally toothed above, rarely lobed, villous-pubescent becoming smooth but dull, the many veins more impressed, prominent beneath; fruit globose ( $l^{\prime}$ broad), red or bright yellow. (C. tomentosa, var. punctata, Gray.) - Quebec to Ont. and south to Ga.

8. C. Crus-gálli, L. (Cockspur Thorx.) Branches horizontal, with slender thorns often 4' long; glabrous; leaves thick, dark green, shining above, wedge-obovate and oblanceolate, tapering into a very short petiole, serrate above the middle; fruit globular, dull red ( $\frac{1^{\prime}}{3}$ broad). - Thickets, common.

* * Corymbs simple, fex- (1-6-) flowered; caly $x$, bracts, etc., glandular.

9. C. flàva, Ait. (Sumar Haw.) Tree 15-20 high, somewhat pubescent or glabrous; leaves uedge-oborate or rhombic-obovate, narrowed into a glandular petiole, unequally toothed and someuhat cut above the middle, rather thin, the teeth glundular; styles 4-5; fruit somewhat pear-shaped, yellowish, greenish, or reddish ( $\frac{1}{2}^{\prime}$ broad) - Sandy soil, Y'a. to Mo., and southward.

Var. pubéscens, Gray. Downy or vill sus-pubescent when young; leaves thickish, usually obtuse or rounded at the summit; fruit larger ( $\frac{8^{\prime}}{4}$ broad), scarlet or sometimes yellow. - Va. to Fla.

10. C. parvifòlia, Ait. (Dwarf Thors.) Shrub $3-6^{\circ}$ high, downy ; leares thick, oborate-spatulate, crenate-toothed $\left(\frac{1}{2}-1 \frac{1}{2}^{\prime} \operatorname{long}\right)$, almost sessile, the upper surface at length shining; flowers solitary or 2-3 together on very short peduncles; calyx-lobes as long as the petals; styles 5 ; fruit globular or pearshaped, yellowish. - Sandy soil, N. J. to Fla. and La.

\section{A M ELÁ NCHIER, Medic. June-berri.}

Calyx 5-cleft; lobes downy within. Petals oblong, elongated. Stamens numerous, short. Styles 5, united below. Ovary 5-celled, each cell 2-ovuled, but a projection grows from the back of each and forms a false cartilaginous partition; the berry-like pome thus 10-celled, with one seed in each cell (when all ripen). - Small trees or shrubs, with simple sharply serrated leaves, and white racemose flowers. (Amelancier is the name of $A$. vulgaris in Saroy.)

1. A. Canadénsis, Torr. \& Gray. (Shad-bush. Service-berry.) A tree $10-30^{\circ}$ high, nearly or soon glabrous; leaves ovate to ovate-oblong, usnally somew hat cordate at base, pointed, very sharply serrate, $1-3 \frac{1^{\prime}}{2}$ long ; bracts and stipules very long-silky-ciliate; flowers large, in drooping nearly glabrous racemes; petals oblong, $6-8^{\prime \prime}$ long; fruit on elongated pedicels, globose, crimson or purplish, sweet and edible. (Var. Botryapium, Torr. \&. Gray.) - Dry open woodlands; Newf. to Fla., west to Minn., E. Kan., and La. Fruit ripen- 
ing in June. - Var. Rot'NDifòla, Torr. \& Gray, appears to be only a brouslleaved form.

Var. (?) oblongifolia, Torr. \& Gray. A smaller tree or shruh (f, $-10^{\circ}$ high), the young leaves and racemes denscly white-tonentose; leaves oblong or sometimes rather broadly elliptical, acute, mostly ronuled at base, finely serrate, 1-2' long; flowers in denser and shorter racemes; potals 3-4" long, oblong-spatulate; fruit similar hut more juicy, on shorter pedicels. - Low moist grounds or swampy woods; N. Brunswick to Va., west tu Minn. and Mo. $-\Lambda$ form of this with broader leaves (broally elliptieal or roumled), often very obtuse at the summit, and rounded, subcordate or atcute at lkise, and msinlly coarsely toothed, is common from Manitoba to Minn. and Iowa, and is sometimes cultivated for its fruit.

2. A. oligocárpa, Roem. A low shrub 2-4 high, soon glatrous; leaves thin, oblony, acute at both ends, finely serrate, 1-2' long; fowers fow $(1-4)$, rather long-pedicelled; petals oblong-obovate; fruit broad-pyriform, diark purple with a deuse bloom. (A. Cauadensis, var. oligocarpa, Torr. \&. Gray.) - Coll swamps and mountain bogs; Lab. to northern N. Eug. and N. Y., and the shores of Lake Superior.

3. A. alnifolia, Nutt. A shrub $3-8^{\circ}$ high, usually glabrate or nearly so; leaves somewhat glaucous and thickish, broudly elliptical or rommlish, very obtuse or racely acute, often subcordate at base, courscly toothed toucurd the summit, $\frac{1}{2}-2^{\prime}$ long; raceme short and rather clense; petals cuneate-oblung, $3-8^{\prime \prime}$ long; fruit globose, purple. (1. Canadensis, var. alnifolia, Torr. \&ै Gray $)-\Lambda$ western mountain species, which occurs in Minn. and N. Mieh., and which the broad-leaved form of $\Lambda$. Canadensis sometimes closely simulates.

\section{Order 34. Calycanthàcea. (Calycantues Famli.)}

Shrubs with opposite entire leaves, no stipules, the sepals and petals similar and indefinite, the anthers alnate and extrorse, and the cotyledons convolute; the fiuit like a rose-hip. Chiefly represented by the genus

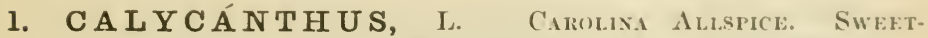 Scexted Silrub.}

Calyx of many sepals, united below into a fleshy inversely (onical ('up) (with sonne leaf-like bractlets growing from it); the lobes lanceolate, inostly colored like the petals, which are similar, in many rows, thickish, inscrterl (nn the tup of the closed ealyx-tube. Stamens unmerous, inserted just within the petals, short; some of the inner ones sterile (destitnte of anthers). l'istils several or many, enclosed in the calyx-tube, insertel on its hase and inner face, resembling those of the Rose; but the enlarged hip dry when ripe, enclosing the achenes. - The lurid purple flowers terninating the leaf branches. Bark and foliage aromatic; the crusherl flowers exhaling more or less the fragrance of stratw.

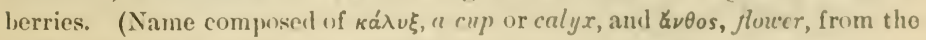
closed cup which contains the pistils.)

1. C. floridus, L. Lences oral, snft-douny underneath. - Virginia(?) and southward, on hillsides in rich soil. Common in garlens. April-Aug. 
2. C. lævigàtus, Willd, Leaves oblong, thin, either blunt or taper-pointed, bright green and giabrous or nearly so on both sides, or rather pale beneath; flowers smaller. - Mountains of Franklin Co., Penn. (Prof. Porter), and southward along the Alleghanies. May - Aug.

3. C. glaùcus, Willd. Leaves oblong-ovate or ovate-lanceolate, conspicuously taper-pointed, glaucous-uthite beneath, roughish above, glabrous, large ( $4-7^{\prime}$ long), probably a variety of the preceding. - Virginia (?) near the mountains and southward. May-Aug.

\section{Order 35. SAXIFRAGÀCEA. (Saxifrage Family.)}

Herbs or shrubs, of various aspect, distinguishable from Rosaceæ by having coprous albumen in the seeds, opposite as well as alternate leaves, and usually no stipules, the stamens mostly definite, and the carpels commonly fewer than the sepais, either separate or partly so, or all combined into one compound pistil. Calyx either free or adherent, usually persistent or withering away. Stamens and petals almost always inserted on the calyx. Ovules anatropous.

Tribe I SAXIFRAGEAE. Herbs. Leaves alternate (rarely opposite in n. 2 and 6).

Fruit dry, eapsular or follicular, the styles or tips of the carpels distinet.

* Ovary 2- (rarely 3-) celled with axile placentas, or of as many nearly distinct carpels.

1. Astilbe. Flowers polygamons, panicled. Stamens ( 8 or 10$)$ twice as many as the small petals. Seeds few. Leaves decompound.

2. Saxifraga. Flowers perfect. Petals 5 . Stamens 10 . Seeds numerous, with a close coat.

3. Boykinia. Flowers perfect. Stamens only as many as the petals, which are convolute in the but and deciduous. Calyx-tube adherent to the ovary. Seed-coat close.

4. Sullivantia. Flowers perfect. Stamens 5. Calyx nearly free. Seeds wing-margined.

* Ovary 1-celled, with 2 parietal placentas alternate with the stigmas. Sterile stamens none.

5. Tiarella. Calyx nearly free from the slender ovary. Petals entire. Stamens 10. Placentas nearly basal.

6. Mitella. Calyx partly cohering with the depressed ovary. Petals small, pinnatifid. Stamens 10.

7. Heuchera. Calyx bell-shaped, coherent with the ovary below. Petals small, entire. Stamens 5.

8 Chrysosplenium. Calyx-tube coherent with the ovary. Petals none. Stamens 10.

* * Ovary 1-celled, with $3-4$ parietal placentas opposite the sessile stigmas. A cluster of united sterile filaments at the base of each petal.

9. Parnassia. Sepals, petals and proper stamens 5. Peduncle scape-like, 1-flowered.

Tribe II. HYDRANGEAE. Shrubs. Leaves opposite, simple Ovary 2-5-celled: the calyx coherent at least with its base. Fruit capsular.

$$
\text { * Stamens } 8 \text { or } 10 \text {. }
$$

10. Hydrangea. Calyx-lobes minute in complete flowers. Petals valvate in the bud.

$$
\text { * * Stamens } 20-40 \text {. }
$$

11. Decumaria. Calyx-lobes sthall. Petals $7-10$, valvate in the bud. Filaments subulate. Style 1.

12. Philadelphus. Calyx-lobes conspicuous. Petals 4-5, convolute in the bud. Filaments linear. Styles $3-5$

Tribe III. ESCALLONIEAE. Shrubs. Leaves alternate and simple. Ovary 2-5celled. Fruit capsular.

13. Itea. Calyx 5-cleft, free from the 2-celled ovary, which becomes a septicidal capsule. 
Tribe IV. RI BESIEAE. Shrubs. Leaves alternate and simple, with stlpules adnate to the petiole or wanting. Fruit a berry.

14. Ribes. Calyx-tube adnate to the 1-celled ovary. Placentas 2, parietal, many-seeded.

\section{AstílBe, Don. False Gostsibari).}

Flowers diceciously polygamous. Calyx 4-5-parted, small. I'etals 4-5, spatulate, small, withering-persistent. Stamens 8 or 10. ()vary 2-cellecl, almost free, many-ovuled; styles 2, short. Capsule 2-celled, separating into 2 folliveles, each ripening few seeds. Seed-coat loose and thin, tapering at each end. Perennial herbs, with twice or thrice ternately-compound ample leaves, cut-loberl and toothed leaflets, and small white or yellowish flowers in spikes or racemes, which are disposed in a compound panicle. (Name composed of a-privatise and $\sigma \tau^{\prime} \lambda \beta \eta, a$ bright surface, hecause the foliage is not shining.)

1. A. decándra, I on. Somewhat pubescent $(3-50$ high); leaflıts mostly heart-shaped; petals minute or wanting in the fertile flowers: stamens 10. - Rich woods; mountains of S. W. Va. to N. C. and Ga. Closely initating Spiraa Aruncus, but coarser.

\section{SAXÍFRA A, I. SAxifraGE.}

Calyx either free from or cohering with the base of the orary, 5-cleft or parted. Petals 5, entire, imbricated in the bud, commonly decicluous. Stamens 10. Styles 2. Capsule 2-beaked, 2-celled, opening down or between the beaks, or sometimes 2 almost separate follicles. Seeds numerous, with a ('luse coat. - Chiefly perennial herbs, with the root-leaves clustered, those of the stem mostly alternate. (Name from saxum, a rock, and frango, to break; many species rooting in the clefts of rocks.)

* Stems prostrate, in tufts, leafy; leaves opposite; calyx free from the capsule.

1. S. oppositifolia, L. (Mountarn Saxifrage.) Leaves fleshy, ovate, keeled, ciliate, imbricated on the sterile branches $\left(1-2^{\prime \prime}\right.$ long): flowers sulitary, large: petals purple, obovate, much longer than the 5-cleft-calyx. Rocks, Willoughby Mountain, Vt., and northward. (Eu.)

* Stems ascending; leaves alternate; calyx colierent below with the capsule.

2. S. rivuláris, I. (Alprve Brook-S.) Small, stems weak, 3-5flowered; lower leawes rounded, 3-5-lobed, on slender petioles, the upper lanceolate; petals white, ovate - Alpine region of the White Mts., to Lab). (Eu.)

3. S. aizoides, L. (Yellow Motxtaix-S.) Low (3-5' high), in tufts, with few or several corymbose flowers; leaves linear-lanceolate, enture, fleshy, distantly spinulose-ciliate; petals yellow, spotted with orange, oblong. $-\mathrm{N}$. It. to S. W. New York, N. Mich., and northwarl. June. (Eu.)

4. S. tricuspidàta, Retz. Stems tuftel ( $4-8^{\prime}$ high), naked ahove; flowers corymbose, leaves oblong or spatulate, with 3 rigid shurp teeth at the summit, petuls obocate-oblong, yellow. - Shore of L. Superior, and northward. (Eu.)

*** Leaves clustered at the root; scape many-floucred, erect, clammy-pubescent.

\section{- Petuls all alike.}

5. S. Aizoon, Jacq. Scape 5-10' high; leaves persistent, thick, spmtulate, with white cartilaginous toothed margins; calyx partly adberent; petals ol 
ovate, cream-color, often spotted at the base. - Moist rocks, Lab. to N. Vt., L. Superior, and northward. (Eu.)

6 S. Virginiénsis, Michx. (EAruy S.) Low (4-9' high); leaves obocate or oval-spatulate, narrowed into a broad petiole, crenate-toothed, thickish ; flowers in a clustered cyme, which is at length open and loosely panicled; lobes of the nearly free calyx erect, not half the length of the oblong olituse (white) petals; follicles united merely at the base, divergent, purplish. - Exposed rocks and dry hillsides; N. Brunswick to Ga., and west to Minn., Ohio, and Tenn.; common, especially northward. April-June.

7. S. Pennsylvánica, L. (SwAmP S.) - Large $\left(1-2^{\circ}\right.$ high) ; leaves ollanreolute, obscurely toothed $\left(4-8^{\prime}\right.$ long), narrowed at base into a short and broal petiole; cymes in a large oblong panicle, at first clustered ; lobes of the nearly free calyx recurved, about the length of the linear-lanceolate (greenish) small petuls; filaments awl-shaped; follicles at length divergent.-Bogs, N. Eng. to Va., west to Minn. and Iowa.

8. S. eròsa, Pursh. (Lettice S.) Leaves oblong or oblanceolate, obtuse, sharply toothed, tapering into a margined petiole (8-12' long); scape slender ( $1-3^{\circ}$ high); panicle elongated, loosely flowered; pedicels slender; caly $x$ reflexed, entirel!y free, nearl!y as long as the oral obtuse (uhite) petuls; filaments clul-shuped; follicles nearly separate, diverging, narrou; pointed, 2-3" long. - Cold mountain brooks, Penn. to Va. and N. C.

9. S. Forbèsii, Vasey. Stem stout, $2-4^{\circ}$ high; leares denticulate, oral to elongated oblong ( $4-8^{\prime}$ long); filaments fil form ; follicles sliort, write; otherwise as in the last. - Shaded cliffs, near Makanda, S. Ill. (Forbes); E. Mo. (Lettermann.)

+ + Petals unequal, with claus, white, all or some of them with a pair of yellow spots near the base; leaves oblong, wedge-shaped or sputulate; calyx fiee and reflexed.

10. S. leucanthemifolia, Michx. Leaves coarsely toothed or cnt, tapering into a petiole; stems $\left(5-18^{\prime}\right.$ high) bearing one or more leaves or leafy bracts and a loose, spreading corymbose or paniculate cyme; petals lanceolate, the 3 larger ones with a heart-shaped base and a pair of spots, the 2 smaller with a tapering base and no spots. - Mts. of Va. to N. C. and Ga.

11. S. stellàris, L., var. comòsa, Willıl. Leaves welge-shapel, more or less tootlıed; scape $\left(t-5^{\prime}\right.$ high $)$ bearing a small contracted panicle, many or most of the flowers changed into little tufts of green leaves; petals all lin. crolate and tapering into the claw. - Mt. Katahdin, Maine, north to Lal. and Greenland. (Eu.)

\section{BOYKÍNIA, Nutt.}

Calyx-tube top-shaped, coherent with the 2-celled and 2-beaked capsule. Stamens 5, as many as the deciluous petals, these mostly convolute in the bud. Otherwise as in Saxifraga. - l'erennial herbs, with alternate palmately 5-7-lobed or cut petioled leaves, and white flowers in cymes. (Dedicated to the late Dr. Boykin of Georgia.)

1. B. aconitifolia, Nutt. Stem glandular $\left(6-20^{\prime}\right.$ high); leares deeply 5-7-lobed. - Mountains of southwestern Va. to Ga. and Tenn. July. 


\section{S ULII V Á N T I A, 'Torr. \& Gray.}

Calyx bell-shaped, collering below only with the hase of the ovary, 5-cleft. I'etals 5, oblanceolate, entire, acutish, withering-persistrnt. St:um 5 , shorter than the petals. Capsule 2-cellerl, 2-beaked, many-sereded, "pponing between the beaks, the seeds wing-nargined, imbricated upward. - A luw and reclinedspreading perenuial herb, with rounded and cut-toothed or slightly lober smooth leaves, on slender petioles, and small white flowers in a branched louscly cymose panicle, raiserl on a searly leafless slender stem (6-12' long). l'eduicles and ealyx glandular; pedicels recurved in fruit. (1)edicated to the distinguished bryologist who discovered our species.)

1 S. Ohionis, Torr. \& Gray, - Limestone cliffs, Ohio to Ind., Iowa, and Hinn. June.

\section{TIA RÉLLA, I. False Mitre-Wort.}

Calyx bell-shaped, nearly free from the ovary, 5-parted. Petals 5, with claws, entire. Stamens 10, long and slender. Styles 2. Ciljsule membranaceus, 1-celled, 2-valved; the valves unequal. Seeds few, at the base of each parietal placenta, globular, smooth. - l'erennials ; flowers white. (Name a diminutive

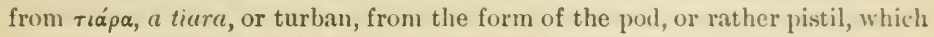
is like that of Mitella, to which the name of Mitre-úort properly belongs.)

1. T. cordifolia, L. Leaves from the rootstock or summer runners heart-shaped, sharply lobed and toothed, sparsely hairy above, downy beneath ; stem leafless or rarely with 1 or 2 leaves $\left(5-12^{\prime}\right.$ high); raceme simple; petals oblong, often subserrate. - Rich rocky woods, N. Eng. to Minn. and lnd, and southward in the mountains. April, Miay.

\section{MItÉLLA, Tourn. Mitre-wotrt. Bishop's-Cip.}

Calyx short, coherent with the base of the vrary, 5-cleft. Petals 5, slender, pinnatiful. Stamens 5 or 10 , included. Styles 2 , very short. Capsule short, 2-beaked, l-celled, with 2 parietal or rather basal several-seederl placentae, 2valved at the summit. Sieeds smooth and shining. - Low and slender perennials, with round heart-shaperl alternate leaves on the rootstock or runners, on slenter petioles; those on the flowerng stems opposite, if auy. Flowers small, in a simple slender raceme or spike Frnit soon wilely dehiscent. (1)iminutive of metre, a cap, allnding to the form of the young prol.)

1 M. diphýlla, L. Hairy; leaves heart-shaped, acute, sommwhat 3-5lobed, touthed, those on the many-flouced stem 2, opposite, nearly sessile, with interfoliar stipules; flowers white, in a raceme $6-8^{\prime}$ long; stanens $10 .-$ Ilillsiles in rich woods; N. Eng. to X. C., west to Minn, and Mo. May.

2. M. nùda, I. Simall and slender; leures rounded or kidney-form, deeply and doubly crenate; stem usully leafless, feu-flouered, very slenter ( $4-6^{\prime}$ high) ; flowers greenish; stamens 10. - Jeep unoist woods, in moss, N. Eng. to N. Y., Mich., Minn, and northward. May-July.

\section{HE Ù CH ER A, I.}

Caly $\mathrm{x}$ bell-shaped, the tube cohering at the base with the orary, 5-cleft. l'etals 5, spatulate, small, entire. Sitimens 5. Styles 2, slender. Capsule 1-celled, 
with 2 parietal many-seeded placentæ, 2-beaked, opening between the beaks. seeds oval, with a rough and close seed-coat. - Perennials, with the round heart-shaped leaves principally from the rootstock; those on the stems, if any, alternate. Petioles with dilated margins or adherent stipules at their base. Flowers in small clusters disposed in a prolonged and narrow panicle, greenish or purplish. (Named in honor of John Henry Heucher, a German botanist of the beginning of the 18th century.)

* Flowers small, loosely panicled; stamens and styles exserted; calyx regular.

1. H. villòsa, Michx. Stems $\left(1-3^{\circ}\right.$ high $)$, petioles, and veins of the acutely 7 -9-lobed leaves villous with rusty hairs beneath; caly $1 \frac{1}{2}$ " long ; petals spatulate-linear, about as long as the stamens, soon twisted. - Rocks, Md. to Ga., west to Ind. and Mo. Aug., Sept.

2. H. Rugélii, Shuttlw. Stems slender, $\frac{1}{2}-2^{\circ}$ high, glandular-hirsute, as well as the petioles, etc.; Icaves round-renfform, with $7-9$ short and broad rounded lobes; flowers ver: s.nall ( $1^{\prime \prime}$ long); petals linear-spatulate, twice as long as the calyx-lobes; fruit uarrow. - Shaded cliffs, S. Ill. to Tenn. and N.C.

3. H. Americàna, L. (Сомmox Alum-Roот.) Stems $\left(2-3^{\circ}\right.$ high), etc., glandular and more or less hirsute with short hairs; leaves roundish, with short rounded lobes and crenate teeth; calyx very broad, $2^{\prime \prime}$ long, the spatulate petals not longer than its lobes. - Rocky woodlands, Conn. to N. C., west to Minn., Mo., and Miss.

* * Flowers larger, in a very narrow panicle; calyx (3-4" long) more or less oblique; stamens short; leaves rounded, slightly 5-9-lobed.

4. H. híspida, Pursh. Stems $2-4^{\circ}$ high; hispid or hirsute with long spreading hairs (occasionally almost glabrous), scarcely glandular; stamens sonn exserted, longer than the spatulate petuls. - Mountains of Va. and N. C., west to Minn. and E. Kan. May, June.

5. H. pubéscens, I'ursh. Stem $\left(1-3^{\circ}\right.$ high $)$ and petioles granularpubescent or glandular above, not hairy, below often glabrous; stamens shorter than the lobes of the culy $x$ and the spatulate petals. - Rich woods, in the mountains, from Penn. to Ky., and southward. June, July.

\section{C H R Y S O S L E N I U M, Tourn. Golden Saxifrage.}

Calyx-tube coherent with the ovary; the blunt lobes 4-5, yellow within. Petals none. Stamens 8-10, very short, inserted on a conspicuous disk. Styles 2. Capsule iuversely heart-shaped or 2-lobed, flattened, very short, 1celled with 2 parietal placentr, 2-valved at the top, many-seeded. - Low and small smooth herbs, with tender succulent leaves, and sniall solitary or leafycymed flowers. (Name compounded of $\chi \rho v \sigma o ́ s$, golden, and $\sigma \pi \lambda \eta \nu$, the spleen; probably from some reputed medicinal qualities.)

1. C. Americànum, Schwein. Stems slender, decumbent and forking; leaves principally opposite, roundish or somewhat heart-shaped, obscurely crenate-lobed; flowers distant, inconspicuous, nearly sessile (greenish tinged with yellow or purple). - Cold wet places, N. Scotia to N. Ga., west to Minn.

2. C. alternifòlium, L. Stems erect; leaves alternate, reniform-cordate, doubly crenate or somewhat lobed; flouers corymbose. - Decorah, Iowa, west to the Rocky Mits., and north through Brit. Amer. (Eu., Asia.) 


\section{PARNÁs I A, Tourn. Grass of Parisastes.}

Sepals 5, imbricated in the bud, slightly united at the hase, and sometimes also with the base of the ovary, persistent. P'etals 5, veiny, sprealing, at length deciduous, imbricated in the bud; a cluster of somewhat united gland-tipjed sterile filaments at the base of each. l'roper stamens 5, alternate with the petals, persistent; authers introrse or subextrorse. Ovary 1-celled, with 4 projecting parietal placenta; stigmas 4, sessile, directly orer the placenta. Capsule t-valved, the valves bearing the placentas on their millle. Siceds very numerous, anatropous, with a thick wing-like seed-cont and little if any albumen. Embryo straight; cotyledons very short. - Perennial smooth herbs, with entire leaves, and solitary flowers on long scape-like stems, which usually bear a single sessile leaf. l'etals white, with greenish or yellowish veins. (Named from Mount l'arnassus ; called Grass of Parnassus by Dioscorides.)

1. P. parviflora, I)C. Petuls sessile, little longer than the calyx ( $3^{\prime \prime}$ loug); sterile filuments about 7 in each set, slender; leaves ovate or oblong, tapering at base. - Sandy banks, Lab. to Mich., N. Minn., and westward.

2. P. palústris, L. Scapes $3-10^{\prime}$ high; leaves heart-shaped; flower nearly $\mathrm{I}^{\prime}$ broad; petals sessile, rather longer than the calyx, few-veined; sterile filaments $9-15$ in each set, slender. - Same range as tlie last. (Eu.)

3. P. Caroliniàna, Michx. Scapes $9^{\prime}-2^{\circ}$ high; flower $1-1 \frac{1}{2}^{\prime}$ broad; petuls sessile, more than twice as long as the calyx, many-veined; sterile filctments 3 in each set, stout, distinct almost to the base; leaves thickish, ovate or rounded, often heart-shaped, usually but one low down on the scape and clasping. - Wet banks, N. Brunswick to Fla., west to Minn., Iowa, and La.

4. P. asarilolia, Vent. Petuls abruptly contracted into a clau at base; sterile filaments 3 in each set; leaves rourded, kidney-shuped; otherwise as in the foregoing. - IIigh mountains of Va. and N. C.

\section{H Y D R À N G E A, Gronov.}

Calyx-tube hemispherical, 8-10-ribbed, coherent with the ovary ; the limb 4-5-toothed. Petals ovate, valvate in the bud. Stamens $8-10$, slencler. Caysule 15-ribbed, crowned with 2-4 diverging styles, 2-celled below, many-seeded, opening by a hole between the styles. - Shrubs, with opposite jetioled leaves, no stipules, and numerous flowers in compound cymes. The marginal-fluwers are usually sterile and radiant, consisting merely of a showy membranacens and colored flat and dilated calyx. (Name from $\tilde{\delta} \omega \rho \rho$, uater, and aryos, a cuse, from the shape of the capsule.)

1. H. arboréscens, L. (Wrun IIrnnaxgea.) Glabrous or nearly so, $1-8^{\circ}$ higln; leaves ovate, rarely heart-shaped, pointed, serrate, green both sules; cymes flat; flowers often all fertile, rarely all radiant.-Rocky banks, l'eun. to Fla., west to Iowa and Mo.

2. H. radiàta, Walt. Leaves densely tomentose and paler or white beneath. - S. C. and Ga. to 'Tenn. aul Mo.

\section{DECU M A R I A, I.}

Flowers all fertile. Calyx-tube turlinate, 7 - 10-toothed, coherent with the ovary. Petals oblong, valvate in the bud. Stamens 20-30. Styles united 
into one, persistent Stigma thick, 7-10-rayed. Capsule 10-15-ribbed, 710-celled, many-seeded, bursting at the sides, the thin partitions at length separating into numerous chaffy scales. - A smooth climbing shrub, with opposite ovate or oblong entire or serrate leaves, no stipules, and numerous fragrant white flowers in compound terminal cymes. (Name said to be derived from decem, ten, referring to the fact of its being often 10-merous.)

1. D. bárbara, L. Leaves shining, sometimes pubesceut; capsule with the persistent style and stigma urn-shaped, pendulous. - Banks of streams; Dismal Swamp, Va, to Fla. and La.

\section{PHILADÉ PHUS, L. Mock Orange or Syringa.}

Calyx-tube top-shaped, coherent with the ovary ; the limb 4-5-parted, spreading, persistent, valvate in the bud. Petals rouncled or obovate, large, convolute in the bud. Stamens 20-40. Styles 3-5. united below or nearly to the top. Stigmas oblong or linear. Capsule 3-5-celled, splitting at length into as many pieces. Seeds very numerous, on thick placentre projecting from the axis, pendulous, with a loose membranaceous coat prolonged at both ends. - Shrubs, with opposite often toothed leaves, no stipules, aud solitary or cymose-clustered showy white flowers. (An ancient name, applied by Linnæus to this genus for no obrious reason.)

1. P. inodorus, L. Glabrous; leaves orate or ovate-oblong, pointed, entire or with some spreading teeth; flowers single or few at the ends of the diverging branches, pure white, scentless: caly.x-lobes acute, scarcely longer than the tube. - Mountains of Va. to Ga. and Ala.

2 P. grandiflorus, Willd. A tall shrub, with long and recurved branches; like the last, but somewhat pubescent, with larger flowers, and the caly.r-loles long and taper-ponted. (I'. modorus, var. grandiflorus, Gray.) Along streams, Va. to Fla. Often cultivaterl.

P. corondrics, L., the common Mock URANGe or SYringa of cultivation, from S. Eu., with cream-colored odorous flowers, has sometimes escaped.

\section{I TEA, Gronov.}

Calyx 5-cleft, free from the ovary or nearly so Petals 5, lanceolate, much longer than the calyx, and longer than the 5 stamens. Capsule oblong, 2. grooved, 2-celled, tipped with the 2 united styles, 2-parted (septicidal) when mature, several-sceled - Shrubs, with simple, alternate, petioled leaves, with. ont stipnles, and small white flowers in smuple racemes. (Greek name of the Willow.)

I I. Virgínica, I. Leaves deciduons, oblong, pointed, minutely serrate; seeds oral, flattish, with a crustaceous coat. - Wet places, Penn and N. J to Fla., west to Mo and La

\section{Ri B E S, L. Curraxt. Gooseberry.}

Calyx 5-lobed, often colored; the tube coherent with the ovary. Petals 5, inserted in the throat of the calyx, small. Stamens 5, alternate with the petals. ()vary 1-celled, with 2 parietal placentie and 2 distinct or united styles. Berry crowned with the shrivelled remains of the calyx, the surface of the numerous seeds swelling into a gelatinous outer cuat unresting a crustaceous one. lim- 
hryo minute at the base of hard albumen. - Low, sometimes prickly shrubs, with alternate and palmately-lobed leaves, which are plaited in the hud ('xrept in one species), often fascicled on the branches; the small thwers from the same clusters, or from separate lateral huds. (Froun riebs, a Cicruan popular name for the currant. Grossularia was the jroper name to have been alupteal for the genus.)

§ 1. GROSSULARIA. (Gonsererry.) Stems mostly benring thorns at the base of the leufstalks or clusters of leures, and often with scuttered bristly prickles; berries prickly or smooth. (Our species are iniliscruminately calleil WiLD Gooseberry ; the flouers greenish.)

* Peduncles 1-3-flowered; calyx as high as brond; leares roundish-heartshaped, 3-ij-lobed.

+ Calyx-lobes decudedly shorter than the tube; berries apt to be prichly.

1. R. Cynósbati, I. Stamens and undivicled style not longer than the broally bell-shaped ealyx; berries large, armed with long prickles or rarely smooth. - Rocky woods, N. Brunswick to the mountains of $N$. C., and west to Minn. and Mo.

+ + Calyx-lobes decidedly longer than the short nud rather narrow ube; bernes smooth, purple, sweet and pleasunt.

2. R. grácile, Michx. (Missorri Goosemerry) Spines often long, stont and red; peduncles long and slender; flowers whte or whitish; filanents capillary, 4-6" long, generally connivent or closely parallel, soon conspuruously longer than the oblong-linear calyx-lobes. (R. rotundifolium, Mann., in part.) Mich. to Tenn., west to Tex., Minn., and the Rocky Mts.

3. R. rotundifòlium, Michx. Sjines short: peduncles short: foucers greensh or the lobes dull purplish; filaments slender, $2-3$ " long, more or less exceeding the narrowly oblon!-spatulate calyx-lobes. - W. Mass. and N. Y., sonth in the Alleghanies to N. C.

4. R. oxyacanthoides, I. Peduncles very short, fowers gremish or dull purplish: stamens usually scarcely equalling the rather brondly oblong caly $x$ lobes. (K. hirtellum, M/chx) - Newf. to N. J., west to Ind., Minn., and westward. The common smooth-fruited gooseberry of the north, the whitish spines often numerous.

* * Flowers sereral in a nodding raceme, small and flattish, greenish.

5. R. lacústre, P'oir. Young stems clothed with bristly prickles and with weak thorus; leaves heart-shajed, 3 -5-parterl, with the lobes deeply cut; calyx broad and flat; stamens and style not longer than the petals; fruit bristly (small, unpleasant). - Cold woods and swamps, Newf. to N. Eng., west to N. Y., Mich., and Minn.

§ 2. RIBìsia. (Cormat.) Thoruless and prickless; racemes few-manyfowered, stamens short.

6. R. prostràtum, L'Iler. (Fetmi, Curmaxt.) Stems reclined; leaves deeply lieart-shaped, $5-7$-lohed, smouth, the lobes ovate, acute, doubly serrate; racemes erect, slender, caly $\mathrm{x}$ flattish; prodirels and the (pule red) fruit glunduIar-bristly. - Cold damp wools and rocks, Lab. to mountains of N. C., west to Mich., Minn., and the Rocky Mls. 
7. R. flóridum, L'Her. (Wild BlaCK CuRrant.) Leaves sprinkled with resinous dots, slightly heart-shaped, sharply 3 -5-lobed, doubly serrate; racemes drooping, downy; bracts longer than the pedicels; flowers large, whitish ; calyx tubular-bell-shaped, smooth; fruit round-ovoid, black, smooth. - Woods, N. Eng. to Va., west to Ky., Iowa, and Minn.

8. R. rùbrum, L., var. subglandulòsum, Maxim. (Red Curraxt.) Stems straggling or reclined; leaves somewhat heart-shaped, obtusely 3-5lobed, serrate, downy heneath when young; racemes from lateral buds distinct from the leaf-buds, drooping, calyx flat (green or purplish); fruit globose, smooth, red. - Cold bogs and damp woods, N. Eng. to N. J., west to Ind. and Minn.

§3. SIPHÓCALYX. Thornless and prickless; leaves convolute in the bud; racemes several-flowered; calyx-tube elongated; berry naked and glabrous.

9. R. aúreum, Pursh. (Missouri or Buffalo Curraxt.) Shrub $5-12^{\circ}$ high ; leares 3-5-lobed, rarely at all cordate; racemes short; flowers golden-yellow, spicy-fragrant; tube of salverform calyx ( $6^{\prime \prime}$ long or less) 3 or 4 times longer than the oval lobes; stamens short; berries yellow or black. Banks of streams, Mo. and Ark. to the Rocky Mts., and westward. Common in cultivation.

\section{Order :36. CRAsSUlàce $A$. (Orpine Family.)}

Succulent herls, with perfectly symmetricul flowers: viz., the petals and pistils erqualling the sepals in number $(3-20)$, and the stamens the same or double their number, - technically different from Saxifrageæ only in this complete symmetry, and in the carpels (in most of the genera) being quite distinct from each other. Also, instead of a perigynous disk, there are usually little scales on the receptacle, one behind each carpel. Fruit dry and deliscent; the pods (follicles) opening down the ventral suture, manyrarely few-seeded. - Stipules none. Flowers usually cymose, small. Leaves mostly sessile, in Penthorum not at all fleshy.

* Not succulent; the carpels united, forming a 5-celled capsule.

1. Penthorum. Sepals 5. Petals none. Stamens 10. Pod 5-beaked, many-seeded. * * Leaves, etc., thick and succulent. Carpels distinct.

2. Tillea. Sepals, petals, stamens, and pistils 3 or 4 . Seeds few or many.

3. Sedum. Sepals, petals, and pistils 4 or 5 . Stamens $8-10$. Seeds many.

\section{PÉ NTHORUM, Gronov. Ditch Stone-crop.}

Sepals 5. Petals rare, if any. Stamens 10. Pistils 5 , united below, forming a 5-angled, 5-horned, and 5-celled capsule, which opens by the falling off of the beaks, many-seeded. - L pright weed-like perennials (not fleshy like the rest of the family), with scattered leaves, and yellowish-green flowers loosely spiked along the upper side of the naked branches of the cyme. (Name from $\pi \boldsymbol{\nu}^{\nu} \tau \epsilon$. fice, and opos, a mark, from the quinary order of the flower.)

1. P. sedoides, L. Leaves lanceolate, acute at both ends. - Open wet places; N. Brunswick to Fla., west to Minn., E. Kan., and Tex. July-Oct. Parts of the flower rarely in sixes or sevens. 
2. TILL安 A, Mich.

Sepals, petals, stamens, and pistils 3 or 4 . l'oils 2-many-sceded. - Very small tufted anumals, with opposite entire leaves aml axillary flowers. (Named in honor of Michael Angelo Tilli, an early Italian brotanist.)

1. T. simplex, Nutt. Rooting at the hase $\left(1-2^{\prime}\right.$ high $)$; leaves linearoblong; flowers solitary, nearly sessile; ealy'x half the length of the (greenishwhite) petals and the narrow 8-10-sceded pods, the litter with a scale at the base of each. - Muddy river-banks, Mass. to Md. July-Sept.

\section{SÉDU M, Tourn. Stone-crol. Orise.}

Sepals and petals 4 or 5 . Stamens 8 or 10 . Follicles many-seederl; a little scale at the base of each. - Chiefly peremnial, smooth, and thick-leaved herbs, with the flowers cymose or one-sided. Petals almost always narrow and acute or pointed. (Name from sedeo, to sit, alluding to the manner in which these plants fix themselves upon rocks and walls.)

* Flowers perfect and sessile, as it were spiked ulong one side of spreading flou'ering branches or of the divisions of a scorpioid cyme, the first or central foncer mostly 5-merous and 10-androus, the others often 4-merous and 8-androus.

- Flowers white or purple.

1. S. pulchéllum, Michx. Stems ascending or trailing $\left(4-12^{\prime}\right.$ high $)$; leaves terete, linear-filiform, much crowded; spikes of the cyme several, densely flowered; petals rose-purple. - Va. to Ga., west to Ky., E. Kan., and Tex.; also cultivated in gardens. July.

2. S. Névii, Gray. Stems spreading, simple $\left(3-5^{\prime}\right.$ high); leaves all alternate, those of the sterile shoots wedge-obovate or spatulate, on flowering stems linear-spatulate and flattish; eyme about 3-spiked, densely flowered; petals white, more pointed than in the next; the flowering 3 or 4 weeks later; leaves and blossoms smaller. - Rocky cliffs, monntains of Va. to Ala.

3. S. ternatum, Michx. Stems spreading $\left(3-6^{\prime}\right.$ high $)$; leaves fart, the lower whorled in threes, wedge-olovate, the upper scattered, oblong; ey me 3-spiked, leafy; petals white. - Rocky woods, N. Y. to Ga., west to Ind. and Tenu.

+ + Flowers yellow.

S. ACre, I. (Mossy Stone-cror.) Spreading on the ground, moss-like; leaves very small, alternate, almost imbricated on the branches, ovate, very thick; petals yellow. - Escaped from cultivation to rocky roadsides, etc. July. (Nat. from Eu.)

4. S. Torrèyi, Don. Aunual; stems simple or brancherl from the base (2-4' high); leaves flat or teretish, scattered, oblong, 2-3" loug; petals rather longer than the orate sepals; carpels at length widely divergent. - Mo. to Ark. and Tex.

* * Flowers in a terminal naked and regular cyme or cluster, more or less peduncled; leaves flut, obneate or oblong, mostly alternate.

+ Flouers perfect, 5-merons, 10-androus.

5. S. telephioides, Michx. Stems ascending $\left(6-12^{\prime}\right.$ high $)$, stout, leafy to the top; leaves oblong or oval, cntire or sparingly toothed; cyme small; petals flesh-color, ovate-lanceolate, taper-pointed ; jollicles tupering into a slender style. - Dry rocks, from western New York to N. Ga. and S. Ind. June. 
S. Teléphium, L. (Garden Orpive or Live-for-ever.) Stems erect $\left(2^{\circ}\right.$ high), stout; leaves oval, obtuse, toothed; cymes compound; petals purple, oblong-lanceolate; follicles abruptly pointed with a short style. - Rocks and banks, escaped from cultivation in some places. July. (Adr. from Eu.)

S. REFléxum, L. Glabrous, erect, $10^{\circ}$ high; leaves crouded, cylindric, subulate-tipped spreading or reflexed; flowers yellow, pedicelled. - Coast of Mass.; western N. Y. ; rare. (Nat. from Eu.)

\section{+- + Flowers dicecious, mostly 4-merous and 8-androus.}

6. S. Rhodiola, DC. (Roseroot.) Stems erect $\left(5-10^{\prime}\right.$ high); leaves oblong or oval, smaller than in the preceding; flowers in a close cyme, greenishyellow, or the fertile turning purplish. - Throughout Arctic America, extending southward to the coast of Maine, and cliffs of Delaware River; also in the western mountains. May, June. (Eu.)

\section{Order 37. DROSERÀCEA. (Sundew Family)}

Bog-herbs, mostly glandular-haired, with regular hypogynous flowers, pentamerous and withering-persistent calyx, corolla, and stamens, the anthers fixed by the middle and turned outward, and a 1-celled capsule with twice as many styles or stigmas as there are parietal placenta. - Calyx imbricated. Petals convolute. Seeds numerous, anatropous, with a short and minute embryo at the base of the albumen. - Leaves circinate in the bud, i. e., rolled up from the apex to the base as in Ferns. A small family of insectivorous plants.

\section{DRÓ SERA, L. Sundew.}

Stamens 5. Styles 3, or sometimes 5, deeply 2-parted so that they are taken for 6 or 10, slender, stigmatose above on the inner face. Capsule 3- (rarely 5-) valved; the valves bearing the numerous seeds on their middle for the whole length. - Low perennials or biennials; the leaves clothed with reddish glandbearing bristles, in our species all in a tuft at the base; the naked scape bearing the flowers in a 1 -sided raceme-like inflorescence, which nods at the undereloped apex, so that the fresh-blown flower (which opens only in sunshine) is always highest. The plants yield a purple stain to paper. (The glands of the leaves exude drops of a clear glutinous fluid, glittering like dew-drops, whence the name, from $\delta \rho \sigma \sigma \rho j s$, deuy.)

1. D. rotundifòlia, L. (Rocxd-Leaved Suxdew.) Leaves orbicular, abruptly narrowed into the spreading hairy petioles; seeds spinclle-shaped, the coat loose and chaff-like ; flowers white, the parts sometimes in sixes. - Peatbogs, Lab. to Minn., Ind., and southward; common. July, Aug. (Eu.)

2. D. intermèdia, Hayne, var. Americàna, DC. Leaves spatulateoblong, tapering into the long rather erect naked petioles; seeds oblong, with a rough close coat; flowers white. (D. longifolia, Gray, Manual.) - Bogs, with the same range but less common. June-Ang. - Plant raised on its prolonged caudex when growing in water. (Eu.)

3. D. linearis, Goldie. (Slexder Sundew.) Leaves linear, obtuse, the blarle (2-3' long, scarcely $2^{\prime \prime}$ wide) on naked erect petioles about the same length ; seels oblong, with a smooth and perfectly close coat; flowers white - Shore of L. Superior, Mich., and Minn. 
4. D. filifórmis, Raf. (Threan-Leaven Suxuew.) Leaves verylng and fliform, erect, with no distinction between hlade and stalk; sects spindle-

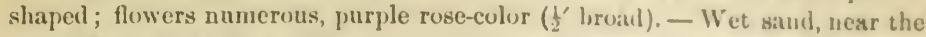
coast, Mass. to N. J. and Fla.

Droxia ycsefrula, Ellis, the Vexrs's Fly-trap, - so noted for the ex traordinary irritability of its leaves, closing quickly at the tonch, - is a natise of the sandy savannas of the eastern part of $\mathrm{N}$. (C. "It differs in several respecets from the character of the oriler given above; the stamens heing 15 , the sivles united into one, and the seeds all at the hase of the pod.

\section{Order 38. Hamamelídede. (Witchilizei, Fami.r.)}

Shrubs or trees, with alternale simple leares and ilecilluous stipules, flouers in heads or spikes, often polygamous or monacious; the calyx collering with the base of the ouary, which consists of 2 pistils uniterl belou, and forms a 2-beaked, 2-relled uoorly cripsule, opening at the summat, with a single briny scell in each cell, or several, only one or two of them ripening. - Prtals inserted on the calyx, narrow, valvate or involute in the burl, or often none at all. Stamens twice as many as the petals, and half of them sterile aud changed into scales, or numerous. Seeds a natropous. Embryo large and straight, in scanty albumen; cotyledons broad and flat.

- Flowers with a manifest calyx, or calyx and cornlla, and a single ovule suspended from the summit of each cell.

1. Hamamelis. Petals 4, strap-shaped. Stamens and scales each 4 , short.

2. Fothergilla. Petals none. Stamens about 24 , long: filaments thickened upward.

* Flowers naked, with barely rudiments of a calyx and no corolla, crowled unto catkinlike heads. Ovules several or many in each eell.

3. Liquidambar. Monecious or polyganous. Stamens very numerous. Capsules consolidated by their bases in a dense head.

\section{H A M A M E LIS, L. Witch-HazeL.}

Flowers in little axillary clusters or heads, usually surrounded by a seale-like 3-leavel involucre. Calyx 4-parted, and with 2 or 3 bractlets at its base. l'etals 4 , strap-shaped, long and narrow, spirally involute in the bud. Stamens 8 . very short; the 4 alternate with the petals anther-hearing, the others imperfect and scale-like. Styles 2, short. Capsule opening loculicidally from the top; the outer coat separating from the inner. which encloses the single larere and bony seed in each cell, but soon bursts elastically iuto two pirces. - Tall sliruls, with straight-veined leaves, and yelluw, perfect or polygamous flowers. (Frm $a ̈ \mu \alpha$, at the same time with, and $\mu \eta \lambda$ is, an apple-tree; a name anciently applied to the Mellar, or some similar tree.)

1. H. Virginiàna, I. Leaves obovate or oval, wary-toothed, somewhat downy when young; hlussoming late in antumn, when the leaves are falling, and maturing its seeds the next summer. - Damp woods, N. Scotia to Fla., west to E. Minn. and La.

\section{FOTHERGÍLLA, I.}

Flowers in a terminal eatkin-like spike, mostly perfect. Calyx hell shaped, the summit truncate, slighty $5-7$-trothed. l'ctals none. Stimens ahout 24 . 
borne on the margin of the calyx in one row, all alike; filaments very long, thickened at the top (white). Styles 2, slender. Capsule cohering with the base of the calyx, 2-lobed, 2-celled, with a single bony seed in each cell. - A low shrub; the oval or obovate leaves smooth, or hoary underneath, toothed at the summit; the flowers appearing rather before the leaves, each partly covered by a scale-like bract. (Dedicated to the distinguished Dr. John Fothergill.)

1. F. Gardèni, L. (F. alnifolia, L. f.) - Low grounds, Va. to N. C. April, May.

\section{LIQ U I D Á M B A R, L. Sweet-Gum Tree.}

Flowers usually monceious, in globular heads or catkins; the sterile arranged in a conical cluster, naked; stamens very numerous, intermixed with minute scales; filaments short. Fertile flowers consisting of many 2-celled 2-beaked ovaries, subtended by minute scales in place of a calyx, all more or less cohering together and hardening in fruit, forming a spherical catkin or head; the capsules opening between the 2 awl-shaped beaks. Styles 2, stigmatic down the inner side. Ovules many, but only one or two perfecting. Seeds with a wingangled seed-coat. - Catkins racemed, nodding, in the bud enclosed by a 4-leared decirluous involucre. (A mongrel name, from liquidns, fluid, and the Arabic ambar, amber; in allusion to the fragrant terebinthine juice which exudes from the tree.)

1. L. Styraciflua, I. (Sweet Gux. Bilsteo.) Leaves rounded, deeply 5-7-lohed, smooth and shining, glandular-serrate, the lobes pointed. Moist woods, from Conn. to $\mathbf{S}$. 11l., and south to Fla. and Tex. April. $-\Lambda$ large and beautiful tree, with fine-grained wool, the gray bark commonly with corky ridges on the branchlets. Leaves fragrant when bruised, turning deep crimson in autumn. The woody pods filled mostly with abortive seeds, resembling sawdust.

\section{Order 39. HALORĀGEA. (Water-Milfoil Family.)}

Aquatic or marsh plants (at least in northern countries), with the inconspicuous symmetrical (perfect or unisexual) flowers sessile in the axils of leaves or bracts, calyx-tube coherent with the ovary (or calyx and corolla wanting in Callitriche), which consists of 2-4 more or less united carpels (or in Hippuris of only one carpel), the styles or sessile stigmas distinct. Limb of the calyx obsolete or very short in fertile flowers. Petals small or none. Stamens 1-8. Fruit indehiscent, 1-4-cellerl, with a single anatropous seed suspended from the summit of each cell. Embryo in the axis of fleshy albumen; cotyledons minute.

1. Myriophyllum. Flowers monœerious or polygamous, the parts in fours, with or withont petals. Stamens 4 or 8 . Leaves often whorled, the immersed pinnately dissected.

2. Proserpinaca. Flowers perfect, the parts in threes. Petals none. Leaves alternate, the immersed pinnately lissected.

3. Hippuris. Flowers usually perfect. Petals none. Stamen, style, and cell of the ovary only one. Leaves entire, in whorls.

4. Callitriche. Flowers moncecious. Calyx and petals none. Stamen 1. Orary 4-celled, with 2 filiform styles. Leaves entire, opposite. 


\section{MYR I O PHÝLLU M, Vaill. WATER-IILFOL.}

Flowers monocious or polygamous Calyx of the sterile fluwers 4-parted, of the fertile 4-toothed. I'etals 4 , or none. Stamens $4-8$. Fruit nut-like, 4 celled, deeply 4-lohed; stigmas 4, recurved.-Perennial aquaties. Leaves crowled, often whorled; those under water pinnately parted into capillary divisions. Flowers sessile in the axils of the upjer leaves, usually above watur in sunimer; the uppermost staminate. (Name from $\mu v \rho i$ os, a thousund, aud $\phi u ́ \lambda \lambda o \nu$, a leaf, i. e., Milfoil.)

* Stamens 8 ; petals deciduous; carpels even; leaves whorled in threes or fours.

1. M. spicatum, I. Leaves all pinnately parted and capillary, except the floral ones or bructs; these ovate, entire or toothed, and chivgly shorter thun the fouer's, which thus form an interrupted spike. - Deep water, Newf. to N. Eng. and N. Y., west to Minn., Ark., and the I'acific. (Eu.)

2. M. verticillàtum, L. Floral leaves much longer than the flovers, pectinate-pinnatifid; otherwise nearly as n. 1.- Ponds, etc., common. (Eu.)

* $*$ Stamens 4; petals rather persistent; carpels 1-2-ridged and roughened on the back; leaves whorled in fours and fives, the lower with capillury divisions.

3. M. heterophýllum, Michx. Stem stout; floral leares orate and lanceolate, thick, crowded, sharply serrate, the lowest pinnatificl ; fruit obscurely roughened. - Lakes and rivers, Ont. and N. Y. to Fla., west to Minn. and Tex.

4. M. scabràtum, Michx. Stem rather slender; lower leaves pinnately parted with few eapillary divisions; floral leaves hnear (rarely scattered), pectinate-toothed or cut-serrate; carpels strongly 2-ridged and roughened on the back. - Shallow ponds, S. New Eng. to S. C., west to Mo. and La.

* * $*$ Stamens 4 ; petals rather persistent; carpels even on the back, leaves chiefly scattered, or wanting on the flowering stems.

5. M. ambíguum, Nutt. Immersed leaves pinnately parted into abont 10 very delieate capillary divisions; the emerging ones pectinate, or the upper floral linear and sparingly toothed or entire; flouers mostly perfect: fruit (minute) smooth. - Ponds and ditches, Mass. to N. J. and I'enn.; also in Ind. - Var. CAPILläeum, Torr. \& Gray, has stems floating, long and very slender, and leaves all immersed and capillary. Var. Lisosum, 'Torr., is small, rooting in the mud, with leaves all linear, ineised, toothed, or entire.

6. M. tenéllum, Bigelow. Flowering stems nerrly leufless and scape-tike $\left(3-10^{\prime}\right.$ high $)$, erect, simple; the sterile shoots creeping and tufted, bracts small, entire; floucrs alternate, monacious ; fruit smouth. - Borders of ponds, Newf. to N. Eng., west to Mich.

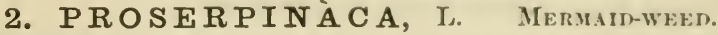

Flowers perfect. Calyx-tube 3-sided, the limb 3-parted. Petals none. Stamens 3. Stigmas 3, eylindrical. Fruit bony, 3-angled, 3-celled, 3-seeled, nutlike. - Low, perennial herbs, with the stems creeping at base, alternate leaves, and small flowers sessile in the axils, solitary or $3-4$ together, in summer. (Name applied by Pliny to a P'olygonum, meaning pertainng to Proserpine.)

1. P. palústris, L. Leaves lanceolate, shurply serrute, the lower pectinate when under water; fruit sharply angled. - Wet swamps, N. Eng. to Fla., west to Minn. and Tex. 
2. P. pectinàcea, Lam. Leaves all pectinate, the divisions linear-awl. shaped; fruit rather obtusely angled. - Sandy swamps, near the coast, Mass. to Fla. and La.

\section{HIPPÙ RIS, L. MARE'S TAIL.}

Flowers perfect or polygamous. Calyx entire. Petals none. Stamen one, inserted on the edge of the calyx. Style single, thread-shaped, stigmatic down one side, received in the groove between the lobes of the large anther. Fruit nut-like, 1-celled, 1-seeded. - Peremial aquatics, with simple entire leares in whorls, and minute flowers sessile in the axils in summer. (Name from " $\pi \pi$ os, a horse, and oủ á, a tail.)

1. H. vulgàris, L. Stems simple $\left(1-2^{\circ}\right.$ high $)$; leaves in whorls of 8 or 12, linear, acnte; fruit nearly $1^{\prime \prime}$ long. - Ponds and springs, Penn. to Ind. and Minn., aud northward. (Eu.)

\section{CA L IÍt R I C H E, L. Water-Starwort.}

Flowers monocious, solitary or 2 or 3 together in the axil of the same leaf, wholly naked or between a pair of membranaceous bracts. Sterile flower a single stamen; filament bearing a heart-shaped 4-celled anther, which by confluence becomes 1-celled, and opens by a single slit. Fertile flower a single 4 celled ovary, either sessile or pedicelled, bearing 2 distinct and filiform sessile. usually persistent stigmas. Fruit nut-like, compressed, 4-lobel, 4-celled, separating at maturity into as many closed 1-seeded portions. Seed pendulous, filling the cell; embryo slender, straight or slightly curved, nearly the length of the oily albumen. - Low, slender and usually tufted, glabrous, or beset with minute (microscopic) stellate scales, with spatulate or linear entire leaves, both forms of leaves often occurring on the same stem. (Name from ka入ós, beautiful, and $\theta$ pík, hair, from the often almost capillary stems.)

* Small unnuals, forming tufts on moist soil, destitute of stellate scates: leaves uniform, very small, obovate or oblanceolate, 3-nerved, crowded; bracts none,

1. C. defléxa, Braun, var. A ustini, Hegelm. Stems $\frac{1}{2}-l^{\prime}$ high ; fruit small ( $\frac{1}{3}$ "broad), broader than high, deeply notched above and below, on a pedicel often nearly of its own length or nearly sessile; lobes of the fruit nar rowly winged and with a deep groove between them; persistent stigmas shorter than the fruit, spreading or reflexed; leaves 1-2" long. (C. Austini, Enyelm) — On damp soil, N. Y. and N. J. to Ill., Mo., and Tex. (S. Am.)

* * A mphibious perennials; leaves with stellate scules, the floating ones obovute and 3-nerved, the submersed linear (all uniform and narrow in terrestrial forms) : flowers usually between a pair of bracts.

2. C. vérna, L. Fruit ( $\frac{1}{2}{ }^{\prime \prime}$ long) higher than broad, obovate, slightly obcordate, usually thickest at the base, sessile, its lobes sharply keeled or rery narrowly winged above, and with a wide groove between them; stigmas shorter than the fruit, almost erect, usually decidnous; floating leaves crowded in a tuft, obovate, narrowed into a petiole. - Common in stagnant waters, New England to Fla., west to Mimn., Tex., and the Pacific. (Eu.)

3. C. heterophýlla, Pursh. Fruit smaller, as broad or broader than high, deeply emarginate, thick, almost ventricose, sessile or nearly so, its lobes 
obtusely angled, with a small groove between them; stigmas as long as the fruit, erect, persistent; floating leaves crowded in a tuft, liroally spatulate, often retuse, abruptly narrowed into a long petiole. - Stugnant water, Mass. and N. J. to S. Ind. and Mo.

* * * Submersed peremual, whth numerous uniform huear 1-neried leaves; flowers urthout bracts; carpels sepurate neurly to the axis.

4. C. autumnàlis, $L$. Stems $3-6^{\prime}$ high ; fruit large (1" wille or more), flattened, circular, deeply and narrowly notched, sessile or nearly so, its lohes broally winged, and with a very deep and narrow groove lutwen them; stigmas very long, reflexed, deciduous; leaves all linear from a broaler base, retuse or notehed at the tip $\left(2-6^{\prime \prime}\right.$ long $)$. - W. Mass., Lake ('hamplain and N. New York, Lake Superior, and westward. (Lu.)

\section{Order 40. MELASTOMACEAE. (MELASTOMA FAMLY.)}

Plants with opposite 3-7-ribbed leaves, and definite stamens, the anthers opening by pores at the apex; otherwise much as in the Onagracex. - Ill tropical, except the genus

\section{RHEXIA, I. Deer-Grass. Meadow-Beatty.}

Calyx-tule urn-shaped, coherent with the ovary below, and continued alove it, persistent, 4-cleft at the apex. Petals 4, convolute in the bud, oblique, inserted along with the 8 stamens on the summit of the calyx-tuhe. Anthers long, l-celled, inverted in the bul. Style 1; stigma 1. Capsule invested by the permanent calyx, 4-celled, with 4 many-seeded placent:e projecting from the central axis. Seeds coiled like a snail-shell, without alhumen. - Low perennial herbs, often bristly, with mostly sessile 3-5-nerved and bristly-edged leaves, and large showy cymose flowers; in summer; the petals falling early. (A name in Pliny for some unknown plant, probably from $\hat{\rho} \hat{\xi} \xi s$, a crevice, from the place of growth.)

* Anthers lineur, curved, with a munte spur on the back at the attachment of the filument above its base; flowers cymose, peduncled.

1. R. Virgínica, L. Stem square, with wing-like angles; lenres orallanceolate, sessile, acute; calyx-tube and pedicels more or less hispicl with glanttipped hairs; petals bright purple. - Sandy swamps; eoast of Maine tu Fla., west to northern N. Y., Ind., Mo., and La. Slender rootstocks tuheriforons.

2. R. aristosa, Britt. Brauches somewhat wing-angled; leaves linearoblong, sessile, not narrowed at hase, naked or very sparsely hairy; hairs of the ealyx mostly below the throat, not gland-tipped; petals sparsily villous, bright purple.- Egg IIarbor City, N.J. (J. E. I'elers); also Sumter Co., S. C. $(J . D$. Smith).

3. R. Mariàna, I. Stems cylindrical; lenes linear-oblomg, narrowerl below, mostly petiolate; petals paler.-Sandy swamps; $\mathbf{N}$.J. to Fla., west to Mo. and Ia.

* * Anthers oblong, straight, uithout any spur; flovers, feu, sessile.

4. R. ciliosa, Michx. Stem square, glabrous; leaves broally ovate, ciliate with long bristles; calyx glabrous. - Md. to Fla. and La. 


\section{Order 41. LYTHRACEAE. (Loosestrife Family.)}

Herbs, with mostly opposite entive leaves, no stipules, the calyx enclosing but fiee from the 1-4-celled many-seeded ovary and membranous capsule, and bearing the 4-7 deciduous petals and 4-14 stamens on its throat; the latter lower down. Style 1 ; stigma capitate, or rarely 2-lobed. - Flowers axillary or whorled, rarely irregular, perfect, sometimes dimorphous or even trimorphous, those on different plants with filaments and style reciprocally longer and shorter. Petals sometimes wanting. Capsule often 1-celled by the early breaking away of the thin partitions; placentæ in the axis. Seeds anatropous, without albumen. - Branches usually 4-sided.

* Flowers regular or nearly so.

- Flowers mostly solitary in the axils of the leaves, sessile or nearly so.

1. Didiplis. Calyx short, without appendages. Petals none. Stamens 4. Capsule indehiscent. Small aquatic.

2. Rotala. Calyx short, the sinuses appenrlaged. Petals and stamens 4. Capsule septicidal, with $3-4$ valves.

3. Ammannia. Flowers not trimorphous. Petals generally 4 or none. Stamens 4. Capsule bursting irregularly.

+ - Flowers in 3-many-flowered axillary cymes (rarely solitary).

4. Lythrum. Calyx tubular. Petals usually 6 . Stamens mostly 6 or 12 . Flowers cymose-spicate in one species.

5. Decodon. Flowers trimorplous. Petals 5 (rarely 4). Stamens 8-10. Capsule 3-4valved, loculicidal.

* Flowers irregular and unsynmetrical, with 6 petals and 11 stamens.

6. Cuphea. Calyx spurred or enlarged on one side at base. Petals unequal.

\section{DIDítis, Raf. Water Pursane.}

Calyx short-campanulate or semiglobose, with no appendages at the sinuses (or a mere callous point). Petals none. Stamens 4, short. Capsule globular, indehiscent, 2-celled. - Submersed aquatic (sometimes terrestrial), rooting in the mud, with opposite linear leaves, and very small greenish flowers solitary in their axils. ("Didiplis means two doubling;" from $\delta / s, t w i c e$, and $\delta \iota \pi \lambda$ óos, $^{\circ}$ double.)

1. D. lineàris, Raf. Leaves when submersed elongated, thin, closely sessile by a broad base, when emersed shorter and contracted at base; caly $\mathrm{x}$ with broad triangular lobes; style very short; capsules very small. (Ammannia Nuttallii, Gray.) - From Minn. and Wisc. to 'Tex., east to N. C. and Fla.

\section{ROTALA, L.}

Calyx short-campanulate or semiglobose, with tooth-like appendages at the sinuses (abnormally, in our species). Petals 4 (in ours). Stamens 4, short. Capsule globular, 4-celled, septicidal, the valves (under a strong lens) trans. versely and densely striate. (Name a diminutive of rota, a wheel, from the whorled leaves of the original species.)

1. R. ramòsior, Koehne. Leares tapering at base or into a short petiole, linear-oblanceolate or somewhat spatulate; flowers solitary (rarely 3 ) in the axils and sessile; accessory teeth of calyx as long as the lobes or shorter. 
(Ammannia humilis, Michx.) - Jow or wet ground, Mass. to Fla., west to Ind., Kan., and Tex. - With Ammannia-like halbit, an exception in the grenus.

\section{A M M Á N N I A, Houstın.}

Flowers in 3- many-flowered axillary cymes. Calyx glubular or hell-shaped, 4-augled, 4-toothed, usually with a little horn-shaped appendage at each sinus. l'etals 4 (purplish), small and deciduous, sometimes wanting. Stamens $4-8$. Capsule globular, 2-4-celled, lursting irregularly. - Low and inconspicuons smooth herbs, with opposite narrow leaves, and small flowers in their axils, prouuced all summer. (Named after P'aul Ammann, a German botanist anterior to Linnaus.)

1. A. coccinea, Rottb. Leaves linear-lanceolate $\left(2-3^{\prime}\right.$ long), with a broad anricled sessile base; cymes subsessile, deuse; petals purplish ; stamens more or less exserted ; style usually slender; capsule included. (A. latifolia, Gray, Manual, not L.) - N. J. to Fla., west to S. Ind., Kan., and Tex. The style varies much in length, sometimes in the same specimen. Apparently the more developed form of the southern $\Lambda$. latifolia, Linn., which, as limited by Koehme, has apetalons flowers, with included stamens and short style.

\section{LÝ TH R U M, L. Loosestifife.}

Calyx cylindrical, striate, $5-7$-toothed, with as many little processes in the sinuses. Petals 5-7. Stamens as many as the petals or twice the number, inserted low down on the calyx, commonly nearly equal. Capsule oblung, 2celled. - Slender herbs, with opposite or scattered innstly sessile leares, and

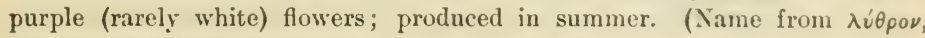
blood; perhaps from the styptic properties of some species.)

* Stamens and petals 5-7 ; flouers small, solitary und nearly sessile in the axils of the mostly scuttered upperleares; proper calyx-teeth often shorter than the intermediate processes; plants smooth.

1. L. Hyssopifòlia, L. Low annual (6-10' ligh), pale; leaves oblonglinear, obtuse, longer than the inconspicuous flowers; petals pale-purple; stamens usually 4-6, included. - Marshes, near the coast, Maine to N. J. (Eu.)

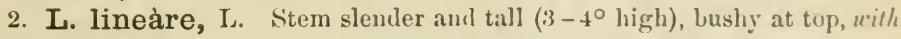
2 margined angles; leaves linear, chiefly opposite; petals whitish; flowers with 6 included stamens and a short style, or the stamens exserted and style short; ovary on a thick short stalk; no fleshy hypoyynous ring. - Brackish marshes, N. J. to Fla. and Tex.

3. L. alàtum, Pursh. Tall and wand-like perennial; branches uith murgined angles; leaves oblong-ovate to lineur-lunceolute, acute, with a cordute or rounded base, the upper mostly alternate; caly $x 2-4$ "long; petals rather large, deep-purple; stamens of the short-styled fouers exsertid; fleshy hypogynums ring prominent. - Ont. to Minn., south to Ga., Ark., and Col.; also near Buston.

* * Stamens 12 (rarely 8 or 10), twice the number of the petuls, 6 longer and 6 shorter; flowers large, crowded and whorled in an interrupted spike.

L. Salicaria, L. (Spiked Looskstrifr.) More or less duwny aud tall ; leaves lanceolate, heart-shaped at base, sometimes whorled in threes; tluwers purple, trimorphons in the relative lengths of the stamens and style. - W et meadows, N. Scotia to Del. (Nat. from Eu.) 


\section{DÉCODON, Gmel. Swamp Loosestrife.}

Calyx short, broadly bell-shaped or hemispherical, with $5-7$ erect teeth, and as many longer and spreading horn-like processes at the sinuses. Petals 5. Stamens 10 (rarely 8), exserted, of two lengths. Capsule globose, 3-5-celled, loculicidal. - Perennial herbs or slightly shrubby plants, with opposite or whorled leaves, and axillary clusters of trimorphous flowers. (Name from $\delta \in ́ \kappa \alpha$, ten, and ósoús, tooth.)

1. D. verticillàtus, Ell. Smooth or downy; stems recurved $\left(2-8^{\circ}\right.$ long), 4-6-sided; leaves lanceolate, nearly sessile, opposite or whorled, the upper with clustered flowers in their axils on short pedicels; petals 5 , wedgelanceolate, rose-purple ( $\frac{1^{\prime}}{2}$ long); stamens 10, half of them shorter. (Neswa verticillata, $H B K$.) - Swampy grounds, N. Eng. to Fla., west to Ont., Minn., and La. Bark of the lower part of the stem often spongy-thickened.

\section{6. $\mathbf{C}$ Ü $\mathbf{P} \mathbf{H} \mathbf{A}$, Jacq.}

Calyx tubular, 12-ribber, somewhat inflated below, gibbous or spurred at the base on the upper side, 6-toothed at the apex, and usually with as many little processes in the sinuses. Petals 6, very unequal. Stamens mostly 12, approximate in 2 sets, included, unequal. Ovary with a curved gland at the base next the spur of the calyx, 1-2-celled; style slender; stigma 2-lobed. Capsule oblong, few-seeded, early ruptured through one side. - Flowers solitary or racemose, stalked. (Name from $\kappa$

1. C. viscosissima, Jacq. (Chamm Cupina.) Annual, very viscidhairy, branching; leaves ovate-lanceolate; petals ovate, short-clawed, purple; seeds flat, borne on one side of the placenta, which is early forced out of the ruptured capsule. - Dry fields, R. I. to Ga., west to Kan. and La.

\section{Order 42. ONAGráceat. (Evening-Primose Family.)}

Herls, with 4-merous (sometimes 2-3- or 5-6-merous) perfect and symmetrical flowers; the tube of the calyx cohering with the 2-4-celled ovary, its lobes valvate in the bud, or olsolete, the petals convolute in the bud, sometimes wanting; and the stamens as many or twice as many as the petals or calyx-lobes, inserted on the summit of the calyx-tube. Style single, slender; stigma 2-4-lobed or capitate. Pollen grains often connected by cobwebby threads. Seeds anatropous, small, without albumen. - Mostly herbs, with opposite or alternate leaves. Stipules none or glandular.

* Parts of the flower in fours or more.

- Fruit a many-seeded pod, usually loculicidal.

+Calyx-limb divided to the summit of the ovary, persistent.

1. Jussiaea. Petals 4-6. Stamens twice as many. Capsule elongated.

2. Ludwigia. Petals 4 or none. Stamens 4. Capsule short.

++ + Calyx-tube prolonged beyond the ovary (scarcely so in $n$ 3) and deciduous from it. Flowers 4-merous.

3. Epilobium. Seeds silky-tufted. Fiowers sinall, not yellow. Lower leaves often opposite.

4. CEnothera. Seeds naked. Flowers mostly yellow. Leaves alternate 
- + Fruit dry and indehiseent, 1-4-seeled. Leaves alternate.

5. Gaura. Calyx-tube obeonieal. Filaments appendaged at bise.

6. Stenosiphon. Calyx-tube tiliform. Filaments not apyendaged.

* * Parts of the flower in twos. Leaves opjosite.

7. Circaea. Petals 2, obcordate or 2-lobed. Stanens 2. Fruit 1-2-seeded, bristly.

\section{J U S SI 宙 A, L.}

Calyx-tube elongated, not at all prolonged beyoud the ovary ; the lohes 4-6, herbaceous and persistent. Petals $4-9$. Stamens twice as many as the petals. Capsule 4-6-celled, usually long, opening hetween the ribs. Seeds very numerous. - Ilerbs (ours glabrous perenuials), with mostly entire anul alternate leares, and axillary yellow flowers, in summer. (Dedicated to Bernurd de Jussieu, the founder of the Natural System of Botany.)

1. J. decúrrens, DC. Stem erect $\left(1-2^{\circ}\right.$ high 1$)$, lranching, winged by the decurrent lanceolate leaves; culy.x-lubes 4, as long as the petals; capsule oblongclub-shaped, wing-angled; seeds in several rows in each cell. - Wet places, Va. to Fla., west to S. Ill., Ark., and La.

2. J. rèpens, L. Stem creeping, or floating and rooting; leaves uhlougr, tupering into a slender petiole; flowers large, long-peduncled ; ruiyx-lobes aul obovate petals 5 ; pod woody, cylindrical, with a tapering base; seeds qualrate, in 1 row in each cell, adlierent to the spongy endocarp. - In water, Ill. and Ky. to E. Kan., Ark., and 'Tex.

\section{LUDW ÍGIA, L. False Loosestrifk.}

Calyx-tube not at all prolonged beyoul the ovary; the lobes 4, usually persistent. Petals 4, often small or wanting. Stamens 4. Capsule sloort or cylindrical, many-seeded. Seeds minute, naked. - Perennial herbs, with axillary (rarely eapitate) flowers, through summer and autumu. (Namel for $C^{\prime}$. $C^{\prime}$. Luduig, Professor of Botany at Leipsic, contemporary with Linnaus.)

* Leaves all alternate, sessile or nearly so.

+ Flowers peduncled in the upper axils, with conspicuous yellow petals (4-8" long), equalling the orate or lanceolate foliaceous lobes of the calyx.

1. L. alternifólia, L. (Sisn-Box.) Smouth or nearly su, brancherl $\left(3^{\circ}\right.$ high) ; leaves lanceolute to linear-lanceolute, acute or jninted at both inds: capsules cubical, rounded at base, wing-angled. - Swamps, L. Masis. to Flit., west to Mich., L. Kan., aurl La.

2. L. hirtélla, Raf. Huiry all over; stems nearly simple $\left(1-2^{\circ}\right.$ high $)$; leaves oblong, or the upper lanceolate, blunt at both ends; eapsules nearly as in the? last, hut scarcely wing-angled. - Moist pine harrens, N. J. to Fla. and Tex.

+ + Flowers small, sessile (solitary or some times clustered) in the axils, with very small greenisk petals (in n. 5) or mostly none; lenress mostly luneolate or lineur on the erect stems $\left(1-3^{\circ}\right.$ high) and numerous branches : but prostrate or crerping sterile shoots uften produred from the base, thickly besit with shorter of ovate or spatulate leaves. (Our sprecies glubious, exiept 11. 3.)

3. L. sphærocárpa, Ell. Minutely pubescent, especially tle calyx, or nearly glabrous; leaves lanceolate or linear, acute, tapering at hase, thuse of the runners obovate with a wedge-shaped base and glaulular-elenticulate; 
bractlets minute, obsolete, or none; capsules globular or depressed (sometimes acute at base), not longer than the calyx lohes (less than $2^{\prime \prime}$ long). - Water or wet swamps, E. Mass. to Fla. and La. Bark below often spongy-thickened.

4. L. polycárpa, Short \& Peter. Leaves narrowly lanceolate, acute at both ends, those of the runners oblong-spatulate, acute, entire; bractlets linearawl-shaped and conspicuous on the base of the 4-sided somewhat top-shriped capsule, which is longer than the calyx-lobes. - Wet places, E. Mass. and Conn. to Mich., Minn., E. Kan., and Ky.

5. L. lineàris, Walt. Slender, mostly low; leaves narrowly linear, those of the short runners obovate; minute petals usually present ; bractlets minute at the base of the elongated top-shaped 4-sided capsule, which is $3^{\prime \prime}$ long and much longer than the calyx-lobes. - Bogs, pine barrens of N.J., and southward.

6. L. cylíndrica, Ell. Much branched; leaves oblong- or spatulatelanceolate, much tapering at the base or even petioled ; lractlets very minute at the base of the cylindrical capsule, which is $3^{\prime \prime}$ long, and several times exceeds the calyx-lobes. - Swamps, S. Ill. to Fla. and Tex.

$$
\text { * Leaves cull opposite; stems creeping or floating. }
$$

7. L. palústris, Ell. (Water Purslane.) Smooth; leaves ovate or oval, tapering into a slender petiole; petals none, or small and reddish when the plant grows out of water ; calyx-lobes very short ; capsules oblong, 4-sided, not tapering at base, sessile in the axils ( $2^{\prime \prime}$ long). - Ditches, common. (En.)

8. I. arcuáta, Walt. Smooth, small and creeping: leaves oblanceolate, nearly sessile; flowers sulitary, long-peluncled; petals yellow, exceeding the calyx ( $3^{\prime \prime}$ long) ; capsules oblong-club-shaped, somewhat curved ( $\frac{1}{3}^{\prime}$ long). Swamps, Va. to Fla.

\section{EPILO BI UM, L. WILLOW-HERB.}

Calyx-tube not or searcely prolonged beyond the ovary; the limb 4-cleft or -parted, deciduons. Petals 4. Stamens 8; anthers short. Capsule linear, many-seeded. Seeds with a tuft of long hairs at the end. - Mostly perennials, with nearly sessile leaves, and violet, purple, or white flowers; in summer. A large genus, many of its species of difficult limitation. The following provisional arrangement has been made by Prof. W. Trelease, mainly in accorlauce with Haussknecht's revision of the genus. (Name composed of érí, upon, and $\lambda \dot{\beta} \beta \iota \nu$, a little pod.)

§ 1. Flowers large, purple, in a long raceme; calyx-limb deeply parted; petals entire; stamens and style successively deflexed; stigma of 4 long lobes.

1. E. angustifòlium, L. (Great Willow-herb. Fire-weed.) Stem simple, tall $\left(4-7^{\circ}\right)$; leaves scattered, ample, lanceolate, nearly entire. - Low grounds, especially in newly cleared lands; N. Eng. to N. C., west to Minn. and E. Kan., and far north and westward. (Eu., Asia.)

§ 2. Flowers mostly small and corymbed or panicled; calyx-limb 4-cleft; petals mostly deeply notched; stamens and style erect.

* Stigma 4-parted; stem terete.

E. hirsùtum, L. 1)ensely soft-hairy, stout, branching $\left(3-5^{\circ} \mathrm{high}\right)$; leaves mostly opposite, lance-oblong, serrulate, sessile, flowers in the upper axils or 
in a leafy short raceme; petals $6^{\prime \prime}$ long, rose-purple. - Waste grounds, Mass.s. to N. Y. and (Unt. (Nat. from Eus.)

* * Stigma clatute; stem terete, without decurrent lines (or with truess in 11.2 ) : leuces numerons, the lower opposite, subentire, with revolute maryius.

2. E. lineàre, Muhl. Usually much branched above and minutely hoaryjubescent, $1-2^{\circ}$ high; leaves linear-lanceolate, tapering to a short hut distinct petiole, acutish; Howers numerous, pale; capsules hoary, on jedicels as long as the leaves. (E. palustre, var. lineare, Gray, mainly.) - Jogs, N. Eing. to l'enn., lowa, and northward.

3. E. stríctum, Muhl. Erect, 1 $-2 \frac{1}{2}^{\circ}$ high, densely beset with soft sprearling somewhat glandular white hairs; leaves broader, more obtuse and with erident veins, very short-petioled or sessile; pubescence of the cinpule soft and spreading. (F. molle, Torr.) - Bogs, Mass. to Mi..n., south to Va. and 111.

* * Stigma clacate; stem somenhat quadrangular with 2-4 ridyes or hariry lines decurrent from some of the lactes.

- Tall and mostly branching, many-flowered; leaves rather large, toothed, not revolute, the lower opposite; seeds papillose.

4. E. coloràtum, Muhl. Somewhat hoary-pubescent above wr glandular, $1-3^{\circ}$ high ; leaves lanceolate, sharply serrulate or denticulate, acute, narrowed to conspicuous petioles; flowers pale, more or less nodding; peduncles shorter than the leares; seeds dark, unappendaged; coma cinnamon-color. Wet places, common.

5. E. adenocaùlon, Haussk. Differs in its more glandular pubescence above, the often blunter and less toothed leaves abruptly contracted to shorter petioles, flowers erect, paler seeds with a slight prolongation at top, and a merely dingy coma. - Wet places through the Northern States.

6. E. glandulòsum, Lehm. Subsimple; pubescence above not glandular; leaves ovate-lanceolate, mostly abruptly rouncled to a sessile base and more glandular-toothed; seeds larger. - Canada to the mountains of $\mathrm{N}$. C. (fide Haussknecht). (Asia.)

- Mostly low, slender and simple (except forms of n. 10); leaves chiefly opposite, less toothed; flowers feu, nodding; sceds appendaged at the upe $x$.

+- Seeds areolate but not papillose; leaves not revolute.

7. E. anagallidifolium, Lam. Glabrate, a span high or less; leaves erect or ascending, about equalling the internodes, elliptical-oblong to narrowly obovate, entire or the upper denticulate, tapering to shurt petioles; flowers purple; sepals rather obtuse; (apsules glabrous on peduncles exceeding the leares. - White Mts. and Adirondacks (fide Ilausikneclit) (Eu.)

8. E. lactiflorum, Ilaussk. Glabrons except the juliescent lines, 6-12' high, with elongated internodes; leaves elliptical or the lowest round-olowate, slightly repand-denticulate, obtuse, tapering into mostly clongated petiules; flowers smaller, white; sepals more acute; seeds moro prominently ajpendaged. - White Mts., and northward (fide Haussknecht). (E.u.)

$$
\text { +- Siceds papillose-rouyhened. }
$$

9. E. Hornemánni, lieichenb. Glabrate, 8-18' high; leaves mostly horizontal, ovate, the upper acutish, remotely denticulate, abruptly contracted 
to winged petioles, not revolute; seeds often only slightly roughened, short and shortly appendager. (E. alpiuum, Man.) - White Mts., dells of the Wisconsin River (Lapham), and northward. (Eu.)

10. E. palústre, L. Slender, $1^{\circ}$ high or less, often branched, finely pubescent; leares erect or ascending, about equalling or longer than the internodes, sessile, linear to linear-lanceolate or elliptic-oblong, obtuse, with revolute margins; capsules pubescent to nearly glabrous, mostly shorter than the slender peduncles; seeds fusiform, with long beak. (E. palustre, var. lineare, Man., in part.) - Penn. to Minn. and the White Mits., north and westward. (Eu.)

\section{4. e nothitha, L. Evening Primose.}

Calyx-tube prolonged beyond the ovary, deciduous; the lobes 4, reflexed. Petals 4. Stamens 8; anthers mostly linear and versatile. Capsule 4-valved, many-seeded. Seeds naked. - Leares alternate. Flowers yellow, white or rose-color. (An old name, of unknown meaning, for a species of Epilobium.)

§ 1. Stigma-lobes linear, elonyated (except in 11.7 ); calyx-tube linear, slightly dilated at the throat; anthers linear.

* Caulescent annuals or biennials; flower's erect in the bud, nocturnal, yellow, the calyx-tips free; cupsules sessile, corraceous; seeds in two rows in each cell.

+ Flovers in a leafy spike; cupsules stout, oblong, slightly narroved above.

1. F. biénnis, L. (Commox Evexing Primrose.) Rather stout, erect $\left(1-5^{\circ}\right.$ high $)$, usually simple, more or less pubescent and hairy; leaves lanceolate to oblong- or rarely ovate-lauceolate (2-6' long), acute or acuminate, repandly denticulate, the lowest petioled; calyx-tube $1-2 \frac{1^{\prime}}{2}$ long, the tijs of the sepals contiguous; petals $\frac{1}{2}-\frac{3^{\prime}}{4}$ long; capsule more or less pubescent or hirsute. Throughout the U. S. - Var. CrUCidta, Torr. \& Gray, with small narrow petals, appears to be merely a rare garlen (?) sport. E. Mass.

Var. grandiflòra, Liudl., has petals as long as the calyx-tube $\left(1-2 \frac{1}{2}^{\prime}\right.$ long). - Same range as the type, but not so common east.

2. GE. Oakesiàna, Robbins. Annual, more slender, not hairy, the puberulence mainly appressed; calyx-tips not contiguous at base; otherwise nearly as in the typical form of the last. (EE. bienuis, var. Oakesiana, Gray.) - Dry places, E. Mlass., R. I., and Conn.

$$
+\ldots \text { Flowers in a leafy spike or axillary; capsules linear. }
$$

3. CE. rhombipétala, Nutt. Rarely branching, appressed-puberulent and subcanescent; leaves narrowly lanceolate, acuminate, denticulate, the lowest attenuate to a petiole and rarely pinnatifid, diminishing upward into the close, elongated, conspicuously bracted spike; calyx silky-canescent (tube

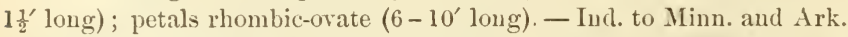

4. CE. humifùsa, Nutt. Stems decumbent or ascending $\left(\frac{1}{2}-2^{\circ}\right.$ long); houry-pubescont with short dense appressed hairs; leares narrowly lanceolate or oblanceolate $\left(\frac{1}{4}-1^{\prime} l o n g\right)$, sparingly repand-dentate or entire, the radical leaves pinnatific, the floral not reduced; capsule $\frac{1}{2}-\mathrm{I}^{\prime}$ long, silky, curved; seeds smooth. - On the sea-coast, N. J. to Fla.

5. GE. sinuàta, L. Stems ascendiug or decumbent, simple or branched ( $1^{\circ}$ high or more), more or less strigose-pubescent and puberuleut; leares oblong or lanceolate $\left(1-2^{\prime}\right.$ long $)$, sinuately toothed or often pinnatifid, the floral simi- 
lar; capsule 1-1 $\frac{1^{\prime}}{2}$ long; seeds strongly pitted. - N. J. to Fla., west to E. Kan. and Tex. Very variable.

* Caulescent perennial; fowers axillary, nodding in the Iud, white turning rose-color; capsules sessile, linear: serds in "simgle rou.

6. CE. albicaùlis, Nutt. Stems erect $\left(\frac{1}{2}-t^{\circ}\right.$ high $)$, simple or hrauched, white and often shreddy, glabrous or puberulent; leaves linear to olblong-lanceolate ( $1-3^{\prime}$ long), entire or repaud-denticulate, or sinuate-pinnatifil toward the base; calyx-tips free, throat naked; pods $\frac{1}{2}-2^{\prime}$ long, often curvel or twisted; seeds lance-linear, smooth. - IV. Miun. to N. Mex., and westwarrl.

* * Caulescent; flowers diurnal, yellow and erect in the bud (e.rerpt in n. 11); capsules ohovate or clavate, quadrangular, the valves ribhed and the angles more or less strongly winged (exrept in n. 7).

7. CE. linifòlia, Nutt. Annual or biennial, erect, very slender, simple or diffuse $\left(6-15^{\prime}\right.$ highl $)$, glahrous, the brauchlets and eapsules puherulent; radical leaves oblanceolate, cauline lineur-fil,form $\frac{1}{2}-1^{\prime}$ long; spikes lousely flowered ; corolla 2-3" long; stignus short ; copsules ubovate to oblong-clavate, 2-3"long, not winged, nearly sessile. - Ill. to E. Kan., La., and 'T'ex.

8. CE. pùmila, L. Biennial, puberulent, $1-2^{\circ}$ high; leuces mustly glabrous, entire, obtuse, the radical spatulate, the cuuline nurrouly obluncenlute: flouers loosely spiked; corolla $4-12^{\prime \prime}$ long; cupsule glabrous, oblong-clavate, $3-6^{\prime \prime}$ long, sessile or on a short pedicel, slightly wmyed. (Incl. (I. chrysantha, Michx.) - 1)ry fields, N. Scotia to N. J., west to Minn. and Kan. Jume.

9. W. fruticòsa, L. (Svxprops.) Bienuial or perennial, erect, often tall and stont $\left(1-3^{\circ}\right.$ high), villous-pubescent or puberulent or nearly glabrous ; leaves oblong-to linear-lanceolate, mostly dentıculate; raceme corymbel or loose: petals 9-12" long; rripsule subsessile or with " pedicel shorter than itself, prominently ribbed and strongly wmiged. - Common and very variable.

Var. lineàris, Watson. Leaves linear to linear-lanceolate; capsule usually shorter than the perlicel, rather less broadly winged. ((E. linearis of M/un., in part. (E. riparia, Nutt.) - Comn. to Fla., west to Mo. and La.

Var. humifùsa, Allen. Low, decumbent, somewhat woody, diffusely branched, puberulent; branches slender, flexuons; leaves narrow; flowers few, small; capsules pubescent, about equalling the pedicel. (CE. linearis of Mun., in part.) - Suffolk Co., L. Island.

10. CE. glaùca, Michx. P'erennial, erect (2-3 high), glubrons and gluncous; leares orate to orute-oblong (2-4' long), repausl-denticulate; flouers in short leafy corymbs; petuls $9-15^{\prime \prime}$ long; copsule glabrons, ovolit-oblong, very broadly winged, usually abruptly contracted into a pedicel equalling or shorter than itself. - Momntains of Va. to Ala., west to Ky. and L. Kan.

11. CE. speciòsa, Nutt. Perennial, erect or sulvdecumbent, finely pubescent; leares oblong-lanceolate to linear, repaud-denticulate, or more or liss deeply sinnate-pinuatifid; flouers large, white or rose; capsule clavate-ohorate, strongly 8-ribbed, rigid, acute, stontly pedicelled. - Mo. to Kan. and Tex.

**** Capsule oblong to orate or irbirulur, broudly unnged, rignd und sessile. - Acaulescent or neurly so; flowers uhte or rose-color.

12. CE. tríloba, Nntt. Biennial or perenuial, nearly glabrous; leares 2-10' long, somewhat ciliate, long-petioled, runciuate-pinuatifil or oblanceo- 
late and only sinuate-toothed; calyx-tips free, the tube slender (2-4' long); petals $6-12^{\prime \prime}$ long; capsile ovate, $\frac{1}{2}-1^{\prime}$ long, strongly winged, net-veined. Ky. to Miss. and Tex., west to the Pacific.

Var. (?) parviflora, Watson. Flowers very small (1-2' long), fertilized in the bud and rarely fully opening; fruit abundant, forming at length a densely crowded hemispherical or cylindrical mass nearly $2^{\prime}$ in diameter and often $2-3^{\prime}$ high. - Plains of Kan. and Neb.

$$
++ \text { Low caulescent perennials; flowers axillary, yellow. }
$$

13. G. Missouriénsis, Sims. Stems decumbent; pubescence short and silky, closely appressed, sometimes deuse or wholly wanting; leaves thick, oval to linear, mostly narrowly lanceolate $\left(2-5^{\prime}\right.$ long), acuminate, entire or

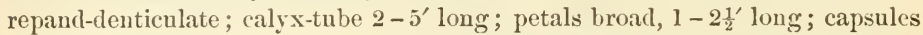
orbicular, very broadly winged $\left(1-3^{\prime}\right.$ long). - Mo, and Kan. to Tex.

14. CE. Fremóntii, Watson. Hoary with appressed silky pubescence; leaves linear, pointer, entire; calyx-tube 1-2' long; petals $\frac{1}{2}-1^{\prime}$ long; capsule hoary, oblong, narrowed at base, $9^{\prime \prime}$ long. - Central Kan.

§ 2. Stigma discoid; calyx-tube more broadly dilated above; anthers oblonglinear; capsule mostly sessile, linear-cylindric; perennial, somewhat woody, with axillary yellow flowers.

15. CE. Hartwègi, Benth., var. lavandulæfòlia, Watson. Stems numerous from a woody base, $3-6^{\prime}$ high; leaves numerons, hoary-puberulent, mostly linear, $\frac{1}{4}-1^{\prime}$ long; calyx-tube $1-2^{\prime}$ long; capsule 8-10" long. - Central Kan. to Col. and N. Mex.

16. CE. serrulàta, Nutt. Slender $\left(3-15^{\prime}\right.$ high $)$, simple or branched, canescent or glabrous; leaves linear to lanceolate ( $1-3^{\prime}$ long), irregularly and sharply denticulate; cal yx-tube broadly funnelform (2-4" long), strongly nerved; petals broadly obovate ( $3-4^{\prime \prime}$ long), crenulate; capsule $9-15^{\prime \prime}$ long. - Wisc. and Minn. to Mo., Tex., and N. Mex.

\section{5. $\mathbf{G} \mathbf{A}$ Ù $\mathbf{R} \mathbf{A}$, L.}

Calyx-tube much prolonged beyond the ovary, deciduous; the lobes 4 (rarely 3), reflexed. Petals clawed, unequal or turned to the upper side. Stamens mostly 8 , often turned lown, as is also the long style. A small scale-like appendage before the base of each filament. Stigma 4-lobed, surrounded by a ring or cup-like border. Fruit hard and nut-like, 3-4-ribbed or angled, indehiscent or nearly so, usually becoming 1-celled and 1-4-seeded. Seeds naked. - Leaves alternate, sessile. Flowers rose-color or white, changing to reddislı in fading, in spikes or racemes, in our species quite small (so that the name, from rav̂pos, superb, (loes not seem appropriate).

\section{* Fruit sessile or nearly so.}

1. G. biénnis, L. Soft-hairy or downy $\left(3-8^{\circ}\right.$ high $)$; leaves oblong-lancenlate, denticulate; spikes wand-like ; fruit oval or oilong, acnte at both ends, $2-3^{\prime \prime}$ long, ribbed, downy. - Dry banks, N. Y. to Minn., and southward. Ang.

2. G. parviflora, Dongl. Soft-rillons and pubernlent, $2-5^{\circ}$ high ; leaves ovate-lanceolate, repand-denticulate, soft-pubesccnt; spikes dense; frmit oblongclavate, narrowed to both ends, 4-nerved, obtusely angled above, $3-4^{\prime \prime}$ long. - Mo. to La. and westward. 
3. G. coccínea, Nutt. Cunescent, puberulent or glalirute ( $i-12^{\prime}$ high), very leafy ; leures lanceolute, linear-oblong or linear, repaul-alenticulatu or cutire; flowers in simple spikes, rose-color turning toscarlet; jimil terre belou, 4-side, and broader aboce, $2-3$ " long. - Minn. to Kan., and westward.

$$
\text { * * Fruit slender-pedicelled. }
$$

4. G. fílipes, Spach. Nearly smooth; stem slender $\left(2-4^{\circ}\right.$ high); leaves linear, mostly toothed, tapering at base; branches of the panicle very shonder, naked ; fruit obovate-club-shaped, 4-angled at the summit. - Open places, Va. to Fla., west to Ill., lian., and Ark.

\section{STENÓSIPHON, spach.}

Calyx prolonged beyond the ovary into a filiform tule. Filaments (8) nut appendaged at hase. Fruit 1-celled, 1-seeded. Otherwise as Gaura, which it also resembles in habit. (From $\sigma \tau \epsilon \nu o ́ s, n(t r r o u$, and $\sigma i \phi \omega \nu, a$ tulu..)

1. S. virgàtus, spaclı. Slencler, $2-4^{\circ}$ high, glabrous, leafy, leaves natrrowly lanceolate to linear, pointed, entire, much reduced above; flowers uumerous in an elongated spike, white, $\frac{1^{\prime}}{2}$ long; fruit pubescent, oblong-rvate, 8-ribbed, small. - F. Kan. to Col. and Tex.

\section{CIRC \& A A Tourn. Exchaxter's Nightsmun,}

Calyx-tube slightly prolonged, the end filled by a cup-shaped disk, deciduous ; lobes 2, reflexed. Petals 2, inversely heart-shapeel. Stamens 2. Fruit indehiscent, small and bur-like, bristly with hooked hairs, 1 -2-celled ; cells 1-seederl. - Low and ineonspicuous perennials, in cool or damp woods, with opposite thin leaves on slender petioles, and small whitish flowers in racemes, produced in summer. (Named from Circe, the enchantress.)

1. C. Lutetiàna, I. Taller $\left(1-2^{\circ}\right.$ high $)$; leaves ovate, slightly toothed; bracts none; hairs of the roundish 2-celled fruit bristly. - Very common. (Ein.)

2. C. alpina, I. Low $\left(3-8^{\prime}\right.$ high $)$, smooth and weak; leaves heart-shaperl, thin, shininy, coursely toothed; bracts minute; hairs of the obovate-olllong l-relled fiut soft and sleuder. - Deep woods, N. Eng. to Ga., Ind., and Minn. (Eu.)

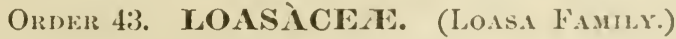

Herbs, with a rough or stinging pubescence, no stipules, the calyx-tube adherent to a 1-celled ovary with 2 or 3 parietul placente; - represented here only by the genus

\section{MENTZELIA, Plumier.}

Calyx-tube cylindrical or club-shaped; the limb 5-parted, persistent. Prtals 5 or 10 , regular, sprealing, flat, convolute in the bul, leciduous. Simmens indefinite, rarely few, inserted with the petals on the throat of the calyx. Styles 3 , more or less united into one; stigmass terminal, minute. Capsule at length dry and opening by valves or irregularly at the summit, few-many-seeded. Seeds flat, anatropons, with little allumen. - Stems erect. Leaves alternate, very adhesive by the harbed pubescence. Flowers terminal, solitary or cymowo clustererl. (I)edicated to C. Mentzel, an early German lotanist.) 
* Seeds few, oblong, not winged; petals 5, not large; filaments all filiform.

1. M. oligospérma, Nutt. Rongh aud adhesive $\left(1-3^{\circ}\right.$ high), much branched, the brittle branches spreading; leaves ovate and oblong, cut-toothed or angled, often petioled ; flowers yellow ( $7-10^{\prime \prime}$ broad ), opening in sunshine; petals wedge-oblong, pointed; stamens 20 or more; capsule small, about 9seeded. - Prairies and plains, Ill. to Kan. and Col., south to Tex.

* Seeds numerous, rounded and uing-margined; petals 10, large and showy; outer filuments petaloid in n. 3; capsule large, oblong; leaves sessile.

2. M. ornàta, Torr. \& Gray. Stout, $1-2^{\circ}$ high; leares oblong-lanceolate, leeply repand-toothed or pinnatifid, the segments acute; calyx-tube leafy-bracteate; petals 2-3' long, yellowish-white; filaments all filiform or the onter dilated below ; capsule $1 \frac{1}{2}-2^{\prime}$ long; seeds narrowly margined. - On the plains, IV. Dak. to central Kan. and Tex.

3. M. nùda, Torr. \& Gray. More slender, $1-5^{\circ}$ high; leaves sor.ewhat lanceolate, rather bluntly or shortly repand-dentate; flouers half as large as in the last; calyx not bracteate; outer filaments narrouly dilated, sterile; capsule about $\mathbf{I}^{\prime}$ long; seeds plainly winged. - Plains of Dak. to central Kan. and Tex.

\section{Order 44. PASSIFlorà CEAE. (Passion-Flower Family.)}

Herbs or woorly plants, climbing by tendrils, with perfect flowers, 5 monadelphous stamens, and a stalled 1-celled ovary free from the calyx, with 3 or 4 parietal placenter, and as many club-shaped styles.

\section{PASSIFIÒ A, L. Passiox-Flower.}

Calyx of 5 sepals united at the base into a short cup, imbricated in the bud, usually colored like the petals, at least within; the throat crowned with a double or triple fringe. Petals 5, on the throat of the calyx. Stamens 5; filaments united in a tube which sheathes the long stalk of the orary, separate above; anthers large, fixed by the middle. Berry (often edible) many-seeded; the anatropous albuminons seeds invested by a pulpy covering. Seed-coat brittle, giooved. - Leaves alternate, generally palmately lobed, with stipules. Peduncles axillary, jointed. Ours are perennial herbs. (An arlaptation of flos passionis, a translation of fior della passione, the popular Italian name early applied to the flower from a fancied resemblance of its parts to the implements of the (rucifixion.)

1. P. lùtea, L. Smooth, slender; leaves oltusely 3-lobed at the summit, the lobes entire; petioles glandless ; fluwers greenish-yellow ( $1^{\prime}$ broad) ; fruit $\frac{1}{2}$ in diameter. - Damp thickets, S. Penn. to Fla., west to Ill., Mo., and La.

2. P. incarnàta, L. Pubescent; leaves 3-5-cleft, the lobes serrate, the base bearing 2 glands; flower large ( 2 ' broad), nearly white, with a triple purple and flesh-colored crown; involucre 3-leared; fruit as large as a hen's egg. - Dry soil, Va. to Fla., west to Mo. and Ark. Fruit called maypops.

\section{Order 45. CUCURBITACEAE. (Gourd Family.)}

Mostly succulent herbs with tendrils, dicecious or monocious (often gamopetalous) flowers, the calyx-tube cohering with the 1-3-celled ov:ary, and the 
5 or usually $2 \frac{1}{2}$ stamens (i.e., 1 with a 1-celled and 2 with 2-celled anthers) commonly united by their often tortuous anthers, and sometimes also by the filaments. Fruit (pepo) fleshy, or sometimes memlranaceous. - Limb of the calyx and corolla usually more or less combined. Stigmas 2 or 3. Seeds large, usually flat, anatropous, with no albumen. Cotyledons leaflike. Leaves alternate, palmately lobed or veineil. - Mustly a tropical or subtropical order; represented in cultivation by the Gotri) (Liti:Niria vulgiris), Pumpkin and Squasis (species of Cucurbita), Mushmelon (Cùcumis Mèlo), Cucumber (C. satìus), and Watermelon (Citrúllus vulgìris).

* Fruit prickly. Seeds few, erect or pendulous. Flowers white. Annual. - Ovary l-celled. Seed solitary, pendulous.

1. Sicyos. Corolla of the sterile flowers flat and spreading, 5-lobed. Fruit indehiscent. ++ Ovary 2-3-celled. Seeds few, ereet or aseending.

2. Echinocystis. Corolla of the sterile flowers flat and spreading, 6-parted. Anthers 3 . Fruit bladdery, 2-celled, 4-seeded, bursting at the top.

3. Cyclanthera. Corolla 5-parted. Anther 1, annular. Fruit oblique and gibbous.

* Fruit smooth. Seeds numerous, horizontal, attached to the 3-5 parietal placentæ. Perennial.

4. Melothria. Flowers small, greenish ; corolla 5-parted. Slender, climbing. Fruit small.

5. Cucurbita. Flowers large, yellow, tubular-campanulate. Prostrate. Fruit large.

\section{S Í Cyo S, L. One-seeded Bur-Cucumber.}

Flowers monœcious. Petals 5, united below into a bell-shaped or flattish corolla. Anthers cohering in a mass. Ovary l-celled, with a single suspended ovule; style slender; stigmas 3 . Fruit ovate, dry and indehiscent, filled by the single seed, covered with barbed prickly bristles which are readily detached. - Climbing annuals, with 3 -forked tendrils, and small whitish flowers; the sterile and fertile mostly from the same axils, the former corymbed, the latter in a capitate cluster, long-peduncled. (Greek name for the Cucumber.)

1. S. angulàtus, L. Leaves roundish heart-shaped, 5-angled or lobed, the lobes pointed; plant clammy-hairy. - River-lonks, and a weed in damp yards, N. H. and Quebec to Fla., west to Minn., E. Kan., and Tex. July-Sept.

\section{ECHINOCÝ STIS, Torr. \& Gray. Wild BALAM-APLE.}

Flowers monocious. Petals 6, lanceolate, united at the base into an open spreading corolla. Anthers more or less united. Ovary 2-ellecl, with 2 erect ovules in each cell; stigma broad. Fruit fleshy, at length dry, clothed with weak prickles, bursting at the summit, 2 -celled, 4 -seeded, the inner part fibrousnetted. Seeds large, flat, with a thickish hard and roughened coat. - Tall climbing annual, nearly smonth, with 3 -forked tendrils, thin leaves, and very numerous small greenish-white flowers; the sterile in compound racemes often $1^{\circ}$ long, the fertile in small clusters or solitary, from the same axils. (Name

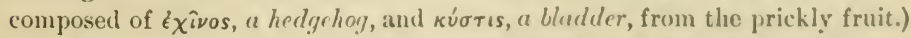

1. E. lobata, Torr. \& Gray. Leaves deeply and sharply 5-lohed; fruit oval (2' long); seeds dark-colured. - Kich soil along rivers, W. New Eing and P'enn. to Minn., E. Kían., and T'ex. Mlso cult. for arbors. July-Oct. 


\section{C Y CLA N THERA, Schrad.}

Flowers monœecious. Corolla rotate, deeply 5-parted. Stamens united into a central column, the anther solitary in our species and annular. Ovary (1 - 3-) usually 2-celled and 4-locellate with 4 erect or ascending orules. Fruit spiny, obliquely ovoid and gibbous, beaked, bursting irregularly. Seeds flattened. - Slender glabrous climbing annuals or perennials, with very small racemose or panicled white sterile flowers and a solitary fertile one in the same axil.

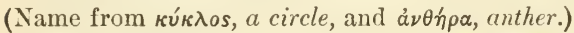

1. C. dissécta, Arn. Annual; leaves digitately 3-7-foliolate, the oblong divisions somewhat lobed or toothed ; tendrils simple or bifid ; fruit $1^{\prime}$ long, on a short peduncle. - Central Kan. to Tex. and Mex.

\section{MELOTHRIA, L.}

Flowers polygamous or moncecious; the sterile campanulate, the corolla 5lobed; the fertile with the calyx-tube constricted above the ovary, then campanulate. Anthers more or less united. Berry small, pulpy, filled with many flat and horizontal seeds. - Tendrils simple. Flowers very small. (Altered from $\mu \eta \dot{n} \lambda \omega \theta \rho \nu$, an ancient name for a sort of white grape.)

1. M. péndula, L. Slender, from a perennial root, climbing; leaves small, roundish and heart-shaped, 5-angled or lobed, roughish; sterile flowers few in small racemes; the fertile solitary, greenish or yellowish; berry oval, green, 4-6" long. - Copses, Va. to Fla., west to S. Ind. and La.

\section{CUCÚ RBITA, L.}

Flowers monøcious, mostly solitary. Calyx-tube campanulate ; corolla campanulate, 5-lobed to the middle. Filaments distinct; anthers linear, united, sigmoid. Ovary oblong, with short thick style, 3-5 2-lobed stigmas, and 3-5 parietal placentas; ovules numerous, horizontal. Fruit smooth, fleshy with a hard rind, indehiscent. - Prostrate scabrous vines, rooting at the joints, with large yellow flowers and large fruit. (The Latin name for the Gourd.)

1. C. fœtidíssima, HBK. Root very large, fusiform; leaves thick, triangular-corlate; flowers $3-4^{\prime}$ long; fruit globose or obovoil, $2-3^{\prime}$ in diameter. (C. perennis, Gray.) - Central Neb. to Tex., and westward.

\section{Order 46. CACtàcem. (Cactus Family.)}

Fleshy and thickened mostly leafless plants, of peculiar aspect, globular or columnar and many-angled, or flattened and jointed, usually with prickles. Flowers solitary, sessile; the sepals and petals numerous, imbricated in several rows, the bases adherent to the 1-celled ovary. - Stamens numerous, with long and slender filaments, inserted on the inside of the tube or cup formed by the union of the sepals and petals. Style 1 ; stigmas numerous. Fruit a 1-celled berry, with numerous campylotropous seeds on several parietal placentæ.

1. Mamillaria. Globose or oval plants, covered with spine-bearing tubercles. Flowers from between the tubercles. Ovary naked; berry succulent.

2. Opuntia. Branching or jointed plants ; the joints flattened or cylindrical. 


\section{MAMILLÀRIA. Haw.}

Flowers about as long as wide, the tube campanulate or funnel-shaped. Ovary often lidden between the lases of the tubercles, naked, the succulent berry exserted. Seeds yellewish-brown to hlack, crustaceous. - Globese or oval plants, covered with spine-bearing cylindrical, oval, or conical tubercles, the flowers from distinct woolly or hristly areoles at their base. (Name from mamilla, a nipple, referring to the tubercles.)

1. M. vivípara, Haw. Simple or cespitose, 1-5' high, the almost terete tubercles bearing bundles of $5-8$ reddlish-brown spines (10" long or less), surrounded by 15-20 grayish ones in a single series, all straight and very rigid; flowers purple, with lance-subulate petals and fringed sepals; berry oval, green ; seels pitterl, light brown. - Plains of Dak. to lian., aud westwarl.

2. M. Missouriénsis, Sweet. Smaller, globose, with fewer $(10-20)$ wakker ash-colored spines; flowers yellow, 1-2' broad; berry subglobose, sciurlet; seeds few, black, pitted. (M. Nuttallii, Engelm.) - S. Dik. to central Kan., Tex., and westward.

\section{O P Ú NTIA, Tourn. Prickli pear. Indan Fig.}

Sepals and petals not united into a prolonged tube, spreading, regular, the inner roundish. Berry often prickly. Seeds flat and margined, covered with a white bony arillus. Embryo coiled around albumen; cotyledons large, foliaceous in germination. - Stem composed of joints (Hattened in ours), bearing very small awl-shaped and usually deciduous leares arranged in a spiral order, with clusters of barbed bristles and often spines also in their axils. Flowers in our species yellow, opening in sunshine for more than one day. ( $\Lambda$ name of Theophrastus, originally belonging to some different plant.)

\section{* Spines small or none; fruit pulpy.}

1. O. vulgàris, Mill. Prostrate or spreading, light green; joints broadly obovate $\left(2-4^{\prime}\right.$ long $)$; leaves minute $\left(2-2 \frac{1}{2}{ }^{\prime \prime}\right.$ long), ovate-sululate, generally appressed; bristles short, greenish yellow, rarely with a few small spines; flowers pale yellow (about 2 ' broad), with alout 8 petals; fruit $\mathbf{l}^{\prime}$ long. - Sandy fields and dry rocks, Nantucket to S. C., near the eoast; Falls of the l'otomac.

2. O. Rafinésquii, Engelm. Prostrate, deep green; joints lnoaldy uhovate or orbicular $\left(3-5^{\prime}\right.$ long); leaves $\left(3-4^{\prime \prime}\right.$ long), spreading; bristles bright red-brown, with a few small spines and a siugle strong one $\left(9-122^{\prime \prime}\right.$ long) or none; flowers yellow $\left(2 \frac{1}{2}-3 \frac{1^{\prime}}{3}\right.$ broul), sometimes wuth a reddish centre; pulals 10-12; fruit $1 \frac{1^{\prime}}{2}$ long, with an attenuated base. - Sterile soil, Nautucket and southward along the coast to Fla., and in the Mississippi valley, from Mich. to Minn., and south to Ky. and $\Lambda \mathrm{rk}$.

$$
\text { * * Very spmy, fimul dry and prickly. }
$$

3. O. Missouriénsis, DC. I'rostrate, jomls light groen, breadly obrevate, flat and tuberculute (2-6' long), leaves small (1 $\frac{1}{2}-2^{\prime \prime}$ long); their axils armed with a tuft of straw-colored bristles and 5-10 slender raduating spines $\left(1-2^{\prime}\right.$ long); flowers light yellow ( $2-3^{\prime}$ broad); fruit with spines of variablo length. - Wisc. to Mo., westward across the plains, very variable.

4. O. frágilis, lIaw. Suldecumbent; joints small (1-2' long or lexs). ovate, compressed or tumid, or eren terete; leaves harlly I" long, red ; brisitis 
few, larger spines 1-4, cruciate, with 4-6 smaller white radiating ones below; flowers yellow - Minn. to Iowa and Kan., and westward.

\section{Order 47. FICOÍDEAE.}

A miscellaneous group, chiefly of fleshy or succulent plants, with mostly opposite leates and no stipules. Differing from Caryophyllaceæ and Portulacaceæ by having the ovary and capsule 2 -several-celled, and the stamens and petals sometimes numerous, as in Cactaceæ (but the latter wanting in most of the genera), seeds, as in all these orders, with the slender embryo curved about mealy albumen. Our genera are apetalous and with the ealyx free from the ovary.

1 Sesuvium. Calyx-lobes 5, petaloid. Stamens 5-60. Capsule circumscissile. Succulent. 2. Mollugo. Sepals 5. Stamens 3 or 5 . Capsule 3-valved. Not succulent.

\section{S E S Ù V I U M, L. Sea Purslaxe.}

Calyx 5-parted, purplish inside, persistent, free. Petals none. Stamens 5 60 , inserted on the calyx. Styles 3-5, separate. Pod 3-5-celled, many-seeded, circumscissile, the upper part falling off as a lid. - Esually prostrate maritime herbs, with succulent stems, opposite leares, and axillary or terminal flowers. (An umexplained name.)

1. S. pentándrum, Ell. Annual, procumbent or sometimes erect; leares oblong- to obovate-spatulate, obtuse; flowers sessile; stamens $5 . \quad$ (S. Portulacastrum, Gray, Manual, not L.) - Sea-coast, N. J. to Fla.

\section{MOLL Ù GO, L. IXDAX-CHICKWEED.}

Sepals 5 , white inside. Stamens hypogynous, 5 and alternate with the sepals, or 3 and alternate with the 3 cells of the ovary. Stigmas 3. Capsule 3-celled, 3-valved, loculicidal, the partitions breaking away from the many-seeded axis. - Low homely annuals, much branched; the stipules obsolete. (An old Latiı name for some soft plant.)

M. verticillata, L. (CArpet-weed.) Prostrate, forming patelies; leaves spatulate, clustered in whorls at the joints, where the l-flowered pedicels form a sort of sessile umbel; stamens nsually 3. - Sandy river-banks, and cultivated grounds. June-Sept. (An immigrant from farther south.)

\section{Order 48. Umbellífer $A$ e. (Parsley famly.)}

Herls, with small flowers in umbels (or rarely in heads), the calyx entirely adhering to the 2-celled and 2-ovuled ovary, the 5 petals and 5 stamens inserted on the disk that crowns the ovary and surrounds the base of the 2 styles. Fruit consisting of 2 seel-like dry carpels. Limb of the calyx obsolete, or a mere j-toothed border. Petals either imbricated in the bud or valvate with the point inflexed. 'The two carpels (called mericarps) cohering by their inner face (the commissure), when ripe separating from each other and usually suspended from the summit of a slender prolongation of the axis (carpophore); each earpel marked lengthwise with 5 primary ribs, and often with 4 intermediate (secondary) ones; in the inter- 
tices or intervals between them are commonly lodged the oil-tulus (vitta), which are longitudinal canals in the substance of the fruit, containing aromatic oil. ('These are best seen in slices male across the fruit.) Sced suspended from the smmmit of the cell, anatropus, with a minute embrvo in hard albumen. - Stems usually hollow. Leaves alternate. mostly compound, the petioles expanded or sheathing at base; rarely with true stipules. Umbels usually compound, in which case the secondary ot:es are termed umbellets: the whorl of bracts which often subtends the crenteral umbel is the involucre, and those of the umbellets the inrolucels. The base of the styles is frequently thickened and cushion-like, and called the stylopodium. In many the flowers are dichogamous, i. e. the styles are protruled from the bud some time before the anthers develop, - an arrangement for cross-fertilization. - A large family, some of the plants innocent and aromatic, others with very poisonous (acricl-narcotic) properties. The flowers are much alike in all, and the fruits, inflorescence, etc., likewise exhibit comparatively small diversity. The family is consequently difficult for the young student.

I. Frnit with the secondary ribs the most prominent, wingerl and armed with barbed or hooked prickles, the primary ribs filiform and bristly.

1. Daucus. Calyx-teeth obsolete. Fruit flattened dorsally. Seed-face flat.

2. Caucalis. Calyx-teeth promincnt. Fruit flattened laternlly. Sced-face deeply suleate.

II. Fruit with primary ribs only (hence but 3 dorsal ones on each carpel).

* Fruit strongly flattened dorsally, with the lateral ribs prominently winged.

+ Caulescent branching plants, with white flowers.

++ Lateral wings distinct; oil-tubes usually more than one in the intervals.

3. Angelica. Stylopodium mostly depressed, lut the disk proninent and crenulate Dorsal ribs strong. Stout perennials, with mostly coarsely dirided leaves.

4. Conioselinum. Stylopodium slightly conical. Dorsal ribs prominent. Tall slender glabrous perennial; leaves thin, finely pimately compound.

++ ++ Lateral wings closely contiguous; oil-tubes solitary ; stylopndium thick-eonieal.

5. Tiedemannia. Dorsal ribs apparently 5 , filiform. Sinooth swamp herbs with leaves few or relnced to hollow cylindrical petioles.

6. Heracleum. Dorsal ribs filiform, the broad wings with a marginal nerve. Oil-tubes obclavate. Petals ennspicuous. Tall stout perennials, with large leaves.

+ + Caulescent branching plants, with depressed stylopoliun and yellow flowers.

7. Pastinaca. Fruit with filiform dorsal ribs, thin wings, and solitary oil-tubes.

8. Polytaenia. Fruit with a thick eorky margin, obscure dorsal ribs, and very numerous oil-tubes.

+++ Aeaulescent or nearly so, with filiform clorsal ribs, thin wings, and no stylopodium.

9. Peucedaumm. Flowers white or yellow. Low western plants, of dry ground, with thick roots and fincly dissected leaves.

* Fruit not flattened either way or but slightly, neither prickly unr scaly.

- Ribs all conspicuously winged : stylopodium depressed or wanting

10. Cymopterus. Low and glabrous, mostly cespitose perennials, with pimately compound leaves and white flowers. Oil-tubes 1 to several. Western.

11. Thasplum. Tall peremials, with tomately divideul or simple leaves, and yellow flowers (rarely lurple). Oil tubes solitury 
+ - Ribs all prominent and equal but not winged; flowers white.

12. Ligusticum. Ribs acute, with broad intervals. Stylopodium conical. Oil-tubes nu० merous. Smooth perennials, with large compound leares.

13. Ethusa. Ribs very broad and corky, acute. Stylopodiun depressed. Oil-tubes solitary. Introduced annual.

14. Colopleurum. Ribs thick, corky (mostly obtuse). Oil-tubes solitary, adherent to the seed, which is loose in the pericarp. Stout glabrous sea-coast perennial.

+++ Dorsal ribs filiform, the lateral very thick and corky; oil-tubes solitary.

15. Crantzia. Small glabrous creeping perenuials, rooting in the mud, with small simple unbels and leaves reduced to hollow eylindrical jointed petioles.

*** Fruit flattened laterally.

+ Carpels depressed dorsally ; fruit short.

+ Seed-face flat; flowers mostly yellow.

16. Fœnicultum. Ribs prominent. Oil-tubes solitary. Stout aromatic herb, with filiformdissected leaves

17. Pimpinella. Ribs filiform. Cil-tabes numerous. Glabrous perennials, with conn. pound leaves.

+* ++ Seed-face concave; flowe:s white (yellow in n. 20); ribs filiform or obsolete.

1. Eulopluus. Oil-tuhes numerous. Stylopodium conical. Glabrous perennials from fascieled tubers, witi pinnately compound leaves.

19. Anthriscas. Fruic linear, long-beaked, withont ribs or oil-tubes, and with conical stylopodium. Leaves ternately decompound.

20. Bupleurum. Fruit oblong, with slender ribs, no oil-tubes, and prominent flat stylopodium. Leaves simple, perfoliate.

+ + Carpels terete or slightly Hattened laterally; flowers white (except n. 24).

++ Seed-face flat (or somewhat concave in n. 28); fruit short.

$=$ Leaves 3 -foliolate; stylopodium conical; oil-tubes solitary.

21. Cryptotrenia. Rils obtuse, equal ; fruit linear-oblong.

$==$ Leaves once pinuate ; stylopodium depressed ; oil-tubes numerous. Aquatic perennials.

¿. Sium. Fruit ovate to oblong ribs prominent, corky, nearly equal.

23. Berula. Fruit nearly globose; ribs inconspicuous; pericarp thick and corky. $===$ Leaves decompound. Oil-tubes solitary (none in n. 27). Perennials.

24. Zizia. Ribs filiform; stylopodium none. Flowers yellow.

2.5. Carum. Rils filiform or inconspicuons; stylopodium short-eonical. Leaf-segments filiform. Roots tuberous.

26. Cicuta. Ribs flattisll, corky, the lateral largest. Marsh perennials, with serrate leaflets, the veins often running to the notches.

27. Rgopodium. Ribs filiform; oil-tubes none; stylopodium conical. Leaves biternate. $====$ Leaves finely dissected; oil-tubes solitary. Very slender annuals.

2९. Leptocaulis. Fruit bristly or tuberculate, with rather proninent equal ribs.

2?. Discopleura. Dorsal ribs filiform, the lateral very thick and corky.

++ ++ Seed-face concave; fruit ovate, glabrous, with depressed stylopodium, and no oil-tubes.

30. Conium. An introduced biennial, with spotted stems, and large decomponnd leaves.

$+++\leftrightarrow$ Seed-face concave. Fruit linear-oblong, with conical stylopodium.

31. Chaerophyllum. Fruit glabrous, with small mostly solitary oil-tubes.

32. Osmorrhiza. Fruit bristly, with oil-tnbes obsolete. +++ Carpels (as well as fruit) strongly flattened laterally.

++ Seed lunate, deeply sulcate on the face; umbels compound, leafy-bracted.

33. Erigenia. Fruit nearly orbicular, with numerons oil-tules. Low, nearly acaulescent. from a deep-seated tuber. Leaves ternately deconıpound. 
++ + Seecl straight, not suleate ; umbels simple.

34. Hydrocotyle. Fruit more or less orbicular, with no cil tules. Low perennials, in or near water, with crecping stems, and peltite or renifurm leares.

**** Fruit obovoid or globose, densely jrickly or sealy.

35. Eryngium. Flowers sessile in dense bracteate heads, white or blue. Icaves mustly rigidl and more or less spinose.

36. Sanicula. Flowers in irregularly compound few-rayed umbels, yellow. Leaves palmate.

\section{D A Ù C US, Tourn. Carrot.}

Calyx-teeth obsolete. Fruit ollong, flattened dorsally; stylopolium depressed; carpel with 5 slemer bristly primary ribs and 4 winged secomlary ones, each of the latter bearing a single row of barbed prickles; oil-tubes solitary under the secondary ribs, two on the eommissural sicle; sect-fare somewhat concave or almost Hat. - Bristly annuals or biennials, with pinnately decompound leaves, foliaceous and eleft involucral bracts, and white flowers in compound umbels which hecome strongly concave. ('The ancient Gireek name.)

D. Cınòrı, L. Biennial; stem bristly ; ultimate leaf-segments lauceolate and cuspidate; rays numerous. - Naturalized everywhere, from Liu.

\section{CA U C À L I S, L.}

Calyx-teeth prominent. Fruit ovate or oblong, flattenerl laterally; stylopodium conical; prickles barberl or hooked ; seed-face deeply sulcate. (1therwise as I)ancus. - ( )ur species annual. (The ancient Greek name.)

C. xonòsı, Hudson. Decumbent, branching only at base, stens $1-2^{\circ} \operatorname{long}$, retrorsely hispid; umbels naked, opposite the leaves and nearly sessile, of 2 or 3 very short rays. - Md., Iowa, and sonthward. (Nitt. from Lu.)

C. Axtnnísces, Hulson, has 1-2-pinnate leaves with broal leaflets, and more regularly compounded umbels. - Ohio, etc. (Nat. from Eu.)

\section{A NGÉLICA, L.}

Calyx-teeth obsolete. Fruit strongly flattened dorsally; primary ribs very prominent, the laterals extended into broal distinct wings, forming a doublewinged margin to the fruit; oil-tules one to several in the intervals or indefinite, 2 to 10 on the commissure. - Stout pereunials, with ternately or pinnately compound leaves, large terminal umbels, scanty or no involucres, small manyleavel involucels, and white or greenish flowers. (Named angelic from its cordial and medicinal properties.)

* Seed adherent to the pericarp; oil-tubes one to several in the interials ; uppermost leaves mostly reduced to large influted petioles.

1. A. Curtísii, Buckley. Glabrons; leaves twice ternate or the divisions quinate; leaflets thin, ovate-lanceolate $\left(1-3^{\prime}\right.$ broad), sharply and irregularly toothed; fruit glabrous, $1 \frac{1}{2}-3^{\prime \prime}$ broad; oil-tubes mostly one in the intervals (sometimes 2 or 3 ). $-\Delta$ long the Alleghanies from I'enn. to N. C. Aug.

2. A. hirsùta, Muhl. Pubescent above; leaves twice pinnately or ternately clivided; leaflets thickish, laneeolate to olulong (5-10" brond), serrute; fruit pubescent, $2^{\prime \prime}$ broal ; oil-tubes $3-6$ in the intervals. (Arehangelica hirsuta, Torr. \&. Gray.) - Dry gromul, Conn. to Minn., 'Tenn., am Fla. July.

* * Seed loose; oil-tubes indefinite $(25-30)$; upper petioles not so prominont.

3. A. atropurpùrea, L. Very stout, glahrons throughout, with dark purple stem; leaves 2-3-ternately diviled, the pinuate segments of $5-7$ lan. 
ceolate to ovate leaflets ( $1-1^{\frac{1}{2}}$ broad), sharply mucronate-serrate. (Archangelica atropurpurea, Hoffin.) - River-banks, Lab. to Del., Ill. and Minn. June.

\section{CON I O SELìn U M, Fisch. Hemlock-Parsley.}

Calyx-teeth obsolete. Stylopodium slightly conical. Fruit oval, flattened dorsally, glabrous, the dorsal ribs very prominent, the lateral ones extended into broad wings; oil-tubes $1-4$ in the intervals, 4-8 on the commissure; seed slightly concave on the inner face. - Tall slender glabrous perennial, with finely 2-3-pinnately compound leaves, few-leaved involucre or none, involucels of elongated linear-setaceous bractlets, and white flowers. (Compounded of Conium and Selinum, from its resemblance to these genera.)

1. C. Canadénse, Torr. \& Gray. Leaflets pinnatifid; wings nearly as broad as the seed; oil-tubes $2-3$ in the intervals, sometimes 1 or 4 . - Swamps and cold cliffs, from Maine to Minn., southward to N. C. (in the higher mountains), Ind., Ill., and Mo. Aug. - Oet.

\section{TIEDEMÁ N N I A, DC.}

Calyx-teeth evident. Fruit orate to obovate, flattened dorsally; dorsal ribs filiform, the lateral broadly wingerl, closely contiguous and strongly nerved next to the body (giving the appearance of 5 dorsal ribs); oil-tubes solitary in the intervals, 2-6 on the commissure; stylopodium short, thick-conical. Glabrous erect aquatic herbs, with leaves reduced to petioles or of few narrow leaflets; involucre and involucels present, and flowers white. (Dedicated to the anatomist Prof. Tiedemann, of Heidelberg.)

1. T. teretifolia, DC. Stem hollow, $2-6^{\circ}$ high; leaves reduced to cylindrical hollow pointed nodose petioles; oil-tubes filling the intervals. - Ponds and swamps, Del. to Fla., and west to La. Aug., Sept.

2. T. rígida, Coult. \& Rose. (Cowbuxe.) Stem $2-5^{\circ}$ high; leaves simply pinnate, with 3-9 linear to lanceolate entire or remotely toothed leaflets; oil-tubes mostly small. (Archemora rigida, DC.) - Swamps, N. Y. to Minn., south to the Gulf. Aug. Poisonous; roots tuberiferous.

\section{H E A C L E U M, L. Cow-Parsxip.}

Calyx-teeth minute. Fruit broadly oval or obovate, like Pastinaca, but with a thick conical styloporlium, and the conspicnous obclarate oil-tubes extending scarcely below the middle. - Tall stout perennial, with large ternately compound leaves, broad umbels, deciduous involucre, and many-leaved involucels, white flowers, and obcordate petals, the outer ones commonly larger and 2-cleft. (Dedicated to Hercules.)

1. H. lanàtum, Michx. Woolly; stem grooved, 4-8 high; leaflets broad, irregularly cut-toothed. - Wet ground, Newf. to the Pacific, and southward to N. C., Ky., and Kan. June.

\section{PASTIN À C A, L. PARSNiP.}

Calyx-teeth obsolete. Fruit oval, very much flattened dorsally; dorsal ribs filiform, the lateral extended into broad wings, which are strongly nerved toward the outer margin; oil-tubes small, solitary in the intervals, $2-4$ on the conmissure ; stylopodium depressed. - Tall stout glabrous biennial, with pin- 
nately compound leares, mostly no involuere or involucels, and yellow flowers. (The Latin name, from pastus, food.)

P. Sativa, L. Stem grooved; leaflets ovate to oblong, cut-toothed.Introduced everywhere. ( $\Lambda$ dv. from Eu.)

\section{POLYT庇NIA, DC.}

Calyx-Leeth conspicuous. Fruit obovate to oval, much flattened dorsilly; dorsal ribs small or obscure in the depressel back, the lateral with broal thick corky closely contiguous wings forming the margin of the fruit; vil-tubes 12-18 about the seed and many scattered through the thick corky pericarp. A perennial mostly glabrous herb, with 2-pinnate leaves (upper opposite and 3-cleft), the segments cuneate and incised, no involncre, narrow involucels, and

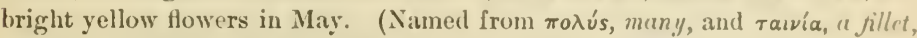
alluding to the numerous oil-tubes.)

1. P. Nuttàllii, 1)C. Plant $2-3^{\circ}$ high; pedicels and involucels pubescent. - Barrens, Mich. to N. Ala., west to the liocky Mts.

\section{PEUCEDAN UM, I.}

Calyx-teeth mostly olsolete. Fruit roundish to oblong, much flattened dorsally; dorsal rilis filiform and approximate; the lateral extencled into broad elosely coherent wings; oil-tubes $1-4$ in the intervals, $2-6$ on the commissure. - I)ry ground acaulescent (or short caulescent) herbs, with fusiform roots, dissected leaves, no involucre, yellow or white flowers, and stylopodium depressed or wanting. (The ancient Greek name.)

1. P. nudicaùle, Nutt. P'ubescent, with peduncles $3-8^{\prime}$ high; leares bipinnate, the small oblong segments entire or toothed; involucels of scurious-margined (often purplish) lanceulute bractlets; flourers uhite or pinkish; finit almost round, emarginate at base, glulirous, with wings liardly as broat as the body, and indistiuct or obsolete dorsal ribs; oil-tubes solitary in the intervals. - Minn. to Iowa aul Kan., and westwart. One of the earliest spring bloomers.

2. P. fœniculàceum, Nutt. 'Tomentose or glabrous, with peduncles 8-12' Jong; leures finely dissected, with short filiform segments; involucels gamophyllous, 5- 7-cleft, with conspicuously hairy margins; flourers ycllour ; finct broadly oblong, glabrous, with wings half as broad as the body, and prominent dorsal ribs; oil-tubes $1-3$ in the intervals. - Minn. to 'Tex. March $-\Lambda$ pril.

3. P. villosum, Nutt. More or less puhescent throughout, $3-8^{\prime}$ high ; leaves fincly dissected, with rery uumerous narrou crouded seyments; imrolucils of ovote to linear bractlets; flowers yellow; finit oenl, with wings half as brout as the boly, and prominent dorsul ribs: vil-tulus $3 \mathrm{or}^{\circ}+$ in the interrals. - Minn. to Neb. and Dak., southwestward to Ariz. lioot much clongated.

\section{CYMÓ PTERUS, Raf.}

Calyx-teeth more or less prominent. Frnit usnally globose, with all the ribs conspicuonsly winged; vil-tules one to several in the intervals, $2-8$ (n the commissure. Stylopodim depressed. Sech-face slightly concave.Mostly low (often cespitose) glabruus perennials, frum a thick elongated rout, with more or less pinnately compound leaves, with or withont an involucre,

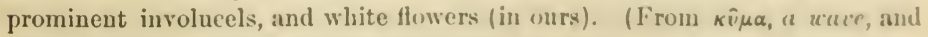
$\pi \tau \in \rho o ́ \nu, a$ wing, referring to the often unlulate wings.) 
1. C. glomeràtus, Raf. Low $\left(3-8^{\prime}\right)$, with a short erect caudex bearing leaves and peduncles at the summit, glabrous; rays and pedicels very short, making a compact cluster; involucre none; involucel of a single palmately 5 - 7parted bractlet ; fruit globose (3-4" in diam.) ; wings rather corky ; oil-tubes 4 or 5 in the intervals. - Minn. and IVisc. to Iowa and Ark., and westward.

2. C. montànus, Torr. \& Gray. Of similar habit ( $1-6^{\prime}$ high $)$, glaucous and mostly glabrous; rays $3-9^{\prime \prime}$ long, pedicels very short; involucre and involucels of mostly broad membranaceous usually green-reined bracts (more or less united); fruit oblong to orbicular in outline (3-6" long); wings thin ; oiltubes $1-3$ in the intervals. - Neb. to central Kan., Tex., and westward. A pril.

\section{THá S P I U M, Nutt. Meadow-Parsnip.}

Calyx-teeth conspicnous. Fruit ovoid to oblong, slightly flattened dorsally; carpel with 3 or 4 or all the ribs strongly winged; oil-tubes solitary in the intervals, 2 on the commissure. Stylopodium wanting; styles long.-Pe:ennials $\left(2-5^{\circ}\right.$ high), with ternately divided leaves (or the lower simple) and broad serrate or toothed leaflets, mostly yellow flowers, and all the fruit pedicelled. (Name a play upon Thapsia, so called from the island of Thapsus.)

1. T. aùreum, Nutt. Glabrous; root-leaves mostly cordate, serrate; stemleares simply ternate (rareily biternate); leaflets ovate to lanceolate, round or tapering at base, serrate; flowers deep yellow; fruit globose-ovoid, about 2" long, all the ribs equally uinged. - Thickets and woodlands, throughout the Atlantic States and west into the Miss. Valley. Fl. in summer and maturing fruit in late summer or antumn. Very variable, an extreme form being

Var. trifoliàtum, Coult. \& Rose. Leaves or leaflets crenate or crenately toothed. (T. trifoliatum, Gray, Man., in part.) - Ohio to IIl., westward to Oregon. The common western form.

Var. atropurpùreum, Coult. \& Rose. Petals dark-purple. ('T. trifoliatum, var. atropurpureum, Gray, Man.) - Same range as the species.

2. T. barbinode, Nutt. Loosely brancher, pubescent on the joints, sometimes puberulent in the umbels; leaves 1 -3-ternate; leaflets orate to lanceolate, acute, with cuneate base, coarsely cut-serrate, often ternately cleft or parted; flowers light yellow; fruit broadly oblong, about $3^{\prime \prime}$ long and $2^{\prime \prime}$ broad, with mostly 7 prominent wings. - Banks of streams, N. Y. to Minn., and southward. May - June. - Var. Axg ustifò Lic y, Coult. \& Rose, has narrower, more sharply cut leaflets, and fruit more or less puberulent. - I'enn. to Ill.

3. T. pinnatifidum, Gray. Resembling the last, but puberulent on the branchlets, umbels, and fruit, weth fewer leaves; leaflets 1-2-pinnatifid, the lobes linear or oblong; one or two leaves near the base often very large and longpetioled; flowers light yellow; fruit oblong, $1 \frac{1}{2}-2 \frac{1^{\prime \prime}}{2}$ long and $1-1 \frac{1}{2}$ " broad, all the ribs winged, generally three of them narrowly so. (T. Walteri, Shuttleu. in herb.) - Barrens and mountains, Ky. to Tenn. and N. C.

\section{LI GÚSTICU M, L. Lovage.}

Calyx-teeth obsolete. Fruit oblong or ovate, flattened laterally if at all, glabrous; carpels with prominent equal acute ribs and broad intervals; oiltubes 2-6 in the intervals, $6-10$ on the commissure. Stylopodium conical. - Smooth perennials, from large aromatic roots, with large ternately com- 
pound leares, mostly no involucre, involucels of narrow bractlets, and whito flowers in large many-rayed umbels. (Niumed from the country Liguriu, whero the officinal Lorage of the garlens alounds.)

1. L. actæifölium, Michx. (Noxno. Axfibuco.) Stem stont, branched above $\left(2-6^{\circ}\right.$ high $)$; leaves very large, $3-4$-ternate; leajlets broadly oblemy (25 'long), coursely serrate; fruit orate $\left(2-3^{\prime \prime}\right.$ long); seed with angled back. kich ground, s. l'enn. to Ky., southwarl to the Gulf.

2. L. Scóticum, L. (Scotci Lovage.) Stem simple (1-20 high);

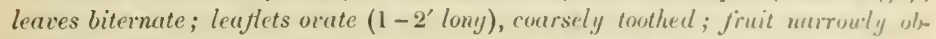
lony $(4-5$ "lony); seed with round hack. - Salt marshes, along tho coast from E. Conn. northward. Ang. (Ein.)

\section{3. 无TH Ù SA, I. Fool's Parstex.}

Calyx-teeth obsolete. Fruit orate-glohose, slightly flattened dorsally ; arpel with 5 thick slarp ribs; oil-tubes solitary in the intervals, 2 on the coninnis:mre. - Poisonous amnals, with 2-3-ternately compound leaves, divisions pinnate, ultimate segments small and many cleft, no involucre, long narrow involucels, and white flowers. (Name from $\alpha$ l $\theta \omega$, to bum, from the acrid taste.)

再. Crxגpius, I. A fetid, poisonous European herb, in cultivated grounds, from $N$. Eng. and Yenn. to Minn. June-Aug.

\section{CEL O P LE U R U M, Lelleb.}

Calyx-teeth obsolete. Fruit globose to oblong, with very prominent nearly equal thick corky ribs (none of them winged); oil-tubes solitary in the intervals and under the ribs, 2 on the commissure. Seed loose in the pericarp. - Stunt glabrous (or inflorescence puberulent) sea-coast perennial, with 2-3-ternate leaves on very large inflated petioles, few-leaved decidnous involucre, involucels of numerous small linear-lanceolate bractlets (rarely conspicuns or even leaf-like), and greenish-white flowers in many-rayed umbels. (From коЋ̈os, hollow, and $\pi \lambda \in v \rho o ́ \nu, a$ rib.)

1. C. Gmélini, Lerleb. Stem $1-3^{\circ}$ high; leaflets ovate, irregularly cutserrate $\left(2-2 \frac{1}{2}^{\prime}\right.$ long); fruit $2-3 \frac{1}{2}^{\prime \prime}$ long. (Archangelica Gmelini, $I C^{\prime}$.) Rocky coasts, Mass. to Greenland.

\section{CRÁ NTZIA, Nutt.}

Calyx-teeth small. Fruit globose or slightly flattened laterally ; dorsal rilis filiform, the lateral thick and corky; oil-tubes solitary in the intervals, 2 on the commissure. - Small perennials, creeping and rooting in the mud, with hollow cylindrical or awl-shaped nodose petioles in place of leaves, simple fewflowered umbels, and white flowers. (Named for Prof. Heury John Crantz, an Anstrian botanist of the 18th century.)

1. C. lineàta, Nutt. Leaves very obtuse, 1-3' long, 1-2" loroal ; fruit $\mathbf{l}^{\prime \prime}$ long, the thick lateral wings forming a corky margin. - In lorackish marshes along the coast, from Mass. to Miss. July. Very willely distributed.

\section{FG $\mathbf{N}$ Í U L U M, Adans. Fixier.}

Calyx-teeth obsolete. Fruit oblong, glabrous, with prominent ribs aul solitary oil-tubes. - Stout glalirous aromatic lierb, with leaves dissected into 
numerous filiform segments, no involucre nor involucels, and large umbels of yellow flowers. (The Latin name, from foenum, hay.)

F. officixale, All., the cultivated fennel from Europe, has become naturalized along the shores of Mcl. and Va., and is a common escape.

\section{PIMPINELLA, L.}

Calyx-teeth obsolete. Fruit oblong to ovate, glabrous, with slender equal ribs, numerous oil-tubes, and depressed or cushion-like stylopodium. - Glabrous perennials, with ternately or pinnately compound leaves, involucre and involucels scanty or none, and white or yellow flowers. (Name said to be formed from bipinmula, referring to the bipinnate leaves.)

1. P. integérrima, Benth. \& Hook. Glaucous, $1-3^{\circ}$ high, slender, branching; leaves $2-3$-ternate, with lanceolate to ovate entire leaflets; flowers yellow; fruit broadly oblong, 2" long; stylopodium small or wanting. (Zizia integerrima, $D C$.) - Rocky hillsides, Atlantic States to Minn., E. Kan., and Ark. May.

P. SixfFrAgA, L., var. wAJor, Koch. Leaves simply pinnate, with sharply toothed leaflets; flowers white; fruit oblong, l" long; stylopodium cushionlike. - Rocky shores of Delaware River; Sycamore, Uhio. (Nat. from Eu.)

\section{E Ù L OPH U S, Nutt.}

Calyx-teeth prominent. Fruit ovate or oblong, glabrous, with equal filiform ribs; oil-tubes $1-5$ in the intervals; stylopodium conical, with long recurved styles; seed-face broadly concave, with a central longitudinal ridge. - Glabrous perennials $\left(3-5^{\circ}\right.$ high $)$ from deep-seated fascicled tubers, with pinnately or ternately compound leaves, involucels of numerous narrowly lanceolate acuminate bractlets, and long-peduncled umbels of white flowers. (Name from $\epsilon \bar{v}, u^{\prime} e l l$, and $\lambda$ ó $\phi o s, a$ crest, - not well applied to a plant with no crest at all.)

1. E. Americànus, Nutt. Radical and lower stem-leaves large, 1 -2. pinnately componud, with leaflets cut into short narrow segments; upper stemleaves ternate, with narrowly linear elongated leaflets; fruit $2-3^{\prime \prime}$ long. Ohio to Ill. and Mo., south to 'Tenn. and Ark. July.

\section{A N THRísCUS, Hoffm. Cinervil.}

Calyx-teeth obsolete. Fruit linear, notched at base, long-beaked, glabrons, without rils (but beak ribher); oil-tubes none, stylopodium conical; seed-face sulcate. - Resembling Charophyllum in regetative characters. (The ancient lioman name.)

A. Cerefòliur, Hoffm. Mature fruit smooth and shining. (Chæro. phyllum sativum, L.) - Naturalized in E. Penn. (From Eu.)

\section{B U P L E U̇ $\mathbf{R}$ M, L. Thorovgh-wax.}

Calyx-teeth obsolete. Fruit oblong, with rery slender ribs, no oil-tubes, dopressed stylopolium, and seed-face somewhat concave. - Smooth annual, with ovate perfoliate entire leaves, no involucre, involncels of 5 rery conspicuous ovate mucronate bractlets, and yellow flowers. (Name from Bov̂s, an ox, and $\pi \lambda \epsilon \nu \rho \delta ́ v, a$ rib.)

B. Rotundifòlem, L., is very common in fields and cultivated ground, N. Y. to N. C., west to Mo. and Ark. (Nat. from Eu.) 


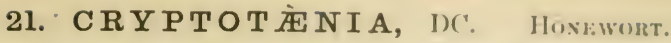

Calyx-teeth obsolete. Fruit linear-oblong, glabrous, with obtuse equal rils; oil-tubes solitary in the intervals and beneath each rib; stylopodium slenderconical; seed-face plane. $-\Lambda$ glabrous perennial, with thin 3-fuliolate leaves, no involucre, involucels of minute bractlets or none, aurl white fluwers. (Name

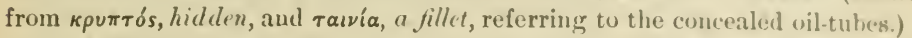

1. C. Canadénsis, 1)C. l'lant $1-3^{\circ}$ high; leaflets large, ovate $\left(2-4^{\prime}\right.$ long), pointed, doubly serrate, often lobed; umbels irregular and unequally few-rayed ; pedicels very unequal; fruit 2-3" long, often becoming curved. N. Brunswick to Ga., west to Minn., E. Kan., and 'Tex. June-Sept.

\section{Sì U in, Tourn. Water Parswil.}

Calyx-teeth minute. Fruit ovate to oblong, glabrous, with prominent corky nearly equal ribs; oil-tubes $1-3$ in the intervals; stylopodium depressed; seel-face plane. - Smooth perennials, growing in water or wet places, with pinnate leaves and serrate or pinnatifil leaflets, involucre and involucels of

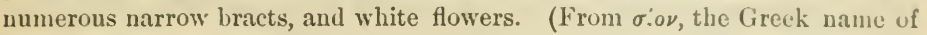
some marsh plant.)

1. S. cicutæfolium, Gmelin. Stout, 2-6 high; leuflets $3-8$ pairs, linear to lanceolate, sharply serrate and mostly acuminate, $2-5$ ' long (lower leares sometimes submersed and finely dissectedl, as in the next); fruit $1 \frac{1}{2}$ " long, with prominent ribs. (S. lineare, Michx.) - Throughout N. America.

2. S. Carsónii, Durand. Weak, $1-2^{\circ}$ high ; leaflets $1-3$ pairs, linear, sharply serrate, 1-2'long; uhen submersed or floating, ver,y thin, ovate to oblong, usually laciniately toothed or dissected, the leaf sometimes reduced to the terminal leaflet; fruit about $\mathrm{I}^{\prime \prime}$ long. - Mass., R. I., Comn., and P'enn,

\section{BÉR U L A, 'Koch.}

Calyx-teeth minute. Fruit nearly round, fmarginate at hase, glabrous; carpels nearly globose, with very slender inconspicuous ribs and thick corky pericarp; oil-tubes numerous and contignous about the sced-cavity ; seed terete. - Smooth aquatic perennial, with simply pinnate leaves and variously cut leaflets, usually conspicuous involucre and involncels of narrow bracts, and white flowers. (The Latin name of the Water-cress, of Celtic origin.)

1. B. angustifolia, Koch. Erect, $\frac{1}{2}-3^{\circ}$ high, leaflets $5-9$ pairs, linear to oblong or ovate, serrate to cut-toothed, often laciniately lobed, sumetimes crenate $\left(\frac{1}{2}-3^{\prime}\right.$ long); fruit scarcely $\mathbf{l}^{\prime \prime}$ long. (Sium angnstifolium, L.) Throughout the L. S. July, Aug.

\section{ZÍZI A, Koch.}

Calyx-teeth prominent. Fruit ovate to oblong, glabrous, with filiform rils; oil-tubes large and solitary in the broad intervals, and a small one in each rib; stylopodium wanting; seed terete. - Smooth perennials $\left(1-3^{\circ}\right.$ high $)$, with mostly Thaspium-like leaves, no involucre, involucels of small bractlets, yellow flowers, and the central fruit of each umbellet sessile. Flowering in early spring in open prairies aud upland meadows. (Named for I. B. Ziz, a Rhenish botanist.) 
1. Z. aùrea, Koch. Leaves (except the uppermost) 2-3-ternate, the radical very long-petioled; leaflets ovate to lanceolate, sharply serrate; rays 15 25 , stout ( $1-2^{\prime}$ long); fruit oblong, about 2" long. (Thaspium aureum, rar. apterum, Gray, Manual.) - Atlantic States, west to Mimn. and Tex.

Var. Bébbii, Coult. \& Rose. A more slender mountain form, with leaflets more coarsely serrate, the radical leaves smaller and more simple; rays $2-8$, slender $\left(2-3^{\prime}\right.$ loug) ; fruit oval, $1-1 \frac{1^{\prime \prime}}{2}$ long. - W. Va. and Va. to Ga.

2. Z. cordàta, DC. Radical leaves mostly long-petioled, cordate or even rounder, crenately toothed, very rarely lobed or divided; stem-leaves simply ternate or quinate, with the ovate or lanceolate leaflets serrate, incised, or sometimes parted ; fruit ovate, $1 \frac{1}{2}$ "long. (Thaspium trifoliatum, var. apterum, Gray, Manual.) - Same range as the preceding, but extending farther westward.

\section{CÁ R U M, L. CARAWAY.}

Calyx-teeth small. Fruit ovate or oblong, glabrous, with filiform or inconspicuous ribs ; oil-tubes solitary ; stylopodium conical ; seed-face plane or nearly so. - Sinooth erect slender herbs, with fusiform or tuberous roots, pinnate leaves, involucre and involucels of few to many bracts, and white (or yellowish) flowers. (Name perliaps from the country, ('aria.)

C. Cárti, L. (CAraway.) Leaves pinnately compound, with filiform divisions. - Naturalized in many places, especially northward. (Nat. from Eu.)

C. Petroselinum, Benth, the common Parsler, from Europe, with 3pinnate leaves, ovate 3 -cleft leaflets, and greenish vellow flowers, is occasionally found as an escape from cultivation. (Petroselinum sativum, Hoffm.)

\section{CI CÙT A, I. Water-HeMlock.}

Calyx-teeth prominent. Fruit oblong to nearly orbicular, glabrous, with strong flattish corky ribs (the lateral largest); oil-tubes conspicuous, solitary ; stylopodium depressed; seed nearly terete. - Smooth marsh perennials, very poisonous, with pinnately compound leaves and serrate leaflets, involucre usually none, involucels of several slender bractlets, and white flowers. (The ancient Latin name of the Hemlock.)

1. C. maculàta, L. (Spotted Cowbane Musquash Root. BeaverPorsox.) Stem stout, 2-6 ${ }^{\circ}$ high, streaked with purple; leaves $2-3$-pinnate, the lower on long petioles; leaflets lanceolate to oblong-lanceolate ( $1-5^{\prime}$ long), acuminate, coarsely serrate, the veins passing to the notches; pedicels in the umbellets numerous, very unequal; fruit broadly orate to oval, $1-1 \frac{1}{2}{ }^{\prime \prime}$ long. - Throughout the U. S. Aug.

2. C. bulbifera, L. Rather slender, 1-3 ${ }^{\circ}$ high; leaves 2-3-pinnate (sometimes appearing ternate); leaflets linear, sparsely toothed (1-2' long); upper axils bearing clustered bulblets; fruit (rare) scarcely 1" long. - Common in swamps, N. Scotia to Del., west to Minn. and Iowa.

\section{7. 无 GOPÒDIU M, I. Goutweed.}

Calyx-teeth obsolete. Fruit ovate, glabrous, with equal filiform ribs, and no oil-tubes; stylopodium conical and prominent; seed nearly terete. - A coarse glabrous perennial, with creeping rootstock, biternate leaves, sharply toothed ovate leaflets, and rather large naked umbels of white flowers. (Name

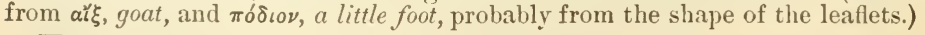

王. Podagraria, I., a common and troublesome weed in Europe, is ro ported from R. I. to Del. and E. Penn. 


\section{LEPTOCA ÙIS, Nutt.}

Calyx-teeth obsolete. Fruit very small, wate, usually bristly or tuberculate, with somewhat prominent ribs; vil-tubes solitary in the intervals ; stylopodium conical; seed-face plane or somewhat concave. - Very slender smouth hranch. ing anmuals, with finely dissected leaves (segments filiform or linear), am small white flowers in very unequally few-rayed pedunculate umbels (Name from $\lambda \in \pi \tau$ 's, slemder, and kaviós, (a stem.)

1. L. divaricatus, 1)C. Plant $1-2^{\circ}$ hight, with branches and umbels diffusely spreading, the very slender rays $\frac{1}{2}-l^{\prime}$ long and the longer perlicels often 3-6" long; fruit tuberculate, $\frac{1}{2}{ }^{\prime \prime} \operatorname{long}$. (A pium divaricatum, Benth. 5 . Ilook.) - N. C. to Fla., west to $\Lambda$ rk. and Tex.; reported from lian. $\Lambda$ pril.

2. L. pàtens, Nutt. Of similar habit, but the umbels shorter and more strict, the rays $3-6^{\prime \prime}$ long or less and the pedicels short; fruit densely sharptuberculate or nearly smooth. (Apiastrum jatens, Coult. \&. Rose.)-Central Neb. to Tex. and N. Mex.

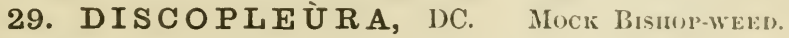

Calyx-teeth small or obsolete. Fruit ovate, glabrons: carpel with dorsal ribs filiform to broad and obtuse, the lateral very thick and corky, those of the two carpels closely contiguous and forming a dilated obtuse or acute corky band; oil-tubes solitary, stylopodium conical; seed nearly terete. - Smooth branching annuals, with finely dissected leaves, involucre of foliaceous bracts, involucels of prominent or minute bractlets, and white flowers. (Name from

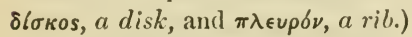

1. D. capillàcea, I)C. I'lant $1-2^{\circ}$ high (or even $\left.5-6^{\circ}\right)$; leaves dissected into filiform divisions; umbel 5-20-rayed; involucre of filiform bracts usually (left or parted, and inrolucels more or less prominent ; fruit $1-1 \frac{1}{2}$ " long, orate, acute. - Wet ground, Mass. to Fla., west to Ill., Mo., and Tex. June-Oct.

2. D. Nuttallii, DC. Similar in habit; involucral bracts short and entire; fruit very small ( $\frac{1}{2}$ "long), as broad as high, blunt. - Ill. (3) to Ark., La., and Tex.

\section{CON İ U M, L. Poison IIEMLock}

Calyx-teeth obsolete. Fruit ovate, somewhat flattened at the sides, glabrous, with prominent wavy ribs; oil-tubes nune, but a layer of secreting cells next the seed, whose face is deeply and narrowly concave. - l'oisonous lien. nial, with spotted stems, large decomponnd leaves with lanceslate pinnatifid leaflets, involucre and involucels of narrow bracts, and white flowers. (Kóveเov, the Greek name of the Ilemlock, by which criminals and philosophers were put to death at $A$ thens.)

C. Macuràtum, I. A large branching European herb, in waste places, N. King. to Penn., and west to Iowa and Minn

\section{CH A ROPHÝ LL U M, L}

Calyx-teeth obsolete. Fruit narrowly oblong to linear, notched at hase, with short beak or none, and equal ribs; oil-tubes solitary in the intervals; seed-face more or less deeply grooved. - Moist ground annuals, with teruately decom. pound leaves, pinnatifid leaflets with oblong obtuse lubes, mostly no involucre, 
involucels of many bractlets, and white flowers. (Name from $\chi \alpha i \rho \omega$, to gladden, and $\phi \dot{v} \lambda \lambda \alpha_{\nu}$, a leaf, alluding to the agreeable odor of the foliage.)

1. C. procúmbens, Crantz. More or less hairy ; stems slender, spreading $\left(6-18^{\prime}\right.$ high) ; umbels few-rayed f fruit narrowly oblong ( $2 \frac{1}{2}-3 \frac{1}{2}{ }^{\prime \prime}$ long), glabrous, contracted but not tapering at the summit, the intervals broader than the ribs. - N. Y. to N. C., west to Mich., Iowa, Ark., and Miss.

Var. Shórtii, Torr. \& Giay, has more broadly oblong to ovate (often somewhat pubescent) fruit, not at all contracted at the summit. - Ky. to Ark. and La.

\section{OS M ORRìzA, Raf. Sweet Cicely.}

Calyx-teeth obsolete. Fruit linear to linear-oblong, with prominent caudate attenuation at base, very bristly, with equal ribs; oil-tubes obsolete; seed-face concave. - Glabrous to hirsute perennials ( $1-3^{\circ}$ high) from thick aromatic roots, with ternately compound leaves, ovate variously toothed leaflets, fewleaved involucres and involucels, and white flowers in few-rayed and few-fruited umbels. (Name from ó $\sigma \mu \eta \dot{\eta}, a$ scent, and $\rho^{\prime} \zeta \zeta \alpha, a$ root.)

1. O. brevístylis, IC. Rather stout, villous-pubescent; leaves 2-3-ternate; leaflets 2-3' long, acuminate; fruit (not including the caudate attenuation) $6^{\prime \prime}$ long; stylopodium and style $\frac{1}{2}$ " lıng. - From N. Scotia westward through the Northern States, and in the mountaius to N. C. May, June.

2. O. longístylis, DC. Glabrous or slightly pubescent; like the last, but with the style $\mathrm{l}^{\prime \prime}$ long or more, and the seed-face more deeply and broadly concave. - N. Scotia to Va., and west to Tenn., E. Kan., and Dak.

\section{ERI G E I A, Nutt. Harbinger-oF-Spring.}

Calyx-teeth obsolete. Petals obovate or spatulate, fiat, entire. Fruit didymous, nearly orbicular and laterally flattened, the carpels incurved at top and bottom, nearly kidney-form, with 5 very slender ribs, and several $(1-3)$ small oil-tubes in the intervals; inner face of the seed hollowed into a broad deep cavity. - A small glabrous vernal plant, producing from a deep round tuber a simple stem, bearing one or two 2-3-ternately divided leaves, and a somewhat imperfect and leafy-bracted compound umbel. Flowers few, white. (Name from $\grave{\eta} \iota \gamma^{\prime} \in \in \in \iota$, born in the spring.)

1. E. bulbòsa, Nutt. Stem 3-9' high; leaf-segments linear-oblong; fruit $1^{\prime \prime}$ long, $1 \frac{1}{2}$ " broad. - W. New York to Md.and Tenn., and west to Wisc., S. E. Minn., aud Kan.

\section{HY D ROCÓTYLE, Tourn. IVater Pennywort.}

Calyx-teeth obsolete. Fruit strongly flattened laterally, orbicular or shieldshaped; the carpels 5-ribbed, two of the ribs enlarged and often forming a thickened margin; oil-tubes none, but usually a conspicuous oil-bearing layer beneath the epidermis. - Low, mostly smooth, marsh or aquatic perennials, with slender creeping stems, and round shield-shaped or kidney-torm leaves, with scale-like stipules. Flowers small, white, in simple umbels or clusters, which are either single or proliferous (one above another), appearing all summer. (Name from $v \delta \omega \rho$, water, and $\kappa \circ \tau \dot{\lambda} \lambda \eta, a$ flat cup, the peltate leaves of several species being somewhat cup-shaped.) 
* Pericarp thin except at the lorual cork!y don'sul und luterul ribs ; leaves roundpeltate, crenate; peduncles as long as the pretiules, frum rou ping routstocks.

- Fruit notched at base and apex; intermediute rils curk $y$.

1. H. umbellàta, I. Cimbels many-fourerel, simple (sometimes proliferous); pedicels 2-6" long; fiuit about $1 \frac{1}{2}$ "broul, strongly motehed, the dorsal ribs promineut but olutuse. - Mass. to Minn., south to thr (iulf.

2. H. Cánbyi, Conlt. \& Rose. Umlw/s 3-9-fourcrel,yrnorully froliferons: pedicels very short, but distinct; fruit ubout 2 lines brond: carpuls broader and more flattened than in the preceding, sharper marginol, the dorsil and lateral rils much more prominent; seerl section much narrower. (H. umbellata, van:? ambi gua, Gra!, Manual). - N. J. to Md.

\section{+ + Fruit not notched; intermediute rils not sorky.}

3. H. verticillàta, Thunb. T'mbels few-flowerel, proliferous, forming an interrupted spike; pedicels very short or none; fruit $1 \frac{1}{2}-2^{\prime \prime}$ brual ; dursal aud lateral ribs very prominent. (H. interrupta, Mull.) - Mass. tu Fla.

* Pericarp uniformly corky-thickened and ribs all filiform; leaves not peltate; peduncles murh shorter thun the petioles.

+ Fruit small, without secondury ribs or reticulations; involurere small or none.

4. H. Americàna, I. Stems filiform, brunching and creeping; lenves thin, round-reniform, crenate-lobed and the lobes crenate, shining; few-flowered umbels axillary and almost sessile; fruit less than $\mathrm{I}^{\prime \prime}$ broal ; internerliate ribs prominent; no oil-bearing layer; seed-section broadly oval. - Common.

5. H. ranunculotdes, L. f. Usull: floating; leaves thicker, round-reniform, 3 - 7 -cleft, the lobes crenate; peduncles $1-3$ 'long, reflexed in fiuit; capitate umbel 5-10-flowered; fruit 1-1 $\frac{1}{2}$ " broal ; ribs rather obseure; seed-section oblong. - E. Penn. to Fla., thence westward.

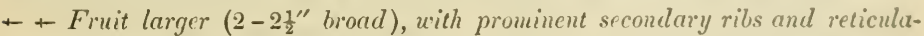
tions; the 2-4-flourered umbel subtended by turo conspicuo:s bracts.

6. H. Asiática, L. Petioles and perluncles (1-2' long) clustered on creeping stems or runners; leaves ovate-corlate, repand-toothed, thickisls; seed-section narrowly oblong. (H. repanda, Pers.) - Mcl. to Fla. and Tex. (Widely distributed in the tropics and sonthern lemisphere.)

\section{ERÝNGIU M, Touru. Enrigo.}

Calyx-teeth prominent, rigiil anul persistent. Styles sleniler. Fruit ovate or ohovate, covered with little lyvaline siales or tubercles, with no ribs, and usually 5 slender oil-tubes on each carpel. - Chicfly perenuials, with coriateuns, toothed, cut, or prickly leaves, and blue or white brated fluwers clusely sessile in dense heads. ( $\Lambda$ name used by I)ioscoritles, of uncertain origriu.)

* Stout, with parallel-veined elonguted linear thich leares.

1. E. yuccæfolium, Michx. (R.ıтtressike-Mlıster. Buttox Sxakenоoт.) Branching above, $1-6^{\circ}$ high ; leaves rigid, tapering to a point (lower sometimes $2-3^{\circ}$ long), the margins remotely listly ; heads ovate-globose ( $9^{\prime \prime}$ long), with ovate-lanceolate mostlp entire cuspilate-tipped bracts shorter than the head, and similar bractlets. - 1)ry or dimp soil, N. J. to Minn., suuth to Fla. and Tex. July-Sept. 
* * Tall and often stout; leaves thick, not parallel-veined.

2. E. Virginiànum, Lam. Slender $\left(1-3^{\circ}\right.$ high); radical and lower stem-leaves linear- to oblong-lanceolate, on long (sometimes $1^{\circ}$ long) fistulous petioles, entire or with small hooked teeth; upper leaves sessile, spiny-toothed or laciniate; heads ovate-oblong ( $6^{\prime \prime}$ long), with spiny-toothed or entire reflexed bracts, and bractlets with 3 spiny cusps (the middle one largest). - Margins of ponds and streams, N. J. to Fla. and Tex., near the coast. Ang., Sept.

3. E. Leavenwórthii, Torr. \& Gray. Stout $\left(1-3^{\circ}\right.$ high) ; lowest stemleaves broadly oblanceolate, spinosely toothed, the rest sessile and deeply palmately-parted into narrow incisely-pinnatifid spreading pungent segments; leads ovate-oblong $\left(1-1 \frac{1}{2}^{\prime} l o n g\right)$, with pinnatifid spinose bracts and $3-7$-cuspidate bractlets, the terminal ones very prominent and resembling the bracts. - Dry soil, E. Kan., Ark., and Tex.

*** Prostrate and slender, rooting at the joints, diffusely branched, with small thin unarmed leaves and very small heads.

4. E. prostràtum, Nutt. Lower leaves oblong, entire, few-toothed, or lubed at base; upper leaves smaller, clustered at the rooting joints, ovate, fewtoothed or entire (occasionally some additional trifid ones); reflexed bracts longer thau the oblong heads $\left(2-4^{\prime \prime}\right.$ long). - Wet places, S. Mo. to Fla. and Tex.

\section{SA N ÍCULA, Tourn. SAricle. Black SNakeroot.}

Calyx-teeth manifest, persistent. Fruit globular; the carpels not separating spontaneously, ribless, thickly clothed with hooked prickles, each with 5 oiltubes. - Perennial rather tall glabrous herhs, with few palmately-lobed or parted leaves, those from the root long-petioled. Umbels irregular or com. pound, the flowers (greenish or yellowish) capitate in the umbellets, perfect, and with staminate ones intermixed. Involucre and involucels few-leaved. (Name said to be from sano, to heal; or perhaps from San Nicolas)

1. S. Marylándica, L. Stem $1-3^{\circ}$ ligh; leaves 3-7-parted, the divisions mostly sharply cut and serrate; sterile flowers numerous and long-pedicelled; fruit $1 \frac{1}{2}-2^{\prime \prime}$ long, the styles longer than the prickles. - Throughout our range, south to Ga. and Tenn., west to E. Kan. and Minn. May - Aug.

Var. Canadénsis, Torr., has comparatively few and short-pedicelled sterile flowers, and styles shorter than the prickles. (S. Canadensis, $L$ ) With the last, but westward only to Minn. and E. Kan.

\section{Order 49. ARAliàceze. (Ginseng Family)}

Herbs, shrubs, or trees, with much the same characters as Umbelliferæ, but with usually more than 2 styles, and the fiuit a few-several-celled drupe. - Albumen mostly fleshy. Petals not inflexed.

\section{A R À I A, Toum. Ginseng. Wild Sarsaparilla.}

Flowers more or less polygamous. Calyx-tube coherent with the ovary, the teeth very short or almost obsolete. Petals 5, epigynous, oblong or obovate, lightly imbricated in the bud, deciduous. Stamens 5, epigynous, alternate witl the petals. Styles 2-5, mostly distinct and slender, or in the sterile 
flowers short and united. Ovary 2-5-celled, with a single anatropous ovule suspended from the top of each cell, ripening into a berry-like drupe, with as many seeds as cells. Embryo minute. - Leaves compoimol or decompunul. Flowers white or greenish, in umbels. lioots (perennial), lark, fruit, etc., warm and aromatic. (Derivation ubscure.)

§ 1. ARALIA. Flouers monaciously polygamous or perfect, the umbels usually in corymbs or panicles; styles and cells of the (blach or durk puryle) fiuit 5 ; stems herbaceous or woody; uttimate divisions of the loures pimute.

* Umbels numerous in a large compound panicle; leaves rery lurye, derompround.

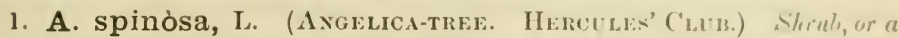
low tree; the stout stem and stalks prickly; leaflets ovate, pointed, serritte, pale beneath. - River-banks, Penn. to Ind., and south to the Gulf. July, $\mathrm{Ang}_{\mathrm{g}}$

2. A. racemósa, L. (SpIKenann.) Herbuceous; slem widely lrunched; leaflets heurt-ovate, pointed, doubly serrate, slightly downy ; umbels racemose; styles united. - Rich woodlands, N. Brunswick to Minn., south to the inountains of Ga. July. Well kuown for its spicy-aromatic large roots.

* Umbrts 2-7, corymbed; stem short, somewhut woody.

3. A. híspida, Vent. (Bristly Sarsaparilla. Wili, liliner.) stem ( $1-2^{\circ}$ high) bristly, leufy, terminating in a peduncle bearing several umbels; leaves twice pinnate; leatlets oblong-ovate, acnte, cut-serrate. - Rocky and sandy places, Newf. to Dak., south to the mountains of N. C. June.

4. A. nudicaulis, L. (WuL SARsararuLLA.) Sitem scorcely rising ont of the ground, snooth, bearing a single lony-stulked leaf ( $1^{\circ}$ highl) and a shorter naked scupe, with 2-7 umbels; leaflets oblong-ovate or oval, pointerl, serrate, 5 on each of the 3 divisions. - Moist woodlands; range of n. 3. May, June. The long horizontal aromatic roots a substitute for officinal Sarsajarilla.

§ 2. GfNSENG. Flouers dixciously polygamous; styles und cells of the red or reddish finit 2 or 3 ; stem herbuceous, low, simple, bearing a whorl of 3 palmately 3-7-foliolute leares, and a simple umbel on a slender peduncle.

5. A. quinquefolia, Decsne. \& Planch. (Grsexr.) liont large and spindle-shaped, ofien forked (4-9' long, aromatic); stem $1^{\circ}$ high ; leuthits longstulked, mostly 5, large and thin, obovate-oblong, pointed; styles mostly 2; fruit bright red. - Rich and cool woods, Vt. and IV. Conn. to Minn., south to the mountains of Ga. July.

6. A. trifolia, Decsne. \& Planch. (Dwarf Grssexg. Gmotind-xit.) Root or tuber globulur, deep in the ground (pumgent to the taste, not aromatic); stems $4-8^{\prime}$ high ; leuflets $3-5$, sessile at the summit of the leafstalk, narrowly oblong, obtuse; styles usually 3 ; fruit yellou'ish. - Rich woods, N. Ficotia to Minu., south to Ga. A pril, May.

\section{Order 50. CORNACEAE. (DOGWOOA FameY.)}

Shrubs or trees (rarely herbaceous), with apposite or allemate simple leaves. the calyx-tube coherent with the 1-2-celled neary, its limb minute, the petals (valvate in the bud) and as many stamens borne on the maryin of an epigynous disk in the perfect flowers; style one; a single anutrupous oule hanging from the top of the cell; the fruit a 1-2-seeded drupe; embruo nearly 
as long as the allumen, with large foliacenus cotyledons. - Including two genera, of which Nyssa is partly apetalous. Bark bitter and tonic.

1. Cornus. Flowers perfect, 4-merous. Leaves mostly opposite.

2. Nyssa. Flowers diœeiously polygamous, 5-inerous. Leaves alternate.

\section{CóRNUS, Tourn. CORnel. Dogwood.}

Flowers perfect (or in some foreign species diøecious). Cályx minutely 4toothed. Petals 4, oblong, spreading. Stamens 4 ; filaments slender. Style slender; stigma terminal, flat or capitate. Drupe small, with a 2-celled and 2 seeded stone. - Leares opposite (except in one species), entire. Flowers small, in open naked cymes, or in close heads surrounded by a corolla-like involucre. (Name from cormu, a horn; alluding to the hardness of the wood.)

$\$ 1$. Flowers greenish, in a head or close cluster, surrounded by a large and showy, 4-leuved, corolla-like, white or rarely pinkish involucre; fruit bright red.

1. C. Canadénsis, L. (Dwarf Cornel. Buxch-berry.) Stems low and simple $\left(5-7^{\prime}\right.$ high) from a slender creeping and subterranean rather woody trunk; leaves scarcely petioled, the lower scale-like, the upper crowded intu an apparent whorl in sixes or fours, orate or oval, pointed; leaves of the involucre ovate; fruit globular. - Damp cold woods, N. J. to Ind. and Minn., and the far north and west. June.

2. C. flórida, L. (Flowerixg Dogwoov.) Tree $12-40^{\circ}$ high; leaves ovate, pointed, acutish at the base; leaves of the involucre obcordate (1 $\frac{1}{2}^{\prime}$ long); fruit oval. - I)ry woods, from S. New Eng. to Ont. a.:d S. Minn., south to Fla. and Tex. May, June. Very showy in flower, searcely less so in fruit.

§ 2. Flowers white, in open flat spreadiny cymes; involucre none; fruit spherical ; leaves all opposite (except in n. 9).

* Pubescence woolly and more or less spreading.

3. C. circinàta, L'Her. (Round-leaved Cornel or Dogwood.) Shrub $6-10^{\circ}$ high ; branches greenish, warty-dotted; leaves round-oval, abruptly pointed, woolly beneath $\left(2-5^{\prime}\right.$ broad); cymes flat; fruit light blue. - Copses, in rich or sandy soil, or on rocks, N. Scotia to Dak., south to Va. and Mo. June.

4. C. serícea, L. (Silky Convel. Kixsikinsik.) Shrub 3-10 high; branches purplish; the branchlets, stalks, and lower surface of the narrowly ovate or elliptical pointed leaves silky-downy (often rusty), pale and dull; cymes flat, close; calyx-teeth lanceolate; firuit pale blue. - IVet places, Canada to Dak., south to Fla. and La. June.

5. C. asperifolia, Michx. Branches brounish; the branchlets, etc., roughpubescent; leaves oblong or ovate, on short petioles, pointed, rongh with a harsh pubescence above, and douny beneath; calyx-teeth minute; fruit white. (C. Drummondii, $M e y$.$) - Dry or sandy soil, N. shore of L. Erie to Minn. and the$ Gulf. May, June. A rather tall shrub.

\section{* Pubescence closely appressed, straight and silky, or none.}

6. C. stolonífera, Michx. (Red-osier Dogwood.) Branches, especially the osier-like shoots of the season, bright red-purple, smooth; leaves ovate, rounded at base, abruptly short-pointed, roughish with a minute close pubescence 
on both sides, whitish underneath; cymes small and flat, rather few-flowered, smooth; fruit white or lead-color. - Wet places; common, especially northward. Multiplies freely by prostrate or subterranean suckers, and forms broad clumps, $3-6^{\circ}$ high. June.

7. C. strícta, Lam. (Strff Conxel.) I shruh 8-150 high; branches brownish or redilish, smooth; leaves ovate or orate-tuncrolute, taper-pointed, acutish at base, glabrous, of nearly the same hue both sides; cymes loosr, flattish; anthers and fruit pale blue. - Swamps, Va. to Ga. and Fla. A pril, May.

8. C. paniculàta, L'Her. (Puxicher Coknel.) Sihrub 4-80 high, much branched; branches gray, smooth; leaves orate-tanceolate, taper-puintoul, acute at base, whitish beneath but not downy ; rymes conver, loose, often panicled; finit white, depressed-globose. - Thickets and river-banks. June.

9. C. alternifolia, L. f. Shrub or tree $8-25^{\circ}$ high; brunches gremish streaked with white, the alternute leates clustered at the ends, ovate or oval, longpointed, acute at base, whitish and minutely pubescent beneath; cymes very broad and open; fruit deep b/ue on reldish stalks. - IIillsides in copses, $\dot{N}$. Brunswick to Minn., south to Ga. aud Ala. May, June.

\section{NÝ S S A, L. Túpeo. Pepperidge. Sotr-Gum Tree.}

Flowers diceciously polygamous, clustered or rarely solitary at the summit of axillary peduncles. Stam. Fl. numerous in a simple or compound denso cluster of fascicles. Calyx small, 5-parted. l'etals as in fertile flower or none. Stamens 5-12, oftener 10, inserted on the outside of a convex disk; filaments slender; anthers short. No pistil. Pist. Fl. solitary, or 2-8, sessile in a bracted cluster, much larger than the staminate flowers. Calyx with a very short repand-truncate or minutely 5 -toothed limb. I'etals very small and fleshy, deciduous, or often wanting. Stamens 5-10, with perfect or imperfect anthers. Style elongated, revolute, stigmatic down one side. Ovary l-celled. 1)rupe ovoid or oblong, with a bony and grooved or striate l-celled and 1-seeded stone. Trees with entire or sometimes angulate-toothed leaves, which are alternate, but mostly crowded at the ends of the branchlets, and greenish flowers appearing with the leaves. (The name of a Nymph: "so called because it [the original species] grows in the water.")

1. N. sylvática, Marsh. (Tupelo. Pepreninge. Buck or Sorr Gcм.) Middle-sized tree, with horizontal branches; leaves oval or obovate, commonly acuminate, glabrous or villous-pubescent when young, at least on the margins and midrib, shining above when old $\left(2-5^{\prime}\right.$ long); firtile floutrs $3-8$, at the summit of a slender peluncle; finit oroid, acid, bluish-black (about $\frac{1^{\prime}}{2}$ long). ( $\mathrm{X}$. multiflora, $W^{\prime}($ ung.) - Rich soil, either moist or nearly dry, S. Maine and N. Vt. to Mich., south to Fla. and Tex. April, May. Leaves turning bright crimson in autumn. Wood firm, close-grained and very unwedgeable, on aceonnt of the oblique direction and crossing of its fibres.

2. N. uniflora, Wang. (LARgE Tupkro.) A large tree; leaves oblong or ovate, sometimes slightly corlate at base, long-petioled, entire or angulate-toothed, pale and downy-pubescent beneath, at least when young ( $4-12$ ' long); fertile flower solitary on a slember pecluncle; fruit oblong, blue (1' or more in length). - Deep swamps, S. Va. to S. Ill. and Mo., south to Fla. and 'Tex. A pril. Wood soft; that of the ruots very light and spong: 


\section{Division II. GAMOPETALOUS DICOTYLEDONOUS PLANTS.}

Floral envelopes consisting of both calyx and corolla, the latter composed of more or less united petals, that is, gamopetalous.*

\section{Order 51. CAPRIfoliàce $\boldsymbol{A}$. (Honeysuchle Family.)}

Shrubs, or rarely herbs, with opposite leaves, no (genuine) stipules, the calyx-tube coherent with the 2-5-celled ovary, the stamens as many as (one fewer in Linnæa, doubled in Adoxa) the lobes of the tulular or rotate corolla, and inserted on its tube. - Fruit a berry, drupe, or pod, 1- severalseeded. Seeds anatropous, with small embryo in fleshy albumen.

Tribe I. SAMBUCEA. Corolla wheel-shaped or urn-shaped, regular, deeply 5-lobed. Stigmas 3-5, sessile or nearly so. Inflorescence terminal and eymose.

* Dwarf herb, witlı stamens doubled and flowers in a capitate cluster.

1. Adoxa. Fruit a dry greenish drupe, with $3-5$ cartilaginous nutlets. Cauline leaves a single prair and ternate.

* Shrubs, with stamens as many as corolla-lobes and flowers in broad compound cymes.

2. Sambucus. Fruit berry-like, containing tlıree small seed-like nutlets. Leaves pinnate.

3. Viburnum. Fruit a 1-celled 1-seeded drupe, with a compressed stone. Leaves simple.

Tribe II. LONICEREA. Corolla tubular, often irregular, sometimes 2-lipped. Style slender ; stignna capitate.

* Herbs, with axillary flowers.

4. Triosteum. Stamens 5. Corolla gibbous at the base. Fruit a 3 celled drupe. Erect; flowers sessile.

5. Linnzea. Stamens 4, one fewer than the lobes of the corolla. Fruit dry, 3-celled, but only 1-seeder. Creeping, with long-pedunculate twin flowers.

* * Erect or climbing shrubs, with sealy wiıter-buds.

6. Symphoricarpos. Stamens 4 or 5 , as many as the lobes of the bell-shaped regular corolla. Berry 4-celled, but only 2 -seeded ; two of the cells sterile.

7. Lonicera. Stamens 5 , as many as the lobes of the tubular and more or less irregular corolla. Berry several-seeded ; all the 2 or 3 cells fertile.

S. Diervilla. Stamens 5. Corolla funnel-form, nearly regular. Pod 2-celled, ¿-valved, many-seeded, slender.

\section{A D Ó X A, L. Moschatel.}

Calyx-tube reaching not quite to the summit of the 3 -5-celled ovary; limb of 3 or more teeth. Corolla wheel-shaped, 4-6-cleft, bearing at each sinus a pair of separate or partly muited stamens with 1-celled anthers. Style 3-5parted. Dry drupe greenish, with 3-5 cartilaginous nutlets. - A dwarf perennial herb with scaly rotstock and teruately divided leaves, the cauline a single pair. Au anomalous genus. (From $\measuredangle \delta \circ \xi o s$, obscure or insignificant.)

* In certain families, as in Ericacex, etc., the petals in some genera are nearly or quite separate. In Compositæ and some others, the calyx is mostly reduced to a pappus, or a mere border, or even to nothing more than a covering of the surface of the ovary. The student might look for these in the first or the third division; but the artificial analysis prefixed to the volmme provides for such anomalies, and will lead him to the proper orler. 
1. A. Moschatéllina, I. Sinooth, musk-scented; radical leaves 1-3. ternate, the cauline 3-cleft or 3-parted; leaflets obovate, 3 -cleft ; flowers several in a close cluster on a slender peduncle, greenish or yellowish. $-\mathrm{N}$. Iowa, Wisc., and Minn., and northward. (Eu., Asia.)

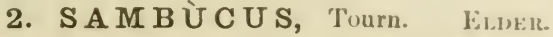

Calyx-lobes minute or olsolete. Corolla open urn-shaped, with a broadly spreading 5-cleft limb. Stamens 5. Stigmas 3. Fruit a lerry-like juicy drupe, containing 3 small seed-like nutlets. - Shrubby plants, with a rank smell when bruisel, pinnate leaves, serrate-pointed leaflets, and numerous small and white flowers in compound (ymes. (The Latin name, perhaps from $\sigma \alpha \mu \beta u ́ \kappa \eta$, an ancient musical instrument.)

1. S. Canadénsis, I. (Comsox Liberr) Stems scarcely woody (5$10^{\circ}$ high); leaflets 5-11, oblony, mostly smouth, the luwer often 3-parted; cymes fat; fruit blach-purple. - Rich soil, in open places, throughout our range, and south and west. June, July.-Pith white.

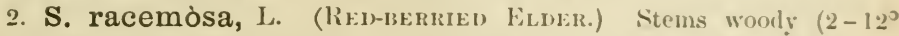
high), the bark warty; leaflets $5-7$, ovate-lunceolate, douny underneath; cymes panicled, convex or pyramidal; finit bruglut red (rarely white). (s. pubens, Michx.) - Rocky woods, N. Scotia to Ga., and westward across the continent. May ; the fruit ripening in Jume. - l'ith brown. Both species occur with the leaflets divided into $3-5$ linear-lanceolate 2-3-cleft or laciniate segments.

\section{VI B Ú R N U M, L. Arrow-Won1\%. LAlrestixts.}

Calyx 5-toothed. Corolla spreading, deeply 5-lohed. Stamens 5. Stigmas 1-3. Fruit a l-celled, 1-seeded drupe, with soft pulp and a thin-(rustacens (flattened or tumid) stone. - Shruls, with simple leaves, and white flowers in flat compound cymes. l'etioles sometimes bearing little apjendages which are evidently stipules. Leaf-buls naked, or with a pair of scales. ('The classical Latin name, of unknown meaning.)

\$ 1. Cyme radiunt, the marginal flowers neutral, with grently enlurged flat corollas as in Hydrangea; drupes coral-red turniny darker, not acid; stone sulcate; leaves pinnately veined; winter-buds naked.

1. V. lantanoides, Michx. (HobmLi-Bisll. AMiricax WayfaringTREE.) Leaves (4-8' across) round-ovate, al)ruptly pointed, heart-shaped at the base, closely serrate, the veins and veinlets beneath with the stalks and branchlets very rusty-scurfy; cymes sessile, very broal and flat. - Cold moist woods, N. Brunswick to Ont. and Penn, and in the monntains to N. C. May. A straggling shrub; the reclining branches often taking root.

\$ 2. C'yme peduncled, radiunt in 11.2 ; drupe light red, acill, glolose; stone very flat, orbicular, not sulcate; leaves pulmately veined: winter-tuds scaly.

2. V. Ópulus, L. (Craxinerny-trke.) Nearly smooth, upright $\left(4-10^{\circ}\right.$ high); leaves 3-5-ribbed, strongly 3-lubed, broally wedge-shaped or truncate at base, the spreading lohes pointed, mostly toothed on the siles, entire in the sinuses; petioles hearing 2 glands at the apex. - Low ground, along streams, from N. Brunswick far westward, and sonth to l'enn. June, July. - The acil fruit is a sulstitnte for cranberries, whence the namor IIigh Cimnlorrydushe 
etc. The well-known Sxow-Ball Tree, or Guelder-Rose, is a cultivated state, with the whole cyme turned into showy sterile flowers. (Eu.)

3. V. pauciflorum, Pylaie. A low straggling shrub; leaves glabrous or lousely pubescent beneath, 5-ribbed at base, unequally serrate nearly all round, with 3 short lobes at the summit; crme few-flowered; stamens shorter than the corolla. - Cold woods, Newf. and Lab. to the mountains of N. Eng., westward to N. Mich. and the Rocky Mits.

§ 3. Cyme never radiant; drupes blue, or dark-purple or black at maturity. * Leaves 3-ribbed from the rounded or subcordate base, somewhat 3-lobed; stipules bristle-shaped.

4. V. acerifòlium, L. (Dockuackie. Arrow-wood.) Shrub $3-c^{\circ}$ ligh; leaves soft-downy beneath, the pointed lobes diverging, unequally toothed; cymes small, slender-peduncled; stamens exserted; fruit crimson turning purple; stone lenticular, hardly sulcate.-Cool rocky woods, from N. Brunswick to N. C., and west to S. Minn.

* Leaves (with base inclined to heart-shaped) coarsely toothed, prominently pinnately veined; stipules narrowly subulate; no rusty scurf; fruit ovoid, blue or purple; the stone grooved; cymes peduncled.

- Stone flut; leares all short-petioled or sulsessile.

5. V. pubéscens, Pursh. (Dowxy A.) A low, straggling shrub; leaves ovate or oblong-ovate, acute or taper-pointed, the veins and teeth fewer and less conspicnous than in the next, the lower surface and very short petioles soft-downy, at least when young; fruit dark-purple; the stone lightly 2-sulcate on the faces. - Rocks, etc., Lower Canada to the mountains of Ga., west to Iowa and Minn. June.

+ + Stone very deeply sulcate ventraliy; leaves rather slender-petioled.

6. V. dentàtum, L. ( $\Lambda$ Rrow-woov.) Smooth, $5-15^{\circ}$ high, with ashcolored bark ; leaves broadly ovate, very numerously sharp-toothed and strongly veined; fruit $3^{\prime \prime}$ long; (ross-section of stone between kilney-and borseshoeshaped. - Wet places, N. Brunswick to N. Ga., and west to Minn. June.The pale leaves often with hairy tufts in the axils of the straight veins

7. V. mólle, Michx. Leaves broally oval, obovate or ovate, scarcely pointed, coarsely crenate or repaud-toothed, the lower surface, branchlets and cymes soft-downy, the latter with stellate pubescence; fruit oily, larger and more pointed, the stone as in n. 6, but less deeply excarated. - Coast of $\mathrm{N}$. Eng. (Martha's Vineyard), to Tex.

* * * Leaves finely serrate or entire, bright green; veins not prominent; stipules none; whole plant glabrous or with some minute rusty scurf; fruit black or with a blue bloom, sueet; stone very flat and even, broadly oval or orbicular.

- Cymes peduncled, about 5-rayed; drupes globose-ovoid, $3^{\prime \prime}$ long, shrubs 5-12 high, in suamps.

8. V. cassinoides, L. (W1THe-Ron.) Shoots scurfy-punctate; leaves thickish and opaque or dull, ovate to oblong, mostly with obtuse acumination, obscurely veiny $\left(1-3^{\prime}\right.$ long), with margins irregularly crenulate-denticulate or sometimes entire; peduncle shorter than the cyme. (V. undum, var cassinoides, Torr. $\delta$ (iray.) - Newf. to N. J. and Minn. Flowers earlier than the next. 
9. V. nùdum, L. Obscurely scurfy-punctate; leares

ish, oval, oblong or lanceolate, entire or ubsolctely denticulate, high, branches 4' long); peduncle usually equalling the cyme. - N. .J. to Fila.

when ull];

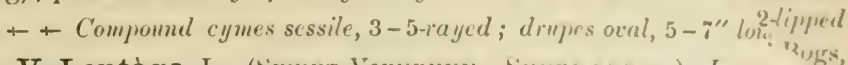

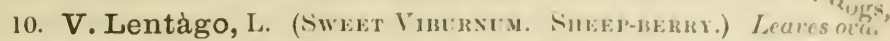
strongly pointed, closely and very sharply serrate; jetioles long and margined; cyme large; fruit oval, $\frac{1^{\prime}}{2}$ long or more, rije in autumn, ellible; tree $15-30^{\circ}$ high. - Woods and banks of streams, from the Atlantic to Mo., Minn., and northward. Fl. in spring.

11. V. prunifolium, L. (Bцаск Hiw.) leeres oral, obtuse or slighty pointed, finely and sharply serrate, smaller than in the precerling (1-2' long); fruit similar or rather smaller. - I)ry or moist ground, N. Y. to Mich., Kan., and sonthward. Flowering early. $-\Lambda$ tall shrub or small tree.

12. V. obovàtum, Walt. N'hrub $2-8^{\circ}$ high; leaves obovate or spatulate, obtuse, entire or denticulate, thickish, small (1-1 $\frac{1^{\prime}}{2}$ long), shining; cymes small; fruit 5" long, black. - River-banks and swamps, Va. to Fla. May.

\section{TRIÓSTEU M, L. Fever-Wort. IIonse-Gextix.}

Calyx-lobes linear-lanceolate, leaf-like, persistent. Corolla tubular, gilibons at base, somewhat equally 5-lohed, scarcely longer than the calyx. Stamens 5. Ovary mostly 3-celled, in fruit forming a rather dry drupe, containing as many ribbed 1-seeded bony nutlets. - Coarse, hairy, perennial herlss leafy to the top; the ample entire pointed leaves tapering to the base, hut comnate round the simple stem. Flowers sessile, solitary or clustered in the axils. (Name an abbreviation of Triosteospermum, alluding to the three bony nutlets.)

1. T. perfoliàtum, L. Softly hairy (2-4 high) ; lares oral, abruptly narroued belou, downy beneatlı; flowers brownish-pur]le, mostly clusteresl; fruit orange-color, $\frac{1^{\prime}}{2}$ long. - Rich woodlauds, Canada and N. Eng. to Minn.,

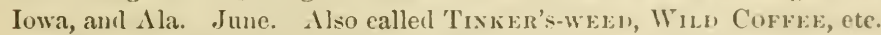

2. T. angustifolium, L. Smaller, bristly-leniry: lences lanceolute, fapering to the base; flowers greenish-crean-color, mostly single in the axils.Shady grounds, Va. to Ill., Mo., and Mla. May.

\section{LI N N 望 A, Gronov. TwiN-Fiowr.r.}

Calyx-teeth 5, awl-shaped, deciduous. Corolla narrow bell-shaped, almost equally 5-lobed. Stamens 4 , two of them shorter, inserted toward the hase of the corolla. Ovary and the small dry pod 3-eplled, but only 1 -seeded, two of the cells having only abortive ovules. - I slender crepping and trailing litte evergreen, somewhat hairy, with roundedtual sparingly crenate leaves comtracted at the base into short petioles, and thread-like upright pechuncles forking into 2 pedicels at the top, each hearing a delicate and fragrant mulding flower. Corolla purple and whitish, hairy inside. (1)edicated to the immortal Linneus, who first pointed out its characters, and with whom this pretty little plant was a special favorite.)

1. L. boreàlis, Linnacus.-Moist mossy woods and cold bogs, N. Ling. to X. J. and the mountains of Mld, west to Mim. ; also far north and west. June. (Fu.) 


\section{etc. The well-kr. P H O R C Á RPOS, Dill. SNowberry.} state, with the

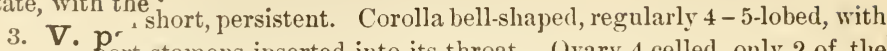
or loose nort stamens inserted into its throat. ()vary 4-celled, only 2 of the ron ${ }^{-}$th a fertile ovule; the berry therefore 4-celled but only 2-seeded. Seeds rony. - Low and branching upright shrubs, with oval short-petioled leaves, which are downy underneath and entire, or wavy toothed or lobed on the young shoots. Flowers white tinged with rose-color, in close short spikes or clusters.

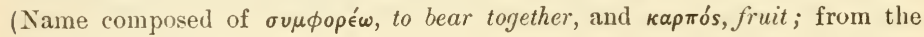
clustered berries.)

\section{* Style bearded; fruit red; flowers all in short dense axillary clusters.}

1. S. vulgàris, Michx. (Ixdiax Cerraxt. Coral-berry.) Flowers in the axils of nearly all the leaves; corolla sparingly bearded; berries small. - Rocky banks, western N. Y. and P'enn. to Dak., Neb., and Tex. July.

* * Style glabrous; fruit uhite: flowers in clusters or sometimes solitary.

2. S. occidentàlis, Hook. (Wolfberry.) Flouers in dense terminal and axillury spikes; corolla much bearded within; stamens and style protruded. - Rocky ground, N. Mich. and Ill., west to the Rocky Mts. - Flowers larger and more funnel-form, and stamens longer, than in the next.

3. S. racemòsus, Michx. (Sxowberri.) Flouers in a loose and somewhat leaf!y interrupted spike at the end of the branches; corolla bearded inside ; berries large. - Rocky banks, N. New Eng. and I'enu., to Minn. and westward; common in cultivation. June-Sept. Berries ripe in autumn. - Var. PAcciFLòrs, Robbins. Low, diffusely branched and spreading; leaves smaller (about $1^{\prime}$ long), the spike rerluced to one or two flowers in the uppermost axils. - Mountains of Vt. and Peun. to Miun., Dak., and westward.

\section{LONÍCERA, L. Hoversichle. Woodine.}

Calyx-teeth very short. Corolla tubular or funnel-form, often gibbous at the base, irregularly or almost regularly 5-lobed. Stamens 5. Ovary 2-3celled. Berry several-seeded. - Leares entire. Flowers often showy and fragrant. (Named in honor of Adam Lonitzer, latinized Lonicerus, a German herbalist of the 16 th century.)

§ 1. XYLÓSTEON. Cpright bushy shrubs; leaves all distinct; peduncles axillary, single, 2-flowered at the summit; the two berries sometimes united into one; calyx-tecth not persistent.

* Bracts (2 or sometimes 4$)$ at the base of the ovaries minute.

1. L. ciliàta, Muhl. (FLY-Hoxerscck LE.) Branches straggling $\left(3-5^{\circ}\right.$ high); leaves oblong-ovate, often heart-shaped, petioled, thin, downy beneath; filiform pechncles shorter than the leaces; corolla funnel-form, almost spurred at the base (greenish-yellow, $\frac{8}{4}$ long), the lobes nearly equal; berries separate (red). - Rocky woods, N. Brunswick to Penn. and Minn. May.

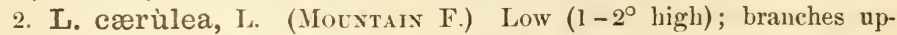
right; leaves oval, llowny when young; peduncles very short; bracts aul-shaped, longer than the oraries, uhich are united into one (blue) berry; flowers yellowish. - Mountain woods and bogs, Lab. to R. I., Minu., and northward. May. (Eu.) 
3. L. oblongifolia, Muhl. (Swame F.) Shrub 2-50 high, branches upright; leares (2-3' long) oblony, downy when young, smoxh when old;

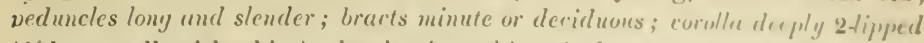

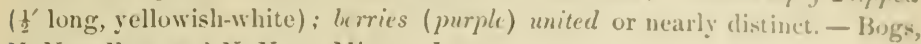
N. New Eng. and N. Y., to Minn. June.

* * The two flourers involucrate by 4 conspicuous and brual fulincents bructs.

4. L. involueràta, Banks. Pubescent, or beconing glalırus ; liranches 4-angular; leaves $\left(2-5^{\prime}\right.$ long) orate-oblong, mostly pointed, petioled, and with a strong midrib, exceeding the peduncle; corollat yellowish, viscid-pubescent, cyllindraceous (6-8" long); ovaries and globose dark-jurple herries distinct. - Deep woods; shores of L. Superior, and north and west ward.

§ 2. CAPRIFOLILM. Twining shrubs, with the flowers in sossile whorled clusters from the axils of the (often comatr) upper leates, forming interrupted terminal spikes; calyx-teeth persistent on the (red or orange) berry.

* Corolla trumpet-shaped, almost regular; stamens and style little exserted.

5. L. sempérvirens, Ait. (Tlimpet Hoversickle.) Flowers in somewhat distant whorls, scentless, nearly 2' long, deep red cutside, yellowish within or rarely throughout; leaves oliong, smooth, the lower petioled, the uppermost pairs comate. - Copses, Conn. to Ind., and southward; common in cultiration. May-Oct. - Leaves deciduous at the north.

* * Corolla ringent; the lower lip narrou; the upper broad and 4-lobed; stamens and style conspicuously exserted.

- Corolla-tube an inch long, glabrons inside; stamens and style glabrous.

6. L. gràta, Ait. (Avericax Wonnbixe.) Leaves smooth, glaucous beneath, obovate, the 2 or 3 upper pairs mited; flowers whorled in the uppermost axils; corolla whitish with a purple tube, falling yellowish, not gibbuns at base, fragrant. - Rocky woodlands, X. J. and Penn. to Mich. and Mu., and southward; also cultivated. May.

+ + Corolla hairy within, the tube 6" long or less.

7. I. hirsùta, Eaton. (HAnY Hoxersceklæ) Twining and rather high-climbing; leaves deep green above, downy-hairy beneath, as well as the branches, veiny, dull, broally oval, the uppermost united, the lower shortpetioled; flowers in approximate whorls; tube of the (orange-yellow) climmypubescent corolla gibbous at base, slender. - Danp, copses and rocks, Maine to I'enn., Mich., and Minn. July. $-A$ coarse large-leaved species.

8. L. Sullivántii, Gray. At length much uhiturel üth yluncous bloom, $3-6^{\circ}$ high, glabrous; leaves oval and olovate-oblong ( $2-4^{\prime}$ long), sessile and mostly connate on the flowering stems, the uppermost into an orlicular clisk ; corolla pale yellow; filuments verurly glabrous. (I. flava of former edlitum, mainly.) - Ohio to 111., Minn., and L. Winnipeg; also in 'Tenu. ant X. ('.

9. L. glaùca, Hill. Glabrous, or lower leaf surface smmetimes puluerulent, $3-5^{\circ}$ high; leaves oblong $\left(2-3^{\prime}\right.$ long), glaucous lut less whitened than in the last, the 1-4 upper pairs connate; corolla greenish-yellow or purplish; tube only $3-4$ "long, within und also style and luse of filuments hirsute. (I.. parvifóra, Lam., and part of var. Douglísii, Gruy.) - Rocky grounds, N. Eng. and Peun. to Minn., and nurthward. 


\section{DIERVÍLLA, Tourn. Besh-Honerscekle.}

Calyx-tube tapering at the summit; the lobes slender, awl-shaped, persistent. Corolla fumnel-form, 5-lobed, almost regular. Stamens 5. Pod ovoid-oblong, pointed, 2-celled, 2-valved, septicidal, many-seeded. - Low upright shrubs, with ovate or oblong pointed serrate leaves, and cymosely 3 -several-flowered peduncles, from the upper axils or terminal. (Named in compliment to Dr. Dierville, who brought it from Canada to Tournefort.)

1. D. trífida, Moench. Leaves oblong-orate, taper-pointed, petioled; peduncles mostly 3-flowered; pod long-beaked. - Rocks, Newf. to the mountains of N. C., west to Minn. June-Aug. - Flowers honey-color, not showy, as are the Japanese species cultivated under the name of WEIGELA.

\section{Order 52. RUBiÁces. (Madder Family.)}

Shrubs or herbs, with opposite entire leaves connected by interposed stipules, or in whorls without apparent stipules, the calyx coherent with the 2-4-celled ovary, the stamens as many as the lolies of the regular corolla $(4-5)$, and inserted on its tube. - Flowers perfect, but often dimorphous (as in Mitchella and Houstonia). Fruit various. Seeds anatropous or amphitropous. Embryo commonly pretty large, in copious hard albumen. - A very large family, the greater part, and all its most important plants (such as the Coffee and Peruvian-Bark trees), tropical.

I. CINCHONEF. Ovules numerons in each cell; leares opposite.

1. Houstonia. Corolla salver-form or fumel-form, 4-lobed. Seeds rather few, thimblesliaped or sancer-shaped. Low herbs.

2. Oldenlandia. Corolla wheel-sliaped in our species, 4-lobed. Seeds very numerous and minute, angrular. Low herbs.

II. COFFEINE.E. Ovules solitary in the cells; leaves mostly opposite.

- Flowers in a close and globose long-peduncled head. Fruit dry. Shrubs.

3. Cephalanthus. Corolla tubular; lobes 4 . Fruit inversely pyramidal, 2-4-seeded. + + Flowers twin ; their ovaries united into one. Fruit a 2 eyed berry.

4. Mitchella. Corolla funnel-form; its lobes 4 . A creeping herb.

+++ Flowers axillary, separate. Fruit dry when ripe. Herbs.

5. Spermacoce. Corolla funnel-form or salver-form; lobes 4 . Fruit separating when ripe into 2 carpels, one or both of them opening.

6. Diodia. Fruit separating into 2 or 3 closed and indehiscent carpels; otherwise as n. 5.

III. STELLATE. Ovules solitary; leaves in whorls, without stipules.

7. Galium. Corolla wheel-shaped, 4-(or rarely 3-) parted. Calyx-teeth obsolete. Fruit twin, separating into 2 indehiscent 1 -seeded carpels.

s. Sherardia. Corolla funnel-form. Calyx-lobes lanceolate. Flowers subsessile, involucrate.

\section{HOUSTONIA, L.}

Calyx 4-lobed, persistent; the lohes in fruit distant. Corolla salver-form or funnel-form, nsually much longer than the calyx-lobes, 4-lobed, the lobes valvate in the bud. Stamens 4; anthers linear or oblong. Style 1; stigmas 2. Ovary 2-celled. Pod top-shaped, globular, or didymous, thin, its summit or upper half free from and projecting beyond the tube of the calyx, loculicidal across 
the top. Seeds rather few (4-20 in each cell), peltate and saucer-shaped or globular-thimble-shaped, pitted. - Simall herbs, with short entire stupules connecting the petioles or narrowed bases of the leaves, aul cymose or solitary and peduncled flowers. 'These are dimorphous, in some individuals with exserted anthers and short included style; in others the authers inchuled and the st le long, the stigmas therefore protruling. (Named for $\mathrm{Lr}$. $11 \mathrm{~m}$. Mouston, an English botanist who collected in Central Ameriea.)

* Simall and delicate, vernul-flouering; peduncles 1-flouered; corolla salverform; upper half of the broad and someulat 2-lobed poul free; secels globular, with a very deep round cavity occupying the inner fuce.

+ Perennial by delicute filiform creeping rootstocks or creeping stems; peuncles filiform, 1-2' long.

1. H. cærùlea, L. (Blexts. Ixxuckxce.) Glabrous; stemserert, slender, sparingly branched from the hase ( $3-5$ high) ; lerces oblomg-sputulate (34 "long); peduncle filiform, erect; corolla light blue, pale lilac or nearly whito with a yellowish eye, with tube much longer than its lobes or than those of the calyx. - Moist and grassy places, N. Eng. to Ga., west to Mich. and Ala. ; producing from early spring to milsummer its delicate little flowers.

2. H. serpyllifollia, Miclıx. Like the last, but tilifurm stems prostrate, extensively creeping and rooting; leures orbiculur to orute $(2-4$ "long); corolla rather larger, and deep violet-blue. - Along streamlets and on mountaintops, Va. to Teun. and S. C.

+ + Winter-annuals, branching from the simple root; peduncles much shorter.

3. H. pàtens, Ell. An inch to at lengrth a span high, with ascending branches and erect peduncles; leaves spatulate to ovate; corolla much smaller than that of n. 1, violet-blue or purplish without yellowish eye, the tube longer than its lobes, twice the length of the calyx-lobes. - Dry or sandy suil, S. Va. to Tex. and Ill. (?)

4. H. mínima, Beck. More eliffuse, common'y scabrous ; stems at length much branched and spreading ( $1-4^{\prime}$ high) ; lowest leaves ovate or spatulate, the upper oblong or nearly linear; earlier perluncles elongated and sprearling in fruit, the later ones short; tube of the purplish corolla not longer then its lobes or the ample culyx-lolies (1 $\frac{1^{\prime \prime}}{2}$ long). - Dry liills, Mo. to Tex. March-May.

* * Erect, mostly perennial herbs (6-20' high), with stem-lecures sessile, and flowers in small terminal cymes or cluster's; corolla funnel-form, purplesh, often hairy inside: seeds meniscoidal, with a rilge arross the hollowed inner fare.

5. H. purpùrea, L. I'uhescent or smonth (8-15' high); Icures rury ing from roundish-oxate to lanceolrete, 3-5-ribhed; (alyx-lobes longer than the half-free globular pod - Woodlauds, Md. to Ark., and sout hward. May-July. - Varying womlerfully; as into -

Var. ciliolata, fray. A span highl, leaves only $\frac{1}{2}$ long, thickish; ('auline oblong-spatulate; ralieal oval or oblong, rosulate, lirsute-ciliate; calyx-lobes a little longer than the poul. - Rocky banks, from the (ireat Iakes and Minn. to ky.; passing into

Var. longifolia, Gray. A span or two high, mostly glabrous, thimerleaved ; leaves oblong-lanceolate to linear $(6-20$ "long $)$; radical oval or oblonf. 
less rosulate, not ciliate. - Rocky or gravelly ground, Maine to Minn., south to Ga. and Mo.; also northward.

Var. tenuifolia, Gray. Slender, lax, diffuse, 6-12' high, with loose inflorescence, and almost filiform branches and peduncles; canline leaves all linear, hardly over $1^{\prime \prime}$ wide. - S. E. Ohio to Va., N. C., and Tenn.

Var. calycòsa, Gray. Almost $1^{\circ}$ high ; leaves broadly lanceolate, thickish; calyx-lobes elongated (2-4" long), much surpassing the pod. - From IIl. (Hall) to Ark. and N. Ala.

6. H. angustifolia, Michx. Stems tufted from a hard or woodr root; leaves nurrouly linear, acute, 1-ribbed, many of them fascicled; flowers crowded, short-pedicelled; lobes of the corolla densely bearded inside; pod oboroid, acute at base, only its summit free, opening first across the top, at length through the partition. - Barrens, Ill. to Kan., south to Tex., Tenn., and Fla.

\section{OLDENLÁ N DIA, Plumier.}

Calyx 4-lobed, persistent. Corolla short, in our species wheel-shaped; the limb 4-parted, valvate in the bud. Stamens 4; anthers short. Style 1 or none; stigmas 2. Pod thin, 2-celled, many-seeded, opening loculicidally across the summit. Seels very numerons, minute and angular. - Low herbs, with small stipules united to the petioles. (Dedicated to the memory of Oldenland, a German physician and botanist, who died early at the Cape of Good Hope.)

1. O. glomeràta, Michx. An inconspicuous, pubescent or smoothish, branched and spreading annual (2-12' high); leaves ovate to oblong; flowers in sessile axillary clusters; corolla nearly wheel-shaped (white), much shorter thau the calyx. - Wet places, near the coast, N. Y. to Fla. and Tex.

\section{CEPHA LÁ NTH US, L. Butrox-вrsh.}

Calyx-tube inversely pyramidal, the limb 4-tootherl. Corolla tubular, 4toothed; the teeth imbricated in the bud. Style thread-form, much protruded. Stigma capitate. Fruit dry and hard, small, inversely pyramidal, 2-4-celled, at length splitting from the base upward into $2-4$ closed 1-seeded portions. Shrubs, with the white flowers densely aggregated in spherical peduncled heads.

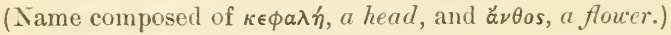

1. C. occidentàlis, L. Smooth or pubescent; leares petioled, ovate or lanceolate-oblong, pointed, opposite or whorled in threes, with short intervening stipules. - Swamps and along streams, throughout the continent. July, Aug

\section{4. mitchílL A, L. Partridge-berry.}

Flowers in pairs, with their ovaries united. Calyx 4-toothed. Corolla funnel-form, 4-lobed; the lobes spreading, densely bearded inside, valvate in the bud. Stamens 4. Style 1; stigmas 4, linear. Fruit a berry-like double drupe, crowned with the calyx-teeth of the two flowers, with 4 small seed-like bony nutlets to each flower. - A smooth and trailing small erergreen herb, with round-orate and shining petioled leaves, minute stipules, white fragrant flowers often tinged with purple, and scarlet edible (but nearly tasteless) berries, which remain over winter. Flowers occasionally 3-6-merous, always dimorphous; all those of some individuals having exserted stamens and included stigmas; of others, included stamens and exserted style. (This very 
pretty plant commemorates I)r. John Mitchell, an early correspondent of Lin. næus, and an excellent hotanist, who resiled in Virginia.)

1. M. rèpens, I. - I)ry woods, creeping about the foot of trees, especially Conifera, throughout onr range and sonthward. Junc, July - I eaves often varlegated with whitish lines Rarely the two flowers are completely confluent into one, with a lo-lobed corolla.

\section{S PERM A COCE, Dill. B!тTON-WER.}

Calyx-tuhe short; the limb partel into 4 teeth. Corulla funnelform or silver-form, valvate in the bul. Stamens 4 . Stigma or style 2-cleft. Fruit small and (lry, 2 celled, 2-seeded, splitting when ripe into 2 carpels, one of them usually carrying with it the partition, and therefore closed, the other open on the mner face. - small herls, the bases of the leaves or petioles connected by a bristle-bearing stipular membrane Flowers small, whitish, crowled into sessile axillary whorled clusters or heads. (Name compoumled of $\sigma \pi \epsilon^{\prime} \rho \alpha$, seed,

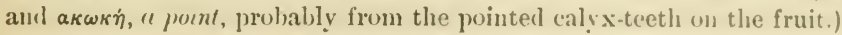

1. S. glàbra, Michx. Glabrous pereunial; stems spreatling $\left(9-20^{\prime} \mathrm{l}(\mathrm{ng})\right.$; leaves oblong-lanceolate: heads many-flowered; corolla little exceeding the calyx, bearded in the throat, hearing the authers at its lowe, filanents and style hardly any. - River-bauks, s. (Hio to Ark., 'Tex., and Fla. Aug.

\section{DIÒ DIA, Gronor. Button-Weeis.}

Calyx-teeth 2-5, often unequal. Fruit 2-(rarely 3-) celled; the crustaceous carpels into which it splits all closed and indehiscent. Flowers $1-3$ in each axil. ()therwise resembling Spermacoce. Flowering all summer. (Name

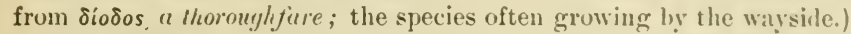

1. D. Virginiàna, I, Smooth or hairy perenuial; stems sprealing (1 -

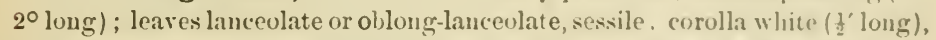
the slender tube abruptly expunded into the large lumb; style 2-purted, fritit oblong, stromyly furroued, crowned mostly with 2 sleuder calyx-teetlı - Low grounds along streams, southern $\mathrm{N}$. J to Fla., west to Ark. aud Tex.

2. D. tères, Walt. Hairy or minutely pubescent annual; stem spreading (3-9' long), nearly terete; leaves linear-lanceolate, closely sessile, rigid; corolla funnel-form (2-3" long, whitish), with short lohes, not exceeding the long bristles of the stipules : style undivided ; finit olowate-turlinate, not furrown, rrowned with 4 short calyx-teeth. - Sandy soil, N J.to W. 111., Fla., and Tex.

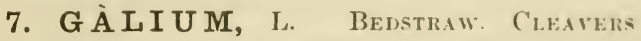

Calyx-teeth obsulete Corolla 4-parted, rarely 3-parted, wheel-shaped, valvate in the bud. Stamens 4, rarely 3, short. Styles 2. Fruit ary or fleshy, globular, twin, separating when ripe into the 2 seerl-like, indehisent, 1 -seeded carpels. - slender herhs, with small cymose flowers (proluced in summer), square stems, and whorled leaves, the routs often containing a red coloring

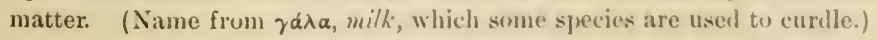

\$1. Naturalized species: fiuit dry.

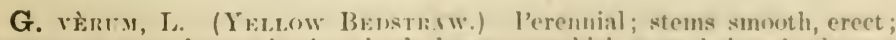
leaves 8 or sometimes 6 in the whorls, lnear, ronghish, soun detlexed; Howers 
very numerous, paniculate, yellow ; fruit usually smooth. - Dry fields, E. Mass. (Nat. from Eu.)

G. Mollùgo, I. Perennial, smooth throughout; stems erect or diffuse, 2 or $3^{\circ}$ long; leaves 8 , or 6 on the branchlets, ollanceolate to nearly linear; flowers very numerous in ample almost leafless panicles; fruit smooth. Roadsides and fields, N. Y. and Penn. (Nat. from Eu.)

G. Ánglicum, Huds. Annual, slender, diffuse, selilom $1^{\circ}$ high, glabrous ; leaves $5-7$, oblanceolate to nearly linear ( $3^{\prime \prime}$ long), their margins and the angles of the stem spinulose-scabrous; flowers rather few, cymulose on leafy branches, greenish-white, very small; fruit glabrous, more or less tuberculate. - Roadsides, Bedford Co., Va. (Curtiss). (Nat. from Eu.)

G. TRICónxe, With. Ammual, resembling $G$. A parine, rather stout, with simple branches; leaves 6 or 8 , oblanceolate, cuspidate-mucronate, the margins and stem retrorsely prickly-hispid ; flowers mostly in clusters of 3 , dull white; fruits rather large, tuberculate-granulate, not hairy, pendulous. - Fields, eastward. (Nat. from Eu.)

\section{§ 2. Indigenous species; fruit dry.}

* Annual; leaves about 8 in a whorl; peduncles 1-3-flowered, axillary; fruit bristly with hooked prickles.

1. G. Aparine, L. (Cledvers. Goose-Grass.) Stem weak and reclining, bristle-prickly backward, hairy at the joints; leaves lanceolate, tapering to the base, short-pointed, rough on the margins and midril ( $1-2^{\prime}$ long); flowers white. - Shaded grounds, throughout the continent; probably as an introduced plant eastward.

* * Perennials; leaves in 4's, comparatively large, and broad (narrover in n. 7 and 8), not cuspidate-pointed, more or less distinctly 3-nerved; fruit uncinatehispid (except in $\mathrm{n} .6$ and 7 ).

- Peduncles loosely 3-severul-flovered; flowers dull purple to yellowsh-white.

2. G. pilòsum, Ait. Hairy; leares oval, dotter, hairy (1'long), the lateral nerves obscure; peduncles 2-3-forked, the flouers all pedicelled. - Dry copses, R. I. and Vt. to Ill., E. Kan., and sonthward.

Var. puncticulòsum, Torr. \& Gray. Almost glabrous ; leaves varying to elliptical-oblong, hispidulous-ciliate. - Va. to Tex.

3. G. Kamtscháticum, Steller. Stems weak, mainly glabrous (10 high); leaves orbicular to oblong-ovate, thin ( $\frac{1}{2}-1^{\prime}$ long), slightly pilose; flowers slenderly pedicellate; corolla glabrous, yellowish-uhite, not turning dark, its lobes merely acute. (G. circæzans, var. montanum, Torr. \&. Gray.) Higher mountains of N. Eng., L. Canada, and far westward. (Asia.)

4. G. circæzans, Michx. (Wild Lięorice.) Smooth or downy (10 high); leaves oval, varving to orate-ohlong, mostly obtuse, ciliate $\left(1-1 \frac{1^{\prime}}{2}\right.$ long) : peduncles usually once forked, the branches elongated and widely diverging in fruit, bearing several remote flowers on very short lateral pedicels, reflexed in fruit; lobes of the greenesh corolla hairy outside, acute or acuminate. - Rich woods, N. Eng. to Minn., south to Fla. and Tex.

5. G. lanceolàtum, Torr. (Wild Liquorice.) Nearly glabrous; leaves (except the lowest) lanceolate or orate-lanceolate, tapering to the apex $\left(2^{\prime}\right.$ long); corolla glabrous, yellowsh turning dull purple, lobes more acuminate; otherwise like the last. - Dry woods, N. Eng. to N. Mich. and Minn.

6. G. latifolium, Michx. Smooth $\left(1-2^{\circ}\right.$ high $)$; leaves lanceolate or ovate-lanceolate, acute ( 2 ' long), the midrib and margins rough: cymes panicleci, 
loosely many-flowered, the purple flowers on slender spreading yedicels ; fruit smooth, rather fleshy. - Dry woods, mountitins of Penn. to X. C. and 'Tenn.

7. G. Arkansànum, Gray. Similar but lower; leaves lancerlate to linear ( $\mathrm{l}^{\prime}$ long or less), the lateral nerves obscure or none. $-\mathrm{S}$. Mo, and Ark.

+ + Leares nurrow; flowers bright white, numerons in a compun prunicle.

8. G. boreàle, 1. (Nortukrs Bkistr.⿲w.) Sinooth $\left(1-2^{\circ}\right.$ high); leaves linear-lanceolate; fruit minutely bristly, sometimes smonth. - Rocky banks of streams, Maine to Penn., Iowa, Minn., and westward. (En, Asia.)

* Leaves in 4's, 5's, or 6's, small, 1-nerved; flowers white; fruit smooth (flowers yrecrish and fruit hispid in 1. 12.)

- Leaves pointless.

9. G. trifidum, I. (Sмגц, Benstraw.) Sitems weak, ascending (5$20^{\prime}$ high), branching, mostly roughened backwards on the angles; leares in whorls of 4 to 6 , linear or oblanceolate, the margins and midrib rough; peduncles scattered, 1-7-flowered; corolla-lohes and stamens often only 3. - Sphagnons bogs and wet ground, thronghout the continent. Exceedingly varialile. - Var. Pusflud, Gray, the smallest form; leaves only in 4's, $3-4$ "long, narrow, in age often reflexed; peduncles 1-flowered. In cold bogs, northward. - Var. LATIFòluM, Torr., the larger and hroadest-leaved form; leaves 6 or $7^{\prime \prime}$ long, often $2^{\prime \prime}$ wide. From Canada, south and west. (Eu., Asia.)

10. G. concinnum, 'Torr. \& Gray. Stems low and slender (6-12' high), with minutely roughened angles; leaves all in 6's, linear, slightly pointed, veinless, the margins upwardly roughened; peduncles $2-3$ times jorked, diffusely panicled; pedicels short. - Dry hills, Penn. to Va., west to Minn., Iowa, and Ark.

\section{+ + Leaves cuspidately mucronate or acuminate.}

11. G. aspréllum, Michx. (Rocgu Benstraw.) Stem much branched, rough backwards with hooked prickles, leaning on bushes $\left(3-5^{\circ}\right.$ high) ; leares in uhorls of 6 , or $4-5$ on the branchlets, ocul-lanceolate, with almost prickly margins and midrib; peduncles short, 2-3 times forked. - Alluvial ground, $\mathrm{N}$. Eng. to N. C., west to Minn., Iowa, and Mo.

12. G. triflòrum, Michx. (SwEet-scenten Benstia.) Stem (1-30 long) bristly-roughened backward on the angles; leaves elliptical-lancenlate, bristle-pointed, with slightly roughened margins (1-2' long); peduncles i3flowered, the flowers all pedicelled, greenish; fruit heset with hooked bristles. - Rich woodlands, thronghout the continent. Sweet-scented in drying. (Eu.)

\$3. Perennial; finit a berry: lcares in 4 's, 1-nerred.

13. G. hispidulum, Michx. Hirsute-puhescent, scabrous, or sometimes nearly smooth, $1-2^{\circ}$ high, diffusely branched; leaves ohlong or uval, mucronate $\left(3-6^{\prime \prime}\right.$ long), pedicels solitary or commonly 2 or 3 from the small invo)lucral whorl, all naked, or one of them bracteolate; flowers white ; herry purple. glabrate. - Dry or sandy soil, southern N. J. to Fla., along the coast.

\section{SHERÁR DIA, Dill.}

Calyx-lobes lanceolate, persistent. C'orolla funnel-form, the limb 4-5-lobed. Stamens 4-5. Style filiform, 2-cloft; stigmas capitate. Fruit dry, twin, of 2 indehiscent 1 -seeded carpels. - A slender prox'umbent herh, with sifuare stems, 
lanceolate pungent leaves in whorls of 4-6, and small subsessile blue or pinkish flowers surrounded by a gamophyllous involucre. (Named for Dr. William Sherard, patron of Dillenins.)

S. ARvéxsis, L. The only species; sparingly naturalized from Eu.

\section{Order 53. VALERIANÁCEAE. (Valerian Family.)}

Herbs, with opposite leaves and no stipules; the calyx-tube coherent with the ovary, which has one fertile 1-ovuled cell and two abortive or empty ones; the stamens distinct, 1-3, fewer than the lolies of the corolla, and inserted on its tube. - Corolla tubular 、 funnel-form, often irregular, mostly 5lobed, the lobes imbricated in the bud. Style slender; stigmas 1-3. Fruit indehiscent, 1-celled (the two empty cells of the ovary disappearing), or 3-celled, two of them empty, the other 1-seeded. Seed suspended, anatropons, with a large embryo and no albumen. - Flowers in panicled or clustered eymes. (Roots often odorous and antispasmodic.)

\section{VALERI À N A, Tourn. VAleriax.}

Limb of the calyx of several plumose bristles (like a pappus) which are rolled up inward in flower, but unroll and spread as the seed-like l-celled fruit matures. Corolla commonly gibbous near the base, the 5-lobed limb nearly regular. Stamens 3. - Pereunial herbs, with thickened strong-scented roots, and simple or pinnate leares. Flowers in many species imperfectly diœcious or dimorphous. (A mediæral Latin name of uncertain origin.)

* Root spindle-shaped, large and deep (6-12'long); leaves thickish.

1. V. édulis, Nutt. Smootl, or minutely downy when very young; stem straight $\left(1-4^{\circ}\right.$ high $)$, few-leaved ; leaves commonly minutely and densely ciliate, those of the root spatulate and lanceolate, of the stem pinnately parted into $3-7$ long and narrow divisions ; flowers in a long and narrow interrupted panicle, nearly diocious; corolla whitish, obconical ( $2^{\prime \prime}$ long). - Wet plains and prairies, Ohio and Out. to Iowa, Minn., and westward. June.

$$
\text { * * Root fibrous; leaves thin. (Stems } 1-3^{\circ} \text { high.) }
$$

2. V. sylvática, Banks. Smooth or minutely pubescent; root-leaves ovate or oblong, entire, rarely with 2 small lobes; stem-leares pinnate, with 3 11 oblong-orate or lanceolate nearly entire leaflets; cyme at first close, manyflowered; corolla inversely conical ( $3^{\prime \prime}$ long, rose-color or white). - Wet ground, Newf. to southern N. Y., N. Mich., westward and nortliward. June.

3. V. pauciflòra, Michx. Smooth, slender, surculose; root-leaves ovate, heart-shaped, toothed, pointed, sometimes with 2 small lateral divisions; stemleaves pinnate, with $3-7$ orate toothed leaflets; branches of the panicled cyme few-flowered ; tube of the (pale pink) corolla long and slender ( $\frac{1^{\prime}}{2}$ long). - Woods and allurial banks, Penn. to S. Ill., Mo., and Tenn. June.

\section{VALERIA N ÉLLA, Tourn. Corn Salad. Lamb-Lettece.}

Limb of the calyx obsolete or merely toothed. Corolla funnel-form, equally or unequally 5-loberl. Stamens 3, rarely 2. Fruit 3-celled, two of the cells empty and sometimes confluent into one, the other 1-seeded. - Annuals and 
biennials, usually smooth, with forking stems, tender and rather succulent leaves (entire or cut-lobed towards the hase), and white or whitish crmoseclustered and bracted small flowers. - (hur species all have the limb if the calyx obsolete, and are so much alike in aspect, flowers, ctu., that good characters are only to be taken from the fruit. They all have a rather short corulla, the limb of which is nearly regular. (Name a liminutive of Valeriana.)

* Corolla bluish: fruit with a corky mass at the back of the fertile cell.

V. olıtòrı, Poll. Fruit flattish, obliquely rhomhoidal; empty cells as large as the fertile, contignous, the thin partition at length breaking up. Uld fields, N. Y. to Pemn. and La. (Nat. from Eu.)

* * Corolla white; no corky mass behind the fertile cell.

- Fertile cell broader than the empty ones; cross-section of fruit triangular.

1. V. chenopodifòlia, I)C. Stems with long internodes and few forks ; glomerate eymes few, slender-peduncled; bracts broally lanceolate; fruit glabrous or pubescent, 2" long. (Fedia Fagopyrum, Torr. \&. Gray.) - Moist grounds, western N. Y. to Minn., south to Va. and liy.

+ + Fertile cell as broad as the empty ones, beaked; cross-scction quadrate.

2. V. radiàta, Dufr. Fruit ovate-tetragonal, dounny-pubescent (sometimes glabrous); empty cells as thick as the oblong-ovate fertile one, or thicker, $a$ broad shallow groove between them. (Fedia radiata, Michx.) - Low grounds, Penu. to Minu., Tex., and Fla.

3. V. stenocárpa, Krok. Fruit oblong-tetragonal, commonly glabrous ; oblong fertile cell thicker than the linear-oblong approximate empty ones. (Fedia stenocarpa, Engelm.) - W. Mo. and E. Kan. to Tex.

+++ Fertile cell much the narrowest, dorsally l-nerved; section roundish.

4. V. Woodsiàna, Walp. Fruit 1" long or more; fertile cell ovate, tipped with a tooth; empty ones inflated, with olılong depression (sometimes an open eavity) in the middle. - Moist groumds, N. Y. and l'enn. to Tex.

Var. umbilicàta, Gray. Empty cells hecoming confluent, vesicular by incurvation of the circular margin, forming a deep and round umbilication. (Fedia umbilicata, Sulliv.) - N. Y. to Ohio and southward.

Var. patellària, Gray. Fruit sancer-slaped, emarginate at base and apex, winged by the divergent cells. (Fedia patellaria, sullir.) - same range.

\section{Order 54. DIPSACEAE. (Teasel Famil.)}

Herbs, with opposile or whorled leaves, no stipules, and the flowers in dense heads, surrounded by an involucre, as in the Composite Family ; lnt the stamens are distinct, and the suspended seed has albumen. - Represented by the following introduced species and by the cultivated sweet Scabious (Scabiosa atropurpurea).

\section{DÍ P S A U S, Tourn. TraskiL.}

Involucre many-leaved, longer than the chaffy leafy-tipued and pointed liracts among the densely capitate flowers; ach flower with a t-leaved calyx-like involucel investing the ovary anil frnit (achene). ('alyx-tuhe colserent with the ovary, the limb cup-shapeil, withont a pappus. ('orolla nearly regular, 4 -cleft. Stamens 4, inserted on the corolla. Style slender. - Stunt and coarse bien. 
nials, hairy or prickly, with large oblong heads. (Name from $\delta \iota \psi a ́ \omega$, to thirst, probably because the united cup-shaped bases of the leaves in some species hold water.)

1. D. sylvéstris, Mill. (Wild Teasel.) Prickly; leaves lance-oblong; leaves of the involucre slender, longer than the head; bracts (chaff) tapering into a long flexible awn with a straight point. - Roadsides; rather rare. (Nat. from En.) Suspected to be the original of

2. D. FLLLOXXM, L., the FELLER'S 'TEASEL, which has a shorter involuere, and stiff chaff to the heads, with hooked points, used for raising a nap upon woollen cloth; it has escaped from cultivation in some places. (Adv. from Eu.)

\section{Order 55. COMpósit'ae. (Composite Family.)}

Flowers in a close head (the compound flower of the older botanists), on a common receptacle, surrounded by an involucve, with 5 (rarely 4) stamens inserted on the corolla, their anthers united in a tube (syngenesious). - Calyx-tube united with the 1-celled ovary, the limb (called a pappus) crowning its summit in the form of bristles, awns, scales, teeth, etc., or cup-shaped, or else entirely absent. Corolla either strap-shaped or tubular; in the latter chiefly 5 -lobed, valvate in the bud, the veins bordering the margins of the lobes. Style 2-cleft at the apex (in sterile flowers usually entire). Fruit seed-like (achene), dry, containing a single erect anatropous seed, with no albumen. - An immense family, in temperate regions chiefly herbs, without stipules, with perfect, polygamous, monœcious or dicecious flowers. The flowers with a strap-shaped (ligulate) corolla are called rays or ray-flowers; the head which presents such flowers, either throughout or at the margin, is radiate. The tubular flowers compose the disk; and a head which has no ray-flowers is said to be discoid. When the head contains two sorts of flowers it is said to be heterogamous; when only one sort, homogamous. The leaves of the involucre, of whatever form or texture, are termed scales. The bracts or scales, which often grow on the receptacle among the flowers, are called the chaff; when these are wanting, the receptacle is said to be naked. - The largest order of Phænogamous plants. 'The genera are divided by the corolla into three series, only two of which are represented in the Northern United States. The first is much the larger.

\section{Systematic Synopsis.}

\section{SERIES I. TUBULIFLORA.}

Corolla tubular in all the perfect flowers, regularly 5- (rarely 3-4-) lobed, ligulate only in the marginal or ray-flowers, which when present are either pistillate only, or neutral (with neither stamens nor pistil).

Tribe I. VERNONIACEAE. Heads discoid; the flowers all alike, perfect and tubular, never yellow. Branches of the style long and slender, terete, thread-shaped, minutely bristly-hairy all over. - Leaves alteruate or scattered.

1. Elephantopus. Heads $3-5$-flowered, several crowded together into a compound head. Involuere of 8 scales. Pappus of several chaffy bristles.

2. Vernonia. Heads several-many-flowered, separate. Involucre of many scales. Pappus doublc, the inner capillary, the outer of minute chaffy bristles. 
Tribe 11. EUPATORIACE.E. Heads discoil, the flowens all alike, perfe t and tuLular, never yellow. Branches of the style thickened upward or chu-shaped, obtuse, very minutely and uniformly [ubescent; the stigmatic lincs indistinct.

* I'apjusis a row of hari siales.

3. Sclerolepis. Head many-flowered. Scales of the involucre equal, Leaves whorled.

* Pappus of slender hristles.

- Achene 5-angled ; bristles of the pappus roughish.

4. Mikania. Flowers and involucral scales only 4. Stems twining.

5. Eupatorium. Involucre of tuore than 4 seales and the Howers few or many. Stems not twining.

- - Achene 10-ribbed; involucral scales striate-nerved

6. Kuhnia. Papuns very strongly plumose. Seales of the involucre firw.

7. Brickellia. Involucral seales in several series. Paplus merely scabrous.

8. Liatris. Pappus plumose or only harbellate. Corolla red-purple, strongly 5-lubes Heads spicate or racemose, the involuere well inbricaterl

9. Trilisa. Pappus minutely birbellate. Corolla rose-purple Ileads coryubed or pauicled, the involucre little imbricated.

Tribe II ASTEROIDEA. Heads discoid, the flowers all alike and tubular ; or else radiate, the outer ones ligulate and pistillate. Anthers not camlate ut hilse. Branches of the style in the perfect flowers flat, smooth up to where the ponspicuons marginal stigmatic: lines abruptly terminate, and prolonged above this into a flattened lance-shajed or triangular aplendage which is evenly hairy or pubescent vutside. - Leaves altermate. Receptacle naked (destitute of chaff) in all our species.

* 1. Ray-flowers yellow (in one species of Śnlidago whitish), or sometimes nore at all.

- Pajpus of not numerous slender bristles. Hearls radiate. Involucre of firm scales with greenish tips, commonly cuated with resin. West of the Mississiplpi.

10. Gutierrezia. Heads suall, numerous. Ray and dish-flowers 3 or 4 each, all fertile. Pappus of several short chaffy seales. Suffrutescent; leaves very uarrow.

11. Amphiachyris. Heads small. Ray-flowers 5-10; palpus eoroniform. Disk-flowers infertile; pappus of several bristle-like seales. Annual; leaves very narrow.

12. Grindelia. Heads large, many-flowered. Flowers all fertile. Pappus of $2-8$ rigid caducous awns. Coarse herbs with toothed leaves.

- + Pappus (at least of the disk) of copious slender or eapillary bristles.

$$
\text { = Papuns double. }
$$

13. Heterotheca. Resembling Chrysopsis, but the achenes of the ray thicker than those of the disk and without pappus or nearly so. Western.

14. Chrysopsis. Heads many-flowered ; rays numerous. The outer pappus of very smant ehaffy bristles, much shorter than the inuer of copious capillary bristles.

$$
==\text { Pappus simple. }
$$

15. A plopappus. Heads many-flowered, many-radiate. Involucre hemispherical, I'apjus of many unequal bristles. Western.

16. Bigelovia. IIeads $3-4$-flowered; rays none, Receptacle awl-sliaped. Pappus a single row of eapillary bristles.

17. Solidago. Heals few-many-flowered; rays 1-16. Pappus of numerous slender and equal eapillary bristles.

18. Brachychata. II earls $8-10-$ Howered, elustered; rays 4 or 5. Pappus a row of minute bristles shorter than the achene.

* 2. Ray-flowers white, blue, or purple, never yellow.

- Pappus noue or very short, with or without a few awns.

$\leftrightarrow$ Recejtraclo conleal. Awns none.

19. Bellis. Achenes inarginless, flattened; papjus none. luvolucral scales equal.

20. Aphanostephus. Achenes frismatic; pappus coroniforn. Outer scales shorter. 
+* Receptacle flat or convex. Pappus usually with awns.

21. Chætopappa. Achenes fusiform; pappus of 5 or fewer thin clatf and alternating awns. Western.

22. Boltonia. Achenes very flat, thick-winged; pappus of short bristles and usually $2-4$ awis.

+ + Pappus of a single row of awns or coarse rigid bristles, or in the ray scale-like.

23. Townsendia. Low or stemless, with linear-spatulate leaves and large aster-like flowers.

+ + + Pappus of numerous long and capillary bristles; recertacle flat.

24. Sericocarpus. Heads 12-20-flowered; rays 4 or 5 . Involucre oblong or club-shaped, inbricated, cartilaginous. Achenes short, narrowed downward, silky.

25. Aster. Heads many-flowered, on leafy pieduncles. Involucral scales unequal, loosely or closely imbricated. Achenes flattish; pappus simple (rarely double), copious.

26. Erigeron. Heads many-flowered, on naked peduncles. Involucre of narrow equal scales, little imbricated. Achenes flattened; papyus simple and rather scanty, or with some outer minute scales.

* 3. Rays none. Heads dicecious (all pistillate or all staminate).

27. Baccharis. Heads many-flowered. Pappus capillary. Smooth glutinous shrubs.

Tribe IV. INULOIDEA. Heads discoid (radiate only in Inula), the pistillate flowers mustly filiform and truncate. Anthers sagittate, the basal lobes attenuate into tails. Style-branches with unappendaged obtuse or truncate naked tips. Pappus capillary or none.

* 1. Receptacle naked, Involucre not scarious, imbricated. Not woolly.

28. Pluchea. Heads containing a few perfect but sterile flower's in the centre, and many pistillate fertile ones around them. Pappus eapillary.

* 2. Receptacle chaffy. Involucral scales few, mostly scarious. Low floccose-woolly annuals; flowers as in n. 28.

29. Evax. Receptacle convex. Achenes obcompressed, Pappus none. Western.

30. Filago. Receptacle subulate. Achenes terete. Outer flowers without pay'uns.

* 3. Receptacle naked. Involucral scales many, scarious. Floceose-woolly herbs.

31. Antennaria. Heads diceious. Pappus of sterile flowers club-shaped, of the fertile united at base and decidnous together.

32. Anaphalis. Heads dioecious or nearly so. Parpus not thickened above nor at all united at base.

33. Gnaphalium. Heads all fertile thronghont. Pappus all capillary.

* 4. Corollas all somewhat broadly tubular and lobed. Involucre not scarious. Reveptacle naked. Pappus none.

34. Adenocaulon. Head few-flowered and scales few ; onter flowers pistillate. Somewhat woolly.

* 5. Heads radiate. Receptacle naked. Involucre herbaceous. Pappus copious.

35. Inula. Heads large, many-flowered. Flowers yellow. Stout perennial.

Tribe V. HELIANTHOIDEA. Heads radiate or discoid. Involucre not scarious (nut-like in fruit in n. 43,44). Receptarle chaffy. Pappus never capillary, sometimes none. Anthers not caudate. Style-branches truncate or hairy-appendaged.

* 1. Heads radiate (obscurely so in n. 41 , sometimes discoid in n. 36 ), the ray pistillate and fertile, the disk perfect but sterile.

- Achenes turgid, triangular-obovoid; parpus none.

36. Polymnia. Involucral scales in 2 rows, the 5 outer leaf-like, the inner small.

+ + Achenes flattened dorsally (obcompressed).

37. Silphium. Achenes wing-margined, in several rows; pappus none or 2 teeth. Scales thick, in several rows. 
38. Berlandiera. Achenes wingless, 5-12 in one row, without pappus. Inner Involueral scales obovate, outer smaller and more foliacens. Westeru,

39. Chrysogonum. Achenes wingless, alont 5 ; pappus a one-sided 2 -3-toothed crown. Inner scales 5 , chaff-like, the 5 outer longer and leaf-like.

40. Engelmannia. Achenes wingless, 8-10; pappus a scarious hispicl crown. Outer scales (about 10) leaf-like, inner coriaccous with green tips. Western.

41. Parthenium. Rays 5, very short, persistent. Pappus of 2 small scales. Involucral scales short, roundish, in 2 rows.

- 2. Fertile flowers $1-5$, the corolla noue or reduced to a tube ; staminate corolla funnel-form. Pappus none.

- Heads with $1-5$ pistillate flowers. Receptacle chaffy.

42. Iva. Achenes short, thick. Involucre of few roundish scales.

- + Heads of two sorts on the same plant, the upler staminate with an open cup-shaped involucre, the lower listillate, of $1-4$ thowers in a closed bur-like involncre.

43. Ambrosia. Seales of staminate involncre united. Fruit l-seeded.

44. Xanthium. S'cales of staminate involucre distinct. Fruit 1-4-celled, 1-4-beaked.

* 3. Ileads radiate, or rarely discoid; disk-flowers all perfect and fertile. Anthers blackish. Pappus none, or a crown or culn, or of one or two chatfy awns, never capillary, nor of several uniform chaffy scales. - Leaves more commonly opposite.

- Involucre double ; the outer forming a cup.

45. Tetragonotheca. Outer involucre 4-leaved. Achenes obovid: pappus none.

++ Involucre of one or more rows of separate scales.

+ Chaff of the flat receptacle bristle-shaped.

46. Eclipta. Ray short. Involucral stales $10-12$, in two rows, herbaceous.

++ ++ Cliaff scale-like, embracing or subtending the achenes.

$=$ Receptacle high, conical or columnar in fruit. Pappus none or a short crown.

47. Hellopsis. Rays fertile. Achenes 4-siled. Leaves opposite.

48. Echinacea. Rays rose-colorel, pistillate, sterile. Achenes short, 4-sided. Chaff spinescent.

49. Rudbeckia. Rays neutral. Achenes 4-sided, flat at the top, marginless.

50. Lepachys. Rays few, nentral. Achenes flattened laterally and margined.

$==$ Receptacle flat to convex. Achenes not winged nor very flat.

51. Borrichia. Achenes 3-4-angled; pappus a short 4-toothed crown. Shrubby.

5:. Helianthus. Achenes flattened, bearing 2 very deciduous chaffy pointed scales.

$===$ Receptacle convex (rarely conical). Achenes flat-compressed laterally, winged or wingless, 2-awned. Leaves decurrent.

53. Verbesina. Involncral scales closely imbricated in 2 or more rows.

54. Actinomeris. Scales few, soon deflexed. Achenes obovate, squarrosely spreading.

* 4. Rays few, neutral, or wanting. Achenes obcompressed, i. e., flattened parallel with the scales of the involucre (rarely terete). Invulucre duuble; the outer spreading and often foliaceous. Receptacle flat. Leaves opposite.

55. Coreopsis. Papjus of 2 (or rarely more) scales, teeth, or awns, which are naked or barbed upward, sometimes obsolete or a mere crown.

56. Bidens. Pappus of 2 or more rigid and persistent downwardly barled awns or teeth.

57. Thelesperma. Inner involucre connate to the middle. Achenes terete. Awns rctrorsely bearded.

* 5. Heads radiate or discoid; disk-flowers all perfect and fertile. Achenes turbiuate, 5angled : paplus of several chaffy scales.

- Leaves altermate, entire. Disk-flowers purplish.

58. Baldwinia. Rays numerous, long, neutral. Involucre much inbricated. Receptacle deeply honey-combed.

59. Marshallia Rays none. Involucre of narrow leafy equal scales. Receptacle chaffj: 
+ + Leaves opposite, serrate. Disk-flowers yellow.

60. Galinsoga. Rays few, short, pistillate, whitish. Involucre of $4-5$ thin ovate scales. Receptacle chaffy.

Tribe VI. HELENIOIDEA. Nearly as Tribe V., but receptacle not chaffy (somewhat so in n.64). In our genera, the disk-flowers perfect and fertile; the pappus a row of several chaffy scales (bristly-dissected in n. 65); the iuvolucre hardly at all imbricated (partly scarious in n. 61).

* Involucral scales distinct, not glandnlar-punctate.

61. Hymenopappus. Rays none. Receptacle flat. Involucre colored. Western.

62. Actinella. Rays fertile, 3-tnothed. Receptacle elevated. Involucre appressed. Western.

63 Helenium. Rays fertile or sterile, 3-5-cleft. Receptacle elevated. Involucre small, reflexed. Leaves decurrent.

61. Gaillardia. Ray 3-toothed, or none. Receptacle usually beset with fine fimbrillate chaff. Outer involucral scales loose and leafy. Pappus-chaff tipped with the projecting midvein. Western.

** Dotted with oil-glands. Involucral scales united into a cup.

65. Dysodia. Pappus a row of chaffy scales dissected into many bristles.

Tribe VII. ANTHEMIDEE. Distinguished from the last two tribes by the more or less dry and scarions imbricated scales of the involucre. Heads radiate (ray mostly white) or discoid, the perfect flowers sometines sterile and the pistillate rarely tubular. Achenes small; pappus a short crown or none. - Mostly strong-scented; leaves alternate.

* Receptacle chaffy, at least in part. Heads radiate, many-flowered.

66. Anthemis. Achenes terete, angled or ribbed. Heads hemispherical, rather large.

67. Achillea. Achenes obcompresserl. Heads small, campanulate or obovate.

** Receptacle naked.

+ Heads rather large, pedunculate, radiate or rarely rayless.

68. Matricaria. Receptacle conical. Rays pistillate or none. Pappus crown-like or none.

69. Chrysanthemum. Receptacle flattish. Rays many, pistillate. Pappus none.

+ + Heads mostly small, discoid, corymbed or panicnlate.

70 Tanacetum. Heads enrymbed. Achene with broad summit; pappus a short crown.

71. Artemisia. Heads in panicled spikes or racemes. Achenes with narrow summit; pappus none.

Tribe VIII. SENECIONIDEA. Heads radiate or discoid, the involucre little or not at all imbricated, not scarious. Receptacle naked. Anthers tailless. Pappus capillary.

* Heads monœcious or subdiceious, the perfect flowers mostly sterile, and the small (ligilate or tubular) ray-flowers in more than one row (at least in the fertile heads). Stylebranches obtuse, not appendaged nor hispid. Leaves all radical.

7.2. Tussilago. Head solitary, yellow-flowered, monœcious.

73. Petasites, Heads corymbed, subdiœcious. Flowers white or purplish.

* * Flowers all fertile. Style-branches truncate or capitellate, often appendaged. Involucral scales connivent-crect.

$$
\text { - Leaves opposite. }
$$

74. Arnica, Heads showy. Pappus rather rigid, scabrous.

$$
\text { + + Leaves alternate. Pappus soft-capillary, copious. }
$$

75. Senecio. Heads usually radiate. Corollas yellow, 5 -toothed.

76. Cacalia. Heads discoid. Corollas white or cream-colnred, 5-cleft.

77. Erechtites. Heads discoid. Flowers whitish, the outer pistillate with filiform corollas. 
Tribe IX. CYNA ROIDEA. Flowers all tubnlar and preffect (the onter ray-like and neutral in n. 82). Involuere inuch imbricated. Anthers caudate, long-ajpentaged at tip. Style-branches short or united, olotuse, unapjendaged, smooth, with often a pubescent ring below. Pappus mostly bristly. - Leaves alterate.

* Achenes attached by the base. Flowers all alike.

- Leaves not prickly. Style-branches partly distinct. Filaments glabrous.

79. Aretium. Involucral scales hooked at the tip. Papjus of short rough bristles. ++ Leaves prickly. Style-branches cohcrent, usually a pubescent ring below.

79. Cnicus. Papjus-bristles plumose. Recejtacle densely bristly.

So. Carduus. Papjus-bristles not plumose. Receptacle densely bristly.

81. Onopordon. Payuus-luristles not plumose. Receptacle decply honeycombel. * Achenes attached obliquely. Marginal fluwers often eularged and ray-like.

82. Centaurea. Involueral scales appendaged. Pappus double and bristly, or very short or none.

\section{Sheres II. LIGULIFLORA. Tribe $x$. CICHORIACE.}

Corolla ligulate in all the flowers of the head, and all the flowers perfect. - Herbs, with milky juice. Leaves alternate.

* Pappus none.

83. Lampsana. Involucre cyliulrical, of 8 scales in a single row, 8 -12-flowered.

* Pappus chaffy, or of both chaff and bristles.

84. Krigia. Involucre simple, not calyculate. Pappus of both chaff and bristles.

S5. Cichorium. Involucre double. Pappus a small erown of many bristle-form scales.

* * Pappus pluminse.

86. Tragopogon. Involucre simple, not calyculate. Achenes long-beaked. Stems leafy

87. Leontodon. Involucre calyeulate. Achenes fusiform. Leaves radical.

88. Picris. Outer involucral scales spreading. Achenes terete. Stems leafy.

* * * Pappus composed entirely of capillary bristles, not plumose.

- Achenes not flattened, columnar or terete, often slender.

* Achenes not beaked.

$=$ Flowers ycllow or orange.

89. Hieracium. Involncre imbricated. Pappus tawny. Pilnse perennials.

90. Crepis. Involucral scales in one row. Palpus white, soft. Not pilnse.

$==$ Flowers white or cream-color or pinkish. Involncre calyculate.

91. Prenanthes. Achenes short, blunt. Papus tawny or brown. Steins leafy and heads often nodling.

92. Lygodesmia. Achenes long, tapering. Pappus white. Sterns nearly leafless; heals erect. Western.

\#++ Achenes beaked (sometimes beakless in n. 93). Flowers yellow.

93. Troximon. Seapose. Involucre loosely imbricated. Achenes 10-ribhed.

94. Taraxacum. Scapose. Involuere calyenlate. Achenes 4-5-ribhed.

95. Pyrrhopappus. Scapose or branched. Pappus reddisl, the base surrounded by a soft villous ring.

96. Chondrilla. Stem branching, leafy. Involuere few-flowered, calyculate. Pappus white.

- + Achenes flat or flattish. Papuus white, fine and soft. Involucre imbricated. Leafy. stemaned, with panicled hearls.

97. Lactuca. Achenes more or less heaked. Flowers yellow or purplish.

98. Sonchus. Achenes fattish, not at all beaked. Flowers yellow. 
The technical characters of the tribes, taken from the styles, require a magnifying-glass to make them out, and will not always be clear to the student. The following artificial analysis, founded upon other and more obvious distinctions, will be useful to the beginner.

\section{Artificial Key to the Genera of the Tubulifiora.}

8 1. Rays or ligulate flowers none; corollas all tubular (or rarely none).

* 1. Flowers of the head all perfect and alike.

Pappus composed of uristles :

Double, the outer of very short, the inner of longer bristles _ . . . . No. 2

Simple, the bristles all of the same surt.

Heads few-flowered, themselves aggregated into a compound or dense cluster . . 1

Heads separate, few-flowered or many-flowered.

Receptacle (when the flowers are pulled off) bristly-iairy . . . . 78, 79, 80

Receptacle deeply honeycomb-like . . . . . . . . . . 81

Receptacle naked.

Pappus of plumose or bearded stiff bristles. Flowers purple . . . . 8

Pappus of very plumose bristles. Flowers whitish . . . . . . 6

Pappus of slender but rather stiff rough bristles . . . . 4, 4, 7, 9, 16

Pappus of very soft and weak naked bristles . . . . . . 76,77

Pappus composed of seales or chaff.

Receptacle naked. Leaves in whorls . . . . . . . . . . 3

Receptacle naked. Leares alternate, dissected . . . . . . . . 61

Receptacle bearing ehaff among the flowers . . . . . . . . 59,64

Pappus of 2 or few awns or teeth . . . . . . . 12, 53, . . . barbed in 55,56

Pappus none, or a mere crown-like margin to the fruit . . . . . . 36, 68,71

* 2. Flowers of two kinds in the same head.

Marginal flowers neutral and stcrile, either conspicuous or inconspicuous . . $\quad 82$

Marginal flowers pistillate and fertile.

Receptacle elongated and bearing broad chaff among the flowers . . . . 29, 30

Receptacle convex, chaffy. Achene flat, 2-awned . . . . . . . 52

Receptacle naked or bearing no conspicuous chaff.

Pappus of capillary bristles. Involucre imbricated . . . . . 28, 32,33

Pappus of capillary bristles. Involucre nerely one row of scales . $\quad$. $26,73,77$

Pappus a short crown or none.

Achenes beconing much longer than the involucre . . . . . . . 34

Achenes not exceeding the involucre . . . . . . . 42,70,71

* 3. Flowers of two kinds in separate heads, the one pistillate, the other staminate.

Heads diœeious : in both kinds many-flowered. Pappus capillary $\quad$. 27, 31, 32, 79 Heads monoeious; the fertile 1-2-flowered and closed. Pappus none . • . 43,44

§ 2. Rays present; i. e. the marginal flowers or some of them with ligulate corollas.

* 1. Pappus of capillary bristles, at least in the disk. (Rays all pistillate.)

Rays occupying several rows . . . . . . . . . . . 26, 72, 73

Rays in one marginal row, and

White, purple or blue, never yellow . . . . . . . 17, 24, 25, 26, 73

Yellow, of the same color as the disk.

Pappus (at least in the disk) double, the outer short and minute . . . 13,14

Pappus simple.

Scales of the involucre equal and all in one row. Leaves alternate . . . 75

Seales of the involucre in two rows. Leaves opposite . . . . . 74

Scales of the involucre imbricated. Leaves alternate . . . 10, 11, 15, 17, 35

* 2. Pappus a circle of awns or rigid bristles (at least in the disk).

Ray yellow, awns few $(2-8)$. . . . . . . . . . 12

Riy rose-color . . . . . . . . . . . . 23 
* 3. Paprus a circle of chaffy scales, dissected into bristles

* 4. l'apjus a cirtle of thin chaffy scales or short chaffy" hristles.

Heads several-flowered. Receptacle ehaffy

Heads 8-10-fluwered. Receptarle naked

Heads many-flowered. Rereptacle deeply honeycombed . . . . . . . 58

Heads nany-flowered. Recepticle naked . . . . . . . . 62,03

Heads many-llowered. Receptacle chatfy . . . . . . . . . . 64

* 5. Pappus none, or a cup or crown, or of 2 or 3 awns, teeth, or chaffy scales corresponding with the edges or angles of the achene, often with intervening minute bristles or si'ales.

- Receptacle naked.

Achene flat, wing-margined. Pappus of seprarate little bristles and usually $2-4$ awns .22 Achene flat, marginless. Pappus none. Receptacle conical . . . . . 19

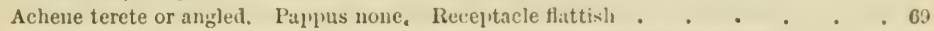
Achene angled. Pappus a little cup or crown (or none). lieceptacle conical _ . 20,6s Achene fusiform. Pappus of few scales, usually with ahternating awns . . . . 21 ++ Receptacle chaffy.

Rays neutral (rarely pistillate but sterile); the disk-flowers perfect and fertile.

Receritacle mostly elevated (varying from convex to columnar), and

Chaffy only at the summit; the chaff deciduous. Pappus none . . . . 66

Chaffy throughout. Achene flattened laterally if at all . . . 48, 49, 50,52,54

Receptacle flat or flattish. Achene flattened parallel with the scales or chatf . 55,56

Receptacle flat. Achene terete, 2-awned . . . . . . . . . 57

Rays pistillate and fertile; the disk-flowers also perfect and fertile.

Achene much flattened laterally, 1-2-awned . . . . . . . . 53

Achene flattened parallel with the scales and chaff. Pappus none. . . . 67

Achene 3-4-angular, terete or laterally flattish, awnless.

Reeeptacle convex or conical. Leaves alternate, dissected . . . . . 66

Receptacle conical. Leaves olposite, simple.

Achene obovoid. Involucre a leafy cup . . . . . . . 45

Achene 4-angular. Involucre of separate scales . . . . . . 47

Receptacle flat. Leaves opposite and simple . . . . . . . 46,51

Rays pistillate and fertile; the disk-flowers staminate and sterile (pistil imperfect).

Receptacle chaffy . . . . . . . . . . . . . 36-4l

\section{ELEPHÁ NTOPUS, I. Elephant's-foot.}

Heads discoid, 2-5-flowered, several together clustered into a compound pedunculate head; flowers perfect. Involucre narrow, flattened, of 8 oblong dry scales. Achenes 10-riblied; pappus of stout bristles, chaffy-dilated at the base. - l'erennials, with alternate leaves and purplish flowers. (Nane composed of $\mathrm{\epsilon}^{\prime} \lambda \epsilon \phi \alpha$ s, elephant, and $\pi$ ous, foot.)

* Stem leafy; upper leaves very like the basal.

1. E. Caroliniànus, Willd. Somewhat hairy, corymbose, leafy ; leaves ovate-oblong, thin. - 1)ry soil, l'enn. to I1l. and Kin., and southward.

* * Stem scape-like, with a few bract-like leaves or naked.

2. E. tomentòsus, L. Somewhat hairy; hasal leaves obovate to narrowly spatulate, silky and prominently veined beneath; lieals large; pappusscales attenuate. - Va., Ky., and southward.

3. E. nudàtus, Gray. Strigose-puberulent; basal leaves thin, green, spatulate-oborate or oblanceolate, not prominently reined beneath; heads smaller; pappus scales broadly deltuid. - I)el. and southward. 


\section{VER NONIA, Schreb. IRON-weEd.}

Heads discoid, 15-many-flowered, in corymbose cymes; flowers perfect. Involucre shorter than the flowers, of many much imbricated scales. Receptacle naked. Achenes cylindrical, ribbed; pappus donble, the outer of minute scale-like bristles, the inner of copious capillary bristles. - Perennial herbs, with leafy stems, alternate and acuminate or very acute leaves and mostly purple flowers. Species very difficult. (Named for Wm. Vernon, an early English botanist who travelled in this country.)

* Heads large, 50-70-flowered.

1. V. Arkansàna, DC. Tall, rather glabrous; leaves linear-lanceolate, retrorsely denticulate; involucre very squarrose, the scales with long filiform tips. - Mo., Kan., and southward.

$$
\text { * * Heads } \frac{1}{2} \text { high or less, 15-40-flowered. }
$$

- Leaves narrowly linear, glabrous, veinless, mostly entire.

2. V. Jamèsii, Torr. \& Gray. Low, nearly glabrous; heads few-flowered; scales obtuse or acute. - Plains of Neb. and southward.

+ + Leaves broader, mostly sharply denticulate or rigidly serrate, veined.

3. V. fasciculàta, Michx. Leaves linear to oblong-lanceolate; heads many, crowded; scales close, obtuse or the uppermost mucronate; achene smooth. - Low grounds, Ohio and Ky. to Dak., and southward. Aug.

4. V. altíssima, Nutt. Usually tall; leaves lanceolate or lance-oblong; cyme loose; scales close, obtuse or mucronate; achenes hispidulous on the ribs. - Low grounds, IV. Penn. to Ill., and southward. - Heads variable, 24 " high and the scales in few or many ranks; the var. GrANdfflòra, Nutt., with large heads, the involucre of $35-40$ scales in many ranks.

5. V. Noveboracénsis, Willd. Rather tall; leaves long-lanceolate to lance-oblong; cyme open; involucre usually purplish; scales ovate and lanceovate tipped with a slender cusp or awn. - Low grounds near the coast, Maine to Va., west to Minn., E. Kan., and southward. Aug.

Var. latifolia, Gray. Leaves broader; heads few ; scales merely acute or acuminate. - Penn, to Ohio and southward.

6. V. Baldwínii, Torr. Tomentulose; heads small, at first globose; leaves lance-oblong or -ovate; involucre hoary-tomentose, greenish, squarrose, the scales acute or acuminate. - Prairies and barren hills; E. Mo. to Kan. and Tex. July, Aug. Passes into n. 4.

\section{SCLERÓLEPIS, Cass.}

Head discoid, many-flowered; flowers perfect. Involucral scales linear, equal, in 1 or 2 rows. Receptacle naked. Corolla 5-toothed. Achenes 5-angled; pappus a single row of 5 almost horny oral and obtuse scales. $-A$ smooth perennial, with simple stems, rooting at the base, linear entire leares in whorls of 4-6, and a terminal head of flesh-colored flowers. (Name composed of $\sigma \kappa \lambda \eta \rho o ́ s$, hard, and $\lambda \epsilon \pi i$, a scale, from the pappus.)

1. S. verticillàta, Cass. - In water; pine barrens, New Jersey and southward. Aug. 


\section{M I K A N I A, Willd. ChmuNg Hemp-WEed.}

Heads discoid, 4 -flowered. Involucre of 4 seales. Receptarle small. Flowers, achenes, ete., as in Eupatorium. - Twining perennials, climbing hushes, with opposite commonly heart-shaped and petioled leaves, and corymbose-panicled flesh-eolored flowers. (Nimed for Proff. Mikron, of l'ragrie.)

1. M. scándens, L. Nearly smooth, twining: leaves somewhat triangular-heart-slaped or halberd-form, pointed, toothed at the hase. - Cupses along streams, E. New Eng. to Ky., and southwarl. July-hept.

\section{EU PATÒ R U M, Tourn. Thonovginort.}

Ileads discoid, 3-many-flowered; flowers perfect. Involuere cyliudrical or bell-shaped, of more than 4 scales. Receptacle flat or conical, naked. Corolla 5-toothed. Achenes 5-angled; pappus a single row of slender capillary barely roughish bristles. - Erect perennial herlss, often sprinkled with hitter resinous dots, with generally corymbose heads of white, bluish, or purple blossoms, appearing near the close of summer. (Dedicated to Eupator Mithridates, who is saill to have used a species of the genus in medicine.)

\section{§ 1. EUPATORIUM proper. Receptacle flat.}

* Heads cylindrical, 5-15-flowered; the purplish scales numerons, closely imbricated in several rows, of unequal length, slightly stricute; stout herbs, with a mple mostly uhorled leaves, and flesh-colored flourers.

1. E. purpùreum, L. (Joe-Pre Wend. Trumpet-Weed.) Stems tall and stout, simple; leaves $3-6$ in a whorl, oblong-ovate or lanceolate, pointed, very veiny, roughish, toothed; corymbs very dense and compound. - Varies greatly in size $\left(2-12^{\circ}\right.$ high), etc., and with spotted or unspotted, often dotted stems, etc., - including several nominal species. - Low grounds ; common.

Var. amœn œum, Gray. Low; leares fewer, ovate or oblong; heads few, 3-5-flowered. - Mountains of Va. and N. Y.

* * Heads 3-20-flowered; involucre of 8-15 more or less imbricated and unequal scales, the outer ones shorter; flowers whte.

- Leaves all alternate, mostly dissected; heads panicled, very small, 3-5-flowered.

2. E. fœniculàceum, Willd. (Dog-Fexsel.) Smooth or nearly so, paniculately much-branched $\left(3-10^{\circ}\right.$ high); leaves $1-2$-pinnately parted, filiform. - Va., near the coast, and southward. $\Lambda d v$. near I'hiladelphia.

+ - Leaves long-petioled, the upper ones alternate; heads 12-15-flowered, in compound corymbs.

3. E. serótinum, Michx. Stem pulverulent-pubescent, bushy-branched (3-70 high); leaves ovate-lanceolate, tapering to a point, triple-nerved and veiny, coarsely serrate $\left(3-6^{\prime}\right.$ long); involucre very pubescent. - Alluvial ground, Md. to Minu., E. Kan., and sonthward.

+ + + Leaves sessile or nearly so, with a narrow base, mostly opposite; heads mostly 5-flowered.

$=$ Involucral scales with white and scarious acute tips.

4. E. álbum, L. Tounhısh-hairy (2० high), lenves oblong-lanceolate, coarsely toothed, veiny; heads clustered in the corymb; involucral scales cluse $\mathrm{v}$ 
imbricated, rigid, narrowly lanceolate, longer than the flowers. - Sandy and barren places, pine barrens of Long Islaud to Va., and southward.

Var. subvenòsum, Gray. Less rough; leaves 1-2' long, fiuely toothed and less reiny - Long Island and N. J.

5. E. leucólepis, Torr. \& Gray. Miuntely pubescent, simple (1-20 high); leares linear-lunceolute, closely sessile, l-nerved, obtuse, minutely serrate, rough both sides; cnrymb hoary. - Sandy bogs, Long Island, N. J., and southward. $==$ Scales not scarious or obscurely so, obtuse, at length shorter than the flowers.

6. E. hyssopifolium, L. Minutely pubescent $\left(1-2^{\circ}\right.$ high $)$; leares nurrou, linear or lanceolute, elongated, obtuse, 1-3-nerved, entire, or the lower toothed, often crowded in the axils, acute at the buse. - Sterile soil, Mass. to Va., E. Ky., and southward.

Var. laciniàtum, Gray. Leares irregularly and coarsely toothed or laciniate. - l'enn., Ky., and southward.

7. E. semiserràtum, DC. Minutely velvety-pubescent, branching (2$3^{\circ}$ high), leares lunceolute or oblong, triple-ribbed and veiny, serrate above the middle, tapering to the base, the lower slightly petioled; heads small. (E. parviflorum, Ell.) - Damp soil, Va. to Ark., and southward. - Leaves sometimes whorled in threes, or the upper alternate.

8. E. altíssimum, L. Stem stout and tall (3-70 high), downy; leaves lanceolate, tapering at both ends, conspicuously 3-nerced, entire, or toothed above the midlle, the uppermost alternate; corymbs dense; scales of the involucre obtuse, shorter than the flowers. - Dry soil, Penn. to Minn. and Ky. - Leaves $3-4^{\prime}$ long, somewhat like those of a Solidago.

+++ + Leares sessile or nearly so, with a broad base, opposite or in threes : heads pubescent.

$=$ Ileuds 5-8-flowered; leaies not clasping.

9. E. teucrifolium, Will. Roughish-pubescent $\left(2-8^{\circ}\right.$ high); leaves ocate-oblong and orate-lancęolate, obtuse or truncate at base, slightly triplenerved, veiny, coarsely toothed or incised touad the base, the lower shortly petioled, the upper alternute; branches of the corymb few, unequal; scales of the involucre oblong-lanceolate, at length shorter than the flowers. - Low grounds, Mass. to Va., and southward near the coast.

10. E. rotundifolium, I. Downy-pubescent ( $2^{\circ}$ high) ; leaces ronndishorate, obtuse, truncate or slightly heart-shaped at the base, deeply crenate-toothed, triple-nerverl, veiny, roughish ( $1-2^{\prime}$ long) ; corymb large and dense; scules of the (5-fowered) involucre linerr-lanceolate, slightly pointed. - Dry soil, R. I. to Va., near the coast, and southward

Var. ovàtum, Torr. Usually taller, leaves ovate, acute, hardly truncate at base, more strongly serrate; heads 5-8-flowered. (E. pubescens, Muhl.) - Mass. to Va., near the coast.

11. E. sessilifòlium, L. (Uplaxn Boxeset.) Stem tall $\left(4-6^{\circ}\right.$ high), smooth, branching; leares oblong-or orete-lanceolate, tapering firom near the rounded sessile base to the sharp point, serrate, veiny, smooth (3-6' long); corymb very compound, pubescent; scales of the 5-floured involucre oval and oblong, obtuse. - Copses and banks, Mass. to Ill., and southwarl along the mountains 
$==$ Leares opposite, clusping or united at the base, long, widcly spreading; heads mostly 10-15-flourered; corymbs rery compound aud larye.

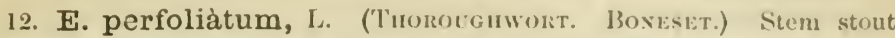
$\left(2-4^{\circ}\right.$ high), hairy; leates lanceolate, united at the base uronul the stem (connateperfoliate), tapering to a slender point, serrate, very veiny, wrinkled, downy beneath $\left(5-8^{\prime}\right.$ long) ; scales of the involucre linear-lanceolate. - Low grounds; common and well-known. - Varies with the heals 30-40-flowered, or with some or all of the leares separated and truncate at base.

Var. cuneàtum, kingelm. Leaves smaller, narrowed at hase and separate, and heads fewer-flowered. I'erhaps a hybrid with 11. 7. - Mo. and southward.

13. E. resinósum, Torr. Minutely ielvely-douny $\left(2-3^{\circ}\right.$ high); leares lineur-lanceolute, elonyated, serrate, partly clusping, tapering to the point, slightly veiny beneath $\left(4-6^{\prime}\right.$ long); scales of the involucre oval, olstuse. - Wet pine barrens, N. J. - Name from the copious resinous glubules of the leaves.

*** Heads 8-30-flouered; inrolucral scales nearly equal, in one row; leaves opposile, ovate, petioled, triple-nerved, not resinous-totted; flowers white.

14. E. ageratoides, L. (Wиite Srake-Root.) Smooth, branching (3 high); leures broadly orate, pointed, coarsely and sharply toothed, long-petioled, thin $\left(3-5^{\prime}\right.$ long) ; corymbs compound. - Rich woods; common northward.

15. E. aromáticum, L. Smooth or slightly downy; stems nearly simple; leaves on short petioles, otute, ruther obtusely toothed, not pointed, thickish. Copses, Mass. to Va., aud southward, near the coast. - Lower and more slender than n. 14, with fewer, but usually larger heads; not aromatic.

§ 2. CONOCLfNIUM. Receptacle conical; involucral scales nearly equal, somewhat imbricated.

16. E. cœlestinum, L. (Mist-flower.) Somewhat pubescent $\left(1-2^{\circ}\right.$ high); leaves opposite, petiolate, triangular-ovate and slightly heart-shaped, coarsely and bluntly toothed ; heads many-flowered, in compact cymes; flowers blue or violet. (Conoclinium colestinum, DC.) - Rich soil, N. J. to Mich., Ill., and southward. Sept.

\section{K Ù H N A , L.}

Heads discoid, 10-25-flowered; flowers perfect. Involucral scales thin, few and loosely imbricated, narrow, striate-nerved. Corolla slender, 5-toothed. Achenes cylindrieal, 10-striate; pappus a single row of very plumose (white) bristles. $-\Lambda$ perennial lierb, resinons-dotted, with mostly alteruate leaves, and paniculate-corymbose heads of eream-colored flowers. (1)edlicated to $\mathrm{Dr}$. Kuhn, of Penusylvania, who carried the living plant to Linnaxus.)

1. K. eupatorioldes, I. Stems $2-3^{\circ}$ high ; pubescence minute; leaves varying from broadly lanceolate and toothesl, to linear aul entire. - I)ry soil, N.J. to Minn., E. Kan., and sunthwarl. Sept. Very variahle. - Var. cokrMBULosi, Turr. \& Gray, is a western form, stuuter and soinewhat noro pubescent, the hearls rather croirded.

\section{BRICKELLIA, Ell.}

Characters as in Kuhnia; involncral scales more numerous, and the bristles of the pappus merely scabrous or at the most harbellate or subplumose; leaves 
often all opposite. (Dr. John Brickell of Georgia, correspondent of Elliott and Muhlenberg.)

1. B. glandiflòra, Nutt. Nearly glabrous, $2-3^{\circ}$ high; leaves deltoid, cordate, the upper deltoid-lanceolate, coarsely dentate-serrate, acuminate, $4^{\prime}$ long or less; heals about 40-flowered. - Shammon Co., Mo. (Bush), Kan to Col., New Mex., and westward.

\section{IIATRIS, Schreb. Button Srakeroot. Blazing-Star.}

Head discoid, few-many-flowered; flowers perfect. Involucral scales well imbricated, appressed. Receptacle naked. Corolla 5-lobed, the lobes long and slencler. Achenes slender, tapering to the base, 10-ribbed. Pappus of 15-40 capillary bristles, manifestly plnmose or only barbellate. - Perennial lierbs, often resinons-dotted, with simple stems from a roundish corm or tuber, rigid alternate narrow entire leaves (sometimes twisted so as to become rertical), and spicate or racemed heads of handsome rose-purple flowers, appearing late in summer or in autumu. (Derivation of the name unknown.)

* Pappus very plumose; scales of the 5-flouered involucre with orate or lanceolate spreading petal-like (purple or sometimes white) tips, exceeding the flowers.

1. I. élegans, Willd. Stem $\left(2-3^{\circ}\right.$ ligh $)$ and involucre hairy; leaves linear, short and spreading; spike or raceme compact (3-20' long). - Barren soil, Va. and southward.

* Pappus very plumose; scales of the cylindrical many-fovered involucre imbricated in many rous, the tips rigid, not petal-like; corolla-lolses hairy within.

2. L. squarròsa, Willd. (BLAziNG-STAR, etc.) Often hairy $\left(6^{\prime}-2^{\circ}\right.$ high); leaves rigid, linear, elongated; heads usually few ( $1^{\prime}$ long $)$; scalcs mostly with elongated and leaf-like spreading tips. - Dry soil, Penn. to Minn., and southward.-Var. INTERmèdi, DC. Heads narrow; scales shorter, erect or nearly so. - Ont. to Neb. and Tex.

3. L. cylindràcea, Michx. Commonly smooth $\left(6-18^{\prime}\right.$ high); leaves linear; heads few $\left(\frac{1}{2}-\frac{2^{\prime}}{3}\right.$ long); scules with short and rounded abruptly mucronate appressed tips. - Dry open places, Niagara Falls to Minn. and Mo.

* * Pappus very plumose; heads 4-6-flowered; scales acuminate; corollalobes naked.

4. L. punctàta, Hook. Stout (10-30' high), from a branching or globose rootstock; leaves narrowly linear or the upper acerose, rigid; heads usually many in a dense spike. - Minn to Kan., and southward.

* * Pappus not obvionsly plumose to the naked eye; corolla-lobes smooth inside.

5. L. scariòsa, Willd. Stem stout $\left(2-5^{\circ}\right.$ high), pubescent or hoary; leares (smooth, rough, or pubescent) lanceolate; the lowest oblong-lanceolate or obovate-oblong, tapering into a petiole; heads few or many, large, 25-40-flowered; scales of the lroad or depressed involucre obovate or spatulatc, very numerons, with dry and scarious often colored tips or margins. - Dry soil, New Eng. to Minn., and southward. - Widely variable; heads $\mathrm{l}^{\prime}$ or less in diameter.

6. I. pycnostàchya, Michx. Hairy or smoothish; stem stout $\left(3-5^{\circ}\right.$ high), very leafy; leaves linear-lanceolate, the upper very narrowly linear; spike thick and dense $\left(6-20^{\prime}\right.$ long); heads about 5-flowered ( $\frac{1}{2}$ long); scales 
of the cylindrical involucre oblong or lanceolate, with recurved or spreading colored tips. - Prairies, from Ind. to Minn., and southward.

7. L. spicàta, Willd. Smooth or somewhat hairy; stems very leafy, stout (2-5० high); leaves linear, the lower 3-5-nerved; hearls 8-12-flowered $\left(\frac{1}{8}-\frac{1}{2}\right.$ ' long), crowded in a long spike; scules of the cylindrical-bell-shaped involucre oblong or oral, obtuse, appressed, with slight margins; achenes pulescent or smoothish. - Moist grounds; common from Mass. to Minn., and soutlwarl. Involucre often resinous, very smooth.

Var. montàna, Gray. Low and stout; leaves broader, obtuse; spike short and heads large. - Mountain-tops, Va., and southward.

8. L. graminifòlia, Willd. Hairy or smoothish; stem ( $1-3^{\circ}$ high) slender, leafy ; leaves linear, elongated, 1-nerved; heads several or numerous, in a spike or raceme, 7-12-flowered; scales of the obconical or oboroid involucre spatulate or oblong, obtuse, or someuhat pointed, rigid, appressed ; achenes hairy. - Va. and southward. - Inflorescence sometimes panicled, especially in

Var. dubia, Gray. Scales of the involucre narrower and less rigid, oblong, often ciliate. - Wet pine barrens, N. J., and southward.

\section{TRÍISA, Cass.}

Heads discoid, 5-10-flowered; flowers perfect. Involucral scales nearly equal, little imbricated. Receptacle naked. Corolla-lobes short-ovate or oblong. Achenes 10-ribbed; pappus of rather rigid bristles, not plumose. Perennial herbs, fibrous-rooted, with broad entire leaves, obscurely or not at all punctate, and cymules of small heals in a thyrse or panicle. Flowers rosepurple, in autumn. (Name an anagram of Liatris.)

1. T. odoratíssima, Cass. (VAxilla-Plant.) Very smooth; leaves pale, thickish, obovate-spatulate, or the upper oval and clasping; heads corymbed. (Liatris odoratissima, Willd.) - Low pine barrens, Va., and southward. - Leaves exhaling the odor of Vanilla when bruised.

2. T. paniculàta, Cass. Fiscid-hairy; leaves narrowly oblong or lanceolate, smoothish, those of the stem partly clasping, heads panicled. (Liatris paniculata, Willd.) - Va. and southward.

\section{GUTIERREZI A, Iag.}

Heads few - several-flowered, radiate; rays $1-6$, pistillate. Involucre oblong-clarate; scales coriaceous with green tips, closely imbricated, the outer shorter. Receptacle sinall, naked. Achenes short, terete; pappus of about 9 chaffy scales, shorter in the ray-flowers. - Suffrutescent (our species), glabrous and often glutinous, much branched, with narrowly linear entire alternate leaves, and small hearls of yellow flowers in fastigiate or paniculate cymes. (From Gutierrez, a noble Spanish family.)

1. G. Euthámiæ, 'Torr. \& Gray. Low; leaves numerous, 1-2' long; heads usually crowcled, the disk-and short ray-flowers usually 3 or 4 each. Dry plains, Mont. and Minn. to central Kan., southward and westward.

\section{A M PHIÁ CHYRIS, Nutt.}

Hearls hemispherical; rays 5-10. I)isk-flowers perfect but infertile. l'appus of the ray minute, coroniform; of the disk-flowers of almost bristle-like 
scales, more or less dilaterl and united at base.-A diffusely much-branched annual, with leads solitary on the branchlets; otherwise as Gutierrezia. (From

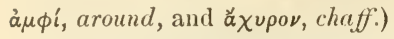

1. A. dracunculoides, Nutt. Rather low, slender; leaves narrowly linear, the upper filiform; disk-flowers $10-20$, their pappus of $5-8$ bristle-like chaff united at base and slightly dilated upward. - Plains, Kan. and southward.

\section{GRIN D ELIA, Will.}

Heads many-flowered, radiate (or rayless); ray pistillate. Scales of the hemispherical involucre imbricated in several series, with slender more or less spreading green tips. Achenes short and thick, compressed or turgid; truncate, glabrous; pappus of $2-8$ caducous awns. Coarse perennial or biennial herbs, often resinous-viscid, ours glabrous and leafy with sessile or clasping alternate and spinulose-serrate or laciniate rigid leaves, and large heads terminating leafy branches. I isk and ray yellow. (Prof. Grindel, a Russian botanist.)

1. G. squarròsa, Dunal. Leaves spatulate- to linear-oblong; involucre squarrose; achenes not toothed; pappus-awns 2 or 3. - Prairies, Minn., southward and westward; Evanston, Ill. - Var. sùDA, Gray. Rays wanting. About St. Louis and westward.

2. G. lanceolàta, Nutt. Leaves lanceolate or linear; involucral scales erect or the lower tips spreading; achenes with 1 or 2 short teeth at the summit; awns 2. - Prairies, eastern Kan. to Ark., and southward.

\section{HETEROTHECA, Cass.}

Characters as in Chrysopsis, but the achenes of the ray thickish or triangular, without pappus or obscurely crowned, and those of the disk compressed, with a double pappus, the inner of numerous long bristles, the outer of many

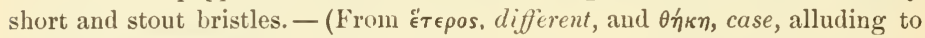
the unlike achenes.)

1. H. Lamárckii, Cass. Annual or biemial, 1-3 high, bearing numerous small heads; leaves oval or oblong, the lower with petioles auricled at base, the upper mostly subcordate-clasping. - S. E. Kan., and southward.

\section{CHRYSÓPSIS, Nutt. Golden Aster.}

Heads many-flowered, radiate; the rays numerous, pistillate. Involucral scales linear, imbricated, without herbaceous tips. Receptacle flat. Achenes obovate or linear-oblong, flattened, hairy ; pappus in all the flowers double, the outer of very short and somewhat chaffy bristles, the inner of long capillary bristles. - Chiefly perennial, low herbs, woolly or hairy, with rather large often corymbose heads terminating the branches. Disk and ray-flowers yellow. (Name composed of $\chi \rho v \sigma o ́ s$, gold, and oै $\psi เ s$, aspect, from the golden blossoms.)

* Leaves narrouly lanceolate or linear; achenes linear.

1. C. graminifòlia, Nutt. Silvery-silky, with long close-presserl hairs; stem slender, often with runners from the base, naked above, bearing few heads; leaves lanceolate or linear, elongated, grass-like, nerved, shining, entire. - Dry sandy soil, Del. to Và., and southward. July - Oct. 
2. C. falcàta, Ell. Stems $\left(4-10^{\prime}\right.$ high) very woolly; leaves crouded, linear, rigid, about 3-nerved, entire, someuhat resurved or scythe-shaped, harry, or smorth when old, sessile; heads (small) corymberl. - Dry sandy soil on tho coast, pine barrens of N. J. to Nantucket and Cape Cod, Mass. Aug.

* * Leaves oblong or lanceolute, entire or slightly serrute, mostly sessile, veined, not nerverl; achenes obovate, fluttened.

3. C. gossýpina, Nutt. Inensely woolly all over; leaves spatulute or ob. long, obtuse ( $1-2^{\prime}$ long); heads larger than in the next. - I'ine harrens, Va., and southward. Ang.-Oct.

4. C. Mariana, Nutt. Silky with long and weak harrs, or when old smonthish; leaves oblong; heals corymbed, on glanlular peiluncles. - 1)ry barrens, from S. New York and l'enn., southwarl, near the coast. Aug. - ()ct.

5. C. villosa, Nutt. IVirsute and villons-pubesrent; stem corymbosely branched, the branches terminated ly single short-peduncled heads; lecres nurrouly oblong, hoary with rough mbescence (as also the involucre), bristly-ciliate toward the base. - Dry plains and prairies, Wisc. to liy., and westward. July Sept. Very variable. - Var. If́spids, Gray. Low, hirsute and hispid, not canescent; heads small. Kall., west and sonthward. - Var. CANéscexs, Gray. Wholly canescent with short appressed pubescence; leaves narrow, mostly oblanceolate. - Kan. to Tex.

6. C. pilòsa, Nutt. Annual, soft-hirsute or villous; leaves oblong-lancoolate; involucre viscid; outer pappus chaffy and conspicuous. - Kan. and southward

\section{A PLOPÁ P P U S, Cass.}

IIeads many-flowered, radiate; rays many, pistillate. Involucre hemispherical, of many closely imbricated scales in several series. Receptacle flat. Achenes short, turbinate to linear; pappus simple, of numerous unequal bristles. - Mostly herbaceous perennials, with alternate rigicl leaves. Ray.

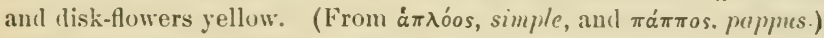

1. A. ciliàtus, I)C. Annual or hiemnial, glabrous, $2-5^{\circ}$ high, leafy; leaves oval (or lower obovate), obtuse, dentate with bristle-pointed teeth; heads very large, few and clustered, the outer seales spreacliug; achenes glabrous, the central abortive. - Mo., Kan., and southward.

2. A. spinulòsus, DC. P'erennial, branching, puberulent or glabrate, low ; leaves narrow, pinnately or bipinnately parted, the lobes and teeth bristletipped; heads small, the appressed scales bristle-tipped; achenes pubescent. - Minn. to Kan., and sonthward.

3. A. divaricàtus, Gray. Annual, 1-2 high, slender and diffuscly paniculate, rough-pubescent or glabrate; leaves rigil, narrow, entire or with a few spinulose teeth, much reduced ahove; heals small and uarrow, the appressed scales subulate, attenuate; achenes silky. - Suntheru lian.

\section{BIGELÒ VIA, IC. Ruress Gomesom.}

Hearls 3-4-flowered, the flowers all perfect and tulular. Involucre clubshaped, yellowish; the rigid somewhat glutinous scales linear, closely imbri. eated and appressed. Receptacle narrow, with an awl-shaped prolongation in the centre. Achenes somewhat obconical, hairy; pappus a xingle row of 
capillary bristles. - Flowers yellow. Leaves scattered, oblanceolate or linear, 1-3-nerver. A large western genus, few species approaching our limits. (1)edicated by De Candolle to Dr. Jacob Bigelou, author of the Florula Bostoniensis, and of the American Medical Botany.)

1. B. nudàta, DC. A smooth perennial; the slender stem ( $1-2^{\circ}$ high) simple or branched from the base, naked above, corymbose at the summit, bearing small heads in a flat-topped corymb. - Low pine barrens, N. J. (rare), and southward. Sept.

\section{S O L I D A G O, L. Goldex-Rod.}

Heads few - many-flowered, radiate; the rays $1-16$, pistillate. Scales of the oblong involucre appressed, destitnte of herbaceous tips (except n. 1 and 2). Receptacle small, not chaffy. Achenes many-ribbed, nearly terete; pappus simple, of equal capillary bristles. - Perennial herbs, with mostly wand-like stems and nearly sessile stem-leaves, never heart-shaped. Heads small, racemed or clustered; flowers both of the disk and ray (except n. 6) yellow. (Name from solidus and ago, to join, or make whole, in allusion to reputed vulnerary qualities.) Flowering in autumn.

\section{Conspectus of Groups.}

Ileads small, sessile in flat-topped enrymbs; leaves linear _ . . . . . 41, 42 Heads all more or less pedicelled.

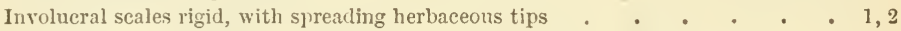
Involueral scales without green tips.

Heads in a compound terminal corymb, not at all racemose . . . . 37-40

Heads small, mostly clustered in the axils of feather-veined leaves . . . 3-7

Heads mostly large, in a terminal thyrse; leaves feather-veined.

Westem species . . . . . . . . . . . . . .8,9

Northern or mountain species . . . . . . . . . 10-12

Ileads mostly small or middle-sized : inflorescence paniculate (sometimes thyrsoidal).

Leaves 3 -ribbed; heads in 1 -sided spreading panicled racemes.

Stem and leares smooth and glabrous . . . . . . . . 29-32

Pubescent or scabrous . . . . . . . . . . . . $33-36$

Leaves not 3-ribbed, or only obscurely triple-nerved.

Hearls large; leaves thickish, very smooth, entire. Seashore . . . . 13

Panicle virgate or thyrsoid; leaves nearly entire . . . . . 14-17

Heads very small in a short broad panicle: leares nearly entire . . . 18-20

Heads racemosely paniculate; leaves ample, the lower serrate • . 21-28

§1. VIRGAUREA. Rays mostly fewer than the disk-flowers; heads all more or less pedicelled.

* Scales of the much imbricated and rigid involucre with abruptly spreading herbaceous tips; heads in clusters or glomerate racemes, disposed in a dense somewhat leafy and interrupted wand-like compound spike.

1. S. squarròsa, Muhl. Stem stout (2-50 high), hairy above; leares large, oblong, or the lower spatulate-oval and tapering into a margined petiole, serrate, veiny; heads numerous; scales obtuse or acute; disk-flowers 16-24, the rays 12-16. - Rocky and wooded hills, Maine and W. Vt. to Penn., Ohio, and the mountains of Va.; rather rare.

2. S. petiolàris, Ait. Minutely hoary or downy; stem strict, simple (1 $3^{\circ}$ high); leaves small ( $\frac{1}{2}-2^{\prime}$ long), oval or oblong, mucronate, veiny, roughciliolate; the npper entire and abruptly rery short-petioled, the lower often ser. 
rate and tapering to the base; heads few, in a wand-like raceme or paniele, on slender bracted pedicels; rays about 10 , elongated ; scales of the pubescent involncre lanceolate or linear-awl-shaped, the outer louse and spreauling, more or less foliaceons. - S. W. Ill. to Kan. and southward. - The nane is misleading, as the leaves are hardly petioled.

* Inrolucral scales without qrepn tips and wholly appressed.

+ Heads small (3"long), clnstered along the stem in the axils of the feathervcined leaves, or the upper forming a thyrse.

\section{+Achenes pubescent.}

3. S. cæsia, L. Smooth; stem terete, mostly glaucons, at length much branched and diffuse; leaves lancerlute or oblong-lanceolate, serrate, pointed, sessile; heads in very short clusters, or somewhat racemose-panicled on the hranches. - Rich woodlands, common ; west to S. E. Minn., Ill., and Ky.

4. S. latifolia, I. Smooth or nearly so; stem angled, zigzag, simple or paniculate-branched $\left(1-3^{\circ}\right.$ high $)$; leaves broadly ovate or oval, very strongly and sharply serrate, conspicuously pointed at both ends (thin, $3-6^{\prime}$ long); hearls in rery short axillary clusters, or the clusters somewhat prolonged at the end of the branches; rays 3-4.- Moist shaded banks; common northward, and south along the mountains.

5. S. Curtísii, Torr. \& Gray. Smooth or nearly so; stem angled, usually branched; leaves oblong to long-lanceolate with narrowed entire base, serrate above with subulate teeth; heads in small, loose clusters; rays $4-7$. - Open woods at low elevations in the mountains of Va. and southward.

\section{+* Achenes glabrous; inflorescence more thyrsoid.}

6. S. bícolor, L. Hoary or grayish with soft hairs; stem mostly simple; leaves oblong or elliptical-lanceolate, acute at both ends, or the lower oval and tapering into a petiole, slightly serrate; clusters or short racemes from the axils of the upper leaves, forming an interrupted spike or crowded panicle; scales very obtuse; rays (5-14) small, cream-color or nearly white. - Var. cóxcolor, Torr. \& Gray, has the rays yellou'. - Dry copses, west to Minn. and Mo.

7. S. montícola, Torr. \& Gray. Nearly glabrous; stem slender, $1-2^{\circ}$ high; leaves oblong-ovate to lanceolate, acute or tapering at both encls, the lower sparingly serrate; heads small, the scales acutish; rays $5-6 .-$ Alleghany Mts., from Md. southward.

+ + Ileads mostly large (smaller in n. 12), many-flowered, forming an erect terminal thyrse; leaves feuther-veined.

* Leaves numerons, short, sessile, entire, nniform in size and shape; western.

8. S. Bigelovii, Gray. Cinereous-puberuleut, $2^{\circ}$ high; leaves oval and oblong, mostly obtuse at both encls; thyrse rather loose; involucre broad. S. Kan. and southward. Probably rmming into the next.

9. S. Lindheimeriàna, Scheele. Less puberulent; leaves lanceolate or oblong, more acute; heals narrower and more densely clustered; acheues glabrous. - S. Kan. and sonthward.

$$
\text { *+ Northern or mountain species, bright green. }
$$

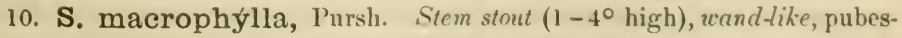
cent near the summit, simple; leav's thin, ovate, irregularly and coarsely serrate 
with sharp salient teeth, large (lower $3-4^{\prime}$ long), all but the uppermost abruptly contracted into long and margined petioles; heads large $\left(5-6^{\prime \prime}\right.$ long), manyflowered, crowded in an oblong or wand-like raceme or contracted panicle (2$18^{\prime}$ long); scales loose and thin, long, lanceolate, taper-pointed; rays 8-10, elongated; achenes smooth. (S. thyrsoidea, E. Mey.) - Wooded sides of mountains, N. Maine to N. Y. (sonth to the Catskills), shore of L. Superior, and northward. - Very near a Enropean form of S. Virgaurea.

11. S. Virgaùrea, Linn. An extremely variable aud confused species in the Old World, represented in North America hy

Var. alpina, Bigel. Dwarf $\left(1-8^{\prime}\right.$ high), with few $(:-12)$ pretty large heads $\left(3-4^{\prime \prime}\right.$ long, becoming smaller as they increase in number); leaves thickish, mostly smooth, spatulate or obovate, mostly obtuse, finely serrate or nearly entire, the uppermost lanceolate; heads few in a terminal cluster or subsolitary in the upper axils; scales lanceolate, acute or acutish; rays about 12. - Alpine summits of Maine, N. H., and N. Y., and shore of L. Superior.

12. S. hùmilis, Pursh. Low $\left(6-12^{\prime}\right.$ high) and smooth, bearing several or numerous loosely thyrsoid smaller heads, which, witl the peduncles, etc., are mostly somewhat glntinous ; scales obtuse ; rays 6-8, short; upper leaves lanceolate to linear, entire, the lower beccming spatulate and sparingly serrate. (S. Virgaurea, var. humilis, Gray.) - Rocky banks, W. Vt., along the Great Lakes, and northward; also on islands in the Susquehanna, near Lancaster, and at the Falls of the Potomac. - It the base of the White Mountains, on gravelly banks, occurs a form with the minutely pubescent stout stem $1-2^{\circ}$ high, the leaves larger, broader, and coarsely toothed, and the heads very numerous in an ample compound raceme; rays occasionally almost white.

Var. Gillmàni, Gray. Larger ( $2^{\circ}$ high), rigid, with compound ample panicle and laciniately toothed leaves. - Sand-hills of the lake-shores, N. Mich. + + + Ileads small or middle-sized (large in n. 13 and 17), panicled or sometimes thyrsoidal, not in a terminal corymbiform cyme; not alpine.

+ Leaves veiny, not 3-ribbed, but sometimes obscurely triple-nerved.

$=1$. Heads commonly large; leaves thickish, very smooth, entire, elongated.

13. S. sempérvirens, L. Smooth and stout $\left(1-8^{\circ}\right.$ high $)$; leaves lanceolate, slightly clasping, or the lower ones lanceolate-oblong, obscurely triplenerved; racemes short, in an open or contracted panicle. - Salt marshes, or rocks on the shore, Maine to Va. - Heads showy; the golden rays 7-10. Varies, in less brackish swamps, with thinner elongated linear-lanceolate leares, tapering to each end, and more erect racemes in a narrower panicle.

= 2. Heads small, in a narrow virgate or thyrsoid panicle; scales thun, acute: leaves nearly entire.

14. S. strícta, Ait. Very smooth throughout; stem strict and simple, wand. like $\left(2-4^{\circ}\right.$ high), slender, beset with small and entire appressed lanceolateoblong thickish leaves, gradually reduced upward to mere bracts; the lowest oblong-spatulate; heads crowded in a very narrow compound spicate raceme; rays 5-7. (S. virgata, Mich.x.) - Damp pine barrens, N. J. and southward.

15. S. pubérula, Nutt. Stem $\left(1-3^{\circ}\right.$ high, simple or branched) and panicle minutely hoary; stem-leaves lanceolate, acute, tapering to the base, smoothish ; the lower wedge-lanccolate and sparingly toothed; heads very numerous and 
mouded in compact short rucemes forming a prolonged and dense narrow or pyramidal pamicle; scales linear-aul-shuped, appressed; rays alout 10. Sandy soil, Maine to Va. and southward, mostly near the coast.

$=3$. Heads middle-sized, in a thyrsoid punicle; incolucral scales rather firm, olunse; leaves entire or little serrate, smooth.

16. S. uliginosa, Nutt. Smooth nearly throughout; stem simple, strict $\left(2-3^{\circ}\right.$ high $)$; leaves lanceolute, pointed, the lower tapering into wingerl petioles, partly sheathing at the base, sparsely serrulate or entire; racemes much crouded and upressed in a dense wand-like punicle; stales linear-oblong; rays 5-6, small. (S. stricta, Man.) - Peat-logs, Maine to P'enn., Minn., and northward. Root-leaves $6-10^{\prime}$ long. Flowers earlier than most species, beginning in July.

17. S. Speciosa, Nutt. Stem stout $\left(3-6^{\circ}\right.$ high), smooth; leares thickish, smooth with rough margins, ovel or ovate, slightly serrate, the uppermost oblong-lanceolate, the lower contracted into a margined petiole; heals somewhat crowded in numerous erect racemes, forming an ample pyramidal or thyrsiform panicle; peduncles and pedicels rough-hairy ; scales of the cylindrical involucre oblong; rays about 5, large. - Var. A.rgestits, Torr. \& Gray, is a dwarf form, with the racemes short and clustered, forming a dense interrupted or compound spike. - Copses, Maine to Minn., and sonthward. - A very handsome species; the lower leaves $4-6^{\prime}$ long and $2-4^{\prime}$ wille in the larger forms.

$=4$. Heads very small in slender spreading secund clusters forming a mostly short and broad panicle; leaces entire or nearly so.

18. S. oddra, גit. (Sweet Goldex-Rod.) Smooth or nearly so tliroughout; stem slender (2-30 high), often reclined; leaves linear-lanceolate, entire, shining, pellucid-dotted; racemes spreading in a small one-sided panicle; rays $3-4$, rather large. - Border of thickets in dry or sandy soil, Maine and $V$ t. to Ky., and southward. - The crushed leaves yield a pleasant anisate odor; but an occasional form is nearly scentless.

19. S. tortifolia, Ell. Stem scabrous-puberulent, $2-3^{\circ}$ high; leares linear, short, commonly twisted, roughish-puberulent or glabrate ; rays very short. - I)ry soil, coast of Va. and southward.

20. S. pilossa, Walt. Stem stout, upright $\left(3-7^{\circ}\right.$ high $)$, clothed with spreading hairs; leaves oblong-lanceolate, roughish, hairy beneath, at least on the milrib, serrulate, the upper ovate-lanceolate or oblong and entire, closely sessile; racemes many, recurved, in a dense pyramidal panicle; rays $i-10$, very short. - Low grounds, pine barrens of N. J. to Va. and southward.

$=5$. Ileuds small or middle-sized, racemosely paniculate; leaves lrond or ample, veiny, at least the lower serrate (or entive in 11. 28); involucral scales obtuse.

21. S. pátula, Muhl. Stem strongl!y angled, smooth $\left(2-4^{\circ}\right.$ high) ; leares (4-8' long) ovate, acnte, serrate, pale, very smooth and veiny underneath, lut the upper surface very rough, like shagreen; racemes rather short and numerous on the spreading branches; heads rather large. - Swamps; common.

22. S. rugosa, Mill. Iiongh-hairy, especially the very leaf!y stem $\left(1-6^{\circ}\right.$ high) ; leaves orate-tanceolnte, elliptical or oblong, often thickish and very rugose; racemes spreading; involucral seales linear; rays $6-9$; the disk-flowers $4-7$. (S. altissima, Torr. \&. Gruy, not L.) - Borders of fields aud copses; very cont- 
mon, presenting a great variety of forms; usually one of the lowest of the common Golden-rods. It flowers early. Aug.-Sept.

23. S. ulmifolia, Muhl. Stem smooth, the branches hairy; leaves thin, elliptical-ovate or oblong-lanceolate, pointed, tapering to the base, loosely veined, beset with soft hairs beneath; racemes panicled, recurved-spreading; involucral scales lanceolate-oblong; rays about 4. - Low copses; common. - Too near the last; distinguished only by its smooth stem and thin larger leaves.

24. S. Ellióttii, Torr. \& Gray. Smooth; stem stout $\left(1-3^{\circ}\right.$ high $)$, very leafy; leaves elliptical or oblong-lanceolate, acute (2-3' long), closely sessile, slightly serrate, strongly veined, thick, smooth both sides, shining above; heads in dense spreading racemes which are crowded in a close pyramidal panicle; peduncles and achenes strigose-pubescent. (S. elliptica, Torr. \& Gray, not Ait.) - Swamps (fresh or brackish) near the coast, Mass. to N. J. and southward. - Heads showy, $3^{\prime \prime}$ long; the rays 8-12.

25. S. neglécta, Torr. \& Gray. Smooth; stem stout $\left(2-4^{\circ}\right.$ high), less leafy; leaves thickish, smooth both sides, opaque; the upper oblong-lanceolate, mostly acute and nearly entire; the lower ovate-lanceolate or oblong, sharply serrate, tapering into a petiole; racemes short and dense, at length spreading, disposed in an elongated or pyramidal close panicle; peduncles and achenes nearly glabrous. - Swamps, Maine to Md., Wisc., and Minn. - Heads rather large, crowderl the racemes at first erect and scarcely one-sided. Very variable, the forms approaching $n .16$ and 27 .

Var. linoides, Gray. The most slender form; radical leaves $4-8^{\prime}$ long and $4-6^{\prime \prime}$ wide, the upper very small, erect; branches of panicle rather few, one-sided; rays 2-5. (S. linoides, Torr. \& Gray.) - Mass. to N. J.

26. S. Boòttii, Hook. Smooth, or scabrous-pubescent or below hirsute, slender, often hranched, $2-5^{\circ}$ high ; leaves rather finely serrate, ovate to oblong-lanceolate, pointed; the upper small, oblong to narrowly lanceolate, often entire; heads loosely racemose; rays $1-5$ or none; achenes pubescent. - Dry grounds, Va. and southward.

27. S. argùta, Ait. Smooth; stem angled; leaves (large and thin) ovate, and the upper elliptical-lanceolate, very sharply and strongly serrate (entire only on the branches), pointed at both ends, the lowest on margined petioles; racemes pubescent, spreading, disposed in an elongated open panicle; rays 6-7, large; achenes usually glabrous. (S. Muhlenbergii, Torr. \& Gray.) - Copses and moist woods, N. H. to Yenn., Ont., and N. E. Minn. - Racemes much shorter and looser than in the next; the involucral scales thin and more slender; the heads somewhat larger, fully $3^{\prime \prime}$ long.

28. S. júncea, Ait. Smooth throughout (1-30 high); radical and lover stem-leaves elliptical or lanceolate-oval, sharply serrate with spreading teeth, pointed, tapering into winged and ciliate petioles; the others lanceolate or narrouly oblong, slightly triple-nerved, tapering to each end, the uppermost entire ; racemes dense, naked, at length elongated and recurved, forming a crowded and flat corymb-like panicle: rays 8-12, small. (S. arguta, Torr. \& Gray.) - Var. SCABRÉlla, Gray, is somewhat roughish-pubescent (Wisc. to Ky.). - Copses and banks; common. Well distinguished by its long or drooping racemes, and the closely appressed rigid scales of the involucre, small rays, etc. Heads seldom over $2^{\prime \prime}$ long, the scales small and pale. 
$\leftarrow+$ Leaves more or less plainly 3-ribbed; hends in one-sided spreading or recurved racemes, forming an ample panicle. Not maritime.

$=$ Simooth and glabrous, at least the stem and bright green leares.

a. Leares firm and rather rigid; involucrul scales thickish, obtuse, quite unequal.

29. S. Missouriénsis, Nutt. Smooth throughout $\left(1-3^{\circ}\right.$ high); leares linear-lanccolute, or the lower broally lanceolate, tapering to. both ends, with very rough margins; teeth, if any, sharp and rigid; heads and dense crowded racemes nearly as in 11.28 ; achenes neurly ylubrous. - Dry prairies, from Wisc. and Ind. soutl and westward. - Ileads $1 \frac{1}{2}-2^{\prime \prime}$ long.

30. S. Shórtii, Torr. \& Fray. Stem slender, simple $\left(2-4^{\circ}\right.$ high $)$, minutely roughish-pubescent above; leaves (the larger 2-3' long) oblong-lanceolate, acute, the lower mostly serrate with a few fine teeth; racemes mostly short in a crowded panicle; urhenes silk!/-pubescent. - Rocks at the Falls of the Olio; $\Lambda$ rk. $-\Lambda$ handsome species; heads $3^{\prime \prime}$ long, narrow.

b. Leaves thinner; involucral scules thin, chiefly linear, obtuse.

31. S. serótina, Ait. Stem stont (2-70 high), smooth, often glaucous; leaves quite smooth both sides, lanceolate, taper-pointed, very sharply serrate, except the narrowed base, rough-ciliate; the ample panicle pubescent; rays 7-14, rather long. (S. gigantea, of previous ed.) - Copses and fence-rows; common, and presenting many varieties. Seldom very tall.

Var. gigantèa, Gray. Commonly tall, 5-8 higlı; leaves more or less pubescent or hispidulous beneath. (S. gigantea, Ait.; S. serotina of previous ed.) - Thickets and low grounds, Can. to Tex.

32. S. rupéstris, liaf. Stem smooth, slender, $2-3^{\circ}$ high ; leaves linearlanceolate, tapering both ways, entive or nearly so; panicle narrow; heads very small; rays 4-6, very short. - Rocky river-banks, W. Va. to Ky. and Ind.

\section{$==$ Pubescent (at least the stem) or hispidulous-scabrous.}

33. S. Canadénsis, L. Stem rough-hairy, tall and stout $\left(3-6^{\circ}\right.$ high); leaves lancelate, pointed, sharply serrate (sometimes almost entire), more or less pubescent benerith and rough above; heads small; rays very short. - Borders of thickets and fields; very common. - Varies greatly in the roughuess and hairiness of the stem and leaves, the latter oblong-lanceolate or clongated linear-lanceolate; - in var. PròckR.1, whitish-woolly underneath; and in var. SCABRA also very rough above, often entire, and rugose-veined.

34. S. nemoràlis, Ait. Clothed with a mimute and close grayish-hoary (soft or roughish) pubescence; stem simple or corymhed at the summit $\left(\frac{1}{2}-22^{\circ}\right.$ high); leaves oblanceolate or spatulate-mblong, the lower somewhat crenatetoothed aud tapering into a petiole; racemes numerous, dense, at length recurved, forming a large and crowded compound raceme or panicle which is usually turned to one sile; seales of the involucre linear-oblong, appressed; rays 5-9.-Dry sterile fields; very common. Flowers very liriglit yellow, beginning early in $\Lambda$ ug. - Var. INè̀xı, Gray, of Minn, and westward, is a dwarf form, with rigid oval or oblong leaves, rather strongly serrate or entire, and the clusters of heads in a dense oblong or conical thyrse.

35. S. rádula, Nutt. Stem and oblong or obovate-spatulate leares rigid and very rough, not hoary, the upper sessile; scales oblong, rigil ; rays 3-6; otherwise nearly as in n. 34. - Dry hills, W. Mll., Minn., Kan., and southwarl. 
36. S. Drummóndii, Torr. \& Gray. Stem $\left(1-3^{\circ}\right.$ high) and lower surface of the broadly orate or oval somewhat triple-ribbed leaves minutely velvetypubescent, some of the leaves almost entire; racemes panicled, short; scales of the involucre oblong, obtuse; rays 4 or $5 .-\mathrm{S}$. IV. Ill., Mo., and southward.

++++ Heads in a compound corymb terminating the simple stem, not at all racemose; leaves mostly with a strong midrib.

+ Leaves flat, not 3-nerved.

37. S. rigida, L. Rough and somewhat hoary with a minute pubescence; stem stout $\left(2-5^{\circ}\right.$ high), very leafy ; corymb dense; leares oval or oblong, copiously feather-veined, thick and rigid; the upper closely sessile by a broal base, slightly serrate, the uppermost entire; heads large, over 30 -flowered; the rays 7-10. - Dry soil, N. Eng. to Minn., and southward.

38. S. Ohioénsis, Riddell. Very smooth throughout; stem wand-like, slender, leafy $\left(2-3^{\circ}\right.$ high $)$; stem-leaves oblong-lanceolate, flat, entire, obscurely feather-veined, closely sessile; the lower and radical ones elongated, slightly serrate toward the apex, tapering into long margined petioles; heads numerous, on smooth pedicels, small, 16-20-flowered; the rays 6 or 7.-Moist mealows or prairies, W. New York to Ind. and Wisc. - Root-leaves $1^{\circ}$ long; the upper reduced to $1-2^{\prime}$, with rough margins, like the rest.

+* Leaves someuhat folded, entire, the lower slightly 3-nerved.

39. S. Riddéllii, Frank. Smooth and stout $\left(2-4^{\circ}\right.$ high $)$, very leafy, the branches of the dense corymb and pedicels rough-pubescent ; leaves linear-lanceolate, elongated (4-6' long), acute, partly clasping or sheathing, mostly recurved, the lowest elongated-lanceolate and tapering into a long keeled petiole; heads very numerous, clustered, 20-30-flowered; the rays 7-9.- Wet grassy prairies, Ohio to Minu. and Mo.; Ft. Monroe, Va. - Heads larger than in the last, $2-3$ " long. Stem-leaves upright and partly sheathing at the base, then gradually recurved-spreading.

40. S. Houghtònii, Torr. \& Gray. Smooth; stem ruther low and slender (1-2 ${ }^{\circ}$ high); leares scuttered, linear-lanceolate, acutish, tapering into a uarrowed slightly clasping base, or the lower into margined petioles; heads few or several, 20-30-flowered; the rays 7-9.-Swamps, north shore of Lake Michigan; Genesee Co., N. Y. July, Aug. - Leares rough-margined, 2 - 5' long, 2-4" wide, 1-nerved, or the lower obscurely 3-nerved above; veins obscure. Heads large, nearly $\frac{1}{2}^{\prime}$ long. Scales of the involucre obtuse.

§2. ЕUTHA.MLA. Corymbosely much branched; heads small, sessile, in little clusters crowded in flat-topped corymbs; the closely appressed involucral scales somewhat glutinous; receptacle fimbrillate; rays 6-20, short, more numerous than the disk-flowers; leaves narrow, entire, sessile.

41. S. lanceolàta, L. Leaves lanceolate-linear,3-5-nerved; the nerves, margins, and angles of the branches minutely rough-pubescent ; heads obovoidcylindrical, in dense corymbed clusters; rays 15-20. - River-banks, etc., in moist soil ; common. - Stem $2-3^{\circ}$ high; leaves $3-5^{\prime}$ long.

42. S. tenuifòlia, Pursh. Smooth, slender; leaves very narrowly linear, mostly 1-nerved, dotted; heads obovoid-club-shaped, in numerous clusters of 2 or 3 , disposed in a loose corymb ; rays 6 - 12. - Sandy fields, Mass. to Ill., and southwarl; common near the coast. 


\section{B R A C H Y C H $\mathrm{A} T$ A, Torr. \& Gray.}

False: Golden-1zon.

lleads and flowers nearly as in Solidago, except the pappus, which is a row of minute rather scale-like bristles, shorter than the achene. $-\Lambda$ prenuial herb, with rouuled or ovate serrate leaves, all the louer on s heurt-shuperl; the small yellow heals in sessile elusters racemed or spiked on the branches. (Namo composed of $\beta \rho \alpha \chi u ́ s$, short, and $\chi \alpha i \tau \eta$, bristle, from the pappus.)

1. B. cordata, Torr. \& Gray. Woorled hills, S. Ind. and E. Ky. tı N. Ga. Oet. - Plant $2-4^{\circ}$ high, slender, more or less pubescent.

\section{BÉLLIS, Tourn. DasY.}

IIeads many-flowered, radiate; the rays numerous, pistillate. Scales of the involucre herbaceous, equal, in ahout 2 rows. Receptacle conical, naked. Achenes obovate, flattened, wingless, and without any pappus. - Low herbs (all but our single species matives of the (Old World), either stemless, like the true Daisy, 13. PERkxis (which is fomml as an occasional escape from cultivation), or leafy-stemmed, as is the following. ('The Latin name, from bellus, pretty.)

1. B. integrifólia, Michx. (Westekx I.⿲丿丨.) Anunal or biennial, diffusely branched $\left(t^{\prime}-1^{\circ}\right.$ high $)$, smoothish; leaves lanceolite or oblong, the lower spatulate-obovate; heads on slender peduncles; rays pale violet-purple. - Prairies and banks, Ky. and sonthwestward. March-June.

\section{A PHA NÓSTEPHUS, DC.}

Involucral scales in few series, broadly lanceolate, the outer shorter. Achenes prismatic, the broal truneate apex bearing a short coroniform pappus. Otherwise as Bellis. - Southwestern leafy-stemmed and branching pubescent herbs, with solitary terminal daisy-like lieads. ('A $\phi \alpha \nu \eta$ s, inconspicuous, and $\sigma \tau \dot{\epsilon} \phi o s$, croun; in allusion to the pappus.)

1. A. Arkansànus, Gray. I)iffuse, $1^{\circ}$ high ; leaves oblong-spatulate to broally lanceolate, the lower often toothed or lobed; rays white to purple, $\frac{1^{\prime}}{2}$ long; pappus mostly 4-5-lobed. - Plains of Kan. and southward.

\section{1. С H Æ}

Ifeads several-flowered, raliate; disk-flowers often sterile. Involueral bracts imbricated in 2 or more rows, the outer shorter. Receptacle flat, nakel. Aehenes fusiform or eompressed; pappus of 5 or fewer thin nerveless palea, alternating with rough bristly awus, or these wanting. - Low soutluestern branching annuals, with narrow entire leaves and solitary terminal heads; ray

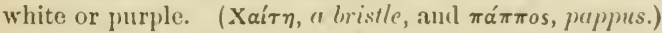

1. C. asteroldes, 1)C. Slenler, 2-10' hight, pubescent; involucres narrow, 2" long; rays 5-12; achenes pubescent.-I)ry grounds, Vernon Co., Mo., and southward.

\section{BOLTON I A, L'Her.}

Heads many-flowered, radiate; the rays numerous, pistillate. Seales of the hemispherical involucre inbricated somewhat in 2 rows, appressed, with narrow nembranaceous margins. Receptacle conical or hemisplerical, naked. Aehenes very flat, obovate or inversely heart-shaped, margined with a callous 
wing, or in the ray 3-winged, crowned with a pappus of several minute bristles and usually 2-4 longer awns. - Perennial and bushy-branched smooth herbs, pale green, with the aspect of Aster; the thickish leares chiefly entire, often turned edgewise. Flowers autumnal; disk yellow; rays white or purplish. (Dedicated to James Bolton, an English botanist of the last century.)

* Heads middle-sized, loosely corymbed.

1. B. asteroides, L'Her. Stems $2-8^{\circ}$ high; leaves lanceolate; involucral scales acuminate; pappus of few or many minute bristles and 2 awns or none. (B. glastifolia, L'Her., the awned form.) - Moist places along streams ; Penn. to Ill., and southward to Fla. Sept., Oct. - Var. DEcúrrexs, Engelm., a large form with the leares alate-decurrent upon the stem and branches. Mo. (Eggert).

2. B. latisquàma, Gray. Heads rather larger; involucral scales oblong to ovate, obtuse or mucronate-apiculate; pappus-awns conspicuous. - W. Mo. and Kan.

* Heads small, panicled on the slender branches.

3. B. diffùsa, L'Her. Stem diffusely branched; leaves lance-linear, those on the branchlets very small and awl-shaped; rays short, mostly white; pappus of several very short bristles and 2 short awns. - Prairies of S. Ill. (Vasey), and southwestward. Aug.-Oct.

\section{TOW N SÉNDIA, Hook.}

lleads many-flowered, the numerous ray-flowers (violet to white) in a single series, fertile. Involucre broad, the lanceolate scariously margined scales imbricated in several series. Receptacle flat, naked. Achenes obovate or oblong, flattened, with thickish margins and beset with forked-capitellate hairs; pappus a single row of long awns or coarse rigid bristles, or reduced in the ray to chaffy scales. - Low scarcely caulescent herbs, with linear to spatulate entire leares and large heads. (Named for David Tounsend, botanical associate of Dr. Darlington of Penn.)

1. T. Sericea, Hook. Acaulescent silky-pubescent perennial; heads sessile, solitary or few, $\frac{1}{2}-1^{\prime}$ ligh ; ray-pappus mostly bristly. - Dry plains, central Neb., north and westward. April, May.

\section{SER I C O C ÁR P S, Nees. White-topped Aster.}

Heads 12-20-flowered, radiate; the rays about 5, fertile (white). Involucre somewhat cylindrical or club-shaped; the scales closely imbricated in several rows, cartilaginous and whitish, appressed, with short and abrupt often spreading green tips. Receptacle alveolate-toothed. Achenes short, inversely pyramidal, very silky; pappus simple, of numerous capillary bristles. - Perennial tufted herbs $\left(1-2^{\circ}\right.$ high), with sessile somewhat 3-nerved leares, and small hearls mostly in little clusters, disposed in a flat corymb. Disk-flowers pale

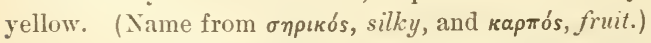

\section{* Pappus rusty; leaves sparingly serrate, veiny, rather thin}

1. S. conyzoides, Nees. Somewhat pubescent; leaves oblong-lanceolate or the lower spatulate, ciliate ; heads rather loosely corymbed, obconical (4-6" long). - Iry ground; Maine to Ohio, and southward. July. 
* Pappus uhite; leaves entire, obscurcly veined, firmer and smaller.

2. S. solidagíneus, Nees. Sinooth, slender; leaves lincatr, rigid, ubtuse, with rough margins, tapering to the base; heads narrow ( $3^{\prime \prime}$ long), in cluse elusters, few-flowered. - Thickets, S. New Eng. to 'Tenn., and suuthward. July.

3. S. tortifòlius, Nees. Hoary-pubescent; leaves obovate or oblongspatulate, short $\left(\frac{1}{2}-l^{\prime}\right.$ loug), vertical, both sides alike; hearls rather lousely corymbel, obovoid ( $4-5^{\prime \prime}$ long). - l'ine woods, Va. and southward. $\Lambda \mathrm{ug}$.

\section{5. Ás T ER, I. Starwort. Mster.}

Heads many-flowered, radiate; the ray-flowers in a single series, fertile. Scales of the involucre more or less imbricaterl, usually with herbaceuus or leaf-like tips. Receptacle flat, alveolate. Achenes more or less flattened; pappus simple, of capillary bristles (double in $\$ \S 4$ and 5). - l'erennial herbs (annual only in $\$ \S 7$ and 8 ), witl corymbel, panicled, or racemose heads; flowering in autumn. Rays white, purple, or blue; the disk yellow, often changing to purple. (Name $\dot{\alpha} \sigma \tau \dot{\eta} \rho, \imath$ star, from the radiate heads of flowers.)

\section{Conspectus of Groups.}

Annuals, with copious fine soft pappus _ . . . . . . . . 53,54

Pappus double . . . . . . . . . . . . . . 46-48

Scales closely imbrieated, not green-tipned, often scarious-edged . . . . 40-52

Sc:ales elosely imbricated, scarcely at all herbaceous ; leaves cordate, serrate . 2, 3

Scales nearly equal, rigid, more or less foliaceous; pappus-bristles rigid, some thickened at top . . . . . . . . . . . . . . . . 1

Scales with herbacenus tips or the onter wholly foliaceons. Asten proper.

Pappus rigid; stem-leaves sessile, none cordate or clasping ; heads few, large . 4-8

Leaves silvery-silky both sides, sessile, entire . . . . . . . 14,15

Lower leaves more or less cordate, petiolate . . . . . . . . 17-24

Leaves entire, lower not cordate, cauline sessile with cordate-claspling base $\quad$. $\quad 16$

Involucre (and branchlets) viseid or glandular ; leaves not cordate, mostly entire, the cauline all sessile or clasping . . . . . . . . . . . 9-13

Lower leaves all acute at base ; not glandular nor viseid nor silky-ranescent.

Smooth and glabrous, usually glaucous; scales coriaceous at base; lexves firm, usually entire

Hoary-pubescent or hirsute; scales squarrose ; stem-leaves small, linear, entire

Scales closely imbricated, not coriaceous at base; branches divaricate; heads many, small

Remaining species; branches erect or ascending.

Stem-leaves auriculate-clasping or with winged-petiole-like base; involucre lax $42-45$ Stem-leaves sessile, but rarely cordate or auriculate at base . . . . 30-41

§ 1. HELIASTRLM. Pappus simple, coarse and rigid, the stronger bristles somewhat charate; scales rigid, more or less fuliucrous, nearly equal.

1. A. paludósus, Ait. Stems $1^{\circ}$ high; glabrous or nearly so; heads 声 ligh, rather few, racemose or spicate; ontex scales lax, foliaceuus; rays purple; leaves linear, entire. - Kan. to Tex., thence to Car. ant Ga.

§2. BIÒTIA. Involucre obovoid-bell-shaped; the scales regularly imbricated in several rows, appressed, nearly destitute of herbaceous tips; rays 6-18 (uhile or nearly so); uchenes slender; pappus slightly rigid, simple; lower leaves large, heart-shaped, petivled, coursely serrate; heads in open corymbs.

2. A. corymbosus, Ait. Stem slender, somewhat zigzag; leaces thin, smoothish, coarsely and unequally serrate with sharp spreading teeth, taprer-pointed, 
orate or ovate-lanceolate, all but the uppermost heart-shaped at the base and on slender naked petioles; rays 6-9.- Woodlands; common; especially northward. July, Aug. - Plant 1-2 ${ }^{\circ}$ high, with smaller heads, looser corymbs, rounder and less rigid exterior involucral scales, and thinner leaves than the next; not rough, but sometimes pubescent.

3. A. macrophýllus, L. Stem stout and rigid $\left(2-3^{\circ}\right.$ high); leaves thickish, rough, closely serrate, abruptly pointed ; the lower heart-shaped $\left(4-10^{\prime}\right.$ long, 3-6' wide), long-petioled ; the upper orate or oblong, sessile or on margined petioles; heads in ample rigid corymbs; rays 10-15 (white or bluish). - Moist woods; common northward, and southward along the mountains. Aug., Sept. - Involucre $\frac{1^{\prime}}{2}$ broad; the onter scales rigid, oblong or ovate-oblong, the innermost much larger and thinner.

§3. ASTER proper. Scales imbricated in various degrees, with herbaceous or leaf-like summits, or the outer entirely foliaceons; rays numerous; pappus simple, soft and nearly uniform (coarser and more rigid in the first group); achenes flattened. (All flowering late in summer or in autumn.)

* 1. Scales vell imbricated, coriaceons, with short herbaceous mostly obtuse spreading tips; pappus of rigid bristles; stem-leaves all sessile, none heart-shaped or clasping; heads few, or when several corymbose, large and showy.

+ Lourest leaves ovate or orate-oblong, some rounded or subcordate at base.

4. A. Hervèyi, Gray. Slightly scabrous, $1-2^{\circ}$ high, the summit and perluncles glandular-puberulent; leaves roughish, obscurely serrate, the lower ovate on nearly naked petioles, the upper lanceolate; heads loosely corymbose, $\frac{1}{2}$ ligh; involucre nearly hemispherical, the scales obscurely glandular, all erect, with very short or indistinct green tips; rays violet, $\frac{1}{2}$ long. - Borders of oak woods, in rather moist soil, E. Mass. and R. I.; Mt. Desert. An ambiguous species, approaching the last.

+ + Radical leaves all tapering into margined petioles; involucres squarrose (hardly so in $\mathrm{n} .8$ ); rootstocls slender.

5. A. spectábilis, Ait. Stems $1-2^{\circ}$ ligh, roughish and glandularpuberulent above; leares oblong-lanceolate, or the lower spatulate-oblong, obscurely serrate or the upper entire; heads few, hemispherical, $\frac{1}{2}{ }^{\prime}$ high ; scales glandular-puberulent and viscid; mostly with tho upper half herbaceous and spreading; rays about 20 , bright violet, nearly $\mathbf{l}^{\prime}$ long. - Sandy soil, Mass. to Del., near the coast, and perhaps southward. Sept.-Nov. One of the handsomest species of the genus.

6. A. surculòsus, Michx. Stems $1^{\circ}$ high or less, from long filiform rootstocks; leaves entire or nearly so, rigid, lanceolate or the upper linear; heads few or solitary, as in the last but generally snuller, the scales hardly glandular. - Noist ground, coast of N. J., and southwart.

7. A. grácilis, Nutt. Rootstocks oceasionally tuberous-thickened ; stems slender, $1^{\circ}$ high; leaves oblong-lanceolate, entire or nearly so, small (1-2' long); heads few or several; involucre top shaped, 3-4" long, glabrous, not glandular nor viscid, the coriaceous whitish scales with very short deltoid or ovate tips ; rays 9-12, 3-6" long. - Pine barrens, N. J. to N. C., E. Ky. and Tenn.

8. A. rádula, Ait. Stem simple or corymbose at the summit, smooth or sparsely hairy, many-leaved $\left(1-3^{\circ}\right.$ high); leares oblong-lanceolate, pomted, 
sharply serrate in the middle, very rouyh both sides and ruyose-2eined, closely sessile (2-3' longr), nearly equal; scules of the hell-shuped involucre oblong, ap)pressed, with ver:y short and slightly spreading herbarrous tips; achenes smooth. - Bugs and low grounds, Del. to Maine and northwarl, near the coast; also Pocono Mountain, l'enn. A dwarf form (var. stuf́cts, Gray) has oblong-to linear-lanceulate nearly entire leaves, and usually sulitary heals; White Mountaius, N. H., to I abb. Aug. - Rays light violet. Involucre nearly smooth, except the ciliate margius.

* 2. Involuere and usually the branchlets visridly or juruinose-ylanululur, ucdl imbricated or loose; pubescence not silky; leures cutire (on the lonter wilh few tecth), the cuuline all sessile or clasping: rays shouy, violet to purple.

+ Ileuls smull; ineolucre not squarrose. Extieme western.

9. A. Féndleri, Gray. Rigirl, $1^{\circ}$ high or less; leaves firm, linear, 1nerved, hispicl-ciliate, $l^{\prime}$ long or mostly much less; heads scattered, $3^{\prime \prime}$ high ; scales linear-ollong, oltuse, or the inuer acute. - Central lian. (Ellis, $D r$. $L$. Watson) and sunthwestward.

+ + Heads larger; involucral scales spreading, in few or mony ronks.

10. A. grandiflorus, I. Rough with mimute hispid hairs; stems slenter, loosely much branched $\left(1-3^{\circ}\right.$ high $)$; leaves very small $\left(\frac{1}{4}-1^{\prime}\right.$ long), oblonglinear, oltuse, rigid, the uppermost passing into scales of the liemispherical squarrose many-ranked involucre; rays bright violet ( $1^{\prime}$ long) ; achenes hairy. - Dry open places, Va. and sonthward. - Heads large and very showy.

11. A. oblongifolius, Nutt. Minutely ylandular-puberulent, much branched above, rigid, paniculate-corymbose ( $1-2^{\circ}$ high); leaves narouly ollong or lanceolate, mucronate-pointerl, partly clasping, thickish (1-2' long by $2-5^{\prime \prime}$ wide); involucral scales nearly equal, broadly linear, appressed at the base; rays violet-purple; achenes cancscent. - Banks of rivers, from l'enn. and Va. to Minn, and Kan. - Ileads middle-sized or smaller.

Var. rigídulus, Gray. Low, with more rigid and hispiclulous seabrons leaves. - In drier places, Ill., Wisc., and southwestward.

12. A. Nòvæ-Ángliæ, L. Sitem stout, hairy (3-8 high), corymbed at the summit; leaves very numerous, lanceolute, entire, acute, auriculute-clusping, clothed with minute puliescence, 2-5' long; scales nearly equal, lineur-aul-shaped, loose, glundular-viscid, as well as the branchlets; rays violet-purple (in var. ròseus rose-purple), very uumerous; achenes hairy. - Moist grounds ; common. - Ileads large. $\Lambda$ peculiar and handsome species.

13. A. modéstus, lindl. I'ulescent or glabrate; stem slender, simple, with few large heals terminating slender branchlets; leaves lanceolate, very acute, narrowed to a sessile base, sparingly serrate or serrulate; scales linearattenuate, equal, mostly herbaceous; rays blue. - N. Dak. and westward.

* 3. Leaves whitened, silvery-silky both sides, all sessile and entire, mucromulate; involucre imbricated in 3 to sereral rous; ruys showy, purple-violet.

14. A. sericeus, Vent. Stems slender, branched; leaves silver-white. lanceolate or ob]ong, heads mostly solitary, terminating the short branchlets ; scales of the globular involucre similar to the leares, spreadiny, except the short coriaceons base; achenes smooth, many-ribbed. - I'rairies and dry bauks, Wisc. aud Minn. to Ky., and suuthward. - Heads large; rays 20-30. 
15. A. cóncolor, L. Stems wand-like, nearly simple; leaves crowcled, oblong or lanceolate, appressed, the upper reduced to little bracts; heads in a simple or compound wand-like racene; scales of the obovoid involucre closely imbricated in several rows, appressed, rather rigid, silky, lanceolate; achenes silky. - Dry sandy soil near the coast, R. I., N..J., and southward. - Plant 1 $3^{\circ}$ high, with the short leaves $1^{\prime}$ or less in length, grayish-silky both sides.

* 4. Leaves entire, the lower not heart-shaped, the cauline all with sessile and cordate-clasping base, the auricles generally meeting around the stem.

16. A. pàtens, Ait. Rough-pubescent; stem loosely panicled above (1 $3^{\circ}$ high), with widely spreading branches, the heads mostly solitary, terminating slender branchlets; leaves oblong-lanceolate or ovate-oblong, often contracted below the middle, rough, especially above and on the margins; scales of the minutely roughish involucre with spreading pointed tips; achenes silky. - Var. PHLOGIFólius, Nees, is a form of shady moist places, with larger and elongated thin scarcely rough leaves, lowny underneath, sometimes a little toothed above, mostly much contracted below the middle. - Dry ground; common, Mass. to Minn., and southward. Heads $\frac{\lambda^{\prime}}{2}$ broad, with showy deep blue-purple rays.

* 5. Lower leaves heart-shaped and petioled; no glandular or viscid pulescence; heads with short and appressed green-tipped scales (except in n. 17 and 24), mostly small and numerous, racemose or panicled.

t- Heads middle-sized, with many rays, and squarrose foliaceous involucre.

17. A. anómalus, Engelm. Somewhat pubescent and scabrous; stems slender $\left(2-4^{\circ}\right.$ high), simple or racemose-branched above ; leaves ovate or ovatelanceolate, pointed, entire, the upper small and almost sessile; scales of the hemispherical involucre imbricated in several rows, appressed, with linear spreading leafy tips; achenes smooth. - Limestone cliffs, IV. Ill. and Mo. to Ark. - Rays violet-purple.

+- Rays 10-20; involucral scales appressed or erect.

${ }_{+-+}$Leaves entire or slightly serrate; heads middle-sized; rays bright-blue.

18. A. azùreus, Lindl. Stem rather rough, erect, racemose-compound at the summit, the branches slender and rigid; leaves rough, the lower ovatelanceolate or oblong, heart-shaped, on long often hairy petioles; the others lanreolate or linear, sessile, on the branches awl-shaped; involucre inversely conical. - Copses and prairies, western N. Y., and Ohio to Minn., and southwestward. Involucre much as in $\Lambda$. læris, but smaller and slightly pubescent.

19. A. Shórtii, Hook. Stem slender, spreading, nearly smooth, bearing very numerous heads in racemose panicles; leaves smooth above, minutely pubescent underneath, lanceolate or orate-lanceolate, elongated, tapering gradually to a sharp point, all hut the uppermost more or less heart-shaped at base, and on naked petioles, none clasping; involucre bell-shaped. - Cliffs and banks, Ohio to IIl., and southward. - A pretty species, $2-4^{\circ}$ high ; leares $3-5^{\prime}$ long.

20. A. undulàtus, L. Pale or somewhat hoary with close pubescence; stem spreading, bearing numerous heads in racemose panicles; leaves ovate or ovate-lanceolate, with wavy or slightly toothed margins, roughish above, downy underneath, the lowest heart-shaped on margined petioles, the others abruptly coniracted into short broadly winged petioles which are dilated and clasping at the 
hase, or directly sessile by a heart-shaperl base; involucre obovoul, the scales less rigid. - 1)ry copses; common.

+ Leaves conspicuonsly serrate; heuds small; rens pale blue or nearly whute.

21. A. cordifolius, L. Stem much branched alove, the sprending or diverging branches buring very numerous panicled heads; lower leaves all heartsliaped, on slender and mestly naked (iliate petioles; scales of the inuersely conical inrolucre all appressed and tipped with irery short green points, olutuse or acutish. - Woollauls ; very common. - Ileals profuse, lut quite small. Va ies with the stem and leaves either smooth, roughish, or sometimes hairy, also with the leaves all narrower. A puparent hybricls with 11. 35) alsi) orecur.

22. A. sagittifolius, Willd. Stem rigil, erect, with ascending branches bearing numerous racemose hends: leaves ovate-lanceolate, prointed; the lower leart-shaped at base, on margined petioles; the upper lanceolate or linear, pointed at both ends; scules of the oblong involucre linear, tapering into aulshaped slender and loose tips. - 1)ry ground, N. Y. and Penn. to Ky., and northward. - Green, but usually more or less hairy or downy; the heals rather larger than in the last, almost sessile.

23. A. Drummóndii, Lindl. Pale with fine gray pubescence; leaves cordute to cordate-lanceolate, mostly on maryined petioles, the uppermust lanceolate and sessile; scales ncute or acutish. - P'assing into the last. ()pen ground, etc., Ill. to Minn. and Kan.

24. A. Lindleyànus, Torr. \& Gray. Rather stont, $1-2^{\circ}$ high, sparsely pubescent or nearly glabrous; radical and locest lcares ovate, moderately or obscurely cordute, the uppermost sessile and pointed at botl ends; heads larger, rather few in a loose thyrse or panicle, the linear-attenuate scales looser and less iminicated; rays pale violet.-Lab. to L. Superior; Lisbon, N. H. (C. E. F(txon), and Mt. Desert (Rand).

* 6. Withont heart-shaped petioled leaves, the radical and loner all acute or uttenuate at buse; not glandular nor viscid, nor silky-canescent.

- Smooth and glubrous throughout (or nearly so, except forms of n. 30), and usually pale and glaucons; involucral scales closely imbricuted, firm and whitishcoriaceuns below, green-tipped ; leares firm, usually entire.

- Ruys violct or blue; scales vather abruptly green-tipped; leures on the branchlets reduced to rigid suluulute brarts.

25. A. turbinéllus, Lindl. Stem slender, $3^{\circ}$ high, paniculitely lirancheal: leaves oblong to narrowly lanceolate, tapering to each end, with ronglı margius ;

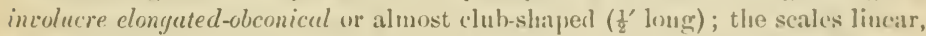
with very short and blunt green tips; riys violet-blue; achenes nearly smooth. - Dry hills, etc., 11l., Mo., and southwestwald. - Well-markerl and landsome.

26. A. læevis, L. Stouter, $2-4^{\circ}$ high; heals in a close panicle; leaves thickish, lanceolate or ovate-lauceolate, chiefly entire, the upper more or lesi clasping by an auricled or heart-shaped hase; scales of the short-oborocic or hemispherical incolucre with short ahrupt green tips; rays sky-blue; achenes smooth. - Borders of woollands; common. A variable and clegant species.

27. A. virgàtus, bll. Sleuder, strict aud simple, with few or several racemose or terminul heads, like those of the last; leaves lunceolate or linear, the lower usually lony and nuron: _- S. W. Va., and sonthward. 
23. A. concínnus, Willd. Not glaucous, slender, 1-30 high; leaves lanceolate, mostly somewhat serrate, the lowest spatulate-lanceolate on winged petioles; heads smaller than in the preceding, numerous, punicled; rays violet. - Rare; Penn. and southward.

+ Rays white or turning purplish; scales narrow, subulately green-tipped; leaves mostly narrow, narroued at base, on the branchlets lax and attenuate.

29. A. polyphýllus, Willd. Often tall (4 or $5^{\circ}$ high), with virgate branches; cauline leaves narrowly lanceolate or linear, 4 or 5 ' long; heads paniculate; scales lanceolate-subulate, the outermost much shorter; rays $4^{\prime \prime}$ long. - N. Vt. to Wisc., and southward. Heads larger and flowering earlier than the next.

30. A. ericoides, L. Smooth or sparingly hairy $\left(1-3^{\circ}\right.$ high $)$; the simple branchlets or peduncles racemose along the upper side of the wand-like spreading branches; lowest leaves oblong-spatulate, sometimes toothed; the others linear-lanceolate or linear-awl-shaped; heads $3^{\prime \prime}$ high or less ; involucral scales often nearly equal, with attenuate or awl-shaped green tips. - Dry open places, S. New Eng. to Minn., and southward. - Var. viluòscs, Torr. \& Gray, is a hairy form, often with broader leaves; chiefly in the Western States. Var. pusflues, Gray, is a dwarf slender and glabrous form of the barrens of Lancaster, I'eun. (Porter), with very narrow or filiform leaves and very small few-flowered hearls. - Var. Príxglei, Gray, a low strict form, with few erect branches and rather small heads. About Lake Champlain.

+ + Hoary-pubescent or hirsute; herbaceons tips of the involucral scales squarrose or spreading; culline leaves small, linear, entire, scarcely narrowed at the sessile or partly clasping base: heads numerous, small, racemose.

31. A. amethýstinus, Nutt. Tall (2-5 high), upright, much branched, puberulent or somewhat hirsute; leaves not rigid ; heads $3^{\prime \prime}$ high, the tips of the scales merely spreading; rays light clear blue. - Moist grounds, E. Mass. to Ill. and Iowa. With the habit of n. 11.

32. A. multiflòrus, Ait. Pale or hoary with minute close pubescence ( $1^{\circ}$ high), much brancherl aul bushy; the heads much crowded on the spreading racemose branches; leaves rigid, crowded, spreading, with rough or ciliate margins, the uppermost passing into the spatulate obtuse scales; heads $2-3^{\prime \prime}$ long; rays white or rarely bluish, 10-20. - Dry sandy soil ; common.

+++ Scales glabrous, closely imilricuted (the outer regularly shorter), not coriaceous, with short appressed green tips; branches slender, divaricate or divergent; leaves lanceolate to subulate; heads small (2-3" high) and numerous.

+ Heads scattered, terminating minutely foliose slender branchlets.

33. A. dumòsus, L. Smooth or nearly so, $1-3^{\circ}$ high; leaves linea. or the upper oblong, crowded, entire, with rough margins; scales linear-spatulate, oltuse, in $4-6$ rows. - Thickets; common. $-\Lambda$ variable species, loosely branched, with small leaves, especially the upper, and an obconical or bellshaped involucre, with more abrupt green tips than any of the succeeding. Rays pale purple or blue, larger than in n. 34. Runs into several peculiar forms.

+ Heads racemosely unilateral upon very short minutely leafy branchlets.

34. A. vimineus, Lam. Smooth or smoothish, $2-5^{\circ}$ high, bushy ; leaves linear or narrowly lanceolate, elongated, the larger ones remotely serrate in 
the middle with fine sharp teeth; scales of the involucre nurrouly linear, acule or acutısh, in 3 or 4 rows. ( $\Lambda$. 'Tradescanti, of previous ed.) - Var. FousoLóscs, Gray, has linear entire leaves, the ascending branches with more seattered paniculate heads. - Moist banks ; very common. - Il ads very numcrons, and usually crowled, smaller than in the last. Rays white or ncarly so.

35. A. diffùsus, גit. More or less pubescent, much branched; leaves lanceolate or oblong-lanceolate, tapering or pointed at each end, sharply serrate in the midlle; scales of the involucre linear, acute or ruther ubtuse, imbricated in 3 or 4 rows. (A. miser, of previous ed.) - Thickets, fields, ctc.; very common, and extensively variable. Leaves larger than in either of the preceding $\left(2-5^{\prime}\right)$; the involucre intermediate between them, as to the form of the scales. Rays mostly short, white or pille bluish-purple. - Var. TurrsofDecs, Gray, with ovate-oblong to lanceolate leates, the branches ascending and often short, and the thyrsoid or spicate-yfomerate heads less secund. N. Y. to Ill. - Var. ninsuticaỦlıs, Gray, the slender stem and the midveins of the long narrow leaves very hirsute. N. Y. and liy - Var. nfFross, Gray, a luxuriant furm with large thin leaves and rather larger heads loosely disposed on the spreading branches. liy. to Ill.

++++ Incolucte varions, the heads when numerous densely or loosely pariculate on erect or ascending brumches.

- Cauline leaves sessile, but the base not cordate nor auriculate (except in forms of n. 41), nor winged-petiole-like; glabrous or neurly so.

$=$ Heads small or middle-sized; scales narrow, in several lengths, the erect green tips not dilated.

36. A. Tradescánti, L. Stem much branched $\left(2-4^{\circ}\right.$ high); the numerous heads (2-3" high) somewhat pauicled or racemed; leaves lanceolate to linear, tapering to a long slender point $\left(2-6^{\prime}\right.$ long), the luwer somewhat serrate in the middle; involucral scales linear, acutish, partly green down the back. (A. tenuifolius, previous ed.) - Low grounds, Mass. to Minn., and south to Va. and Ill. Rays short and narrow, white or purplish. Some forms approach n. $32-34$, others differ from $A$. paniculatus only in the smaller heads and shorter ray.

37. A. paniculàtus, Lam. Stem $\left(2-8^{\circ}\right.$ high $)$ much branched; the branches aud scattered heads (about $t^{\prime \prime}$ high) loosely paniculate; leaves longoblong to narrowly lanceolate, pointed, the lower serrate; scales narrowly linear, with attenuate green tips or the ontermost wholly green. (1. simplex, previous ed.) - Shady moist banks ; common. Rạs white or purplish, $3-4^{\prime \prime}$ long. Approaches in its different forms the preceding and the two following. A slender form with linear leaves, in northern bogs, resembles n. 40.

38. A. salicifolius, Ait. Like the last; the leaves commonly shorter, firmer, often scabrous, less serrate or entire; involucre nore imbricated, the firmer linear seales with shorter acute or obtusish green tips; heals as large, disposed to be thyrsoid or racemose-clustered; rays rarely white. (A. carneus, previous ed.) - Low grounds, N. Eng. to Minn., and southward ; most abundant westward. - Var. su Báspen, Gray, a rigid scal,rous form, with contracted leafy inflorescence, the broad heads usually leafy-bracteate and the broader scales often obtuse. Ill. to Tex. 
$==$ Heads small or middle-sized, the looser linear scales somewhat equal and erect, and the acute green tips not dilated, the outer often wholly herbaceous.

39. A. júnceus, Ait. Slender, $1-3^{\circ}$ high, simple with few heads or loosely branching; leaves linear or narrow, 3-5' long, entire or the lower sparsely denticulate; heads small ( $3^{\prime \prime}$ ligh); scales small, narrow, in 2 or 3 rows, the outer more or less shorter; rays light purple, $4-5^{\prime \prime}$ long. (A. astivus, previous ed., mainly.) - Wet meadows and cold bogs, N. Scotia and N. Y. to Mich. and Minn.

40. A. longifolius, Lam. (not of previous ed.) Stem $1-3^{\circ}$ high, more or less branched and corymbosely panicled ; leaves long-lanceolate to linear-lanceolate $\left(3-\tau^{\prime}\right.$ long), narrowed to both ends, entire or sparsely serrulate; heads $4-5^{\prime \prime}$ high, the scales nearly equal and usually little imbricated, the outer looser; rays 3-4" long, violet or purplish, rarely whitish. - Low grounds, Lab. and northern N. Eng. to Minn. - Var. villica Ùlis, Gray, a low simple form, with few or solitary heads, and the stem and midrib of the leaves densely white-villous beneath. N. Maine, at Fort Kent (Miss Furbish).

$===$ Heads middle-sized; srales in few to several rows, more or less unequal,

linear to spatulate, more herbaceous and firmer, the tips often slightly spreading or siquarrose.

41. A. Nòvi-Bélgii, L. Rarely tall; leaves oblong to linear-lanceolate, entire or sparsely serrate, the upper partly clasping and often somewhat auriculate; heads $4-5$ " long; rays bright blue-violet. (A. longifolius, previou; ed.) - N. Bruuswick to Ill. and Ga. The commonest late-flowered Aster of the Atlantic border, and very variable. The typical form has thin narrowly to oblong-lanceolate leaves, sometimes scabrous abore, and linear scales with narrow acute spreading or recurved tips. - Var. L.evigates, Gray, is usually glabrous throughout, the thin leaves mostly oblong-lanceolate, the upper halfclasping by an abrupt base; scales nearly equal, loosely erect, with short acutish tips. N. Eng. and eastward. - Var. Litònets, Gray, rigid, usually low, very leafy; leares thickish, usually very smooth, oblong to lanceolate, the upper sometimes auriculate; scales in several loose rows, all but the innermost with broadish obtuse tips, the onter usually spatulate. Salt-marshes and shores, Can. to Ga. - Var. Elònes, Gray, slender, often low and simple; leaves thickish, long, narrowly linear, entire, the uppermost small and bract-like; scales narrow, with short and mostly spreading acutish tips. Swamps, N. J. to Va. + Cauline leaves conspicuously contracted into a winged-petiole-like base or auriculate-clasping; involucre lax.

42. A. pátulus, Lam. Glabrous or subpubescent, 1-4 ${ }^{\circ}$ high; leaves ovate- or oblong-lanceolate, sharply serrate in the middle, narrowed at both ends, the lower to a wingerl petiole, none auricnlate or only obscurely so; heads loosely panicled, about $4^{\prime \prime}$ high ; scales unequal, erect or nearly so; rays light purple or white. - N: Brunswick and eastern N. England.

43. A. tardiflorus, L. Glabrous or stem somewhat pubescent (not hispid), $1-2^{\circ}$ high; leaves lanceolate or oblong-lanceolate, acuminate, mostly with gradually narrowed and somewhat auricled base; heads often few, corymbose, $4-5^{\prime \prime}$ high; scales subequal, the outer foliaceous; rays pale violet. Lab. to the Mass. coast and White Mts. Not late-flowering. 
44. A. prenanthoides, Muhl. Stem 1-30 high, corymbose-panicled, hairy above in lines; leaves rough above, smonth underneath, ovate-lanceolate, slarply cut-toothed in the middle, conspicuously taper-pointed, and rather abruptly narrowed to a loug contracted entire portion, which is abruptly dilated into a conspicnonsly anricled base; heads mostly $t^{\prime \prime}$ hight, on short dirergent peduncles; scales narrowly linear, tips recurved-spreading; rays light blne. - Borders of streams and rich woods, W. New Ling. to l'eun., Iowa, and Wisc.

45. A. puniceus, I. Stem tall anl stout $3-7^{\circ}$ high, rughh-hairy all over or in lines, usually purple below, pauicled above ; leaves oblong-lanceolate, not narrowel or but slightly so to the auricled base, coarsely scrrate to sparingly denticulate in the midlle, rough above, nearly smooth heneath, pointed; heads $4-6^{\prime \prime}$ high, subsessile; scales narrowly linear, acute, loose, eyual, in alout 2 rows; rays long anul showy (lilac-hlue, paler in shaule). - Low thickets and swanps, very common. - Var. L.JVICAL̀ Lı, Gray ; stem mostly green, smonth and nakel below, sparsely hirsute alove, $1-3^{\circ}$ high; leaves scrrate. - Var. Lucfoutus, Gray; the very leafy stems glabrous or sparingly hispidulous; leaves lanceolate, entire or slightly denticulate, glabrous anl somewhat shining; heads usually numerous, the seales less loose and less attenuate.

§ 4. D(ELLINGERIA. Pappus manifestly double, the inner of long capillary bristles (some thickened at top), the onter of very short and rigid bristles; scales short, without herbaceous tips; heads small, corymbose or solitary; rays rather feu, white; leaves not rigid, veiny.

46. A. umbellàtus, Mill. Smooth, leafy to the top $(2-7 \circ$ high $)$; leares lanceolate, elongated, tuper-pointed and tajering at the hase $\left(3-6^{\prime}\right.$ long $)$; heads very numerous in compound flat corymbs; involucral scales rather close, obtusish, scarcely longer than the achenes. (Diplopappus umbellatus, Torr. $\oint^{\circ}$ Gray.) - Moist thickets; common, especially northward. Aug. - Var. PùBExs, Gray; the lower surface of the leaves and the branchlets tomentulose. Upper Mich. to Mim. - Var. LAtrodırs, Gray; with shorter leaves ovatelanceolate to ovate, less narrowed or even rounded at base. (I). amygilalinus, Torr. \&. Gra!y.) Pine barrens, etc., N. J., Penu., and southwart.

47. A. infírmus, Miclix. Stem slender, often flexuous, $1-3^{\circ}$ high, less leafy, bearing few or several lieads on divergent peluncles; leaves ubovate to ovate or oblong-lanceolate, narrowed at base and ciliate, the midrib hairy heneath; scales more imbricated, thicker and more obtuse; pappus more rigid. (1). cornifolius, $\mathrm{Da} \%$ - - Open woodlands, E. Mass. to Tenn., and southward.

§5. IANTHE. Papuns less distinctly double, the inner of bristles not thickened at top, the outer shorter; scales well imbricated, appressed, unthunt herbuceons tips; rays violet; achenes narrow, villous; leares numerous, rigid, smull, linear, l-nerved and reinless.

48. A. linarifolius, I. Stems $3-20^{\prime}$ high, several from a wooly root; heads solitary or terminating simple hranches, rather large; leaves about I' long, rongh-margined, patsing above into the rigid acutisls scales. (1). linariifolius, Hook.) - Dry soil, common. Sept., Oct. liay rarely white.

§6. ORTHÓMERIS. Pappus simple. scales imbricated, appressed, without herbaccoustips, often scurious-edyed or dry. Peremial, as all the preceding. 
49. A. ptarmicoldes, Torr. \& Gray. Smooth or roughish ; stems clustererl (6-20' high), simple; leaves linear-lanceolate, arute, rigid, entire, tapering to the base, 1-3-nerved, with rough margins (2-4' long); heads small, in a fat corymb; scales imbricated in 3 or 4 rows, short; ra!ys white (2-4" long). - Dry rocks, W. New Eng. to Minn., along the Great Lakes, and northward. Aug. - Var. Lutéscexs, Gray ; rays small, pale yellow. - N. Ill. and Sask.

50. A. acuminàtus, Michx. Somewhat hairy; stem (about $1^{\circ}$ high) simple, zigzag, panicled-corymbose at the summit; peduncles slender; leares oblong-lanceolate, conspicuously pointed, coarsely toothed above, wedge-form and entire at the base; involucral scales few and loosely imbricated, linear-lanceolate, pointed, thin $\left(3-5^{\prime \prime}\right.$ long); heads few or several; rays $12-18$, white, or slightly purple.-Cool rich woods; S. Lab. to Penn., and sonthward along the Alleghanies. Aug. - There is a depauperate narrow-leaved variety on the White Mountains. A monstrous form occurs in Maine, liaving a chaffy receptacle and the flowers turned to tufts of chaffy pale:e.

51. A. nemoràlis, Ait. Minutely roughish-pubescent; stem slender, simple or corymbose at the summit, very leafy $\left(1-2^{\circ}\right.$ high); leares small (1 $1 \frac{1}{2}$ long), rather rigid, lanceolate, nearly entire, with revolute margins; scales of the inversely conical involucre narrowly linear-lanceolate, the outer passing into awl-shaped bracts; rays lilac-purple, elongated. - Bogs and swamps, N. J. to Newf. and Hudson's Bay. Sept.

52. A. tenuifolius, L. Very glabrous; stem often zigzag, simple or forked, $6^{\prime}-2^{\circ}$ high ; heals rather large, terminal ; leaves few, long-linear, tapering to both ends, rather thick and fleshy, entire, the upper subulate, pointed; involucre top-shaped, the scales subulate-lanceolate with attenuate acute points; rays large, numerous, pale purple. (A. flexuosus, Nutt.) - Salt marshes, Mass. to Fla. Sept.

$\S 7$. OXYTRIPÒLILM. Involucre as in $\S 6$; pappus simple, fine and soft; glabrous annuals, bearing numerous small heads and with narrow entive leaves.

53. A. subulàtus, Michx. Stem 6-24' high; leaves linear-lanceolate, pointed, flat, on the branches awl-shaped; scales of the oblong involucre linearawl-shaped, iu few rows; rays somewhat in two rows, short, not projecting beyond the disk, more numerous than the disk-flowers, purplish. (A. linifolius. of previous ed.) - Salt marshes on the coast, Maine to Va. Aug. - Oct.

§ 8. CONYZÓPSIS. Scales of the campanulate involucre in 2 or 3 rous, nearly equal, linear, the outer foliaceous and loose; pappus copious, very soft ; rays very short or without ligules; low annuals with numerous rather small heads.

54. A. angústus, Torr. \& Gray. Branching, 6-20' high, nearly glabrons ; leaves linear, entire, more or less short-ciliate; ray-flowers reduced to a tube much shorter than the elongated style.-Minn. to Sask. and westward, spreading east to Chicago, etc. (Siberia.)

\section{ERÍGERON, I. Fleabane.}

Heads many-flowered, radiate, mostly flat or hemispherical; the narrow rays very numerous, pistillate. Involucral scales narrow, equal and little imbricated, never coriaceons, foliaceous, nor green-tipped. Receptacle flat or convex, raked. Achenes flattened, usually pubescent and 2-nerved; pappus a 
single row of eapillary bristles, with minuter nnes intermixed, or with a distinct short outer pappus of little hristles or chaffy scales. - Iferhs, with entire or toothed and generally sessile leaves, and solitary or corymbed naked-pedunculate heads. Disk yellow; ray white or purple. (Name from $引 \rho$, spring, and $\gamma$ '́⿴囗十, an old man, suggested by the hoariuess of some vernal species.)

§ 1. CANO'TL'S. Ruys inronspicuons, in several rous, scarcely longer thun the pripus ; prepus simple; anruals.

1. E. Canadénsis, L. (Horse-wrew. Butter-ween.) Bristly-hairy; stem erect, wand-like ( $1-5^{\circ}$ high $)$; leaves linear, mostly entire, the radical cutlobed; heuls very numerous and small, eylindrical, penicled. - Waste places ; a eommon weed, now willely diffused over the world. July-Oct. - Ligule of the ray-flowers unch shorter than the tube, white.

2. E. divaricàtus, Michx. Iliflise und tecumbent $\left(3^{\prime}-1^{\circ}\right.$ high); leaves linear or awl-shaped, entire; heols loosely corymbed; rays purple; otherwise like n. 1.- Ind. to Minn., and soutlıward.

\$2. ThIMORPII isd. Like \$1, but u series of filiform rayless pistillate fluwers within the outer row of ray-flou'er's ; bienniul or sometimes perennial.

3. E. àcris, I. Hirsute-pubescent or smoothish; stem erect (10-20' high); leaves lanceolate or the lower spatulate-oblong, entire; heads several or rather numerous, racemose or at length corymbose, uearly hemispherical $\left(t-5^{\prime \prime}\right.$ long), hirsute; rays purplish or bluish, equalling or a little exceeding the copious pappus. - Lower St. Lawrence, across the continent and northwarl. The var. 1)reвacı́nsss, Blytt, more glabrous and with the green iuvolucre nearly or quite naked, occurs on the shores of L. Superior. (Eu.)

§3. ERIGERON proper. Rays elongated (short in a form of $\mathbf{n} .5$ ), crowded in one or more rows.

* Annuals (or sometimes biennial), leafy-stemmed and branching; pappus double, the outer a crown of minute scales, the inner of deciduous fragile bristles, usually wunting in the ray.

4. E. ánnuus, Pers. (Daisy Fleabaxe. Sweet Scabiols.) Stem stout (3-50 ligh), hranched, beset with spreading hairs; leaves coarsely and sharply toothed; the lowest oxate, tapering into a margined petiole, the upper orate-lanceolate, acute and entire at both ends; heals corymbed; rays white, tinged with purple, not twice the length of the hristly involucre. - Fiells and waste places; a very common weerl. June-Aug. (Nat. in Eu.)

5. E. strigósus, Muhl. (DaIsy FLFAbaNe.) Stem panicled-corymbose at the summit, roughish like the leaves with mimute appressed hairs, or almost smooth; lences entire or nearly so, the upper luneolute, scatteresl, the lowest oblong or spatulate, tapering into a slender petiole; rays white, twice the length of the minutely hairy involnere. Fields, ete., common. JuneAug. - Stem smaller and more simple than the last, with smaller heads but longer rays. $\Lambda$ form with the rays minute, scarcely exceeding the involucre, oceurs in S. New England.

* * Leafy-stemmed perennials; pappus simple (double in $\mathrm{n} .6$ ).

6. E. glabéllus, Nutt. Stem $\left(6-15^{\prime}\right.$ highl) stout, hairy above, the leafless summit bearing $1-7$ large heals; leaves nearly glabrous, except tho 
margins, entire, the upper oblong-lanceolate and pointed, closely sessile or partly clasping, the lower spatulate and petioled ; rays (more than 100 , purple) more than twice the length of the hoary-hispil involncre; pappus double, the outer of minute bristles. - Plains of $\mathrm{N}$. Wisc., and westward. Jume.

7. E. hyssopifolius, Michx. Slightly puhescent, slender $\left(6-12^{\prime}\right.$ high), from filiform rootstocks; leaves short, very numerous, narrowly linear; lranches prolonged into slender naked peduncles, bearing solitary small heads; rays 20-30, rose-purple or whitish. (Aster graminifolius, Pursh.) Northern borders of $N$. Eng., L. Superior, and northward.

8. E. bellidifòlius, Muhl. (Robin's Plantain.) Hairy, producing offsets from thr. lise: stem simple, rather naked above, bearing few (1-9) large hearls on slender peduncles; root-leaves obovate and spatulate, sparingly toothed, the cauline distant, lanceolate-oblong, partly clasping, entire; rays (about 50) rather lnoad, light blecish-puple. - Copses and moist banks; common. May.

9. E. Philadélphicus, L. (Commox FleAbaxe.) Hairy; stem leafy, corymbel, bearing several small heads; leaves thin, with a liroad midrih, oblong; the upper smoothish, clasping by a heart-shaped base, mostly entire, the lowest spatulate, toothed; rays innumerable and very narrow, rose-purple or flesh-color. - Moist ground; common. June-Aug.

*** Perennial by rosulute offsets, with scape-like stems : pappus simple.

10. E. nudicaùlis, Michx. Glabrous; leaves clustered at the root, oval or spatulate; scape leafless, slender $\left(1-2^{\circ}\right.$ high $)$, bearing $5-12$ small corymbed heads; rays white. (E. vernum, Torr. \&. Gray). - Low grounds, E. Va. and southward. May.

\section{BÁ C CH A I S, L. Grouxuser-Tree.}

Heads many-flowered; the flowers all tubular, diøcious, i. e., the pistillate and staminate borne by different plants. Involucre imbricated. Corolla of the pistillate flowers very slender and thread-like; of the staminate, larger and 5-luberl. Anthers tailless. Achenes ribbed; pappus of capillary bristles, in the sterile plaut scauty and tortuons; in the fertile very long and copious. - Shruls, commonly smooth and resinous or glutinous. Flowers whitish or yellow, antumnal. (Name of some shrub anciently dedicated to Bacchns.)

1. B. halimifòlia, L. Smooth and somewhat scurfy; hranches angled; leaves obovate and wedge-form, petiolate, coarsely toothed, or the upper entire; heads scattered or in leafy panicles; scales of the involucre acutish. - Sea beaches, Mass to Va., and southward. - Shrub $6-12^{\circ}$ high; the fertile plant conspicuous in autumn ly its very long and white pappus.

2. B. glomeruliflòn, Pers. Leaves spatulate-oblong, sessile or nearly so; heals larger, sessile in the axils or in clnsters; scales of the bell-shaped involucre broader, very obtuse. - Pine barrens, E. Va. (?), and southward.

\section{PI U CHEA, Cass. Marsh-Fleabane.}

Heads many-flowered ; the flowers all tubular; the central perfect, hut sterile, few, with a 5-cleft corolla; all the others with a thread-shaped trumcate corolla, pistillate and fertile. Involucre imbricated. Receptacle flat, naked. Anthers with tails. Achenes grooved; pappus capillary, in a single row. - Herbs, 
somewhat glaulular, emitting a strong or camphoric oflor, the heads cymosely clustered. Flowers purplish, in summer. (Derlicated to the Abhe Pluche.)

1. P. bifrons, 1)C. P'erennial, $2-3^{\circ}$ high; leaves closely sessile or half: clasping, oblong to lanceolate, sharply denticulate, veiny (only ㄴ.-3' long); heads clustered in a corymb; scales lanceolate. - Low yround, Cape May, N. J., and southward.

2. P. camphoràta, IC. (Siıt-мansi Flesisane) Ammal, pale $\left(2-5^{\circ}\right.$ high $)$; lentes scarcely petioled, oblong-ovate or lanceolate, thickish, obscurely veiny, serrate; corymb that; involucral scales ovate to lanceolate. (I'. foetida, $D C^{\prime}$.) - Salt marshes, Mass. to Va., and southward, and on riverbanks westward to Ky., Ill., and Neb. (!)

\section{E V A X, Gaertı.}

Heads rather many-flowered, discoid ; flowers as in Pluchea, the central usually sterile. Involucral scales few, woolly. Receptacle convex to subulate, chaffy, the scarious chaff not embracing the smooth dorsally compressed achenes. Anthers with tails or acutely sagittate ; pappus none. - Low, densely floccose-woolly annuals; extreme western. (Name of uncertain signification.)

1. E. prolífera, Nutt. $\Lambda$ span high or less, simple or branching from the base; leaves numerous, small and spatulate; heads in dense proliferous clusters ; receptacle convex; chaff subtending the sterile flowers woolly-tipped, the rest more scarious and naked, oval or oblong. - Dak. and W. Kan. to Tex.

\section{FIL À G O, Tourn. Cottox-Rose.}

Heads and flowers as in Evax. Receptacle elongated or top-shaped, naked at the summit, but chaffy at the margins or toward the base; the chaff resembling the proper involucral scales, each covering a single pistillate flower. Achenes terete; pappus of the central flowers capillary, of the outer ones mostly none. - Annual, low, branching woolly herbs, with entire leaves, and small heads in capitate clusters. (Name from filum, a thread, in allusion to the cottony hairs of these plants.)

F. Germáxica, L. (Herisa Impia.) Stem erect, short, clothed with lanceolate and upright crowded leaves, producing a capitate cluster of woolly heads, from which rise one or more branches, each terminated by a similar head, and so on ; - hence the common name applied to it by the old botanists, as if the offspring were undutifully exalting themselves above the parent. Dry fields, N. Y. to Va. July-Oct. (Nat. from Eu.)

\section{A N T $\mathbf{E} \mathbf{N} \mathbf{N} \mathbf{A} \mathbf{A}$, Gaertn. Everlastixg.}

Heads many-flowered, diceions; flowers all tubular; pistillate curollas very slender. Involucre dry and scarious, white or colored, imbricated. Receptacle convex or flat, not chaffy. Anthers caudate. Achenes terete or flattish ; pappus a single row of bristles, in the fertile flowers capillary, united at base so as to fall in a ring, and in the sterile thickened and club-shaped or barbellate at the summit. - Perennial white-woolly herbs, with entire leaves and corymbed (rarely single) heads. Corolla yellowish. (Name from the resemblance of the sterile pappus to the antenne of certain insects.)

1. A. plantaginifolia, Hook. (Plaxtaix-leaven EVErlastixi.) Spreading by offsets and rumers, low (3-18' high); leaves silky-woully when young, at length green above and hoary beneath; those of the simple and scal $e$ 
like flowering stems small, lanceolate, appressed; the radical obovate or ovalspatulate, petioled, ample, 3-nerved; heads in a small crowded corymb; scales of the (mostly white) involucre obtuse in the sterile, and acutish and narrower in the fertile plant. - Sterile knolls and banks; common. March-May.

\section{A N ÁPHALIS, DC. Everlastixg.}

Characters as of Antennaria, but the pappus in the sterile flowers not thickened at the summit or scarcely so, and that of the fertile flowers not at all united at base; fertile heads usually with a few perfect but sterile flowers in the centre. (Said to be an ancient Greek name of some similar plant.)

1. A. margaritàcea, Benth. \& Hook. (PEarly Everlastixg.) Stem erect $\left(1-2^{\circ}\right.$ high), corymbose at the summit, with many heads, leafy; leaves broadly to linear-lanceolate, taper-pointed, sessile, soon green above; involncral scales pearly-white, very numerous, obtuse or rounded, radiating in age. (Antennaria margaritacea. K. Br.) - Dry hills and woods; common northward. Aug. (N. Li. Asia.)

\section{G N A P H L L U M, L. Cuneed.}

Heads many-flowered; flowers all tubular, the outer pistillate and very slender, the central perfect. Scales of the involucre dry and scarious, white or colored, imbricated in several rows. Receptacle flat, naked. Anthers caudate. Achenes terete or flattish; pappus a single row of capillary rough bristles. Woolly herbs, with sessile or decurrent leares, and clustered or corymbed heads; fl. in summer and antumn. Corolla whitish or yellowish. (Name from

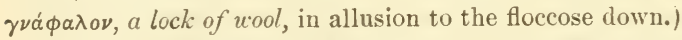

\section{$\S 1$. GXAPHALIUM proper. Bristles of the pappus distinct.}

1. G. polycéphalum, Michx. (Commox Everlastivg.) Erect, woolly annual $\left(1-3^{\circ} \text { high }\right)_{2}$ fragrant; leaves lanceolate, tapering at the base, with undulate margins, not decurrent, smoothish above; heads clustered at the summit of the panicled-rorymbose branches, ovate-conical before expansion, then obovate; scales (whitish) orate and oblong, rather obtuse; perfect flowers few. - Old fields and woods; common.

2. G. decúrrens, Ives. (Everlastixg.) Stout, erect ( $2^{\circ}$ high), annual or biennial, branched at the top, clammy-pubescent, white-woolly on the branches, bearing numerous heads in dense corymbed clusters; leaves linearlanceolate, partly clasping, decurrent; scales yellowish-white, oval, acutish. Hillsides, N. J. and Penn. to Maine, Mich., Minn., and northward.

3. G. uliginòsum, L. (Low Cuwwero.) Diffusely branched, appressed-woolly annual (3-6' high); leaves spatulate-oblanceolate or linear, not decurrent; heads (small) in terminal sessile capitate clusters subtended by leaves; scales brownish, less imbricated. - Low grounds ; common, especially east and northward; perhaps introdnced. (Eu.)

4. G. supinum, Villars. (Movxtary Cunweed.) Dwarf and tufted perennial (2' high); leaves linear, woolly; heads solitary or few and spiked on the slender simple flowering stems; scales brown, lanceolate, acute, nearly glabrous; achenes broader and flatter. - Alpine summit of Mount Washington; very rare. (Eu.) 
§2. GAMOCIIXTA. Bristles of the pappus united at the very base into a ring, so fralling off all together.

5. G. purpùreum, I. (P'irplsir Cumwer.) Annual, simple or branched from the base, aseending $\left(6-20^{\prime}\right.$ ligh $)$, silvery-canescent with dense white wool ; leaves oblong.spatulate, obtuse, not decurrent, green alove; hends in sessile clusters in the axils of the upper leaves, and spiked at the wand-like summit of the stem; scales tawny, the inuer often marked with purple. Saudy or gravelly soil, coast of Maine to Va., and southward.

\section{A D E N O A Ù L N, Hook.}

Hearls 5-10-flowered; the flowers all tubular and with similar corollas; the marginal ones pistillate, fertile; the others perfoct but sterile. Involucral scales few, equal, in a single row, not scarious. Recoptacle flat, naked. Anthrrs caudate. Achenes elongated at maturity, (club-shaped, beset with stalkerl glairls above; pappus none. - Slender perennials, with the alternate thin and petioled leaves smooth and green above, white-woolly beneath, and few small (whitish) heads in a loose panicle, beset with glands (whence the name, from

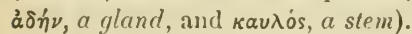

1. A. bícolor, Hook. Leaves triangular, rather heart-shaped, with angular-toothed margins; petioles margined. - Moist woods, shore of Lake Superior, and westward. Stem $1-3^{\circ}$ high.

\section{I N U L A, T. ELECAMPANE.}

Hearls many-flowerel, radiate; disk-flowers perfect and fertile. Involucre imbricated, hemispherical, the outer scales herbaceous or leaf-like. Receptacle naked. Anthers eaudate. Achenes more or less 4-5-ribbed; pappus simple, of eapillary bristles. - Coarse herbs, not floccose-woolly, with alternate simple leaves, and large yellow flowers. (The ancient Latin name.)

I. Ilelèriry, L. (Elecampaxe.) Stout perennial $\left(3-5^{\circ}\right.$ high); leaves large, woolly beneath; those from the thick root ovate, petioled, the others partly clasping; rays very many, narrow. - Roalsicles and (lamp pastures. Aug. - Heals very large. Root mucilaginous. (Nat from Eu.)

\section{POLÝ M N I I. LEAF-CUP.}

Heads broad, many-flowered, radiate; rays several (rarely ahortive), pistillate; disk-flowers perfect hut sterile. Involncral seales in two rows ; the onter about 5, leaf-like, large and spreading; the inner small and membranaceous, partly embracing the thick triangular-obovoid achenes. liceeptacle flat, membranous-chaffy. Pappus none. - Tall branching perennial herbs, viscid-hairy, exhaling a heavy odor. Leares large and thin, opjosite, or the uppermost alternate, lobed, and with dilated appendages like stipules at the base. Heads in panicled corymhs. Flowers light yellow; in summer aud antumu. (1)edicated to the Muse, Polyhymnia, for no obvious reasou.)

1. P. Canadénsis, I. Clummy-hair"y, 2-50 hight ; lower leaves deeply pinnatifid, the uppermost triangulas-ovate and 3-5-lobed or angled, petioled; hearls small; rays 5, obourate or wedge-form, shorter than the mrolucre, often minute or ahortive, whitish-yellow ; achenes 3-costate, not striate. - Moist sladed ravines, Conn. to W. Vt., Minn., and soutlwarl. - Var. 1.ıni t., Gray; ligules more developed, 3-lobed, 3-6" long, whitis'l. Ill. to Kan., and southwarl. 
2. P. Uvedàlia, L. Roughish-hairy, stout ( $t-10^{\circ}$ high); leaves broadly orate, angled and toothed, nearly sessile; the lower palmately lobed, abruptly narrowed into a winged petiole; outer involncral scales very large ; rays 10-15, linear-oblong, much longer than the inner scules of the involucre, yellow; achenes strongly striate. - Rich soil, W. New York and N. J. to Mo., and sonthward.

\section{SílPHIUM， L. Rosix-Wend.}

Ileads many-flowered, radiate; rays numerous, pistillate and fertile, their broad flat ovaries imbricated in 2 or 3 rows; disk-flowers apparently perfect, but with entire style and sterile. Scales of the broad and flattish involucre imbricated in several rows, thickish, broad and with loose leaf-like summits, except the innermost, which resemble the linear chaff of the flat receptacle. Achenes broal and flat, dorsally compressed, surrounded by a wing notched at the top, without pappus, or with 2 teeth confluent with the winged margin, the achene and its subtending chaff usually falling together; those of the disk sterile and stalk-like. - Coarse and tall rough perennial herbs, with copious resinous juice, and large corymbose-panicled yellow-flowered heals. ( $\Sigma_{i}$ i $\phi \iota \%$, the ancient name of some resinous plant, transferred by Linnæus to this American genus.)

* Stem terete, alternate-leaved (root very large and thick).

1. S. laciniàtum, L. (Rosin-ween. Compass-Plaxt.) Rough-bristly thronghont, stem stout $\left(3-12^{\circ}\right.$ high $)$, leafy; leaves pimately parted, petioled but dilated and clasping at the base; their divisions lanceolate or linear, acute, cut-lobed or pinnatifid, rarely entire; heads few (1-2' broad), sessile or shortpeduncled along the naked summit; scales ovate, tapering into long and spreading rigid points; achenes broadly winged and deeply notched, 6" long.Prairies, Mich. to Dak., and southward. July. - Lower and root-leaves vertical, 12-30' long, ovate in ontline; on the wide open prairies disposed to present their edges north and sonth; hence called Compass-Plant.

2. S. terebinthinàceum, L. (Priırie Dock.) Stem smooth, slender $\left(4-10^{\circ}\right.$ high), panicler at the summit and bearing several or nany, large headr, leafless except toward the base; leaves orate and ovate-oblong, somewhat heart-shaped, serrate-foothed, thick, rough, especially beneath ( $1-2^{\circ} \mathrm{long}$, on slender petioles); scales roundish, obtuse, smooth; achenes narrowly winged, slightly notehed and 2-toothed. - Var. PIxvatífidru, Gray, has the leares deeply cut or pinnatifid, but varies into the ordinary form. - Prairies and oakopenings, Ohio and Mich. to Minn., and southward. July-Sept.

* Stem terete or slightly 4-angled, leafy; leaves undivided (not large), some opposite.

3. S. trifoliàtum, L. Stem smooth, often glaucous, rather slender $\left(4-7^{\circ}\right.$ high), branched above; stem-leaves lanceolate, pointed, entire or scarcely serrate, rough, short-petioled, in whorls of 3 or 4 , the uppermost opposite; heads loosely panicled; achenes rather broarly winged, and sharply 2-toothed at the top. Dry plains and banks, Penn. to ()hio, and southward. Aug.

4. S. Asteríscus, I. stem hispid $\left(2-4^{\circ}\right.$ high); leaves opposite, or the lower rarely in whorls of 3 , the "pper alternate, oblong or oval-lanceolate, coarsely toothed, rarely entire, rough-hairy, the lower short petioled; heads nearly soli- 
tary (large), squarrose; achenes obovate, winged, 2-toothed, the teeth usually awn-like. - 1)ry sandy suil, Va. and sonthwarl.

5. S. integrifolium, Michx. Stem smooth or rough, rather stout $\left(2-4^{\circ}\right.$ high), rigill, 4-angular and grooved; leares ull opposite, rigid, lunces'ale-orate, entire or denticulate, tapering to a sharp point fiom a ronndish hrart-shaped and purtly clasping base, rough-pubescent or nearly smooth, thick (3-5' long) ; heads in a close forking (orymb, short-peduncled; achenes broally winged, deeply notched. - P'rairies, Mich. to Minu., and southward. Ang.

** * Stem syuare; leaves apposite, comnate (thin and large, 6-15' long).

6. S. perfoliàtum, L. (C'P-l'LAxr.) Stem stout, often branched ahove $\left(4-8^{\circ}\right.$ high $)$, leafy; leaves ovate, coarsely toothed, the upper united ly their bases and forming a cup-shaped disk, the lower abruptly narrowed into winged petioles which are commate by their bases; heads corymbose; scales ovate; achenes winged and variously notchel. - Kich soil along streams, Mich. to Minn., and southward ; common. Also eseaped from gardens eastward. July.

\section{BERLA NDIERA, I)C.}

With the characters of Silphium, but the 5 - 12 fertile ray-fowers in a single series. Involucral scales in about 3 series, thinner, the inner dilated obovate, exeeeding the disk, the onter smaller and more foliaceons. Achenes obovate, not winged nor notched at the apex, and without pappus, deciduous with the subtending scale and 2 or 3 of the inner chaff. - Alternateleaved perennials of the southern and sonthwestern States; head pedunculate. (Named for J. L. Berlandier, a Swiss botanist who collected in Texas and Mexico.)

1. B. T'exàna, DC. Hlirsute-tomentose or villons, $2-3^{\circ}$ high, very leafy ; leaves crenate, the radical oblong, petiolate, the cauline oblong-cordate to subcorlate-lanceolate, the upper closely sessile; heads somewhat cymose, $\frac{t^{\prime}}{2}$ broad. - S. IV. Mo. to La. and 'Tex.

\section{C H R Y S Ó G O N U M, I.}

Heads many-flowered, radiate; the rays about 5, pistillate and fertile; the disk-flowers perfect but sterile. Involucre of about 5 outer leaf-like oblong scales, which exceed the disk, and as many interior shorter and chaff-like concare seales. Receptacle flat, with a linear chaff to each disk-flower. Achenes all in the ray, obovate, obeompressed, 4-angled, each one partly enclosed by the short scale of the involuere behind it; pappus a small chaffy crown, 2-3toothed, and wanting on the inner side. $-\Lambda$ hairy, perennial herh, with opposite long-petioled leaves, and solitary long-peduncled heals of yelluw flowers, nearly stemless when it hegins to flower, the flowerless shoots forming runners. (The Greek name of some plant, composed of $\chi \rho v \sigma o ́ s$, golden, and róvv, knee.)

1. C. Virginiànum, L. I'sually low (2-15' ligh); leaves orate, mostly obtuse, erenate, rarely somewhat cordate, or the radical obovate with cuneate base; rays $\frac{1}{2}$ long. - Dry suil, from southeru Penn. to Fla. May-Aug. Var. nхтдтим, Gray; leaves deltoid-ovate, acute, roarsely dentate-serrate; iuvolucral stales more acute, - Iligh Island at the Falls of the l'otomac. 


\section{E N GELMÁ N NIA, Torr. \& Gray.}

Heads and flowers of the preceding genera. Rays 8-10. Involucre of about 10 outer loose foliaceous scales, more or less dilated and coriaceous at base, and several firm-coriaceous, oval or obovate, concave inner ones with short abrupt green tips. Chaff of the flat receptacle firm and persistent. Achenes flat, olovate, wingless, tardily deciduous with the attached scale and chaff; pappus a firm scarious hispid crown, more or less lobed. $-A$ coarse hispid perennial, with alteruate deeply pinnatifid leaves, and somewhat paniculately disposed heads on slender naked peduncles; flowers yellow. (Named for the eminent botanist, Dr. George Engelmann.)

1. E. pinnatífida, Torr. \& Gray. Stems $1-2^{\circ}$ high; heads $\frac{1^{\prime}}{2}$ broad, and rays $\frac{1}{2}$ long. - Central Kan. to La., and westward.

\section{PARTHìNIUM, I.}

Heads many-flowered, inconspicuously radiate; ray-flowers 5, with very short and broad obcordate ligules not projecting beyond the woolly disk, pistillate and fertile; disk-flowers staminate with imperfect styles, sterile. Involucre hemispherical, of 2 ranks of short orate or roundish scales. Receptacle conical, chaffy. Achenes only in the ray, obcompressed, surrounded by a slender callous margin, crowned with the persistent ray-corolla and a pappus of 2 small chaffy scales. - Leaves alternate. Heads small, corymbed; the flowers whitish. (An ancient name of some plant, from $\pi \alpha \rho \theta \dot{\nu} \nu$ s, virgin.)

1. P. integrifollium, L. Rough-pubescent perennial $\left(1-3^{\circ}\right.$ high $)$; leaves oblong or ovate, crenate-toothed, or the lower (3-6' long) cut-lobed below the midlle; heads many in a very dense flat corymb. - Dry soil, Md. to Ill., Minn., and southward. June-Aug.

\section{I V A, I. Marsh Elder. Highwater-shrub.}

Heads several-flowered, not radiate; the pistillate fertile and the staminate sterile flowers in the sume hearls, the former few (1-5) and marginal, with a small tubular or no corolla; the latter with a funnel-form 5-toothed corolla. Anthers nearly separate. Scales of the involucre few, roundish. Receptacle small, with narrow chaff among the flowers. Achenes obovoid or lenticular. pappus none. - Herbaceous or shrubly coarse plants, with thickish leares, tlie lower opposite, and small nodding greenish-white hearls of flowers; in summer and autumn. (Name of unknown derivation.)

§. Heads spicate or racemose in the axils of leaves or leaf-like bracts; fertile flowers with evident corolla.

1. I. frutéscens, L. Shrubby at the base, nearly smooth $\left(3-8^{\circ}\right.$ high $)$; leaves oval or lanceolate, coarsely and sharply toothed, rather fleshy, the upper reduced to linear bracts, in the axils of which the heads are disposed, in leafy panicled racemes; fertile flowers and scales of the involucre 5. - Salt marshes, coast of Mass. to Va. and southward.

2. I. ciliàta, Willd. Annual ( $2-6^{\circ}$ high), rough and hairy; leaves ovate, pointed, coarsely toothed, downy beneoth, on slender cillate petioles; heads in dense spikes, with conspicuous ovate-lanceolate rough-ciliate bracts; scales of the involucre and fertile flowers 3-5. - Moist ground, from Ill. southward. 
§ 2. CYCLACH FNA. Heads in panicled spikes, searcely bracteate; corollu of the 5 fertile flowers a mere rudiment or none.

3. I. xanthiifolia, Nutt. Annual, tall, roughish; leaves nearly all opposite, hoary with minute down, ovate, rhombic, or the lowest heart-shaped, doubly or cut-tootherl, or ohscurely lobed; heads small, crowded, in axillary and terminal panicles. - N. W. Wise. to Minn., Kan., and westward.

\section{A M BRÒSIA, Tourn. RaGweEd.}

Stcrile and fertile flowers ocenpying different heads on the same plant; the fertile $1-3$ together and sessile in the axil of leaves or bracts, at the base of the racemes or spikes of sterile heads. Sterile involucres flattish or top-shapeil, of $7-12$ scales united into a cup, containing 5-20 funnel-form staminate flowers, with slender chaff intermixed, or none. Anthers almost separate. Ferti?e involucre (fruit) oblong or top-shaped, closed, pointed, resembling an achene (usually with 4-8 tubercles or horns near the top in one row), and enclosing a single flower which consists of a pistil only ; the elongated style-branches protruding. Achenes ovoid; pappus none. - Coarse homely weeds, with opposite or alternate lobed or dissected leaves, and inconspicuous greenish flowers, in late summer and autumn; ours annuals, except the last. (The Greek and later Latin name of several plants, as well as of the food of the gods.)

$\S 1$. Sterile heads sessile in a dense spike, the top-shaped involucre extended on one side into a large, lanceolate, hooded, bristly-hairy tooth or appendage; fertile involucre oblong and 4-angled.

1. A. bidentàta, Michx. Hairy $\left(1-3^{\circ}\right.$ high), very leafy; leares alternate, lanceolate, partly clasping, nearly entire, except a short lobe or tooth on each side near the base; fruit with 4 stout spines and a central beak. - Prairies of Ill., Mo., and southward.

$\S 2$. Sterile heads in single or panicled racemes or spikes, the involucre regular. * Leares opposite, only once lobed; sterile involucre 3-ribbed on one side.

2. A. trífida, I. (Great Ragweed.) Stem stout $\left(3-12^{\circ}\right.$ high), rough-hairy, as are the large deeply 3-lobed leaves, the lobes oval-lanceolite and serrate; petioles nargined; fruit obovate, 5-6-ribhed and tubercled.Var. Ixtegrifolda, Torr. \& Gray, is only a smaller form, with the upper leaves, or all of them, undivicled, ovate or oval. - Moist river-hanks ; common.

* * Leaves many of them alternate, all once or twice pinnatifid.

3. A. artemisiæfollia, L. (Romax Wormwood. Hog-Weed. BitTER-WEED.) Much branched ( $1-3^{\circ}$ high), hairy or roughish-puhesceut; leaves thin, twice-pinnatifid, smoothish above, paler or hoary beneath; fruit obovoid or globular, armed with alout 6 short acute teeth or spines. - Waste places everywhere. - Extremely variable, with finely cut leaves, on the flowering branches often undivided; rarely the spikes hear all fertile heals.

4. A. psilostàchya, I)C. Paniculate-brancherl $\left(2-5^{\circ}\right.$ high $)$, rough and somewhat hoary with short hispid hairs; leaves once pimatifid, thickish, the lobes acute, those of the lower leaves often inciserl; fiuit obovoid, without tubercles or with very small ones, pubescent. - l'rairies and plains, Ill., W'isc., Minn., and southwestward. Perennial, with slender ruming rootstocks. 


\section{Xá NThIU M, Tourn. Cocklebur. Clotblr.}

Sterile and fertile flowers occupying different heads, the latter clustered below, the former in short spikes or racemes above. Sterile involucres and flowers as in Ambrosia, but the scales separate and receptacle cylindrical. Fertile involucre closed, coriaceous, oroid or oblong, clothed with hooked prickles so as to form a rough bur, 2-celled, 2-flowered; the flower consisting of a pistil and slender thread-form corolla. Achenes oblong, flat, destitute of pappus. - Coarse and vile weeds, with annual roots, low and branching stout stems, and alternate toothed or lobed petioled leaves; flowering in summer and autumn. (The Greek name of some plant that was used to dye the hair yellow; from $\xi \alpha \nu \theta o ́ s$, yellow.)

$$
\text { * Leaves attenuate to both ends, with triple spines at the base. }
$$

X. spixòsum, L. (Sprxy Clotbur.) Hoary-pubescent; stems slender, with slender yellow 3-parted spines at the axils; leaves lanceolate or ovatelanceolate, tapering to a short petiole, white-downy beneath, often $2-3$-lobed or cut; fruit ( $\frac{1}{3}^{\prime}$ long) pointed with a single short beak. - Waste places on the sea-board and along rivers, Mass. and southward. (Nat. from Trop. Amer.)

* Leaves cordate or ovate, 3-nerved, dentate and often lobed, long-petiolate; axils unarmed; fruit 2-beaked.

X. strciaricu, L. Low $\left(1-2^{\circ}\right.$ high) ; fruit $6-8^{\prime \prime}$ long, glabrous or puherulent, with usually straight beaks and rather slender spines. - A weed of barnyards, etc., sparingly nat. from Eu. (?) or Ind. (?).

1. X. Canadénse, Mill. Stouter, the stem often brown-punctate; fruit about l' long, densely prickly and more or less hispid, the stont beaks usually hooked or incurved. - River-banks and waste places, common. - Var. ECHIxÁtu, Gray, usually low, with still denser and longer, conspicuously hirsute or hispid prickles. Sandy sea-shores and on the Great Lakes.

\section{TETRAGONOTHECA, Dill.}

Heads many-flowered, radiate; the rays $6-9$, fertile. Involucre donble; the onter of 4 large and leafy orate scales, united below by their margins into a 4-angled or winged cup; the inner of small chaffy scales, as many as the ray-flowers, and partly clasping their achenes. Receptacle convex or conical, with narrow and membrauaceous chaff. Achenes rery thick and obovoid, flat at the top; pappus none.- Erect perennial herbs, with opposite coarsely toothed leaves, their sessile bases sometimes comnate, and large single heads of pale yellow flowers, on terminal perluncles. (Name compounded of $\tau \in \tau \rho a ́$ -

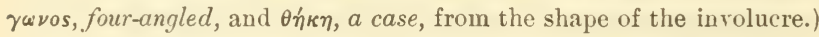

1. T. helianthoides, L. Villous and somewhat viscid, $1-2^{\circ}$ high, sinuple; leaves ovate or rhombic-oblong, sessile by a narrow base; involucral scales and rays about $\mathrm{l}^{\prime}$ long. - Sandy soil, Ta. and southward. June.

\section{ECLÍPTA, L.}

Heads many-flowered, radiate; rays short; disk-flowers perfect, 4-toothed, all fertile. Involucral scales 10-12, in 2 rows, leaf-like, ovate-lanceolate. Receptacle flat, with almost bristle-form chaff. Achenes short, 3-4-sided, or in the disk laterally flattened, roughened on the sides, hairy at the summit; pappus none, or an obscure denticulate crown. - An annual rough herb, with 
slender stems and opposite leaves. Heads solitary, small. Flowers white;

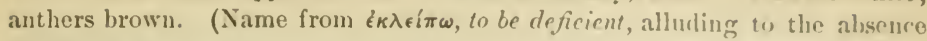
of pappus.)

1. E. alba, llassk. Rongl with fine appressed hairs; stems procumbent, or ascending and $1-3^{\circ}$ high; leaves lincenlate or oblong, ar'ute at each end, mostly sessile, slightly serrate; rays equalling the disk. (E. procumbens, Michx.) - Wet river-banks, N. J. to 11l. and southward. Peduncles very variable. (All tropical countries.)

\section{HELIÚPSIS, Pers. Ox-EYE.}

Heads many-flowered, radiate; rays 10 or more, fertile. Involucral scales in 2 or 3 rows, nearly equal; the outer leaf-like and somewhat spreading, the inner shorter than the disk. Receptacle conical; chaff linear. Achenes smooth, thick, 4-angular, truncate; pajpus none, or a mere border. - J'erennial herbs, like Heliantlus. Ileads showy, peduncled, terminal. Leaves opposite, petioled, triple-ribhed, serrate. Flowers yellow. (Name composed of i) $\lambda$ ios, the sun, and ơ $\psi$ s, appearance, from the likeness to the Sunflower.)

1. H. lævis, Pers. Nearly smootlı (1-4 high); leaves ovate-lanccolate or oblong-ovate, rather narrowly pointed, occasionally teruate; scales (as in the next) with a rigid strongly nerved base; rays linear; pappus none or of $2-4$ obscure teeth. - Banks and copses, N. Y. to Ill. and southward. Aug.

2. H. scabra, Dunal. Roughish, especially the leaves, which are disposed to be less narrowly pointed, the upper sometimes entire; rays broadly oblong to linear or oblanceolate; pajpus coroniform and chaffy or of 2 or 3 (conspicuous teeth. (H. lavis, var. scabra, Torr. \&. Gray.) - Western N. Y. to Minn., Mo., and southward.

\section{E C H I N A E A, Moench. Perple Cone-rlower.}

Heads many-flowered, radiate; the rays very long, drooping, pistillate but sterile. Scales of the involncre imbricated, lanceolate, spreading. Receptacle conical; the lanceolate cariuate spiny-tipped chaff longer than the disk-flowers. Achenes thick and short, 4-sided; pappns a small toother border. - Perenuial herbs, with the stout and nearly simple stems naked above and terminated by a single large head; leaves chiefly alternate, 3-5-nerved. hays rose-purple, rather persistent; disk purplish. (Name formed from é $\chi$ ivos, the hedgehog, or sea-urchin, in allusion to the spiny chaff of the disk.)

1. E. purpurea, Moench. Leares rough, often serrate; the lowest ovate, 5-nerved, veiny, long-petioled; the others orate-lunceolate: involucre imbricated in $3-5$ rows; stem smooth, or in one form rough-bristly, as well as the leaves. - Prairies and banks, from W. l'enn. and Va. to Iowa, and sonthward; occasionally adv, eastwarl. July. - liays 15-20, dull purple (rarely whitish), 1-2' long or more. Iiont thick, black, very pungent to the taste, used in popular medicine under the name of Black sampson. - Very variable, and probably comnects with

2. E. angustifolia, DC. Leares, as well as the slenrler simple stem, uristly-hairy, lanceolate and linear-lanceulate, altenuate at base, 3-nerved, cutire: involucre less imbricated and heads often smaller; rays $12-15$ (2' long), rosecolor or red. - Plains from Ill. and Wisc. sunthwestward. June $-\mathrm{Aug}$. 


\section{R U D B É CKI A, L. Cone-flower.}

Heads many-flowered, radiate; the rays neutral. Scales of the involucre leaf-like, in about 2 rows, spreading. Receptacle conical or columnar; the short chaff concave, not rigid. Achenes 4-angular (in our species), smooth, not margined, flat at the top, with no pappus, or a minute crown-like border. - Chiefly perennial herbs, with alternate leaves, and showy terminal heads; the rays generally long, yellow, often darker at base. (Named in honor of the Professors Rudbeck, father and son, predecessors of Linnæus at Upsal.)

* Disk columnar in fruit, dull greenish-yellow; leaves divided and cut.

1. R. laciniàta, L. Stem smooth, branching $\left(2-7^{\circ}\right.$ high $)$; leaves smooth or roughish, the lowest pinnate, with $5-7$ cut or 3-lobed leaflets; upper leaves irregularly 3-5-parted, the lohes ovate-lanceolate, pointerl, or the uppermost undivided; heads long-peduncled; disk at first globular or hemispherical; chaff truncate, downy at the tip ; rays oblanceolate ( $1-2^{\prime}$ long), drooping. Low thickets; common. July-Sept. - Var. Hù MILIs, Gray, low and glabrous, some of the radical leaves undivided or with roundish divisions; heads smaller ( $\frac{1^{\prime}}{2}$ high) and ray shorter. Mountains of Va. and southward.

* Disk hemispherical to oblong-ovoid in fruit, dark purple or brown.

+ Lover leares 3-lobed or parted.

2. R. tríloba, I. Hairy, biennial, much branched $\left(2-5^{\circ}\right.$ high $)$, the branches slencler and spreading; upper leaves ovate-lanceolate, sparingly toothed, the lower 3-lobed, tapering at the base, coarsely-serrate (those from the root pinnately parted or undivided); rays 8 , oval or oblong; chaff of the black-purple depressed-globular disk smooth, awned. - Dry soil, Penn. to Mich., Mo., and southward. Aug. - Heads small, but numerous and showy.

3. R. subtomentòsa, Pursh. Stem branching above $\left(3-4^{\circ}\right.$ high), downy, as well as the petiolate ovate or ovate-lanceolate serrate leaves beneath; heads short-peduncled; disk globular, dull brown; receptacle sweet-scented; chaff downy at the blunt apex. - Prairies, Wisc., Ill., Mo., and southward.

+ + Leaves undivided, rarely laciniately toothed.

4. R. hírta, L. Biennial, very rough and bristly-hairy throughou' ; stems simple or branched near the base, stout $\left(1-2^{\circ}\right.$ high), naked above, bearing single large heads; leaves nearly entire; the upper oblong or lanceolate, sessile; the lower spatulate, triple-nerved, petioled; rays (about 14) more or less exceeding the involucre; chaff of the dull brown dish hairy at the tip, acutish. Dry soil, western N. Y. to Wisc., and southwarl. Now common as a weed in eastern meadows, introduced with clover-seed from the West. JuneAug.

5. R. fúlgida, Ait. Hairy, the branches naked at the summit and bearing single heads; leaves spatulate-oblong or lanceolate, partly clasping, triplenerved, the upper entire, mostly obtuse; rays about 12 , equalling or exceeding the ample involucre; chaff of the dark purple disk nearly smooth and blunt. Dry soil, N. J. and P'enn. to Ky., Mo., and southward. - Variable, $1-3^{\circ}$ high ; the rays orange-yellow.

6. R. spathulàta, Michx. Pubescence short and appressed; slender, $8^{\prime}-3^{\circ}$ high; leares obovate or spatulate or the upper ovate to lanceolate, 
sometimes all lanceolate or oblancenlate to linear, denticulate; heads longpeduncled, smaller than in the preceding, the rays fewer and broader. - Pine woods, Va. to 'Teun., and southwarl.

7. R. speciosa, Weuleroth. Roughish-hairy $\left(1-2^{\circ}\right.$ high $)$, branched; the branches upright, elongated and naked above, terminated hy single large heads; leares lanceolate or orate-lanceolate, pointerl at both ends, petioled, 3-5nerved, coarsely and unequally toothed or incised; involucre much shorter than the numerous elongated $\left(1-1 \frac{1^{\prime}}{2}\right)$ rays; chaff of the dark purple disk acutish, sinooth. - Dry soil, W. J'enn. to Mich., Mo., and southward. July.

\section{LÉ PACH Y S, Raf.}

Hearls many-flowered, radiate; the rays few, nentral. lnvolucral seales few and small, spreading. Receptacle oblong or colnmmar; the chaff truncate, thickened and bearded at the tip. partly embracing the flattened and margined achenes. Pappus none or 2 teeth. - P'erenuial herbs, with alternate pinnately divided leaves; the grooved stems or branches naked above, bearing single showy heads. Rays yellow or party-colored, drooping; disk grayish. (Name from $\lambda \in \pi i s, a$ scale, and $\pi a \chi u$ s, thick, from the thickened tips of the chaff.)

1. I. pinnàta, Torr. \& Gray. Hoary with miuute appressed hairs, slender $\left(4^{\circ}\right.$ high $)$, brauching; leaflets $3-7$, lanceolate, acute; disk oblong, much shorter than the large and drooping light-yellow rays (which are $2^{\prime}$ long). Dry soil, western N. Y. to Miuu., and southward. July. - The receptacle exhales a pleasant anisate odor when bruised. Achenes slightly margined on the inner edge, obscurely 2 -toothed at the top.

2. L. columnàris, Torr. \& Gray. Branching from the base, $1-2^{\circ}$ high ; leaflets 5-9, oblong to narrowly linear, entire or 2-3-cleft; disk colnmnar, often $l^{\prime}$ long or more; ray as long or shorter, yellow or (var. PU lchérRima, Torr. \& Gray) in part or wholly brown-purple. - Minn. to Tex.

\section{BORRÍCHIA, Adans. SEA OX-EYe.}

Heads many-flowered, radiate; rays fertile. Scales of the hemispherical involucre imbricated. Receptacle flat, covered with lanceolate rigid and persistent chaff. Achenes somewhat wedge-shaped, 3-4-angled; pappus a short 4-toothed crown. - Shrubby low maritime plants, coriaceous or Heshy, with opposite nearly entire leaves. and solitary peduncled terminal heads of yellow flowers; anthers blackish. (Named for Olof Borrich, a 1)anish botanist.)

1. B. frutéscens, I)C. Whitened with a minnte silky pulsescence (6'$3^{\circ}$ high); leaves oborate to spatulate-oblong or lanceolate, often toothed near the base; chaff rigidly pointed. - Va. and southward.

\section{H EIIÁ NTHUS, L. Sunfower.}

Heads many-flowered, radiate; rays several or many, neutral. Involucre imbricated, herbaceous or foliaceous. Receptacle flat or convex; the persistent chaff embracing the 4-sided and laterally compressed smooth achenes, which are neitler winged nor margined. I'appus very deciluous, of 2 thin chaffy scales on the principal angles, and sometimes 2 or more small intermediate scales. - Coarse and stont herls, with solitary or corymbed heads, and yellow rays; flowering toward antumn. (Named from $\ddot{\eta} \lambda$ ios, the sun, and ¿ 0 os, a flower.) 
$\S 1$. Annuals; leaves mostly alternate, petiolate; receptacle flat; disk brownish.

1. H. ánnuus, L. (Commox Suxroower.) Tall, rongh; leaves tripleribbed, ovate or the lower cordate, serrate; involucral scales broadly ovate to oblong, long-pointed, ciliate; disk usually $\mathbf{l}^{\prime}$ broad or more. - Minn. to Tex., and westward ; long cultivated, and occasionally found in waste grounds.

2. H. petiolàris, Nutt. More slender, $1-3^{\circ}$ high; leaves oblong- or ovate-lanceolate, smaller ( $1-3^{\prime}$ long), mostly entire; scales lanceolate or oblong-lanceolate, seldom ciliate; disk $\frac{1^{\prime}}{2}$ broad or more. - Minn. to Tex., and westward.

§ 2. Perennials; receptacle convex or at length low-conical; lower leaves usually opposite.

* Involurral scales loose, becoming squarrose, narrowly lanceolate, pointed ( $\frac{1}{2}^{\prime}$ long); disk usually purple or brounish; leares lineur, 1-neried.

3. H. orgyàlis, DC. Stem glabrous, tall, very leafy; leaves mostly alternate, linear to filiform and entire, or the lowest lanceolate and serrulate; scales filiform-attenuate. - Dry plains, Mo. to Neb., south and westward.

4. H. angustifolius, L. Stem slender $\left(2-6^{\circ}\right.$ high $)$, usually scabrous ; leaves long and linear, sessile, entire, with revolute margins; heads loosely corymbed, long-peduncled; scales acute or pointed. - Low pine barrens, N. J. to Ky., and southward.

* Involucral scales closer, more imbricated, short, unequal and not foliaceous : leaves lanceolate to orate, mostly opposite and 3-neried.

+ Disk dark.

5. H. atròrubens, L. Rough-hary; stem slender $\left(2-4^{\circ}\right.$ high $)$, smooth and uaked and forking above; leaves thimnish, ovate or oval to oblong-lanceolute, or the lowest heart-shaped $\left(3-6^{\prime}\right.$ long), serrate, abruptly contracted into a margined petiole; heads small, corymbed; scales ovate, obtuse, ciliolate, appressed; rays 10-16; pappus of 2 fringed scales. - Iry soil, Va. to Ark., and sonthward.

6. H. rígidus, Desf. Stem stout $\left(2-6^{\circ}\right.$ high or more), simple or sparingly branched, rough; leaves very thick and rigid, rough both sides, oblong-lan. ceolate, usually pointed at both ends, nearly sessile, entire or serrate, the lowest oval; heads nearly solitary, pretty large; scales ovate or oblong, obtuse, or mostly acute, ciliate, appressed ; rays 20-25, pappus of 2 large and often sev. eral small scales. - Dry prairies, Mich. to Ill., and westward.

$$
++ \text { Trsk yellou: }
$$

7. H. lætiflòrus, Pers. Closely resembling the last; leaves rather thinner; heads single or corrmbed; scales rather fewer (in 2 or 3 rows), nar rower and acute or mostly acuminate. - Iny open places, Ohio to Wisc. and Minn., and southward. - Rays showy, 1-2' long.

8. H. occidentàlis, Riddell. Somewhat hairy, stem slender, simple, naker above ( $1-3^{\circ}$ high, seuding out runners from the base), bearing $1-5$ small heads on long peduncles; lowest leaves oval or lanceolate-ovate, entire or obscurely serrate, roughrsh-pubescent beneath, abruptly contracted into long harry petioles; the upper small and remote; scales ovate to lanceolate, acute or pointed, sometimes ciliate. - Dry barrens, Ohio to Wisc. and Minu., and southward. 
* * Involucre looser, the scales more acuminate or elongated or foliaceous; dish yelluw (anthers dark).

- Leares all opposite, sessile, serrulate; pubescence rather snfl.

9. H. móllis, Lam. Stem simple, leafy to the top $\left(2-3^{\circ}\right.$ high $)$; leaves ovate to lanceolate, with broad cordate clasping hase, pointed; scales laueeolate, seldom exeecling the disk. - J)ry barrens, (1hio to Iowa and sonthward. + + Leaves mostly alternate and 3-neried, sofi-pubessent beneath, scabrons aboire; scales very long and loose, hairy; tips of chafj and corolla-lobes hirsute.

10. H. tomentòsus, Michx. Stem hairy, stout $\left(4-8^{\circ}\right.$ high); leaves oblong-lanceolate, or the lowest ovate, tapering at both enls, obscurely serrate, large (5-12' long), somewhat petioled; disk $1^{\prime}$ broad; rays $12-16$, about $1^{\prime}$ long. - Rich woods, Ill. (?), Va., and southward along the mountaius.

+++ Leaves narrow, chiefly ulternate, not 3-nerved, scabrous both sides; heads rather small; scales loose, uttenuate.

11. H. grósse-serràtus, Martens. Stem smooth and glaucous, 6-10 high; leares elonguted-luncelate or ovate-lanceolate, taper-pointed, sharj]ly serrate or denticulate, acute or attenuate at base, petioled, often whiter aul finely pubescent beneath; scales lance-awl-shaped, slightly ciliate. - Iry plains, Ohio to Dak., Mo., and southwestward.-Probably ruus into the next.

12. H. gigantèus, L. Stem hairy or rough $\left(3-10^{\circ}\right.$ high $)$, brancheul above; leaves lanceolute, pointed, minutely serrate or nearly entire, green both sides, narrowed and ciliate at base, but nearly sessile; scales long, linear-lanceolate, pointed, hairy or strongly ciliate. - Var. A unf́cucs, Torr. \& Gray; leaves mostly opposite and closely sessile ly an obtuse base; perhaps a lyybrid with n. 17. - Low thickets and swamps ; common. Heads somewhat corymbed; the pale yellow rays 15-20; roots often becoming tuber-like.

13. H. Maximiliàni, Schrad. Resembling the last; stout, often simple, $1-10^{\circ}$ high; leaves becoming rigid and very scabrous, entire or sparingly denticulate; heads rather large, usually short-pedumeled, terminal and in the upjer axils; scales longer attenuate, more rigid. - Prairies, Minn. to Tex.

++++ Leaves all or most of them opposite, 3-nerved (faintly in 11.15 ).

- Meads very small (about 4" broad) ; ruys 5-8; scales feu", short, irreyularly imbricated, the outer with spreading fuliaccous pointed tips; stems smooth.

14. H. parviflorus, Beruh. Stem $3-6^{\circ}$ high, witl mumerous slender branches above; leaves thin, ovute-lanceolate, taper-pointed, somewhat serrate, petivled, rough abore, pale and puberulent beneath; peduncles sleuder, rough ; scales ovate and ovate-lanceolate, ciliate. (H. microcephalus, Torr. \&. (iray.) - Thickets, I'enn. to Ill., and sonthward.

15. H. lævigàtus, Torr. \& Gray. Stem slencler $\left(1-6^{\circ}\right.$ high $)$, simple or sparingly branched, glancous, glabrous throughout, as well as the slightly serrate lancolate lences which are usually narrow and attenuate to the base. Dry soil, Alleghany Mts., and southwarl.

+ Heads lurger; rays usually over 10 ; spreadin!y by creeping rootstocks.

$=$ Leaves sessile or subsessile to short-petiolute, serrulute or entire.

16. H. doronicoides, Lam. Finely pubescent and roughish, $3-7^{\circ}$ high; leaves sessile, wrate-oblong, acute, triply-neried above the broadly cuneate 
base, servulate; scales loose, attenuate, mostly 6-8" long, hairy. (H. cinereus, var. Sullivantii, Torr. $\oint^{*}$ Gray.) - Dry ground, Ohio to Mo.

17. H. divaricàtus, L. Stem simple or forked and corymbed at the top ( $1-4^{\circ}$ high), smooth below; leaves all opposite and diraricate, orate-lanceolate, 3-nerved fiom the rounded or truncate sessile base, tapering gradually to a sharp point $\left(3-6^{\prime}\right.$ long), serrate, thickish, rough both sides; scales narrowly lanceolate, attenuate, ciliate, equalling the disk; rays 8-12. - Thickets and barrens; common. - Disk 6" wide ; rays $1^{\prime}$ long.

18. H. hirsùtus, Raf. Stem simple or forked above, stout ( $1-4^{\circ}$ high), bristly-hairy; leaves all shortly petioled, ovate-lanceolate, gradually pointed, slightly serrate, rounded or obtuse at the base, very rough above, usually roughhairy beneath; scales orate-lanceolate, pointed, equalling the disk; rays about 12.- Dry plains, Ohio to Wisc., and southward.

19. H. strumòsus, L. Stem $\left(3-6^{\circ}\right.$ high) very smooth below, often glaucous; leaves ovate-lanceolate, tapering gradually to a point, or the lower ovate and acute, abruptly contracted into short margined petioles, rough above, whitish and naked or minutely downy underneath; scales broadly lanceolate with spreading tips, ciliate, equalling the disk; rays 9-15. - Var. Móllis, Torr. \& Gray, has the leaves downy underneath, often subcordate, the scales looser and more attenuate. - River-banks and low copses ; common, especially westward.

20. H. tracheliifolius, Willd. Like the last; leaves thinner and nearly equally green both sides, more sharply serrate, all distinctly petioled; scales all loose and spreading, exceeding the disk, often much elongated. Copses, Penn. and Ohio to Minn., and southward.

$==$ Leaves longer-petiolate, thinnish or soft, coarsely serrate, commonly broad: scales loose, hirsute-ciliate.

21. H. decapétalus, I. Stem branching $\left(2-5^{\circ}\right.$ high $)$, smooth below; leaves smooth or roughish, ovate, pointed, abruptly contracted into margined petioles; scales lanceolate-linear, elongated, loosely spreading, sometimes foliaceous, the outer longer than the disk; rays about 10. - Copses and low banks of streams ; N. Eng. to Minu. and southward, common.

22. H. tuberósus, L. (Jercsalem Artichoke.) Pubescent or hirsute, $5-10^{\circ}$ high; leaves ovate or subcordate to oblong-lanceolate, acuminate, scabrous above, minutely pubescent or cinereous beneath; scales lanceolate, attenuate, little exceeding the disk; rays 12-20. (H. doronicoides, former ed.) - N. Y. to Minn., and southward; often cultivated. - Var. scrbcaxésCENs, Gray; usually dwarf, the lower side of the leaves whitish with soft fine pubescence. Minn. to Mo.

\section{VERBESİN A, L. Crownbeard.}

Heads several - many-flowered; the rays pistillate, or sometimes neutral and sterile, few, or sometimes none. Involucral scales imbricated in 2 or more rows. Receptacle rather convex (conical in 1. 3); the chaff concave. Achenes flat (compressed laterally), winged or wingless, 2-awned.-Mostly perennial herbs; the toothed leaves decurrent on the stem. Flowers mostly yellow. ("Name metamorphosed from Verbena.") 
* Ileads narrow, small, cymosely paniculate; rays feu, pistillate, usually fertile ; iniolucre erect.

1. V. occidentàlis, Walt. Stem tall, 4-winged; leures opposite, orate to oblong-lanceolate, triple-nerverl, serrate, pointed at both ends, often jubescent beneath (large and thin); heals in compound corynls; receptarle flattish; flowers yellow; rays 1-5, lanceolate; achenes wingless. (V. Siegesbeckia, Michx.) - Rich soil, S. I'enn. to 111., and southward. July.

2. V. Virgínica, L. Stem narrowly or interruptedly winged, dounypubescent, like the louer surface of the ovate-lanceolate feather-veined alternate leares; heads in componnd corymbs ; receptacle convex; flowers uhite; rays 3-4, oval; achenes winged. - I)ry soil, Penn. (?) to Ill., and southward. Aug.

* Heads broader, solitary or few.

3. V. helianthoides, Michx. l'erenniul; stem hairy $\left(1-3^{\circ}\right.$ high $)$, widely winged by the ovate to the ovate-lanceolate sessile alternate leaves, which are rough above and soft-hairy beneath; involucre appressed; rays 8-15, pistillate or neutral, usually sterile; achenes winged, tipped with 2 fragile awns. (Actinomeris helianthoides, $\boldsymbol{N} u t t$.) - Prairies and copses, Ohio to Iowa and southward. July.

4. V. encelioides, Benth. \& Hook. Anmual, branching, l-20 high, cinereous; leaves alternate, ovate or cordate to deltoid-lanceolate, the petioles mostly winged and auriculate at base; involucral scales linear, equal, foliaceous, spreading; rays numerous, fertile. - Kan. to Tex., and westward.

\section{ACTINómERIS, Nutt.}

Heads many-flowered; rays neutral, few or none. Involucral scales few, herbaceous, nearly equal, soon leflexed beneath the globular disk. Receptacle small, chaffy. Achenes flat, obovate, winged or wingless, at maturity spreading in all directions; pappus of 2 or 3 smooth persistent awns. - Tall branching perennials, with serrate feather-veined leaves, tapering to the base and mostly decurrent on the stem. Hearls corymbed; flowers chiefly yellow. (Name from ákris, a ray, and $\mu \in \rho / s, a$ part; alluding to the irregularity of the rayss.)

1. A. squarrosa, Nutt. Stem somewhat hairy, nsually winged above $\left(4-8^{\circ}\right.$ high); leaves alternate or the lower opposite, oblong or ovate-lanceolate, pointed at both ends; rays 2-8, irregular. - Rich soil, l'env. and $W$. New York to Iowa, and southward. Sept.

\section{COREÓPSIS, L. Ticksen.}

Heads many-flowered, radiate; rays mostly 8 , nentral, rarely wanting. Involucre double; each of alout 8 scales, the outer rather foliaceous and somewhat spreading; the inner broader and appressed, nearly membranaceous. Receptacle flat, with membranaceous chaff deciluous with the fruit. Achenes flat, obcompressed (i. e., parallel with the scales of the involucre), often winged, not narrowed at the top, 2-toothed or 2-awned, or sometimes naked at the summit, the awns not barbed dowuwardly. - Herbs, generally with opjosite leaves, and yellow or party-colored, rarely purple, rạs. (Name from kópis, a bug, and $\tilde{o} \psi$ is, resembiance; from the form of the achene.) 
$\S 1$. Style-tips truncate or nearly so; outer involucre small and short; rays rosecolor or yeliow with broun base; pappus an obscure border or none.

1. C. ròsea, Nutt. Perenuial; stem branching, leafy, smooth $\left(6-20^{\prime}\right.$ high); leares linear, entire; heads small, somewhat corymbed, on short peduncles; rays rose-color, 3-toothed; achenes oblong, wingless. - Sandy grassy swamps, Plymouth, Mass., to N. J., and southward; rare. Aug.

2. C. cardaminefòlia, Torr. \& Gray. Annnal, $6^{\prime}-2^{\circ}$ high; leares 1-2-pinnately divided, the lobes oval to lanceolate or above linear; rays yellow with brown-purple base; achenes short, smooth or papillose, winged. Kan. to La. and Tex.

3. C. tinctòria, Nutt. Annual, glabrous, 2-3o high; leaves 1-2-pinnately divided, the lobes lanceolate to linear; achenes oblong, wingless; rays yellow with more or less of crimson-brown. - Minn. to Tex., etc.; common in cultivation.

§2. Style-tips abruptly cuspidate, hispid; involucres nearly equal; ackenes roundish, winged, incurved, often papillose and with a callus inside at base and apex; pappus 2 small teeth or none; ray mostly yellow and palmately lobed; perennials, with long-pedunculate heads; lower leaves petiolate.

4. C. lanceolàta, L. Smooth or hairy $\left(1-2^{\circ}\right.$ high), tufted, branched only at the base; leaves all entire (the lower rarely with a pair of small lateral lobes), lanceolate, the lowest oblanceolate or spatulate; onter scales oratelanceolate. - Rich or damp soil, Mich. and Ill. to Va., and southward. July. Also cultivated in gardens. Heads showy; rays $l^{\prime}$ long. - Var. AxgustFòli, Torr. \& Gray, is a low form with crowded narrow leaves and elongated peduncles. - Var. villósA, Michx., is hirsute below, the leaves rather broad.

5. C. grandiflora, Nutt. Mostly glabrous; lower leaves lanceolate and spatulate, entire, the upper 3-5-parted with lanceolate to linear and sometimes 2-3-parted lubes; heads as in the last or larger. - S. Mo. to Tex. and Ga.

6. C. pubéscens, Ell. More leafy, 1-4 high, pubescent or nearly glabrous; leaves thickish, oblong or the lower oval-obovate and the upper oblong-lanceolate, entire or with 2-4 small lateral lobes; heads usually smaller. - Va. to S. Ill., Mo., and southward.

7. C. auriculàta, Linn. Pubescent or glabrous; stems $1-4^{\circ}$ high, branching, sometimes with rumners; leares mostly petioled, the upper oblong or oral-lanceolate, entire; the lower oral or roundish, some of them variously 3-5-lobed or divided; outer scales oblong-linear or lanceolate; achenes narrowly winged and strongly involute. - Rich woods and banks, Va. to Ill., and southward. June-Sept.

§3. Style-tips cuspidate; achenes oblong, nearly straight, without callus, the wing narrow or none; rays yellow, mostly entire or slightly toothed.

* Outer scales narrow, about the length of the inner, all more or less united at base; rays mostly entire, acute; pappus 2-toothed or none; leaves opposite, sessile, mostly 3-divided, appearing as if whorled; perennial, $1-3^{\circ}$ high.

+ Leaves 3-cleft, but not to the base.

8. C. palmàta, Nutt. Nearly smooth, simple; leaves broadly wedgeshaped, rigid; the lobes broadly linear, entire, or the middle one 3-lobed.Prairies, Mich. to Minn., and southwestward. July. 
+ + Leaves divided to the buse, uppermost and lonest sumetimes simple.

9. C. senifòlia, Michx. Plant minutely soft-pubescent; leaves each divided into 3 sessile oute-lunceolate entive leaflets, therefore apjearing like 6 in a whorl. - Samly wooks, Va. and suuthward. July.

Var. stellàta, Torr. \& Gray. Glabruns, and the leaves narrower. - Va., Ky., ausl southwaril.

10. C. delphinifolia, Lam. Glahrous or nearly so; leaves divided into 3 sessile leaflets which are 2-5-parted, their divisions lence-lineur ( 1 - 3 " bruad), rather rigid; disk brownish. - Pine woods, Va. aud southward. July.

11. C. verticillàta, L. Glabrous; leaves clivided into 3 sessile leaftets which are 1-2-pinnately parted into narrouly linear or filiform dirisions.I)amp suil, from Ont. and Mich. to Md., Ark, and southwaril. Cultivated in old gardens, but not sliowy. July-sept.

* * Outer scales narron, shorter, ull united at base; rays entire, obituse; pappus none; leaves petivlate, pinnately 3-5-divided; perenniul.

12. C. trípteris, I. ('TALL Corforsis.) Smooth; stem simple $\left(4-9^{\circ}\right.$ high), corymbed at the top; leaflets lanceolate, acute, entire. - Penn. to Wisc., Iowa, and southward. Aug.-Sept. - Heads exlialing the odor of anise when bruised; disk turning brownish.

* * Scales mostly distinct, the outer leafy, reflexed or spreading; achenes flat, oborate or cuneate-oblong, l-neried on each fuce, 2-toothed or 2-auned (rarely 4-auned) ; leaves petiolate, usually pimately 3-7-divided, the lobes serrate; annuals (or biennial), branching. Approaching Bidens.

\section{- Rays conspicuous, golden yellow.}

+ Achenes cuneate, obscurely ciliate or naked; outer scales about 8.

13. C. aùrea, Ait. Nearly glabrous, $1-3^{\circ}$ high; leaves variable, commonly $3-7$-divided, or some or all mudivided, the segments incisely serrate or lobed; achenes broadly cuneate, 1-2" long, with 2 very short biunt spreading teeth. - Wet ground, Va. to Fl.

14. C. trichospérma, Michx. ('Tickseed Suxfloweri.) Smooth, branched ; leares shurt-petioled, nearly all 3 - - -livided; leaflets lanceolate or linear, eut-toothed, or the upper leaves only $3-5$-cleft and almost sessile; heads panicled-corymbose; achenes narrouly wedyp-oblong or the inmer ones uedgelinear, about $4^{\prime \prime}$ long, smooth or sparsely hairy, marginless, crowned with 2 erect triangular or aul-shaped stont tecth. - Swamps, Mass. to Va. near the coast. Also Cayuga, N. Y., to Ill., where is a var. Textflon., Gray, with shorter achenes, approaching the last. Iug. - ()ct.

$$
\text { + + Achenes whavate, very flut, with thin ciliate margins. }
$$

15. C. aristòsa, Michx. Somewhat pubescent; leaves 1-2-pinuately 5$i$-divided, petioled; leaflets lanceolate, cut-toothed or pinnatifil; heads panicled-corymbose; onter scales 8-10, not exceeling the inner, barely ciliate; achenes with 2 (rarely 4) long und slender diverging auns as long as the achene itself. - Swamps, Ohio to Mich., Minu., and southwestward. Aug. - Oct. Var. MƯricA has two short divergent tecth or points in place of the awns. W. Ill. and southwestward. Forms occur with the barbs of the awns spreading or retrurse, hỵbids with Bidens fiondosa or other species. 
16. C. involucràta, Nutt. Heads rather larger, the outer scales 12-20, mostly exceeding the inner, slender and hispid; achenes with 2 short acute teeth. - W. Ill. to Kan. and Tex.

+- + Rays none, or rarely rudimentary; outer scales usually 3-5, loose, leafy, commonly surpassing the short-pedunculate heads; achenes narrowly cuneate; plants glabrous, $1-3^{\circ}$ high; leares petiolate.

17. C. bidentoides, Nutt. Paniculately branched; leaves undivided, lanceolate, coarsely toothed, tapering at both ends; heads 6-10" long; achenes nearly subulate, bearing a pair of tery slender upwardly roughened awns surpassing the corolla (4" long), bnt shorter than the achene, often also 2 minute teeth alternate with the awns. - Shores of Delaware River, near Philad, and Delaware Bay, to MId. Hybridizes with Bidens frondosa.

18. C. discoídea, Torr. \& Gray. Diffusely branched, 1-20 high; leares ternately divided, slender-petioled; leaflets ovate-lanceolate, pointed, coarsely serrate; heads 2-3" long; achenes linear-wedge-shaped (2-3" lorg), bearing a pair of short and stout upwardly-barbed auns of the length of the corollr. Wet banks and swamps, Conn. to Ohio, Ill., and southward. July.

\section{Bİ D E S, L. BLR-MARIGOLD.}

Heads many-flowered; the rays when present 3-8, neutral. Involucre double, the outer commonly large and foliaceous. Receptacle flattish; the chaff deciduous with the fruit. Achenes flattered parallel with the scales of the involucre, or slender and 4 -sided, crowned with 2 or more rigid and persistent awns which are downwardly barbed. - Annual or perennial herbs, with opposite various leaves, and mostly yellow flowers. (Latin, bidens, two-toothed.)

* Achenes flat, not tapering at the summit; outer involucre foliaceous; annuals, + Heads erect, nearly rayless; leaves mostly petiolate.

1. B. frondòsa, L. (Common Beggar-ticks. Stick-tight.) Smootl or rather hairy, tall $\left(2-6^{\circ}\right.$ high), branching; leaves $3-5$-dicided; leaflets mostly stalked, lanceolate, pointed, coarsely toothed; outer involucre much longer than the head, ciliate below; achenes wedge-obovate, 2-awned, ciliate (tho bristles ascending except near the summit). - Moist waste places; a coarse troublesome weel, the achenes, as in the other species, adhering to clothing, ete., by their retrorsely barbed awns. Hylrids occur with Coreopsis aristosa and other species. July-Oct.

2. B. connàta, Muhl. (Swamp BegGar-ticks.) Smooth (1-2 ${ }^{\circ}$ high); leares lanceolate or oblong-lanceolate, pointed, sharply serrate, tapering into margined slightly united petioles; the lower often 3-divided, their lateral divsions united at the hase and decurrent on the petiole; outer scales longer than the head, few, mostly obtuse; rays none; achenes narrouly wedge-form, 3- (24-) awned, the margins minutely retrorsely ciliate. - E. New Eng. to Minn., and southward. - Var. comòs , Gray, is stouter, the leares commonly all simple, upper ones nearly sessile, the heads larger and with very leafy involucre. Ill., Ky., and westward. Aug. - Oct. - Var. pixsdita, Watson; leaves nearly all pinnately divided, the $5-7$ narrow divisions sparingly incised; achenes 4 -awned. Hennepin Co., Minn. (F. L. Couillard). 
- + Heads somenchat nodding, commonly radiute; leares sessile, undirided.

3. B. cérnua, I. (Simater Btr-Maniguth.) Nearly smonth (5) $-3^{\circ}$ high); leaves luncoulate, umequally serrate, scurcaly conume: heads unduling, with or without (light yellow) ruys; outer involucre longror than the heal; achenes wedge-oborate, 4-awned, the inargins downwarlly bithed. - Wet places, $\mathbf{N}$. Eng. to Va., Mo., Minn., and northwarl. July-Sept. - liays, if any, smaller than in n. 4, and the outer involucre more leaf-like. (lin.)

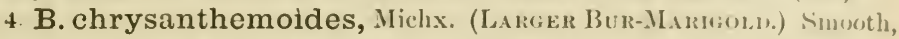
erect, or reclining at the base $\left(6^{\prime}-2^{\circ}\right.$ high $)$; lecuces lunceolute, tapering at both ends, more or less comnate, regulurly serrate, outer involucre mostly shorter than the shou'y golden-yellow ( $1^{\prime}$ long) rays; achenes wedge-shaped, with almost prickly downwardly barbed margins; awus 2, 3, or 4. - Swanps; common. Aug - Oct

* Achenes linear, 4-sided, the inner longer and tapering upuard.

5. B. bipınnàta, L (SPAxisir Needles.) Smooth anmual, hranched; leaves 1 -3-pinnately parted, petiulerl; leaflets orate-lanceolate, mustly werlgeshaped at the base; heals small, on slenter peluncles; onter iuvolucre of linear scales equalling the short pale vellow rays, achenes 4-grooved and augled, nearly smouth, 3-4-awned. - Danup soil, R. I. to N. Y., Ill., and suuthward.

* * Achenes terete, truncate at both ends, with 3-6 very long auns smooth belou:

6 B. Béckii, Torr. (Water Marigorn.) Aquatic, perhaps perennial, smooth; stems long and slender; immersed leaves crowled, capillary, many times dissected, the few emerging ones lanceolate, slightly connate, toothed; heads single, short-perluncled ; involucre much shorter than the showy (golden yellow) rays; achenes thickish, smooth ( $\frac{1^{\prime}}{2}$ long), the stout divergent awns ( $I^{\prime}$ long) barbed only toward the apex. - Ponds and slow deep streams, Mass. to N. J., Mo., and northward. Aug. - Oct.

\section{THELESPERMA, Less.}

Heads many-flowered; rays about 8 , neutral, or none. Involucre as in Coreopsis, the inner connate to the middle, scarious-margined. Receptacle flat, the scarious chaff falling with the nearly terete wingless and beakless achenes; pappus of 2 stout subulate retrorsely hispid awns. - Smooth lierbs, with opposite dissected leaves and pedunculate heads of yellow flowers. (Frum $\theta \eta \lambda \hat{\eta}, a$ nipple, and $\sigma \pi \epsilon \cos \mu \alpha$, seed, on accomnt of the papillose achenes.)

1. T. grácile, Gray. Perennial, rather rigid, $1-2^{\circ}$ high; leaves with narrow or filiform divisions or the upper entire; onter scales very short; rays short or usually none; achenes papillose. - Kan., south and westward.

\section{BALDWÍNIA, Nutt.}

Heads globular, many-flowerel, radiate; the long and narrowly welge-shaped rays neutral. Involucre short, of many thickish small scales imbricated in 3 or 4 rows, the outer obovate and obtuse. Receptacle strongly convex, with deep honeycomb-like cells containing the obconical or oblong silky-villous achenes; pappus of $7-9$ lance-oblong erect chaffy scales. $-A$ perennial herb, smootlish, with sleuder simple stems $\left(2-3^{\circ}\right.$ high $)$, bearing alternate oblauceulate leares, 
and a large showy long-pedunculate head. Rays yellow ( $1^{\prime}$ long); the disk often turning dark purple. (Named for the late Dr. William Baldwin.)

1. B. uniflòra, Nutt. - Borders of swamps, Va. (?) and southward. Aug.

59. M A R S HÁ L L I A, Schreb.

Heads many-flowered; flowers all tubular and perfect, the corolla-lobes slender and spreading. Involucral scales linear-lanceolate, foliaceous, erect, in one or two rows, nearly equal. Receptacle convex or conical, with narrowly linear rigid chaff. Achenes top-shaped, 5-angled; pappus of 5 or 6 membranaceous and pointed chaffy scales. - Smooth and low perennials, with alternate entire 3-nerved leaves, and long-pedunculate heads (like those of a Scabious) terminating the simple stem or branches. Flowers purplish; anthers blue. (Named for IIumphrey Marshall, of Pennsylvania, author of Arbustum Americanum, one of the earliest works on the trees and shrubs of this country.)

1. MI. latifolia, Yursh. Stems leafy ; leares ovate-lanceolate, pointed, sessile. - Dry soil, Va. and southward.

2. M. cæspitòsa, Nutt. Stem commonly leafy only at base; leaves narrowly oblanceolate to linear or the radical spatulate, obtuse. - Kan. to Tex.

\section{G A L I N S Ò G A, Ruiz \& Pavon.}

Heals several-flowered, radiate; rays 4-5, small, romndish, pistillate. Invo. lucre of 4 or 5 ovate thin seales. Receptacle conical, with narrow chaff. Achenes angled; pappus of small oblong cut-fringed chaffy scales (sometimes wanting). - Annual herbs, with opposite triple-nerved thin leaves, and small heads; disk yellow; rays whitish. (Named for Galinsoga, a spanish botanist.)

G. PARviflòrA, Cav. Smoothish ( $1^{\circ}$ high); leaves ovate, acute, somewhat toothed; scales of the pappus 8-16. - Waste places, especially eastward; spreading from year to year. (Adv, from S. Amer)

\section{HY M E N O PÁ P P U S, l'Her.}

Heads many-flowered; flowers all tubular and perfect, with large revolute corolla-lobes. Involucral scales $6-12$, loose and broad, thin, the upper part petal-like (usually white). Receptacle small, naked. Achenes top-shaped, with a slender base, striate; pappus of 15-20 blunt scales in a single row, very thin (whence the name of the genus, from $\dot{\mu} \mu \eta \dot{\nu}$, membrane, and $\pi a$ a $\pi$ os, pappus.) - Biennial or perennial herbs, with alternate mostly dissected leaves, and corymbed small heads of usually whitish flowers.

* Pappus of very small roundish nerveless scales.

1. H. scabiosizus, L'Her. Somewhat flocculent-woolly when young, leafy to the top $\left(1-3^{\circ}\right.$ high $)$; leaves $1-2$-pinnately parted into linear or oblong lobes; involucral scales roundish, mainly whitish. - Sandy barrens, Ill. and southward. May, June.

2. H. corymbosus, Torr. \& Gray. More slender, glabrate, naked above; scales obovate-oblong, petaloid at apex. - Neb. to Ark. and Tex.

* * Pappus of conspicuous spatulate 1-nerved scales; involucre greener.

3. H. tenuifolius, Pursh. Slightly tomentose or glabrate, leafy, $1-2^{\circ}$ high; clivisions of the leaves narrowly linear or filiform, revolute; involucral scales ubovate-oblong; achenes long-villous. - Neb. to Ark. and Tex. 


\section{A C T I ÉLLA, Pers., Nutt.}

Heads many-flowered; rays several, wedge-olilong, 3-toothed, pistillate. Scales of the liemispherical involuere ovate or lanceulate, membranaceous or coriaceous, nearly equal, appressed in 2 or 3 ranks, little shorter than the disk. Receptacle hemispherical or conical, naked. Achenes top-shapert, densely silky-villous; pappus of 5 or more ovate or lanceolate very thin chaffy seales. - Low herbs, with narrow alternate leaves, dotted or sprinkled with resinous atoms as in the next genus and bitter-aromatic; the solitary hearls terminatiug scapes or slender naked peduncles; flowers yellow. (Name a diminutive of Actinea, from $\dot{a} \kappa \tau i s, ~ r a y$.

* Involucre of numerous distinct not rigid scules; leaves entire.

1. A. linearifolia, Torr. \& Gray. Annual or biennial, villous or glabrate, $1^{\circ}$ high or less, simple or branched; leaves linear; peduncles filiform. -S. Kan. to La., and Tex.

2. A. acaulis, Nutt. Perennial, densely cespitose, the branches of the caudex short and thick, with scape-like peduncles, canescently villous or silky; leaves spatulate to linear, short. - Hills and plains bordering the Rocky Mts. and scarcely reaching our limits; the var. GLABßA, Gray (A. scaposa, var. glabra, Man.), a greener glabrate form, has been found on an Indian inound near Joliet, Ill. The less densely cespitose A. sca ròsA, Nutt., more loosely villous and the caudex with more slender branches, is probably in S. Kan.

* Scales rigid, in 2 rows, the outer connate at base; leaves ternately parted.

3. A. odoràta, Gray. Annual, 1-2 high, branching, leafy, somewhat floccose-woolly; heads small, scattered; leaves 1-3-pinnately divided, the lobes filiform. - Central Kan. to Tex., and westward.

\section{HEL E N I M, I. SNEEZE-WEED.}

Heads many-flowered, radiate; rays several, wedge shaped, 3 - 5-c'left, fertile or rarely sterile. Involucre small, reftexed, the seales linear or awl-shaped. Receptacle globose or oblong, naked. Achenes top-shaped, ribherl; pappus of $5-8$ thin and 1-nerved chaffy scales, the nerve usually exteuled into a bristle or point. - Erert, branching herbs (ours perenuial), with alternate leaves decurrent on the angled stem and branches, which are terminated by single or corymbed (yellow, rarely purple) hearls; often sprinkled with bitter aromatic resinous globules. (The Greek name of some plint, said to be named after Helenus, son of Priam.)

1. H. nudiflorum, Nutt. Somewhat pulerulent, $1-3^{\circ}$ high; leaves narrowly lanceolate or oblong to linear, entire, or the radical spatulate and dentate; heads mostly small ; disk browuish, globose; ray yellow or partly brownpurple, sterile (nentral or style abortive), shorter than or exceeding the disk. (Leptopoda brachypoda, Torr. \& Gruy.) - Ill. and Mo. to N. Car. and Tex.; uat. near Philadelphia. Hybridizes with the next. June-Aug.

2. H. autumnàle, I. Nearly smooth, $1-6^{\circ}$ high ; leaves mostly toothed, lanceolate to ovate-oblong; heads liarger (alout $6^{\prime \prime}$ broal); disk yellow; ray fertile, yellow. - Alluvial river-banks and wet ground, Conu. to Minn., south and westward. Sept. 


\section{G A I LLÁ R D A, Foug.}

Heads many-flowered; rays 3-cleft or -toothed, neutral or sometimes fertile, or none. Involucral scales in 2-3 rows, the outer larger, loose and foliaceous. Receptacle convex to globose, beset with bristle-like or subulate or short and soft chaff. Achenes top-shaped, 5-costate, villous; pappus of 5-10 long thin scales, awu-tipped by the excurrent nerve. - Erect herbs with alternate leaves and large showy heads of yellow or purplish fragrant flowers on terminal or scapiform pedincles. (Named after Gaillard de Merentonneau.)

1. G. símplex, Scheele. Annual; leaves all radical, usually spatulate, pinnatificl to entire; hearl globose on a naked scape, usually rayless. - S. Kan. to Tex.

2. G. lanceolàta, Michx. Annual, leafy-stemmed, branched, $1-2^{\circ}$ high, finely pubescent; leaves oblanceolate to linear, mostly entire; rays rather few or none; chaff very short or obsolete. - S. Kan. to Tex. and Fla.

3. G. aristàta, Pursh. Perenuial, hirsute, often $2^{\circ}$ high ; leaves lanceolate to oblanceolate, broad or narrow, entire to coarsely pinnatifid ; rays usually numerous and long; chaff bristly or subulate. - Dak., west and southward.

\section{D Y S Ò D I A, Car. Fetil Marigold.}

Heads many-flowered, usually radiate; rays pistillate. Involucre of one row of scales united into a firm cup, at the base some loose bractlets. Receptacle flat, not chaffy, but beset witl short chaffy bristles. Achenes slender, 4-angled ; pappus a row of chaffy scales dissected into uumerous rough bristles. - Herbs, mostly annuals or biennials, dotted with large pellucid glands, which give a strong odor (as in Tagètes, the Frexci Marigold of the gardens, which belongs to the same group); heads terminating the branches; flowers yellow. (Name $\delta v \sigma \omega \delta i \alpha$, an ill smell, which the plauts exemplify.)

1. D. chrysanthemoides, Lag. Nearly smooth, diffusely branched (6$18^{\prime}$ high) ; leares opposite, pinnately parted, the narrow lobes bristly-toothed or cut; rays few, scarcely exceeding the involucre. - Roadsides, and banks of rivers, Miun. to Ill., Tenn.. and southwestward. Aug. - Oct.

\section{6. Á N T H $\mathrm{MIS}$, L. Chaмomile.}

Heads many-flowered, rarliate; rays pistillate or (in n. 1) neutral. Involucre hemispherical, of many small imbricated dry and scarious scales shorter than the disk. Receptacle conical, with slender chaff at least near the summit. Achenes terete or ribbed, glabrous, truncate; pappus none or a minnte crown. - Branching strong-scented herbs, with finely punately dissected leaves and solitary terminal heads; rays white; disk yellow. ('A $\nu \theta \epsilon \mu$ 's, the ancient Greek name of the Chamomile.)

A. Cótula, DC. (Mar-ween.) Annual, acrid; rass mostly neutral; receptacl without chaff near the margin; pappus none; leaves finely 3-pinnately clissected. (Maruta Cotula, DC.) - Common by roadsides. (Nat. from Eu.)

A. Arvéxsis, L. (Cors Chamomile.) Pubescent annual or biennial, resembling May-weed, but not ill-scented; leaves less finely 1-2-pinnately parted, chaff of the receptacle lanceolate, pointed; pappus a minute border. - Wraste places; rare. ( $(d \mathrm{~d}$ v. from Eu.)

A. xóbilis, L. (Garwix Chamomile.) More downy and perennial, pleasantly strong-scented; sterile shoots depressed or creeping; leaves very 
finely dissected; cliaff of the receptacle blunt; pappus none. - Established near Lewiston, Delaware, Nuttall. ( $\Lambda d v$. from Eu.)

\section{A CHILLEA, L. YArRow.}

Heaas many-flowered, radiate; the rays few, fertile. Involucral scales inbricated, with scariuus margins. Receptacle chaffy, flattish. Achenes oblong, flattened, margined; pappus none.-Pereunial herbs, with small corymbose heads. (So named because its virtues are said to have been discovered by Achilles.)

1. A. Millefolium, L. (Commox Yarrow or Milforl.) Stems simple; lcaves ucice-pinnately parted; the divisions linear, 3-5-cleft, crowded; corymb compound, flat-topped; involucre oblong; ra.js 4-5, short, white (sometimes rosecolor). - Fields and hills; common. Green and more glabrate in fielis in the Atlantic States, and perhaps in such cases introduced. Aug. (Lu.)

A. P'tánica, L. (SNeEzewont.) Leaves simple, lancelinear, sharply serrate with appressed teeth; corymb loose; rays 8-12, much longer than the bronder campanulate involucre; flowers white. - Mass., Mich., ete.; rare. Apparently indigenous on the Lower St. Lawrence. ( $\Lambda$ dv. from Eu.)

\section{M A T R I À I A, Tourn. Wild Chamomile.}

Heads many-flowered ; rays pistillate, or wanting. Seales of the involucre imbricated, with scarious margins. Receptacle conical, at least in fruit, nakerl. Achenes 3-5-ribbed, wingless ; pappus a membranaceous crown or border, or none. - Smooth and branching herbs (ours annuals or biemnials) with finely divided leaves and single or corymbed heads. Rays white or none; disk yellow. (Named for reputed medicinal virtues.)

M. rvonors, L. Leaves twice-pinnately divided into fine almost filiform lobes; heads large, naked-peduncled, and with manyl long ruls; achenes strongly 3-ribbed; pappus a short crown or border. - (Wild far northward.)

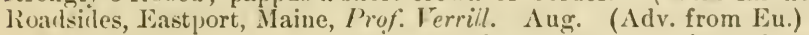

M. Irscónes, DC. Low $\left(6-9^{\prime}\right.$ high); leaves $2-3$-pinnately parted into short linear lobes; hearls rayless, short-peduncled; scales oval, with hroad margins, much shorter than the conical disk; achenes more terete; pappus obsolete. - Banks of the Mississippi opposite St. Louis. An immigrant from Oregon, extending eastwarl and becoming naturalized near railroad stations; also estahlished in N. Europe. July - Sept.

\section{CHRYSÁNTHEMU M, Tourn. Ox-EYe DAsY.}

IIeads many-flowered; rays numerous, fertile. Seales of the broad and flat involucre imbricated, with scarious margins. Receptacle flat or convex, naked. Disk-corollas with a tlattened tuhe. Achenes of disk and ray similar, striate, without pappus. - Perennial herhs, with toothed, pinnatifid, or divided leaves, and single or corymbel heads. Rals white; disk yellow. (Old Greek name, $\chi \rho \nu \sigma a ́ \nu \theta \in \mu o \nu, \mathrm{i}$. e. golden Hower.)

C. Leccistienum, J. (Ox-eye or White l)aisy. White-Weed.) Stem erect, nearly simple, naked abore and bearing a single large head ; rootleaves spatulate, jetioled, the others partly clasping, all cut or pinnatifil-toothed; scales of the involucre with rusty-browi margins. (Leueanthemum vulgare, L.um.) - Fields and meadows; ahundant eastward. June, July. A pernicious weed, with large and showy heads. It occurs with abortive, deformed, or tubular and laciniate rays. (Nat. from Eu.)

C. Pantuknum, Pers. (Fiveriw.) Tall, branched, leafy; leares twice-pinnately divided, the divisions ocate, cut; heads corymbed, rather small. (Leucanthemum Parthenium, Godron.) - Escaped from gardeus in some places. (Arv. from ku.) 


\section{TANACETUM, L. TANSY.}

Heads many-flowered, nearly discoid; flowers all fertile, the marginal chiefly pistillate and 3-5-toothed. Involucre imbricated, irry. Receptacle convex. naked. Achenes angled or ribbed, with a large flat top; pappus a short crown. - Bitter and acrid strong-scented herbs (ours perennial), with 1-3-pinnately dissected leaves, and corymbed heads. Flowers yellow; in summer. (Name of uncertain derivation.)

T. velgare, L. (Commox TAxsy.) Stem (2-40 high) smooth; leaflets and the wings of the petiole cut-toothed; corymb dense; pistillate flowers terete, with oblique 3-toothed limb; pappus 5-lobed. - Var. crispu $u$ has the leaves more cut and crisped. - Escaped from gardens to roadsides; Atlantic States. (Nat. from Eu.)

1. T. Huronénse, Nutt. Hairy or woolly when young, stout $\left(1-3^{\circ}\right.$ ligh); lobes of the leaves oblong; heads large ( $\frac{1}{2}-\frac{2}{3}$ wide) and usually few; pistillate flowers flattened, 3-5-cleft; pappus toothed.-St. John's River, Maine (G. L. Goodale), shores of the upper Great Lakes, and westward.

\section{ARTEMÍSIA, L. Wormwood.}

Heads discoid, few - many-flowered ; flowers all tubular, the marginal ones pistillate, or sometimes all similar and perfect. Involucre imbricated, dry and scarious. Receptable small and flattish, naked. Achenes obovoid, with a small summit and no pappus. - Herbs or shrubby plants, bitter and aromatic, with small commonly nodding heads in panicled spikes or racemes; flowering in summer. Corolla yellow or purplish. (Ancient name of the Mugwort, in memory of Artemisia, wife of Mausolus.)

§ 1. Receptacle smooth; marginal flowers pistillate and fertile; disk-flowers perfect but sterile, the style mostly entive; root perennial, except in $\mathbf{n} .1$.

* Leaves dissected.

1. A. caudàta, Michx. Smooth $\left(2-5^{\circ}\right.$ high $)$; upper leaves pinnately, the lower 2-3-pinnately divided; the divisions thread-form, diverging; heads small, the racemes in a wand-like elongated panicle; root biemuial. - Sandy soil, coast of N. Il. to Va.; also Mich. to Minn., and sonthward.

2. A. Canadénsis, Michx. Smooth, or hoary with silky down $\left(1-2^{\circ}\right.$ high); lower leaves twice-pinnately divided, the upper 3-7-divided, the divisions linear, rather rigid; heads rather large, in panicled racemes. - Northern N. Eng. to the Great Lakes, Minn., and northward. (Eu.)

$$
\text { * Leaves entire or some 3-cleft. }
$$

3. A. dracunculcides, Pursh. 'Tall $\left(2-5^{\circ}\right)$, somewhat woody at base, slightly hoary or glabrous; leaves linear and entire or the lower 3-cleft; heads small and numerous, panicled. - Sandy banks of streams, Minn. to Ill., Mo., and westward.

4. A. glaùca, Pall. Strict, $1-2^{\circ}$ high, somewhat woody at base, minutely silky-pubescent or glabrate; leaves linear- to oblong-lanceolate; heads as in the last. - Sask. to Minn. (Sib.)

5. A. filifòlia, 'Torr. Suffruticose, finely canescent, $1-3^{\circ}$ high ; leaves all filiform, the lower commonly 3 -parted; heals very small and numerous, crowded in a long leafy panicle. - Central Kan. to Neb., and southwestward. 
§2. Receptacle smooth; flowers all fertile, a feu pistillute, the others perfect.

Two cultivated shrubby species, from Europe, with filiformly divided leaves, have oceasionally escaped from gardens and become spmutaneous, viz., A. A $\mathrm{B}$ Rótroum, I. (the Sot THEkxwoOs)), of strict habit, with leaves 1-2-pinnatifid and pubescent hearls, and $\Lambda$. Inockis, L., with more spreading branches, all the leaves finely 2-pinnatifid, and heads glabrous.

* Tall $\left(1-5^{\circ}\right)$ and branching perennials, uhitened with fine and close-pressed wool; heads small, in leafy panicles.

6. A. serrata, Nutt. Very leafy, 6-9 high; leaves lanceolate or the npper linear, serrate, white-tomentose beneath, green above; heads greenish, oblong, 2" long or less. - Ill. to 1)ak.

7. A. longifolia, Nutt. Stem $2-5^{\circ}$ high ; leaves linear or linear-lanceolate, entire, usually glabrate above; heads oblong, canescent, 2-3" long Minn. to Neb., and westward.

8. A. Ludoviciana, Nutt. (Westerx Mrgwort.) Whitened woolly throughout; leares lanceolate, the upper mostly entire, the lower usually cutlobed, toothed or pinnatifil, the upper surface sometimes glabrate and green; heals campanulate, mostly sessile in narrow panicles. - Dry banks, Sask. to Mich., Ill., 'Tex., and westward. Very rariable.

A. velfidris, I. (Commox Mugwort.) Lenves mostly glabrous and green above, beneath and the branches white-woolly, all pinnatifil, with the divisions often cut-lobed, linear-lanceolate; heads small in open panicles. Wraste places, near dwellings. (Adv. from Eu.)

* Densely white-tomentose peremial: heads large, racemose-glomerate.

9. A. Stelleriàna, Bess. Stont, $1-2^{\circ}$ high, from a creeping hase; leaves obvate or spatulate, pimatifid, the lobes ubtuse. - Saudy sea-beaches, F. Mass. ; locally nat. from N. E. Asia?

$$
\text { ** Less branched }\left(1-3^{\circ}\right) \text {, biemnial or annual, glabrous. }
$$

10. A. biénnis, Willd. Strict, $1-3^{\circ}$ high; luwer leaves twice-pinnately parted, the upper pinnatifid; lobes linear, acute, in the lower leaves cuttoothed; hearls in short axillary spikes or clusters, crowled in a narrow and glomerate leafy panicle. - Gravelly banks, Ohio to Tenm., Mo., and northwestward; rapidly extending eastward by railroad to Buffalo, l'hilarlejphia, ete.

A. Áxua, L. Tall, much branched; leaves 2-pinnately divided, the oblong segments deeply pinnatifid; heads small, in a lonse ample panicle. - Ind. to kian. (Nat. from Old WV orld.)

§ 3. Rereptacle hairy; fonurrs all fertile, the marginal ones pistillate.

A. Ansíxtuicu, I. (Wormono.) Rather shrubly $\left(2-3^{\circ}\right.$ high), silkyhoary; leaves 2-3-pinnately parted, lobes lancelate; heads hemisplerical, panicled. - Roadsides, escaped from gardens. ( $\Lambda \mathrm{d} v$. from Eu.)

11. A. frigida, Willd. Low $\left(6-20^{\prime}\right.$ high $)$, in tufts, slightly woody at the base, white-silky; leaves pinnately parted and 3 -5-cleft, the divisions narrowlinear; heads glohose, racemose.- Dry lills and rocks, Sask. to Minn., W. Tex., and westward

\section{TUS SILÀ G O, Tourn.}

\section{Coltsfoot.}

Head many-flowered; ray-fluwers in several rows, narrowly ligulate, pistillate, fertile; disk-flowers with undivided style, sterile. Involucre nearly simple. Receptacle flat. Achenes cylindrical-obling; pappus copious, soft and capil- 
lary. - A low perennial, with horizontal creeping rootstocks, sending up simple scaly scapes in early spring, bearing a single head, and producing roundedheart-shaperl angled or toothel leaves later in the season, woolly when young. Flowers yellow. (Name from tussis, a cough, for which the plaut is a reputed remedy.)

T. Fírfars, L. - Wet places, and along brooks, N. Eng., N. Y., and Penn.; thoroughly wild. (Nat. from Eu.)

\section{PETA I I T E S, Tourn. Sweet Coltsfoot.}

Heads many-flowered, somewhat diœecious; in the substerile plant with a single row of ligulate pistillate ray-flowers, and many tubular sterile ones in the disk; in the fertile plant wholly or chiefly of pistillate flowers, tubular or distinctly ligulate. Otherwise as 'Tussilago._- Perennial woolly herls, with the leaves all from the rootstock, white-woolly beneath, the scape with sheathing scaly bracts, bearing heads of purplish or whitish fragrant flowers, in a corrml. (The Greek name for the coltsfoot, from $\pi \epsilon \tau^{\prime} \alpha \sigma o s$, a broad-brimmed liat, on account of its large leaves.)

\section{* Pistillate flowers ligulate; flowers whitish.}

1. P. palmàta, Gray. Leaves rounded, somewhat kidney-form, palmately and deeply $5-7$-lobed, the lobes toothed and cut. (Nardosmia palmata, Hook.) - Swamps, Maine and Mass. to Mich, Minn., and northwestward; rare. A pril, May. - Full-grown leaves $6-10^{\prime}$ broad.

2. P. sagittàta, Gray. Leaves deltoid-ollong to reniform-hastate, acute or obtuse, repaud-deutate. - N. Minn. and westward.

\section{* Ligules none; flowers purplish.}

P. vurfaris, Desf. Rootstock very stont: leaves round-cordate, angulatedentate and denticulate. - About Philadelphia. (Nat. from Eu.)

\section{4. Á R N I C A, L.}

Ileads many-flowered, radiate; rays pistillate. Sicales of the hell-shaped involucre lanceolate, equal, somewhat in 2 rows. Receptacle flat, fimbrillate. Achenes slender or spindle-shaped; pappus a single row of rather rigid and strongly roughened-denticulate bristles. - Peremial herbs, chiefly of mountains and cold northern regions, with simple stems, bearing single or corymbed large heads and opposite leaves. Flowers yellow. (Name thought to be a corruption of Ptarmicr.)

1. A. Chamissònis, Less. Softhairy ; stem leafy $\left(1-2^{\circ}\right.$ high $)$, bearing 1 to 5 heads; leaves thin, veiny, smoothish when old, toothed; the upper oratelunceolate, closely sessile, the lower narrower, tapering to a margined petivle; scales pointed ; pappus almost plumose. (A. mollis, IIook.) - N. Maine, mountains of N. H. and northern N. Y., shores of L. Snperior, and westward. July.

2. A. nudicaùlis, Nutt. Hairy and rather glandular $\left(1-3^{\circ}\right.$ high $)$; leaves thickish, 3-5-nerved, ovate or oblong, all sessile, mostly entire and near the root, the cauline small and only one or two pairs: hearls several, corymbed, showy. - Damp pine barrens, S. Penn. and southward. April, May.

\section{SENECIO, Tourn. Grocxidel.}

Heads many-flowered ; rays pistillate, or none ; involucre cylindrical to bellshaped, simple or with a few bractlets at the base, the scales erect-connivent. 
Receptacle flat, naked. Pappus of numerous very soft and slender capillary bristles. - Herbs, in the L'nited States, with alternate leaves and solitary or corymbed heads. Flowers chiefly yellow. (Name from sem.r, an old man, alluling to the hoariness of many species, or to the white hairs of the pappus.)

* Root annual or in n. 3 biennial; heads several or man!y in a corymb; herbage glabrous or soon becoming so.

+ liays none or minute.

S. velgaris, L. (Conmox Grofrnsel..) Low, corymbosely branched, glabrate; leaves pinnatifid and toothed; clasping tips if involiceral scales blackish; ravs none. - Waste gromuls. July - Sept. (Aclv. from En。)

S. visosis, L. Coarser, viscid-pubescent and strong-scented; leaves 2pinnatifid; scales not blach-tipped; rays minute. - Waste grounds, coast of N. Lug. (Nat. from Eu.)

$$
++ \text { Heads conspicuonsly radiate. }
$$

1. S. lobàtus, Pers. (ButTer-WeE1).) Rather tall; leaves somewhat fleshy, lyrate or pinnate, the divisions or leatlets crenate or cut-lobed, variaisle; heads small in a naked corymb; rays $6-12$, conspicuous. - Wet grounds, $\mathrm{X}$. Car. to S. Ill., Mo., and southward. A pril-July.

2. S. palústris, Ilook. Annual or biemial, loosely woolly or glabrate; stem stout, 6' - 2 high ; lerres oblong-lanceolate, irregularly toothed or laciniate, the upper with a heart-shaped clasping hase; rays 20 or more, short, pale yellow; pappus copious and becoming very long. - Wet ground, Iowa to $\mathrm{N}$. Wisc., Minn., and northward. June. (Eu.)

* * Root perennial; heads smali or middle-sized, in a naked corymb.

3. S. aureus, L. (Goldex Ragwort. Sqraw-weed.) Smooth, or floccose-woolly when young $\left(1-3^{\circ}\right.$ high); leaves thin, the radical simple and rounded, the larger ones mostly heart-shaped, crenate-toothed, long-petioled; lou'er stem-leaves lyrate; upper ones lanceolate, cut-pinuatitid, sessile or partly clasping; corymb umbel-like; rays 8-12. - Commou everywhere. May, June. Varies greatly.

Var. obovàtus, Torr. \& Gray. Root-leaves thicker, romul-obovate with a cuneate or truncate base, or the earliest almost sessile in rosulate tufts. (\$. Elliottii, Torr. \&. (íray.) - Open grounds, Can. to Ind. and Ga.

Var. Balsámitæ, Torr. \& Gray. Iess glabrate; root-leaves oblong, spatulate, or lanceolate, narrowed to the petiole, serrate, the upper lyrate-piunatifid; heads rather small and numerous. - Common.

4. S. tomentósus, Michx. (Woolw Ragwort.) Clothed with scarcely deciduous hwar.j wool (1-20 high); rooltenres oblong, olituse, (renate or entire, often large, on elongated stont petioles; the upper sessile, similar or lyratepinnatifid; corymb flat-topped; rays 12-15. - 1)el. and mountains of l'emu. (Pursh.), to Fla. and Ark. May.

5. S. cànus, Hook. Lsually low, persistently tomentose, rarely at all glabrate; leaves much smaller, spatulate to oblong, all entire or some cuttoothed or pinnatifid; achenes glabrous. - N. Minn., I)ak., and westward.

6. S. integérrimus, Nutt. Woolly pubescent when young, soun glabrate and green; leaves oblong-lanceolate or oblong, entire or denticulate, the upper bract-like, attenuate from a broal base; lieads rather large (6" high), with green-tipped seales. - Sask. to .Minn., and westward. 
7. S. lùgens, Richards. Like the last; leaves usually repand- or callousdenticulate; heads usually smaller, with mostly black-tipped scales. - Subarc. Amer. to New Mex., in the mountains; reported from Minn. and $\mathrm{N}$. Iowa.

* * Root perennial; leads large and often solitury.

8. S. Pseùdo-Árnica, Less. Loosely white-woolly, sometimes becoming glabrous; stem stout, $6-12^{\prime}$ high, leafy to the top; leaves oblong, repand, tapering into a narrow petiole-like base; leads $1-4$, over an inch in diameter; rays 20 or more, large. - Grand Manan Island, off Maine (Prof. Verrill), to Lab., and northward.

\section{CA C A L I A, L. Ixdiax Plaxtaix.}

Heads 5-many-flowered; the flowers all tubular and perfect. Involucral scales in a single row, erect-connivent, with a few bractlets at the base. Receptacle naked. Corolla deeply 5-cleft. Achenes oblong, smooth; pappus of numerous soft capillary bristles. - Smooth and tall pereunial herbs, with alternate often petioled leaves, and rather large heads, in flat corymbs. Flowers white or whitish. (An ancient name, of uncertain meaning.)

* Involucre 25-30-flowered, with several bracts at its base; receptacle fat.

1. C. suavèolens, L. Stem grooved $\left(3-5^{\circ}\right.$ high $)$; leaves triangularlanceolate, hallierd-shaped, pointed, serrate, those of the stem on winged petioles. - Rich woods, Conn. to Mich., Iowa, and southward; rare. Sept.

* * Inrolucre 5-leaved and 5-flowered, its bracts minute or none; receptacle bearing a more or less evident scale-like pointed appendage in the centre.

2. C. renifórmis, Muhl. (Great Ixdiax Plaxtais.) Notglaucous; stem $\left(4-9^{\circ}\right.$ high) grooved and angled; leaves green both sides, dilated fansliaped, or the lowest kidney-form $\left(1-2^{\circ}\right.$ broad), repand-toothed and angled, palmately veined, petioled; the teeth pointed; corymbs large. - Rich damp woods, N. J. to Ill., Minn., and southward along the mountains. Aug.

3. C. atriplicifolia, L. (PAle Ixdix P.) Glancous; stem terete $\left(3-6^{\circ}\right.$ high) ; leares palmately veined and angulate-lobed, the lower triangularkidney-form or slightly heart-shaped, the upper rhomboid or wedge-form,toothed. - Rich woodlauds, western N. Y. to Wisc., Minn., and southward. Aug.

4. C. tuberòsa, Nutt. (Teberots Irinax P') Stem angled and grooved $\left(2-6^{\circ}\right.$ high), from a thick or tuberous root; leaves green both sides, thick, strongly 5-7-nerved; the lower lance-orate or oral, nearly entire, tapering into loug petioles; the upper on short margined petioles, sometimes toothed at the apex. - Wet prairies, etc., Ohio to Wisc., Minn., and southward. June.

\section{ERECHTITES, Raf. FireweEd.}

Heads many-flowered; the flowers all tubular and fertile; the marginal pistillate, with a slender corolla. Scales of the cylindrical involucre in a single row, linear, acute, with a few small bractlets at the base. Receptacle naked. Achenes oblong, tapering at the end; pappus copious, of very fine and white soft hairs. - Erect and coarse annuals, of rank smell, with alternate simple leaves, and paniculate-corymbed heads of whitish flowers. (The ancient name of some species of Groundsel, probably ealled after Erechtheus.) 
1. E. hieracifolia, Raf. (Fireween.) Often hairy; stem grooved $\left(1-6^{\circ}\right.$ high $)$; leaves lanceolate or oblong, acute, cut-tootlied, sessile, the upper auricled at base. - Moist woods ; common, especially northwarl, and in recent clearings that have been burned over; whence the popular name. July-Sept.

\section{8. ÁRCTIUM, L. Bстиock.}

Heads many-flowered; flowers all tubular, perfect and similar. Involucre globular; the imbricated scales coriaceous and appressed at base, attenuate to long stiff points with hooked tips. Receptacle bristly. Achenes oblong, thattened, wrinkled transversely; pappus short, of numerous rough hristles, separate aud rleciduous. - Coarse biennial weeds, with large unarmed and petioled leaves, and small solitary or clustered heads; flowers purple, rarely white. (Name probably from ápкios, a bear, from the rough involucre.)

A. LÁpA, L. Stout, $1-3^{\circ}$ high; leaves roundish or ovate and mostly curdate, or lanceolate with cuneate base, smooth above, somewhat floccosetomentuse beneath, mostly sinuate-denticulate. (Lappa officinalis, All.) The several reputed species of the genus are scarcely ilistinguishable even as varieties. Var. uìs's, has rather small ovoid sulıacemose heads (about 8" broad), on short peduncles, glabrous or somewhat cottony, the inner scales somewhat purplish-tipped, effnalling the flowers; leaves occasionally cuttoothed. By roadsides; very common. - Var. uis's, with broaler ( ${ }^{\prime}$ ) green and glabrous subcorymbose rather long pedunculate heads. Less frequent. Var. Tomexroscu, a furm of the last with more spherical wehbed heads, with purplish scales shorter than the flowers. Rare.-July-Uct. (Nat. from Eu.)

\section{C N I C U S, Touru.}

Comion or Plemed Tinstie.

Heads many-flowered; flowers all tubular, perfect and similar, rarely imperfectly diœcious. Scales of the oroid or spherical involucre imbricated in many rows, tipped with a point or prickle. Receptacle thiekly clothed with soft bristles or hairs. Achenes oblong, flattish, not ribbed; pappus of numerous bristles united into a ring at the base, plumose to the midllle, fleciluous. Herbs, mostly biennial, with sessile alternate leaves, often pinnatifid, prickly. Heads usually large, terminal. Flowers reldish-purple, rarely white or yel-

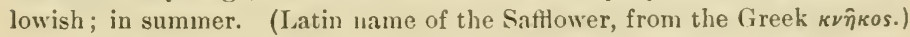

* Scales of the incolncre all tipped with spreading prickles.

C. Laxceolatis, Hoffm. (Common Tustle.) Leaves decurrent on the stem, forming prickly lobed wings, pinnatificl, rough and bristly above, woolly with deciduous webby hairs beneath, prickly; flowers purple. (Cirsinm, Scop.) - Pastures and roadsides, everywhere, at the North. (Nat. from Eu.)

* * Heads ler.fy-bracteate at base (see also n. 8) ; proper scales not prickly.

1. C. horrídulus, Pursh. (Yellow Tuisti.e.) Stem stont ( $1-3^{\circ}$ high), webby-haired when young; leaves partly clasping, green, soon smooth, lanceolate, pinnatifid, the short tootherl and cut lobes very spiny with yellowish prickles; heads ( $1-1 \frac{1^{\prime}}{2}$ broad) surrounled by latiflike and very prickly bracts, which usually equal the narrow scales; flowers pale yellow or purple. (Cirsium, Michx.) - Sandy fields, Mass. to Va., and southward, near the coast.

*** Scales appressed, the imer not at ull prickly.

- Leaves white-woolly bencath, and sometimes also above; outer scales successively shorter, and tipped with short prickles.

2. C. Pitcheri, Torr. White-uoolly throughout, low; stem very leafy ; leaces all pinnatcly parted into rigid narrouly linear and elongated, sometimes 
again pinnatifid divisions, with revolute margins; flowers cream-color. (Cir sium, Torr. \&. Gray.) - Sandy shores of Lakes Michigan, Huron, and Superior.

3. C. undulàtus, Gray. White-woolly throughout, low and stout, leafy; leaves lanceolate-o'long, partly clasping, undivided, undulate-pinnotifid, or rarely pinnately parted, moderately prickly; flowers reddish-purple. (Cirsium, spreng.) - Islands of L. Huron to Minn., Kan., and westward. The heads vary much in size.

4. C. altissimus, Willd. Stem downy, branching $\left(3-10^{\circ}\right.$ high $)$, leafy quite to the heads; leaces roughish-hairy above, whitened with close wool beneath, oblong-ovate to narrouly lanceolute, undivided, sinuate-toothed, undulatepinnatifid, or tuice pinnatifid, the lobes or teeth weakly prickly; heads $1 \frac{1}{2}-2^{\prime}$ high; flowers chiefly purple. (Cirsium, spreng.) - Fields and copses, Mass. to Mimn., and southward.

Var. discolor, Gray. Stem $2-6^{\circ}$ high; leaves nearly all deeply pinnat. ifid into lanceolate or linear lobes. (Cirsium discolor, sirreng.) - Common; N. Eng. to Ill., and southward.

5. C. Virginiànus, Pursh. Stem woolly, slender, simple or sparingly branched ( $1-3^{\circ}$ high), the branches or long peduncles naked; leares lancealate, green above, whitened with close wool beneath, ciliate with prickly bristles, entire or sparingl!y sinnate-lobed, sometimes the lower deeply sinuate-pinnatifid; heads small; outer scales scarcely prickly; flowers purple. (Cirsinm, IVichx.) - Woods and plains, Va., Ohio, and southwark.

+- Leaves green both sides, or only with loose coluebly hairs underneath; heads large; scales scarcely prickly-pointed.

6. C. mùticus, Pursh. (Swamp Tinstle.) Stem tall $\left(3-8^{\circ}\right.$ high), angled, smoothish, panicled at the summit ; branches sparingly leafy, bearing single or few rather large heads; leaves somewhat hairy above, whitened with loose webhy hairs beneath when young, deeply pinnatifid, the dusions lanceolate, acute, cut-lobed, prickly-pointed; scales of the velby and glutinous (sometimes glabrate) incolucre closely appressed, pointless or barely mucronate; flowers purple. (Cirsium, Michx.) — Swamps and low woods; common.

7. C. pùmilus, Torr. (Pastere Thistle.) Stem lou and stout $\left(1-2^{\circ}\right.$ high), hairy, bearing $1-3$ very large heads ( $1 \frac{1}{2}$ broal), which are often leafybracted at the base; leaves green, lanceolate-ohlong, partly clasping, someuhat hairy, pinnatifid, with short and cut very prickly-margined lobes; outer scales prickly-pointed, the inner very slender; flowers purple or rarely white (fragrant, 2' long). (Cirsium, spreng.) - Dry fields, N. Eng., near the coast, to Penn.

**** Outer scales of the appressed involucre barely prickly-pointed; heads imperfectly diccious, small and numerous.

C. Arvéxsis, Hoffm. (Caxada Thistle.) Perennial, slender, $1-2^{\circ}$ high, the roots extensively creeping; leaves oblong or lanceolate, smooth, or slightly woolly beneath, sinuate-pinnatifid, prickly-margined; flowers rose-purple. (Cirsium, Scop.) - Cultirated fields, pastures, and roadsides, common; a most troublesome weed, extremely difficult to eradicate. (Nat. from Eu.)

\section{C Á R D U S, Tourn. Plumeless Thistle.}

Bristles of the pappus naked (not plumose), merely rough or denticulate. Otherwise as in Cnicus. (The ancieut Latin name.) 
C. Nùtaxs, I. (Mcsk Turstue.) Biennial; leaves decurrent, sinuate, spiny; heads solitary, drooping; flowers purple.-Fielils near llarrisburg, l'a., Prof. P'orter. (Adv. from Lu.)

\section{O N O Pó R D O N, Vaill. Coтtox or Sсотси Turstu.}

Receptacle deeply honeycombed, not setuse. P'apuns not plumose. Otherwise as Cnicus. - Coarse, branching annuals, or bicmnials, with the stems winged by the decurrent base of the lobed and toothed somewhat prickly leares. Heads large; flowers purple. ('The ancient (ireck name of the jlant.)

O. Ac.́xтинм, I. Stem $\left(2-t^{\circ}\right.$ high) and leaves cotton-woolly; scales linear-awl-shaped. - Roadsides and waste places in the Atlantic States; rather lare. July-Sept. (Adv. from Lu.)

\section{CENTA U RE A, L. Star-Thistle.}

Heads many-flowered; flowers all tubular, the margmal often much larger (as it were radiate) and sterile. lieceptacle bristly. Involucre ovoid or globuse, imbricated, the seales margined or appendaged. Achenes oboroid or oblong, attached obliquely at or near the hase; pappus setuse or partly chaffy. or none. - Herlss with alternate leaves and single heads. (Named from tho ('entaur, Chiron, famous for his skill in healing.)

* Acheres terete, 10-dentute; papjus of 10 long bristles and 10 shoit inner ones.

C. BEXEIfCTA, L. Low lranching annual, with clasping scarcely pinuatifil cut leaves, and large sessile leafy-bracted heads; Howers yellow." (C'nicus henedictus, L.) - lioadsides and waste grounds, S. Atlantic States; rare. (Adv. from Eu.)

* * Achenes compressed or 4-angled; pappus very short or none.

C. Cianes, L. (Bi,ebottle.) Scales of the globular involucre fringemargined; false rays lurge; pappus very short; leaies linear, cntire, or toothed at the base; root annual. - lioadsides, escapel from gardens. July. - Flowers blue, varying to purplish or white. (Adv. from Eu.)

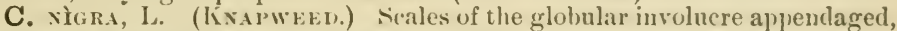
and with a black pectinately ciliate fringe; rays wonting; papjus very short; lraves lanceolate, entire, or the lower lyrate-toothed, rough; root perenuial. Waste places, E. New Eng. Aug. - Flowers purple. (Adv. from Eu.)

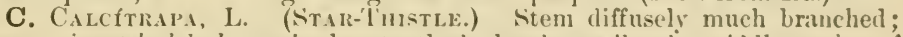
leares pimnatcly lobed or spinuluse-tuotherl; heads sessile, the midlle scales of the ovoid involucre spiny; pappus none; flowers purple; root annual. - Seaports, N. Y., and suuthwari. (Aiv. from Eu.)

C. JACEA, L. Like the list; heals rather larger, the brownish scaleappendages lacerate; rays conspicuous, palmate. - Charlotte, V't. (Pringle); near N. Y., etc., on ballast. (Nat. from Lu.)

\section{L Á M P A N A, Tourn. Nirnte-wokt.}

llearls 8-12-flowered. Scales of the cylindrical involucre 8 , erect, in one row. lieceptacle naked. Achenes blolong; pappus none._- -lender branching annuals, with angled or toother leaves, and lonsely panicled small heads; flowers yellow. (The $\lambda a u \psi a ́ \nu \eta$ of l luscoriles was evilently a wild Mustard.)

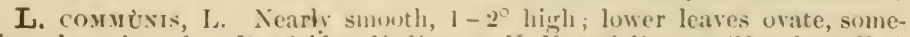
times lyre-shaped. - Roadsides, N. ling. to N. I. aud l'enn. (Nat. from lin.)

\section{KRÍGia, Schreher. Dwarf Daxielion.}

Heads several-many-flowered. Involucral scales several, in about 2 rows, thin. Acheries short and truncate, top-shaped or columnar, terete or augled; 
pappus double, the outer of thin pointless chaffy scales, the inner of delicate bristles. - Small herbs, branched from the base; the leaves chiefly radical, lyrate or toothed; the small heads terminating the naked scapes or branches. Flowers yellow. (Named after D. Krieg, an early German botanical coliector in this country.)

§ 1. KRIGIA proper. Achenes turbinate, 5-angled; pappus of $5-7$ short roundish chaff and as many alternating bristles. Annual.

1. K. Virgínica, Willd. Stems or scapes several (1-10' high), becoming branched and leafy ; earlier leaves roundish and entire, the others narrower and often pinnatificl. - New Eng. to Minn., and southward. April-Aug.

§ 2. CÝNTHLA. Achenes more slender: pappus of 10-15 small oblong chaff and 15-20 bristles. Perennial.

2. K. Dandélion, Nutt. Roots slender, tuberiferous; scapes leafless, 6-18' high; leaves varying from spatulate-oblong to linear-lanceolate, entire or few-lobed. (Cynthia, $\mathcal{L}^{\prime}$.) - Moist ground, Md. to Ky., and southward. March - July.

3. K. amplexicàulis, Nutt. Roots fibrous; stem-leares $1-3$, oblong or oral, clasping, mostly entire; the radical ones on short wingerl petioles, often toothed, rarely pinnatifid; peduncles 2-5. (Cynthia Virginica, Don.) - Moist banks, Conn. to Minn., and southward. June. - Stem 1 - $2^{\circ}$ high.

\section{CICHORIUM, Tourn. Succory or CHicory.}

Heads several-flowered. Involucre double, herbaceous, the inner of $8-10$ scales, the outer 5, short and spreading. Achenes striate; pappus of numerous small chaffy scales, forming a short crown. - Branching perennials, with deep roots; the sessile heads 2 or 3 together, axillary and terminal. Flowers bright blue, varying to purple or pink, showy. (Altered from the Arabian name of the plaint.)

C. fxтruts, L. Stem-leaves oblong or lanceolate, partly clasping, the lowest runcinate, those of the rigid flowering branches minute.-Roadsides; N. Eng. to Iowa and Minn. July - Oct. (Nat. from Eu.)

\section{TRAGOPOGON, I. Goat's-beard.}

Heads many-flowered. Involucre simple, of several erect lanceolate attenuate equal scales. Achenes narrowly fusiform, 5-10-ribbed, long-beaked; pappus of numerous long-plumose bristles. - Stout glabrous biennials or perennials, with entire grass-like clasping leaves and large solitary heads of yel,low or purple flowers. (Name from $\tau \rho \alpha$ 'os, goat, and $\pi \omega ́ \gamma \omega \nu$, beard.)

T. porrifòlius, L. (Salsify. Orster-plaxt.) Stem $2-3^{\circ}$ high; peduncle thickened and fistulous below the head; flowers purple; achenes and pappus 3' long. - Sparingly escaped from cultivation. (Nat. from Eu.)

T. PRAténsis, L. (GoAT'S-BEARD.) Very similar; leaves somewhat broader at base; peduncle little thickened; flowers yellow. - Fields, etc., N. Eng. to N. J. and Minn. (Nat. from Eu.)

\section{L}

Heads many-flowered. Involucre scarcely imbricater, but with several bractlets at the base. Achenes spindle-shaped, striate, all alike; pappus persistent, composed of plumose bristles which are enlarged and flattened toward the base.

- Low and stemless perennials, with toothed or pinnatifid root-leaves, and scapes 
bearing one or more yellow heads. (Name from $\lambda \epsilon^{\prime} \omega \nu$, a lion, and óôús, a tooth, in allusion to the toothed leaves.) - The following belongs to the subgenus Oporfsis, with a tawny pappus of a single row of equal liristles.

L. altumalis, L. (FAll Daxillox.) Leaves lieiniate-toothed or pinnatifil, somewhat pubescent; scape brancherl, 5-15' high; pecluncles thickened at the summit, scaly-bracteate. - Neadows and roalsides; N. Eug. to P'eun. June-Nov. (Nat. from Eu.)

\section{PÍCRIS, L.}

Heads many-flowered, terminating leafy stems. Outer scales lonse or sprearing. Achenes terete, with $5-10$ rugose rils ; pappus of 1 or 2 rows of plumose bristles. - Coarse rough-bristly annuals or biennials, with yellow flowers. (The Greek name of some allied bitter herb, from nıkpós, bitter.)

P. meraciotoes, L. Rather tall, corrmboscly branched, the bristles somewhat barbel at tip; leaves lanceolate or broader, clasping, irregularly toothed; achenes oblung, with little or no beak. - Sparingly introduced. (Nat. from Eu.)

\section{H I ERÀ I U M, Tourn. HAWKWEN.}

Heads 12-many-flowered. Involucre more or less imbricated. Achenes short, oblong or columuar, striate, not beaked; pappus a single row of tawny and fragile capillary rough bristles. - Hispid or hirsute and often glandular perennials, with entire or toothed leaves, and single or panicled heads of mostly yellow flowers; summer and early autumn. (Name from if́pa $\xi, a$ hawk.)

§ 1. Involucre not much imbricate, scarcely calyculate; achenes oblong; pappns not copious.

H. Acranticum, L. Low, long-hirsute, above hispid and glandular, the involucral hairs dark; leaves all near the base of the simple peiluncle; heads clustered; flowers deep orange to flame-color. - Roadsides and fields ; N. Eng. to N. Y. (Nat. from Eu.)

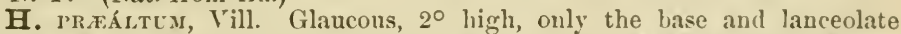
leaves hairy; heads in an open cyme; flowers yellow. - N. New York ( W $\mathrm{Nrd}$ ). (Nat. from Eu.)

$\$ 2$. Heads large; imolucre irregnlarly imbricated ; achenes columnar ; pappus copious, unequal.

H. mukorrar, I. Stem seape-like, low; leaves oval or oblong, obtuse, toothed toward the subcordate hase; heads few, dark-glandular. - ( ) pen woods near Brooklyn, N. Y. (Nat. from Eit.)

1. H. Canadénse, Michx. Stems simple, leafy, corymbed at the summit $\left(1-3^{\circ}\right.$ high); leaves sessile, lanceolate or ovate-ohlong, acute, remotely and very coarsely toothel, somewhat hairy, the uppermost slightly clasping. - Dry woods, N. Eng. to l'enn., Minn., and northward.

§. IIeads small; involucre cylindrical, scarcely imbricatid.

* Achenes columnar, not attenuate upward when muturc; punicle not virgate.

2. H. paniculàtum, I. Sitem slender, lenfiy, diffusely brunclical, hairy only below ( $1-3^{\circ}$ high); leaves lanceolate, acnte at both ends, slightly toothed, smooth; heads (very small) in a loose pmicle, on slender and diverg. ing pedicels, 12-20-flowered; arhenes short.-Open wools; rather common.

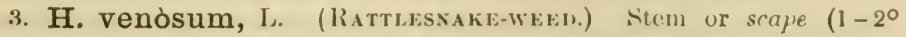
high) nated or with a single leaf, smooth and slender, forking above into a spread- 
ing loose corymb; leaves all radical or near the base, obovate or oblong, nearly entire, scarcely petioled, thin and pale, purplish and glaucous underneath (often hairy along the midrib), inarked above with purple veins; pedicels very slender; involucre 12-35-flowered; achenes linear. - Dry plains and pine woods; common from the Atlantic to Minn. and Iowa.

4. H. Marianum, Willd. Somewhat leafy, 2-30 high, hairy below; leaves obovate-oblong, narrowed below, the radical petiolate, rarely purplishveiny; heads $20-40$-flowered in a very open cymose panicle, the slender inflo. rescence conmonly whitish-tomentulose and sparingly glandular-hispid. - Open woods and clearings; Ii. I. to western N. Y., and southward. - Var. spathuLAтum, Gray, a mountain form with leaves all or mainly radical and very hairy. On Two-top Mountain, Penn.

5. H. Scàbrum, Michx. Stem rather stout $\left(1-3^{\circ}\right.$ high $)$, leafy, roughhairy, the stiff panicle at first racemose, at length rather corymbose; the thickish pedicels and the hoary $40-50$-flowered involucre densely clothed with dark glandular bristles; leaves obovate or oval, nearly entire, hairy. - Dry open woods; common.

* * Achenes tapering upward; heads 15-30-flowered in a narrow or virgate panicle.

6. H. Gronòvii, L. (HaIRY H.) Stem wand-like, mostly simple (1-3을 high), leafy and rery hairy below, naked above and forming a long and narrow panicle; leaves oblong or obovate, nearly entire, liairy; slender peduncles and involucre sparingly glandular-bristly; achenes with a very taper summit. - Dry sterile soil ; common, especially southward.

7. H. longípilum, Torr. (Lovg-Bearded H.) Stem wand-like, simple, stout $\left(2-3^{\circ}\right.$ highl), very leafy, toward the base, naked above, and bearing a small racemed panicle; the lower portion and both sides of the oblong-lanceolate or spatulate entire leares thickly clothed with very long and upright bristles (often $\mathrm{I}^{\prime}$ long); pelluncles and involucre glandular-bristly; achenes narrowed at the apex. - Prairies, Mich. to Minn., and southwestward.

\section{C R È PIS, L.}

Involucre few-many-flowered, commonly of a single row of equal scales, often becoming thickened at base. Pappus copious, white and soft. Annuals or biennials, not pilose. Otherwise as Hieracium. (The Greek name of some plant, from $\kappa \rho \eta \pi i s, a$ sandal.)

C. Bı́́xxis, L. Somewhat pubescent, $2^{\circ}$ high, leafy; leares runcinate-pinnatifid; heads rather large, corymbose ; achenes oblong, glabrous. -Vt., Mass.; rare. (Nat. from Eu.)

С. тестовги, L. Slentler, branching from the base, $1^{\circ}$ high; leaves narrow, runcinate; heads small, in a loose panicle; achenes fusiform, the ribs scalorous. - In fields, Lansing, Mich., and on ballast. (Nat. from Eu.)

\section{PRENántehes, Vaill. Rattlessake-root.}

Heads 5-30-flowered. Involucre cylindrical, of 5 to 14 linear scales in a single row, and a few small bractlets at base. Achenes short, linear-oblong, striate or grooved, not contracted at the apex. Pappus of copious straw-color or brownish and rough capillary bristles. - Perennial herbs, with upright leafy stems arising from spindle-shaped (extremely bitter) tubers, very variable 
leaves, and racemose-panicled mostly nodding heads. Flowers greenish-white or yellowish, often tinged with purple; late summer and autumn. Our species belong to the subgenus Nabalus. The original liuropran species has soft white pappus. (Name from $\pi \rho \eta \nu \eta \dot{s}$, drooping, and $\measuredangle \nu 0 \eta$, blossom.)

* Heads ruther broad, 25-35-flouered, in u corymbose panisle.

1. P. crepidínea, Michx. Somewhat smooth ; stem stuut (5-9 high), bearing numerous nodding heads in loose clusters; leaves large ( $6-12^{\prime}$ long), broadly triangular-ovate or halberl-form, strongly-toothed, contracted inin winged petioles; pappus brown. (Nabalns, I)C.) - Rich soil, l'enn. aurl western N. Y. to Minn., and southward. - Flowers cream-color.

* * IIeads narrow, 8-15-flowered, in a long raceme-like or thyrsoid inflorescence; ste $m$ s simple; cauline leares sessile; jappus straw-color.

- Inflorescence pubescent, strict; heals nearly erert, 12 -15-fowered.

2. P. racemòsa, Michx. Stem $2-5^{\circ}$ high, smooth and glaucous, as well as the oval or oblung-lanceolate denticulate leaves; the lower tapering into winged petioles (rarely cut-pinuatifil), the upper partly clasping; heads in crowled clusters ; flowers purplish. (Nabalus, $L C^{\prime}$.) - Plains, N. Maine to N. J., Mo., and nurthwarl. - Var. PINxatfFiDa, Gray, the leaves all lyrately pinnatifil. Hackensack marshes, N.J.

3. P. áspera, Michx. Stem $2-4^{\circ}$ high, rongh-pubescent, as well as the oval-oblong or broadly lanceolate toothed leaves; upper leaves not clasping; heads in small clusters; flowers larger, cream-color. (Nabalus asper, Torr. \&. Gray.) - Dry prairies and barrens, (Jhio to Iowa, and southward.

+ +Whole plant glabrous; heads nodding, 8-12-flowered; thyrse looser.

4. P. virgàta, Michx. (Slexder Rattlessake-root.) Slightlyglaucous; stem 2-4. high, prolonged into a naked and slender spiked raceme ( $1 \frac{1}{2}-$ $2^{\circ}$ long); heads clustered and mostly unilateral; leaves lanceolate, acute, closely sessile, the upper reduced to bracts, the lower toothed or pinnatifid; involucre (purplish) of abont 8 scales. (Nabalus, $D C^{*}$.) - Sandy piue barrens, N. J. to Va., and southward.

5. P. Mainénsis, Gray. Stem $2^{\circ}$ high, leafy; leares as in 11.2 , but the radical ovate and more abruptly narrowed to the short petiole; heads porsistently drooping on slender pedicels. - St. John's River, N. Maine (Pringle). I'erhaps a hybrid between $\mathrm{n} .2$ and 7 .

* * Ileads 5-18-flowered, recemose or pan culute, commonly pendulous; leaves varialle, mostly petiolate, the louer cordate or truncute or hastate at buse.

- Involucre cylindrical; scales scarions-margined, the onter ver.y short, uppressed. +Puppus reddish-broun; stem tull, generally purplish.

6. P. álba, I. (Wuite Letrick. R.tтlissike-root.) Smooth and glancons $\left(2-4^{\circ}\right.$ high); stem corymbose-panicled at the summit: leaves angulate or triangular-halberd-form, sinuate-toothed or $3-5-$-left, the uppermost oblong and undiviled; involuere (purplish) of about \& scales, 8-12-flowered. (Nabalus, IIook.) - Borders of rich woorls; common, especially northward. $\rightarrow+$ Pappus dirty strau-color or whitish; leaves very variuble.

7. P. serpentària, l'ursh. (Liox's-font. Gall-of-тue-eartu.) Nearly smooth; stem corymbuse-panicled at the summit, commonly $2^{\circ}$ high; leaves 
mostly deltoid, roughish; the lower varionsly $3-7$-lobed, on margined petioles ; the upper oblong-lanceolate, mostly undivided, nearly sessile; involucre (greenish, rarely purplish, sometimes slightly bristly) of about 8 scales, $8-12$-flowered; flowers purplish, greenish white, or cream-color. (Nabalus Fraseri, DC.) - Dry sandy or sterile soil, New Eng. to Va., and sonthward.

Var. nàna, Gray. Stem more simple and strict, 6-16' high, smooth and glabrous; inflorescence contracted, the clusters often sessile in most of the axils. (Nabalus nanus, DC.) - Mountains of northeru N. Eng. and N. Y., and northeastward.

8. P. altíssima, L. Smooth; stem tall and slender $\left(3-7^{\circ} \mathrm{high}\right)$; the heads in small axillary and terminal loose clusters forming a long and wandlike leafy panicle; leaves membranaceous, all petioled, ovate, heart-shaped, or triangular, and merely toothed or cleft, with naked or winged petioles, or frequently 3-5-parted, with the divisions entire or again cleft; involucre slender (greenish), of 5 scales, 5-6-flowered. (Nabalus, Hook.) - Rich moist woods; N. Eng. to Minn., and southward in the mountains to Ga.

4- +- Involucre campanulate-oblong; secondary basal scales 2-3, linear, loose.

9. P. Boottii, Gray. Stem simple, dwarf ( $5-6^{\prime}$ high $)$, pubescent at the summit; the heads in an almost simple raceme; lowest leaves halberd-shaped or heart-shaped, the middle oblong, the upper lanceolate, nearly entire, tapering into a margined petiole; involucre (livid) 10-18-flowered, the proper scales $10-15$, very obtuse; pappus straw-color. - Alpine region, mountains of Maine, N. H., and N. New York.

\section{I Y GODÉS S I A, Don.}

Heads and flowers $(5-10)$ nearly as in Nabalus; the cylindrical involucre more elongated, and the achenes long and slender, tapering at the summit; pappus whitish. - Smooth, often glaucons, low perennials, with single erect heads of rose-purple flowers terminating almost leafless or rush-like stems or

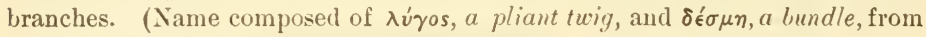
the fascicled twiggy or rush-like stems.)

1. L. júncea, Don. Stems $\left(1^{\circ}\right.$ high) tufted, lranched, striate; lower leaves lance-linear, $1-2^{\prime}$ long, rigid, the upper awl-shaped and minute, heads 5 -flowered. - St. Croix River, Wisc., to Kan., and westward. July.

\section{TRÓXIMON, Nutt.}

Head large, solitary, many-flowered. Scales of the bell-shaped involucre ovate or lanceolate, pointed, loosely imbricated in 2 or 3 rows. Achenes smooth, 10-ribhed, with distinct beak or none; pappus longer than the achene, white, of copious and unequal rigid capillary bristles. - Perennial scapose herbs, with elongated linear tufted root-leaves, and yellow flowers. (Name

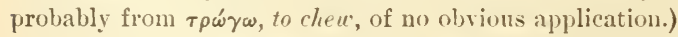

1. T. cuspidàtum, Pursh. Seape $1^{\circ}$ high, from a thickened caudex, leaves lanceolate, elongated, tapering to a sharp point, entire, woolly on the margins; scales of the involucre lanceolate, sharp-pointed, achene beakless - Prairies, Wisc., N. 1ll., and westward. April, May. 
2. T. glaùcum, Nutt. Scape $1-2^{\circ}$ high; leaves linear to lanceolate, entire to dentate or laciniate; head often pubescent or villous; achene longbeaked. - Minu. to Neb. and southwestward.

\section{TARÁ X A C U M, Haller. DANIELIOX.}

Head many-flowered, large, solitary on a sleuder hollow scape. Involucre double, the outer of short scales; the immer of long linear scales, erect in a single row. Achenes oblong-ovate to fusiform, 4-5-ribhed, the ribs ronglened, the apex prolonged into a very slender beak, bearing the copions soft and white capillary pappus. - l'erennials or biennials; leares radical, piunatifid or runcinate; flowers rellow. (Name from $\tau \alpha \rho \dot{\sigma} \sigma \sigma \omega$, to disquict or dis. order, in allusion to menlicinal properties.)

T. officisale, Weber. (Commox Daxielox.) Smonth, or at first pulescent; onter involucre reflexed. ('T. Lens-leonis, Imsf.) - l'astures and fields everywhere. Indigenous forms occur northward and in the liocky Mountains. A pril-sept. - A fter blossoming, the inner involucre closes, and the slencler beak elongates aud raises up the pappus while the fruit is forming; the whole involucre is then reflexed, exposing to the wind the naked fruits, with the pappus displayed in an open globular head. (Eu.)

\section{PYRRHOPÁPPUS, DC. FALE INNDELON.}

Heads, etc., nearly as in 'Taraxacum, lut the soft pappus reddish or rustycolor, and surrounded at base by a soft-rillous ring. - Mostly annual or biennial herbs, scapose or often branching and leafy below. Ileads solitary, terminating the naked summit of the stem or branches. Flowers deep yellow. (Name

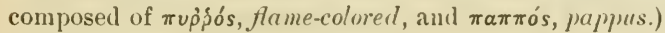

1. P. Caroliniànus, DC. Anmual or biennial, stem brauching $\left(1-2^{\circ}\right.$ high); leaves oblong or lanceolate, entire, cut, or pimatificl, the stem-leaves partly clasping. - Sandy fields, from Maryland southward. A pril -July.

2. P. scaposus, DC. Low, scapose, perennial by roundish tubers; leaves all radical, pinnatifid. - Prairies; Kan. to Tex.

\section{CHONDRÍLLA, Tourn.}

Heads few-flowered. Involucre cylindrical, of several narrow linear equal scales, and a row of small bractlets at base. Achenes terete, several-ribbed, smooth below, roughened at the summit by little scaly projections, from among which springs an abrupt slender beak; pappus of copious verv fine and soft capillary bristles, bright white. - Herlss of the Old World, with wand-like branching stens, and small heads of yellow flowers. (A nume of Dioscorides for some plant which exniles a gum.)

C. JúxceA, L. Biennial, bristly-hairy below, smooth above $\left(1-3^{\circ}\right.$ high); root-leaves runcinate; stem-leaves few and small, linear; heads scattered on nearly leatless branches, $6-8^{\prime \prime}$ long. - Fields and roadsides, abundant in Md. and northern Va. $\Lambda \mathrm{ug}$. ( $\ \mathrm{dv}$, from Eu.)

\section{L A C T Ù C A, Tourn. Letruce.}

Heads several-many-flowered. Involucre cylindrical or in fruit conical ; scales imbricated in 2 or more sets of unequal lengtlis. Achenes flat (obcompressed, parallel to the scales), abruptly contracted into a beak, which is dilated at the apex, bearing a copious and fugacious very soft and white capillary pap- 
pus, its bristles falling separately. - Leafy-stemmed herbs, with panicled heads : flowers of variable color, produced in summer and autumn. (The ancient name of the Lettuce, L. sativa; from lac, milk, in allusion to the milky juice.)

§ 1. SCARIOLA. Achenes very fat, orbicular to oblong, 1-nerved on each face, with a filiform beak; biennial or annual; cauline leares sagittate-clasping.

L. Scariola, L. (Prickly Lettcce.) Stem below sparsely pricklybristly, as also the midrib on the lower face of the oblong or lanceolate spinulose-denticulate vertical leaves; panicle narrow; heads small, 6 - 12 -flowered; achenes striate. - Waste grounds and roadsides, Atlantic Siates to Mo. and Minn. (Adv, from Eu.)

1. L. Canadénsis, L. (Wild Lettcce.) Mostly tall ( $4-9^{\circ}$ high), very leafy, smooth or nearly so, glaucous; leaves 6-12' long, pale bemeath, mostly sinnate-pinnatifid, the upper lanceolate and entire (rarely all but the lower narrow and entire); heads about 20-flowered, $3-6^{\prime \prime}$ long, numerous, in long and narrow or diffuse panicles; flowers pale yellow; achene oval, rather longer than the beak. - Rich damp soil, borders of fields or thickets; common.

2. L. integrifolia, Bigel. Less leafy, $3-4^{\circ}$ high, loosely branched above or heads loosely panicled; leaves undivided, oblong-lanceolate, pointed, denticulate or entire; flowers yellow or purplish. (L. Canadensis, var. integrifolia, Torr. \& Gray.) - N. Eng. to Ill., and southward.

3. L. hirsùta, Muhl. Rather few-leaved, $2-3^{\circ}$ high, commonly hirsute at base; leares hirsute buth sides or only on the midrib, mostly runcinate-pinnatifid; heads in a loose open panicle; achenes oblong-oval, about as long as the beak; flowers yellow-purple, rarely whitish. (L. Canadensis, var. sauguinea, Torr. \&. Gray.) - E. Mass. to Minn., and southward.

4. L. Ludoviciana, 1)C. Glabrous, leafy, 2-5 high; leaves oblong, sinuate-pinnatifid and spinulosely dentate, ciliate; heads in an open panicle; involucre more imbricate; Howers yellow. - Minn., Iowa, and southwestward.

§ 2. LACTLCÁSTRUM. Achenes fat, lanceolute-oblong, tapering to a short slender beak; perennial; flowers blue.

5. L. pulchélla, DC. Pale or glancons; stem simple, l-2 $2^{\circ}$ high; leaves sessile, oblong- or linear-lanceolate, entire, or the lower runcinate-pinnatifid; heads few and large, racemose, erect on scaly-bracted peduncles; inrolucral scales imbricated in 3 or 4 ranks. (Mulgedium, Nutt.) - Upper Mich. to Minn.; common on the plains westward.

§ 3. MLLGEDILM. Achenes thichish, oblong, contracted into a short thick beak or neck; annual or biennial; flowers chiefly blue.

6. L. acuminàta, Gray. Tall biennial $\left(3-7^{\circ}\right.$ high $)$, with many small heads in a loose panicle, on diverging peduncles; leaves ovate to oblong-lanceolate, pointed, sharply and sometimes doubly serrate, sometimes hairy on the midrib beneath, contracted into a winged petiole, the lowest occasionally sinuate or cleit at base, and the cauline sagittate or hastate; achenes beakless; pappus white. (Mulgedium, DC.) - Borders of woods, N. Y. to Ill. and Fla.

7. L. Floridàna, Gaertn. Leaves all lyrate or runcinate, the upper often with a heart-shaped clasping base; panicle larger; achenes distinctly beaked; otherwise as n. 6. - Rich soil, Peun. to Ill., and southward. 
8. L. leucophæaa, Gray. Nearly smooth bieunial; stem tall $\left(3-12^{\circ}\right.$ high), very leafy; leaves irregularly pinnatifid, sometimcs runcinate, coarsely toothed, the upper canline sessile and auriculate, sometimes clasping; heads in a large and dense compound panicle; flowers bluish to crean-color ; achene short-beaked; pappus tawny. (Mulgedium, $/ C^{\prime}$.) - Low grounds; rather common. - Var. integriólı, Gray. Leaves undivided, or the lower sinuate-pinnatificl. Uhio to Ill.

\section{SÓ N C H U S, L. Sow-Tuistle.}

IIeads many-flowered, becoming tumid at hase. Involucre more or less imbricated. Achenes obcompressed, ribbed or striate, not beaked ; pappus copious, of very white exceedingly soft and fine bristles mainly falling together.-Ieafystemmed coarse weeds, chiefly smooth aud glancons, with corymbed or umbellate heads of yellow flowers; produced in summer and autumn. (The ancient Greek name.)

$$
\text { * Annual }\left(1-5^{\circ} \text { high }\right) \text {; flowers pale yellow. }
$$

S. olvrdeecs, L. (Common Sow-Turstre.) Stem-leaves runcinate-pinnatifid, or rarely undivided, slightly toothed with soft spiny teeth, clasping ly a heart-shaped base, the auricles acute; involucre downy when young; achenes striate, also wrinkled transversely. - Waste places in maunred soil and around dwellings. (Nat. from Eu.)

S. Ásper, Vill. (SinY-leaven S.) Stem-leaves less divided and more spiny-toothed, the auricles of the clasping base ronnded; acheues marcined, 3-nerved on each sile, smooth. - With and like the last. (Nat. from Eir.)

* Perennial, with creeping rootstocks; flowers bright yellow, in large heads.

S. ARVÉxsIs, I. (FIEld S.) Leaves runcinate-pinnatifid, spiny-toothed, clasping by a heart-shaped base; peduncles and involucre bristly; achenes transversely wrinkled on the ribs. - Roadsides, etc., N. Eng. and $\mathrm{N}$. Y.; becoming more common. (Nat. from Eu.)

\section{Order 56. LOBELiÁce}

Herbs with acrid milky juice, alternate leaves, and scattered flowers, an irregular monopetalous j-lobed corolla. the 5 stamens fiee from the corolla, and united into a tube commonly by their filaments and aluays by their anthers. - Calyx-tube arlherent to the many-seeded pod. Style 1, stigma often fringed. Seeds anatropous, with a small straight embryo, in copious albumen. - Nearly passing into the following order.

\section{LOB E LIA, L.}

Calyx 5-cleft, with a short tube. Corolla with a straight tube, split down on the (apparently) upper sicle, somewhat 2-lipped: the upper lip of 2 rather erect lobes, the lower lip spreading and 3-cleft. 'Two of the anthers in our species bearded at the top. I'od 2-celled, many-sceded, opening at the top. - Fluwers axillary or chiefly in bracted racene's, in summer and early autumu. (1)edicated to Matthius De l'Obel, an early Flemish herbalist.)

$$
\text { * Flowers deep red, large: stem simple. }
$$

1. L. cardinalis, L. (Carnisal-Flower.) Tall $\left(2-4^{\circ}\right.$ high), smoothish; leaves oblong-lanceolate, slightly toothed; raceme elongated, rather l-sided; the pedicels much shorter than the leaf-like bracts. - Low grounds, common. 
- Perennial by offsets, with large and very showy intensely red flowers, vary. ing rarely to rose-colur or even white. Hybrids with the next species also occur.

* *louers blue, or blue variegated with white.

- Flowers rather large (corolla-tube 5-6" long), spicate-racemose; stems leafy, $1-3^{\circ}$ high; perennial.

+ Leaves ovate to lanceolate, numerous; lip of corolla glabrous.

2. L. syphilitica, L. (Great Lobelia.) Somewhat hairy; leaves thin, acute at both ends (2-6' long), irregularly serrate; flowers (nearly l' long) pedicelled, longer than the leafy bracts; calyx lirsute, the sinuses with consprenous deftexed auricles, the short tube hemispherical. - Low grounds, common. - Flowers light blue, rarely white.

3. L. pubérula, Michx. Finely soft-pmliescent; leares thickish, obtuse (1-2' long), with small glandular teeth; spike rather 1 -sided; loracts ovate; sinuses of the calyx with short and rounderl or often inconspiruons auricles, the hairy tube top-shriped. - Moist sandy grounds, N. J. to Iowa, and south to Tex. and Fla. - Corolla bright blue, $\frac{1^{\prime}}{2}$ long.

4. L. amœna, Michx. Glubrous or nearly so; raceme virgate; leaves narrower; hracts lanceolate or linear, often glandular-denticulate; calyx-lobes long and very slender, usually without auricles, the tube grlabrous. - S. Atlantic States, in swamps. - Var. GLAxdúf́fers, Gray; a slevder form with secund raceme, oval to lance-oblong oltuse gland-toothed leaves, and the bracts and calyx-teeth beset witl slender gland-tipped teetl. S. Va. and southward.

+ +. Leaves long and narrou, sparse above; lip of corolla pubescent at base.

5. I. glandulòsa, Walt. Glabrous, or sparingly pubescent; leaves, bracts, and usually the lobes of the calyx, strongly glaudular-toothed; calyxtube densely hispid, rarely sparsely so or smoothish, the sinuses not auriculate. - Pine-barren swamps, S. Va. to Fla.

$$
\text { +- Flouers smaller (corolla-tube not more than 2-3"long). }
$$

+ Stem leafy, mostly simple, continued into an elongated virgate spike-like raceme; leares lanceolate to obovate, barely denticu'ate or repand.

6. L. leptóstachys, A. DC. Smooth abore; leaves obtuse, denticulate, oblong-lanceolate, the upper gradually reduced to awl-shaped bracts; calyxlobes nearly equalling the corolla, with 10 reflexed awl-shaped appendages as long as the hemespherical tube. - Sandy soil, Ohio to Ill. and Mo.; also Va. to Ga.

7. L. spicàta, Lam. Stem slender, strict ( $1-4^{\circ}$ high) from a biennial (?) root, below and the barely denticulate leaves minutely pubescent; lower and root-leaves obovate or spatulate, the upper reduced to linear or club-shaped hracts; calyx-tube short, obconical or becoming almost hemispherical, sinuses not appendaged. - Moist or dry, mostly gravelly or sandy soil, N. New Eng. to Sask., south to Ark. and La. Fl. through summer. - Var. PARviflòra, Gray, a small form, with calyx-lubes broadly subulate, and pale corolla but $3^{\prime \prime}$ long. Swamps, Lancaster, Penn. (Porter); beginning to flower in June. - Var. Hirtélla, Gray; with somewhat scabrous pubescence, and minutely hirsuteciliate bracts and calyx-lobes. Chiefly toward and beyond the Mississippi. 
+ + Stem leufy, often puniculutely branched ; flowers lousely rucemuse; sinuses if caly.r not uppenduged; annual or biennial.

= Leares chiegly lincur, cutire or denticulute; poul not inflated.

8. L. Cánbyi, Gray. Stem strict $\left(1-2^{\circ}\right.$ high), minutcly angled ; perlicels shorter than the bracts and flourers, minutely roughened under a lens; bractlets none; allyx-inlse top-shuped, acute at base, only half the length of the lobes (which, with the linear leaves, are sparsely glandular-denticulate), in fruit becoming oblong, covering the whole jod; corolla deep blue (fully $5^{\prime \prime}$ long), more or less beurded in the throut. - Wet places, N. J., Del., and S. C.

9. L. Kálmii, L. Stem mostly low ( $4-18^{\prime}$ high $)$, minutely angled; pedicels filiform, not ixceeding the linear or sctaceous bracts but as long as the flower, minutely 2-bracteolute or 2-ylandular abore the middle; calyx-tube top-shuped or obocoid, fully half the length of the loles, in fruit rather longer than they, corering the whole pod ; corolla liglit blue, 4-5" long. - Wet limestone rocks and banks, N. Eng. to L. Winnipeg, soutl to Penn., Ind., and Minn.

10. L. Nuttallii, Roem. \& Schult. Stem very slemiler $\left(1-2^{\circ}\right.$ high), terete; pedicels mostly longer than the bract and shorter than the flower, usually with very minute bractlets near the loase; caly.tube very short, depressedhemısphericul in finit, the globular pod half free; corolla pale blue, barely $3^{\prime \prime}$ long. - Sandy swamps, N. J. and P'enn. to Ga.

$==$ Leaves ovate or oblong, obtusely touthed; pod unflated, uholly inferior.

11. L.inflàta, L. (Ixmıx Toвıcco.) Stems paniculately much branched from an annul root, pubescent with sprealing hairs $\left(1-2^{\circ}\right.$ high); leaves gradually diminishing into leaf-like bracts, which exceed the lower short-pedicelled flowers; calyx-tube ovoisl. - Dry ojen fields. - Corolla only $1 \frac{1}{2}-2^{\prime \prime}$ long. I'lant poisonous and a noted quack medicine.

++ ++ Stem scupe-like, mostly simple, hollow; leaves fleshy; filnous-rooted perennials, very glabrous, mostly aquatic, with pule blue or whitish flowers.

12. L. paludosa, Nutt. Nearly smooth; stem slender (1-4 high); lenves flut, scatlered nent the base, linear-sputulate or oblong-linear, glandulardenticulate, mostly tapering into a petiole; lower lip of corolla bearded in the middle; calyx-tube about half the length of the short lobes, hemisplierical in fruit. - In water (but foliage emerged), Del. to Fla. ancl La.

13. L. Dortmánna, I. (W Aten LomEul.) Very smooth; scripe thichish (5-12' ligh), feu-flowered; lenes all tufted at the root, linear, terete, hollow;, with a partition lengthwise; lower lip of corolla slightly hairy; calyx-tube about as long as the lobes, in fruit much longer. - lionlers of ponls (often immersed), N. Eng. to N. I'enu., L. Superior, and northwarl. (Eu.)

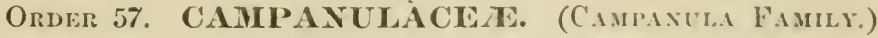

Herlis, with milk:y juice, alternate lenes, and scatteral flowers . calyx adherent to the outry; the regular 5-lobed corolla bell-shaped, valvate in the bud; the 5 stamens usually firee fiom the curclla and distinct. - Style 1, usually beset with collecting hairs alove; stigmas 2 or more. Capsule 2-several-celled, many-seeded. Seed small, anatropous, with a straight embryo in fleshy albumen. Flowers generally blue and showy. 


\section{SPECULA R I A, Heister. Vexus's Looking-glass.}

Calyx 5- (or 3-4-) lobed. Corolla wheel-shaped, 5-lobed. Stamens 5, sepa. rate; the membranaceous hairy filaments shorter than the anthers. Stigmas 3. Capsule prismatic or elongated-oblong, 3-celled, opening by 3 small lateral valves. - Low annuals, with axillary blue or purplish flowers, in American species dimorphous, the earlier being cleistogamous. (Name from Speculum Veneris, the early name of the common European species.)

1. S. perfoliàta, A. DC. Somewhat hairy $\left(3-20^{\prime}\right.$ high); leaves roundish or ovate, clasping by the heart-shaped base, toothed; flowers sessile, solitary or 2-3 together in the axils, only the upper or later ones having a conspicuous and expanding corolla; capsule oblong, short, straight, opening rather below the middle; seeds lenticular. - Sterile open ground; common. May-Aug.

2. S. leptocárpa, Gray. Minutely hirsute or nearly glabrous (6-12' high); leaves lanceolate, with flowers closely sessile in their axils; calyx-lubes of lower flowers 3 ; capsule nearly cylindrical (6-9" long, $1^{\prime \prime}$ thick), inclined to curve, opening by one or two uplifted valves near the summit; seeds oblong. W. Mo. and Ark. to Col. and W. Tex. Expanded corolla 6-9" wide.

\section{C A M P Á N ULA, Tourn. Bellflower.}

Calyx 5-cleft. Corolla generally bell-shaped, 5-lobed. Stamens 5, separate; the filaments broad and membranaceous at the base. Stigmas and cells of the capsule 3 in our species, the short pod opening on the sides by as many valves or holes. - Herbs, with terminal or axillary flowers; in summer. (A diminutive of the Italian campana, a bell, from the shape of the corolla.)

* Style straight; openings of capsule below the middle.

+ Coarse pubescent many-flowered European species, sparingly naturalized; perennial.

C. RAPUxCuloìnes, L. Smoothish, slender, erect; stem-leares orate-lanceolate, pointed, the lower long-petioled and heart-shaped; flowers nodding, single in the axil of bracts, forming racemes; corolla oblong, $\mathrm{l}^{\prime}$ long. - Roadsides and fields, Canada and N. Eng. to Penn.

C. Glomerata, L. (Clustered B.) Somewhat hairy, stout and erect, $1^{\circ}$ high; stem-leaves oblong or lanceolate, cordate-clasping; flowers sessile, clustered in the upper axils, forming a leafy head; corolla open-bell-shaped, $1^{\prime}$ long. - Roadsides, E. Mass.

+ + Slender perennials, mostly glabrous; flowers one or few, on slender peduncles.

1. C. rotundifòlia, L. (HAREBELL.) Slender, branching (5-12' high), 1-10-flowered; root-leaves round-heart-shaped or ovate, mostly toothed or crenate, long-petioled, early withering away; stem-leaves numerous, linear or narrowly lanceolate, entire, smooth; calyx-lobes awl-shaped, from $\frac{1}{3}$ to $\frac{2}{3}$ the length of the bright-blue corolla (which is $6-9^{\prime \prime}$ long); capsule nodding. - Rocky shaded banks, throughout the northern part of our range, and southward in the monntains. - A delicate and pretty species, but with a most inappropriate name, since the round root-leaves are rarely obrious. (Eu.)

Var. árctica, Lange. Stems more upright aud rather rigid; lowest leaves spatulate; the very slender calyx-lobes soon spreading or deflexed; corolla $\ddot{3}-l^{\prime}$ long. (C. rotundifolia, var. linifolia, of Man.) - Shores of the Great Lakes, and northward. (Eu.) 
Var. velutina, IC., has the whole herbage canescently pubescent. Sand-hills of Burt Lake, Mich. (E. J. Hill).

2. C. aparinoides, l'ursh. (Marsu Bellfuowris.) Stem simple and slender, weak (8-20' high), few-flowered, somewhat 3-angled, rough backuard on the angles, as are the slightly toothed edges and midrib of the linear-lanceulace leaces; peduncles diverging, slender; lobes of the calyx triangulur, half the length of the bell-shaped nearly white corolla; capsule erect. - Wet grassy grounds, throughout our range. With somewhat the habit of a Galinm.

3. C. divaricàta, Michx. Very sinooth; stem loosely branched $\left(1-3^{\circ}\right.$ high); leaves oblong-lanceolate, pointed at both ends, coursely and sharply toothed; flowers numerous on the branches of the large compound panicle; "alyx-lobes aul-shaped, about half the length of the pale-blue small corolla (3" long); style exserted. - Dry woods and rocks, mumutains of Va., E. Ky., and southward.

* Style declined and upuardly curved, much longer than the rotate corolla; openings of the capsule close to the summit; inflorescence spicate.

4. C. Americàna, I. (Tall Bellflower.) Annual; stem mostly simple $\left(3-6^{\circ}\right.$ high $)$; leaves ovate and ovate-lanceolate, taper-pointed, serrate, mostly on marginei petioles, thin, somewhat hairy $\left(2 \frac{1}{2}-6^{\prime} \mathrm{long}\right)$; spike $1-2^{\circ}$ long; corolla light blue, $l^{\prime}$ broad. - Moist rich soil, western N. Y. to Minn., south to Ga. and Ark.

\section{Order 58. ERicàceze. (Heath Family.)}

Shrubs, sometimes herbs, with the flowers regular or nearly so; stamens as many or twice as many as the 4-5-lobed or 4-5-petalled corolla, free from but inserted with it: anthers 2-celled, commonly appendaged, or opening by terminal chinhs or pores, introrse (except in Suborder 3); style 1; ovary 3-10-celled. Pollen compound, of 4 united grains (except in Suborder 4). Seeds small, anatropous. Embryo small, or sometimes minute, in fleshy albumen. - A large family, very various in many of the characters, comprising four well-marked suborders, as follows :-

Suborder I. Vacciniea. (Whortleberry Family.) Calyxtube adherent to the ovary, which forms an edible berry or berry-like fruit, erowned with the short ealyx-teeth. Anther-eells opening at the apex. - Shrubs or somewhat woody plants, with scaly buds.

1. Gaylussacia. Ovary 10-celled, with a single ovule iu each cell. Fruit a berried drupe with 10 small seed-like nutlets.

2 Vaccinium. Berry 4-5-cellel (or imperfectly 8 -10-celled by false partitions), manyseeded. Anther-cells tapering upward intu a tube.

3 Chiogenes. Berry 4-celled, many-seederl, its sumuit free. Anther-cells not prolonged intu a tube, but each 2-pointed. Slender trailing evergreen.

Suborder II. Ericineae. (Heati Family proper.) Calyx free from the ovary. Corolla gamopetalous, rarely polypetalous, hypogynous. - Shrubs or small trees.

Tribe I. A RBUTFA. Fruit indehiscent, a berry or drupe. Corolla deciduous.

4. Arctostaphylos. Corolla urn-shaped. Drupe berry-like, 5-10-seedecl. 
Tribe II. ANDROMEDEAE. Fruit a loculicidal capsule (berry-like in n. 6). Corolla deciduous.

* Anther-cells opening through their whole length, not appendaged.

5. Epigaea. Corolla salver-shaped. Calyx of 5 separate dry and pointed sepals.

* * Anther-cells opening only at the top. Corolla not salver-shaped.

- Calyx becoming enlarged and berry-like in fruit.

6. Gaultheria. Calyx 5-cleft, in fruit enclosing the capsule. Anthers 4-awned at top.

- + Calyx dry, not becoming fleshy after flowering.

++ Corolla urceolate to cylindrical, 5-toothed; not heath-like.

7. Andromeda. Calyx valvate and very early open, naked. Capsule globular. Seeds mostly hanging on the central placenta.

8. Oxydendrum. Calyx short, early open, naked. Capsule oblong-pyramidal. Seeds all ascending. A small tree.

9. Leucothoe. Calyx slightly or much imbricated, naked or bibracteate. Corolla cylindraceous. Capsule depressed, 5-lobed, the valves entire.

10. Cassandra. Calyx of rigid imbricated ovate sepals, bibracteate. Corolla cylindraceous. Capsule splitting when ripe into an outer and inner layer, the inuer of 10 valves.

++++ Corolla campanulate, 4-5-lobed or -parted; heath-like, with acerose inbricated leaves.

11. Cassiope. Calyx of ovate imbricated sepals. Capsule globular-ovoid, 4-5-valverl, the valves 2-cleft.

Tribe III. ERICEA. Corolla persistent, becoming scarious. Capsule septicidal.

12 Calluna. Corolla bell-shaped, 4-parted. Leaves minute, opposite, imbricate.

Tribe IV. RHODODENDIEAE. Fruit a septicidal capsule. Corolla deciduous.

* Anther-cells opening by a hole or chink at the top.

- Flowers not from scaly buds; the bracts leaf-like or coriaceous.

13. Bryanthus. Corolla ovate or urn-shaped. Leaves narrow and heath-like.

14. Kalmia. Corolla broadly bell-shaped or wheel-shaped, with 10 pouches receiving as nany anthers. Leaves oblong or linear.

+ + Flowers developed from large scaly buds, the scales or bracts caducous.

15. Menziesia. Corolla globular-bell-shaped, 4-toothed. Stamens 8. Leaves deciduous.

16. Rhorlodendron. Flowers usually 5-merous. Corolla bell-shaped or funnel-form, lobed or parted, often somewhat irregular Leaves deciduous or evergreen.

17. Ledum. Corolla regular, all 5 petals nearly separate. Stamens 5-10. Leaves evergreen.

* Anther-cells opening lengthwise. Leaves evergreen. Bud-scales firm and persistent.

18. Leiophyllum. Corolla of 5 separate petals Stamens 10, exserted.

19. Loiseleuria. Corolla deeply j-cleft. Stamens 5, included.

suborder III. Pytoleze. (Pyrola Family.) Calyx free from the ovary. Corolla polypetalous. Anthers extrorse in the bud. opening by pores at the base (inverted in the flower). Seeds with a loose and translucent cellular coat much larger than the nucleus.

Tribe I. CLETHREAE. Shrubs or trees, with deciduous foliage (in ours). Pollengrains simple. Capsule 3-celled.

20. Clethra. Sepals and petals 5. Stamens 10. Style 3-cleft at the apex.

Tribe II. PYROLEAE. Herbs or nearly so, with evergreen foliage. Pollen-grains compound. Capsule 5- (rarely 4-) celled.

21. Chimaphila. Stems leafy. Flowers corymbed or umbelled. Petals widely spreading. Style very short and top-shaped. Valves of the capsule smooth on the edges.

22. Moneses. Scape 1-flowered. Petals widely spreading. Style straight, exserted; stigna 5-rayed. Valves of the capsule smooth on the edges. 
23. Pyrola. Acaulesent. Flowers in a raceme. I'etals not widely spreading. Filaments awl-shaped. Style long. Valves of the capsule cobwebby on the erloges.

Suborder IV. Monotropece. (Ixplaxiple Faniry.) Flow. ers nearly as in Suborders 2 or 3 , but the plants herbaceous, ruot-parae sitic, entirely destitute of green foliage, and with the aspect of Beceli-drops.s. Seeds as in Suborder 3.

* Corollamonopetalous ; anthers 2-celled.

24. Pterospora. Corolla ovate, 5-toothed; anthers 2-awned on the back, opening lengthwise.

25. Schweinitzia. Corolla broadly bell-shaped, 5-lobed; anthers ojening at the top.

* Corolla of 4 or 5 separate petals; calyx imperfect or bract-like.

26. Monotropa. l'etals narrow. Anthers kidney-shaped, opening across the top.

\section{G A Y I US S Á CI A, HBK. Húckemirry.}

Corolla tubular, ovoid, or bell-shaped; the border 5-cleft. Stamens 10; anthers awnless; the cells tapering npward into more or less of a tnbe, opening by a chink at the end. Fruit a berry-like drupe, containing 10 seed-like nutlets. - Branching shrubs, with the aspect of Vaccinium, commonly sprinkled with resinous dots; the flowers (white tinged with purple or red) in lateral and bracted racemes. (Named for the distinguished chemist, (iay-Lussac.)

* Leaves thick and evergreen, someuthat serme, not resinous-dotted.

1. G. brachýcera, Gray. (Box-Hcckleblerr.) Very smooth (10 high); leaves oral, finely crenate-toothed; racemes short and nearly sessile; pedicels very short ; corolla cylindrical-bell-shaped - Wooded hills, Perry Co., Yenn., to Del. and Va. May. - Leaves resembling those of the Box.

* Leaves decuduous, entire, sprinkled more or less with resinous or uaxy atoms.

2. G. dumòsa, Torr. \& Gray. (Dwarf Heckleberry.) Somerhat hairy and glandular, low ( $1-5^{\circ}$ high from a creeping base), hushy; leares ob. ovate-oblong, mucronate, green both sides, rather thick and shining when old: racemes elongated ; bracts leaf-like, ocal, persistent, us long as the pedicels; orary bristly or glundular; corolla bell-shaped; fruit black (insipiol) - Var. nntÉ LLA has the young branchlets, racemes, and often the leaves hairy - Sandy swamps. Newf., along the coast to Fla. and La.; the var. chiefly southward. June.

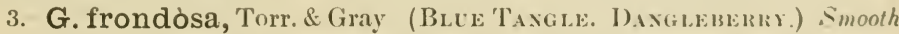
$\left(3-6^{\circ}\right.$ high); branches slender and divergent; leares obovate-oblong, blunt, pale, glaucous beneuth; racemes slender, loose, bracts oblong or lnear, decidu. ous, shorter thun the slender drooping pedicels: corolla globular-lell-shaped. fruit dark blue with a white bloom (sweet and edible) - Low copses coast of N. Eng. and mountains of Penn, to Ky., sonth to La and Fla. May. June

4. G. resinòsa, Torr \& Gray. (Веаск Ilискцввеки.) Much hranched, rigid, slightly pubescent when young ( $1-3^{\circ}$ high), leuves oval, oblong-ovate, or oblong, thickly clothed and at first clummy, as well as the flowers, wh shunin? resinous globules; racemes short, clustered, one-siled; pedicels about the length of the flowers; bracts and brastlets (reddesh) small and derednous, corolla ovoid. conical, or at length cylindrical with an open mouth; fruit black, without bloom (pleasant, very rarely white). - Rocky woodlands and swamps, Newf. to Minn., south to N. Ga. May, June.-The common Iluckleberry of the markets. 


\section{V A C Cí N I U M, L. Blemberry. Bilberry. Cranberry.}

Corolla various in shape; the limb 4-5-cleft, revolute. Stamens 8 or 10 ; anthers sometimes 2-awned on the back; the cells separate and prolonged upward into a tube, opening by a hole at the apex. Berry 4-5-celled, many-seeded, or sometimes 8-10-celled by a false partition stretching from the back of each cell to the placenta. - Shrubs with solitary, clustered, or racemed flowers; the corolla white or reddish. (Ancient Latin name of obscure derivation.)

§ 1. BATODENDRON. Corolla open-campanulate, 5-lobed; anthers with long tubes, and 2-auned on the back; berry (hardly edible) spuriously 10-celled; leaves deciduous but firm; flowers solitary or in leafy-bracted racemes, slender-pedicelled.

1. V. arbòreum, Marshall. (FArkLE-Berry.) Tall (6-250 high), smoothish; leaves obovate to oblong, entire or denticulate, mucronate, bright green, shining above, at the south evergreen; corolla white; anthers included; berries black, globose, small, many-seeded. - Sandy soil, S. Ill. to Tex., Fla., and N. C.

2. V. stamíneum, I. (Deerberry. Sqcaw Heckleberry.) 1)iffusely branched $\left(2-3^{\circ}\right.$ high), somewliat pubescent; leaves ovate or oval, pale, glaucous or whitish underneath; corolla greenish-rchite or purplish; anthers much exserted; berries greenish or yellowish, globular or pear-shaped, largo, few-seeded. - Dry woods, Maine to Minn., south to Fla. and La.

§2. CYANOCÓCCLS. (Buteberries.) Corolla cylindraceous to campanulate, 5-tonthed; filuments hairy; anthers included, un:nless; berry (sweet and edible) blue or black with bloom, completely or incompletely 10-celled; flowers in fascicles or short rucemes, short-pedicelled, appearing from large scaly buds with or before the leaves.

\section{* Corolla cylindraceous when developed.}

3. V. virgàtum, Ait. Low, more or less pubescent; leaves ovate-oblong to cumeate-lanceolate, usually acute and minutely serrulate, thinnish, shining at least above; flower-clusters sometimes virgate on naked branches; corolla rose-color; berry black. - In swamps, south of our range, but represented by

Var. tenéllum, Gray. Low form, mostly small-leaved, with smaller nearly white flowers in shorter or closer clusters. - Va. to Ark., and southward. * Corolla shorter and broader. (Blueberries or Ble Heckleberries.)

4. V. Pennsylvánicum, Lam. (Dwarf Blveberry.) Dwarf (6$15^{\prime}$ high), smooth, with green warty stems and hranches; leaves lanceolate or oblong, distinctly servulate with bristle-ponted teeth, smooth and shining both sides (or sometimes downy on the midrib underneath); corolla short, cylindricalbell-shaped; berries bluish-black and glaucous. - Dry hills, N. J. to 1ll., north to Newf. and Sask. The lowest and earliest ripened of the blueberries. - Var. AXgustifóliux, Gray ; a dwarfer high-mountain or northern form, with narrower lanceolate leaves. - White Mts. of N. H., Newf., and far northward.

5. V. Canadénse, Kalm. Low (1-2 high) ; leaves oblong-lanceolate or elliptical, entire, downy both sides, as well as the crowded branchlets; corolla shorter; otherwise as the last. - Swamps or moist woods, N. New Eng. to mountains of Penn., Ill., Minn., and northward. 


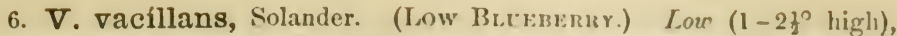
glalwous, with yellowish-green branchlets; leaves obocate or oral, very pale or dull, glaucous, at least underneath, minutely ciliolate serrulate or entire; corolla between bell-shaped and cylindraceons, the month sonewhat contracted. - Dry places, esprecially in sandy soil, New Eng. to Mich. and lowa, south to N. C. and Mo. - Berries ripening later than those of 11.4 .

7. V. corymbòsum, L. (Cомmox or SWAMp-Bhilizemr.) Tall (5$10^{\circ}$ high); leures ovate, oval, oblong, or ellipticul-tanceolate; corolla varying from turgid-ovate and cylindrical-urn-shaped to oblong-cylindrical, 3-4" long. - Siwamps and low thickets, throughout our range and southward. This yiclils the common blueberry or blue hurhleberry of the latter part of the season. 'The typical form has leaves with naked entire margins, and may be pubescent or glabrous (var. glíbrum, Gray, Man.) Numerous gradations unite the following varieties :-

Var. amœnum, Gray. Leaves bristly-ciliate, shining above, green both sides, heneath somewhat pubescent on the veins. - Middle Atlantic States.

Var. pállidum, Gray. Leaves mostly glahrous, pale or whitish, glaucous especially underneath, serrulate with bristly teeth. - Common in the Alleghanies southward, mostly on the higher rilges.

Var. atrocóccum, Gray. The most distinet form; leaves entire, downy or woolly underneath even when old, as also the branchlets; berries smaller, black, without bloom. - New Eng. to Penn.

§3. VACCINIUMI proper. (Bilibrines.) Corolla ovate to globular, 4-5toothed; filaments glabrous; anthers 2-auned on the back, included; berry 4-5-celled; leares deciduous; flowers on drooping pedicels, solitary or few together, appearing with or after the leaves; mostly glabrous.

* Parts of the flower mostly in fours; stamens 8 .

8. V. uliginósum, L. (Bog BiLlerrr.) Low and spreading $\left(4^{\prime}-2^{\circ}\right.$ high), tufted; leaves entire, dull, obovate or oblong, pale and slightly pubescent underneath; flowers single or 2-3 together from a scaly bud, almost sessile; corolla short, urn-shaped; berries black with a bloom, sweet. $-A l p i n e$ tops of the high mountains of N. Eng. and N. Y., shore of L. Superior, and northwestward. (Eu.)

* * Parts of the flower in fives; stanens 10 ; leaves membranaceous; flowers solitary on short axillary peduncles, nodding.

9. V. cæspitòsum, Michx. Dwarf ( $3-6^{\prime}$ high), tufted, leares ohorate, narrowed at the base, smooth and shining, servate: corolla oblong, slightly urnshaped; berries blue. - Alpine region of the White $\mathrm{Mts.}$, and high northwarl. - Var. cuxwroinum, Nutt., is a foot high or less, bushy, with cuneate-spatulate leaves rounded at the apex, passing in one form to spatulate-lanceolate and acute. - Shores of L. Superior and westward.

10. V. myrtilloldes, Hook. More erect, $1-5^{\circ}$ high ; branehlets somewhat angled; leaces mostly orate and acute or pointed, sharply and closely serrulate, bright green, nearly smouth; borler of the calyx almos: entire; corolla depressed-globular, rather large ; berries large, black, rather acid. - Damp woods, shores of L. Superior, and northwestward. May, June. - Pedicels 3 $6^{\prime \prime}$ long, drooping in flower, erect in fruit. 
11. V. ovalifolium, Smith. Straggling, $2-12^{\circ}$ high; leares elliptical, obtuse, nearly entire, pale, mostly glaucous beneath, smooth; corolla ovoid; berries blue. - Peat-bogs, shores of L. Superior, and northwestward. May.

§. VITIS-ID À $\Lambda$. Corolla, berry, etc., as in 3 ; filaments hairy; anthers awnless; leares coriaccous and persistent; flowers in clusters from sepurute luds, 4-merous (in our species); mostly glabrous; leares $3-6$ "long.

12. V. Vitis-Idæea, I. (Cowberry. Mountaix Cranberry. FoxBERRY.) Low (6-10' high) ; branches erect from tuftel creeping stems; leaves obovate with revolute, margins, dark green, smooth and shining above, dotted with blackish bristly points underneath; corolla bell-shaped, 4-cleft; berries dark red, acid and rather litter, edible when cooked. Coast and mountains of N. Eng. to N. shore of L. Superior, and far northward. June. (Eu.)

\$5. OXYCÓCCLS. Corolla deeply 4-parted or -cleft, with linear reflexed lobes: anthers exserted, awnless, with rery long terminal tubes: lerry 4celled; flowers uxillary or terminal, nodding on long filiform pedicels.

* Stem upright and leaves deciduous, as in common Blweberries; flowers axillary and solitary; corolla deeply 4-cleft; berries light real, turning purple, insipid.

13. V. erythrocárpon, Michx. Smooth, divergently branched $\left(1-4^{\circ}\right.$ high); leares oblong-lauceolate, taper-pointed, bristly serrate, thin. - Damp woods, higher Alleghanies, Va. to Ga. July.

* Stems rery slender, creeping or trailing; leaves small, entive, whitened heneath, evergreen; pedicels erect, the pale rose-colored flourer nodding; corolla 4-parted; berries red, icid.-Craxbernies.

14. V. Oxycóccus, L. (Suall Craxberry.) Stems very slender (4$\left.9^{\prime} \mathrm{long}\right)$; leaves ovate, acute, with stiongly revolute margins $\left(2-3^{\prime \prime} \mathrm{long}\right)$; perlicels $1-4$, terminal; filaments fully $\frac{1}{2}$ as long as the anthers. - l'eat-bogs, $\mathrm{N}$ Eng. and Penn. to Minn., and northward. June. - Berry 3-4" broad, often speckled with white when young; seldom gathered for market. (Eu., Asia.)

15. V. macrocárpon, Ait. (LARge or Auericix Craxberry.) Stems elongated ( $\left.1-4^{\circ} \mathrm{long}\right)$, the flowering branches ascending ; lear os oblom y, obtuse. less revolute $\left(4-6^{\prime \prime}\right.$ long) ; pedicels sereral, becoming lateral, filaments scarcely one third the length of the anthers. - Peat-bogs, N C. to Minn., and everywhere northward, but scarcely westward. June. - Berry $\frac{1}{2}-1^{\prime}$ long.

\section{CHIÓGENES, Salisb. Creepixg Sxowberky.}

Calyx-tube adherent to the ovary ; limb 4-parted, persistent. Corolla bellshaped, leeply 4-cleft. Stamens 8, included, inserted on an 8-toothed disk. filaments very short and broad; anther-cells orate-oblong, separate, not awned on the back, but each minutely 2-pointed at the apex, and opening by a large chink down to the micldle. Berry white, globular, rather dry, 4-celled, many. seeded. - A trailing and creeping evergreen, with very slender and scarcely woody stems, and small Thyme-like, orate and pointed leares on short petioles, with revolute margins, smooth above, the lower surface and the branches beset with rigid rusty bristles. Flowers very small, solitary in the axils, on short nodding peduncles, with 2 large bractlets under the calyx. (Name from $\chi \iota \omega ́ \nu$, snow, aud $\gamma$ '́vos, offspring, in allusion to the suow-white berries.) 
1. C. serpyllifolia, Salisb. Leaves $3-4^{\prime \prime}$ long; berries $3^{\prime \prime}$ broad, hright white. (C. hispidula, Torr. \& Gray.) - l'eat-bogs, and mossy woods, N. J. and Penn. to Minn., and northward; also southward in the Alleghanies to N. C. May. - Plant with the aromatic flavor of Gaultheria or Swect Birch.

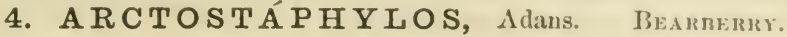

Corolla ovate and urn-shaped, with a short revolute 5 -toothed limb. Stamens 10, included; anthers with 2 reflexed awns on the back near the apex, opening by terminal pores. Drupe berry-like, with 5-10 seed-like nutlets. - Shruls, with alternate leaves, and scaly-bracted nearly white flowers in terminal racemes or clusters. Fruit austere. (Name composed of Koктоs, a bear, and $\sigma \tau a \phi \nu \lambda \eta$, a grape or berry, the Greek of the popular name.)

1. A. Ùva-úrsi, spreng. (Benrierrr.) Trailing; leaves thick and evergreen, obovate or spatulate, entire, smooth; fruit red.- Rocks and bare hills, N. J. and Penn. to Mo., and far north and westward. May. (Eu., Asia.)

2. A. alpina, Spreng. (Alpixe Bearbeirr.) Dwarf, tufted and depressed; leaves decidnons, serrate, wrinkled with strong netted veins, obovate: fruit black. - Alpine summits in N. Eng., and high northward. (Arctic-alpine around the world.)

\section{EPIG 离 A, L. Grovxd Laurel. Trailing Arbutes.}

Corolla salver-form; the tube hairy inside, as long as the orate-lanceolate pointed and scale-like nearly distinct sepals. Stamens 10, with slender filaments; anthers oblong, awnless, opening lengthwise. Style slender, its apex (as in Pyrola) forming a sort of ring or collar around and partly adnate to the 5 little lobes of the stigma. Capsule depressed-globular, 5-lobed, 5-cellerl, many-seeded. - A prostrate or trailing scarcely shrubby plant, bristly with rusty hairs, with evergreen and reticulated rounded and heart-sliaped alternate leaves, on slender petioles, and with rose-colored fluwers in small axillary clusters, from sealy bracts. (Name composed of $\dot{\epsilon} \pi \dot{i}$, upon, and $\gamma \hat{\eta}$, the carth, from the trailing growth.)

l. E. rèpens, L. - Sandy woods, or in rocky soil, especially in the shade of pines, Newf. to Minn., south to Fla., and Ky.-Fluwers appearing in early spring, exhaling a rich spicy fragrance, dimorphous as to style and stamens and subdiocious. In New England called MAYrLower.

\section{G A U L T H E I A, Kalm. Aromatic Whimergren.}

Corolla cylindrical-oroid or a little urn-shaped, 5-toothed. Stamens 10, included; anther-cells each 2-awned at the summit, opening by a terminal pore. Capsule depressed, 5-lobed, 5-celled, 5-valved, many-seeded, enclosed when ripe by the ealyx, which thickens and turns fleshy, so as to appear as a globular red berry ! - Shrubs, or almost herbaceous plants, with alternate evergreen leaves and axillary (nearly white) flowers; pedicels with 2 bractlets. (Dedicated by Kialm to "Dr. Gaulthier," of Quebec.)

1. G. procúmbens, L. (Creerixg Wristergreex.) Stems sleuder and extensively creeping on or below the surface; the flowering branches ascending, leafy at the summit $\left(3-5^{\prime}\right.$ high); leaves obovate or oval, obscurely serrate; flowers few, mostly single in the axils, nodding. - Cool damp woods, 
mostly in the shade of evergreens, Maine to Minn., and southward to N. Ga. ; also far northward. July. - The bright red berries (formed of the calyx) and the foliage have the well-known spicy-aromatic flavor of the Sweet Birch. Usually called Wintergreen, or sometimes in the interior Tea-berry. Eastward it is often called Checkerberry or Partridge-berry (names also applied to Mitchella, the latter especially so), also Boxberry.

\section{ANDRÓMEDA, L.}

Calyx without bractlets, of 5 nearly or partly distinct sepals, valvate in the bud, but very soon separate or open. Corolla urceolate (in ours), 5-toothed. Stamens 10; anthers fixed near the middle, the cells opening by a terminal pore. Capsule globular, 5-celled, 5-valved; the many-seeded placentæ borne on the summit or middle of the columella. Seeds pendulons or spreading. Shrubs, with umbelled, clustered, or panicled and racemed (mostly white) flowers. (Fancifully named $1:$ Limnæus in allusion to the fable of Andromeda.)

* Anthers auned; capsuce wore or less globose; leaves thick and evergreen.

1. A. polifolia, L. Glabrous, 6-18' high; leares linear to lanceolateoblong, strongly revolute, white beneath; flowers in terminal nubels; pedicels from axils of persistent scaly bracts ; each anther-cell with a slender terminal ascending aun. - Wet hogs, N. J. and Penn. to Minn., and northward.

2. A. floribúnda, Pursh. Very leafy, $2-6^{\circ}$ high ; young branchlets, etc., strigose-lıairy; leares lanceolate-oblong, acute or acuminate, ciliate-serrulate, glandular-dotted benerth (2' long); racemes crowded in short terminal panicles, densely flowered ; each anther-cell with a slender deflexed awn on the back.-Moist hillsides, in the Alleghanies from Va. to Ga.

* Anthers aunless; capsule 5-angled, with a thickened ridge at the dorsal sutures; leares thinnish and deciduous.

3. A. Mariàna, L. (Stagger-Brsm.) Mostly glabrous, 2-4 ${ }^{\circ}$ high ; leaves oblong or oval ( $1-3^{\prime}$ long); fascicles of nodding flowers racemose on naked shoots; filaments 2-toothed near the apex; capsule orate-pyramidal, truncate at the contracted apex. - Low grounds, R.I. to Fla.; also in Tenn. and Ark. Foliage said to poison lambs and calves.

4. A. ligustrina, Muhl. Minutely pubescent, $3-10^{\circ}$ high; leaves obo vate to lanceolate-oblong ( $1-2^{\prime}$ long), serrulate or entire; racemes crouded in naked or leafy panicles; filaments flat, not appendaged; capsule globular. Wet grounds, Canada to Fla. and Ark. - Var. Pubéscexs, Gray, is a form with dense soft pubescence. - Va. to Ga.

\section{OXYDENDRUM, DC. Sorrel-tree. Sour-wood.}

Calyx without bractlets, of 5 almost distinct sepals, valvate in the bud. Corolla ovate, 5-toothed, puberulent. Stamens 10; anthers fixed near the base, linear, awnless, the cells tapering upward and opening by a long chink. Capsule oblong-pyramidal, 5-celled, 5-valved; the many-seeded placentæ at the base of the cells. Seeds all ascending, slender, the thin and loose reticulated coat extended at both ends into awl-shaped appendages. - A tree with deciduous, oblong-lanceolate, pointed, soon smooth, serrulate leaves, on slender petioles, and white flowers in long one-sided racemes clustered in an open pan- 
icle, terminating the branches of the season. Bracts and loractlets minute, deciduous. Foliage acid (whence the name, from ókús, sour, and $\delta \in \epsilon^{\prime} \delta \rho o \nu, t r e c$.)

1. O. arboreum, 1)C. Tree $15-40^{\circ}$ high; leaves in size and shape like those of the peach. - Lich woods, from I'enn. to Ind., and southward, mostly along the Alleghanies, to Fla. June, July.

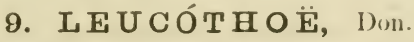

Calyx of 5 nearly distinct sepals, imbricated in the bucl. Corolla ovate or cylindraceous, 5-toothed. Stamens 10; anthers naked, or the cells with 1 or 2 erect awns at the apex, opening by a pore. Capsule depressed, more or less 5-lobed, 5-celled, 5-valved, the sutures not thickened; valves entire; the manyseeded placenta borne on the summit of the short columella. Seeds mostly pendulous. - Shrubs with petioled and serrulate leaves, and white scaly-liracted flowers in dense axillary or terminal spiked racemes. (A mythological name.)

* Anthers awnless; stigma 5-rayed ; racemes sessile, dense, with persistent bracts, in the axils of thick and shining evergreen leaves; calyx not bracteolate.

1. I. axillàris, Don. Leaves lanceolate-oblong or oval, abruptly pointed or acute, somewhat spinulose-serrulate, on very short petioles; sfpals brondly osate. - Low grounds, Va. to Fla. and Ala. Feb. $-\Lambda$ pril. - Shrub $2-4^{\circ}$ high.

2. I. Catesbæi, Gray. Leaves ovate-lanceolate, taper-pointed, serrulate with ciliate-spinulose appressed teeth, conspicuously petioled $\left(3-6^{\prime}\right.$ long); sepals orate-ablong, often acute. - Moist lanks of streams, Va. to Ga. along the mountains. May. - Shrub $2-4^{\circ}$ high, with long spreading or recurved branches. Flowers exhaling the umpleasant scent of Chestnut-blossoms.

* * Anthers auned; stigma simple; flowers very short-pedicelled, in long onesided racemes mostly terminating the branches; bracts deciduous; leares membranaceous and deciduous, servulate; calyx bibracteolate.

3. 工. recúrva, Buckley. Branches and racemes recurved-spreading; leaves lanceolate or ovate, taper-pointed; sepals ovate; anther-cells l-auned; pod 5-lobed; sceds fat and cellular-winged. - Dry hills, Alleghanies of Va. to Ala. April. - Lower and more straggling than the next.

4. L. racemosa, Gray. Branches and racenes mostly erect: leaves oblong or oval-lanceolate, acute; sepals orate-lanceolate: anther-cells each 2-awned: pod not lobed; seeds angled and wingless. - Moist thickets, Mass. to Fla. and La., near the coast. May, June. - Shrub $4-10^{\circ}$ high. Corolla cylindrical.

\section{Ca S S Á N D R A, Don. Leatmer-Leaf.}

Calyx of 5 distinct rigil ovate and acute sepals, imbricated in the bud, and with a pair of similar bractlets. Corolla cyliudrical-oblong, 5-toothed. Stamens 10; anther-cells tapering into a tubular beak, and opening by a pore at the apex, awnless. Capsule depressed, 5-celled, many-seeded, the pericarp of 2 layers, the outer 5-valved, the cartilaginons inner layer at length 10-valved. Seeds flattened, wingless. - Low and much branched shrubs, with nearly evergreen and coriaceous leaves, which are scurfy, especially underneath. Flow. ers white, in the axils of the upper small leaves, forming small 1 -sided leafy racemes. (Cassandra, a daughter of 'riam and Hecuba.) 
1. C. calyculàta, Don. Leaves oblong, obtuse, flat.-Bogs, Newf. to Minn., and south to Ga.

\section{C A S S I O PE, Don.}

Calyx without bractlets, of 4 or 5 nearly distinct ovate sepals, imbricated in the bud. Corolla broadly campanulate, deeply 4-5-cleft. Stamens 8 or 10; anthers fixed by the apex; the ovoid cells each opening by a large terminal pore, and bearing a long recurved awn behind. Capsule ovoil or globular, 4-5-celled, 4-5-valved, the valves 2-cleft; placentr many-seeded, pendulons from the summit of the columella. Seeds smooth and wingless. - Small, arctic or alpine evergreen plants, resembling Club-Mosses or Heaths. Flowers solitary, nodding on slender erect peduncles, white or rose-color. (Cussiope was the mother of Andromeda.)

1. C. hypnoides, Don. 'Tufted and procumbent, moss-like ( $1-4^{\prime}$ high) ; leaves needle-shaped, imbricated; corolla 5-cleft; style short and conical. Alpine summits of $\mathrm{N}$. New Eng. and N. Y., and high northward.

\section{C A L L Ù N A, Salisb. Heather. Livg.}

Calyx of 4 colored sepals. Corolla bell-shaped, 4-parted, much shorter and less conspicuous than the calyx, both becoming scarious and persistent. Stamens 8 , distinct; anthers with a pair of leflexed appendages on the back, the cells opening each by a long chink. Capsule 4-celled, septicidally 4-valved. Evergreen undershrub, with no scaly buds, opposite and minute leaves (mostly extended at base into 2 sharp auricles), crowded and imbricated on the branches. Flowers axillary, or terminating very short shoots and crowded on the branches, forming close mostly one-sided spikes or spike-like racemes, rose-colored or sometimes white, small, bracted by 2 or 3 pairs of leaves, the innermost of which are more or less scarious. (Named from $\kappa \alpha \lambda \lambda \dot{\nu} \nu \omega$, to brush or sweep, hrooms being made of its twigs.)

1. C. vulgàris, Salisb. Low grounds, Mass., at 'Tewksbury and W. Andover; Maine, at Cape Elizabeth; also N. Scotia, C. Breton, Newf., etc. Probably only introduced.

Two European heaths, Erìca cris̀res and E. Tétrallx, have been found in small patches on Nantucket Island.

\section{BR Y Á N T H U S, Steller.}

Corolla urn-shaped or bell-shaped, 5-toothed or 5-cleft, decidnous. Stamens 10 ; anthers pointless, shorter than the filaments, opening by terminal pores. Capsule 5-celled, 5-valved, septicidal (as are all the succeeding), many-seeded. - Low alpine Heath-like evergreen undershrubs, clothed with scattered linear and obtuse smooth or rough-margined leaves. Flowers usnally nodding on solitary or umbelled peduncles at the summit of the branches. Onr species

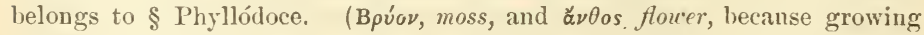
among mosses.)

1. B. taxifòlius, Gray. Calyx pubescent; corolla oblong-ırn-shaped, 5-toothed, purplish, smooth; style included. (Plyllodoce taxifolia, Salisb.) Alpine summits of the mountains of $\mathrm{X}$. H. and Maine, and northward. July. 


\section{K Á L M I A, I. Americas Lacrél.}

Calyx 5-parted. Corolla between wheel shaped aud hell-shaped, 5-lohed, furnished with 10 depressions in which the 10 anthers are severally loulged; filaments long and threal-form. Capsule globose, 5-celled, many-seceded. kvergreen mostly smooth shrubs, with alternate or opposite entire coriaceus leaves, naked buds, and showy flowers. (Dedicated to l'cter Kulm, a pupil of Limnans, who travelled in this country about the middle of the last century, afterwarls P'rofessor at $\Lambda$ bo.)

$\$ 1$. Flowers in simple or clustered naked umbel-like rorymlss; pedirels from the axils of small and firm folinceons porsistent bracts; caly.r smaller than the pod, persistent; leuves and brauches glabrous, or nearly so.

1. K. latifolia, L. (Calico-besir. Motxtais Latrie. Spoox-wonto.) Lraces mostly alternute, bright green both sides, ovate-lunseolute or ohlong, acute at each end, petioled; flowers profuse, large and very showy, varying from deep rose-color to nearly white; corymbs terminal, many-flowered, clammypubescent; pod depressed, glandular. - Rocky hills and damp soil, Canada and Maine, chiefly along the mountains to $\mathrm{W}$. Fla., west to Ohio, Ky., and Tenn. Usually a shrub $4-8^{\circ}$ high, but in the mountains from I'enn. sonthward forming rlense thickets and often tree-like $\left(10-30^{\circ}\right.$ high). May, June.

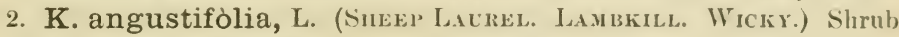
$1-3^{\circ}$ high; leaves commonly opposite or in threes, pale or whitish underneath, light green above, narrouly oblong, obtuse, petioled; corymbs lateral (appearing later than the shoots of the season), slightly glandular, many-flowered; pod depressed, nearly smooth; pedicels recurved in fiuit.-Hillsides, Newf. to Mich., south to N. Ga.; common. May, June. The flowers more crimson and two thirds smaller than in the last.

3. K. glaùca, Ait. (PAle LACrin.) Branchlets 2-edged; lentes opposite, nerrly sessile, oblong, white-glancous beneath, with revolute margins; ('orymbs terminal, few-flowered, smooth; bracts large; flowers $\frac{1}{2}$ broal, lilac-purple; pod orvil, smooth. - Cold peat-bogs and mountitus, Newf. to Penn., Minn., and northward. May, June. - Straggling, about $10 \mathrm{high}$.

\$2. Flowers scattered, solitury in the uxils; caly, leafy, larger thun the porl, nearly equalling the corolla, deciduous; leaves and branches bristly-hairy.

4. K. hirsùta, Walt. Branelies telete; leaves oblung or lanceolate (t" long), becoming glabrous. - Sandy pine-barren swamps, S. E. Va. to Fla. May - Sept. - Shrub $1^{\circ}$ high; corolla rose-color.

\section{MENZIESIA, Smith.}

Calyx very small and flattish, 4-tootlied or 4-lobed. Corolla cylindraceousurn-shaped and soon bell-shaped, oltusely 4-lobed. Stamens 8, included; anther-cells opening at the top by an oblique pore. Capsule ovoid, woody, 4-celled, 4-valved, many-seeded. Seeds narrow, with a loose coat. $-\Lambda$ low shrul); the straggling branches and the alternate decidnous leaves usually hairy and eiliate with rusty rather thaff-like bristles. Flowers small, cleveloperl with the leaves, in terminal clusters from sealy buils, greenish-white and purplish, nodling. (Namerl for Archibuld Mcnzies, who in Vanconver's royage brought the original species from the Northwest Coast.) 
1. M. glabélla, Gray. Strigose-chaffy scales mostly wanting; leares obovate, barely mucronate-tipped, glalrous or nearly so (1-2'long); filaments ciliate below; capsule glabrous or nearly so; seeds long-caudate at euch end. Minnesota Point, L. Superior, and northwestward.

2. M. globulàris, Salisb. More or less chaffy, $2-5^{\circ}$ high; leares obovate-oblong, prominently glandular-mucronate, strigose-hirsute especially above; filaments glabrous; capsule beset with short gland-tipped bristles; seeds merely apiculate. (M. ferruginea, var. globularis, of Manual.) - In the Alleghanies from Penn. to Ga.

\section{RHODODENDRON, L. Rose BAY, Azalea, etc.}

Flowers almost always 5-merous. Calyx mostly small or minute. Corolla various (but not contracted at the orifice), lobed or cleft, or even parted, often somewhat irregular. Stamens sometimes as few as the corolla-lobes, more commonly twice as many, usually declined; anther-cells opening by a round terminal pore. Capsule 5-celled, 5-valved, many-seeded. Seeds scale-like. Shrubs or small trees, of diverse habit and character, with chiefly alternate entire leaves, and large and showy flowers in umbelled clusters from large scaly-bracted terminal buds. ('Po $\delta \delta \delta \in \nu \delta \rho \circ \nu$, rose-tree; the ancient name.)

§ 1. AZALEA. Leaves deciduous, glandular-mucronate; stamens (5 to 10) and style more or less exserted and declined.

* Flouer-buds of numerous much imbricated scales; corolla with conspicuous funnel-form tube; stamens (chiefly 5) and style long-exserted; 3-10 $0^{\circ}$ igh, with leaves obovate to oblong-oblanceolate.

+- Flowers appearing after the leaves.

1. R. arboréscens, Torr. (Sмоотн Azalea.) Branchlets sniooth; lenves obovate, obtuse, very smooth both sides, shining above, glaucous beneath, the margins bristly-ciliate; calyx-lobes long and conspicuous, corolla slightly clammy. (Azalea arborescens, Pursh.) - Mountains of Penn. to N. C. June. Rose-colored flowers very fragrant.

2. R. viscosum, Torr. (Clamy A. White Swamp-Hoveysckle.) Branchlets bristly, as well as the margins and midrib of the oblong-obovate otherwise smooth leaves; calyx-lobes minute; corolla clammy, the tube much longer than the lobes. (Azalea viscosa, L.) - Swamps, mostly near the coast, Canada and Maine, to Fla. and Ark. June, July. - Var. GLAÙcuM, Gray. Leaves paler, often white-glaucous underneath or on both sides, sometimes rough-hairy. N. Eng. to Va. - Var. Nfтrdu, Gray. Dwarf, with oblanceolate leaves green both sides. Mountains, N. Y. to Va.

+ + Flowers appearing before or with the leaves.

3. R. nudiflorum, Torr. (Purple A. Pinxter-flower.) Leaves lowny underneath; tube of the corolla scarcely longer than the ample lobes, slightly glandular. (Azalea nudiflora, L.) - Swamps, Canada to Fla., Ill., Mo., and Tex. April, May. The showy flowers vary from flesh-color to pink and purple. There are numberless varieties, some of them with 10 stamens.

4. R. calendulàceum, Torr. (Flame-colored AzAle..) Leaves lairy; tube of the corolla shorter than the lobes, hairy. (Azalea caleudulacea, 
Michx.) - Wonds, mountains of Penn. to Ga. May. Covered just when the leaves appear with a profusion of large orange blussoms, usually turuing to flame-color, not fragrant.

* * Flower-buds of fewer and early caducous scales; corolla irregular, with short or hardly any tube, anteriorly divided to the base; the limb equalling the 10 stamens and style.

5. R. Rhodora, 1)on. Young parts sparingly strigose-hairy ( $1-2^{\circ}$ high); leaves oblong, pale, more or less pubescent; corolla hardly l' long, purplishrose-color, bilabiate, with the posterior lip 3-lobed, the anterior of 2 oblonglinear and recurving nearly or quite distinct petals. (Rhodora Canadensis, L.) - Cool bogs, Newf. and N. Eng. to mountains of Penn.

§ 2. RHODOIEENIRON proper. Leaves coriacens and persistent; stamens (commonly 10) and style rarely exserted, somewhat declined, or sometimes equally spreading.

6. R. máximum, L. (Great Laurel.) Leaves 4-10' long, very thick, elliptical-oblong or lance-oblong, acute, narrowed toward the base, very smooth, witl somewhat revolute margins; pedicels viscid; corolla bell-shaped, $l^{\prime}$ broad, pale rose-color or nearly white, greenish in the throat on the upper side, and spotted with yellow or reddish. - Damp deep woods, rare from Maine to Ohio, but very common through the Alleghanies from N. Y. to Ga. July. - Shrub or tree $6-35^{\circ}$ high.

7. R. Catawbiénse, Michx. Leaves oral or oblong, rounded at both ends, smooth, pale beneath ( $3-5^{\prime}$ long); corolla broadly bell-shaped, lilac-purple; pedicels rusty-downy. - High Alleghanies, Va. to Ga. June. Shrub $3-6^{\circ}$ (rarely $20^{\circ}$ ) high.

8. R. Lappónicum, Wahl. Duarf, prostrate in broad tufts ( $6^{\prime}$ high); leaves ( $\frac{1^{\prime}}{2}$ long) elliptical, obtuse, dotted (like the branches) with rusty scales; umbels few-flowered; corolla open bell-shaped, dotted, violet-purple; stamens 5-10. - Alpine summits of northern N. Y. and N. Eng., to the Arctic Coast. July. (Arct. Eu. and Asia.)

\section{LEDU M, I. LABRADOR TEA.}

Calyx 5-toothed, very small. Corolla of 5 obovate and spreading distinct petals. Stamens 5-10; anthers opening by terminal pores. Capsule 5-celled, splitting from the base upward, many-seeded; placenta borne on the summit of the columella. - Low shrubs, with the alteruate entire leares clothed with rusty wool underneath, persistent, the margins revolute; herbage slightly fragrant when bruised. Flowers white, small, in terminal umbel-like clusters from large scaly buds; bracts or scales thin and caducous. $(\Lambda \hat{\eta} \delta o \nu$, the ancient Greek name of the Cistus.)

1. L. latifolium, $A$ it. Erect, $1-3^{\circ}$ high; leaves oblong or linear-oblong ( $1-2^{\prime}$ long), mostly $\frac{1}{2}{ }^{\prime}$ wille, very obtuse; stamens $5-7$; capsule oblong, acutish. - N. Lng. to I'enn., Mich., Minn., and northward, in cold bogs and mountain woods.

L. Palústre, L., with linear leaves, 10 stamens, and short-uval capsule, is found in Newfoundland and northwestward. (Eu.) 


\section{LEIOPHÝLLU M, Pers. Saxi Myrtle.}

Calyx 5-parted. Corolla of 5 distinct obovate-oblong petals, spreading. Stamens 10, exserted; anthers opening lengthwise. Style filiform. Capsule 2-3-celled, splitting from the apex downward, many-seeded.-A low muchbranched evergreen, with the aspect, foliage, etc., of the last genus, but the crowded leaves sometimes opposite, scarcely petioled. Flowers small, white, in terminal umbel-like clusters. (Name formed of $\lambda \epsilon \hat{\imath} o s$, smooth, and $\phi u ́ \lambda \lambda o \nu, l e a f$.)

1. I. buxifolium, Ell. Shrub 6-10' high; leaves oval or oblong, smooth and shining, 3-6" long. - Sandy pine barrens, N. J. to Fla. May.

\section{LOISELEÙRIA, Desv. Alprye AzłleA.}

Calyx. 5-parted, nearly as long as the bell-shaped and deeply 5-cleft regular corolla. Stamens 5, not declined, included; anthers opening lengthwise. Style short. Capsule ovoid, 2-3-celled, many-seeded, 2-3-valved; valves 2cleft from the apex; placentæ borme on the middle of the columella. - A small depressed shrubby evergreen, much branched and tufted, smooth, with coriaceous opposite elliptical leaves, on short petioles, with revolute margins. Flowers small, white or rose-color, 2-5 in a cluster, from a terminal scaly bud; scales or bracts thick and persistent. (Named for Loiseleur-Delongchamps, a French botanist.)

1. L. procúmbens, Desv. - Alpine summits of the White Mountains, N. H., and northward. June. (Eu., Asia.)

\section{CLÈ Th A, Gronov. Winte Alder.}

Calyx of 5 sepals, imbricated in the bud. Corolla of 5 distinct obovate-oblong petals. Stamens 10, often exserted; anthers arrow-shaped, erect in the bud, becoming inverted and opening by basal pores or short slits. Style slender, 3-cleft at the apex. Capsule 3-ralved, 3-celled, many-seeded, enclosed in the calyx. - Shrubs or trees, with alternate serrate deciduous leaves, and white flowers in terminal hoary racemes. Bracts deciduous. (K $\lambda \hat{\eta} \theta \rho \alpha$, the ancient Greek name of the Alder, which this genus somewhat resembles in foliage.)

1. C. alnifòlia, L. (Sweet Pepperbusir.) Shrub $3-10^{\circ}$ high; leaves werlge-obovate, sharply serrate, entire toward the base, prominently straightveined, smooth, green both sides, racemes upright, panicled; bracts shorter than the flowers: filaments smooth. - Wet copses, Maine to Va., near the coast, and southward. Covered in July and August with handsome fragrant blossoms.

2. C. acuminàta, Michx. A tall shrub or small tree; leaves oval or oblong, pointed, thin, finely serrate $\left(3-7^{\prime} \mathrm{long}\right)$, pale beneath; racemes solitary, drooping; bracts longer than the flouers; filaments and pods hairy. - Woods in the Alleghanies, Va. to Ga. July.

\section{CHIMÁ PHILA, Pursh. Pipsissewa.}

Petals 5, concave, orbicular, widely spreading. Stamens 10; filaments enlarged and hairy in the middle ; anthers as in Pyrola, but more or less conspicuously 2-horned. Style very short, inversely conical, nearly immersed in the depressed summit of the globular ovary ; stigma broad and orbicular, diskshaped, the border 5-crenate. Capsule, etc., as in Pyrola, but splitting from 
the apex downward, the edges of the valves not woolly - Low, nearly herbaceous plants, with long running undergromul shoots, and evergreen thick and shining leaves, somewhat whorled or seattered along the short ascending stems ; the fragrant (white or purplish) flowers corymbed or umbelled on a terminal peduncle. (Name from $\chi \epsilon \hat{\imath} \mu \alpha$, vinter, and $\phi: \lambda \epsilon ́ \omega$, to loce, in allusion to one of the popular names, viz., Wintergreen.)

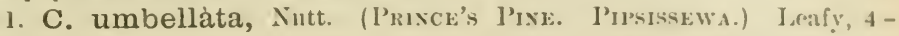
10 high; leaves uedye-tancealute, sharply serrate, not spotled; peduncles $4-7$ flowered; petals flesh-eolor; anthers violet. - I)ry woods, Nova Seotia to Gia., west to the l'acific. June. (liu.)

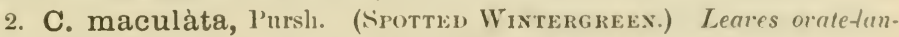
ceolate, obtuse ut the lase, remotely toothed, the upper surface raviegated with uhite; peduncles 1-5-flowered.-1)ry wools, N. Eng. to Ga., west to Minn. and Miss. June, July. - Plant 3-6' high.

\section{MONESES, Salisb. ONE-FLOWlei, PYrola.}

Petals 5, widely sprealing, orbicular. Filaments awl-shaped, naked; anthers as in l'yrola, but conspicuously 2-horned. Style straight, exserted: stigma large, peltate, with 5 narrow and conspicuous raliating lobes. Valves of the capsule naked. (Flowers occasionally tetramerous.) Sicape I-flowered. ()therwise as l'yrola; intermediate between it and Chimaphila. (Name formed of $\mu$ óvos, single, and $\hat{\eta} \sigma \iota s$, delight, from the pretty solitary flower.)

1. M. grandiflora, Salisb. A small perenuial, with the rounded and veiny serrate thin leaves $\left(6-9^{\prime \prime}\right.$ long) (lustered at the ascending apex of creeping subterrancan shoots; the $1-2$-bracted scape $\left(2-t^{\prime}\right.$ high) bearing a white or rose-colored terminal flower 6" wile. (M. unithora, Gray.) - 1)eep cold woods, Labrador to Peun., Ind., Minn., and westward. June. (Eu.)

\section{PÝROLA, 'Toum. Wintergrene. Shin-leal,}

Calyx 5-parted, persistent. l'etals 5, concave and more or less converging, deciduous. Stamens 10; filaments awl-shaped, naked: anthers extrorse in the bud, but in the flower inverted by the inflexion of the apex of the filament, more or less 4-celled, opening by a pair of pores at the blunt or somewhat 2-horned base (by inversion the apparent apex) style generally loug; stigma 5-lobed or 5-rayed. Capsule depressed-globose, 5-lobed, 5-celled, 5 . valved from the base upward (loculicilial); the valves colbwebby on the edges. Seeds minute, innumerable, resembling sawdust, with a vory luse cellular-reticulated coat. - Low and smooth perennial herbs, with running subterranean shoots, bearing a cluster of rounderl petioled evergreen rootleaves, and a simple raceme of nolding flowers, on an upright more or lexs sealy-bracted scape. (Name a diminutive of Pyrus, the l'ear-tree, from some fancied resemblance in the foliage.)

* Style straight, much narrover thun the peltate 5-rayed stigma, petais and stamens erect and connivent; unthers not narroxed belou the openings.

1. P. minor, I. Seape 5-10' high; leaves roundish, slightly crenulate, thickish, mostly longer than the margined petiole flowers small, crowilerl, white or rose-color; calyx-lobes triangular-ovate, very much shorter than the 
nearly globose corolla: style short and included.-Cold woods, Lab., White Mts., L. Superior, and northward.

2. P. secúnda, L. Subcaulescent, $3-6^{\prime}$ high ; leaves ovate, thin, longer than the petiole, scattered, finely serrate; racemes dense and spike-like, the numerous small (greenish-white) flowers all turned to one side, scarcely nodding; calyx-lobes ovate, very much shorter than the oblong-oval petals; style iong. exserted. - Rich woods, Lab. to Minn., south to Md., and far northward. July. (Eu.)

Var pùmila, Gray, is a smaller form, with rounded leaves $6^{\prime \prime}$ or little more in diameter, and 3-8-flowered scape. - High peat-bogs, N. Y. to L. Superior, and northward. July, Aug.

* * Style strongly declined, the apex curved upward, longer than the connivent or spreading petals; stıgma much narrower than the truncate excavated ring-like apex of the style; anthers contracted below the openings, forming a short neck; leaves denticulate or entire.

- Petals and leaves acute, the latter ovate, coriaceous.

3. P. oxypétala, C. F. Anstin. Leaves ovate, small (8-12" long), shorter than the slender petiole; scape $\left(7-8^{\prime}\right.$ high) several-flowered; flowers on ascending pedicels, not nodding ; calyx-lobes triangular-ovate, acute, short ; petals lanceolate-oblong, acuminate, greenish; anthers conspicuously mucronate at the apex, obtusely 2-horned at base, not inverted; style straightish, scarcely exserted. - Wooded hill near Deposit, Delaware Co., N. Y. (C. F. A ustiu, in 1860). Not since found; probably monstrous.

+ + Petals and leaves orbicular to oblong, very obtuse.

4. P. chlorántha, Swartz. Leaves small (1'long), roundish, thick, dul', shorter than the petiole; scape few-flowered, naked $\left(5-8^{\prime}\right.$ high); calyx-lobes roundish-ovate, very short; the elliptical petals converging (greenish-white); anther-cells contiacted into a distinct neck; style little exserted. - Open woods, Lab. to Penn., Minn., north and westward. June, July.

5. P. ellíptica, Nutt. (Shrx-LeAf.) Leaves thin and dull, elliptical or oborate-oval, louger thun the margined petiole; raceme many-flowered; calyxlobes ovate, arute, not one fourth the length of the obovate rather spreading (greenish-white) petals: anther-cells blunt.-Rich woods, N. Eng. to Md., Iowa, Minn., and northward. June.

6. P. rotundifolia, L. Leaves orbicular, thick, shining, usually shorter than the petiole; scape many-bracted $\left(6-12^{\prime}\right.$ high) ; raceme elongated, manyflowered; calyx-lobes lanceolate or oblong-lanceolute, acutish, with somewhat spreading tips, one half or one third the length of the roundish-obovate rather spreading (chiefly white) petals: anther-cells nearly blunt.-Damp or sandy woods, throughout the continent, south to N. Ga. Exhibits many varieties, such as: Var. INCARNATA, I)C., with flesh-colored to rose-purple flowers, and triangular-lanceolate calyx-lobes. Cold woods and bogs, N. Eng. to Minn., and northward. - Var. AsARIFòlı, Hook., with oblate or round-reniform leaves, and shorter orate calyx-lobes; petals flesh- or rose-colored (rarely white). With same range. - Var. ULIGrooss, Gray, with short broadly ovate calyx-lohes, subcorlate to obovate dull leaves, and rose-colored or purple flowers Same range. (Eu.) 


\section{PTERós POR A, Nutt. I'INe-Inors.}

Calyx 5-parted. Corolla ovate, urn-shaped, 5-toothed, persistent. Stamens 10; anthers 2-celled, awned on the back, opening lengthwise. Style short; stigma 5-lubed. Capsule globose, depressed, 5-lobed, 5-celled, loculicidal, but the valves cohering with the columella. Seeds very numerous, ovid, tapering to each end, the apex expauded into a broad reticulated wing many times larger than the boly of the seed. $-\Lambda$ stout and simple jurplish-brown clammy-pulescent root-parasitic herb $\left(1-2^{\circ}\right.$ ligh $)$; the wand-like stem furnished towards the base with scattered lanceolate scales in place of leaves, above hearing many nodding (white) flowers, in a long bracted raceme. (Name from $\pi \tau \epsilon \rho o ́ \nu, ~ a ~ w i n g$, and $\sigma \pi o p a ́$, seed, alluding to the singular wing burne by the secils.)

1. P. Andromedea, Nutt. - Hard clay soil, parasitic apparently on the roots of pines, from W. New ling. to N. l'enu., N. Mich., and westward; rare.

\section{S CH W E I I I TZI A, Ell. Sweet PiNe-SAl?}

Calyx of 5 oblong-lanceolate acute scale-like sepals, erect, persistent. Corolla persistent, bell-shaped, rather fleshy, 5-lobed, slightly 5-gibbous at the base. Stamens 10; anthers much shorter than the filaments, fixed near the summit, awnless; the two sac-shaped cells opening at the top. Capsule ovoid, 5-celled, with a short and thick style, and a large 5-augular stigma. Seeds innumerable. $-\Lambda$ low and smooth brownish plant, $3-4^{\prime}$ high, with the aspect of Monotropa, scaly-bracted, the flowers several in a terminal spike, at first nodding, flesh-color, with the fragrance of violets. (Named for the late L. D. von Schweinitz.)

1. S. odoràta, Ell. - Wuods, parasitic on the roots of herbs, Md. (uear Baltimore) to N. C. April.

\section{MONÓTROPA, I. Indax Pipe. Pixe-sap.}

Calyx of 2-5 lanceolate bract-like scales, deciduous. Corolla of 4 or 5 separate erect spatulate or welge-shaped scale-like petals, which are gibbous or saccate at the base, and tardily deciduous. Stamens 8 or 10 ; filaments awlshaped; anthers kidney-slaped, becoming l-celled, opening across the top. Style columnar; stigma disk-like, 4-5-rayed. ('apsule ovoid, 8-10-grooverl, 4-5-celled, loculicidal; the very thick placenta coveres with innumerable minute seeds, which have a very loose coat. - Low aud fleshy herhs, tawny, redelish, or white, parasitic on roots, or growing on decomposing vergetable matter like a Fungus; the clustered stems springing from a ball of matted fibrons rootlets, furnished with scales or bracts in place of leaves, I-severalflowered; the summit at first nolding, in fruit erect. (Name composed of

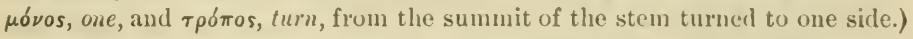

§ 1. MONOTROPA proper. Plant inndorous, 1-flowered; caly $x$ of $2-4 \mathrm{ir}$ regular scales or bracts; anthers transverse, apening equally by 2 chinks; style short and thick.

1. M. uniflora, I. (Ismax Prpe. Corpse-Plaxt.) Smooth, waxywhite (turning blackish in drying, 3-8' high); stigma naked. - Dark and rich woods, nearly throughout the continent. June-Aug. ( $\Lambda$ sia.) 
§ 2. HYPÓPITYS. Plant commonly fiagrant; flowers several in a scaly raceme; the terminal one usually 5-merous, the rest 3-4-merous; bract-like sepals mostly as many as the petals; anthers opening by a continuous line into 2 very unequal valves; slyle longer than the oxary, hollow.

2. M. Hypópitys, L. (Prive-sap. False Beech-drops.) Somewhat pubescent or downy, tawny, whitish, or reddish (4-12' high); pod globular or oval; stigma ciliate. - Oak and pine woods, from Canada to Fla., west to Oregon. June-Aug. (Ěu.)

\section{Order 59. DIA PENSIACEAE.}

Low perennial herbs or suffiuticulose tufted plants, glabrous or nearly so, with simple leaves, no stipules, regular 5-merous flou'ers (except the 3celled ovary), stamens adnate to the corolla and sometimes monadelphous (those opposite its lobes when present reduced to staminorlia); pollen simple; loculicidal capsule and seeds of Ericaceæ. - Flowers solitary or racemose. Style 1, with 3-lobed stigma. Distinguished from the Ericaceæ chiefly by the insertion of the stamens upon the corolla.

Tribe I. DIAPENSIEAE. Dwarf woody evergreens, with small entire crowded coriaceous leaves. Staminodia none; filaments adnate to the campanulate corolla up to the simuses; anthers 2-celled. Calyx conspicuously bracteolate. Flowers solitary.

1. Pyxidanthera. Flowers sessile on short leafy branchlets. Anther-cells awn-pointed at base, opening transversely.

2. Diapensia. Flower (or at least fruit) on a scape-like peduncle. Anther-cells blunt, obliquely dehiscent.

Tribe II. GALACINEA. Acaulescent, with creeping rootstocks sending up longpetioled evergreen leaves, and a 1 -several-flowered scape. Staminodia present.

3. Galax. Calyx minutely 2-bracteolate. Stamens monadelphous : anthers 1-celled.

\section{PYXIDA NTHERA, Michx.}

Sepals thin. Anther-cells awn-pointed at base, opening by a strictly trausverse line. Otherwise much as in I)iapensia. - Prostrate and creeping, with narrowly oblanceolate and awl-pointed leaves, mostly alternate on the sterile hranches and somewhat hairy near the base. Flowers solitary and sessile, very numerous, white or rose-color. (Name from $\pi v \xi$ 's, a small box, and $\dot{\alpha} \nu \dot{\theta} \dot{\rho} \rho$, anther, the anther opening as if by a lid.)

1. P. barbulàta, Michx. (Flowerisg Moss. Prxie.) Leaves $3^{\prime \prime}$ long. - Sandy pine barrens of N. J. to N. C. April, May.

\section{DIA P É N I A, L.}

Calyx of 5 concave imbricated coriaceous sepals. Corolla bell-shaped, 5lobed; lobes rounded. Filaments broad and flat, adherent to the corolla up to the sinuses, short; anthers adnate, of 2 ovoid pointless cells, diverging below, each opening therefore by a transverse-descending line. Capsule, enclosed in the calyx, cartilaginous; cells few-seeded. - Alpine, growing in very dense convex tufts, with the stems imbricated below with cartilaginous narrowly spatulate mostly opposite leaves, terminated by a scape-like 1-flowered peduncle, 3 -bracted under the calyx. Corolla white ( $\frac{1^{\prime}}{2}$ wide). (Said to be an 
ancient Greek name of the Sanicle, of obscure meaning, strangely applied by Limnixus to this plant.)

1. D. Lappónica, L. Leaves $3-5^{\prime \prime}$ long; pecluucle at length $1-2^{\prime}$ long. - Alpine summits of $N$. Eng. and N. Y., and northward to Lab. and the Arctic coast. July. (Eu., Asia.)

\section{G À L A X, I.}

Calyx 5-parted, imbricate, persistent. l'etals 5, hypogynous, obovate-spatulate, rather erect, decicluons. Filiments muited in a lo-toothed tube, slightly colering with the hase of the petals, the 5 teeth opposite the petals naked, the alternate ones shorter and bearing romdish l-celled anthers, which open across the top. Style short, stigma :3-lobed. Capsule ovoid, 3-celled; columella none. Seeds numerous, the cellular loose coat tapering to each end. livergreen herb, with a thick matted tuft of scaly ('reeping rootstocks, beset with fibrous red roots, sending up round-heart-shaped crenate-toothed and veiny shıning leaves (about ' 2 ' wille) on slender petioles, and a slender naked scape, $1-2^{\circ}$ high, bearing a wand-like spike or raceme of small and minutely-

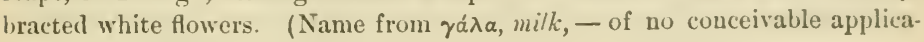
tion to this plant.)

1. G. aphýlla, L. - Open woods, Va. to Ga. Juue.

\section{()rina 60. PLUMBAGINÄCEAE. (Leadwort Famly.)}

Marlime herls, with regular 5-merous flowers, a plaited calyx, the 5 stamens opposite the separate pelals or the lobes of the corolla, and the free ovary one-celled, with a solitary orule hanging fiom a long cord which rises from the base of the cell. - Only the Statíced: or Marsh-Rosmari Tribe is represented in our region, in gardens by the Thrift (Armèria vulgàris), on the coast by a single species of

\section{S Tá T I C E, Tourn. Sea-Lavender. Marsi-Rosemary.}

Flowers scattered or loosely spiked and 1-sided on the branches, 2-3-bracted. Calyx funnel-form, iry and membranaceous, persistent. Corolla of 5 nearly or quite distinct petals, with long claws, the 5 stamens severally attached to their bases. Styles 5, rarely 3, separate. Fruit membranous and indehiscent, in the bottom of the calyx. Embryo straight, in mealy albumen. - Sea-sicle pereunials, with thick and stalked radical leaves; the naked flowering stems or scapes branched into panicles ( $\Sigma_{\tau \alpha \tau \iota \kappa}$, an ancient name given to this or some other herb, on accuunt of its astringeney)

1. S. Limonium, I. Root thick and woody, very astringent; leaves oblong, spatulate or olsovate-lanceolate, l-ribbed, tipped with a deciduous bristly point, petioled ; scape much-branched, corymbose-panicled ( $1-2^{\circ}$ high); spikelets 1 -3-flowered; flowers lavenler-color; calyx-tube hairy on the angles, the lobes ovate-triangular, with as many teeth in the sinnses. (Eu.)

Var. Caroliniàna, Gray, the plant of the Northerı States, has more erect branches, rather panicled inflorescence with at length seattered flowers, and very acute or acuminate calyx-lobes. - Salt marshes aloug the coast, from Lab. to Tex. Aug., Sept. 


\section{Order 61. Primulàceze. (Primrose Family.)}

Herbs, with simple leaves, and regular perfect flowers, the stamens as many as the lobes of the monopetalous (rarely polypetalous) corolla ana inserted opposite them (on the tube or base), and a 1-celled ovary with * central free placenta rising from the base, bearing several or many seeds. Calyx free from the ovary, or in Samolus partly coherent. (Corollia none in Glaux.) Stamens 4 or 5, rarely 6 or 8 . Style and stigma one. Seeds with a small embryo in fleshy albumen. Ovules amplitropous, except in Tribe $\mathrm{I}$.

Tribe I. HOTTONIEAE. Ovary wholly free ; ovules anatropous. Aquatic ; immersed leaves pectinate.

1. Hottonia. Corolla short salver-form. Flowers verticillate and racemose.

Tribe II. PRIMULEA. Ovary wholly free.

* Stemless, leaves all in a cluster from the root; capsule dehiscent by valves or teeth.

2. Dodecatheon. Corolla reflexed, 5-parted. Stamens exserted, connivent in a cone.

3. Primula. Corolla funnel-form or salver-shaped, open at the throat. Stanens included.

4. Androsace. Corolla short, very small, constricted at the throat. Stamens included.

* Stems leafy ; corolla rotate (none in Glaux); leaves entire.

+ Capsule dehiscent vertically by valves or irregularly, mostly globose.

5 Trientalis. Corolla mostly $\boldsymbol{\imath}$-parted. Stem leafy only at the summit.

6. Steironema. Cornlla 5-parted. Five slender staminodia between the fertile stamens.

7. Lysimachia. Corolla 5-6-parted or 5-6-petalled. Staminodia none. Leaves dotted

8. Glaux. Corolla none ; the calyx petal-like. Flowers axillary.

+ - Globose capsule circumscissile, the top falling off as a lid ; flowers axillary.

9. Anagallis. Corolla longer than the calyx, 5-parted. Leaves opposite.

10. Centunculus. Corolla shorter than the calyx, 4-5-cleft. Leaves alternate.

Tribe III. SAMOLEA. Ovary connate at base with the base of the calyx.

11. Samolus. Corolla bell-shaped, with 5 staminodia in the sinuses. Flowers racemose.

\section{1. hottònia, L. Featherforl. Water Violet.}

Calyx 5-parted, the divisions linear. Corolla salver-shaped, with a short tube; limb 5-parted. Stamens 5, included. Capsule many-seeded, 5-valved; the valves cohering at the base and summit. Seeds anatropous. - Aquatic perennials, with pectinate immersed leaves, and the erect hollow flower-stems almost leafless. Flowers white or whitish, whorled at the joints, forming an interrupted raceme. (Named for Prof. Hotton, a botanist of Leyden.)

1. H. inflàta, Ell. Leaves dissected into thread-like divisions, scattered on the floating and rooting stems, and crowded at the base of the cluster of peduncles, which are strongly inflated between the joints (often as thick as one's finger); pedicels short — Pools and ditches, Mass. to S. Ind., and south to the Gulf. June-Aug.

\section{DODECÀtheoN, L. American Cowslip.}

Calyx deeply 5-cleft, the divisions lanceolate, reflexed. Corolla with a very short tube, thickened throat, and 5-parted reflexed limb; the divisions long and narrow. Filaments short, monadelphous at base; anthers long and linear, approximate in a slender cone. - Perennial sinooth herb, with fibrous roots, a cluster of oblong or spatulate leaves, and a simple naked scape, involucrate 
with small hracts at the summit, bearing an ample umbel of showy flowers, nodding on slender pedicels. Corolla rose-color, or sometimes white. (Name from $\delta \omega \delta \epsilon \kappa a$, tuclce, and $\theta \epsilon o$, gods, given by l'liny to the primrose, which was beliered to be under the care of the superior gocls.)

1. D. Meàdia, L. (Suootusg-Srar.) Rich woods, P'eun. and Md. to Wise, suth tu Gia. and Tex. May, June. - Very hamdsome in cultivation.

\section{PRÍ M U L A, I. P'rmuose. Cowsir.}

Calyx tubular, angled, 5-cleft. Corolla salver-shaped, enlarging above the insertion of the stamens; the 5 lobes often notched or inversely heart-shaped. Stamens 5, included. Capsule many-seeded, splitting at the top into 5 valves or 10 teeth. - Low perennial herbs, producing a tuft of veiny leaves at the root, and simple seapes, bearing the flowers in an umbel. (Name a diminutive of primus, from the flowering of the true I'rimrose in early spring.)

1. P. farinosa, L. (Binu's-ere P'rimnose.) Seape 3-10' high; leares elliptical or obovate-lanceolate, denticulate, the lower side and the 3-20-flowered inwolucre, etc., covered with a white mealiness, at least when young; corolla pale lilac with a yellow eye. - Maine to N. shore of L. Superior, and northwarl. June, July. (Eu., Asia.)

2. P. Mistassínica, Miclix. Scape 2-6' high; leaves spatulate or wedge-oblong, thin and veiny, not mealy; involucre 1-8-flowered; lobes of the flesh-colored corolla broadly and deeply obcordate. - Wet banks and shores, northern N. Eng. and N. Y. to L. Superior, and northward. May. (Eu.)

\section{ANDRÓSACE, Tourn.}

Calyx 5-cleft; tube short. Corolla salver-shaperl or fuunel-form; the tube shorter than the calyx, contracted at the throat; limb 5-parted. Stamens and style included. Capsule 5-valved. - Small herbs, with clustered root-leaves, and very small solitary or umbelled flowers. (An ancient Greek name of a polyp, formerly believed to be a plant.)

1. A. occidentàlis, Pursh. Smoothish amual; scapes diffuse $\left(2-4^{\prime}\right.$ high), many-flowered; leaves and leaflets of the involucre oblong-ovate, entire, sessile; calyx-lobes leafy, triangular-lanceolate, longer than the (white) corolla. - Bare hills, from Minn. to Ill. aud Ark., aud west to the mountains.

\section{TRIENTÁ LIS, I. Chickwed-Wintergiex.}

Calyx mostly 7-parterl; the divisions linear-lanceulate, pointel. Corolla mostly 7 -parted, spreading, fat, withont tube. Filaments slender, mited in a ring at the base; anthers oblong, revolute after flowering. Capsule few-seeded. - Low and smooth peremials, with simple erect stems, bearing a few alternate usually minute and scale-like leaves helow, and a whorl of thin veiny leaves at the summit. P'eluncles one or more, very slender, hearing a delicate white and star-shaped flower. ( $A$ Latin name, meaning the third part of a foot, alluding to the height of the plant.)

1. T. Americàna, Pursh. (Stalt-Flowkr.) Spreading by very slender elongated rootstocks ; leaves elongated-lanceolate, tapering to both ends ; petals finely pointed. - Damp cold woods, from Lab. to Minn., south to N. Ind., and the mountains of Va. May. - Rootstocks often 1-2 $2^{\circ}$ loug (Hitchings). 


\section{STEIRON È A, Raf.}

Calyx 5-parted Corolla rotate, with no proper tube, deeply 5-parted, the sinuses rounded; divisions ovate, cuspidate-pointed, erose-denticulate above, each separately iuvolute around its stamen. Filaments distinct or nearly so on the ring at base of corolla, alternating with 5 subulate staminodia; anthers linear. Capsule 10-20 seeded. - Leafy-stemmed perennials, glabrous except the ciliate petioles, not punctate, the leaves all opposite, but mostly in seeming whorls on the flowering branches. Peduncles slender, axillary, bearing yellow

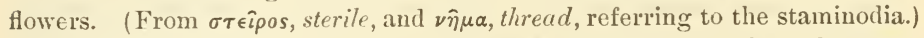

1. S. ciliàtum, Raf. Stem erect $\left(2-4^{\circ}\right.$ high); leures lanceolate-ovate $\left(2-6^{\prime}\right.$ long), tapering to an acute point, rounded or heart-shaped at base, all on loug and fringed petioles; corolla longer than the calyx. (Lysimachia ciliata, L.) - Low grounds and thickets, common. July.

2. S. radicans, Gray. Stem slender, soon reclined, the elongated branches often rooting in the mud; leaces ovate-lunceolate, mostly rounded at base, on slender petioles; corollit about the length of the calyx. (Lysimachia radicans, Hook.) - Swampy river-banks, W. Va. to Ark. and La. - Leaves and flowers nearly one half smaller than in the last.

3. S. lanceolàtum, Gray. Stem erect $\left(10^{\prime}-2^{\circ}\right.$ high $)$; leaves lanceolate, varying to oblong und linear, nurroued into a short margined petiole or tapering base, or the lowest short and broad on long petioles. (Lysimachia lanceolata, Wralt.) - Low grounds and thickets, Ont. to Fla., Dak., and Tex. Polymorphous; the extremes are var. IIŕbridus, Gray, with cauline leaves from ob. long to broally linear, common north and west, - and var. AxGUSTIFólicm, Gray, with stems more branched, a span to $2^{\circ}$ high, and the cauline leaves linear, acute at both ends, more sessile, 1-2" broad; mainly southward.

4. S. longifòlium, Gray. Stem erect, 4-angled, slender ( $1-3^{\circ}$ high), often branched below; stem-leares sessile, narroxly linear, elongated (2-4' long, $2-3^{\prime \prime}$ wide), smooth and shining, rather rigid, obtuse, the margins often a little revolute, the veins obscure; the lowest oblong or spatulate; corolla $\left(8-9^{\prime \prime}\right.$ hroal) longer than the calyx, the lobes conspicuously pointed. (Lysimachia longifolia, Pursh.) - Banks of streams, from western N. Y. to Va., Minn., and Iowa July-Sept.

\section{LY SIMÁ CH I A, Tourn. Loosestrife.}

Calyx 5-6-parted. Corolla rotate, the divisions entire, convolute in bud. Filaments commonly monadelphous at base; anthers oblong or oval ; staminodia none. Capsule few-sereral-seeded. - Leafy-stemmed perenuials, with herbage commonly glandular-dotted. (In honor of King Lysimachus, or from $\lambda \dot{v} \sigma \iota s$, a release fiom, and $\mu \alpha \dot{\chi} \eta$, strife.)

§ 1. LYSLMACHIA proper. Corolla yellow, rotate, and very deeply parted, and with no teeth between the lobes; stamens more or less monadelphous, often unequal; leaves opposite or whorled, or some abnormally alternate.

* Flowers (middle-sized) in a termunal leafy panicle; corolla without marks.

L. vulgáRIs, L., a coarse and tall European species, pubescent and branching, with ovate-lanceolate distinctly petioled leaves, and glandular filaments united to near the middle. - Naturalized in a few places in E. Mass. 
* Flowers (small) in a virgate terminal raceme or in the upper axils; coralla dark-dotted or streaked; filaments conspicuously monudelphous, unequal.

1. L. quadrifolia, I. Somewhat hairy; stem simple $\left(1-2^{\circ}\right.$ high $)$; leaves whorled in fours or fives (sometimes in twos, threes, or sixes, rarrly only opposite or partly altemate), ovate-lanceolite; flouers on long ("upillary peduncles from the axils of the leaves; lobes of the corulla ovate-oblung. Moist or sandy soil, N. Brunswick to Minn., and Ga. June.

2. L. strícta, $\Lambda$ it. Stems $1-2^{\circ}$ high, often hearing oblong or moniliform bulblets in the axils; smooth, at length liranched, very leafy; leures opposile or rarely alternate, lanceolate, acute at each end; flowers on slender pedicels in a long raceme $\left(5-12^{\prime}\right)$, leafy at base; lobes of the corolla lance-oblong. Low grounds, Newf. to Minn., Ark., and N. Ga. June-Aug.

*** Flouers (rather large) solitary in the axils of ordinary leares; corolla not dark-dotted nor streaked; filuments slightly monalelphons.

L. Numuları, L. (Moxwrokt.) Simooth: stems trailing and creeping: leaves romblish, small, short-petioled; peduncles axillary, 1-Howered; divisious of the corolla broadly ovate, ohtnse, longer than the lance-ovate calyxlobes and stanens. - Escaped from gardens intu damp ground in some places. July-sept. (Nat. from Lu.)

§ 2. NALMBÚRGIA. Corolla very deeply 5-(or 6-i-) parted into linear divisions (somewhat purplish-dotted), with a small tooth in each sinus; fila. ments distinct, equal ; leaces opposite, the lowest scule-like.

3. L. thyrsifiòa, L. ('Terten Loosestrifl.) Smooth; stem simple (1-2 $2^{\circ}$ high); all but the lower leaves lanceolate, the axils of une or two middle pairs bearing short-peduncled head-like or spike-like clusters of small light yellow flowers. - Cold swamps, from Penn. to S. 11l., Iuwa, and northwestward. June, July. (Eu.)

\section{G L A Ù X, Toum. SeA-MilKwort.}

Calyx bell-shaped, 5-cleft; lohes ovate, petal-like. Corolla wanting. Stamens 5, on the base of the calyx, alternate witl its lobes. Capsule 5-valved, few-seeded. - A low and leafy fleshy peremnial, with opposite oblong and entire sessile leares, and solitary nearly sessile (purplish and white) flowers in their

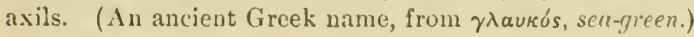

1. G. marítima, L. - Sea-shore of N. Eng. from Cape Cod northward. Also in subsaline soil, Minn. to Neb., and westward. June. (Eu.)

\section{A N A G Á L L I S, Tourn. Pimpersel.}

Calyx 5-parted. Corolla wheel-shaped, with alnost no tube, 5-parted, longer than the calyx; the clivisions hroad. Stamens 5: filaments beariled. Capsule membranacenus, circumscissile, the top falling off like a licl, many-seeded. Low, spreading or procumbent herlss, mustly anmuls, with opposite or whorled entire leaves, and solitary flowers on axillary peilnncles. ('The ancient Greek

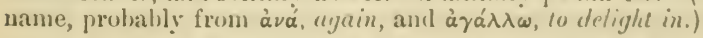

A. arvéxsis, L. (Commox Pruplenve..) Leaves ovate, sessile, shorter than the peduncles; petals oborate, obtuse, fringed with minute teeth or stalked glands. - Waste sandy ficlds. June-Aug. - Flowers varial,le in size, scarlet, sometimes purple, blue, or white, quickly closing at the approach of bad weather; whence the English popular nane of " Poor. Mun's Weather. glass." (Nat. from Eu.) 


\section{CENTÚN C U L U S, Dill. Chaffwen1.}

Calyx 4-5-parted. Corolla shorter than the calyx, 4-5-cleft, wheel-shaped, with an urn-shaped short tube, usually withering on the summit of the pod (which is like that of Anagallis). Stamens 4 or 5 ; filaments beardless. small annuals, with alternate entire leares, and solitary inconspicuous flowers in their axils. (1)erivation obscure.)

1. C. mínimus, L. Stems ascending $\left(2-6^{\prime}\right.$ long); leaves ovate, oborate, or spatulate-oblong; flowers nearly sessile, the parts mostly in fours. - Low grounds, from Ill. and Miun. to Fla. and Tex., and westward. (Eu.)

\section{SÁ MOLUS, Tourn. Water Pimpersel. Brook-weed.}

Calyx 5-cleft ; the tube allherent to the base of the ovary. Corolla somewhat bell-shaped, 5-cleft, commonly with 5 sterile filaments in the sinuses. True stamens 5, on the corolla-tube, included. Capsule globose, 5-ralverl at the summit, many-seeded. - Smooth herbs, with alternate entire leares, and small white racemed fluwers. ("According to Pliny, an ancient Druidical name.")

1. S. Valerándi, I. Stem erect $\left(6-12^{\prime}\right.$ high $)$, leafy; leaves obovate or spatulate, the basal rosulate; bracts none; slender pedicels ascending, bracteolate in the middle. (Eu.) - Var. Americànus, Gray. More slender, becoming diffuse ; racemes often panicled, the pedicels longer and spreading. - Wet places, through the L.S. June-Sept.

\section{Order 62. SAPOTÁCEA. (SAPOdlla Fayily.)}

Trees or shrubs, mostly with a milky juice, simple and entire alternate leaves (often rusty-downy beneath), small and perfect regular flowers usually in axillary clusters; the calyx free and persistent; the fertile stamens commonly as many as the lobes of the hypogynous short corolla and opposite them, inserted on its tube, along with one or more rou's of appendages and scales (or sterile stamens); anthers turned outward; ovary 4-12celled, with a single anatropous ovule in each cell; seeds large. - Albumen mostly none; but the large embryo with thickened cotyledons. Style single, pointed. - A small, mostly tropical order, producing the Sapodilla or Star-apple, and some other edible fruits.

\section{B U M Ė I A, Swartz.}

Calyx 5-parted. Corolla 5-cleft, with a pair of internal appendages at each sinus. Fertile stamens 5; anthers arrow-shaped. Sterile stamens 5, petallike, alternate with the lobes of the corolla. Ovary 5-celled. Fruit small, resembling a cherry, black, containing a large oroid and erect seed, with a roundish scar at its hase. - Flowers small, white, in fascicles from the axils of the leaves. Branches often spiny. Leares often fascicled on short spurs. Wood very hard. (The ancient name of a kind of Asli.)

1. B. lycioides, Pers. (Socthers Bccktuors.) Spiny $\left(10-25^{\circ}\right.$ high); leaves wedge-oulong varying to oval-lanceolate, with a tapering base, often acute, reticulated, nearly glabrous (2-4' long); clusters densely many-flowered, glabrous, fruit uvoid. - Moist ground, Va. to S. Ill., Fla., and Tex. May, June. 
2. B. lanuginosa, Pers. Spiny $\left(10-40^{\circ}\right.$ high $)$; leaves oblong-rlorate or wedge-abovate, rusty-u'volly beneuth, obtuse (1 $\frac{1}{2}-3^{\prime}$ loug) ; clusters 6 - 12-flowered, pubescent; fruit globular. - Woods, S. 11l. to Fla. and Tex. July.

\section{ORder 63. IBBNACIAA. (EBONY FAMUY.)}

Trees or shruls, with alternate entive leaves, and polygamous regular flowers which have a calyx fiee from the 3-12-celled orary; the stumens 2-4 times as many as the lobes of the corolla, often in pairs before them, their anthers turned inwarl, and the fruit a several-celled berry. Oicules 1 or 2, suspended from the summit of each cell. Seeds anatropous, mostly single in each cell, large and flat, with a smooth coriaceous integument; the embryo shorter than the hard albumen, with a long raclicle anil flat cotyledons. Styles wholly or partly separate. - Woorl hard and darkcolored. No milky juice. - A small family, chiefly tropicanl.

\section{Dios PÝros, I. DAte-Plem. I'ERsimmoy}

Calyx 4-6-lobed. Corolla $4-6$-loberl, convolute in the bud. Stamens commonly 16 in the sterile flowers, and 8 in the fertile, in the latter imperfect. Berry large, globular, surrounded at hase by the thickish calyx, 4 -8-celled, 4-8-seeded. - Flowers dia(cionsly polyganous, the fertile axillary and solitary, the sterile smaller and often clustered. (Name, $\Delta$ 's, of Jore, aud rupós, grain.)

1. D. Virginiàna, L. (Commox P’ensmumx.) Leaves thickish, ovateoblong, smooth or nearly so: peduncles very short; calyx 4-parted; corolla pale yellow, thickish, hetween bell shaped and urn-shaped, $6-8^{\prime \prime}$ long in the fertile flowers, much smaller in the sterile; styles 4 , two-lobed at the apex; ovary 8-celled. - Woods and old fields, R. I. and N. Y. to Iowa, and south to Fla. and La. June. - Tree $20-70^{\circ}$ high, with very hard blackish wood; plum-like fruit $\mathrm{I}^{\prime}$ in diameter, exceedingly astringent when green, yellow when ripe, and sweet and edible after exposure to frost.

\section{Order 64. STYRACACEA. (Storax FAMIY.)}

Shrubs or trees, with alternate simple leaves destitute of stipules, and perfect regular flowers; the calyx either free or adherent to the 2-5-celled ouary; the corolla of 4-8 petals, commonly more or less united at base; the stamens twice as many as the petals or more numerous, monadelphous or polyadelphous at base; style 1; fruit dry or drupe-like, 1-5-celled, the rells commonly 1-seeded. - Seels anatropous. Embryo nearly the length of the albumen; radicle slender, as long as or longer than the flat cotyledons. Corolla hyporynous when the calyx is free; the stamens allherent to its base. ()vules 2 or more in each cell. - A small family, mostly of warm countries, comprising two very distinct trilues.

Tribe I. STYRACEA. Calyx 4 - s-toothed or entire. Stamens $2-4$ tintes as many as the petals, in one series : anthers linear or oblong, alnate, introrse. Cotyledous flat. - Flowers white, handsome. Pubescence soft and stellate.

1. Styrax. Calyx colıerent only with the base of the 3-celled ovary. Corulla mostly 5-purted. Fruit 1-relled, l-seeded. 
2. Halesia. Calyx eoherent with the whole surface of the 2 -t-celled ovary, which is 2-4-winged and 2-4-celled in fruit. Corolla 4-lobed.

Tribe II. SYMPLOCINEAE. Calyx 5-cleft, imbricate. Stamens in several series; anthers short, innate. Eubryo terete. Flowers yellow. Pubescence simple.

3. Symplocos. Calyx coherent. Petals 5, united merely at the base.

\section{S T $\mathbf{Y} \mathbf{R} \mathbf{A} \mathbf{X}$, Tourn. Storax.}

Calyx truncate, somewhat 5-toothed, the base (in our species) coherent with the base of the 3-celled many-ovuled ovary. Corolla 5-parted (rarely 4-8. parted), large; the lobes mostly soft-downy. Stamens twice as many as the lobes of the corolla; filaments flat, united at the base into a short tube; anthers linear, adnate. Fruit globular, its base surrounded by the persistent calyx, 1-celled, mostly 1-seeded, dry, often 3-valved. Seed globular, erect, with a hard coat. - Shrubs or small trees, with commonly decidnous leaves, and axillary or leafy-racemed white and showy flowers on drooping peduncles; produced in spring. Pubescence scurfy or stellate. (The ancient Greek name of the tree which produces storax.)

1. S. grandifolia, Ait. Shrub $4-12^{\circ}$ high; leaves obovate, acute or pointed, white-tomentose beneulh (3-6' long); flourers mostly in elonyuted racemes: corolla ( $\xi^{\prime}$ long) convolute-imbricated in bud. - Woods, S. Va. to Fla.

2. S. pulverulénta, Michx. Shrub $1-4^{\circ}$ high; leaves oval or obovate (1 or 2' long), aboce sparingly puberulent, and scurf.y-tomentose beneath; flowers ( $\frac{1}{2}$ ' long) I -3 together in the arils and at the tips of the brauches, fragrant. Low pine harrens, S. V'a. to Fla. and Tex.

3. S. Americàna, Lam. Shrub 4-8 ${ }^{\circ}$ high; leaves oblong, acute at both ends ( $1-3^{\prime}$ long), smooth, or barely pulverulent beneath: flowers axillary or in 3-4-flowered racemes ( $\frac{1}{2}^{\prime}$ long); corolla valvate in the bud. - Along streams, Va. to Fla., La., and Ark.

\section{HA L E S I A, Ellis. Syowdrop or Silver-bell-Tree.}

Calyx inversely conical, 4-tootherl ; the tube 4-ribbed, coherent with the 2 4-celled ovary. Petals 4, united at base, or oftener to the middle, into an open bell-shaped corolla, convolute or imbricated in the bud. Stamens 8-16; filaments united into a ring at base, and usually a little coherent with the base of the corolla; anthers linear-oblong. Orules 4 in each cell. Fruit large and dry, 2-4-winged, within bony and 1-4-celled. Seeds single, cylindrical. Shrubs or small trees, with large and reiny pointed deciduous leaves, and showy white flowers, drooping on slender pedicels, in clusters or short racemes, from axillary buds of the preceding year. Pubescence partly stellate. (Named for Stephen Hales, author of Vegetable Statics, \&c.)

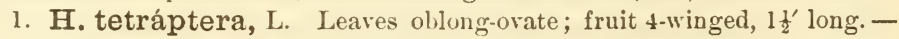
Banks of streams, IV. Ya. to Ill., south to Fla.

\section{SÝ M PLOCO S, Jacq. Sweet-Leaf.}

Calyx 5-cleft, the tube coherent with the lower part of the 3-celled ovary. Petals 5, imbricated in the bud, lightly united at base. Stamens very numerous, in 5 clusters, one cohering with the base of each petal; filaments slender; anthers very short. Fruit drupe-like or dry, mostly l-celled and l-seeded. 
- Shrubs or small trees, the leaves commonly turning yellowish in drying, and furuishing a yellow dye. Flowers in axillary clusters or racemes, yellow. (Name $\sigma \dot{u} \mu \pi \lambda$ коко, connerted, from the union of the stamens.)

1. S. tinctoria, L'Her. (Honsk-Sigak, \&r.) Leaves elongated-oblung. acute, obscurely toothed, thickish, almost persistent, minutely pulsescrent and pale beneath $\left(3-5^{\prime}\right.$ long) ; Howers $6-14$, in cluse and bracted clusters, whor. ous. - lich grouud, Del. to Fla. and La. A pril. - Leaves swect, grecedily eaten by cattle.

\section{()RDER 6.5. OLEACEAE. (()LIVE FAMily.)}

Trees or shrubs, with opposile and pinnate or simple leates, a 4-clefi (or sometimes olsolele) calyx, a regular 4-cieft or nearly or quite 4-petalous corolla, sometimes apelalous; the stamens only 2 (rarely or accidentally 3 or 4) ; the ovary 2-celled, with 2 (rorely more) ovules in each cell. - Seeds anatropous, with a large straight embryo in hard fleshy albumen, or without albumen. - The Olive is the type of the true Oleacex, to which belongs the Lilac (Syringa), etc.; and the Jussamine (Jasminum) represents another division of the order.

Tribe I. FRAXINEAE. Fruit dry, inclehiscent, winged, a samara. Leaves pinnate.

1. Fraxinus. Flowers diøeions, mostly apetalous, sometimes also without calyx.

Tribe II. OLEINEAE. Fruit, a drupe, or rarely a berry. Leaves simple.

2. Forestiera. Flowers apetalous, dioecious or polygamous, from a scaly catkin-like bud. Stamens $2-4$

3. Chionanthus. Flowers complete, sometimes polygamous. Calyx and corolla 4-nerous, the latter with long and linear divisions.

4 Ligustrum. Corolla funnel-form, 4-cleft, the tube Ionger than the calyx.

\section{FRÁXIN U S, T'ourn. Ası.}

Flowers polyganous or (in our species) diceciuns. Calyx small and t-cleft, toothed, or entire, or olssulcte. l'etals 4 , or altugether wanting in our species. Stamens 2, sometimes 3 or 4 ; antlers linear or oblong, large. Stỵle single; stigma 2-cleft. Fruit a 1 -2-c(elled samara or key-fruit, flattened, winged at the apex, 1-2-seeded. Cotyledons elliptical; ralicle sleuder. - Light timbertrees, with petioled pinnate leaves of $3-15$ either toothed or entire leaflets; the small flowers in crowded panicles or racemes from the axils of last year's leaves. (The classical Jatiı name.)

* Leciflets peliolulute; anthers linear-oblong; "aly.r smull, persistent.

- Frunt winged only at the upper murt of the terete or neurly terete body.

1. F. Americàna, I. (Wurte Asir.) Branchlets and petioles glabrous; leaflets $7-9$, ovate- or lance-ohlong, pointed, pale and either smooth or pubescent underneath, entire or sparingly serrate or denticulate; fruit (about $1 \frac{1^{\prime}}{}{ }^{\prime}$ long) murginless belou, abruptly dilated into a lanceolate, ollanreolute, or vedlye. linear wing 2 or 3 times as long as the terete cylindraceous hody. - Rich or moist woods, eommon from the Atlantic to Minin., E. Neb. and Kan. April, Il:y - A large and very valuahle forest tree, with gray furrowed hark, smooth gray hranchlets and rusty-enlored huts. Monccious flowers rarely occur. 
+* Body of fruit more slender, tapering gradually from summit to base, more or less margined upward by the decurrent wing.

2. F. pubéscens, Lam. (RED Asm.) Branchlets and petioles relvetypubescent; leaflets 7-9, ovate or oblong-lanceolate, taper-pointed, almost en-

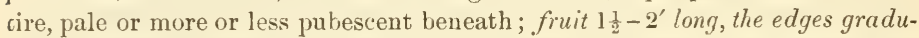
ally dilated into the linear or spatulate wing. - Low grounds, thronghout our range; rare west of Ohio. - Tree of middle or large size; inner face of outer bark of the branches red or cinnamon-color when fresh.

3. F. víridis, Michx.f. (Greex Asr.) Glabrous throughout; leaflets $5-9$, orate or oblong-lanceolate, often wedge-shaped at the base and serrate above, bright green both sides; fruit much as in n. 2. - Along streams; common. - Intermediate forms occur with paler leaves somewhat pubescent beneath. A small or middle-sized tree.

\section{+ + Fruit with compressed and wing-margined body.}

4. F. platycárpa, Michx. (WATER-Ash.) Branchlets terete, glabrous or pubescent; leaflets $5-7$, ovate or oblong, acute at both ends, short-stalked; fruit broadly winged (not rarely 3-winged), oblong ( $9^{\prime \prime}$ wide), with a tapering base. - Deep river-swamps, Va. to La. March. Tree of middle size.

5. F. quadrangulàta, Michx. (Blev Ash.) Branchlets square, at least on vigorous shoots, glabrous; leaflets $7-9$, short-stalked, oblong-orate or lanceolate, pointed, sharply serrate, green both sides; fiuit narrowly oblong, blunt, and of the sume width at both ends, or slightly uarrowed at the base, often notched at the apex (1 $\frac{1}{2}^{\prime}$ long, $3-4^{\prime \prime}$ wide). - Dry or moist rich woods, ( hio to Mich. and Minn., south to 'Tenn. - Large timber tree, the in.ner bark yielding a blue color to water.

* Lateral leaflets sessile; anthers short-oblong; flowers wholly naked.

6. F. sambucifolia, Lam. (BLACK Ash.) Branchlets and petioles glabrous; leaflets $7-11$, oblong-lanceolate, tapering to a point, serrate, obtuse or rounded at the base, green and smooth both sides, when young with some rusty hairs along the midrih; fruit linear-oblong or narrowly elliptical, blunt at both ends. - Swamps and wet banks, N. Scotia to Minn., south to Va. and Mo. - Small or middle-sized tree, with rery tough and fissile wood. Bruised foliage exhales the odor of Elder.

\section{FORESTI ERA, Poir.}

Flowers dicecions, crowded in catkin-like scaly buds from the axils of last year's leaves, imbricated with scales. Corolla none. Calyx of 4 minute sepals. Staneus 2-4; anthers oblong Ovary ovate, 2-celled, with 2 pendnlous orules in each cell; style slender; stigma somewhat 2-lobed. Drupe small, orvid, 1-celled, 1-seeded. - Shrubs, with opposite and often fascicled deciduous leares and small flower's. Fertile peduncles short, 1-3-flowered. (Named for 11. Forestier, a French physician.)

1. F. acuminàta, Poir. Glabrous, somewhat spinescent, $5-10^{\circ}$ high ; leaves thin, ohlong-ovate or ovate-lanceolate, acuminate at both ends, often serrulate; drupe elongated-oblong, usually pointed. - Wet river banks, S. W. Inil. to Mo., south to 'Tex. A pril. 


\section{CHIONÁN TH U S, L. FinN; te-TREe.}

Calyx 4-parted, very small, persistent. Corolla of 4 long and linear petals, which are barely united at base. Stanens 2 (rarely 3 or 4 ), on the very base of the corolla, ;ery short. Stigma notcherl. Inrupe fleshy, globular, hecoming 1-celled, 1-3-seeded. - Low trees or shrubs, with deciduons and entire petioled leaves, and delicate flowers in loose and drooping graceful panicles, from lat-

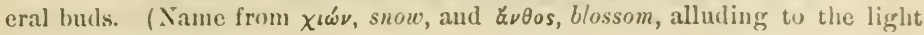
and snow-white clusters of flowers.)

1. C. Virgínica, I. Leaves oval, oblong, or obovate-lanceolate; flowers on slencler pediccls; petals l' long, narrowly linear, acute, varying to 5 or 6 in number; drupe purple, with a bloom, ovoil ( $6-8^{\prime \prime}$ long). - River banks, N. J. and S. Penn. to Fla., Tex., and Mo.; very ornamental in cultivation. June.

\section{I I G Ù S R U M, Tonrn. Prvit.}

Calyx short-tubular, 4-toothed, decidnous. Stamens 2, on the tuhe of the corolla, included. Berry 2-celled, 1-2 seeded. - Shrubs, with entire leaves and small white flowers in terminal panicles. (The classical name.)

L. vulgare, I. (Privet, or Prim.) Leaves very smooth; berries black. - Used for low hedges, and naturalized eastward; from Europe.

\section{Order 66. ApocyNÄCeAe. (Doghane Family.)}

Plants almost all with milky acrid juice, entire (chiefly opposite) leaves without stipules, regular 5-merous and 5-androus flowers; the 5 lobes of the corolla convolute and twisted in the bud; the flaments distinct, inserled on the corolla, and the pollen granular; calyx free from the two ovaries, which (in our genera) are distinct (forming follicles), though their styles or stigmas are united into one. - Seeds amphitropous or anatropous, with a large straight embryo in sparing albumen, often bearing a tuft of down (comose). - Chiefly a tropical family (of acrid-poisonous plants), represented in gardens by the Oleander and Periwinkle.

I. Amsonia. Seeds nakerl. Corolla-tube hearded inside. Anthers longer than the filaments. Leaves alternate.

2. Trachelospermum. Seeds comose. Corolla funnel-form, not appendaged. Filaments slender. Calyx glandular inside. Leaves opposite.

3. A pocynum. Seeds comose. Corolla bell-shajed, appendaged within. Filaments short, broad and flat. Calyx uot glandular. Leaves opposite.

\section{A M S Ò N I A, Walt.}

Calyx 5-parted, small. Corolla with a narrow funuel-form tube bearden inside, especially at the throat; the limb divided into 5 long linear lobes. Stamens 5, inserted on the tube, included ; anthers obtuse at both ends, longer than the filaments. Ovaries 2 ; style 1; stigma rounded, surrommled with a cup-like membrane. Pod (follicles) 2, long and sleuter, many-seeded. Seeds cylindrical, abrupt at both ends, packed in one row, naked. - Perennial herbs, with alternate leaves, and pale blue flowers in terminal paniclerl cymes. (Said to he nameil for a .Mr. Charles A mson.) 
1. A. Tabernæmontàna, Walt. Loosely pubescent or hairy when young, soon glabrous; leaves from orate-lanceolate to linear-lanceolate, taperpointed; calyx-lobes slort, awl-shaped; tube of the bluish corolla little longer than the lobes, the upper part either hairy when young or glabrous. - Low grounds, N. C. to S. Ind. and Mo., south to Fla. and Tex. May, June.

\section{TRACHELOSPÉRMU M, Lemaïre.}

Calyx 5-parted, with 3-5 glands at its base inside. Corolla funnel-form, not appendaged; limb 5-lobed. Stamens 5, included; filaments slender; anthers arrow-shaped, with an inflexed tip. Pods (follicles) 2, slender, manyseeded. Seeds oblong, with a tuft of down. - Twining plants, more or less woody, with opposite leaves and small flowers in cymes. (Name from $\tau \rho a ́ \chi \eta \lambda o s, u$ neck, and $\sigma \pi \epsilon \rho_{\mu}$, seed, upon the supposition that the seed was beakell.)

1. T. diffórme, Gray. Nearly herbacevus and glabrous; leaves oval-lan. ceolate, pointed, thin; calyx-lobes taper-pointed; corolla pale yellow. (Forsteronia difformis, A. $U C$.) - Damp grounds, Va. to Fla. and Tex. April.

\section{A P Ó CYN U M, Tourn. Dogbane. Inday Hemp.}

Calyx 5-parted, the lobes acnte. Corolla bell-shaped, 5-cleft, bearing 5 triangular appendages below the throat opposite the lobes. Stamens 5, on the very base of the corolla; filaments flat, shorter than the arrow-shaped anthers, which converge around the stigma, aud are slightly adherent to it. Style none; stigma large, ovoid, slightly 2-lobed. Fruit of 2 long $\left(2-7^{\prime}\right)$ and slender follicles. Seeds comose, with a tuft of long silky down at the apex. l'erennial herbs, with upright branching stems, opposite mucronate-pointed leaves, a tough fibrous bark, and small and pale cymose flowers on short pedi. cels. (Ancient name of the Dogtrane, composel of à $\pi \dot{b}$, fiom, and $\kappa \dot{\omega} \omega \nu, a d o g$ )

1. A. androsæmifolium, L. (SPREAdivg Dogbaxe.) Sinooth, or rarely soft-tomentose, brauched ahove; branches divergently forking: leares orate, distinctly petioled: rymes loose, spreading, mostly longer than the leaves; corolla (pale rose-color, $4^{\prime \prime}$ broad) open-bell-shaped, "uth recolute lobes, the tulie much longer than the orate pointed divisions of the caly $x$. - Borders of thickets: common. June, July.

2. A. cannábinum, L. (Ixpiax Hexp.) Glabrous or more or less soft-pnbescent: stem and branches upright or ascending $\left(2-3^{\circ}\right.$ high), terminated by erect and close many-flouered cymes, which are usually shorter than the leaves; leaves from oval to oblong and even lanceolate, short-petioled or sessile, with rounded or obscurely corlate base; corolla (greenish-white) with nearly erect lobes, the tube not longer than the lanceolate dursions of the calyx. Moist grounds and banks of streans; common. Very variable. July, Aug.

\section{Order 67. ASCLEPIADÀCEAE. (Milkweed Family.)}

Plants with milky juice, and opposite or whorled (rarely scattered) entire leaves; the follicular polls, seeds, anthers (connected with the stigma), sen. sible properties. etc., just as in the last family. from uhich they differ in the 
commonly valvate corolla, and in the singular connection of the anthers with the stigma, the cohesion of the pollen into uax-like or yranular masses (pollinia), etc., as explained under the typical genus Asclepias.

Perfoloca Griecs, L., a wooly climbing plant of the ()ld World, in oruamental cultivation, and in one or two places inclined to be spontaneous, represents a trike with granulose pollen loosely aggregated in two masses in each anther-cell. It has a brownish rotate corolla, very hairy within, and with 5 awned scales in the throat.

Tribe I. CYNANCHEX. Anthers tipped with an inflexed or sometimes erect scarious membrane, the eells lower than the top of the stigna ; pollinia suspended.

* Stems erect or merely decumbent.

1 Asclepiodora. Corolla rotate, merely spreading. Crown of 5 hooded fleshy bodies, with a salient crest in each. Leaves alternate.

2. Asclepias. Corolla reflexed, deeply 5-prarterl. Crown as in n. 1, but with an incurved horn rising from the eavity of each hood. Leaves usually olposite.

3. Acerates. Corolla reflexel or merely spreading. Crown as in n. 1, but with neither crest nor horn inside. Leave's mainly alternate.

* * Stems twining. Leares nostly opposite.

4. Enslenia. Cornlla erect. Crown of 5 membranaceous that bodies, terminated by a 2. cleft tail or awn.

5. Vincetoxicum. Corolla rotate, spreading. Crown a fleshy 5-10-lobel ring or disk.

Tribe II. GONOLOBEX. Anthers with short if any scarious tip, borne on the margin of or close under the disk of the stigna ; pollinia horizontal.

6. Gonolobus. Corolla rotate. Crown a wary-lobed fleshy ring. Stems twining.

\section{A SCLEPIO D ò RA, Gray.}

Nearly as in Asclepias; but the corolla-lobes ascending or spreading, and the hoods destitute of a horn, widely sprealing and somewhat incurved, slipper-shaped and laterally compressed, the cavity divided at the apex by a crestlike partition. - Umbels solitary and terminal or corymbed, loosely-flowered. Follicles oblong or ovate, often somewhat muricate with soft spinous projections. ('A $\sigma \kappa \lambda \eta \pi$ เós and $\delta \hat{\omega} \rho \circ \nu$ or $\delta \omega \rho \in a$, the gịt of - L'sculıpius.)

1 A. víridis, Gray. Almost glabrous; stems short $\left(1^{\circ}\right.$ high $)$; leaves alteruate, short-petioleil, ovate-oblong to lanceolate, 1-2' wide; umbels several in a cluster, short-peduncled; flowers large ( $l^{\prime}$ in diameter), green, with a purplish crown. (Acerates paniculata, Decaisne.) - Prairies, 11l. to Tex. and S. Car. June.

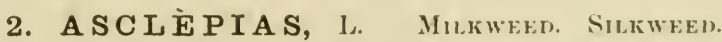

Calyx 5-parterl, persistent; the divisions small, reflexed. Corolla deeply 5-parted, the divisions valvate in the bud, reflexerl, decirluous. Croun of 5 hooded bodies seated on the tube of stamens, each containing an incurved horm. Stameus 5 , inserted on the base of the corolla ; filaments united in a tule which encloses the pistil; anthers arlherent to the stigma, each with 2 vertical cells, tipped with a membranaceous appendage, each cell containing a flattened pearshaped and waxy pollen-mass; the two contiguous pollen-masses of adjacent anthers, forming pairs which laang by a slender prolongation of their summits from 5 cloven glands that grow on the angles of the stigma (extricaterl from the cells hy insects, and directing copious pollen-tulies into the point 
where the stigma joins the apex of the style). Ovaries 2, tapering into very short styles; the large depressed 5-angled fleshy stigmatic disk common to the two. Follicles 2, one of them often abortive, soft, ovate or lanceolate. Seeds anatropous, flat, margined, bearing a tuft of long silky hairs (coma) at the hilum, downwardly imbricated all over the large placenta, which separates from the suture at maturity. Embryo large, with broad foliaceous cotyledons in thin albumen. - Perennial upright herbs, with thick and deep roots; peduncles terminal or lateral and between the usually opposite petioles, bearing simple many-flowered umbels, in summer. (The Greek name of Lsculapius, to whom the genus is dedicated.)

§. Corneous anther-uings broadest and usually angulate-truncate and salient at base; horn conspicuous.

* Flovers orange-color; leaves mostly scattered; juice not milky.

1. A. tuberósa, L. (Butterfly-weed. Plecrisy-root.) Roughishhairy $\left(1-2^{\circ}\right.$ ligh); stems erect or ascending, very leafy, branching at the summit, and bearing usually numerous umbels in a terminal corymb; leares from linear to oblong-lanceolate, sessile or slightly petioled; divisions of the corolla oblong (greenish-orange); hoods narrowly oblong, bright orange, scarcely longer than the nearly erect and slender awl-shaped horns; pods hoary, erect on deflexed pedicels. - Dry fields, common, especially southward. - Var. necúmbers, Pursh. Stems reclining; leaves broader aud more commonly opposite, and umbels from most of the upper axils. - Ohio to Ga., etc.

* * Corolla bright red or purple; follicles naked, fusiform, erect on the deflexed pedicels (except in n. 5); leares opposite, mostly broad.

- Flowers rather large; hoods about $3^{\prime \prime}$ lorig and exceeding the anthers; leaves transiersely veined.

2. A. paupércula, Michx. Glabrous; stem slender $\left(2-4^{\circ}\right.$ high $)$; leaves elongated-lanceolate or linear $\left(5-10^{\prime} \mathrm{long}\right)$, tapering to both ends, slightly petioled, umbels 5-12-flocered; divisions of the red corolla narrowly oblong; the lright orange hoods broarly ollong, obtuse, much exceeding the incurved horn. - Wet pine-barrens on the coast, N. J. to Fla. and Tex.

3. A. rùbra, L. Glabrous; leaves or ate or lanceolate and tapering from a rounded or heart-shaped base to a very acute point, sessile or nearly so $(2-6$ ' long, $\frac{1}{2}-2 \frac{1}{2}$ wide), bright green; umbels many-flowered; divisions of the corolla and hoods oblong-lanceolate, miple-red; the hoin long and slender, straightish. - Wet pine-harrens, etc., N. J. and Pemn. to Fla., La., and Mo.

4. A. purpuráscens, L. ('’tiple M.) Stem rather slender $\left(1-3^{\circ}\right.$ high); leates elliptical or orute-ollong, the upper taper-pointed, minutely velvetydowny underneuth, smooth above, contracted at base into a short petiole; pedicels shorter than the peduncle, 3-4 times the length of the dark purple lanceolateovate divisions of the corolla; hoods oblong, abruptly narrowed above; the horn broadly scythe-shriped, with a narow and abruptly inflexed horizontal puint. Dry ground, N. Eng. to Minn., Tenn., and southward. - Flowers 6" long.

+- Flowers small; hoods 1" long, equalling the anthers; veins ascending.

5. A. incarnàta, L. (Swamp Milkweed.) Smooth, or nearly so, in the typical form, the stem with two downy lines above and on the branches 
of the peluncles $\left(2-3^{\circ}\right.$ high $)$, very leafy; leaves oblong-lanceolate, acute or pointel, obtuse or olsseurely heart-shaped at hase; flowers rose-purple; hoods scarcely equalling the slender needle-pointed horn. - Swamjs, common. Var. Ṕ́ lcuks, l'ers.; leaves broader and shorter-petiuled, more or less hairypubescent, as well as the stem. Milky juice seanty. - With the smooth form.

* * Flowers greenish, yellowish, uhite, or merely furplish-tinged : leaves opposite or uhorled, or the upper rarely scattered.

- Follicles echinate with soft spinous processes, densely tomentose (smooth, and only minutely eclinate at the ape $x$ in $\mathrm{n} .8)$, lurge $\left(3-5^{\prime}\right.$ long), orate and acuminate, erect on deflexed pedicels; leures large and broad, short-petioled; umbels terminal and lateral.

6. A. speciòsa, Torr. Finely canescent-tomentose or glabrate, the manyflowered umbel and calyx densely tomentose: leaves sulcordute-oval to oblong; corolla-lobes purplish, ovate-oblong, $4-5$ " long; hoorls $5-6^{\prime \prime}$ long, with a short inflexed horn, the truncate summit alirnstly produred into a very long lanceoluteligulute appenduge. - Along streams, Mimn. to Ark., and westward.

7. A. Cornùti, Decaisne. (Commox Mnkwekn or Sikwern.) Stem tall and stout, finely soft-pubescent; lecres oval-oblong $\left(t-8^{\prime}\right.$ long $)$, pale, minutely douny beneath, as well as the pednncles, etc.; corolla-lobes dull purple to white, $3-4^{\prime \prime}$ long; hoods rather longer than the anthers, orate, oltuse, with a tooth each side of the short stout claw-like lorm. - Rich ground, everywhere.

8. A. Sullivántii, Engelm. Tery smouth throughont, tall; leares orateoblong with a somewhat heart-shaped base, nearly sessile; hoods obovate, entire, obtusely 2-eared at the base outside; flowers larger (9" long) and more purple than in the last; anther-wings 2-toothed at base; porl nearly glabrous, obscurely spiny chiefly on the beak. - Low grounds, Ohio to Kan. and Minn.

+- Follicles wholly unarmed, either glabrous or tomentulose-pubescent,

+ Erect or ascending on the deflexed or decurted fruiting pedicels.

= Umbel solitary, on a naked terminal peduncle; leares sessile, lroat, trans. versely reined, wary; glabrous and pule or glaucous.

9. A. obtusifolia, Michx. Stem $2-3^{\circ}$ high; leures oblong with a herrtshuped clasping base, very obtuse or retuse ( $2 \frac{1}{2}-5^{\prime}$ long); peduncle $3-12^{\prime}$ long ; corolla pale greenish purple; hoods truncate, somewhat toothed at the summit, shorter than the slender awl-pointed horn. - Sandy woods and fields, not rare, especially southward. A second umbel at the base of the peduncle oecasionally occurs.

10. A. Meádii, Torr. Stem slender (1-20 high $)$; leaves oxate or obloniforate, obtuse or acutish ( $1 \frac{1}{2}-2 \frac{1^{\prime}}{2}$ long), peluncle only twice the length of the upper leaves, pedicels rather short, corolla greenish-white, hools romudeitruncate at summit, and with a sharp tooth at each margin, somewhat exceeding the stouter horn. - Dry ground, Ill. and Iowa. June.

$==$ Umbels mostly more than one; peduncle not overtoping the leates.

a. Leaves large, orbicular to oblong-lanceolate: hoods broad, little if at all excecd. ing the anthers; glabrous or some minute pubescence on young parts.

11. A. Jamèsii, Torr. Stem stout (10 high or more); leaves about 5 pairs, approximate, remarkably thick, rounded or bi oally orwl, nften emarginate, 
subcordate at base, neaily sessile; umbels 2-3, densely many-flowered, on short peduncles , corolla-lobes ovate, greenish; hoods truncate, entire. - Plains of central Kansas and southwestward.

12. A. phytolaccoides, Pursh. (Poke-Mrlkweed.) Stem 3-50 high; leares broully orate, or the upper oval-lanceolate and pointed at both ends, short-petioled, smooth or slightly downy underneath $\left(5-8^{\prime} \mathrm{long}\right)$; lateral umbels several; pedicels loose and noddiug, numerous, long and slender ( $1-3^{\prime}$ long), equalling the peduncle; corolla-lobes orate-oblong, greenish; hoods (white) truncate, the margius 2-toothed at the summit, the horn with a long projecting awl-shaped point. - Moist copses, N. Eng. to Minn., south to Ga and Ark.

13. A. variegàta, L. Stem $1-2^{\circ}$ high; leaves ( $4-5$ pairs) ovate, oval, or obovate, somewhat wary, contracted into short petioles, middle ones sometimes whorled; pedicels (numerous and crouded) and peduncle short, douny; divisions of the coralla orate (ichite); hoods orbicular, entire, purplish or reddish, the horn semilunar with a horizontal point. - Dry woods, southern N. Y. to Ind., south to Fla., Ark., and WV. La. July.-Remarkable for its compact umbels of nearly white flowers.

b. Leaves mostly pubescent or puberulent; hoods obtuse, entire, twice or thrice the length of the anthers.

14. A. ovalifolıa, Decaisne. Low $\left(6-18^{\prime}\right.$ high), soft-downy, especially the lower surface of the ovate or lanceolate-oblong acute short-petioled leaves (1 $\frac{1}{2}-3^{\prime}$ long) ; umbels loosely 10-18-flowered, sessile or peduncled ; pedicels slencler, hoorls oblong, yellowish, with a small horn, about the length of the oval greenish-white corolla-lobes (tinged with purple outside). - Prairies and oak-openings, $\mathrm{N}$. Ill. and Iowa, to Wisc. and Dak.

+ Follicles and pedicets erect; leaves often whorled; glabrous or nearly so. $=$ Leares orate to broadly lanceolate, thin, rather slender-petioled.

15. A. quadrifòlia, L. Stem slender $\left(1-2^{\circ}\right.$ high $\left.)\right)$, mostly leafless below, bearing usually one or two whorls of four in the middle and one or two pairs of oicate or ovate-lanceolate taper-pointed petioled leaves (2-4' long); pedicels slender; corolla-lohes ( pale pink) oblong; hoods white, elliptical-ovate, the incurved horn short and thick. - Dry woods and hills, N. Eng. to Minn., sonth to $\mathrm{N}$. C. and Ark.

16. A. perénnis, Walt. Stems $\left(1-2^{\circ}\right.$ high) persistent or someuhat uoody ut the base; leaves lanceolate or lanceolate-ovate, tapering to both ends, thin, rather slender-petioled; flowers white, small; the small hoods of the crown shorter than the needle-shaped horn; seeds sometimes destitute of a coma!-Low grounds, S. Ind. and Ill. to Tex, and eastward.

$==$ Leaves narrouly linear to filiform; horn subulate, exserted; column conspiruons.

17. A. verticillàta, L. Stems slenter, simple or sparingly branched, very leafy to the summit; leaves filiform-linear, with revolute margins (2-3' long, l" wide), 3-6 in a whorl; umbels small, lateral and terminal; divisions of the corolla ovate (greenish-white); hoods roundish-oval, about half the length of the incurved claw-shaped horus. - Iry hills, common, especially southward. - Var pt̀mLA, Gray, is low and many-stemmed from a fascicled rout; leaves much crowded, filiform. - Dry plains, Neb. to Kan and N. Mex. 
§ 2. Anther-uings broadly rounded at base and conspicuously auriculate-notched just above it; hoods with a minute hom exserted from the 2-lobed apex.

18. A. stenophýlla, Gray. Puberulent, but foliage glabrous; stems slender $\left(1-2^{\circ}\right.$ high $)$, leaves narrowly linear $\left(3-7^{\prime}\right.$ long, $1-2 \frac{1}{2}{ }^{\prime \prime}$ wide), the upper alternate, lower opposite; umbels several, short-peduncled, 10 - 15-flowered; corolla-lobes oblung, greenish; hoods whitish, equalling the anthers, conduplicate-concave; follicles erect on ascending pedicels. - Dry prairies, Neb. to E. Kan., south and westwarl.

\section{A C E R Àtes, ell. Green Mhlikweed.}

Nearly as in Asclepials; but the hoods destitute of crest or horn (whence the name, from a privative, and $\kappa$ épas, a horn). - Flowers greenish, in compact many-flowered umbels. Leaves opposite or irregularly alternate, short-petioled or sessile. l'ullen-masses slenter-stalked. Follicles smooth, slender.

* Croun upon a short column and shorter than the glolular mass of anthers and stigma, leares mainly alternate-scattered.

1. A. longifòlia, Ell. Minutely roughish-hairy or smoothish; stem erect $\left(1-3^{\circ}\right.$ high $)$, very leafy ; leaves linear $\left(3-7^{\prime}\right.$ long); mulsels lateral, on peduncles of about the length of the slender pedicels; flowers $3^{\prime \prime}$ long when expanded. - Moist prairies and pine-barrens, Ohio to Minn., south to Fla. and 'Гех. July-Oct.

* Croun sessile, the oblong hoods nearly equalling the anther's; leaves often opposite and broader.

2. A. viridiflora, Ell. Minutely soft-douny, becoming smoothish; stems ascending $\left(1-2^{\circ}\right.$ high); leaves oval to linear, thick $\left(1 \frac{1}{2}-4^{\prime}\right.$ long); umbels nearly sessile, lateral, dense and globose; flower (when the corolla is reflexed) nearly $\frac{1}{2}$ long, short-pedicelled. - Dry soil, common, especially southward. July - Sept. - Runs into var. LAxCEoLdTA, Gray, with lanceolate leaves $2 \frac{1}{2}-4^{\prime}$ long; - and var. Liwsirıs, Gray, with elongated linear leaves and low stems ; umbels often solitary. 'The latter form from Mim., Dak., and sonthward.

3. A. lanuginosa, Decaisue. Iair./, low (5-12' high); leaves lanceolate or ovate-lanceolate; umbel solitur!" and tirnimal, peduncled; flowers smaller; pedicels slender. - I'rairies, N. Ill. to Minn., and westward. July.

\section{ENSLÉ IA, Nutt.}

Calyx 5-parted. Corolla 5-parted; the divisions erect, orate-lanceolate. Crown of 5 free membranaceous leaflets, which are truncate or obscurcly lobed at the apex, where they hear a pair of flexuous awns united at base. Anthers nearly as in Asclepias; pollen-masses oblomg, obtuse at hoth ends, fixed below the summit of the stigma to the descenting glands. Follicles ublong-lanceolate, smooth. Sceds with a tuft, as in $\Lambda$ sclepias. $-\Lambda$ peremial twining herb, smooth, with opposite heart-ovate and pointed long-petioled leares, and small whitish flowers in raceme-like clusters, on slender axillary peduncles. (Dedicated to A. Enslen, an Austrian botanist who collected in the Southeru Luited States early in the present century.)

1. E. álbida, Nutt. Climbing 8-120 high; leaves $3-5^{\prime}$ wide - Riverbanks, s I'enn. and Va. to Ill, Mo., and Tex July-Sept. 


\section{VI N CETÓXICUM, Moench.}

Calyx 5-parted. Corolla 5-parted, wheel-shaped. Crown flat and fleshy, disk-like, 5-10-lobed, simple. Anthers, smooth follicles and seeds much as in Asclepias. - Herbs, often twining. (Name from vincens, binding, and toxicum, poison.)

V. xìgrcy, Moench. More or less twining, nearly smooth; leaves ovate or lance-ovate; flowers small, dark purple, in an axillary cluster, on a peduncle shorter than the leaves. - N. Eng. to Penn.; a weed escaping from gardens. (Adv. from Eu.)

\section{GONÓLOBUS, Michx.}

Calyx 5-parted. Corolla 5-parted, wheel shaped, sometimes reflexed-sprearing; the lobes convolnte in the bud. Crown small and fleshy, annular or cupshaped, in the throat of the corolla. Anthers horizontal, partly hidden under the flattened stigma, opening transversely. Pollen-masses 5 pairs, horizontal. Follicles turgit, mostly nuricate with soft warty projections, sometimes ribbed. Seeds with a coma. - Twining herbs or shrubs (ours herbaceous), with opposite heart-shajed leares, and corrmbose-nmbelled greenish or dark purple flowers, on peduncles rising from between the petioles. Our species belong to the typical section, with the crown simple and unappendaged, and the corolla nearly veinless. (Name composed of $\gamma \omega \nu i \alpha$, an angle, and $\lambda o \beta o s, a$ pod, from the angled follicles of some species.)

* Crown a low undulately 10-lobed fleshy disk; follicles unarmed, glabrous, 3-5costate or angled.

1. G. suberòsus, R. Br. Leaves cordate with an open shallow or sometimes deeper and narrow sinus, pointed, glabrate or hairy $\left(3-5^{\prime}\right.$ long); umbels 3-9-flowered, much shorter than the petiole; corolla broadly conical in bud, abruptly pointed, twisted; lobes ovate or triangular-lanceolate, acute, pubescent insirle; calyx half as long. (G. macrophyllus, Chapman.) - Near the coast, Va. to Fla.

2. G. lævis, Michx. Leaves oblong-cordate with a deep and narrow open sinus, conspicuously acuminate (3-6' long); umbels 5-10-flowered, barely equalling the petiole; corolla elongated-conical in bud, not twisted; lobes narrouly or linear-lanceolate, obtuse, glabrous inside, 3-4 times as long as the calyx. - South of our range. - Passes into var. MAcropn ŕlucs, Gray, with larger broadly cordate leaves, the sims often closed, finely pubescent beneath. (G. macrophyllus, Michx.) - River-banks, Va. to S. Ind., Mo., S. C., and Tex.

* Crou'n cup-shaped, as high as the anthers; follicles muricate, not costate.

- Croun fleshy, merely 10-crenate, or the crenatures bidentute.

3. G. obliquus, R.Br. Leaves rounded-to ovate-cordate with a narrow sinus, abruptly acuminate $\left(3-8^{\prime} \mathrm{long}\right)$; umbel many-flouered; corolla in bud oblong-conical; its lobes linear-ligulate (5-6" long, $1^{\prime \prime}$ wide), crimson-purple inside, dull or greenish and minutely pubescent ontside. - River-banks, mountains of Penn. and Va., to Ohio and Mo. Flowers said to be fragrant.

4. G. hirsùtus, Michx. Commonly more hairy; leares with the basal lobes sometimes overlapping; peduncles fewer-flowered; corolla in bud ovate, its lobes elliptical-oblong (3-4" long), barely puberulent outside, dull or brownishpurple. - Md. and Va. to Tenn. and Fla. 
$\leftarrow+$ Crown thinner, the border lobed or tonthed: leuces as in the preceding.

5. G. Shórtii, Gray. Resembles n. 3, but larger-leavert; corolla oblongconical in bud, dark crimson-purple, its lobes ligulate (fully 6" long); croun about 10-toothed, the alternate teeth thinner, narrower and longer, pither emarginate or 2-parted. - Along the mountains, E. liy. (Short) to N. W. Ga. (Chapmon).

6. G. Carolinénsis, R. Br. Hlower-bucl oblong; corolla brownishpurple; its lobes oblong or linear-oblong (4-5" long); crounn undulately and very obtusely 5-lobed and with a longer bifid subulate process in each sinus. From Va. to La., extending north to Ark. and central Mo.

\section{Order 68. LOGANícede. (Logania Family.)}

Herbs, shrubs, or trees, with opposite and entire lenves, and stipules or a stipular membrane or line letween them, and with regular 4-5-merous 4-5androus perfect flower's, the ocary fiee from the calyx; a connecting group between Gentianacere, A pocynacex, Serophulariacex (from all which they are known by their stipules) and liubiaces, from which they differ in their free ovary; our representatives of the family are ail most related to the Rubiacer, to which, indeed, they have been appended.

* Woody twiners; leaves evergreen; stigmas 4.

1. Gelsemium. Corolla large, the 5 loles imbricated in the but. Style slender.

* Herbs ; stigma single, entire or 2-lobed.

2. Polypremum. Corolla 4-lobed, not longer than the calyx, imbricated in the bud.

3. Spigelia. Corolla 5-lobed, valvate in the bud. Style single, jointed in the middle.

4. Mitreola. Corolla 5-lobed, valvate in the bud. Styles 2, short, converging, united at the summit, and with a common stigma.

\section{GELSÉMIUM, Juss. Yellow (FALSE) Jessamise.}

Calyx 5-partel. Corolla open-funnel-form, 5-lobed; the lobes imbricated in the bud. Stamens 5, with ollong sagittate anthers. Style long and slender; stigmas 2, each 2-parted, the divisions linear. Capsule elliptical, flattened contrary to the narrow partition, 2-celled, septicilally 2-valved. Seeds many or several, wingerl. Embryo straight, in fleshy albumen; the ovate flat cotyledons much shorter than the slender radicle. - Smooth and twining shrubby plants with orate or lanceolate leaves, minute deciluous stipules, and showy yellow fluwers, of two surts as to relative length of stamens and style. (Gielsumino, the Italian name of the Jessamine.)

1. G. sempérvirens, גit. (Yeluow Jessanine of the South.) Stem climbing high; leaves short-petioled, shining, nearly persistent; flowers in short axillary clusters; pedicels scaly-bracted; flowers very fragraut (the bright yellow corolla $1-1 \frac{1^{\prime}}{2}$ long); capsule flat, pointed. - Low grounds, E. Va. to Fla. and Tex. Mareh, April.

\section{POLY P R E M M, L.}

Calyx 4-parted; the divisions awl-shaped from a broad scarious-margined base. Corolla not longer than the calyx, almost wheel-shaped, bearded in the throat; the 4 lobes imbricated in the hud. Stamens 4 , very short; anthers globular. Style 1, very short; stigma ovoid, entire. Capsule ovoid, a little 
flattened, notched at the apex, 2-celled, loculicidally 2-ralved, many-seeded. A smooth, diffuse, much-branched, small annual, with narrowly linear or awlshaped leaves, connected at base by a slight stipular line; the snall flowers solitary and sessile in the forks and at the ends of the branches; corolla inconspicuous, white. (Name altered from $\pi \circ \lambda \dot{v} \pi \rho \in \mu \nu o s$, many-stemmed.)

1. P. procúmbens, L. - Dry fields, mostly in sandy soil, Md. to Tex.; also adventive in Penu. June-Oct.

\section{SPIGELI A, I. Pink-Root. Worm-grass.}

Calyx 5-parted; the lobes slender. Corolla tubular-funnel-form, 5-lobed at the summit, valvate in bud. Stanens 5; anthers linear. Style 1, slender, hairy above, jointed near the middle. Capsule short, 2-celled, twin, laterally Hattened, separating at maturity from a persistent base into 2 carpels, which open loculicidally, few-seederl. - Chiefly herbs, with opposite leaves united by stipules, and the flowers spiked in one-sided cymes. (Named for Adrian Spiegel, latinized Spigelius, who wrote on botany early in the 17th century, and was perhaps the first to give directions for preparing an herbarinm.)

1. S. Marilándica, L. (Marylaxd Pink-koot.) Sitems simple and erect from a perennial root $\left(6-18^{\prime}\right.$ high); leaves sessile, ovate-lanceolate, acute; spike simple or forked, short; corolla $1 \frac{1}{2}^{\prime}$ long, red outside, yellow within; tube 4 times the length of the calyx, the lobes lanceolate; anthers and style exserted. - Rich woods, N. J. to Wisc. and Tex. June, July. - A well-known officinal antlelmintic, and a showy plant.

\section{MITREOLA, I. Mitrewont.}

Calyx 5-parted. Corolla little longer than the calyx, somewhat funnel-form, 5-lobed, valvate in the hud. Stamens 5, included. Ovary at the base slightly adnate to the bottom of the calyx, 2-celled; styles 2 , short, converging and united above by a common stigma. Capsule exserted, strongly 2-horned or mitre-shaped, opening down the inner side of each horn, many-seeded. - Annual smooth lierbs, $6^{\prime}-2^{\circ}$ high, with small stipules between the leares, and small white flowers spiked along one side of the branches of a terminal petioled cyme. (Diminutive of mitra, a mitre, from the shape of the pod.)

1. IM. petiolàta, Torr. \& Gray. Leaves thin, oblong-lanceolate, petioled. - Damp soil, from E. Va. to Tex.

\section{Order 69. GENTIANACEAE. (Gentax Famil.)}

Smooth herbs, with a colorless bitter juice, opposite and sessile entire and simple leaves (except in Tribe II.) without stipules, regular flowers with the stamens as many as the lobes of the corolla, which are conrolute (rarely imbricated and sometimes valvate) in the bud, a 1-celled orary with 2 parietal placentce, or nearly the whole inner face of the ovary ovuliferous; the fruit usually a 2-ialved and septicidai many-seeded capsule. - Flowers solitary or cymose (racemose in n.8). Calyx persistent. Corolla mostly withering-persistent; the stamens inserted on its tube. Seeds anatropous, with a minute embryo in fleshy albumen. (Bitter-tonic plants.) 
Suborder I. Gentianea. Leaves always simple and entire, sessile, never alternate. Estivation of corolla never valvate.

- Lobes of corolla convulute in the lund.

- Stylo filiforn, usually decicluous ; anthers oblong to linear, mostly twisting or curving in age.

1. Erythraea. Parts of flower 5 or 4 : corolla salver-form ; anthers twisting spirally.

2. Sabbatia. Parts of flower $5-12$; corolla rotate; authers recurverl or revolute.

3. Eustoma. Parts of flower 5 or 6 ; corolla campanulate-funnel-form; anthers versatile, straight or recurving; calyx-loles long-acuminate.

- - Style stout and persistent or uone; anthers remaining straight.

4. Gentiana. Corolla funnel-form or bell-shaped, mostly plaited in the sinuses, without spurs or glands. Calyx 4-5-cleft.

5. Frasera. Corolla 4-parted, rotate; a fringed glandular spot on each lobe.

6. Halenia. Corolla $4-5$-clcft, camplanulate, and $4-5$-spurred at the base.

* Lobes of corolla imbricate in the bud; no aljuendagres.

7. Bartonia. Calyx 4-parted. Corolla deeply 4-cleft, somewhat campanulate.

8. Obolaria. Calyx of 2 foliaceons sepals. Corolla 4-lobed, oblong-('ampranulate.

Suborder II. Menyantheare. Leaves all alternate and mostly petioled, sometimes trifoliolate or crenate. Estivation of corolla induplicate-valvate. Marsh or aquatic perennials.

9. Menyanthes. Corolla bearded inside. Leaves 3-foliolate.

10. Limuantlienum. Corolla naked, or bearded on the margins only. Leaves simple, rounded.

\section{ERYTHR 亩 A, Richard. Cextacry.}

Calvx 4-5-parted, the divisions slencler. Corolla funnel-form or salver-form, with slender tube and 4-5-parted limb. Anthers exserted, erect, twisting spirally. Style slender, single; stigma capitate or 2-lipped. - Low and small branching amuals, chiefly with rose-purple or redlish flowers (whence the name, from é $\rho v \theta$ pós, red); in summer.

E. Cextaúriua, Pers. (Cextalri.) Stem upright (6-12' high), corymbosely branched above; leaves oblong or elliptical, acutish, the liasal rosulate, the uppermost linear; cymes clustered, flut-topped, the flowers all nearly sessile: tube of the (purple-rose-colored) corolla not twice the leugth of the oval lobes. - Waste grounds, shores of Lakes ()ntario and Michigan. (Adv. from Eu.)

E. Ramosfssima, Pers. Low $\left(2-6^{\prime}\right.$ high); stem many times forked above and forming a diffuse cyme: leaves ovate-oblong or oval, not rosulate below; flowers all on short pedicels; tube of the (pink-purple) corolla thrice the length of the elliptical-oblong lobes. - Wet or shady places, N. J., E. Yeun., and southward. (Nat. from Eu.)

E. spicAta, Yers. Stem strictly upright (6-10' high); the flovers sessile und spiked along one side of the simple or rarely forked branclies : leaves oval and oblong, rounded at base, acutish; tube of the (rose-colored or whitish) corolla searcely longer than the calyx, the lobes oblong. - Sandy sea-shore, Nautucket, Mass., and P'ortsmouth, Va. (Nat. from Lis.)

\section{S A B B A T I A, Adans.}

Calyx 5-12-parted, the divisions slencler. Corolla 5-12-parted, wheelshaped. Stamens 5-12; anthers soon recurved. Style 2-cleft or -parted, slender.- Biemnials or annuals, with sleuder stems, and cymose-panicled handsome (white or rose-purple) Howers, in summer. (Dedicated to L. Sulw bati, an early Italian hotauist.) 
* Corolla 5-parted, or rarely 6-7-parted.

- Branches all opposite and stems more or less 4-angled; flowers cymose; calyx with long and slender lobes.

* Corolla white, often turning yellowish in drying.

1. S. paniculàta, Pursh. Stem brachiately much-branched $\left(1-2^{\circ}\right.$ high); leaves linear or the loucr oblong, obtuse, 1-nerved, nearly equalling the internodes; calyx-lobes much shorter than the corolla. - Low grounds, Va. to Fla.

2. S. lanceolàta, Torr. \& Gray. Stem simple $\left(2-3^{\circ}\right.$ high $)$ bearing a flat-topped cyme; leaves ovate-lanceolate or ovate, 3-nerved, the upper acute, much shorter than the internodes; calyx-lobes longer and flowers larger than in n. 1. - Wet pine barrens, N. J. to Fla.

+ + Corolla rose-pink, rarely white, with a yellowish or greenish eye.

3. S. brachiàta, Ell. Stem slightly angled, simple below $\left(1-2^{\circ}\right.$ high); leaves linear and lineur-oblong, obtuse, or the upper acute; branches rather fewflowered, forming an obloug panicle; calyx-lobes nearly half shorter than the corolla. - Dry or low places, Ind. and N. C. to La. and Fla.

4. S. angulàris, Iursh. Stem someuliat 4-uinged-angled, much branched

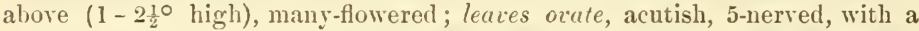
somexhat heart-shaped clusping base; calyx-lobes one third or half the length of the corolla. - Rich soil, N. Y. to Ont. and Mich., south to Fla. and La.

+ + Branches alternate (or the lower opposite in n. 5) ; peduncles 1-flowered.

$$
\text { + Calyx-lobes foliaceous. }
$$

5. S. calycòsa, Pursh. Diffusely forking, pale, $1^{\circ}$ high or less; leaves oblong or lance-oblong, narrowed at base; calyx-lobes spatulate-lanceolate $\left(\frac{2}{3}-1^{\prime}\right.$ long), exceeding the rose-colored or almost white corolla. - Sea-coast and near it, Va. to Tex.

+ Culyx-lobes slender and tube very short (prominently costate in n. 6, and longer, nearly or quite enclosing the retuse capsule).

6. S. campéstris, Nutt. Span or two high, divergently branched above ; leaves ovate with subcordate clasping base ( $\frac{1}{2}-1^{\prime}$ long), on the branches lanceulate; calyx equalling the lilac corolla $\left(1 \frac{1}{2}-2^{\prime}\right.$ broad $)$. - Prairies, S. E. Kan. anä W. Mo. to Tex.

7. S. stellàris, Pursh. Loosely branched and forking; leaves oblong to lanceolate, the upper narrowly linear; calyx-lobes aul-shaped-linear, varying firom half to neurly the length of the bright rose-purple corolla; style nearly 2parted. - Salt marshes, Mass. to Fla. Appears to pass into the next; corolla in botl at times pink or white.

8. S. grácilis, Salisb. Stem very slender, at length diffusely branched; branches and long peduncles filiform; leaves linear, or the lower lance-linear, the uppermost similar to the setaceous calyx-lobes, which equal the rose-purple corolla; style cleft to the middle. - Brackish marshes, Nantucket, Mass., and N. J., to Fla. and La.

9. S. Ellióttii, Stend. Effusely much hranched; leaves small, lower cauline ( $6^{\prime \prime}$ long or less) thickish, from oliovate to lancolate, upper narrowly linear and rather longer, on the flowering branches sululate; calyx-lobes slen- 
der-subulate, very much shorter than the white corollu; style 2-parted. - Pine barrens, S. Va. (!) to Fla.

* Corolla 8-12-parted, large (about 2' broad).

10. S. chloroides, l'ursh. Stem ( $1-2^{\circ}$ high), loosely panicled above; peduncles slender, 1-flowered; leares oblong-lanceolate; calyx-lobes linear, half the length of the deep rose-colored (rarcl! white) corolla. - Borders of brackish ponds, Mass. to Fla. and Ala.

\section{E Ù S T O M A, Salisb.}

Calyx 5- (rarely 6-) parted; its lobes long-acuminate, with carinate midril). Corolla campanulate-funnel-form, deeply 5-6-lobed. Anthers oblong, versatile, straight or recurving in age. Style filiform, nearly persistent ; stigma of 2 broad lamellæ. - Glaucous large-flowered annuals, with more or less clasping and connate leaves, and slender terminal and more or less paniculate 1-Howered perluncles. (From $\epsilon \bar{U}$, well, and $\sigma \tau o \dot{\mu} \mu$, mouth, alluding to the openmouthed corolla.)

1. E. Russellianum, Griseb. ()ne or two feet high: leaves from ovateto lanceolate-oblong; lobes of lavencler-purple corolla obovate ( $\left.1 \frac{1}{2}^{\prime} \ln \mathrm{ng}\right), 4$ times longer than the tube; anthers hardly curving in age. - Neb. to 'Tex.

\section{Gentià N A, Tourn. Gentian.}

Calyx 4-5-cleft. Corolla 4-5-lobed, regular, usually with intermediate plaited folds, which bear appendages or teeth at the sinuses. Sityle short or none; stigmas 2, persistent. Capsule oblong, 2-valved; the innumerable seeds either borne on placentæ at or near the sutures, or in most of our species covering nearly the whole inner face of the pod.-Flowers solitary or cymose, showy, in late summer and autumn. (Name from Cientius, king of Illyria, who used some species medicinally.)

§ 1. GENTIANÉLLA. Corolla (not rotate) destitute of extended pluits or lobes or teeth at the sinuses: root annual.

* (Frixged Gentrixs.) Flouers large, solitary on long terminal peduncles, mostly 4-merous; corolla campanulate-funnel-form, its lobes usully fimbriate or erose, not crouned; a row of glands betieen the bases of the filaments. A utumn-flourering.

1. G. crinita, Froel. Stem $1-2^{\circ}$ high; leares luncelate or orate-lancfolate fiom a partly herit-shaped or rounded base; lobes of the 4-eleft caly $\mathbf{x}$ unequal, ovate and lanceolate, as long as the hell-shaped tube of the blue corolla ( 2 ' long), the lobes of which are uedge-obovate, and strong!! firinged around the summit; oxary lanceolute. - Low grounds, N. Eng. to I)ak., south to Iowa, Ohio, and in the mountains to Ga.

2. G. serràta, Gunner. Stem 3-18' high; leaves linear or lanceolatelineur; lobes of the 4-(rarely 5-) cleft ealyx unequal, ovate or triangular and lanceolate, pointed; lobes of the sky-blue corolla sputulate-oblong, with ciliatefringed margins, the fringe shorter or almost absolete at the summit; ovary elliplical or oborate. (G. detonsa, Munual.) - Moist grounds, Newf. and W. New York, to Iowa and Minn., north and westward. 
* Flowers smaller, 4-5-merous; corolla somewhat funnel-form or salver-form, its lobes entive: peduncles short or none, terminal and lateral on the acuteangled stem.

3. G. Amarélla, L. Stems 2-20' high; leaves lanceolate to narrowly oblong, or the lowest ohovate-spatulate, the margins minutely scabrous; calyxlobes $(4-5)$ foliaceous, lanceolate or linear; corolla mostly blue, $\frac{1}{2}^{\prime}$ long or more, with a fimlriate crou'n at the base of the oblong acute lobes; capsule sessile. - Var. acùta, Hook. f. Calyx almost 5-parted; crown usually of fewer and sometimes very few setæ. - Lab. to N. Vt. and N. Minn., west and northward.

4. G. quinqueflòra, Lam. Stem rather slender, branching $\left(1-2^{\circ}\right.$ high); leaves ovate-lanceolate from a partly clasping and heart-shaped base, 3-7-nerved, tipped with a minute point; branches racemed or panicled, about 5-flowered at the summit; lobes of the small 5-cleft calyx awl-shaped-linear; corolla pale blue, 6-9"long, its lobes triangular-ovate, in istle-ponted, without croun, but the glands at the base of the slender obconical tube munfest; capsule stipitute. - Moist hills, Maine to Ont., Ill., and sonth along the mountains to Fla. - Var. occidextals, Gray. Sometimes $2-3^{\circ}$ high, and paniculately much-branched; calyx-lobes more leaf-like, linear-lanceolate, reaching to the middle of the broader funnel-form corolla. - Va. and Ohio to Minn., south to Tenn. and La.

§ 2. PXELMONÁNTHE. Corolla (funnel-form or suler-form) with thinmembranaceous toothed or lobed plaits in the sinuses; no croun nor glands; capsule stipitate; autumn-flouering perennials, the flouers large, sessile or short pedunculate and bibracteate (except in $\mathrm{n} .12$ ).

* Anthers unconnected or soon sepurate; leaves rough-margined; seeds winged.

5. G. affinis, Griseb. Stems clustered, $1^{\circ}$ high or less; leaves oblong or lanceolate to linear; flouers numerous and thyrsoid-racemose or few or rarely almost solitary ; caly $x$-lobes unequal, the longest rarely equalling the tube, the shortest sometimes minute; corolla (blue or bluish) l' long or less, rather narrowly funnel-form, with ovate spreading lobes, the plaits with conspicuous laciniate appendages sometimes equalling the lobes. - Minn. to the Pacific.

6. G. pubérula, Michx. Stems (mostly solıtrry) erect or asceniling (8-16' high), mostly rough and minutely pubescent above ; leares rigid, linearlanceolate to oblong-lanceolate ( $1-2^{\prime}$ long); flowers clustered, rarely solitary: calyx-lobes lanceolate, much shorter than the bell-funnel-form open bright-blue corolla, the spreading ovate lobes of which are tuice or thrice the length of the cut-toothed appendages. - Dry prairies and barrens, western N. Y., Ohio, and Ky., to Minn. and Kan. Oct.

* * Anthers cohering in a ring or short tube; flowers in terminal and often axillary clusters.

+ Calyx-lobes and bracts ciliolate-scabrous; sceds conspicuously winged; leaves rough-margined.

7. G. Saponària, L. (Sołpwort G.) Stem erect or ascending, smooth; leaves ovate-lanceolate, oblong, or lanceolate-obovate, narrowed at the base: ralyx-lobes limear or spatulate, acute, equalling or exreeding the tube, half the length of the corolla; lobes of the club-bell-shaped light-blne corolla obtuse, 
erect or converging, short and broal, but distinct, and more or less longer than the ronspicuous 2-cleft and minutely tootherl appendages. - Moist woods, N. Y. and N. J. to Minn., sonth to Fla. and La.

8. G. Andréwsii, Griseb. (Closen G.) Stems upright, smouth; leaves orate-lanceolate and linceolate from a narrower hase, graulually puintexl ; culyxlobes lanceolate to ovate, recurved, shorter than the tin)-shuped tulse, and much shorter than the more oblong and truncate mostly blue corolla, which is closed at the mouth, its proper lobes obliterated, the apparcut lobes consisting of the hroad fringe-toothed and notched appendages. - Moist ground, N. ling. to Minn., south to N. Ga. Corolla blue with white plaits, or sometimes all white + + Maryins of leaves, bracts, etc., smooth and nated; terminal fower-luster leaf!y-inolucrate; seeds winged.

9. G. álba, Muhl. Stems upright, stout; flowers sessile anl crowled in a dense terminal cluster; leaves ovate-lanceolate from a heart-shaped closely clasping base, gradually tapering; calyx-lobes ovate or sulcourdate, many times shorter than the tube of the corolla, reflexed-spreading; corolla white more or less tinged with greenish or yellowish, inflated-club-shaped, at length open, its short and broal orate lobes twice the length of the broad toothed appendages. - Low grounds and mountain meadows, Ont. to Ill., Ky., and Va.

10. G. lineàris, Froel. Stems slender and strict, $1-2^{\circ}$ high; flowers $1-5$ in the terminal cluster; leaves lincar or narrowly lanceolate, with somewhat narrowed base; bracts sometimes very finely scalnous; calyx-lobes linear or lanceolate; corolla blue, narrow funnel-form, its erect roundish-orate lobes little longer than the triangular acute appendages. (G. Saponaria, var. linearis, (ircly.) - Bogs, mountains of MId. to N. Y., N. Eng., and northward.

Var. lanceolàta, Gray. Leaves lanceolate, or the upper and involuerate ones almost orate-lanceolate, appendages of corolla sometimes very short and broad. - Minn. and L. Superior ; also Herkimer Co., N. Y.

Var. latifòlia, Gray. Stout; leaves closely sessile, not contracted at base, the lowest oblong-linear, the upper ovate-lanceolate; appendages broad, acute or subtruncate. - L. Superior; N. Brunswick (Howers blue).

$++C^{\prime}$ alyx-lobes and bracts with smooth margins or nearly so; seeds completely marginless.

11. G. ochroleùca, Froel. Stems ascending, mostly smooth; leares obovate-oblong, the lowest broally olovate and olstuse, the uppermost somewhat lanceolate, all narrowed at base, calyx-lobes linear, unequal, much lomger than its tuhe, rather shorter than the greenish-white open corolla, which is painted inside with green reins and lilac-purple stripes; its lobes ovate, very much exceeding the small and sparingly toothed oblique appendages. - Dry or damp grounds, l'enu. to Fla. and La.

* * Anthers not comected: flouers terminal, solitury, commonly peduncled and nuked: seeds uingless.

12. G. angustifolia, Michx. Sitems slender and ascendling $\left(6-15^{\prime}\right.$ high), mostly simple; leaves linear or the lower ublanceolate, rigid; corolla openfunnel-form (2' long), azure-blue, also a greenish and white variety, about twice the lengtl of the thread-like calyx-lobes, its ovate spreading lobes twice as long as the cut-tuothed appendages. - Muist piue barrens, N. J. to Fla. 
Pleurógye Carixtuìaca, Griseb., var. pusflla, Gray, a low few-flowered annual, with rotate blue or bluish $4-5$ parted corolla and a pair of scale-like appendages on the base of its divisions, is found from the Arctic Coast to the Lower St. Lawrence and Newfoundland, and was reported by Pursh from the summits of the White Mountains, but has not since been found.

\section{FRÁs $\mathbf{S} \mathbf{R}$, Walt. Americax Columbo.}

Calyx deeply 4-parted. Corolla deeply 4-parted, wheel-shaped, each division with a glandular and fringed pit on the face. Filaments awl-shaped, usually somewhat monadelphous at base; anthers oblong, versatile. Style persistent; stigma 2-lobed. Capsule oval, flattened, 4-14-seeded. Seeds large and flat, wing-margined. - Tall and showy herbs, with a thick root, upright and mostly simple stems, bearing whorled leaves, and numerous peduncled flowers in open cymes, disposed in an ample elongated panicle. (1)edicated to John Fraser, an indefatigable collector in this country toward the close of the last century.)

1. F. Carolinénsis, Walt. Smooth biennial or triennial $\left(3-8^{\circ}\right.$ high); leaves mostly in fours, lance-oblong, the lowest spatulate, veiny ; panicle pyramidal, loosely flowered; corolla ( $\mathrm{l}^{\prime}$ broad) light greenish-yellow, marked with small brown-purple dots, its divisions oblong, mucronate, longer than the narrowly lanceolate caly-lobes, each with a large round gland below the middle; capsule much flattened parallel with the Hat valves. - Rich dry soil, western N. Y. to Wisc., south to Ga.

\section{HALENIA, Borkh. Spurred Gextian.}

Calyx 4-5-parted. Corolla short bell-shaped, 4-5-cleft, without folds or fringe, prolonged at the base underueath the erect lobes into spurs, which are glandular in the bottom. Stigmas 2, sessile, persistent on the oblong flattish capsule. Seeds rather numerous, oblong. - Small and upright herbs, with yellowish or purplish panicled-cymose flowers. (Named for John Halen, a German botanist.)

1. H. defléxa, Grisebach. Leafy annual or biennial $\left(9-18^{\prime}\right.$ high), simple or branched above; leaves 3-5-nerved, the lowest oblong-spatulate and petioled, the others oblong-lanceolate, acute; spurs cylindrical, obtuse, curved, descending, half the length of the acutely 4-lobed corolla.-1)amp and cool woods, from N. Maine and W. Mass. to L. Superior, Minn., and northward.

\section{BARTÒNIA, Muhl.}

Calyx 4-parted. Corolla deeply 4-cleft, destitute of glands, fringes, or folds. Stamens short. Capsule oblong, flattened, pointed with a large persistent at length 2-lobed stigma. Seeds minute, innumerable, covering the whole inner surface of the pod. - Small annuals or biennials $\left(3-10^{\prime}\right.$ high), with threadlike stems, and little awl-shaped scales in place of leaves. Flowers small, white, peduncled. (Dedicated to Prof.'Benjamin Smith Barton, of Philadelphia.)

1. B. tenélla, Muhl. Stems branched above, the branches or peduncles mostly opposite, 1-3-flowered; lobes of the corolla oblong, acutish, rather longer than the calyx, or sometimes twice as long; anthers roundish ; orary 4-angled, the cell somewhat cruciform. - Open woods, Newf. to Wisc., south to Va. and La. Aug. - Scales and brauches occasionally alternate. 
2. B. vérna, Mull. Stem 1-few-floweverl; fluwers 3-4" long, larger: lubes of the corolla spatulate, olituse, sprcading, thrice the length of the calyx; anthers oblong; ovary flat. - Bogs near the coast, S. Va. to Fla. and La. March.

\section{O BOLÀ RIA, L.}

Calyx of 2 spatulate spreading sepals, resembling the leaves. Corulla tubular-bell-shaped, withering-persistent, 4 -cleft; the lohes oval-oblong, or with age spatulate, imbricated in the bud! Stamens inserted at the sinuses of the corolla, short. Style short, persistent; stigma 2-lipped. Capsule oroid, 1-celled, the cell cruciform; the seeds covering the whole face of the walls. $-A$ low and very smooth purplish-green perennial ( $3-8^{\prime}$ high), with a simple or sparingly brauched stem, opposite werlge-obovate leaves; the lull white or purplish flowers solitary or in clusters of three, terminal and axillary, nearly sessile; in spring. (Name from oßoxós, a small Greek coin, from the thick rounded leaves.)

1. O. Virgínica, L. Herbaceous and rather fleshy, the lower leaves scale-like; flowers $t^{\prime \prime}$ long. - Moist woods, N. J. to Ill, sonth to Ga. and Tex.

\section{MENYÁN THES, Tourn. Весквел.}

Calyx 5-parted. Corolla short funnel-form, 5-cleft, clecidnous, the whole upper surface white-bearded, valvate in the hul with the margins turned inward. Style slender, persistent; stigma 2-lobed. Capsule bursting somewhat irregularly, many-seeded. Seed-coat hard, smooth, and shining. - A perennial alternate-leaved lierb, with a thickish creeping rootstock, sheathed by the membranons bases of the long petioles, which hear 3 oral or oblong leaflets; the flowers racemed on the naked scape $\left(1^{\circ}\right.$ ligh $)$, white or slightly reddish.

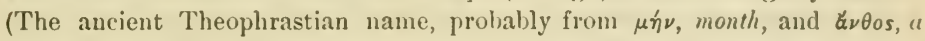
flower, some say from its flowering for about that time.)

1. M. trifoliàta, L. - Bogs, N. J. and l'eun. to Ind. and Iowa, and far north and westward. May, June. (Eu., גsia.)

\section{I I M N Á N T H M U M, Gmelin. Flonting Heart.}

Calyx 5-parted. Corolla almost wheel-shaper, 5-parterl, the divisions fringed or bearded at the hase or margins only, folded inward in the bud, bearing a glandular appendage near the hase. Style short or none; stigma 2-lobel, persistent. Capsule few-many-seeded, at length burstiug irregularly. Seed-coat hard. - Perenuial aquatics, with rounded floating leaves on very long petioles, which, in most species, hear near the summit the umbel of (polygamons) flowers, along with a cluster of short and spur-like roots, sometimes shooting forth new leaves from the same place, and so sprealing ly a surt of proliferous stolons; flowering all summer. (Name componuled of $\lambda i \mu \nu \eta$, $\iota$ mursh or pool, and $\& \nu \theta \epsilon \mu \nu \nu, a$ blossom, from the situations where they grow.)

1. L. lacunosum, Grisehach. Leairs enfire, round-heart-shaped (1-2' broad), thickish; petioles filiform; lobes of the (white) corolla loroadly oval, naked, except the crest-like yellowish gland at the base, twice the length of the lanceolate calyx-lobes; style none: seeds smooth and even. - Shallow water, from Maine to Minn., south to Fla. and La. 
2. L. trachyspérmum, Gray. Leaves larger (2-6'broad) and rounder, thicker, often wayy-margined or crenate, roughish and dark-punctate or pitted Deneath; petioles stouter; seeds glandular-roughened.- Ponds and streams, IId. and Va. to Fla. and Tex.

\section{Order 70. Polemoniáce. (Polemoniem Family.)}

Herbs, with alternate or opposite leaves, regular 5-merous and 5-androus flowers, the lobes of the corolla convolute in the bud, a 3-celled ovary and 3-lohed style; capsule 3-cellerl, 3-valved, loculicidal, few-many-seeded . the valves usually brealing away from the triangular central column. Seeds amphitropous, the coat frequently mucilaginous when moistened and emitting spiral threads. Embryo straight in the axis of copious albumen. Calyx persistent, imbricated. Corolla with a 5-parted border. Anthers introrse. (Insipid and innocent plants; many are crnamental in cultivation.)

1 Phlox. Corolla salver-form. Calyx narrow. Leaves opposite, entire.

2. Gilia. Corolla tubular-funnel-form or salver-form. Calyx narrow, partly scarious. Leaves mostly altermate, entire.

3. Polemonium. Corolla open-bell-shaped. Calyx herbacenus, bell-shaped. Filaments slencler, equal. Leaves altermate, pimate or pinnately parted.

\section{PHLOX, L.}

Calyx narrow, somewhat prismatic, or plaited and angled. Corolla salverform, with a long tube. Stamens very unequally inserted in the tube of the corolla, included. Capsule oroid, with sometimes 2 ovules but ripening only a single seed in each cell. - l'eremnials (except a few southern species, such as P. Drummondii of the gardens), with opposite and sessile perfectly entire leaves, the floral often alternate. Flowers cymose, mostly bracter; the open clusters terminal or crowderl in the upper axils. ( $\Phi \lambda \dot{\lambda} \xi$, flame, an ancient name of Lychnis, transferred to this North American genns.) Most of our species are cultivated in gardens.

\section{\$. Herbaceous, with flat (broad or narrou) leares.}

* Stem strictly erect; panicle pyramidal or oblong, many-flowered; peduncles (und pedicels very short; corolla-lohes entire. (V'ery common in gardens.)

1. P. paniculàta, L. Stem stout $\left(2-4^{\circ}\right.$ high $)$, smooth; leares oblonglanceolate and ovate-lanceolate, pointed, large, tapering at the base, the upper often heart-shaped at the base; panicle ample, nyramidal-corymbed: calyx-teeth awn-ponted: corolla pink-purple varying to white.-Open woods, Penn. to Ill., south to Fla. and La. June, July.

2. P. maculàta, L. (Wild Sweet-Willia.) Smooth, or barely roughish; stem spotted with purple, rather slender $\left(1-2^{\circ}\right.$ high $)$; lower leaves lanceolate, the upper nearly ovate-lanceolate, tapering to the apex from the broad and rouncled or somewhat heart-shaped base; panicle narrou; oblong, leafy below; calyx-tecth trianyular-lanceolute, short, scurcely pointed; corolla pink-purple. - Rich woodlands and along streams, N. J. and $\mathbf{N}$. Penn. to Minu., south to Fla. and Ark. - Var. Cávind, Michx., is a white-flowered form, commonly with spotless stem. With the ordinary form. 
* * Stems, at least the flowering ones, ascendiny or erect; fluners in corymlied or simple cymes; curnllatobes obocato or obrordate.

+ Culyx-teeth triangular-sululate; corolla-tobes rounded, culire; glalnous or nearly so.

3. P. ovàta, I. Stems ascending $\left(\frac{1}{2}-2^{\circ}\right.$ high), often from it prostrate

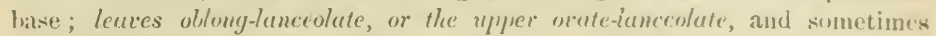
heart-shaped at the base, acute or pointed ; flowers pink or rose-red, crowded, short-peduncled; caly. $x$-teeth short and hroal, acute. (I’. Carolina, L.) - ()pen woods, in the mountain region froin l'enn. to Mla. June, July.

4. P. glabérrima, I. Nitems slender, erect $\left(1-3^{\circ}\right.$ high $)$; leures linerr. lanccolate or rurely obloni-lunceolule, very smooth (except the rough and some. times revolute margins), tapering griulually to a point $\left(3-4^{\prime}\right.$ long); cymes few-flowered and loosely corymbed; Howers peluncled (pink or whitish); colyx-leeth narrower and very shupp-pointed. - l'rairies and open woods, $\mathrm{N}$. Va. to Ohio and Minn., south to Flil. and Mo. July.

+ + Calyx-teeth long and slender; more or less hairy or glandular-pubescent.

+ No iunners or prostrate sterile showts.

5. P. pilosa, L. stems slenter, nearly erect ( $1-1 \frac{1}{2}^{\circ}$ high), usually hairy, as are the lancedate or linear leaves $\left(1-4^{\prime}\right.$ long), which commonly lieper to a sharp point; cymes at length open; calyx-teeth slender axt-shaped and aunlike, longer than the tube, loose or spreading; lobes of the pink-purple or rosered (rarely white) corolla oborate, entire. - Dry or sandy woods, prairies, etc., N. J. to Minn., south to Fla. and Tex. May, Jume.

6. P. amœena, sims. Stems ascending $\left(\frac{1}{2}-1 \frac{1}{2}^{\circ}\right.$ high $)$, mostly simple; leaves broadly lincur, lanceolute or orale-oblong, abruptly acnte or blunt ( $\frac{1}{2}-1 \frac{1}{2}$ long), on sterile shoots often orate; cyme mostly compuct and sissile, leafylracted; calyx-leeth arl-shaped or linear, sharp-pointed, but solshm awned, rather longer than the tuhe, straight; lobes of the corolla obovate and entire (or rarely notcherl), purple, pink, or sometimes white. (P. procumbens, Cru!n: not Lehm.) - Dry hills and harrens, Va. to Ky., south to Fla.

++ + Sterile shoots firom the buse crepping or decumbent; lentes rather broad.

7. P. réptans, Michx. liumers rrefping, hearing round ish-ohorute smoothssh and thickish leaves; flowering stems $\left(t-8^{\prime}\right.$ high) and their oblong or orale obtuse lectes ( $\frac{1^{\prime}}{2}$ long) pubessent, often clammy; cyme clnse, few-flowered; (alyx-teeth linear-awl-shaped, abut the length of the tube; lubes of the red. dish-purple corolla round-olorate, mostly entire. - Damp woots, in the Alleghany region, Penn. to Ky and Ga. May, June.

8. P. divaricàta, I. Stems sprealing or ascending from a decumbent hase $\left(9-18^{\prime}\right.$ high) ; leuves oblomy- of lanre-nente or the lower ohlong-lanceolate

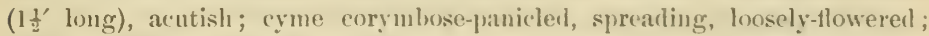
calyx-teeth slender awI-shaped, longer thin the tube; lobes of the pale lilue or bluish corolla obcordate or uedgr-uborate and notrhed at the end, or often entive, $\frac{1}{2}-\frac{2}{3}$ ' long, equalling or longer than the tube, with rather wide sinuses between them. - Rocky damp woods, IV. Camalis and N. Y. to Minm., south to Fla. and Ark. May. $-\Lambda$ form oceurs near Crawfordsville, Ind., with reduced flowers, the narrow entire acmminate corolla-lohes scarcely half as long as the tube. 
* * Stems lou, diffuse and branching; flourers scattered or barely cymulose; corolla-lobes nurrouly cuneate, bifid; calyx-lobes subulate-lunceolate.

9. P. bífida, Beck. Minutely pubescent; stems ascending, branched (5-8' high); leares linear, becoming nearly glabrous ( $\frac{1}{2}-1 \frac{1}{2}^{\prime} \operatorname{long}, 1 \frac{1}{2}^{\prime \prime}$ wide); flower's few, on slender peduncles; calyx-teeth awl-shaped, about as long as the tube ; lobes of the pule purple corolla 2-cleft to or below the middle ( $t^{\prime \prime}$ long), equalling the tube, the divisions iinear-oblong. - Prairies of Ind. to Iowa and Mo.

10. P. Stellària, Gray. Tery glabrous; leaves barely somewhat ciliate at base, linear ( $1-2^{\prime}$ long, $1^{\prime \prime}$ wide or more), acute, rather rigid ; flowers scattered, mostly long-peduncled; lobes of the pale blue or almost white corolla bifid at the apex into barely oblong lobes. - Cliffs of Ky. River (Short), S. Ill., and Tenn. (Gattinger). May.

\$ 2. Suffruticulose and creeping-cespitose, crergreen, with mostly crouded and fascicled subulate and rigid leares.

11. P. subulàta, L. (Grorxd or Moss Pixk.) Depressed, in broad mats, pubescent (glabrate when old); leaves awl-shaped, lanceolite, or narrowly linear (3-6" long); cymes few-flowered ; calyx-teeth awl-shaped, rigid; corolla pink-purple or rose-color with a darker centre (sometimes white); lobes welge-shaped, notched, rarely entire. - Dry rocky hills and sandy banks, southern N. Y. to Mich., south to Fla. and Ky.

\section{GIII A, Ruiz \& Pav.}

Calyx-lobes narrow and acnte, the tube scarious below the sinuses. Corolla tubular-funnel-form or salver-form. Stamens equally or unequally inserted. Capsule with solitary to numerous seeds. - Mostly herbs with alternate leares. Our species belongs to the $\S$ Colloma, in which the flowers are capitate-glomerate and foliose-bracted or scattered, stamens unequally inserted in the narrow tube of the salver-form corolla, orules solitary, and leares sessile and entire; anuuals. (1)edicated to Philip Gil, a Spanish botanist.)

1. G. lineàris, Gray. Branching and in age spreading, 6-18' high ; leares linear- or oblong-lanceolate; calyx-lobes triangular-lanceolate, acute; corolla 6 " long, from lilac-purple to nearly white, very slender, with small limb. (Collomia linearis, Nutt.) - From Minn. west to the Pacific.

\section{POIEM Ò I UM, Tourn. Greek VAleriax.}

Calyx bell-shaped, heroaceous. Stamens equally inserted at the summit of the very short tube of the open-bell-shaped or short funnel-form corolla; filaments slender, declined, hairy-appendaged at the base. Capsule few-severalseedled.-Perennials, with alternate pinnate leaves, the upper leaflets sometimes confluent; the (blue or white) corymbose flowers nearly bractless. (An ancient name, from $\pi o^{\prime} \lambda \epsilon \mu o s, w a r$, of doubtful application.)

1. P. réptans, L. Smooth throughout or slightly pubescent; stems weak and spreading (6-10' high, never creeping as the name denotes); leaflets 5-15, ovate-lanceolate or oblong; corymbs few-flowered; flowers nodding ; calyx-lobes ovate, shorter than the tube; stamens and style included; corolla light blue, about $\frac{1^{\prime}}{2}$ wide; capsules about 3-seeded. - Woods, N. Y. to Minn., south to Ala. and Mo. May, June. 
2. P. cærùleum, I. (JAcon's LAmmks.) Sitem erect (1-30 high); leaflets 9-21, linear-lanceolate, oblong- or ovate-lanceulate, mostly crowded; Howers numerons, in a thyrsus or contracted panicle; lobes of the calyx longer than the tube ; stamens and style mostly exscrted beyond the bright blue corolla, which is nearly l' broad; capsule several-seeded. - Rare in our range, occurring in swamps and on mountains in N. II., N. Y., N.J., and Md., but common in the western mountains and far northwarl.

\section{ORDER 71. HY DROPHYLIACLAE. (WATERLAF FAMH.}

IIterbs, commonly hairy, with mostly alternate leares, regular j-merous and 5-androus flowers, in aspect between the foregoing and the next order; but the ovary entire and 1-celled with 2 parietal 4-many-ovuled placenta, or rarely 2-celled by the union of the placenta in hine axis; style 2-cleft, or 2 separate styles; fruit a 2-raleed 4 -many-scedud capsule. - Seeds mostly reticulated or pitted. Embryo small in copious albumen.-Flowers chiefly blue or white, in one-siled cymes or false racemes, which are mostly bractless and coiled from the apex when young, as in the Borage Family. A small order of plants of no marked properties; some cultivated for ornament.

Tribe I. H YDROPHYLLE. Ovary and eapsule 1-eelled. Seeds pitted or reticu-

lated; albunen eartilaginous. Leav'es ent-toothed, lobed or pinnate. Style 2-cleft.

* Ovary lined with the dilated and Heshy placentæ, which enclose the ovules and seeds (in our plants only 4) like an inner pericarp.

1. Hydrophyllum. Stamens exserted; anthers linear. Calyx unchanged in fruit.

2. Nemophila. Stamens included; anthers short. Calyx with appendages at the sinuses.

8. Ellisia. Stamens included. Calyx destitute of ajpendages, enlarged in fruit.

* * Ovary with narrow parietal placentze, in fruit projecting inward more or less.

4. Phacelia. Corolla-lobes imbrieated in the bud. Calyx destitute of appendages.

Tribe II. HYDROLE.E. Ovary and capsule 2-celled, the placentæ often projecting from the axis far into the cells. Albumen fleshy Leaves entire. Styles 2.

5. Hydrolea. Corolla between wheel-shaperl and bell shaped.

\section{HYDROPHÝLLUM, Tourn. Waterleaf.}

Calyx 5-parted, sometimes with a small appendage in each sinus, early open in the bud. Corolla bell-shaped, 5-cleft; the lobes convolute in the bud; the tube furnished with 5 longitudinal linear appendages opposite the lobes, which cohere by their middle, while their edges are folled inward, forming a nectariferous groove. Stamens and style mostly exserted; filanents more or less bearled; anthers linear. ()vary liristly-hairy (as is usual in the family); the 2 fleshy placentie expanded so as to line the cell and nearly fill the eavity, soon free from the walls except at the top and hottom, each bearing a pair of ovnles on the inner face. Capsule rijening $1-4$ seeds, spherieal. - Perennials, with petioled ample leaves, and white or pale blue cymose-clustered flowers. (Name formed of $\tilde{\delta} \delta \omega \rho$, water, and $\phi \dot{v} \lambda \lambda \nu \nu$, leaf; of no olvious application.)

* Calyx with minute if any appendages; rootstocks creeping, scaly-toothed.

1. H. macrophýllum, Nutt. Rough-hairy; leares oblong, pinnate and pinnatifid; the divisions $9-13$, ovate, obtuse, coarsely cut-toothed; root-leaves 
$1^{\circ} \operatorname{long} ;$ peduncle shorter than the petiole; calyx-lobes lanceolate-pointed from a broad base, very hairy ; flowers ( $6^{\prime \prime}$ long) crowded in a globular cluster; anthers short-oblong. - Rich woods, Ohio to Va. and Ala., west to the Mississippi. July.

2. H. Virgínicum, L. Smoothish $\left(1-2^{\circ}\right.$ high $)$; leaves pinnately divided; the dirisions $5-7$, orate-lanceolate or oblong, pointed, sharply cut-toothed, the lowest mostly 2-jarted, the uppermost confluent; peduncles longer than the petioles of the upper leaves, forked; calyx-lubes narrowly linear, bristly-ciliate; Howers $3^{\prime \prime}$ long; anthers oblong-linear. - Rich woods. June-Aug.

3. H. Canadénse, L. Nearly smooth ( $1^{\circ}$ high); leares $\left(3-5^{\prime}\right.$ broad) palmately 5-7-loled, rounded, heart-shaped at base, unequally toothed, those from the root sometimes with 2-3 small and scattered lateral leaflets; peduncles mostly shorter than the petioles, forked, the nearly white flowers on very short pedicels; calyx-lobes linear-aw]-shaped, nearly smooth, often with minute teeth in the sinuses. - Damp rich woods, $\mathrm{N}$. Eng. to the mountains of Va., and west to the Mississippi. June-Ang. - Rootstocks thickened and very strongly toothed in 2 rows by the persistent bases of the stout petioles.

* * Calyx with a small reflexed lobe in each sinus; stamens little exserted.

4. H. appendiculàtum, Michx. Hairy; stem-leaves palmately 5-lobed, rounded, the lobes toothed and pointed, the lowest pinnately divided; cymes rather loosely flowered; filiform pedicels and calyx bristly-hairy. - Damp woods, Ont. to mountains of N. C., west to Minn., Iowa, and Mo. June, July.

\section{NEMÓPHILA, Nutt.}

Calyx 5-parted, with a reflexed appendage in each sinus, more or less enlarged in fruit. Corolla bell-shaped or almost wheel-shapel ; the lobes convolute in the bud; the tube mostly with 10 small folds or scales inside. Stamens included; anthers oroid or heart-shaped. Placenta (bearing each 2-12 ovules), capsule and seeds as in Hydrophyllum. - Diffuse and fragile annuals, with opposite or partly alternate pinnatifid or lobed leaves, and one-flowered peduncles ; the corolla white, blue, or marked with purple. (Name composed of $\nu$ éros, a grove, and $\phi(\lambda \epsilon \omega$, to love.) Some handsome species are garden annuals.

1. N. microcalyx, Fisch. \& Meyer. Small, roughish-pubescent; stems diffusely spreading $\left(2-8^{\prime}\right.$ long $)$; leaves parted or deeply cleft into $3-5$ rouncish or wedge-obovate sparingly cut-lobed divisions, the upper leaves all alternate; peduncles opposite the leaves, shorter than the long petioles; flowers minute; corolla white, longer than the calyx ; placentæ each 2-oruled; capsule 1-2-seeded. - Moist woods, Va. to Fla., west to Ark. and 'Tex. April-June.

\section{ELLÍSIA, L.}

Calyx 5-parted, without appendages, enlarged and foliaceous in fruit. Corolla bell-shaped or cylindraceous, not longer than the calyx, 5-lobed above; the lobes imbricated or convolute in the bud, the tube with 5 minute appendages within. Stamens included. Placentæ (each 2-oruled), fruit, and seeds much as in Hydrophyllum. - Delicate and branching annuals, with lobed or divided leares, the lower opposite, and small whitish flowers. (Named for John Ellis, a distinguished naturalist, an English correspondent of Linuæus.) 
1. E. Nyctèlea, I. Minutely or sparingly roughish-hairy, divergently branched $\left(6-12^{\prime}\right.$ lighli) ; leaves pinnately parted into $7-13$ lanceulate or linearollong sparingly cut-toothed divisions; peluncles solitary in the forks or opposite the leaves, I-Howered; calyx-lobes lanceolate, printed, aluut the length of the cylindraceous (whitish) corolla (in fruit ovate-lan(enlate, nearly $t^{\prime}$ long), ('apsule pendulous. (K. ambigua, Nitt.; merely a slencler form.) - shady damp places, N. J. to Va., West to Minn. and Mo. May-July.

\section{P H A C E L I A, Juss.}

Calyx 5-parted; the sinuses naked. Corolla open-bell-shaped, 5-lobed; the lobes imbricated in the hul. Filaments slender, often (with the 2-cleft style) exserted ; anthers ovoid or oblong. Ovary with 2 narrow linear placenta alherent to the walls, in fruit nsually projecting inward more or less, the two often forming an imperfect partition in the oroil 4 - many seederl capsule. (Orules 2-30 on each placenta.) - Perennial or mostly annual herbs, with simple, lobed, or divided leaves, and often hamlsome (blue, purple, or white)

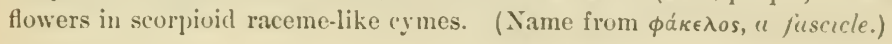

§ 1. PHACELIA proper. Seeds and orules only + (two on each placenta): corolla cumpanulute, with nairow folds or appenduges withu, the lolies enture.

1. P. bipinnatífida, Michx. Biennial; stem upright, hairy $\left(1-2^{2}\right.$ high), leaves long-petioled, piunately 3-5-(livided, the divisions or leaflets ovate or oblong-ovate, acute, coarsely and often sparingly cut-loled or pin natificl ; racemes elongated, lonsely many-flowered, glandular-pubescent; perlicels about the length of the ealyx, spreading or recurvel. - Shaded banks, in rich soil, Ohio to I1l. and southward. May, June. - Corolla bright blue, 6" broad, with 5 pairs of longitudinal ciliate folds, covering as many externally keeled deep grooves. Stamens bearded below and witl the style exserted.

\$2. COSMANTIUS. Ovules and seeds as in $\$ 1$; corolla almost rotate, wrth fimbriute lobes, and no appendages within: filuments villous-beurded, rarely exserted; leaves pinnatifid, the upper clasping.

2. P.Púrshii, Buckley. Sparsely hairy; stem erect or ascending, branched (8-12' high); lobes of the stem-lenes 5-9, oblong or lanceolute, urule; rurume many-flowered; culyx-lobes lance-lineur; rorolla light blue, varying to white (about $\frac{1^{\prime}}{2}$ in riameter). - Moist wooded banks, W. Penn. to Minn., and southward. A pril-June.

3. P. fimbriàta, Michx. Slightly hairy, slender: stems sprealing or ascending $\left(5-8^{\prime}\right.$ long), few-leaved ; lowest leaves $3-5$-divided into rounlish leaflets ; the upper 5 - 7 -eleft or cut-toothed, the lobes obtuse: raceme 3 - 10-floured ; caly.x-lobes linerur-oblon!y, olutuse, becoming spatulate; corollu uchute (3-4" broad). - Woods, high mountains of Va. to Mla. May.

§3. COSMANTHOIIES. Orules and seeds $2-8$ on each plarenta; corolla rolute or campanulate, with entire lobes and no appondages.

4. P. parviflò, Pursh. Sionewhat hairy, slender, liffusely spreading $\left(3-8^{\prime}\right.$ high $)$; leaves pinnately cleft or the lower livided into $3-5$ short lobes; racemes solitary, loosely 5-15-Howered, pedicels filiform, at length several times longer than the oblong calyx-lobes; corolla open-campanulate, hluish- 
white (4-6" broad) ; filaments hairy ; capsule globular, 6-12-seerled, a half shorter than the calyx. - Shaded banks, Penn. and Ohio to Mo., south to \& C. and Tex. April-June.

Var. hirsùta, Gray. More hirsute and the stems less slender, apparently growing in more open dry soil ; corolla larger, $5-\tau^{\prime \prime}$ in dianeter; seeds $4-8$. - Prairies and barrens, S. W. Mo. to E. Tex.; also Va. and Ga.

5. P. Covíllei, Watson. Like the last; racemes 2-5-flowered; calyxlobes linear, in fruit $3^{\prime \prime}$ long or more ; corolla tubular-campanulate with erect limb; filaments glabrous; capsule depressed-globose; seeds 4, large. - Larkspur Island in the Potomac, five miles above Washington. ( $F . V$. Coville.)

$\S 4$ EÙTOCA. Ovules and seeds numerous on each placenta; corolla rotatecampanulate, with 10 vertical lamelle within.

6. P. Franklínii, Gray. Soft-hairy; stem erect $\left(6-15^{\prime}\right.$ high), rather stont; leaves pimnately parted into many lanceolate or oblong-linear lobes, which are crowded and often cut-toothed or pinnatifid; racemes short, dense, crowded unto an oblong spike; calyx-lobes linear; corolla blue. - Shores of I. superior, thence north and westward.

\section{HY D R L LA, L.}

Calyx 5-parted. Corolla short-campanulate or almost wheel-shaped, 5-cleft. Filaments dilated at base. Styles 2, distinct. Capsule globular, 2-celled, with very large and fleshy many-seeded placentæ, thin-walled, 2-4-valved or bursting irregularly. Seeds minute, striate-ribbed-Herbs or scarcely shrubby, growing in water or wet places (whence the name, from $v \delta \omega \rho$, water), with entire leaves, often having spines in their axils, and clustered blue flowers.

1. H. affinis, Gray. Glabrous throughout; stem ascending from a creeping base, armed with small axillary spines; leaves lanceolate, tapering to a very short petiole; flowers in small axillary leafy-bracted clusters; divisions of the calyx lance-orate, equalling the corolla and the irregularly-bursting globose capsule. - Banks of streams, S. Ill. to Tex.

\section{Order 72. BORRAGINACEAE. (Borage Family.)}

Chiefly rough-hairy herbs, with alternate entire leaves, and symmetrical flowers with a 5-parted calyx, a regular 5-lobed corolla (except in Echium), 5 stamens inserted on its tube, a single style and a usually deeply 4-lobed orary (as in Labiatæ), forming in fruit 4 seed-like 1-sceded nutlets, or separating into two 2-seeded or four 1 -seeded nutlets. - Albumen none. Cotyledons plano-convex; radicle pointing to the apex of the fruit. Stigmas 1 or 2. Calyx valvate, the corolla imbricated (in Myosotis convolute) in the bud. Flowers mostly on one side of the branches of a reduced ('yme, imitating a spike or raceme. which is rolled up from the end, and straightens as the blossoms expand (circinate or scorpioid), often bractless. (A rather large family of innocent, mucilaginous, and slightly bitter plants; the roots of some species yielding a red dye.)

Tribe I. HELIOTROPIEA. Ovary not lobed; fruit separating into $2-4$ untlets

1. Heliotropium. Corolla salver-form. Stamens included. Nutlets 1-2-celled. 
Tribe II. HOIRAGINEX. Ovary depply 4-parteil, forming as many separate 1seeded uuclets in fruit; style rising fron the centre between them.

* Corolla and stamens regular.

- Nutlets armed, attached laterally : comolla short, closed by 5 scales.

2. Cynoglossum. Nutlets horizontally radiate, mu.h produed downwarl, covered with barbed prickles.

3. Echlnospermum. Nutlets erect or ascending, the margin or back armed with burbed frickles.

- + Nutlets not armed, attached more or less laterally.

4. Krynitzkia. Corulla short, white, with closed thruat. Nutlets attached along the imer angle.

5. Mertensia. Corolla trumpet-shaped with ofren throat, usually blue. Nutlets fleshy, attacherl just above the base.

+++ Nutlets unarmed, attached by the very base, ovoid, mostly smooth and shining. ++ Scar flat, small. Racemes leafy-bracteate, excejt in n. 6.

6. Myosotis. Corolla short salver-form, its lobes rounded, and throat crested.

7. Lithosperumm. Corolla salver-form to funnel-form, its rounded lobes spreading : the throat either naked or with low erests.

8. Onosmodium. Corolla tubular, unappendaged, its erect lobes acute.

++ Sear large and exeavated.

9. Symphytum. Corolla oblong-tubular, enlarged above and closed hy 5 scales.

* Corolla irregular, limb and throat oblique and lobes unernal.

10. Lycopsis. Corolla-tube curved, closed with hispid scales. Stamens included.

11. Echium. Dilated throat of corolla unappendaged. Stamens unequal, exserted.

Asperúgo procúmbens, L., a European annual, well markell by its much enlarged membranaceous and veiny fructiferous calyx, has sparingly appeared in waste grounds about New York and P'hiladelphia, and at l'ipestone, Miun.

\section{1. heliotrò Pi U M, Tourn. Toursole, Heliotrope.}

Corolla salver-form or fumnel-form, unappendaged, more or less plaited in the bud. Anthers nearly sessile. Style short; stigma conical or capitate. Fruit 2-4-lobed, separating into 2 indurated 2-celled and 2-seeded closed carpels, or more commonly into 4 one-seeded nutlets. - Herbs or low shrubby plants; leaves entire; fl. in summer, white (in our species). (The ancient name, from $\ddot{\eta} \lambda \iota s$, the sun, and $\tau \rho \circ \pi \dot{\eta}, a$ turn, with reference to its flowering at the summer solstice.)

§ 1. HELIOTROPIUM proper. Fruit 4-lobed, separuting into four l-celled 1-seeded nutlets. Style short.

* Flourers in bractless one-sided scorpioid spikes.

H. Europ.tum, L. Erect annual (6-18' high), hoary-pubescent; leaves oval, long-petioled; lateral spikes single, the terminal in pairs; calyx sprealing in fruit, hairy. - Waste places, sonthward; scarce. (Alv. from Eu.)

1. H. Curassávicum, I. A pparently annual, glabrous; stems ascending; leaves lance-linear or spatulate, thickish, pale, almost veinless; spikes in pairs. - Sandy seashore, Va.; saline soils, s. Ill, and south and westward.

* Inflorescence not at all scorpioid; flowers scattered.

2. H. tenéllum, Torr. A span to a foot high, paniculately branched, slender, strigose-eanescent; leaves narrowly linear, with revolute margins; flowers often hractless. - Upen dry ground, Ky. to Mo. and Kan., south to Ala. and Tex. 
§. 2. EUT POCA. Frunt didymous, the 2 carpels each splitting into two 1-seeded nutlets; style elongated; flowers scattered, large.

3. H. convolvulàceum, Gray. Low anıual, strigose-hirsute and hoary, much branched; leaves lanceolate, or ovate or even linear, shortpetioled; flowers opposite the leaves and terminal; corolla 6 " broad, the strigose-hirsute tube about twice as long as the linear sepals. - Sandy plains, Neb. to W. Tex. A showy plant, with sweet-sceuted flowers.

§ 3. TIARÍDIUM. Frnit 2-lobed, separating mo tuo 2-celled 2-seeded carpels, with sometines a puir of empty false cells; style very short; flowers in biactless scorpioid spikes.

H. f́nıcu, L. Frect and hairy annual; leaves petioled, ovate or oval and somewhat heart-shaped; spikes single; fruit 2-cleft, mitre-shaped, with an empty false cell before each seed-bearing cell. (Heliophytum Indicum, I C.) - iraste places, along the great rivers, from S. Ind. to Mo., and sonthward. (Adv. from ludia.)

\section{C Y N O G L Ó S S U M, 'Tourn. IIound's-Toxgue.}

Corolla funnel-form, the tube about equalling the 5-parted calyx, and throat (Josed with 5 obtuse seales; lobes rounded. Stamens included. Nutlets depressed or convex, oblique, fixed near the apex to the base of the style, roughened all over with short barhed or hooked prickles. - Coarse herbs, with a strong scent and peticled lower leaves; the mostly panicled (so-called) racemes naked above, usually bracted at base. Fl. all summer. (Name from $\kappa v ́ \omega \nu, a$ $\boldsymbol{l} \log$, and $\gamma \lambda \hat{\omega} \sigma \sigma \alpha$, tongne; from the shape and texture of the leaves.)

C. officisale, L. (Commox Hocxu's-Toxgue.) liennial; clothed with short soft hairs, leafy, pauicled above; upper leaves lanceolate, closely sessile by a rounded or slightly heart-sliaped base ; racemes nearly bractless; corollı reddish-purple (rarely white); nntlets flat on the broad upper face, somewhat margined. - Waste ground and pastures; a familiar and troublesome weed; the farge nutlets adhering to the fleece of sheep, ete. (Nat. from Eu.)

1. C. Virgínicum, I. (Wrind Confrey.) Perennial; ronghish with spreading bristly hairs; stem simple, few-leaved (2-30 high); stem-leaves lanceolate-oblong, clasping by a leep heart-slaped hase; racemes few and corymbed, raised on long naked peduncles, bractless; rorolla pale blue; uutlets strongly convex. - Open woods, Ont. anil Sask. to Fla. and La.

\section{ECH I N O S P ÉRM U M, Lehm. Sticksen.}

Corolla salver-form, short, imbricated in the bud, the throat closed with 5 short scales. Stamens inclinded. Nutlets erect, fixed laterally to the base of the style or central column, triangular or compressed, the back armed all over or with $1-3$ marginal rows of prickles which are barbed at the apex, otherwise naked.-Rough-hairy and grayish herbs, with small blue to whitish flowers in racemes or spikes; ours annuals or biennials, flowering all summer. (Name

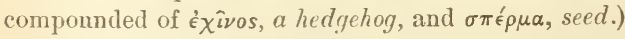

* Racemes panicled, leafy-bracteate at base; slender pedicels recurved or deflexed in fruit; calyx-lobes short, at length reflexed; biennial, not hispid.

1. E. Virgínicum, Lehm. (BegGar's Lice.) Stem $2-4^{\circ}$ high ; radical leaves round-orate or cordate, slender-petioled ; cauline $\left(3-8^{\prime}\right.$ long) orate- 
oblong to obloug-lanceolate, acuminate at loth encls; lonsely paniculate racemes divaricate; pelicel and flower each a line long, muthts of the globuse frnit equally short-glochidiate over the whole buck. (Cynoglossum Morisoni, $\left.I C^{\prime}\right)$ - Borders of woods and thickets, N. Eng. to Minn., sunth to Va. and I a.

2. E. defléxum, Lehm., var Americànum, (Gray I)iffusely liranched, about $1^{\circ}$ high, leaves oblong to lanceolate, racemes lax, lonsely faniculate; flowers small; nutlets of the globular-p!yramidal finut only murginally glochidiate. - Iowa, Minn., and northward.

3. E. floribúndum, Lehm liather strict, $2^{\circ}$ high or more; leavos oblong-tolinear-lanceolate, the lowest tapering into margined petioles; ratcemes numerous, commonly geminate and in fruit rather strict; corolla larger (blue, sometimes white), $2-3$ ' in diameter; nutlets scabrous and margined with a close row of flat subulate prickles. - Minn and Sask, and westward.

* * Racemes leafy-bracteate. stout pedirels not deflexed; calyx beroming foliaceous; leaves limear, lanceolate, or the lower spatulate. hispud annuals.

E. LÁptLA, Lelın. Erect, $1-2^{\circ}$ high, nutlets rough-granulate or tuherculate on the hack, the margins with a clonble row of slender distinct prickles, or these irregular over most of the back - Waste and eultivated grounds, from Canadia to the Middle Atlantic States. (Nat. from Eu.)

4. E. Redówskii, Lehm., var occidentàle, Watson. Erect, 1-2 high, at length diffuse; nutlets irregularly and minutely sharp-tuberculate, the margins armed with a single row of stout flattened prickles sometimes confluent at base. - Minn. to Tex., and westward.

\section{KRY NÍTZKIA, Fisch. \& Meyer.}

Calyx 5-parted or deeply cleft, erect or little spreading in fruit. Corolla short, usually with more or less fornicate throat. Nutlets erect and straight, unarmed, attached to the axis either at imner edge of base or ventrally from the base upwarl. - Ours are very hispicl anmuls or biennials, with small white flowers in scorpioid spikes. A large western genus. (Derlicated to Prof..J. Krynitzki, of Cracow.)

1. K. crassisépala, Gray. Annual, diffusely much branched, a span high, very rough-hispid; leaces oblanceolate and lineu-spatulate; flowers very small, short-pedicelled, mostly bracteate; lobes of the persistent calyx closert over the fruit, the midrib below becoming much thickened and indurated; nutlets ovate, acute, dissimilar, 3 of them muricate-granulate and 1 larger aud smooth, attached from the base to the middle. - l'lains, Sask. to Kan., 'Tex. ant N. Mex.

\section{MERTÉN SIA, Roth. Іекњшот.}

Corolla trumpet-shaped or bell-funnel-shaperl, longer than the deeply 5-cleft or 5-parted calyx, naked, or with 5 small glandular folds or appendages in the open throat. Anthers oblong or arrow-shaped. Style long and thread-form. Nutlets ovoid, fleshy when fresh, smooth or wrinkled, obliquely attached next the hase by a prominent internal angle, the scar small. - Smootl or softhairy perenuial herbs, with pale and entire leaves, and handsone purplish-blue (rarely white) flowers, in loose and short panicled or corymbed raceme-like clusters, only the lower one leafy-bracted; pedicels slender. (Named for Prof. Francis C'harles Mertens, a German botanist.) 
* Corolla trumpet-shaped, with spreading nearly entire limb and naked throat; filaments slender, exserted; hypogynous disk 2-lobed.

1. M. Virgínica, DC. (Virginian Cowslip. Lungwort. Blé Bells.) Very smooth, pale, erect $\left(1-2^{\circ}\right.$ high $)$; leaves obovate, veiny, those at the root $\left(4-6\right.$ ' long) petioled; corolla trumpet-shaped, $l^{\prime}$ long, many times exceeding the calyx, rich purple-blue, rarely white; nutlets dull and roughish. - Alluvial banks, N. Y. to Minn., S. C, and Ark. May. Cultivated for ornament.

* * Corolla with conspicuously 5-lobed limb, and crested throat.

\section{+ Filaments broad and short; nutlets dull, wrinkled or roughish when dry.}

2 M. paniculàta, Don. Roughish and more or less hairy, erect $\left(1-2^{\circ}\right.$ high), loosely branched, leaves ovate and orate-lanceolate, taper-pointed, ribled, thin; corolla (6" long) somewhat funnel-form, 3-4 times the length of the lance-linear acute divisions of the calyx, filaments broader and shorter than the anthers. - Shore of L. Supcirior and north and westward. July and Aug

3. M. lanceolàta, 1) ( . Glabrous or hirsute, pale, $1^{\circ}$ high or less, simple or branched, leares spatulate-oblong to lanceolate-linear, smaller (1-2'long), nearly veinless, obtuse or acute; corolla-tube somewhat longer than the lanceolate calyx-lohes; filaments generally longer than the anthers.-Dak. to N. Mex. and westward.

+- Filaments longer and narrover than the anthers; mutlets shining, utricular.

4. M. marítima, Don. (SEA Lrsgwort.) Spreading or decumbent, smooth, glaucous; leaves fleshy, ovate or obovate or spatulate, the upper surface becoming papillose; corolla white, bell-funnel-form ( $3^{\prime \prime}$ long), twice the length of the calyx. - Sea-coast, on rocks and sand, Cape Cod to Maine and northward; scarce. June-Aug.

\section{MYOSÒTIS, Dill. Scorpion-grass. Forget-ye-Not.}

Corolla salver-form, the tube about the length of the 5-toothed or 5-cleft calyx, the throat with 5 small and blunt arching appendages opposite the rounded lohes; the latter convolute in the bud! Stamens included, on very short filaments. Nutlets smooth, compressed, fixed at the base; the scar minute. - Low and mostly soft-hairy herbs, with entire leaves, those of the stem sessile, and with small flowers in naked racemes, which are entirely bractless, or occasionally with one or two small leaves next the base, prolonged and straightened in fruit. Flowering through the season. (Name composed of $\mu$ ús, mouse, and oủs, $\dot{\omega} \tau o ́ s$, ear, in allusion to the aspect of the short and soft leaves in some species; one popular name is MocsE-EAR.)

* Calyx open in fruit, its hairs appressed, none of them hooked or glandular.

M. Palústris, Withering. (Trte Forget-me-xot.) Perennial; stems ascending from an oblique creeping base $\left(9-20^{\prime}\right.$ high), loosely branched, smoothish; leaves rough-pubescent, ohlong-lanceolate or linear-oblong; calyxlobes much shorter than its tube; limb of corolla 3 or 4 lines broad, sky-blue with a yellow eye. - In wet ground, probably only escaped from cultivation. (Nat. from Eu.)

1. M. láxa, Lehm. Perennial from filiform subterranean shoots; stems very slender, decumbent; pubescence all appressed; leaves lanceolate-oblong 
or somewhat spatulate; calyx-lobes as long as its tube; limb of corolla 2 or 3" brual, paler blıe. (M. palustris, var. laxa, (iruy.) - In water and wet ground, Newf. to N. Y. (Eu.)

* Culyx closing or the lubes erect in fruit, clothed with spreadiny hairs, some minutely hooked or gland-tipped; corolla sinull ; unnual or biennial.

2. M. arvénsis, Iloff $m$. Uirsute with sprearling hairs, erect or ascending $\left(6-15^{\prime}\right.$ high $)$; leares oblong-lanceolate, acutish ; rucemes naker at the base and stulked; corolla blue, rarely white; pediesls spreuding in fruit and longer than the 5-cleft equal calyx. - Ficlis, etc.; not very common. (Eu.)

3. M. vérna, Nutt. Bristly-hirsute, branched from the base, erect (4$12^{\prime}$ high); leaces obtuse, linear-oblong, or the lower spatulate-oblong; rucomes leafy at the buse; corolla very small, white, with a short limb; pedicels in fruit crect and appressed at the base, usually abruptly bent outward near the apex, ra'ier shorter than the deeply 5-cleft unequal (somewhat 2-lipped) very hispid cal.jx. - Dry ground, rather common. May-July.

M. VERsf́oLor, I'ers. More slender than the last, simple at hase; racemes loose, mostly naked at base; fluwers almost sessile; corolla pale yellow changing to blue or violet; calyx deeply and equally 5-clefi. - Fields, Del. (Nat. from Eu.)

\section{L I T H O P ÉR NI U M; 'Tourn. Gromwell. Pcccoon.}

Corolla funuel-form, or sometimes salver-shaped; the open throat naked, or with a more or less evillent transverse foll or scale-like appendage opposite each lobe; the spreading limb 5-cleft, its lobes rounded. Anthers oblong, almost sessile, included. Nutlets wate, smooth or roughened, mostly bony or stony, fixed by the hase; scar nearly flat. - Herbs, with thickish and commonly red roots and sessile leaves; flowers solitary and as if axillary, or spiked and leafy-bracted, sometimes dimorphous as to insertion of stamens and length of style. (Name formed of $\lambda i \theta_{o s}$, stone, and $\sigma \pi \dot{\epsilon} \rho \mu \alpha$, secel, from the hard nutlets.)

$\S 1$. Nutlets tubercled or rough-urinkled and pitted, gray and dull ; throat of the (nearly uthite) corolla destitnte of any evident fulds or appendages.

L. ARvéxse, i. (CORx GRomwelz.) Minutely rough-hoary, annual or biennial; stems erect $\left(6-12^{\prime}\right.$ high); leaves lanceolate or linear, veinless; corolla scarcely longer than the calyx. - Sandy banks and roadsides. MayAug. (Nat. from Eu.)

§ 2. Nutlets smooth and shining, white like irory; coro'lu greenish-uhite or paleyellow, small, with 5 distinct mheseent scales in the throat; peremiul.

L. orficinde, L. (Commox Gromweri.) Much hranched ahove, erect $\left(1-2^{\circ}\right.$ high); leares thinnish, broadly lanceolate, arute, with a few distiuct veins, rough alove, soft-pubescent beneath; corolla excerdiny the calyx. Roadsides, N. Eng. to Mimm. (Nat. from Eu.)

1. L. latifolium, Michx. Stem loosely branched, erect $\left(2-3^{\circ}\right.$ high $)$, rough; leaves ovate and orate-lancolate, mostly taper-pointed (even the floral ones $2-4^{\prime}$ long), ribled-reined, roughish above, fuely soft-puhescent beneath, the root-leaves large and rounled; corolla shorter than the calyx. - Open ground and borders of woods, W. New York to Minn., south to Va. and Ark.

§3. BÁTSCHIA. Nutlets white, smooth and shining; corolla large, sulverform or nearly so, deep orange-yellow, somewhat pubescent, the tube much 
exceeding the calyx, and the throat appendaged. (Roots perennial, long and deep, yielding a red dye.)

* Corolla-tube one half to twire longer than the caly.x, not much longer than the ample limb, the lobs entive; appendages little if at all projecting.

2. I. hírtum, Lehm. Itispid with bristly hairs $\left(1-2^{\circ}\right.$ high $)$; stemleaves lanceolate or linear, those of the flowering branches ovate-oblong, bristly-ciliate; corolla woolly-bearded at the base inside (limb 8-12" broad); flowers distinctly peduncled, crowded, showy; fruiting calyx ( $\left(\frac{1}{2}^{\prime}\right.$ long) 3-4 times longer than the nutlets. - Pine barrens, etc., N. Y. to Minn., south and westward. April-June.

3. L. canéscens, Lehm. (Prccoox of the Indians.) Softly hairy and more or less houry $\left(6-15^{\prime}\right.$ high); leaves obtuse, linear-oblong, or the upper ovate-oblong, more or less downy beneath and ronghish with close appressed lairs abose; flowers sessile; corolla naked at the base within; fruiting caly $x$ $\left(3^{\prime \prime}\right.$ long) burely twice the length of the nutlets. - Plains and open woods, in sandy soil, Ont. to Va., Ala., and westward. May.

* * Corolla-tule in well-developed flowers $2-4$ times the length of the calyx and of its erose-toothed lobes, and the appendages conspicuous and arching; later flowers small, cleistogenous.

4. I. angustifolium, Michx. Erect or diffusely branched from the base, $6-18^{\prime}$ bigh, minutely rongh-strigose and hoary; leares linear; flowers pedicelled, leafy-bracted, of two sorts; the earlier large and showy (corollatube $8-18^{\prime \prime}$ long), the later and those of more diffusely branching plants, with inconspicuous or small and pale corollas, without crests, and the pedicels commonly recurved in fruit; nutlets usually punctate. (L. longiflorum, Siment.; the long-flowered form.) - Dry and sterile or sandy soil, Ind. and Mich. to Dak. and Tex., and westward.

\section{ONOSMÒdUM, Michx. False Gromwell.}

Calyx 5-parted; the divisions linear and erect. Corolla tubular, or tubularfunuel-form, not crested (the sinuses minutely hooded-inflexed), the 5 acute lobes converging or barely spreading. Anthers oblong-linear or arrowshaped, mucronate, inserted in the throat. style thread-form, much exserted. Nutlets hony, ovoid, smonth, erect, fixed by the base; the scar minute, not hollowed out. - Chiefly perennial herhs, coarse and hispid, with oblong and sessile ribbed-veined leaves, and white, greenish, or yellowish flowers, in at length elongated and erect leafy raceme-like clusters; in summer. - Our species belong to true (xosmonium, with smooth included anthers on very short filaments; the corolla rarely twice the length of the calyx. (Named from the likeness to the genus Onosmu, which name means ass-smell.)

1. O. Virginiànum, DC. Clothed all over with harsh and rigid appressed short bristles; stems rather slender $\left(1-2^{\circ}\right.$ high); leaves narrowly oblong, or oblong-lanceolate ( $1-2 \frac{1^{\prime}}{2}$ long), the lower narrowed at base; lobes of the narrow corolla lance-aut-shaped, sparingly bearded outside with long bristles. - Banks and hillsides, N. Eng. to Fla., Mo., and La.

2. O. Caroliniànum, DC. Shaggy all orer with lony und spreading bristly hairs; stem stout, upright $\left(2-4^{\circ}\right.$ high $)$; leaves ovute-lanceolate or 
oblong-lanceolate, acute; lobes of the rather broad corolla ovntetriangular or triungular-tanceolate, thickly hirsute outside. - Alluvial grounds, W. New York to Minn., south to Ga. and 'Tex.

Var. mólle, Gray. Pubescence shorter and less spreading or appressed, $1-2^{\circ}$ lighl, leaves mostly smaller ( $2^{\prime}$ long), when young softly strigose-canescent beneath. (O. molle, Michx.) - Ill. to Minn., Tex., and westward.

\section{SÝ M P H Y T U , Tourn. CoMrkY.}

Corolla oblong-tubular, inflated above, 5-tootherl, the short teeth sprearing; the throat closed with 5 converging linear-awl-shaped scales. Stamens includerl; anthers elongaterl. Style threal-form. Nutlets smooth, wate, erect, fixed by the large hollowed hase, which is funcly toothed on its margin. - Coarse perennial herbs, with thickened bitterisli nucilaginous roots; the nodling raceme-like elusters either single or in pairs. (Ancient (ireek name from $\sigma \nu \mu \phi \epsilon i \nu$, to grow together, probably for its reputed healing virtues.)

S. officixale, I. (Consox Comfrey.) Hairy, branched, winged above by the decurrent leaves; the lower leaves ovate-lanceolate, tapering into a petiole, the upper narrower; corolla yellowish-white, rarely purplish.

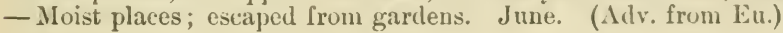

\section{I Y C Ó P I S, I. Buciloss.}

Corolla funnel-shaped, with curved tuhe and slightly unequal limb; the throat closed with 5 convex obtuse bristly scales opposite the lobes. Stamens and style included. Nutlets rongh-wrinkled, erect, fixed by a hollowed-out

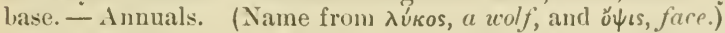

L. ARvéxsis, I. (SMald, Bugloss.) Very rongh-hristly (10 high); leaves lanceolate; flowers in leafy raceme-like clusters; calyx as long as the tube of the small blue corolla. - Dry or sandy fields, New Fing. to Va.; scarce. (Adv. from Eu.)

\section{1. ÉCHIUM, Tonrn. V'Hl'ER's Bugloss.}

Corolla with a cylindracenus or fnunel-form tube, and a more or less unequal sprearling 5-lobed horder; lobes rounded, the expanded throat naked. Stamens mostly exserted, unequal. Style threal-form. Nutlets roughenerl or wrinkled, fixed by a flat base. ( $A$ name of Dioscoricles, from $\breve{\epsilon} \chi\llcorner$, 1 i viper.)

E. VLlgAne, L. (BLE-WEen.) liough-bristly hiennial; stem erect ( $2^{\circ}$ high), mostly simple; stem-leaves linear-lanceolate, sessile; flowers showy, in short lateral clusters, disposed in a long and narrow thyrsus; corolla reildish-purple changing to brilliant blue (rarely pale). - lioadisides and meadow: of the Middle Atlantic Nitates. June. (Nat. from Eu.)

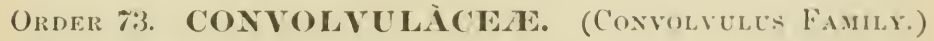

Chiefly twining or trailing herbs, often with some milky juice, rith alternate leaves (or scales) and regular 5-androus flowers; a calyx of 5 imbricated sepals ; a 5-plaited or 5-lohed corolla convolute or twisted in the but (imbricate in n. 6); a 2.celled (rarely 3-celled) ocary (or in one tribe 2 separate pistils), with a pair of erect orules in each cell, the cells sometimes doubled by a false partition. letween the seeds, so becoming 4-celled; the embryo large, curcer or coiled in mucilaginous albumen.Fruit a globular 2-6-seederl capsule. Flowers mostly showy, on axillary peduncles; pedicels artienlated, often 2-bracted. (Many are culti- 
vated for ornament, and one, the Sweet Potato, for its edible farinaceous roots; those of several species are cathartic; e. g. Jalap.)

Tribe I. DICHONDREA. Carpels 2 or 4, distinet or nearly so; styles 2, basilar. Creeping herbs.

1. Dichondra. Corolla deeply 5-cleft. Pistils 2, one-seeded.

Tribe II. ConvolvULEA. Ovary entire. Leafy plants, mostly twiners

2. Ipomøa. Style undivided, with stigma capitate or 2-3-globose.

3. Convolvulus. Style undivided or 2-cleft only at apex; stigmas 2, linear-filiform to subulate or orate.

4. Breweria. Style 2-cleft or 2-parted; the divisions sinıle; stigmas capitate.

5. Evolvulus. Styles 2, each 2-cleft; stigmas linear-filiform. Not twining.

Tribe III. CUSCUTEAE. Ovary entire. Leafless parasitic twining herbs, never green. Embryo filiform, coiled, without cotyledons.

6. Cuscuta. The only genus of the group.

\section{D I C HÓ N D R A, Forst.}

Calyx 5-parted. Corolla broadly bell-shaped, 5-cleft. Stamens included. Styles, ovaries, and utricular 1-2-seeded capsules 2, distinct. Stigmas thick. - Small and creeping perenuial herbs, soft-pubescent, with kidney-shaped entire leaves, and axillary 1-flowered bractless peduncles. Corolla small, yel-

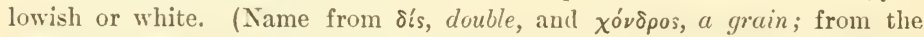
fruit.)

1. D. rèpens, Forst. Leaves round-kidney-shaped, pubescent, green both sides; corolla not exceeding the calyx (1-1 $\frac{1}{2}$ " long). - Wet ground, Va. to Tex., near the coast.

\section{IPOMEA, L. Morxing Glory}

Calyx not bracteate at base, but the outer sepals commonly larger. Corolla salver-form or funnel-form to nearly campanulate; the limb entire or slightly lobed. Style undivided, terminated by a single capitate or 2 - 3-globose stigma. Capsule globular, 4-6 (by abortion fewer)-seeded, 2-4-valved. (Name,

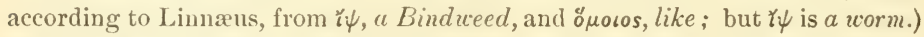
§ 1. QUAMOCLIT. Corolla salver-form, or with somewhat funnel-form but nar. row tube; stamens and style exserted; flowers red. Annual twiners.

I. Quámoclit, L. (CYpress-Vixe.) Leares pinnately parted into linearthread-shaped delicate parallel lobes; peduncles 1-flowered; corolla narrow, scarlet-red, or sometimes white. (Quanoclit vulgaris, Choisy.) - Sparingly spontaneous southward. (Trop. Amer., ete.)

I. coccfies, I. Leaves heart-shaped, acuminate, entire or angled ; sepals awn-pointed; corolla light scarlet ( $l^{\prime}$ long). (Quamoclit coccinea, Moench.) River-banks, etc., Ohio to Ill., Va., and southward. (Probably indigenous in N. Mex. and Arizona.)

$\S 2$. IPOMCEA proper. Corolla funnel-form or nearly campanulate, contorted in the bud; stamens and style not exserted.

* (Moring Glori.) Lobes of stigma and cells 3 ; sepals long and narrow, attenuate upward, mostly hirsute below, corolla purple, b/ue, and white.

I. HEDERACEA, Jacq. Stems retrorsely hairy, leaves lieart-shaped, 3-lobed, the lobes acute or acuminate; peduncles short, or rather long, 1-3-flowered; calyx densely hairy below; corolla white and purple or pale blue $\left(1-1 \frac{1}{2}\right.$, long). (I. Nil. of Manual, not Roth.) - Waste and cultivated ground, Penn. to Fla., and La. (Trop. Amer.) 
I. purpúrea, Lam. (Commox Morvisg-(iıorr.) Annual; stems retrorsely hairy; leares heart-shoped, acuminate, entire; perluncles long, umbellately 3-5-flowered ; calyx bristly-hairy below; corollit funtel-form ('2' long), purple, varying to white. - Lseajed in cultivated gromuls. ('lrop. Amer.)

* * Stigma 2-lobed or entire; cells 2, each 2-seeded; sepals brouder, imbricated.

\section{- Leaves cordate, acuminate.}

1. I. panduràta, Meyer. (Wild Potato-rixe. Max-of-the-Earth.) Perennial, smooth or nearly so when old, trailing or sometines twining; leaves occasionally contracted at the sides so as to be fildle-shaped; perluncles longer than the petiolss, 1-5-flowered; sepuls smooth, ovate-oblong, very obtuse; corolla open-funnel-form ( $3^{\prime}$ long), white with purple in the tube.-1)ry ground, Conn. to Mich., south to Fla. and Tex. June-Aug. Stems long and stout, from a liuge root, which often weighs $10-20$ pounds.

2. I. lacunòsa, L. Annual ; rather smooth; stem twuing and ereeping, slender; leaves entire or angled-lobed; peduncles short, 1-3-fowered; sepuls lance-ablong, pointed, bristly-ciliate or hairy, half the length of the sharply 5-lobed (white, $\frac{1}{2}-\frac{1^{\prime}}{3}$ long) corolla. - liver-banks and low grounds, Yenn. to 1ll., south to S. C. and Tex.

\section{+ + Leaves linear; not twining.}

3. I. leptophýlla, Torr. Perennial, very glabrous; stems erect or ascending $\left(2-4^{\circ}\right.$ high), with slender recurving branches, from an immense root (weighing 10-100 pounds); leaves 2-4' long, 2-3" wide, short-petioled, acute; peduncles short, 1-2-flowered; sepals broadly ovate, very obtuse, outer ones shorter; corolla pink-purple, funnel-form, about $3^{\prime}$ long. - Plains of Neb. to central Kian., Tex., and westward.

\section{CONVÓLVULUS, Tourn. Bisdweed.}

Corolla funnel-form to campanulate. Stamens included. Style undividei or 2-cleft only at the apex; stigmas 2 , linear-filiform to subulate or ovate. Capsule globose, 2-celled, or imperfectly 4 -celled by spurious partitions betyeen the 2 seerls, or by abortion 1-celled, mostly 2-4-valred. - Herlss or somewhat shrubby plants, either twining, erect, or prostrate. (Name from convolvo, to entwine.)

§1. CAlistégiA. Stigmas oval to oblong; calyx enclosed in a hroarl leafy bracts.

1. C. spithamæus, I. Downy; stem low and mostly simple, upright or ascending (6-12' long); leaves oblong, with or without a heart-shaped or auricled base ; corolla white ( $2^{\prime}$ long) ; stigmas oral. (Calystegia spithamra, Pursh.) - J)ry and sandy or rocky soil; not rare.

2. C. sèpium, L. (HEnge Brwwlen.) Glabrous, or more or less pubescent; stem twining or sometimes trailing extensively; leaves triangularhalberd-shaped or arrow-shaped, acute or pointed, the basal lobes obliquely truncate and often somewhat toothed or sinuate-lobed; peduncles 4-angled; bracts commonly acute; corollia white or tinged with rose-color ( $1 \frac{1}{2}-2^{\prime}$ long). (Calystegia sepium, R. Br.) - Moist alluvial soil, or along streams; N. Atlantic States and westward. (Eu., ete.)

Var. Americànus, Sims. Glabrous ; corolla pink or rose-purple; bracts obtuse. (C. sepium of Am. authors mainly.) - Common, across the continent. 
Var. rèpens, Gray. More or less pubescent; sterile and sometimes flowering stems extensively prostrate; leaves more narrowly sagittate or cordate, the basal lobes commonly obtuse or rounded and entire; corolla from almost white to rose-color; bracts very obtuse or acute. (Calystegia sepium, var. pubescens, Gray.) - Common.

\section{§. Sigmas filiform; no bracts at or near the base of the calyx.}

C. Arvéxsis, L. (Brinween.) Peremnial; stem procumbent or twining, and low ; leaves ovate-oblong, arrow-shaped, with the lobes at the base acute; peduncles mostly 1-flowered ; bracts minute, remote; corolla (9" long) white or tinged with reddish. - Old fields, N. Atlantic States. (Eu.)

\section{BRE W E R A, R. Br.}

Styles 2, or rarely 3, simple and distinct, or else united into one below; stigmas depressed-capitate. Otherwise as Convolvulus and Evolvulus. Perennial prostrate or diffusely spreading herbs; flowers small; in summer; corolla more or less hairy or silky ontside. (Named for Samuel Brewer, an English botanist or amateur of the 18th century.)

1. B. humistràta, Gray. Sparsely hairy or nearly smooth; leaves varying from oblong with a somewhat heart-shaped base to linear, mucronate or emarginate; peduncles $1-7$-flowered; bracts shorter than the pedicels; sepals pointed, glabrous or nearly so; corolla white; filaments hairy; styles united at base. (Bonamia humistrata, Gray.) - Dry pine barrens, Va. to La.

2. B. aquática, Gray. Minutely soft downy and somewhat hoary; peduncles 1-3-flowered; sepals silky; corolla pink or purple; filaments smooth; styles chmost distinct; otherwise nearly as n. 1. (Bonamia aquatica, Gray.) Wet pine barrens and margins of pouds, N. C. to Tex., extending into Mo.

3. B. Pickeríngii, Gray. Soft-pubescent or smoothish; leaves very murouly linear or the lowest linear-spatulate, tapering to the base, nearly sessile; peduncles 1 -3-flowered ; bracts resembling the leaves, mostly exceeding the flowers; sepals hairy; filaments. (scarcely hairy) and styles (united far above the middle) exserted from the open white corolla. (Bonamia Pickeringii, Gray.) - Dry pine barrens and prairies, N. J. and southward; also W. Ill.

\section{E V ÓL V U L S, L.}

Calyx of 5 sepals, naked at base. Corolla open funnel-form or almost rotate. Styles 2, each 2-cleft; stigmas obtuse. Capsule 2-celled; the cells 2-seeded. - Low and small herbs or suffrutescent plants, mostly diffuse, never twining (hence the name, from evolvo, to unroll, in contrast with Convolvulus).

1. E. argénteus, Pursh. Many-stemmed from a somewhat woody base, dwarf, silky-rillous all over; leaves crowded, broadly lanceolate, sessile, or the lower oblong-spatulate and short-petioled, about $\frac{1}{2}$ long; flowers almost sessile in the axils; corolla purple, $3^{\prime \prime}$ broad. - Sterile plains and prairies, Dak. and Neb. to Mo. and Tex.

\section{CÚS CUTA, Tourn. Donder.}

Calyx 5- (rarely 4-) cleft, or of 5 sepals. Corolla glohular-urn-shaped, bellshaped, or short-tubular, the spreading border 5- (rarely 4-) cleft, imbricate. Stamens with a scale-like often fringed appendage at base. Ovary 2-celled, 
4-oruled; styles distinct, or rarely united. ('apsule mostly 4-seeded. Embryo thread-shaperl, spirally coiled in the rather fleslyg allumen, destitute of cotylerlons, sometimes with a few alternate scales (lwlonging to the plumule); germination oceurring in the snil. - Leafless anumal herhs, with threal-like yellowish or roldish stems, hearing a few minute scales in place of leaves; on rising from the gromel becoming cutirely parasitic: on the lark of herlss and shruls on which they twine, and to which they adhere ly means of suckers dereloped on the surfite in contiut. Flowers small, rynose-clustered, mostly white; usually proluced late in summer and in autumn. (Name supposed to be of $\triangle$ rabic derivation.)

\section{$\S 1$. Stigmas elonyated; capsule circumscissile.}

C. Erfuxu, Weihe. (Fux Downer) Stems very slender, low: flowers globular, sessile in ilense scattered heals; corolla 5-paited, slort-cylindrical, scarcely exceeling the hroally ovate acute divisions of the caly, persistent around the capsule; stamens incluled ; scales short, broad, crenulate, shorter than the globose ovary. - Flax-fields; in Europe very injurious; sparingly introduced with flax-seed into the Northern State's. Junc.

C. EpfruYuvu, Murr. Stems very slender; flowers (apitate; corolla-lobes spreading, the cyliutrical tube longer than the suberect achte sepals; scales lirge, contiguous, toothed; stamens exserted. - ()ceasionally found in cloverticlds. (Int. from Eu.)

\section{$\S 2$. Stigmas copritate; capsule indehiscent.}

* Calyx gamosepalous; ovary and cupsule depressed-globose.

+ Flowers in dense or globular chusters; corolla with short and wide tuthe, persistent at the buse of the capsule; styles mostly shorter thun the outury.

1. C. chlorocárpa, Engelm. Stems coarse, orange-colored: flowers white ( $1-1 \frac{1^{\prime \prime}}{4}$ long); lobes of caly.r and rorolla (mostly 4) cucute, often longer than the tube; scales small, 2-cleft, often reducerl to a few tecth; the thin rapsule pale greenish-yellow. - Wet places, from Wisc. and Minn. to Ark.; alsu in I'enn. and Del., often on l'olygonum.

2. C. arvénsis, Beyrich. Stems pale and slentler, low; fincers smaller (hardly $\mathrm{l}^{\prime \prime}$ long) ; cully $x$-lobes (5) obtuse, mostly very broad; those of the corolla acuminate, longer than the tube, with inflexed points; scales large, deeply fringed. - Rather dry soil on various low plauts, $N$. Y. to Fla., west to the l'acific. Very variable.

+ + Flowers in panicled ofien compound cymes; styles slender, mostly longer than the ovary; corolla withering on the summit of the large copsule.

3. C. tenuiflora, Engelm. Sitems coarse and yellow, nsually rather high"limbing; flowers ( $l^{\prime \prime}$ long or less) on short thick pelicels, often 4-merous; lobes of calyx and corolla oblong, olotuse, the latter mostly shorter than the slender deeply campanulate tube; scales shorter than the tube, fringedl. - 1 n tall herbs ancl shrubs in wet places, l'enn. to Minn., and south to 'Tex.

* * Calyx gamosepulous; ocary and rapsule pointed, the latter enveloped or capped by the marcescent corolla; flocers in lewse panicled cymes.

$$
\text { - Arute tips of the corollatolios inflexed. }
$$

4. C. decora, Engelm. Stems coarse; fowers fleshy and more or less papillose; calyx-lobes triangular, acute; those of the broally campanulate 
corolla ovate-lanceolate, minutely crenulate, spreading; scales large, deeply fiinged; capsule enveloped by remains of corolla. (C. indecora, Choisy.) - Var. PUlchérrina, Engelın. The larger form, with coarser stems, and conspicuons flowers $1 \frac{1}{2}-2 \frac{1}{2}$ "long and wide; anthers and stigmas yellow or deep purple. - Wet prairies, on herbs and low shrubs (principally Leguminosæ and Compositx), from Ill. to Fla. and Tex., and westward.

5. C. infléxa, Engelm. Similar to the preceding; flowers of the same structure, but smaller (only $1^{\prime \prime}$ long), generally 4-merous; corolla deeper, with erect lobes, finally. capping the capsule; scales reduced to "few teeth. - Open woods and dry prairies, on shrubs (hazels, etc.) or coarse herbs, southeru $\mathrm{N}$. Eng. to Neb. and Ark.

+- + Corolla-lobes obtuse, spreading.

6. C. Gronòvii, Willd. Stems coarse, often climbing high; corollalobes mostly shorter than the deeply campanulate tube; scales copiously fringed; capsule globose, umbonate. - Wet shady places, Cauada to Minn., sonth to Fla. and Tex. The commonest of our species. Flowers very variable in size and compactness of clusters. - Var. LAtiflòn, Engelm., is a form with flowers of more delicate texture, and shorter tube and longer lobes to the corolla. Common northward.

7. C. rostràta, Shuttleworth. Similar to the preceding; flower's larger $\left(2-3^{\prime \prime}\right.$ long), more delicate and whiter; lobes of corolla and calyx shorter than its tuhe; slender styles longer; ovary bottle-shaped; capsule long-pointed. — Shady valleys in the Alleghanies, from Md. and Va., southward; on tall herbs, rarely shrubs.

* * Sepals 5, distinct, surrounded by 2 or more similar bracts; styles capillary; scales large, deeply fringed ; capsule capped by the marcescent corolla.

8. C. cuspidàta, Engelm. Stems slender; flowers $\left(1 \frac{1}{2}-2 \frac{1{ }^{\prime \prime}}{4}\right.$ long) thin, on brarteolate pedicels in loose panicles; the ovate-orbicular bracts and sepals and the oblong corolla-lobes cuspidate or mucronate, rarely obtuse, shorter than the cylindrical tube; styles many times longer than the ovary, at length exserted. - Wet or dry prairies, on Ambrosia, Iva, some Leguminosæ, etc., Neb. to Tex., occasionally down the Missouri as far as St. Louis.

9. C. compácta, Juss. Stems coarse; flouers closely sessile in densely compact clusters; bracts $(3-5)$ and sepals orbicular, concave, slightly crenate, appressed, nearly equalling or much shorter than the cylindrical tube of the corolla; stamens shorter than the oblong obtuse spreading lobes of the latter. - Along the west side of the Alleghanies from Ont. to Ala., west to Mo. and Tex. In damp woods, almost always on shrubs.

10. C. glomeràta, Choisy. Flowers very densely clustered, forming knotty masses closely encircling the stem of the foster plant, much imbricated with scarious oblong bracts, their tips recured-spreading; sepals nearly similar, shorter than the oblong-cylindrical tube of the corolla; stamens nearly as long as the oblong-lanceolate obtuse spreading or reflexed corolla-lobes; style several times longer than the orary. - Wet prairies, Ohio to Minn., Kan., and Tex., mostly on tall Compositæ. The rope-like twists $\left(\frac{1}{2}-\frac{8^{\prime}}{4}\right.$ thick), of white flowers with golden yellow anthers imbedded in a mass of curly bracts, have a singular appearance. 


\section{Order 74. SOLANACEAl: (Nigitsmade Family.)}

Herbs (or rarely shruls), with colorless juice and alternale leares, regular. 5-merous and 5-androus flowers, on bractless perlicels; the corollu imbricate or valcule in the bul, and mostly plaited; the finit a 2-crelled (rarely 3-5-celled) many-seeded capsule or berr\%. - Seeds campylotropous or amphitropous. Embryo mostly slender and curved in fleshy albumen. Calyx usually persistent. Stamens mostly equal, inserted on the corolla. Style and stigma single. Placente in the axis, often projecting far into the cells. (Foliage rank-scented, and with the fruits mostly narcotic, often very poisonous, while some are edible.) - $A$ large family in the tropics, but very few indigenous in our district. It shates off into Serophulariacese, from which the plaited regular corolla and 5 equal stamens generally distinguish it.

* Corolla whcel-shaped, 5-parted or 5-lobed; the lobes valvate and their margins usually turned inward in the bud. Anthers connivent. Fruit a berry.

1. Solanum. Anthers opening by pores or chinks at the tip.

* * Corolla various, not wheel-shaped, nor valvate in the lud. Antliers separate.

- Fruit a berry, closely invested by an herbaceous (not angled) calyx.

2. Chamæsaracha. Corolla plicite, 5-angulate. Pedicels solitary, recurved in fruit.

+ + Fruit a berry, enclosed in the bladilery-inflated calyx. Corolla widely expanding.

3. Physalis. Calyx 5-cleft. Corolla 5-lubed or nearly entire. Berry juicy, 2-celled.

4. Nicandra. Calyx 5-parted. Corolla nearly entire. Berry dry, 3-5-celled.

+++ Fruit a berry witl the unaltered calyx persistent at its base.

5. Lycium. Corolla funnel-form or tubular, not plaited. Berry snall, 2-celled.

+++- Fruit a eapsule.

6. Hyoscyamus. Calyx urn-shaped, enclosing the smonth 2-celled capsule, which opens by the toj, falling off as a lisl. Corolla and stamens somewhat irregular.

7. Datura. Calyx prismatir, 5-tonthel. Capsule prickly, naked, more or less 4-celled, 4-valved. Corolla funnel-form.

8. Nicotiana. Calyx tubnlar-bell-shaped, 5-cleft. Capsule enclosed in the calyx, 2-celled.

\section{SOL À N U M, Tourm. Nightsiade.}

Calyx and wheel-shaped corolla 5-parted or 5-cleft (rarely 4-10-parted), the latter plaited in the bud, and valvate or induplicate. Stamens exserted; filaments very short; anthers converging around the style, opening at the tip by two pores or chinks. Berry usually 2-celled. - Herls, or shruhs in warm climates, the larger leaves often accompanied hy a smaller lateral (rameal) one; the perluncles also mostly lateral and extra-axillary. $-\Lambda$ vast genus, chiefly in warmer regions, including the Potsto (S. TrmEnostu) and the

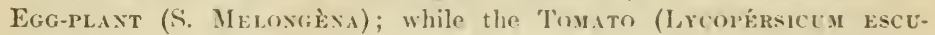
LÉxtcu) is elosely related. (Name of unknown derivation.)

* Not prickly; anthers blunt; flowers and globose naked berries sm:ll.

$$
\text { - Perennial, climbing or tuining. }
$$

S. Dilcamara, I. (Butrenswert.) More or less pubescent; leaves ovate-heart-shaped, the upper halberd-shaped, or with two ear-like lobes or leaflets at hase; flowers (purple or blue) in small (ymes; herries oval, red. Moist banks and around dwellings. June-Sept. (Nat. from Eu.) 


\section{+ + Simple-leaved annuals.}

1. S. triflorum, Nutt. Low, spreading, slightly hairy or nearly glabrous; leaves oblong, pinnatifid $(7-9$-lobed) with romded sinuses; peduncles $1-3$ flowered; corolla white; berries green, as large as a small cherry. - Central lian., and westward; chiefly a weed near dwellings.

2. S. nigrum, L. (Connox Nigitshade.) Low, much branched and often spreading, nearly glabrous, rough on the angles; leares ovate, uavytoothed; flowers white, in small umbel-like lateral chusters, drooping; calyx spreading; filaments hairy; berries globular, black. - Shaded grounds and fields; common, appearing as if introduced, but a cosmopolite. July-Sept.

Var. viluossu, Mill. Low, somewhat viscil-pubescent or villous; leaves small, conspicuously angular-dentate; filaments glabrous; berries yellow. Established near l'hiladelphia, from ballast. (Adr. from Eu.)

S. Grácile, Link. Cinereous-pubescent or puberulent, rather tall $\left(2-3^{\circ}\right.$ high), with virgate spreading branches; leaves or ate and orute-lanreolute, nearl!y entire; corolla white or bluish ; crly.x somenhat uppressed to the blark berry Coast of N. C., and about lallast near Philadelphia. (Adr. from S. Am.)

* Hore or less prichiy; unthers tapering upuard; pubescence stcllate

+ Perennial; fruit naked; anthers equal; corolla volet, rareiy white.

3. S. Carolinénse, L. (Honse-Nettle.) Hirsute or roughish-pubescent with 4-8-rayed huirs: prickles stout, yellowish, copious (rarely scanty); leaves oblong or orate, obtusely sinuate-toothed or lobed or sinuate-pinnatifid, ra. cemes simple, soon lateral; culyx-lobes acuminate: berries about 6" broad. Sandy soil and waste grounds, Conn. to Iowa, south to Fla. and Tex.

4. S. elæagnifòlium, Cav. Silvery-ranescent with dense scurf-like pu hescence of many-rayed hairs; prickles small, slender, more or less copious or wanting; leaves lanccolate to oblong and linear, sintiate-repand or entire, calyx-lobes slender; berry seldom $6^{\prime \prime}$ in dumeter. - Prairies and plains, E Kan. to Tex., and westward.

5. S. Torrèyi, Gray. Cinereous with a someuhat clnse pubesrence of about equally 9-12-rayed hairs: mickles small and stout, scanty or nearly wanting; leares orate with truncate or slightly cordate base, sinuately $5-7$-lobed $\left(4-6^{\prime}\right.$ long) culyx-lobes short-orate, abruptly long.acuminute: berry 1 ' in diumeter. Prairies, etc., E. Kan. and Tex.

+ + Annual: fruit closely covered: lowest anther mach the iongest, corolla yellow.

6. S. rostràtum, Dunal. Tery prickly, somewhat hoary or yellowish with a copious wholly stellate pubescence $\left(1-2^{\circ}\right.$ high $)$ : leaves $1-2$-pinnatifid: (alyx densely prickly; stamens and style much declined. - Plains of Neb. to Tex.; spreading eastward to 111 and Tenn

\section{CHA M}

Calyx herbaceous, closely investing the globose berry (or most of it), obscurely if at all veiny. Corolla rotate, 5-angulate, plicate in the bud. Filaments filiform; anthers separate, oblong. - Perennials, with mostly narrow entire or pinnatifid leaves tapering into margined petioles, and filiform naked pedicels solitary in the axils, refracted or recurved in fruit. (Saracha is a tropical American genus dedicated to Isidore Saruchu, a Spanish Benedictine; the prefix $\chi a \mu a i$, on the ground.) 
1. C. sórdida, Gray. Much branched from root or hase, somewhat ciuereous with short viscil pubescence; leaves obovate-spatulate or cuneate-ohlong to oblanceulate, repand to inciscly pinnatifil ; caly $x$ when young villous-viscidl; corolla pale yellow or violet-jurple ( $6^{\prime \prime}$ broal) ; herry as lirge as a pea. - 1)ry or elayey snil, central and W. Kan. to Tex. and Arizona.

\section{PHÝSALIS, L. Grotin, Cивит.}

Calyx 5-cleft, reticulated and cularging after flowering, at length much inflated and enclosing the a-celled globular (edible) berry. (corolla between wheel-shaped and funnel-form, the very short tube markerl with 5 concare spots at the base; the plaited horder somewhat 5-lohed or barely 5-10-tootherl. Stamens 5, erect ; anthers separate, opening lengthwise. - Herbs (in this country.), with the leaves often unequally in pairs, and the l-flowered nodding pe-

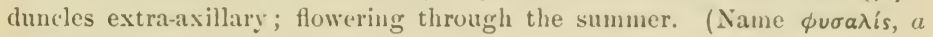
bludder, from the iuflated ealyx.)

* Corolla large, white or tinged with blue, without durk centre, with almost cutire border; pubescence simple.

1. P. grandiflora, Hook. Clammy-pubescent, erect; leaves lance-nvate, pointed, entire or nearly so; corolla $1-2^{\prime}$ wide when expanded, and with a woolly ring in the throat; fruiting calyx glolular, apparently nearly filled by the berry. - S. shore of I. Superior to Sask.; Proviclence Island, L. Champlain (Perkins).

* Corolla lurid greenish-white or yellow, mostly with dark centre, 3-10" broad.

- Annuals, glabrous or pulescence minute; anthers violet.

2. P. Philadélphica, Lam. Leaves ovate or ubloug-ovate, oblique at base, entire, repand, or very sparingly angulate-tootled ; corollu brounish- or. riolet-spotted in the centre, 7-10" broud; calyx at maturity globose and completely filled by the large rectlish or purple berry and open at the muuth. In fertile soil, Penn. to Minn. and Tex.

3. P. angulàta, L. Much branched; leaves ovate or ovate-oblong, sharply and irregularly luciniate-toothed; peduncles filiform; corolla unspotted, very small $\left(3-6^{\prime \prime}\right.$ broad when expanded); fruiting calyx conical-ovate with a truneate or sunkeu hase, 10-angled, loosely inflated, at length well filled by the greenish-yellow berry. - Open rich grounds, l'enn. to Minn., and southwaril.

+ + Strong-scented, villous or pubescent with viscid or glandular simple hairs; fruiting ralyx ovate-pyramidal, curinutely 5-angled, closed, loosely enrelopiny the green or yellow berry; leates orute or corlate.

4. P. pubéscens, L. Inmual, diffusely much branched or at length decumbent; leaves angulate- or repand-tonthed or nearly entire; corollu spotterl with brown purple in the centre, 5-6" broul when expanded, olscurely 5-10toothed; anthers violet. - Low gromels, N. Y. to Mimn., sonth to Fla. and Tex., and westward. - A very doultful form, found at Independence, Mo. (B. F. Bush), has the small (corolla (2" broal) yellow, without a brown centre, the anthers yellow, the fruiting caly $\mathrm{x}$ smaller, and the berry viscid.

5. P. Virginiàna, Mill. Perenniel, diffusely much branched and widely sprealing, or at first erect; leaves sometimes oblong, repand or ubtusely tonthed, rarely entire; corollu 9-12" broud, 5-angled or 5-10-twothed; unthers yellou. 
(P. viscosa, Gray, Man., not L.) - Light or sandy soils, Ont. and Minn. to Fla. and Tex. - Var. AMBfGUA, Gray, is a coarse and very villous form with violet anthers. Wisc., and westward.

+ ++ Perennials, mostly low, not viscid; pubescence stellate or simple or nearly none; anthers almost always yellow.

6. P. viscòsa, L. Cinereous or when young almost canescent with short stellate or 2-3-forked pubescence; stems ascending or spreading from slender creeping subterranean shoots; leares ovate or oval, varying to oblong and obovate, entire or undulate; corolla greenish-yellow, with a more or less dark eye; fruiting calyx globose-ovate; lerry yellow or orange. - In sands on and near the coast, Va. to N. C. and Fla.

7. P. lanceolàta, Michx. More or less hirsute-pubescent with short stiff mostly simple hairs, varying to nearly glabrous; stems from rather stout subterranean shoots, angled, somewhat rigid; leaves oblong-ovate to narrowly lanceolate, sparingly angulate-toothed to undulate or entire; corolla ochrolencous, with a more or less dark eye; calyx commonly hirsute, in fruit pyramidal-ovate (1-1 $\frac{1}{2}$ long); berry reddish. (P. Pennsylvanica, Gray, MIan., in part; not $L$.) - Dry open ground, Penn. to Ill., Minn., and south and westward.

Var. lævigàta, Gray. Glabrous or almost so throughout, or with some rery short hairs on young parts. - Neb. to 'Tex., and westward.

Var. hírta, Gray. A remarkable ambiguous form, with much of the hirsute-pubescence of the leaves 2-3-forked, as also are some of the abundant villous-hispid hairs of the stem. - Wet woods, Tex. to Mo., and E. Kan.

\section{N I C ÁndRA, Adans. Apple of Peru.}

Calyx 5-parted, 5-angled, the divisions rather arrow-shaped, enlarged and bladder-like in fruit, enclosing the 3-5-celled globular iry berry. Corolla with border nearly entire. Otherwise much like Physalis. - An annual smooth herb $\left(2-3^{\circ}\right.$ high), with orate sinuate-toothed or angled leaves, and solitary pale blue flowers on axillary and terminal peduncles. (Named after the poet Nicander of Colophon.)

N. PHrsaloìnes, Gaertn. - Waste grounds, near dwellings and old gardens. (Adr. from I'eru.)

\section{LÝ CIU M, L. Matrimony-Vine.}

Calyx 3-5-toothed or -cleft, not enlarging, persistent at the base of the berry. Corolla funnel-form or salver-shaped, 5-lobed, the lobes imbricated and not plaited in the bud. Stamens 5; anthers opening lengthwise. Style slender; stigma capitate. Berry small, 2-celled. Shrubby, often spiny plants, with alternate and entire small leaves, and mostly axillary small flowers. (Named from the country, Lycia.)

L. vilgàre, Dunal. (Commox M.) Shrub with long sarmentose recurveddrooping branches, smooth, sparingly if at all spiny ; leares oblong- or spatulate-lanceolate, often fascicled, narrower into a short petiole; flowers on slender peduncles fascicled in the axils; corolla short funnel-form, greenish-purple; style and slender filaments equalling its lobes; berry oval, orange-red. - About dwellings, and escaped into waste grounds in Penn., etc. (Adv. from Eu.)

\section{HY O SCỲ A M U S, Tourn. Henbane.}

Calyx bell-shaped or urn-shaped, 5-lubed. Corolla funnel-form, oblique, with. a 5 -lobed more or less unequal plaited border. Stamens declined. Capsule 
enclosed in the persistent ealyx, 2-celled, opening transsersoly all round near the apex, which falls off like a lid. - ('lammy-pubsscent, fretil, narcotic herbs, with lurid flowers in the axils of angled or tiotherl leates. (Aame composed

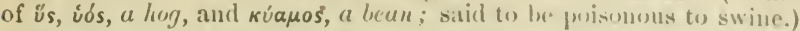

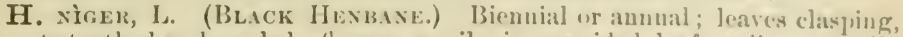
sinuate-toothed and angled ; flowers sessile, in one-sided leafy spikes ; corullia dull yellowish, strongly reticulated with purple veius. - Escaped from gardens to roadsides. (Adv. from liu.)

\section{D A T U R A, I. JAMestow-Wend. THORN-Arile.}

Calyx prismatic, 5-toothed, separating transversely above the base in fruit, the upper part falling away. Corolla fumbl-form, with a large and spreadiug 5-10-tuothed plaited border. Stigma 2-lipped. Capsule globular, prickly, 4-valved, 2-celled, with 2 thick placenta projected from the axis into the middle of the cells, and commected with the walls by an imperfect false partition, so that the capsule is t-relled except near the top, the placentas as if on the mudle of these false partitions. Seeds rather large, flat. - lauk weeds, narcoticpoisonous, witl ovate leaves, and large showy flowers on short perlancles in the forks of the branching stem ; produced all summer and autumn. ( $\Lambda$ ltered from the Arabic name, Tutoruh.)

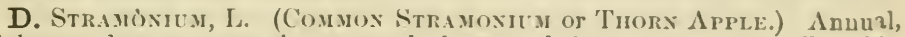
glabrous; leaves ovate, sinuate-toothed or angled; stem grcen; corolla white (3'long), the border with 5 teeth; lower prickles of the capsule mostly shorter. - Waste grounds; a well-known ill-scented weed. ( $\mathrm{d}$ dv. from $\Lambda$ sia?)

D. Tátila, L. (Purrie T.) Mostly taller; stem purple: corolla pale violet-purple; prickles of the capsule nearly equal. - Waste grounds, in the Atlantic States. (Adv. from trop. Amer.)

\section{NICOTIÀNA, Tourn. Toвacco.}

Calyx tubular-bell-shaped, 5-cleft. Corolla funnel-form or salyer-form, usually with a long tube; the plaited border 5-lobed. Stigma capitate. Capsule 2-celled, 2-4-valved from the apex. Seeds minute. - liank acril-narcutic herbs, mostly clammi-pubescent, with ample entire leaves, and racemed or panicled flowers. (Named after John Nicot, who was thought to have introduced Tobaceo (N. 'TAв.́ctu, L.) into Europe.)

N. rústici, I. (Wild Tobacco.) Annual; leaves ovate, petiolel; tube of the dull greenish-yellow corolla eylindrical, two thirds longer than the calyx. the lobes rounded. - Old fields, from $\mathrm{N}$. Y. Westward and suuthward; a relic of cultivation by the Indians. (Of unkmown nativity.)

\section{Order 75. SCROPHULARiACEAE. (Figwort Famhy.)}

Chiefly herls (rarely trees), with dillynamons stamens (or perfect stamens often only 2, rarely 5) inserted on the tube of the 2-lipped or more or less irregular corolla, the lobes of which are imbricated in the bud: finit a :celled and usually many-seeded capsule, with the placente in the axis : seeds anatropous, or amphitropous, with a small emlryo in copious allumen. - Sityle single; stigma entire or 2-lobed. Leaves and inflorescence various; but the flowers not terminal in any genume representatives of the order. A large order of bitterish plants, some of them narcotic-poisonous.

I. ANTIRRHINIDEA. Clper lip or lubes of the eorollat (overing the lower in the bud (with oceasional exceptions in Mimulus, etc.) Capsule usually septicidal. 
Tribe I. VERBASCEAE. Corolla rotate. Flowers racemose. Leaves alternate.

1. Verbascum. Stamens 5 , all with anthers, and 3 or all with bearded tilaments.

Tribe II. ANTIRRHINEAE. Corolla tubular, with a spur or sac at the base below, the throat usually with a palate. Capsule opening by chinks or holes. Flowers in sinple racemes or axillary. Lower leaves usually opposite or whorled. Stamens 4.

2. Linaria. Corolla spurred at base; the palate seldom closing the throat.

3. Antirrhinum. Corolla merely saccate at base; the palate closing the throat.

Tribe III. CHELONEZE. Corolla tubular, or 2-lipped, not spurred nor saccate below. Capsule 2-4-valved. Leaves opposite Iuflorescence usually compound, of small axillary spiked or racemed or umbel-like clnsters or cymes, or whien reduced to a single flower the peduncle mostly 2-bracteate. Stamens 4 , and usually a rudimeut of the fifth.

4 Scrophularia. Corolla inflated, globular or oblong, with four erect lobes and one spreading one Ruliment of the sterile stanen a scale on the upper lip.

5 Collinsia. Corolla 2-cleft, the short tube saccate on the upper side; the middle love of the lower lip sac-like and enclosing the declined stimens.

6. Chelone. Corolla tubular inflated above. Sterile stamen shorter than the others. Anthers very woolly. Seeds winged.

7 Pentstemon. Corolla tubular. Sterile stamen about as long as the rest. Seeds wingless.

Tribe IV. GIATIOLEA. Corolla tubular, not saceate nor spurred. Capsule 2valved. Flowers solitary in the axils of bracts or leaves : peduncles naked (or 2-bracteolate in n. 12). Leaves all or the lower ones oplosite. No trace of a fifth stamen.

* Stamens 4, all anther-bearing and similar.

8. Mimulus. Calyx prismatic, 5-angled, 5-toothed. Corolla elongated.

9. Conobea. Calyx 5-parted, the divisions equal. Corolla short.

10. Herpestis. Calyx 5-parted, unequal, the upper division largest. Corolla short.

11 Limosella. Calyx 5 -toothed. Corolla open bell-shajed, 5 -cleft, nearly regular. Leaves alternate or fascicled, fleshy. Dwarf aquatic or marsh plant.

* Anther-bearing stamens 2 ; usually also a pair of sterile filauents.

12. Gratiola. Calyx 5-prarted. Stamens included : the sterile pair short or none.

13 Ilysantles Calyx 5-parter. Stamens included the sterile filaments protruded.

14. Micranthemum. Flowers miuute. Calyx 4-toothed or cleft. Upper lip of corolla short or none. Filaments with an alpeudage; sterile pair none. Dwarf aquatic.

II. RHINANTHIDEE. Under lıp or the lateral lobes of the corolla covering the upper in the bud. Capsule commonly loculicidal.

Tribe V. DIGITALFAE. Corolla wheel-shaped, salver-shaped, or bell-shaped. Stamens 2 or 4 , not approaching in pairs nor strongly didynamous; anthers 2 celled.

15. Syuthyris. Calyx 4-parted. Corolla bell-shaped, 2-4-lolsed, irregular Stanens 2 or 4. Leaves alteruate Flowers racemed.

16. Veronica Calyx 4-(rarely 3-5-) parted. Corolla wheel-shaped or salver-shaped, almost regnlar Stamens 2. Leaves chiefly oplosite or whorled. Flowers racemed.

Tribe VI. GEIARDIEA. Corolla with a spreading and slightly unequal 5-lobed limb Stanens 4, approximate in pairs. Leaves orposite, or the uppermost alternate.

* Corolla salver-shaped. Anthers 1-celled. Flowers in a spike.

17. Buclnera. Calyx tubular, 5-toothed. Limb of the elongated corolla 5-cleft.

* Corolla bell-shaped to funnel-form; antlıers 2-celled.

18. Seymeria. Stamens nearly equal. Tube of the corolla broad, not longer than the lobes.

19. Gerardia. Stamens strongly unequal, included.

Tribe VII. EUPHRASIEA. Corolla tubular, obvionsly 2-lipped; the upper lip narrow, erect or arched, euclosing the 4 usually strongly didynamous stamens.

* Anther-cells unequal and separated Capsule many-seeded.

20. Castilleia. Calyx tubular, cleft down the lower, and often also on the ulper, side. Upper lip of eorolla elongated; the lower short, often very small. 
21. Orthocarpus. Calyx tubular-campanulate, 4-c'left. Ujier lip of corolla little lunger and usually inuch narrower than the inflated lower one.

* Anther-cells equal. Capsule many-several-secded.

22. Schwalbea. Calyx 5-toothed, very oblique, the upper touth mun the smallest.

23. Euphrasia. Calyx 4-cleft. Cpper lip of the corolla 2-lobed, and sides folded baek. Crapsule oblong.

24. Bartsia. Cilyx 4-cleft. Upper lip of corolla entire and silles not folded back.

25. Rhinanthus. Calyx intlated, ovate Capsule orticular : seeds winged.

26. Pedicularis. Calyx not inflated. Capsule ovate or sword-shaped: seeds wingless. * * Anther-cells equal. Capsule 1-4-seeded.

27. Melampyrum. Calyx 4-cleft. Ovary 2-cellerl, 4-ovuled. Cajsule flat, olndique.

\section{VERBás C U M, L. Mluleix.}

Calyx 5-parted. Corolla 5-lobed, open or concave, wheel-shaped; the lobes broad and romnded, a little uneynal Stamens 5, all the filanents, or the 3 upper, woolly. Style flattenerl at the apex. Capsule globular, many-seeded. - Tall and usualli woully biennial herbs, with alternate leaves, those of the stem sessile or decurrent. Flower's in large terminal spikes or racemes, ephemeral; in summer. (The ancient Latin name, altered from Barbascum.)

V. Tuápses, L. (Commox Muldeix) Densery woolly throughout; stem tall and stout, simple, winged by the decurrent bases of the olilong acute leaves: flowers (vellow, very rarely white) in a prolonged and very dense cylindricul spike; lower stamens usually bearlless. - Fiells, a common weed. (Nat. from Eu.)

V. BlatтAria, L. (Mоти M.) (ireen und smoothish, slender; lower leaves petioled, oblong, doubly serrate, sumetimes lyre-shaped, the upper partly clasping; raceme loose; filaments all bearled with violet wool. - Roarlsides, throughout our range. Corolla either yellow, or white with a tinge of purple. (Nat. from Eu.)

V. Lxcuxitss, L. (Wuite M.) Clothed with thin poudery uoolluness; stem and branches angled abore; leaves ovate, acute, not decurrent, greenish above; flowers (vellow, rarely white) in a pyramilal panicle; filaments with whitish wool. - Fields, د. Atlantic States, rather rare. (Adr. from Eu.)

\section{LIN À RIA, Tourn. ToAD-Flax.}

Calyx 5-parted. Corolla persouate, with the prominent palate often nearly closing the throat, spurrel at base on the lower side. Stamens 4. Capsule thin, opening helow the summit by one or two pores or clinks. Seeds many. - Herbs, with at least all the upper leaves alternate (in ours), fl. in summer. (Name from Linum, the Flax, which the leaves of some species resemble.)

* Slender glabrons annual or liennal: leares lincar, entire and altermate (or smaller, whlong, and opposite on procumbent shoots), small hlue flowers in a naked leminal iareme.

1. L. Canadénsis, Dumont. Flowering stems nearly simple $\left(6-30^{\prime}\right.$ high); leaves flat (1-2" wile); pedicels erect, not lunger than the filiform curved spur of the corolla. - Sandy suil, coummon.

* * Peremial, ereut $\left(1-3^{\circ}\right.$ high). glalirous, with nurron entire and alternate pale leaves, and yollou' flourers in a terminal ruceme.

L. velgaris, Mill. (Ramsten, IButter asn Eigs.) Leaves linear or nearly so, extremely numerous, raceme dense; corollat l' long or more, in. cluding the slender subulate spur; seeds winged. - Fields and roadsides, throughout our range. (Nat. from Eu.) 
L. Gexistifòlis, Mill. Glaucous, paniculately branclued; leaves lanceolate, acute; flowers smaller and more scattered ; seeds wingless. - Sparingly naturalized near New York. (Nat. from Eu.)

* * Annual, procumbent, much branched, with broad petioled reiny alternate ieaves, and small purplish and yellow flowers from their axils.

工. Eldtive, Mill. Spreading over the gromul, slender, hairy ; leaves hastate or the lower ovate, much surpassed by the filiform peduncles; calyx-lobes lanceolate, acute; corolla $3-4$ " long, including the subulate spur. - Sandy banks and shores, Canada to N. C., rather rare. (Nat. from Eu.)

L. SPÚriA, Mill. Like the precerling, but with romdish or cordate leaves and ovate or cordate calyx-lobes. - Occasionally occurs on ballast or waste grounds near cities. (Nat. from Eu.)

\section{A NTIRRHì N U M, Tourn. Sxapdragox.}

Corolla saccate at the base, the throat closed by the large bearded palate. Seeds oblong-truncate. Otherwise nearly as Linaria. - Corolla commonly showy, resembling the face of an animal or a mask; whence the name (from

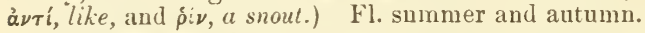

A. Orósticm, L. A small-flowered annual or biennial, low, erect; leaves lance-linear; spike loose, leafy : sepals longer than the purplish or white corolla. - Abont gardens and old fields in Atlantic states. (Adv. from Eu.)

A. MAJts, L. (LARGE SxAPIRAGox.) A large-flowererl perennial, with oblong smooth leaves and a glandular-downy raceme ; sepals short ; corolla $1 \frac{1}{2}-$ $2^{\prime}$ long, purple or white. - Eastward, escaping from gardens. (Adv. from Eu.)

\section{S C RO PHULÀRIA, Tourn. Figwort.}

Calyx deeply 5-cleft. Corolla with a somewhat globular tube; the 4 upper lobes of the short border erect (the two upper longer), the lower spreading. Stamens 4, declined, with the anther-cells transverse and confluent into one; the fifth stamen a scale-like rudiment at the summit of the tube of the corolla. Capsule many-seeded. - Rank herbs, with mostly opposite leaves, and small greenish-purple or lurid flowers in loose cymes, forming a terminal narrow panicle. (So called because a reputed remedy for scrofula.)

1. S. nodòsa, L., var. Marilándica, Gray. Smooth perennial $\left(3-5^{\circ}\right.$ high); stem 4-sided; leaves ovate, oblong, or the upper lanceolate, acuminate, cut-serrate, rounded or rarely heart-shaped at base. - Damp grounds, N. Fng. to Fla., west to the Rocky Mts. (Eu., Asia, the type.)

\section{COLLÍNSIA, Nutt.}

Calyx deeply 5-cleft. Corolla declined, with the tube saccate or bulging at the base on the upper side, deeply 2-lipped; the upper lip 2-cleft, its lobes partly turned backward, the lower 3-cleft, its midrle lobe keeled and sac-like, enclosing the 4 declined stamens and style. Fifth stamen a gland-like rudi. ment. Capsule 4-many-seeded - Slender branching annuals or biennials, with opposite leaves, and handsome party-colored flowers in umbel-like clusters, appearing whorled in the axils of the upper leares. (Dedicated to the late Zacchens Collıns, of Philadelphia, an accurate botanist.)

1. C. vérna, Nutt. Slender $\left(6-20^{\prime}\right.$ high $)$, lower leaves ovate, the upper ovate-lanceolate, clasping by the heart-shaped base, tootlied; uhorls alout 6 flowered: flowers long-peduncled; corolla (blue and white) twice the length of the calyx. - Moist soil. western N. Y. to W. Va., Wisc. and Ky. May, June. 
2. C. parviflora, Dougl. Small; lower leaves ovate or rounded, the upper obloug-lanceolate, mostly entire; whorls 2-6-flowered; flou:ers shortpeduncled; the small (blue) corolla scarcely excecding the calyx. - Shore of L. Superior, N. Mich., and westward.

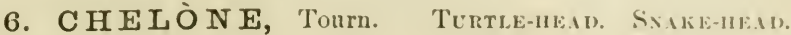

Calyx of 5 distinct imbrieated sepals. Corolla inflated-tubular, with the mouth a little open; upper lip broad and arched, keeled in the midllle, notched at the apex; the lower woolly-bearded in the throat, 3-lobed at the apex, the middle lobe smallest. Stamens 4, with woolly filaments and very woolly heart-shaped authers, and a fifth sterile filament smaller than the others. Seeds many, wing-margined. - Smooth perenuials, with upright branching stems, opposite serrate leaves, and large white or purple flowers, which are neqy $y$ sessile in spikes or clusters, and closely imbricated with round-orate concave bracts and bractlets. (Name from $\chi \in \lambda \omega \nu \eta, a$ tortoise, the corulla resembling in shape the heal of a reptile.)

1. C. glàbra, L. A foot or two (or even 6-70) ligh ; lences narrouly to rather broudly lunceo'ute (4-5' long, 4-12" wide), graulually acuminate, serrate with sharp appressed teeth, narrowed at base usually into a very short petiole; bracts not ciliate; corollu white, or burely tinged with rose. - Wet places, Newf. to Minn., south to Fla and Tex.

2. C. obliqua, L. Less strict or with spreading branches, $1-2^{\circ}$ high; leaves broadly lanceolute to oblong ( $2-5^{\prime}$ long), sometimes liciniately serrate, more veiny and duller, acute or obtuse at base, mostly short-petioled; bracts ciliolate; corolla deep and bright rose-color. - S. Ill. to Va. and Fla.

\section{PENTSTEMON, Mitchell. Beard-tongue.}

Calyx 5-parted. Corolla tubular and more or less inflated, or bell-shaperl, either decidedly or slightly 2-lipped; the upper lip 2-lobed, and the lower 3-cleft. Stamens 4, declimed at the base, ascending above, and a fifth sterile filament usually as long as the others, either naked or bearded. Seeds uumeruus, wingless. - Perennials, branched from the base, simple above, with opposite leares, the upper sessile and mostly clasping. Flowers mostly showy, thyrsoid or racemose-panicled. (Name from $\pi \dot{\epsilon} \nu \tau \epsilon$, five, and $\sigma \tau \eta \dot{\eta} \omega \nu$, stamen; the fifth stamen being present and couspicuous, although sterile.)

* Viscad or glandulur above, more or less pubescent or glubruus beluu; leaves often toothed or denticulate.

- Thyrse somewhat open; leaves ovate-lanceolate to lineur ; corolla 9-12" long, the louer lip usually bearded within.

1. P. pubéscens, Solander. Stem 1-20 high, viscid-puliescent (at least the inflorescence); leares oblong to lunceolute (2-4' long), the lowest and radical ovate or oblong, usually denticulate; thyrse nurrou; corollu dull violet or purple (or partly whitish), very moderutely diluted, the throut neurly clused by a villous-bearded palate; sterile filument densely bearded.-Dry or rocky grounds, S. Maine (Miss Furbish) to Minn., sonth to Fla. and Tex.

2. P. lævigàtus, Solander. stem $2-4^{\circ}$ high, mostly glabrous except the infloresceuce; leaves firmer, somewhat gloysy, the culine vicute- or ublong. 
lanceolate with subcordate clasping base $\left(2-5^{\prime}\right.$ long); thyrse broader; corolla white (commonly tinged with purple), abruptly and broadly inflated, the throat widely open; sterile filament thinly bearded above. - Moist or rich soil, Penn. to Fla. and westward, where the common form is

Var. Digitàlis, Gray. Stem sometimes $5^{\circ}$ high ; corolla larger and more abruptly inflated, white. (P. Digitalis, Nutt.) - Penn. to Iowa, Mo., Ark., etc.

3. P. grácilis, Nutt. Glabrous or puberulent, viscid-pubescent above, $1^{\circ}$ high or less; stem-leaves mostly linear-lanceolate, the radical spatulate or oblong; corolla tubular-funnel-form or nearly cylindrical with open throat, lilac-purple or whitish. - Minn. to Mo., and westward.

\section{- + Thyrse raceme-like. All extreme western.}

4. P. Cobrea, Nutt. Sift-puberulent, $1^{\circ}$ high; leares ovute or oblong, or the lower broadly lanceolate and the upper cordate-clasping, nostly sharply tuothed; thyrse short; corolla 2' long, broadly ventricose, dull purple or whitish. - Prairies, Kan. to Tex.

5. P. tubiflorus, Nutt. Wholly glabrous excepting the viscid ovate sepals, $2-3^{\circ}$ ligh ; leaves oblong or ovate-lanceolate, entire or sparsely toothed, the floral shorter than the remote dense clusters of the virgate thyrse; corolla 9 "long, the narrow tube gradually dilated upuard, white or whitish. Low prairies, Kan. and Ark.

6. P. álbidus, Nutt. Viscid-pubescent, 6-10' high; leaves oblong-lanceolate or narrow, entire or sparsely toothed; clusters of the strict thyrse fewflowered, approximate; sepals lanceolate, densely pubescent; corolla 9" long, with shorter tube and more dilated throat. - Plains, Neb. to Dak. and Tex.

* Glabrous throughout and glaucous : leares sessile, entive; thyrse raceme-like.

7. P. grandiflòrus, Nutt. Stem $2-4^{\circ}$ high ; leaves thickish, the upper and floral rounded, all but the obovate radical ones clasping or perfoliate; pedicels short; corolla 2 ' long, oblong-campanulate, nearly regular, lilac or lavenderblue; sterile filament hooked and mintely bearded at the apex. - Prairies, from Ill. and Wisc. to Dak., Neb., and Kan.

8. F. glàber, Pursh. Stems $1-2^{\circ}$ high; leaves mostly oblong-lanceolate or the upper ovate-lanceolate; thyrse elongated, the peduncles and pedicels very short; corolla $1-1 \frac{1^{\prime}}{2}$ long, bright blue to violet-purple, dilated above; anthers and apex of sterile filament glabrous or sparsely hirsute. - Plains of E. Neb. to Dak., and westward.

9. P. acuminàtus, Dougl. Stem $6-20^{\prime}$ high, stout; leares thick, the lower obovate or oblong, the upper lanceolate to broadly ovate or cordate-clasping, acute or acuminate; thyrse leafy below, very narrow; corolla 9 " long, lilac or violet; sterile filament mostly bearded above. - Kan. to Minn., and westward.

\section{MÍ M U L U S, L. MoNkeY-Flower.}

Calyx prismatic, 5-angled, 5-toothed, the upper tooth largest. Corolla tubular; upper lip erect or reflexed-spreading, 2-lobed; the lower spreading, 3 lobed. Stamens 4. Stigma 2-lobed, the lobes ovate. Seeds numerous. Herbs, with opposite leaves, and mostly handsome flowers on solitary axillary and bractless peduncles. (Diminutive of mimus, a buffoon, from the grinning corolla.) 
* Erect from a perennial root, glabrous; leaves feathrr-leined; corolla violetpurple.

1. M. ríngens, I. Stem square $\left(1-2^{\circ}\right.$ high $)$; leares ablony or lanceolute, pointed, clasping by a heart-shaped base, serrate; peduneles longer than the flower; calyx-tecth taper-pointed, nearly equal; corolla personate. - Wet places, N. Eng. to Minu., and southward; common. July-Sept. - Flower $1-1 \frac{1^{\prime}}{2}$ long, rarely white.

2. M. alàtus, Ait. Stem somewhat wingerl at the angles; leaves ollongovate, tapering into a petiole; peduncles shorter than the caly: which has very short abruptly pointed teeth; otherwise like the last. - Wet places, western N. Eng. to Ill., sonth to N. C. and Tex.

* Leaves several-nrred and veiny, dentate, the upper sessile and clasping; caly.x oblique, the upper tooth longest; corolla yellou, the lower lip bearded.

3. M. Jamèsii, Torr. Diffusely spreading, smooth or smoothish; stems creeping at base; stem-leaves roundish or kidney-shaped, nearly sessile, equalling the peduncles; calyx ovate, inflated in fruit; throat of corolla broad and open. - In water or wet places, usually in springs, N. Mich. and Minn. to III., Kian., and westward.

M. LÙTEUs, L. Erect or with later branches spreading; leaves ovate to roundish or subcordate; corolla deep yellow, with brown-purple dots or blotches, often large. - Wet meadows, Norfolk, Ct. (Adv. from Calif.)

\section{CON ÒBEA, A ublet.}

Calyx 5-parted, equal. Upper lip of corolla 2-lobed, the lower 3-parted. Stamens 4, fertile; anthers approximate. Stigma 2-lobed, the lobes wedgeform. Seeds numerous. - Low hranching herhs, with opposite leares, and small solitary flowers ou axillary peduncles. (Name unexplained.)

1. C. multífida, Benth. Anuual, diffusely spreading, much hranched, minutely pubescent; leaves petioled, pinuately parted, divisions linear-wedgeshaped; peduncles naked; corolla (greenish-white) scarcely longer than the calyx. - Along streams and slwres, Ohio to 11l., Ark., and Tex.; also adr. below Philadelphia. July-Sept.

\section{H ER P È T I S, Gaertn. f.}

Calyx 5-parted; the upper division broadest, the innermost uften very narrow. Lpper lip of the corolla entire, notched or 2-cleft, and the lower 3-lobed, or the limb nearly equally 5-lobed. Stamens 4, all fertile. Style dilated or 2-lober at the apex. Seerls numerous. - Low herhs, with opposite leaves, and solitary axillary flowers; in summer; ours rather suculent perenuials. (Name from $\dot{\epsilon} \rho \pi \eta \sigma \tau \dot{n}$ s, a creeping thing, the species being chiefly procumbent.)

* Corolla plainly bilabiate, the 2 upper lohes united to form the upper lip; leaves many-neried.

1. H. nigréscens, Benth. Erect or ascending, very leafy, glabrous; leaves pinnately veined, oblong to cuneate-lanceulate $\left(1-2^{\prime}\right.$ long), serrate; pedicels equalling and the upper surpassing the leaves; corolla whitish or purplish. - Wet places, II aul N. C. to Tex., along and near the coast. 
2. H. rotundifolia, Pursh. Nearly smooth, creeping; leaves round. obovate, half-clasping ( $\frac{1}{2}-1^{\prime}$ long), entire, basally nerved; peduncles twice or thrice the length of the calyx ; upper sepal ovate; corolla white or pale blue. - Margins of ponds, Ill. to Minn., Mo., and southward.

3. H. amplexicaùlis, Pursh. Stems hairy, creeping at base; leaves ovate, clasping, entire, basally nerved; peduncles shorter than the caly $x$; upper sepal heart-shaped; corolla blue. - Margin of pine-barren ponds, N. J. and Md. to La. - Aromatic when bruised.

* * Corolla obscurely bilabiate, the limb subequally 5-lobed; stamens almost equal.

4. H. Monnièra, HBK. Glabrous, prostrate and creeping; leaves spatulate to obovate-cuneate, entire or somewhat toothed, nearly nerveless, sessile ; corolla pale blue. - River-banks and shores near the sea, Md. to Tex.

\section{LIMOSÉLLA, L. Mudwort.}

Calyx bell-shaped, 5-toothed. Corolla short, widely bell-shaped, 5-cleft, nearly regular. Stamens 4; authers confluently 1-celled. Style short, clubshaped. Capsule globular, many-seeded; the partition thin and vanishing. Small annuals, growing in mud, usually near the sea-shore, creeping by slender runners, without ascending stems; the entire fleshy leaves in dense clusters around the simple l-flowered naked peduncles. Flowers small, white or purplish. (Name from limus, mud, and sella, seat.)

1. L. aquática, L., var. tenuifòlia, Hoffm. Leaves (with no blade distinct from the petiole) awl-shaped or thread-form. - Brackish river-banks and shores, Lab. to N. J., and far north and west. (Eu., Asia, etc.)

\section{GRATİOLA, L. Hedge-Hrssop.}

Calyx 5-parted, the narrow divisions nearly equal. Upper lip of corolla entire or 2-cleft, the lower 3-cleft. Fertile stamens 2, inclucled, posterior; the auterior mere sterile filaments, or wanting. Style dilated or 2-lipped at the apex. Capsule 4-valved, many-seeded. - Low herbs, mostly perennials, some apparently annuals, with opposite sessile leaves, and axillary 1-flowererl peduncles, usually with 2 bractlets at the base of the calyx. Flowering all summer; all inhabiting wet or damp places. (Name from gratia, grace or favor, on account of supposed excellent medicinal properties.)

$\S 1$. Anthers with a broad connective, the cells transverse; stems mostly diffusely branched, or creepirg at base, soft viscid-pubescent or smooth; corollas 4-6" long; bractlets foliaceons, equalling the calyx.

* Sterile filaments minute or none; corolla whitish, with the tube yellowish.

1. G. Virginiàna, L. Stem clammy-puberulent above $\left(4-6^{\prime}\right.$ high); leaves lanceolate with narrow base, acute, entire or sparingly toothed; peduncles almost equalling the leaves $\left(\frac{1}{2}-1^{\prime}\right.$ long); pod ovoid (2" long). - Very common.

2. G. sphærocárpa, Ell. Smooth, rather stout $\left(5-10^{\prime}\right.$ high); leaves lance-orate or oblong to oval-obovate (1-2'long), toothed; peduncles scarcely longer than the calyx and the large (3") globular pod. - N. J. and Md. to Ill., south to Fla. and Tex. 


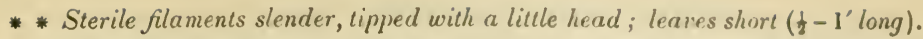

3. G. viszòsa, Schwein. C'lammy-pubescent or glandular; leaves ovatelanceolate or obiong, acute, tuothed, mostly shorter than the peduncles; corolla whitish, yellow within. - Ky. to N. C. and Gia.

4. G. aùrea, Muhl. Nearly glabrous; leaves lanceolate or ublong-linear,

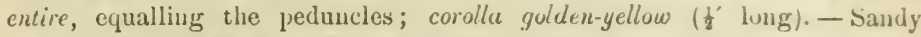
swamps, V't. and N. H. to Uhio, and suuth to Fla.

\$2. Anthers with no broad conncctive, the cells vertical; stcrile filaments tipped with a head; hairy apparently annual plunts, with erect rigid and moie simple stems.

5. G. pilosa, Michx. Leaves ovate or oblong, sparingly toothed, sessile ( $\frac{1}{2}$ ' long); flowers nearly sessile; corolla white, $3 \mathbf{- 4} \mathbf{4}^{\prime \prime}$ long, scarcely exceeding the calyx. - Low ground, N. J. to Fla. and Tex.

\section{ILYSÁNTHES, Raf.}

Calyx 5-parted, nearly equal. Lpper lip of corolla short, erect, 2-lobed; the lower larger and spreading, 3-cleft. Fertile stamens 2, included, posterior ; the anterior pair sterile, inserted in the throat, 2-lobed, without anthers; one of the lobes glandular, the other smooth, usually short and tooth-like. Stigma 2 lobed. Capsule ovate or oblong, many-seeded. - Small and smooth annuals, with opposite leaves, and small axillary (purplish) flowers, on filiform naked pedicels, or the upper racemed, produced all summer. (Name from i $\lambda$ ús, mnd, or mire, and áveos flower.)

1. I. ripària, Raf. (False Prapernel.) Much branched, diffusely spreading $\left(4-8^{\prime}\right.$ high $)$, or at first simple and erect, leaf $y$; leaves orate, rounded, or oblong, sparingly toothed or entire, the upper partly clasping; corolla $3^{\prime \prime}$ long. (I. gratioloides, Benth.) - Wet places; common.

\section{M I CRÁNTHEMUM, Michx.}

Calyx 4-lobed or 4- (rarely 5-) parted. Corolla short, 2-lipped, with the upper lip considerably shorter than the lower, or l-lipped, the upper lip obsolete; lower lip 3-cleft, the middle lobe longest. Stamens 2, anterior, the short filaments with a glandular (mostly basal) appendage; anthers 2-celled, didymous ; no sterile filaments. Style short; the stigma 2-lobed. Capsule glohular, thin, with a very delicate or evanescent partition, several-many-seeded. - Small, smooth, depressed and tufted or creeping annuals, in mud or shallow water, with opposite and entire rounded or spatulate sessile leaves, and minute white or purplish flowers solitary in the axils of some of the mildlle leaves (usually

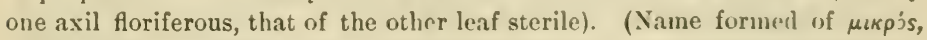
smull, and $\not \alpha \nu \theta \epsilon \mu \nu$, flower.)

1. M. Nuttàllii, Gray. Branches ascending, 1-2' high; leaves obovatespatulate or oval; peduncles at length recurved, abont the length of the calyx, which is bell-shaped, 4-toothed and usually split down on one side, in fruit becoming pear-shaped; middle lobe of the corolla linear-oblong, nearly twice the length of the lateral ones; appendage of the stamen nearly as long as the filament itself : stigunas subulate. - Tidal mud of rivers, N. J. to Fla. Aug.Oct. 


\section{SÝ NTHYRIS, Benth.}

Calyx 4-parted. Corolla somewhat bell-shaped, variously 2-4-lobed or cleft. Stamens 2, inserted just below the upper sinuses, occasionally with another pair from the other sinuses, exserted; anther-cells not confluent. Strle slender; stigma simple. Capsule flattened, rounded, obtuse or notched, 2-celled (rarely 3-lobed and 3-celled), many-seeded, loculicidal; the valves cohering below with the axis. - Perennial herbs, with the simple stems beset witl partly clasping bract-like alternate leaves, the root-leaves rounded and petioled, crenate. Flowers in a raceme or spike, bracteate. (Name from ov́v, together, and Ovpis, a little door; in allusion to the closed valves of the pod.)

1. S. Houghtoniàna, Benth. Hairy; root-leaves ovate, heart-shaped; spike dense (5-12' long); corolla (greenish-white or yellowish) not longer than the calyx, usually 2-3-parted. - Oak-barrens and prairies, Mich. to Minn., south to Ind., Ill., and lowa.

\section{VERÓNICA, L. SPEedwell.}

Calyx 4- (rarely 3-5-) parted. Corolla wheel-shaped or salver-shaped, the border 4-parted (rarely 5-parted) ; the lateral lobes or the lower one commonly narrower than the others. Stamens 2, one each side of the upper lobe of the corolla, exserted; anther-cells confluent at the apex. Style entire; stigma single. Caysule flattened, obtuse or notched at the apex, 2-celled, few - manyseeded. - Chiefly herbs; leaves mostly opposite or whorled ; flowers blue, fleshcolor, or white. (Derivation doubtful; perhaps the flower of St. Veronica.)

§1. LEPTÁNDRA. Tall perennals, with mostly whorled leaves; racemes terminal, dense, spiked; bracts very small; tube of the corolla longer than its limb and much longer than the caly $x$; both somctimes 5-cleft.

1. V. Virgínica, I. (Cruver's-root. Celver's Pirsic.) Smooth or rather dlowny; stem simple, straight $\left(2-6^{\circ}\right.$ high); leaves whorled in fours to sevens, short-petioled, lanceolate, pointed, finely serrate; spikes panicled; corolla small, nearly white; stamens much exserted; capsule oblung-ovate, not notcherl, opening by 4 teeth at the apex, many-seeded. - Rich wools, Vt. to Miun., F. Kan., and southward. July, Aug.

§ 2. VERONICA proper. Corolla uheel-shaped; capsule more or less notched, strongly flattened except in $\mathrm{n} .2$ and 3 ; low herbs.

* Perennials, stoloniferons or rooting at base, uith opposite usually serrate leaves ; racemes axillary, mostly opposite; corolla pale biue.

+ Capsule turgid, orbicular, many-seeded.

2. V. Anagállis, L. (WAter Speedwel...) Smooth, creeping and rcoting at base, then erect; leaves sessile, most of them clasping by a heart-shaped base, ovate-lanceolate, acute, serrate or entire (2-3' long); pedicels spreading; corolla pale blue with purple stripes; capsule slightly notched. - Brooks and ditches, N. Eng. to N. J., west to the Rocky Mts. June-Aug. (Eu., Asia.)

3. V. Americàna, Schweinitz. (Americax Brooklue.) Smooth, decumbent at hase, then erect $\left(8-15^{\prime}\right.$ high) ; leaves mostly petioled, ovate or oblong, serrate, thickish, truncate or slightly heart-shaped at base; the slender pedicels sprearling. - Brooks and ditches, common. June-Aug. 


\section{++ Capsule strongly fluttened, several-seeded.}

4. V. scutellàta, L. (Marsh Spke?wzl..) simooth, slender and weak (6-12' high); leures sessile, linear, arute, remotely denticulute; raremes several, very slender and zigzag; flowers jew and scuttered, on elongated spreading or reflexed pedicels; capsule very flat, much broaler than long, notched at both ends or dirlymons. - Bogs, common. June-Aug. (Lu., Asia.)

5. V. officinàlis, I. (Сомmox S'PEenwelt.) Pubesrent; stem prostrate, rooting at base; leaves short-petioled, obovate-ellipticul or urdye-oblony, obtuse, serrate; racemes densely many-flowerol; perlicels shorter than the calyx ; capsule obovate-triangular, broally notched. - 1)ry hills and open woods, $x$. Eng. to Mich., and southward. July. (Eu., Asia.)

V. CudM⿻上丨s, I. Stem pubescent, at least in two lines, ascending from a creeping base; leares sulssssile, outute or cordate, incisely crenute; racemes loosely-flovered; pedicels little longer than calyx; capsule triangular-obcordate. - Sparingly introduced into Canada, $\mathrm{N}$. Y., and I'enn. ( $\mathrm{Adv}$. from Eu.)

* * Leaves opposite; flowers in u terminul raceme; the louer bracts leaf-like; capsules flut, severul-seeded. Perennials (mostly turning blackish in drying).

6. V. alpina, L. Stem branched from the hase, erect, simple $\left(2-12^{\prime}\right.$ high); leaves elliptical, or the luwest rounded, entire or toothed, neurly sessile; raceme hairy, few-flouered, crowded ; capsule obovate, notched. - Alpine summits of the White Mts. (Eu., Asia.)

7. V. serpyllifólia, L. ('Tичue-LEAven ŚPEedwel..) Much branched at the creeping base, nearly smooth ; branches ascending and simple ( $2-4^{\prime}$ high $)$; leaves ovute or oblong, obscurely crenate, the lourest petioled and rounled, the upper passing into lanceolate lracts; raceme loose; corolla whitish, or pale blue, with deeper stripes; capsule rounded, broader than long, obtusely notched. - Roadsides and fields, common; introduced and indigenous. May-July (Eu., Asia.)

* * Annuals; floral leares like those of the stem (or someuhat reduced), the flowers appearing to be axillary and solitury, mostly alternate; corolla shorter than the culyx.

- Flouers short-pedicelled; floral leaves reduced; corolla shorter than the caly.x.

8. V. peregrina, L. (Neckweed. Purstase Spennell.) Glandular-puberulent or nearly smooth, erect $\left(4-9^{\prime}\right.$ high), hranched; lowest leaves petioled, ovul-oblong, toothed, thickish, the others sessile, ol,tuse; the upper oblong-linear and entire, longer than the almost sessile (whitish) Howers; cupsule orbicular, slightly notched, many-seeded. - Waste and cultivated grounds, in damp soil; throughout U. S., and almost cosmopolite. A pril-June.

V. ARvéxsis, L. (CORx SPEedwell.) Simple or diffusely lranched (3-8' high), hairy; lower leaves petioled, ovate, crenute; the upperinost sessile, lanceolate, entire; capisule inverscly herit-shaped, the lohes ronuded. - ('nltivated grounds, Atlantic States to Tex., rather rare. (Nat. from Fu.)

++ Flowers long-pedicelled in axils of ordinary leaves; seeds cup-shaped.

V. Agréstis, I. (FIEld Speedwell.) Leaves round or ovate, crenatetoothed, the floral somewhat similar; calyx-lobes oblong; flower small ; orury many-ovuled, but the nearly orlucular and sharply notched capsule 1-2-seculed. - Sanrly fields, N. Brunswick to La., near the coast. (Arlv. from Eu.)

V. Buxbutum, 'lenore. Lerues round or heart-ovate, (renately cut-toothed $\left(\frac{2}{3}-\mathrm{l}^{\prime}\right.$ long); flower large (nearly $\frac{1}{2}$ wide, blue) ; calyx-lobes lanceolate, widely 
spreading in fruit; capsule obcordate-triangular, broadly notched, 16-24-seeded. - Waste grounds, rare in Atlantic States. (Adv. from Eu.)

V. heinerefolia, L. (IVY-Leaved Spendwell.) Leaves rounded or heart-shaped, 3-7-toothed or lobed; calyx-lobes somewhat heart-shaped; flowers small; capsule turgid, 2-lobed, 2-4-seeded. - Shaded places, N. J., Penn., etc. April-June. (Adv. from Eu.)

\section{B Ú CH N E A a L. Blve-Hearts.}

Calyx tubular, obscurely nerverl, 5-toothed. Corolla salver-form, with a straight or curved tube and an almost equally 5-cleft limb, the lobes oblong or wedge-obovate, flat. Stamens 4, included, approximate in pairs; anthers one-celled (the other cell wanting). Style club-shaped and entire. Capsule 2-valved, many-seeded. - Peremial rough-hairy herbs (doubtless root-parasitic), turning blackish in drying, with opposite leaves, or the uppermost alternate; the flowers opposite in a terminal spike, bracted and with 2 bractlets. (Named in honor of $I$. G. Buchner, an early German botanist.)

1. B. Americàna, L. Rough-hairy; stem wand-like $\left(1-2^{\circ}\right.$ high $)$; lower leaves obovate-oblong, the others ovate-oblong to linear-lanceolate, sparingly and coarsely toothed, veiny; spike interrupted; calyx longer than the bracts, one third the length of the deep-purple corolla ( $1^{\prime}$ long). - Moist sandy grouud, westeru N. Y. to Minu., and southward. June-Aug.

\section{SEYMERIA, Pursh.}

Calyx bell-shaped, deeply 5-cleft. Corolla with a short and broad tube, not longer than the 5 ovate or oblong nearly equal and spreading lobes. Stamens 4, somewhat equal; anthers approximate by pairs, oblong, 2-celled; the cells equal and pointless. Capsule many-seeded. - Erect brauching herbs, with the general aspect and character of Gerardia ; leaves mostly opposite and dissected or pinnatifil, the uppermost alternate and bract-like. Flowers yellow, interruptedly racemed or spiked. (Named for Henry Seymer, an English naturalist.)

1. S. macrophýlla, Nutt. (Muluis-Foxglove.) Rather pubescent $\left(4-5^{\circ}\right.$ high $)$; leaves large, the lower pinnately divided, with the broadly lanceolate divisions pinnatifid and incised, the upper lanceolate; tube of the corolla incurved, very woolly inside, as are the filaments except at the apex; style short, dilated and notched at the point ; capsule orate, pointed. - Shady riverbanks, Ohio to Iowa, south to Tex. July.

\section{GERÁRDIA, L.}

Calyx bell-shaped, 5-toothed or 5-cleft. Corolla campanulate-funnel-form, or somewhat tubular, swelling above, with 5 more or less unequal spreading lobes, the 2 upper usually rather smaller and more united. Stamens 4 , strongly didynamons, included, hairy; anthers approaching by pairs, 2-celled, the cells parallel, often pointed at base. Style elongated, mostly enlarged and flattened at the apex. Capsule globular or ovate, pointed, many-seeded. - Erect branchmg herbs (more or less root-parasitic) ; stem-leaves opposite, or the upper alternate, the uppermost reduced to bracts and subtending 1 flowered peduncles, which often form a raceme or spike. Flowers showy, purple or yellow; in late summer aud autumn. (1)edicated to the celebrated herbalist, John Gerarde.) 
§ 1. DASÝSTOMA. Corolla yellow, the tube woolly inside, as well as the anthers and filaments; anthers alike, aun-pointed at base; leaves rather laige, more or less incised or pinnatifid.

* Pubescence partly glandular and viscid; corolla pubescent ontside.

1. G. pedicularia, L. Annual or biennial, smoothish or pubeseent, much branched $\left(2-3^{\circ}\right.$ ligh), very leafy; leaves ovate-lanceolate, pinnatifil, and the lobes cut and toothed; pedicels longer than the hairy mostly serrate calyx-lobes. - Dry eopses; N. Eng. to Minm., south to Fla. and Ark.

* * No glandular pulescence; corolla glabrous outside; perennial.

2. G. grandiflora, Benth. Minutely douny; stem much branched (2$4^{\circ}$ high); leaves ovate-lanceolate, coarsely toothed or cut, the lower pinnatifid; pedicels rather shorter than the calyx; corolla ( $\left(2^{\prime}\right.$ long) 4 times the length of the broadly lanceolate entire or toothed calyx-lobes. - Oak openings, Wisc. and Minn. to Tenn. and Tex.

3. G. flàva, L. (Dowxy False Foxglorw.) Pubescent with a fine close down; stem $\left(3-4^{\circ}\right.$ high) mostly simple; If ares orate-lanceolate or oblong, obtuse, entire, or the lower usually simuate-toothed or pmnatifid; pedicals very short; calyx-lobes ollong, obtuse, rather shorter than the tube, corolla $1 \frac{l^{\prime}}{2}$ long. - Open woods, N. Eng. to Wisc. and Iowa, south to Ga. and Ark.

4. G. quercifolia, Pursh. (Smootu False Foxgrove.) Smooth and ylaucous (3-6ㄱigh), usually branching; lower leaves commonly twice-pinnatifid; the upper oblong-lanceolate, pimatifid or entre; pedicels nearly as long as the calyx; calyx-lobes lance-linear, acute, as long as the at length inflated tube; corolla 2 ' long. - 1)ry woods, N. Eng. to Minn., south to Fla. and Ill.

5. G. lævigàta, Raf. Smooth, not glaucous; stem $\left(1-2^{\circ}\right.$ high $)$ mostly simple; leaves lanceolate, acute, entire, or the lowest olscurely toothed; pedicels shorter than the calyx-tube; corolla 1' long. (G. integrifolia, Gray.) Oak-barrens, etc., Penn. to Mich. and Ill., south in the mountains to Ga.

§ 2. OTOPHÝLLA. Corolla purple (rarely white), naked within, as well as the rery unequal filaments, anthers dissmilar, pointless, glabrous or sparingly hairy.

6. G. auriculàta, Michx. Rough-hairy; stem erect, nearly simple $\left(9-20^{\prime}\right.$ high $)$; leaves lanceolate or orate-lanccolate, scssile, the lower entire, the others with an oblong-lanceolate lobe on each side at the hase; flowers nearly sessile in the axils (I'long). - Low grounds and prairies, W. I'enn. to Mimn., south to N. C. and Mo.

7. G. densiflòra, Benth. More lispid and rongh, very leafy; leaves rigid, pinnately parted into 3-7 narrouly linear acule dirisions, those subtending the densely spicate flowers sinilar and crowded; corolla over $1^{\prime}$ long. - Prairies, E. Kan. to Tex.

§ 3. GERARDIA proper. Corolla purple or rose-color (rarely white); calyxteeth short; anthers alike, nearly pointless, pubescent; cauline leaves linear or narrouer, entire.

* Perennial; leaces erect, very narrow; pedicels crect, as long as floral leaves.

8. G. linifolia, Nutt. Glabrons, $2-3^{\circ}$ high, sparingly or paniculately brauched; leaves flat, thickish, $1^{\prime \prime}$ wille; calyx teeth minute; corolla $l^{\prime}$ long. 
minutely pubescent outside, villous within and lobes ciliate; anthers and fila. ments very villous. - Low pine barrens, Del. to Fla.

* * Annuals; herbage blackish in drying (except n. 13).

- Pediceis little if at all longer than the calyx and rapsule.

9. G. áspera, Dougl. Sparingly branched $\left(1-2^{\circ}\right.$ high $)$; leares long and linear, rough; pedicels (most of them alternate) equalling or modterately exceeding the calyx, which has triangular-lanceolate acnte lobes about half as long as the tube; corolla over $\mathrm{l}^{\prime}$ long. - Plains and prairies, Mich. and W. Ind. to Dak, and W. Ark.

10. G. purpùrea, L. (Purple Gerarnia.) Stem ( $1-2^{\circ}$ high) with long and rigid widely spreading branches; leares linear, acute, rough-margined; flowers large ( $1^{\prime}$ long), bright purple, often downy; pedicels shorter than the calyx, mainly opposite; calyx-teeth sharp-pointed, from very short to about half as long as the tule. - Low grounds, mainly near the coast and in the region of the Great Lakes. Very variable. - Var. PALPÉRCLLA, Gray. Smoother, more simple; corolla usually only $\frac{1^{\prime}}{2}$ long, lighter rose-purple. N. Eng. to l'enn., N. Ill., Minn., and northward.

11. G. marítima, Raf. (SEA-side G.) Low (4-12' high), with shorter branches; leaves and short broad calyx-teeth rather fleshy and obtuse; pedicels about as long as the calyx; corolla $\frac{1^{\prime}}{2}$ long. - Salt marshes along the coast. + + Pedicels usually exceeding the corolla; woolly anthers cuspidate at base.

12. G. tenuifòlia, Vahl. (Slexder G.) Leaves narrowly linear, acute, the floral ones mostly like the others; culyx-teeth very short, acute; capsule globular, not exceeding the calyx ; corolla about $\frac{1}{2}$ long. - Low or dry ground, common. - Var. MAcrophýlda, Benth. Stouter; larger leaves $1 \frac{1}{2}-2^{\prime}$ long and almost 2" wide, scahrous; pedicels ascending; calyx-teeth larger; corolla little over $\frac{1^{\prime}}{2}$ long. W. Iowa to W. La. and Col. - Var. Aspérela, Gray. Leares all nearly filiform and upper face hispidulous scabrous; inflorescence more paniculate; corolla small, the expanded limb only 6 " in diameter. I)ry bare hills, Mich. and N. Inel. to Minn. and Mo.

13. G. Skinneriana, Wood. Leaves bristle-shaped, as are the branchlets, or the lower linear; capsule orate, mostly longer than the caly $x$, which has short setaceous teeth; corolla $4-6^{\prime \prime}$ long. (G. setacea, Gray, Man., not of $W^{\prime}$ alt.) - Sandy low ground, Mass. to Minn., sonth to Fla. and La.

\section{CA A TILLEIA, Mutis. Paisted-Cup.}

Calyx tubular, flattened, cleft at the summit on the anterior, and usually on the posterior side also; the divisions entire or 2-lobed. Tube of the corolla included in the calyx; its upper lip (galea) long and narrow, arched and keeled, flattened laterally, enclosing the 4 unequal stamens; lower lip short, 3-lobed. Anther-cells oblong-linear, unequal, the outer fixed by the middle, the inner pendulons. Capsule many-seeded. - Herbs (root-parasitic), with alternate entire or cut-lobed leares; the floral ones usually dilated, colored, and more showy than the yellow or purplish spiked flowers. (Dedicated to Castillejo, a Spanish botanist.)

1. C. coccínea, Spreng. (Scarlet Painted-Cup.) Hairy biennial эr annual; stem simple; root-leares clustered, mostly eutire, obovate or 
oblong; those of the stem incised ; the floral 3-5-cleft, bright starlet toward the summit (rarely yellow); caly $\mathrm{x}$ about the length of the pale yllow corolla, equally cleft both sides, the lobes quadrate-oblong, entire or retnse. - Low sandy ground, Mlaine to Minn., south to N. J., Tenn., aul 'Tex.

2. C. pállida, Kunth, var. septentrionalis, Gray. Perennial, smooth or sparingly liairy, at the summit woolly; leaves mainly entire, the lower linear, upper broaler; the floral oblong or obovate, greenish-white, varying to yellowish, purple, or red; caly $x$ equally cleft, the lobes oblong or lanreolate, 2-clejt; corolla 1 - l'long, the galea decidedly shorter than the tulop, not over 2 or 3 times as long as the lip. - Alpine summits of N. Eng., N. shore of I. Superior, west and northwarl.

3. C. sessiliflora, P'ursh. P'erennial, $6-8^{\prime}$ high, very leafy, cinereous. pubescent; leaves mostly 3-5-cleft, with narrow diverging sometimes eleft lobes; the floral similar or broaler, not at all colorcd; culyx deeper cleft in front, the narrow lobes deeply 2-cleft; corolla 2' long, the short galea but tuice as long as the slender-lubed lip. - Prairies, Wisc. and IIl. to Dak. and Tex.

\section{ORTHOCÁRPUS, Nutt.}

Corolla with the upper lip (galea) little longer and usually much narrower than the inflated 1-3-saccate lower one. Otherwise nearly as Castilleia.

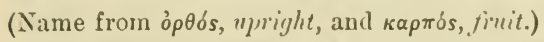

1. U. lùteus, Nutt. Annual, pubescent and hirsute, sometimes viscid, erect, $1^{\circ}$ high; leaves linear to lanceolate, occasionally 3 -cleft; spike dense; bracts broader, mostly 3-cleft, about equalling the flowers, not colored; corolla golden-yellow, not $6^{\prime \prime}$ long, $2-3$ times as long as the calyx. - Plains, N. Minn. to Col., and westward.

\section{SCH W ÁL BEA, Gronor. Chaff-seed.}

Calyx oblique, tubular, 10-12-ribbed, 5-toothed; the posterior tooth much the smaller, the 2 anterior united higher than the others. Lpper lip of the corolla arched, oblong, entire; the lower little shorter, erect, 2-plaited, with 3 very short anil broal obtuse lobes. Stamens 4, included in the upper lip; anther-cells equal and parallel. Capsule ovate, many-seeded. Seeds linear, with a luose chaff-like coat. $-\Lambda$ perennial minntely pulescent upright herb (1-2 ${ }^{\circ}$ high), with leafy simple stems, terminated by a loose spike of rather large dull purplish-yellow flowers; leaves alternate, sessile, 3-nerved, entire, ovate or oblong, the upper gradually reduced to narrow hracts; pedicels very short, with 2 hractlets under the calyx. (I)eclicated to $C^{*}$. G. Schualbe, an obscure German hotanist.)

1. S. Americàna, I. - Wet sandy soil, Mass. to La., near the coast. May-July.

\section{EUPH R Ás I A, Tourn. EYentigit.}

Calyx tubular or bell-shaped, 4-cleft. Lpper lip of the corolla erect, scarcely arched, 2-lobed, and the sides folded back; lower lip spreanling, 3-cleft, the lohes oltuse or notehed. Stamens 4, under the upper lip; anthercells equal, pointed at the hase. Capsule oblong, flattened. Sceds numer- 
ous. - Herbs, with branching stems, and opposite toothed or cut leares. Flowers, small, spiked. (Name eùpparía, cheerfulness, in allusion to its reputed medicinal properties.)

1. E. officinàlis, L. Low annual; leaves ovate or lanceolate, the lowest crenate, the floral bristly-toothed; loles of the lower lip of the (whitish, yellowish, or bluish) corolla notched. - Coast of Maine and Lower Canada; perhaps introduced from Eu. - Var. TAtárica, Benth., a low form with small flowers $\left(2-3^{\prime \prime} \mathrm{long}\right)$, and mostly rounded leaves. - Alpine region of N. II., shore of L. Superior, and far northward.

\section{BÁ R T I A, L.}

Calyx equally 4-cleft. Corolla with upper lip entire and sides not folded back. ()therwise much as Euphrasia. - Herbs, with opposite sessile leares, and subsessile flowers, in the upper axils and in a terminal leafy spike.

B. ()Doxtìtes, Huds. A span or two high from an annual root, branching, scabrous-pubescent; leaves oblong-lanceulate, coarsely and remotely serrate; spikes elongated, loosely-flowered; corolla small, rose-red.-Coast of Maine and N. Scotia. (Nat. from Eu.)

\section{RHINÁNTHUS, L. Yellow-Rattle.}

Calyx membranaceous, flattened, much inflated in fruit, 4-toothed. Upper lip of corolla arched, ovate, obtuse, flattened, entire at the summit, but with a minute tooth on each side below the apex; lower lip 3-lobed. Stamens 4, under the upper lip; anthers approximate, hairy, transverse; the cells equal, pointless Capsule orbicular, flattened. Seeds many, urbicular, winged. Annual upright herbs, with opposite leares; the yellow flowers crowded in a one-siled leafy-bracted spike. (Name composed of $\rho^{\prime} \iota$, , snout, and $\alpha$ L $\nu$ os, $a$ flower, from the beaked upper lip in some species formerly of this geuus.)

1. R. Crista-gálli, L. Leaves narrowly oblong to lanceolate, coarsely serrate, the floral bracts more incised with bristle-tipped teeth; corolla 6" long; seeds broadly winged (when ripe they rattle in the inflated calyx, whence the popular name.) - Coast of N. Eng. and alpine region of N. H., to L. Superior, and northward. (Eu., Asia.)

\section{PEDICULÀ RIS, Tourn. Locsewort.}

Calyx rarious. Corolla strongly 2-lipped; the upper lip arched, flattened, often beaked at the apex; the lower erect at base, 2-crested above, 3-lubed; lobes commonly spreading, the lateral ones rounded and larger. Stamens 4, uncler the upper lip; anthers transverse; the cells equal, pointless. Capsule ovate or lanceolate, mostly oblique, several-seeded. - Perennial herls, with chiefly pinnatifid leares, the floral bract-like, and rather large flowers in a spike. (Name from pediculus, a louse; of no obvious application.)

1. P. Canadénsis, L. (Common Locsewort. Woov Betory.) Hairy ; stems simple, clustered $\left(5-12^{\prime}\right.$ high) ; leares scattered, the lourest pinnately parted, the others half-pinnatifid; spike short and dense; calyx split in front, otherwise almost entre, oblique; upper lip of the (dull greenish-yellow and purplish) corolle hooded, incurved, 2-toothed under the apex; capsule flat, somewhat sucord-shriped. - Copses and banks, common. May-July. 
2. P. lanceolàta, Michx. Stem upright $\left(1-3^{\circ}\right.$ high $)$, nearly simple, mostly smooth; leares partly opposite, oblong-lancenlate, doubly cul-toothed; spike crowded; calyx 2-lobed, leafy-crested; upper lip of the (pale ycllow) corolla incurved and bearing a short truncate beak at the apex, the lower erect, so as nearly to close the throat; capsule ovate, scarcely longer than the calyx. - Swamps, Conn. to Va., Ohio, and Minn.

3. P. Furbíshiæ, Watson. Tall $\left(2-3^{\circ}\right.$ high $)$ pubescent or glabrate; leaves lanceolate, pinumely parted and the short oblong divisions pinnatifidincised, or the upper simply pinnatifid and the lobes serrate; bracts ovate, laciniate-dentate; caly,y-lobes 5, rather mequal, linear-lanceolate, entire or toothed; upper lip of corolla straight and heakless, the truncate apex bicuspidate, the lower erect, truncately 3-lobed ; capsule broadly orate. - Banks of the St. John's, Aroostook Co., Ilaine (Wiss Kate Furbish), and adjacent N. Brunswick.

\section{M E L A M P Ỳ R U M, Tourn. Cow-WheAt.}

Calyx bell shaped, 4 -cleft; the taper loles sharp-pointed. Tulue of corolla cylindrical, enlarging above; upper lip arched, compressed, straight in front; the lower erect-spreading, biconvex, 3-lobed at the apex. Stamens 4, under the ur,per lip; anthers approximate, oblong, nearly vertical, hairy; the equal cells minutely pointed at base. Ovary with 2 ovules in each cell. Capsule flattened, oblique, 1-4-seeded. - Erect branching annuals, with opposite leaves, the lower entire, the upper mostly toothell at base. Flowers solitary in the upper axils. (Name from $\mu$ é $\lambda$ as, black, and $\pi u \rho j s$, wheat; from the color of the seeds of some species as they appear mixed with grain.)

1. M. Americanum, Michx. Leaves lanceolate, short-petioled, the floral ones like the lower, or truncate at base and beset with a few bristly teeth; calyx-teeth linear-awl-shaped, not half the length of the slencler tube of the pale greenish-yellow corolla (5"long). - Open wools; common, from the Atlantic to Minn. and Iowa, especially eastwaril. June-Sept.

\section{Oriner 76. OROBA NCHÀCEAE. (Bronm-rape, Famiy.)}

Herbs destitute of green foliage (root-parasiles), monopetalons, didynamous, the ovary one-celled with 2 or 4 parietal placentce: pord very manyseeded; seeds minute, with albumen and a very minute embryo. - Calyx persistent, 4-5-toothed or parted. Corolla tubular, more or less 2lipped, ringent, persistent and withering; upper lip entire or 2-loberl, the lower 3-lobed. Stamens 4, didynamous, inserted on the tube of the corolla; anthers 2-celled, persistent. Ovary free, ovoil, pointed with a long style; stigma large. Capsule 1-celled, 2-valved; each valve bearing on its face one placenta or a pair. Seels very numerous, minute. - Low, thick or fleshy herbs, bearing s'ales in place of leaves, lurid yellowish or brownish thronghont. Flower's solitary or spikel.

* Flowers of two surts, scattered along slender panicled branches.

1. Fpiphegus. Upper flowers sterile, with a tubular corolla; the lower fertile, with the corolla miunte and not expanding. Bracts inconspicuous. 
* Flowers all alike and perfect; stems mostly simple.

2. Conopholis. Flowers densely spicate. Calyx deeply cleft in front. Corolla 2-lipped. Stamens exserted.

3. Aphyllon. Flowers pedicellate, sometimes subsessile and thyrsoid-spicate. Calyx regularly 5-cleft. Corolla somewhat 2-lipyed. Stamens included.

4. Orobanche. Flowers sessile, spicate. Calyx cleft before and behind almost to the base. Corolla 2-lipped. Stamens included.

\section{EPIPHE GUS, Nutt. BeEch-Drops. Caxcer-Root.}

Flowers racemose or spiked, scattered on the branches; the upper sterile, with a long tubular corolla and long filaments and style; the lower fertile, with a very short corolla which seldom opens, but is forced off from the base by the growth of the pod; stamens and style very short. Calyx 5-toothed. Stigma capitate, a little 2-lobed. Capsule 2-valved at the apex, with 2 approximate placentæ on each valve. - Herbs slender, purplish or yellowishbrown, much branched, with small scattered scales, 6-12' high. (Name from $\epsilon \pi i$, upon, and $\phi \eta \gamma$ 's, the Beech, because it grows on the roots of that tree.)

1. E. Virginiàna, Bart. Corolla of the upper (sterile) flowers whitish and purple, $6-8^{\prime \prime}$ long, curverl, 4-toothed. - Cominon under Beech-trees, prirasitic on their roots; N. Brunswick to Wisc., south to Fla. and Ark. Ang.-Oct.

\section{CONÓPHOLIS, Wallroth. SQUaW-Root. Caxcer-Root.}

Flowers in a thick scaly spike, perfect, with 2 bractlets at the base of the irregularly 4-5-toothed calyx; its tube split down on the lower side. Corolla tubular, swollen at base, strongly 2-lipped; upper lip arched, notched at the summit, the lower shorter, 3-parted, spreading. Stamens protruded. Stigma depressed. Capsule with 4 placentie, a pair on the middle of each valve. Cpper scales forming bracts to the flowers, regularly imbricate, not unlike those of a fir-cone (whence the name, from $\kappa \hat{\omega} \nu 0 s$, a cone, and $\phi \circ \lambda i s$, a scale).

1. C. Americàna, Wallroth. - Oak woods, growing in clusters amoug fallen leares; N. Eng. to Mich., south to Fla. and Tenn. May, June. - A singular plant, chestnut-colored or yellowish throughout, as thick as a man's thumb, $3-6^{\prime}$ high, covered with fleshy scales, which become dry and hard.

\section{A PHÝLLON, Mitchell. NАKЕD Broom-RAPE.}

Flowers perfect, pedicellate, sometimes subsessile and thyrsoid-spicate. Calyx 5-cleft, regular. Corolla somewhat 2-lipper; the upper lip more or less spreading and 2-lobed, the lower spreading, 3-lohed. Stamens included. Stigma broadly 2-lipper or crateriform. Capsule with 4 placentæ, equidistant or contiguous in pairs. Plants brownish or whitish. Flowers (purplish or yellowish) and naked scapes minutely glandular-pubescent. (Name from aprivative and $\phi \dot{ } \lambda_{\lambda \lambda}{ }^{\nu}$, foliage, alluding to the naked stalks.)

* Flowers solitary on long naked scapes or peduncles, without bractlets; corolla with a long curved tube and spreading 5-lobed limb.

1. A. uniflòrum, Gray. (Oxe-flowered CAxcer-root.) Stem sulterranean or nearly so, very short, scaly, often branched, each branch sending up $1-3$ slender one-flowered scapes $\left(3-5^{\prime}\right.$ high) ; divisions of the calyx lancea $u$-shriped, half the length of the corolla, which is $I^{\prime}$ long, with 2 yellow 
bearded folds in the throat, and oborate lobes. - 1)amp woodlauds, Newf. to Va. and 'Tex., and west to the Pacific. A pril-July.

2. A. fasciculàtum, Gray. Scaly stem erect and rising 3-4' out of the ground, mostly longer than the crowded peduncles; divisions of the calyx triangular, very much shorter than the corolla, which has rounled short lobes. Sandy ground, L. Michigan to Minu., southward west of the Mississippi, and westward. On Artemisia, Eriogonum, etc. May.

* *aulescent; flouers denstly spirate, with 1-2 brartlets at base of calyx; corolla 2-lipped, the upper lip less or not at all 2-cleft.

3. A. Ludoviciànum, Gray. Glandular-pubescent, branched (3-12' high); corolla somewhat curved, twice the length of the narrow lanceolate calyx-lobes; the lips equal in length. (Phelipiea Ludoviciana, IFalp.) Minn. to 1ll. and 'Tex., and westward.

\section{OROBÁ N C H E, 'Tourn. Broom-rape.}

Flowers spicate, sessile. Calyx cleft before and behind almost or quite to the base, the divisions usinally 2 -cleft. Corolla 2-lipped; upper lip erert, 2 lobed or emarginate, the lower spreading, broadly 3-lobed. Stamens included. - Old World parasites, on roots of various plants.

O. vixor, I. A span to a foot high, pubescent, pale yellowish-brown, or with purplish-tinged flowers in a rather loose spike; corolla 6 " long. - Parasitic on clover, N.J. to Va. Sparingly and probably recently introluced.

\section{Order 77. LENTIBULARI ICEAE. (BLAdDerwort Family.)}

Small herbs (growing in water or uet places), with a 2-lipped calyx, and a 2-lipped personate corolla, 2 stamens with (confluently) one-celled anthers, and $a$ one-celled ovary with a free central placenta, learing several anatropous seeds, with a thick straight embryo, and no albumen. - Corolla deeply 2-lipped, the lower lip larger, 3-lobed and with a prominent palate, spurred at the base in front; the palate usually bearded. Ovary free; style very short or none; stigma 1 - 2-lipped. Capsule often bursting irregularly. Scapes 1 - few-flowered. - The following are the two principal genera.

1. Utricularia. Calyx-lobes mostly entire. Upper lip of corolla erect. Filanents strongly incurved. Foliage dissected; bladdler-bearing.

2. Pinguicula. Calyx witl upper lip deeply 3 -and lower 2 -cleft. Corolla-lobes spreading. Filaments straighter. Terrestrial, with entire rosulate leaves next the ground.

\section{UTRICULÀ I A, I. Bhanerwort.}

Lips of the 2-parted calyx entire, or nearly so. Corolla personate, the palate on the lower lip projectiug, often closing the throat; upper lip erect. Anthers convergent. - A (yuatic and immersed, with capillary dissected leaves bearing little bladders, which float the plant at the time of flowering; or rooting in the mud, and sometimes with few or no leaves or bladders. Scapes 1 few-flowered; usually flowering all summer. Bladders furnished with a valvular lid and usually with a few bristles at the orifice. (Name from utriculus, a little bladiler.) 
* Upper leaves in a whorl on the otherwise naked scape, floating by means of large bladders formed of the inflated petioles; the lower leaves dissected and capillary, bearing small bladders; rootlets few or none.

1. U. inflàta, Walt. Swimming free; bladder-like petioles oblong, pointed at the ends and branched near the apex, bearing fine thread-like divisions; flowers 3-10 (large, yellow); the appressed spur half the length of the corolla; style distinct. - In still water, Maine to Tex., near the coast.

* Scapes naked (except some small scaly bracts), from immersed branching stems, which commonly swim fiee, bearing capillary dissected leaves with small bladders on their lobes; roots few and not affixed, or none. (Mostly perennial, propagated from year to year by tuber-like buds.)

- Cleistogamous flou:ers along the submersed copiously bladder-bearing stems.

2. U. clandestina, Nutt. I.eaves numerous on the slender immersed stems, sereral times forked, capillary ; scapes slender $\left(3-5^{\prime}\right.$ high $)$; lips of the yellow corolla nearly equal in length, the lower broader and 3-lobed, somewhat longer than the approximate thick and blant spur. - Ponds, from N. Brunswick and N. Eng. to N. J., near the coast.

\section{+ - No cleistogamous flouers.}

- Pedicels recurved in fiuit; corolla yellow.

3. U. vulgàris, L. (Greater Bladderwort.) Iminersed stems ( $1-3^{\circ}$ long) crowded with 2-3-pinnately many-parted capillary leaves, bearing many bladders ; scapes 5-12-flowered (6-12' long); corolla closed (6-9" broad), the sides reflexed; spur conical, rather shorter than the lower lip, thick and blunt in the European and the high northern plant; in the common American plant less thick and rather acute. - Common in ponds and slow streams, Newf. to Minn., south to Va. and Tex., and westward. (Eu., Asia.)

4. U. minor, I. (SMAller B.) Leaves scattered on the thread-like immersed stems, 2-4 times forked, short; scapes weak, 2-8-flowered (3-7' ligh); upper lip of the gaping corolla not longer than the depressed palate; spur very short and blunt, or almost none. - Shallow water, E. Mass. to Minn., south to N. J. and Ark., and westward. (Eu.)

+ + Pedicels erect in fiuit, few and slender; corolla yellow.

5. U. gíbba, I. Scape (1-3' high) 1-2-flovered, at base furnished with very slender short branches, bearing sparingly dissected capillary rootlike leaves and scattered bladders: corolla $3-4^{\prime \prime}$ broarl, the lips broad and rounded, nearly equal; the lower with the sides reflexed, exceeding and approximate to the very thick and blunt conical gibbous spur. - Shallow water. Mass. to Mich., south to Va. and Ill.; Mt. Desert (F. M. Day).

6. U. biflòra, Lam. Scape $\left(2-5^{\prime}\right.$ high) 1 -3-flocered, at the base bearing somewhat elongated submersed branches with capillary root-like leaves and numerous bladders; corolla 4-6" broad, the spur oblong, equalling the lower lip; seeds scale-shaped. - Ponds and shallow waters, S. Ill. and Iowa to Tex.; also S. Ya. (?), and Barnstable, Mass. ( $W$. Deane).

¡. U. fibròsa, Walt. Leaves crowded or whorled on the small immersed stems, several times forked, cupillary; the bladders borne mainly along the stems; flowars 2-6 ( $6^{\prime \prime}$ broad); lips nearly equal, broad and expanded, the 
upper undulate, concave, plaited-striate in the middle; spur nearly linear, obtuse, approaching and almost equalling the lower lip. (U. striata, Le Confe.) - Shallow pools in pine larrens, L. Island and N. J. to Fla. and Ala.

8. U. intermedia, Hayue. Leaves crowled on the inmersed stems, 2-ranked, 4-5 times forked, rigid, the divisions linear-awl-shapel, minutely bristle-toothed along the margins; the bladders borne on sopurute leajless branches; upper lip of corolla much longer than the palate; spur conical. subulate, acute, appressed to the very broud (6-8") lower lip and nearly as long as it. - Shallow pools, Newf. to N. J., west to Iowa, Minn., and northward. (Eu., Asia.)

$\ldots+$ Pedicels erect in fruit, rather long: corolla violet-purple.

9. U. purpùrea, Walt. Leaves whorled along the long immersed free floating stems, petioled, decompound, capillary, bearing many bladders; flowers 2-4 (6" wide); spur appressed to the 3-lobed 2-saccate lower lip of the corolla and about half its length. - Ponds, Maine and X. P'eun. to Fla., mainly near the coast; also Lake Co., Iud.

* * * Scape solitary, slender and naked, or with a few small scales, the base rooting in the mud or soil; leaves small, aul-shaped or grass-like, often raised out of the water, commonly few or fugacious; air-bladders few on the leaves or rootlets, or commonly none.

- Flower purple, solitary; leaves bearing a few delicate lobes.

10. U. resupinàta, B. D. Greene. Scape (2-8' high) 2-bracted above ; leaves thread-like, on delicate creeping branches; corolla $\left(4-5^{\prime \prime}\right.$ long) deeply 2-parted; spur oblong-conical, very obtuse, shorter than the dilated lower lip) and remote from it, both ascending, the flower resting transversely on the summit of the scape. - Sandy margins of ponds, E. Maine to R. I., near the coast; also N. New York and Presque Isle, I. Frie.

+- Flowers 2-10, (chiefly) yellow: leaves entire, rarely seen.

11. U. subulàta, I. Stem eapillary $\left(3-5^{\prime}\right.$ high $)$; pedicels capillar!l: lower lip of the corolla flat or with its margins recurved, equally 3 -lobed, much larger than the ovate upper one; spur ublong; acute, straight, appressed to the lower lip, which it nearly equals in length. - Sandy swamps, and pine-barrens, Nantucket, Mass., to N. J., Fla., anil Tex., near the coast.

Var. cleistógama, Gray. Only $1-2$ ' high, bearing 1 or 2 evidently cleistogamous purplish flowers, not larger than a pin's head; capsule lecoming l" long. (The unnamed Utricularia in the Man., p. 320). - With the ordinary form ; Barnstable and Nantucket, Mass., pine-harrens of N. J., and southward.

12. U. cornùta, Michx. Sitem strict $\left(3^{\prime}-1^{\circ}\right.$ high $), 1-5$-flowered; pedicels not longer than the raly.x; corolla $1^{\prime}$ long, the lower liplarge and helmetshaped, its centre very convex and projecting, while the sides are strongly reflexed; upper lip obovate and much smaller; spur aul-shaped, turned dounward and outward, about as long as the lower lip. - Peat-bogs, or sandy swamps, Newf. to Minn., suuth to Fla. and Tex.; common.

\section{PINGUÍ C U L A, Tourn. Bitterwort.}

Upper lip of the calyx 3-cleft, the lower 2-cleft. Corolla with an open hairy or spotted palate, the lohes spreading. - Small and stemless perennials, grow- 
ing on damp rocks, with 1 -flowered scapes, and broad and entire leaves, all clustered at the root, soft-fleshy, mostly greasy to the touch (whence the name, from pinguis, fat).

1. P. vulgàris, L. Leaves ovate or elliptical; scape and calyx a little pubescent; lips of the violet corolla very unequal, the tube funnel-form; spur straightish. - Wet rocks, northern N. Eng. and X. Y. to Minn., and far northward. (Eu., Asia.)

\section{Order 78. BigNoniàceAE. (Bignonia Family.)}

Woody plants, monopetalous, didynamous or diandrous, with the ovary commonly 2-celled by the meeting of the two parietal placentce or of a projection from them, many-ovuled; fivit a dry capsule, the large flat winged seerls with a flat embryo and no albumen, the broad and leaf-like cotyledons notched at both ends. - Calyx 2-lipped, 5-cleft, or entire. Corolla tubular or bell-shaped, 5-lobed, somewhat irregular or 2-lipped, deciduous; the lower lobe largest. Stamens inserted on the corolla; the fifth or posterior one, and sometimes the shorter pair also, sterile or rudimentary ; anthers of 2 diverging cells. Ovary free, bearing a long style, with a 2-lipped stigma. - Ieaves compound or simple, opposite, rarely alternate. Flowers large and showy. - Chiefly a tropical family.

1. Bignonia. Pod flattened parallel with the partition. Leaves compound, tendril-bearing.

2. Tecoma. Pod flattish contrary to the partition. Leaves compound, without tendrils.

3. Catalpa. Pod terete. Fertile stamens only 2. Trees; leares simple.

\section{BIG NòNIA, 'Tourn.}

Calyx truncate, or slightly 5-toothed. Corolla somewhat bell-shaped, 5-lobed and rather 2-lipped. Stamens 4, often showing a rudiment of the fifth. Capsule linear, 2-celled, flattened parallel with the valves and partition. Seeds transversely winged. - Woody climbers, with chiefly compound leaves, terminating in a tendril. (Named for the Albé Bignon.)

1. B. capreolàta, L. (Cros-rive.) Smooth; leaves of 2 ovate or oblong leaflets and a branched tendril, often with a pair of accessory leaves in the axil resembling stipules; peduncles few and clustered, l-flowered; corolla orange, 2' long; pod 6' long; seeds with the wing $1 \frac{1^{\prime}}{2}$ long. - Rich soil, Va. to S. Ill and south to Fla. and La. April. Climbing tall trees; a transverse section of the wood showing a cross.

\section{TÉ COM A, Juss. Trumpet-flower.}

Calyx bell-shaped, 5-toothed. Corolla funnel-form, 5-lobed, a little irregular. Stamens 4. Capsule 2-celled, with the partition at right angles to the convex valves. Seeds transversely winged. - Woody, with compound leaves, climbing by aerial rootlets. (Abridged from the Mexican name.)

1. T. radicans, Juss. (Trumpet Creeper.) Leaves pinnate; leaflets 9-11, ovate, pointed, toothed; flowers corymbed; stamens not protruded be-

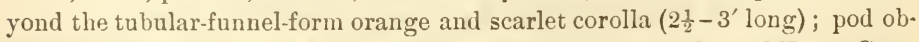
lanceolate, 4-5' long. - Moist soil, Penn. to Ill., south to Fla. and Tex. Common in cultivation farther north. 


\section{CA T Ál PA, Seop., Walt. Catalpa. Inmax Beas.}

Calyx deeply 2-lipped. Corolla bell-shaped, swelling; the undulate 5-Inbed spreading borler irregular and 2-lipped. Fertile stamens 2, or sometimes 4 ; the 1 or 3 others sterile and rudimentary. Capsule very long and slender, nearly eylindrical, 2-celled, the partition at right angles to the valves. Sechls winged on each side, the wings cut into a fringe. - l'rees, with orate or cordate and mainly opposite leaves. (The ahoriginal name.)

1. C. speciòsa, Warler. A large and tall tree, with thick bark; leaves ample, heart-shaperl, long-acuminate; corolla '2' long, nearly white, incon. spicunusly spotted, with obconical tube and slightly oblique limb, the lower lobe emarginate; capsule thick. - Jow rich woodlands, s. Iud. to Tenn., Mo., and Ark. May.

C. Bıxoxıònıs, Walt., of Ga., Ala. anıl Miss., very widely cultivated, and formerly including the above species, is a low much branclied tree, with thin bark, smaller ( $1 \frac{f^{\prime}}{2}$ long) thickly spotted corolla (with obligue limb and lower lobe entire), and a much thinner capsule.

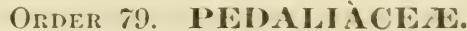

Herbs, with chiefly opposite simple leaves, and flowers as of the precening Order, except in structure of ovary and fiuil, the former being 1-celled, the latter fleshy-rlrupaceous, with wingless seerls and thich entire cotyledons. - Ovary (in ours) 1-celled, with 2 parietal intruded placentae expanded into 2 broad lamellæ or united into a central columella.

\section{M A RTÝ N I A, I. UxicorN-Plant.}

Calyx 5-eleft, mostly unequal. Corolla gibbous, bcll-shaped, 5-lobed and somewhat 2-lipped. Fertile stamens 4, or only 2. Fruit fleshy, the flesh at length falling away in 2 valies; the inner part woody, terminated by a beak, which at length splits into 2 hooked horns, and opens at the apex between the horns, imperfectly 5-celled, owing to the divergence of the two plates of each placenta, leaving a space in the centre, while by reaching and cohering with the walls of the fruit they form 4 other cells. Seeds several, wingless, with a thick roughened coat. - Low branching annuals, clammy-pubescent, exhaling a heavy odor, stems thickish; leaves simple, rounded; flowers racemed, large. (Dedicated to Prof. John Martyn, of Cambriclge, Englant.)

1. M. proboscídea, Glox. Leaves heart-shaped, ohlique, entire or undulate, the upper alternate; corolla dull white or jurplish, or spotterl with yellow and purple; endoearp of the fruit crested on une side, long-beaked. Banks of the Mississippi and its lower tributaries, from S. Ind., Ill., and Iowa, to northern Mexico. Also cultivated and naturalized farther north.

\section{Order 80. ACANTHACHA. (ACAxtuts Famis.)}

Chiefly herbs, with opposite simple leaves, didynamous or diundrous stamens, inserted on the tube of the more or less 2-lipped corolla, the lobes of which are convolute or imbricated in the bul ; fruit a 2-celled and few- (412-) seeded capsule: seeds anatropous, without albumen, usually flat and 
supported by hooked projections of the placentce (retinacula). - Flowers commonly much bracted. Calyx 5-cleft. Style thread-form; stioma simple or 2-cleft. Pod loculicidal, usually flattened contrary to the valves and partition. Cotyledons broad and flat. - Mucilaginous and slightly bitter, not noxions. A large family in the warmer parts of the world; represented in gardens by 'THLxibria, which differs from the rest by the globular pod and seeds, the latter not on hooks.

* Corolla not obviously bilabiate, the 5 lobes broad and roundish, spreading; stamens 4.

1. Calophanes. Calyx-lobes long-filiform. Capsule 2-4-seeded.

2. Ruellia. Calyx-lobes mostly linear or lanceolate. Capsule 6-20-seeded.

* Corolla bilabiate, upper lip erect and concave, lower spreading; stamens 2.

3. Dianthera. Capsule obovate, flattened, 4-seeder.

\section{C A L Ó PHA NES, Don.}

Calyx deeply 5-cleft or parted; its lobes elongated setaceous-acuminate or aristiform. Corolla funnel-form, with ample limb, convolute in the bud. Stamens 4 , the anthers mucronate or sometines aristate at base. Ovules a single pair in each cell. Capsule oblong-linear, 2-4-seeded. - Low branching perennials, pulescent or hirsute, with proportionally large axillary nearly sessile flowers (solitary or few), and blue corolla. (Name from ka入ós, beuutiful, and $\phi$ ain $\omega$, to appecir.)

1. C. oblongifolia, Don. Stems usnally erect and simple, $\frac{1}{2}-1^{\circ}$ high ; leaves from narrowly oblong to oval, very obtuse, sessile ( $l^{\prime}$ long or less); corolla blue, sometimes purple-dotted or mottled, seldom l'long; calyx-lobes nearly distinct, filiform-setaceous, hirsute. - Pine-barrens, S. Va. to Fla.

\section{RUÉLLIA, Plumier.}

Calyx 5-parted. Corolla fumel-form, with spreading ample border, convolute in the bud. Stamens 4 , the cells of the somewhat arrow-shaped anthers parallel and nearly eqnal. Capsule narrow, in our species somewhat flattened, contracted and seedless at the base, above 8-12-seeded. Seeds with a mucilaginous coat, when wet exhibiting under the microscope innumerable tapering short bristles, their walls marked with rings or spirals. - Perennials, with rather large and showy blue or purple flowers, mostly in axillary clusters, sometimes also with small flowers precocionsly close-fertilized in the bud. Ca. lyx often 2-bracteolate. (Named for the early herbalist, John Ruelle.)

1. R. ciliòsa, Pursh. Hirsute with soft whitish hairs $\left(1-3^{\circ}\right.$ high); leaves nearly sessile, oval or orate-oblong ( $1-2^{\prime} \operatorname{long}$ ); flowers $1-3$ and almost sessile in the axils; tube of the corolla $\left(1-1 \frac{1}{2}^{\prime} \mathrm{long}\right)$ fully twice the length of the staceous calyx-lobes; the throat short. - Dry ground, Mich. to Minn., south to Fla. and La. June-Sept. - Var. AuBŕGUA, Gray. Sparingly hirsute-pubescent or glabrate; leares orate-oblong, usually short-petioled, larger ; tube of corolla little exceeding the hardly hirsute calyx. - Va. and Ky. to Ala. Appearing like a hybrid with the next.

2. R. strèpens, L. Gilabrous or sparingly pubescent $\left(1-4^{\circ}\right.$ high); leaves narrowed at base into a petiole, ovate, obovate, or mostly oblong $\left(2 \frac{1}{2}-5^{\prime} \mathrm{long}\right)$; tube of the corolla (about $1^{\prime}$ long) little longer than the dilated portion, slightly 
exceeding the lanceolate or linear calyx-lobes. - Rich soil, I'enn. to Wisc., Bouth to Fla. and 'Tex. July-Sept. - Var. CLeist Axtu, Gray. Leaves commonly narrower and oblong; flowers for most of the season cleistogamous. - Common with the ordinary form.

\section{DI A N T H E A, Grouov. WATER-WiLlow.}

Calyx 5-parted. Corolla deeply 2-lipped; the upper lip erect, notcherl; the lower spreading, 3-parted, external in the bud. Stamens 2; anthers 2-celled, the cells separated and somewhat unequal. Capsule obovate, flattened, contracted at base into a short stalk, 4-seeded. - P'erennial herbs, growing in water or wet places, witl entire leaves, and purplish flowers in axillary pe.

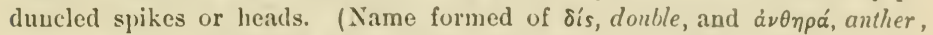
the separated cells giving the appearance of two anthers ou each filament.)

1. D. Americàna, L. Stem $1-3^{\circ}$ high; leares linear-lanceolate, clongated; spikes obloug, dense, long-peduncled ; corolla 4-5" long. - In water, N. W. Vt. to Wisc., south to S. C. and Tex. July-Sept.

\section{Order 81. VERBENÀCEAE. (Vervaix Famty.)}

Herbs or shrubs, with opposite leaves, more or less 2-lipped or irregular corolla, and didynamous stamens, the 2-4-celled (in P'lryma 1-celled) fruit dry or drupaceous, usually splitting when ripe into as many 1-seeded indehiscent nutlets; differing from the following order in the ovary not being 4-lobed, the style therefore terminal, and the plants seldom aromatic or furnishing a rolatile oil. - Seeds with a straight embryo and little or no albumen. - A large order in the warmer parts of the world, sparingly represented in cool regions.

Tribe I. VERB ENE E. Ovary 2-4-celled, with an erect anatropous ovule in each cell.

1. Verbena. Flowers in spikes ur heads. Calyx tubular. Fruit spllitting into 4 nutlets.

2. Lippia. Flowers in spilies or heads. Calyx short, 2-cleft. Fruit spllitting into 2 nutlets.

3. Callicarpa. Flowers in axillary cymes. Calyx short. Fruit berry-like, with 4 nutlets.

Tribe II. PHIRMEIE. Ovary l-celled; ovule erect, orthotropous.

4. Phryma. Flowers in slender spikes. Calyx cylindrical, 2-lipped. Fruit an achene.

\section{VER B E N A, Tourn. VervaiN.}

Calyx tubular, 5-tootherl, one of the teeth often shorter than the others. Corolla tubular, often curverl, salver-form ; the border somewhat unequally 5 cleft. Stamens included; the upper pair occasionally without anthers. Sityle slender; stigma mostly 2-lohed. Fruit splitting into 4 secullike nutlets. Flowers sessile, in single or often panicled spikes, bracted ; produced all summer. (The Latin name for any sacred herb; derivation obscure.) - The species present numerous spontaneous hybrids.

$\S 1$. Anthers not appendaged; flowers small, in narrow spikes.

* Spikes filiform, with flowers or at least fruits scattered, naked, the inconspicuous bracts shorter than the calyx.

V. officinalis, L. (Euruíean V.) Anuual, glabrous or nearly so, loosely branched (1-3० high); leares pinnatifid or 3-cleft, oblong-tanceolate, 
sessile, smooth above, the lobes cut and toothed; spikes panicled; flowers purplish, very small. - Roadsides and old fields, N. J. to Minn., south to 'Tex., and westward. (Nat. from Eu.)

1. V. urticæfólia, I. (Whrte V.) Perennial, from minutely pubescent to almost glabrous, rather tall $\left(3-5^{\circ}\right.$ high $)$; leaves oval or ollong-orate, acute, coarsely serrate, petioled; spikes at length much elongated, loosely panicled; flowers very small, white. - Waste or open grounds. (Trop. Am.)

* * Spikes thicker or densely flowered; the fruits crouded, mostly overlapping each other; bracts inconspicuous, not exceeding the flowers; perennial.

2. V. angustifòlia, Michx. Low $\left(6-18^{\prime}\right.$ high), often simple; leaves narrowly lanceolate, tapering to the base, sessile, roughish, slightly toothed; spikes few or single; the purple flowers crowded, larger than in the next. 1)ry or sandy ground, Mass. to Minm., south to Fla. and Ark.

3. V. hastàta, I. (Ble V Vrvalx.) Tall ( $4-6^{\circ}$ high); leaves lanceolate or oblong-lanceolate, taper-pointed, cut-serrate, petioled, the lower often lobed and sometimes halberd-sluped at base; spikes linear, erect, corymbed or panicled ; flowers blue. - Waste grounds and roadsides; common.

4. V. strícta, Vent. (HoARY V.) Downy with soft whitish hairs, erect, simple or branched (1-2 ${ }^{\circ}$ high); leaves sessile, obovate or oblong, seriate; spikes thick, somewhat clustered, hairy; flowers rather large, purple. - Barrens and prairies, Ohio to Dak., south to Tex. and N. Mex.

$$
\text { * * Spikes thick, sessile and leafy-bracted; ammul. }
$$

5. V. bracteòsa, Michx. Widely spreading or procumbent, hairy; leares wedge-lanceolate, cut-pinnatifil or 3-cleft, short-petioled ; spikes single, remotely flowered; bracts large, the lower pinnatifid, longer than the small purple flowers. - Prairies and waste grounds, Ohio to Minn., south and westward.

$\S 2$. Anthers of the longer stamens glandular-tipped; flowers showy, from depressed-capitate becoming spicate.

6. V. bipinnatifida, Nutt. Hispid-hirsute, $\frac{1}{2}-1^{\circ}$ high; leares $\left(1 \frac{1}{2}-4^{\prime}\right.$ long) bipinnately parted, or 3-parted into more or less bipinnatifid divisions, the lobes commonly linear or broader; bracts mostly surpassing the caly $x$; limb of bluish-purple or lilac corolla 4-5" broad. - Plains and prairies, Kan. to Ark. and Tex., and westward.

7. V. Aubletia, L. Slender, $1^{\circ}$ high or less, soft-pubescent or glabrate; leaves (1-2' long) ovate or ovate-oblong in outline, with a wedge-shaped base, incisely lobed and toothed, often more deeply 3-cleft; bracts shorter than or equalling the calyx; limb of reddish-purple or lilac (rarely white) corolla 6-8" broad. - Open woods and prairies, Ind. and IIl. to Fla., Ark., and N. Mex.

\section{LI P P I , Houst.}

Calyx short, often flattened, 2-4-toothed, or 2-lipped. Corolla 2-lipped; upper lip notched, the lower much larger, 3-lobed. Stamens included. Style slender; stigma obliquely capitate. Fruit 2-celled, 2-seeded. (Dedicated to Augustus Lippi, an Italian naturalist and traveller.)

1. L. lanceolàta, Michx. (Fog-Fruit.) Creeping extensively, roughish, green; leaves oblanceolate or wedge-spatulate, serrate above; peduncles axillary, slender, exceeding the leaves, bearing solitary closely bracted heads of bluish- 
white flowers; bracts mucronate or pointless. - liver-banks, E. I'enn. to Minn., soutlı to Fla. and Tex. July-Sept.

2. L. cuneifolia, Steud. Diffusely branched from a woody base, procumbent (not crepping), minutely cancscent thoughout; leates rigul, runeutelinear, incisely 2-6-toothed above the midhllo; perluncles axillary, mostly shorter than the lenes; bracts rigid, broally cumeate, uhruptly acuminate; corolla white (!). - P'lains, W. Nels. to central Kan. and Arizona.

\section{CALIICÁR P A, I.}

Calyx 4-5-tonthel, short. ('urollit tubular bell-shatped, 4-5-Juleel, nearly regular. Stamens 4 , nearly equal, exserted; anthers opening at the apex. Style sleuder, thickened upward. Frnit a suall herry-like drupe, with 4 uutlets.Shrubs, with scurfy pubescence, and small flowers in axillary cymes. (Name

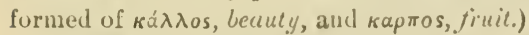

1. C. Americàna, L. (Frexcu Mulnkrm.) Leaves-urateoblong with a tapering base, acuminate, torthed, whitish beneath; cymes many-flowered; calyx obscurely t-toothed; corolla bluish; fruit violet-color. - Kich soil, Va. to 'Tex., theuce north to Mo. May-July.

\section{PHRY் A, I. Lopsen.}

Calyx cylindrical, 2-lipped; the upper lip of 3 bristle-awl-shaped tce:h; the lower shorter, 2-toothed. Corolla 2-lipped; upper lip notehed; the lower much larger, 3-lubed. Stamens included. Style slender; stigna 2-lubed. Fruit dry, in the bottom of the calyx, oblong, l-celled and 1-seeded. Seed orthotropous. Cotyledons convolute round their axis. $-\Lambda$ perennial herb, with slender branching stems, and coarsely toothed ovate leaves, the lower long petioled ; the small opposite flowers in elongated and slender terminal spikes, strictly reflexed in fruit. Corolla purplish or rose-color. (Derivation of the name unknown.)

1. P. Leptostàchya, L. I'lant $2-3^{\circ}$ high: leaves $3-5^{\prime}$ long, thiu ; calyx strongly ribled and clused in fruit, the long siender teeth hooked at the tip. - Moist and open wouls, (common. (L. Asia.)

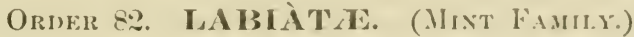

Chiefly herbs, with square stems, opposite aromatic lecires, more or less 2 lipped corolla, dielynamous nr dirmdrous stamens, and a deeply t toberl ouary. which forms in fruit 4 little seed-like nutlets or achenes, survounding the base of the single style in the bottom of the persistent calyx, euch filled with a single erect seed. - Nutlets smooth or barely ronghish and fixed by their base, excrpt in the first tribe. Albumen mostly nome. Embryostraight (except in Sentellaria); rarlicle at the base of the fruit. Ipper lip of the corolla 2-lobed or sometimes entive: the lower 3-lobed. Stanens inserted on the tube of the corolla. Style 2-loled at the apex. Flowers axillary, chiefly in cymose chusters, these often agrerenated in terminal spikes or racemes. Foliage mostly dotted with small glands containing a volatile oil, upon which depends the warmth and aroma of the plants of this large and well-known family. 
I. Nutlets rugose-reticulated, attached obliquely or ventrally; ovary merely 4-lobed.

Tribe I. AJUGOIDEE. Stamens 4, ascending aud parallel, mostly exserted from the upper side of the corolla. Calyx 5-10-nerved.

* Limb of corolla merely oblique, of 5 nearly equal and similar lobes.

1. Trichostema. Curolla-lobes all declined. Calyx oblique. Stamens exserted.

2. Isanthus. Calyx bell-shaped. Corolla small, the lobes spreading. Stamens included.

* Limb of corolla irregular, seemingly unilabiate, the upper lip being either split down or very short; stamens exserterl from the cleft.

3. Tencrium. Corolla deeply cleft between the 2 small lobes $n f$ the upper lip.

4. Ajuga. Corolla with a very short and as if truncate upper lip.

II. Nútlets smooth or granulate; scar basal, small; ovary deeply 4-parted.

Tribe II. SATUREINEA. Upper pair of stamens shorter or wanting; anthers 2celled. Ulyer lip of corolla not galeate or concave.

* Flowers in loose terminal panicled racemes; calyx 2-lipped, enlarcerl and declined in fruit.

5. Collinsonia. Lower lobe of corolla fimbriate, much the largest. Stamens 2.

6. Perilla. Corolla short, the lower lobe little larger. Stamens 4, included.

* * Flowers in incre or less crowded cluster's or whorls, axillary or spicate.

- Corolla not evidently 2-lipred, but almost equally 4-lohed, small. Stamens erect, distant.

7. Mentha. Fertile stamens 4 , nearly equal.

8. Lycopus. Fertile stamens 2 , and often 2 sterile filaments without anthers. + + Corolla more or less 2-lipped.

++ Stamens distant and straight, often divergent, never convergent nor curved.

$=$ Stamens 2, with or without rudiments of the upper pair.

9. Cunila. Calyx very laairy in the throat, equally 5-toothed. Corolla small.

$==$ Stamens 4 ; caly $\times 10-13$-nerved, and hairy in the throat (except $\mathrm{n} .10$ ).

10. Hyssopus. Calyx tubular, 15-nerved, equally 5-toothed. Stamens exserted.

11. Pycnanthemum. Calyx ovate or short-tubular, equally 5-toothed or somewhat 2lipped. llowers in dense heads or clusters.

12. Origanum. Calyx ovate-bell-shaped, 5-tonthed. Spikes with large colored bracts.

13. Thymus. Calyx ovate, nodding in fruit, 2-lipped. Bracts minute; leaves very small.

+++ Stamens (often 2 only in $\mathrm{n} .16$ ) ascending or arcuate, often more or less converging (or ascending parallel under the erect uprer lip in $\mathrm{n} .14$ and 15).

14. Satureia. Calyx bell-shaped, 10-nerved, naked in the throat, equally 5 -toothed.

15. Calamintha. Calyx tubular, often hairy in the throat, 13-nerved, 2-lipped. Tube of corolla straight.

16. Melissa. Calyx tubular-bell-shaped, flattish on the upper side. Corolla curved upward.

17. Hedeoma. Calyx gibbous on the lower side, hairy in the throat. Flowers loose.

Tribe III. MONARDEA. Stamens 2, ascending and parallel; anthers apparently or really 1-celled. Corolla strongly 2-lipped.

18. Salvia. Calyx 2-lipped. Anthers with a long connective astride the filament, bearing a linear cell at the upper end, and none or an imperfect cell on the lower.

19. Monarda. Calyx tubular and elongated, equally 5-toothed. Anthers of 2 cells confluent into one, the connective inconspicuous.

2). Blephilia. Calyx ovate-tubular, 2-lipped. Anthers as in the last.

Tribe IV. NEPETEAE. Stamens 4, the upper (inner) pair longer than the lower, ascending or diverging. Corolla 2-lipped ; the upper lip concave or arched, the lower spreading. Calyx mostly 15 -nerved.

* Anthers not approximate in pairs ; their cells parallel or nearly so.

21. Lophanthus. Stamens divergent, exserted; upper pair declined, lower ascending.

22. Cedronella. Stamens all ascending, not exceeding the lip of the corolla. 
- Anthers more or less approximate in pairs; their cells divuricate or divergent; flaments ast:encling, not exserted.

23. Nepeta. Calyx more or less curverl, equaliy j-tuotlied.

24. Dracocephalum. Calyx straight, the upper tooth much the lurger.

Tribe V. SCUTELLA RINEAE. Stanens 4, ascensling and parallel. Calyx bilabiate, closed in fruit; the rumbled lips entire. Corolla bilabiate, the upler lip arched.

25. Scutellaria. Calyx with a helmet-like projection on tlıe upper side.

Tribe VI. STACHYDEA. Stanens 4, parallel and ascending under the galeate or concave upper lip, the lower (outer) pair longer (except in n. 31, 32). Calyx 5-10nerved, not 2-lipped (except in n. 26).

* Calyx reticulate-reıny, deeply bilabiate, closed in fruit.

26. Brunella. Calyx nerved and veiny ; upler lip flat, 3-toothed, the lower 2-cleft.

* Calyx thin, inflated in fruit, obscurely nerverl, 3-5-lobed, open.

27. Physostegia. Calyx 5-toothed or 5-lobed. Antl,er-1'ulls parallel.

28. Synandra. Calyx almost equally 4 -lohed! Anther-cells widely divergent.

** Calyx of firmer texture, distinctly 5-10-nerved or striate, 5-10-tootlied.

- Stamens included in the short corolla-tube, its upjer lip nerely concave.

29. Marrubium. Calyx tubular, 5-10-nerved, and with 5 or 10 awl-shaped teeth.

- + Stamens ascending under the galeate upper lip of the corolla.

++ Stamens not deflexed after anthesis ; naturalized from the Old World.

30. Ballota. Calyx somewliat funnel-form, expanding above into a spreading 5-toothed border. Nutlets roundish at top. Uplyer lip of the corolla erect.

31. Phlomis. Calyx tubular, the 5 teetlı abruptly awned. Upper lip of the corolla arched.

32. Leonurus. Calyx top-shaped, the rigid sjiny-pointed teeth soon spreading. Nutlets truncate and acutely 3-angled at top. Leaves cleft, or incised.

33. Lamium. Calyx-teeth not spiny-pointed. Nutlets sharply 3-angled, truncate.

34. Galeopsis. Calyx tubular-bell-shaped; the 5 teeth spiny-pointed. Anthers transversely 2-valved, the smaller valve ciliate.

++ Stamens often deflexed or contorted after antliesis.

35. Staehys. Calyx tubular-bell-shaped, equally 5 -toothed or the 2 upper teeth united into one. Nutlets rounded at top.

\section{TRICHOSTEMA， L. Blue CURls.}

Calyx bell-shaped, oblique, deeply 5-cleft; the 3 upper teeth elongated and partly united, the 2 lower very short. Corolla 5-lobed; the lohes narrowly oblong, declined, nearly equal in length; the 3 lower more or less united. Stamens 4, with very long capillary filaments, exserted much beyond the corolla, curved; anther-cells divergent and at length confluent. - Low annuals, somewhat clammy-glandular and balsamic, branched, with entire leaves, and mostly solitary l-flowered pedicels terminating the branches, beeming lateral hy the production of axillary branchlets, and the flower appearing to be reverseil, namely, the short teeth of the ealyx upward, etc. Corolla blue, rarying to pink, rarely white, small; in summer aud autumu. (Nane composed of $\theta \rho / \xi$, hair, and $\sigma \tau \hat{\eta} \mu a$, stamen, from the capillary filaments.)

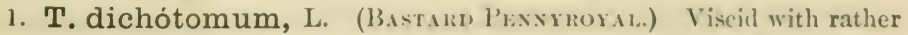
minute pubescence ; leaves lance-oblong or rhombic-lanceolute, rarely lance-linear, short-petioled. - Sandy fields, E. Mass. to Ky., south to Fla. and Tex.

2. T. lineàre, Nutt. I'uberulent, more slender and less forked; leures linear, nearly smooth.-Coun. to La., near the coast; in sandy ground. 


\section{Is Á NTHU U, Michx. False Pexyyroyal.}

Calyx bell-shaped, 5-lobed, equal, eularged in fruit. Corolla little longer than the calyx ; the border bell-shaped, with 5 nearly equal and oborate spreading lobes. Stamens 4, slightly didynamous, incurved-ascending, scarcely exceeding the corolla. - A low, nuch branched annual, clammy-pubescent, with nearly entire lance-oblong 3-nerved leaves, and small pale blue flowers on

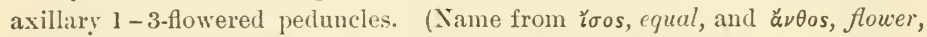
referring to the almost regular corolla.)

1. I. cærùleus, Michx. Corolla 2-3" long, little exceeding the calyx. - Dry or sterile ground, Maine to Ill., Minn., and southward. July, Angust.

\section{TE U̇ C RIU M, Tourn. Germaxder.}

Calyx 5-toothed. Corolla with the 4 upper lobes nearly equal, oblong, turned forward, so that there seems to be no upper lip; the lower lobe much larger. Stamens 4, exserted from the deep cleft between the 2 upper lobes of the corolla ; anther-cells confluent. (Named for Teucer, king of Troy.)

1. T. Canadénse, L. (Americax Germaxder. Wood Sage.) Peremnial, douny, erect $\left(1-3^{\circ}\right.$ high) ; leaves orate-lanceolate, serrate, rounded at base, short-petioled, hoary underneath, the floral scarcely longer than the oblique unequally-toothed calyx; whorls about 6-flowered, crowded in a long and simple wand-like spike; culyx canescent, the 3 upper lobes very obtuse or the midldle one acutish; corolla purple, rose, or sometimes cream-color (6" long). - Low grounds; not rare. July-Sept.

2. T. occidentàle, Gray. Loosely pubescent; calyx villous with viscid hairs, the upper lobes acute or middle one acuminate; corolla 4-5" long; otherwise like the last. - A western form, from Neb. southwestward, and extending eastward (Ont., and near I'hiladelphia).

\section{4. Á J U G A, L.}

Calyx 5-toothed. Corolla with very short and as if truncate upper lip; the large and spreading lower lip with the middle lobe emarginate or 2 -cleft. Stamens as in Teucrium, but anther-cells less confluent. (From $\alpha$ - privative, and suov (Latin jugum), yoke, from the seeming absence of a yoke-fellow to the lower lip of the corolla.)

A. RÉPtass, L. Perennial, about $1^{\circ}$ high, with copious creeping stolons; leares obovate or spatulate, sometimes sinuate, the cauline sessile, the floral approximate, subtending several sessile blue flowers. - Naturalized near Saco, Maine, Montreal, etc. (Eu., N. Asia.)

\section{COLIINSÒNIA, L. Horse-Balm.}

Calyx ovate, enlarged and declined in frnit, 2-lipped; upper lip truncate and flattened, 3-toothed, the lower 2-cleft. Corolla elongated, expanded at the throat, sumewhat 2-lipped, the tube with a bearded ring within; the 4 upper lobes nearly equal, but the lower much larger and longer, pendent, toothed or lacerate-fringed. Stamens 2 (sometimes 4, the upper pair shorter), nuch exserted, diverging; anther-cells divergent. - Strong-scented perennials, with large ovate leaves, and yellowish flowers on slender pedicels, in loose and panicled terminal racemes. (Named in honor of Peter Collinson, a well-known patron of science and correspondent of Linnæus, who introduced it into England.) 
1. C. Canadénsis, I. (Rıсh-WEkw. Stovi-Root.) Nearly smooth ( $1-3^{\circ}$ high $)$; leaves serrate, pointed, petioled $\left(3-6^{\prime}\right.$ long); panicle lonse; corolla 8-9" long, lemon-scented ; stamens 2. - lich noist woods, N. Brunswick to Wisc., south to Fla. aut Mo. July-sept.

\section{PERÍLLA, I.}

Calyx as in Collinsonia. Corollat-tube includerl, the limb 5-cleft; lower lohe a little larger. Stamens 4, included, erect, distant. - Coarse aromatic annual, with small flowers in pauicled and axillary racemes. (A Greek and Latiu proper name.)

P. ocruònes, I. Erect, branching, 2-3० high; leaves ovate, coarsely toothed; flowers white. $-\Lambda$ bout dwellings and roalsides, S. Ill. (Selntek.) (Adv. from L. Asia.)

\section{MÉ N THA, Tourn. Miт.}

Calyx bell-shaped or tubular, 5-toothed, equal or nearly so. Corolla with a short included tube; the bell-shaped border somew hat enually 4-cleft ; the upjer lohe broadest, entire or notched. Stamens 4, expal, erect, distant. - Odorous perennial herbs; the small flowers mostly in close clusters, forming axillary capitate whorls, sometimes approximated in interrupted spikes, produced in summer, of two sorts as to the fertility of the stamens in most species. Corolla pale purple or whitish. Species mostly adventive or naturalized from Europe, with many hybrids. (Miv $\theta \eta$ of 'Tlieophrastus, from a Nymph of that name, fabled to have been changed into Mint by l'roserpine.)

* Spikes narrow and leafless, densely crouded; leares sessile or nearly so.

M. syuvéstris, L. (Horse Mrxt of Eu.) Finely pubescent or canescent; leares ovate-oblong to olilong-lanceolute, acute, sharply serrate, often glabruns above; spikes rather slender, cunescently pubeseent. - Roalsides, etc., l'enn. Var. ALOPEccuol̀ns, Baker. Leares larger, more nearly sessile, broadly oval and obtuse, often subcorlate, coarsely serrate, more veini, but not rugose; approaching the next. - P'enn. and N.J.

M. Rotexdfómi, L. Softhuiry or downy; lenes broally elliptical to ronud-orate and somewhat heart shaped, rugose, crenate-toothed; spikes slender, not eanescent. - Atlantic States, at a few stations, Maine to 'Tex.

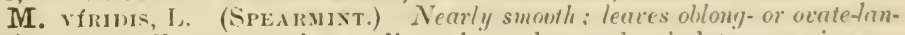
reolate, unequally serrate; bracts linear-lanceolate and subulate, conspicuous. - Wet places; in all cultirated districts.

* Flowers pedicellate, less crouded, in intemupted loufless spikes, or some in the upper axils; leures petioled.

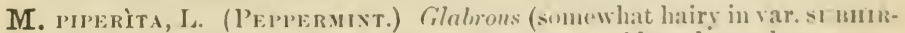
siva), very pungent-tasted; leaves ovate-ohlong to oblong-linceulate, acute, sharply serrate; spikis murou, loose. - Alung lrooks, escaped everywhere.

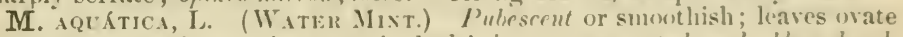
or round-ovate; flowers in a terminal globular or intermpled and oblong head, often with one or more clusters in the axils of the upper leaves; calyx and usually the perlicels hairy. The common form has the stems hary dorinued. - Wet places, N. Eng. to Del. ; rare. - Var. Cnfsps, Benth., is a glalirous or glabrate form, with lacerate-dentate and crisperl leaves. - bitches, N. J., ete.

* * Flouers in globulur uhorls or clusters, alt in the a rils of the leares, the uppermost axils not flouter-bearing; leates more or less petioled, toothed.

M. Satria, I. (Whorien Mixt.) Stem hairy donnurd; leaves ovate, sharply serrate; calyx oblong-cylindrical with rery struler teeth. - Waste lamp places, Mass. to Penm. ; not common. l'asses into the nest. 
M. ARvéxsis, L. (CoRn Mint.) Lower and smaller-leaved than the last; leaves obtusely serrate; calyx bell-shaped, the teeth short and broader. - Moist fields, N. Eng., ete. ; rare.

1. M. Canadénsis, L. (Wild Mixт.) Leares varying from ovateoblong to lanceolate, tapering to both ends; calyx oblong-bell-shaped, the teeth rather short; hairs on the stem not conspicuously reflexed. The commoner form is more or less hairy, and has nearly the odor of Pennyroyal. - Wet places, through the northern U. States across the continent, and northward.

Var. glabràta, Benth. Leaves and stems almost glabrous, the former sometimes very short-petioled; scent sweeter, as of Monarda. - Similar range.

\section{LÝ COPUS, Tourn. Water Horehouxd.}

Calyx bell-shaped, 4-5-toothed, naked in the throat. Corolla bell-shaped, scarcely longer than the calyx, nearly equally 4-lobed. Stamens 2, distant; the upper pair either sterile rudiments or wanting. Nutlets with thickened margins. - Perennial low herbs, glabrous or puberulent, resembling Mints, with sharply toothed or pinuatifid leaves, the floral ones similar and much longer than the dense axillary whorls of small mostly white flowers; in sum-

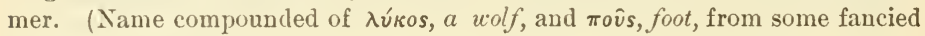
likeness in the leares.)

* Stoloniferous, the long filiform runners often tuberiferous; leaves only serrate.

+ Calyx-teeth usually 4, barely acutish, shorter than the mature nutlets.

1. L. Virgínicus, L. (Bugle-ween.) Stem obtusely 4-angled $\left(6^{\prime}-2^{\circ}\right.$ high); leares oblong or ovate-lanceolate, toothed, entire toward the base, acuminate at both ends, short-petioled; calyx-teeth ovate. - Shady moist places, Lab. to Fla., Mo., and northwestward across the continent.

++ Calyx-teeth usually 5, very acute, longer than the nutlets.

+ Bracts minute; corolla twice as long as the calyx.

2. I. sessilifolius, Gray. Stem rather acutely 4-angled; leaves closely sessile, ovate or lanceolate-oblong ( $1-2^{\prime}$ long), sparsely sharply serrate; calyxteeth subulate, rigid. (L. Europæus, var. sessilifolius, Gray, Man.) - Pine barrens of $\mathrm{N}$. J. to Cape Cod, Mass. (Deane).

3. L. rubéllus, Moench. Stem rather obtusely 4-angled; leaves petioled, ovate-oblong or oblong-lancerlate, sharply serrate in the middle, uttenuate-acuminate at both ends ( $3^{\prime}$ long $)$; calyx-teeth triangular-subulate, not rigid-pointed. (L. Europæus, var. integrifolins, Gray.) - Penn. to Minn, and southward.

++ Outer brocts conspicuous; corolla hurdly exceeding the calyx.

4. L. lùcidus, Turez., var. Americànus, Gray. Stem strict, stout, $2-3^{\circ}$ high ; leaves lanceolate and oblong-lanceolate $\left(2-4^{\prime}\right.$ long), acute or acuminate, very sharply and coarsely serrate, sessile or nearly so; calyx-teeth attenuate-subulate. - Sask. and Minn. to Kan., thence west to Calif.

* Not stoloniferous ; leaves incised or pinnatifid.

5. L. sinuàtus, Ell. Stem erect, 1-30 high, acutely 4-angled; leaves oblong or lanceolate $\left(1 \frac{1}{2}-2^{\prime}\right.$ long), acuminate, irregularly incised or laciniate. pinnatifid, or some of the upper merely sinuate, tapering to a slender petiole: calyx-teeth short-cuspidate; sterile filaments slender, conspicuous, with globular or spatulate tips. (L. Europæus, var. sinuatus, Gray.) - Common. 


\section{CUNILA, L. Dittany.}

Calyx ovate tubular, equally 5-toothed, very hairy in the throat. Corolla 2lipped; upper lip erect, tlattish, mostly notehed; the luwer spreading, 3-eleft. Stamens 2, erect, exsertell, distint; sterile filaments short, minute. - l'erennials, with small white or pmplish flowers, in corymbed cymes or clusters. ( $\mathrm{An}$ ancient Latiu name, of unknown origin.)

1. C. Mariàna, I. (Coмmox l)irtaxy.) Stems tufted, corymbnsely much branched $\left(1^{\circ}\right.$ high $)$; leaves smooth, ovate, serrate, rounded or heartshaped at base, nearly sessile, dotted ( $\mathrm{I}^{\prime}$ long); cymes peduncled; calyx striate. - Dry hills, southern N. Y. to S.. Ind., suuth to Ga. and Ark.

\section{HY S S Ò P U S, Touru. IIrssop.}

Calvx tubular, 15-nerved, equally 5-toothed, uaked in the throat. Corolla short, 2-lipped; upper lip erect, tlat, olsscurely notehed, the lower 3-cleft, with the middle lobe larger aud 2-cleft. Stanens 4, exserted, diverging. - P'erennial herb, with wand like simple hranches, lanceolate or linear entire leaves, and blue-purple flowers in small ('lusters, crowded in a spike. (The ancient name.)

H. officridus, L. - Roadsides, ete., sparingly escaped from gardens. (Adv, from Eu.)

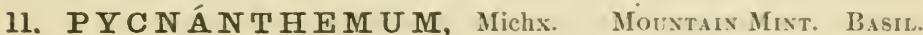

Calyx orate-oblong or tubular, about 13-nerved, equally 5-toothed, or the three upper teeth more or less united, naked in the throat. Corolla short, more or less 2-lipped; the upper lip straight, nearly flat, entire or slightly notched; the lower 3-cleft, its lobes all ovate and obtnse. Stanens 4, distant, the lower pair rather longer; anther-cells parallel. - Perennial upright herbs, with a pungent mint-like tlavor, corymbosely branched above, the floral leaves often whitened; the many-fluwered whorls dense, crowded with bracts, and usually forming terminal heads or close eymes. Corolla whitish or purplish, the lips mostly dotted with purple. Fl. summer and early autumn. - Varies, like the Mints, with the stamens exserted or included in different flowers.

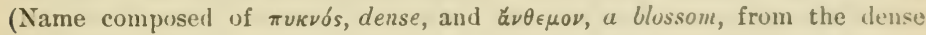
inflorescence.)

* Bracts and equal calyx-teeth awn-tipped, rigid, naked, as long as the corollu; flowers in rather dense mostly terminal heads; leuves rigid, slightly petioled.

1. P. aristàtum, Michx. Minutely hoary-puberulent $(1-20$ high $)$; leaves ovate-oblong and oblong-lanceolate, acnte, sparingly denticulate-serrate ( $1-2^{\prime}$ long), roundish at the base. - I'ine barreus, N. J. to Fla. and La.

Var. hyssopifolium, Gray. Icaves narrowly oblong or broadly linear, nearly entire and obtuse. - Va. to Fla.

$$
\text { * Bracts and equal und similar calyx-teeth not auned. }
$$

- Leaves linear or lanceolate, nearly sossile, entire, ver!y numerons ; cupitut glomerules sinall and numerous, densely cymose, imbricuted with man!y sh rt uppressed rigiel bructs.

2. P. lanceolàtum, Pursh. Smonthish or mimutely pubesrent ( $2^{\circ}$ high); Iraves lanceolute or lence-linear, olituse at lanse; houls douny; hracts ovate or lanceolate; calyx-teeth short and triangular. - Dry thickets, Mass. to Dak., south to Ga. and $\mathrm{Ark}$. 
3. P. linifòlium, Pursh. Smoother and leaves narrouer and heads less downy than in the last; the narrower bracts and lance-aul-shaped calyx-teeth pungently pointed. - Dry ground, Mass. to Minn., south to Fla. and Tex. + + Leaves lanceolute to ovate, sessile or nearly so, denticulate or entire ; herri's larger and fewer, with fewer and looser bracts.

4. P. mùticum, Pers. Minutely hoar'y throughont, or becoming almost smooth, corymboscly much branched $\left(1-2 \frac{1}{2}{ }^{\circ}\right.$ high $)$; leaves ovate or broadly ovate-lanceolute, varying to linceolate, rather rigid, acute, rounded or slightly heart-shaped at base, mostly sessile and minutely sharp-toothed, prominently veined, green when old; the florul ones, short bracts, and triangular or ovate calyx-teeth, houry with a fine close down; flower-clusters very dense. - Maine to s. Ill., south to Fla. and Ark.

Var. pilosum, Gray. Iloary with loose pubescence; leaves thinner, oblonglanceolate, mostly acute or acutish at base ; bracts and especially the narrower (often somewhat unequal) calyx-teeth often villous-pubescent. (P. pilosum, Nutt.) - ()hio to Iowa, Kan., and Ark.

5. P. léptodon, Gray. Soft-pubescent, or glabrate below, loosely branched; leares membranuceous, green $\left(1 \frac{1}{2}-2^{\prime}\right.$ long), lanceolate or oblong-lanceolate, subsessile; clusters larger and looser, canescent-hirsute ; long-acuminate bracts and caly.x-teeth slender-subulate, villous-hirsute. - S. Mo. to northwestern N. C.

+ + + Leaves linear- or oblong-lanceolate, short-petioled, not at all hoary; flowors in mostly terminal dense capitate clusters; calyx hoary-pubescent.

6. P. Torrèyi, Benth. Puberulent; stem strict and nearly simple (2$3^{\circ}$ high); leures thin, linear-lanceolate, tapering to both ends (mostly 2 ' long and $2-3^{\prime \prime}$ wide), nearly entire; heads small; awl-shaped calyx-teeth and mostly appressed bracts canescent. - I)ry soil, sonthern N. Y. to Penn. and Del.

7. P. clinopodioldes, Giray. Pubescent; leaves broadly or oblong-lanceolate, sharply denticulate (sometimes entire) ; heads fewer and larger ; bracts loose. - Dry soil, southern N. Y. to E. Yenn.

* * Calyx bilabiate ( 3 upper teeth united), the teeth and the tips of the loose bracts not rigid; flowers in dense fattened gionerate cymes; leares thin, mostly serrate, petioled, the uppermost more or less canescent.

8. P. Túllia, Benth. Leaves greener and loosely soft-douny, only the floral ones whitener, otherwise resembling those of the next; cymes dense; bracts murh surpussing the flovers, their long awn-like points and the awnpointed caly x-teeth hearded with long loose hairs. - S. Va. and N. C. to Tenn. and Ga.

9. P. incànum, Michx. Leares ovate-ohlong, acute, remotely toothed. douny above and mostly hoary with whitish wool underneath, the uppermost whitened both sides; cymes open; bracts linear-awl-shaped and, with the calyx-teeth, more or less awn-pointed. - N. Eng. to Ont. and Ind., south to Fla. and Tex. * * * * Calyx equally 5-toothed; heads few, large and globose (terminal and in the upper axils of the thin petioled leaves); bracts loose, ciliate-bearded.

10. P. montànum, Michx. Stem $\left(1-3^{\circ}\right.$ high) and ovate- or oblonglanceolate serrate leaves glabrous; bracts very acute or awl-pointed, the nutermost ovate and leaf-like, the inner linear; teeth of the tubular calyx short and acute. - Alleghanies, from S. Va. and Temn. to Ga. and Ala. 


\section{O R ÍGA N U M, Tourn. Wild Marsoram.}

Calyx ovate-bell-shaped, hairy in the throat, striate, 5-tonthed. Tuhe of the corolla about the length of the calyx, 2-lipped; the upper lip rather erect and slightly notehed, the luwer longer, of 3 nearly equal sprearling lobes. Stamens 4 , exserted, diverging. - Perennials, with nearly entire leaves, and purplish flowers erowded in eylindrical or oblong spikes, inbricated with colored bracts. (An ancient Greek name, composed of úpos, a mountain, and gávos, delight.)

O. virghe, I. Upright, hairy, coryubose at the summit; leaves petioled, round-ovate; bracts ovate, obtuse, purplish. - Roarlsides, Atlantic states. June-Uct. (Nat. from Eu.)

\section{THYMUS, Tourn. Tичме.}

Calyx ovate, 2-lipped, 13-nerved, hairy in the throat; the upper lip 3-tootherl, spreading; the lower 2-cleft, with the awl-shaped divisions ciliate. Corolla short, slightly 2-lipped; the upper lip straight and flattish, notehed at the apex, the lower 3-cleft. Stamens 4 , straight and clistant, usually exserted. - Low perennials, with small and entire strongly-veined leaves, and purplish or whitish flowers. (The ancient (ireek name of the 'Thyme, probably from $\theta \dot{v} \omega$, to bu'n perfume, because it was used for incense.)

T. Serpŕluy, L. (Creepixg Tirya.) l'rostrate; leaves green, flat, ovate, entire, short-petioled; flowers crowded at the ends of the brauches. Old fields, E. Mass. to l'enn. (Adv. from Eu.)

\section{SA T U R E I A, Tourn. Sivorr.}

Calyx bell-shaped, 10-nerved, equally 5-toothed, naked in the throat. Corolla 2-lipped; the upper lip erect, flat, nearly entire, the lower 3-cleft. Stamens 4, somewhat ascending. - $\Lambda$ romatic plants, with narrow entire leares, often clustered, and somewhat spiked purplish flowers. (The ancient Latin uame.)

S. hortéxsis, L. (Sumer Sayory.) Pubescent annual; clusters fewflowered; hracts sulall or nonc. - Escaping from gardens and sparingly wild in Ohio to Ill., etc. (Adv. from Eu.)

\section{CALA M Í N THA, Tourn. Calimist.}

Calyx tubular, 13-nervel, mostly hairy in the throat, 2-lipped; the upper lip 3-cleft, the lower 2-cleft. Corolla with a straight tube and an inflated throat, distinctly 2-lipped; the upper lip erect, flattish, entire or notehed; the lower spreading, 3-parted, the middle lobe usually largest. Stamens 4 , mostly ascending; the anthers usually approximate in pairs. - Perennials, with mostly purplish or whitish flowers, producerl all summer; inflorescence various.

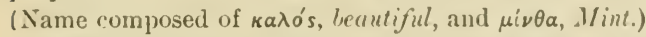

$\$ 1$. Flowers loose, without long-subulate lwacts : calyx rillous in the throat.

* Pubescent; peduncles short but mostly distiuct; bructs minute.

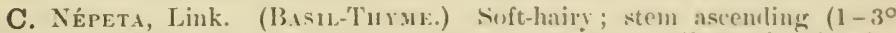
high) ; leaves petioled, broadly ovate, obtuse, crenate ; corolla (3" long) twice the length of the calyx. - 1)ry waste grounds, Md. to Ark. (Nat. from Eu.)

* Glabrous or nearly so; common peduncles hardly any; pedicels $1-5$, slender, the conspicuous bracts subulate-acuminate; on uct limestone river-bank's.

1. C. glabélla, Benth. Smooth; stems diffuse or spreading $\left(1-2^{\circ}\right.$ long $)$; leaves slightly petioled, oldong or oblong-linenr, narrowed at hase ( $8^{\prime \prime}-2^{\prime}$ long), sparingly toothed or nearly entire; clusters 3-5-fowered; corolla (purplish, $5-6^{\prime \prime}$ long) fully twice the length of the calyx. - \$. Inl., Ky., and Tenn. 
2. C. Nuttàllii, Gray. Smaller; the flowering stems more upright (5-9' high), with narrower mostly entire leaves and fever-flowered clusters, while sterile runners fiom the base bear orate thickish leares only 2-5" long. (C. glabella, var. Nuttallii, Gray.) - Niagara Falls to Minn., south to Mo. and Tex.

§2. Flowers in sessile dense many-flowered clusters, and involucrate with conspicuous setnceous-subulate rigid bracts; calyx nearly naked in the throat.

3. C. Clinopòdium, Benth. (BAsıl.) Hairy, erect $\left(1-2^{\circ}\right.$ high); leaves ovate, petioled, nearly entire ; flowers (pale purple) in globular clusters ; hairy bracts as long as the calyx. - Borders of thickets and fields, naturalized extensively, but indigenous from the Great Lakes to the Rocky Mts. (Eu., Asia.)

\section{M ELÍSSA, L. Balm.}

Calyx with the upper lip flattened and 3-toothed, the lower 2-cleft. Corolla with a recurred-ascending tube. Stamens 4, curvel and conniving under the upper lip. (Otherwise neas? as Calamintlia. - Clnsters few-flowered, loose, one-sided, with few and $m$, ly ovate bracts resembling the leaves. (Name from $\mu \epsilon^{\prime} \lambda \iota \sigma \alpha \alpha, a$ bee; the fiuners yielding abuulance of honey.)

M. officinalis, L. (Common Balis.) Upright, branching, perennial, pubescent; leaves broadly orate, crenate-toothed, lemon-scented; corolla nearly white. - Sparingly escaped from gardens. (Xat. from Eu.)

\section{H EDEÒM A, Pers. Mock Pexxrroyal.}

Calyx ovoid or tubular, gibbous on the lower sile near the base, 13-nerved, bearcied in the throat, 2-lipped; upper lip 3-toothed, the lower 2-cleft. Corolla 2-lipperl ; upper lip erect, flat, notched at the apex, the lower spreading, 3-cleft. Fertile stamens 2 ; the upper pair reduced to sterile filaments or wanting. - Low, odorous annuals, with small leaves, and loose axillary clusters of flowers (in summer), often forming terminal leafy racemes. (Altered from $\dot{\eta} \delta v \delta \sigma \mu o \nu$, an ancient name of Mint, from its sweet scent.)

* Sterile filuments manifest; leaves oblong-ovate, petioled, somewhat serrate.

1. H. pulegioides, l'ers. (Avericas Pexryroral.) Erect, branching, hairy; whorls few-flowered; upper calyx-teeth triangular, the lower setaceous-subulate ; corolla (bluish, pubescent) scarcely exserted (2-3" long); taste and odor nearly of the true Pennyroyal (Mentha Pulegium) of Europe. Common from N. Eng. to Dak., and sonthward.

* * Sterile filaments minute or obsolete; leares narrow, entire, sessile or nearly so.

2. H. híspida, Pursh. Mostly low; leaves linear, crowded, almost glabrous, somewhat hispid-ciliate; bracts spreading or reflexed; upper flowers rather crowded ; caly $x$-teeth all subulate, equalling the bluish corolla. - Plains, Minn. and Dak. to W. Ill. and La.

3. H. Drummóndi, Benth. Pubescent or puberulent, a span or two high; leaves oblong to linear; bracts mostly erect; calyx hirsute or hispid, its teeth at length connirent, the lower nearly twice as long as the upper. - Central Neb. and Kan. to Tex., and westward.

\section{SÁ L VIA, L. SAgE.}

Calyx 2-lipped; upper lip 3-toothed or entire, the lower 2-cleft. Corolla deeply 2-lipped, ringent; upper lip straight or scythe shaped, entire or barely 
notched, the lower spreading or pendent, 3-lohed, its milllle lobe larger. Sitamens 2, on short filaments, jeinterl with the elongated transverse connective, one end of which, ascending umler the upper lip, licars a liucar l-colled (half) anther, the other, usually descending, bears an imperfect or leformed (half-) anther or none at all. - Flowers mostly large and showy, in spiked, racencel, or panicled whorls, produced in summer. (Name from salvo, to save, in allusion to the reputed healing qualities of sage.)

* Both anther-cells polliniferous; leaies mostly lyrately Inbed or pinnatifid.

1. S. lyràta, L. (LYRE-LEAved SAGE.) Low perennial (10-20' high), somewhat hairy; stem nearly simple and naked; ront-leaves lyre-shaped or sinnate-pinnatifid, sometimes almost entire; those of the stem mostly a single jair, smaller and narrower; the floral oblong-linear, not longer than the calyx; whorls loose and distant, forning an interrupted raceme; upjer lip of the blue-purple pubescent corolla (nearly l' long) short, straight, not vaulted. - Woodlands and meadows, N. J. to Ill., south to Fla. and Tex.

* * Lover anther-cell wanting; the sterile ends of the connectives mostly united. + Calyx obscurely bilabiate; corolla 8-12"long, with prominently exserted tube.

2. S. azùrea, Lam., var. grandiflora, Benth. Cinereous-puberulent, $1-5^{\circ}$ high ; lower leaves lancenlate or oblong, obtuse, denticulate or serrate, tapering to a short petiole; upper narrower, often linear, entire; inflorescence spike-like, tomentulose sericeous; calyx-teeth short, the broad upper lip entire ; corolla deep blue (varying to white). - E. Neb. to Miss., Tex., and Col. +- Calyx deeply bilabiate; corolla $4-6$ "long, the tube hardly at all exserted.

3. S. lanceolàta, Willı. Pulerulent or nearly glabrous, 5-12' high; leaves lanceolate or linear-oblong, irregularly serrate or nearly entire, tapering to a slender petiole; inflorescence virgate-spiciform, interrupte.t; upper lip of calyx entire, lower 2-cleft; corolla blue, $4^{\prime \prime} \mathrm{long}$, little exserted; style glabrous or nearly so. - Plains, Iowa and Neh. to 'Tex. and Ariz.

4. S. urticifolia, L. Fillous-pubescent and someuhat viscid, or glabrate, $1-2^{\circ}$ high; lenves coarsely serrate, orate, with truncate or cuneate base decurrent into a winged potiole ; inflorescence racemose-spicate, of numerous distant clusters; calyx-lips divergent, the upper 3-toothed, lower 2-cleft; corolla hlue and white, $5-6^{\prime \prime}$ long, twire the length of the calyx; style strongly beardal. Woodlands, Md. to Ky., south to Ga. and I a.

S. Sclarea, L. (Clari.) Villons-pubescent, viscid, stout, 2-30 high; leaves ample, long-petioled, ovate and corlate, crenate, ruguse; the floral forming bracts of the spike, tinged with white and rose-color; corolla white and bluish, rather large, the long upper lip falente and compressed. - Escaped from gardens, l'enn. (Nat. frum Eu.)

S. veruexíre., I. P'ubescent or villous, $1-2^{\circ}$ high; leaves wate or oblong, often cordate at hase, mostly sinuate-incised or moderately pinuatifid, the lobes crenate-toothed, rugose; the fow cauline mostly sessile, the floral inconspicuous; raceme interrupted; calyx reflexed after fowering; corollar bluish, small, the upper lip nearly straight. - Sparingly seen in the Middle States. (Nat. from liu )

\section{MONÁ R D A, I. Hoßš-.Mıт.}

Calyx tubular, elongated, 15 nerved, nearly equally 5-toothel, usinally hairy in the throat. Corolla elongated, with a slightly expanded throat, and a 
strongly 2-lipped limb; lips linear or oblong, somewhat equal, the upper erect, entire or slightly notched, the lower spreading, 3-lobed at the apex, its lateral lobes ovate and obtuse, the middle one narrower and slightly notched. Stamens 2, elongated, ascending, inserted in the throat of the corolla; anthers linear (the divaricate cells confluent at the junction). - Odorous erect herbs, with entire or toothed leaves, and pretty large flowers in a few whorled heads, closely surrounded with bracts. (D)edicated to Nicolas Monurdes, author of many tracts upon medicinal and other useful plants, especially those of the New World, in the latter lalf of the 16th century.)

* Stamens and style exserted beyond the linear straight acute upper lip of the corolla; heads solitary and terminal or sometimes 2 or 3 ; leaves acutely more or less serrate; peremials.

- Leares petioled; calyx-teeth scarcely longer than the width of the tube.

1. M. didyma, I. (Oswego Tex. Ben-Balm.) Somewhat hairy (20 high), acntely 4-anglen; leaves orate-lanceolate, acuminate, the floral ones and the lurge onter bracts tinged with red; calyx smooth, incurved, neariy naked in the throat; corolla smooth (2' long), bright red, showy. - Moist woods by streams, N. Eng. to Mich., south to Ga. in the mountains. July-Aug.

2. M. clinopodia, L. Nearly glabrous to villous-pubescent; leaves orate-lanceolate and ovate; bructs whitish; calyx moderately hirsute in the throut: corollu slightly pulsescent ( $1^{\prime}$ long), dull white or flesh-colored. - Shady places, ravines, etc., ()nt. to Ill., and along the mountains to Ga.

3. M. fistulosa, L. (Win Benganot.) Smoothish or downy, 2-50 high; leares orate-lanceolate, the uppermost and onter bracts somewhat colored (whitish or purplish); calyx slightly curved, very hairy in the throat; corolle ( $1^{\prime}$ long or more) purple or purplish dotted, smootl or hairy. - Dry soil, Vt. and E. Mass. to Fla., and far westward. Very varialle; the following are the more marked forms. - Var. RùBrA, Gray. Corolla bright crimson or rose-red; habit of 11.1 , but upper lip of corolla villons-bearded on the back at tip; throat of calyx with the outer bristly lairs widely spreading. In moist ground, Alleghany Mts. - Var. sı̀̀ı, Gray. Corolla deep purple. Alleghany MIts. - Var. sóclis, Benth. Corolla flesh-color to lilac, glandular, its upper lip hairy outside or more bearded at the tip; leaves paler, softpubescent beneath; throat of calyx mostly filled with dense beard, with sometimes an onter row of bristles. Extends to Minn. and westward.

+- Leares nearly sessile; ralyx-teeth elongated, lax; head solitary.

4. M. Bradburiàna, Beck. Leaves clothed with long soft hairs, especially underneath; the floral aud the onter bracts somewhat heart-shaped, purplish; calyx smoothish, contracted above, very hairy in the throat, with awl-shaped awned teeth; corolla smoothish, bearded at the tip of the upper lip, scarcely twice the length of the calyx, pale-purplish, the lower lip dotted with purple. - Thickets, Ind. to Tem. and Kan.

* * Stamens not exceeding the falcate upper lip of the short corolla; heads axillary or interrupted spicate; leares lanceolate or oblong, sparsely serrate. tapering into the petiole.

5. M. punctàta, L. (Honse-Mint.) Perennial, minutely downy $\left(2-3^{\circ} \mathrm{high}\right)$; leares petioled, lanceolate, narrowed at base; lracts lanceolate, 
blunt, obtuse at base, sessile, yellowish and purple; teeth of the downy calyx short and au'nless, rigid, soon spreading; corollat nearly smouth, yellowish, the upper lip spotted with purple, notched at the apex, the tube scarcely exceeding the calyx. - Sandy gromnd, N. Y. to Miun., south to Fila. and 'Tex.

6. M. citriodora, C'erv. Anumel, 1-30 high ; bracts narrewly oblong, their slender aned tips spreading or recurving; ruly $x$-terth slender, at length usually spreading; corolla white or pinkish, not spotted. - Neb. to 'Tex.

\section{BLEPHÍLIA, liaf.}

Calyx ovoid-tulular, l3-ıervel, 2-lippenl, nakel in the throat; upper lip with 3 awned teeth, the lower with 2 nearly awnlss teeth. Corolla inflated in the thwat, strongly and nearly equally 2-lipped; upper lip erect, entire, the lower spreading, 3-cleft, its lateral lobes ovate and rounded, larger than the oblong and notched middle one. Stamens 2, ascenting, exserted (the upper pair minute or none); authers, etc., as in Monarda. - l'erenuial herbs, with nearly the foliage, etc., of Monarda; the small pale hluish purple flowers crowdel in axillary and terminal globose whorls; in smmmer. (Name from $\beta \lambda \in \phi a \rho$ /s, the eyslush, in reference to the hairy-fringed bracts and (aly $\mathrm{x}$-teeth.)

1. B. ciliàta, Raf. Sumewhat downy (1-20 high); lectes ulmost sessile, oblong-ovate, narroued at base, whitish-downy underucath; outer bructs orate, acute, colored, ciliate, as long as the ealyx ; corollat hairy - Iry open places, Mass. to Miun., south to Ga. and Kan.

2. B. hirsùta, Benth. 'Taller, laairy throughont; leaves long-petioled, ocute, pointed, rounded or heart-shaped at base; the lower floral ones similar, the uppermost and the bracts linear-aul-shaped, shorter than the long-haired (alyx; corolla smoothish, pale, with darker purple spots. - Moist shady places, Vt. to Minn., south to Ga. and E. Tex.

\section{LOPHÁNTH U S, Benth. Gint Hrssop.}

Calyx tubular-bell-shaped, 15-nerved, oblique, 5-toothed, the upper teeth rather longer than the others. Corolla 2-lippel; upper lip nearly erect, 2lohed, the lower somewhat spreading, 3-cleft, with the millle lobe erenate. Stamens 4, exserted; the upper pair declined, the lower and shorter juir as('ending, so that the pairs cross; anther-cells nearly parallel. - l'erennial tall herbs, with petioled serute leaves, and small flowers crowled in intermpted

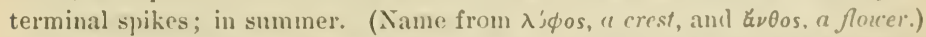

1 L. nepetoides, Benth. Stem stout, $2 \frac{1}{2}-6^{\circ}$ high, sharply 4-angled, smooth, or nearly so; leaves ovate, somewhat pointed, coarsely' ('reuate-toothed $\left(2-4^{\prime}\right.$ long); spikes $2-6^{\prime}$ long, crowded with the ovate pointed bracts ; culy $x$ teeth ovate, rather obtuse, little shurter than the jule greenish-yellow corolla. Borders of woods, Vt. to Minu., sonth to N. C'. and 'Tex.

2. L. scrophulariafolius, Benth. Stem (olutusely 4-angled) andlower surface of the ovate or somewhat heart-shajed acute leaves more or less pubscent; calyx-teeth lancenlate, urute, shorter thun the purplish corolla (spikes 4-15' long); otherwise like the last. — same rauge.

3. L. anisàtus, Benth. Smooth, but the ovate acute leares glaucous white underneath with minute down; culy.r-tecth lancenlute, arute. - Plains, Wise. to Minn., Neb., and westward. - Foliage with the scent of anise. 


\section{CEDRONÉLLA, Moench.}

Calyx rather obliquely 5-toothed, many-nerved. Corolla ample, expanded at the throat, 2-lipped; the upper lip flattish or concave, 2-lobed, the lower 3cleft, spreading, the midlle lobe largest. Stameus 4, ascending, the lower pair shorter; anther-cells parallel. - Sweet-scented perennials, with pale purplish flowers. (Name a diminutive of cedrus, the cedar-tree, from the aromatic leaves of C. triphylla, the Balm-of-(rilead of English gardens.)

1. C. cordàta, Benth Low, with slender runners, hairy ; leaves broadly heart-shaped, crenate, petioled, the floral shorter than the calyx; whorls fewflowered, at the summit of short ascending stems; corolla hairy inside ( $1 \frac{1}{2}^{\prime}$ long); stamens shorter than the upper lip. - Moist shady banks, W. Penn. to Ky., south to the mountains of $\mathrm{N}$. C. and 'Tenn.

\section{N ÉP TA, L. Cat-Mint.}

Calyx tubular, often incurved, obliquely 5-toothed. Corolla dilated in the throat, 2-lipped; the upper lip erect, rather concave, notched or 2-cleft; the lower spreading, 3-cleft, the middle lobe largest, either 2-lobed or entire. Stamens 4, ascending under the upper lip, the lower pair shorter; anthers approximate in pairs, the cells divergent. - Peremnial herbs. (The Latin name, thought to be derived from Nepete, an Etrurian city.)

$\S 1$. Cymose clusters rather dense and many-flowered, forming interrupted spikes or racemes: upper floral leaves small and bract-like.

N. Cataria, L. (CAtrip.) Downy, erect, branched; leaves heart-shaped, oblong, deeply crenate, whitish-downy underneath; corolla whitish, dotted with purple. - Near dwellings; a very common weed. July-Sept. (Nat. from Eu.)

§ 2. GLECHÖMA. Leaves all alike; the axillary clusters loosely few-flowered.

N. Glechòma, Benth. (Ground Iry. Gill-over-tile-Ground.) Creeping and trailing; leares petioled, round kirlney-shaped, crenate, green both sides; corolla thrice the length of the calyx, light blue. - Damp or shady places, common. (Nat. from Eu.)

\section{DRACOCÉPHALU M, Tourn. Dragox-Head.}

Calyx tubular, 13-15-nerved, straight, 5-toothed; the upper tooth usually much the largest. Corolla 2-lipped; the upper lip slightly arched and notched: the lower spreading, 3-cleft, with its middle lobe largest and 2-cleft or notched at the end. Stamens 4 , ascending under the upper lip, the lower pair shorter. anthers approximate by pairs, the cells divergent. - Whorls many-flowered, mostly spiked or capitate, and with awn-toothed or fringed leafy bracts. (Name from $\delta \rho \alpha \kappa \omega \nu, a d r a g o n$, and $\kappa \in \phi \alpha \lambda \eta$, head, alluding to the form of the corolla in the origina! species.)

1. D. parviflòrum, Nutt. Annual or biennial; stem erect, leafy (8$20^{\prime}$ high); leares orate-lanceolate, sharply cut-toothed, petioled; whorls (rowled in a terminal hear or spike; upper tooth of the calyx ovate, nearly equalling the bluish small slender corolla. - Rocky or gravelly soil, northern N. Y. to Iowa and Minn., and westward.

\section{SCUTELLÀ RIA，L. Skcllcap.}

Calyx bell-shaped in flower, 2-lipped; the lips entire, closed in fruit, the upper with a helmet-like at length concave and eularged appendage on the back 
(the upper sepal); calyx splitting to the base at maturity, the upper lip usu. ally falling away. Corolla with an elougated curved ascending tube, dilaterl at the throat, 2-lipped; the upper lip arched, entire or barely notched, the lateral lobes mostly connected with the upper rather than the lower lip; the lower lobe or lip spreading and convex, notched at the apex. Stamens $f$, ascendiug under the upper lip; anthers approximate in pairs, ciliate or lwarded, these of the lower stamens 1-celled (halved), of the upper 2-celled and heart shaped. Bitter perennial herbs, not aromatic, the short peduncles or pedicels chiefly opposite, 1-flowered, often l-sided, axillary or spiked or racened; in summer. (Name from scutella, a dish, in allusion to the appendage to the fruiting calyx.)

§ 1. Nutlets uingless, mostly marginless, on a low gynobase.

* Flowers small ( $3^{\prime \prime}$ lony), in axillury and sometimes terminal 1-sided racemes.

1. S. lateriflora, I. (MAn-Dog SkLLcar.) Smooth; stem upright, much branched $\left(1-2^{\circ}\right.$ high $)$; leaves lanceolate-orate or ovate-oblung, pointed, coarsely serrate, rounded at base, petioled $\left(2-3^{\prime}\right.$ long), the lower floral ones similar; flowers blue, rarely white. - Wet shaded places, common.

* Flowers larger (6-12" long) in terminal single or panicled racemes, the floral leaves gradualiy reduced to bracts.

- Stem-leaves all cordute, crenate-toothed, slender-petioled; lateral lobes of the corolla almost equalling the short upper lip.

2. S. versícolor, Nutt. Soft hairy, the hair's of the inflorescence, etc., partly viscidl-glandular; stem mostly erect $\left(1-3^{\circ}\right.$ ligh $)$; leuves ocate or roundovete, very veiny, rugose, the floral reluced to broally ovate entire bracts about equalling the glandular-hairy calyx; racemes mostly simple; corolla bright blue with lower side and lip whitish. - Banks of streams, Penn. to Wisc., Minn., and southward. - Var. urxon, Chapm. Low, slender, and thin-leaved; floral leaves small. - Mountains of Va., etc.

3. S. saxátilis, Riddcll. Glabrous or slightly hairy; stem weak, ascending $\left(6-18^{\prime} \mathrm{long}\right)$, often producing rumers, branched; leaves ovate or orateoblong (1-2' long), thin, obtuse; upper bracts oblong or ovate, small, entire; raceme simple, loose. - Muist shadled banks, Del. to Ohio, south in the mountains to Va. and 'Tenu.

+ + Stem-leatcs crenate-dentate or scrrate (or nearly entire in $\mathrm{n}$. 7 ), only the lowest if any cordate at base, more or less petioled; lateral lobes of the blue corolle shorter than the galcate upper lip.

4. S. serràta, Andrews. Green and nearly glabrous: stem rather simple ( $1-3^{\circ}$ high), with single loosely flowered racemes; leares serrate, acuminate at both ends, ovate or ovate-oblong; calyx, etc., somewhat hairy ; corolla $\mathrm{l}^{\prime}$ long, narrow, its lips equal in leugth. - Woods, Penn. to 111. and N. C.

5. S. canéscens, Nutt. Stem branched above $\left(2-4^{\circ}\right.$ high $)$, with the panicled many-flowered racemes, flowers, and the lower surface of the orate or lance-ovate acute (at the base acute, obtuse, or cordate) crenate leares whitish with fine soft doun, often becoming rather glabrous; bracts oblong or lanceolate; corolla 8-9" long. - River-banks, Ont. and l'enn. to the mountaius of N. C. and N. Ala., west to Kan. and Ark.

6. S. pilosa, Michx. Pubescent urith spreading hairs; stem nearly simple $\left(1-3^{\circ}\right.$ high); leaves rather distant, crenate, oblong-ovate, olt: se varino to 
roundish-orate, the lower abrupt or heart-shaped at base and long-petioled, the upper on short margined petioles, reiny ; bracts oblong-spatulate ; racemes short, often branched; corolla $6^{\prime \prime}$ long, rather narrow, the lower lip a little shorter. - Dry or sterile ground, southern N. Y. to Mich., south to Fla. and Tex.

Var. hirsuta, Gray, is a large form (sometimes $3^{\circ}$ high), more hirsute, with larger very coarsely crenate leares (2-3' long). - Richer soil, Ky.

Var. ovalifolia, Benth., is a form with shorter and finer pubescence, and narrower less veiny leaves. - N. J. to Va.

7. S. integrifolia, L. Doxny all over with a minute hoariness; stem commonly simple ( $1-2^{\circ}$ high) ; leares oblong-lanceolate or linear, mostly entire, obtuse, very short-petioled; corolla $\mathrm{l}^{\prime}$ long, much enlarged above, the ample lips equal in length. - Dry ground, N. Eng. to Fla. and Tex.

*** Flowers solitary in the axils of the upper mostly sessile leaves, which resemble the louer ones but are occasionally reduced.

8. S. Wrìghtii, Gray. Firm and woody at base, not stoloniferous nor tuberiferous, low, many-stemmed in a tuft, minutely cinereous-puberulent, very leafy; leaves ovate or spatulate-oblong, entire, subsessile ( $\frac{1}{2}^{\prime}$ long), the upper floral shorter than the flowers; corolla pubescent ( $\frac{1}{2}^{\prime}$ long), usually violet. - Kan. to Tex.

9. S. párvula, Michx. Herbaceous; subterranean stolons moniliformtuberiferous; minutely downy, dwarf $\left(3-6^{\prime}\right.$ ligh $)$, branched and spreading; all but the lower leaves sessile and entire, the lowest round-ovate, the others ovate or lance-ovate, slightly heart-shaped $\left(6-8^{\prime \prime}\right.$ long); corolla $2-4^{\prime \prime}$ long. Sandy banks, W. New Eng. to Minn., south to Fla. and 'Tex. - Var. nóluss, Gray, is more spreading, softly pubescent throughout, with larger less firm leaves. - Sandy banks, S. Ill. to Kan.

10. S. galericulàta, L. Herbaceous; subterranean stolons not tuberiferous; smooth or a little downy, erect $\left(1-2^{\circ}\right.$ high), simple; leares ovatelanceolate, acute, serrate, romdish and slightly heart-shaped at base $\left(1-2^{\prime}\right.$ long); corolla violet-blue, $8-9^{\prime \prime}$ long, with slencler tube, the large lower lip nearly erect. - Wet sharly places; common especially northward. (Eu.)

§ 2. Nutlets conspicuously winged, each raised on a slender base.

11. S. nervòsa, Pursh. Smooth, simple or branched, slender, 10-20' high ; lower leaves roundish, the middle orate, toothed, somewhat heart-shaped ( $l^{\prime}$ long), the floral ovate-lanceolate, entire; nerve-like reins prominent beneath; corolla bluish, $4^{\prime \prime}$ long, the lower lip exceeding the concave upper one. - Moist thickets, N. Y. to Ind., south to Va. and Mo.

\section{BRU N É L L A, Tourn. Self-heAL.}

Calyx tubular-bell-shaped, somewhat 10-nerved and reticulated-reiny, flattened on the upper side, naked in the throat, closed in fruit, 2-lipped; upper lip broad and flat, truncate, with 3 short teeth, the lower 2-cleft. Corolla ascending, slightly contracted at the throat and dilaterl at the lower side just beneath it, 2-lipped; upper lip erect, arched, entire; the lower reflexedspreading, 3-cleft, its lateral lobes oblong, the midlle one rounded, concave, denticulate. Stamens 4, ascending under the upper lip; filaments 2-toothed at the apex, the lower tooth bearing the anther; anthers approximate in pairs, 
their cells diverging. - Low perennials, with nearly simple stems, and 3-flow. ered clusters of flowers sessile in the axils of romul and bract-like memlira-

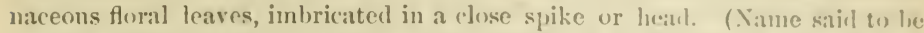
from the German braune, a disease of the throat, for which this plant was a reputed remed!r.)

1. B. vulgàris, L. (Commox SELF-HEגL or IHLAL-ALl.) T.eave owateohlong, entire or tuothed, petioled, hairy or smoothish; corollat (viulet or flc:shcolor, rarely white) not twice the length of the purplish caly - Wouls and fields, Newf. to Fla., westward across the continent. 'June-sipt. (liu.)

\section{PH Y SOSTEG I A, Benth. False Dragox-Heal).}

Calyx nearly equally 5-toothed, obscurely 10-nerved, short-tubular or bellshaped, more or less enlarged and slightly inflated in fruit. Corolla funnelform, with a much inflated throat, 2-lipped; upper lip erect, nearly entire ; the lower 3-parted, spreading, small, its middle lohe larger, broal and rounded, notched. Stamens 4, ascending moler the upper lip; anthers approximate; the cells parallel. - Smooth perennials, with upright wand-like stems, and sessile lanceolate or oblong mostly serrate leaves. Flowers large and showy, rose or flesh-color varicgated with purple, opposite, crowrled in simple or

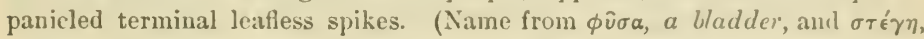
a covering )

1. P. Virginiàna, Benth. Stem $1-4^{\circ}$ high, terminated ly a simple virgate or several panicled spikes; leaves thickish ; culyx tubulur-rampanulute, its teeth half the length of the tube; rorolla l' long. - Wet grounds, from N. Vt. west and southward. Varies greatly. - Var. mixtculdit, Gray. Slender and commonly low, with crenulate-denticulate or obscurely serrate leaves, and slender or loosely-flowered spikes. - Middle Atlantic States.

2. P. intermèdia, Gray. Slender, $1-3^{\circ}$ high, remotely leaved; leaves linear-lanceolate, repand-denticulate; spikes filiform, rather remotely flowered; caly $x$ short and broadly campanulate, its teeth ahout as long as the tube; corolla 5-6" long, much dilated upuard. - Barrens, W. Ky. and Ark. to La. and Tex.

\section{SY NÁ N D RA, Nutt.}

Calyx bell-shaped, inflated, membranaceous, irregularly veiny, almost cqually 4-toothed! Corolla with a long tuhe, much expanded abnve and at the throat ; the upper lip slightly arched, entire, the lower spreading and 3-cleft, with owate lohes, the middle one broadest and notched at the end. Stamens 4 , ascending; filaments hairy; anthers approximate in pairs under the upper lip; the two upper each with one fertile and one smaller sterile cell, the latter cells colhering together (whence the name; from $\sigma \dot{v} \nu$, ingether, and àvíp, fur anther).

1. S. grandiflora, Nitt. Ilairy hienuial, $1^{\circ}$ high; lower leaves longpetioled, broadly ovate, heart-shaped, crenate, thin, the floral sessile, gradually reduced to bracts, each with a single sessile flower; corolla $1 f^{\prime}$ long, yellowishwhite. - Shady banks of streams, S. ()hio to Ill. and Tenm. In spring.

\section{M A R R Ù B I U M, 'Tourn. HorenotND.}

Calyx tubular, 5-10-nerved, nearly equally 5-10-toothed, the teeth more or less spiny-pointed and spreading at maturity. Ciper lip of the corolla erect, 
notched, the lower spreading, 3-cleft, its middle lobe broadest. Stamens 4, included in the tube of the corolla. - Whitish-woolly bitter-aromatic perennials, branched at the base, with rugose and crenate or cut leaves, and many-flowered axillary whorls. (A name of Pliny, from the Hebrew marrob, a bitter juice.)

M. vulgàne, L. (Commox Horehocxid) Stems ascending; leaves round-ovate, petioled, crenate-toothed; whorls capitate; calyx with 10 recurved teeth, the alternate ones shorter; corolla small, white.-Escaped from gardens into waste places. (Nat. from Eu.)

\section{B A LLòt A, L. Fetid Horehouxd.}

Calyx nearly funnel-form; the 10-ribbed tube expanded above into a spreading regular border, with 5-10 teeth. Anthers exserted beyond the tube of the corolla, approximate in pairs. Otherwise much as in Marrubium. (The Greek name, of uncertain origin.)

B. xìgra, L. (BLACK Horenorxd.) More or less hairy, but green, erect; the root perennial; leares orate, toothed; whorls many-flowered, dense; calyxteeth 5, longer than the tube of the purplish corolla. - Waste places, N. Eng., Penn., ets. (Nat. from Lu.)

\section{PHLòmis, Tourn. Jertsalem Sage.}

Calyx tubular, 5-10-nerved, truncate or equally 5-toothed. Upper lip of the corolla arched; the lower spreading, 3-cleft. Stamens 4, ascending and ap. proximate in pairs uncler the upper lip; the filaments of the upper pair longer than the others in P. tuberosa, with an awl-shaped appendage at base; anthercells divergent and confluent. - Leaves rugose. Whorls dense and many-flowered, axillary, remote, bracted. (An old Greek name of a woolly plant.)

P. tuberósA, I. Tall peremnial (3-50 high), nearly smooth ; leaves ovateheart-shaped, creuate, petioled, the floral oblong-lanceolate; bracts awl-shaped, hairy; upper lip of the purple corolla densely bearded with white hairs on the inside. - S. shore of Lake Untario, N. Y. June, July. (Nat. from Eu.)

\section{LEON ÚR US, L. Mотнerwort.}

Calyx top-shaped, 5-nerved, with 5 nearly equal teeth which are awl-shaped, and when old rather spiny-pointed and spreading. Upper lip of the corolla oblong and entire, somewhat arched; the lower spreading, 3-lobed, its middle lobe larger, narrowly oblong-obovate, entire, the lateral ones oblong. Stamens 4, ascending uncler the upper lip; anthers approximate in pairs, the valves naked. Nutlets truncate and sharply 3-angled. - Lpright herbs, with cut-lobed leaves, and close whorls of flowers in their axils; in summer. (Name from $\lambda \epsilon^{\prime} \omega \nu$, a lion,

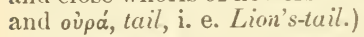

L. CArnìaca, L. (Commox Motherwort.) Tall perennial; leaves longpetioled, the lower rounded, palmately lobed, the floral wedge-shaped at base, 3-cleft, the lobes lanceolate; upper lip of the pale purple corolla bearded. Waste places, around dwellings. (Nat. from Eur.)

L. IArrubiástrum, I. Tall biennial, with elongated branches; stemleaves oblong-ovate, coarsely toothed; corolla (whitish) shorter than the calyxteeth, the tube naked within; lower lip rather erect. - Roadsides, N. J. to Del., and southward. (Adv. from Eu.)

L. Sibínicus, L. Tall biennial; leaves 3-parted, the divisions 2-5-cleft, or deeply 3-7-cleft and incised ; corolla (purplish) twice as long as the calyx, the upper lip fornicate, the lower little spreading. - Waste grounds, Penu.; also far west. (Adv. from Eu. and Asia.)

\section{L À M I U M, L. DedD-Netrte.}

Calyx tubular-bell-shaper, about 5-nerred, with 5 nearly equal awl-pointed teeth. Corulla rlilated at the throat; upper lip ovate or oblong, arched, nar- 
rowed at the hase; the middle lobe of the spreading lower lip loroad, notelied at the apex, contracted as if stalked at the hase, the lateral ones small, at the margin of the throat. Stamens 4 , ascending nuler the "ujer lip; anthers approximate in pairs, 2-celled, the cells divergent. Nutlets truncite. - I) nemmbent herbs, the lowest leares small and long-petioled, the milhlle heart-shajuel and doubly toothed, the tloral subtending the whorled flower-chuster; sjring to

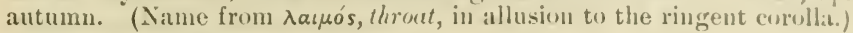

* Annuals or biennials, low" flowers small, purple, in few whorls or heuds.

L. AMPLEXICAUtLE, L. Leaves rounded, deeply crenate-toothed or cut, the upper ones clasping; corolla elongated, upper lip liearded, the lower spotted; lateral lobes truncate. - Rather common. (Nat. from liu.)

L. PCRPÙneu, L. Leares roundish or oblong, heart-shaped, crenatetouthed, all petioled. - N. Eng. and l'enu. (Nat. from Liu.)

\section{* Perenniul, taller; flowers lurger, in several axillary whorls.}

L. ALı1\%, I. Hairy; leaves ovate, heartshaped, petioled; calyx-teeth very slender, sprearling; corolla white, the tube curved upward, obliquely enntracted near the base, where there is a ring of hairs insicle; lateral lobes of lower lip bearing a long slender tooth. - E. New Eng. (Nat. from Eu.)

L. IACULAт:M, I. Like the last, but leaves more frequently marked with a white spot on the upper face, and Howers purplish, with the ring of hair's transverse instead of oblique. - sparingly escaped. (\dv. from Eu.)

\section{GALEÓ PSIS, L. IIEMP-Nettle.}

Calyx tubular-bell-shaped, about 5-nerved, with 5 somewhat equal and spinytipperi teeth. Corolla dilated at the throat; upper lip ovate, arched, entire; the lower 3-cleft, spreading, the lateral lobes ovate, the midclle one inversely heart-shaped; palate with 2 teeth at the sinuses. Stamens 4 , ascending under the upper lip; anther-cells transversely 2-valied: the inner valve of each cell bristly-fringed, the outer one larger and naked. - Annuals, with spreading branches, and several - many-flowered whorls in the axils of Horal leaves which are nearly like the lower ones. (Name composed of yadé $\eta$, a weasel, and ó $\downarrow$ is, resemblance, from some fancied likeness of the ('orolla to the hearl of a weasel.)

G. Tethant, L. (Comsox Hlinp-Netтte.) Stem suollen below the joints, bristly-hairy; lenes ou ate, coarsely serrate; corolla purplish or variegated, abont twice the length of the calyx; or, in var. Graxnifons, $3-4$ times the length of the calyx, often yellowish with a purple spot on the lower lip. Waste places, common. Aug., Sept. (Nat. from Eu.)

G. LÁndxis, I. (REI) H.) Stem smooth or puleseent; leaves ablongtanceolate, more or less downy ; corolla red or rose-color (often spotted with yellow), much exceeding the calyx. - E. New Eng., rare. Aug. ( $\mathrm{A}(\mathrm{l}$. from Eu.)

\section{STACHYS, Tourn. Hemie-Nettle.}

Caly $\mathrm{x}$ tubular-bell-shaped, 5- 10-nerved, equally 5-toothed, or the upper tecth united to form an upper lip. Corolla not dilated at the throat; upper lip) erect or rather spreading, often arohed, entire or uearly so ; the lower usually longer and spreading, 3-lobed, with the middle lobe largest and nearly entire. Stamens 4, ascending uncler the upper lip (often reflexed on the throat after flowering); anthers approximate in pairs. Nutlets obtuse, not truncateWhorls 2 -many-flowered, approximate in a terminal raceme or spike (whence the name, from $\sigma \tau a ́ \chi v s$, a spike). Flowers purple or rose-red, in summer.

\section{* Root anmual; stems decumbent, lou.}

S. ARvéxsis, L. (Wozxnwort.) IIairy; leares petioled, corlate-orate, obtuse, crenate; whorls 4-6-flowered, distant; corolla (jurplish) scarcely longer than the unamed calyx. - Waste places, E. Mass. (Adv. from Eu.) 
* Root perennial; stem erect.

+ Leares obscurely or not at all cordate, sessile or short-petioled.

1. S. hyssopifolia, Michx. Smooth and glabrous, or the nodes hirsute; stems slender ( $1^{\circ}$ high); leaves linear-oblong or narrouly linear, sessile, obscurely toothed toward the apex; whorls 4-6-flowered, rather distant; corolla glabrous, twice or thrice the length of the triangular-arl-shaped spreading calyx-teeth. - Wet sandy places, Mass. to Mich., south to Fla. and Mo. - Var. AubígcA, Gray, is stouter $\left(1-2^{\circ}\right.$ high), sometimes with scattered retrorse bristles on the angles of the stem, and with broader $\left(3-6^{\prime \prime}\right)$ serrulate leaves. - Ill. and Ky. to Ga.

2. S. palústris, I. Stem 4 -angled $\left(2-3^{\circ}\right.$ higll $)$, leafy, hirsute with spreading or reflexed hairs, especially on the angles; leares sessile, or the lower short-petioled, oblong- or ovate-lanceolate, crenately serrate, rounded at base, doun!y or hairy-mubescent, obtusish (2-4' long), the upper floral ones shorter than the nearly sessile calyx; whorls 6-10-flowered, the upper crow .ed into an interrupted spike; calyx hispid; the lance-subulate teeth somewhat spiny, half the length of the corolla, diverging in fruit; upper lip of corolla pubescent. - Wet ground, Newf. to Penn., westward across the continent.

3. S. áspera, Michx. Taller; stem more commonly smooth on the sides, the angles beset with stiff reflexed bristles; leaves hairy or smoothish, as in the last, but neurly all distinctly petioled, the lower floral as long as the flowers; spike often slender and more interrupted; calyx mostly glabrous, the tube rather narrower and the teeth more awl-shaped and spiny; corolla glabrons thiroughout. (S. palustris, var. aspera, Gray.) - Wet ground, common.

Var. glàbra, Gray. More slender, smooth and glabrous throughout, or with few bristly hairs; leaves taper-pointed, more sharply toothed, mostly rounded or truncate at the base, all more conspicuously petioled. (S. palustris, var. glabra, Gray.) - Western N. Y. to Ill., aud sonthward.

\section{+- Nearly all the leaves long-petioled and cordate.}

4. S. cordàta, Riddell. Rather weak, hirsute, $2-3^{\circ}$ high; leaves all orate- or oblong-cordate, acuminate, crenate $\left(2-5^{\prime}\right.$ long), the floral mostly minute; spikes slender, of numerous few-flowered clusters; calyx only $2^{\prime \prime}$ long; corolla glabrous throughout (or nearly su), barely 5" long. (S. palustris, var. cordata, Gray.) - Thickets, S. Ohio to Iowa, south to Va., Tenn., and Mo.

\section{() Irder 83. PLAN'TAGINACEAE. (Plantain Family.)}

Chiefly stemless herbs, with regular 4-merous spilied flowers, the stamens inserted on the tube of the dry and membranaceous veinless monopetalous corolla, alternate with its lobes; - chiefly represented by the two following genera.

\section{PLANTAg O, Tourn. Plantain. Ribwort.}

Calyx of 4 imbricated persistent sepals, mostly with dry membranaceous margins. Corolla salver-form or rotate, withering on the pod, the border 4 parted. Stamens 4 , or rarely 2 , in all or some flowers with long and weak 
exserted filaments, and fugaciuns 2-celled anthers. () vary 2- (or in 11.5 fillsely $3-4-)$ celled, with 1 - several orules in each cell. Style and long hairy stigma

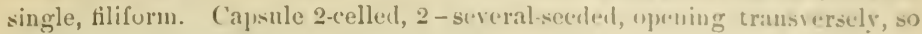
that the top falls off like a lid and the loose partition (which bears the peitate seeds) falls away. Embryo straight, in tleshy albumen. - Lo'aves ribled. Fluwers whitish, small, in a bracted spike or head, raised un a nakenl scape. (The Latin name.)

\$ 1. Stamens 4; flouers all perfect; corolla not closed orer the finit.

* Flowers proterogynous, the style first projecting firom the unopened corolla, the anthers long-exserted ufter the corolla has opened; sceds not hullowed on the face (except in P. lanceulata).

- Corolla glabrous; leuves strongly ribbed; perenniul.

- Ribs of the broad leares rising from the midrib.

1. P. cordàta, Lam. Tall, glabrons; leaves heart-shaped or round-ovato (3-8' long), long-petioled; spike at length loosely fluwered; bracts ruuniovate, fleshy; capsule 2-4-secded. - Aloug streams, N. Y. to Minu., and southwarl.

+ + Ribs of the leaf fiee to the cuntracted buse.

2. P. màjor, L. (Cosmox P'lastar.) smootlı or rather hairy, rarely roughish; leaces viate, oblony, ovul, or slightly heart-shaped, often toothed, abruptly narrowed into a chamnelled petiole; spike dense, obtuse; sepals ruundovate ur obovate; cupsnle oroul, circumscissile near the midlle, 8-18-seeded; seeds angled, reticuluted. - Waysiles and near dwellings everywhere. Duubtless introduced from Eu., but uative from L. Superior and N. Minn., northward.

3. P. Rugélii, Decaisne. Leaves as in the last, but paler and thinner; sprikes long and thin, attenuate at the upex: sepals oblong, acutely carinate; cupsules eylindraceous-olilon!, circumscissile much below the middle, 4-9-seeved; seeds ovcil-ablony, not reticulated. (P'. Kamtschatica, Gruy, Mau., not Cham.) - Vt. to Minn., soutlı to Gia. and Tex.

+ P. eriòpoda, Torr. Lsually a mass of yellou ish wool at the hase: leaves thickish, oblunceolute to obovate, with short stout petioles; spike dense or loose; sepuls und bract more or less srarious but not rarinate: inpsule oionil. nerer oier t-seeded. - Moist and saline soil; Redl River valley, Minn., and westward; also on the Lower St. Lawrence.

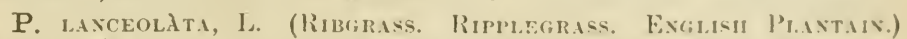
Mostly hairy; scape grooved-angled, at length mucl, loager than the luncrulate oi lance-ohlon!y len'es, slender $\left(9^{\prime}-2^{\circ}\right.$ lingh $)$; spuike ilense, at first capitate, in age cylindrical; hract and sepals scarions, hrownish; secels 2 , holloued on the fitce. - Very common. (Nat. from Eur.)

+- + Corolla-tube externally pubescent; leures linear or filyorm, fleshy, indis-

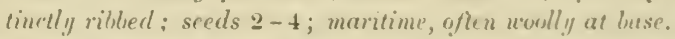

5. P. decípiens, Barmeonul. Annual, or sometimes bicmual with a stout rootstock, smouth, or the sc:ipe pullescent ; leaves flat or flat tish and chaunelled, erect, nearly as long as the s(ape: $\left(5-12^{\prime}\right)$, acuminate; spike slonder, rather loose. (l'. maritina, var. juncoiles, Grry, Man.) - Salt marshes, Atlantic coast, from Labrador to $\mathrm{N}$.J. 'The characters distinguishisg bieunial specimens of this from the next are obseure. 
6. P. maritima, L. Perennial; spikes dense.-Coast of Mass.; Gulf of St. Lawrence to Lab. and Greenland. (Eu.)

* * Flowers of 2 sorts (as respects length of anthers and filaments) on different plants, mostly cleistogamous; corolla-lobes broad, rounded, persistently spreading; seeds 2, boat-shaped; inflorescence and narrow leaves silky-pubescent or voolly; annual.

7. P. Patagónica, Jacq., var. gnaphalioides, Gray. White with silky wool; leaves 1-3-nerved, varying from oblong-linear to filiform; spike very dense $\left(\frac{1}{4}-4^{\prime}\right.$ long), woolly; bracts not exceeding the calyx; sepals very obtuse, scarious, with a thick centre. - Prairies and dry plains, Minn. to Ind., Ky., and Tex., westward to the Pacific. Very variable. - Var. xìdd, Gray • with sparse and loose pubescence, green and soon glabrate rigid leaves, and short bracts. - Var. spixelósA, Gray; a canescent form with aristately prolonged and rigid bracts. - Var. ARIstATA, Gray; loosely hairy and green, or becoming glabrous, with narrowly linear bracts $2-3$ times the length of the flowers. (Nat. on Martha's Vineyard, and about Boston.)

§ 2. Flowers subdiocious or polygamo-cleistogamous; the corolla in the fertile (or mainly fertile) plant closed over the maturing capsule and forming a kind of beuk, and anthers not exserted; sterile flowers with spreading corolla and long-exserted filaments; seeds mostly flat; small annuals or biennial.

* Leaves comparatively broad, short-petioled or subsessile; stamens 4.

8. P. Virgínica, L. Hairy or hoary-pubescent $\left(2-9^{\prime}\right.$ high $)$; leaves oblong, varying to obovate and spatulate-lanceolate, $3-5$ nerved, slightly or coarsely and sparingly toothed; spikes mostly dense ( $1-2^{\prime}$ long); seeds usually 2. - Sandy grounds, S. New Eng. to S. Ill., south to Fla. and Ariz.

* Leaves linear or filiform; flowers very small; stamens 2 ; spike slender.

9. P. pusílla, Nutt. Minutely pubescent $\left(1-4^{\prime}\right.$ hígh); leaves entire; capsule short-ovoid, 4-seeded, little exceeding the calyx and bract. - Sandy soil, southern N. Y. to Va., west to the Rocky Mts. Apr.-Aug.

10. P. heterophýlla, Nutt. Leaves rather fleshy, acute, entire, or some of them below 2-4-lobed or toothed; cupsule oblong-conoidal, 10-28-seeded, nearly twice the length of the calyx and bract. - Low sandy ground, Penn. to Fla. and Tex. Apr.-June.

\section{IITTORÉLI, L.}

Flowers monœcious; the male solitary on a mostly simple naked scape; calyx 4-parted, longer than the cylindraceous 4-cleft corolla; stamens exserted on very long capillar! filaments. Female flowers usually 2, sessile at the base of the scape ; calyx of 3 or 4 unequal sepals; corolla urn-shaped, with a 3-4toothed orifice. Ovary with a single cell and ovule, tipped with a long laterally stigmatic style, maturing as an achene. (Name from litus or littus, shore, from the place of growth.)

1. I. lacústris; L. Stoloniferous but otherwise stemless; leaves terete, linear,subu'ate, $1-2^{\prime}$ long. - In water or on gravelly shores, Nova Scotia and N. Pórunswick, to L. Champlain (Pringle) and Ont. 


\section{Division III. APETALOLS DICOTYLEDONOUS PLAN'TS.}

Corolla none; the floral envelopes in a single series (calyx), or sometimes wanting altogether.

\section{Order 84. NYC'TAGINACHAS. (FuLróclock Famli.)}

Herbs (or in the tropics often shrubs or trees), with mostly opposite und entire leaves, stems tumil at the joints, a delicule tubular or funnel-form calyx which is colored like a corolla, its persistent base constrictal ubove the 1-celled 1-seeded ovary, and indurated into a sont of mut-like pericury); the stamens few, slender, and hypogynous; the cmbryo coiled arourl the ontside of meuly albumen, with broarl foliaceous colyledons (in Abronia monocotyledonous by abortion). - Represented in our gardens by the louk-

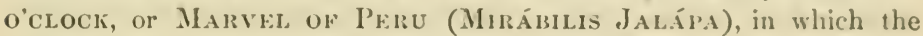
calyx is commonly mistaken for a corolla, the cup-like involucre of each flower exactly imitating a calyx.

1. Oxybaphus. Involucre of united bracts. Fruit wingless. Calyx bell-shajeed.

2. Abronia. Involncre of distinet liracts. Fruit 5-winged. Calyx salver-form.

\section{OXÝBAPH US, Vahl.}

Flowers 3-5 in the same 5-lubed memloranaceous broad and open involucre, which enlarges and is thin and reticulated in fruit. Calyx with a very short tube and a bell-shaped (rose or purple) decidnons limb, plaited in the bud. Stamens mostly $3(3-5)$, hypogrnous. Style filiform; stigma capitate. Fruit achene-like, several-rubed or angled (pubescent in ours). - Herbs, abounding (n) the western plains, with very large and thick pereunial roots, op posite leaves,

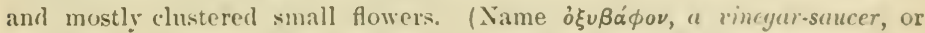
small shallow vesscl; from the shape of the involucre.)

1. O. nyctagíneus, siweet. Nearly smooth; stem becoming repeatedly forked, $1-3^{\circ}$ ligh; leares all petioled (except the uppermust reduced ones), from broally orate to lanceolate, rounded or cordute or sumeate at buse; influrescence loose and but slightly pubescent, the peduncles slender (at first solitary in the axils) ; fruit oblong-obovate, $2^{\prime \prime}$ long, rather acutcly angled. - Minn. and $W$ isc. to Tex. and La. ; rare escape from gardens in L. Mass. and R. I.

2. O. hirsùtus, Sweet. More or less glandular-hirsute, especially about the nodes aul the usually contracted inflorescence, $1-3^{\circ}$ high; leaves lameolute to linear-iunceolute, sessile and cuneate at base or narrowed to a short jetiole; stameus often 5; fruit with thickened olstuse angles. - l'lains of the Sask. to Wisc., Iowa., Neb., and Tex.

3. O. angustifolius, Sweet. ()ften tall, glubrons except the more or less hirsute perluncles and involucres; leaces lineur, thick and glaucous, often elongated $(2-6$ ' long); fruit as in the list. - Minn. to 'Tex., and westward.

\section{A B R Ò N I A, Juss.}

Involucre of 5-15 distinct bracts, enclosing numerous sessile flowers. Calyx salver-form, with obcordate lubes. Stamens 5 , included, alnate to the calyxtube. Style included; stigma linear-clawate. Perfect fruit 3-5.winged. 
Embryo monocotyledonous. - Low herbs, with thick opposite petioled nnequal leares, axillary or terminal peduncles, and showy flowers in solitary heads. (Name from åßpós, graceful.)

1. A. fràgrans, Nutt. More or less viscid-pubescent, from a perennial root; leaves oblong or ovate, truncate or cuneate at base; involucre conspicuous, of broad orate white and scarious bracts ; flowers white, fragrant, 4-10" long; fruit coriaceous, obprramidal, with narrow undulate coarsely reticulated wings. - From W. Iowa to Utah and N. Mex.

\section{Order 85. ILLECRBRACEAE. (Куотwort Family.)}

Ilerbs, with mostly opposite and entire leaves, scarious stipules (except in Scleranthus), a 4-5-toothed or -parted herbaceous or coriaceous persistent calyx, no petals, stamens borne on the calyx, as many as the lobes and opposite thcm or fewer, styles 2 and often uniterl, and finit a 1-seeded utricle. Seed upon a basal funicle, the embryo (in ours) surrounding the mealy albumen. -- Small diffuse or tufted herbs, with small greenish or whitish flowers in clusters or dichotomous cymes.

1. Anychia. Stamens on the base of the 5-parted awnless calyx. Styles hardly any.

2. Paronychia. Stamens on the base of the 5-parted calyx; the sepals hooded at the summit and bristle-pointed. Style 1, 2-cleft at the top.

3. Sclerantlus. Stamens borne on the throat of the indurated 5-cleft and pointless calyx. Styles 2. Stipules none.

\section{A NÝCHIA, Michx. Forked Chickweed.}

Sepals 5, scarcely concave, indistinctly mucromate on the back, greenish. Stamens 2-3, rarely 5. Stigmas 2, sessile. Utricle larger than the calyx. Kadicle turned clowuward. - Small, many times forked annuals, with small stipules, and minute flowers in the forks, produced all summer. (Same derivation as the next gemus.)

1. A. dichótoma, Michx. More or less pubescent, short-jointed, low and spreading; leaves sumewhat petioled, mostly very narrowly lanceolate or oblanceolate; flowers nearly sessile and somewhat clustered. - Mustly in open places, N. Eng. to Fla., west to Minn. and Ark.

2. A. capillàcea, DC. Simooth, longer-jointed, slender and erect; leaves thinner, brouder and longer (5-15" long); flouers more stallied and diffuse. (A. dichotoma, var. capillacea, Torr.) - Dry woodlands, same range as the last, lut more abundant northward.

\section{PARONÝCHIA, Tourn. Whitlow-wort.}

Sepals 5, linear or oblong, concave, awned at the apex. Petals (or staminodia) bristle-form, or minute teeth, or none. Stamens 5. Style 2-cleft at the apex. Utricle enclosed in the calyx. Radicle ascending. - Tufted herbs (ours perennial), with dry and silvery stipules, and clustered flowers. (Greek name for a whitlow, and for a plant thought to cure it.)

1. P. argyrócoma, Nutt. Forming broad tufts, branched, spreading; leares linear ( $\frac{1^{\prime}}{2}$ long); flowers densely clustered, surrounded by conspicuous large silvery bracts; calyx hairy, short-awned; petals mere teeth between the 
stamens. - Bare mountain slopes of the White Mts., ant in the Alleglıauirs from Va. to Ga.; also coast of Maine and near Newhur! port, Mass. July.

2. P. dichótoma, Nutt. Smooth, tufterl; stems ( 6 - $122^{\prime}$ high $)$ ascouding

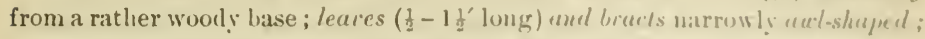
cymes open, muny-times forked; sepals short-pointed: minute bristles in place of petals. - liocks, Mi. to N. C. and Tex. Ju!y-sept.

3. P. Jamèsii, 'Torr. \& Gray. Sulscespituse, much hrancherl from the somewhat wooly base, minutely puherulent; leaves filifuru subulate, ohtuse or mucronate; forked crmes rather close; calyx narlow-campanulate with turbinate base. - Central Kan. to W. Neb., Col., and Tex.

\section{SCLERÁ N THU S, I. Kмхพ亡..}

Sepals 5, united below in an inclurated cup, enclosing the utricle. Ttamens 10 or 5. Styles 2, distinct. - Homely little weeds, with awl shatpen leaves, obscure greenish clustered flowers, aud no stipules. (Name from $\sigma \kappa \lambda \eta p o ́ ;$, hard, and ăvos, flower, from the hardened (aly: $x$-tule.)

S. Axxucs, L. Much branched, spreacling $(3-5$ ' highl $)$; fluwers sessile in the forks; calyx-lobes scarcely margined. - Waste plicess. (Nat. from Liu.)

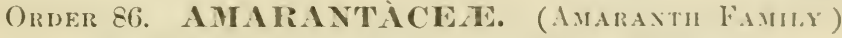

Wecdy herbs, with nearly the characters of the next fumily, but the flowers mostly imbricated with dry and scarious persistent brats; these ofien colored, commonly 3 in number; the 1-celled ovary in our genera 1-ovuled. (The greater part of the order tropical.)

* Anthers 2-celled; flowers unisexual; leaves alternate.

1. Amarantus. Flowers monocious or polygamous, all with a calyx of 3 or 5 dist net erect sepals, not falling off with the fruit.

2. Acnida. Flowers dicecions. Calyx none in the fertile flowers.

* Anthers l-celled; flowers perfent; leaves opposite.

3. Iresine. Calyx of 5 sepals. Filaments united beluw into a cup. Flowers paniculate.

4. Frolichia. Calyx 5-cleft. Filanents uniten into a tube. Flowers spicate.

\section{A M A RÁNTUS, 'Toum. Aмавакт.}

Flowers momcecious or polygamoms, 3-bractel. Calyx of 5, or sometimes 3, equal erect sepals, glabrous. Stameus 5 , rarely 2 or 3 , separate; anthers 2 celled. Stigmas 2 or 3 . Fruit an ovoid 1 -seeded ntricle, $2-3$-heaked at the apex, mostly longer than the calyx, openiug transtersely or sumetimes hursting irregularly. Embryo coiled into a ring around the albumen. - Anmusl weeds, of coarse aspect, with alternate aml entire petioled setosely tippel leares, and small green or purplish Howers in axillary or torminal spiked

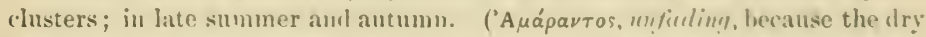
calyx and hracts do not wither. The limmans, like the Greeks, wrote Amarantus, which the early hotanists incorrectly altered to A furcunllus.)

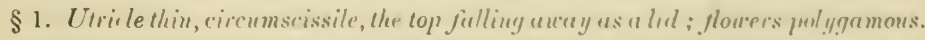
* Flouers in terminal and axillary simple or mostly panieled sprites: stem ereet $\left(1-6^{\circ}\right.$ high); leares long-petioled: stamins und sepuls 5 .

- Rev Amaraxtus. Flowers and often luces tinged with crimson or purple.

A. Irpochonmiacis, I. Glabrous; leaves ohlong-lanceolite, acute or pointed at both ends; spities rery olduse, thick, crowiled, the torminal mos 
elongated and interrupted; bracts long-awned; fruit 2-3-cleft at the apex, longer than the calyx. - Rarely spontaneous about gardens. (Adv. from Trop. Amer.)

A. PANiCulatus, I. Stem mostly pubescent; leaves oblong-ovate or ovatelanceolate; spikes mumerous and slender, panicled, erect or spreading; bracts acn-pointed; flowers small, green tinged with red, or sometimes crimson; finit $2-3$-toothed at the apex, longer tlian the calyx. - Roadsides, etc. (Adr. from Trop. Amer.)

\section{+ + Green Auarantus, Pigweed. Flowers green, rarely a little reddish.}

A. Retrofléxts, L. Roughish and more or less pubescent; leaves dull green, long-petioled, orate or rhombic-ovate, undulate; the thick spikes crowderl in a stiff or glomerate panicle; bracts awn-pointed, rigid, exceeding the acute or obtuse sepals. - Cultivated grounds, common; indigenous southwestward. (Adv. from Trop. Amer.)

A. ChLokóstachys, Willd. Very similar, but smoother and deeper green, with more slender, linear-cylindric, more or less flexuous spikes, the lateral ones spreading or divaricate, and the sepals more frequently acute or acuminate. (A. retroflexus, var. chlorostachys, Gray.) - Cultirated grounds ; apparently also indigenous southwestwari. - Var. urinives, Watson, is similar, but smooth and still more loosely panicled. (A. retroflexus, var. hybridus, Giray.) (Adv. from 'Trop. Amer.)

* *louers rrouded in close and small axillary clusters; stems low, spreading or ascending; stamens and sepals 3, or the former only 2.

1. A. álbus, L. (Truble Weed.) Smooth, pale green; stems uhitish, erect or ascending, diffusely branched; leaves small, obovate and spatulateoblong, very obtuse or retuse; flowers greenish; sepals acuminate, half the length of the rugose fruit, much shorter than the sululate rigid pungently pointed bracts; seed small, $\frac{2}{3}$ "broad. - Waste grounds, common.

2. A. blitoides, Watson. Like the last, but prostiate or decumbent: spikelets usually contracted; bracts orate-oblong, shortly acuminate; sepals obtuse or acute; fruit not rugose; seed about $\mathrm{l}^{\prime \prime}$ broad. - From Miun. to Mo. and Tex., and westwarl, and introduced eastward as far as western N. Y.

A. Buitux, L., resembles the last, hut is nsually erect, with shorter and more scarious bracts, and a smaller seel more notched at the hilum. - Near N. Y. City and Boston. ( $\mathrm{d} d \mathrm{v}$. from Eu.)

§ 2. Utricle thimuish, bursting or imperfectly cirrumscissile; flouers monocious.

A. spixóss, L. ('Гhorxy Amaraxtн.) smooth, bushy-branclied; stem reddish; leaves rhombic-orate or orate-lanceolate, dull green, a pair of spines in their axils; upper clusters sterile, forming long and slender spikes; the fertile globular and mostly in the axils; flowers yellowish-green, small. Waste grounds, N. Y. to E. Kan., and southward. (Nat. from 'Trop. Amer.)

§ 3. FU XOLLS. Ciricle rather fleshy, remaining closed or bursting irregularly: no spines; bracts inconspicuous.

3. A. pùmilus, Raf. Low or prostrate; leaves fleshy and obovate, emarginate, strongly nerved; flower-clusters small and axillary; stamens and sepals 5, the latter half the length of the olscurely 5-ribbed fruit. - Sandy beaches, R. I. to Va.

A. críspcs, Braun. Very slender, procumbent, pubescent; leaves small, light green, rhombic-ovate to -lanceolate, acute, the margin crisped and undulate; flowers in small axillary clusters; bracts and sepals scarious, oblancenlate, acute or ohtuse; utricle about as long, roughened, not nerved nor angled. (A. viridis, M/an.) - Streets of Alhany, New York City and Brooklyn; doubtless introduced, but the native habitat unknown. 
2. A C N I D A, Mitch. WATEル-HEMr。

Characters of Amarantus, except that the flowers are completely diocious and the pistillate ones without calyx. Bracts $1-3$, unequal. Staninate calyx of 5 thin oblong mucronate-tipped sepals, longer than the bracts; stancins 5 , the anther-cells united only at the middle. Stigmas 2-5, often long and plumose-hispid. Fruit somewhat coriaceous and indehiscent, or at thin membranous utricle dehiscing irregularly (rarely circumscissile), usnally 3-5-angled. (Name from $\alpha$-privative, and $\kappa \nu i \delta \eta, a$ nettle.)

\section{\$1. ACNIIDA proper. Fruit indehiscent, with firm and close pericurp.}

1. A. cannábina, I. L'sually stout, 2-6 high or more, glabrous; leaves lanceolate to linear-lanceolate, acuminate, long-petioled; sepals of sterile flowers ovate-oblong, obtuse or acutish; bracts usually thin and lax, much shorter than the fruit, sometimes more rigil and longer; fruit absut l" Iong, obovate, the pericarp rather thin, more or less rugosely angled; sced somewhat turgil, not angled, usually less than $1^{\prime \prime}$ long, shiniug. _ Rialt or brackish marshes, coast of $\mathrm{N}$. ling. to Fla.

2. A. rusocárpa, Michx. Very similar; fruit larger, $1 \frac{1}{2}-2$ " long, the pericarp thicker, and the larger seed flattened with thick margins, 11sually thickest on the cotyledonar side. - N. Y. (') and P'eun. to S. Car.; apparently much less common than the last, though it is often difficult to pusitively distinguish the species from the immature fruit.

\section{§ 2. MONTELIA. Fruit dehiscing irregularly, the pericarp thin, loose and usu- ally roughened; not salt-marsh plants.}

3. A. tuberculàta, Moy. Tall and erect, or sometimes low and decumbent; leaves lanceulate, acute or acutish or sometimes obtuse; sepals of sterile flowers lanceolate, acute or acuminate; pistillate flowers closcly clustered in more or less dense naked or leafy axillary and terminal spikes (or the axillary capitate); bracts rather rigil, acuminate, equalling or exceeding the fruit: utricle about $\frac{1}{2}$ " loug; seed shining, $\frac{1}{2}-\frac{1}{3}$ " in diameter. (Montclia tamariscina, Gray, in part.) - ()hio to I)ak., Mo., Mla., and La.

Var. subnuda, Watson. Erect or often prostrate, the lower clusters at least of pistillate flowers more or less cymose and often in globose heads; bracts thinuer, narrow and lax, shorter than the fruit. (M. tamariscina, var. concatenata, Gray, in part.) - W. Vt. (Oakes); Ont. to Minn., and sonthward. Often appearing quite distinct from the type, but intermediate forms are not rare.

\section{I R E S I N E, l'. Browne.}

Flowers mostly polygamous or cliociums, 3-bracted. Calyx of 5 sepals. Stamens mostly 5; filaments slender, united into a short cup at hase; anthers l-celled, ovate. Fruit a globular utricle, not opening. - llerls, with opposite petioled leaves, and minute scarious-white flowers, crowled into clusters or spiked and branching panicles; the calyx, etc., often bearing long woul (whence the name, from $\epsilon i p \in \sigma \iota \dot{\nu} \eta$, a wreatlı or staff entwined with fillets of wool).

1. I. celosiotdes, I. Nearly glabrous, anuual, erect, slender $\left(2-4^{\circ}\right.$ high); leaves ovate-lanceolate; panicles very slender, often broad and diffuse, naked; bracts and calyx silvery-white, the fertile calyx twice louger than the 
broad bracts and densely silky-villous at base. - Dry banks, Ohio to Kan., and far southward. Sept.

\section{FRCLÍ CHIA, Moench.}

Flowers perfect, 3-bracted. Calyx tubular, 5-cleft at the summit, below 2-5crested lengthwise, or tubercled and indurated in fruit, enclosing the indehiscent thin utricle. Filaments united into a tube, bearing 5 oblong 1-celled anthers, and as many sterile strap-shaped appendages. - Hairy or woolly herbs, with opposite sessile leaves, and spiked scarious-bracted flowers. (Named for J. A. Froelich, a German botanist of the last century.)

1. F. Floridàna, Moquin. Root anuual; stem leafless above $\left(1-3^{\circ}\right.$ high); leaves lanceolate, silky-(lowny beneath; spikelets crowded into an interrupted spike; calyx very woolly, becoming broadly winged, the wings irregularly toothed. - Dry sandy places, S. Minn. to Ill., Col., 'Tex., and Fla.

2. F. grácilis, Moq. More slender, with narrow leaves, the spikelets sinaller, and the erests of the matured calyx of nearly distinct rigid processes. - Col. to 'Tex., and is reported from Kausas.

\section{Order 87. CHENOPODiACEAE. (Goosefoot Family.)}

Chiefly herbs, of homely aspect, more or less succulent, with mostly alternate leaves and no stipules nor scarious bracts, minute greenish flowers, with the firee calyx imbricated in the bud, the stamens as many as its lobes, or occasionally fever, and inserted opposite them or on their base; the 1-celled ovary becoming a 1-seeded thin utricle or rarely an achene. Embryo coiled into a ring around the mealy albumen, when there is any, or else conduplicate, or spiral. - Calyx persistent, mostly enclosing the fruit. Styles or stigmas 2, rarely $3-5$. (Mostly inert or innocent, weedy plants; several are pot-herbs, such as Spinach and Beet.)

* Embryo coiled into a ring abont usually copious central albumen. Leaves flat, not spiny. Stem not jointed.

- Flowers perfect (or stancus only occasionally wanting), clustered or panicled; calyx obvious, persistent. Seed-coa crustaceous.

1. Cycloloma. Calyx 5-cleft, in fruit surrounded by a horizontal continuous menibrana(eous wing. Seed horizontal, crustaceous. Leaves simuate-toothed.

2. Kochia. Like n. 1, but wing 5-lohed and seed-coat membranaceous. Leaves entire.

3. Chenopodium. Calyx 3-5-parted, unchanged or becoming flesliy in fruit.

4. Roubieva. Calyx 3-5-toothed, becoming saccate. Leaves pinnatifid.

+ + Flowers moncecious or diœeious ; the stamiuate in clusters, mostly spiked : the pistil. late without calyx, enclosed between a pair of appressed axillary bracts

5. Atriplex. Fruiting bracts with margins often dilated and sides often nuricate

+++ Flowers perfect, naked or 1-sepaled, solitary in the axils of the reduced upper leavec

6. Corispermum. Pericarp oval, flattened, adherent to the vertical seed. Leaves linear.

* Eubryo narrowly horseshoe-shaped or conduplicate no albumen. Stem fleshy, jointed ; leaves reduced to opposite fleslyy scales or teeth. Flowers densely spiked, perfect.

7. Salicornia. Flowers sumk in hollows of the axis of the fleshy spike. Calyx utricle-like.

*** Embryo coiled into a spiral ; albumen mostly none. Leaves fleshy, alternate.

8. Suzeda. Embryo flat-spiral. Calyx wingless. Leaves succulent.

9. Salsola. Eubryo conical-spiral. Calyx in fruit horizoutally winged. Leaves spinescent. 


\section{CYCLOLÒ MA, Moquin. WISGEn PIGWEeD.}

Flowers perfect or pistillate, bractless. Calyx 5-cleft, with the concave lobes strongly keeled, enclosing the depressed fruit, at length alplendaged with a broad and continuous horizontal scarions wing. Stausess 5. Styll.s 3 (rarely 2). Seed horizontal, flat; coats crustaceous. Linbryo cucircling the mealy albumen. - An annual and much-branched coarse herb, with alteruate sinuate-toothed petioled leaves, and very small scattered sessile flowers in open

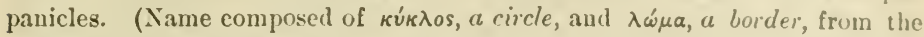
encircling wing of the (alyx.)

1. C. platyphýllum, Moquin. - I)iffuse (6-15' ligh), more or less arachnoid-pubescent or glabrate, light green or often deep purple. - Saudy soil, Minn. to W. Ill., S. Ind., Ark., and westward across the plains.

\section{K Oे H I A, Roth.}

Characters nearly as in Cycloloma, but the seed-coat membranaceous and the albumen wanting. - Anumals or suffruticose perennials, with flat or more usually linear and terete leaves. (Named for W. L. J. Koch, a German botanist.)

K. scopdria, Schrad. Anmual, erect, puberulent or glabrate, branching; leaves narrowly lanceolate to linear; fluwers in small axillary clusters, sessile, each sepal developing a thick wing. - Sparingly introduced; Vt., ( )nt., and Ill. (Nat. from Eu.)

\section{CHE N O P Ò D I U M, Tourn. Goosefoot. P'igneed.}

Flowers perfect, all bractless. Calyx 5-(rarely 4-) parted or lobed, unchanged in fruit or becoming succulent and berry-like, more or less enveloping the depressed fruit. Stamens mostly 5 ; filaments filiform. Styles 2, rarely 3. Seed horizontal or vertical, lenticular; the coat crustaceous; embryo coiled partly or fully round the mealy allumen. - Weeds, usually with a white mealiness, or glandular. Flowers sessile in small clusters collected in spiked panicles. (Named from $\chi \dot{\eta} \nu$, " goose, and $\pi o v$ s, foot, in allusion to the shape of the leaves.) - ()ur species are mostly annuals, flowering through late summer and autumn, growing around dwellings, in manured soil, cultivated grounds, and waste places.

\$ 1. Amual, more or less mealy, not glandular nor aromatic; finiting calyx dry; seed horizontal; emlnyo a complete ring.

* Pericarp very easily separated from the seed; lentes entire or rarely sinuatedentate.

1. C. Bosciànum, Moq. Erect, slender ( $2^{\circ}$ high $)$, loosely branched, often nearly glalrous; leures oblong-to lineur-tanceolute (1-2' long), attenuate into a slender petiole, acute, the lower sinuate-dentate or often all entire; flowers small, solitary or in small clusters upon the slender branchlets; caly $x$ not strongly carinate. (C. album, var. Boscianm, Gray, Manual.) - N. Y. to Minn., south to N. C. and Tex.

2. C. leptophỳllum, Nutt. Densely mealy or rarely nearly glabrous $\left(\frac{1}{2}-1 \frac{1}{2}^{\circ}\right.$ high), simple or branched, often strict; leaves lineul ( $\frac{1}{2}-1^{\prime}$ long), entire, rather shortly petioled; fluwers clusely clustered, in dense or interrupted spikelets; culyx-lobes strongl!y curinute. - Sica-coast, Conn. to N. J., north shore of L. Erie, and from Mak. to Col., N. Mex., and westwarl. 
* Pericarp persistent upon the smooth seed; leaves more or less sinuate-dentate (except in C. polyspermum).

C. POLYSPÉrucu, L. Low, often spreading, green and wholly destitute of mealiness; leares all entire, oblong or ovate and on slender petioles; flowers very small, in slender panicles in all the axils, the thin lobes of the calyx very incompletely enclosing the fruit; seed obtuse-edged. - Sparingly naturalized in the Eastern States. (Adv. from Eu.)

C. Áliuir, L. (LAmb's-Quartens. Pigweed.) Erect $\left(1-4^{\circ}\right.$ high), more or less mealy; leaves varying from rhombic-ovate to lanceolate or the uppermost even linear, acute, all or only the lower more or less angulate-toothed; clusters spiked-panicled, mostly dense; calyx ( ${ }_{4}{ }^{\prime \prime}$ wide in fruit) with strongly carinate lobes, nearly or quite covering the seed. - Introduced everywhere. (Nat. from Eu.) - Var. vínide, Moq., more common eastward, is less mealy and with less dense inflorescence.

C. ÚRBicus, L. Rather pale or dull green, nearly destitute of mealiness, with erect branches (1-30 high); lecies triangular, acute, coarsely and shaiply many-toothed: spikes erect, crourded in a long and narrow racemose panicle; calyx-lobes not keeled; seed with rounded margins. - Apparently throughout our range. (Nat. from Eu.)

C. MIRALE, L. Resembles the preceding, but less erect, loosely branched (1-2 ${ }^{\circ}$ high); leares rhomboid-niate, acute, coarsely and sharply unequally toothed, thin, bright green; spikes or racemes diverging, someuhat corymbed; calyx-lobes scarcely keeled; seed sharp-edyed. - From N. Eng. to Mich. and Mo. (Adr. from liu.)

3. C. hýbridum, L. (Maple-leaved Goosefoot.) Bright green throughout; stem widely much branched (2-4 high); leaves thin $\left(2-6^{\prime}\right.$ long), somewhat triangular and heart-shaped, taper-pointed, sinuate-angled, the angles extending into a few large and pointed teeth; racemes diffusely and loosely panicled, leafless; calyx not fully covering the fruit, its lobes keeled. - Indigenous from western N. Y. and Ky., westward across the continent; introduced eastward.

§2. Annual or perennial herbs, somewhat mealy, not glandular-pubescent: fruiting calyx dry; seed large, subglobose, vertical, exserted; embryo a complete ring.

C. GLA U̇Cun, L. (OAK-Leaved Goosefoot.) Low (5-12' high), spreading, glaucous-mealy; leaves sinuately pinnatifid-toothed, oblong, obtuse, pale green above; clusters in axillary spikes, small ; seed sharp-edged. - Throughout our range and westward. (Nat. from Eu.)

C. Boxus-Hexrices, L. (Good-King-Hexry.) Stout, erect $\left(1-2^{\circ}\right.$ high), mostly simple; leares broadly triangular-hastate $\left(2-3^{\prime}\right.$ long), obtuse or acute, subsinuate or entire; flouers someuhat densely paniculately spiked; seed with obtuse edges. (Blitum Bonus-Henricus, Reichenb.) - Sparingly introduced. (Adv. from Eu.)

§3. Annual, glabrous; calyx more or less fleshy in fruit and often colored, enclosing the utricle; seed mostly vertical; embryo a complete ring; flowers in crowded clusters, axillary or in spikes.

4. C. rùbrum, I. (Const Blite.) Stem angled, much branched; leaves thickish, triangular-lanceolate, tapering below into a wedge-shaped base and above into a slender point, sparingly and coarsely toothed, the upper linear-lanceolate; clusters scattered in axillary leafy spikes; calyx-lobes 2-4, vather fleshy; stamens 1-2; seed shining, the margin acute. (Blitum maritimum, Nutt.) - Sea-coast of Northern States, and in saline places to Minn. (Eu.)

5. C. capitàtum, Watson. (Strawberry Blite.) Stem ascending, branching; leaves triangular and somewhat halberd-shaped, sinuate-toothed; 
clusters simple (large), interruptedly spiked, the upper leafless; stamens 1-5; calyx berry-like in fruit; seed ovoid, flattish, smouth, with a very narrow margin. (Blitum capitatum, L.) - Dry rich gromud, along the fireat Lakes, northward and westward. The calyx becomes pulpy and bright red in fruit, when the large clusters look like strawherries. (Eu.)

\$4. Aunual, not mealy, but more or less glandular-pubesrent, aromutir; calyx 2-3-parted, dry in fruit; seed often vertiral; embryo wot a complete ring.

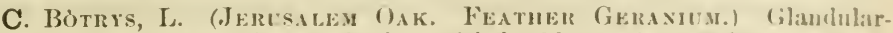
pubescent and viscid; leures slender-petioled, oblong, obtuse, sinuate-pinnatifid; racemes cymose-diverying, loose, leajless'; fruit not perfectly enclosed. Widely introduced. (Nat. from Ein.)

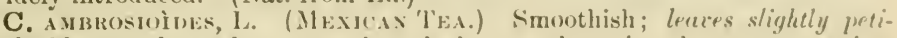
oled, oblong or lanceolate, repand-toothed or uearly entire, the upper tapering to both ends; spikes densely flowered, leafy, or intermixed with leaves; fruit perfectly enclosed in the calyx. - Waste places, common throughout our range, especially soutliward. (Nat. from Trop. Amer.)

Var. Axthelmíntioum, Gray. (Woruseew.) Leaves more strongly toothed, the lower sometimes alınost laciniate-pinnatifil; spikes more elongated, mostly leafless. - From Long Island and southward, west to Wisc. and Tex. (Nat. froin 'Trop. Amer.)

\section{ROU B I E V A, Moquin.}

Flowers minute, perfect or pistillate, solitary or 2-3 together in the axils. Calyx urceolate, 3-5-toothed, becoming enlarged and saccate, contracted at the apex and enclosing the fruit. Stameus 5, included; styles 3, exserted. Fruit membranaceous, compressed, glandular-lotted. Seed vertical. Embryo annular. - Perennial glandular herb, with alteruate pinnatifil leaves.

R. wLLtfFIDA, Moq. Prostrate or ascending, branching and leafy; leares lanceolate to linear $\left(\frac{1}{2}-1 \frac{1^{\prime}}{2}\right.$ long), deeply pinnatifid with uarrow lobes; fruiting calvx oborate. (Chenopodium multifidum, L.) - Sparingly introduced in the Atlantic States. (Adv. from S. Amer.)

\section{5. Á TRIPLEX, Tourn. Orı́ne.}

Flowers monœrions or diccious; the staminate like the flowers of Chenoporlium, but sterile by the abortion of the pistil; the fertile cousisting simply. of a naked pistil enclosed between a pair of appressed foliaceous bracts, which are enlarged in fruit, and sometimes united. Seed vertical. Embryo coiled into a ring around the albumen. In one section, incluling the Garlen Orache, there are some fertile flowers with a calyx, like the staminate, but without stamens, and with horizontal seeds. - Herbs (ours anuuals) usually mealy or scurfy with bran-like seales, with spiked-clustered flowers; in summer and sutumn. (The ancient Latin name, a corruption of the Greek, àrpdфałıs.)

A. Rósecu, I. Hoary-mealy; leaves short-petioled or the upper sessile, rhombic-ovate or ohlong with a wedge-shaped base, coarsely sinuate-tonthed; fertile flowers mostly clustered in the axils; fruiting liracts boal, often cuttoothed and warty. - Sparingly introduced at the east. (Adv. from ku.)

1. A. pátulum, L. Erect or prostrate $\left(1-4^{\circ}\right.$ high), llark green aud glabrous or somewhat scurfy; leaves narrowly lanceolate-hastite ( 1 - $4^{\prime}$ long), the lower sometimes opposite, entire or sparingly sinuate-dentate, petioled, the upper laneeolate to linear; flowers clustered in rather slender spikes, the two kinds together or separate; fruiting loracts ovate-triangular or rhombichastate, entire or thothed, often muricate on the back, united to near the 
middle. - Very variable. The typical form scarcely occurs except as naturalized from Europe.-Var. HastAтus, Gray. Erect or spreading, stout, at least the lower leaves broadly triangular-hastate, often coarsely and irregularly toothed. Salt and brackish places, on the coast from Can. to Va., along the Great Lakes, and far westward. - Var. Littokd Le, Gray. Slender; leaves linear-lanceolate to linear, rarely subhastate or toothed. Canada to N. J., and westward along the Great Lakes. - Var. subspicàtum, Watson. A low erect and often simple form (3-12' high), usually quite scurfy; leaves lanceolate-hastate $\left(\frac{1}{2}-1^{\prime}\right.$ long). Minn. to central Kan., and westward.

2. A. arenàrium, Nutt. Silvery-mealy, diffusely spreading; leaves oblong, narrowed at base, nearly sessile; fruiting bracts broadly wedge-shaped, united, 3-nerved, 2-5-toothed at the summit, and usually strongly muricate and reticnlate on the sides. - Sandy beaches, along the coast, Mass. to Fla.

3. A. argénteum, Nutt. Usually low, much branched, gray-scurfy, leafy; leaves deltoid or subrhombic, often subhastate; staminate flowers in terminal spikes; fruiting bracts round-rhombic, indurated, united, the free margins more or less dilated and deeply toothed, the sides variously appendaged.-Red River Valley, Minn., south and westward.

\section{CORISPÉRIU M, A. Juss. Bug-SEed.}

Flowers perfect, single and sessile in the axils of the upper leaves reduced to bracts, usually forming a spike. Calyx of a single delicate sepal on the inner side. Stamens 1 or 2, rarely 5. Styles 2. Fruit oval, flat, with the outer face rather convex and the inner concave, sharp-margined, a caryopsis, i. e. the thin pericarp adherent to the vertical seed. Embryo slender, coiled around a central albumen. - Low hranching anmuals, with narrow linear alternate 1-nerved leaves. (Name formed of кópıs, a lug, and $\sigma \pi t \rho \mu a$, seed.)

1. C. hyssopifolium, L. Somewhat hairy when young, pale; floral leaves or l,racts awl-shaped from a dilated base or the upper ovate and pointerl, scarious-margined; fruit wing-margined. - Sandy beaches along the Great Lakes, central Neb., Tex., and westward. - Leaves usually pungent.

\section{SALICór N I A, Tourn. Glassmont. Samphire.}

Flowers perfect, 3 together immersed in each hollow of the thickened upper joints, forming a spike; the two lateral sometimes sterile. Calyx small and bladder-like, with a toothed or torn margin, at length spongy and narrowly wing-bordered, enclosing the flattened thin utricle. Stamens 1 or 2. Styles 2, nnited at base. Seed vertical, without albumen. Embryo thick, the cotyledons incumbent upon the radicle.- - Low saline plants, with sncculent leafless jointed stems, and opposite branches; the flower-bearing branchlets forming the spikes. (Name composed of sal, salt, and cormu, a horn; saline plants with horn-like branches.)

1. S. mucronàta, Bigel. Annual, erect, stout, naked below (2-12' high), turning red in age; spikes thick, closely jointed; scales mucronute-pointed and conspicuous, especially when dry; middle flower half higher than the lateral ones or less, occupying nearly the whole length of the joint; fruit pubescent; seed $\frac{1}{2}-\frac{8^{\prime \prime}}{4}$ long. (S. Virginica, Gray, Manual; not L.) - Sea-coast from N. Scotia to Va. 
2. S. herbàcea, I. Anuual, erect or at length sprealing $\left(6-18^{\prime}\right.$ high $)$, green; scales obscure and very blunt, making a truncate barely emarginate termination of the longer joints of the stem or elunguted narrouer spikes; midlle flower much higher than the lateral oues, slightly shorter than the joint; fruit pubescent; seed $\frac{3}{3}-l^{\prime \prime}$ long. - Salt marshes of the coast and interior salt springs, and alkaline localities.

3. S. ambigua, Michx. Numerons tufted stems $\left(3-12^{\prime}\right.$ long) decumbent or ascending from a hard and rather uoody creeping buse or rootstoch, greenish, turning learl-colored; spikes sleniler, short-jointed, the scules short, arutish or ucute: flowers nearly equal in height and eqnalling the joint; seed pubescent, $\frac{1}{8}$ "long. (S. fruticosi, var. ambigua, Gray, Manual.) - Sea-coast, Mass. to Fla. and Tex.

\section{SU 宛D A, Forskal. SEA BLITE.}

Flowers perfect, sessile in the axils of leafy bruts. Calyx 5-parted, fleshy, enclosing the fruit (utricle) and often carinate or crested. Stamens 5 . Stigmas 2 or 3 . Seed vertical or horizontal, with a flat-spiral embryo, dividing the scanty albumen (when there is any) into two portions. - Fleshy saline plants, with alternate nearly terete linear leaves. ( $A$ u $\Lambda$ rabic nams.)

1. S. lineàris, Moq. Annual, prostrate or usually erert, $1-2^{\circ}$ high, branched; leaves nuriou ut buse, $\frac{1}{2}-2^{\prime}$ long, acute; floral loracts acuminate, on slender branchlets; sepals very thick; anthers exserterl; secel horizontal, round-oval, black, $\frac{1}{2}$ " brual. (S. maritima, firuy; not Dumort.) - Sea-coast, N. Scotia to Fla. - A toubtful form of E. Mass. has the hracts and shorter leaves obtuse, larger fluwers on less slender branchlets, and reddish seeds nearly l" broaul.

2. S. depréssa, Watson. Annual, decumbent or erect, branching from the base; leates broudest "t buse, the cauline 3-12" long, the floral lanceolate to ovate; one or more of the calyx-lobes rery strongly carinate or crested. Saline soil, Red River Valley, Minn., to Col, and westward.

\section{SÁLSOLA, L. SALTwort.}

Flowers perfect, with 2 bractlets. Calyx 5-parted, persistent and enclosing the depressed fruit in its base; its divisions at length horizontally winged on the back, the wings forming a broal and circular s(arious border. Stamens mostly 5. Styles 2. Seed horizontal, without albumen, filled by the embryo, which is coiled in a conical spiral (cochleate). - Herbs or slightly shrubly hranching plants of the sea-shore, with fleshy and rather terete or awl-shaped leaves, and sessile axillary flowers. (I)iminutive of sulsus, salty.)

1. S. Kàli, I. (Commox SAltwort.) Annual, diffusely branching. bushy, rough or smoothish; leaves all alternate, awl-shaped, pricky-puintel; flowers single; calyx with the converging lobes forming a sort of heak orer the fruit, the large rose or flesh-colored wings nearly orbicular and sprealing. - Sandy sea-shore, N. Eng. to Ga. Ang. (En.)

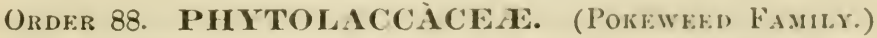

Plants with alternate entire leaves and perfect flowers, having the generul characters of Chenopodiacex, but usually a several-celled ovary composul of as many carpels uniled in a ring, and forming a berry in fruit. 


\section{PHYTOLÁ CCA, Tourn. Pokeweed.}

Calyx of 5 rounded and petal-like sepals. Stamens 5-30. Ovary of 5-12 carpels, united in a ring, with as many short separate styles, in fruit forming a depressed-globose 5-12-celled berry, with a single vertical seed in each cell. Embryo curved in a ring around the albumen. - Tall and stout perennial herbs, with large petioled leaves, and terminal racemes which become lateral and opposite the leaves. (Name compounded of quróv, plant, and the French lac, lake, in allusion to the crimson coloring matter which the berries yield.)

1. P. decándra, L. (Commox Poke or Scoke. Garget. PigeoxBERrY.) Stamens and styles 10. - Low grounds. July-Sept. - A smooth plant, with a rather unpleasant odor, and a very large poisonous rout, often $4-6^{\prime}$ in diameter, sending up stout stalks at length $6-9^{\circ}$ high ; calyx white ; ovary green; berries in long racemes, dark-purple and filled with crimson juice, ripe in autumı.

\section{Order 89. Polygonaceas. (Buckwheat family.)}

Herbs, with alternate entive leaves, and stipules in the form of sheaths (ocrex, these sometimes obsolete) above the sucllen joints of the stem; the flowers mostly perfect, with a more or less persistent calyx, a 1-celled orary bearing 2 or 3 styles or stigmas, and a single erect orthotropous seed. Fruit usually an achene, compresserl or 3-4-angled or -wingerl. Fmbryo curved or straightish, on the outside of the albumen, or rarely in its centre. Stamens 4-12, inserted on the base of the 3-6-cleft calyx. (Juice often acrid, sometimes agreeably acid, as in Sorrel; the roots, as in Rhubarb, sometimes (athartic.)

* Flowers involucrate; stauens 9 ; stipules none.

1. Eriogonum. Involucre several-flowered, with flowers exserted. Calyx 6-cleft.

* Flowers without involuere; stamens 4 to 8 .

- Stipular sleaths nuanifest; ovule erect from the base of the cell.

+4 Sepals 4 or 6 , the outer row reflexed, the iuner erect and enlarging in fruit.

2. Oxyria. Sepals 4. Stignias 2. Achene orbicular-winged. Leaves reniform.

3. Rumex. Sepals 6 . Stignıs 3 , Achene 3-angled.

++ ++ Sepals 5 (sometimes 4), equal and erect in fruit. Achene triangular or lenticular.

4. Polygonum. Embryo slender, curved around one side of the albumen. Pedicels mostly fascicled.

5. Facopyrum. Enbryo in the albumen, its very broad cotyleclons twisted-plaited.

6. Polygonella. Enbryo slender, nearly straight. Pedicels solitary. Leaves jointed it base.

+ + Stipules obsolete; ovule hanging from the apex of a slender stalk.

7. Brunnichia. Calyx 5-parted, in fruit with a wing decurrent on the pedicel. Tendrileliuber.

\section{ERIÓ GON UM, Michx.}

Flowers perfect, involucrate; involucre 4-8-toothed or lobed, usually manyflowered; the more or less exserted pedicels intermixed with narrow scarious bracts. Calyx 6-parted or -cleft, colured, persistent about the achene. Stamens 9 , upon the base of the calyx. Styles 3 ; stigmas capitate. Achene 
triangular. Embryo straight and axile, with foliaceous cotyledenss. - Innuals or perenuials, with radieal or alteruate or whorled entire leaves, without stipules. (Name from є́pıov, ưoul, and gúvo, knee.)

1. E. ánnuum, Nutt. Amnal, erect, leafy, naked above, 2" high, whitefloccose-tomentose throughout; leaves ol,long-lancolate, accute at hoth r.nds, short-petiolate, Hat ; bracts small, triangular; involucres numerous in terminal cymes, turbinate, shortly perlicelled, I-1 f" long, very tomentusin; flowers white, the outer sepals obloug-obovate, l" long or less. - Central hian. to (onl., and southwarl.

\section{OXÝRIA, Hill. Mouxtax Sorrel.}

Calyx herbaceous, of 4 sepals; the outer smaller and spreading, the inner broaler and erect (but unchanged) in fruit. Stamens 6. Stigmas 2, spssile, tufted. Achene lenticular, thin, flat, much larger than the calyx, surrounded by a broad veiny wing. Seed flattened contrary to the wing. Embryostraight, in the centre of the albumen, sleuter. - Low alpine perennial, with romukilney-form and long-petioled leaves chiefly from the root, oblipuely truncate sheaths, and small greenish Howers clustered in panicled racemes on a slender scape. (Name from ógús, sonr, in allusion to the acill leaves.)

1. O. dígyna, llill. Leaves all round-kidney-form, usually noteloel at the end; fruit orbicular. - Mlpine region of the White Mts., and far morth and westward. (Eu.)

\section{3. $\mathbf{R} \mathbf{U} \mathbf{M} \mathbf{X}$, I. Dоск. Sorrit.}

Calyx of 6 sepals; the 3 onter herbaceons, sometimes mited at base, sprearling in fruit; the 3 inner larger, somewhat colored, enlarged after flowering (in fruit called valies) and convergent over the 3-angled achene, veiny, often bearing a grain-like tubercle on the back. Stamens 6. Styles 3; stigmas tufted. Embryo slightly curved, lying along one side of the albumen, slender. - Coarse herbs, with small and homely (mostly green) flowers, which are crowled and commonly whorled in panicled racemes; the petioles somewhat sheathing at base. ('The ancient Latin name; of unknown etymology.)

§ 1. LÁد'THUM. (1)ock.) Flowers perfect or monuciously polygumous; herbage not sour or szarcely so; none of the leaves hulberd-shuped. (Floucring through the summer.)

* Perennials, $1-7^{\circ}$ high, mostly uith fusiform roots; valies not bearing lristles.

+ Talves (large, 3 " broad or more, thin) all naked or nue with "s small grain.

R. Patiésia, L. (Patizace Dock.) A very tall species, with owateoblong and lanceolate leaves (broadest aluve the hatse), those from the root 2 $3^{\circ}$ long, and one of the heart-shaped no:arly or quite entire valves ( $3^{\prime \prime}$ hroall) bearing a small grain, or its millrib thickened at base. $-\mathrm{N}$. Ling. and N. Y. (Ailv. from Eu.)

1. R. venosus, P'ursh. Stems from ruming rootstocks, erect ( ${ }^{\circ}$ high or less), with conspicunus dilated stipules; leaves on short hut rather slender petioles, ovate or oblong to lanceolite $\left(3-6^{\prime}\right.$ long $)$, acute or acuminate, only the lowest obtuse at base; panicle nearly sessile, short, clense in fruit; valves entire, glandless, broadly cordate with a deep sinus, $9-12$ " in diameter, lright rose-color. - Sask. to central Mo. and Kan., aud westwarl. 
- Valves smaller, one or more of them conspicuously grain-bearing.

- Indigenous; leaves not wav'y, none heart-shaped, except the lowest of $\mathbf{n} . \mathbf{5}$.

2. R. Británnica, L. (Great WAter-Dock.) 'Tall and stout $\left(5-6^{\circ}\right.$ high); leaves oblong-lanceolate, rather acute at both ends, transversely veined, and with obscurely erose-crenulate margins (the lowest, inclucling the petiole, $1-2^{\circ}$ long, the middle rarely truncate or obscurely cordate at base); racemes upright in a large componud pa _icle, nearly leafless; whorls crowded; pedicels capillary, nodding, about twice the length of the fruiting caly. $x$; the vulves orlicular or round-ovate, very obtuse, obscurely heart-shaped at base, finely reticulated, entire or repand-denticulate $\left(2-3^{\prime \prime}\right.$ broad), all grain-bearing. (R. orbiculatus, Gray.) - Wet places, N. Eng. to N. J., west to Minn. and Kan.

3. R. altíssimus, Wood. (PALE Dock.) Rather tall (2-6 high); leaves ovate-or oblong-lanceolate, acute, pale, thickish, obscurely veiny (the cauline 3-6' long, contracted at base into a short petiole); racemes spike-like and panicled, nearly leafless; whorls (rowded; pedicels nodding, shorter than the fruiting calyx; valves broadly orate or obscurely heartshaped, obtuse or acutish, entire, loosely reticulated (about $2^{\prime \prime}$ broad), one with a conspicuous grain, the others with a thickeued midrib or naked. (R. Britannica, Gray; not L.) - Moist grounds, N. Y. and N. J. to Minn. and Kan.

4. R. salicifolius, Weimmann. (Whгте Dock.) Rather low ( $1-3^{\circ}$ high); root white; leares nurrowly or linear-lanceolate, or the lowest oblong; whorls much crowiled; pedicels much shorter than the fruiting calyx; ralves deltord-oxate, obtusish or acutish (about $1 \frac{1}{2}$ " long), one, two or sometimes all with a conspicuous often very large grain; otherwise nearly as n. 3. - Salt marshes, from Newf. to N. Eng., about the Great Lakes, and far westwart.

5 R. verticillàtus, L. (Swaup Dock.) Rather tall (3-5 high); leaves lanceolate or oblong-lanceolate, rather obtuse, thickish, pale-green, the lowest often heart-shaped at base; racemes nearly leafless, elongated, Iovse, the whorls crowled or the lower ones distant; fruit-bearing pedicels slender, clubshaped, abruptly reflexed, $3-4$ times longer than the fruiting caly. ; valves dilatedrhomboid, obtusely somexhat pointed, strongly rugose-reticulated, each bearing a very large grain. - Wet swamps, common.

+.. Naturalized European weeds; lower leaves mostly heart-shaped at base.

R. Críspis, I, (Cirled Dock.) Smooth (3-4 high); leaves with strongly wavy-curled margins, lanceolute, acute, the lower trumcate or scarcely heart-shaped at base; whorls crouded in prolonged wand-like raremes, lenffess chove; valies round-heart-shuped, obscurely denticulate or entire, mostly all grainhearing. - In cultivated and waste ground, very common. A hybrid of this with the next is reported from Mass., N. Y., and Mcl.

R. obtcifòlils, L. (Bitter Dock.) Stem ronghish; louest leaves ovate-licart-shaped, obtuse, rather downy on the veins beneath, somewhat warymarginerl, the upper oblong-lanceolate, acute; whorls loose and distant: ralies orate-halberd-shuped, with some sharp axt-shaped teeth at base, strongly reticulaterl, one of them principally grain-bearing. - Fields, etc., common.

R. sixfifnets, L. Lenives oblong-lanceolate, often fildle-shaped, wavymargined; whorls distant, in long slender leafless spikes; pedicels rery short, jointed at base ; valres namouly oblong, obtuse, entire, one at least grain-bearing ; reins of the leaf red, or green. - Waste and cultivated gromnd.

R. Congloneratrs, Murray. (Smaller Greex Dock.) Iike the last, but leaves not fidlle-shaped, and panicle leafy; pericels short, jointed below the middle; valies acutish, all grain-bearing. - Moist places. 
* Annuals, low; valves bearing long au'ns or bristles.

6. R. marítimus, L. (GoLbs: I)ock.) Minutely pulsescent, diffusely branched, 6-12' ligh; leaves lance-linear, way'-margined, the lower auricled or heart-shaped at base; whorls excessively crowderl in leafy aud compact or interrupted spikes; valves rhombic-oblong, lance-pointed, each bearing $2-3$ long awn-like bristles on each site, and a large grain on the hatck. - Sea-shore, Mass. to N. C.; also from Ill. to Minn., and westward.

§ 2. ACE'TÓSA. (Somme.) Flouers dicecious, smull, in a terminal naked panicle: herbage sour; some leaves halberd-shaped; smouth perennials, spreading by running rootstocks, flowering in spring.

7. R. hastátulus, Balliw. Stem simple, $1-2^{\circ}$ high; leaves nearly as in the next; pedicels jointed at or below the midlle; valves of the fruiting caly.x round-heart-shaped, thin, finely reticulated, nakerl, many times larger than the uchene. (R. Engelmanni, Ledeb.) - S. IV. Ill. to L. Kan., Tex, and Fla.; Riverhead, Long Island (Youny).

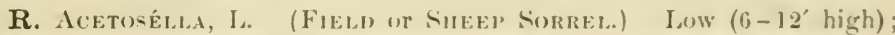
leaves narrow-lanceolate or linear, hall,erl-form, at least thuse of the root, the narrow lobes entire; pedicels jointed woth the flocer: interes secticely enlargung in finil, octer, naked. - Abundant evervwhere. (Nat. from Lin.)

R. Acetosi, I. (Sorrer. Iock.) Like the last, lut lulle (1 - $3^{\circ}$ high); leaves oblong or broally lanceolate; culves enlurging in finit and orluculur, the outer reflexed. - Clairlotte, Vt., and I'enn Yan, N. Y. (Nat. from Eu.)

\section{POLÝGONUM, Tourn. KNotwed.}

Calyx mostly 5-parted; the divisions often petal-like, all erect in fruit, withering or persistent. Stamens 4-9. Styles or stigmas 2 or 3 ; achene accordingly lenticular or 3-angular. Embryo placed in a groove on the ontsicle of the albumen and curved half-way around it; the radicle and usually the cotyledons sleuder. - l'edicels jointed. Ours all herbaceons, with filirous roots (except n. 19), flowering through late summer and early antumu. (Name composed of moגús, muny, and róvv, knee, from the numerous juints.)

§ 1. POLYGONLXI proper. Flouers in axillury fuscirles or spirate with foliaceous lnucts: leures and bracts jointed upon a very short petiole adnate to the short sheath of the 2-lohed or lacerute scarious stipules: stems striute: calyx 5-6-parted, usuully more or less herbarcous: stumens 3-8, the 3 inner filuments liroud at buse; styles 3 ; rotylestons momblent; ulbumen horny; glubrous ammuls, exrept n. 1. (\$ Avicularia, .Metsn.)

\section{* Leufy thronghout.}

1. P. maritimum, L. Perennial, at length wooly at hase (or sumetimes annual), prostrate, gluucons, the stont stems very shortly jointed: lences thick, oval to linear-oblong ( $3-10^{\prime \prime}$ loug), exceeding the nodes; stipules very conspicuous; sepals petaloid; stamens 8 ; achene smooth und shining, exserted.Sea-const from Mass. to Ga. (En.)

2. P. aviculàre, I. Slender, mostly prostrute or ascending, Ulush-green; leaves oblong to lanceolate $\left(3-10^{\prime \prime}\right.$ long), usually acute or acutish; sepuls hurdly $\mathbf{l}^{\prime \prime}$ long, green with piukish margius; stamens 8 (rarely 5); acheue dull and mimtely gramular, mostly included. - Common everywhere in yards, waste places, etc. (Eu., Asia.) 
3. P. eréctum, L. Stouter, erect or ascending $\left(1-2^{\circ}\right.$ high $)$, yellowish; leaves oblong or oval $\left(\frac{1}{2}-2 \frac{1^{\prime}}{2}\right.$ long), usually obtuse; flowers mostly $1 \frac{1}{2}$ "long, often yellowish, on more or less exserted pedicels; stamens 5-6; achene dull, included. (P. aviculare, var. erectum, Roth.) - Common, by waysides, etc.

* * Leaves much reduced above and bract-like.

4. P. ramosíssimum, Michx. Erect or ascending $\left(2-4^{\circ}\right.$ high $)$, yel . lowish-green; leaves lanceolate to linear (1-2 $\frac{1}{2}^{\prime}$ long), acute; flowers and achene as in n. 3, but sepals more frequently 6 , the stumens $3-6$, and the achene mostly smooth aud shining. - Sandy shores and banks of streams, I. Mass. to N. Y., west to Miun., Ark., 'Tex., and far westwarl.

5. P. ténue, Michx. Stem angled, erect $\left(\frac{1}{2}-1 \frac{1}{2}{ }^{\circ}\right.$ high), glabrous, or slightly scabrous at the nodes; leares narrowly linear to lanceolate $\left(1-2^{\prime}\right.$ long), 3-nerved, acute at each end and often cuspidate, the margins somewhat scabrous and at length revolute; flowers often solitary, nearly sessile; strmens 8 ; achene included, dull black. - Dry soil, N. Eng. to S. C., west to Minn., Mo., and 'T'ex.

6. P. campòrum, Meisin. Stem terete, erect or ascending $\left(2-3^{\circ}\right.$ high $)$, glabrous; leaves decuduous, linear to oblong, usmally short; pedirds slender, exserted firom the scurious sheuth; stamens 8. - E. Kan. to Tex.

§ 2. PERSICARIA. Flowers in dense spikes, with suall scarious bracts; leaves not jointed on the petiole; sheaths cylindrical, truncute, entire, naked or ciliate-finged or margined; calyx colored, 5-parted, apmessed to the fruit; stamens 4-8; filaments filiform; cotyledons accumbent.

* Sheaths and brasts not ciluate or firinged; sepals not punctute; style 2-cleft.

7. P. lapathifolium, L. Annual, branching, 1-40 high, glabrous or the peduncles often minutely glandular; leaves lanceolate, attenuate upward from near the cuneate base and acuminate, somewhat scabrous with short appressed hairs on the millrib and margin, or rarely floccose-tomentose beneath; sheaths and bracts rarely somewhat ciliolate; spikes oblong to linear $\left(\frac{1}{2}-2^{\prime}\right.$ long), dense, erect or nearly so ; flowers white or pale rose-color; stamens 6 ; achene ovate, rarely $\mathrm{l}^{\prime \prime}$ broad. (l'. nodosum, Pers. P. incarnatum, Man., in part.) - Wet places; N. Eng. and Can. to Ill., Wisc., and far westward. Very variable. (Eu.)

Var. incarnàtum, Watson. Leaves often large $\left(6-12^{\prime} \operatorname{long}, 1-3^{\prime}\right.$ wide) ; spikes more slenter and elongated $\left(2-4^{\prime}\right.$ long), nodding. (P. incarnatum, Ell.) - Penn. to 11l., Mo., and southward.

Var. incánum, Koch. Low (6-12' high); leaves small, obtusish, more or less hoary leneath with floccose tomentum; spikes short. - Cayuga Lake, N. Y., ()nt., shores of L. Superior, and northwestward (Eu.)

8. P. Pennsylvánicum, L. A similar species, but the branches abore and! sspeciull!y the peduncles beset with stipitate glands : flowers lirger and often bright rose-color, in short erect spikes, often on exserted perlicels; stamens usually 8 ; achene nearly orbicular, over $1^{\prime \prime}$ broad. - Moist soil, in open waste places, common.

9. P. amphíbium, L. Perennial, aquatic or rooting in the mud, stout and giabrous or nearly so, not branching above the rooting base; leares usually flouting, thick, smooth and shining above, mostly long-petioled, elliptical 
to ollong or sometimes lanceolate, acutish, cuneate or corclate at hase $\left(2-5^{\prime}\right.$ lopg); spike terminal, dense, ovate or ublong ( $\frac{1}{2}-I^{\prime}$ long) ; flowers bright rusecolor ( $1 \frac{1}{2}-3^{\prime \prime}$ loug); the 5 stamens and 2-cleft style exserterl. - Widely distributed and rather common. (En., Asia.)

10. P. Muhlenbérgii, Watson. Perenial, in muddy or dry places, decumbent or suberect, scabrous with short appressed or glandular hairs; laves thinner, rather broadly lanceolute, narroxly acuminute $\left(4-\tau^{\prime} \mathrm{l}\right.$ mg $)$; spilies more elonguted (1-3'long), often in pairs; flowers and fruit nearly as in the last. (1'. amphibium, var. terrestre, Giray, Mamual ; not Leers.) - N. Ling. to Flis. westward across the continent.

* * Sheaths and bracts bristly ciliute or the sheathis foliaceonsly margined.

- Sepals not punctate; style 2-cleft; achene someuhut flattenal.

11. P. Hartwrightii, Gray. Perennial, very closely allied to n. 9, growing usually in mul, the ascending stems rooting at hase and very leafy, more or less rongh-hairy, at least on the sheaths and hracts, the former ciliate and often with alungtly spreading foliureons borders; leaves rather narrow (2-7' long), on very short petioles; flowers and finit as in n. 9. - N. Eng. aml N. Y., to Minn., Iowa, and far westward. When growing in water the floating leaves are thicker and glabrous.

12. P. Càreyi, Olney. Annual, erect, the stem $\left(3-5^{\circ}\right.$ ligh $)$ and peduncles ylandular-luristly; leuces narrouly lanceolate, attenuate to both ends, roughish; sheaths eiliate or sometimes margined; spikes slencler, loose and nodding; flowers purplish; stamens mostly 5. - Shady swamps, S. Maine and N. II. to Penn. and Unt.

P. oriextale, L. (P'rixce's Feather.) 'Tall l,ranching annual, sofhairy; leaves ovute or oblong, pointed, distinctly petioled; sheuths ciliate or often with an abrupt spreading border; flowers large, brightit rose-color, in $d$ 'nse cylindricul noddiug spikes; stumens 7 . - Sparingly escaped from gardens into waste grounds. (Adv. from India.)

P. Pkrsiciri., L. (I.Amy's 'Tutum.) Nearly smooth and glabrous (12$18^{\prime}$ high); sheatlss more or less bristly-ciliate; leaves lanceoliate, pointerl, roughish, often marked with a dark triangular or lunar sput near the midhle; sprikes ovoid or ollong, druse, erert, on smooth (or at least not glandular) pednncles; stamens mostly 6 ; styles hulf 2-3-rleft; achene gihhons-flattened or sometimes triangular, smooth and shining. - Waste and damp places, very common. (Nat. from Eu.)

+- Sepals conspicuously dotted and leaves punctate (except n. 13), with an id juice; style mostly 3-jnited, and achene triangular; shealhs bristle-fringed.

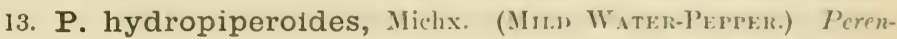
nial, not acrid; stem smooth $\left(1-3^{\circ}\right.$ high), branching; the narrow shenths hairy; leaves narrowly lanceolate, sometimes oblong; sprikes rect, slender, sometimes filiform, often interrupted at base ( $1-2 \frac{1}{2}$ long); flowers small, fleshcolur or nearly white; sepals nut dotted ; stermens 8; achene sharply triangular, smoth and shining. - Wet places and in shallow water; common, esprecially southward.

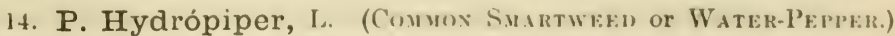
Annual, 1-2 high, smooth; leaves narmw! to linear-lanceolate; spikes nodding, usually short or intermuted; fluwers mostly grecnish; stamens 6; style 2-3-partesl; achene dull, minutely striate. - Moist or wet grounds; apparently introduced eastwaril, but indigenous north and westward. (Eu.) 
15. P. àcre, HBK. (Water Syartweed.) Perennial, nearly smooth; stems rooting at the decumbent base, $2-5^{\circ}$ high; leaves larger and longer than in the last, taper-pointed; spikes erect; flowers whitish, sometimes fleshcolor; stamens 8; style mostly 3-parted; achene smooth and shining. - Wet places; common, especially southward.

§3. BISTÓRTA. Glabrous alpine perennials, with thick creeping rootstocks and simple stems; flowers in a spike-like raceme; calyx colored, deeply 5cleft; stamens 8 ; styles 3 , long.

16. P. vivíparum, I. Smooth, dwarf $\left(4-8^{\prime}\right.$ high), bearing a linear erect spike of flesh-colored flowers (or often little red bulblets in their place); leaves lanceolate. - Alpine summits of N. Eng., shores of L. Superior, and northward. (Eu.)

§ 4. TOVARA. Perennials; flouers in lonse nated long and slender spikes; calyx rather herbareous (greenish), unequally 4-parted; stumens 5; styles 2, distinct, rigid and persistent on the smooth lentirular achene.

17. P. Virginiànum, L. Almost smooth; stem terete, upright $\left(2-4^{\circ}\right.$ high); sheaths cylindrical, hairy and fringed; leaves ovate, or the upper ovatelanceolate, taper-pointed, rounded at the base, short-petioled, rough-ciliate (3$6^{\prime}$ long); flowers $1-3$ from each bract, somewhat (urved, the styles deflexed in fruit, minutely hooked. - Thickets in rich soil, common. (Asia.)

§5. TINIARIA. Anmuals or peremials, mostly twining or climbing, and with petioled cordate or sagittute leaves; flouers in loose panicles or rucemes or in terminal or axillary clusters; calyx green with colored margins, 5- (rarely 4-) parted; stamens mostly 8 ; styles or stigmas 3 (2 in n. 18).

* Annuals, erect, or somewhat climbing by reflexed prickles on the angles of the stem and petioles; sepals (pale rose-color or white) not keeled; bracts chaff-like.

18. P. arifolium, L. (Hatberd-leaven Tear-tirmb.) Stem groovedangled; leaves halberd-shaped, taper-pointed, long-petioled; flowers somewhat racemed (few); peduncles glandular-bristly ; calyx often 4-parted ; stamens 6 ; styles 2, very short; achene lenticulur (large). - Low grounds. (Asia.)

19. P.sagittàtum, L. (Arrow-Leaven Tear-thumb.) Stem 4-analed; leaves arrow-shuped, short-petioled ; flowers capitate; peduncles smooth; stamens mostly 8; styles 3, slender; achene sharply 3-rny?ed. - Low grounds, common. - Slenrler, smooth except the angles of the stem and midrib beneath, which are armed with fine and very sharp saw-toothed prickles. (Asia.)

* Stems not prickly; calyx with the 3 outer divisions kceled, at least in fruit; flouters in loose panicled racemes; bracts short-sheathing.

P. Covrólvulus, L. (Black Bindweed.) Annual, twining or procum. bent, low, rouglish, the joints naked; leaves halberd-heart-shaped, pointed; flowens in small interrupted corymbose racemes; outer calyx-loles keeled; achene smoothish. - Cnlt. and waste grounds, common. (Nat. ifom Eu.)

20. P. cilinòde, Michx. Perennial, minutely douny; the sheaths fringed at the base with reflexed bristles; leaves heart-shaped and slightly halberdshaped, taper-pointed; racemes panicled; culyx-lolies obscurely keeled; achene very smooth and shining. - Copses and rocky hills, N. Eng. to mountains of N. C., west to Mich. and Minn. Climbing 3-9० high. 
21. P. dumetòum, L., var scándens, Gray. (Cumbixg FAlse BrскWneat.) Perennal, smooth; sheaths naked: leaves heart-shaped or slightly halberd-shaped, pointed ; racemes interrupted, leafy ; tho 3 outer culy.xlobes strongl!y keeled and in fruit winged; achene smorth and shining. - Moist thickets, common. Twining $8-12^{\circ}$ high over bushes.

P. cuspunitus, Sieh. \& Zuec. I'eremuial, erect, stout and tall, glahrous except the loose axillary panicled racemes; leaves round-ovate, shortly acilminate, truncate or corclate at base; outer sepals broadly winged in frint. Occasionally escaped from gardens. (Japan.)

\section{F A GO PỲ R U M, Tourn. Вıскинат.}

Calyx petal-like, equally 5.partel, withering and nearly unchanged in fruit. Stamens 8. Styles 3; stigmas capitate. Achene 3-sided, longer than the calyx. Embryo large, in the centre of the albumen, which it divides into 2 parts, with very broad and foliaccous plaited and twisted cotyledons. - Glabrons annuals, with triangular-heart-shaped or halberd-shaped leaves, semicylindrical sheaths, and corymbose racemes or panicles of white flowers, often tinged with green or rose-color. (Name from fugus, the hechl, and mupós, wheat, from the resemblance of the grain to the bech-nut; so the English name lunckwheat, from the German buche, beech.)

F. esculéxtcy, Moench. (Bискwisıt.) Smoothish; flower with 8 honey-bearing yellow-glauls interposed between the stamens; achene acute and entire, smooth and shining. - (1)l fields, remaining as a weed after cultivation, and escaping into copses. June-Sept. ( $\Lambda d v$. from Liu.)

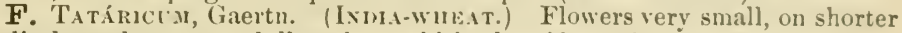
pedicels; achenc very dull and roughish, the sides sulcate. $-\Delta n$ occasional escape from cultivation. ( $A d \mathrm{~d}$. from $A$ sia.)

\section{POLYGONÉLLA, Michx.}

Flowers perfect or polygamous-diocious. Calyx 5-parted, petaloid, loosely persistent about the achene, the 3 inner divisions often enlarging in fruit, in which ease the outer are usually spreading. Stamens 8 . Styles 3 , and achene 3-angular Embryoslender, straight or nearly so, toward one side of the albumen. - Slender glabrous annuals or perennials, with alternate mostly linear leaves jointed at the hase, and rather rigid truncate or oblique naked sheaths and bracts. Flowers on solitary jointed pedicels (nodding in fruit) in slender panicled racemes. (1)iminutive of Polygonum.)

1. P. articulàta, Meisn. Annual, erect, branching, glauenus, 4-12' high; leaves linear filiform, deciduous; flowers rose-color, notding, in ver slender racemes, the calyx a little enlarged in fruit ; 3 inner filaments dilated at base; achene exserted, smooth. (Polygonum articulatum, Gray.) - Dry, sandy soil; on the coast from Maine to N. J., and along the Great Lakes.

\section{BRU N NÍCHIA, Bauks.}

Calyx 5-parted; the divisions somewhat petal-like, ollong, connivent and coriaceous in fruit, the base and almost the whole length of the pedicel winged on one side. Stamens 8; filaments capillary. Styles 3 , slender; stigmas depressed-capitate. ()rule pendulous on a slender erect funiculus; seed erect, 6-grooved. Achene obtusely triangular, partly 3-celled, enclused in the indırated calyx. Embryo in one of the angles of the mealy albumen, somewhat curved. - Somewhat shrubly with grooved stems, climbing by tendrils from the encis of the brauches. (Named for $F$. Brumnch, a Danish naturalist.) 
1. B. cirrhòsa, Banks. Glabrous; leaves orate or heart-shaped, pointed, entire; petioles dilated at base and partly clasping, but with no distinct sheath or stipules; flowers greenish, $2-5$ in a fascicle from the axil of an awl-shaped bract, these crowded in axillary and terminal racemes; pedicel jointed near the base; fruiting calyx with the wing $\mathrm{l}^{\prime}$ long. - S. Ill. to S. C. and Fla.

\section{Order 90. PODOSTEMÀCEA. (River-weed Family.)}

Aquatics, growing on stones in running water, some with the aspect of Sea-weeds, or others of Mosses or Liverworts; the minute naked flowers bursting from a spathe-like involucre as in Liverworts, producing a 2-3celled many-seeded ribbed capsule; - represented in North America by

\section{PODOSTÈ MON, Michx. River-weed.}

Flowers solitary, nearly sessile in a tubular sac-like involucre, destitute of floral envelopes. Stamens 2, borne on one side of the stalk of the orary, with their long filaments united into one for more than half their length, and 2 short sterile filaments, one on each side; anthers 2-celled. Stigmas 2, aw1-shaped. Capsule pedicellate, oval, 8-ribbed, 2-celled, 2-ralred. Seeds minute, very numerous on a thick persistent central placenta, destitute of albumen. - Leaves 2-ranked. (Name from $\pi$ ovs, foot, and $\sigma \tau \dot{\eta} \mu \omega \nu$, stumen; the two stamens being apparently raised on a stalk by the side of the ovary.)

1. P. ceratophýllus, Michx. Leares rigid or horny, dilated into a sheathing base, above mostly forked into thread-like or linear lobes. - Not rare in shallow streams, E. Mass. to Minn., and southward. July-Sept. A small olive-green plant, of firm texture, resembling a Seaweed, tenacionsly attached to loose stones by fleshy disks or processes in place of roots.

\section{Order 91. Aristolochiàceat. (Birthwort Family.)}

Tuining shruls, or low herls, with perfect flowers, the conspicuous lurid calyx valiate in bul and coherent (at least at base) with the 6-celled ovary, uhich forms a many-seeded 6-celled capsule or berry in fruit. Stamens 612, more or less united with the style; anthers adnate, extrorse. - Leaves petioled, mostly heart-shaped and entire. Seeds anatropous, with a large Aeshy rhaphe, and a minute embryo in fleshy albumen. A small family of bitter-tonic or stimulant, sometimes aromatic plants.

1. Asarum. Stemless herbs. Stamens 12, with more or less distinct filaments.

2. Aristolochia. Caulescent herbs or twining shrubs. Stamens 6 , the sessile anthers adnate to the stigna.

\section{1. Ás $\mathbf{A} \mathbf{R} \mathbf{M}$, Tourn. Asarabacca. Wild Ginger.}

Calyx regular; the limb 3-cleft or parted. Stamens 12, with more or less distinct filaments, their tips usually continued beyond the anther into a point. Capsule rather fleshy, globular, lursting irregularly or loculicidal. Seeds large, thick. - Stemless peremnial herbs, with aromatic-pungent creeping rootstocks hearing 2 or 3 scales, then one or two kidney-shaped or heart-shaped leaves on long petioles, and a short-peduncled flower close to the ground in the lower axil; in spring. (An ancient name, of obscure derivation.).. 
\$1. Calyx-tube wholly adnate to the ourary, the tips inflexed in lud; filuments slender, much longer than the short anthers; style barely 6-Inlied at the summit, with 6 radiating thick stigmas; leaves a single puir, unspulled.

1. A. Canadénse, I. Soft-pubescent; leaves membranaceous, kidneyshaped, more or less puinted $\left(4-5^{\prime}\right.$ wide when full growu); calyx bell shapreul, the upper part of the short-peninted lobes willy and ahrupely spreading, brown-purple inside. - Hillsisles in rich wooks ; common, especially northwart.

\$ 2. Calyx-tube inflated bell-shaped, somewhat contructed at the thrort, its bass adnate to the lower half of the ovary; limb 3-cleft, short; unthers sessile on. nearly so, oblong-linear; styles 6, fleshy, diverying, 2-rleft, bearing a thick extrorse stigma below the cleft; leuves thickish, persistent, usually only one each year, often whitish-mottled; preduncle very short; rootstocks clustered, ascending.

2. A. Virgínicum, I. Nearly glahrous; leaces round-heart-shaped (about $2^{\prime}$ wide); (alyx short, reticulated within; anthers pointless. - V'a. tu Ga., in and near the mountains.

3. A. arifolium, Michx. Leaveshalberd-heart-shaped $\left(2-4^{\prime}\right.$ long); calyx oblong-tubular, with very short and blunt lobes; anthers ohtusely short-pointed. - Va. to Fla.

\section{ARISTOLOCHIA, Tourn. Bıтишогт.}

Calyx tubular; the tube varionsly inflated above the ovary, mostly contracted at the throat. Stamens 6 , the sessile anthers wholly aduate to the short and fleshy 3-6-lobed or angled style. Causule uaked, septicidally 6-valved. Sieeds very flat - Twining, climbing, or sometimes upright peremial herhs or shruls, with alternate leaves and lateral or axillary greenish or lurid-purple fluwers. (Named from reputed medicinal properties.)

\$ 1. Calyx-tube bent like the letter $S$, enlarged at the turo ends, the small limb obtusely 3-tobed; anthers contiguous in pairs (making 4 cells in " rou under each of the three truncate lobes of the stigma); lou herls.

1. A. Serpentària, L. (Virgixia Sxakzвоот.) Stems (8-15' high) branched at base, pubescent ; leaves ovate or oblong (or narower) from a heartshaped base or halherd-form, mostly acute or pointed; flowers all next the root, short-peduncled. - Rich woods, Comn. to Fla., west to Mich., Mo., and La. July. - The fibrous, aromatic-stimulant root is well kuown in medicine.

\$2. Calyx-tube strongly curced like a Dutch pipe, contructed at the mouth, the short limh obscurely 3-lobed; anthers contiguons in pairs under each of the 3 short and thick lobes of the stigma; very tall turining shivbs ; flowers fiom one or tuo of the superposed accessory axillary buds.

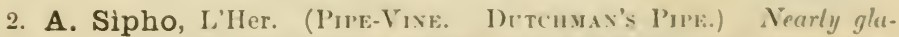
brous; leaves round-kidney-shuped (sometimes 8-12' hroad); peduncles with a

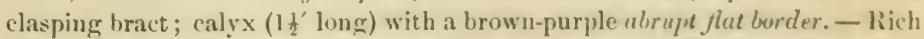
woods, Jeun. to Ga., west to Minn. and Kan. May.

3. A. tomentòsa, Sims. Dou'ny or soft-hairy; leates round-hoart-shuped, very veiny $\left(3-5^{\prime}\right.$ long); culyx yellowish, with an oblique dark purple closed orifice and a rugose reflexed limb. - Rich woods, mountains of X. C. to Fla., west to S. Ill. and Mo. June. 
§3. Calyx-tube straight, open, with ample 6-lobed limb, the lobes appendaged; anthers equidistant; erect herbs; flowers in axillary cymose fascicles.

A. Clemátitis, L., with long-petioled cordate leares, from Europe, is said to have permanently escaped near Ithaca, N. Y. (Ludley).

\section{Order 92. Piperaceat. (Pepper Family.)}

Herbs, with jointed stems, alternate entire leaves, and perfect flowers in spikes, entirely destitute of floral envelopes, and with 3-5 more or less separate or united ovaries. - Ovules few, orthotropous. Embryo heartshaped, minute, contained in a little sae at the apex of the albumen. The characters are those of the Tribe Saururea, the Piperacece proper (wholly tropical) differing in having a 1-celled and 1-ovuled ovary.

\section{S A U R Ù R U S, L. Lizard'S-TAIL.}

Stamens mostly 6 or 7 , hypogynous, with distinct filaments. Fruit somewhat fleshy, wrinkled, of $3-4$ indehiscent carpels united at base. Stigmas recurved. Seeds usually solitary, ascending. - Perennial marsh herbs, with heart-shaped converging-ribbed petioled leaves, without distinct stipules ; flowers (each with a small bract adnate to or borne on the pedicel) crowded in a slender wand-like and naked peduncled terminal spike or raceme (its appearance giving rise to the name, from $\sigma \alpha \hat{v} \rho o s$, a lizard, and oủ $\rho$, tail).

1. S. cérnuus, L. Flowers white, fragrant; spike nodding at the end; bract lanceolate; filaments long and capillary. - Swamps, Conn. to Ont., Minn., Mo., and southward. June-Aug.

\section{Order 93. Lauricefe. (Laurel Family.)}

Aromatic trees or shrubs, with alternate simple leaves mostly marked with minute pellucid dots, and flowers with a regular calyx of 4 or 6 colored sepals, imbricated in 2 rous in the bud, free from the 1-celled and 1-oruled ovary. and mostly fexer than the stamens; anthers opening by 2 or 4 uplifted valies. - Flowers clustered. Style single. Fruit a 1-seeded berry or drupe. Seel anatropous, suspended, with no albumen, filled by the large almond-like embryo.

* Flowers perfect, panicled; stamens 12, three of them sterile, three with extrorse anthers.

1. Persea. Calyx persistent. Anthers 4-celled. Evergreen.

** Flowers diœcious, or nearly so ; stamens in the sterile flowers 9 . Leaves deciduous.

2. Sassafras. Flowers in corymb- or umbel-like racemes. Anthers 4-celled, 4-valved.

3. Litsea. Flowers few in involucrate umbels. Anthers 4-celled, 4-valved.

4. Lindera. Flowers in umbel-like clusters. Anthers 2-celled, 2-valved.

\section{PÉrsea, Gaertn. Alligator pear.}

Flowers perfect, with a 6-parted calyx, persistent at the hase of the berry-like fruit. Stamens 12, in four rows, the 3 of the innermost row sterile and glandlike, the rest bearing 4-celled anthers (i. e. with each proper cell divided trans versely into two), opening hy as many uplifter valves; the anthers of 3 stamens turned ontwarl, the others introrse. - Trees, with persistent entire leaves, and small panicled flowers. (Au aucient name of some Oriental tree.) 
1. P. Carolinénsis, Nees. (R1:1) B.r.) Ho:ury with a fine lown, at least when young; leaves ublong, pale, soun sinooth abuve; peduncle bearing few flowers in a close cluster; sepals downy, the outer shorter; berries dark blue, on a red stalk. - Swamps, s. I)el. to Fla. aud 'lex. May. A small tree.

\section{SÁS SA F RAS, Nees.}

Flowers diocious, with a 6-parted spreatling calyx; the sterile kind with 9 stamens inserted on the base of the calyx in 3 rows, the 3 inuer with a pair of stalked glands at the hase of each; anthers 4-celled, 4-valved; fertile flowers with 6 short rudiments of stamens and an oroid ovary. Drupe ovoid (blue), supported on a club-shaped and rather fleshy reddish pedicel. - 'Trees, with spicy-aromatic bark, and rery mucilaginous twigs and foliage; leaves decidnous, often lobed. Fluwers greenisli-yellow, naked, in clustered and peduncled corymbed racemes, appearing with the leaves, iuvolucrate with scaly bracts. Leaf-buds sealy. (The popular mame, applied by the early Fremch settlers in Florida.)

1. S. officinale, Nees. Trees $15-125^{\circ}$ high, with yellowish-green twigrs; leaves ovate, entire, or some of them 3-lubed, suon glabrous. - lich woods, E. Mass. to S. Ont., Mich., E. Iowa and Kan., and sunth to the Gulf. A pril.

\section{LITSEA, Lam.}

Flowers dioceious, with a 6-parted deciduous calyx; the sterile with 9 stamens in 3 rows; their anthers all introrse, 4-celled, 4-valved; fertile fluwers with 12 or more rudiments of stamens and a globular ovary. 1)rupe globular. - Shrubs or trees, with entire leaves, and small flowers in axillary clustered umbels. (Name of ('hinese vrigin.)

1. L. geniculàta, Benth. \& Hook. (Poxy Spice.) Flowers (vellow) appearing before the deciduous oblong leaves, which are hairy on the midrib beneath; branches forked and divaricate, the branchlets zigzag; involucres 2-4-leared, 2-4-flowered; fruit red. ('Tetranthera geniculata, Nees.) Swamps, Va. to Fla. April.

\section{Lín dera, Thuab. Wild Allspice. Fever-Busii.}

Flowers polygamous-dicecious, with a 6-parted open calyx; the sterile with 9 stamens in 3 rows, the inner tilaments $1-2$-lobed and gland-bearing at base; anthers 2-celled and 2-valved; fertile flowers with 15 - 18 rudiments of stamens in 2 forms, and a globular ovary. Drupe obovoid, red, the stalk not thickened. - Shrubs, with deciduous leaves, and honey-yellow flowers in almost sessile lateral umbel-like elusters, appearing hefore the leaves (in our spocies); the clusters composed of smaller clusters or umbels, each of $4-6$ flowers and surrounded by an involuere of 4 deciduous seales. I,eaf-buds scaly. (Naned for John Linder, a swedisl botanist of the early jart of the 18th century.)

1. L. Benzòin, Blume. (Srick-nesu. Bexsamisusn.) Nearly smooth $\left(6-15^{\circ}\right.$ high); leaves oblong-obovate, pale underneath. - I)amp woods, N. Eng. to Ont., Mich., E. Kían., and southwaril. Mareh, April.

2. L. melissæfòlia, Blume. Young branches and buds pubescent; leaves oblong, obtuse or heart-shaped at base, downy beneath; umbels few. - Low grounds, N. C. to Fla., west to S. Ill. and Mo. April. 


\section{Order 94. THYMELAEÀEA. (Mezereum FAMILY.)}

Shrubs, with acrid and very tough (not aromatic) bark, entire leaves, and perfect flowers with a regular and simple colored calyx, bearing usually twice as many stamens as its lobes, free from the 1-celled and 1-ovuled ovary, which forms a berry-like drupe in fruit, with a single suspended anatropous seed. Embryo large; albumen little or none.

1. Dirca. Calyx tubular, without spreading lobes. Stamens and style exserted.

2. Daphne. Calyx-lobes (4) spreading. Stamens included. Style very short or none.

\section{Dírca, L. Leatherwood. Moosewood.}

Calyx petal-like, tubular-funnel-shaped, truncate, the border wavy or obscurely abont 4-toothed. Stamens 8 , long aud slender, inserted on the calyx above the middle, protruded, the alternate ones longer. Style thread-form; stigma capitate. Drupe oval (reddish). - A much-branched bush, with jointed branchlets, oval-obovate alternate leaves, at length smooth, deciduous, on very short petioles, the bases of which conceal the buds of the next season. Flowers light yellow, preceding the leaves, 3 or 4 in a cluster from a bud of as many dark-hairy scales, forming an involncre, from which soon after proceeds a leafy branch. (Name of uncertain derivation.)

1. D. palústris, L. Shrub $2-5^{\supset}$ high; the wood white, soft, and very brittle; but the fibrous bark remarkably tough (used by the Indiaus for thongs, whence the popular names). - Damp rich woods, N. Brunswick to Minn. and Mo., south to the Gulf. April.

\section{D Á P H N E, Linn. Mezereum.}

Calyx salver-shaped or somewhat funnel-shaped, the border spreading and 4-lobed. Stamens 8, includel; the anthers nearly sessile on the calvx-tube. Style very short or none; stigma capitate. Drupe red. - Harly low shrub. (Mythological name of the nymph transformed by A pollo into a Laurel.)

D. Mezk̀réx, I. Shrub $1-3^{\circ}$ high, with purple-rose-colored (rarely white) flowers, in lateral clusters on shoots of the preceding year, before the lanceolate very smooth green leaves; berries red. - Escaped from cultivation in Canada, Mass., and N. Y. Early spring. (Nat. from Eu.)

\section{Order 95. EleAGNAiceAe. (Oleaster Family.)}

Shrubs or small trees, with silvery-scurfy leaves and perfect or diocious flowers; further distinguished from the Mezereum Family by the erect or ascending albuminous seed, ancl the calyx-tube becoming pulpy and berry-like in fruit, strictly enclosing the achene.

1. Elseagnus. Flowers perfect. Stamens 4. Leaves alternate.

2. Shepherdia. Flowers diœeious. Stamens 8. Leaves opposite.

\section{EL无Á G N U S, Tourn.}

Flowers perfect. Calyx cylindric-campanulate above the persistent oblong or globose base, the limb valvately 4 -cleft, deciduous. Stamens 4 , in the throat. Style linear, stigmatic on one side. Fruit drupe-like, with an oblong, 8-striate stone. - Leaves alteruate, eutire and petioled, and flowers axillary and pedi- 


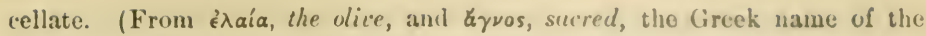
Chaste-tree, Vitex Aynus-rustus.)

1. E. argéntea, Pursh. (StLvik-BEkrr.) A stoloniferous unarmed shrub $\left(6-12^{\circ}\right.$ high), the younger branches covered with forruginus scales; leaves elliptic to lanceolate, undulate, silvery scurfy and more or less ferruginons; Howers numerous, deflexed, silvery withut, pale ycllow within, fra-

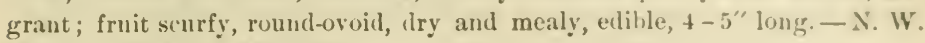
Minn. to Ctah and Montana.

\section{SHEPHÉRDIA, Nutt.}

Flowers dinecions; the sterile with a 4-parted calyx (valvate in the bud) and 8 stamens, alternating with as many processes of the thick disk; the fertile with an urn-shaped 4-cleft calyx, enclosing the ovary (the orifice cluserl by the teeth of the disk), and becoming herry-like in fruit. Style slender; stigma 1-sided. - Leaves opposite, entire, decidnous; the small flowers nearly sessile in their axils on the branches, clustered, or the fertile solitary. (Named for John Shepherd, formerly curator of the Liverpool botanic (iarden.)

1. S. Canadénsis, Nitt. Leaves elliptieal or orate, nearly naked and green above, silvery-lowny and scurfy with rusty scales beneatlı; fruit yellowish-red, insipid. - Rocky or gravelly banks, Vt. and X. Y. to Mich., Minn., and north and westward. May. - Shrul, $3-6^{\circ}$ high, the branchlets, young leaves, yellowish flowers, etc., covered with rusty scales.

2. S. argéntea, Nutt. (BLFralo-Berky.) Somewhat thorny, 5-18 high; leaves cuneate-oblong, silvery on both sides; fruit orvid, scarlet, acid and edible. - N. Minn. to Col., and westward.

\section{Order 96. LORANTHACEAs. (Mistletof Famly.)}

Shrubby plants with coriaceous greenish foliage, parasitic on trees, represented in the northern temperate zone chicfly by the Mistletoe and its near allies; distinguished from the next family more by the parasitic growth and habit, and by the more reduced flowers, thin by essential characters.

1. Phoradendron. Anthers 2-celled. Berry globose, pulpy. Leaves fuliaceous.

2. Arceuthobium. Anthers a single orbicular cell. Berry compressed, tleshy. Leaves scale-like, connate.

\section{PHORADÉ N D RON, Nutt. Filse Mistletoe.}

Flowers dicecious, in short catkin-like jointed sjuikes, usually several to each short fleshy bract or scale, and sunk in the juint. Calyx glubular, 3- (rarely 2-4-) lobed; in the staminate flowers a sessile anther is horme on the hase of each lobe, transversely 2-celled, each cell opening by a pore or slit; in the fertile flowers the calyx-tulie adheres to the ovary; stigmal scisile, ubtuse. Berry 1-secded, pulpy. Embryo small, half imbediled in the summit of mucilaginous albumen. - Yellowish-green woody parasites on the hranches of trees, with jointed much-branched wtems, thick and firm persistent leaves (or only scales in their place), and axillary small spikes of flowers. (Name composed of $\phi \omega \rho, a$ thief, and $\delta \varepsilon \nu \delta o \nu$, tree; from the parasitic habit.) 
1. P. flavéscens, Nutt. (Anericas Mistletoe.) Leaves obovate or oval, somewhat petioled, longer than the spikes, yellowish; berries white. On various deciduous trees, N. J. to S. Ind., Mo., and southward.

\section{ARCEUTH ȮBIUM, Bieb.}

Flowers axillary or terminal, solitary or several from the same axil. Calyx mostly compressed; the staminate usually 3-parted, the pistillate 2-toothed. Anthers a single orbicular cell, opening by a circular slit. Berry compresseil, fleshy, on a short recurved pedicel. - Parasitic on Conifers, glabrous, with rectangular branches and connate scale-like leaves; flowers often crowded in apparent spikes or panicles, opening in summer or autumn and maturing fruit the next autumn (From ă $\rho \kappa \epsilon u$ Oos, the juniper, and Bíos, life.)

1. A. pusíllum, Peck. Very dwarf, the slender scattered or clustereil stems 3-10" high, usually simple, olive-green to chestnut; suales obtuse; flowers solitary in most of the axils; fruit narrowly oblong, $\mathrm{l}^{\prime \prime}$ long. - On Alıes nugra; N. New York; Hanover, N. H. (Jesup).; Pocono Mt., Penn.

\section{Order 97. SANTALACEA. (Sandalwood Famly.)}

Herbs, shrubs, or trees, with entire leaves ; the 4-5-cleft calyx valvate in the bud, its tube coherent with the 1-celled ovary, which contains $2-4$ ovules suspended from the apex of a stalk-like firee central placenta which rises from the base of the cell, but the (indehiscent) fruit always 1-seeded. Seed destitute of any proper seed-coat. Embryo small, at the apex of copious albumen; radicle directed upward ; cotyledons cylintrical. Stamens equal in number to the lobes of the calyx, and inserted opposite them into the edge of the fleshy disk at their base. Style 1. A small order, the greater part belonging to warm regions.

1. Comandra. Flowers perfect, in umbel-like elusters. Low herbacenus perennials.

2. Pyrularia. Flowers dioecious or polyganous, in short spikes or racemes. Shrub.

\section{Comá N D R A, Nutt. Bastard Toad-Flax.}

Flowers perfect. Calyx bell-shaped or soon urn-shaped, lined above the ovary with an adherent disk which has a 5-lobed free border. Stamens inserted on the edge of the disk between its lobes, opposite the lobes of the calyx, to the middle of which the anthers are connected by a tuft of thread-like hairs. Fruit drupe-like or nut-like, crowned by the persistent calyx-lobes, the cavity filled by the globular seed. - Low and smooth (sometimes parasitic) perenuials, with herbaceous stems from a rather woody base or root, alternate and almost sessile leaves, and greenish-white flowers in terminal or axillary small umbel-like clusters. (Name from $\kappa \dot{\jmath} \mu \eta$, hair, and ă $\nu \delta \rho \in s$, for stumens, in allusiun to the hairs on the calyx-lobes which are attached to the anthers.)

1. C. umbellàta, Nutt. Stem $8-10^{\prime}$ high, branched, very leafy ; leaves oblong, pale ( $I^{\prime}$ long); peduncles several and corymbose-clustered at the summit, several-flowered; calyx-tube conspicnonsly continued as a neck to the dry globular-urn-shaped fruit; the lobes oblong; style slender. - Dry ground, common. May, June. Root forming parasitic attachments to the roots of trees.

2. C. pállida, A. DC. Leaves narrover, more glaucous and acuter, linear to narrouly lanceolate (or those upon the main stem oblong), all acute or some- 
what cuspiclate; fruit onoid, larger ( $3-4^{\prime \prime}$ lougr), sessilo or un short stmut pudicels. - IV. Minn. to S. IV. Kan., and westward.

3. C. lívida, Richardsen. Peduncles slember, arillary, 3-5-flumend, shorter than the oval leaves; (alyx-tuhe not continued heyoud the ovary, the lobss orcate; style short; fruit pulpy when ripe, red. - Newf., N. Vt., siusly shores of L. Superior, and northward.

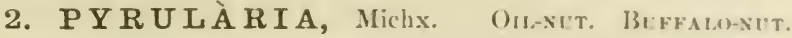

Flowers diœcious or polygamous. Calyx 4-5-cleft, the lohes reinrved, laairy-tufted at hase in the male flowers. Stamens 4 or 5 , on very short filatments, alternate with as muny rounded glands. Fertile flowers with a pearshaped ovary iuvested by the allherent tule of the calyx, naked at the that summit; disk with 5 glands; stỵle short and thick; stigma capitate-flattened. Fruit fleshy and drupe-like, pear shaped ; the globose endocarp thin. Embryo small ; albumen very vily. — Shrubs or trees, with alternate short-petioled and deciduous leaves; the small greenish fluwers in short and simple spikes or racemes. (Name a diminutive of Pyrus, from the shape of the fruit.)

1. P. pùbera, Michx. Shrub straggling (3-12 high), minntely downy when young, at length nearly glabrous; leaves ohovate-ublong, acute or pointed at both ends, soft, very veiny, minutely pellucid-punctate; spike small and few-flowered, terminal ; calyx 5-cleft; fruit l' long. (P'. oleifera, Cimu.) - Rich woods, mountains of Peun. to Gis. Whole plant, esperially the fruit, imbued with an acrid oil.

\section{Order 93. EUPHORBIA CIA. (SPURGe Fami.t.)}

Plants usually with a milky acril juice, and monæcious or direcious florers, mostly apetalous, sometimes achlamiydeous (occasionally polypetalous or monopetalous); the orary free and usually 3-celled, with a single or sometimes a pair of orules hanging from the summit of each cell: stigmas or branches of the style as many or trice as many as the cells: fruit commonly a 3-loberl capsule, the lolies or carpels separating elastically from a persistent axis and elastically 2-ralved; seel anatropous; embryo straight, almost as long as and the flat cotyledons mostly as wide as the Reshy or oily allumen. Stipules often present. - $\Lambda$ vast family in the warmer parts of the world; most numerously represented in northern countries by the genus Euphorbia, which has very reduced flowers within a calyx-like involuere.

* Flowers all withont calyx, inelnder in a eup-shaped calyx-like involuere, - the whole liablo to be mistaken for a single flower.

1. Euphorbia. Involuere surrounding nany staminate fluwers (each of a single naked stamen) and one pistillate flower (a 3-lolned pistil)

* Flowers with a calyx, withut involuere.

+ Seeds and ovules 2 in each eell ; fowers munecinns.

2. Pachysandra. Flowers in basal spikes. Calyx 4 -parted. Stamens 4, distinct.

3. Plyllanthus. Flowers axillary. Stamens 3, united. $\leftarrow+$ Seeds and ovules 1 in each cell.

a. Flowers apetalous, in cymose pranicles (2-3-chotomous); stamens 10, erect in the bud.

4. Jatropha. Calgx corolla-like, the staminate salver-form ; armed with stingiug hairs. 
b. Flowers in terminal racemes or spikes. Stamens inflexed in the bud. Stellate-downy or scurfy, or hairy and glanılular; leaves mostly entire.

5. Croton. Flowers spiked or glomerate. Ovary and fruit 3- (rarely 2-4-) celled.

6. Crotonopsis. Flowers scatteret on the branchlets. Ovary and fruit 1-celled.

c. Flowers in axillary spikes or racemes (except n. 9), apetalons (except n. 7). Stamens $\mathrm{S}$ or more; anthers ereet in the bud.

7. Argythamnia. Petals and sepals 5. Stamens $10-15$, united. Styles bifid, linear.

8. Acalypha. Calyx 4- (3-5-) parted. Stamens mostly 8. Fertile flowers in the axils of leafy bracts. Stigmas finely dissected.

9. Ricinus. Racemes terminal, subpanicled. Calyx 3-5-parted. Stamens very numerous; the filaments repeatedly branched. Styles 2-parted.

d. Flowers apetalous, in racemes or spikes pistillate at base. Stamens 2 or 3 . Styles simple.

10. Tragia. Flowers racemose. Calyx-lobes valvate in bud. Hirsute or pubescent.

11. Stillingia. Flowers spicate. Calyx-lobes imbricate in bud. Fertile bracts glanduliferuus. Glabrous.

\section{1. e e P H ÓRBiA, L. Spurge.}

Flowers monœcious, included in a cup-shaped 4-5-lobed involncre (flower of older authors) resembling a calyx or corolla, and usually bearing large thick glands (with or witlout petal-like margins) at its sinuses. Sterile flowers numerous and lining the base of the involucre, each from the axil of a little bract, and consisting merely of a single stamen jointed on a pedicel like the filament; anther-cells globular, separate. Fertile flower solitary in the middle of the involucre, soon protruled on a long pedicel, consisting of a 3-lobed and 3-celled ovary with no calyx, or a mere vestige. Styles 3, each 2-cleft; the stigmas therefore 6 . Pod separating into 31 -seeded carpels, which split elastically into 2 valves. Seed often caruncled (ours only in $\$ \S 5$ and 6). - Plants (herbs in the United States), with a milky acrid juice. Peduncles terminal, often umbellate-clustered; in the first section mostly appearing lateral, but not really axillary. (Named after Euphorbus, physician to King Juba.)

A. Glands of the involucre with petal-like, usually uchite or rose-co'ored, maryins or appendages; these almost obsolete in $\mathbf{1 .} 1$.

§1. ANISOPHÝLLLM. Leares all opposite, short-petioled, small, oblique at base; stipules aul-shaped or scaly and often firinged, persistent; stems much branched, spreading or usually procumbent; involucres solitary in the forks or in terminal or pseudo-lateral clusters, small, with 4 glands; seeds ashcolored (except in n. 10); annuals.

* Seeds smooth and even; leaves entire; whole plant glabrous.

1. E. polygonifòlia, L. Prostrate-spreading; leares oblong-linear, obtuse, mucronate, slightly corlate or obtuse at base $\left(4-8^{\prime \prime}\right.$ long); stipules setaceously dirided; peduncles in the forks, as long as the petioles; lobes of the involucre longer than the minute not appendaged glands; pods obtusely angled; seeds orate (over l" long, the largest of this section). - Sandy shores of the Atlantic and of the Great Lakes.

2. E. Géyeri, Engelm. Procumbent; leares oblong-ovate, obtuse, slightly mucronate, mostly acutish at base, lowermost curdate $\left(3-6^{\prime \prime}\right.$ long) ; stipules setaceously divided; peduncles as long as the petioles, at length in loose foliaceous lateral clusters; glands with narrow white or red appendages; pods 


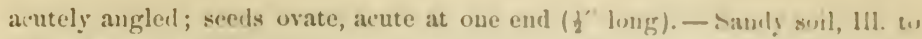
Wisc., Minu., and lian.

3. E. petaloidea, Engelm. liesembling the l:sst, hut halferect and

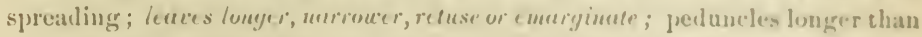
the petioles; involucres larger, the biocedly campunulate appe neluges much langer and conspicums; pud ubtuscly angled; seeds nearly l" long. - From lowa and Mo., westwarl.

4. E. sérpens, 1IBK. Stems filiform, prostrate, and of ten rooting; licses s round-ocute, obtuse or cordate at base (only $\frac{1}{2}-1 \frac{1}{2}{ }^{\prime}$ long ; stipules membrumeceons, trinngular; peiluncles much longer than the petioles, at length in luose foliaceous lateral dusters; glands of the very small involucre with monute cremulate appendayes ; pods acutely angled; seri?s obtusely angled ( $\frac{1}{2}$ " long or less). - lich soil, Ill. and Iowa to Kan., and sunchward. Rarely adv. eastward.

* * seeds minutely roughened or trunsversely "rinkled or pitted; leaves unore or less serrulute, smooth or often hairy.

5. E. serpyllifolia, l'ers. (ilabruns, prostrate-spreading; leaces obourute. oblon!, narrowed at the very oblique base, sharply serrulate tuward the ubtuse

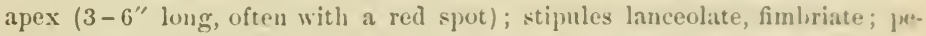
duneles as long as or longer than the petioles, at length in loose foliaceous lateral clusters; glands of the small involuere with narrow somewhat toothed appendages; prods sharply angled; sceds acutely quulrungular, slightly crossurinkled, often pitted (nearly $g^{\prime \prime}$ long). - Wisc. to Mo., and westwarl.

6. E. glyptospérma, Engelm. Glabruus (or very rarely puberulent), erect-spreading; leaves linear-oblong, mostly falcate, very uneçual at base, slightly serrulate towarl the obtuse apex $\left(2-5^{\prime \prime}\right.$ long); stipules lanceulate, setaceously divided; peduncles as long as the petioles, in dense foliaceous lateral clusters; glands of the very small involuere with narrow crenulate appendages; pods sharply angled; sceds shurply 4-ungled and with 5 or 6 shurp transverse urinkles ( $\frac{1}{2}$ "long). - Ont. to Wisc., Ill., Mo, and westward.

7. E. maculàta, L. l'rostrate; stems puberulent or hairy; leuves oblonglinear, very oblique at base, serrulate upward, more or less pubescent or sumetimes smoothish ( $4-6^{\prime \prime}$ long), usually with a brown-red spot in the centre; stipules lanceolate, fimbriate; pelumeles as long as the petioles, in dense foliaceous lateral clusters; glands of the small involucre minute, with narrow slightly crenate (usually red) appendages; pods acutely angled, pulerulent; seeds ovate ( $\frac{2}{5}$ " long), sharply 4-ringled and with ubout 4 shallow grooves across the concuve sides. - (t)en places, roulsides, etc., common.

8. E. humistràta, Engelm. I'rocumbent, juherulent or hairy ; leares elliptical or obocute, very ohlique at hase, serrulate toward the apex, sparsely hairy underneath $\left(4-9^{\prime \prime}\right.$ long, sometimes with a brown spot ahove); stipules lanceulate, fimbriate; peiluncles rather shorter than the petioles, in dense scarcely foliaceuns litural clusters; inculuere cleft on the beteh, its (rect or white) appendages truncate or crenate; pods sharply anglerl, pulerulent; serds ortule, obtusely angled, minutely roughened ( $\frac{1}{2}$ " long). - Rich suil, Ind. and W. Tenn. to Minn. and Kinn.

9. E. Préslii, Guss. Smooth or with seattered hairs, ascenting or erect $\left(1-2^{\circ}\right.$ high); leaves oblique at the obtuse or slightly curlate hase, ovate-rblong or oblong-linear, sometimes falcate, serrate $\left(\frac{1}{2}-1 \frac{t^{\prime}}{2} \mathrm{long}\right)$, often with a 
red spot or red margins; stipules triangular; peduncles longer than the petioles, collected in loose leafy terminal cymes; appendages entire, larger and white, or smaller and sometimes red; pod glabrous, obtusely angled; seeds ovate, obtusely angled, wrinkled and tubercled ( $\frac{1}{2}{ }^{\prime \prime}$ long), blackish. (E. hypericifolia of Man., not L.) - Common throughout the U. S. east of the plains.

§ 2. ZYGOPHYLLIDIUM. Leaves opposite, on short petioles, not oblique, with stipular glands; stems dichotomously branched, erect; cymes terminal; involucres with 5 glands; seeds tuberculate.

10. E. hexágona, Nutt. Somewhat hairy ( $1^{\circ}$ high or more); branches striate-angled; leaves linear-lanceolate, entire; involucre hairy without and within; glands with green orate-triangular appendages twice their length; capsule smooth; seeds ovate. - Iowa to Tex., west to Col. and Montana.

§3. PETALÒMA. Uppermost leaves with conspicuous white petal-like margins, whorled or opposite, the others scattered; erect annuals, with leaves equal at base and entire, and with lanceolate deciduous stipules; involucres 5-lobed, in an umbel-like inflorescence.

11. E. marginàta, Pursh. Stem stout $\left(2-3^{\circ}\right.$ high $)$, erect, hairy; leaves sessile, ovate or oblong, acute; umbel with 3 dichotomous rays; glauds of the involucre with broad white appendages. - Minn. to Mo., west to Col., also spreading eastward to Ohio, and frequently escaped from gardens, where it is often cultivated for its showy broadly white-margined floral leaves.

§ 4. 'TITHYMALÓPSIS. Only the uppermost leaves whorled or opposite; erect perennials, with entire leaves equal at base; stipules none; involucres mostly 5lobed, in the forks of the branches and terminal; inflorescence umbelliform.

12. E. corollàta, L. Glabrous or sometimes sparingly hairy $\left(2-3^{\circ}\right.$ high); leares ovate, lanceolate, or linear, entire, obtuse; umbel 5- (3-7-) forked, and the forks again 2-3- (or rarely 5-) forked; involucres long-peduucled, with showy white appendages (appearing like petals), the lobes minute and incurred; pod slemder-pedicelled, smooth; seeds thick ( $1^{\prime \prime}$ long or more), ash-colored, slightly uneven. - Rich or sandy soil, N. Y. and N. J. to Fla., west to Minn. and La., also adventive in Mass. July-Oct.

B. Glands of the involucre without petaloid appendages.

§5. POINSÉTTIA. Involucres in terminal clusters, 4-5-lobed, with few (or often solitary) cup-shaped glands; erect annuals, with variable, entire, dentate, or simute leaves, all or only the upper ones opposite; the uppermost often colored, especially at base; stipules small and glandular.

13. E. dentàta, Michx. Erect or ascending, hairy (1० high); leares orate, lanceolate, or linear, petioled, coarsely toothed (1-2' long), only the lowest alternate, the upper often paler at base; involucres almost sessile, with 5 oblong dentate lobes, and one or sometimes more short-stalked glands; seeds orate-globular, slightly tubercled. - Rich soil, Penn. to Tenn., Iowa, E. Kan., and southward. July-Sept.

14. E. heterophýlla, L. Erect $\left(1-3^{\circ}\right.$ high), glabrous; leaves alternate, petioled, ovate-fiddle-shaped and sinuate-toothed, or lanceolate or linear and entire, often ouly those of the branches linear; the upper usually with a 
red hase; involucres about the length of the peiluncle, with 5 ovate incised lubes and a single or few and almost sessile glunels; seeds nearly globular, tubercled. - Slopes and rocky soil, Minn. to W. III., Iowa and Mo.

\$ 6. 'TITHÝMALUS. Incolucres in a terminal dirlustomons or commusonly umbelliform inflerescener, 5- or usucully 4-luded, with as muny glut or contex cutire or crescent-shuped glands; serds rurunculate (-xcept II. 15) ; ours ascenting or evet, und mostly glabrous, without stipules.

* Peremuiuls with entire leaves, all or ouly the upper opposite; involucres long. peduncted in a dichotomous inflorescence, mostly with 5 transeersely oblong glunds; seeds without caruncle.

15. E. Ipecacuánhæ, I. stems many from a very loug perpendicular root, erect or diffuscly sprealing $\left(5-10^{\prime}\right.$ long), forking from near the hase: leaves varying from obovate or oblong to narrowly linear, almost sessile, glabrous; peduncles elongated ( $\frac{1}{2}-l^{\prime}$ long); pod long-pedicelled, obtusely angled, nearly smooth; seed ovate, white, sparsely marked with impressed dots. - Sandy soil, near the coast; Conn. to Fla.; also barrens of S. Ind.

* Leuves scattered, only the florul in the umbelliform inflorescence whorled or opposite and of a different shape; ylands mostly 4.

- Leaves serrulate or rarely entire; ylands trunsversely oval, obiuse.

+ Seeds smooth and even; jool uarty or rough.

16. E. Darlingtonii, Gray. Tall perennial (2-4 high); lenves entire, minutely douny beneuth; those of the stem lanceolate-oblong from a narrow hase; the floral oval, very obtuse ; the upper roundish-dilated with a truncate base; umbel 5-8-rayed, then simply forked; pod minutely wurty: large globular seed with a small caruncle. - Copses, X. Y. and P'enn., to the mountains of N. C. July-sept.

17. E. obtusàta, Pursh. Erect annual (1-20 high); Iereres olilong-spatulate, minutely serrulate, smooth, all obtuse; upper ones cordate at base; floral ones ovate, dilated, barely mucronate; nmbel once or twice divided into 3 rays, then into 2; inrolucre with naked lobes and small stipitate glands; styles distinct, longer than the ovary, erect, 2-cleft to the middle; pod besit witl long warts. - Damp woods, Va. to S. C., west to lowa and Kan. May-July.

E. PLATYruÝl, I, I. Frect anuual $\left(8-18^{\prime}\right.$ high); upper stemdertes lanceolateoblong, acute, cordate at hase, minutely serrulate, mostly with scritterch huirs beneath; floral ones triangular-ovate, sulcordate; umbel 5-rayed ; inolucre with ciliate loles and large sessile glands; styles longer than the ovary, united at hase, slightly 2-rleft; pod corered with depressed warts. - Along the St. Lawrence and Great Lakes to Mich. June- Iug. (Adv. from Eiu.)

廿 Seeds rugose or reticulated: leures serrulate; annuals.

18. E. dictyospérma, Fischer \& Meyer. Stem erect $\left(8-1 s^{\prime}\right.$ high); leaves oblong- or obovate-spatulate, smooth, all obtuse and obtusely serrate; upper ones cordate at hase; floral ones roundish-ovate or ohscurely heartshaped, slightly muronate; umbels once or twice 3-forked, then 2-forked; involucre with nearly naked lobes and smull almost sessile glauds: styles shorter than the ovary, spreading or recurved; pol uarty; seeds delicutely reticulated. - Prairies and roalsides, Md. to Minn., Ala., and westwarl May-July. 
E. Helioscòria, L. Stems ascending $\left(6-12^{\prime}\right.$ high), stout; leaves all oborate and very rounded or retuse at the end, finely serrate, smooth or a little hairy, those of the stem wedge-shaped; umbel divided into 5 rays, then into 3 , or at length simply forked; glards orbicular, stalked; pods smooth and even; seeds with coarse honeycomb-like reticulations. - Waste places, eastward and along the Great Lakes to Mich. July - Sept. (Nat. from Eu.)

\section{+- + Leares entive; glands crescent-shaped or 2-horned.}

+. Seeds smooth and dark-colored; perennials, with running rootstocks.

E. Ésula, L. Stems clustered $\left(1^{\circ}\right.$ high) ; leaves lanceolate or linear, the fluial (vellowish) broadly heart-shuped, mucronate; umbel divided into many rays, then focking; glands short-horned (brown); pods smoothish and granular. - Mass., western N. Y., and Mich.; rare. (Adv. from Eu.)

E. Crparíssias, L. Stems densely clustered $\left(6-10^{\prime}\right.$ high); stem-leaves linear, crowded, the floral heurt-shaped; umbel many-rayed; ylands crescentshaped; pods granular. - Escaped from gardens, common. (Nat. from En.)

E. Nic zéxisis, All. Stout und tall glabrous perennial; leares oblong or oblong-lanceolate, the floral broadly heart-shaped, mucronate; terminal umbel many-rayed, the rays forking; glands short-horned; pods finely wrinkled. A rire eseape; Binghampton, N. Y. (Adr. from Eu.)

\section{+ Seeds sculptured, ash-colored; pod snooth; annuals or biennials.}

E. PÉplus, L. Erect or ascending $\left(5-10^{\prime}\right.$ high); leaves petioled, thin, round-obovate, the upper floral ones ovate; umbel 3-rayed, then forking; glands long-horned; lobes of the pod 2-wing-crested on the back; seeds 2-yrooved on the inner ficce, pitted on the back (scarcely orer $\frac{1}{2}$ "long). - Waste places, N. Eng. to N. J. and western N. Y. (Adv. from Eu.)

19. E. commutàta, Eugelm. Stems branched from a commonly decumbent base $\left(6-12^{\prime}\right.$ high); leares obovate, obtuse; the upper all sessile, the upper floral ones roundish-dilated, broader than long; umbel 3-forked; glands with slender horns; capsule obtusely angled; seeds ovate, pitted all over (1" long). - Along streams and shady slopes, Md. to Fla., Minn., and Mo.

** Glabrous annual or biennial with entire opposite and decussate leaves, an umbelliform inflorescence, and short-horned glands.

E. L.ítuyris, L. Stem stont $\left(2-3^{\circ}\right.$ high $)$; leaves thick, linear or oblong, the floral oblong-ovate and heart-shaped; umbel 4-rayed, then forking. sparingly escaped from gardens, N. Eng. to N. C. (Adv. from Eu.)

\section{PACHYSÁ N D RA, Michx.}

Flowers monocious, in naked spikes. Calyx 4-5-parted. Petals none. Ster. Fl. Stamens 4, separate; filaments long-exserted, thick and flat; anthers oblong-linear. Fert. Fl. Ovary 3-celled; styles 3, thick, awl-shaped, recurved, stigmatic down their whole length inside. Orules a pair in each cell, suspended, with the rhaphe dorsal (turned away from the placenta). Capsule deeply 3-horned, 3-celled, splitting into 3 at length 2-ralved 2-seeded ('arpels. - Nearly glabrous, low and procumbent perennial herbs, with matted creeping rootstucks, and alternate, orate or oborate, coarsely toothed leaves, narrowed at base into a petiole. Flowers each 1 -3-bracted, the upper staminate, a few fertile ones at base, unpleasantly scented; sepals greenish or purplish; filaments white (their size and thickness giving the name, from $\pi u \chi u ́ s$, thick, and áv'́p, used for stamen).

1. P. procúmbens, Michx. Stems $\left(6-9^{\prime}\right.$ long) bearing several approximate leaves at the summit on slender petioles, and a few many-flowered 
spikes along the base; the intervening portion nakerl, or with a few small scales. - Wouks, mountains of $\mathrm{Ky}$., W. Va., and suutluwarl. March-..lay.

\section{PHYLLÁNTHUS, L.}

Flowers monocious, axillary. (alyx usually 5-6-parted, imbricated in tho bud. P'etals none. Stamens mostly 3, erect in the bud, often united. ()vules 2 in each cell of the ovary. Capsule depressed; each carpel 2-valved, 2 seederl. Sieeds not carmuculate. - Leaves alternate, 2-ranked, with small stipules.

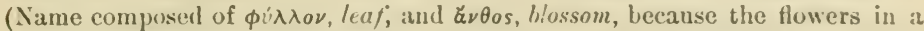
few species are borne upon leaf-like dilated branches.)

1. P. Carolinénsis, Walt. Anuual, low and slender, branched; leaves obovate or oval, short-petioled; flowers commonly 2 in each axil, almost sessile, one staminate, the other fertile; calyx 6-parted; stamens 3 ; styles 3 , each 2-cleft; glands of the disk in the fertile flowers united in a cup. - Gravelly banks, E. l'enn. to Fla., west to S. Ind. and Ill. July-Sept.

\section{JÁ TROPHA, r.}

Flowers monœcious, rarely diøcious, in a terminal open forking cyme; the fertile ones usually in the lower forks. Calyx corolla-like, in the staminate flowers often salver shaped, 5-lobed ; in the pistillate, 5-parted, imbricated or convolute in the bud. Corolla of 5 distinct or apparently united petals, or none. Glands of the disk opposite the calyx-lobes. Stamens 10-30, in 2 or more whorls; filaments monadelphous at base. Ovary mostly 3 -celled; styles 3, united below, their summits once or twice forked. Capsule 3-celled, 3 -seeded, separating into 3 two-valved carpels. Sced carunculate. - l'erennial herbaceous or shrubby plants, ehiefly tropical, with alteruate mostly long-petioled palmately-veined leaves, and stipules. - Our species is of the section Cxibóscolus, with apetalous flowers, the staminate corolla salverform, and the plants mostly armed with stinging bristles. (Nane said by Linnzus to be formed of iarpòv, a remedy, and $\phi a ́ \gamma \omega$, to eat.)

1. J. stimulòsa, Michx. (Trea D-softly. Spurge-Nettle.) Herbaceous, from a loug perenuial root, branching $\left(6^{\prime}-2^{\circ}\right.$ high) ; leaves roundishheart-shapeil, 3-5-lohed nearly to the base, on long petioles; the divisions entire or acutely toothed, cut, or even pinnatifid, often discolored; flowers white, fragrant, $9^{\prime \prime}$ long or more; filaments 10, monadelphous only at the woolly base, or the outer set almost distinct. (J. urens, var. stimulosa, J. Muell.) - I)ry sandy soil, Va. to Fla. and La. June-Sept.

\section{CRÖTON, L.}

Flowers monocious, rarely dinecious, mostly in terminal spike-like racemrs or spikes. Ster. Fl. Calyx 5-(rarely 4-6-) parterl; the divisions lightly imbricated or nearly valvate in the bud. Petals usually present, as many, but mostly small or rudimentary, hypogynous. Glands or lobes of the disk as many as and alternate with the petals. Receptacle usually hairy. Stamens 5 or more; filaments with the anthers inflexed in the bud. Fert. F\% Calyx 5-10-cleft or parted, nearly as in the staminate flowers; but petils none or minute ruliments. ()vary 3- (rarely 2-4-) celled, with a single ovule in each cell; styles as inany, from once to thrice 2-cleft. Cilpsule separating 
into as many 2-valved 1-seeded carpels. Seeds carunculate. - Stellate-downy, or scurfy, or hairy and glandular plants, mostly strong-scentell; the fertile flowers usually at the base of the sterile spike or clnster. Leaves alternate,

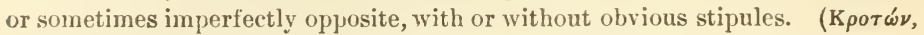
the Greek name of the Castor-oil Plant, of this family.)

* Sterile flowers with 4-parted calyx, as many petals, a 4-rayed disk, and 8 stamens; fertile flouers with 5-parted calyx, very minute rudimentary petals, and the 3 styles 2-cleft.

1. C. glandulòsus, L. Annual, rongh-hairy ant glantular ( $1-2^{\circ}$ high), somewhat umbellately branched; leaves oblong or linear-oblong, obtusely toothed, the base with a saucer-shaped gland on each side; fertile flowers capitate-clustered at the base of the sterile spike, sessile in the forks and terminal. - ( )pen waste places, Va. to Iowa, E. Kan. and sonthward.

* Sterile flowers with 5-parted calyx, as many glands alternating with the petals, and 10-14 stamens; fertile flowers with 7-12-parted calyx, no petals, and the 3 styles twice or thrice 2-parted.

2. C. capitàtus, Michx. Annual, densely soft-woolly and somewhat glandular ( $1-2^{\circ}$ high), branched; leaves long-petioled, lance-oblong or elongated-oblong, rounded at base, entire; petals obovate-lanceolate, densely fimbriate; fertile flowers several, capitate-crowded at the base of the short terminal sterile spike. - Barrens, N. J. to Ga., west to S. Ind., Iowa, and l. Kan. July - Sept.

* * Sterile flouers with unequally 3-5-parted calyx, as many petals and scale-like glands, and 3-8 stamens: fertile flowers with equally 5-parted calyx, no petals, 5 glands, and 2 sessile 2-parted stigmas.

3. C. monanthógynus, Michx. Annual, whitish-stellate-pubescent and rusty-glandular; stems ( $1-2^{\circ}$ high) slender, erect, below often umbellately 3 -4-forked, then repeaterlly $2-3$-forked or alternately branched; leaves oblong-vvate or narrowly oblong, entire, often acutish $\left(6-12^{\prime \prime}\right.$ long, about twice the length of the petioles); flowers in the forks, the sterile few on the summit of a short and erect peduncle, the fertile few and clustered or mostly solitary on short recurved peduncles; orary 2-celled; fruit often by abortion 1-celled and 1-seeded; the seed broally oval. - Barrens and dry prairies, S. Ind. to N. C. and Fla., west to E. Kan. June-Sept.

* * * Diøcious; cal yx equally 5-parted; petals none; stamens 10 or more, st.jles tuice or thrice dichotomously 2-parted.

4. C. Texénsis, Muell. Annual, covered with a close canescent stellate pubescence, dichotomously branched or spreading $\left(1-2^{\circ}\right.$ high); leaves narrowly oblong-lanceolate to linear; staminate spikes or racemes very short, often sessile; capsule stellate-tomentose and somewhat muricate. - Mo. and Kan. to Ala., Tex., and westward.

\section{CROTON ÓPSIS, Michx.}

Flowers monocious, in very small terminal or lateral spikes or clusters, the lower fertile. Ster. Fl. Calyx equally 5-parted. Petals 5, spatulate. Stamens 5 , opposite the petals; filaments distinct, inflexed in the bud, enlarged 
at the apex. Fert. F\%. Calyx unequally 3-5-parted. I'etals none. Glands (petal-like scales) 5, opposite the sepals. Ovary 1-celled, simple, 1-ovuled, hearing a twice or thrice forked style. Fruit dry and iudehiscent, small, I-seeded. Siced without caruncle. $-\Lambda$ slender low annual, with alternate or opposito short-petioled linear or elliptical-lanceolate leaves, which are green and smoothish above, hut silvery hoary with starry hairs and scurfy with brownish scales underneath, as well as the branches, etc. (C'roton and ú $\psi$ is, appearance, for a plant with the aspect and general character of ('roton.)

1. C. lineàris, Michx.-1)ry sandy soil, N. J. to Fla., west to Ill. and Kan. July - Sept. - Fruit about I" long.

\section{ARGYTHÁ MNIA, P. Browne.}

Flowers monncions. Calyx 5-parted, valvate in the staminate flowers, imbricate in the pistillate. Petals alternate with the calyx-lolses and with the prominent lohes of the glaudular disk. Stamens 5-15, united into a central column in 1-3 whorls. Styles 1-3-cleft. Capsule depressed, 3-lobed. Sieeds subglobose, roughened or reticulated, not carunculate. - Erect herbs or undershrubs, with purplish juice, and alternate usually stipulate leaves. (Name from á $\rho \gamma v \rho o s$, silver, and $\theta a \dot{\mu} \nu$ os, bush, from the hoariness of the original species.)

1. A. mercurialina, Muell. Stem erect, nearly simple $\left(1-2^{\circ}\right.$ high $)$, sericeous; leaves sessile, oblong-ovate to lanceolate, entire, pubescent with appressed hairs or glabrate, somewhat rigid; raceme many-flowered, exceeding the leaves; ovary sericeous; capsule appressed-pubescent. - Kan. to Ark. and Tex.

\section{A C A L Ỳ P h A, L. Three-seeded Mercliry.}

Flowers monœcious; the sterile very small, clustered in spikes, with the few or solitary fertile flower's at their base, or sometimes in separate spikes. Calyx of the sterile flowers 4-parted and valvate in bud; of the fertile, 3-5-parted. Corolla none. Stamens 8-16; filaments short, monadelphous at base; anthercells separate, long, often worm-shaped, hanging from the apex of the filament. Styles 3, the upper face or stigmas cut-fringed (usually redi). Capsule separating into 3 globular 2-valved carpels, rarely of only one carpel. - Herbs (ours annuals), or in the tropics often slirubs, resembling Nettles or A maranths; the leaves alternate, petioled, with stipules. Clusters of sterile flowers with a minute bract; the fertile surrounded by a large and leaf-like cut-lobed persisteut

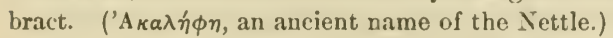

* Fruit smooth or merely pubescent; seeds nearly smooth.

1. A. Virgínica, I. Smoothish or hairy (1-20 high $)$, often turning purple; leaves ovate or oblong-ovate, obtusely and sparsely serrate, long-petioled; sterile spike rather few-flowered, mostly shorter than the large leaf-like palmately 5-9-cleft fruiting bracts; fertile flowers $1-3$ in each axil. - Fields and open places, $\mathrm{X}$. Eng. to Ont. and Minn., south to the Gulf. July-Sept.

Var. grácilens, Muell. Leaves lanceolate or even linear, less toothed and shorter-petioled; the slender sterile spike often I' long, and much surpassing the less cleft or few-toothed fruiting bracts. - Sandy dry soil, R. I. and Coun. to Fla., west to Ill., E. Kan. and 'Tex. 
* Fruit echinate with soft bristly green projections; seeds rough-wrinkled.

2. A. Caroliniàna, Ell. Leaves thin, ovate-cordate, sharply and closely serrate-toothed, abruptly acuminate, long-petioled; sterile spikes short, axillary; the fertile ones mostly terminal and elongated, their bracts deeply cut into many linear lobes. - N. J. to Fla., west to Ohio, Kan., and Tex

\section{RÍCINUS, Linn. Castor-oil Plant.}

Flowers in racemose or panicled clusters, the fertile above, the staminate below. Calyx 5-parted. Stamens very numerous, with repeatedly branching filaments. Styles 3, united at base, each bifid, red. Capsule large, 3-lobed, with 3 large seeds. - A tall stately annual, with very large alternate peltate and palmately $7-11$-cleft leaves (often $1-2^{\circ}$ broad). ('ihe ancient Roman name of the plant.)

R. Commúxis, L. - Cultivated extensively for ornament, and sparingly escaped in Md., Mo., and southward. Very variable.

\section{0. ' $\mathrm{R} \dot{\mathrm{A}} \mathrm{G}$ I A, Plumier.}

Flowers monœcious, in racemes, apetalous. Ster. Fl. Calyx 3-5- (chiefly 3-) parted, valvate in the bud. Stamens 2 or 3 ; filaments short; anther-cells united. Fert. Fl. Calyx 3-8-parted, persistent. Style 3-cleft or 3-parted; the branches 3 , simple. Capsule 3-celled, 3-lobed, bristly, separating into three 2-valved 1-seeded carpels. Seeds not carunculate. - Erect or climbing plants (perennial herbs in U.S.), pubescent or hispid, sometimes stinging, with mostly alternate stipulate leares; the small-flowered racemes terminal or opposite the leaves; the sterile flowers above, the few fertile at the base, all with small bracts. (Named for the early herbalist Bock, latinized Tragus.)

1. T. innócua, Walt. Erect, paniculate-branched, softly hairy-pubescent (6-12' high); leaves varying from obovate-oblong to narrowly linear, acute at base, obtusely or sinuately few-toothed or lobed, sometimes entire, short-petioled or sessile, paler beneath ; sterile calyx usually t-parted; stamens 2. (T. urens, L.) — Dry sandy soil, E. Va. to Fla. and La. May - Aug. - Not stinging.

2. T. nepetæfolia, Cav. Erect or reclining or slightly twining, hirsute with stinging hairs; leaves ovate-ianceolate or triangular-lanceolate, or the lower ovate, all somewhat cordate or truncate at base, coarsely cut-tuothed, short-petioled; sterile calyx usually 3-parted and stamens 3. (T. urticæfolia, Michx.) -Virginia (Pursh), and common southward to Fla. and Tex., Mo., Kan., and westward. - T. STYLARIs, Muell., of the southwest, which is reported from Kan., may be distinguished by its 4-5-parted sterile calyx, 4-5 stamens, and elongated styles.

3. T. macrocárpa, Willd. Tuining, somewhat hirsute; leaves deeply cordate, ovate, mostly narrowly acuminate, sharply serrate $\left(3-5^{\prime} \mathrm{long}\right)$, all but the uppermost long-petioled; pod $\frac{1^{\prime}}{2}$ broad. (T. cordàta, Michx.) - Ky. to Ga., Fla., and La.

\section{STILLÍNGIA, Garden.}

Flowers monœcious, aggregated in a terminal spike. Petals and glands of the disk none. Calyx 2-3-cleft or parted; the divisions imbricated in the bud. Stamens 2 or 3 ; anthers adnate, turned outward. Style thick; stigmas 3 , 
diverging, simple. Capsule 3-celled, 3-loberl, 3-seeded. Seed carunculate. Sinooth upright plants, with the alteruate leaves mostly 2 -glandular at base; the fertile flowers few at the base of the dense sterile spike (rarely separate); the bract for each cluster with a large gland on each side. (Nained for I): B. Stillingfleet.)

1. S. sylvática, L. Herbaceous $\left(1-3^{\circ}\right.$ high $)$; leaves almost sessile, ob. long-lan eolate, serrulate; glands of the spike saucer-shaped. - Sandy and dry soil, Va. to Fla., west to Kan. and Tex. June-Sept.

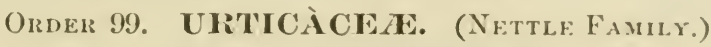

Plants with stipules, and monocious or diacious or ravely (in the Elm Family) perfect flowers, furnished with a regular calyx, fiee from the 1 . celled (rurely 2-celled) ovary which forms a 1-seeded fiuit; the embryo in the albumen when there is any, its radicle pointing upuard; stamens as many as the lobes of the calyx and opposite them, or sometimes feurer. Cotyledons usually broad. Stipules often deciduous. - A large order (far the greater part tropical).

Tribe I. ULMEAE. Flowers mostly yolygamous, upon the last year's branches. An. thers erect in the bud, extrorse. Styles or stigmas 2 . Fruit a winged samara or nutlike. Seed susplended. Eimbryo straight. - Trees, with alternate serrate pinnately veined leaves and fugacious stipules.

1. UImus. Flowers preceding the leaves Ovary 1 - 2-oruled. Fruit winged all aromd.

2. Planera. Fluwers appearing with the leaves. Orule one. Fruit wingless, nut-like.

Tribe II. CELTIDEA. As in Tribe I., but the diceious-polygamons flowers upion branches of the same year; anthers introrse; fruit a drupe ; embryo curved.

3 Celtis. Ovary l-ovuled. Flowers appearing with the leaves. Leaves 3 -nerverl at base.

Tribe III. CANNABINEA. Flowers diœcious: the sterile racemed or panicled; the fertile in elusters or catkins, the calyx of one sepal embracing the ovary. Filaments short, erect in the bud. Stigmas 2, elongated. Ovary l-selled, with a pendulous orule, forming a small glandular achene in fruit. Eubbryo curved or coiled. - Erect or clint)ing herbs, with watery juice, mostly opposite lobed or divided leaves, persistent stipules, and a filorous inuer bark.

4. Cannabis. Fertile flowers spiker-rlustered. Leaves 5-7-divided. Erert.

5. Humulus. Fertile flowers in a short spike forming a membranaceous eatkin in fruit. Leaves 3 -5-lober. Climbing.

Tribe IV. MOREA. Flowers unisexual, racemosc, spicate or capitate; calyx beconing fleshy or juicy in fruit. Anthers inflexed in the bud. Style undivided or 2-parted, filiform; ovule pendulous; fruit an achene, embryo curved.-Trees or shrubs, with milky juice, alternate leaves, and fugacious stipules.

6. Maclura. Sterile flowers in loose racemes; fertile in glohose heads. Leaves entire.

7. Morus. Fertile and sterile flowers in separate spikes. Lenves dentate, 3-nerved.

Tribe V. URTICEA. Flowers unisexual. Filaments inflexed in the bud. Style or stigma simple. Ovary 1-celled, with an erect nvule, forming an achene in fruit. Embryo straight. - Herbs with watery juice, tough tibrous bark, and opposite or alternate leaves; often armed with stinging hairs.

* Caly $x$ in the fertile flowers of $2-5$ separate or nearly separate sepals.

+ Plant beset with stinging bristles.

8. Urtica. Sepals 4 in both fertile and sterile flowers. Achene straight and erect, enclosed by the 2 inner and larger sepals. Stigina capitate-tufted. Leaves opposite. 
9. Laportea. Sepals 5 in the sterile flowers, 4 in the fertile, or apparently only 2. Stigmit long-subulate. Achene very oblique, deflexed, nearly naked. Leaves alternate.

- + Plant wholly destitute of stinging bristles. Leaves opposite.

10. Pilea. Sepals 3 or 4 , those of the fertile flowers unequal, all or all but one sinall. Achene partly naked, straiglit and erect. Stigma pencil-tufted. Smooth and shining.

* Fertile calyx tubular or enp-shaped, enclosing the achene. Unarmed.

11. Bohmeria. Flower-clusters spiked, not involucrate. Style long and thread-shaped, stigmatic down one side. Leaves opposite, serrate.

12. Parietaria. Flowers in involucrate-bracted clusters. Stigma tufted. Leaves alternate, entire.

\section{1. Ú L MUS, L. EuM.}

Calyx bell-shaped, 4-9-cleft. Stamens 4-9, with long and slender filaments. Ovary I - 2-celled, with a single anatropous ovule suspended from the summit of each cell; styles 2, short, direrging, stigmatic along the inner edge. Fruit a 1-celled and 1-seeded membranaceous samara, winged all around. Albumen none; embryo straight; the cotyledous large. - Flowers polygamous, purplish or yellowish, in lateral clusters, in our species preceding the leaves, which are strongly straight-reined, short-petioled, and oblique or unequally somewhat heart-shaped at base. Stipules small, caducous. (The classical Latin name.)

* Flouers nearly sessile; fruit orbicular, not ciliate; leaves very rough above.

1. U. fúlva, Michx. (Slippery or Red Ely.) Buds before expansion soft-downy with rusty hairs (large) ; leaves ovate-oblong, taper-pointed, duubly serrate $\left(4-8^{\prime}\right.$ long, sweet-scented in drying), soft-downy beneath or slightly rough downward; branchlets downy; calyx-lobes and stamens 5-9; fruit (8-9" wide) with the cell pubescent. - Rich soil, N. Eng. to I)ak., and southward. March, April. - A small or middle-sized tree $\left(45-60^{\circ}\right.$ high), with tough reddish wood, and a very mucilaginous inner bark.

* * Flowers on slender drooping pedicels, which are jointed above the middle; fruit orate or oval, fringed-ciliate; leaves smooth above, or nearly so.

2. U. Americàna, L. (Averichx or White Ely.) Buds and branchlets glabrous; branches not corky; leaves obovate-oblong or oval, abrnptly pointed, sharply and often doubly serrate ( $2-4^{\prime}$ long), soft-pubesceut beneath, or soon glabrous; flowers in close fascicles; calyx with $7-9$ roundish lobes; fruit glabrous except the margins ( $\frac{1^{\prime}}{2}$ long), its sharp points incurved and closing the notch. - Moist woods, especially along rivers, in rich soil. A pril. - A large and well-known ornamental tree, variable in habit, usually with spreading branches and drooping branchlets.

3. U. racemòsa, Thomas. (CоRк or Rоск Eıм.) Bud-scales downyciliate and somewhat pubescent, as are the young branchlets; branches often with corky ridges; leares nearly as in the last, but with veins more simple and straight ; flowers racemed ; fruit much as in the last, but rather larger. - Riverbanks, S. W. Vt. to Ont. and central Minn., south to Mo. and Ky. A large and very valuable tree.

4. U. alàta, Michx. (WAnoo or Wrxged Elu.) Bud-scales and branchlets nearly glabrous; branches corky-winged, at least some of them; leaves downy beneath, ovate-oblong and oblong-lanceolate, acute, thickish, small 
(1-2 $\frac{l^{\prime}}{2}$ long) ; calyx-lobes obovate; fruit downy on the face at least when young. - Va. to S. Ind., S. Mo., and southward. March. A small tree.

\section{PLÁ Ner A, Gimelin. l'taner-trek.}

Flowers moncecionsly polygamous. Caly $4-5-$ - left. Stamens $4-5$. Ovary ovoil, l-celled, l-ovuled, crowned with 2 spreading styles which are stignatose down the inner sille, in fruit becoming coriacrous and nut-like, not winged. Albumen none; embryo straight. - Trees with small leaves, like those of Elms, the flowers appearing with them, in small axillary clusters. (Named for J.J. Planer, a German botanist.)

1. P. aquática, Gmel. Nearly glabrous; leaves ovate-oblong, small; fruit stalked in the calyx, beset with irregular rongh projections. - Wet banks, N. C. to Ky., S. Ill., and southward. A pril. A rather small tree.

\section{CÉltis, Tourn. Nettle-trei. Hackberiry.}

Flowers monceiously polygamons. Calyx 5-6-parted, persistent. Stamens 5-6. ()vary 1-celled, with a single suspended ovule; stigmas 2, long and pointed, recurved. Fruit a globular drupe. Embryo curved, nearly enclosing a little gelatinous albumen ; cotyledons folded and crumpled. - Leaves pointed, petioled, inequilateral. Stipules calucous. Flowers greenish, axillary, the fertile solitary or in pairs, peduncled, appearing with the leaves, the lower usually staminate only, fascicled or racemose along the base of the branches of the season. (A name of Pliny's for an African species of Lotus.)

1. C. occidentàlis, L. (Sugarberry. Hackberry.) Leaves reticulated, ovate, cordate-ovate and ovate-lanceolate, taper-pointed, usually conspicnonsly and sharply so, more or less oblique at base, sharply serrate, sometimes sparingly so or only toward the apex, scabrous but mostly glabrous above, usually soft-pubescent heneath, at least when young; fruit reddish or yellowish, turning dark purple at maturity, its peduncle once or twice the length of the petiole. - Woods and river-banks, N. Eng. to Mimn., and sonthward. April, May. - A small or sometimes large tree, with the aspect of an Elm, bearing sweet and edible fruits as large as bird-cherries, at first obovate, ripe in autumn; the flesh thin. Very variable in the form, texture, etc., of the leaves. - Var. rùmLA, Gray. Low and straggling $\left(t-10^{\circ}\right.$ ligh $)$; leaves thin when mature, and smooth, slightly acuminate. River-banks, on rocks, from Maryland southward.

2. C. Mississippiénsis, Bosc. Leaves entire (rarely few-toothed), very long taper-pointed, rounded at base, mostly oblique, thin, and sinonth; fruit small. - Ill. to Tenn., and southward. A small tree with warty bark.

\section{CÁ N N A BIS, Tunrn. Hemp.}

Flowers dicecious; the sterile in axillary componnd racemes or panicles, with 5 sepals and 5 drooping stameus. Fertile flowers spiked-clustered, 1-hracted; the calyx of a single sepal enlarging at the hase and folded roum the ovary. Achene crustaceons. Embryo simply curvel. $-\Lambda$ tall roughish anual, with digitate leaves of 5-7 linear-lanceolate eoarsely tonthed leaflets, the uppor alternate; the inner bark of very tough fibres. ('The ancient Greek name, of olscure etymology.)

C. Sativa, L. (Hswr.) Stem $4-8^{\circ}$ high; leaves $4-8^{\prime}$ broad; flowers green. - Waste and cultivated grounil. ( $\Lambda \mathrm{dv}$. from Eu.) 


\section{H Ù M U L U S, L. Hop.}

Flowers dioecious; the sterile in loose axillary panicles, with 5 sepals and $\mathbf{5}$ erect stamens. Fertile flowers in short axillary and solitary spikes or catkins ; bracts foliaceous, imbricated, each 2-flowered, in fruit forming a sort of membranaceous strobile. Calyx of a single sepal, embracing the ovary. Achene invested with the enlarged scale-like calyx. Embryo coiled in a flat spiral. Twining rough perennials, with stems almost prickly downward, and mostly opposite heart-shaped and palmately $3-7$-lobed leaves, with persistent ovate stipules between the petioles. (A late Latin name, of Tentonic origin.)

1. H. Lùpulus, L. (Consos Hop.) Leares mostly 3-5-lobed, commonly longer than the petioles; bracts, etc., smoothish; the fruiting calyx, achene, etc., sprinkled with yellow resinous grains, which give the bitterness and aroma to the hop. - Alluvial banks, N. Eng. to western N. Y., the Great Lakes and westward, and south in the mountains to Ga. July. (Eu., Asia.)

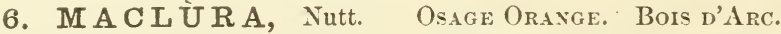

Flowers diøcious; the staminate in loose short racemes, with 4-parted calyx, and 4 stamens inflexed in the bud; the pistillate in a dense globose hearl, with a 4-cleft calyx enclosing the orary. Style filiform, long-exserted; orule pen. dulous. Fruit an acheue, buried in the greatly enlarged fleshy calyx. Albumen none. Embryo recurved. - Trees with milky juice, alternate entire pinnately veined leaves, caducous stipules, axillary peduncles, and stout axillary spines. (Named for the early American geologist, Willium Maclure.)

1. M. aurantiaca, Nutt. A tree $30-50^{\circ}$ high; leaves ovate to oblonglanceolate, pointed, mostly rounded at base, green and shining; syncarp globose, yellowish green, $2-3^{\prime}$ in diameter. - E. Kan. and Mo. to N. 'Tex.: extensively used for hedges. Wood bright orange.

\section{MOR U S, Tourn. Mclberry.}

Flowers monœcious or diøcious; the two kinds in separate axillary and catkin-like spikes. Calyx 4-parted; lobes ovate. Stamens 4; filaments elastically expanding. Ovary 2-celled, one of the cells smaller and disappearing; styles 2, thread-form, stigmatic down the inside. Achene orate, compressed, covered by the succulent berry-like calyx, the whole spike thus becoming a thickened oblong and juicy (edible) aggregate fruit. - Trees with milky juice and broad leaves; sterile spikes rather slender. (The classical Latin name.)

1. MI. rùbra, L. (RED MrLberRY.) Leaves heart-orate, serrate, rough above, downy beneath, pointed (on young shoots often lobed); flowers frequently diøecions; fruit dark purple, long. - Rich woods, W. New Eng. to S. Ont., Dak., E. Kan., and southward. May. - Large tree, ripening its blackberrylike fruit in July.

M. ÁlbA, L. (White Mulberry.) Leaves obliquely heart-ovace, acute, serrate, sometimes lobed, smooth and shining; fruit whitish. - Spontaneous near houses. (Adv. from Eu.)

\section{U R tì C A, Tourn. Nettle.}

Flowers monœcious, or rarely diœcious, clustered, the clusters mostly in racemes, spikes, or loose heads. Sier. Fl. Sepals 4. Stamens 4, inserted around 
the cup-shaped rudiment of a pistil. Fert. Fl. Sepals 4 , in pairs; the 2 outer smaller and spreading; the 2 inner that or concave, in frnit membranaceous and enclosing the straight and erect ovate flatteneil achene. Stigma sessile, capitate and pencil-tufted. - Herls, armed with stinging laairs. Leaves opposite; stipnles in our species distinct. Flowers greenish; in summer. (The classical Latin name; from uro, to burn.)

* Perenniuls; floucr-clusters in branching punicled spikes, often diurions.

1. U. grácilis, Ait. Sparingly bristly, slevder $\left(2-6^{\circ}\right.$ high $)$; leares oratelanceolate, pointed, serrate, 3-5-nerved from the rounded or scarcely heartshaped base, almost glabrous, the elongated stender petioles sparingly bristly; spikes slender and loosely panicled. - Feuce-rows and moist ground, common. Stiugs few.

U. mòncA, L. I'ery bristly and stinging $\left(2-3^{\circ}\right.$ high); leaves ovate, heartshaped, pointed, very deeply serrate, down!y beneath as well as the upper part of the stem; spikes much branched. - Waste places and roadsides, rather rare. Canada and X. King. to S. C., west to Minn. and Mo. (Nat. from Eu.)

* Annuals; flower-clusters chiefly axillary and shorter than the petiole, androgynous.

U. ÙRExs, I. Leaves elliptical or orate, very coarsely and deeply serrate with long spreading teeth, the terminal teeth not longer than the lateral ones; flouer-chusters 2 in each axil, small and loose. - Waste grounds, near dwellings, eastward; searce. Plant 8-12' high, with sparse stings. (Nat. from Ku.)

2. U. chamædryoides, Pursh. Leares ovate and mostly heurt-shaped, the upper orate-lanceolate, coarsely serrate-toothed; flower-clusters globular, $1-2$ in each axil, and spiked at the summit. - Alluvial shaded soil, from Kiy. to the Gulf States. Slender, 6 $-30^{\prime}$ high, sparsely beset with stings.

\section{L A P Ó R E A, Gaudichaud. Woon-Nettre.}

Flowers moncecious or diocious, clustered, in loose cymes; the upper widely spreading and chiefly or entirely fertile; the lower mostly sterile. Ster. Fl. Sepals and stamens 5, with a rudiment of an ovary. Fert. Fl. Calyx of 4 sepals, the two outer or one of them nsually minute, and the two inner much larger. Stigma elongated awl-shaped, hairy down one side, persistent. Achene ovate, flat, extremely oblique, reflexed on the winged or margined pedicel, nearly naked. - Perennial herbs, with stingiug hairs, large alternate serrate leaves, and axillary stipules. (Named for $1 /$. Laporte.)

1. L. Canadénsis, Gaudichaud. Stem $2-3^{\circ}$ high ; leaves ovate, pointerl, strongly feather-veined ( $3-7^{\prime}$ long), long-petioled; fertile cymes divergent ; stipule single, 2-cleft. - Moist rich woods. July-Sept.

\section{PÍtitia, Lindl. Richween. Clearweed.}

Flowers monœcious or dinecious. Ster. Fl. Sepals and stamens $3-4$. Fert. $F$. Sepals 3, oblong, more or less unequal; a rudiment of a stamen commonly before each in the form of a hooded scale. Stigma sessile, pencil-tufted. Achene ovate, compressed, erect, partly or nearly naked. - Stingless, mostly glabrous and low herbs, with opposite leaves and united stipules; the staminate flowers often mixed with the fertile. (Named from the shape of the larger sepal of the fertile flower in the original species, which partly covers the achene, like the pileus, or felt cap, of the Romans.) 
1. P. pùmila, Gray. (Richweed. Clearweed.) Low $\left(3-18^{\prime}\right.$ high); stems smooth and shining, pellucirl; leaves ovate, coarsely toothed, pointed, 3-ribbed and veiny; flower-clusters much shorter than the petioles; sepals of the fertile flowers lanceolate, scarcely unequal. - Cool and moist shaded places. July - Sept.

\section{B}

Flowers monœcious or diœcious, clustered; the sterile much as in Urtica; the fertile with a tubular or urn-shaped entire or 2-4-toothed calyx enclosing the ovary. Style elongated awl-shaped, stigmatic and papillose down one side. Achene elliptical, closely invested by the dry and persistent compressed (alyx. - No stings. (Named after G. R. Boehmer, Professor at Wittenberg in the last century.)

1. B. cylíndrica, Willd. Perennial, smoothish or pubescent and more or less scabrous; stem $\left(1-3^{\circ}\right.$ high) simple; leares chiefly opposite (rarely all alternate), ovate to ovate- or oblong-lanceolate, pointed, serrate, 3-nerved; stipules distinct; petioles short or elongated; flowers diœcious, or the two kinds intermixed, the small clusters densely aggregated in simple and elongated axillary spikes, the sterile interrupted, the fertile often continuous, frequently leaf-bearing at the apex. - Moist or shady ground, common. Very variable.

\section{PARIETÀ RIA, Tourn. Pellitory.}

Flowers monœciously polygamous; the staminate, pistillate, and perfect intermixed in the same involucrate-bracted cymose axillary clusters; the sterile much as in the last; the fertile with a tubular or bell-shaped 4-lobed and nerred calyx, enclosing the ovary and the oroid achene. Style slender or none; stigma pencil-tufted. - Homely, diffuse or tufted herbs, not stinging, with alternate entire 3-ribbed leaves, and no stipules. (The ancient Latin name, because growing on old walls.)

1. P. Pennsylvánica, Muhl. Low, anuual, simple or sparingly branched, minutely downy; leaves oblong-lanceolate, thin, veiny, roughish with opaque dots; flower's shorter than the involucre; stigma sessile. — Shaded rocky banks, E. Mass. and Vt. to Minn., and sonthward. June-Aug.

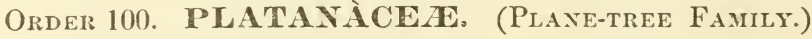

Trees, with watery juice, alternate palmately-lobed leaves, sheathing stipules, and monocious flowers in separate and naked spherical heads, destitute of calyx or corolla; the fruit merely club-shaped 1-seeded nutlets, furnished with a ring of bristly hairs about the base; consists only of the following genus (of uncertain relationship).

\section{PLÁt A N US, I. Sycamore. Buttoxwood.}

Sterile flowers of numerons stamens, with club-shaped little scales intermixed; filaments very short. Fertile flowers in separate catkins, consisting of inversely pyramidal ovaries mixed with little scales. Style rather lateral, awl-shaped or thread-like, simple. Nutlets coriaceous, small, tawny-hairy below, containing a single orthotropous pendulous seed. Embryo in the axis of 
thin albumen. - Large trees, with the bark deciluous in broal thin brittle plates; dilated base of the petiole enclosing the bud of the next season. ('The ancient name, from $\pi \lambda a \tau$ is, broud.)

1. P. occidentàlis, I. Leaves mostly truncate at base, angularly sinuate-lohed or toothed, the short lohes sharp-pointed; fertile heads solitary. langing on a long peduncle. - Nlluvial hanks, S. Maine to N. Vt., Ont., S. L. Minn., F. Kan., and southward. Our largest tree, often $90-130^{\circ}$ high, with a trunk $6-14^{\circ}$ in diameter.

\section{Order 101. JUGLANDACEAs. (Walnet Famity.)}

Trees, with alternate pinnate leaves, and no stipules; flowers monocious. the sterile in catkins (aments) with an irregnlar calyx alnate to the bract; the fertile solitary or in a small cluster or spike, with a regular 3-5-lobed calyx allherent in the incompletely 2-4-celled but only 1-ovuled ovary. Fruit a kind of dry drupe, with a crustaceous or bony nut-shell, containing a large 4-lobed orthotropous seed. Albumen none. Cotyledons fleshy and oily, sinuous or corrugated, 2-lobed; radicle slort, superior. Petals sometimes present in the fertile flowers. $-\Lambda$ small family of important trees, consisting chiefly of the two following genera.

\section{J ÜGL A N S, I. WALNut.}

Sterile flowers in long and simple lateral catkins from the wood of the preceding year; the calyx adherent to the entire bracts or scales, unequally $3-6$ cleft. Stamens 12-40; filaments free, very short. Fertile flowers solitary or several together on a peduncle at the end of the branches, with a 4-tootheil calyx, bearing 4 small petals at the sinuses. Styles 2, very short; stigmas 2, somewhat club-shaped and fringed. Fruit with a fibrous-fleshy iudehiscent epicarp, and a mostly rough irregularly furrowed endocarp or nut-shell. Trees, with strong-scented or resinous-aromatic bark, few-scaled or almost naked buds (3 or 4 superposed, and the uppermost far above the axil), odd-pinnate leaves of many serrate leaflets, and the embryo sweet and edible. l'ith in plates. (Name contracted from Joris glans, the nut of Jupiter.)

1. J. cinèrea, I. (Butrernet. White Walxut.) Leaflets $5-8$ pairs, oblong-lanceolate, pointed, rouuded at base, downy, especially heneath, the petioles and branchlets downy with clamm! hairs ; fruit oblony, clammy, pointed, the nut deeply sculptured and rough with ragged rilges, 2-celled at the base. - Rich woods, N. Eng. to the monntains of Ga., west to Minn., K. Kan., and Ark. Tree $50-75^{\circ}$ high, with gray bark, widely spreading branches, and lighter brown wool than in the next.

2. J. nigra, I. (Виск WАLхт.) Leaflets 7-11 pairs, orate-lanceolate, taper-pointed, somewhat heart-shaped or meqqual at hase, smooth ahove, the lower surface and the petioles minutely douny; fruit sphericul, ronghly dotted, the nut corrugated, 4-celled at top and hottom. - Rich woods, W. Mass. and Conn. to Fla., west to Minn., F. Neb., F. Kan., and southward. A large and handsome tree (often $90-150^{\circ}$ high), with rough brown bark, and valuable parplish-brown wood turning blackish with age. 


\section{CÁRYA, Nutt. Hickory.}

Sterile flowers in slender lateral and clustered catkins; calyx naked, adherent to the bract, unequally 2-3-parted. Stamens 3-10; filaments short or none, free. Fertile flowers $2-5$ in a cluster or short spike, on a peduncle terminating the shoot of the season; calyx 4-toothed; petals none. Stigmas sessile, 2 or 4, large, papillose, persistent. Fruit with a 4 -ralved, firm and at length dry exocarp (involucre), falling away from the smooth and crustaceous or bony endocarp or nut-shell, which is incompletely 2-celled, and at the base mostly 4-celled. - Fine timber-trees, with hard and very tough wood, and scaly buds, from which in spring are put forth usually both kinds of flowers, the sterile below and the fertile above the leaves. Nuts ripen and fall in October. (Kapv́a, an ancient name of the Walnut.)

$\S 1$. Sterile catkins fascicled (no common peduncle or sometimes a very short one) from separate lateral scaly buds near the summit of shoots of the preceding year; bud-scales few; fruit elongated-oblong; the thin-shelled nut 2-celled below; seed sweet; leaflets short-stalked, numerous.

1. C. olivæfórmis, Nutt. (Pecıx-xet.) Minutely downy, becoming nearly smooth; leaflets 13-15, oblong-lanceolate, tapering gradually to a slender point, falcate, serrate; nut olive-shaped. - River bottoms, S. Ind., S. Ill., and Iowa, to La. and Tex. A large tree $\left(90-160^{\circ}\right.$ high), with delicious nuts.

\$2. Sterile catkins in threes (rarely more) on a common peduncle from the axil of the inner scales of the common bud, therefore at the base of the shoot of the season, which, then beuring 3 or 4 leaves, is terminated by the fertile flowers; fruit globular or oval; nut 4-celled at base; leaflets sessile or nearly so.

* Bud-scales numerons, about 10, successively enurapping, the inner ones accrescent, becoming thin and membranaceous and rather tardily deciduous; husk of the fruit splitting promptly into $4 \mathrm{~m}$ re or less thick and when dry hard or woodly valies; seed suect and delicious. (The hickory nuts of the market.)

2. C. álba, Nutt. (Shell-Bark or Shag-Bark Hickorr.) Bark of trunk shaggy, exfoliating in rough strips or plates; inner bud-scales becoming large and conspicuous, persistent till the flowers are fully dereloped; leaflets $5-7$, when young minutely downy beneath, finely serrate, the three upper obovate-lanceolate, the lower pair much smaller and oblong-lanceolate, all taperpointed; fruit globular or depressed; nut white, flattish-globular, barely mucrouate, the shell thimnish. - N. Eng. to N. shore of I. Frie and S. E. Minn., south to Fla., E. Kan., and Tex. Large and handsome tree $\left(70-90^{\circ}\right.$ high, or more), of great economic value. The principal hickory-unt of the markets.

3. C. sulcàta, Nutt. (Big Shell-bark. Kivg-Net.) Bark, etc., as in n. 1 ; leaflets 7-9, more downy beneath; fruit oval or ovate, 4-ribbed above the middle, the husk very thick; nut large (1 $\frac{1}{4}-2^{\prime}$ long) and usually angular, dull white or yellowish, thick-ualled, usually strongly pointed at both ends. Central N. Y. and Penn. to S. Ind., E. Kan., and Ind. Terr. Tree 70-90 high, or more, in rich soil of bottom lands.

4. C. tomentòsa, Nutt. (Mocker-ect. White-heart Hickory.) Bark close, rough, but not shaggy and exfoliating on old trunks; catkins, shoots, and lower surface of the leares tomentose when young, resinous-scented; 
leaflets 7-9, lance-obovate or the lower oblung-lanceolate, pointed ; finit glubulur or ovoid, with a very thick and hard husk; mut globulur, wot compresserd, 4-ridged tourud the slightly pointed summit, brocnish, very thick-shelled, I' in diameter or smaller. - N. ling. to N. shore of L. Erie, L. Neb, and south to the Gulf. 'Tree $70-100^{\circ}$ high, usually on rich upland hillsilles.

5. C. microcárpa, Nutt. With rough close bark, small ovate l,urls, and the glabrous foliage, ete, of n. 6; fruit small, subglobose, with rather thin husk; nut thin-shelled, not angled. - N. Y. to Del., west to Mich. and 111.

* * Bud-scales numerous or few ; husk of the fruit thin and rather fiuble at muturity, t-calved only to the middle or tardily to near the base; seed more or less bitter; bark of old trunk not exfoliating.

6. C. poreina, Nutt. (I'IG-Nut or Broom H.) Bud-scales nearly as in 11. 4, but smaller, carlucous; shoots, eatkins, aud leaves glubions or nearly so; leaflets 5- $\boldsymbol{i}$, ohlong- or obovate-lanceolate and taper-pointed, seriate; fruit pear-shaped, oblong, or oval; nut oblong or oval (1 $\frac{1}{2}-2^{\prime}$ long), with a thick bony shell; the oily seed at first sweet in taste, then bitterish. - $\mathbf{S}$. Maine to Fla., west to Mimm., E. Neb., and Tex. 'Tree $70-90^{\circ}$ high (rarely 120 $)$, on dry hills and uplands.

7. C. amara, Nutt. (Bitter-xut or Swam II.) Seales of the small yellowish buds about 6, valvate in pairs, caducous in leafung; catkins and young herbage more or less pubescent, soon becoming almost glabrous: leaflets 7-11, lanceolate or oblong-lanceolate; fruit globular, narrowly 6-ridged ; nut globular, short-pointed, white (barely 1'long), thin-ualled; seed at first sweettasted, soon extremely bitter. - Moist soil, N. Eng. to Fla., west to Minn., E. Neb., and Tex. Tree 50-75 high; liusk aud nut-shell thinner and less hard than in other species.

\section{Order 102. MIRICACEAE. (SWhet-(GAle FamlY.)}

Monæcious or diccious shrubs, with both hinls of flowers in short scaly catkins, and resinous-dotted oflen fragrant leaves, - differing from the Birches chiefly in the 1-celled ovary with a single erect orthotropous ovule, and the drupe-like nut. Involucre and perianth none.

\section{M Y R İ $\mathbf{A}$ A, I. Bayerri. Wax-Myrte.}

The only genus. - Flowers solitary under a scale-like bract and with a pair of bractlets, the sterile in oblong or cylindrical, the fertile in ovoid or globular catkins, from axillary scaly buls; stamens $2-8$; filaments somewhat united below; anthers 2-celled. Ovary with $2-8$ seales at its base, and 2 thread-like stigmas. Fruit a small globular or oblong uut, or dry drupe, coated with resinous grains or wax. (Mupik $\eta$, the ancient name of the Tamarisk or some other shrub; perhaps from $\mu$ pi $\zeta \omega$, to perfume.)

* Mostly diccious; fertile cathins ornd ; ovar!y with 2-4 scales at base; nut globular; leaves entire or someuhat serrate.

1. M. Gale, I. (Sweet GıLE.) Shrub 3-50 high; leaves wedge-tanceolate, serrate toward the apex, pale, later than the flowers; sterile catkins slosely clustered; nuts in imbricated heads, 2-winged by the two thick orate 
scales which cualesce with its base. - Wet borders of ponds, Newf. to N. Fing. and along the Great Lakes to Minn., south in the mountains to Va.

2. M. cerifera, L. (DAYberry. Wax-MYrtle.) Leaves oblong-lanceolate, narrowed at the base, entire or wary-toothed toward the apex, shining and resinons-dotted both sides, someuhat preceding the flowers, fragrant; sterile catkins scattered, oblong; scales wedge-shaped at the base; nuts scattered and naked, bony, and incrusted with white wax. - Sandy soil near the coast, from Nova Scotia to Fla. and Ala.; also on L. Erie. Shrub $3-8^{\circ}$ high, but sometimes a tree $35^{\circ}$ high ; fruit sometimes persistent for 2 or 3 years.

* * Frequently monocious; fertile catkins globular; ovary surrounded by 8 long linear-awl-shaped persistent scales; nut ovoid-oblong; leaves pinnatifid with many rounded lobes.

3. M. asplenifolia, Endl. Shrub $1-2^{\circ}$ high, with sweet scented fernlike linear-lanceolate leaves; stipules half heart-shaped; scales of the sterile catkins kidney-heart-shaped, pointed. (Comptonia asplenifolia, Ait.) - Sterile hills, N. Eng. to N. C., west to Minn. and Ind. Known as Sweet Fern.

\section{Order 103. CUPULíferA. (OAK Family.)}

Moncecious trees or shrubs, with alternate simple straight-veined leaves, deciduous stipules, the sterile flowers in cathins (or capitate-clustered in the Beech), the fertile solitary, clustered, spiked, or in scaly catkins, the 1-celled and 1-seeded nut with or without an involucre. Ovary more or less 2-7-celled, with 1 or 2 pendulous anatropous ovules in each cell ; but all the cells and ovules except one disappearing in the fruit. Seed with no albumen, filled with the embryo.

Tribe I. BETULE $\boldsymbol{A E}$. Flowers in scaly catkins, 2 or 3 to each bract. Sterile catkins pendulous. Stamens $2-4$, and calyx usually $2-4$-parted. Fertile flowers with no calyx, and no involucre to the compressed and often winged small nut. Ovary 2-celled, 2-ovuled.

1. Betula. Stamens 2, bifid. Fertile scales thin, 3-lobed, deciduous with the nuts.

2. Alnus. Stamens 4. Fertile scales thick, entire, persisting after the nuts have fallen.

Tribe II. CORYLEAE. Sterile catkins pendulous, with no calyx; stamens 3 or more to each bract and more or less adnate to it, the filaments often forked (anthers 1-celled). Fertile flowers in a short ament or head, 2 to each bract, and each with one or more bractlets which form a foliaceous involucre to the nut. Ovary 2-celled, 2-oruled.

* Bract of staminate flower furnished with a pair of bractlets inside ; fertile flowers few.

3. Corylus. Involucre leafy-coriacenus, enclosing the large bony nut.

* * Bract of staminate flower simple ; fertlle flowers in short catkins ; nut small, achene-like.

4. Ostrya. Each ovary and nut inclnded in a bladdery and closed bag.

5. Carpinus. Each nut subtended by an enlarged leafy bractlet.

Tribe III. QUERCINEA. Sterile flowers with $4-7$-lobed calyx and stamens indefinite $(3-20)$. Fertile flowers 1 or few, enclosed in a cupule consisting of consolidated bracts, which becomes indurated (scaly or prickly) and surrounds or encloses the nut.

* Sterile flowers in slender catkins.

6. Quercus. Cupule 1-flowered, scaly and entire; nut hard and terete.

7. Castanea. Cupule 2-4-flowered, forming a prickly hard bur, 2-4-valved when ripe.

* * Sterile flowers in a small head.

8. Fagus. Cupule 2-flowered, 4-valved, containing 2 sharply triangular nuts. 


\section{BÉTULA, Tourn. Bırn.}

Sterile flowers 3, and hractlets 2, to each shield-shaped scale or bract of the catkins, consisting each of a calyx of one scale hearing 4 short filaments with 1-celled anthers (or strictly of two 2-parted filaments, each division hearing an anther-cell). Fertile flowers 2 or 3 to each 3-hohed bract, without bractlets or calyx, each of a naked ovary, becoming a broadly winged and scale-like nutlet (or small samara) crowned with the two spreading stigmas. - ()uter bark usually separable in sheets, that of the branchlets dotted. Twigs and leaves often spicy-aromatic. Foliage mostly thin and light. Buds sessile, scaly. Sterile eatkins long and drooping, terminal and lateral, sessile, formed in summer, remaining waked thropgh the suceeding winter, and expanding their golden flowers in early spring, with or preceding the leaves; fertile catkius oblong or cylindrical, pecluncled, usually terminating very short 2-leaved early lateral branches of the season. (The ancient Latin name, of Celtic origin.)

* Trees, with brown or yellow-gray bark, sweet-aromatic as well as the twigs, nembranaceous and straight-ceined Hornbeam-like leaves heart-shaped or rounded at base, on short petioles, and sessile very thick fruiting catkins; their scules about equally 3-cleft, rather persistent; wing of fruit not broader than the seed-bearing body.

1. B. lénta, I. (Cherry R. Sweet or Black Bircir.) Bark of trunk daik broun, close (outer layers scarcely laminate), very sweet-aromatic; leaves ovate or oblong-ovate from a more or less heart-shaped base, acuminate, sharply and finely doubly serrate all round, when mature shining or bright green above and glabrous except on the veins beneath; fruiting catkins oblong-cylindrical (1-1 $\underline{x}^{\prime}$ long), the seales with short and divergent lobes. - Rich woodlands, Newf. to N. Del., and south in the mountains, west to Miun., and S. Ind. Tree $50-75^{\circ}$ high, with reddish bronze-colored spray; wood rose-colored, finegrained, valuable for cabinet-work.

2. B. lùtea, Miehx. f. (Yellow or Gray Bircu.) Bark of trunk yellawish-or silvery-gray, detaching in very thin flmy layers, within and the twigs much less aromatic; leaves $\left(3-5^{\prime}\right.$ long) slightly or not at all heart-shaped and often narrowish toward the base, duller-green above and usually more downy on the veins beneath ; fruiting catkins oblong-oroid ( $l^{\prime}$ or less in length, 6-9" thick), the thinner scales (5-6" long) twice as large as in $\mathrm{n}$. 1, and with uarrower burely spreading lobes. - Rich moist woodlands, Canada and N. Eng. to Del., west to Minn.; also along high peaks to 'Tenn. and N. C. Often 60-90 high at the north; wood whiter and less valuable.

* * Trees, with chalky-white bark separable in thin sheets, orate or triangular leaves of firmer texture, on long slender petioles; fruiting catkins cylindrical, usually hanging on ruther slender peduncles; their scales glabrous, with short diverging lobes, freely deciduous; uing of the fruit much broader than its body.

3. B. populifolia, Ait. (Amerrcan White Burch. Gray Birch.) Trunk usually ascending $\left(15-30^{\circ}\right.$ high) ; leaves triangular (deltoill), very taperpointed (usually abruptly), truncate or nearly so at the broad base, smooth and shining both sides, except the resinous glands when young. (B. alba, var. 
populifulia, Spach.) - Poor sandy soils, N. Brunswick to Del., west to L. ()ntario. Bark much less separable than the next; leares on slender petioles, tremulous as those of the aspen.

4. B. papyrifera, Marshall. (Paper or Cayoe Birch. White Birch.) Leaves ovate, taper-pointed, heart-shaped or abrupt (or rarely wedgeshaped) at base, smooth and green above, pale, glandular-dotted, and a little hairy on the veins beneath, sharply and unequally donbly serrate, $3-4$ times the length of the petiole. (B. papyracea, Ait.) - Rich woodlands and streambanks, N. Eng. to N. Penn., N. Ill., and Minn., and far north and westward. Tree $50-75^{\circ}$ high, with bark freely splitting into paper-like layers. - Var. Mixor, Tuckerman, is a dwarf form of the alpine region of the White Mts.

* * Tree, with greenish-brown bark, somewhat laminate, and reddish twigs, ovate leares whitish beneath, and soft-downy peduncled fruiting cathins.

5. B. nigra, L. (RIVER or RED Birch.) Leaves rhombic-ovate, acutish at both ends, irregularly doubly serrate, whitish and (until old) downy underneath; petioles and peduncle of nearly the same length $\left(3-7^{\prime \prime}\right)$ and with the oblong catkin tomentose; the bracts with oblong-linear nearly equal lobes; fruit broadly winged. - Banks of streams, Mass. to Fla., west to Minn., E. Kan., and Tex. 'Tree $50-75^{\circ}$ high, with light-colored wood and somewhat Alder-like leares.

* * * * Shrubs, with brounish bark, rounded or wedge-shaped crenate and mostly small leaves of thichish or coriaceous texture, and oblony or cylindrical glabrous and mostly erect cathins, on short peduncles.

6. B. pùmila, L. (Low Bırсн.) Stems $\left(2-8^{\circ}\right.$ high) erect or ascending, not glandular; young branches and lower face of young leaves mostly soft-downy; leaves oborate, roundish, or orbicular $\left(6-16^{\prime \prime} \mathrm{long}\right)$, pale beneath, veinlets on both faces finely reticulated; wing of the fruit mostly narrower than the body.-Bogs, W. Conn. and N. J. to Ind. and Minn., and northward throughout Canada. Leaves usually not at all resiniferous or glandular-lotted.

7. B. glandulòsa, Michx. (DWARF Birch.) Stems erect or mostly spreading $\left(1-4^{\circ}\right.$ high), or when alpine procumbent; branchlets glabrous, conspicuously dotted with resinous wart-like glands; leaves roundish wedge-cbovate or sometimes orbicular $\left(6-9^{\prime \prime}\right.$ long), green and glabrous both sides, less reticulated; fruiting catkins mostly shorter and oblong or wal; wing of the fruit narrower than or sometimes equalling the body. - High mountains of N. Eng. and N. Y., to L. Superior, and far northward.

\section{2. Á I $\mathbf{N}$ U S, Tourn. Alder.}

Sterile catkins elongated and drooping, with 4 or 5 bractlets and 3 (rarely 6) flowers upon each short-stalkerl shield-shaped scale; each flower usually with a 3-5-parted calyx and as many stamens; filaments short and simple; anthers 2-celled. Fertile catkins ovoid or oblong; the fleshy scales each 2-3flowered, with a calyx of 4 little scales adherent to the scales or bracts of the catkin, which are thick and woody in fruit, welge-obovate, truncate, or 3-5lobed, and persistent. - Shrubs or small trees, with few-scaled leaf-buds, and solitary or often racemose-clustered catkins, terminating leafless branchlets or peduncles. (The ancient Latin name.) 
\$1. Flowers developed in spring with the leures; the sterile from catkins which have remuined naked over winter; while the jertile have been enclosed in a sculy lud: fruit with a conspicuous thin wing, us in Birch.

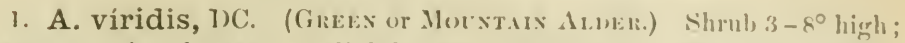
leaves romul-(nal, ovate, or slightly heart shaped, glutinous and smouth or softly duwuy beneath, irregularly serrulate or biscrulate with very sharp and clusely set teeth, sometimes sinuate-tuothed and serrulate (var. sividta, Regel), on young shoots often cut-toothed; fertile catkins slender-stalkerl, clustered, ovoid $\left(6-8^{\prime \prime}\right.$ long). - On monntains and mountain streams, Newf. to W. Mass., N. Y., L. Superiur, and far north and west; also in the Alleghanies to N. C. (Eu., Asia.)

\$2. Flowers developed in carliest spring, be fore the leaves, from mostly clustered catkins which (of both sorts) were formed the foregoing summer and have remained naked over winter, fruit wingless or with unarrow coriaceous margin.

2. A. incàna, Willd. (Specklen or HonRY A.) Lcaves broadly oval or ovale, rounded ut buse, sharply and often doubly serrate, whitened and mostly douny beneath; stipules oblong-lanceolate; fruit orbicular. - Borders of streams and swamps, Newi. to Mass., E. Neb., Minn., and westward. Shrub or tree 8-20 high; the common Alder northward. (Eu., Asia.)

3. A. serrulàta, Willd. (Sноотш A.) Leaves olovate, acute at base, sharply serrate with minute teeth, thickish, green loth sides, smooth or often downy beneath; stipules oval ; fruit ovate. - Borlers of streams and swamps, Mass. to Fla., west to S. E. Mimn. and Tex.; common. Shrub forming dense thickets, or sometimes at the south a small tree $6-35^{\circ}$ high.

\$3. Flou'ers in autumn (Sept.) from catkins of the scason; the fertile mostly solitary in the axils of the leares, ripening the fruit a year later; fruit wingless.

4. A. maritima, Muhl. (SEA-SIDE A.) Glabrous; learesoblong, orate, or obovate with a wedge-shaped base, slender-petioled, sharply serrulate, bright green, or rather rusty beneath ; fruiting eatkins large, oroid or oblong (9-12' long, $6^{\prime \prime}$ thick). - Borlers of streams and swamps. S. Del. and E. Md., near the coast. Small tree $15-25^{\circ}$ high. (F. Asia.)

\section{CÓRYLUS, Tourn. HAzEL-NLT. Filbert.}

Sterile flowers in drooping cylindrical catkins, consisting of 8 (half-) stamens with l-celled authers, their short filaments and pair of scaly bractlets cohering wore or less with the inner face of the scale of the catkin. Fertile flowers several in a sealy bud, each a single ovary in the axil of a scale or bract, and accompanied by a pair of lateral bractlets; orary tipped with a short limb of the adherent ealyx, incompletely 2-celled, with 2 penduluus ovnles, one of them sterile; style short; stigmas 2, clongated aud slender. Nit ovoid or ublong, bony, enclosed in a leafy or partly coriacents cup or involucre, consisting of the two bractlets enlarged and often grown together, lacerated at the bordce. Cotyledons very thick (raised to the surface in germination), edille; the short radicle included. - Shrmbs or small trees, with thinnish dunlyly-toothed leaves, folded lengthwise in the bud, flowering in early spring; sterile catkins single or fascicled from scaly buds of the axils of the preceding year, the fertile ter- 


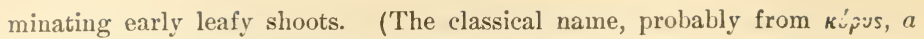
helmet, from the involucre.)

1. C. Americàna, Walt. (WILd HAzEL-Nut.) Leaves roundish-heartshaped, pointed; involucre open above down to the globose nut, of 2 broad foliaceous cut-toothed almost distinct bracts, their base coriaceous and downy, or with glandular bristles intermixed. - Thickets, N. Eng. to Ont. and Dak., and southward. Twigs and petioles often glandular-bristly.

2. C. rostràta, Ait. (BeAken HAzEL-xit.) Leaves ovate or ovateoblong, somewhat heart-shaped, pointed; involucre of united bracts, much prolonged above the oroid nut into a narrow tubular beak, densely bristly. $-\mathrm{N}$. Scotia to northern N. J., Mich., Minn., and westward, and south in the momntains to Ga. Shrub $2-6^{\circ}$ high.

\section{4. ÓSTRY A, Micheli. Hop-Hornbean. Iron-wood.}

Sterile flowers in drooping cylindrical catkins, consisting of several stamens in the axil of each bract; filaments short, often forked, bearing l-celled (half-) anthers; their tips hairy. Fertile flowers in short catkins; a pair to eacl deciduous bract, each of an incompletely 2-celled 2-ovuled ovary, crowned with the short bearded border of the adherent calyx, tipped with 2 long-linear stigmas, and enclosed in a tubular bractlet, which in fruit becomes a closed bladdery oblong bag, very much larger than the small and smooth nut; these inflated involucres loosely imbricated to form a sort of strobile, in appearance like that of the Hop. - Slender trees, with very hard wood, brownish furrowed bark, and foliage resembling that of Birch ; leaves open and concave in the bud, more or less plaited on the straight veins. Flowers in spring, appearing with the leaves; the sterile catkins $1-3$ together from scaly buds at the tip of the branches of the preceding year; the fertile single, terminating short leafy shoots of the season. (The classical name.)

1. O. Virgínica, Willd. (American Hop-Hornbeam. Lever-wood.) Leaves oblong-orate, taper-pointed, very sharply doubly serrate, downy beneath, with 11-15 principal veins; buds acute; involucral sacs bristly-hairy at the base.-Rich woods, common, from the Atlantic to N. Minn., Neb., E. Kan., and southward. Tree 25-45 high ; lop-like strobiles full-grown in Aug.

\section{CARPİN US, L. Hormban. Irox-wood.}

Sterile flowers in drooping cylindrical catkins, consisting of several stamens in the axil of a simple and entire scale-like bract; filaments very short, mostly 2-forked, the forks bearing 1-celled (half-) anthers with hairy tips. Fertile flowers several, spiked in a sort of loose terminal catkin, with small deciduous bracts, each subtending a pair of flowers, as in Ostrya ; but the single involucrelike bractlet is open, enlarged in fruit and foliaceous, merely subtending the small ovate several-nerved nut. - Trees or tall shrubs, with smootl close gray bark, in this and in the slender luds and straight-veined leaves resembling the Beech; leaf-buds and inflorescence as in Ostrya. (The early Latin name.)

1. C. Caroliniàna, IValter. (American Hornbeam. Blee or Water Веєсн.) Leares ovate-oblong, pointed, sharply doubly serrate, soon nearly smooth; bractlets 3-lobed, halberd-shaped, sparingly cut-toothed on one side, acute. (C. Americana, Michx.) - Along streams, N. Scotia to Fla., west to 
Minn., Iowa, F. lian., and Tex. 'Tree or shrub, $10-45^{\circ}$ high, with ridged trunk, and very hard wood.

\section{QUÉRCUS, І. ОАк.}

Sterile flowers in slender naked catkins; hracts ealucous; caly 2 -8-parted or lobed; stamens 3-12 ; anthers 2-celled. Fertile flowers scattereil or somewhat clustered, consisting of a nearly 3-celled and 6-oruled ovary, with a 3-lubed stigma, euclosed by a scaly bud-like involucre which becomes an indurated ('n) (cupule) around the base of the rounded nut or acorn. Cotylerlons remaining unlerground in germination; radicle very short, includerl. - Flowers greenish or yellowish. Sterile catkins single or often several from the same lateral scaly hul, filiform and hanging in all our species. (The classical Latin name.) All flower in spring, and shed their unts in Oct. of the samo or the next year.

$\$$ I. LEUCOBAL.INUs. Bark pule, oflen scaly; leuves and thcir lobes or teeth obtuse, never bristle-pointed; stamens 6-8; scules of the cup more or less knobby at base; stigmes sessile or nearly so; abortive orules at the base of the perfect seed; inner surface of nut glabrous; fruit maturing the first year, often peduncled; hernel commonly succtish; wood tongh and dense.

* Leaves deciduous, lyrate or sinuate-pinnalifid, pale bencuth. - White OAKs.

1. Q. álba, L. (Wnite O.ı.) Mature leares smooth, pale or glaurons underneath, bright green above, obovate-oblong, obliquely cut into 3 -9 oblong or linear and obtuse mostly entire lobes; cup hemispherical-saucer-shuped, rongh. or tubercled at maturity, naked, much shoiter than the ovoid or oblong acorn (1'long). - All soils, Maine to S. E. Minn., E. Kan., and south to the Gulf. A large and valuable tree; lubes of the leares short and bruad (3-5), or deep and narrow $(5-9)$.

2. Q. stellàta, Wang. (Post OAk. Irox ().k.) Leaves grayish or yellowish-douny underneath, pale and rough aboce, thickish, sinuately cut into 5-7 rounded divergent lobes, the upper ones much larger and often $1-3$ notched; cup deep saucer-shaped, naked, one third or half the length of the ovoid acorn (6-9" long). (Q. obtusiloba, Michx.) - Sandy or sterile soil, Martha's Vineyard to Mich. and E. Neb., south to Fla. and 'Tex.; common, especially southward. A small tree with very durable wond.

3. Q. macrocárpa, Michx. (Bur OAk. Over-cup or Mossi-cle OAK.) Leaves obovate or oblong, lyrately-pinnatifid or deeply sinuate-lobed, or nearly parted, sometimes nearly entire, irregular, downy or pale beneath; the lobes sparingly and obtusely toothed, or the smaller ones entire; cup drep, thick ami woody (9" $-2^{\prime}$ across), conspicuously imbrieated with hard and thick pointed scales, the upper on's an'ned, so as usually to make a mossy-fringed border; acorn broadly oroid ( $1-1 \frac{f^{\prime}}{2}$ long), half immersed in or entirrly enclosed by the cup. Rich soil, N. Seotia to Wr. Mass. and I'emn., west to Minn., central Neb., and Kan. A large aud valuable tree; extremely variable in the size and fringe of the acorns. - Var. olıғғómur, Gray, is ouly a narrower-leaved form with unusually small oblong acorns.

4. Q. lyràta, Walt. (Over-cul OAk. Swamp Post O.к.) Leaves crowded at the end of the branchlets, obovate-oblong, acute at base, more or less deeply 7 -9-lobed, white-tomentose beneath or at length smoothish, the lobes triangulur to vblong, acute or obtuse, entire or sparingly toothed; fruit short-peduncled 
or sessile; cup round-ovate, thin, with rugged scales, almost covering the depressedg'obose acorn $\left(8-10^{\prime \prime}\right.$ long). - River swamps, N. E. Mo. to S. Ind., Tenn., N. C., and southward. - A large tree, with flaky bark; intermediate between n. 3 and n. 5 .

* Leaves coarsely sinuate-toothed, bui not lobed (except slightly in n. 5), whitish and more or less downy beneath; cup hoary, hemispherical or a little depressed, about half as long as the oblong-ovvid edible acorn. - Chestrut-OAKs.

5. Q. bícolor, Willd. (Swaмp White OAk.) Leaves. obovate or oblong-obovate, wedge-shaped at base, coarsely sinuate-crenate and often rather pinnatifid than toothed, usually soft-rlowny and white-hour:j beneath, the main primary veins 6-8 pairs, lax and little prominent; fruiting peduncle much longer than the petiole; upper scales of the cup awn-pointed, sometimes forming a mossy-fringed margin; acorn scarcely $l^{\prime}$ long. - Borders of streams and swamps, S. Maine to Ont., Minn., and E. Kan., and south in tle mountains to N. Ga. - A large tree, with flaky bark.

6. Q. Michauxii, Nutt. (Basket-OAk. Cow-OAк.) Leaves (5-6' long) oval or obovate, acute, obtuse or even cordate at base, regularly dentate (commonly not deeply), rather rigid, usually very tomentose beneath; stamens usually 10 ; fruit short-peduncled; cup shallow, tuberculate with hard and stout acute scales, without fringe; acorn 1 $\frac{1^{\prime}}{2}$ long. (Q. Prinus, var Nicl:auxii, Chapm.) - Borders of streams and swamps, Del. to Fla., and in the west from S. Ind. to Mo., and south to the Gulf. - A large and valuable tree, with gray flaky bark and large sweet edible acorus. Intermediate forms appear to connect with n. 5, of which Dr. Engelmann considered it a subspecies.

7. Q. Prinus, L. (Chestyct-OAк.) Leaves thick, varying, obovate or oblong to lanceolate, sometimes acuminate, with an obtuse or ucute base, undulately crenate-toothed, pale and minutely douny beneath, the main primary ribs 10-16 pairs, straight, prominent beneath; fruiting peduncles shorter than the petioles, often very short: (up thick $\left(6-12^{\prime \prime}\right.$ wide), mostly tuberculate with hard and stout scales; acorn large (sometimes $1-l_{\frac{1}{4}}^{\prime}$ long). (Incl. var. monticola, Michx.) - Rocky banks and hillsides, E. Mass. to N. Y. and Ont., and south in the mountains to N. Ala. A large tree, with thick and deeply furrowed bark, rich in tannin.

8. Q. Muhlenbérgii, Engelm. (Ýllow OAk. Chestrut-Oak.) Leaves (5-7' long) slender-petioled, often oblong or even lanceolate, usually acute or pointed, mostly obtuse or roundish at base, almost equably and rather s.larply toothed; cup subsessile, shallow, thin, of small appressed scales, $5-7^{\prime \prime}$ broad; acorn globose or obovate, $7-9^{\prime \prime}$ long. (Q. Prinus, var. acuminata, Michx.) - Dry hillsides and rich bottoms, Mass. to Del., along the mountains to N. Ala., west to Mimn., E. Neb., and Tex. - Leares more like those of the Chestnut than any other; the primary veins very straight, impressed above, prominent beneath. A tall tree, with thin flaky bark.

9. Q. prinoides, Willd. Like ihe last, but of low stature (usually $2-4^{\circ}$ high), with smaller more undulate leaves on shorter petioles (3-6" long), and deeper cups with more tumid scales. (Q. Prinus, var. humilis, Marsh.) - Same range as last. Apparently quite distinct at the east, where it is very low, but running into Q. Muhleubergii at the far west. 
* Leaves coriaceous, everyreen, entire or rarely spiny-toothed. - Lrvi: OAks.

10. Q. virens, Ait. (Live Oлк.) Leaves small, oblong or elliptical, hoary beneath as well as the branchlets; peduncle usually conspicunus, 1 - 3 fruited; ('up top-shaperl; acorn oblong ; cotyleslons completely united intu one mass. - Aloug the coast from Va. to Fla. and Tex. Breoning a large tree at the south, and formerly extensively used in ship-luilding.

§2. MEIANOBSLANLS. Burk dark, furroued; leates dreidnots, the ir lobes and tecth acate and bristle-pointed (at least in youth); stumens mostly 4-6; cup-scales membranacenus; styles long and spreading; abortire orules near the top of the perfect seed; inner surfuce of nut tomentose; finit maturing the second year, sessile or on short thick peduncles; uood porous and brittle.-B̈.аск OAкs.

* Leates yimuatifid or lobed, slender-petioled, not coriaceous, the lobes or teeth conspicuously bristle-pointed.

- Mature leaves glabrous on both sides or marly so, ocal, oblong or somerhat obovate in outline, from moderately sinuate-pinnatifid to deeply pinnatifid, turning various shades of red or crimson in late autumn; large trees, with reddish course-yrained woorl; species closely related and apparently readily hybridizing.

11. Q. rùbra, I. (RED OAK.) Cup saucer-shaped or flat, with a narrow raised borler $\left(9-12^{\prime \prime}\right.$ in diameter), of rather fine closely appresied scales, sessile or on a very short and alıupt narrow stalk or neek, very much shorter than the oblong-ovoid or ellipsoidal acorn, which is $\mathrm{l}^{\prime}$ or less in length; leaves rather thin, turning dark red after frost, moderately (rarely very decply) pinnatifil, the lobes acuminate from a broad base, with a few coarse teeth; bark of trunk dark gray, smoothish. - Common both in rich and poor soil, westward to E. Minn and E. Kan. Timler eoarse and poor. - Var. RcxcIs..., A. 1)C., is a form with regular nearly entire lobes and the fonit nearly a half smaller; found near St. Lonis.

12. Q. coccínea, Wang. (Scarlet OAk.) Cup top-shapied, or hemispherical with a conical base (7-9" broad), coarsely scaly, covering half or more of the broadly or globular-ovoid acorn, the scales somewhat appressed and glabrate, or in western localities yellowish-canescent and squarrose as in var. tinctoria; leaves in the ordinary forms, at least on full-grown trees, bright green, shining above, turning red in antumn, deeply pimatificl, the slender lobes divergent and sparingly cut-toothed; buds small; acorns 6-9" long; hark of the trunk gray, the interior reddish. - Moist or dry soil; ("ommon, from S. Maine to Del., Minn., N. Mo., and sonth in the mountains.

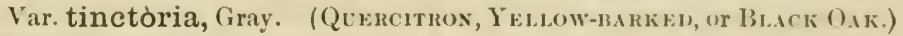
I.eares with broader nndivided lobes, commonly paler and somewhat pulescent beneath, turning brownish, orange, or dull red in antmmu; ('up-scales large and loosely imbricated or sfunarrose when dry, yellowisl gray, pubescent; bark of trunk darker-colored and rougher on the surface, thicker, and internally orange, much more valuable for the tanner and dyer; buils longer and more pointed ; cup sometimes less top shaped. (Q. tinctoria, Burtram.) - Dry or gravelly uplands, S. Maine to S. Minn., E. Neb. and Tex. Intermediate forms counect this with the type. The bark is largely used in tamning. 
Var. ambigua, Gray. (GRAy OAk.) Found along our northeastern borders to Lake Champlain and northward, figured and briefly characterized by Michaux as with the foliage of Q. rubra and the frnit of Q. coccinea. It was considered by Dr. Engelnamn as a form of Q. rubra with cups hemispherical or even turbinate.

13. Q. palústris, Dn Roi. (Swamp Spanish or Pix Oar.) Cup flatsaucer-shaped, sometimes contracted iuto a short scaly base or stalk, fine-scaled (5- $\because "$ broad), very much shorter than the usually giobose or depressed acorn, which is $5-7^{\prime \prime}$ long; leaves deeply pinnatifid with divergent lobes and broad rounded sinuses. - Low grounds; rather common, from Mass. to Del. and Md., west to Minn., E. Kan., and Ark.

+- - Mature leaves soft-downy beneath; cup saucer-shaped, with a somewhat top-shaped base, about half the length of the fully dereloped small acoin.

14. Q. falcàta, Michx. (SPAxish OAк.) Leares grayish-downy or fulvous underneath, obtuse or rounded at base, 3-5-lobed above (sometimes entire); 'the lobes pro'onged, mostly narrow and more or less scythe-shaped, especially the terminal one, entire or sparingly cut-toothed; acorn globose, 4-5" long. Dry or sandy soil, Long Island to Fla., and from S. Ind. to Mo. and Tex. A large or small tree, extremely variable in foliage; bark excellent for tanning.

15. Q. ilicifolia, Wang. (BEAR or BLACK SCRLb-OAK.) Dwarf (3$8^{\circ}$ high), straggling; leaves $\left(2-4^{\prime}\right.$ long) thickish, obovute, wedge-shaped at buse, angularly abont 5- (3-7-) lobed, white-donny beneath; lobes short and triangular, spreading; acorn ovoid, globular, 5-6" long. - Sandy barrens and rocky hills, X. Eng. to Ohio and Ky.

* * Leaves entire or with a feu teeth (or someuhat 3-5-lobed at the summit), coriaceous, commonly bristle-pointed; acorns globular, small (not over 6"long).

- Leaves thick, widening or often-much dilated upward and more or less sinuate or someuhut 3-5-lobed; acorns globular-ovoid.

16. Q. aquática, Walter. (WATER-OAK.) Leaves glabrous and shining, obocate-spatulate or nurrowly wedge-form, with a long tapering base and an often obscurely 3-lobed summit, varying to oblanceolate; cup saucer-shaped or hemispherical. - Wet grounds, around ponds, etc., Del. to the Gulf, and from Ky. aud Mo. to Tex. - Tree $30-40^{\circ}$ high ; runuing into many varieties, especially southward; the leares on seedlings and strong shoots often incised or sinuatepinnatifid; then mostly bristle-pointed.

17. Q. nigra, L. (BLACK-JACK or BARRex OAK.) Leaves broadly wedqeshaped, but sometimes rounded or obscurely cordate at the base, widely diluted and somewhat 3-lobed (rarely 5-lobed) at the summit, occasionally with one or two lateral conspicuously bristle-tipped lobes or teeth, rusty-pubescent beneath, shining above, large $\left(4-9^{\prime}\right.$ long); cup top-shaped, coarse-scaly; acorn shortovoid. - Dry sandy harrens, or heavy clay soil, Long Islaud to S. Minn., E. Neb., and sonthward. A small tree (sometimes $30-40^{\circ} \mathrm{high}$ ), of little value.

+ + Leares not dilated upuard, generally entire; acorn globose.

18. Q. imbricària, Michx. (LAurel or Shixgle OAk.) Leaves lan ceolate-oblong, thickish, smooth, and shining above, downy underneath, the down commonly persistent; cup between saucer-shaped and top-shaped. - Rich woodlands, Penn. to Ga., west to S. Wisc., Iowa, E. Neb., and N. Ark. - 
Tree $30-90^{\circ}$ high. The specific name is in allusion to its early use for shingles.

19. Q. Phéllos, L. (Wrulow-Osk.) Lenies linear-lanceolate, narroured to both ends, soon glabrous, light green (3-4' long); cup sancer-shaped. Bottom lands or rich sandy uplands, Staten Island to N. Fla., west to S. Ky., Mo., and Tex.

In addition to the above, the following hybricls have been recognized :-

Q. AlBA X MACROCARPA; N. Ill. (Bebl) ; central Ill. (II all).

Q. Alba X stellata; N. Ill. (Bebb); 1). C. (Vasey) ; N. C. (Jellichamp).

(2. Alba $\times$ Prives; near Washington, 1). C. (Viisey.)

Q. imbicira $X$ xigri (Q. trillentata, Engelmemn); s. Ill. (Engelmann).

Q. imuricania $X$ Palestris; Mo. (Engelinenn).

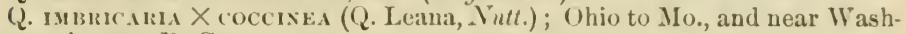
ington, 1). C.

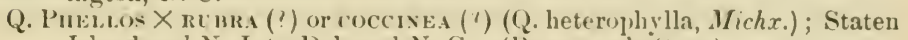
Islaud and X. J. to Del. and N. C. (B.1RTRAM's () AK.)

Q. Phellos X xigra (Q. Rnalkini, Britt.); N. J. (Rudkin).

Q. ILICIFolia $\times$ coccinea (?); Uxbridge, Mass. (K'obbins.)

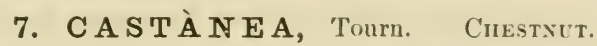

Sterile flowers interruptedly clustered in long and naked cylindrical catkins ; calyx mostly 6-parted; stamens 8-20; filaments slender; anthers 2-celled. Fertile flowers few, usually 3 together in an ovoid scaly prickly involucre; calyx with a 6-lobed border crowning the 3-7-celled 6-14-ovuled ovary; abortive stamens 5-12; styles linear, exserted, as many as the cells of the orary; stigmas small. Nuts coriaceous, oroid, enclosed $2-3$ together or solitary in the hard and thick very prickly 4-valved involucre. Cotyledons very thick, somewhat plaited, cohering together, remaining undergronud in germination. Leaves strongly straight-reined, undivided. Flowers appearing later than the leares, cream-color; the catkins axillary near the end of the branches, wholly sterile or the upper ones and.rogynous with the fertile flowers at the base. (The classical name, from that of a town in Thessaly.)

1. C. sativa, Mill., var. Americàna. (Cunstxut.) A large tree; leaves oblong-lunceolute, pointed, serrate with coarse pointed teet acute at hase, when mature smooth and green both sides; nuts 2 or 3 in each involucre, therefore flattened on one or both sides, very sweet. (C. vesea, var., of the Manual.) - Rocky wooks and hillsides, S. Maine to J)el., along the mountains to $\mathrm{X}$. Ala., and west to S. Mich., S. Ind., and Tenn.

2. C. pùmila, Mill. (Cuxomurix.) A spreading shrub or small tree; leaces oblong, acute, serrate with pointed tecth, whitened-rloun! beneath; involucres small, often spiked; the ovoid pointerl nut searcely half as large as a common chestnut, very sweet, solitary, not flattened. - Rich hillsides and borders of swamps, s. I'enu. to Fla., west to S. Ind. and Tex.

\section{F A G US, Tonrn. Beech.}

Sterile flowers in small hearls on dronping peduncles, with decidnous sealelike bracts; calyx bell-shaperl, 5-7-cleft; stamens 8-16; filaments slender; anthers 2-celled. Fertile flowers usually in pairs at the apex of a short peduncle, invested by numerous awl-shajed bratlets, the inner coherent at base 
to form the 4-lobed involucre; calyx-lobes 6, awl-shaped; ovary 3-celled with 2 ovules in each cell; styles 3 , thread-like, stigmatic along the inner side. Nuts sharply 3 -sided, usually 2 in each urn-shaped and soft-prickly coriaceons involucre, which divides to below the middle into 4 valves. Cotyledons thick, folded and somewhat united; but rising and expanding in germination.-Trees, with a close and smooth ash-gray bark, a light horizontal spray, and undivided strongly straight-reined leares, which are open and convex in the tapering bud and plaited on the veins. Flowers appearing with the leaves, the yellowish staminate flowers from the lower, the pistillate from the upper axils of the leaves of the season. (The classical Latin name, from $\phi a ́ \gamma \omega$, to eat, in allusion to the esculent nuts.)

1. F. ferrugínea, Ait. (Aмericax Beech.) Tree 75-100 ${ }^{\circ}$ high ; leaves oblong-ovate, taper-pointed, distinctly and often coarsely toothed; petioles and midrib soon nearly naked; prickles of the fruit mostly recurved or spreading. - N. Scotia to Fla., west to Wise., E. Ill., Mo., and Tex.

\section{Order 104. SALICÀCEAE. (Willow Family.)}

Diocious trees or shrubs, with both hinds of flowers in catkins, one to each bract, without perianth; the fruit a 1-celled and 2-4-valved pod, with 2-4 parietal or basal placenta, bearing numerous sceds furnished with long silky down. - Style usually short or none; stigmas 2, often 2-lobed. Seeds ascending, anatropons, without albumen. Cotyledons flattened. Leaves alternate, undivided, with scale-like and deciduous, or else leaflike and persistent, stipules. Wood soft and light; bark bitter.

1. Salix. Bracts entire. Flowers with small glands; disks none. Stamens few. Stigmas short. Buds with a single seale.

2. Populus. Bracts lacerate. Flowers with a broad or cup-shaped disk. Stamens nnmerous. Stigmas elongated. Buds scaly.

\section{SÀ I I X, Tourn. Willow. Osier. (By M. S. Bebb, Esq.)}

Bracts (scales) of the catkins entire. Sterile flowers of 3-10, mostly 2, distinct or united stamens, accompanied by 1 or 2 small glands. Fertile flowers also with a small flat gland at the base of the ovary; stigmas short. - Trees or shrubs, generally growing along streams, with terete and lithe branches. Leaves mostly long and pointed, entire or glandularly toothed. Buds covered by a single scale, with an inner adherent membrane (separating in n. 14). Catkins appearing before or with the leaves. (The classical Latin name.)

$\S 1$. Aments borne on short lateral leafy branchlets; scales yellouish, falling before the capsules mature; filaments hairy below, all free; style very short or obsolete; stigmas thick, notched. Trees or large shrubs; leaves taper-pointed.

* Leaves closely serrate with inflexed teeth; capsules glabrous.

- Stamens 3-5 or more.

+- Trees $15-50^{\circ}$ high, with rough bark and slender twigs; no petiolar glands; sterile ameuts elongated, narrowly cylindrical; flowers somewhat remotely subverticillute: scales entire, short and rounded, crisp-villous on the inside.

1. S. nigra, Marsh. (Bцаск WrLlow.) Leaves narrowly lanceolate, very long-attenuate from near the roundish or acute base to the usually curced tip, 
often downy when young, at length green and glubrous except the petiole and midrib; stipules large, semicordate, pointed and persistent, or small, ovoid and deciduous; fruiting aments $\left(1 \frac{1}{2}-3^{\prime}\right.$ long) more or less dense; capsules ovate conical, shortly pedicelled. - Banks of strenus and lakes, hending over the water; common. - Var. FAlcdta, Torr. Leaves narower and seytheshaped. - Var. Wánur, Bebb. Leaves broater, often l' wide, glaucous and veined beneath; stipules large, round-reniform; aments long, loosely flow: ered; capsules globose-conical, long-pedicelled. Rocky islands of the l'otomac ( $\mathrm{W}$ ard); Falls of the ()hio (short); Mo. The leaves alone are easily mis. taken for those of n. 14. - A hybrid of this species with S. alba, var. vitellina, is found in Wayne Co., N. Y. (E. L. Hankenson).

2. S. amygdaloides, Anders. Leaves lunccolate or ovate-lanceolate, $2-4$ ' long, attenuate-cuspidate, pule or gluurous beneath; petioles long and slender; stipules minute, very early deciduons; fertile aments becoming very loose in fruit from the lengthening of the slender pelicels. - Central N. Y. (Dudle $y$ ) to Mo.; conimon westward.

+ A shrub or small bushy tree, 6-15 ligh, with smooth bark and rather stout polished twigs; petioles glandular; sterile aments thick, oblong-cylindrical, densely flowered; stamens commonly 5 ; scales dentate, hairy at base, smooth above.

3. S. lùcida, Muhl. (Surixg W.) Leaves ovate-lanceolate or narrower, tapering to a very long acuminate point, at length coriaceous, smooth and shining both sides; stipules small, oblong; fruiting aments often persistent, the capsules becoming rigid and polished, as in the nearly allied $\mathrm{S}$. pentandra of Europe.-Banks of streams, N. Eng. to Penn., west and northward. A beautiful species on account of its showy staminate aments and large gloss. leaves.

+- + Stamens mostly 2; capsules subsessile or ver!y shortly pedicelled; leaves lancrolate, long-acuminate.

S. FRÁilis, I. (Crack Wiliow.) Lea s green and glabrous, pale or glancous beneath, $3-6^{\prime}$ long; stipules when present half-cordate; stamens rarely 3-4; capsule long-comical, shortly pedicelled. - A tall and handsome tree, which was planted at an early day about Boston and elsewhere. - The var. Decfplexs, Smith, with vellowish-white or crimson twigs, buds black in winter, and smaller and brigliter green leaves, onght perhaps to be excluded, the plant so named by Barratt, etc., heing one of the hybrids mentioned below. (Adv, from Eu.)

S. ÁlBA, L. (WHite W.) Leaves ashy-qray or silky-uhite on both sides, except when olll, 2-4' long; stipules ovate-lanceolate, deciluous; capsule's ovate-conical, sessile or nearly so. - Var. ckntuted, Koch; twigs olive; old leaves smooth, glancoms beneath, dull hluislı green. - Var. Virkilìis, Koch; twigs yellow or reddisl $I_{1}$ old leaves glabrous above. $-\Lambda$ familiar tree of rapid growt $\hat{l}_{1}$, attaining a height of $50-80^{\circ}$. 'The typical form, with olive twigs and old leaves silky on both sides, is rarely fonnd with us, but the var. vitiı.ıN is common. P'ure S. FRAGilis is also scarce, but a host of hrlirils between the two, representing S. viridis, Fries, S. Russelliana, simith, etce, are the commonest of introdnced willows. These forms are rendered almost inextricable by a further cruss, by no means rare, with our native s. lueida. (Adv. from Eu.)

S. Babróxica, Tourn. (WEerixg W.) Extensively planted for ornament, and in some plates widely spread along river-lanks and lake-shores by the drifting of detached limbs. (Aw. from Eu.) 
* Leaves remotely denticulate with projecting teeth; stamens 2 ; capsule glabrous or silky.

4. S. longifòlia, Mulıl. Leaves linear-lanceolate, 2-4' long, tapering at each end, nearly sessile, more or less silky when young, at length smooth and green both sides; stipules small, lanceolate, deciduous; aments linearcylindric, often clustered at the ends of the branchlets ; capsule shortly pedicelled; stigmas large, sessile. - Found sparingly along the Atlantic coast from Maine to the Potomac; common westward. A shrub, rooting extensively in alluvial deposits and forming dense clumps. This species is a peculiar American type, and exceedingly variable; the earliest leaves after germination pimuately lobed.

$\S 2$. Aments lateral or terminal, with or without bracts; scales persistent, colored at the tip; stamens 2 (usually 1 in $\mathrm{n} .19$ ), with glabrous filaments (united and hairy in S. purpurea); shrubs or small trees.

\section{* Capsules tomentose.}

+ Pedicels 3-6 times the length of the gland; style medium or none.

+ Large shrubs or sinall trees $\left(8-15^{\circ}\right.$ high $)$; leaves obovate or elliptic-lanceolate, 2-4' long, acute or acuminate, more or less obscurely and irregularly serrate, thin becoming rigid, glancous beneath; fertile aments oblong-cylindric, 2-3' long, loosely flowered.

5. S. rostràta, Richardson. Leaves dull grcen and douny above, stoutly reined and soft-lictiry bencuth, serrate, crenate or subentire; stipules when present semi-corlate, toothed, acute; aments appearing with the leaves, the sterile narrowed at hase, pale yellow; capsnles tapering to a very long slender beak; pedicels thread-like, mnch exceeding the pale, rose-tipped, linear, thinly villous scales; style scarcely auy; stigma-lobes entire or deeply partel. (S. livida, var. oc(identalis, (ira!). - Moist or dry ground, N. Eng. to Penn., and far west and northward. N t spreading from the root hut having rather the habit of a small tree, with a distinct trunk.

6. S. díscolor, Mubl. (Guccors W.) Leaves smooth and bright green above, soon smorth bicielth, irregularly crenate-serrate, the serratures remote at base, closer, finer and becoming obsolete toward the point; stipules $\frac{1}{2}$ long or more, and sharply toothed, or small and nearly entire; aments closely sessile, thick, oblong-cylindrical, l' long or more, appearing before the leaves in earliest spring; scales dark rer or brown, becoming black, copiously clothed with long glossy hairs; style short but distinct. - Var. Erıocépridla, Anders. Aments inore densely flowered and more silvery silky; leaves sometimes retaining a ferruginons pubescence beneath even when fully grown. - Var. PRixoìdes, Anders. Aments more loosely flowered, less silky; capsules more thinly tomentose; style longer; stigma-lobes laciniate ; leares narrower. (S. prinoides, Pursh.) Includes narrow-leaved forms of the type, and others which are probably hybrids with S. cordata. - Low meadows and river-banks, common. The just expanding leaves are often overspread with evanescent ferruginous hairs.

+ Upland grayish shrubs, 1-8 ${ }^{\circ}$ high; leaves oblanceolate, pointed, the lowest obtuse, dounn ubove becoming glabrate, beneath glancous, rugose-reined and softly tomentose, the margin revolute, undulate-entive; aments ovoid or 
oblong, closely sessile, appearing bejore the lewes, naked at base; capsules rather shortly pedicelled, greenish or reddish, spreading; scales durk red or brounish; style distinct; stigmas bifid.

7. S. hùmilis, Marsh. (Prairiv IV.) Leares oblanceolute or oblung-tunceolate, the lowest obovate; stipules medium-sized, semi-ovate, entire or oftener toothed; petioles distinct; aments often recurved, abont I' long. - I)ry plains and barrens, common. A shrub, $3-8^{\circ}$ high, varying much in the size and shape of the leaves. Hybrits with $n, 6$ have equally broad and large but duller green leaves, softly tomentose beneath and with shorter petioles, the aments eyually thick but usually recurved, and the capsules on shorter pedicels. Small forms apparently jass into the next.

8. S. trístis, Ait. (I)WARF GRAY W.) Leaces small (1-2'long), crouded, linear-ablanceolate, tapering to a very short petiole; stipules minute, deciduous; aments very small, glolular or oval, ahout $\frac{1^{\prime}}{2}$ long in fruit. - Sandy plains or on the borders of hillside thichets, common. A tufted shrub, $1-1 \frac{1}{2} \circ$ high, rising from a strong large root.

+ Low shrubs, $3-10^{\circ}$ high, of cold swomps, with slender yellonish or reddish twiys; leares lanceolate, smooth above, glancons beneuth and corered when young with appressed silvery-silky hairs; aments (especially the fertile) with a few leafy bructs at base; capsule pedicelled, silvery-silky; stigmas bifid.

= Shrubs oflouland swamps; leaves narrowly lanceolate, 2-3' lng,taper-pointed, finely and evenly serrate; stipules lineur or semi-cordate, deciduous; aments sessile or in fruit slightly peduncled; style rer.y short.

9. S. serícea, Marsh. (SiLKY W.) Leaves at first (principally beneath) very silky, turning black in drying; aments narrowly cylindricai, the fertile densely flowered; (apsule short-pedicelled, ovate-oblong, rather olstuse. - Com. mon, but more prevalent from the region of the Great Lakes eastward.

10. S. petiolàris, Smith. Leaves only slightly silky when young, soon smooth, with less tendency to blacken in drying; fertile aments ovoid-cylindric, in fruit broad and loose from the lengthening of the pedicels; capsule rostrate from an ovate hase, rather acute. - Var. Grícılıs, Inders., has extremely loose aments, and very long-pedicelled attenuate-rostrate capsules. - Common, but more prevalent from the Great Lakes westward. 'This species, like the preceding, hybridizes freely with $\mathrm{S}$. cordata.

$==\Lambda$ Ipine shrub; leaves $1-2^{\prime}$ long, repand-crenate; stipules minute, fugacions; uments leafy-peduncled; style distinct.

11. S. argyrocárpa, Anders. Leaves tapering evenly to hoth ents, acute, or the earliest ohovate and olstuse, at length rigid, the margin slightly revolute; petiole short; fruiting ament short (about $l^{\prime}$ long), loosely flowererl; capsule tapering, densely silky-silvery ; gland of the staminate flower variously doubled. - Moist alpine ravines in a few limited localities on or near Mt. Washington, N. H. ; also in Lower Canada and Lab. A buslỵ liranched slırub, erect or depressed at base, $1-2^{\circ}$ high, growing in wille dense patehes. A hybrid with n. 13 was detected hy Mr. E. Faxon in Tuckerman's ravine (its leaves collected by Dr. Gray as early as 1842 !), appearing like a large form of the species with the aments of S. phylicifolia. 


\section{+- + Pedicels twice we length of the gland; st.jle elonyated.}

12. S. cándida, Willd. (SAGE W. HoARY W.) Leaves lanceolate or linear-lanceolate, $2-4^{\prime}$ long, taper pointed or the lowest obtuse, rather rigid, downy above, becoming glabrate, beneuth cocered with a dense white tomentum, the revolute margin subentire; stimules lanceolate, abont as long as the petioles; aments cylindrical, densely flowered, $2^{\prime}$ long in fruit; anthers red; the dark gland elongated; capsule densely white-woolly ; style dark red ; stigmas short, spreading, notched. - Cold bogs, N. Eng. and N. J. to Iowa, and northwarl. - A hoary shrub 2-50 high; young shoots white-woolly, the older red. Two beautiful hybrids, with n. 10 and n. 14, have been found near Flint, Mich. (Dr. Clarke).

13. S. phylicifolia, L. Leaves lanceolate, ovate-lanceolate or elliptic, somewhat equally pointed or obtuse at both ends, remotely and minutely repandtoothed, 2-3' long, rery smooth on both sides, dark green and shining above, glaucous beneath, at length coriaceous; stipules obsolete; aments sessile with a few small bracts at base, $1^{\prime}$ long, rather densely flowered, oblong-cylindric, the fertile somewhat stipitate, becoming $2^{\prime}$ long in fruit; scales dark, silkyvillous; capsule conic-rostrate from an ovoid base; stigmas bifid or entire, yellow drying black. (S. chlorophylla, of Man.; S. chlorophylla, var. denudata, Auders.) - Moist ravines on alpine summits of the White Mountains, and of Mt. Mansfield, Vt. - A divaricately much branched shrub 1 - 1 no high; twigs glabrous, sometimes corered with a glaucous bloom. (Eu.)

S. Vimixilis, L., the Osier Willow of Europe, is occasionally planted, but soon dies out. Some of its hybrids, as S. Smituixa, Willd., etc., stand our climate better, but cannot he regarded as adventive.

+++ Capsules sessile; filaments and often the reddish anthers united so as to appear as one.

S. Ptrpùtea, L. (Purple IV.) Leaves oblanceolate or tongue-shaped, slightly serrulate, very smooth, glaucescent, subopposite; stipules obsolete; aments densely flowered, narrow-cylindrical, the sterile at least closely sessile, with only very small bracts at base; scale small, romnd, crisp-villous, tipped with dark priple; cajsules grayish-tomentose, ovate-conical, obtuse. - Low grounds; commonly cultivated for basket-rods. (Adv. from Eu.)

* Capsules glabrous.

- Tall shrubs, 4-10 high; leaves lanceolate or ovate-lanceolate, $2-4^{\prime}$ long, acute or acuminate (on vigorous shoots rounded, truncate or cordate at base), serrate; sterile aments very silky, with a few bracts at base, 1' long or more, the fertile leafy-peduncled, in fruit $\mathbf{2}^{\prime}$ long or more; capsules tapering, pointed.

+ Leares soon smooth; capsules long-pedicelled; style medium.

14. S. cordàta, Muhl. (Heart-Leaven W.) Leaves oblong-lanceolate or narrouer, on the flowering branches often tapering at base, sharply serrate, finely denticulate or subentire, green both sides or scarcely paler beneath, the young often silky or dowuy, especially on the midrib, not turning black in drring; stipules reniform or ovate, serrate, usually large and conspicuous; ainents rather slender; capsules greenish or rufescent, 2-3" long. (S. rigida, Muhl.) - Var. Avgustata, Anders. Leaves narrower, gradually acuminate, finely serrate. - In wet places and along streams, etc.; our most widely distributed and rariable species. - S. mricoìnes, Muhl. (S. cordata, var. myri- 
coides, Ihurl., Fl. Cestr., 3 ed.), is a hybrid between this species and S. sericea, having the leaves, even those of the most vigorous shoots, tapering and rather acute at base, glancous or glaucescent beneath and sparsely appressech-hairy; stipules small, ovate, pointed; 'ajsules more or less silky when young, becoming glabrate, shortly pedicelled; twigs brittle at base. A hybrid with the European s. incana (surprising on account of the rarity of the cultivated parent) is found at Ithaca, N. Y. (Dudley).

15. S. glaucophýlla, Bebb. Leaves varying from ovate with a broaily rounded base to oblong-lanceolute and equally pointed at both ends ( $3-4^{\prime}$ long. nearly 2' wide), glandular-serrate, subcoriaceous, glabrous throughout, dark gron" and shining above, gluncous beneuth, the young drying black; stipules large, earshaped, dentate; anents thich, oblong-cylindricul, in size and silkiness resembling n. 6 ; capsules attennate-rostrate, $3-5^{\prime}$ long, greenish, drying brown. Var. Axgustriòlı, Bebb; leaves narrower ( $3^{\prime}$ long, $\frac{8^{\prime}}{4}$ wide), pointed at botlı ends. (S. angustata, of ed. 2, in part.) - Var. BREviròıı, Bebb; leaves obovate, about 1' long, strongly reinel. - Common on the sand dunes of Lake Michigan, and occasionally found away from the lake-shore in $\mathrm{N}$. Ill and Wisc.

16. S. balsamífera, Barratt. Leaves broadly rounded and nsually subcordate at base, at first very thin, sulpellucid and of a rich reddish color, at length rigid, dark green above, paler or glaurous and prominently reteculate-reined beneath, slightly glandular-serrulate; petioles long aud slender; stipules obsolete; fertile aments becoming very lax in fruit, the long slender pedicels $6-8$ times the length of the gland; style short. (S. pyrifolia, Anders.) - In open swamps along our northern boundary, Maine to Minn., and northward; White Mountains of N. H. (Little, 1823; rediscovered by Pringle, and C. E. and $E$. Faxon). A much branched shrub, growing in clumps; recent twigs shiningchestnut on the sunny side.

+ Leaves clothed, even when fully grou'n, with a long silky tomentum on both sides, which is finally deciduous; capsule subsessile; style elongated.

17. S. adenophýlla, Hook. Leaves orate or very broally lanceolate, cuspidate-acuminate $\left(1-2^{\prime}\right.$ long), dull green both siles, very closely serrate with fue projecting gland-tipped teetls; stipules conspicuous, ovate-cordate, glandular-serrate, exceeding the short stout petioles, which are dilated at hase and embrace the obtuse silky buds; aments leafy-peduncled, the fertile not rarely becoming 4' long, densely flowered. - Shores of the Great Lakes, rooting extensively in the sand-dunes. A large straggling shrub, with stout to. mentose twigs and crowded leaves. Hybridizes with $\mathbf{S}$. cordata.

- + Low erect shrub, 1-3high; loaves small, entire; capsules oblong-cylindric; stigmas sessile or neurly so.

18. S. myrtilloides, I. Leaves elliptic-nbovate, about l' long, obtuse or somewhat pointed, entire, smooth on both sides, somewhat coriaceous when mature, revolute, reticulated, pale or glancous beneath ; fertile aments oblong, loosely few-flowered, borne on long leafy peduncles; capsules reddish green; pedicels slender, twice the length of the nearly sumoth greenish yellow scale. - Var. pedicercaris, Anters.; leaves oblong-linear or oblanceolate, $1-2 \frac{1}{2}$ long. - Cold peat-bogs, N. Eng. and N. J. to Iowa, and northward. (Eu.) 
+++ Prostrate or creeping and matted alpine shrubs.

19. S. Uva-úrsi, Pursh. (Bearberry W.) Leaves elliptical and pointed, or obovate and obtuse, less than $\mathrm{l}^{\prime}$ long, $3-4^{\prime \prime}$ wide, tapering at base, slightly toothed, strongly veined, smooth and shining above, pale and rather glaucous beneath; aments borne on slender lateral leafy peduncles, oblong-cylindric, 6-9" long, the fertile lengthening to $2^{\prime}$ and narrowly cylindric, densely flowered above, often loose below; scales obovate, rose-red at the tip, covered with long silky hairs; stamens rarely 2 ; capsule ovate-conical, brownish at maturity; pedicel scarcely exceeding the gland; style distinct. (S. Cutleri, Tuckerm.) - Abundant over all the alpine summits of N. New Fng. and N. Y. Closely prostrate, spreading from a stout central root over an area $1-2^{\circ}$ in diameter.

20. S. herbàcea, L. Leaves roundish oval, heart-shaped, obtuse or retuse, less than $l^{\prime}$ long, serrate, smooth and shining, reticulately veined; aments terminating 2-leaved branchlets, small, ovoid,4-10 flowered; scales concave, obovate, obtuse, glabrous or slightly pubescent; capsule subsessile. - Alpine summits of the White Mountains, and far northward. A very small herb-like species, the half-underground stems creeping and rooting to a considerable extent, the branches seldom rising above 1-2' from the ground. (Eu.)

\section{Pó PUIUS, Tourn. Poplar. Aspen.}

Bracts (scales) of the catkins irregularly cut-lobed at the apex. Flowers from a cup shaped disk which is obliquely lengthened in front. Stamens $8-30$, or more; filaments distinct. Stigmas 2-4, elongated. Capsules 2-4-valved. Trees, with broad and more or less heart-shaped or ovate toothed leaves, and often angular branches. Burls scaly, covered with resinous varnish. Catkins long and drooping, appearing before the leaves. (The classical Latin name, of uncertain origin.)

§ 1. Styles 2, with 2-3 narrow or filiform lobes; capsules thin, oblong-conical, 2-ralved; seeds very small; leaves ovate.

* Petioles laterally flattened; bracts silky; stamens 6-20; capsules numerous, small, on very short pedicels.

P. Álba, L. (White Poplar. Abele.) The younger branches and the under surface of the rhombic-oval sinuate-tootlied acute leaves white-tomentose; scales crenate, fringed. - Frequently cultivated for shade, spreading widely by the root, and occasionally spontaneous. (Adr. from Eu.)

1. P. tremuloides, Michx. (Ayericix Aspex.) Small tree 20-50 high, with smooth greenish-white bark; leaves roundish-heart-shaped, with a short sharp point, and small somexchat regular teeth, smooth on both sides, with downy margins, on long slender petioles; scales cut into 3-4 deep linear divisions, fringed with long hairs. - Maine to the mountains of Penn., N. Ky., Minn., and far north and westward.

2. P. grandidentàta, Michx. (LARge-toothed Aspex.) Tree 60$75^{\circ}$ high, with smoothish gray bark; leaves roundish-ovate, with large and irregular sinuate teeth, when young densely covered with white silky wool, at length smooth both sides; scales cut into 5-6 unequal small divisions, slightly fringed. - Rich woods and borders of streams, N. Scotia to the mountains of N. C., west to N. Minn. and Tenn. 
* Petioles terete; bracts not silky; stanens 1.2 -60 .

3. P. heterophýlla, I. (Dowxy Por'an.) Tree $40-80^{\circ}$ high ; leares ovate with a somewhat truncate or cordate base, obtuse, crenate, white-woolly when young, at length nearly smooth, except on the elevated veins beneath; fertile catkins few-flowered; capsules f' long, equalling the pedicels. - Borders of river swamps, Conn. to Ga., and in the west from S. Ind. and Ill. to Ark. and W. La.

$\S 2$. Styles 2-4, with dilated lobes; capsules large, oflen thick, subglobose to ovate-oblong, 2-4-ralved: bracts mostly glabrous; seeds 1 -2" long.

4. P. balsamifera, L. (Balsam Porlar. Tacamanac) Tree 50$75^{\circ}$ high, the large buds varuished with a copious fragrant resin; leaves ovate-lanccolate, gradually tapering and pointed, finely crenate, smooth on both sides, whitish and reticulately veined beneath, on terete petioles $\frac{1}{2}-2^{\prime}$ long; scales dilated, slightly hairy; stamens 20-30; capsule ovate, 2-valved. - Borders of rivers and swamps, N. New Eng. to Mich. and Minn., and far north and westward. - Var. CAxicicas, Gray. (BALy of Giled D.) Leaves broader and more or less heart-shaped; petiole commonly hairy. Common in eultivation, but rare or unknown in a wild state.

5. P. monilifera, Ait. (Cotton-wood. Necklace Poplar.) Tree $75-150^{\circ}$ high; leates broudly deltoid, with numerous crenate serratures and narrow very acute acumination, sometimes ovate, rarely cordate, on elongated flattened petioles; scales lacerate-fringed, not hairy; stamens 60 or more; capsules on slender pedicels $\left(4-5^{\prime \prime}\right.$ long) in long catkins, oblong-ovate, $3-4$-valved. (Incl. P. angulata, Ait.) - Borders of streams, western N. Eng. to Fla., west to the Rocky Mts.

\section{Order 105. EMPETRACEA. (Crowberry Family.)}

Low shrubby evergreens, with the foliage, aspect, and compound pollen of Heaths, and the drupaceous fruit of Arctostaphylos, but the divided or laciniate stigmas, etc., of some Euphorbiacese; - probably only an apetalous and polycamous or liœeious degenurate form of Ericacese, - comprising three genera, two of which occur within the limits of this work, and the third farther south.

1. Empetrum. Flowers scattered and solitary in the axils. Sepals 3 , somewhat petallike.

2. Corema. Flowers collected in terminal heads. Calyx none.

\section{1. ÉmPETRU M, Tourn. Crowberry.}

Flowers polygamons, scattered and solitary in the axils of the leaves (inconspicuous), sealy-bracted. Calyx of 3 spreadiug and somewhat petal-like sepals. Stamens 3. Style very short; stigma 6-9-rayed. Fruit a berry-like drupe, with 6-9 seed-like nutlets, each containing an erect anatropous seed. Embryo terete, in the axis of ('opious albumen, with a slender inferior radicle and very small cotyledous. ( $\Lambda \mathrm{n}$ ancient name, from $\epsilon^{\nu}, u p o n$, and $\pi \dot{\tau} \tau \rho$ os, $a$ rock.)

1. E. nigrum, L. (Brick Crowrerry.) Procumbent and spreading; leaves linear-oblong, scattered; fruit hlack. - Newf., Mount Desert and 
adjacent coast of Maine, alpine summits in N. Eng. and N. Y., L. Superior, and northward. (Eu.)

\section{COR È M A, Don. Broow-Crowberry.}

Flowers diœcious or polygamous, collected in terminal heads, each in the axil of a scaly bract, and with 5 or 6 thin and scarious imbricated bractlets, but no proper calyx. Stamens 3, rarely 4, with long filaments. Style slender, 3- (or rarely 4-5-) cleft; stigmas narrow, often toothed. Drupe small, with 3 (rarely 4-5) nutlets. Seed, etc., as in the last. - Diffusely muchbranched little shrubs, with scattered or nearly whorled narrowly linear heathlike leaves. (Name кó $\rho \mu \alpha, a$ broom, from the bushy aspect.)

1. C. Conrádii, Torr. Shrub $6^{\prime}-2^{\circ}$ high, diffusely branched, nearly smooth; drupe very small, dry and juiceless when ripe. - Sandy pine harreus and dry rocky places, N. J. and L. Island (?), Shawangunk Mts., N. Y., coast of S. E. Mass. and Maine, to Newf. The sterile plant is handsome in flower, ou account of the tufted purple filaments and brown-purple anthers.

\section{Order 106. Ceratophyllà CEA. (Hornwort Family.)}

Aquatic herls, with whorled finely dissected leaves, and mimute axillary and sessile monocious flowers without floral envelopes, but with an 8-12cleft involucre in place of a calyx, the fertile a simple 1-celled ovary, with a suspended orthotropous ovule; seed filled by a highiy developed embryo with a very short radicle, thick oval cotyledons, and a plumule consisting of several nodes and leaves. - Consists only of the genus

\section{CERA TOPHÝLLU M. L. Hornwort.}

Sterile flowers of 10-20 stamens, with large sessile anthers. Fruit an achene, beaked with the slender persistent style.- Herbs growing under water, in ponds or slow-flowing streams; the sessile leares cut into thriceforked threal-like rigid divisions (whence the name from $\kappa$ ćpas, $a$ horn, and $\phi u ́ \lambda \lambda \nu^{\prime}$, leaf $)$.

1. C. demérsum, L. Fruit smooth, marginless, beaked with a long persistent style, and with a short spine or tubercle at the base on each side. - Var. echixatus, Gray, has the fruit mostly larger (3" long), rough-pimpled on the sides, the narrowly winged margin spiny-toothed. - Slow streams and ponds, across the contineut. (Eu., etc.) 


\section{Subclass II. GYMNOSPÉRMA.}

Pistil represented by an open scale or leaf, or else entirely wanting; the ovules and seeds therefore naked (without a peri(arp), and fertilized by the direct application of the pollen. Cotyleclons of ten more than two.

\section{ORDER 1(17. CONÍFERAE. (PINE Family.)}

Trees or shrubs, with resinous juice, mostly aul-shaped or needle-shaped entire leaves, and monœcinus or rurely dicecions flowers in cathins or solitary, destitule of calyx or corrollu. (Ivi'es orthotropous or inverted. Embryo in the axis of the albumen, nearly its length. (Wood destitute of ducts, composed ehiefly of a lomogneous large wondy fibre which is marked with circular disks on two silles.)

Suborder I. Pinaceae. Fertile flowers in scaly aments becoming cones or berry-like. Ovules 2 or more at the base of each scale. Mostly moncecions and evergreen.

Tribe I. A BIETIXE. (Prie Famitr proper.) Fertile fowers in catkins, consisting of ummerous open spirally imbricated carpels in the torm nt scales, each scale in the axil of a thin persistent bract; in fruit forming a strobile or eone. Orules 2, alherent to the base of each scale, inverted. Seeds winged. Cotyledons 3-16. Anthers spirally arranged upon the stumineal column, which is subtencled by involucral seales. Buds scaly. Leaves scattered (or fascieled in n. 1 and 5), linear to needle-shajed.

* Cones matmring the second year, their scales hecoming thickened and corky.

1. Pinus. Leaves $2-5$ in a cluster, surmunded by a slieath of scarious bnd-scales.

* Cones maturing the first jear, their scales remaining thin.

- Cones pendulous, their scules persistent; bracts smaller than the scales; leaves jointed "1on a prominent persistent base, solitary.

2. Picea. Leares sessile, keeled on both sides (tetragonal!

3 Tsinga. Leaves petiolerl, flat.

+ + Cones ereet; bracts lomger than the scales; leaf-sears not srominent.

4. A bies. Scales of the large eme rlecidunus. Leaves persistent, solitary, keeled beneath.

5. Larix. Suales of tlıe small eome persistent. Leaves mostly fascieled, flat, decidums.

Tribe II. TAXODIEA. lertile aneuts of several spirilly arranged imbriented scales. without bracts, becouning a globular woorly cone. Ovules 2 or more at the base of each seale, erect. Leaves linear, alternate; leaf-buds not scaly.

6. Taxodium. Seeds 2 to darh scale. Leaves 2-ranked, decidunus.

Tribe III. CUPRESSINEX. Sinles of the fertile ament few; decussately opposite or ternate, becwing a small ilusel cone or sort of drupe. Ovules 2 or more in their axils, erect. Cotyledons 2 (rarely more) Leaves decussately oplosite or ternate, usu. ally scale-like and alnate, the earlier free aul sulmlate; leaf-buds not scaly.

* Monocious; fruit a small coue; leaves opposite and follage more or less 2-ranked.

7 Chamaecyparis. Come globose: scales peltate. Seeds 1 or 2 , narrowly winged.

8. Thuya. Cone pendulous, oblong, of $8-12$ imbricated scales. Seeds 2, 2-winged.

\footnotetext{
* Diccious. Fruit berry-like, with hony ovate seenls.
}

9. Juniperus. Fruit-scales 3 -6, coalesent. Foliage not 2-ranked. 
Suborder II. Taxàcex. (Yew Family.) Flowers diœcious, axillary and solitary, the fertile consisting of a naked erect ovule which becomes a bony-coated seed more or less surrounded or enclosed by the enlarged fleshy disk (or scale).

10. Taxus. Leaves linear, scattered. Seed surrounded by a red berry-like cup.

\section{P İ N U S, Tourn. Pine.}

Sterile flower at the base of the shoot of the same spring, involucrate by a nearly definite number of scales, consisting of numerous stamens spirally inserted on the axis, with very short filaments and a scale-like connective; anther-cells 2, opening lengthwise. Pollen of 3 united cells, the 2 lateral ones empty. Fertile catkins solitary or aggregated immediately below the terminal bud, or lateral on the young shoot, consisting of imbricated carpellary scales, each in the axil of a persistent bract, bearing a pair of inverted orules at the base. Fruit a cone formed of the imbricated woody carpellary scales, which are thickened at the apex (except in White I'ines), persistent, sprealing when ripe and dry; the 2 nut-like seeds partly sunk in excarations at the base of the scale; in separating carrying away a part of its lining as a thin fragile wing. Cotyledons 3-12, linear. - Primary leaves thin and chafflike, merely bud-scales; from their axils immediately proceed the secondary needle-shaped evergreen leaves, in fascicles of 2 to 5 , from slender buds, some thin scarious bud-scales sheathing the base of the cluster. Leaves when in pairs semicylindrical, becoming channelled; when more than 2 triangular; their edges in our species serrulate. Blossoms developed in spring; the cones maturing in the second antumn. (The classical Latin name.)

$\S 1$. Leaves 5 , ench with a single fibro-rascular bundle; sheath loose, deciduous; cones subterminal, their scales but slightly thickened at the end and without prickle or point; bark smooth except on old trunks.

1. P. Stróbus, L. (White Pixe.) Tree $75-160^{\circ}$ high; leaves very slender, glaucous; sterile flowers oval ( $t-5$ " loug), with $6-8$ inrolucral scales at base; fertile catkins long-stalked, cylindrical; cones narrow, cylindrical, nodding, often curred $\left(t-6^{\prime}\right.$ long); seed smooth; cotyledons $8-10$. - Newf. to Penn., along the mountains to Ga., west to Minn. and E. Iowa. Invaluable for its soft, light, white or yellowish wood, in large trees nearly free from resin. \$ 2. Leares in twos or threes, each with two fibro-rascular bundles; sheath close; woody scales of the cones thickened at the end and usually spiny-tipped.

* Cones lateral; their scales much thickened at the end; leaves rigid.

$$
\text { - Leares in threes (rarely in twos in n. 2). }
$$

2. P. Tæada, L. (Loblolly or Old-field Pine.) Leares long $\left(6-10^{\prime}\right.$ ) with elongated sheaths, light green; cones elongated-oblong $\left(3-5^{\prime}\right.$ long) and tapering; scales tipped with a stout incurved spine. - Wet clay or dry sandy soil, Iel. to Fla, near the coast, thence to Tex. and Ark. - A tree 50-150 high; staminate flowers slencler, 2 ' long, with nsually $10-13$ involucral scales: seeds with 3 strong rongh ridges on the under side.

3. P. rígida, Mill. (Рітси Pıге.) Leaves (3-5' long) dark green, from short sheaths; cones ovoid-conical or ovate $\left(1-3 \frac{1}{2}^{\prime}\right.$ long), often in clusters; scales with a short stout recurved prickle. - Sandy or barren soil, N. Brunswick 
to $\mathbf{N}$. Ga., western N. Y. and L. Ky. $-\Lambda$ tree $30-80^{\circ}$ high, with very rough dark bark and hard resinous wood; sterile flowers shorter; scales 6-8. ++ Leaves in twos (some in threes in $\mathrm{n} .4$ and 7 ).

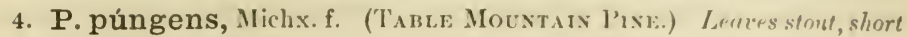
$\left(1 \frac{1}{4}-2 \frac{1^{\prime}}{2}\right.$ long), crowded, bluish, the sheath short (very short on old foliage); cones ovate $\left(3 \frac{1^{\prime}}{2} \mathrm{long}\right)$, the srales armed with a strong hooked spine ( $f^{\prime}$ long). Alleghany Mts., I'enn., to $\mathbf{X}$. C. and 'Tenn. $-A$ rather small tree $\left(20-60^{\circ}\right.$ high); cones long-persistent.

5. P. inops, Ait. (Jersey or Scrta Pine.) Leaves short (1 $\frac{1}{2}-3^{\prime}$ long); cones oblong-conical, sometimes curved (2-3' long), the srales tipped with a straight or recurved au/-shoped mickle. - Barrens and sterile hills, Long Island to S. C., mostly near the coast, west through $\mathrm{Ky}$. to S. Ind. - A straggling tree at the east, $15-40^{\circ}$ high, with spreading or drooping branchlets; larger westward. Young shoots with a purplish glancous bloom.

6. P. Banksiàna, Lambert. (Gray or Northers Scrub Pine.) Leaves

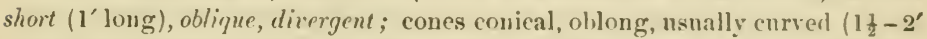
long), smooth, the srales pointless. - Barren sandy soil, S. Maine and $\mathbf{N}$. Vt. to s. Mich., central Minn., and northward. Straggling shrub or low tree.

7. P. mitis, Michx. (Yellow P'xe.) Leaves sometimes in threes, from long sheuths, slender (3-5' long); cones ovate- or oblong conical (harely 2' long), the srales with a mimule weak prickle. - Usually dry or sandy suil, Staten Island to Fla., S. Ind., S. E. Kan. and Tex. - A straight tree, 50-100 high, with dark green leaves more soft and slender than the preceling. 'The western form has more rigid leaves and more tuberculate and spiny cones.

* * Cones terminal; leaves long and slender, in twos or threes.

8. P. resinòsa, Ait. (Red Prve.) Leaves in tu'os from long sheaths, elongaterl ( $\left.5-6^{\prime} l o n g\right)$, lark green; cones orate-conical, smooth (about $2^{\prime}$ long), their scales slightly thickened, pointless; sterile flowers oblong-linear (6-9" long), subtended ly alont 6 involueral scales which are early decicluous by an articulation above the base. - Dry wook, Mass. to N. Penn., Mich., and Minn., and northward. $-\Lambda$ tall tree, with reddish, rather smooth bark and hard wood, not very resinous.

9. P. palústris, Mill. (Long-leaved, Yellow, or Georgia Pine.) Leaves in threes from long sheaths, very long $\left(10-15^{\prime}\right)$, crowded at the summit of very scaly branches; sterile flowers $2 \frac{1}{2}-3^{\prime}$ long, rose-purple; cones large, cylindrical or conical-oblong $\left(6-10^{\prime}\right.$ long), the thick scales urmed with a short recurved spine. (I'. anstralis, Mirhx.) - Sandy soil, S. Va. to Fla. and Tex. A large tree, with thin-scaled bark and exceedingly hard and resinous wood.

\section{Pİ C E A, Link. SPRtCE.}

Sterile flowers axillary (or sometimes terminal) on liranchlets of the precediug year; anthers tipped with a rounded recurved appentage, their cells opening lengthwise. Fertile catkins and cones terminal; cones maturing the first year, pendnlons; their scales thin, not thickened nor prickly-tipped, persistent. Leaves scattered, needle-shaped and keeled above and below (4-sided), pointing every way. Otherwisc nearly as in l'iums. (The classical Latin nane.)

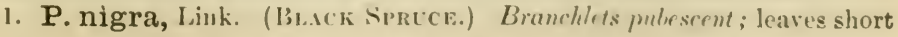
(usually $4-8$ "long), either dark green or glaucous-whitish ; romes orele or orate- 
oblong (10 - 20"long), mostly recurved, persistent, the rigid scales with a thin denticulate edge. (Abies nigra, Poir.) - Swamps and cold mountain woods, New Eng. to Penn., central Mich., Minn., and northward, and south in the mountains to Ga. A tree $40-70^{\circ}$ high. - Var. Rưbra, Engelm. Leaves larger and darker; cones larger, bright red-brown, more readily deciduous.

2. P. álba, Link. (White Spruce.) Branchlets glabrous; leaves more slender, pale or glaucous; cones nodding, cylindricai (about $2^{\prime}$ long), pale, deciduous, the thinner scales with an entire edge. (Abies alba, Michx.) Northern New Eng. and N. Y. to L. Superior, and northward. - A handsomer tree than n. 1,50-150 high, in aspect more like a Balsam Fir.

\section{TS Ù G A, Carrière. Henlock.}

Sterile flowers a subglobose cluster of stamens, from the axils of last year's leaves, the long stipe surrounded by numerous bud-scales; anthers tipped with a short spur or knob, their confluent cells opening transversely; pollen-grains simple. Fertile catkins and cones on the end of last year's branchlets ; cones maturing the first year, pendulous; their scales thin, persistent. Leaves seattered, flat, whitened beneath, appearing 2-ranked. ('The Japanese name of one of the species.)

1. T. Canadénsis, Carr. Leaves petioler, short-linear, obtuse ( $\frac{1}{2}^{\prime}$ long); cones oval $\left(6-8^{\prime \prime} \mathrm{long}\right)$, of few thin scales much longer than the bracts. (Abies Canadensis, Mich.x.) - Mostly hilly or rocky woods, N. Scotia to Del., and along the mountains to Ala., west to Mich. and Mimn. - A tall tree, with light and spreading spray and delicate foliage, bright green above, silvery beneath.

\section{4. À B I E S, Link. Fir.}

Sterile flowers from the axils of last year's leaves; anthers tipped with a knob, their cells lursting transversely; pollen as in Pinus. Fertile catkins and cones erect on the upper sille of spreading branches; cones maturing the first rear ; their thin scales and mostly exserted hracts decirluous at maturity Seeds and hark with balsam-bearing resicles. Leares scattered, sessile, flat, with the midrib prominent on the whitenel lower surface, on horizontal branches appearing 2-ranked. (The classical Latin name.)

1. A. balsàmea, Miller. (BAlsam or BALM-OF-Gilead Fir.) Leaves narrowly linear $\left(6-10^{\prime \prime} \mathrm{long}\right)$; cones cylindrical (2-4' long, $1^{\prime}$ thick), violetcolored ; the bracts obovate, serrulate, tipped with an abrupt slender point, shorter than the srales. - Damp woods and mountain swamps, Newf. to Penn., along the mountains to Va., west to Minn., and northward. A slender tree or at high elevations a low or prostrate shrub.

\section{L $\mathbf{A} \mathbf{R} I \mathbf{X}$, Tourr. IARCH.}

Catkins lateral, terminating short spurs on loranches of a year's growth or more, short or globular, developed in early spring; the sterile from leafless buds; the fertile mostly with leaves below. Anther-cells opening transversely. Pollen-grains simple, globular. Cones as in Spruce, the scales persistent. Leares needle-shaped, soft, deciduous, all foliaceous, very many in a fascicle developed in early spring from lateral scaly and globular buds, and scattered along the developerl shoots of the scason. Fertile catkins crimson or red in flower. (The ancicut name.) 
1. L. Americàna, Michx. (American or Bhack Larch. ThMarack. НАскматаск.) Leaves short; cones ovoid $\left(6-9^{\prime \prime}\right.$ long), of few runurled seales, arranged in $\frac{2}{5}$ orler. - Chiefly in coll swampls, N. I'enu. to N. Ind. and central Minn., and far northward. A slender tree, $30-100^{\circ}$ high, with hard and very resinous wood.

\section{TAX O D I U, Richard. BALD CYPRess.}

Flowers monœcious, the two kinds on the same branches. Siterile flowers spiked-pauicled, of few stanens; filaments scale-like, shichl shaped, beari, 2-5 anther-cells. Fertile catkins ovoid, in small clusters, scaly, with a pair of ovules at the base of each s'ale. Cone glohnlar, closed, composed of very thick and angular somewhat shielı-shaped scales, bearing 2 angled seeds at the base. Cotyledons 6-9.-Trees, with narrow linear 2-ranked light and decicluous leaves; a part of the slender leafy branchlets of the season also de-

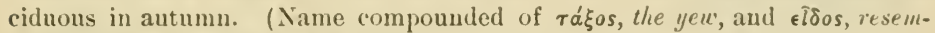
blance, the leaves being Yew-like.)

1. T. distichum, Richard. (American Bahi Cypress.) Leaves linear and spreading; also some awl-shaped and imbricated on flowering branchlets. - Swamps, S. Del. to S. Ill. and Mo., and southward, where it is a very large and valuable tree. March, $\Lambda_{\text {p }}$ ril.

\section{CHA M 无 CÝPARIS, Spach. White Cedar. Criress.}

Flowers monocious on different branches, in terminal small catkius. Sterile flowers composed of shield-shaped scale-like filaments bearing $2-4$ anther-cells under the lower margin. Fertile catkins globular, of shicld-shaped scales decussate in pairs, hearing few $(1-4)$ erect bottle-slaped ovules at base. Cone glolnlar, firmly elosed, but opening at maturity; the scales thick, pointed or bussed in the midlle; the few angled or somewhat winged seeds attached to their contracted hase or stalk. Cotyledons 2 or 3. - Strong-seented evergreen trees, with very small and seale-like or some awl-shaped closely appressedimbrieated leaves, distichous liranchlets, and exceedingly durable wood. (From

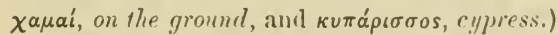

1. C. sphæroídea, Spach. (Wute CEnAr.) Leaves minute, pale, ovate or triangular-awl-shaped, often with a small gland on the back, closely imbricated in 4 rows; anther-cells 2 under each scale; cones small $\left(3-5{ }^{\prime \prime}\right.$ in diameter) of about 3 pairs of scales: sceds slightly winged. (Cupressus thyoides, L.) - Swamps, S. Maine to Fla. and Miss. A tree $30-90^{\circ}$ high, the wood and fibrous shredly bark, as well as foliage, much as in $\mathrm{Arbor}$ Vitae.

\section{TH U Y A, Tonrn. Aввок Viт.є.}

Flowers mostly monocious on different branches, in very small terminal oroid catkins. Stamens with a seale-like filament or eonnective, bearing 4 anther-cells. Fertile catkins of few imbricated scales, fixed by the base, each bearing 2 erect orules, dry and spreading at maturity. Cotyledons 2. - Small evergreen trees, with very flat 2-ranked spray, and closely imbricated, small, appressed, persistent leaves; these of two surts, on different or successive branchlets; one awl-shaped; the other scale-like, hlunt, short, and adnate to the branch. (Ovía or $\Theta \dot{\alpha} \alpha$, the ancient name of some resin-bearing evergreen.) 
1. T. occidentàlis, L. (Arbor Vitæ. White Cedar.) Leaves appressed-imbricated in 4 rows on the 2-edged branchlets; scales of the cones pointless; seeds broadly winged all round. - Swamps and cool rocky banks, N. Brunswick to Peun., along the mountains to N. C., west to Minn. A tree $20-50^{\circ}$ high, with pale shreddy bark, and light, soft, but very durable wood.

\section{JUNÍPERU S, L. JUNiper.}

Flowers diœcious, or occasionally monœecious, in very small lateral catkins. Anther-cells 3-6, attached to the lower edge of the shield-shaped scale. Fertile catkins ovoid, of 3-6 fleshy coalescent scales, each 1-ovuled, in fruit forming a sort of berry, which is scaly-bracted underneath, bluish-black with white bloom. Seeds 1-3, ovate, wingless, bony. Cotyledons 2. - Evergreen trees or shrubs, with awl-shaped or scale-like rigid leares, often of two shapes in $\S 2$. ('The classical name.)

§ 1. OXYCÉDRUS. Aments axillary; lecives in whorls of 3 , free and jointed at base, linear-subulute, prickly-pointed, channelled and white glaucous above.

1. J. commùnis, L. (Commox Junzper.) Shrub or small tree, with spreading or pendulous branches; leaves rigid, more or less spreading (5-9" long); berry dark blue ( $3^{\prime \prime}$ or more in diameter). - Dry sterile hills, common.

Var. alpina, Gaud., is a decumbent or prostrate form, with shorter (2-4" long) less spreading leaves. - Maine to Minn., and northward.

§ 2. SABÌNA. Aments terminal; leaves mostly opposite, of tuo forms, i. e., awl-shaped and loose, and scale-shaped, appressed-imbricuted and crowded, the latter with a resiniferous gland on the back.

2. J. Sabina, L., var. procúmbens, Pursh. A procumbent, prostrate or sonctimes creeping shrub; scale-like leaves acute; berry on short recurved peduncles, 3-5" in diameter. - Rocky bauks, borders of swamps, etc., N. Eng. to N. Minn., and northward.

3. J. Virginiàna, L. (RED CEDAR or SAvix.) From a shrnb to a tree $60-90^{\circ}$ high, pyramidal in form; scale-like leaves obtuse or acutish, entire; berries on straight peduncles, abont $3^{\prime \prime}$ in diameter. - Dry hills or deep swamps, common. Bark shreddy, and heart-wood red and aromatic.

\section{TÁ XUS, Tourn. YEw.}

Flowers mostly diœcious, or sometimes monœcious, axillary from scaly buds; the sterile small and globular, formed of a few naked stamens; anther-cells 3-8 under a shiell-like somewhat lobed connective. Fertile flowers solitary; scaly-bracted at base, consisting merely of nn erect sessile ovule, with an annular disk, which becomes cup-shaped around its base and at length pulpy and berry-like, globular and red, nearly enclosing the nut-like seed. Cotyledons 2. - Leaves evergreen, flat, mucronate, rigirl, scattered, 2-ranked. (The classical

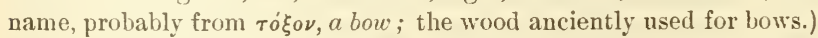

1. T. Canadénsis, Willd. (Avericax Yew. Grouxd Hemlock.) A low straggling bush, the stems diffusely spreading; leaves linear, green both sides. ('T. baccata, var. Canadensis, Willd.) - Moist banks and hills, especially under erergreens; Newf. to N. J., Iowa, Minn., and northward. 


\section{Class II. MONOCOTYLEDONOUS OR EMTDOGENOUS PLANTS.}

Stems with no manifest distinction into bark, wood, and pith, but the woody fibre and vessels in bundles or threads which are irregularly imbedded in the cellulir tissue; peren nial trunks destitute of annual layers. Leaves mostly parallelveined (nerved) and sheathing at the base, seldom separating by an articulation, almost always alternate or scattered and not toothed. Parts of the flower commonly in threes. Em. bryo with a single cotyledon, and the leaves of the plumule alternate.

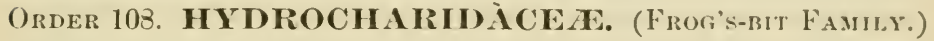

Aquatic herbs, with dixcious or polygamons: regulur floucers, sessile or on scape-like peduncles from a spathe, and simple or double floral cuvelopes. which in the ferlile flowers are united into a tulbe and colerent with the 1 3-celled ocary. Stamens 3-12, distinct or monadelphous; anthers 2-celled. Stigmas 3 or 6 . Fruit ripening under water, indehiscent, many-seeded. Seeds ascending, without albumen; embryo straight.

Tribe I. H XDILLEX. Stem clongated, submerged, leafy. Spathes small, sessile.

1. Elodea. Leaves verticillate (rarely opjosite). Perianth-tube long-filiform.

Tribe II. VALLISNEIIEA. Stemless. Leaves elongated. Spathes pedunculate.

2. Vallisneria. Submerged: grass-like. Fertile flower solitary on a very long scape.

Tribe III. STRATIOTEA. Stem very short, with crowded leaves. Spathes pedunculate. Ovary 6-9-celled.

3. Limnobium. Stemless, floating; broad leaves long-petioled.

\section{ELODĖ, Michx. Water-weEd.}

Flowers polygamo-diccious, solitary and sessile from a sessile tubular 2-cleft axillary spathe. Sterile flowers small or minnte, with 3 sepals barely uniterl at base, and usually 3 similar or narrower petals; filaments short and unitur at hase, or none; anthers 3-9, oval. Fertile flowers pistillate or apparently perfect; perianth extended into an extremely long capillary tube; the limb 6-partell; the small lohes vhovate, sprealing. Stamons 3-9, often with imperfect anthers or none. ()vary 1-cellerl, with 3 parietil placentie, each hearing a few orthotropons orules; the apillary style coherent with the tuhe of the periantlı; stigmas 3, large, 2-lubed or notched, exserted. Fruit oblong, coriaceous, few-seeded. - Perennial slenter submercerl herbs, with clongated branching stems, thickly leset with pellucid and reinless, 1-nerved, sessile, whorled or opposite leaves. The staminate fluwers (rarely seen) commonly break off, as in Vallisneria, and fioat on the surface, where they expand and shed their pollen around the stigmas of the fertile flowers, raised to the surface 
by the prolonged calyx-tube, which varies in length according to the depth of the water. (Name from $\mathfrak{\epsilon} \lambda \omega \dot{\delta} \eta s$, marshy.)

1. E. Canadénsis, Michx. Leaves in 3's or 4's, or the lower opposite, varying from linear to oval-oblong, minutely serrulate; stamens 9 in the sterile flowers, 3 or 6 almost sessile anthers in the fertile. (Anacharis Canadensis, Planchon.) - Slow streams and ponds, common. July.

\section{VALIIS N E R A, L. Tape-grass. Eel-grass.}

Flowers strictly dicecious; the sterile numerous and crowded in a head on a conical receptacle, enclosed in an ovate at length 3 -valved spathe which is borne on a very short scape; stamens mostly 3 . Fertile flower's solitary and sessile in a tubular spathe upon an exceedingly lengthened scape. Perianth (calyx) 3 -parted in the sterile flowers; in the fertile with a linear tube coherent with the 1-celled orary, but not extended beyond it, 3-lobed (the lobes obovate); also 3 linear small petals. Stigmas 3, large, nearly sessile, 2-lobed. Ovules very numerous, scattered over the walls, orthotropous. Fruit elongated, cylindrical, berry-like. - Stemless plants, with long linear grass-like leaves, wholly submerged. The staminate clusters being confined to the bottom by the shortness of the scape, the flower-buds themselves break from their short pedicels and float on the surface, where they shed their pollen around the fertile flowers, which are raised to the surface by sudden growth at the same time; afterwards the thread-form scapes (2-4 feet long) coil up spirally, drawing the fruit under water to ripen. (Named for Ant. Vallisneri, an early Italian botanist.)

1. V. spiràlis, L. Leaves linear, thin, long and ribbon-like $\left(1-6^{\circ}\right.$ long), obscurely serrulate, obtuse, somewhat nerved and netted-veined. - Common in slow waters, N. Eng. to Fli., west to Minn. and Tex.

\section{LIM N O BI U M, Richarl. AMericax Frog's-Bit.}

Flowers diøcions, (or moncecious?) from sessile or somewhat peduncled spathes; the sterile spathe 1-leaved, producing about 3 long-pedicelled flowers; the fertile 2 leaved, with a single short-pedicelled flower. Calyx 3-parted or cleft; sepals oblong-oval. Petals 3, oblong-linear. Filaments entirely united in a central solid column, bearing 6-12 linear anthers at unequal heights; there are 3-6 awl shaped rudiments of stamens in the fertile flowers. Ovary 6-9-celled, with as many placente in the axis, forming an ovoid many-seeded berry in fruit; stigmas as many as the cells, but 2-parted, awl-shaped. - A stemless perennial herb, floating in stagnant water, proliferous by rumners, with long-petioled and round-heart-shaped leares, which are spongy-reticulated and purplish underneath; rootlets slender, hairy. Sterile flowers rather small ; the fertile larger; peduncle nodding in fruit. Petals white? (Name from $\lambda$ ı $\mu$ ó $\beta$ เos, living in pools.)

1. L. Spóngia, Richard. Leaves $1-2^{\prime}$ long, faintly 5-nerved; peduncle of sterile flower about $3^{\prime}$ long and filiform, of the fertile only $l^{\prime}$ long and stout. - Stagnant water, N. J. to Fla.; also L. Ontario, Ill., and Mo.

\section{Order 109. BURManNiÀCEA. (Burmania Famly.)}

Small annual herbs, often with minute and scale-like leaves, or those at the root grass-like; the flowers perfect, with a 6-cleft corolla-like perianth, the 
tute of which allheres to the 1-celled or 3-celled ocary; stamens 3 and distinct, opposite the inner divisions of the perianth; capsule many-seeded, the seeds very minule. - A small, chiefly tropical family.

\section{B U R M Á N N I A, I.}

Ovary 3-celled, with the thick placenta in the axis. Filaments 3, very short. Style sleuler; stigma capitate-3-lobed. Capsule often 3-winged. (Named for .J. Burmenn, an early Dutch botanist.)

1. B. biflòra, L. Stem low and slender $\left(2-4^{\prime}\right.$ high $), 2$ flowered at the summit, or soon several-flowered; perianth ( $2-3^{\prime \prime}$ long) briglit blue, 3 -winged. - l'eaty bogs, Va. to Fla.

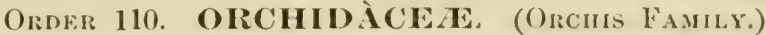

Herbs, clearlyllistinguished by their perfect imegular flowers, with 6-merous periunth adnate to the 1-celled ovary, with innumerable ovules on 3 parietul placenta, and with eilher one or two gynandrous stamens, the pollen cohering in masses. Fruit a 1-celled 3-valved eapsule, with innmmerable minute seeds, appearing like fine saw-clust. P'erianth of 6 divisions in 2 sets ; the 3 outer (sepals) mostly of the sime petal-like texture and appearance as the 3 inner (pelals). One of the inner set cliffers more or less in figure, direction, ete., from the rest, and is called the lip; only the other two taking the name of petals in the following deseriptions. The lip is really the upper petal, i. e. the one next to the axis, but by a twist of the ovary of half a turn it is more conmonly directed forward and brought next the bract. Before the lip, in the axis of the flower, is the column, comp:oserl of a single stamen, or in Cypripedium of two stamens and a rudiment of a third, variunsly coherent with or borne on the style or thick fleshy stigma; antler 2-celled; each cell containing one or more masses of pollen (pollinia) or the pollen granular (in Cypripedium). Stigma a broal glutinous surface, except in Cypripedium. - Perenuials, often tuber-bearing or tuberous-rooted; some epiphytes. Leaves parallel-nerved, all alternate. Flowers often showy, commonly singular in shape, solitary, racemed, or spiked, each subtended by a bract, - in all arranged for fertilization by the aid of insects, very few capable of unaided self-fertilization.

Tribe I. EPIDENDREA. Anther teminal, erect or inclined, operculate. Pollinia smooth and waxy, 4 or 8 ( 2 or 4 in each cell), distisct, or thuse in each cell (or all in $\mathrm{n} .8$ encl 7 ) united at base. (Pollinia 8 only in $\mathrm{n} .7$ of our genera.)

* Green-foliaged plants, from solid lullus, with 1 or 2 leases.

+ Column very short ; leaf sulitary.

1. Microstylis. Flowers racemose, minnte, greenish. Petals flliform.

++ Colnm clongaterl: leaves raclieal.

++ Whole plant (except the fowers) green.

2. Liparis. Leaves 2. Raceme few-fluwered. Lip flat. entire.

3. Calypso. Leaf solitary. Flower larye, solitary. lip saceate.

++ A single green antmumal leaf: otherwise mainly brownish or purplish.

4. Tipularia. Raceme many-flowerell; flowers small, greenish; lip 3-lobed.

5. A plectrum. Raeeme lnose : flowers rather large; lip 3 -ridged, not spurred or saccate. 
* Leafless, with coralloid roots; whole plant brownish or yellowish; flowers racemose.

6. Corallorhiza. Pollinia 4, in 2 pairs. Flower gibbous or somewhat spurred, and lip with $1-3$ ridores; seprals and petals 1-3-nerved.

7. Hexalectris. Pollinia 8 , united. Flower not gibbous; sepals and petals severalnerved; lip with $5-6$ ridges.

Tribe II. NEOTTIEA. Anthers erect upon the back of the column at the sunmit, or terminal and opercular. Pollinia granular or powdery, more or less cohering in 2 or 4 delicate masses, and attached at the apex to the beak of the stigma.

* Anthers without operculum, erect upon the back of the short column. Flowers small, in spikes or racemes.

8. Listera. Stem from a fibrous root, 2-foliate. Lip flat, 2-lobecl.

9. Spiranthes. Stems leafy below, from tuberous-fascicled roots. Flowers 1-3-ranked in a twisted spike. Lip embracing the column below, with 2 callosities at base.

10. Goodyera. Leaves radical, white-reticulated. Lil entire, free from the column, saccate, without callosities.

* Anther opereulate, erect and jointed upon the short coluinn. Stem stout, very leafy.

11. Epipactis. Flowers racemose; perianth sprealing; lip dilated above.

* * Anther terminal, operculate, incumbent; column elongated. Stem scapose or fewleaved; flowers large, solitary or few.

12. Arethusa. Leaf and flower solitary. Lip bearded, its base adherent to the linear column. Pollinia 4.

13. Calopogon. Leaf solitary, grass-like. Lip bearded, stalked, free. Column winged at the apex. Pollinia 4.

14. Pogonia. More or less leafy. Lip erested, free. Column clavate. Pollinia 2.

Tribe III. OPHRYDEA. Anther without opereulum, the cells adnate to the top of the column and often continuous with the beak of the stigma. Pollinia 2, of coarse grains united by an elastic web, each attached at base by a stalk to a riscid gland. Flower (in ours) ringent and spurrerl, spicate upon a leafy stein.

15. Orchis. The two glands or viscid disks enclosed in a common pouch.

16. Habenaria. The two glands naked, either aplroximate or widely separated.

Tribe IV. CYPRIPEDIEA. Perfect anthers 2, lateral, the sterile one forming a dilated fleshy appendage above the terminal stigma. Pollen granular, not in masses.

17. Cypripedium. Stems mere or less leafy. Perianth spreading; lip an inflated sac.

\section{MICRÓSTYLIS, Nutt. Adder's-Mocth.}

Sepals oblong, spreading. Petals thread-like or linear, spreading. Lip auricled or ovate at base, not tubercled, entire or nearly so. Column very small, terete, with 2 teeth or auricles at the summit and the erect anther between them. Pollen-masses 4 , in one row ( 2 in each cell), cohering by pairs at the apex, waxy, without any stalks, threads, or gland. - Low herbs, from solid bulbs, producing simple stems, which bear in our species a single leaf and a raceme of minute greenish flowers. (Name composed of $\mu$ ıкós, small, and $\sigma \tau v \lambda i$ s, a column or style.)

1. IM. monophýllos, Lindl. Slender (4-6' high); leaf sheathing the base of the stem, ovate-elliptical; racemes spiked, long and slender; pedicels not longer than the flowers; lip long-pointed. - Cold wet swamps, N. New Eng. to Peun., N. Ind., Minn., and northward. July. (Eu.)

2. M. ophioglossoides, Nutt. Leaf near the middle of the stem, orate, clasping; raceme short and obtuse; pedicels much longer than the flowers; lip truncate-3-lobed at the summit, the middle lobe very small. - Low moist ground, N. Scotia to Fla., west to Minn. and Mu. July. - Pollinia (at least sometimes) ouly 1 in each cell. 


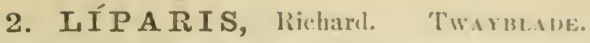

Sepals and petals nearly equal, linear, or the latter thread-like, spreading. Lip flat, entire, often bearing 2 tubercles ahove the base. ('olumn elongated, incurved, margined at the apex. Anther lid-like, terminal ; pollen-masses 4, in one row (2 to each cell), slightly united in pairs, without stalk, threads, or gland. - Simall, low herbs, with solid bulls, producing 2 root-leaves and a low scape, which bears a raceme of few purplish or greenish flowers. (Name from $\lambda$ irapos, fit or shining, in allusion to the smooth or unctuons leaves.)

1 L. liliifolia, Richard. Leaves ovate; jetals thread-like, reflexed; lip)

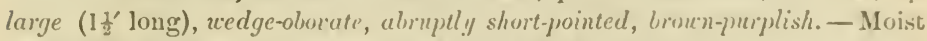
woodlands, N. Eng. to Ga., west to Minn. and Mo. June.

2. L. Lœsèlii, Richard. Leaves elliptic-lanceolate or oblong, keeled; lip olvocate or oblong (2" long), mucronate, ycllowish-green, shorter than the linear unequal petals and sepals. - Bogs, N. Scotia to Md., S. Ill., and Minn. (Eu.)

\section{C A L Ý P SO, Salisb.}

Sepals and petals nearly similar, ascending, spreading, lanceolate, pointed. Lip larger than the rest of the fluwer, sac-shaped, inflated (9" long), 2-pointed underneath the apex. Column broadly winged and petal-like, ovate, bearing the lid-like anther just below the apex; pollen-masses waxy, 2, each 2-parted, all sessile on a square gland. - $\Lambda$ little bog-herb; the solid hulbs producing a single orate or slightly heart-shaped thin leaf, as in Aplectrum, and a short (3-5' high) scape, slieathed below, bearing a large and showy (variegated purple, piuk, and yellow) Hower. (Name from the goddess C'alypso.)

1. C. boreàlis, Salisb. - Cold bogs and wet woods, the bulbs resting in moss, with a coralloid root beneath; Maine and Vt. to Mich. and Minn., aud northward. May.-A very local and beantiful plant. Lip somewhat resembling that of a Lady's slipper, woolly-hairy inside. (Eu.)

\section{TIPULÀ RIA, Nutt. Crane-fly Orchis.}

Sepals and petals spreading, oblong; the latter rather uarrower. Lip prolonged beneath into a thread-like ascending spur twice or thrice the length of the flower (9-12" long), 3-lobed; the midlle lobe linear, a little wavy, as long as the petals, the side lobes short and triangular. Columu narrow and wingless. Anther lid-like, terminal ; pollen-masses 2, waxy, each 2-parted, connected by a linear stalk with the transwerse small gland. - Ilerb with large solid bulbs connected horizontally, on a distinct pelicel, produring in autumu a single ovate nerved and plaited leaf on a slender petiole, purplish bencath, and in summer a long slender scape, with 1 or 2 sheaths at base, bearing a raceme of many small greenish flowers tinged with purple. (Name from a fancied resemblance of the flowers to insects of the genus Tipulu.)

1. T. díscolor, Nutt. Scape 10-18' high; lip blunt at the tip. - Sandy woods, Vt. to N. J. and Fla., west to Mich.; very scarce.

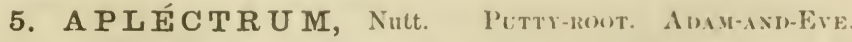

Perianth neither gibbous nor with auy trace of a spur or sac at the basse. Lip free, the palate 3-ridged. Otherwise the flower's and scape (invested be- 
low with 3 greenish sheaths) as in Corallorhiza; but, instead of a coral-like root, a slencler naked rootstock produces each year a thick, globular, solid bulb or corm, often $\mathrm{l}^{\prime}$ in diameter (filled with exceedingly glutinous matter), which sends up late in summer a large, oval, many-nerved and plaited, petioled, green leaf, lasting through the winter, and early in the succeeding summer its scape is terminated by a loose raceme of dingy rather large flowers. (The name composel of $a$-privative and $\pi \lambda \hat{\eta} \kappa \tau \rho o \nu, a s p u r$, from the total want of the latter.)

1. A. hiemàle, Nutt. Stem $1^{\circ}$ high or more; perianth greenish-brown, or the lip whitish, and somewhat speckled with purple, 5-6" long. - IVoods, in rich mould; rather rare or local, N. Eng. to Ga., west to Minn. and Mo. Each corm lasts 2 or 3 years before it shrivels, so that 3 or 4 are found horizontally connected.

\section{CORALLORHízA, Haller. Coral-root.}

Perianth somewhat ringent, oblique and gibbous or obscurely spurred at base; the oblong or lanceolate sepals and petals nearly alike, 1 -3-nerved, the upper arching; the lateral sepals ascending, their bases with that of the lip forming the gibbosity or short spur which is mostly adnate to the summit of the ovary; lip slightly adherent to the base of the 2-edged straightish column, hearing a pair of projecting ridges on the face below, spreading or recurved at the apex. Anther terminal, lid-like. Pollen-masses 4, obliquely incumbent, soft-waxy, free. - Brownish or yellowish herbs, lestitute of green foliage, with much-branched and toothed coral-like root stocks (probably root-parasitical), sending up a simple scape, with sheaths in place of leaves and bearing a raceme of rather small dull-colored flowers; fruit reflexed. (Name composed of

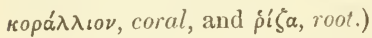

§ 1. Small spur or sac adnate to the summit of the ovary; flowers small; lip uhitish or purplish, often mottled with crimson.

1. C. innàta, R. Brown. Plant slender, light brownish or yellowish (3$9^{\prime}$ high), 5-12-flowered ; pedicels very short; perianth $2-2 \frac{1}{2}{ }^{\prime \prime}$ long; lip somewhat hastately 3-lobed above the base, the lamellae thick and rather short; spur a very small protuberance; capsule oral or elliptical $\left(3-4^{\prime \prime}\right.$ long $)$. - Swamps and damp woods, N. Eng. to northern N. J., Ohio, Mich., Minn., and northward, and south in the mountains to Ga. May, June. (Eu.)

2. C. odontorhiza, Nutt. Plant light brown or purplish; stem rather slender, bulbous-thickened at base $\left(6-16^{\prime}\right.$ high $), 6$ - 20-flowered; pedicels rather slender; perianth about $3^{\prime \prime}$ long; lip entire or merely denticulate, thin, lroadly ovate or obovate, abruptly contracted into a claw-like base, the lamellæ a pair of short projections ; the spur represented by a small cavity wholly adnate to the summit of the ovary ; capsule at first very acute at base, at length short-oval (4" long). - Rich woods, E. Mass. (Hitchings) and Vt. to N. J. and Fla., west to Mich. and Mo. May - July.

3. C. multiflòra, Nutt. Plant purplish, rather stout $\left(9-18^{\prime}\right.$ high $), 10-$ 30-flowered; perianth $2 \frac{1}{2}-4^{\prime \prime}$ long; lip deeply 3-lobed, with a short narrowed base and with prominent lamellæ; spur manifest and protuberant; capsule oblong (6-9" long), short-pedicelled. - Dry woods, N. Eng. to Mid., west to Mo., Iowa, and Minu. July - Sept. 
§. S. Spur none; the broadly gibbous someuthat sarcute luse wholly free from the ovary; flourers lurge for the genus, purple, unspotted, more expanding.

4. C. striàta, Liull. I'lant purplish, stout (6-16' high), bearing 15-25 large flowers in a crowled spike, on very short pedicels; perianth $6-7$ " long; lip oval or obovate, perfectly entire, concare, barely narrowel at the base, where it bears 1-3 short lamella ; all the parts of the perianth marked with 3 darker nerves; pod oblong ( $9^{\prime \prime}$ long). (C. Macrxi, Gray.) - Woods, from L. Erie westward along the Great Lakes and to the Pacific.

\section{HEXALÉCTRIS, Raf.}

Sepals and petals nearly equal, somewhat spreacling, several-nerved, not gibbous nor spurred at base, free. Lip oborate, with 5-6 prominent ridges down the middle, 3-lobed above, the middle li:e somewhat concave. Pollenmasses 8, united into a single fascicle. Otherw ise as in Corallorhiza. (Name probally from $\ddot{\epsilon}^{\prime} \xi$, six, and $\dot{a} \lambda \epsilon \kappa \tau \rho \nu \omega ́ \nu$, a cock, from the crests of the lip.)

1. H. aphýllus, Raf. Stem $1-2^{\circ}$ high, beset with purplish scales, the lower sheathing; flowers racemed, hracteate, brownish-purple, 6-8" long. (Bletia aphylla, Nutt.) - Rich woods, Ky. and Mo. to Fla. and Mex.

\section{LÍsteRA, R. Brown. Twaybade.}

Sepals and petals nearly alike, spreading or reflexed. Lip mostly drooping, longer than the sepals, 2-lobed or 2-cleft. Column wingless; stigma with a rounded beak. Anther borne on the back of the column at the summit, erect, ovate; pollen powdery, in 2 masses, joinerl to a minute gland. - Roots fibrous. Stem bearing a pair of opposite sessile leaves in the middle, and a spike or raceme of greenish or brownish-purple small flowers. (Dedicated to Martin Lister, an early and celebrated British naturalist.)

* Column very short; sepals ovate, reflexed; plants delicate, 4-8' high.

1. L. cordàta, R. Brown. Leaves round-ovate, somewhat heart-shaped $\left(\frac{1}{2}-l^{\prime}\right.$ long); raceme smooth; flou'ers minute, crouded, on pedicels not longer than the ovary; lip linear, twice as long as the sepals, 1-toothed each side at base, 2-cleft. - Cold woods, N. J. to Mich., Minn., and northward. June. (Eu.)

2. L. austràlis, Lindl. Leaves ovate; raceme loose and slender; flowers very small, on minutely glandulur-pubescent pedicels twice the length of the ovary; lip linear, 3-4 times the length of the sepals, 2-parted, the divisions linearsetaceous. - Damp thickets, Uswego Co., N. Y., and from N. J. to Fla. June. * *olumn longer, arching or straightish.

3. L. convallarioides, Nutt. Plant 4-9' high ; leaves oval or roundish, and sometimes a little heart-shaped $\left(1-1 \frac{1^{\prime}}{2} \ln n\right)$; raceme loose, puhescent; pedicels slender, lip werlge-oblong. 2-lobed at the dilated apex, and 1toothed on each side at the hase, nearly twice the lengtl of the narrowly lanceolate spreadling sepals, purplish, $\frac{1}{3}$ long. - I )amp mossy woods, N. New Eng. to Mich., Minn., aud northward, and south in the mountains to N. C.

\section{SPIRÁ N THES, Richarel. LAnís' Tresses.}

Perianth somewhat riugent, oblique on the orary; the sepals and petals all narrow, mostly erect or connivent, the three upper pieces sticking together 
more or less, the two lower covering the base of the lip. Lip oblong, shortstalked or sessile, the lower part involute around the colnmn, and with a callous protuberance on each side of the base; the somewhat dilated summit spreading or recurved, crisped, wary, or rarely toothed or lobed. Column short, oblique, bearing the ovate stigma on the front, and the sessile or shortstalked (mostly acute or pointed) 2-celled erect anther on the back. Pollenmasses 2 (one in each cell), narrowly obovate, each 2-cleft, and split into thin and tender plates of granular pollen united by elastic threads, and soon adhering at base to the narrow boat-shaped viscid gland, which is set in the slender or tapering thin beak terminating the column. After the removal of the gland, the beak is left as a 2-toothed or 2-forked tip. - Roots clusteredtuberous; stem more or less naked ahove, leaf-bearing below or at the base. Flowers small (ours all white or greenish-white), bent horizontally, 1 - 3-ranked in a spike, which is commonly more or less spirally twisted (whence the name, from $\sigma \pi \epsilon i \rho$, a coil or curl, and ă 0 os, flower).

* Flowers in 3 ranks, crowded in a close spike: leaves at the root and base of the stem present at the flowering season.

1. S. latifòlia, Torr. Low; naked stem or scape $4-9^{\prime}$ ( rarely 12') high, smooth; leaves all next the base, oblong or lance-oblong ( $1-t^{\prime}$ long, $3-9^{\prime \prime}$ wide), 3-5-nerved, contracted into a sheathing base; spike narrow (1-3' long); flowers small (2-3" long); lip quadrate-oblong, yellowish on the face, not contracted in the midlle, thin, wavy-crisped at the very obtuse or truncate apex, the small callosities at the base oblong, marginal and adnate for their whole length; gland and beak of the stigma short. - Moist banks, Vt. and W. Mass. to Mich. and Minn., south to Del. and Md.

2. S. Romanzoffiàna, Cham. Stem leafy below and leafy-bracted above (5-15' ligh); leaves varying from oblong-lanceolate to grassy-linear; spike dense, oblong or cylindrical ( $1-4^{\prime}$ long); perianth curved and the summit manifestly ringent, pure white $\left(t^{\prime \prime}\right.$ long), the sepals and petals all connivent in the upper portion or galea; the lip ovate-oblong, contracted below the rounded wavy-crenulate much recured summit, otherwise entire, the callosities at base globular and smooth; gland oblong-linear and the 2-horned beak of the stigma short. - High and cool bogs, N. New Eng. to Mich. and Minn., and northward; Norfolk, Conn. (Barbour); central N. Y. July, Aug. (Ireland.)

3. S. cérnua, Richard. Stem leafy below and leafy-bracted above $\left(6-20^{\prime}\right.$ high); leaves linear-lanceolate, the lowest elongated (4-12' long, 2-9' wide); spike cylindrical, rather dense $\left(2-5^{\prime}\right.$ long) and with the white fragrant flowers either pubescent or nearly smooth; perianth horizontal or recurving (4$5^{\prime \prime}$ long), the lower sepals not upturned or connivent with the upper; lip oblong and very obtuse when outspread, but conduplicate or the margins much incurved, wavy-crisped above the middle, especially at the flattish and recurvedspreading apex, the callosities at the base prominent, nipple-slaped, somewhat hairy ; gland of the stigma linear, in a long and very slender beak. - Common in wet places, especially eastward and southward. Sept., Oct. Very variable in size and foliage, often nearly losing its root-leaves at flowering time. - A variety, growing in dry ground but retaining its leaves and blooming somewhat later, has greenish cream-colored or yellowish stronger-scented flowers. E. Mass and Del. 
* Flowers in one straight or spirally twisted rank.

- Stem bearing elongated leaves at and toward the base, which mostly persist during the flowering season.

4. S. pràcox, Watson. Root of fleshy or tuhernus-thickened fibres; stem $9^{\prime}-2^{\circ}$ high; lower and root-leaves linear or lance-linear $\left(3-8^{\prime} \operatorname{long}, 2-\right.$ 4 " wide) gralually tipering to the base, the upper reluced to sheathing hracts ; spike linear, lense $(2-5$ ' long), usually much twisted, the axis, ovaries, ete., downy-pubescent; bracts ovate and gradually, or rhombic-ovate and abruptly taper-pointed, surpassing the ovary, the margins broadly hyaline; perianth 3 " long; lip ovate-oblong when outspread, with rather small callosities at base, crisped at the romuled slightly recurved apex; anther and beak of the stigma very acute. (S. graminea, var. Walteri, Gray.) - Wet, grassy places, Mass. to N. J. and Fla.

+ - Scupe very slender, merely bracted; the leares with a blade all in a cluster at the ground, orate or oblong, abruptly contracted into a petiole, commonly withering away at or before flowering; flowers small, and whole plant glabrous or nearly so; bracts small, sharp-pointed, not longer than the capsule.

5. S. grácilis, Bigelow. Roots clustered, tuberous-thickened: scape 8-18' high, bearing a slender many-flowered one-sided or twisted spike; perianth barely $1 \frac{1}{2}-2^{\prime \prime}$ long; lip oval when outspread, narrowly oblong in natural form, thickish and green above with thin white margins, the recurved obtuse or acutish apex wary-crisped, the callosities at the base nipple-shaped. - Hilly woods and sandy plains, common. July-Oct.

6. S. símplex, Gray. Root a solitary oblong or spindle-shaped tuber; no leaves at flowering time; scape $5-9^{\prime}$ high, bearing a small narrow (rarely 1 . sided) spike (1-3' long) of very short flowers (perianth $1-1 \frac{1^{\prime \prime}}{2}$ long); lip thin, white, oborate-oblong, the apex eroded and crisped, the callosities at the base slender. - Dry sandy soil, E. Mass. to N. J., Del., and Md. Aug., Sept.

\section{GOODY E RA, R. Br. Rittlesnake-Plantain.}

Lip sac-shaped, sessile, entire, and without callosities at base. Otherwise as Spiranthes. - Root of thick fibres, from a somewhat fleshy ereeping rootstock, bearing a tuft of thickish petioled leaves, usually reticulated with white veining. Scape, spike, and the greenish-white small flowers usually glandulardowny. (Dedicated to John Goodyear, an early English botanist.)

§ 1. Lip strongly saccate-inflated and with a short spreading or recurved tip; anther short, borne on a distinct filament attached to the back of the short column, blunt; gland-bearing tip or beak of the stigma very short.

1. G. rèpens, R. Br. Small $\left(5-8^{\prime}\right.$ high) and slender; leaves ovate, more or less white-reticulated (ahout I'long); flowers several, in a loose 1-sidel spike; lip with an ovate recurved tip; sepals ovate. - Woods, under evergreens, common northward and through the Alleghanies. July. (Eu.)

2. G. pubéscens, R. Br. Larger; leares strongly white-reticulated; seape 6-12' high, the mumerous crowded flowers not one-sided: tip of the glohular lip ver!y short: otherwise like the preeding, and too near to it. Rich woods, Newf. to Fla., west to Mich. and Minn. 
§ 2. Lip barely saccate below, tapering and its sides involute above; anther ovate, long-pointed, borne on the base of the very short column, which is continued above the stigma into a conspicuous tupering aul-shaped gland-bearing beak.

3. G. Menzièsii, Lindl. Leaves ovate-oblong, acute (2-3' long), less white-reticulated than the preceding, some not at all so; scape 9-12' high; flowers rather numerous in a looser often 1-sided spike; Hower-buds less pubescent, elongated-ovate and pointed; lip with the saccate-conduplicate lower portion gradually tapering into the narrow barely spreading summit. - Woods, Gaspe and Tadousac, L. Can. (J. A. Allen, Goodule); Crawford, N. H. (Miss Minns); western N. Y. to Minn., and westward. July.

\section{EPIPÁCTIS, Haller.}

Sepals and petals nearly equal, spreading. Lip free, deeply concave at base, narrowly constricted and somewhat jointed in the middle, the upper portion dilated and petaloid. Column short, erect. Anther sessile behind the broad truncate stigma, on a slender-jointed base; pollen-masses coarsely granular, becoming attached to the gland capping the small rounded beak of the stigma. - Stem leafy, with racemed flowers, conspicuous bracts, and ovaries reflexed at maturity. (The ancient Greek name of a plant.)

1. E. Helleborine, Crantz. Stems $1-2^{\circ}$ high ; leares broadly ovate $(2-$ 3 ' long), pointed, plicate, the upper narrower; raceme pubescent, 30-50-flowered, 1-sided; flowers varying from light greenish-yellow to dark purple; sepals ovate-lanceolate, $3-4^{\prime \prime}$ long; petals rather smaller; lip ovate, pointed above, with a dark centre. (E. latifolia, All.) - Near Syracuse and Buffalo, N. Y.; the only known stations. (Eu.)

\section{A RETH U S A, Gronov.}

Flower ringent; the lanceolate sepals and petals nearly alike, united at base, ascending and arching over the column. Lip dilated and recurved-spreading toward the summit; very slightly gibbous at base. Column adherent to the lip below, petal-like, dilated at the apex. Anther lid-like, terminal, of 2 approximate cells; pollen-masses powdery-granular, 2 in each cell. - Beautiful low herbs, consisting of a sheathed scape from a globular solid bulb, terminated usually by a single large rose-purple flower. Leaf solitary, linear, nerred, hidden in the sheaths of the scape, protruding after flowering. (Dedicated to the nymph Arethusa.)

1. A. bulbòsa, L. Flower single (rarely 2$)$, erect $\left(1-2^{\prime}\right.$ long), with an entire lip recurved at the apex and bearded-crested down the face.-Bogs, Newf. to the mountains of $\mathrm{N}$. C., west to Ind. and Minn.

\section{CALOPOGON, R. Br.}

Flower with the ovary or stalk not twisting, therefore presenting its lip on the upper or inner side. Sepals and petals nearly alike, lance-ovate, spreading, distinct. Lip spreading, distant from the column, raised on a narrowed base or stalk, dilated at the summit, strongly bearted along the upper side. Column free, slender, winged at the apex. Anther terminal and lid-like, sessile; pollenmasses 4 (two in each cell), of soft powdery grains, lightly connected by deli- 
cate threads. - Scape from a small solil bull, sheathel below by the hase of the grass-like leaf, naked above, hearing several large flowers. Bracts minute.

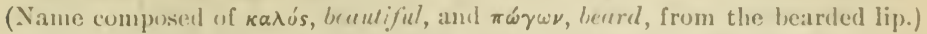

1. C. pulchélius, li. I3r. Leaf linear; scipe about $1^{\circ}$ high, 2-6-flowered; flowers l' broal, pink-jurple; lip as if hinged at the insertion, beautifully bearded toward the dilated summit with white, yellow, and purple club-shaped hairs. - Bogs, Newf. to Fla., west to Minn. and Mo.

\section{POG ON I A, Juss.}

Flower irregular, the sepals and petals scparate. Lip erested or 3-lobel. Column free, elongated, club-shaped, wingless. Anther terminal and lid-like,

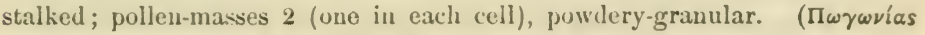
bearded, from the lip of some of the original species.)

$\$ 1$. Sipals and petals nearly equal and alike, pale rose-color, sometimes white.

1. P. ophioglossoides, Nutt. Rout of thick filıres; stem (6-9' high) bearing a single oval or lance-oblong leaf near the middle and a smaller one or bract near the terminal flower, rarely one or two others with a flower in the axil; flower 1' long, sweet-scented; lip spatulate, appressed below to the column, beard-crested and fringed.-Bogs, Newf. to Fla., west to N. Ind. and Minn. June, July. (Japan.)

2. P. péndula, Lindl. Stem $\left(3-8^{\prime}\right.$ high) from oblong tubers, bearing 3 to $;$ alternate ovate-clasping very small $\left(3-6^{\prime \prime}\right)$ leaves, the upper $1-4$ with drooping flowers in their axils on slender pedicels ; perianth $\frac{f^{\prime}}{2}$ long, narrow; lip spatulate, somewhat 3-lobed, roughish or crisped above, crestless. - 1)amp woods, N. Eng. to Fla., west to Wise. and Mo.

§2. Sepals linear, ding!y or brownish, longer and much narrower than the erect

- or connuvent petals: lip 3-lobed at the apex, crested doun the middle, beardless; flowers solitary (or rarely a pair), terminal; root a cluster of fibres.

3. P. divaricàta, R. Br. Stem $\left(1-2^{\circ}\right.$ high) learing a lanceolate leaf in the middle, and a leafil bract next the flower, which is recurred on the ovary; but the sepals ascending or diverging, spatulate-linear, longer than the lanceolate-spatulate pointed and flesh-colored petals, these about $1-1 \frac{1^{\prime}}{2}$ long. Wet pine-barrens, N. J. to Fla. June, July.

4. P. verticillàta, Nntt. Stem $\left(6-12^{\prime}\right.$ high $)$ naked, except some small siales at the base and a whorl of mostly 5 oborate or obovute-oblong sessile leaves at the summit; flower dusky purplish, on a peduncle longer than the ovary and capsule; sepals more than twice the length of the petals, narrowly linear, spreading from a mostly ereet base $\left(1 \frac{1}{3}-2^{\prime}\right.$ long); lip with a narrow erest down the middle. - Low woods, N. ling. to Flit., west to Ind. and Wisc.; rather rare, especially eastwarl. May, June. Glaucous when young. Fruit-stalk erect, about $1 \frac{1^{\prime}}{2}$ long, more than half the length of the leaves.

5. P. affinis, Austin. Somewhat smaller than the preceding; leaves paler and rather narrower; flowers (nut rarely in pairs) yellowish or greenish; peduncle much shorter than the ocary and copsule; sepals but little longer than the petals, tapering to the base; lip crested over the whole face and on the midlle of the lobes. - Low woods, S. W. Conn., S. New York, and N. New Jersey; rare. 


\section{5. Ó RCHIS, L.}

Flower ringent; the sepals and petals nearly equal. Lip turned downward, coalescing with the base of the column, spurred below. Anther-cells contiguous and parallel. Pollen cohering in numerous coarse waxy grains, which are collected on a cobweb-like elastic tissue into 2 large masses (one filling each anther-cell) borne on a slender stalk, the base of which is attached to a gland or sticky disk of the stigma, the two glands contained in a common little pouch or hooded fold, placed just above the orifice of the spur. Flowers showy, in a spike. - Our species with low scape-like stems, with 1 or 2 leares at base, from Hleshy-fibrous roots. (O $\rho \chi i s$, the ancient name.)

1. O. spectábilis, L. (Sноw Ү (J)H1s.) Root of thick fleshy fibres, producing 2 oblong-obovate shining leaves (3-6' long), and a few-flowered 4 angled scape $\left(4-\tau^{\prime}\right.$ higlı); bracts leaf-like, lanceolate; serals and petals all lightly united to form the raulted galea or upper lip, pink-purple, the ovate undivided lip white. - Rich woods, N. Brunswick to Ga., west to Minn. and Mo. Mav.

2. O. rotundifòlia, Pursh. Stem naked above, 1-leaved at base $\left(5-9^{\prime}\right.$ high), from a slender creeping rootstock; leaf varying from almost orbicular to oblong $\left(1 \frac{1}{2}-3^{\prime}\right.$ long); flowers rose-purple, the lip white and spotted with purple, 3-lobed, and the larger middle lobe dilated and 2--lobed or strongly notched at the summit $\left(4-6^{\prime \prime}\right.$ long), exceeding the ovate-oblong petals and sepals, and the slender depending spur. (Hahenaria rotundifolia, Richardson.) - Damp woods and bogs, X. Maine to Vt., N. Y., Minn., and northward.

\section{HA BE NÀ RA, Willd. Rein-Orcus.}

Glands or riscid disks (to which the pollen-masses are attached) naked and exposed, separate, sometimes widely so (becoming attached, some to the proboscis, others to the face or head of insects feeding upon the nectar of the spur, the pollen thus carried from one blossom to anther); otherwise nearly as in true Orchis; the lateral sepals, however, mostly spreading. (Name from habena, a thong or rein, in allusion to the shape of the lip or spur of some species.)

§ 1. GYMNADENIA. Cells of the anther paiallel and approximate, their glands therefore contiguous. (Appendages of the stigma in our species two or three and much developed, oblong or club-shaped.)

1. H. tridentàta, Hook. Stem slender (6-12' high), with a single ob long or oblanceolate obtuse leaf below, and 2 or 3 small ones like bracts above; spike 6-12-flowered, oblong; fowers greenish or whitish, very small; lip wedge. nblong, truncate, and with 3 shont teeth at the apex; the slender and slightly clubshaped spur curved upward, longer than the ovary. - Wet woods, N. Eng. to Minn. and Ind., and south in the mountains to N. C. June, July. - Root of few fleshy fibres. Appendages of the stigma three, oblong-club-shaped, one outside each orbicular gland and one between them, rising as high as the anther-cell, their cellular viscid summits receiring pollen in the unopened flower, and penetrated by pollen-tubes!

2. H. integra, Spreng. Root of very fleshy fibres (or some of them tuber-like); stem several-leaved (15' high), the 1 or 2 lower leaves elongated, oblong-lanceolate, acute, the others becoming smaller and bract-like; spike densely many-flowered, oblong-cylindrical; flowers orange-yellou, small; lip 
orate, entive or slightly crenulate or wavy, shorter than the awl-shaped descending spur. - Wet pine-barrens, N. J. to Fla. July- $-\Lambda_{\text {ppendages of the }}$ stigma two, lateral, oblong, fleshy; beak or midlle appendage narrow.

3. H. nívea, spreng. Stem slender, $1-1 \frac{1}{2}$ high, many-leaver, the 1 or 2 lower leaves lance-linear and $4-8^{\prime}$ long, the others small and bract-like; spike cylindrical, loosely many-flowered; flowers uhite, small; petals and entire lip linear-oblong: spur thread-shaped, ascending, as long as the white ovary, which is not twisted. - P'ine-barren swamps, S. Del. to Fla. Aug.

§2. PERLLARIA. Cells of the anther nrarly parallel, the ralves of each extended at base so us to form the sides of a deep oblong groove or cavity, which is lined by the dilated orbicular and incurved gland. (Flowers small, greenish, slender-spurred.)

4. H. viréscens, Spreng. Leaves ovate-oblong or oblong-lauceolate, the uppermost linear-lanceolate and pointed, passing into the bracts of the elongated raceme; petals ovate; flowers dull green; lip furnished with a tooth on each side and a stroing nasal protuberance in the middle of the base, oblong, truncate-obtuse, abont the length of the scpals, half the length of the slender club-shaped spur. - Wet places, common; N. Eng. to Fla., west to Minn. and Mo. June, July. - Stem 10-20' high; the spike at first dense, with the bracts longer than the flowers, at length elongated and often loose, the upper bracts shorter than the flowers, which are quite small, and with scarcely a tinge of yellow, drying brownish.

\$ 3. PLATANTIERA. Cells of the anther sometimes parallel, more commonly divergent, so that thetr tapering bases and the exposed glands are more or less distunt. (Root a cluster of fleshy fibres, or tuberons-thickened.)

* Flouers greenish or white, small, numerous in a close spike; spur not longer than the entire or merely notched narrow lip; anther-cells almost parallel, wholly adnate: stem leafy.

- Spur short and sac-like; the 3 sepals and 2 narrow petals erect; glands small, rather widely sepurated.

5. H. bracteàta, R. Br. Stem 6-12' high ; lower leaves obovate, the upper oblong and gradually reduced to lanceolate acute bracts $2-4$ times the length of the green flowers ; spike 10-30-flowered ; lip oblong-linear or slightly spatulate, truncate and 2-3-toothed or lobed at the tip, more than twice the length of the white spur. (H. viridis, var. bracteata, Reichenb.) - Damp woods and meadows, N. Eng. to Minn., Iowa, Ind., south in the mountains to N. C., and far northward.

- Spur slender, incurved, abont equalling the entire lip; lateral sepals spreading.

6. H. hyperbòrea, R. Br. Stem very leafy $\left(6^{\prime}-2^{\circ}\right.$ high) ; leares lanceolate, erect; spike dense (2-15' long); lower bracts lanceolate, longer than the (greenish) flowers; lip and petals lancelate, somewhat equal, the latter spreading from the base; anther somewhat overhanging the transversely dilated stigma; glands orbiculur; stalk of the pollen-masses very slender and weak. - Peat bogs and wet cold woods, N. Eng. to N. Y., S. Ill., Iowa, and nortliward. June, July. (Eu.)

7. H. dilatàta, Gray. Resembles n. 6, hut usually more slender, with narrower commonly linear leaves; flouers white; lip lanceolate from a rhom. 
boidal-dilated base, entire, its base with the bases of the petals and sepals erectconnivent, above spreading; anther-cells almost parallel; glands approximate, large and strap-shaped, vertical, nearly as long as the pollen-mass and its short flat stalk together; stigma narrow; a trowel-shaped conspicuous beak between the bases of the anther-cells. - Cold bogs, Conn. to N. Y., Mich., Minn., and northward.

* *louers greenish or white, 5-15 in a loose spike, rather large for the size of the plant; scape or stem naked above, 1-leaved at base (5-9' high); spur not longer than the lip; anther-cells wholly adnate, arcuate and widely separated.

8. H. obtusàta, Richardson. Leaf obovate or spatulate-oblong; upper sepal very broad and rounded, the others and the petals lance-oblong; lip entire, linear or lanceolate, deflexed ( $3^{\prime \prime}$ long), about the length of the tapering and curving spur. - Cold peat bogs, Maine and N. New Eng. (Mt. Wachusett, Mass.), to Minn. and northwir.l. (Eu.)

* * Flowers white or yrecu si, numerous in a loose spike, on a naked scape, 2 leaved at base; spur longer than the narrow entire lip; anther-cells widely diverging, their narrowed beak-like bases projecting forward; stalk of the pollen-mass laterally affixed to the back of the orbicular gland, the viscous face of which looks obliquely inuard.

9. H. Hoókeri, Torr. Leares orbicular, spreading $\left(3-4^{\prime}\right.$ broad); scape mostly naked $\left(\frac{1}{2}-1^{\circ}\right.$ high), bearing $10-20$ upright sessile yellowish-green flouers in a strict spike; sepals ovate-lanceolate; lip lanceolate, pointed, incurved, longer than the lance-aul-shaped petals; spur slender, acute, abont the length of the ovary (nearly $\mathrm{I}^{\prime}$ long). - Damp woods and border's of swamps, N. Scotia to N. J., west to Minn. and Iowa. - Var. obloxgroùra, Paine, lıas oblong leaves $\left(3-5^{\prime}\right.$ by $\left.1 \frac{1}{2}-2^{\prime}\right)$. N. Y. and Can.

10. H. orbiculàta, Torr. Leaves very large $\left(4-8^{\prime}\right.$ wide), orbicular, spreading flat on the ground, shining above, silvery beneath; scape bracted ( $1-2^{\circ}$ high), bearing many spreading greenish-uhite flowers in a loose raceme; upper sepal orbicular, the lateral orate; lip narrouly linear and slightly spatulate, obtuse, drooping, nearly thrice the length of the oblong-lanceolate and falcate obtuse petals ; spur curved, slender (about $1 \frac{1^{\prime}}{2}$ long), gradually thickened toward the blunt apex, tuice the length of the ovary; anther-cells strongly projecting at the free beak-like base (the glands nearly $\frac{1}{4}$ apart). - Rich woods (especially coniferous), Newf. to Penn. and in the mountains to N. C., west to Mich. and Minu.

* * * (Frixged Orchis.) Flouers several or many in an open spike, with mostly foliaceous bracts; stem (rather tall) leafy; spur thread-shaped or scarcely club-shaped, longer than the fringed, cleft, or dissected lip; anthercells widely separated and usually diverging, their narrow beak-like bases, supported by the arms of the stigma, strongly projecting forward or partly upward.

- Lip pectinately fringed but undivided; flowers golden yellow or white; anthercells widely divergent, the orbicular glands as if raised on a tentacle projecting far forward or slightly inward; ovary long, tapering to the summit.

11. H. cristàta, R. Br. Lower leaves lanceolate, elongated; the upper gradually reduced to sharp-pointed bracts, nearly the length of the crowded 
(yellow) flowers; spike oblong or eylindrical ; petals rounded, crenate; lip orete, with a lacerate-fininged maigin, scurcely shorter then the slender obtuse incurverl spur, which is not half the length of the ovary. - Liogs, N. J. to Fla. July. Flowers very much smaller than in the next.

12. H. ciliàris, R. Br. (Y'ELLOW Frivged-Orans.) Stem $1 \frac{1}{2}-2^{\circ}$ high; leaves oblong or lanceolate; the upper passing into pointed lracts, which are shorter than the ovaries; spike oblung, rather closely many-flowered; flouers bright oranye-yellow; lateral scpal rounded, retlexed; petals linear, cut-fringed at the apex; lip, oblong (6" long), about half the length of the spur furnisher with a very long and copious capillary fringe. - Wet sandy places, N. Eng. to Fla. and Tex., west to Miclı. and Ind. Our most handsome species.

13. H. blephariglóttis, Torr. (Whiт: Fmsien-()rсns.) Stem $1^{\circ}$ high ; leaves, etc., as in the list; flowers white, rather sinaller; petals spatulate, usially slightly cut or toothed at the apex; lip ovate- or lanceolate-olilong, wic.' the irregular capillary fringe of the margins usually shorter than its disk, one third the length of the spur. - Peat bogs and borders of ponds, Newf. to N. J., west to Mich. and Minn. July. - Var. IIOLOPÉTALA, Torr., lıas narrower petals with the toothing obsolete, and the lip less fringed.

++ (Greexisin Fringed-Orcuis.) Lip 3-parted above the stalk-like base, the divistons cut into capillary, fringes: flouers greenish-or yellowish-uhite; anther-cells not very divergent, the beaked buses projecting forwurd; the large glands oxal or lanceolate, nearly facing each other; ovary shorttapering above; spurs long, clavate.

14. H. leucophæa, Gray. Stem $2-4^{\circ}$ high ; leaves oblong-lanceolate; the bracts similar, rather shorter than the (large, fragrant) flowers; spike commonly elongated, loose; petals obovate, minutely cut-toothed; divisions of the lip ( $\bar{i}-10^{\prime \prime}$ long) broadly wedye-shaped or fun-shaped, many-cleft to the middle into a copions thread-like finge; spur longer than the ovary $\left(1-1 \frac{1}{2}\right.$ long) ; glands transversely oral. - Moist meadows, western N. Y. to Ky., Mo., and Minn. July.

15. H. lácera, R. Br. (RAgGit) Frisged-Orchis.) Leares ollong or lanceolate; raceme loosely many-flowered; petals oblong-linear, entire; divisions of the lip narrow, deeply parted into a few long nearly capillary lobes; spur about the length of the orary; glands oblong-lineur, as long as the stalk of the pollen-mass. - Bogs and moist thickets, N. Scotia to N. C. and Ga., west to Minn. and Mo.; common. July.

t- + - (Purple Fungen-Orcirs.) Lip fan-shaped, 3-parted above the stalklike base, the divisions erosely fringed; flowers purple; anther-cells widely separated, little dirergent, the orbicular ylands oblique: orary contracted only at the summit; the long curving spur someuhat clurate.

16. H. psycodes, Gray. Leaves oblong or lanceolate, the uppermost passing into linear-linceolate hracts; ruccme cylindrical, densely many-flowered; lower sepals round-ocal, obtuse; petuls wedye-oborate or spatulate, denticulate above; divisions of the spreading lip broadly wedge-shaped, many-cleft into a short fringe. - Wet meadows and bogs, common; Newf. to N. C., west to Ind. and Minn. July, Aug. - Flowers sliort-pedicelled, crowded in a spiko of 4-10' in length, small, hut very handsome, fragrant; lip short-stalked, 
barely $\frac{1}{2}$ broad and not so long; the middle lobe broadest and more closely fringed, but not so deeply cleft as the lateral ones.

17. H. fimbriàta, R. Br. Lower leaves oval or oblong, the upper few, passing into lanceolate bracts; spike or raceme oblong, loosely-flowered; lower sepals ovate, acute; petals oblong, toothed down the sides; divisions of the pendent large lip $\left(\frac{3}{4}-1^{\prime}\right.$ broad $)$ fan-shaped, more fringed. - Wet meadows, N. Scotia to N. J. and N. C., west to Mich. June. - Flowers fewer (lilac-purple), 3 or 4 times larger than those of the preceding.

18. H. peram ¿̀na, Gray. Lower leaves oblong-ovate, the upper lanceolate; spike oblong or cylindrical, densely flowered; lower sepals round-ovate; petals rounded-obovate, raised on a claw; divisions of the large lip very broadly wedge-shaped, irregularly eroded-toothed at the broadly dilated summit, the lateral ones truncate, the middle one 2-lobed. - Moist meadows and banks, Penn. and N. J. to Ill., and south in the mountains. Aug. - Flowers large and showy (violet-purple); the lip paler and $8-10^{\prime \prime}$ long, variably toothed, but not fringed.

\section{C Y P R I PÈ D I U M, L. Lady's Slipper. Moccason-Flower.}

Sepals spreading; all three distinct, or in most cases two of them united into one under the lip. P'etals spreading, resembling the sepals but usually narrower. Lip a large inflated sac. Column declined; on each side a fertile stamen, with its short filament bearing a 2-cellerl anther; the pollen loose and pulpy or powdery-granular; on the upper side a dilated-triangular, petal-like but thickish body, which answers to the fertile stamen of other (orchids, and corers the summit of the style; stigma terminal, broad, obscurely 3-lobed, moist and roughish (not smooth and viscid as in the rest of the order). Pollen in most of our species, especially in n. 6 , exposed by the conversion of the face of the anther into a viscid, varnish-like film, which adheres to whatever touches it, carrying away some of the pollen. - Root of many tufted fibres. Leaves large, many-nerved and plaited, sheathing at the base. Flowers solitary or few, large and showy. (Name composed of Kú $\pi \rho \iota$, T'enus, and $\pi o^{\prime} \delta$ เov, a sock or buskin, i. e. Tenns's slipper.)

§ 1. The three sepuls sepurute; stem leafy; flower solitary, drooping.

1. C. arietinum, R.Br. (RAx's-HeAD L.) Stem slender $\left(6-10^{\prime}\right.$ high); upper sepal ovate-lanceolate, pointed: the 2 lower and the petals linear and nearly alike (greenish-brown), rather longer than the red and whitish reiny lip (6"loug), which is somewhat pubescent, especially within, and prolonged at the apex into a short blunt conical point; leaves 3 or 4 , elliptical-lanceolate, nearly smooth. - Cold swamps and damp woods, Maine to N. Y., Mich. and Minn., and northward.

\section{§2. Tun of the sepals united into one under the lip.}

* Stem leafy to the top, 1-3-flowered; lip slipper-shaped or roundish, much inflater, horizontal, and with a rounded open orifice.

+ Sepals and linear wavy-twisted petals brounish, pointed, longer than the lip.

2. C. cándidum, Muhl. (Siall Winte Lady's Slipper.) Slightly pubescent, l-flowered; leaves lance-oblong, acute; petals and sepals greenish, purple-spotted; sepuls ovate-lanceolate; lip (not l' long) white, striped with 
purple inside, flattish laterally, convex above; sterile stamen lanceolate. Bogs, N. Y. and Penn. to Minn., Mo, and Ky. ; rare. May, June.

3. C. parviflorum, Salisb. (NMallek Ykloow L.) Stem $1-2^{\circ}$ high leaves oval, pointed; sepals ovate or ovate-tanceolate; lip fluttish from above, bright yrllow ( $l^{\prime}$ long or less); sterile stamen triangular. - Bugs and low woods, Newf. to Ga., west to Minn. and E. Kan. May, June. - Flowers fragrant; sepals and petals more brown-purple than in the next, into which it seems to pass.

4. C. pubśscens, Willd. (Lakger Yeruow L.) Stem $2^{\circ}$ high, pubescent, as are the broadly oval acute leaves; sepals elonguted-lanceolate; lip flattened laterally, very convex and gibbous above, $1 \frac{1}{2}-2^{\prime}$ long, pale yellow. Bogs and low woods; same range as the last.

+ + Sepals and petuls plane, rounded, white, not longer than the lip.

5. C. spectábile, Salisb. (Suowy L.) Downy, $2^{\circ}$ high; leaves ovate, pointed; scpals round-ovate or orbicular, rather longer than the oblong petals ; lip inuch inflated, uhite, pink-purple in front ( $\left.1 \frac{1^{\prime}}{2} \mathrm{long}\right)$; sterile stameu heartovate. - Peat-bogs, Maine and W. New ling. to Minn. and Mo., and south in the mountains to N. C. Jnly. - The most beantiful of the genus.

* Scape naked, 2-leaved at base, 1-flowered; sepals and petals greenish, shorter than the drooping lip, which has a closed fissure down its achole length in front.

6. C. acaùle, Ait. (Stemless I.) Downy; leaves ohlong; scape 8-12' high, with a green bract at top; sepals oblong-lanceolate, pointed, nearly as loug as the linear petals; lip obovoid or oblong, rose-purple (rarely white), nearly ' 2 ' long, veiny ; sterile stamen rhomboid. - Dry or moist woods; Newf. to N. C., west to N. Ind., Mich., and Minn. May, June.

\section{Order 111. BromediACAd. (Pine-apple Famir.)}

Herls (or scarcely uoolly plants, nearly all tropical), the greater part epiphytes, with persistent dry or fleshy and channelled crowded leaces, sheathing at the base, usually covered with scurf; 6-androus; the 6-cleft perianth adherent to the ovary in the PINE-APPLE, etc., or free from it in

\section{TILLÁ N D S A, L. Loxg Moss.}

Perianth plainly donble, 6-parted ; the 3 onter divisions (scpals) nembranaceous; the 3 inner (petals) colored; all connivent below into a tube, spreading ahove, lanceolate. Stamens 6 , hypogynous ! or the alternate ones cohering with the base of the petals; anthers introrse. Ovary free; style thread-shaped; stigmas 3. Capsule cartilaginous, 3-celled, loculicillally 3-valverl; the valves splitting into an inner and an onter layer. Seeds several or many in each cell, anatropons, club-shaped, pointed, raised on a long hairy-tufted stalk, like a coma. Embryo small, at the hase of (opions albumen. - Scurfy-leaved epiphytes. (Named for Prof. Tillands of $\mathrm{A}$ bo.)

1. T. usneoldes, I. (Commox Loxg Moss or BLack Moss.) Stems thread sliaperl, branching, pendulons; leaves thread-shaped; perluncle short, l-flowered; flower yellow. - East Shore, Va., south to Fla., and westward; growing on the branches of trees, forming long hanging tufts. 


\section{Order 119. H AEMOdORÀCEA. (Bloodwort Family.)}

Herbs, with fibrous roots, usually equitant leaves, and perfect 3-6-androus regular flower's, which are woolly or scurfy outside; the tube of the 6-loberl perianth coherent with the whole surface, or with merely the lower part, of the 3-celled ovary. - Anthers introrse. Style single, sometimes 3-partible; the 3 stigmas alternate with the cells of the ovary. Capsule crowned or enclosed by the persistent periantll, 3-celled, loculicidal, 3 - many-seeded. Embryo small, in hard or fleshy albumen. A small family; chiefly of the southern hemispliere.

* Ovary wholly adherent to the calyx-tube; style filiform ; seeds peltate. amphitropous.

1. Lachnanthes. Stamens 3 , exserted; anthers versatile. Leaves equitant.

* * Ovary free except at the base; style 3-partible; seeds anatropous.

2. Lophiola. Stamens 6 , on the base of the woolly 6 -cleft perianth. Leaves equitant.

3. Aletris. Stamens 6 , in the throat of the warty-roughened and tubular 6 -toothed perianth. Leaves flat, spreading.

\section{LACHNÁNTHES, L. ReD-root.}

Perianth woolly outside, 6-parted down to the adherent ovary. Stamens 3, opposite the 3 larger or inner divisions; filaments long, exserted; anthers linear, fixed by the middle. Style thread-like, exserted, declined. Capsule globular. Seeds few on each fleshy placenta, flat and rounded, fixed by the middle. - Herb, with a rell fibrous perennial root, equitant sword-shaped leaves, clustered at the base and scattered on the stem, which is hairy at the top and terminated by a dense compound cyme of dingy yellow and loosely woolly flowers (whence the name, from $\lambda \dot{\alpha} \chi \nu \eta$, wool, and ă $\nu \theta 0 s, b l o s s o m$ ).

1. L. tinctoria, Ell. - Sandy swamps, near the coast, S. E. Mass., R. I., and N. J. to Fla. July - Sept.

\section{LOPHIOLA, Ker.}

Perianth densely woolly, deeply 6-cleft; the divisions nearly equal, spreading, longer than the 6 stamens, which are inserted at their base. Anthers fixed by the base. Capsule ovate, free from the perianth except at the base, pointed with the awl-shaped style, which finally splits into 3 divisions, one terminating each valve. Seeds numerons, oblong, ribbed, anatropous. - A slender perennial herb, with creeping rootstocks and fibrons roots, linear and nearly smooth equitant leaves; the stem leafless and whitened with soft matted wool toward the summit, as also the crowled or panicled cyme. Perianth dingy yellow inside; the lobes naked only toward the tip, each clothed with a woolly tuft

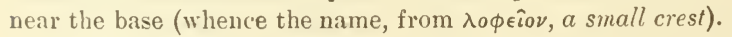

1. L. aùrea, Kerer. - Boggy pine-barrens, N. J. to Fla. June-Aug.

\section{3. Á LETRis, L. Colic-root. Star-grass.}

Perianth cylindrical, not woolly, but wrinkled and roughened outside by thickly-set points which look like scurfy mealiness, the tube cohering below with the base only of the ovary, 6-cleft at the summit. Stamens 6, inserted at the base of the lobes; filaments and anthers short, includerl. Style awl-shaped, 3-cleft at the apex; stigmas minutely 2-lobed. Cansule orate, eucloserd in the 
roughened perianth; the dehiscence, seeds, ete., ncarly as in Lophiola. - Peremnial and smooth stemless herbs, very bitter, with filmous roots, and a spreasling cluster of thin and flat lanceolate leaves; the small flowers in a want-like spiked raceme, terminating a naked slonder seape $\left(2-3^{\circ}\right.$ lighl $)$. Bracts awlshaped, minute. ('A $\lambda \epsilon \tau \rho$ /s, a female slave who griuls corn; the name applied to these plants in allusion to the apparent mealiuess dusted over the blossoms.)

1. A. farinosa, 1. Flowers oblong-tubular, white; lubes lincenlateohlong. - Grassy or sandy wonds, Mass. to Fla., Ill., and Mim. July, Aug.

2. A. aùrea, Walt. Flowers bell-shaped, yellow (fewer and shorter); lobes short-ovate. - Barrens, N. J. to Fla. July.

\section{Order 11:3. IRIDíCLA. (IRIS FAMHL.)}

Herbs, with equitant 2-ranked leaves, and regular or irregular perfect flowers; the divisions of the (j-cleft petal-like perianth convolute in the bud in 2 sets, the tube colierent with the 3-celled ovary, and 3 ilistinct or monadelphous stamens, alternate with the inner divisions of the perianth, with extrorse anthers. - Flowers from a spathe of 2 or more leaves or bracts, usually showy. Style single, usually 3-cleft; stigmas 3, opposite the cells of the ovary, or 6 by the parting of the style-branches. Capsule 3-celled, loculicidal, many-seederl. Seeds anatropous; emloryo straight in fleshy albumen. Rootstocks, tubers, or corms mostly acrid.

* Bramches of the style (or stigmas) opposite the anthers.

1. Iris. Outer divisions of the perianth recurved, the inner erect; stigmas petal-like.

** Branches of the style alternate with the antliers. Perianth regular.

2. Nemastylis. Stem from a coated bulb. Filaments united. Style-branclies 2-cleft.

3. Belamcanda. Stems from a creeping rhizome. Filaments distinct. Stigmas dilated.

4. Sisyrinchium. Root fibrous. Filaments united, Stigmas thread-like.

\section{1. İRIS, Tourn. Flower-De-Ltce.}

Perianth 6-cleft; the tube more or less prolonged beyond the ovary ; the 3 outer divisions spreading or reflexed, the 3 inner smaller, erect. Stameus distinct; the oblong or linear anthers sheltered under the overarehing petallike stigmas (or rather branches of the style, bearing the true stigma iu the form of a thin lip or plate under the apex); most of the style connate with the tube of the perianth. Capsule 3-6-angled, coriaceous. Seeds depressedflattened, usually in 2 rows in each cell. - Perennials, with sword-shaped or grassy leaves, and large showy flowers; ours with creeping and more or less tuberous rootstocks. ('I $\rho$ is, the ruinbow, anciently applied to this genus on account of its bright and varied colors.)

* Stems leafy and rather tall $\left(1-3^{\circ}\right.$ high), from thickened rootstocks, often branching; tube of the perianth shorter than the divisions, which are beardless and crestless, the erect inner ones (petals) much smaller than the outer.

- Flou'ers violel-blue, variegated with green, yellow or white, and purple-veined.

1. I. versícolor, L. (LARGer BLíl: Flag.) Stem stout, angled on one side; leares sword-shaped ( $q^{\prime}$ wide); uvary obtusely triangular with the sides flat; flowers ( $2 \frac{1}{2}-3^{\prime}$ long) short-peduncled, the funnel-form tube shorter 
than the ovary; capsule oblong, turgid, with rounded angles. - Wet places, Newf. to Fla., west to Minn. and Ark. May, June.

2. I. prismática, Pursh. (Slender Blee Flag.) Stem very slender, terete; leaves narrowly linear $\left(2-3^{\prime \prime}\right.$ wide) ; flowers slender-peduncled $\left(1 \frac{1}{2}-2^{\prime}\right.$ long), the tube extremely short; ovary 3 -angled, each side 2 -grooved; capsule sharply triangular. (I. Virginica, Man.; not L.) - Marshes near the coast, Maine to N. C. June.

I. CARolividxa, Watson, resembling n. 1, but with longer laxer and greener leaves, and the very large seeds in one row in each cell, probably occurs in S. Va.

+ +- Flowers copper-colored or dull reddish-brown; petals widely spreading.

3. I. fúlva, Ker. Stem and leaves as n. 1 ; tube of the perianth cylindrical, as long as the 6-angled orary; style-branches narrow. (I. cuprea, Pursh.) - Swamps, S. Hll. and Mo. to La. and Ga. May.

* Stems low (3-6' high), from tufted and creeping slender (or here and there tuberous-thickened) rootstocks, 1-3-flowered; tube of the perianth long and slender; the violet-blue divisions nearly equal.

4. I. vérna, L. (Dwarf Iris.) Leaves linear, grass-like, rather glaucous; the thread-like tube of the perianth about the length of the divisions, which are oblong-obovate and on slender claws, the outer ones slightly hairy down the orange-yellow base, crestless; capsule obtusely triangular. - Wooded hillsides, Lancaster Co., Penn., to S. C., west to Ky. and Ala. April. - Flowers sometimes white with yellowish centre.

5. I. cristàta, Ait. (Crested Dwarf Iris.) Leaves lauceolate (3-5' long when grown); those of the spathe ovate-lanceolate, shorter than the threadlike tube of the perianth, which is $2^{\prime}$ long and much longer than the light blue obovate short-clawed divisions, the outer ones crested but beardless; capsule sharply triangular. - In the mountains from Md. to N. C.; Trumbull Co., Ohio (Ingraham); knobs of S. Ind. May. - Flowers fragrant.

6. I. lacústris, Nutt. (LAkE Dwarf IRIs.) Tube of the perianth rather shorter than the divisions (yellowish, $\frac{1}{2}-\frac{8^{\prime}}{4}$ long), dilated upuard, not exceeding the spathe; otherwise as in the last, and too near it. - Gravelly shores of Lakes Hurom and Michigan. May.

I. Pseudícorcs, L., the Yellow Iris of European marshes, with very long linear leaves and bright yellow beardless flowers, is reported as having become established in Mass. and N. Y.

\section{NEMÁSTYLIS, Nutt.}

Perianth spreading, the segments similar and nearly equal. Filaments more or less united into a tube. Style short, its slender 2-parted branches alternate with the anthers and exserter between them; stigmas minute, terminal. Capsule oblong or ovate, truncate, dehiscent at the summit. Seeds globose or angled. - Stems terete, from coated bulbs, with few plicate leaves, and few fugacious flowers from 2-bracted spathes. (Name from $\nu \hat{\eta} \mu a, a$ thread, and $\sigma \tau u \lambda i$ s, style, for the slender style-branches.)

1. N. geminiflòra, Nutt. Stem 1-2。 high; spathes 2-flowered; perianth pale blue-purple, $1-2^{\prime}$ broad, the divisions oblong-obovate; capsule obovate, $\frac{1}{2}$ long. - E. Kan. to Tex. 


\section{BEL A M C Á N D A, Adans. Веасквеrm-Lily.}

Perianth 6-parted almost to the ovary; the divisions widely and equally spreading, all nearly alike, oblong with a narrowel hase, naked. Stamenis nonadelphons muly at base; anthers oblong. Sityle club-shaped, 3-eleft, tho narrow divisions tipped with a small dilated stigma. Capsule pear-shaped; the valves at length falling away, leaving the central column covered with the globose black and fleshy-coated seeds, imitating a blackberry (whence the popular name). - l'eremial, with rootstoeks, foliage, etc., of an Iris: the branching stems $\left(3-t^{\circ}\right.$ high) hosely many-fluwered; the orange-yellow perianth mottled above with erimson-purple spots. (An last Inclian name of the species.)

B. Cunḱxsıs, Mclans. (l'ardanthus (hinensis, Ker.) - sparingly escaped from gardens, Md. to s. Ind. and Mo. (Adv. from China, etc.)

\section{SIS YRI N CHI U M, L. BLEk-EYEI, Grass.}

Perianth 6-parted; the divisions alike, spreading. Stamens monadelphous to the top. Stigmas threal-like. Capsule globular, 3-angled. Seeds globular. - Low slender perennials, with fibrons roots, grassy or lanceolate leaves, mostly branchung 2-edged or winged stems, and fugacious umbelled-clustered small flowers from a 2-leavel spathe. (A meaningless name, of Greek origin.)

1. S. angustifolium, Mill. Scape $\left(t-12^{\prime}\right.$ high) winged or wingless, simple, the sputhe solitary and terminal, its onter bract more or less elongated; Howers delicate blue, changing to purplish (rarely white), the divisions of the perianth more or less notched, bristle-pointed and ciliate; mature seeds globose, lurge ( $\frac{1}{2}$ " broad), faintly pitted or nerrly smooth. (S. Bermudiana, var. nu('ronatum, Gray, excl. descr.) - Moist meadows, etc., among grass; common everywhere. June-Aug.

2. S. ánceps, Cav. Scape $\left(6-18^{\prime}\right.$ high) usually branching and bearing 2 or more peduucled spathes; sceds more ovate, much smaller, deep]y pitted. (s. Bermuliana, var. auceps, Gruy, excl. descr.) - Similar localities ; common.

\section{Order 114. AMARYLLIDACEAE. (Amaryllis Famly.)}

Chiefly bulbous and scape-bearing herbs, not scurfy or woolly, with linear flat root-leaves, and regular (or nearly so) and perfect 6-androus flowers, the tube of the corolline 6-parterl perianth coherent with the 3-celled ovary; the lobes imbricaterl in the burl. - Anthers introrse. Style single. Capsule 3-celled, several-many-seeded. Seeds anatropous or nearly so, with a straight embryo in the axis of fleshy albumen. - An order represented in our gardens by the Narcissus, Daffodil, Snourlrop, ete., but with very few indigenous representatives in this country. Bulbs acrid. Differs from Liliacese chiefly in the inferior ovary.

* Cajısule 3-valved, Ioenliciulal : anthers versatile; perianth funnel-slapeel; glabrous.

1. Zephyranthes. Flower uaked in the throat : the tube short or noue. Bulbs coated.

2. Hymenocallis. Flower with a slender tule and narrow recurved lobes : a cup-shaped arown connecting the stamens. Bulbs conted.

3. Agave. Flower equally 6-cleft, persistent, no crown. Fleshy-leaved, not bulbous.

* Capsule indehiscent ; anthers sagittate; villous.

4. Hypoxis. Perianth 6-parted nearly flown to the ovary, persistent. Bulb solicl. 


\section{ZEPHYRÁNTHES, Herb.}

Perianth funnel-form, from a tubular base; the 6 divisions petal-like and similar, spreading above; the 6 stamens inserted in its naked throat; anthers versatile. Pod membranaceous, 3-lobed. - Leares and low scape from a coated

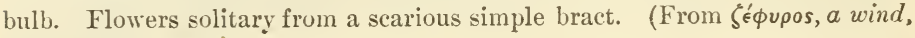

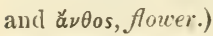

1. Z. Atamásco, Herb. (Atanasco Lily.) Leaves bright green and shining, very narrow, channelled, the margins acute; scape $6-12^{\prime}$ high; peduncle short; spathe 2-cleft at the apex; perianth white and pink, $3^{\prime}$ long; stamens and style declined.- Penn. to Va. and Fla. June.

\section{HYMENOCÁLLIS, Salisb.}

Perianth with a long and slender tube, and an equal 6-parted limb; lobes long and narrow, recurved; the throat bearing a tubular or cup-shaped corollike delicate crown, which connects the bases of the 6 exserted stamens. Anthers linear, versatile. Capsule thin, 2-3-lobed; seeds usually 2 in each cell, basal, fleshy, often like bulblets. - Scapes and leaves from a coated bulb. Flowers white, fragrant, large and showy, sessile in an umbel-like head or cluster, subtended by 2 or more scarious bracts. (Name composed of $\dot{v} \mu \eta \dot{\nu}, a$

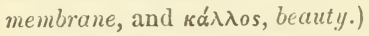

1. H. occidentàlis, Kunth. Leaves strap-shaped, glaucous, $1-1 \frac{1}{2}^{\circ}$ long; $9-18^{\prime \prime}$ broad ; scape $3-6$-flowered ; bracts narrow, 2 ' loug ; perianth-tube about $2 \frac{1}{2}-4^{\prime}$ long, the linear segments scarcely shorter; the crown $12-15^{\prime \prime}$ long, tubular below, broadly fumel-form above, the margin deltoid and entire, or 2-toothed and erose, between the white filaments, which are twice longer; anthers yellow; style green. - Marshy bauks of streams, S. Ill. to N. Ga. and Ala.- Apparently distiuct from II. lacera, Salisb. (Pancratium rotatum, Ker), of the southern coast.

\section{A G $\dot{\mathbf{A}} \mathrm{V}$ E, L. Americax Aloe.}

Perianth tubular-fumnel-form, persistent, 6-parted ; the dirisions nearly equal, narrow. Stamens 6; anthers linear, versatile. Capsule coriaceous, manyseerled. Seeds flattened. - Leares thick and fleshy, often with cartilaginous or spiny teeth, clustered at the base of the many-flowered scape, from a thick fibrous-rooted crown. (Name from ảyavń, noble, - not inappropriate as applied to A. Anericaxi, the Cexturi-plaxt.)

1. A. Virgínica, L. (FAlse Aloe.) Herbaceous; leares entire or denticulate; scape $3-6^{\circ}$ high; flowers scattered in a loose wand-like spike, greenish-yellow, fragrant, the perianth 9-12" long, its narrow tube twice longer than the erect lobes. - Dry or rocky banks, Md. and Va. to Fla., west to S. Ind., Mo., and Tex.

\section{HYPÓXIS, L. Star-Grass.}

Perianth persistent, 6-parted, spreading; the 3 outer dirisions a little herbaceous outside. Stamens 6 ; anthers sagittate, erect. Capsule crowned with the withered or closed perianth, not opening by valves. Seeds globular, with a crustaceous coat, ascending, imperfectly anatropous, the rhaphe not adherent 
quite down to the micropyle, the persistent seed-stilk thus forming a sort of lateral heak. Radicle inferior!-- Stemless small herlss, with grassy and hairy linear leaves and slender few-flowered scapes, from a solid bulb. ( $A$ n old

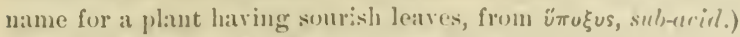

1. H. erécta, I. Leaves linear, grass-like, longer than the umbellately 1-4-flowered scape; divisions of the perianth hairy and greenish ontside, yellow within. - Meadows and open woods, N. Eng. to Fla., west to Minn., F. Kan., and 'Tex.

\section{ORDER 115. DIOSCOREACEAS. (YAM FAMHY.)}

Plants with lwining stems from large tulierous roots or knolled roolstocks, and ribberl and nelled-veined petioled leaves, small diocimus 6-androus and regular flowers, wilh the 6-cleft calyx-lilie perianth allierent in the fertile plant to the 3-celled orary. Styles 3, distinct. - Ovules 1 or 2 in each cell, anatropous. Fruit usually a membranaceous 3 -angled or winged capsule. Seeds with a minute cmbryo in hard albumen.

\section{DIOSCOREA, Plumier. YA.}

Flowers very small, in axillary panicles or racemes. Stamens 6 , at the base of the divisions of the 6-parted perianth. Capsule 3-celled, 3-winged, loculicidally 3-valverl hy splitting through the wingerl angles. Seerls 1 or $2 \mathrm{in}$ each cell, flat, with a membranaceous wing. (Dedicated to the Greek naturalist, Dioscurides.)

1. D. villosa, J. (Wrid Yam-Roor.) Herbaceous. Stems slencler, from knotty and matted rootstocks, twining over bushes; leaves mostly altemate, sometimes nearly opposite or in fours, more or less downy heneath, heartshaped, conspicuously pointed, 9-11-ribbed; flowers pale greenish-yellow, the sterile in drooping panicles, the fertile in drooping simple racemes; capsules 8-10" long. - Thickets, S. New ling. to Fla., west to Minn., Kan., and Tex.

\section{ORDER 116. IILI ICIE. (LIMY FAMIMY.)}

Herbs, or rarely woody plants, with regular and symmetrical almost aluays 6-androus flowers; the perianth not glumaccous, fice from the chiefly 3 celled ovary; the stamens one before each of its ditisions or lobes (i. e. 6, in one instance 4), with 2-celled anthers; fruil a few-many-seeded pod or berry; the small embryo enclosed in copious albumen. Seeds anatropous or amphitropous (orthotropous in Smilax). Flowers not from a spathe, except in Allimm; the outer and inner ranks of the perianth colored alike (or nearly so) and generally similar, except in Trillium.

Sumordir I. Smilaceac. Shrubby or rarely herbaceons, the petiole of the 3 - 9-nerved netted-veined leaves often tendril-bearing. Flowers (in ours) dicecious, in axillary umbels, small, with regular 6-parted deciduous perianth. Anthers apparently 1-celled. Stigmas 3, sessile. Fruit a 3-celled berry, with 1-2 pendulous orthotropous seeds in each cell. Embryo minute in horny albumen.

1. Smllax. Characters as above. 
Suborder II. Liliacea proper. Never climbing by tendrils. Very rarely diœcious. Seeds anatropous or amphitropous.

Series A. Floral bracts scarious. Stamens perigynous on the usually withering-persistent nerved perianth ; anthers introrse. Style undivided, mostly persistent. Fruit a loculicidal capsule or a berry. Leares transversely veined.

Seape from a coated bulb; fruit capsular ; leaves linear.

- Flowers umbellate; segments I-nerved; pedicels not jointed.

2. Allium. Perianth 6-parted. Capsule deeply lobed, often erested; cells 1-2-seeded. Very alliaceous.

3. Nothoscordum. Perianth 6-parted. Seeds several in each cell. Not alliaceous.

4. Androstephium. Perianth tubular-funnel-form. Filaments in the throat, united into a crown.

+ + Flowers racemose, 6-parted, the segnients 3 - several-nerved.

5. Camassia. Flowers light blue, long-racemose. Filaments filiform.

6. Ornithogalum. Flowers greenish white, sub-corymbose. Filaments dilated.

+++ Flowers densely racemose ; perianth urn-shaped, 6 toothed.

7. Muscari. Flowers deep blue, small. Stamens included.

* Stem or seape not from a bulb, sereral-flowered; eapsule many-seeded.

8. Hemerocallis. Scape from a fleshy-fibrous root. Flowers few, large, yellow, tubular-fumel-form; limb 6-parted. Stamens and long style declined. Seeds globose.

9. Yucca. Stem woody, leafy. Flowers white, campanulate, 6-parted. Stigmas sessile. seeds flat.

*** Leafy stems (scape in n. 10) from running rootstocks; fruit a berry ; leaves cordate to lanceolate (exeept 11,12 ) ; flowers white; pedicels jointer.

- Perianth gamophyllous, 6-lobed.

10. Convallaria. Leaves sheathing the scape. Flowers racemose; perianth bell-shaped.

11. Polygonatum. Stem leafy. Flowers axillary ; perianth cylinlrical.

+- Perianth-segments distinct, small, spreading, persistent.

12. Asparagus. Stems branching, the apparent leaves thread-like. Flowers axillary.

13. Smilacina. Stem simple, leafy. Flowers 6-parted, racemose or paniculate.

14. Maianthemum. Stem low, 2-leared. Flowers 4-merous, racemose.

Series B. Floral bracts none or foliaceous. Stamens hypogynous or at the base of the distinct segments of the deciduous perianth (persistent in n. 23) ; anthers extrorse or dehiscent laterally. Style undivided, decidnous (stigmas sessile and persistent in n. 23). Fruit a loculicidal capsule or a berry. Veinlets anastomosing (transverse in $1.15,17-19$ ).

* Fruit a berry ; stem or scape from a creeping rootstock ; leaves broad, alternate or radical ; flowers narrowly eampanulate.

15. Streptopus. Stem leafy. Flowers axillary, on bent pedicels. Anthers sagittate, acute ; filaments deltnid or subulate.

16. Disporum. Stem leafy. Flowers few, in terminal umbels. Anthers oblong, obtuse : filaments slender. Veinlets anastomosing.

17. Clintonia. Flowers umbellate on a scape, few or many.

* * Fruit a capsule.

- Stems leafy, from a short or ereeping rootstock; flowers few, solitary, pendulous ; capsule few-seeded.

18. Uvularia. Stem terete. Leaves perfoliate. Flowers terminal. Capsule truncate, 3-lobed.

19. Oakesia. Stem angled. Leaves sessile. Flowers opposite the leaves. Capsule acutely 3 -winged. 
+ - Stem or scale from a bulb or corm; cajsule many-seeded.

20. Erythronium. Scape from a solid bulb, with a plair of leaves. Flower solitary. Seeds angled, obovid.

21. Lilium. Stem leafy from a scaly bulb. Seeds horizontal, flattersed,

*** Fruit a berry; stem from a tuber-like rootstock, hearing 1 or 2 whorls of leaves; flowers terninal; stigmas sessile.

22. Mredeola. Leaves in 2 whorls. Flowers unbellate. Perianth-segments similar, colored, deciduous.

23. Trillium. Leaves (3) in a terminal whorl. Flower solitary; outer sepals leaf-like, persisteut.

Sinus C. Floral bracts green or greenish (rarely scarious), or none. Stamens at the base of the distinct 1 -several-nerved persistent perianth-segments; anthers small, versatile. Styles or sessile stignas distinct. Capsule mostly septicidal. Seeds with a loose testa or appendaged. Leares with transverse veinlets (except in 11.24 and 25 ).

* Stems leafy or bracteate, from a thick tubcrous rootstock; flowers racemose ; anthers 2-celled; stigmas linear.

24. Helonias. Leaves radical, oblanceolate. Flowers jerfect. Capsule broadly obovate, many-seeded.

25. Chamaelirium. Stem very leafy. Flowers diøcious. Capsule oblong, many-seeded.

26. Xerophyllum. Sten rery leafy; leaves very narrow. Flowers perfect. Capsule few-seerled.

* * Stems distichously equitant-leafy, from a creeping rootstock ; flowers on bracteolate pedicels, racemose ; anthers 2-celled ; stigmas small, terminal : seeds often appendaged.

27. Tofieldia. Bractlets 3 , verticillate. Styles short. Seeds horizontal.

23. Narthecium. Bractlet linear. Stigna slightly lobed. Seeds ascending.

* * Antiners heart- or kiùney-shaped, contluently l-celled, and peltate after opening: stigmas terminal; capsule 3-beaked by the persistent styles; seeds angled or flattened and maryined.

- Stens tall, leafy, fror a thick rootstock, pubescent above; flowers polygamous, racemose-paniculate; seeds flat, winged.

29. Melanthlum. Sepals free from the ovary, their long claws bearing the filaments.

30. Veratrum. Sepals without claws, slightly adnate to the ovary. Leaves strongly $\mathrm{n}$ :rved and plicate.

++ Root mostly bulbous ; glabrous ; flowers racemose or panicled ; seeds narrow, angled ; leaves linear.

31. Stenanthiun. Sepals lanceolate, acuminate, without glands.

32. Zygadenus. Sepals oblong to ovate, glandular toward the base.

33. Amianthium. Flowers in a dense raceme. Sepals ovate-oblong, glandless, free from the ovary. Cells of the capsule widely divergent, 1-2-seeded.

\section{S Milda X, Tourn. Greenbrier. Cat-Brier.}

Flowers diœcions in umbels or axillary peduncles, small, greenish or yellowish, regular, the perianth-segments distinct, deciduons. Filaments linear, inserted on the very base, the introrse anthers linear or oblong, fixed by the base, apparently l-celled. Ovary of fertile fluwers 3-celled (l-celled, with single stigma, in n. 11); stigmas thick and spreading, almost sessile; ovules 1 or 2 in each cell, pendulous, orthotropous ; fruit a small berry. - Shrubby or rarely herbaceous, usually climbing or supported by a pair of tendrils on the petiole of the ribbed and netted-veined simple leaves. ('The ancient Greek name, of obscure meauing.) 
§ 1. Stems herbaceous, not prickly; flowers carrion-scented; ovules 2 in each cell; leaves membranous, mucronate-tipped; berries bluish-black with a bloom.

1. S. herbàcea, I. (CArmiox-Flower.) Stem climbing, 3-15० high; leaves ovate or rounded, mostly heart-shaped or truncate at base, abruptly acute to short-acuminate, 7 -9-nerved, smooth; petioles $\frac{1}{2}-1^{\prime}$ long; peduncles elongated $\left(3-4^{\prime}\right.$ long, or sometimes eren $6-8^{\prime}$ and much longer than the leares), 20-40-flowered; seeds 6. - Moist meadows and river-banks: common, from the Atlantic to Minn., Mo., and Tex. June. Very variable. - Var. PulverVLÉxta, Gray, has the leaves more or less soft-downy beneath.

2. S. tamnifolia, Michx. Stem upright or climbing; leares mostly 5nerved, smooth, broadly ovate to lanceolate, truncate or cordate at base, abruptly acute to acuminate, some of them hastate with broad rounded lobes; peduncles longer than the petioles; berry smaller, 2-3-seeded. - Pine-barrens, N. J. to S. C.

3. S. ecirrhàta, Watson. Erect, $\frac{1}{2}-3^{\circ}$ high, without tendrils (or only the uppermost petioles tendril-bearing), glabrous; lower leaves reduced to narrow scale-like bracts, the rest thin, 5-7-nerved, broadly ovate-elliptical to roundish, acute, mostly cordate at base, $2-5^{\prime}$ long, sometimes verticillate, sparsely pubescent beneath; peduncles about equalling the petioles ( $1-2 \frac{1^{\prime}}{2}$ long), on the lower part of the stem; umbels 10-20-flowered; berry 3-seeded.-MId. to S. C., west to Mich. and Mo. May, June.

§ 2. Stems woody, often prickly; ovules solitary; glabrous throughout.

* Leaves ovate or roundish, etc., most of them rounded or heart-shaped at base, and

5-9-nerved, the three middle nerves or ribs stronger and more conspicuous.

- Peduncles shorter or scarcely longer than the petioles $\left(2-6^{\prime \prime}\right)$, flattened; leaves thickish, green both sides.

4. S. Wálteri, Pursh. Stem low, somewhat angled, prickly near the base or unarmed; leaves ovate to ovate-lanceolate or oblong, somewhat heart-shaped or rounded at base $\left(3-4^{\prime}\right.$ long) ; berries coral-red. - Pine barrens, N. J. to Fla.

5. S. rotundifòlia, L. (Commox Greexbrier. Horse-brier.) Stem armed with scattered prickles, as well as the terete branches; branchlets more or less 4-angular; leaves ovate or round-ovate, often broader than long, slightly heart-shaped, abruptly short-pointer (2-3'long); berries blue-black, with a bloom. - Moist thickets, N. Eng. to Ga., west to Minn. and Tex. Very variable, passing into rar. QUADRAXGULARIS, Gray, which has branches, and especially branchlets, 4 -angular, and is more common west.

+ + Peduncle longer than but seldom twice the length of the short petiole, flattened; leaves tardily deciduous or partly persistent; berries black, with a bloom.

6. S. glaùca, Walt. Terete branches and somewhat 4-angular branchlets armed with scattered stout prickles, or naked; leaves ovate, rarely subcordate, glaucous beneath and sometimes also above, as well as the branchlets when young (about 2' long), abruptly mucronate, the edges smooth and naked. - Dry thickets, E. Mass. to Fla., west to S. Ind., Mo., and Tex.

7. S. bona-nox, L. Branches and the angular (often square) branchlets sparsely armed with short rigid prickles; leaves varying from round-heartshaped and slightly contracted above the dilated base to fiddle-shaped and halberd-shaped or 3-lobed, green and shining both sides, cuspidate-pointed, the 
margins often somewhat bristly-ciliate or spinulose. (S. tamnoides, Mun.; probably not L.) - Thickets; Nantucket, Mass. (L. L. Dame); N. J. to Fla., west to Ill., Mu., and 'lex.

+++ Peduncle 2-4 times the length of the petiole; lenves ample (3-5' long), thin or thimish, green both sides; berries black; stem terete and branchlets nearly so.

8. S. híspida, Mulıl. Rootstock cylindrical, elengated; stem (climling high) below densely beset with long and weak blackish bristly prickles, the flow: ering branchlets mostly naked; leaves ovate and the larger heart-shaped, pointed, slightly rough-margined, membranaccous and deciduous; peduncles $1 \frac{1}{2}-2^{\prime}$ long; sepals lanceolate, alınost $3^{\prime \prime}$ long. - Moist thickets, Conn. to Va., west to Minn. and 'Tex. June.

9. S. Pseùdo-China, L. Rootstock tuberous; stems and branches unarmed, or with very few weak prickles; leaves ovate-heart-shaped, or on the branchlets ovate-ohlong, cuspidate-pointed, often rough-ciliate, lecoming firm in texture; peduncles flat $\left(2-3^{\prime}\right.$ long $)$. - Dry or sandy soil, N. J. to Fla., west to S. Ind. and Mo. July.

* * Leaves rarying from oblong-lanceolate to linear, narroued at base into a short petiole, 3-5-nerved, shining above, paler or glaucous beneath, man! without tendrils; peduncles short, seldom exceeding the petioles, terete; the umbels sometimes panicled; branches terete, unarmed.

10. S. lanceolàta, I. Leuves thinnish, rather deciduous, ovate-lanceolate or lance-oblong; stigmas 3 ; berries dull red. - Rich woods and margius of swamps, Va. to Fla., west to Ark. and Tex. June.

11. S. laurifolia, L. Leaves thick and coriaceous, evergreen, varying from oblong-lanceolate to linear $\left(2 \frac{1}{2}-5^{\prime}\right.$ long); stigmas solitary and orary 1 -celled; berries black when ripe, 1-seeded, maturing in the second year. - Pine-barrens, N. J. to Fla., west to Ark. and La. July, Aug.

\section{2. Á LII U M, L. Onion. Garlic.}

Periantl of 6 entirely colored sepals, which are distinct, or united at the very base, 1-nerved, often becoming dry and scarious and more or less persistent; the 6 filaments awl-shaped or dilated at base. Style persistent, but jointed npon the very short axis of the orary, thread-like; stigma simple. Capsule lohed. loeulicidal, 3-valved, with 1 - 2 ovoid-kidney-shaped amphitropons or campr lotropous black seeds in each cell. - Strong-scented and pungent stemless lierls ; the leaves and scape from a coated bulb; flowers in a simple umbel, some of them frequently changed to bulblets; spathe scarious, 1-2-valved. (The ancient Latin name of the Garlic.)

§ 1. Bulbs cespitose, narrowly ollong and crowning a rhizome; coats membranous.

* Teaves ( 2 or 3 ) elliptic-lunceolate; ovules solitary in cach cell.

1. A. tricóccum, גit. (WIL1) LErk.) Scape naked ( $4-12^{\prime}$ high from ('lustered pointed bulbs, 2' long), bearing an erect many-flowered umbel; leaves 5-9' long, 1-2' wide; sepals oblong (greenish white), equalling the nearly distinct filaments; capsule strongly 3-lubed. - Rich woods, W. N. Eing. to Minn. and Iowa, south in the monntains to N. C. Leaves appearing in early spring and dying before the flowers are developed. 
* Leaves linear; ovules a pair in each cell.

2. A. Schœnóprasum, L. (Chives.) Scape naked or leafy at base (6-12' high), bearing a globular capitate umbel of many rose-purple flowers; sepals lanceolate, pointed, lunger than the simple downwardly dilated filaments; leaves awl-shaped, hollow; capsule not crested. - From N. Brunswick and the Great Lakes to the Pacific. (Eu., Asia.)

3. A. cérnuum, Roth. (Writd Oxiox.) Scape naked, angular $\left(\frac{1}{2}-2^{\circ}\right.$ high), nodding at the apex, bearing a loose or drooping few-many-flowered umbel; leaces linear, flattened, sharply keeled ( $1^{\circ}$ long); sepals oblong-ovate, acute (rose-color), shorter than the slender filaments and style; capsule 6crested. - In the Alleghanies to S. C., west to Minn., Mo., Tex., and westward.

§ 2. Bulbs mostly solitary, not rhizomatous; coats often fibrous; leaves narrowly linear, flat or clannelled (terete in A. vineale).

4. A. stellàtum, Fras. Scape terete $\left(6-18^{\prime}\right.$ high $)$, slender, bearing an erect umbel; bulb-coats membranous; sepals broad, acute; stamens and style exserted; capsule prominently 6-crested. - Rocky slopes, Minn. to W. Ill. and Mo., and westward.

5. A. reticulàtum, Fraser. Scape $3-8^{\prime}$ high ; bulbs densely and coarsely fibrous-couted; spathe 2-valved; umbel rarely bulbiferous; sepals ovate- to narrowly lanceolate, thin and lax in fruit, a third longer than the stamens; capsule crested. - Sask. to Iowa and N. Mex.

6. A. Nuttàllii, Watson. Scape $4-6^{\prime}$ high, from a very fibrous-coated bull); spathe usually 3-valved; sepals usually broader, rather rigid in fruit; capsule not crested. - Central Kían. to Tex., and westward.

7. A. Canadénse, Kalm. (Wild Garlic.) Scape $1^{\circ}$ high or more; bulb-coats somewhat fibrous; umbel densely bulbiferous or few-flowered; sepals narrowly lanceolate, obtusish, equalling or exceeding the stamens; capsule not rrested. - Moist meadows, N. Eng. to Minn., sonth to the Gulf. May, June.

A. vinedle, L. (Fieli) Gakic.) Scape slender, clothed with the sheathing bases of the leaves below the middle $\left(1-3^{\circ}\right.$ high); leaves terete and hollow, slencler, channelled above; umbel often densely bulbiferous; filaments much diluted, the altemate ones cuspidate on each side of the anther. - Moist meadows and fields; a vile weed eastward. June. (Nat. from Eu.)

\section{NOTHÓSCORDUM, Kunth.}

Flowers greenish or yellowish white. Capsule obloug-oborate, somewhat lobed, obtuse, with the style obscurely jointed on the summit; cells severaloruled and -seeded. Filaments filiform, distinct, adnate at base. Bulb tunicated, not alliaceous. Otherwise as in Allium. (Name from $\nu^{\prime} \theta_{o s}$, false, and $\sigma \kappa o ́ \rho \delta เ o \nu$, garlic.)

1. N. striàtum, Kuntl. Scape $1^{\circ}$ high or less; bulb small, often bulbiferous at base; leaves narrowly linear; flowers few, on slender pedicels, the segments narrowly oblong, 4-6" long; ovules 4-7 in each cell. (Allium striatum, J $(c q$.$) - Prairies and open woods, Va. to Ind., Neb., and southward.$

\section{A N DROSTÉPHIUM, Torr.}

Perianth funnel-form, the cylindrical tube equalling the somewhat spreadiug limb or shorter; segments 1-nerved. Stamens 6, in one row upon the throat; 
the filaments united to form an erect tubular crown, with bifid lobes alternate with the oblong versatile authers. Cajsule sessile, suliglohose-triquetrons, beaked by the stout persistent style; seeds large, few to several in each coll. - Scape and linear leaves from a membranojs- or fibrous coated corm; pa:le lilac flowers umbellate; pedicels not jointed; iuvolucral bracts several. (Name

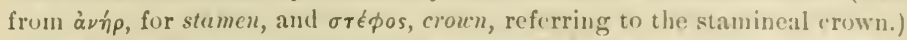

1. A. violàceum, Torr. Scape $2-6^{\prime}$ highl ; flowers $8-12^{\prime \prime}$ long or more, usually exceeling the stont pedicels, the tube nearly as long as the limb ; crown scarcely shorter than the limb. - Kan. to 'l'ex.

\section{C A M Á S S I A, Lindl.}

l'erianth of 6 colored (blue or purple) spreading sepals, $3-7$-nerved, slightly irregular, mostly deciduous ; the 6 filiform filaments at their base. Style threadlike, the base persistent. C'apsule oblong or obovate, 3-anglecl, loculicidal, 3valved, with several black roundish seeds in eacli cell. - Scape and linear leaves from a coated bulb; the flowers in a simple raceme, mostly bracted, on jointed pedicels. (From the riative Indian name quamush or cumass.)

1. C. Fràseri, Torr. (Easterx Cayass. WirJ Mracistir.) Scape $\mathrm{l}^{\circ}$ high or more; leaves keeled; raceme elongated; loracts longer than the pedicels; sepals pale blue, 3-nerved, $4-7^{\prime \prime}$ long; capsule acutely triangularglobose. (Scilla Fraseri, Gr(\%) - Rich ground, W. I'emn. to Minn. and E. Kan., and in the mountains to Ga.

\section{O R N I thó G A L U M, Tourn. Star-of-Bethlehem.}

Perianth of 6 colored (white) spreading $3-7$-nerved sepals. Filaments 6 , flattened-awl-shaped. Style 3-sided; stigma 3-angled. Capsule membranous, roundish-angular, witl few dark and roundish seeds in each cell, loculicidal. - Scape and linear channelled leaves from a coated bulb. Flowers corrmbed, bracted; pedicels not jointed. (In ancient whimsical name from ö $p \nu$ s, a bird, and ráxa, milli.)

O. LMBELLATUM, L. Seape 4-9' high ; flowers 5-8, on long and spreading pedicels; sepals green in the milllle on the outside. - Escaped fron gardens. (Nat. from Eu.)

O. Nìtaxs, L. S'cape $1^{\circ}$ high or more; flowers 5 or 6 , large ( $l^{\prime}$ long), nodding on very short pedicels; filaments very broad. - Rarely escaped from garuens; l'enn. (Adv, from Eu.)

\section{M U S C À R I, Tourn. Grape-IYYacixtri.}

Terianth globular or oroid, minutely 6 tootherl (blue). Stamens 6 , included ; anthers short, introrse. Style slort. (ansule loculicilal, with 2 lilack angular seeds in each cell. - Leaves and scape (in carly spring) from a coated lunlb; the small flowers in a dense raceme, sonmtimes misk scented (whence the name).

M. Botrroìns, Mill. Leaves linear, 3- $t^{\prime \prime}$ hroal: flowers globular (1 -

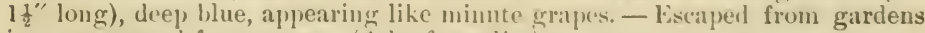
inco copses and fence-rows. (Adv. from kin.)

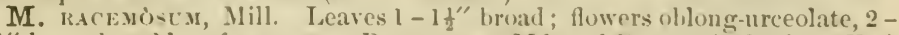

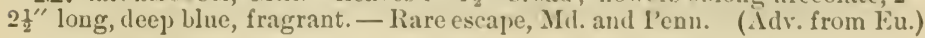

\section{HEMEROCÁLLIS, L. DAr-LILY.}

Terianth funnel-form, lily-like; the short tuhe enclising the ovary, the spreading limb 6-parted; the 6 stamens inserted on its throat. Inthers as in 
Lilium, but introrse. Filaments and style long and thread like, declined and ascending; stigma simple. Capsule (at first rather fleshy) 3-angled, loculicidally 3-ralved, with several black spherical seeds in each cell. - Showy perennials, with fleshy-fibrous roots; the long and linear keeled leaves 2-ranked at the hase of the tall scapes, which bear at the summit sereral bracted and large yellow flowers; these collapse and decay after expanding for a single

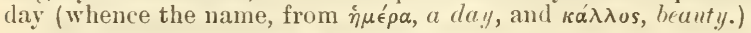

H. Fúlya, L. (Commox DaY-Lily.) Inner divisions (petals) of the tawny orange periantl wavy and obtuse. - Roadsides, escaped from gardens. (Adv. from Eu.)

\section{Y Ú C C A, L. Bear-Grass. Spanish Bayonet.}

Perianth of 6 petal-like (white or greenish) oval or oblong and acute flat sepals, withering-persistent, the 3 inner broader, longer than the 6 stamens. Stignias 3, sessile. Capsule oblong, somewhat 6-sided, 3-celled, or imperfectly 6.celled by a partition from the back, fleshy, at length loculicidally 3-valved from the apex. Seeds rery many in each cell, flattened. - Stems woody, either very short or rising into thick and columnar palm-like trunks, bearing persistent rigid linear or sword-shaped leaves, and an often ample compound panicle or branched raceme of showy flowers. (The native Haytian name for the root of the Cassava-plant.)

1. Y. angustifollia, Pursh. Caudex none or very short; leaves straight very stiff and pungent, $\frac{1}{2}-2^{\circ}$ long by $1-6^{\prime \prime}$ wide, filiferous on the margin ; raceme mostly simple, nearly sessile $\left(1-4^{\circ}\right.$ long); flowers $1 \frac{1}{2}-2 \frac{1}{2}^{\prime}$ wide; stigmas green, shorter than the ovary; capsule 6-sided ( $3^{\prime}$ long); seeds 5-6" broad - Dak. to Iowa, Kan., and N. Mex. May, June.

2. Y. filamentosa, L. (Adau's Neenle.) Caudex $1^{\circ}$ high or less, from a running rootstock; leaves numerous, coriaceous, more or less tapering to a short point, rough on the back, $1 \frac{1}{2}-2^{\circ}$ long by $1-3^{\prime}$ wide, filiferous on the margin ; panicle p pramidul, densely flowered, on a stout bracteate scape, 4$9^{\circ}$ high; flowers large; stigmas pale, elongated; capsule $1_{\frac{1}{2}}^{\prime}$ long; seeds $3^{\prime \prime}$ broud. - Near the coast, Md. to Fla. and La. July. Very variable.

\section{CON V ALLÀ R A, L. Lily of the Valley.}

Perianth bell-shaped (white), 6-lobed, deciduous; the lobes recurved. Stamens 6, included, inserted on the base of the perianth; anthers introrse. Ovary 3-celled, tapering into a stout style; stigma triangular. Ovules 4-6 in each cell. Berry few-seeded (red). - A low perennial herb, glabrous, stemless, with slender running rootstocks, sending up from a scaly-sheathing bud 2 oblong leares, with their long sheathing petioles enrolled one within the other so as to appear like a stalk, and an angled scape bearing a one-sided raceme of pretty and sweet-scented nodding flowers. (Altered from Lilium convallium, the popular name.)

1. C. majàlis, L. - High mountains of Va. to S. C. Apparently identical with the European Lily of the VAlley of the gardens.

\section{POIYGON T T M, Tourn. Solonon's SeAL.}

Perianth cylindrical-oblong, 6-lobed at the summit; the 6 stamens inserted on or above the middle of the tube, included; anthers introrse. Ovary 3-celled. 
with $2-6$ ovules in each cell; style slender, decilnous by a joint; stigma obtuse or capitate, olscurely 3-lohed. Berry glubular, black or lilue; the colls 1-2-seeded. - Perenuial herlss, with simple erert or curving strus, from creeping thick and knotted rootstocks, naked below, above hearing nearly sessile or half-clasping nerved leaves, and axillary nodding greenish fluwers;

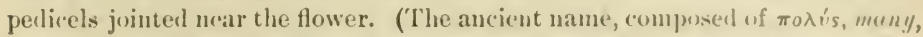
and góvv, knre, alluding to the numerons joints of the rootstuck and ste.m.) Ours are alternate-leaved species, the stem terete or scarcely angled when fresh.

1. P. biflorum, Ell. (Siarler Solomox's SEal.) Glibrons, except the ovate-oblong or lance-oblong nearly sessile leares, which are commonly minutely pubescent as well as pale or ylancous underneath; stem slender $\left(1-3^{\circ}\right.$ high); peduncles 1-3. but mostly 2-florered; perianth 4-6" long; filuments pupillose-ronghened, inserted towarl the summit of the perianth. - Wooded hillsiles, N. Brunswick to Fla., west to Minn., E. Kan., and 'Tex.

2. P. giganteum, Dietrich. (Gre.s S.) Gilabrous thronghont; stem stont and mostly tall $\left(2-7^{\circ}\right.$ high), terete; leaves ovate, partly claspring $\left(3-8^{\prime}\right.$ long), or the upper oblong and nearly sessile, many-nerved; pednucles severul(2-8-) flowered, jointed below the flower; flowers 5-9" long; filaments smooth and nuked, or nearly so, inserted on the midlle of the tube. - Meaduws and river-banks, N. Eng. to Va., west to the Rocky Mts. June.

\section{A S P Á R A G S, 'Touru. Asparagus.}

Perianth 6-partel, sprealling above; the 6 stamens on its hase; anthers introrse. Style short; stigma 3-lobed. Berry spherical, 3-celled; the cells 2-seeded. - Perennials, with much-branched stems from thick and matted routstocks, and small grecuish-yellow axillary flowers on jointed pedicels. The narrow, commonly threarl-like, so-called leaves are really l,ranchlets, acting as leaves, chnstered in the axils of little scales which are the true leaves. (The ancient Greek name.)

A. officinalis, I. (Garnes Aspirafis.) Herhaceous, tall, bushybranched; leaves thread-like. - A frequent escape from gardens. June. (Adv. from Eu.)

\section{S M I LA C I N A, Desf. FAlse Solomox's SFat.}

Perianth 6-parted, sprealing, withering-persisteut (white). Stamens 6, inserted at the hase of the divisions; filanents slender, anthers short, iutrorse. Ovary 3-celled, with 2 orules in each cell ; style short and thick stigma obscurely 3-lubed. Berry globular, 1-2-seeded. - Perenuial herhs, with simple stems from creeping or thickish rootstocks, alternate nervel mostly sessile leaves, and white, sometimes fragrant flowers in a terminal and simple or compound raceme. (Name a dimiuutive of Smilax, to which, however, these plauts bear little resemblance.)

* Flowers on very short pedicels in a terminal racemose panicle: stamens exceeding the smull ( $1^{\prime \prime}$ lony) segments; ocules collateral; rootstock stout, Heshy.

1. S. racemósa, Desf. (Fatse Sikisarb.) Minutely downy $\left(1-3^{\circ}\right.$ high); leaves numerous, oblong or oval-lanceolate, taper-jointed, ciliate, abruptly somewhat petioled; berries pale red, speckled with purple, aromatic. Muist copses, N. Brnnswick to S. C., west to Minu., E. Kan. and Ark. 
* * Flowers larger (2-3"long), on solitary pedicels in a simple few-flowered raceme; stamens included; ovules not collateral; rootstock rather slender.

2. S. stellàta, Desf. Plant $\left(1^{\circ}\right.$ high or less) nearly glabrous, or the 7 12 oblong-lanceolute leares minutely downy beneath when young, slightly clasping; raceme sessile or nearly so; berries blackish. - Moist banks, Lab. to N. J., west to E. Kan., Minn., and westward. (Eu.)

3. S. trifòlia, Desf. Glabrous, dwarf (2-6' high) ; leaves 3 (sometimes 2 or 4), oblong, tapering to a sheathing base; raceme peduncled; berries red. — Cold bogs, Lab. to N. Eng., west to Mich. and Min. (Sib.)

\section{M A I Á N THEM U M, Wigg.}

Perianth 4-parted, with as many stamens. Ovary 2-celled ; stigma 2-lobed. Otherwise as in Smilacina. - Flowers solitary or fascicled, in a simple raceme upon a low 2-3-leaved stem. Leaves ovate- to lanceolate-cordate. (Name from Hecius, May, and å $\nu \theta \epsilon \mu \nu \nu$, a flower.)

1. M. Canadénse, Desf. Pubescent or glabrous $\left(3-5^{\prime}\right.$ high); leaves lanceolate to ovate, cordate at base with a very narrow sinus, sessile or very shortly petioled; perianth-segments l" long. (Smilacina bifolia, var. Canadensis, Gray.) - Moist woods, Lab. to N. C., west to Minn. and Iowa. May.

\section{STRÉt P U S, Nichx. Twisted-Stalk.}

Perianth recurved-spreading from a bell-slaped base, decidnous; the 6 distinct sepals lanceulate, acute, the 3 inner keeled. Anthers arrow-shaped, extrorse, fixed near the base to the short flattened filaments, tapering above to a slender entire or 2-cleft point. Ovary with many ovules in each cell; style and sometimes the stigmas one. Berry red, roundish-ovoid, many-seeded. IJerbs, with rather stout stems from a creeping rootstock, forking and livergent branches, ovate and taper-pointed romuled-clasping membranaceous leaves, and small (extra-) axillary flowers, either solitary or in pairs, on slender thread-like peduncles, which are abruptly bent or contorted near the middle (whence the name, from $\sigma \tau \rho \in \pi \tau$ ós, trisled, and $\pi$ ov̂s, foot or stalk).

1. S. amplexifolius, DC. Stem $2-3^{\circ}$ high, glabrous; leaves very smooth, glaucous undermeath, strongly clasping; flower greenish-white (4-6" long) on a long abruptly bent peduncle; anthers tapering to a slender entire point; stigma entire, truncate. - Cold moist woods, N. Eng. to N. Miun., south to Ohio, Penn., and in the mountains to N. C. June. (Eu.)

2. S. roseus, Michx. Lower leures green both sides, finely ciliate, and the branches sparingly beset with short bristly hairs; flower rose-purple (3-4" long), more than half the length of the slightly bent peduncle; anthers 2horned; stigmu 3-cleft. - Cold damp woods, N. Eng. to N. Minn., and south in the mountains to Ga. May.

\section{DIS POR U M, Salisb.}

Perianth narrowly bell-shaped, the 6 sepals lanceolate or linear, deciduous. Filaments thread-like, much longer than the linear-oblong bluut anthers, which are fixed by a point above the base and extrorse. Ovary with 2 ovules (in our species) suspended from the summit of each cell; style one; stigmas 
short, reenrved-spreading, or sometimes united into one! Berry ovoid or oblong, pointed, 3-6-seefled, red. - Downy low herbs, with crecping rootstocks, erect stems sparingly brancheil above, with clusely sussile ovate thin and transversely veined leaves, and greenish-yellow dronping flowers, on slender terminal peduneles, solitary or few in an umbel. (Name from sis, double, and $\sigma \pi o \rho \alpha$, seed, in allusion to the 2 ovules in each (ell.)

1. D. lanuginosum, Benth. \& Ilook. Leaves ovate-ohlong, taperpointed, rounded or slightly heart-shaped at base, elosely sessile, downy beneath; flowers solitary or in pairs; sepals linear-lanceolate, taper-pointed ( $\frac{1}{2}^{\prime}$ long), soon spreading, twice the length of the stamens, greenish; style smooth; stigmas 3. (l'rosartes lanuginosil, Don.) - Rich woods, western N. Y. to Va. aud Ga., west to Ky. and Tenn. May.

\section{CLI N T ÒN I, Raf.}

Perianth of 6 separate sepals, bell-shaped, lily-like, deciduous; the 6 stamelis inserted at their base. Filaments long and thread-like; anthers linear or oblong, extrorsely fixed by a point above the base, the cells opening down the margins. Ovary ovoid-oblong, 2-3-celled ; style long; stigmas 2 or 3 , or in ours united into one. Berry few - many-seeded. - short-stemmed perennials, with slender creeping rootstocks, bearing a naked peduncle sheathed at the base by the stalks of $2-4$ large oblong or oval ciliate leaves; flowers rather large, umbelled, rarely single. (Dedicated to De Witt Clinton.)

1. C. boreàlis, Raf. Scape and leaves 5-8' long; umbel 3-6-flouered; perianth greenish-yellow, somewhat downy outside $\left(3-4^{\prime \prime}\right.$ long); berry ovoid, blne; ovules 20 or more. - Cold moist wools, Lab. to N. C., west to Minn.

2. C. umbellata, Torr. Flowers half the size of the last, white, speckled with green or purplish dots; nmbel many-flonered; berry globular, black; ovules 2 in each cell. - Rich woorls, in the Alleghanies from N. Y. to Ga.

\section{U V U L ÀRIA, L. Bellwort.}

Perianth narrowly hell-shapel, lily-like, decilluous; the 6 distinct sepals s:)atulate-lanceolate, acuminate, obtusely gibbous at base, witlı a leep honeybearing groove within bordered on each side by a callus-like ridge. Stamens much shorier, barely adherent to their base; authers linear, much longer than the filaments, adnate and cxtrorse, but the long narrow cells opening laterally. Style deeply 3-cleft; the divisions stigmatic along the inner side. Capsule truncate, coriaceous, 3-lobed, loculicilal at the summit. Seeds few in each cell, ubovoid, with a thin white aril. - Stems rather low, terete, from a short rootstock with fleshy roots, naked or scaly at base, forking above, bearing oblong perfoliate tlat and membranaceus leaves with smooth margins, and yellowish drooping flowers, in spring, solitary on terminal peduncles. (Name "from the flowers hanging like the uvula, or palate.")

1. U. perfoliàta, L. Glaucous throughout, $\frac{1}{2}-1 \frac{1}{2}$ high, with $1-3$ leaves below the fork; leures glalirous, oblong- to ovate-lanceolate, acute; perianthsegments granulur-pubescent within (8-16" long); stumens shorter than the styles : tip of the connective acuminate; cells of the eapsule with 2 corsal rilges and 2-beaked at the apex. - Rich woods, N. Eng. to Dak., and southwarl. 
2. U. grandiflòra, Smith. Yellowish-green, not glaucous; stem naked or with a single leaf below the fork; leaves whitish-pubescent beneath, usually somewhat acuminate; perianth-segments smooth within or nearly so (12-18" long); stamens exceeding the styles, obtusely tipped; capsule obtusely lobed. (U. Hava, Smith.) - Rich woods, Canada to Ga., west to Minn. and Mo.

\section{OAKESIA, Watson.}

Flowers resembling those of Uvularia, but the segments obtuse or acutish, carinately gibbous and without ridges within. Capsule membranous, elliptical, acutish at each end or shortly stipitate, triquetrous aud acutely winged, very tardily dehiscent. Seeds globose, with a very tumid spongy rhaphe. Stem acutely angled, from a slender creeping rootstock, with sessile clasping leaves scabrous on the margin, and 1 or 2 flowers terminal on slender peduncles but soon appearing opposite to the leaves by the growth of the branches. (1)edicated to ITilliam Oukes.)

1. O. sessilifolia, Watson. Leares lance-oblong, acute at each end, pale, glaucous beneath, sessile or partly clasping; sepals $7-12^{\prime \prime}$ long; anthers ohtuse; capsule short-stipitate, $6-10$ " long. (Crularia sessilifolia, L.) - Low wools, N. Brunswick to Fla., west to Minn., Neb. and Ark.

2. O. pubérula, Watson. Slightly puberulent; leaves bright green both silles and shining, oval, mostly rounded at base, with rongher edges; styles separate to near the base, not exceeding the acute anthers; capsule not stipitate, 10-12" long. (Uvularia puberula, Michx.) - Mountains, Va. to S. C.

\section{ERYTHR Ò N U M, L. Dog's-tooth Violet.}

Perianth lily-like, of 6 distinct lanceolate sepals, recurved or spreading abore, deciduous, the 3 inner usually with a callous tooth on each side of the erect lase, and a groove in the middle. Filaments 6, awl-shaped; anthers oblong-linear, continuing erect. Style elongated. Capsule oborate, contracted at hase, 3-ralved, loculicidal. Seeds rather numerous, oroid, with a loose membranaceous tip. - Nearly stemless herbs, with two smooth and shining flat leaves tapering into petioles and sheathing the base of the commonly one-flowered scape, rising from a deep solid-scaly bulb. Flowers rather large, nodding, in spring. (The Greek name for the purple-flowered European species, from é $\rho v \theta \rho o ́ s$, red.)

1. E. Americànum, Ker. (Yellow Adder's-toxgce.) Scape 6- $\xi^{\prime}$ high; leaves elliptical-lanceolate, pale green, mottled with purplish and whitish anil conmonly minntely dotted; perianth light yellow, often spotted near the base $\left(10-20^{\prime \prime}\right.$ long); style club-shaped; stigmas united. - Rich ground, N. Brunswick t, Fla., west to Minn. and Ark.

2. E. álbidum, Nutt. (Wите Dog's-тооти Violet.) Leaves elliptical-lanceolate, less or not at all spotted; perianth pinkish-uchite; inner divisions toothless; style more slender except at the apex, bearing 3 short spreading stigmus. - Rich ground, N. Y. to N. J., west to Minn. and Kan.

3. E. propúllans, Gray. Offshoot arising from the stem, near the middle: leaves smaller and more acuminate; flouers bright rose-colm, yellowish at base (6" long) ; style slender ; stigmas united. - In rich soil, Minn. and Ont. 


\section{LÍ I I U M, I。 L L}

Perianth funnel-form or bell-shaped, colored, of 6 distinct sepals, spreading or recurved alouve, with a honey-bearing furrow at the latse, deciduous; the 6 stamens somewhat allhering to their bases. Anthers linear, extrorsely attached near the mildle to the tapering apex of the long filament, which is at first included, at length versitile; the cells dehiscent by a lateral or slightly introrse line. Style elongated, somewhat ('lub-shaped; stigma 3-lobed. Capsule oblong, containing numerous flat and horizontal (depressed) soft-coatenl seeds densely packed in 2 rows in each cell. Bulbs scaly, producing simpli: stems, with numerous alternate-scattered or whorled narrow sessile leaves, and from one to several large and showy flowers; in summer. (The classical Latin name, from the Greek $\lambda \in l \rho \iota 0 \nu$.

* Flourers erect, the sepals narroued below into claws; bulbs not rhizomatous.

1. L. Philadélphicum, L. (Wild Oraxge-Red Lily. Wood Litr.) Stem 2-3० high; leares linear-lanceolute, whorled or scattered ; flowers $\left(2-4^{\prime}\right.$ long) 1-3, open-bell-shaped, reddish-orange spotted with purplish inside; the lanceolate sepals not recurved at the summit; bulb of thick fleshy jointed scales. - Dry or sandy ground, N. Eng. to N. C., west to Minn. and Mo.

2. L. Catesbiei, Walt. (Soctneks Red Licy.) Leaves linear-lanceolate, scattered ; flower solitary, open-bell-shaped, the long-clawed sepals wavy on the margin and recurved at the summit, scarlet, spotted with dark purple and yellow inside; bulb-scales thin, narrow and leaf-bearing. - Pine-barrens, N. C. to Fla., west to Ky. and Mo.

$$
\text { * * Flowers nodding, the sepals sessile; bulls rhizomatons. }
$$

3. L. supérbum, I. ('Turk's-cap Lily.) Stem $3-7^{\circ}$ high; loxer leaves uhorled, lanceolate, pointed, 3-nerved, smooth; flowers (3'long) often many $(3-20$ or 40$)$ in a pyramidal raceme; sepals strongly revolute, bright orange, with numerous dark purple spots inside.-Rich low grounds, $\mathbf{N}$. Brunswick to Ga., west to Minn. and Mo.

4. L. Canadénse, I. (WILI) Yellow Liry.) Stem $2-7^{\circ}$ high ; leares remotely uhorled, lanceolate, strongly 3 -nerved, the margins and nerves rough ; flowers few $\left(2-3^{\prime}\right.$ long), long-peduncled, oblong-bell-shaped, the sepals reclirved-spreading above, yellow or orange, usually spotted with brown. - Moist meadows and bogs, N. Brunswick to Ga., west to Minn. and Mo.

5. L. Gràyi, Watson. Stems $2-3^{\circ}$ high ; leaves in whorls of $4-8$, lanceolate, acute or slightly acuminate, smooth; flowers 1 or 2, nearly horizontal, the sepals (11-2.j' long) but little spreading abore the rather broad buse. rather abruptly acute, deep reddish orange, thickly spotted within. - I'eaks of ()tter, Va., and southward in the mountains to N. C.

L. Tignivin, Ker. (Tiger Litr.) Tall, pubseent above; leaves scattered, narrowly lanceolate, lark green, 5-7-nerved, the upper axils bulbiferous; fowers large, rescmbling those of L. superbum. - $\mathrm{An}$ escape from

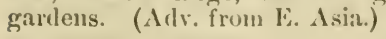

\section{M E D EOLA, Gronor. Intan Crovmer-Root.}

Perianth recurved, the 3 sepals and 3 petals oblong and alike (pale greenishyellow), decilnous. Stamens 6 ; anthers shorter than the sleniler filaments, oblong, extrorsely attached above the base, but the line of dehiscence of the 
closely contiguous parallel cells lateral or slightly introrse. Stigmas, or styles, stigmatic down the upper side, recurved-diverging from the globose ovary, long and thread-form, deciluous. Berry globose (dark purple), 3-celled, fewseedled. - A perennial herb, with a simple slender stem $\left(1-3^{\circ}\right.$ high, clothed with flocculent and (leciduous wool), rising from a horizontal and tuberous white rootstock (which has the taste of cucumber), bearing near the middle a whorl of 5-9 obovate-lanceolate and pointed, sessile, lightly parallel-ribbed and netted-veiny, thin leaves; also another of 3 (rarely 4 or 5 ) much smaller ovate ones at the top, subtending a sessile umbel of small recurved flowers. (Named after the sorceress 1 edea, for its supposed great medicinal virtues.)

1. M. Virginiàna, L. - Rich damp woods, N. Eng. to Minn., Ind., and southward. June.

\section{TRÍILIU M, L. Wake Robin. Birthroot.}

Sepals 3, lanceolate, spreading, herbaceous, persistent. Petals 3, larger, withering in age. Stamens 6 ; anthers linear, on short filaments, adnate, usually introrse; the cells opening down the margins. Stigmas sessile, awlshaped or slender, spreading or recurved above, persistent, stigmatic down the inner side. Ovary 3-6-angled. Berry ovate, usually 6-angled or -winged, 3-celled (purple or red). Seels orate, horizontal, several in each cell. - Low perennial herbs, with a stout and simple stem rising from a short and pramorse tuber-like rootstock, naked, bearing at the summit a whorl of 3 ample, commonly broadly orate, more or less ribbed but netted-reined leaves, and a terminal large flower; in spring. (Name from triplum, triple; all the parts being in threes.) - Monstrosities are not rare with the calyx and sometimes petals changed to leaves, or the parts of the flower increased in number.

* Ovary and fruit 6-angled and more or less uinged.

- Flower sessile; the very broad connective produced beyond the anther-cells.

1. T. séssile, L. Leaves sessile, orate or rhomboidal, acute, often blotched or spotted; sepals spreading; scssile petals erect-spreading, narrowly lanceolate or oblanceulate, dark and dull purple, varying to greenish; fruit globose, $6^{\prime \prime}$ long. - Moist wools, Penn. to Fla., west to Minn. and Ark.

2. T. recurvàtum, Beck. Leaves contracted at the base into a petiole, ovate, oblong, or obovate; sepals reflexed; petals pointed, the base narroued into a cla $x$, oblong-lanceolate to -ovate, dark purple; fruit orate, strongly winged above, 9" long. - Rich woods, Ohio and Ind. to Minn. and Ark.

- + Flower pedicelled; connective narrow, not produced; leaves subsessile.

+ Pedicel longer than the flower; filament shorter than the anther.

3. T. eréctum, L. Leaves very broadly rhombic $\left(2 \frac{1}{2}-6^{\prime}\right.$ wide), shortly acuminate; pedicel (1-3' Jung) usually more or less inclined or declinate; petals orute to lanceolate $\left(9-18^{\prime \prime} \mathrm{long}\right)$, brown-purple or often white or greenish or pinkish; stamens equalling or exceeding the stout distinct spreading or recurved stigmas; fruit ovate, 1' long, reddish. - Rich woods, N. Scotia to N. C., west to Minn. and Mo. Flowers ill-scented.

4. T. grandiflòum, Salisb. Leaves less broadly rhombic-orate $\left(1 \frac{1}{2}-4^{\prime}\right.$ wide); pedicel erect or ascending ; petals oblanceolate, often broadly so ( $1 \frac{1}{2}-2 \frac{1}{2}$ long), white turning rose-color or marked with green; stamens with stout 
filaments (persistently green about the fruit) and anthers, exceeding the very sifnder erect or suberect und someuhat colierent stigmens; fruit globose, $\frac{1}{2}-\mathrm{I}^{\prime}$ long. - Rich woods, Vt. to N. C., west to Miun. and Mo.

+ Pedicel short, recurved or strongly declinate; jiluments slender, ulout equalling the anther.

5. T. cérnuurn, L. Leares very hroally rhombic-orate $\left(2-4^{\prime}\right.$ hroal); petals white or pink, ovate- to oblong-lanceolate $\left(6-12^{\prime \prime}\right.$ long), wavy, recurversprealing; stamens with short anthers, shcrter than the stout recurved distinct stigmas; fruit ovate. - Moist woods, N. Engg. to Minn., south to Gia. and Mo.

* Oeary and fruit 3-obed or angled, not winged; filuments slender, about equalling the anther's: pedicel erect or inclined; leates petiolute.

6. T. nivale, Riddell. (1)wanf W'nte T.) Small (2-4' high); leares oral or orate, obtuse $\left(1-2^{\prime}\right.$ long $)$; petuls oblong, obtuse $(6-15)^{\prime \prime}$ long), white, scarcely wary, spreading from an erect base, equalling the peduncle; styles long and slender; fruit depressed glohose, with 3 rounded lobes, $3-4^{\prime \prime}$ long. - Rich woods, W. Penn. and Kiy. to Minn. and Iowa.

7. T. erythrocárpum, Michx. (Panted T.) Leares orate, taperpointed; petuls orcute or orcl-lanceolute, pointed, wu'y, widely spreading, uhite painted with purple stripes at the base, shorter than the peduncle; fruit broatovate, obtuse, $7-9^{\prime \prime}$ long. - Cold damp woods and logs, N. Brunswick to Ga.* west to Wise. and Mo.

\section{H E L Ò N I A S, L.}

Flowers perfect. Perianth of 6 spatulate-oblong purple sepals, persistent, several-nerved, glandless, turning green, shorter than the threal-like filaments. Anthers 2-celled, roundish-oval, blue, extrorse. Styles revolute, stigmatic down the inner side, deciduons. Cansule obeordately 3-lohed, loculicidally 3 -ralved; the valves divergently 2-lobed. Sceels many in each cell, linear, with a tapering appendage at both ends. $-\Lambda$ smooth perennial, with many oblongspatulate or oblanceolate evergreen flat leaves, from a tuberous rootstock, producing in early spring a stout hollow sparsely bracteate scape $\left(1-2^{\circ}\right.$ high $)$, sheathed with broad bracts at the base, and terminated by a simple and short dense raceme. Braets obsolete; pelicels shorter than the flowers. (Name probably from "̈̇os, a su'(ump, the place of growth.)

1. H. bullàta, L. - Wet places, Penn. and N. J. to Vá, rare and local.

\section{CHA M 仺LÍRI U M, Willd. DeriL's-Bit.}

Flowers cliacions. P'erianth of 6 s platulate-linear (white) spreading 1-nersed? sepals, withering-persistent. Filaments and (white) anthers, as in Ilelenias; fertile flowers with rulimentary stamens. Styles linear-(luh-shaped, stigmatic along the inner side. Capsule oroil-oblong, not lobed, of a thin texture, loculicidally 3 -valved from the apex, many-seederl. Seeds linear-oblong, winged at each end. - Smooth herb, with a wand-like stem from a (bitter) thick and abrupt tuberous rontstock, terminated by a long wand-like spiked raceme $\left(t-12^{\prime}\right.$ long) of small hractless flowers; fertile plant more leafy than the staminate. Leaves flat, lanceolate, the lowest spatulate, tapering into a 
petiole. (Name formed of $\chi a \mu a l$, on the ground, and $\lambda \in i \rho t o \nu, l i l y$, the genus having been founded on a dwarf undereloped specimen.)

1. C. Caroliniànum, Willd. (Blazixg-Star.) Stem 1-40 high. (C. luteum, Gray.) - Low grounds, N. Eng. to Ga., west to Neb. and Ark. June.

\section{XEROPHÝLLUM, Michx.}

Flowers perfect. Perianth widely spreading; sepals petal-like (white), oval, distinct, without glands or claws, 5-7-nerved, at length withering, about the length of the awl-shaped filaments. Anthers 2-celled, short, extrorse. Styles thread-like, stigmatic down the inner side, persistent. Capsule globular, 3-lobed, obtuse (small), loculicidal; the valves bearing the partitions. Seeds 2 in each cell, collateral, 3-angled, not margined. - Ilerb with the stem simple, $1-4^{\circ}$ high, from a thick tuberous rootstock, bearing a simple dense bracteate raceme of showy flowers, and thickly beset with needle-shaped leaves, the upper reluced to bristle-like bracts; those from the root very many in a dense tuft, reclined, a foot long or more, $1^{\prime \prime}$ wide below, rough on the margin, re-

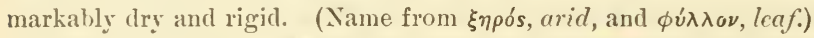

1. X. setifòlium, Michx. Stem $1-4^{\circ}$ high. (X. asphodeloides, $N u t t$.) - Pine-barrens, N. J. to Ga. June.

\section{TOFI E L D I A, Hudson. FAlse Asphodel.}

Flowers perfect, usually with a little 3-bracted involucre underneath. Peri anth more or less spreading, persistent; the sepals (white or greenish) concave, oblong or obovate, without claws, 3-nerved. Filaments awl-shaped; anthers short, innate or somewhat introrse, 2-celled. Styles awl-shaped; stigmas terminal. Capsule 3-angular, 3-partible or septicidal; cells manyseeded. Seeds oblong, horizontal. - Slender perennials, mostly tufted, with short or creeping rhizomes, and simple stems leafy only at the base, bearing small flowers in a close raceme or spike. Leares 2-ranked, equitant, linear, grass-like. (Named for Mr. Tofield, an English botanist of the last century.)

* Glabrous; pedicels solitary, in a short raceme or head; seeds not appendaged.

1. T. palústris, Hudson. Scape leafless or nearly so $\left(2-6^{\prime}\right.$ high), slen. der, bearing a globular or oblong head or short raceme of whitish flowers; leares tufted, $\frac{1}{2}-1 \frac{1}{2}^{\prime}$ long. - L. Superior, and northward. (Eu.)

* * Stem and inflorescence pubescent; pedicels fascicled in threes; seeds candate.

2. T. glutinòsa, Willd. Stem $\left(6-16^{\prime}\right.$ high) and pedicels very glutinous with dark glands; leaves broadly linear, short; perianth not becoming rigid; capsule thin ; seeds with a contorted tail at each end. - Moist grounds, Maine to Minn., and northward; also south in the Alleghanies. June.

3. T. pùbens, $\Lambda$ it. Stem $\left(1-3^{\circ}\right.$ high) and pedicels roughened with minute glunds; leaves longer and narrower; perianth rigid about the firm capsule; seeds with a short white appendage at each end.-Pine-barrens, N. J. to Fla. and Ala. July.

\section{N A R T H E C I U M, Moehring. Bog-Asphodel.}

Sepals 6, linear-lanceolate, yellowish, persistent. Filaments 6, woolly ; anthers linear, intror'se. Capsule cylindrical-oblong, attenuate upward and bearing 
the slightly lobed sessile stigma, loculicidal, many-seeded. Sceds ascending, appendaged at each end with a long bristle-form tail. - Routstuck creeping, bearing linear equitant leaves, and a simple stem or scape, terminated by a simple dense bracteate raceme; peclicels bearing a linear bractlet. (Name an

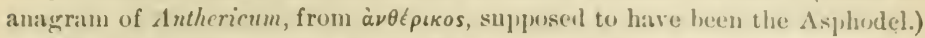

1. N. Americànum, lier. Stem $1^{\circ}$ high or more; leaves l" wille, 7 -9-nerved; raceme dense ( 1 -2' long); periantl-segments narrowly linear $\left(2-2 t^{\prime \prime}\right.$ long), searcely exceeding the stamens. (N. ussifragum, var. Ameri; (anum, Gruy.) - Siandy bogs, pine-barrens of N. J. June, July.

\section{M ELÁ N TH I U M, Limu.}

Flowers monacionsly polyganums. l'erianth of 6 separate and free wirlely spreading somewhat heart-shaped or oblong and halheril shapeel or oblanceolate sepals, raised on slender claws, cream-colorerl or grrenish, the hase markerl with 2 approximate or confluent glands, or glandless, turning greenish brown aud persistent. Filaments shorter than the sepals, alhering to their claws of ten to near the summit, persistent. Anthers heart-shaped or kidney-shaped, confluently l-celled, shieli-shaped after opening, extrorse. Stỵles 3, awl-shaped, diverging, tipped with simple stigmas. Capsule ovoid-conical, 3-loberl, of :3 inflated membranaceous carpels united in the axis, separating when ripe, and splitting down the inner edge, several-seeded. Seeds flat, broadly winged. Stems tall and leafy, from a thick routstock, roughish-downy above, as well as the open and ample prramidal panicle (composed chiefly of simple racemes), the terminal part mostly fertile. Leaves linear to oblanceolate or oval, nut plaiterl. (Name composed of $\mu \epsilon$ inas, black, and ă $\nu \theta o s$, flower, from the darker (color which the persistent periauth assumes after hlossuming.)

* Sepals with a conspicuous doulle gland at the summit of the clau.

1. M. Virgínicum, I. (Bixch-Fuweli.) Stem 3-50 higlı, leafy, rather slender; leaves linear $\left(4-10^{\prime \prime}\right.$ wille); sepals flat, ovate to ublong or

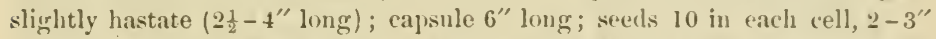
long. - Wet mealows, N. Eng. to N. C., west to Minn. and Tex.

2. M. latifolium, Desrouss. Leares more oblanceulate, often 2' broad; sepals nudulate $\left(2-3^{\prime \prime}\right.$ long), the very narrow claw nearly equalling the orbicular or ovate blade; capsule $6-8^{\prime \prime}$ lung; styles more slender; seculs $4-8$ in each cell, 3-4" long. (M. racemosum, Michx.) - W. Conn. to s. C.

\section{* Sepals oblanceolate, without glanrls.}

3. M. parviflòum, Watson. Stem ratler slenler $\left(2-5^{\circ}\right.$ light $)$, sparingly leafy, naked above; leaves oval to oblunceolate (2-4' wide), on long petioles ; sepals 2-3" long, oblanceolate or spatulate, those of the sterile flowers on claws; stamens very short ; capsule 6" long ; seeds $4-6$ in each cell, $4^{\prime \prime}$ long. (Veratrum parviflorum, Mir/h.) - lu the Alleghanies, Va. to S. C.

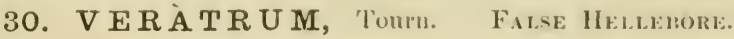

Fluwers monceiously polygamous. J'erianth of 6 sprealing aurl separate ohovate-oblong (greenish or brownish) sepals, more or less contracted at the base (but not clawed), nearly free from the ovary, not gland-bearing. Filaments free from the sepals and shorter than they, recurving. Anthers, pistils, 
fruit, etc., near.y as in Melanthium. - Somewhat pubescen pereunials, with simple stems from a thickened base producing coarse fibrous roots (very poisonous), 3-ranked, plaited and strongly veined leaves, and racemed-panicled dull or dingy flowers; in summer. (Name from vere, truly, and ater, black.)

1. V. víride, Ait. (American White Hellebore. Indax Poke.) Stem stout, very leafy to the top $\left(2-\tau^{\circ}\right.$ high $)$; leaves broadly oval, pointed, sheath-clasping; panicle pyramidal, the dense spike-like racemes spreading; perianth yellowish-green, moderately spreading, the segments ciliate-sermlate; ovary glabrous; capsule many-seeded. - Swamps and low grounds, common.

2. V. Woódii, Robbins. Stem slender, sparingly leafy $\left(2-5^{\circ}\right.$ ligh $)$; leaves oblanceolate, only the lowest sheathing; panicle very narrow; perianth greenishpurple, with entive segments; ovary tomentose, soon glabrate ; capsule few-seeded. - Woods and hilly barrens, S. Ind. to Mo.

\section{S T E N Á N T H U M, Graỵ.}

Flowers polygamous. Perianth spreadiug; the sepals narrowly lanceolate, tapering to a point from the broader base, where they are united and coherent with the base of the ovary, not gland-bearing, persistent, much longer than the short stamens. Anthers, capsules, etc, nearly as in Veratrum. Seeds nearly wingless. - Smooth, with a wand-like leafy stem from a bulbous base, long and grass-like conduplicate-keeled leaves, and numerous small flowers in compound racemes, forming a long terminal panicle; in summer. (Name composed of $\sigma \tau \in \nu o ́ s, n a r r o u$, and ă $\nu$ os, flower, from the slender sepals and panicles.)

1. S. angustifolium, Gray. Stem leafy $\left(3-4^{\circ} \mathrm{high}\right)$, very slender; leaves $2-3^{\prime \prime}$ broad; panicle elongated, nearly simple, very open, with slender flexuous branches; flowers nearly sessile or the fertile on short pedicels; sepals linearlanceolate (white), 2 - $3^{\prime \prime}$ long; capsule strongly reflexed, narrowly oblong-ovate, with spreading beaks. - In the Alleghanies from Va. to S. C.

2. S. robústum, Watson. Resembling the last; stem stont, leafy, erect $\left(3-5^{\circ}\right.$ high $)$; leaves $4-10^{\prime \prime}$ lroad ; panicle or raceme often $2^{\circ}$ long, frequently compound with numerous slender branches; sepals (white or green) $3-4^{\prime \prime}$ long; capsule erect, ovate, with recurved beaks. - Penn. to S. C., Ohio and 'Tenn.

\section{Z Y GADi N U S, Michx.}

Flowers perfect or polygamous. Perianth withering-persistent, spreading; the petal-like oblong or ovate sepals 1-2-glandular near the more or less narrowed but not unguiculate base, which is either free, or united and coherent with the base of the orary. Stamens free from the sepals and about their length. Anthers, styles, and capsule nearly as in Melanthium. Seeds angled, ravely at all margined. - Very smooth and somewhat glancous perennials, with simple stems from creeping rootstocks or coated bulbs, linear leaves, and rather large panicled greenish-white flowers; in summer. (Name composed of surós, a yoke, and $a \dot{\delta} \eta v$, a glund, the glands being sometimes in pairs.)

* Glands on the perianth conspicuous.

- Rootstock creeping; glands 2, orbicular, above the broad claw.

1. Z. glabérrimus, Michx. Stems $1-3^{\circ}$ high; leaves grass-like, channelled, conspicuously nerved, elongated, tapering to a point ; panicle pyranidal, 
many-flowered; flowers perfect ; sepals nearly free ( $f^{\prime}$ long), ovate, becomiug lance-ovate, with a short claw. - Grassy low grounds, Va. to Flit. and Ala.

+ + Root bulbous; glands covering the buse of the sepuls.

2. Z. élegans, Pursh. Stem $1-3^{\circ}$ high; leaves flat, carinate; raceme simple or sparingly branched and few-flowered; bracts ovate-lanceolate; base of the perianth coherent with the base of the ovary, the thin ovate or obovate sepals marked with a large obcordate gland, the inner abruptly contracted to a broad claw. (Z. glaucus, Nutt.) - N. Eng. to N. 11l., Minn., and westward.

3. Z. Nuttallii, Gray. Like the last; raceme rather ilensely tlowered, with narrow bracts; perianth free; sepals with an ill-defined gland at base, not at all clawed; seeds larger (3" long). - Kan. to 'Tex. and Col.

* Glands of the perianth obscure; perianth small, rotate; bulb somewhat fibrons.

4. Z. leimanthoides, Gray. Stem 1-40 high, slender; leaves narrowly linear ; flowers small ( $t^{\prime \prime}$ in diameter) and numerous, in a few crowded panicled racemes; only a yellowish spot on the contracted base of the divisions of the free perianth. - Low grounds, piue-barrens of N. J., to Ga.

\section{A M I Á N T H U M, Gray. FLY-Poisox.}

Flowers perfect. l'erianth widely spreading; the distinct and free petal-like (white) sepals oval or oborate, without claws or glands, persistent. Filaments capillary, equalling or exceeding the periantl. Anthers, ('ajsules, ete, nearly as in Melanthium. Styles thread-like. Seeds wingless, oblong or linear, with a loose coat, 1-4 in eacn cell. - Glabrous, with simple stems from a bulbous base or eoated bulb, scape-like, few-leaved, terminated by a simple dense raceme of hand some flowers, turning greenish with age. Leaves linear, keeled, grass-like.

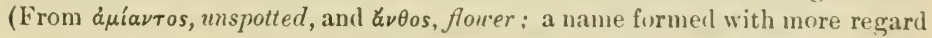
to euphony than to good construction, alluding to the glandless perianth.)

1. A. muscætóxicum, Gray. (Fur-Porsox.) Leaces brondly limear, elongated, obtuse ( $\frac{1}{2}-\mathrm{I}^{\prime}$ wicle) ; raceme simple ; capsule abruptly 3 -horned ; seeds oblong, with a fleshy red coat. - Open woods, N. J. to Fla., west to Ky. aud Ark. June, July.

\section{Order 117. PONTEDERIÀ CIAs. (Pickerel-Wead Family.)}

Aquatic herbs, with perfect more or less irregular. fourers from a spathe : the petal-like 6-merous perianth free from the 3-celled orary; the 3 or 6 mostly unequal or dissimilar stamens inserted in its throat. - Perianth with the 6 divisions colored alike, imlricated in 2 rows in the but, the whole together sometimes revolute-coiled after flowering, then withering away, or the base thickened-persistent and enclosing the fruit. Inthers introrse. Ovules anatropons. Style 1 ; stigma 3-lobed or 6-toothed. Fruit a perfectly or incompletely 3-celled many-seceled capsule, or a 1-celled 1-seeded utricle. Embryo slender, in floury albumen.

1. Pontederia. Sjuike many-flowered. Perianth 2-lipped, its fleshy persistent båse en. clusing the 1-seeded utricle. Stamens 6.

2. Heteranthera. Spathe 1-few-tlowered. Perianth salver-shaped. Stamens 3. Caj)sule mans-seeded. 


\section{PONTEDERIA， L. Pickerel-ween.}

Perianth funnel-form, 2-lipped; the 3 upper divisions united to form the 3 lobed upper lip; the 3 lower spreading, aud their claws, which form the lower part of the curving tube, more or less separate or separable to the base; after flowering the tube is revolute-coiled from the apex downward, and its fleshythickened persistent base encloses the fruit. Stamens 6 ; the 3 anterior longexserted ; the 3 posterior (often sterile or imperfect) with very short filaments, unequally inserted lower down; anthers versatile, oval, blne. Ovary 3-celled; two of the cells empty, the other with a single suspended ovule. Utricle 1celled, filled with the single seed. - Stout herbs, growing in shallow water, with thick creeping rootstocks, producing erect long-petioled mostly heartshaped leaves, and a I-leaved stem, bearing a spike of violet-blue ephemeral flowers. Root-leaves with a sheathing stipule within the petiole. (Dedicated to Pontedera, Professor at Padua at the beginning of the last century.)

1. P. cordàta, L. Leaves arrow-heart-shaped, blunt, or sometimes triangular-elongated and tapering and scarcely cordate (var. AxGcstifólis, 'Torr.) ; spike dense, from a spathe-like bract; upper lobe of perianth marked with a pair of yellow spots (rarely all white) ; calyx-tube in fruit crested with 6 toothed rirges. - N. Scotia to Fla., west to Minn. and Tex. July-Sept.

\section{HETERA THERA, Ruiz \& Pav. Med-Plaxtain.}

Perianth salver-form with a slenter tube; the limb somewhat equally 6 parted, ephemeral. Stamens 3, in the throat, usually unequal; anthers erect. Capsule l-celled or incompletely 3-celled by intrusion of the placentæ, manyseeded. - Creeping, floating or submerged low herbs, in mud or shallow water, with a $\mathbf{l}$-few-flowered spathe bursting from the sheathing side or base of a

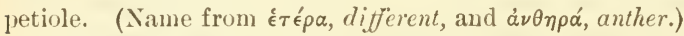

* Stamens unequal; 2 posterior filaments with ovate yellow anthers; the other longer, with a larger oblong or sugittute greenish anther; capsule incompletely 3-celled; leaves rounded, long-petioled; creeping or floating plants.

1. H. renifórmis, Ruiz \& Pav. Leaves round-kidney-shaped to cordate and acute; spathe 3-5-flowered ; flowers white or pale blue. - Conn. to N. J., west to Ill. and E. Kan., and sonthward. (S. Am.)

2. H. limòsa, Vahl. Leaves oblong or lance-oblong, obtuse at both ends ; spathe 1-flowered; flowers larger, blue. - Va. to Mo. and La. (S. Am.)

* * Stamens alike, with sagittate anthers; capsule 1-celled, with 3 parietal placente; leaves linear, translucent, sessile; submerged grass-like herbs, with only the flowers reaching the surface.

3. H. gramínea, Vahl. The slender branching stems clothed with leaves and bearing a terminal l-flowered spathe (becoming lateral); Howers small, pale yellow, with a very long thread-like tube. (Schollera graminifolia, Willd.) - N. Eng. to N. C., west to Minn. and E. Kan.

\section{Order 118. XYRIDA Cie. (Yellow-eyed-grass Family.)}

Rush-like herbs, with equitant leaves sheathing the base of a naked scape, which is terminated by a head of perfect 3-androns flowers, with extrorse 
anthers, glumaceous calyx, and a regular colored corolla; the 3-valed mostly 1-celled capsule containing several or many orthotropous sceds with a minute cmbryo at the apex of fleshy albumen.

\section{XỲRIS, Gronov. Yellow-eyei Grass.}

Flowers single in the axils of coriaceous scale-like bracts, which are denscly imbrieated in at head. Sepals 3 ; the 2 lateral glume-like, boat-shaped or kecled and persistent; the anterior oue larger and membranaceous, enwrapping the corollat in the bud and decidnuts with it. l'etals 3, with claws, which cohere more or less. Fertile stamens 3, with linear anthers, inserterl on the claws of the petals, alternating with 3 sterile filaments, which are cleft and in our spe(cies plumose or bearded at the apex. Style 3-cleft. Capsule oblong, free, 1cellel, with 3 parietal more or less projecting placenta, 3-valved, many-seederl. - Flowers yellow, producerl all summer. Ours apparently all peremnials.

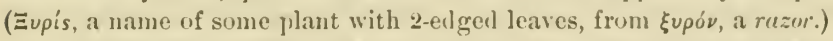

1. X. flexuosa, Muhl. Scape slender (10-16' highi), barely flattened at the summit, often from a bulbous hase, very smooth, much longer than the narrowly linear leaves, both commonly twisted with age; heat roundish-ovid $\left(3-4^{\prime \prime}\right.$ long $)$; luteral sepals oblong-lanceolate, fimely ciliute-scrarious on the nurrow wingless keel, usually with a minute bearded tuft at the apex, shorter than the bract. - Sandy or peaty bogs, Mass. to Fla., west to Minm. and Mo.

Var. pusilla, Gray. Small and very slender, seldom twisted, 2-9' high, the base not bulbous; head 2-3" long. - White MIts. to Penn., west to L. Superior.

2. X. tórta, Smith. Scape terete, with one sharp elge, slenler, $9-20^{\prime}$ high, from a lark bulbous base, and with the linear-filiform rigid leaves becoming spirally twisted; hearl ovoid, becoming spindle-shaped, or oblong and acute $\left(5-9^{\prime \prime}\right.$ long); sepals exceeding the bract; lateral sepals winged on the keel and fringed above the middle. - l'ine barrens, in dry sand, N. J. to Fla., Tex. and Ark.

3. X. Caroliniàna, Walt. Scape flattish, 1-angled below, 2-edged at the summit, smouth, $\frac{1}{2}-2^{\circ}$ high, the base harlly bulbous; leaves linear-su'ordshaped, flut, $2-4^{\prime \prime}$ broad; heal glubular-ovoil ( $5-7^{\prime \prime}$ long); luteral sepals ob. scurely lacerate-finged above on the winged keel, rather shorter than the bract. - Sandy swamps, near the coast, Mass. to Fla.

4. X. fimbriàta, Ell. Sicape somewhat anglell, 2-elged ahove, rough ( $2^{\circ}$ high), rather longer than the linear-sword-shaped or strap-shaped leaves, the base not bulhons; heal oblong-ovate $\left(6-10^{\prime \prime}\right.$ long) ; luteral sepals lauceolate-linear, neurly ticice the length of the bract, above the middle conspiruously fringed on the u'ing-margined ked, und even plumose at the' summit. - l'ine-barrens, N. J. to Fla. and Tex.

\section{Oroer 119. Mayichat. (Mayaci Famby.)}

Moss-like aquatic plants, denscly leafy, with narracly-linear sessile pellucid leaces, axillary naked peduncles terminated by a solitur?! perfert 3anilrous flower, herbaceous calyx, white corolla, and a 3-valied 1-celled sereral-sceded capsule. 


\section{M A Y À C A, Aublet.}

The only genus. Perianth persistent, of 3 herbaceous lanceolate sepals, and 3 obovate petals. Stamens alternate with the petals. Ovary with 3 parietal few-ovuled placentæ; style filiform; stigma simple. - Creeping or floating in shallow water; the leaves 1-nerved, entire, notched at the apex; the peduncle solitary, sheathed at base. (An aboriginal name.)

1. M. Michaúxii, Schott \& Endl. Peduncles not much exceeding the leaves, nodding in fruit. - Va. to Fla. and Tex.

\section{Order 120. COMHELINȦCEA. (Spiderwort Family.)}

Herls, with filrous or sometimes thickened roots, jointed and often branching leafy stems, and chiefly perfect and 6-androus, often irregular flowers, with the perianth fice from the 2-3-celled ovary, and having a distinct calyx and corolla; viz., 3 persistent commonly herbaceous sepals, and 3 petals, ephemeral, decaying or leciduous. Stamens hypogyncus, some of them often sterile; anthers with 2 separated cells. Style 1; stigma undivided. Capsule 2-3-celled, 2-3-valved, loculicidal, 3-severalseeded. Seeds orthotropous. Embryo small, pulley-shaped, partly sunk in a shallow depression at the apex of the albumen. Leaves ovate, lanceolate or linear, parallel-veined, flat, sheathed at base; the uppermost often dissimilar and forming a kind of spathe. - Chiefly tropical.

1. Commelina. Cyme sessile within a cordate or connate bract (spathe). Petals unequal. Perfect stamens 3 ; filaments naked.

2. Tradescantia. Bracts leaf-like or small and scarious. Petals equal. Perfect stamens 6 ; filaments bearled.

\section{CO M M ELİ N A, Dill. I).YY-FLOWER.}

Flowers irregular. Sepals somewhat colored, unequal; the 2 lateral partly united by their contiguous margins. Two lateral petals rounded or kidneyshaped, on long claws, the odd one smaller. Stamens unequal, 3 of them fertile, one of which is bent inward; 3 of them sterile and smaller, with imperfect cross-shaped anthers; filaments naked. Capsule 3-celled, two of the cells 2seeded, the other 1-seeded or abortive. - Stems branching, often procumbent and rooting at the joints. Leaves contracterl at base into sheathing petioles; the floral one heart-shaped and clasping, folled together or hooded, forming a spathe enclosing the flowers, which expand for a single morning and are recurved on their pedicel before and afterwards. Petals blue. Flowering all summer. Ours all with perennial roots, or propagating by striking root from the joints. (Dedicated to the early Dutch botanists.$I$. and $G$. Commelin.)

* Ventral cells 2-ovuled (usually 2-seeded), the dorsal 1-ovuled.

1. C. nudiflòra, I. Slender and creeping, glabrous; leaves lanceolate, small ( $1-2^{\prime}$ long); spathe cordate, acute, with margins not united; seeds reticulated. (C. Cayennensis, Richard.) - Alluvial banks, Del. to Fla., west to Ind., Mo. and Tex.

2. C. hirtélla, Vahl. Stont, erect $\left(2-4^{\circ}\right.$ high) ; leaves large, lanceolate, the sheaths brown-bearded; spathes crowded, with margins united; seeds smooth. 
(C. erecta, Gray, Man., not L.) - River-banks, I'enn. to Fla., west to Mo. and Tex.

* Cells 1-oruled, 1-sceded; sceds smooth; spathe encullate; roots sub tuberous.

3. C. erécta, I. Slender, often low; leaves linear; cells all dehusreut.Penn. to Fla.

4. C. Virgínica, L. Slenler, usually tall; leaves lanceolute to linear; dorsal cell indehiscent, scubrous. - Bamp rich woods and banks, southern $\mathrm{X}$. Y. to Fla., west to Mich., Iowa, aud Mo.

\section{T R A D E SCÁ N T I A, L. SPIDerwort.}

Flowers regular. Sepals herbacens. I'etals all alike, ovate, sessile. Stamens all fertile; filaments bearilerl. Capsule 2-3-cellerl, the cells 1- 2-seederl. - Y'eremuials. Stems unciliginous, mostly upright, nearly simple, leafy. Leaves keeled. Flowers epliemeral, in unbelled clusters, axillary and terminal, prorlucel through the summer; floral leaves nearly like the others. (Named for the el ler Trutcscant, garlener to Charles the First of England.) * Umbels terminal or sometimes lateral, sessile, subtended by 1 or 2 leaf-like bracts; leaves lincur to narrouly lanceolate: flowers blue.

1. T. Virgínica, I. (Commox SPmerwort.) Roots fleshy-fibrous; smooth or ouly slightly villous, more or less glaucons, often tall and slender and with linear leaves, ratluer rarely with 1 or 2 long lateral peduncles, hracts usually a pair. - Rich ground, N.Y. to Fla., west to Minn., Tex., and the Rocky Mts. Very variahle. - Var. vilıòs, Watson. Often dwarf, more or less villous throughout as well as pubescent. Mississippi valley and Gulf States. - Var. Flextòs., Watson. Stout and dark green, with large linearlanceolate pubescent leaves, the stem usually flexuous, and with several short lateral branclies or sessile axillary heals. ('T flexuosa, Ruf.) - Ohio to Ky. and Ga. T. pilosa, Lchm., is an intermediate form.

* Eimbel pedunculate, subtended by small subscarious biacts; flouers small, rose-rulor.

2. T. ròsea, Vent. Small, slender $\left(6-10^{\prime}\right.$ high $)$, smooth, erect from a running rootstock; leaves very narrowly linear, grass-like. - Sandy woods, Md. to Fla., west to Ky. and Mo.

\section{Order 121. JUNCiCEA. (Resh Famir.)}

Grass-like or rush-like herls, with small flowers, a regular and hypogynous: persistent perianth of 6 sumilar glumaceous sepals, 6 or ruvely 3 stamens uilh 2-celled anthers, a single short style, 3 filifurm hairy stigmas, and an ovary either 3-celled or 1-celled with 3 parietal plarentce, forming a loculicidal 3-ralverl capsule. Seeds anatropous, with a minute cmbrvo enclosed at the base of the fleshy albumen. - Flowers liliaceous in structure, but sedrelike in aspect and texture.

1. Juncus. Capsule 3-celled (or imperfectly so), many-seeded. Plants never hairy, in moist ground or water.

2. Luzula. Capsule 1-celled, 3-seeded. Plants often hairy, in dry ground. 


\section{J Ú N C U S, Tourn. Rush. Bog-Rush.}

Capsule many-seeded, 3-celled, or 1-celled by the placentæ not reaching the axis. Stamens when 3 opposite the 3 outer sepals. - Chiefly perennials, and in wet soil or water, with pithy or hollow and simple (rarely branching) stems, and panicled or clustered small (greenish or brownish) flowers, chiefly in summer. Plant never hairy. (The classical name, from jungo, to join, alluding to the use of the stems for bands.)

1. Stems leafless and scrpe-like, from matted running rootstocks, sheathed at base; the sheaths sometimes bearing terete knotless leaves like the scape; flowers in sessile apparently lateral panicles, the involucral leaf being similar to and continuing the scape. - Juxcus proper.

* Flowers solitary on the pedicels or ultimate ramifications of the panicle. + Sheaths at base of the stem leafless.

+ Stamens 3.

1. J. effùsus, L. (Commox or Soft Rush.) Scape soft and pliant (2$4^{\circ}$ high); inner sheaths awned; panicle diffusely much branched, many-flowered ; flowers small ( $1 \frac{1}{4}$ " long), greenish; sepals lanceolate, very acute, as long as the narrow triangular-obovate retuse and pointless greenish-brown capsule; anthers as long as the filaments; style very short; seeds small (about $\frac{1^{\prime \prime}}{4}$ long), with short pale points. - Marshy ground, very common. (Eu.) - Var. conglomerdtus, Engelm. Scape more distinctly striate; panicle closely crowded; capsule short-pointed. In sphagnous swamps.

+ Stamens 6.

2. J. filifórmis, L. Scape very slender $\left(1-2^{\circ}\right.$ highl $)$, pliant; panicle fewflowered, almost simple; flowers $1 \frac{1}{2}{ }^{\prime \prime}$ long; sepals lanceolate, the inner a little shorter and less acnte, longer than the broally ovate obtuse but mucronate greenish capsule; anthers shorter than the filaments; style very short; seed (less than $\frac{1}{3}$ "long) short-pointed at both ends, indistinctly reticulated. $-\mathrm{N}$. Eng. to Mich., Neb., and northward. (Eu.)

3. J. Smíthii, Engelm. Scape rather slender $\left(2-3^{\circ}\right.$ high $)$; panicle few Howered, nearly simple; flowers brown ( $1 \frac{1{ }^{\prime \prime}}{4}$ long); onter sepals lanceolate, acute, the inner a little shorter, obtusish, shorter than the broadly ovate rather triangular acute deep chestnnt-brown capsule; anthers as long as the filaments ; style short; seeds large ( $3^{\prime \prime}$ long or more), obtuse, short-appendaged at both ends, many-ribbed and reticulated. - Sphagnous swamps, on Broad Mt. and in Lebanon Co., Penn.

4. J. Bálticus, Dethard, var. littoràlis, Engelm. Scape rigid $\left(2-3^{\circ}\right.$ high); panicle loose; flowers larger ( $2^{\prime \prime}$ long), chestnut-brown with green; sepals orate-lanceolate, the outer sharp-pointed, the inner obtusish, as long as the elliptical rather triangular obtuse and mucronate deep brown capsule; anthers much longer than the broad filaments; style about the length of the ovary; seerls rather large ( $\frac{1}{2}$ "long or more), nearly obtuse, delicately ribbed and cross.lined. - Sandy shores, Newf. to Mass., west to Penn., along the Great Lakes, and westward. - Var. Moxtàxus, Engelm. Sepals nearly equal; anthers 4 times longer than the filament; capsule ovate-pyramidal, angled, beaked ; seeds smaller, narrower, apiculate, - Minn., west and northward. 


\section{+ + Innermost sheaths leaf-bearing; stamrns 6.}

5. J. setàceus, Rostkovius. Seape slender ( $1-3^{\circ}$ high) ; panicle lonse, rather few-flowered; flowers greenish (2" longr); sepals lanceolate, sharppointed, especially the 3 shining exterior ones, spreading in fruit, as long as the nearly globose beak-pointed greenish or light-brown ajsule; anthers as long as the filaments ; style conspicuons ; seeds ( $\frac{1}{3}$ "long) almost globose, ribbed and (ross-lined. - Va. to Fla., west to Mo. and La.

* * Flowers in clusters, 6-androus; innermost sheuths at base of stem leaf-bearim,

6. J. Rœmeriànus, Schcele. S(an)e stuut and rigid $\left(2-3^{\circ}\right.$ high), its apex as well as the leaves pungent; paude compound, open and spreading, brown; 3-6 greenish or light-brown Howers (1 1 $2^{\prime \prime}$ long) in a cluster; outer sepals lauceolate, sharp-pointed, longer than the obtusish inner ones, as long as the clliptical rather triangular obtuse mucronate l,rown cajsule; anthers much longer than the broad filaments; styles shorter than the ovary; seeds $\left(\frac{1}{3}\right.$ "long) oval, obtuse, very delicately ribbed. - Brackish marshes, N. J. to Fla. and Tex.

7. J. marítimus, I. Resembling the last, but with a rigid contracted green panicle, an ovary attenuated into a style of nearly its own length, a greenish acute capsule which usually exceeds the acute sepals, and seeds with distinct tails and stronger rils. - Known in this eountry only from Coney Island, N. Y., where it is apparently indigenous. (Eu.)

\$ 2. Stems simple (rarely branched), leafy at base or throughout; leaves flat, or somewhat terete or setaceous and channelled, never knotted; panicle or head terminal. - GrassY-LEA VED JuXCi.

* Flowers in close heads (produced in late summer).

- Leaves thread-like, hollow; stamens 6; seeds few, large and caudate; the single head (sometimes 2) 1-4-flowered.

8. J. stýgius, I. Stems slender $\left(6-16^{\prime}\right.$ high) from slencler branching rootstocks, 1 -3-leaved below, naked above; heals 1 or rarely 2 , of 3 -4-flowers, about the leugth of the sheathing scarions awl-pointed bract; flowers pale and reddish (21-3" long); sejals lanceolate, the inner ohtusish, $\frac{8}{4}$ the length of the oblong acuminate capsule, as long as the slencler stanens; filaments many times longer than the ohlong anthers; recurved stigmas shorter than the style; seeds oblong, with a very louse coat prolonged at both ends (1 $\frac{1}{2}{ }^{\prime \prime}$ long). - l'eatbogs, Newf. to northern N. Y., West to Mich. and N. Minn. (Eu.)

9. J. trífidus, L. Stems densely tufterl from matted creeping rootstocks, erect $\left(5-10^{\prime}\right.$ high), sheatherl and mostly leatless at base, 2-3-leaved at the summit, the upper threal-like leaves subtending the sessile heal ; flowers brown ( $1 \frac{1}{2}-2^{\prime \prime}$ long) ; sepals orate-lauceolite, acute, equalling or rather shorter than the ovate heak-pointed derep brown capsule; anthers much longer than the filaments; seeds few, oblong, angled ( $I^{\prime \prime}$ long), short-tailed. - Alpine summits of X. Eng. and N. Y., and far northward; also in N. J. (Eu.)

+ + Lenves flat and grass-like; stamens 3 ; stems flattened, simple, leafy.

10. J. rèpens, Michx. Stems ascending $\left(4-6^{\prime}\right.$ high) from a fibrous an nual root, at length creeping or fluating; leaves short, linear, those of the stem nearly opposite and fascicled; heads few in a loose leafy panicle, 3-12-flow. 
ered; flowers green ( $3^{\prime \prime}$ long); sepals rigid, lance-subulate, slender-pointed, the 3 outer as long as the linear triangular obtuse capsule, the inner much longer; stamens as long as the outer sepals; filaments many times longer than the oblong anthers; seeds small ( $\frac{1}{5}$ "long), obovate, slightly pointed, very delicately ribbed and cross-lined. - Miry banks, Md. to Fla. and La.

11. J. marginàtus, Rostk. Stem erect, from a bulbous and stoloniferous base ( $1-3^{\circ}$ high); leaves long-linear; heads 3-8-flowered, panicled; flowers purplish with green ( $1 \frac{1}{2}{ }^{\prime \prime}$ long) ; sepals oblong, the 3 outer acute and slightly awned, the inner longer, mostly obtuse, as long as the almost globular scarcely mucronate capsule; stamens exceeding the outer sepals; purple anthers shorter than the filaments; style very short; seeds $\left(\frac{1}{4}-\frac{1}{3}{ }^{\prime \prime} \operatorname{long}\right)$ slender, pointed at both ends and strongly ribbed. - Moist sandy places, S. New Eng. to Fla., west to Mich., Mo., and Tex. - Var. Paucicapitatus, Engelm., has few large 815-flowered heads; and var. Bıflòrus, Engelm., has numerous small 2-3flowered heads in much-branched panicles.

* Flowers solitary, panicled; stamens 6 .

+ Stems slender, simple, tufted, leafy below; root perennial ( $f$. early in summer). +- Seeds tail-pointed at both ends.

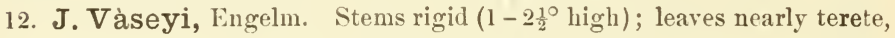
very slightly channelled on the inner side; panicle longer than the involucral leaf, loose; flowers few, often one-sided, greenish or light brown $\left(2^{\prime \prime}\right.$ long or more); sepals lanceolate, acute, appressed, shorter than the oblong and retuse green-brown capsule; anthers as long as the filaments; style very short; seeds slender ( $\frac{1}{2}-\frac{2}{3}$ " long), closely ribber. - N. Maine (Pringie); Mich. to Iowa and westward.

13. J. Greénii, ()akes \& Tuckerm. Stems rigid ( $1-2^{\circ}$ high); leaves nearly terete, very deeply channelled (almost involute) on the inner side; panicle usually much shorter than the principal erect involucral leaf, dense, the numerous flowers often one-sider ( $1 \frac{8^{\prime \prime}}{4}$ long); sepals lanceolate, acute, light greenish-brown, appressed, shorter than the ovoid-oblong obtuse greenish-brown capsule; anthers as long as the filaments ; style very short; seeds oroid $\left(\frac{1}{3}-\frac{2}{5}\right.$ " long), ribbed and delicately cross-lined. - Sandy coast of N. Eng, N. Y., and N. J., and abont the head of Lake Michigan.

$$
\rightarrow+\text { Seeds merely apiculate at both ends. }
$$

14. J. ténuis, Willd. Stem wiry $\left(9-18^{\prime}\right.$ high) ; leaves flat or channelled; panicle shorter than the involucral leaves, loose, or rarely crowded; flowers green (2" long or more); sepals lanceulate, very acute, spreading in fruit, longer than the ovoid retuse scarcely pointed green capsule; anthers nearly equal to the filaments ; style very short; seeds small (about $\frac{1}{t}$ " long), delicately ribbed and cross-lined. - Fields and roadsides, very common. (Eu.) - Var. secúvous, Engelm. ; flowers smaller, secund along the incurved branches. N. Eng. to Penn. and Del. - Var. Cosgéstus, Engelm. ; branches contracted into a hearl and the flowers darker-colored. Minn. and westward.

15. J. dichótomus, Ell. Stems rigid $\left(1 \frac{1}{2}-2^{\circ}\right.$ high) from a tumid base; leaves filiform, nearly terete, slightly grooved on the inner side; panicle loose, often with 1-sided forked branches, mostly longer than the involucral leaf; flowers greenish (2" long or more); sepals lanceolate, sharp-pointed, sprear- 
ing in fruit, as long as the globular heaked light mahogany-colored capsule, anthers nearly as long as the filaments; style short; scerls small ( $\frac{1}{5}-\frac{1}{4}$ "long), coarsely cross-lined. - Low siucly gromuls, N. J. to Fla.

16. J. Gerárdi, Loisel. (BLAck-(inasi.) Stems starcely Hattened, rigid (1-2 ${ }^{\circ}$ high); panicle contracted, nsually longer than the bracteal loaf ; flowers chestnnt-brown with green (1 $1{ }^{\prime \prime}$ long) ; sepals oval-oblong, obtuse, incurverl, as long as the oval obtuse and mucronate cajsule; anthers much longer than the short filaments; style as long as the ovary; seeds (nearly $\frac{1}{8}$ "long) obuvate, delicately ribbed and cross lined. - Salt marshes; common along the coast and in W. New York; rare about the Great Lakes. (Eu.)

$$
\text { + + Stems branched, diffuse, leafy; root anmual, fibrus. }
$$

17. J. bufonius, L. Stems low and sleuder $\left(3-9^{\prime}\right.$ lighlı), leafy, often branched from the base; panicle spreading, mostly with one-sided lichoto. mous branches; flowers remote, greenish ( $2-3 \frac{1}{2}$ "long); sepals linear-lanceolate, awl-pointed, the 3 outer much exceeding the inner and the oblong obtuse (apsule; stamens short ; filaments scarcely longer than the antlier's, seeds elliptical, obtuse $\left(\frac{1}{5}-\frac{1}{6}\right.$ " long). - Low grounds, by roadsides ; common. (Eu.)

§ 3. Stems leafy; leares terete or laterally fluttened, more or less distinctly knotted by internal transverse partitions; panicle terminal, with flouers chiefly in heads. - KNotTY-LEAVED JexCl.

* Seeds barely pointed, not caudate.

- Flowers solitary or 2 together, panicled; stamens 6 .

18. J. pelocárpus, E. Meyer. Stems slender and erect from a slender running rootstock $\left(6-18^{\prime}\right.$ high), bearing few thread-like slightly knottel leaves, branching alove into a compound spreading panicle, bearing the flowers in the forks and along one side of the branches; often with the flowers or in place of them are tufts of leaves; flowers small ( $1-1$ 1 ${ }^{\prime \prime}$ long), greenish with red; sepals oblong, oltuse, the 3 inner ones longer, but shorter than the oblong taper-beaked, 1-celled capsule; anther's much longer than the filaments; style slender; seeds ( $4^{\prime \prime}$ long) obovate, short-pointed. - Sandy, wet or swampy places, Newf. to Fla., west along the Great Lakes to Minn. The proliferous plants are usually sterile and much larger, with larger diffuse panicles. Var. súbrilrs, Engelı. Creeping or floating, with a single pair of flowers at the end of the short stems. - Somerset Co., Maine (C. E. Smith); Canada.

++ Heads numerous, of 3-12-flozers (rarely more); in early summer. +Stumens 6.

19. J. articulàtus, L. Stems ascending or erect $\left(9-15^{\prime}\right.$ high), tufted from a short creeping rootstock, with 1 or 2 slencler leaves; panicle short, spreading, the crowded heads 3 -8-flowered; flowers brown, rarely pale ( $1 \frac{1}{4}-$ $1 \frac{1}{2}$ " long); sepals lance-ol)long, acute or mncronate, or the 3 inner obtuse and a little longer, shorter than the ovate-oblong acnte or abruptly mucronatepointed incompletely 3-celled commonly deep chestmut-brown shining capsule; anthers as long as the filaments; ovary attenuate into a slort style; scerls (less than $\frac{1}{3}$ "long) obovate, attenuate below, abruptly pointed above. - Wet grounds, Newf. to Del., west to western N. Y. and Mich. (Eu.) 
20. J. alpinus, Villars, var. insígnis, Fries. Stems erect $\left(9-18^{\prime}\right.$ high) from a creeping rootstock, with 1 or 2 sleuder leaves; panicle meagre, with erect branches bearing distant greenish or light-brown heals, each of 3-6 flowers $\left(1 \frac{1}{4}-1 \frac{1}{2}{ }^{\prime \prime}\right.$ long) ; sepals oblong, obtuse, the outer mucronate or cuspidate and usually longer than the rounded inner ones, as long as or shorter than the obtuse short-pointed incompletely 3-celled light-brown capsule; anthers as long as the filaments; style short; seeds ( $\frac{1}{3}$ " or more in length) spindle-shaped. - Wet sandy banks, L. Champlain, Cayuga Lake, along the Great Lakes, and far west and northward. (Eu.)

21. J. militàris, Bigel. Stem stout $\left(2-4^{\circ}\right.$ high $)$ from a thick creeping rootstock, bearing a solitary stont erect leaf $\left(\frac{1}{2}-3 \frac{1}{2}^{\circ} \mathrm{long}\right)$ below the middle, which overtops the crowded and rather contracted panicle; heads numerous, 5-12- (rarely 25-) flowered; flowers brownish (1 $\frac{1}{2}{ }^{\prime \prime} \mathrm{long}$ ); sepals lanceolate, the outer awl-pointed, as long as the ovate-oblong triangular taper-beaked 1-celled capsule; anthers longer than the filaments; ovary attenuate into a slender style; seeds $\left(\frac{1}{4}-\frac{1^{\prime \prime}}{3}\right.$ long) globose-obovate, obtuse, abruptly pointed. In bogs and streams, Maine to Md. Sometimes producing, in flowing water, numberless capillary submersed leaves, $2-3^{\circ} \mathrm{long}$, from the rootstock.

\section{$\rightarrow+$ Stamens 3.}

22. J. acuminàtus, Michx. Stems tufted, erect, slender (1-2 ${ }^{\circ}$ long), bearing abont 2 leaves and a very loose spreading panicle; heads rather few and large, 5-many-flowered, greenish, at length straw-colored or darker; se-

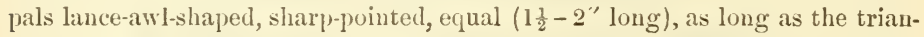
gular-prismatic short-pointed 1-celled straw-colored or light brown capsule; anthers a little shorter than the filaments; style almost noue; seeds small $\left(\frac{1}{5}-\frac{1}{4}\right)^{\prime \prime}$ long), acute at both ends, ribbed-reticulated. - N. Eng. to Ga., Minn. and Tex. May, June. Very variable. Heads often proliferous in antumn.

Var. débilis, Engelm. Stems slender (9-18' high); heads green, 3-6flowered, in a loose panicle; flowers smaller ( $1 \frac{1}{4}-1 \frac{1}{2}$ " long); cajsule longer than the sepals. - Wet sandy soil, N. J. to S. C., west to Ohio, Mo., aud Miss. Stem sometimes decumbent and rooting.

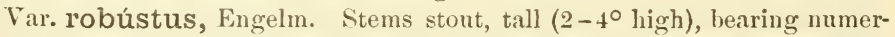
ous 5-8-flowered light-brown heads in a large much-brancherl panicle; flowers small ( $1-1 \frac{1}{5}$ "long); oroid capsule scarcely longer than the sepals. - Deep swamps, Ill. to Mo. and La.

+++ Heads few, crowded, of numerous flowers.

- Stamens 3 ; stem rigid from a thick uhite horizontal rootstock.

23. J. brachycárpus, Engelm. Stem erect ( $1-2 \frac{1}{2} \circ$ high), bearing abont 2 leaves and 2-10 densely flowered spherical heads $\left(4-5^{\prime \prime}\right.$ wide) in a slightly spreading crowded panicle much exceeding the involucral leaf; flowers pale green (2" long); sepals lance-linear, awl-pointed, the 3 outer much longer than the inner, and the ovoid pointer 1-celled capsule rather shorter; anthers much shorter than the filaments; style very short; seeds ( $\frac{1}{5}$ "long) ahruptly apicnlate. - Moist places in open woods and prairies, Ohio and Mich. to Mo., Miss., and Tex.

24. J. scirpoides, Lam. Stem erect $\left(1-3^{\circ}\right.$ high $)$, rather slender, bearing about 2 terete leaves with wide and open sheaths, and a panicle of few or 
many densely-flowered pale-green spherical heads, much longer than the invoJucral leaf, its loranches erect and often elongaterl; heads (3-4" wille) 15-40-

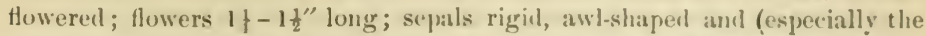
outer) bristly pointed, at length pungent, as long as the stamens and nearly equalling the oblong-triangular taper-pointed l-elled capsule; anthers very small; style elongated or very short; seeds ovoil, alsuptly pointed at each end ( $t^{\prime \prime}$ long). - Wet sandy soil, Mass. to N. J. and s. C., west to Ind., Mo., and 'lex.

Var. echinàtus, Engelm. Stouter; leaves terete; branches of the compact panicle short; heads larger (5-6" wide), 40-80-flowered; Howers $1 \frac{8}{4}-2^{\prime \prime}$ long); sepals narrower and more sharply pointed, the outer a little longer than the inner; stamens shorter and anthers longer than in the preceding, and seeds rather sinaller and more slender. - Md. to Fla.

Var. polycéphalus, lingelm. Much stouter; leaves laterally flattened (3-6" wide); panicle spreading, branched, bearing many distant heads as large as in the last; flowers $2-2 \frac{1}{2}$ " long; the 3 outer sepals the longer ; anthers about as long as the filaments; seeds larger ( $\frac{1}{3}$ "long). - S. Va. to Fla., west to Mo. and 'Tex.

\section{+* Stamens 6 .}

25. J. nodósus, I. Stem erect $\left(6-15^{\prime}\right.$ or $2^{\circ}$ high), slenter from a creeping thread-like and tuber-bearing rootstock, mostly with 2 or 3 slender leaves; heads few or several, rarely single, $8-20$-flowered $\left(3 \frac{1}{2}-4^{\prime \prime}\right.$ wide), orertopjed by the involucral leaf; flowers brown ( $1 \frac{1}{2}-2^{\prime \prime}$ long); sepals lance linear, awlpointed (the 3 vuter mostly a little shorter), nearly as long as the slender triangular taper-pointed l-eelled capsule; anthers oblong, shorter than the filaments; style very short; seeds (about $1_{4}^{\prime \prime}$ long) obovate, abruptly mucronate. - Swamps and gravelly banks, N. J. and Penn. to N. Ind. and Iowa, and northward. - July, Aug. - Var. MegACérHalis, Torr. Stem stout $\left(1-3^{\circ}\right.$ high), with thick leaves; heads few and large (6-8" wide), $30-80$-flowered; flowers pale green (21-23" long); outer sepals longest; anthers linear, shorter than the filaments. - Western N. Y. to Minn. and Mo., and westward.

* Seeds caudate.

- Stanens 3 .

26. J. Canadénsis, J. Gay. Tufted stems erect, terete, smooth, bearing 2-3 leaves; hearls few-or many-flowered, paniculate; sepals lanceolate, the 3 outer shorter than the inner, not much longer than the stamens, equal to or shorter than the triangular-prismatic almost 1-celled usually short-pointed (apsule; style mostly short; seeds more or less distinctly tail-pointed, delicately many ribbed. - Common almost everywhere. Aug., Sept. Easily distinguished by its late flowering from the similar n. 22. Very variable.

Var. longicaudàtus, Engeln. Stem stont and rigid $\left(1 \frac{1}{2}-3^{\circ}\right.$ high $)$, bearing in a lecompound somewhat sprealing panicle the numerous 5-50-

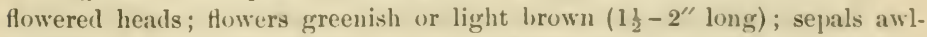
pointed, mostly shorter than the abruptly short-pointed capsule; seeds slender $\left(\frac{2}{3}-1^{\prime \prime}\right.$ long), conspicuonsly tail-pointed. - Maine to S. C., west to Minu. aud la. The most common form.

Var. subcaudàtus, Engelm. Stem slender, often decumbent $\left(1-2^{\circ}\right.$ high), bearing in simpler spreading panicles fewer 8 -20-Howered heads; 
flowers greenish, as large as in the last; sepals awl-shaped, but not so rigid; capsule mostly tapering; seeds large ( $\frac{1}{2}-\frac{2}{3}$ " long), with short white membranous appendages, not reticulated. - Conn. to Penn. and Ga.

Var. brachycéphalus, Engelm. Stem slender ( $1 \frac{1}{2}_{2}-2 \frac{1}{2}^{\circ}$ high), bearing numerous small 3-5-Howered heads in a large spreading panicle; flowers greenish or light brown $\left(1 \frac{1}{4}-1 \frac{1}{2}{ }^{\prime \prime}\right.$ long); sepals mostly obtuse, shorter than the brown abruptly short-pointed capsule; style longer than in other forms; seeds smaller $\left(\frac{1}{4}-\frac{1}{3}\right.$ "loug), slender, with rather short appendages.-Yenn. and western N. Y., to Wisc. and 111.

Var. coarctàtus, Engelm. Stem slender, shorter $\left(9-1 \mathrm{~s}^{\prime}\right.$ high), bearing fewer deep-brown 3-5-flowered heads in a somewhat erect contracted panicle; flowers as large as in the last; sepals acute, or rarely obtusish, much shorter than the prismatic abruptly pointed deep-brown capsule; seeds as in the last. - N. Eng. to N. J., N. Minn., and westward.

\section{++ Stamens 6 .}

27. J. ásper, Engelm. Stems tufted, erect $\left(2-3^{\circ}\right.$ high), terete, stout, rigid, and with the rigid leares rough; panicle with rigid slightly spreading branches, bearing scattered few- $(2-6$-) flowered heads; Howers greenish with brown ( $2 \frac{1}{2} "$ long); sepals ovate-lanceolate, awl-pointed, rigid and strongly nerved, the outer much shorter than the inner, these a little shorter than the triangular-ovoid beaked incompletely 3-celled lrown capsule; orary tapering into a conspicuons style; seeds large, oblong, with white or often reddish appendages (1 $1 \frac{1}{4}$ long). - Sphagnous swamps, N. J. Aug.

\section{I U̇ZUIA, DC. Wood-Resh.}

Capsule 1-celled, 3-seeded, one seed to each parietal placenta. - Perennials, often hairy, usually in dry ground, with flat and soft usually hairy leaves, and spiked-crowded or nmbelled flowers. (From Gramen Luzula, or Luxula, dim. of lux, light, - a name given to one of the species from its shining with dew.)

$$
\text { * Pedicels 1-flowered, in a loose compond cyme or umbel. }
$$

1. I. vernàlis, DC. Plant $6-9^{\prime}$ high ; leaves lance-linear, hairy ; umbel mostly simple; sepals pointed, shorter than the obtuse capsule; seeds with a curved appendage. (L. pilosa, Willd.) - Woods and banks, Newf. to the mountains of N. C., west to Miun. (Eu.)

2. I. spadícea, DC., var. melanocárpa, Meyer. Nearly smooth (1$3^{\circ}$ high); leaves broadly linear; corymb decompound, loose; pedicels drooping; sepals pointed, straw-color, about the length of the minutely pointed and brown capsule; seeds not appendaged. (L. parrifora, var. melanocarpa, Gray.) Mountains of Maine, Vt., and northern N. Y., to Mich. and N. Minn. (Eu.)

* * Flowers crouded in spikes or close clusters. (Plants 6-12' high.)

3. I. campéstris, DC. Leares flat, linear; spikes 4-12, someuhat umbelled, ovoid, straw-color, some of them loug-pednucled, others nearly sessile; sepals bristle-pointed, longer than the obtuse capsules; seeds with a conical appendage at base. - Dry fields and woods, common. May. (Eu.)

4. I. arcuàta, Meyer. Leaves channelled, linear; spikes 3-5, on unequal often recurved peduncles, oroid, chestuut-brown; bracts ciliate-fringed; sepaIs 
taper-pointed, longer than the obtuse capsule; seeds not appendaged. - $\mathrm{Al}$ pine summits of the White Mts. and far northward. (Fu.)

5. L. spicàta, Desvaux. Lenves channelled, narrowly linear; fouers in sessiie clusters, forming a nodding interrupted spiked punicle, brown; sepals bristle-pointed, scarcely as long as the abruptly short-prointed capsule; sceds merely with a rumblish projection at base. - With the last, and more comnon. (Eu.)

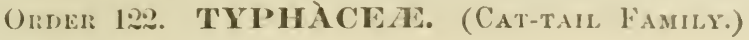

Marsh or aquatic herbs, with neried and linear sessile leures, and moncecious flowers on a spadix or in heads, restitute of proper floral envelopes. Ovary 1-2-celled, with as many jersistent styles and (usually elongated) 1-sided stigmas; cells 1-ovuled. Fruit nut-like when ripe, 1-seeded, rarely 2-scecled. Seed suspented, anatropous; embiryo straight in copious albumen. Root perennial.

1. Typha. Flowers in a cylindrical compact terminal spike; spathe-like bract deciduons.

2. Sparganium. Flowers in globula heads with fulia eous bia.ts.

\section{TỲ PH A, Tourn. (CAt-Tail Flag.)}

Flowers in a long and very dense cylinlricil spike terminating the stem; the upper part consisting of stamens unly, inserted directly on the axis, and intermixed with long hairs; the lower part consisting of stipitate 1-celled ovaries, the stipes bearing club-shaped bristles, which form the copious down of the fruit. Nutlets minute, very long-stalked. - Spathes marely deciduous bracts, or none. Root-stucks reeping. Leaves long, sheathing the base of the simple jointless stems, erect, thickish. Flowering in summer. (Tú $\eta$, the old Greek name.)

1. T. latifolia, L. (Commox Cat-тan..) Stont and tall ( $4-6^{\circ}$ high), the flat sheathing leaves $3-10^{\prime \prime}$ broad, exceeling the stem; the staminite and dark brown pistillate parts of the spike (each 3-6' long or more) usuully rontuguous, the latter at length $\mathrm{l}^{\prime}$ in diameter; pustillate flower's without bractlets; stigma rhombic-lanceolate; pollen-grans in fours. - In marshes, through. out N. $\Lambda \mathrm{m}$. (Eu.)

2. T. angustifolia, L. Leaves narrower (3-6" broad), taller, somewhat convex on the back; pistillate and staminate inflorescence usually separated by a short interval, the light brown spike becoming $5-6^{\prime \prime}$ in diameter; pollengrains simple; pistillnte flowers with a linear stigma and a hair-like bractlet slightly dilated at the summit. - N. Eng. to N. J., west to Mich. and Mo.; less frequent, and mainly near the coist. (Eu.)

\section{S P A R G À N I U M, 'Tourn. [B'R-IELE.}

Ilowers collected in separate dense and spherical leafy-bracted heads, which are seattered along the summit of the stem; the upper sterile, cousisting merely of stamens, with minute scales irregularly interposed; the lower or fertile larger, consisting of numerous sessile 1 - 2-celled pistils, each surrounded by $3-6$ scales much like a calyx. Fruit wedgeslaped or cluh-shaped, nure or less corky toward the summit, the hard endoearp perforated at the apex. - 
Rootstocks creeping and stoloniferous; roots fibrous. Stems simple or branch. ing, sheathed below by the base of the linear leares. Flowering through the summer. (Name from $\sigma \pi a ́ \rho \gamma \alpha \nu o \nu$, a fillet, from the ribbon-like leaves.)

* Fruit sessile, broad and truncate, often 2-seeded; stigmas often 2, elongated; scales rigid, nearly equalling the fruit; erect, with branched inflorescence.

1. S. eurycárpum, Engelm. Stems stout, erect $\left(2-4^{\circ}\right.$ high $)$; leaves mostly flat and merely keeled; pistil attenuate into a short style bearing 1 or 2 elongated stigmas; fruit-heads $2-6$ or more, $l^{\prime}$ wide; fruit many-angled $\left(3 \frac{1}{2}-4^{\prime \prime}\right.$ long) when mature, with a broad and depressed or retuse summit abruptly tipped in the centre. - Borders of ponds, lakes, and rivers, N. Eng. to Va., west to the Pacific.

* * Fruit comparatively narrow, and mostly someuchat stipitate, 1-celled, longer than the scales.

2. S. simplex, Huds. Stems slender, erect $\left(\frac{1}{2}-2^{\circ}\right.$ high); leaves more or less triquetrous $\left(2 \frac{1}{2}-4^{\prime \prime}\right.$ wide) ; fertile heads $(1-4)$ of the usually simple inflorescence often above the axils, sessile or peduncled, $6-8^{\prime \prime}$ wide in fruit; stigma linear, equalling the rather slender style or shorter; nutlets pale, fusiform or narrowly oblong (about $2^{\prime \prime}$ long), more or less contracted in the middle. $-\mathrm{N}$. Eng. to N. J., west to Mich., Minn., and northward. (Eu.)

Var. andrócladum, Engelm. Stouter (1 $\frac{1}{2}-3^{\circ}$ high), with usually brouder leares $\left(4-9^{\prime \prime}\right)$ aut branching inflorescence, the head or peduncles axillary or nearly so; fruiting heads $(1-7)$ often larger $\left(6-12^{\prime \prime}\right.$ broad), the nutlets $2-3^{\prime \prime}$ long. (S. androcladum, Morong.) - In bogs or shallow water, common ; N. Eng. to Fla., west to Minn. and Mo.

Var. angustifolium, Engelı. Very slender; leaves floating, long and narrow ( $\frac{1}{2}-2 \frac{1}{2}^{\prime \prime}$ wide), flat; influrescence simple; heads $\left(4-6^{\prime \prime}\right.$ broad) and nutlets smaller. - Mountain lakes aud slow streams, N. Y., N. Eng., and northward; sometimes nearly out of water, dwarf and with shorter erect leares.

Var. flùitans, Engelm. Floating in deep water, with long slender stems and flat narrow leaves; inflorescence usually short, sparingly branched; style stout with a short oval stigma; fruiting leads 4-6" broad; nutlets dark, as large as in the type. (S. androcladum, var. fluctuans, Morong.; not S. fluitans, Firts.) - Ponds, Penn., W. Conn., White Mts., N. Mimn., and northward.

3. S. mínimum, Fries. C'sually floating, with very slender stems and thin flut narrow leaves; fertile heads 1 or 2 , axillary, sessile or pelluncled (4-5) wide); stigma oval, about as long as the short style, scarcely surpassing the oval or obovate denticulate scales; firuit ollong-obovate (1-2" long), pointed, somewhat triangular, the stipe rery short or none. - N. Eng. to Penn., N. Ind., Minn., north and westward. - Stems 3-6' high when growing out of water, much longer when submerged. (Eu.)

\section{Order 123. ArÁCeAe. (Arum Family.)}

Plants with acrid or pungent juice, simple or compound often veiny leaves, and flowers crowded on a spadix, which is usually surrounded by a spathe. - Florai envelopes none, or of 4-6 sepals. Fruit usually a berry. Seeds with fleshy albumen, or none, but filled with the large fleshy em- 
byyo. A large family, chiefly tropical. Ilerbage abounding in slender rhaphicles. - The genuine Aracea have no floral envelopes, and are almost all monnecious or dixecious; but the genera of the second section, with more highly developed flowers, are not to be separated.

* Spathe surrounding or subtendiug the spidix ; Howers naked, i, e. without perianth.

1. Arisama. Flowers monœeious or dicecious, covering only the base of the spadix.

2. Peltandra. Fluwers monocious, covering the spadix; anthers above, ovaries below.

3. Callar. Fluwers perfect (at least the luwer ones), covering the whole of the short spadix. Spathe open and spreading.

* Spathe surrouncling the spadix in $n .4$, none or inperfect in the rest; flowers with a ealyx or perianth and ferfect, covering the whole spadix.

4. Symplocarpus. Spadix globular, in a fleshy shell-shaped spathe. Stemless.

5. Orontium. Spadix narrow, naked, terminating ti.e terete scape.

6. Acorus. Spatix eylindrieal, borne on the side wi a itedf-like seape.

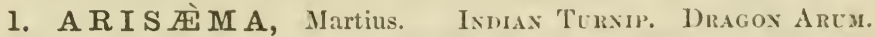

Spathe convolute below and mostly arched above. Flowers moncecious or by abortion dicecions, covering only the base of the spadix, which is elongated and naked above. Floral envelopes none. Sterile flowers above the fertile, each of a cluster of almost sessile 2-4-celled anthers, opening by pores or chinks at the top. Fertile flowers consisting each of a 1-celled ovary, tipped with a depressed stigma, aud containing 5 or 6 orthotropous ovules erect from the base of the cell; in fruit a 1 -few-seeded scarlet berry. Embryo in the axis of albumen. - Low perennial herbs, with a tuberous rootstock or corm, sending up a simple scape sheathed with the petioles of the simple or compound veiny leaves. (Name from àpis, a kind of arum, and $\alpha \hat{i} \mu \alpha, b l o o d$, from the spotted leares of some species.)

1. A. triphýllum, Torr. (Ixwian Turxip.) Leaves mostly 2, divided into 3 elliptical-ovate pointed leaflets; spadix mostly diocious, club-shaped, obtuse, much shorter than the spathe, which is flattened and incurved-hooded at the ovate-lanceolate, pointed summit. - Rich woods, N. Scotia to Fla., west to Minn. and E. Kan. May.-Corm turnip-shaped, wrinkled, farinaceous, with an intensely acrid juice; spathe with the petioles and sheatlis green, or often variegated with dark purple and whitish stripes or spots.

2. A. Dracóntium, Schott. (Greex Dragox. Dragox-root.) Leaf usually solitury, pedutely divided into $7-11$ oblong-lanceolate pointed leaflets; spadix often androgynous, tapering to a long and slender point beyond the oblung and convolute pointed greenish spathe. - Low grounds, N. Eng. to Fla., west to Minn., E. Kan., and Tex. June.-Corms clustered; petiole $1-2^{\circ}$ long, much longer than the peduncle.

\section{PELTÁ N D R A, Raf. Arrow Arus.}

Spathe elongated, convolute throughout or with a dilated blade above. Flowers moncecious, thickly covering the long and tapering spadix throughout (or only its apex naked). Floral envelopes none. Anther-masses sessile, naked, covering all the upper part of the spadix, each of $4-6$ pairs of cells imbelled in the margin of a thick and shield-shaped connective, opening by terminal pores. Ovaries at the base of the spadix, each surrounded by $4-5$ distinet, scale-like, white staminodia, 1-celled, bearing 1 -few amphitropous 
ovules at the base; stigma truncate. Fruit a leathery or fleshy berry, 1-3seeded. Seed obovate, surrounded by tenacious jelly, the base empty, the upper part filled with a large fleshy spherical embryo; no albumen. - Stemless herbs, with arrow-shaped or hastate leares, palmately 3-nerved and pinnately veined, and simple scapes from a thick-fibrous or subtuberous root. Fruit in a globose cluster, enclosed by the persistent fleshy base of the spathe. (Name from $\pi \dot{\varepsilon} \lambda \tau \eta$, a target, and $\dot{\iota} \eta \dot{p}$, for stamen, from the shape of the latter.)

1. P. undulàta, Raf. Root of thick tufted fibres; scape $1-1 \frac{1}{2}^{\circ}$ high, about equalling the leaves; basal lobes of the leaves rather long and often acutish ; spathe convolute throughout, wavy on the margin, mostly green, 4-7'long; sterile portion of the spadix several times longer than the pistillate; ovules several; fruit green; seeds $1-3$. (P. Virginica, Kunth, and most authors.) Shallow water, New Eng. to Fla., west to Mich. and Ind. June.

2. P. álba, Raf. Rootstock tuberous, covered with thick-fleshy roots and propagating by offshoots; lobes of the leaves mostly short and broad, obtuse; spathe $3-4^{\prime}$ long, the blade broader, acuminate, somewhat expanded, white; sterile part of the spadix searcely longer than the pistillate; orules and seeds solitary; berry scarlet, $5-6^{\prime \prime}$ long. (P. Virginica, Schott. Xanthosoma sagittifolia, Chapm., not Schott. Caladium glaucum, Ell. Arum Virginicum, L., in part?) - Marshes, S. Va. (?) and N. C. to Fla.

\section{CÁl工A, L. Water Arum.}

Spathe open and spreading, ovate (abruptly pointed, the upper surface white), persistent. Spadix oblong, entirely covered with flowers; the lower perfect and 6-androus; the upper often of stamens only. Floral envelopes none. Filaments slender; anthers 2-celled, opening lengthwise. Ovary 1celled, with 5-9 erect anatropous ovules; stigma almost sessile. Berries (red) distinct, few-seeded. Seeds with a conspicuous rhaphe and an embryo nearly the length of the hard albumen. - A low perennial herb, growing in cold bogs, with a long creeping rootstock, bearing heart-shaped long-petioled leaves, and solitary scapes. (An ancient name, of unknown meaning.)

1. C. palústris, L. - Cold bogs, N. Scotia to N. J., west to Mich. and Minn., and northward. June.- Seeds surrounded with jelly. (Eu.)

\section{SYMPLOCÁRPUS, Salisb. Skurk CAbBage.}

Spathe hooded-shell-form, pointed, very thick and fleshy, decaying in fruit. Spadix globular, short-stalked, entirely and densely corered with perfect flowers, their 1-celled or abortively 2-celled ovaries immersed in the fleshy receptacle. Sepals 4 , hooded. Stamens 4 , opposite the sepals, with at length rather slender filaments; anthers extrorse, 2-elled, opening lengthwise. Style 4-angled and awl-shaped; stigma small. Ovule solitary, suspended, anatropous. Fruit a globular or oval mass, composed of the enlarged and spongy spadix, enclosing the spherical seeds just beneath the surface, which is roughened with the persistent fleshy sepals and pyramidal styles. Seeds filled by the large globular and fleshy corm-like embryo, which bears one or several plumules at the end next the base of the ovary; albumen none.-Perennial herb, with a strong odor like that of the skunk, and also somewhat alliaceous; a very thick rootstock, bearing a multitude of long and coarse fibrous roots, 
and a cluster of very large and broad entire veiny leaves, precerled in earliest spring by the nearly sessile spathes, which barely rise nut of the ground.

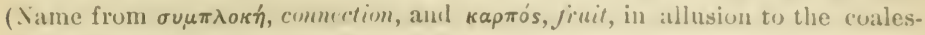
cence of the oraries into a (compomul fruit.)

1. S. fœ̀tıdus, Salisb. Leaves ovate, cordate, heconing $1-2^{2}$ long, shortpetioled; spathe spotterl and striped with purple and yellowish-green, ovate, incurved; fruit (in autumn) $2-3^{\prime}$ in diam., in decay shedding the bull,let-like seeds, which are $4-6^{\prime \prime}$ long. - Bogs and moist grounds, N. Scotia to N. C., west to Mim. and Iowa.

\section{O R Ó N T I U M, L. Golnex-ur.}

Spathe incomplete and llistant, merely a leaf-sheath investing the lower part of the slender scape, and hearing a small and imperfect bract-like blade. Flowers crowded all over the narrow spalix, perfect; the lower with 6 concare sepals and 6 stamens; the upper ones with 4 . Filaments flattened; anthers 2-celled, opening obliquely lengthwise. Ovary 1.celled, with an anat ropous orule; stigma sessile, entire. Fruit a green utricle. Fieed without albumen. Embryo thick and Heshy", "with a large concealed eavity at the summit, the plumule curred in a grvore on the outside." (Torr.) - An aquatic perennial, with a deep rootstock, long-petioled and entire oblong and werved floating leaves, and the spalix terminating the elongated scape; its rather club-shaped emersed apex as thick as the spadix. (Origin of the name obscure.)

1. O. aquáticum, L.-Ponds, Mass. to Fla. May.

\section{6. Á Co R U S, L. Sweet Flag. Calanus.}

Spadix cylindrical, lateral, sessile, emerging from the side of a simple 2-edged scape which resembles the leaves, densely covered with perfect flowers. Sepals 6 , concave. Stamens 6 ; filanents linear ; anthers kidney-shaped, 1-celled, opening across. Ovary $2-3$-celled, with several pendulous orthotropous orules in each cell; stigma minute. Fruit at length dry, gelatinous inside, 1 -fewseeled. Embryo in the axis of albumen. - Pungent aromatic plants, especially the thick creeping rootstocks (calamus of the shops), which send up 2edged sworl-like leaves, and seapes somewhat like them, bearing the spadix on one edge ; the upper aud nore foliaceous prolongation sometimes considered as a kind of open spathe. ('A kораs, the ancient name, of no known meaning.)

1. A. Cálamus, I. Sicape leaf-like and prolonged far beyond the (yellowish-green) spadix. - Margins of rivulets, swamps, etc., N. Scotia to Fla., west to Minn., Iowa, and E. Kan.

\section{OrDER 124. LEMNACEA. (D)СKWEN FAMLY.)}

Minute stemless plants, floating fiee on the uater, destitute of distinct stem and foliage, being merely a fromd, producing one or few monocious flowers from the edge or upper surface, and commonly hanging roots from underneath; ounles rising from the buse of the cell. Frut a 1-i-sceded utricle. Seed large; the apex or radicular extremity of the seel-coat separable as an operculum or lid (as in Cabomba, ('tc.). Embryo straight, surrounded by fleshy or sometimes very scanty albumen. - The simplest, and 
some of them the smallest of flowering plants, propagating by the proliferous growth of a new individual from a cleft in the edge or base of the parent frond, remaining connected for some time or separating, also by autumnal fronds in the form of minute bulblets, which sink to the bottom of the water, but rise and vegetate in spring; the flowers (in summer) and fruit scarce, in some species hardly ever seen. Frond more or less cavernous; the upper surface furnished with stomata. - These plants may be regarded as very simplified Araceæ.

1. Spirodela. Frond 7-11-nerved, with several rootlets.

2. Lemna. Frond $1-5$-nerved, with a single rootlet.

3. Wolffia. Frond thick, very minute $\left(\frac{1}{4}-\frac{2}{3}\right.$ ' broad), without rootlets.

\section{SPIRODEIA, Schleiden.}

Anther-cells bilocellate by a vertical partition and longitudinally dehiscent. Ovules 2. Frond 7-11-nerved or more; rootlets several, with axile vascular tissue. Otherwise as Lemna. (From $\sigma \pi \in \hat{\imath} \rho \alpha, u \operatorname{cor} d$, and $\delta \hat{\eta} \lambda$ os, evident.)

1. S. polyrrhiza, Schleid. Fronds round-obovate $\left(2-4^{\prime \prime}\right.$ long), thick, purple and rather convex beneath, dark green above, palmately (mostly 7 -) nerved. (Lemna polyrrhiza, L.) - Very common in ponds and pools, througiout N. Am., but very rarely found in flower or fruit. (Eu.)

\section{LÉ MI N A, L. DúcKWeED. DüK's-мeat.}

Flowers produced from a cleft in the margin of the frond, usually three together surrounded by a spathe; two of them staminate, consisting of a stamen only; the other pistillate, of a simple pistil ; the whole therefore imitating a single diandrous flower. Ster. Fl. Filament slender; anther 2- celled, didy. mous; the cells dehiscent transversely; pollen-grains large, spherical, muricate. Fert. Fl. Ovary l-celled; style and truncate or fumnel-shaped stigma simple. Ovules and seeds $1-7$. - Fronds $1-5$-nerved, producing a single rootlet beneath (which is destitute of vascular tissue), proliferous from a cleft in the margin toward the base, and at length stipitate ; the tissue abounding with bundles of rhaphides. (An old Greek name of uncertain meaning.)

* Oivule solitary, orthotropous or nearly so; frond 1-3-nerved, thin.

+ Fronds oblong, stalked at base, remaining connected.

1. I. trisúlca, L. Fronds oblong to oblong-lanceolate $\left(6-9^{\prime \prime}\right.$ long), attenuate at base into a slender stalk, denticulate at the tip, very obscurely 3 nerved, often without rootlets, usually several series of offshoots remaining connected; spathe sac-like; seerls ovate, amphitropous, with small round operculum. - Ponds and springy places, N. Scotia to N. J., west to the Pacific. (Eu.)

+ + Fronds oblong to elliptical or round-ovate, sessile, soon separating.

2. L. Valdiviàna, Philippi. Fronds elliptic-oblong, small (about $1^{\prime \prime}$ long), rather thick, usually somewhat falcate, obscurely 1-nerved; spathe broad-reniform; utricle long-ovate, pointed by the long style; seed orthotropous, oblong, with a prominent acute operculum. (L. Torreyi, Austin.) - Pools, N. J. and southward, westwarl across the continent. (S. Am.)

3. L. perpusílla, Torr. Fronds obovate or roundish-obovate, oblique (1 $1 \frac{1}{2}$ "long), obscurely 3-nerved; utricle orate; style rather long; seed orthotro- 
qous, ovate or oval, obtuse, with scarcely apiculate operculum. - N. Y. and N. J., west to Mich. and Wise. - Var. Tmánvis, Austin, has larger, distinetly 3uerved fronds, and an uneigually cordate seed.

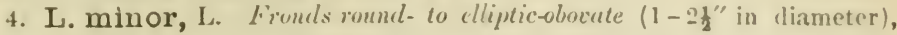
rather thick, very obscurely 3-nerved; spathe suc-like; utricle short-urn-shined, tipped with a short style; sced oblong-ohorate, amphitropous, with prominent rounded operculum. - Stagnant waters, throughout N. Am. (Eu.)

* Oiules 2-7, anatropons; fronds very thick and spongy, flat above, very obscurely 5-nerced ( $1 \frac{1}{2}-3^{\prime \prime}$ lony).

5. L. gíbba, I. Fronds obovate-elliptic to nearly orbicular, almost hemispherical, soon separating; bract sae-like. - Mo. (?) to Ariz. and Calif.

\section{W Ó L F F I A, Ilorkel.}

Flowers central, bursting throngh the upper surface of the globular (or in some foreign ones flat) and loosely cellular fromd, only 2 ; one consisting of it single stamen with a 1-celled 2-valved anther; the other of a globular ovary, tipped with a very short style and a depressed stigma. Ovule orthotropous, rather oblique in the cell. Ltricle spherical. Albumen thin. - Fronds rootless, proliferous from a cleft or funnel-shaped opening at the base, the offspring soon detached; no rhaphides. - The simplest and smallest of flowering plants, from $\frac{1}{4}-\frac{2}{3}$ " long (an $A$ frican and Cuban species much larger), floating as little grains on the water. (Namel for John Fred. Wolff; who wrote on Lemna in 1801.)

1. W. Columbiàna, Karsten. Glohose or globular, $\frac{1}{3}-\frac{2}{3}$ " long, very loosely cellular, light green all over, not dotted; stomata $1-6$; the opening at the base circular and with a thin border. - Floating rather beneath the surface of stagnant waters, Conn. to N. J., west to Minn. and I a.

2. W. Brasiliénsis, Weddell. () blong, smaller and more densely cellular, flattish and deep green with many stomata above, tumid and pale helow, brown-dotted all over, anterior edge sharp, opening at base circular. - Growing with the last, but floating on the surface.

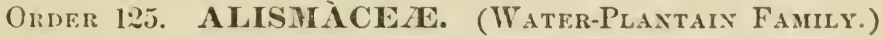

Marsh herbs, with scape-like stems, sheathingleaves, and perfect or monecious or dixcious flowers; perianth of 3 herbaceous persistent sepals and as many (often conspicuous) white deciduous petals, which are imbricate or involute in bud; stamens 6 or more, included; ovaries numerous, distinct, 1-celled and mostl!y 1-ovulerl, becoming achenes in firuit (in our genera) ; seeds erect; campylutropous. - Roots fibrous; leaves radieal, petiolate and strongly nerved with transverse veinlets, the earlier sometimes without blade; flowers long-pedicellate, mostly verticillate, in a loose raceme or panicle, with lanceolate scarious bracts slightly comnate at base.

1. Alisma. Flowers perfect, usually 6-androus. Carpels flatteued, in one whorl.

2. Sagittaria. Flowers mostly unisexual. Stamens rarely few. Carpels flattened, in dense heads, winged.

3. Echinodorus. Flowers perfect. Stamens 6 or more. Carpels cupitate, turgicl am ribbed, often beaked. 


\section{A I Ís im A, L. Water-Plaxtais.}

Flowers perfect. Petals involute in the bud. Stamens definite, mostly 6 . Ovaries many in a simple circle on a flattened receptacle, forming flattened coriaceous achenes, which are dilated and 2-3-keeled on the back. - Roots fibrous. Leaves all from the root, several-ribbed, with connecter veinlets. Scape with whorled panicled branches. Flowers small, white or pale rosecolor. (The Greek name; of uucertain derivation.)

1. A. Plantàgo, L. Perennial by a stout proliferous corm; leaves longpetioled, ovate, oblong, or lanceolate or even linear, acute, mostly rounded or lieart-shaped at base, 3-9-nerved; panicle loose, compound, many-flowered ( $1-2^{\circ}$ long); carpels obliquely oborate, forming an obtusely triangular whorl in fruit. - Slıallow water and ditches, across the continent. Very variable as to foliage, but the leaves usually more broadly cordate-orate than in Old World forms (val. Americànum, $R . \oint . S$.$) ; when growing uuder water thin-$ ner and uarrowly lauceolate. (Eu., etc.)

\section{SAGITtàr I A, I. ARrow-heAd.}

Flowers monœcious, or often dicecious in $\mathrm{n} .1$ and 4 , and polygamous in $\mathrm{n} .7$. Petals imbricated in the bud. Stanens indefinite, rarely few. Oraries many, crowded in a spherical or somewhat triangular depressed head on a globular receptacle, in fruit forming flat membranaceous winged achenes. - Marsh or aquatic, mostly perennial, stoloniferous herbs, with milky juice and filrous roots; the scapes sheathed at base by the bases of the long cellular petioles, of which the primary ones, and sometimes all, are flattened, werved, and destitute of any proper blade (i. e. are phyllodia); when present the llade is arrowshaped or lanceolate, nerved and with cross-reinlets as in Alisma. Flowers produced all summer, whorled iu threes, with membranous bracts; the sterile above. (Name from sayitta, an arrow, from the prevalent form of the leaves.)

1. SAGITTARIA proper. Flowers monccious, with the lower whorls pistillate, or diceions; stamens, few or numerous, covering the receptacle; sepals spreading or reflexed in finit.

* Filaments numerous, narrou, as long as or lonyer than the linear-oblong anthers : bracts 3 , distinct; fruiting heads larger.

1. S. variábilis, Engelm. Scape $\left(\frac{1}{4}-4^{\circ}\right.$ high) angled, with one or more of the lower whorls fertile; leaves very various, almost always sagittate; bracts mostly pointed; pedicels of the fertile flowers at least half the length of the sterile ones; petals wholly white; filaments glabrous, nearly twice the length of the anthers; achenes obovate (about $l^{\prime \prime}$ long), winged on both margins, with a long eurved or usually horizontal beak $\frac{1}{4}-\frac{1}{3}$ its length. (S. sagittæfolia, $L$., var. variabilis, $M$.Micheli.) - In water or wet places, very common ; exceedingly variable in size aud foliage, ordinarily with narrow halberd-shaped or sagittate leares, - sometimes diœcious, with large, broad and obtuse leaves (var. овтÙsA), or monoecious, with large, broad and acute leaves (var. LAt1FòlIA), or the narrow leaves with long and linear diverging lobes (var. ANGUSTIFòLIA), or with some leaves lanceolate or ovate-lanceolate, others more or less sagittate (var. DIVERSIFòria), etc. Root propagating by stolons tuberiferons at the extremity. - The European species has the fertile pedicels only 
$\frac{1}{3}$ or $\frac{1}{t}$ the length of the sterile; claws of the petals purple-tinger; filaments not longer than the anthers; and achenes almost orbicular, very broally winged aud with a short straight beak.

Var. pubéscens, lingelm. I per part of petiole and scape and especially the orbicular-ovate obtuse bracts and sepals pubescent or woolly; beak of fruit horizontal. - N. J. and Y'enn. to (ia.

Var. (?) grácilis, Engelm. Lubes of the sagittate leaves very narrowly linear $\left(\hat{f}-2^{\prime \prime}\right.$ wide) ; achene narrowly cuneate-obovate (2" long), the beak long, stont, and strongly recurved, the sides usually strongly l-3-crested. (\$. cristata, Engelm.?) - Matss. to western X. Y.; lowa.

2. S. lancifolia, I. Seape $2-5^{\circ}$ high, with several of the lower whorls fertile; leaves lanceolate or lance-oblong, rurely linear, all with a tapering base, thick or coriaceous $\left(6-18^{\prime}\right.$ long and on a long and stout petiole, never sagittate), the nerves mostly arising from the very thick midrib; bracts ovate, acute or acuminate; pedicels slender, the fertile scarcely shorter than the sterile ones; filaments pubescent; achenes falcate, winged on the back, pointed with an incurved beak. - Swamps, Md. to Ky., Mo., and southwara. (W. Ind.)

* Filaments very short, with enlarged mostly glandular base; anthers ovate or short-oblong; fruiting heads small; bracts more or less connate; leaves very rarely sagittate.

3. S. heterophýlla, Pursh. Scape weak $\left(3^{\prime}-2^{\circ}\right.$ high $)$, at length procumbent; leaves lanceolate or lance-oval, entire, or with one or two narrow basal sagittate appendages; bracts roundish, obtuse; flowers of the lowest whorl fertile and almost sessile; the sterile on long pedicels; filaments glandular-pubescent; achenes narrouly oborate with a long ercet beak. - N. Eng. to Fla., west to Minn. and Mo. Varies as to foliage, the leaves being lroad (var. ELLípteA, Engelm.), or rigid aud narrowly lanceolate with stont petioles (var. rfGind, Engelm.), or nearly linear (var. AxG t'stı́òlı, Engelm.)

4. S. graminea, Michx. Scape $3^{\prime}-2^{\circ}$ high; phyllodia flrt, mostly broadly linear, acuminate; leaves ovate-lanceolate to linear, on long slender petioles, sometimes recluced to the petiole merely; bracts rather obtuse ; whorls of flowers often few, all staminate or the lower fertile; pedicels slender, spread-

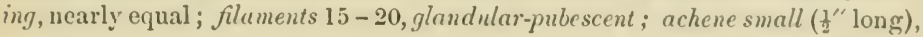
narrowly obovate, almost beakless, winged on the back, flat and scarcely costate on the sides. - N. Eng. to Mimn., south to the Gulf; very varialle.

5. S. tères, Watson. Phyllodia terete, very acutely attenuate upward, 3$12^{\prime}$ long, very rarely learing a narrow blade; scape $\frac{1}{2}-1 \frac{1}{2}{ }^{\circ}$ high; bracts connate at base; pedicels in $1-3$ whorls, all very slender and spreading, 1 or 2 fruiting, $\frac{1}{2}-1$ ' long; filaments 12, dilated, pubescent; archene obovate, 1" long, with an erect beak, the margius and sides crenately several-crested. - In shallow water, S. New Eng. to N. J. (Hyannis, Mass., Deane; Wading River, I. I., Willer: barrens of N. J., Torrey.) Phyllodia usually very strongly nodose.

6. S. nàtans, Michx., var. loràta, Chapm. Isually dwarf; leares linear, strap-shrped, obtuse or ar'utish, 1-6' long, equalling or shorter than the scape, very rarely with a narrow blade; pedicels in $1-3$ whorls, only 1 or 2 fruiting, stouter and recureed; bracts connate or spathe-like; filaments $6-8$, glabrous; achene obovate, short-beaked, $\mathrm{l}^{\prime \prime}$ lony, the margins and sides crenately 
crested. (S. pusilla, Pursh.) - In mud or shallow water, near the coast; N. Y. to Fla.

Var. (?) gracíllima, Watson. Scape and the almost or wholly bladeless leaves very slender and greatly elongated $\left(2-4^{\circ}\right.$ long, $1^{\prime \prime}$ wide); pedicels all elongated, in usually distant whorls, the lower pistillate, slender and spreading; fruit unknowu. (S. natans, Engelm. in Torr. Bull. ix. 4.) - In deep water of streams in E. Mass. (Hitchings, Boott, C. E. Faxon, etc.) Wholly submerged, only 1 or 2 flowers appearing at a time, floating on the surface. The fruit, maturing under water, has not yet been collected.

§ 2. LOPHIOCÁRPUS. Fertile flowers perfect; stamens $9-15$, at the base of the receptacle; sepals erect and embracing the fruit.

7. S. calycina, Engelm. Scape weak $\left(3-9^{\prime}\right.$ high $)$, at length mostly procumbent; usually only the lowest whorl fertile, with pedicels as long as those of the sterile flowers, recurved in fruit ; bracts orbicular, obtuse or rarely pointed; filaments slightly rough, as lı: g as the anthers; achenes obovate with a short horizontal style; leaves bruilily halberd-shaped, obtuse or acutish, with wide spreading lobes, often wider than long, or lanceolate or sometimes reduced to linear phyllodia. - Maine to Del., west to Wisc., Mo., and Tex. Quite variable, several forms being enumerated, as var. spoxiòs , with spongy texture and bladeless submerged leaves, eastward; and westward, var. FLÙraxs, with lance-linear floating leaves.

\section{ECHINÓDORUS, Richard.}

Flowers perfect. Petals imbricated in the but. Stamens 6-21 or more. Ovaries several or many, imbricated in a head, forming thick and ribbed achenes in fruit, often beaked with a projecting persistent style.-Mostly annuals, with the habit of Sagittaria, the naked stems sparingly branched or simple, and the flowers on rather short pedicels, in whorls of $3-6$ or more.

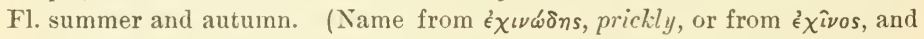

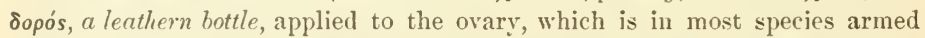
with the persistent style, so as to form a sort of prickly head of fruit.)

1. E. párvulus, Engelın. Scapes $1-3^{\prime}$ high ; shoots often creeping and proliferous; leaves lanceolate or spatulate, acute $\left(\frac{1}{2}-1 \frac{t^{\prime}}{2} \mathrm{long}\right.$, including the petiole); umbel single, 2-8-flowered; pedicels reflexed in fruit; flower $3^{\prime \prime}$ broad; stamens 9 ; styles much shorter than the ovary; achenes beakless, obtusely few-ribbed. - In mud, Mass. to Mich. and E. Minn., south to Fla. and Tex. (S. Am.)

2. E. rostràtus, Engelm. Scape erect, $3^{\prime}-2^{\circ}$ high, longer than the leaves; leaves broadly ovate, cordate or truncate at base, obtuse (the blade 1-3' long); umbel proliferous, in a branched panicle; flower $5^{\prime \prime}$ broad ; stamens 12 ; styles longer than the ovary; achenes beaked, acutely many-ribbed. - Swamps and ditches, Ill to Fla., Mo., and Tex. - A low form (var. LAxceoldtus, Engelm.) has the leares lanceolate with an acute base. Ill., Mo.

3. E. radicans, Engelm. Stems or scape prostrate, creeping $\left(2-4^{\circ}\right.$ long), proliferous, bearing many whorls of flowers; leaves somewhat truncately broadly heart-shaped, obtuse (2-8' broad), long-petioled ; flowers 6 - $9^{\prime \prime}$ broad ; stamens about 21 ; styles shorter than the ovary; achenes short-beaked, the keeled back denticulate. - Swamps, Ill. to N. C. and Fla., west to Mo. and Tex. 


\section{Order 126. NAIADACEAE. (I'ONIWEe FamLy.)}

Marsh or mostly immersed aquatic herbs, with stems jointed and leafy or (in Triglochin) naked and scape-like, leaves shenthing at base or stipulate, and flowers perfect or unisexual, often spathaceous, with perianth of $4 \mathrm{nr} 6$ herbaceous distincl valvate segments, or membranous and tubular or cupshuped, or none. Stamens 1, 2, 4 or 6, with extrorse anthers. Ovaries 1-6, distinct or more or less colierent, 1-celled, usually 1-ovuled, in fruit follicular or capsular or an indehiseent berry or utricle.

Suborder I. Juncaginea. Marsh plants, with terete bladeless leaves; fluwers perfect, spicate or racemose, with herbaceous 6- (rarely 3-) lobed perianth; carpels 3 or 6, more or less united, separating at maturity. Seeds anatropous; embryo straight.

1. Trigluchin. Ovaries $3-6$, united until maturity. Leaves radical. Flowers bractless, in $n$ slike-like raceme terminating a jointless scape.

2. Scheuchzeria. Ovaries 3 , nearly distinct, at length divergent. Flowers bracteate in a loose raceme upon a leafy stem.

Suborder II. Naiadea. Immersed aquatics, with flat leaves; oraries solitary or distinct, 1-ovuled.

- Fluwers perfect, spiked or clustered; anthers 4 or 2, sessile; leaves alternate.

3. Potamogeton. Spike peduncled. Sepals 4, herbaceous. Anthers 4. Ovaries 4, sessile.

4. Ruppia. Fluwers on an enclosed spadix, at length long-exserted, without perianth. Anther-cells 4, distinct. Oraries 4, becoung stipitate.

+ + Flnwers monœcious or diøcious, axillary, naked, unonandrous; leaves opposite (alternate in $\mathbf{n} .6)$.

5. Zannichellia. Moncecions. Pistils $(2-5)$ from a cup-shaped involucre or sheatls.

6. Zostera. Pistils and stamens alternate in 2 vertical rows on the inner side of a leaf-like enclosed spadix. Stigmas 2, linear. Stem creeping.

7. Naias. Diœeious ; pistil solitary, naked. Stamen enclosed in a membranous spathe. Stems floating, with opposite or ternate leaves.

\section{TRIGLOCHIN, L. AnRow-grass.}

Sepals and petals nearly alike (greenish), ovate, concave, lecilnous. Stamens 3-6; anthers oval, on very short filaments. Pistils united intu a $3-6$ celled compound ovary; stigmas sessile; orules solitary. Capsule splitting when ripe into $3-6$ carpels, which separate from a persistent central axis.Perennials, with rush-like, fleshy leaves, brlow sheathing the base of the wandlike naked and jointless scape. Flowers small, in a spiked raceme, bractless. (Name composed of $\tau \rho \in \hat{\imath}$, three, and $\gamma \lambda \omega \chi^{i} \boldsymbol{\nu}$, point, from the three points of the ripe fruit in $\mathrm{n} .1$ when dehiscent.)

$$
\text { * Fruit of } 3 \text { carpels. }
$$

1. T. palústris, L. Scape $\left(6-18^{\prime}\right.$ high) and leaves slender; sepals and stamens 6 ; fruit linear-club-shaped; carpels when ripe separating from helow upward, leaving a triangular axis, anl-pointed at base. - Marshes, western N. Y. to Ill., Minn., and westward. Aug. (Eu., Asia, ete.)

2. T. striata, Ruiz \& Pav. Scape $\left(6-12^{\prime}\right.$ high) and leaves slender; flow. ers very small; sepals and stamens 3 ; fiuit globosetriangular, or when drj 3-lobed. (T. triandra, Michx.) - Sea-shore, Md. to Fla. (S. Am., ete.) 
* Fruit of 6 carpels (rarely 5).

3. T. marítima, L. Scape $\left(1-3^{\circ}\right.$ high) and leaves thickish, fleshy; fruit ovate or oblong, acutish; carpels rounded at base and slightly grooved on the back, the edges acute. - Salt-marshes along the coast, Lab. to N. J., and in saline, boggy or wet places across the continent. (Eu., Asia, etc.)

\section{SCHEUCHZÈ IA, L.}

Sepals and petals oblong, spreading, nearly alike (greenish-yellow), but the latter narrower, persistent. Stamens 6 ; anthers linear. Ovaries 3 , globular, slightly united at base, 2 -3-ovuled, bearing flat sessile stigmas, in fruit forming 3 diverging and inflated 1 -2-seeded pods, opening along the inside. $-\mathrm{A}$ low bog-herb, with a creeping jointed rootstock, tapering into the ascending simple stem, which is zigzag, partly sheathed by the bases of the grass-like conduplicate leaves, and terminated by a loose raceme of a few flowers, with sheathing bracts; leaves tubular at the apex. (Named for John and John Jacob scheuchzer, distinguished Swiss botanists early in the 18th century.)

1. S. palústris, L. - Peat-bogs, N. Brunswick to N. J., westward across the contiuent. June. (Eu., Asia.)

\section{POTAMOGETON, Tourn. Poxdwed.}

Flowers perfect. Sepals 4, rounded, valvate in the bud. Stamens 4, opposite the sepals; anthers nearly sessile, 2-celled. Uvaries 4 (rarely only one), with an ascending campylotropons orule; stigma sessile or on a short style. Fruit drupe-like when fresh, more or less compressed; endocarp (nutlet) crustaceous. Embryo hooked, annular, or cochleate, the radicular end pointing downward. - Herbs of fresh, or one in brackish, ponds and streams, with jointed mostly rooting stems, and 2-ranked leaves, which are usually alternate or inperfectly opposite; the submersed ones pellucid, the floating ones often dilater and of a firmer texture. Stipules membranons, more or less united and sheathing. Spikes sheathed by the stipules in the bud, mostly raised on a pedumcle to the surface of the water. ( $1 \mathrm{n}$ ancient name, composed of

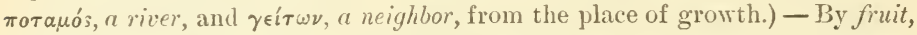
the full-grown fresh or macerated fruit is intencled; by nutlet, that with the fleshy outer portion or epicarp removed. All except n. 19 flower in summer: the month mentioned indicates the time of ripening of the fruit.

$\$ 1$. Leaves of two sorts; floating ones more or less coriaceons, with a dilated petioled blade, different in form from the thinner submersed ones.

* Submersed leaves reduced to narrowly grass-like or filiform sessile phyllodia.

- Stems rather stout; stipules fiee; spikes all emerser, cylindrical and densel.y fruited; fruits fleshy and turgid, obliquely obovate.

1. P. nàtans, L. Stem simple or sparingly branched; floating leaves all long-petioled, elliptical or ovate, somewhat cordate at base, obtuse but with a blunt point, 2I-29-nerved; upper submersed leaves lanceolate, early perishing, the lower (later in the season) very slender $\left(3-\tau^{\prime}\right.$ long, barely $I^{\prime \prime}$ wide); upper stipules very long, acute; peduncle about the thickness of the stem; spikes $1-2^{\prime}$ long; sides of the turgid nutlet with a small deep impression in the middle; 
embryo coiled into an incomplete elliptical ring. - Ponds and ditches, N. Scotia to Va., westwarl aeross the continent. In deeper or flowing water the plant becomes more slender and often wholly submersed (var. platfxis, Koch). - Aug., Sept. (Eu., Asiu.)

2. P. Oakesiànus, liollins. Stem more slender, much l,ranclied; floating leaves smaller ( $1-1 \frac{1^{\prime}}{2}$ long), ovate- or oblong-elliptical, ulstuse, fewer(17-23-) nervell ; lowest submersed ones almost capillary (only $1-\frac{1}{2}$ " wide), continuing through the flowering seasos; spikes shorter (y-l' $1^{\prime}$ long), on peduncles much thicker then the stem; fruit smaller and more acute; sides of the turgid nutlet not at all impressed; curvature of the embryo nearly circular, its apex directed to a point ahove its base. - P'onds, and especially pools and stagnant ditches, Mass. to N. J. ; also Anticosti. Ang.

3. P. Pennsylvánicus, Cham. sitems compressed, often sinple from the creeping rootstocks; fluating leaves chiefly opposite $\left(1-3 \frac{y^{\prime}}{2}\right.$ long $), 11-17$ nerved, oblong, tapering into a short petiole, the lower gradually narrowing and passing into the submersed ones, which are very nunerons and approximate, 2-ranked, linear (2-5' long, and 1-2 $12^{\prime \prime}$ wide), 5-7-nerved, the lateral nerves slender and nearly marginal, the space within the inner nerves coarsely cellular-reticulated; stipules very obtuse; spikes numerous, about the leugth of the thickened peduncle; finit round-obocote, flattish, 3-keeled when dry ; nutlet distinctly impressed on the sides; curvature of the embryo trausversely oval. (I'. Claytonii, Tuckerm.) - Still or flowing water, N. Brunswick to S. C., west to N. Ind. and Minn. July, Aug.

+ + Like the preceding section, lut all the purts small, slender and delicate, only the fertile plants producing flouting leaves; spikes very small and jewflowered; propugated by autumn buds.

4. P. Vasèyi, Roblins. Very delicate; stem almost capillary ; floating leares oborute $\left(3-5^{\prime \prime}\right.$ long) and about the length of their filiform petioles, with 5 nerves deeply impressed beneath, cross-yeins distinct; submersed leaves filiform-linear, very attenuate $\left(1-2^{\prime} \operatorname{long}, \frac{1}{s-1 x^{\prime \prime}}\right.$ wide) and acute; stipules not adnate, scarious, long, acnte; spikes all emersed, few, interrupted-oblong, $3-5$-flowered, on a thickish peduncle; fruit oblique, round-oborate $\left(\frac{2}{3}{ }^{\prime \prime}\right.$ long $)$, compressed, slightly sharp-margined, tipped with a distinct recurved style, the sides impressed and face acute; upper portion of the embryo circularly in. curved, its apex transverse to the fruit. - Canada and N. Eng.; also Ill. The fruiting form, with floating leaves, rare; the submerged form apparently much more abundant.

5. P. lateràlis, Morong. Stem filiform, branching; floating leaves elliptical (4-6" long by 2" wide), with $5-7$ nerres deeply impressed beneath, tapering at hase into a somewhat dilated petiole shorter than the blade; submersed leares linerr, arute ( $1-3^{\prime}$ long by $f-f^{\prime \prime}$ wide), 1-3-nerved, the midnerve with fine veius or cellular reticulations on each side, bi-glandular at hase; stipules short; perluncles with a ver." peruliur luteral appearan'e, widely sprealing at maturity, sometimes even recurvel, often thicker than the stem; spikes often intermpted (2-4-flowered) : fruit obliquely ohovate (hardly $1^{\prime \prime}$ long), the hack much curved, with two fine grones upon it; embryo oval in its curve, the apex nearly tonching the base. - Mass and Mich.; rare. Undeveloped specimens resemble P. jusillus. 
+ + + Stems slender or filiform, much branched; floating leaves sometimes uanting; stipules adnate to the base of the leaf; spikes of two kinds, one emersed, cylindrical and many-flowered, on a club-shaped peduncle, the other submersed, globular and few-flowered; fruit flat, cochleate, with thin or scarcely any flesh and a thin nutlet; embryo spiral.

6. P. Spirillus, Tuckerm. Floating leaves oval to lance-oblong and lanceolate (the largest $10^{\prime \prime} \mathrm{long}, 4^{\prime \prime}$ wide), usually obiuse, about equalling the rather dilated petioles, with 5-many nerves beneath deeply impressed; upper submersed leaves either with or without a lance-oblong or broad-linear proper blade; the numerous lower ones narrow-linear, tapering toward the obtuse apex ( $\frac{3}{4}-1 \frac{1}{2}^{\prime}$ long, $\frac{1}{4}-\frac{2^{\prime \prime}}{3}$ wide) ; stipules early lacerate; submersed flowers usually so'itary on rery short erect peduncles; fruit with the back either winged and with 4-5 distinct teeth or wingless and entire; embryo coiled $1 \frac{3}{4}$ turns. Rivers, and even far up small streams, N. Eng. to Va., west to Mich. and Mo. June-Aug. - Stem less slender than in the next.

7. P. hýbridus, Michx. Floating leaves oval to lance-oblong (the largest $10^{\prime \prime}$ long, $6^{\prime \prime}$ wide), often acute, longer than the filiform petioles, with about $5-7$ nerves beneath deeply impressed; submersed leaves very numerous, almost setaceous ( $1-3^{\prime}$ long, very rarely $\frac{1^{\prime \prime}}{2}$ wide); stipules obtuse; emersed spikes 4-7" long; submersed spikes 1-4-flowered, their peduncles (of their own length) frequently recurved; fruit minute, about 8-toothed on the margin; embryo coiled $1 \frac{1}{2}$ turns. - Shallow stagnant waters, N. Brunswick to Fla., west to Mich., Mo., and N. Mex. June-Aug.

* Submersed leaves lanceolate, rarely oval or linear, membranaceous ; spikes dense, many-flowered, on stout peduncles.

8. P. ruféscens, Schrad. Stem simple; floating leaves (often wanting) $2-5^{\prime}$ long, rather thin, wedge-oblanceolate, narrowed into a short petiole, 11 17 -nerved; submersed leaves almost sessile, lanceolate and lance-oblong, smooth on the margin, fewer-nerved; stipules broad, hyaline, obtuse, upper ones acuminate; spike $1-2^{\prime}$ long, often somewhat compound; fruit obovate, len. ticular, pitted when immature, with an acute margin and pointed with the rather long style; embryo incompletely anuular. - In streams or ponds, N. Brunswick to N. J., west to Minn. and Tex. Aug., Sept. (Eu.)

9. P. flùitans, Roth. Stem often branching below; floating leaves thinnish, lance-oblong or long-elliptical, often acute, long-petioled, 17-23-nerved; submersed leaves very long $\left(3-12^{\prime}\right.$, by $2-12^{\prime \prime}$ wide), lanceolate and lance-linear, 7-15-nerved, coarsely reticulated; peduncles somewhat thickened upward; fruit obliquely oborate, obscurely 3 -keeled when fresh, and distinctly so when dry, the middle one winged above and sometimes with $3-5$ shallow indentations; the rounded slightly curved face surmounted by the short style; nutlet with the sides scarcely impressed; upper part of the embryo circularly incurved. (P. Ionchites, Tuckerm.) - In streams or rarely in ponds, N. Brunswick to N. J., west to Minn. and Iowa. Aug., Sept. (Eu.)

10. P. púlcher, Tuckerm. Stem simple, black-spotted; leaves of three kinds; floating ones becoming very large $\left(4 \frac{1}{2}\right.$ by $\left.3 \frac{1}{2}^{\prime}\right)$, roundish-ovate and cordate or ovate-oblong, 25-37-nerved, all alternate; upper submersed ones $(3-5)$ usually lanceolate, acute at base and very long-acuminate, 10-15-nerved, rery thin, cellular each side of the midrib, undulate, short-petioled; lowest (2-4 
near the base of the stem) thicker, plune, oral or ollong with a rounded base, or spatulate-oblong, on longer petioles; stipules rather short and obtuse; pedumcles thicker than the stem; fruit with a romulerl back aul angular face, pointed, distinctly 3-keeled when fresh, sharply so when dry; nutlet with two deep dorsal furrows, and a sinus below the angle in front; sicles that; embryo circularly much incurved above. - Ponds, Vt. to Ga. and Mo. July, Aug.

11. P. amplifolius, Tuckerm. Stems simple, of very variable leugth; floating leares (sometimes wanting) large, oblong or lance-ocate, sometimes slightly cordate at base, abruptly acutish, 30-50-nerved, on rather long petioles; submersed leaves often very large (reaching $\tau^{\prime}$ by $2^{\prime}$ ), lanceolate or oval, acute at each end, usually much recurved, undulate, mostly on short petioles; stipules very long and tapering to a point, soon becoming loose; peduncles thickened upwarl, in deep water much elongated; fruit very large (urer 2" long), rather obliquely obovate, 3-keeled, with a broad stont beak; nutlet slightly impresserl on the sides; upper part of the embryo curved into a ring. - Ponds and rivers, N. Eug. to N. J., west to Minn, and Kan. Aug., Sept.

12. P. Illinoénsis, Morong. Stem stout, branching towards the summit; floating leaves opposite, oval or ovate (2-5' long by $1 \frac{1}{2}-2^{\prime}$ broad), $19-$ 25-nerved, rounded or subcordate at base, with a short blunt point at apex, on short petioles; submersed leaves rather feu, oblong-elliptical, acute at each end, usually ample (largest $8^{\prime}$ by $\left.1 \frac{1}{2}^{\prime}\right)$; stipules coarse, obtuse, strongly bicarinate ( $2^{\prime}$ long); peduncles often clustered at the summit $\left(2-4^{\prime}\right.$ long), thickening upward; fruit roundish-obovate (1 $\frac{3}{4}-2^{\prime \prime}$ long), 3-keeled on the back, midclle keel prominent; nutlet flattened and slightly impressed on the sides, obtuse or pointerl at base; apex of embryo directed transversely inward. - Streams and (litches, western N. Y. to Ill., Iowa, and Minn. Very near the last.

13. P. heterophýilus, Schreb. Stem slender, very branching below; floating leaves mostly thin, variable, but with a short blunt point, 9 -15-nerved, usually $1-2^{\prime}$ long and $6-9^{\prime \prime}$ widle; submersed ones usually lanceolate or linearlanceolate, acuminate or cuspidate, narrowed toward the base, about 7 -nerved on the stem and 3-nerved on the branches; upper ones petioled, lower sessile; stipules obtuse, loose; peduneles somewhat thickened upward; fruit small, roundish, compressed, scarcely keeled ; embryo anuular alıve. (l’.gramineus, Fries.) - Still or flowing water, common. Varies exceelingly in its submersed leaves, peduucles, etc.; the var. Gramifócús (Frics), growing in rapid streans, with stems much elongated and less branched, and the flaccid submersed leaves $2-7^{\prime}$ lung by $2-10^{\prime \prime}$ wide.

Var. (?) myriophýllus, Robbins. Sending up from running rootstocks many short repeatedly dichotomous and densely leafy stems; fertile stems very slender; floating leaves small, delicate, lance-oblong, on long filiform petioles; submersed stem-leaves larger, early perishing; those of the branches (deep-green) linear-oblanceolate, very small ( $\frac{8}{4}-1^{\prime}$ long), acute, sometimes minutely serrulate; spike slender, loosely-flowered, much shorter than the thickened peduncle. - Apponaug Pond, R. I., without fruit.

13. P. Zizii, Mert. \& Koch. Resembling P. lucens, but smaller, much branched at base; upper leaves coriaceous or subcoriaccous, long-petioled and sometimes emersed, the others subsessile, all usually numerous, undulate and shining; peduncle elongated. (P. lucens, var. nimor, Nolte. Also P'. gramineus, var. (?) spathulæformis, Kiobbins; P. spathæformis, Tuckerm.; "P. vari- 
ans, Morong.") - N. Eng to Fla., and westward. Connecting with the next section. ( $\mathrm{Eu}$ )

$\S 2$. Leaves all submersed and similar, mostly sessile, membranaceous and dilated, lanceolate, oblong, or oval; stipules obtuse, becoming loose.

14. P. lùcens, L. Stem thick, branching, sometimes very large; leaves more or less petioled, oval or lanceolate, mucronate, often rough-serrulate, frequently shining; peduncles often elongated; fruit roundish and compressed, with obtuse margins, slightly keeled; embryo circularly incurved above.Ponds, N. Eng. to Fla., west to the Pacific. Ang., Sept. (Eu.)

Var. (?) Connecticuténsis, Robbins. Stem flexuous; leaves all submersed, nearly sessile, lanceolate, acuminate, crisped, not shining nor serrulate; fruit larger, distinctly keeled; nutlet thick and hard. — Lake Saltonstall, East Haven, Conn.

15. P. prælóngus, Wulf. Stem rery long, branching, flexuous; leares lance-oblong or lanceolate (sometimes $i^{\prime}$ long), half-clasping, obtuse with a boatshaped cavity at the extremity, thence splitting on pressure; stipules scarious, very obtuse; spikes rather loose-flowered; peduncles very long (sometimes reaching $20^{\prime}$ ); fruit obliquely oborate, compressed, sharply keeled when dry ; style terminating the nearly straight face; curre of the embryo oval and longitudinal. - Ponds and large rivers, N. Scotia to Mass., west to Minn. and Iowa. Sept., Oct. - Stem white; foliage bright green. (Eu.)

16. P. perfoliàtus, L. Stem branching; leares orbicular, orate or lanceolate from a cordate-clasping base, usually obtuse and often minutelr serrulate; peduncles short, cylindrical; fruit irregularly oborate, obtusely margined; embryo incurved in an oral. - Ponds and slow streams, common. N. Scotia to Fla., west to Minn. and Iowa. Sept., Oct. (Ku.)

Var. lanceolàtus, Robbins. Larger; leaves long-lanceolate from a corlate-clasping base and acuminate, wavy, $3-4 \frac{1}{2}$ long; peduncles thickened up. $w$ ird. - Same range as the species, and extending west to the Pacific.

17. P. críspus, L. Stem compressed; leaves linear-oblong, half-clasping, obtuse, serrulate, crisped-uavy, 3-nerved: fruit long-beaked; upper portion of the embryo incurred in a large circle. - Flowing and stagnant waters, Mass. to N. J. and Va., west to western N. Y. June, July. (Eu.)

18. P. Mýsticus, Morong. Stem rery slender and irregularly branching, nearly filiform $\left(1-3^{\circ}\right.$ high) ; leaves oblong-linear $\left(\frac{1}{2}-1 \frac{1}{2}\right.$ long by $2-3^{\prime \prime}$ wide), 5-i-nerved, finely nndulate and entire, obtuse or bluntly pointed, abruptly narrowing at base, sessile or partly clasping; spikes few, capitate (4-6-flowered), on erect peduncles $\left(1-2^{\prime}\right.$ long); fruit (immature) obovate, small (hardly ${ }^{\prime \prime \prime}$ 1 ing), obscurely 3-keeled on the back, a little beaked by the slender recurred style. - Mystic Pond, Medford, Mass.

$\S 3$. Leaves all submersed and similar, mostly membranaceous and sessile, linear or setaceous.

* Stipules free from the sheathing base of the leaf.

19. P. zosteræfòlius, Schum. Stem branching, wing-flattened; leares linear and grass-like (commonly $4^{\prime}$ by $\left.1 \frac{1}{2}{ }^{\prime \prime}\right)$, abruptly pointed, with many fine and 3 larger nerves; stipules (seen young) oblong, very obtuse; spikes cylindrical, 12 - 15-flowered, not half as long as the peduncle; fruit obliquely obovate, somewhat keeled and with slight teeth on the back, the sides not impressed, 
the face arching aud terminated by the shurt style; summit of the large embryo lying transwerse to the firut. (I'. compressus, Fries; not L.?) - Still and slowflowing waters, N. Eng. to N. J., Icwa, and Minn. Ang., Sept. (Ku.)

20. P. Hillii, Morong. Stem slender, widly branrking, flutish; leares linear, acute ( $1-2 \frac{1}{2}{ }^{\prime}$ loug by $\frac{1}{2}-1 t^{\prime \prime}$ wide), 3-nerved, the lateral nerves delicate and near the uargin; stjpules whitish, striate, ohtuse $(3-5)^{\prime \prime}$ long); spikes capitate (3-6-fruited), on short spreading or recurved peduncles; fruit as in the last. - Mich. and western N. Y.

21. P. obtusifolius, Merteus \& Koch. Stem flattenel, very brunching; leaves linear, tapering toward the base, ubtuse and uncronate or very acute, 3- (rarely 5-) nerced; stipules elongated, very obtuse; sprike orate, continuous, 5-8-flowered, about the length of the peduncle; fruit oval, apiculate with the style, not keeled when fresh, upper portion of embryo coiled iuward and lying transverse to the finit:- Slow streams and ponds, Canada and $\mathrm{N}$. Eng. to western N. Y. and Mich. Sept., Uct. (Eu.)

22. P. pauciflòrus, l'ursh. Sitem filiform, fluttish and very branching; leaves nurrouly linear (1-2' long and seldom $\frac{1}{2}$ " wide), acute, obscurely 3 nerved; stipules obtuse; spikes capitate, 1-4- (usually 2-) flowered, on short club-shaped peduncles; fruit roundish-lenticular ; the bach more or less crested; upper portion of the embryo incurved in a circle. - Still or stagnant waters, N. Brunswick to Ga., Iowa, Minn., and westward.

Var. Niagarénsis, Gray. Stem often longer $\left(1-3^{\circ}\right)$; leares larger $\left(1 \frac{1}{2}-\right.$ $3 \frac{1^{\prime}}{2}$ long ly $1^{\prime \prime}$ wide or less), 3-5-nerved at base, very acute and mucronate, narrowed to the subpetiolate hase. (P. Niagarensis, Tuckerm.) - Running water, Great Lakes to S. C.; also in Cal.

23. P. pusíllus, I. Stem slender, flattish or nearly cylindrical, often very hranching; leares narrou- or setaceous-linear, acumiuate, acute or subacute, 1 3-nerved, furnished with translucent glands on each side at the base; stipules at first obtuse; spikes interrupted or capitate, 2-8-flowered, on rather long peduncles; fruit obliquely elliptical, scarcely keeled ; apex of embryo incurved and directed obliquel.y downurd. - Pools and ditches, N. Scotia to N. J., west to Minn. and Mo., and westward. - Leaves sometimes almost setaceous (var. tenuissinus, $K$ holl).

Var. polyphýllus, Morong. Dwarf form (3-5' high), divaricately branching from the base, very leafy throughout; leaves very olutuse, not euspidate, 3-nerved ; non-flowering but abundantly provided with propagating buds which are formed on the thickened and hardened ends of the branches and closely invested by imbricated leaves. - In a shallow pool, S. Natick, Mass.

24. P. mucronàtus, Schraul. Resemlling P. pusillus, hut stem less branching; lenves brouder (almost $1^{\prime \prime}$ wille), offen 5-nerled: spikes interrupted. (1'. pusillus, var. major, Fries.) - N. Brunswick to western N. Y., Mich., and Minn. July. (Eu.)

25. P. gemmíparus, Rollins. Stem filiform, branching, terete, varying greatly in lreight; leaves hur-like, sometimes unt as broal as the stem, often with no apparent midrib, tapering to the finest point ( $1-3^{\prime}$ long), hi-glandular at base; stipules $\frac{1}{2}-1^{\prime}$ long; spikes few (3-6-flowered), interrupted, on long filiform peluncles; propagating buds very numerous : fruit like that of P'. pusillus, very rare. (P. pusillus, var.? gemmiparus, lioblins.) - Slow-moving streans and still water, Mass. Aug., Sę̣t. 
26. P. Tuckermàni, Robbins. Very slender and delicute from a creeping rootstock, of a fine light green ; stem filiform with several short and repeatedly dichotomous leaf-bearing branches; leaves thin and flat, but setaceous and tapering to near the fineness of a hair ( $1-4^{\prime}$ long and $\frac{1}{3}$ " extreme willth), obscurely 1-3-nerved, with a few coarse reticulations; stipules rather persistent below, $\frac{1}{3}$ 'long, obtuse; peduncle solitary, very long, rather thickened upward ; spike 48-flowered, in fruit continuous, oblong; fruit thick-lenticular, obscurely 3-keeled; nutlet slightly impressed on the sides; shell thick and hard; embryo nearly annular. - Cold ponds, White Mountains of N. H., N. Y., and N. J.

* Stipules united with the sheathing base of the leaf.

27. P. pectinàtus, L. Stem filiform, repeatedly dichotomous; leaves very narrowly linear, attenuate to the apex, 1-nerved with a few transverse veins; spikes interrupted, on long filiform peduncles; fruit obliquely broad-obovate, compressed, bluntly keeled; shell of nutlet very thick; embryo spirally incurved. - N. Brunswick to Fla., westward across the continent. Aug.-Oct. (Eu.)

28. P. marinus, L. Resembling narrow-leaved forms of the last species, low and very leaf!y; peduncles much elongated; fruit much smaller ( $\mathrm{I}^{\prime \prime}$ long) and thinner, round-obovate, not keeled upon the rounded back, tipped with the broad sessile stigma ; embryo annular. - Western N. Y., Ill., Mich., and southward. Probably the range of this species is much more extensive than indicated, as it has been confounded with $\mathrm{P}$. pectinatus.

29. P. Robbínsii, Oakes. Stem ascending from a creeping base, rigid, very branching, invested by the bases of the leaves and stipules; leaves crowded in two ranks, recurved-spreading, narrow-lanceolate or linear $\left(3-5^{\prime}\right.$ long and 2$3^{\prime \prime}$ wide), acuminate, ciliate-serrulate with translucent teeth, many-nerved ; stipules obtuse when young, their nerves soon becoming bristles; spikes numerous, loosely few-flowered, on short peduncles; fruit oblong-obovate (2" long), keeled with a broadish wing, acutely beaked; embryo stout, ovally annular. In ponds and slow streams, N. Brunswick to N. J., the N. shore of L. Superior, and far westward.

\section{R Ú P P I A, I. Diтch-grass.}

Flowers perfect, 2 or more approximated on a slender spadix, which is at first enclosed in the sheathing spathe-like base of a leaf, entirely destitute of floral envelopes, consisting of 2 sessile stamens, each with 2 large and separate anther-cells, and 4 small sessile ovaries, with solitary campylotropous suspended orules; stigma sessile, depressed. Fruit small obliquely ovate pointed drupes, each raised on a slender stalk which appears after flowering; the spadix itself also then raised on an elongated thread-form peduncle. Embryo oroid, with a short and pointed plumule from the upper end, by the side of the short cotyledon.- Marine herbs, growing under water, with long and thread-like forking stems, and slender almost capillary alternate leaves, sheathing at the base. Flowers rising to the surface at the time of expansion. (Dedicated to $H . B$. Ruppius, a German botanical author of the early part of the 18th century.)

1. R. marítima, L. Leaves linear-capillary; nut orate, obliquely erect, $1 \frac{1}{2}$ " long; fruiting peduncles capillary $\left(3-6^{\prime}\right.$ long); stipes $1-12^{\prime \prime}$ long. Shallow bays, along the eutire coast; also occasionally in saline places in the interior. (Eu., Asia, etc.) 


\section{ZAN NICHELIA, Micheli. Hormed Poniwed.}

Flowers monacions, sessile, naked, usmally both kinds from the same axil; the sterile consisting of a single stamen, with a slencler tilament bearing a 2 4 -celled auther; the fertile of $2-5$ (usmally 4 ) sessile pistils in the same cupshaped involucre, forming obliquel y oblong untlets in fruit, leated with a short style, which is tipped by an obliquely disk-shaped or somewhat 2-lobed stigma. Siced orthotropous, suspended, straight. Cotyledon tiper, bent and coiled. Slender branching herbs, growing under water, with mostly opposite long and linear threal-form entire leaves, and sheathing membranous stipules. (Named in bonor of Zannichelli, a Venetian botanist.)

1. Z. palústris, I. Style at least half as long as the fruit, which is flattish, somewhat incurved, even, or occasionally more or less toothed on the back (not wing-margined in our plant), nearly sessile; or, in var. peduncuddta, both the cluster and the separate fruits evilently peduncled. - Ponds and slow streams, throughout N. America, but not common. July. (Eu., Asia.)

\section{ZOSTERA, L. Grass-wrack. Eetegrass.}

Flowers monoccious; the two kinds naked and sessile and alternately arranged in two rows on the midrib of one side of a linear leaf-like spadix, which is hidden in a long and sheath-like base of a leaf (spathe); the sterile flowers consisting of single ovate or oval l-celled sessile anthers, as large as the ovaries, and containing a tuft of threads in place of ordinary pollen; the fertile of single ovate-oblong ovaries attached near their apex, tapering upward into an awlshaped style, and containing a pendulons orthotropous ovule; stigmas 2, long and bristle-form, deciduous. Utricle bursting irregularly, enclosing an oblong longitudinally ribbed seed (or nutlet). Embryo sliort and thick (proper cotyledon almost obsolete), with an open chink or cleft its whole length, from which protrudes a doubly curved slender plumule. - Grass-like marine herbs, growing wholly under water, from a jointed creeping stem or rootstock, sheathed by the bases of the very long and linear, obtuse, entire, grass-like, ribbon-shaped

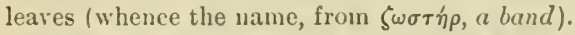

1. Z. marina, L. Leares obscurely 3-5-nerved. - Common in shoal water of bays along the coast, from Newf. to Fla. (Eu.)

\section{N À I A S, L. NAIAD.}

Flowers diocious or monocious, axillary, solitary and sessile; the sterile consisting of a single stamen enclosed in a little membranous spathe; anther at first nearly sessile, the filament at length elongated. Fertile flowers consisting of a single ovary tapering into a short style; stigmas $2-4$, aw-shaped; ovule erect, anatropous. Fruit a little seed-like nutlet, enclosed in a loose and separable membranous epicarp. Embryo straight, the radicular end downward. Slender branching herbs, growing under water, with opposite and linear leaves, somewhat crowded into whorls, spiumlose-toothed, sessile and dilated at base. Flowers very small, solitary, but often clustered with the branch-leaves in the axils; in summer. (Nä̈ás, a water-n!/mph.)

1. N. marina, I. Stem rather stout and ofen armed with broad prickles; leaves broadly linear ( $\left.3-18^{\prime \prime} \mathrm{lnng}\right)$, coarsely and sharply tonthed, the dilated base entire; fruit 2-2t" long; seed very fincly lineate. oblong, slightly compressed. 
(N. major, All.) - Marshes and salt-springs of western N. Y. and Mich. Teeth of one or more brownish cells upon a many-celled base. (Eu.)

Var. grácilis, Morong. Internodes long (1-3') and nearly naked, with only a few teeth above; leaves very narrow, the dilated base also toothed; fruit smaller. - Canoga marshes, western N. Y.; also in Fla.

Var. recurvàta, Dudley. Stems short, inclined to be dichotomously branched, recurved-spreading; leares usually recurved, the teeth prominent, the dilated base with a projecting tooth each side. - Cayuga marshes, N. Y.

2. N. fléxilis, Rostk. \& Schmidt. Stems usually very slender; leaves very narrouly linear ( $\frac{1}{2}-1^{\prime}$ long), very minutely serrulate; fruit $1 \frac{1}{2}{ }^{\prime \prime}$ long, narrowly oblong; seeds lance-oral, smooth and shining. - Ponds and slow streams, N. Scotia to S. C., Iowa and Minn. 'Teeth on the margins of the leaves 1-celled. (Eu.) - Var. Robústa, Morong. Stem stout, few-leaved, sparsely branching, elongated; leaves flat, abruptly acute.- E. Mass., Mich., and Tex.

3. N. Índica, Cham., var. gracíllima, A. Br. Branches alternate; leaves very narrowly linear, nearly capillary, straight, serrate, the rounded lobes of the sheathing base spinulose-ciliate; fruit linear, impressed-dotted betueen the numerous ribs. - Mass. to Penu., west to Ind. and Mo. Teeth of 3 cells each.

\section{Order 1:3\%. ERIOCA ULEAE. (Pipewort Family.)}

Aquatic or marsh herbs, stemless or short-stemmed, with a tuft of fibrous roo's, a cluster of linear and often loosely cellular grass-like leaves, and nuked scapes sheathed at the base, bearing dense heads of monœcious or rarely dicecious small 2-3-merous flowers, each in the axil of a scarious bract; the perianth double or rarely simple, chaffy; anthers introrse; the fruit a 2-3-celled 2-3-seeled capsule; seerls pendulous, orthotropous: embryo at the apex of mealy albumen.-- Chiefly tropical plants, a few in northern temperate regions.

1. Eriocaulon. Perianth double, the inner (corolla) tubular-funnel-form in the staminate flowers; stamens twice as many as its lobes (4). Anthers 2-celled.

2. Prepalanthus. Perianth as in the last; stamens only as many as the corolla-lobes (3). Anthers 2-celled.

3. Lachnocaulon. Perianth simple, of 3 sepals. Stamens 3, monadelphous below. Anthers I-celled.

\section{ERIOCA ÙLON, L. Pipewort.}

Flowers monœcious and androgynous, i. e. both kinds in the same head, either intermixed, or the central ones sterile and the exterior fertile, rarely dicecious. Ster. Fl. Calyx of 2 or 3 keeled or boat-shaped sepals, usually spatulate or dilated upward. Corolla tubular, 2-3-lobed, each of the lobes bearing a black gland or spot. Stamens twice as many, one inserted at the base of each lobe and one in each sinus; anthers 2-celled. Pistils rudimentary. Fert.Fl. Calyx as in the sterile flowers, often remote from the rest of the flower (therefore perhaps to be viewed as a pair of bractlets). Corolla of 2 or 3 separate narrow petals. Stamens none. Ovary often stalked, 2-3-lobed, 2-3-celled; style 1; stigmas 2 or 3 , slender. Capsule membranaceous, loculicidal. - Leaves mostly smooth, loosely cellular and pellucid, flat or concave above. Scapes or pedun- 
cles terminated by a single head, involucrate by some outer empty bracts. Flowers, also the tips of the bracts, etc., usually white-heariled or woully:

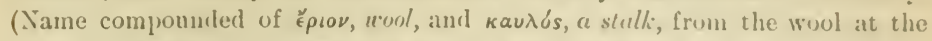
base of the scape.) - ()ur species are all stemless, wholly glabrous excepting at the base and the flowers, with a depressed head and dimerous flowers.

1. E. decangulàre, I. Lenves obtuse, varying from linear-lanceolate to linear-awl-shaped, rather rigid; scapes 10-12-ribbed (1-30 high); head homispherieal, becoming globular $\left(2-7^{\prime \prime}\right.$ wide); scales of the involuere acutish, straw-color or light brown; chaff (bracts among the flowers) pointed. - Pinebarren swamps, N. J. to Fla. July-sept.

2. E. gnaphalodes, Miehx. Lenres spreading (2-5'long), grassy-aw\%shaped, rigid, or when submersed thin and pellucid, tapering gradually to a shaip point, mostly shorter than the sheath of the 10-ribbed scape; scales of the involucre rery obtuse, turning lead-color; chaff obtuse. - Pine-barren swamps, N. J. to Fla.

3. E. septangulàre, Withering. Leaces short (1-3'long), awl-shaped, psllucid, soft and very cellular; scape 4-7-striate, slender, 2-6' high, or when submersed becoming $1-6^{\circ}$ long, according to the depth of the water; chatj acutish; head $2-3^{\prime \prime}$ broad ; the bracts, chaff, etc., lead-color, except the white coarse beard. - In ponds or along their borders, Newf. to N. J., west to Ind., Mich., aud Minn. July, Aug. (Eu.)

\section{P无PAĹ́NTHUS, Martius.}

Stamens as many as the (often involute) lubes of the funnel-form corolla of the sterile flowers, and opposite them, commonly 3 , and the flower $t$-ruary

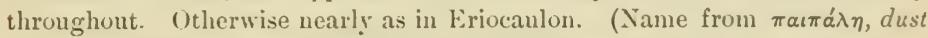

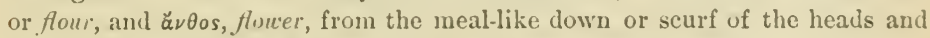
flowers of many South American species.)

1. P. flavídulus, Kunth. Tufted, stemless; leaves bristle-awl-shaped (1' long); scapes very slender, simple, mimutely pubescent (6-12' high), 5angled; bracts of the involucre oblong, pale straw-color, those among the flowers mostly obsolete; perianth glabrous; sepals and petals of the fertile flowers linear-lanceolate, scarious-white. - Low pine-barrens, s. Va. to Fla.

\section{L A CHNOCA Ù L ON, Kunth. Hairy Pipewort.}

Flowers monocious, ete, as in Eriocaulon. Calyx of 3 sepals. Corolla none! Ster. Fl. Stamens 3 ; filuments below coalescent into a club-shaped tube around the rudiment of a pistil, above separate and elongated; anthers 1-celled! Fert. Fl. () vary 3-celled, surrounded by 3 tufts of hairs (in place of a corolla). Stigmas 3 , two-cleft. - Leares linear-sword-shaped, tufted. Scape slender, bearing

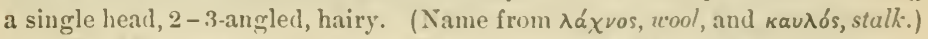

1. L. Michauxii, Kunth. - Low pine-barrens, Va. to Fla.

\section{Order 128. Cypericest. (Sedge Famly.)}

Grass-like or rush-like herls, with fibrous roots, mostly solid stems (culms), closed sheaths, and spitied chiefly 3-androus flowers, one in the axil of each of the glume-like imbricated bracts (scales, glumes), destitute of any perianth, 
or with hypogynous bristles or scales in its place; the 1-celled ovary with a single erect anatropous ovule, in fruit forming an achene. Style 2-cleft with the fruit flattened or lenticular, or 3-cleft and fruit 3-angular. Embryo minute at the base of the somewhat floury albumen. Stem-leaves when present 3-ranked. - A large, widely diffused family.

I. Flowers all perfect, rarely some of them with stamens or pistil abortive; spikes all of one sort.

Tribe I. SCIRPEAE. Spikelets mostly many-flowered, with only 1 (rarely 2) of the lower scales empty.

* Seales of the spikelet strictly 2-ranked, conduplicate and keeled.

+ Flowers destitute of bristles and of beak to the achene; inflorescence terminal.

1. Cyperus. Spikelets few - many-flowered, usually elongated or slender.

2. Kyllinga. Spikelets 1-flowered (but of 3 or 4 scales), glomerate in a sessile head.

+- + Flower furnished with bristles; achene beaked; inflorescence axillary.

3. Dulichium. Spikelets 6-10-flowered, slender, clustered on an axillary peduncle.

* * Scales of the several - many-flowered spikelet imbricated all round (subdistichous in n. 5 ).

- Achene crowned with the bulbous persistent base of the style (usually deciduous in n. 7) ; flowers without inner scales (bractlets).

++ Hypogynous bristles (perianth) generally present; culm naked.

4. Eleocharis. Spikelet solitary, terminating the culm. Stamens 3. +++ Bristles always none; culm leafy.

5. Dichromena. Spikelets crowded into a leafy-involucrate head, laterally flattened, the scales more or less conduplicate and keeled. Many of the flowers imperfect or abortive.

6. Psilocarya. Spikelets in broad open cymes. Style almost wholly persistent.

7. Fimbristylis. Spikelets in an involucrate umbel. Culm leafy at base. Style usually wliolly deciduous.

+ + Style not bulbous at base.

++ Flowers without inner scales, but bristles generally present.

8. Scirpus. Spikelets solitary or clustered, or in a compound umbel, the stem often leafy at base and inflorescence involucrate. Barbed bristles 3-8 or none. Stamens mostly 3 .

9. Eriophorum. As Scirpus, but the bristles naked, exserted and often silky in fruit. Stamens 1-3.

+++ Flower with one or more inner seales.

10. Fuirena. Scales of the spikelet awned below the apex. Flower surrounded by 3 stalked retal-like scales alternating with 3 bristles.

11. Hemicarplua. Flower with a single very minute hyaline scale next the axis of the spikelet; bristles none.

12. Lipocarpha. Flower enclosed by 2 inner scales, one next the axis, the other in front of the achene; bristles none.

Tribe II. RHYNCHOSPORE AE. Spikelets mostly 1-2-flowered, with 2-many of the lower scales empty.

13. Rhynchospora. Spikelets terete or flattish; scales convex, either loosely enwrapping or regularly imbricated. Achene crowned with a persistent tubercle or beak, and commonly surrounded by bristles.

14. Cladium. Spikelets terete, few-flowered, the scales, etc., as in the preceding. Achene destitute of tubercle. No bristles.

\section{Flowers unisexual.}

Tribe III. SCLERIEAE. Flowers monocious; the staminate and pistillate in the same or in different clustered spikes. Achene naked, bony or crustaceous, supported on a hardened disk.

15. Scleria. Spikes few-flowered; lower scales empty. No bristles or inner scales. 
Tribe IV. CARICEA. Flowers monoecions in the same (anilrogynous) or in separate spikes, or sometimes divecious. Achene enclosed in a sac (perigynium).

16. Carex. Hypogynous bristle short and enclosed in the perigynium or none.

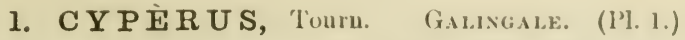

Spikelets many-few-flowered, mostly flat, varionsly arranged, mostly in clusters or heals, which are commonly disposed in a simple or compound terminal umbel. Scales 2-ranked, conduplicate and kecled (their decurrent base below often forming margins or wings to the hollow of the joint of the axis next below), deciduous when old. Stamens $1-3$. No bristles or imer scales. Style 2-3-cleft, deciduous. Achene lenticular or triangular, naked at the apex.Culms mostly triangular, simple, leafy at base, and with one or more leaves at the summit, forming an involucre to the umbel or head. I'erluncles or rays unequal, sheathed at base. All flowering in late summer or autumn.

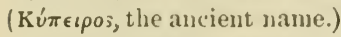

§ 1. PYCRELS. Achene lenticular, the edge turned to the rhachis; spikelet flattened, many-flowered; rhachis narrow, not winged. Annuals.

* Cinbel simple or capitate, rarely slightly compound.

1. C. flavéscens, L. Culms 4-10' high; spikelets 5-8" long; involucre 3-leaved, very unequal; spikelets becoming linear, obtuse, clustered on the 2-4 very short rays (peduneles); scales obtuse, strau-yellou; stamens 3 ; achene shining, orbicular, its superficial cells oblong. - Low grounds, N. Eng. to Mich., Ill., and southward. (Eu., etc.)

2. C. diándrus, Torr. (Pl. 1, fig. 1-4.) Spikelets lance-oblong $\left(3-9^{\prime \prime}\right)$, scattered or clustered on the $2-5$ very short or unequal rays; scales rather ohtuse, puple-brown on the margins or nearly all over; stamens 2, or sometimes 3 ; achene dull, oblong-oblorale; otherwise much like the last. - Low grounds, common from the Atlantic to Minn., Ark., and N. Mex. - Var. CAstaxet's, Torr. Scales more firm and browner; with the type.

3. C. Nuttàllii, Torr. Culms 4-12' high; spikelets lance-linear, acute and very flat ( $\frac{1}{2}-l^{\prime}$ long), crowded on the few usually very short for some of them distinct) rays; scales oblong, yellowish-brown, rather loose; stamens 2; achene oblong-obovate, very blunt, dull. - Mostly in salt or brackish marshes, along the coast, from Mass. to the Gulf.

4. C. polystàchyus, Rottb., var. leptostàchyus, Boeckl. Culms very slender, $6-15^{\prime}$ high; leaves and elongated involucre very narrow; spikelets few to many on the $4-8$ rays, linear, acute, 2-9" long; scales thin, ovate, acute, closely imbricaled, pale brown; stamens 2 ; achene linear-oblong or clavate, short-pointed, grayish and minutely pitted. (C. microdontus, Torr.) - Margins of ponds and streams, Va. to Fla. and Tex.

* * Limbel compound.

5. C. flavícomus, Vahl. Culm stont $\left(1-3^{\circ}\right.$ high $)$; leaves of the involucre $3-5$, very long; spikelets linear $\left(4-9^{\prime \prime}\right.$ long), spiked and crowded on the whole length of the branches of the several-rayed umbel, spreading; scales oval, very obtuse, yellowish and bronnish, broully scarious-(uhilish-) margined; stamens 3; achene obovate, mucronute, blackish. - Low grounds, Va. to Fla. 
§ 2. CYPERUS proper. Achene triangular; spikelets usually many-flowered, more or less flattened, with carinate scales, the rliachis marginless or nearly so (winged in n. 12).

* Stamen I; spitielets short and small (1 $\frac{1}{2}-5^{\prime \prime}$ long) in globular heads, ovate or linear-oblong, many-flowered; achene oblong-obovate to linear.

-Low annuals; involucre 2-3-leaved; heads few; scales pointed.

6. C. aristàtus, Rottb. Iwarf $\left(1-5^{\prime}\right.$ high); spikelets chestnut-brown, oblong becoming lineur, 7 -13-flowered, in 1-5 ovate heads (sessile and clustered, or short-peduncled); scales nerved, tapering to a long recurved point: achene oblong-obovate, obtuse. (C. inflexus, Muhl.) - Sandy wet shores; common. Sweet scented in drying.

7. C. acuminàtus, Torr. Slender $\left(3-12^{\prime}\right.$ high); spikelets ovate, hecoming oblong, 16-30-flowered, pale; scales obscurely 3-nerved, short-tipped; achene oblong, pointed at both ends. - Low ground, Ill. and southwestward.

++ Tall perennial $\left(1-4^{\circ}\right.$ high); heads many, greenish; scales pointless.

8. C. calcaràtus, Nees. Culm obtusely triangular; leaves and involucre very long, keeled; umbel compound, many-rayed; spikelets ovate ( $1 \frac{1}{2}{ }^{\prime \prime}$ long), in numerous small heads • achenes pale, linear, on a slender stipe; scales narrow, acntish, obscurely 3-nerved. (C. vireus, Gran, in part; not Michx. C. Luzulæ, var. umbellatus, Britt.) - Wet places, Deı. to Fla. and Tex.

* * Stamens 3 (2 in C. fuscus); spikelels clustered on the rays of a simple umbel (or in a single sessile head); scales mostly green or greenish and many-nerved, abruptly sharp-pointed; achene obovate, sharply triangular.

+ Lou annuals.

9. C. compréssus, L. Culms $3-9^{\prime}$ high, with a simple sessile or a few umbellate clusters of oblong to linear spikelets (15-30-flowered and $3-8^{\prime \prime}$ long) with crowded strongly keeled and very acute pale scales. - Sterile fields along the coast, Md. to Fla. and Tex.; also adventive near Philadelphia.

C. Fúscts, L. Of similar habit; spikelets much smaller (2-4" long), the thin brown scales (greenish only on the keel) barely acutish and very faintly nerved. - Revere Beach, Mass. (Young); on ballast at Philaclelphia. (Adv. from Eu.)

+ + Perennial, propagating from hard clustered corms or bulb-like tubers.

10. C. Schweinitzii, Torr. Culm rough on the angles $\left(1-2^{\circ} h u g h\right)$; umbel 4-8-rayed, rays very unequal, erect ; spikelets loosely or somewhat remotely 6-12-flowered, with conex many-nerved scules ; joints narrowly winged. - Dry saudy shores and rilges, western N. Y. and Penn. to Minn. and Kan.

11. C. filicúlmis, Vahl. Culm slender, wiry, often reclined (8-15' high); leaves linear ( $\frac{1}{2}-2^{\prime \prime}$ wide) or filiform ; spikelets mumerous and clustered in one sessile dense head, or in $1-7$ additional looser heads on spreading rays of an irregular umbel; joints of the axis naked; scales blunt, greenish. - Dry sterile soil; common, especially southward.

12. C. Gràyii, Torr. Culın thread-form, wiry $\left(6-12^{\prime}\right.$ high); leaves almost bristle-shaped, channelled; umbel simple, 4-6-rayed; spikes 5-10 in a loose head, spreading; joints of the axis winged; scules rather obtuse, greenishchestnut-color. - Barren sands, Plymouth, Mass., to N. J., near the coast. 
§ 3. PAPỲRUS. Style 3-clefl; achenetriungular; stamens 3; spikelets many. flowered, flattened, the carinate scales decurrent upon the thachis as scarinits uings; sprikes in simple or compound umbels.

* Wings of the rhachis soon separating to the base as a pair of fiee scales; annuul.

13. C. erythrorhizos, Muhl. (Pl. 1, fig. 5-8.) Culın olitusely triangular $\left(3^{\prime}-3^{\circ}\right.$ high); umbel many-rayed; involucre 4-5-leavell, very long; involucels bristle-form; spikelets very numerons, (rowded in ob]ong or cylindrical nearly sessile heads or spikes, spreading horizontally, linear, flattish (36" long), bright chestmut-colored; seales lanceolate, mucronulate. - Alluvial lanks, L. I. to l'enn., Mich., Minn., and southward; also adventive in N. Eng.

* * Wings of the rhachis persistently attached; perennial by slender running rootstocks.

+ Achene round-obovate; scales mucronute or acnte, free or spreading.

14. C. Háspan, I. Culms sharply angled (1-1 $\frac{1}{2}^{\circ}$ high $)$; leaves linear, often reduced to membranous sheaths; unbel spreathing, the filiform rays mostly longer than the 2-leaved involucre; spikelets narrowly linear; scales light reddishbrown, oblong, mucronate, 3-nerved. - l'onds and ditches, Va. to Fla. and Tex.

15. C. dentàtus, Torr. (l'l. 1, fig. 9.) Culms slender $\left(1^{\circ}\right.$ high $)$; leaves rigid and keeled; umbel erect, shorter than the 3-4-leaved involucre; scales reddish-brown, with green keel, ovate, acute, i-nerved. - Sanly swamps, N. Eng. and northern N. Y. to S. C. and IV. Ya. Spikes often abortive and chauged into leafy tufts.

++ Achene linear to oulong; scales uppressed, pointless or nearly so.

$\rightarrow$ Perennial by tuberiferous stolons.

16. C. rotúndus, L. (Nur-Grass.) Culm slender $\left(\frac{1}{2}-1 \frac{1}{2}^{\circ}\right.$ high), longer than the leaves; umbel simple or slightly compound, about equalling the involucre; the few rays each bearing $4-9$ tlark chestnut-purple 12-40-flowered acute spikelets (t-9" long); scales ovate, closely appressed, nerveless except on the keel. - Sandy fields, Va. to Fla. and Tex.; also adrentive near I'biladelphia and New York city. (Eu.)

17. C. esculéntus, L. Culm ( $1-2 \frac{1}{2}^{\circ}$ high) equalling the leaves; umbel often compound, 4-7-rayed, much shorter than the long involucre; spikelets numerous, light chestnut or straw-culor, acutish; 12-30-flowered (4-7" long) ; scales ovate or orate-oblong narrouly scarions-margined, nerved, the acutish tips rather loose; achene oblong-obovate. (C. phymatodes, Muhl.) - Low grounls, along rivers, ete., N. Brunswick to Fla., west to Minn. and Tex.; spreading exteusively by its small nut-like tubers and becoming a pest in cultivated grounds.

+ + Perennial, propaguting by corm-like tubers from the base; spikelets nurrou, acuminate, ofien teretish; scales oblong-lanceolate; uchene linear-oblong.

18. C. strigòsus, I. Culm mostly stout $\left(1-3^{\circ}\right.$ high $)$; most of the rạs of the nmbel elongated $\left(1-5^{\prime}\right)$, their sheaths 2-bristled; sprikelets 5-25-Aouered, spreading; scales several-nerved, much longer than the achene. - Damp or fertile soil, Canada to Fla., west to Minn., Tex., and the Yacific. Very variable in the number and length of the rays of the simple or compouml umbel, and in the size of the spikelets ( $2 \frac{1}{2}-6$ or even $12^{\prime \prime}$ long), more or less densely crowded on the axis. 
§4. DICLfDIUM. Style 3-cleft; spikelets narrow, terete or nearly so, fewmany-flowered, the scales closely appressed and the broad wings of the jointed rhachis enclosing the triangulur achene.

19. C. speciòsus, Vahl. Culm stout, mostly low (5-20' high); rays of the simple or componnd umbel mostly all short and crowded; spikelets 10-20flowered, yellowish-brown at maturity $\left(3-7^{\prime \prime}\right.$ long), the short joints of its axis winged with very broar scaly margins which embrace the ovate triangular achene; the scales ovate, oltusish, inbricately overlapping. (C. Michauxianus, Gray, Manual; not Schultes.) - Low grounds and sandy banks, N. Eng. to Fla., west to Minn. and Tex.

20. C. Engelmánni, Stend. Resembles n. 19; but the spikelets more slender and terete, somewhat remotely 5-15-flowered, the zigzag joints of the axis slender and narrowly winged, and the oblong or oval broadly scarious scales proportionally shorter, so as to expose a part of the axis of each joint, the successive scales not reaching the base of the one above on the same side; achene oblonglinear, very small. - Low grounds, Mass. to Wisc. and southward.

§5. MARÍSCUS. Spikelets 1-4-flowered, subterete, usually in dense heads; scales appressed, several-nerved, the lower empty and often persistent after the fall of the rest of the spikelet; joints of the rhachs winged, enclosing the triangular achene. Perennial.

* Spikelets slender and acuminate, more or less refracted in usually close umbelled spikes. - Connecting with $\$ 4$.

21. C. Lancastriénsis, Porter. Culm $\left(1-2^{\circ}\right.$ high $)$ triangular; leaves rather broadly linear; umbel of $6-9$ mostly elongated rays; spikelets very numerous in short-oblong close heads, suon reflexed, of 3-6 narrow scales, the upper and lower empty, twice the length of the linear-oblong achene, which is nearly $\mathbf{l}^{\prime \prime}$ long. - Rich soil, Penn. and N. J. to Ala.

22. C. retrofráctus, Torr. Culm and leaves usually minutely downy and rough on the obtusish angles $\left(1-3^{\circ}\right.$ high $)$; umbel many-rayed; spikelets slender-aul-shaped, very numerous in obovate or oblong heads terminating the elongated rays, soon strongly reflexed, 1 - 2-flowered in the middle $\left(3-5^{\prime \prime}\right.$ long); scales usually 4 or 5 , the two lowest orate and empty, the fertile lanceolate and pointed, the uppermost involute-awl-shaped; achene linear, $1_{4}^{1 / \prime}$ long. Sandy fields, N. J. to Fla. and Tex.

23. C. refráctus, Engelm. Culm $1-2^{\circ}$ high ; rays usually more or less elongated; spikelets very slender, in rather loose heads, divaricate or more or less reflexed, 2-4-flowered; achene linear, $1 \frac{1{ }^{\prime \prime}}{4}$ long. - N. J. to N. C. and Mo. * * Spikelets very short, blunt, in densely compacted globose or cylindrical heads.

24. C. ovulàris, Torr. Culm sharply triangular $\left(6^{\prime}-2^{\circ}\right.$ high $)$; umbel 1 -6-rayed; spikelets $(50-100)$ in a globular head, 3-flowered, oblong, Ulunt $\left(1 \frac{1}{2}-\right.$ $2^{\prime \prime}$ long); scales ovate, obtuse, a little longer than the orate-oblong achene. Sandy dry soil, southern N. Y. to Fla., west to Ill., Ark., and Tex. - Var. roBústrs, Boeckl., is a form with large heads $\left(4-8^{\prime \prime}\right.$ long), the spikelets $3-$ 4-flowered. (C. Wolfii, Wood.) - Ill. to Ark., and southward.

25. C. Torrèyi, Britton. Like the last, but the heads cylindrical or oblong, spikelets usually 2-flowered, and achene linear-oblong. - L. Island to Fla., west to Tex. 


\section{KYLLÍNGA, Rottboell. (Pl. 1.)}

Spikelets of 3 or 4 two-ranked scales, $1-1 \frac{1}{2}$-flowered; the 2 lower scales minute and empty, as in Cyperus, $\$ 4$, but style oftener 2-rleft and achene lenticular; spikes densely aggregated in solitary or triple sessile heads. Culms leafy at base; involucre 3-leaved. (Named after P'eter Kylling, a I)anish botanist of the 17th century.)

1. K. pumila, Michx. Annual; culms 2-9' high; head globular or 3-lobed, whitish-green (about $4^{\prime \prime}$ broall); spikelets strictly 1-flowered; upper scales orate, pointed, rough on the keel; stamens and styles 2; leaves linear - Low grounds, Ohio to Ill., south to Fla. and 'Tex. Aug.

\section{DULÍ C В I M, Pers. (Pl. 1.)}

Spikelets many- (6-10-) flowered, linear, flattened, sessile in 2 ranks on axillary solitary peduncles emerging from the sheaths of the leaves; scales 2ranked, lanceolate, decurrent, forming flat wing-like margins on the joint beluw. Perianth of 6-9 downw:trdly barbed bristles. Stamens 3. Style 2-cleft above. Achene flattened, linear-oblong, beaked with the long persistent style. $-A$ perennial herb, with a terete simple hollow culm $\left(1-2^{\circ}\right.$ high $)$, jointed and leafy to the summit; leaves short and flat, linear, 3-ranked. ( $\mathrm{An}$ alteration of Dulcichinum, an old name for a species of Cyperus.)

1. D. spathàceum, Pers. - Borders of ponds, N. Scotia to Fla., west to Minn. and Tex. July-Sept.

\section{ELEÓ CHARIS, R. Br. Spike-Rúsir. (Pl. 3.)}

Spikelet single, terminating the naked culm, many-several-flowered. Scales imbricated all round in many (rarely in 2 or 3) ranks. Periantl of 3-12 (commonly 6) bristles, usually rough or barbed downward, rarely ohsolete. Stamens 2-3. Style 2-3-cleft, its bulbous hase persistent as a tubercle jointed upon the apex of the lenticular or triangular achene. - Leafless, chiefly perenuial, with tufted culms sheathed at the base, from matted or creeping rootstocks; flowering in summer. (Name from $\tilde{\epsilon} \lambda o s, a$ marsh, and $\chi \alpha a i \rho \omega$, to deliglıt in; being marsh plants.)

§1. Spikelet terete, hurdly if at all thicker than the spongy-cellular culm; scales firmly persistent; style mostly 3-cleft; bristles 6 (rarely 7 ), firm or rigid, mostly barbed dounward, equalling or surpassing the triangular or lenticular achene.

* Sipikelet linear or lanceolate-awl-shaped, few-flowered; scales (only 3-9) fewranked, convolute-clasping the long flattened joints of the axis, lanceolute, herbaceous (green) and several-nerved on the back, and with thin scarious margins.

1. E. Robbínsii, Oakes. Flouer-bearing culms exactly triangular, rather stout, erect $\left(8^{\prime}-2^{\circ}\right.$ high $)$, also producing tufts of cajillary abortive stems or fine leaves, which fluat in the water; sheath obliquely truncate; spikelet 410" long; achene oblong-obovate, triangular, minutely reticulated, ahout half the length of the bristles, tipped with a flattened awl-shaped tubercle. - Shallow water, N. Eng. to Fla. 
* * Spikelet cylindrical, many-flowered, 1-2' long; scales in several rnnks, firmcoriaceous with scarious margin, pale, nerveless or faintly striate; culms large and stout $\left(2-4^{\circ}\right.$ high $)$; basal sheaths often leaf-bearing.

2. E. equisetoides, Torr. Culm terete, knotted as if jointed by many cross-partitions; achene smooth (the minute reticulation transversely linearrectangular), with a conical-beaked tubercle. - Shallow water, R. I. to Fla., west to Mich. and Tex.

3. E. quadrangulàta, R. Br. (Pl. 3, fig. 6-9.) Culm continuous and sharply 4-angled; achene finely reticulated, with a conical flattened distinct tubercle. - Shallow water, central N. Y. to Mich., and southward; rare.

§ 2. Spikelet terete and turgid-orate, much thicker than the very slender culm; scales thin-coriaceous or firm-membranaceous, persistent, ovate; style 3-cleft; bristles stout, barbed dounuard (or sometimes upuard), as long as the striate and pitted-reticulated triangular achene and its tubercle; culms tufted from fibrous roots, $1-2^{\circ}$ high.

4. E. tuberculòsa, R. Br. (Pl. 3, fig. 10.) Culms flattish, striate; spikelet 3-6" long, many-flowered; tubercle flattish-cap-shaped, as large as the body of the achene. - Wet sandy soil, from Mass. alung the coast to Fla.

5. E. tórtilis, Schult. Culms sharply triangular, capillary, twisting when dry ; spikelet 2-3" long, few-flowered; conical-beaked tubercle much smaller than the achene. (E. simplex, Torr.) - Eastern shore of Md. to Fla.

§3. Spilielets terete, much thicker than the culm, many-flowered; scales imbricated in many or more than 3 ranks, thin-membranaceons or scarious, with a thicker midrib, usually brounusn or purplish, sometimes deciduous.

* Style 2-cleft (often 3-cleft in $\mathrm{n} .7$ and 10) and the smooth achene lenticular: culms slender or thread-form, terete or compressed.

+ Annuals; culms tufted, from fibrous roots.

6. E. capitàta, R. Br. Culms terete, $\frac{1}{4}-8^{\prime}$ high or more; spikelets ovate to oblong ( $1-3^{\prime \prime}$ long), obtuse, 15 -40-flowered; scales thickish, round-ovate, obtuse, brown or brownish with green keel and paler margins; stamens 2 ; achene obovate, black, about equalling the 6-8 bristles, tipped with a flattened or sallcer-shaped tubercle. (E. dispar, E.J.Hill.) - In sand or gravel near sloughs, Md. (Canby) to Fla. and Tex.; N. Ind. (Hill). (S. Am., etc.)

7. E. ovàta, R. Br. Culms nearly terete, $8-14^{\prime}$ high; spikelet gloloseovoid to ovate-oblong, obtuse, 1-6" long (dull brown) ; scales very obtuse, densely crouded in many ranks; style 3- (rarely 2-) cleft; achene obovate with narrow base, pale-brownish, shining, shorter than the 6-8 bristles, broader than the short-deltoid, acute and flattened tubercle. (E. obtusa, Schult.) - Muddy places, N. Brunswick to Minn., south and westward. Variable as to the length of its lristles. A low form, with smaller and more narrowly obovate achenes, and the bristles very short or none, is E. diandra, Wright. A dwarf form occurs with very small and few-flowered heads. (Eu.)

8. E. Engelmánni, Steud. Like the last; spikelets usuaìy narrowly cylindrical and acute or acutish, 2-8" long; achene broad and truncate, the tubercle covering the summit; bristles not exceeding the achene. (E. obtusa, var. detonsa, Gray.) - Mass. to Peun. and Mo. 
$\leftarrow+$ Perenniuls, with running rootstorks.

9. E. olivàcea, Torr. (Pl. 2, fig. 1-5.) Culms flattish, grooved, diffusely tufted on slender matted rootstocks (2-4' high); spikelet orale, acutish, 20-30-flouered; scules orate, obtuse, rather loosely imbricated (purple with a green midrib and slightly s(arious margins); achene obovate, dull, abruptly beaked with a narrow tubercle, shorter than the 6-8 bristles. - Wet, sandy soil, Mass. to N. C., and western N. Y.

10. E. palústris, R. Br. Culms nearly terete, striate, $1-5^{\circ}$ ligh ; spikelct oblong-lanceolute, pointed, muny-flowered ; scales ovate-oblong, loosely imbricated, reddish-brown with a broal and translucent whitish margin and a greenish keel, the upper acutish, the lowest rounded and often enlarged; achene rather narrowly obovate, somewhat shining, crowned with a short ovate or ovate-triangular flattened tubercle, shorter than the usually 4 bristles. - Very common, either in water, when it is pretty stout and tall, or in wet grassy grounds, when it is slender and lower. (En., Asia.) - Var. Gudtcéscess, Gray. Culms slender or filiform ; tubercle narrower, acute, beak-like, sometimes half as long as the achene. With the type.-Var. cás, Gray. Bristles none; tubercle short, but narrower than in the type.-Var. vigess, L. H. Bailey. Culms very stout, rigid; achene more broally obovoid. Lake Champlain and along the Great Lakes to Minn.

\section{* Achene triangular or turgid; style 3-cleft}

- Bristles at least equalling the smooth achene, downwardly barbed, persistent.

11. E. rostellata, Torr. Culms flattened and striate-grooved, wiry, erect $\left(1-21_{2}^{\circ}\right.$ high), the sterile ones reclining, rooting and proliferous from the apex $\left(1-2^{\circ}\right.$ high), the sheath transversely truncate; spikelet spindle-shaped, 12-20flowered; scales ovate, obtuse (light-brown); achene obovate-triangular, narrowed into the confluent pramidal tubercle, which is overtopped by the $4-6$ bristles. - Marshes, $\mathbf{N}$. Eng. to S. C., west to Mich. and Ky.

12. E. intermèdia, Schultes. C'ulms capillary, wiry, striate-grooved, densely tufted from fibrous roots, diffusely spreading or reclining $\left(6-12^{\prime}\right.$ long $)$; spikelet oblong-ovate, acutish, loosely $10-20$-flowered (2-3" long) ; scales oblong, obtuse, green-keeled, the sides purplish-brown; achene obovoid with a narrowerl base, beaked with a slender conical-awl-shaped distinct tubercle, which nearly equals the 6 bristles. - Wet slopes, l'enn. to Iowa, north to Canada.

13. E. Torreyàna, Boeckl. Like the preceding, hut more capillary and hears smaller ( $1 \frac{1}{2}-2^{\prime \prime}$ long), sometimes proliferous, the one or more short new culms from the axil of its lowest scale, which persists as an herbaceous bract; achene very much smaller, with sharper angles and a short conical tuhercle, which is hardly equalled by the $3-6$ slender bristles. (E. microcarpa, var. filiculmis, Torr.) - Wet pine-harrens, N. J. to Fla.

+- Bristles 2-4, shorter than the achene, slender and fragile, or none.

14. E. ténuis, Schultes. Culms almost capillary, erect from running rootstocks, 4-ungular and flattish ( $1{ }^{\circ}$ high), the sides concave; spikelet ellijtical, acut. ish, 20-30-flouered ( $3^{\prime \prime}$ long) ; scules ovate, oh/use, chestunt-purple with a broad scarious margin and green keel; achene obocute, roughish-urinkled, crouned with a small depressed tubercle, persistent after the fall of the scales; bristles $\frac{1}{2}$ as long as the achene or uone. $-\mathrm{N}$. Seotia to N. C., Minn., anil Mo. June. 
15. E. compréssa, Sullivant. Culms flut, striate, tufted, erect $\left(1 \cdots 2^{\circ}\right.$ high); spikelet ovate-oblong, or at length lanceolate, 20-30-flovered (4-7" long); scales lanceolate-ovate, acute, dark purple with broad white pellucid margins and summit; achene yellowish, obovate-pear-shaped, obtusely triangular, wrinkled, crouned with a small conical and pointed tubercle; bristles 1-4, very slender, fragile, shorter than or equalling the achene (sometimes none or a single rudiment). - Wet places, N. Y. and Ont. to Minn. and Mo.

16. E. melanocárpa, Torr. Culms flattened, grooved, wiry, erect (9$18^{\prime}$ high); spikelet cylindrical-ovoid or oblong, thick, obtuse, densely many-flowered $\left(3-6^{\prime \prime}\right.$ long); scales closely many-ranked, roundish-ovate, very obtuse, brownish with broad scarious margius; achene smooth, obovate-top-shaped, obtusely triangular, the broad summit entirely covered like a lid by the flut depressed tubercle, which is raised in the centre into a short abrupt triangular point; bristles often obsolete; achene soon blackish. - Wet sand, Mass. to Fla.

17. E. tricostàta, Torr. Culms flattish $\left(1-2^{\circ}\right.$ high $)$; spikelet soon cylindrical, densely many-flowered (6-9' long), thickish ; scales ovate, very obtuse, rusty brown, with broal scarious margins; achene obovate, with 3 prominent thickened angles, minutely rough-urinkled, crowned with a short-conical acute tubercle; bristles none. - N. J. to Fla.

18. E. Wólfii, Gray. Culms slender ( $1^{\circ}$ high $)$, from very small creeping rhizomes, 2-erlgerl; spikelet ovate-oblong, acute; scales ovate-oblong, obtuse, scarious, pale purple; achene pyriform, shining, with 9 nearly equidistant obtuse ribs and transverse urinkles between them; tubercle depressed, truncate, more or less apiculate; bristles not seen. - IVet prairies, N. Iowa and S. Minn.

\$ 4. Spikelet more or less flattened, thicker than the slender or capillary culm, few-many-flowered; the thin membranaceous scales somewhat 2-3-ranked; style 3-cleft; bristles of the perianth 3-6, fragile or fugacious. Small or delicate species, differing fiom the last division chiefly in the flattish spikelets.

* Tubercle contracted at its junction with the achene.

19. E. aciculàris, R. Br. Culms finely capillary $\left(2-8^{\prime}\right.$ long), more or less t-rmulur; spikelet 3-9-flowered; scales ovate-oblong, rather obtuse (greenish with purple sides); achene obovate-oblong, with 3-ribbed angles and 2-3 times as man!y smaller intermediate ribs, also transversely striate, longer than the 3-4 rery fugacious bristles; tubercle conical-triangular. - Muddy shores, across the continent. (Eu., Asia.)

20. E. pygmæa, 'Torr. Culms bristle like, flattened and grooved $\left(1-2^{\prime}\right.$ ligh); spikelet orate, 3-8-flowered; scales ovate (greenish), the upper rather acute; achere oroid, acutel!y trianyular, smooth and shining, tipped with a minute tubercle; bristles mostly longer than the fruit, sometimes wanting. Brackish marshes, from N. Brunswick to Fla.

* * Tubercle continuous with the nutlet and not contracted at base.

21. E. pauciflòra, Link. Culms striate-angled, very slender (3-9' high), scarcely tufted, on slender running rootstocks, with a short truncate sheath at base; scales of the orate spikelet evidently 2-ranked, chestnut-brown, pointless, all flower-bearing, the two lower larger; bristles $3-6$, about as long as the conspicuonsly beaked triangular achene. (Scirpus pauciflorus, Lightfoot.) Wet places, N. Y. to N. Ill. and Minn., north and westward. (Fu., Asia.) 


\section{DICH R Ò MEN A, Kichard. (I'l. 4.)}

Spikelets aggregated in a terminal leafy-involucrate head, more or less compressed, few-Howered, all but 3 or 4 of the flowers usually imperfect or abortive. Scales imbricated somewhat in 2 ranks, more or less conduplicate or boat-shaped, keeled, white or whitish. Stamens 3. Style z-cleft l'erianth, bristles, etc., none. Achene lenticular, wrinkled transversuly, arowned with the persistent and broal tubercled base of the style. - C'ulms leafy, from creepr ing perennial rootstucks; the leaves of the involucre mostly white at the bisie (whence the name, from $\delta$ is, dunbie, and $\chi \rho \hat{\omega} \mu \alpha$, color).

1. D. leucocéphala, Michx. Culm triangular $\left(1-2^{\circ}\right.$ high $)$; leaves narrow; those of the involucre $4-7$; achene truncate, not margined. - I)amp) pine-harrens, N. J. to Fla. Aug., Sept.

2. D. latifolia, Ballwin. (1'l. 4, fig. 1-5.) Culm stonter, nearly terete; leaves broadly linear, those of the involucre 8 or 9 , tapering from base to apex; achene round-obovate, faintly wrinkled, the tubercle decurrent on its edges. - Low pine-barrens, Va. to Fla.

\section{PSILOCÁRYA, Torr. BALD-Resir. (Pl. 4.)}

Spikelets ovoid, terete, the numerous scales all alike and regularly imbricated, each with a perfect flower. Perianth (bristles) wholly wanting. Stamens mostly 2. Style 2-cleft, its base or the greater part of it enlarging aud hardening to form the beak of the lenticular or tumil more or less wrinkled achene. - Annuals, with leafy culms, the spikelets in terminal and axillary

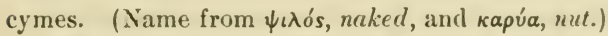

1. P. scirpoides, 'Torr. Annual (4-10' high), leafy; leaves flat; spikelets 20-30-flowered; scales oblong-ovate, acute, chestnut-colored; achene somewhat margined, beaked with a sworl-shaped almost wholly persistent style. (Rhynchospora scirpoides, Gray.) - Inumlated places, S. N. Eng.

\section{FI M B R Í S T Y I S, Vahl. (l’l. 3.)}

Spikelets several-many-flowered, terete; scales all floriferous, regularly imbricated in several ranks. Perianth (bristles, etc.) none. Stamens 1-3. Style 2-3-cleft, often with a dilated or tumirl base, which is deciduous (except in n. 4) from the apex of the naked lenticular or triangular achene. Otherwise as in Scirpus. - Culms leafy at base. Spikelets in our species umbellel, and the involucre 2-3-leaved. (Name compounderl of fimbriu, a fringe, ani st.jlus, style, which is fringed with hairs in the genuine species.)

* Style 2-cleft, flattened and ciliate; achene lenticular ; tubercle soon deciduous ; spikelets many-flowered.

1. F. sp̈adícea, Vahl, var. castànea, Gray. Culms $\left(1-2 \frac{1}{2}{ }^{\circ}\right.$ high) tufted from a perennial root, rigid, as are the thread-form comrolute-channelled leaves, smooth; spikelets ovate-oblong becoming cylindrical, dark chestmutcolor (2" thick); stamens 2 or 3 ; achene very minutoly striute and reticulated. - Salt marshes along the coast, N. Y. and N. J. to Fla. July-Sept. - Seales lighter colored than in the tropical form.

2. F. láxa, Valıl. (11.3, fig. 1-5.) Culms sleuder $\left(2-12^{\prime}\right.$ high) from an unnual ront, weak, grooverl and thattish; lcuves limur, fat, riliute-denticulat. 
glaucous, sometimes hairy ; spikelets ovate, acute ( $3^{\prime \prime}$ long); stamen 1 ; achene conspicuonsly 6-8-ribled on each side, and with finer cross-lines. - Low ground, Penn. to Fla., west to 11l. and La. July-Sept.

* * Style 3-cleft and achene triangular; tubercle soon deciduous; spikelets smaller and feuer-flowered.

3. F. autumnàlis, Roem. \& Schult. (Pl. 3, fig. 6-9.) Annnaı (3$16^{\prime}$ high), in tufts; culms flat, slender, diffuse or erect; leaves flat, acute; umbel componnd; spikelets oblong, acute ( $1-2^{\prime \prime}$ long), single or $2-3$ in a cluster; scales ovate-lanceolate, mucronate; stamens 1-3. - Low grounds, Maine to Fla., west to 11l. and La.

* * Style 3-cleft, filiform and not ciliate; achene acutely triangular; tubercle more or less persistent.

4. F. capillàris, Gray. Low annual, densely tufted $\left(3-9^{\prime}\right.$ high $)$; culm and leaves nearly capillary, the latter short; umbel compound or panicled; spikelets (2" long) oroid-oblong; stamens 2 ; achene minutely wrinkled, very obtuse. - Sandy fields, N. Eng. to Fla., west to Minn., Tex., and the Pacific.

F. VÁHL11, Link (F. congesta, Torr.), a diminutive southern species, with long filiform leaves, sessile capitate spikelets, narrow acuminate scales, and the style 2-cleft and not ciliate, has been found in ballast-sand along the northeru coast.

\section{SCÍRPUS, Tourn. Brlrusir or Club-Resir. (Pl. 3.)}

spikelets several-many-flowered, solitary or in a terminal eluster which is subtenderl by a 1 -sereral-leaved involucre (this when simple often appearing like a continuation of the (ulm), terete, the scales being regularly imbricated all round in many or several ranks, or rarely somewhat compressed and the fewer scales inclining to be 2-ranked. Flowers to all the scales, or to all but one or two of the lowest, all perfect. Perianth of 3-6 mostly retrorsely barbed or ciliate bristles (not elongate(l), or sometimes wanting. Stamens inostly 3. Style 2-3-cleft, simple, not bulbons at base, wholly deciduous, or sometimes leaving a tip or point to the lenticnlar or triangular achene. - Culms sheathed at base; the sheaths usually leaf-bearing. Mostly perennials; flowering in summer. ('The Latin name of the Bulrush.)

* Spikelets solitary, feu-flowered, small, often flattish : achene triangular, smooth.

+ Involucre a short aul-shaped bract: rulms tnfted (3-12' high), filiform.

1. S. cæespitosus, L. Culms terete, wiry, densely sheathed at base, in compact turfy tufts; the upper sheath bearing a very short aul-shaped leaf; spikelet oroid, rusty-color; involucral bract a rigid-pointed scale, resembling the lowest proper sale of the spikelet and scarcely surpassing it; bristles 6 , smooth, longer than the abruptly short-pointed achene. - Coast of Maine, alpine sumnits of N. Eng., swamps of northern N. Y., N. Ill., Minn., and northward; also on Roan Mt., N. C. (Eu.)

2. S. Clintònii, Gray. Culms acutely triangular, almost bristle-like; sheaths at the base bearing a very slendor almost bristle-shaped leaf shorter (usually very much shorter) than the culm; involucral bract awl-shaped, mostly shorter than the chestnut-colored ovate spikelet, which has pointless scales; otherwise as the next. - Rather dry plains, N. Y. Jume. 
3. S. planifolius, Muhl. Culms triangulur, lerify at base; leaves linear, flat, as lony as the culm, and like it rough-edged; involucral bract it bristletipped seale usually overtupping the ovate or oblong chestnut-colored spikelet, the green millrib of the scules extended into shomp points; bristles upuardly hairy, as long as the pointless achene. - Dry or moist ground, N. Eing. to Del., west to western N. Y. and I'enu. ; W. Mo (B. F. Bush.).

+ + One-leaved involucre more conspicuous, and as if continuing the culm.

4. S. subterminàlis, Torr. Aquatic; culms $\left(1-3^{\circ}\right.$ long, thickish-filiform) partly and the shorter filiform leaves wholly submersed, cellular; the filiform green bract 6-12" long, much surpassing the oblong spikelet; scales somewhat pointed; bristles 6 , bearded (luwwward, rather shorter than the abruptly-pointed achene. - Slow streams and pouds, N. Eng. to N. J., west to Mich. and X. Incl. - Var. TEßnéstus, P'ane; less tall, with firmer stem aud leaves, and fruiting spike more turgid. Growing chiefly emersed; Herkimer ('o., N. Y.

* $*$ Spikelets clustered (rarely only one), appearing laterul, the one-lenced involucre resembling and seeming to be a continuation of the naked culm.

- Culm sharply triangular, stout, chiefly, from running rootstocks ; spikelets manyflouered, rusty broun, closely sessile in one cluster; sheuths at base more or less leaf-bearing.

5. S. púngens, Vahl. Running rootstocks long and stout ; culm sharply 3-angled throughout ( $1-4^{\circ}$ high) with concave sides; leares $1-3$, elongated (4-10' long), keeled and channelled; spikelets 1-6, capitate, ovoid, usually long, overtopped by the pointed involucral leaf; scales ovate, sparingly ciliate, 2-eleft at the apex and awn-pointed from between the acute lobes; anthers tipped with an aul-shaped minutely fringed appenduge; style 2-cleft (rarely 3-cleft); bristles 2-6, shorter than the obovate plano-convex and mucronate smooth achene. - Borders of salt and fresh ponds and streams, throughout N. $\Lambda$ m. (Eu., S. $\Lambda \mathrm{m}$.)

6. S. Torrèyi, Olney. Rootstocks slender if any (so that the plant is readily pulled up from the mud); culm 3-angled, with concave sides, rather slender $\left(2-4^{\circ}\right.$ high $)$, leafy at base; leaves 2 or 3 , more than half the length of the culm, triangular-channelled, slender; spikelets 1-4, oblong or spindle-shaped, acute, distinct, pale chestnut-color, long overtopped by the slender erect involucral leaf; scales ovate, smooth, entire, barely mucronate; style 3-cleft; bristles longer than the unequally triungular-abovate very smooth long-pninted achone. - Borders of ponds, brackish and fresh, N. Eng. to I'eun., Mich., and Minn.

7. S. Olnèyi, Gray. C'ulm 3-uxing-angled, with deeply excuratcd sides, stout $\left(2-7^{\circ}\right.$ high), the upper sheath bearing a short triangular leaf or none: spikelets 6-12, closely capitate, ovoid, obtuse, orertopped by the short invo. lucral leaf; scales orbicular, smooth, the inconspicuous mucronate point shorter than the scarious apex; anthers with a very shunt and blunt minutely beurded tip; style 2-cleft; bristles 6 , scarcely equalling the narrowly obovate plano-convex and mucronate achene. - Salt marshes, S. New Eing. to Fla., west to the Pacific.

S. Mcroxitus, I. Resembling the last, $1-3^{\circ}$ high ; spikelets numerons in a dense cluster, oblong-ovate, $6-8^{\prime \prime}$ long or less; scales ovate, mucronate. 
firm, scarcely at all scarious; style 3-cleft; achene smaller, broadly obovate. - Iu a single locality in Delaware Co., l'emn.; probably introduced from s. Eurupe.

+- Culm triangular, tall and stout, from slender running rootstocks; spikelets many-flowered, loosely umbellate or corymbed, involucellate-bracted.

8. S. Cánbyi, Gray. Culm $\left(3-5^{\circ}\right.$ high $) 3$-angled, usually sharply so above, obtusely below, the sheath at base extended into a long slender trian. gular and channelled leaf $\left(2-4^{\circ}\right.$ long $)$; involucral leaf similar $\left(4-8^{\prime}\right.$ long), continuing the culm; spikelets oblong $(4-6$ " long), single or sumetimes proliferously 2 or 3 together, nodding on the apex of the 5-9 long filiform and flattened peduncles or rays of the dichotomous umbel like corymb, or the central one nearly sessile; scales loosely imbricated, oblong orate, acute, pale, thin and scariuus, with a greenish nerved back; bristles 6 , firm, furnished above with spreading hairs rather than barbs, equalling the sleuder abrupt beak of the obovate-triangular shining achese ( $1 \frac{1}{2}{ }^{\prime \prime}$ loug). - In a pond near' Salisbury, Md.

+ + + Culm terete, very tall and stout, from a deep running rootstock, leafless or very nearly so; spikelets numerous, clustered in a one-sided compound umbel-like panicle longer than the involucral leaf; incolucellate bracts small, scale-like and rusty-scarious; scales of the spikelets rusty or chestnut-broun, scarious, the midrib extended into a mucronate point.

9. S. lacústris, L. (Great Bulrush.) Culm $3-9^{\circ}$ high, $\frac{1}{2}-1^{\prime}$ thick at base ; spikelets ovate-oblong $\left(3-4^{\prime \prime}\right.$ long); scales mostly a little downy on the back and ciliate; style 2-cleft; achene pale and dull, obovate with a uarrowed base, plano-convex, mucronate-pointed, usually overtopped by the 4-6 slender downwardly barbed bristles. (S. validus, Vahl.) - Common everywhere in still fresh water. (Eu., Asia, etc.)

++++ Culms slender from an annual root, terete, plano-concex or obtusely triangular, naked; the sheaths rarely bearing a short leaf; spikelets few or several in a sessile cluster, sometimes solitary, much overtopped by the involucral leaf; bristles often few or wanting.

10. S. débilis, Pursh. (1'l. 3, fig. 1-5.) Culms obtusely triangulur, with \$omewhat hollowed sides, $1-2^{\circ}$ high, yellowish-green, shining; spikelets 3 12 , capitate, ovate-oblong, obtuse $\left(3-4^{\prime \prime}\right.$ long), chestnut-brown; involucral leaf often horizontal at maturity; scales roumlish; stamens 3 ; style $2-3$. aleft; bristles 6, stout, downwardly barbed, equalling or two surpassing the obovate turgidly plano-convex (or hluntly 3-sided) abruptly mucronate-pointed smoothish achene. - Swamps, Mass. to S. C., Minn. and Neb. Aug., Sept.

11. S. Smithii, Gray. Culms terete, slender, 3-12' high, often leafbearing from the upper sheath, dull green as are the $\mathbf{1}-3$ oblong-ovate acute spikelets; involucral leaf always erect; scales oblong-oval; style 2-cleft; bristles 1 or 2 minute rudiments or none; achene someuhat lenticular, smooth, deciduous with the scales. - IVet shores, Delaware Bay to L. Ontario, Mich., N. Ind., aud Ill. July.

12. S. supinus, L., var. Hállii, Gray. Culms filiform, 5-12' high; upper sheath rarely distinctly leaf-bearing; spikelets $1-7$ in a sessile or sometimes geminately proliferous cluster, ovate-oblong becoming cylindrical, green 
ish; scales ovate, strongly keeled, mucronate-pointed; stamens 2 or 3 ; style 2-cleft ; bristles none; achene obovate-orbiculur, mucronate, plano-convex, strongly urinkled transversely. - Wet shores, Ill. to 'Tex.; also found in L. Mass. (Mitchings). (Eu.)

* * Spritelets in simple or mostly componnd umbellate or cymose-punicled clusters, many-flowered, terete; incolure of mostly several flut leaves ; culm tull, from tuficel or running rootstochs, triangular, leafy, sedge-like: leaces rough on the margin; style mostly 3-cleft.

+ Spikelets large $\left(6-15^{\prime \prime}\right.$ long); midrib of the scales extended beyond the mostly lacerate or two-clefi apex into a distinct au'n.

13. S. marítimus, L. (SEA Clen-licsir.) Leaves flat, linear, as long as the stuut culm $\left(1-3^{\circ}\right.$ high $)$, those of the involucre $1-4$, very unequal; spikelets few-several in a sessile cluster, and often also with $1-4$ unequal rays bearing $1-7$ ovate or oblong-cylindrical (rusty-brown) spikelets; awus of the scales soon recurved; achene obocate-orbicular, compressed, flat on one side, convex or obtuse-angled on the other, minutely pointed, shining, shorter than the 1-6 unequal and deciduous (sometimes obsolete) bristles. - Saline localities, on the coast from N. Scotia to Fla., and in the interior across the continent. (Eu.) - Var. macrostícmos, Michx.; larger, with very thick ollongcylindrical heads ( $1-1 \frac{1}{2}^{\circ}$ long), and longer involucral leaf (often $1^{\circ} \mathrm{long}$ ).

14. S. fluviátilis, Gray. (Rrver C.) Culm very stout, $3-5^{\circ}$ high ; leaves flat, broadly linear ( $\frac{1^{\prime}}{2}$ wide or more), tapering gralually to a point, the upper and those of the very long involucre very much exceeding the compound umbel; rays 5-9, elongated, recurved-spreading, each bearing $1-5$ ovate or oblong-cylindrical acute paler heads; scales less lacerate and awns less recurved; achene obovate, sharply and exactly triungular, conspicuously pointed, opaque, scarcely equalling the 6 rigid bristles. - Borders of lakes and large streams, W. Vt. to Conn. and Penn., west to Minn. and Iowa.

+ + Spikelets very numerous, small $\left(1-3^{\prime \prime}\right.$ long); scales mucronate-pointed or blunt; umbel-like cymose panicle irregular, compound or decompound: culm $2-5^{\circ}$ high, unusually leafy; leaves broadly linear, green and ruther sofi: bristles very slender, often more or less tortuous and naked below.

15. S. Sylváticus, I. Spikelets lead-rolored, clustered 3-10 together at the end of the mostly stender ultimute divisions of the open decompound panicle, ovoid or lance-orate, $2^{\prime \prime}$ long; scales bluntish; bristles 6 , downwarlly barbed throughout, rather exceeding the triangular short-pointed achene; style 3-cleft. - Along brooks, E. Mass. to N. Y. and F. Penn.

Var. dígynus, Boeckl. Style 2-cleft and the acliene not at all angled on the back; stamens 2, and bristles 4. (S. microcarpus, Presl.) - N. Scotia and N. Eng. to Minn., and westward.

16. S. atròvirens, Muhl. Leaves somewhat more rigid; spikelets dull greenish-brown, densely conglomerate (10-30 toyether) into close heads, these also usually densely clustered in a less compound panicle; scales pointed ; bristles sparsely and strongly dou'nu'ardly barbed ubove the middle, nuked belon', nearly straight, as long as the conspicuously pointed and obovate-oblong triangular achene. - Wet meadows and bogs, N. Scotia and N. Eng., west to Minn., Kan., and the Pacific. 
17. S. polyphýllus, Vahl. Culm usually more leafy; spikelets yellow. brown, ovate, becoming cylindrical, clustered 3-8 together in small heads on the short ultimate divisions of the open decompound umbel; scales mucronate ; bristles 6, usually twice bent, soft-barbed touard the summit only, about twice the length of the achene. - Swamps and borders of ponds, western N. Eng. to N. C., west to Minn. and Ark.

\section{ERIÓ PHOR U M, L. Cottox-Grass. (Pl. 3.)}

Bristles naked, usually very numerous, often silky and becoming greatly elongated. Otherwise as in Scirpus. - Spikelets single or clustered or umbellate, usually involucrate with erect scale-like bracts, upon a leafy or naked stem; scales membranaceous, 1-3-nerved. Style very slender and elongated, 3-cleft. Achene acutely triangular. (Name composed of ép and popós, bearing.)

* Bristles 6, rust-colored, becoming tortuous and entangled ; culm very leafy, bearing numerous spikelets in an involucrate decompound cymose-panicled umbel.

1. E. lineàtum, Benth. \& Hook. Culm triangular, leafy $\left(1-3^{\circ}\right.$ high $)$; leaves linear, flat, rather broad, rough on the margins; umbels terminal and sometimes axillary, loose, drooping, the terminal with a 1 -3-leaved involucre much shorter than the long slender rays; spikelets oblong, becoming cylindrical (2-4" long), on thread-like drooping pedicels; bristles at maturity scarcely exceeding the ovate green-keeled pointed scales; achene sharp-pointed. (Scirpus lineatus, Mich $x$.) - Low grounds, western N. Eng. to Ga., west to Minn. and Mo.

2. E. cyperinum, L. (Pl. 3, fig.6-10, under Scirpus.) (Wool-Grass.) Culm nearly terete $\left(2-5^{\circ}\right.$ high $)$; leaves narrowly linear, long, rigid, those of the involucre $3-5$, longer than the umbel, the rays at length drooping; spikelets exceedingly numerous, orate, clustered, or the lateral pedicelled, woolly at maturity ( $1 \frac{1}{2}-3^{\prime \prime}$ long); the rust-colored bristles much longer than the pointless scales; achene short-pointed. (Scirpus Eriophorum, Ifich $x$.) - Wet meadows and swamps, Newf. to Fla., west to Minn. and lowa. Exceedingly variable in the character and size of the umbel, the typical form having the spikelets mostly clustered in small heads. - Var. Láxu has the spikelets scattered, the lateral long-pedicelled.

* * Bristles 6, crisped, white; spikelet single, small ; involucre of one short bract.

3. E. alpinum, L. (Pl. 3, fig. 1-6.) Culms slender, many in a row from a running rootstock ( $6-10^{\prime}$ high), scabrous, naked; sheaths at the base awl-tipped. - Cold bogs, Lab. to N. Eng., west to Minn. June. (Eu.)

* * Bristles very mumerous, not crisped, forming dense cottony heads in fruit.

- Culm bearing a single spikelet; involucre none.

4. E. vaginattum, L. Culms in close tufts $\left(1^{\circ}\right.$ high $)$, leafy only at the base, above with 2 inflated leafless sheaths; root-leaves long and thread-form, triangular-channelled; scales of the ovate spikelet long-pointed, lead-color at maturity. - Cold and high peat-bogs, N. Eng. to Penn., Mich., Minn., and northward. May, June. (En.) 
++ Culm leafy, bearing several umbellate-clustered heads, involucrate.

5. E. Virgínicum, L. Culm rigirl $\left(2-4^{\circ}\right.$ high); leaves very narrowly linear, elungated, tlat; spikelets neurly scssile, crouded in a dense cluster or head; woul rusty or copper-color, only thrice the length of the seale; stamen 1. - Bogs and low meadows, Newf. to Fla., west to Minn. and Neb. July, Aug. - Var. Áıс s, Gray, has the wool white. N. New York.

6. E. polystáchyon, L. Culın rigid ( $1-2^{\circ}$ high), obseurely triangular; leaves linear, flat, or baicl!y channelled below, triangular at the point ; incolucre 2-3-lected; spikelets several ( $4-12$ ), on smooth nodling peduncles, sone of them elongated in fruit; achene obovate; wool $u$ hite, very straight ( $l^{\prime}$ long or more). - Bogs, Newf. tu Ga., Minu., and westward. June, July. (Eu.) - Var. LATIFòlily, Gray; peduncles rough; leaves sometimes broader and flatter.

7. E. grácile, Kíoch. Culm slender $\left(1-2^{\circ}\right.$ high $)$, rather triangular; leaves slender, channelled-triangular, rough on the angles; imolncre short and scale-like, mostly 1-leaved; peduncles rough or roughish-pubescent; spikelets $3-7$, small, when mature the copious white wool 6-9"long; achene ellipticallinear. - Cold bogs, Newf. to N. J., West to Minn. and Mo. Scales in our plant mostly light chestnut and about 3-nerved. June-Aug. (Eu.)

\section{FUIR E N A, Rottboell. Cinrella-Grass. (PI. 2.)}

Spikelets many-flowered, terete, clustered or solitary, axillary and terminal. Seales imbricated in many ranks, awned below the apex, all floriferous. Perianth of 3 ovate or heart-shaped petaloid scales, mostly on claws, and usually with as many alternating small bristles. Stamens 3. Style 3-cleft. Achene triangular, pointed with the persistent base of the style. Culms from a perennial root, obtusely triangular. (Named for G. Fuiren, a Danish botanist.)

1. F. squarròsa, Michx., var. hispida, Chapm. (Pl. 2, fig. 1-7.) Stem ( $1-3^{\circ}$ high) leafy; leaves and sheaths usually densely hairy ; spikelets ovoid-oblong ( $4-6$ " long), clustered in heads, bristly with the spreading awns of the scales; perianth-seales rhombic or deltoid-ovate, with a short thick awn or point, the interposed mostly barbed bristles shorter than the achene. Sandy wet places, N. J. to Fla., west to $\mathrm{Ky}$. and Tex.

Var. pumila, Torr. Lsually low ( $1-6^{\prime}$ high or more), with $1-6$ spikelets; perianth-scales narrowly to broadly oblong or ovate, long-stipitate and attenuate to a long awn; harbed bristles usually exceeding the achene. - Mass. to N. J., Fla., and La.; Mich. The commonest form.

\section{H E M I C Á R P H A, Nees. (1’l. 2.)}

Spikelet, flowers, etc., as in S(cirpus, except that there is a minute translucent scale (readily overlooked) between the flower and the axis of the spikelet. Stamen only one. Style 2-cleft. Bristles or other perianth none. (Name from

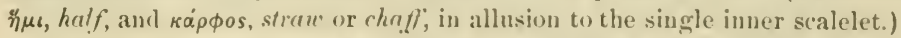

1. H. subsquarıosa, Nees. Dwarf or minute annual $\left(1-5^{\prime}\right.$ ligh $)$; involucre $\mathrm{i}$-leaved, as if a continuation of the bristle-like culm, and usually with another minute leaf; spikelets $2-3$ (barely $2^{\prime \prime}$ long); seales brown, tipped with a short recurved point. - Sandy borders of ponds and rivers, $N$ Eng. to Fla., west to the Pacific. 


\section{LIPOCÁRPHA, R. Br. (Pl. 2.)}

Spikelets terete, many-flowered, in a terminal close cluster involucrate by leafy bracts. Scales spatulate, regularly imbricated all round in many ranks, awnless, deciduous, a few of the lowest empty. Inner scales (bractlets) 2 to each flower, thin, one between the scale of the spikelet and the flower, one between the latter and the axis of the spikelet. Bristles or other perianth none. Stamens 1 or 2. Style 2-3-cleft. Achene flattish or triangular, naked at the

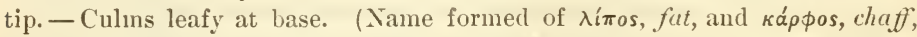
from the thickness of the inner scales of some species.)

1. L. maculàta, Torr. Annual; culı $\left(4-8^{\prime}\right.$ high) much longer than the linear concave leaves; spikelets ( $1-2^{\prime \prime}$ long) green and dark-spotted ; inner scales delicate; stamen one; achene obloug with a contracted base. Springy or miry places, Va. to Fla. ; near Philadelphia, probably adventive.

\section{RHYNCHÓSPORA, Vahl. BEAK-Resh. (Pl. 4.)}

Spikelets panicled or variously clustered, ovate, globular, or spindle-shaped, terete, or sometimes flattish; but the scales open or barely concave (not boatshaped nor keeled); the lower commonly loosely imbricated and empty, the uppermost often subtending imperfect flowers. Perianth in the form of bristles (mostly 6). Stamens mostly 3. Achene lenticular, globular, or flat, crowned with a conspicuous tubercle or beak consisting of the persistent indurated base or even of the greater part of the style. - Chiefly perennials, with more or less triangular and leafy culms; the spikelets in terminal and axillary clusters;

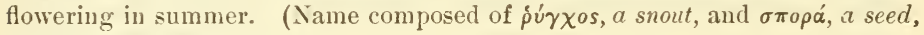
from the beaked acliene.)

§ 1. RHYNCHOSPORA proper. Spikelets terete or biconvex, few-nanyflowered; style conspicuously 2-cleft, its base only forming the tubercle of the mostly lenticular achene; bristles usually present, merely rough or barbeddenticulate (not plumose).

* Achene transversely urinkled; bristles mostly 6, upuardly denticulate.

1. R. cymòsa, Nutt. Culm triangular; leaves linear ( $\frac{1^{\prime}}{4}$ wide); cymes corymbose, the spikelets crouded and clustered; achene round-obocate, twice the length of the bristles, four times the length of the depressed-conical tubercle. - Low grounds, Penu. and N. .J. to Fla., west to N. Ind. and Ill.

2. R. Torreyàna, Gray. (Pl. 4, figs. 1-5.) Culm nearlyterete, slender; leaves bristle-form; cymes panicled, somewhat loose, the spikelets mostly pedicelled; achene oblong-obovate, longer than the bristles, thrice the length of the broad compressed-conical tubercle. - Swamps; pine-barrens of N. J. to S. C.

3. R. inexpánsa, Vahl. Culm triangular, slender; leares narrowly lin. ear; spikelets spindle-shaped, mostly pedicelled, in drooping panicles; achene oldony, half the length of the slender bristles, twice the length of the triangularsubulate tubercle. - Low grounds, Va. to Ga.

* Achene smooth and even.

+ Bristles 6, long and conspicuous, upuardly denticulate.

4. R. fúsca, Roem. \& Schultes. Culm 6-12' high; leaves bristle-forn channelled; spikelets ovate-oblong, few, clustered in 1-3 loose heads (darh 
chestnut-color); achene obovate, half the length of the bristles, equalling the triangular-sworl-shaped acute tubercle, which is rough serrulate on the margins. - Low grounds, N. Brunswick to N. J., west to L. Superior. (Eu.)

5. R. gracilénta, Gray. Culms very slender, $1-20$ high; leaves narrowly linear; spikelets ovoid, in 2-4 small clusters, the lateral long-peduncled; achene ovoid, rather shorter than the bristles, about the length of the flat awlshaped tubercle. - Low grounds, southern N. Y. and N. J. to Fla.

6. R. oligántha, Grạy. Culm and leaves filiform, 6-12' high ; spikelets very few $(1-4)$, orate-oblong; bristles plumose below the midtle; achene obovate-oblong, bearing a conical tubercle $\frac{1}{3}$ its lengtl. - I)el. (Canby) to Flat.

+ + Bristles norre, or $1-3$ and minute; spikelets pale, 1-flowered.

7. R. pállida, M. A. Curtis. Culm (1-2 high) acutely triangular; leaves and spikelets as in the next species, but only a terminal dense cluster, which is less white or turns pale reddish-tawny; achene obovate-lenticular, tipped with a minute depressed and apiculate tubercle; the delicate bristles 4-5 times shorter or obsolete. - Bogs in pine-barrens of N. J. and N. C.

+++ Bristles long, denticulate dounuard, or both ways in n. 11.

- Spikelets uhite or whitish, becoming tauny with age, perfecting only a single flouer: stamens usully 2 ; bristles $9-12$, or even 20.

8. R. álba, Vahl. Culm slender ( $1-2^{\circ}$ high), triangular above; leaves narrowly linear or almost bristle-form; spikelets lanceolate, densely crowded in a head-like terminal corymb and usually one or two lateral ones; achene oblong-oborate with a narrowed base, scarcely longer than the flattened-awlshaped tubercle, shorter than the bristles. - Bogs, Newf. to Fla., west to N. Ind., Minn., and Oregon. (Eu.)

- Spikelets chestnut-colored or daiker in $\mathrm{n} .10$ and 11 , few-several-flowered; stamens 3 ; bristles nsually 6.

9. R. capillàcea, 'Torr. Culm 6-9' high, slenter; leaves bristle-form ; spikelets $3-6$ in a terminal cluster, and conmonly 1 or 2 on a remote axillary peduncle, oblong-lanceolate (pale chestnut-color, $3^{\prime \prime}$ long); achene oblong-or.oid, stipitate, very obscurely wrinkled, about half the length of the (6, rarely 12$)$ stout bristles, and twice the length of the lanceolate-beaked tubercle. - Bogs and rocky river-banks, N. Vt. to I'enn., west to western N. Y. and Minu. - Var. LEVisk̀tA, Hill. Bristles perfectly smooth. N. W. Ind.

10. R. Knieskérnii, Carey. Culm 6-18' higlı, slender; leaves narrowly linear, short; spikelets numerous, crowded in 4-6 distant clusters, oblon!yovate (scarcely $1^{\prime \prime}$ long); achene nbovate, narrowed at base, equalling the bristles, twice the length of the triangular flattened tubercle. - Pine-barrens of $\mathrm{N}$. J. (on bog iron ore exclusively) to Va.; rare.

11. S. glomeràta, Valıl. Culm $1-3^{\circ}$ high; leaves linear, flut; spikelets numerous in distunt clusters or heads (often in pairs from the same sheath), ovoid-oblong; achene obovate, marginel, narrowed at base, as long as the lanceawl-shaped flattened tubercle, which equals the always dounucarlly barbed bristles. - Low grounds, N. Eng. to Fla., west to Mich. and N. Ind.

12. R. cephalántha, Gray. Culın stout $\left(2-3^{\circ}\right.$ highli); leaves nurrouly linear, flat, keeled; spikelets very numerous, crouded in 2 or 3 or more dense globular heads which are distant (and often in pairs), oblong-lanceolate, dark 
brown; achene orbicular-obovate, margined, narrowed at base, about as long as the awl-shaped beak; bristles twice longer, stout, barbed dounuard and sometimes also upward. - Sandy swamps, Long Island to N. J. and Fla.

§ 2. CERATOSCHCLNUS. Spikelets lanceolate, acuminate, in fruit flattish, cymose-panicled, of only one perfect and 1-4 staminate flowers; scales few; bristles rigid, minutely scabrous upuard; style simple or barely 2-toothed, filiform and gradually thickened downward, in fruit persistent as an exserted, slender-awl-shaped, upuardly roughened beak, several times longer than the smooth flat obovate achene; coarse perennials; spikelets in flower $4^{\prime \prime}$, in fruit including the projecting beak about $\mathbf{l}^{\prime}$ long.

13. R. corniculàta, Gray. (Horsed Rusir.) Culm 3-6 high; leaves about 6 "wide; cymes decompound, diffuse; brisiles awl-shaped, stout, unequal, shorter than the achene. - IVet places, Penn. to Fla., west to S. Ind. and Mo.

14. R. macrostàchya, Torr. (Pl. 4, fig. 1-4.) Cymes decompound, or in the northern form somewhat simple and smaller, and the spikelets usually more clustered; bristles capillary, twice the length of the achene. - Borders of ponds, Mass. to N. J. and Fla.; rare.

\section{C L À D I U M, P. Browne. Twig-Rush. (Pl. 5.)}

Spikelets ovoid or oblong, of several loosely imbricated scales; the lower empty, one or two above bearing a staminate or imperfect flower; the terminal flower perfect and fertile. Periauth none. Stamens 2. Style 2-3-cleft, deciduous. Achene ovoid or globular, somewhat corky at the summit, or pointed, without any tubercle, in which it differs from Rhynchospora. (Diminutive of

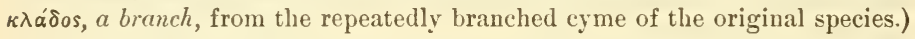

1. C. mariscoides, Torr. Perennial; culm obscurely triangular $\left(1-2^{\circ}\right.$ high); leaves narrow, channelled, scarcely rough-margined ; cymes small; the spikelets clustered in heads $3-8$ together on $2-4$ peduncles; style 3 -cleft. Bogs, N. Scotia to Del., west to S. Minn. and Iowa. July.

\section{SCL亡 RIA, Berg. Nut-Resh. (Pl. 5.)}

Flowers monøcious; the fertile spikelets 1-flowered, usually intermixed with clusters of few-flowered staminate spikelets. Scales loosely imbricated, the lower empty. Stamens 1-3. Style 3-cleft. Achene globular, stony, bony, or enamel-like in texture. Bristles, etc., none. Perennials, with triangular leafy culms, mostly from creeping rootstocks; flowering in summer; all in low ground or swamps. Inflorescence, in our species, of terminal and axillary clusters, the lower clusters usually peduncled. (Name, $\sigma \kappa \lambda \eta \rho_{i}^{\prime} \alpha$, hardness, from the indurated fruit.)

\section{* Achene smooth.}

1. S. triglomeràta, Michx. Culm $\left(1 \frac{1}{2}-3^{\circ}\right.$ high) and broadly linear leaves roughish; fascicles of spikelets few, the lowest peduncled, the upper somewhat in threes; achene ovate-globose or depressed, on an obscure crustaceous disk. - Mass. and Vt. to Fla., west to Minn. and Tex. - Var. GRÁcilis, Britton. Culms slender ( $1-2^{\circ}$ long); fascicles few-flowered, the lower $(2-$ 3-flowered) on very long filiform peduncles; achene not more than half as large, acutish. $-\mathrm{N}$. J. 
2. S. oligántha, Ell. Culms slender, $2^{\circ}$ high, the angles somewhat winged; leuves linear ( $2^{\prime \prime}$ wide), smooth except the scahrous apex; lateral fascicles 1 or 2, usually on long exserted peduncles; achene ovate, on a tuberculate disk. - Va. to Fla. aud 'Tex.

\section{* Achene papillose or uarty.}

3. S. pauciflora, Muhl. Smoothish or hairy ; culn slender $\left(9-24^{\prime}\right.$ high $)$; leares narrowly linear; fascicles few-flowered, the lateral pedunculate, sessile, or wanting; bracts ciliate; acliene globose-ovate; the disk a narrow ring bearing 3 pairs of minute tubercles. $-\mathbf{N}$. H. to Ohio, south to Fla. and Tex.

***Achene reticulated or urinkled.

4. S. reticulàris, Michx. (1'l. 5, fig. 6-10.) Culms slender, erect, scabrous ( $1-2 \frac{1}{2}^{\circ}$ high); leares linear ( $1-1 \frac{1}{2}^{\prime \prime}$ wide), smooth; lateral fascicles $1-3$, loose, remote, ncarly erect, on short often included peduncles; bracts glabrous; achene globose, reqularly reticulated and pitted, not hairy, resting upon a double greenish conspicuonsty 3 -lohed disk, the inner appressed to and deciduous with the achene. - E. Mass. to Fla. - Var. PL béscess, Britton. Fdges of reticulations more or less hairy, especially toward the apex; lateral fascicles geverally on longer peduncles. J'ine-barrens of N.J. to Fla. - Var. osscínA, Britton. Achene bony, its surface with very obscure reticulatious, nearly smooth at the summit. R. I. and N. C.

5. S. Torreyàna, Walpers. Culms weak, diffuse, slightly scabrous or smooth; leaves linear (2-4" wide), smooth; lateral fascicles loose, on more or less elongated and drooping filiform jeduncles; achene irregularly pitted-reticulated or pitted-rugose with the ridges someuhat spirally arranged and more or less hairy (sometimes smooth); otherwise as in the last. (S. laxa, Torr.) Pine-barrens, N. J. to Fla. and 'l'ex.

6. S. verticillàta, Muhl. Smooth; culms simple, slender $\left(4-2 t^{\prime}\right.$ high); leaves narrowly linear; fuscicles 3-9-flowered, 4-6, sessile in an interrupted spikelet; achene globose ( $\frac{1}{2}$ "broad), somewhat triangular at base, roughwinkled with short elevated ridges; disk obsolete. - L. Mass. to Ont., Minn., and south to the Gulf.

\section{C À R X, Ruppins. SEnge. (By I. H. BaIley.)}

Flowers unisexual, destitute of floral envelopes, disposed in spikes; the staminate consisting of three stamens, in the axil of a bract, or srale; the pistillate comprising a single pistil with a bifid or trifid style, forming in fruit $n$ hard lenticular or triangular achene, which is enclosed in a sac (perigymum) formed by the complete union of the borders of a bractlet or of connate bractlets and borne in the axil of a bract, or scale. Staminate and pistillate flowers borne in different parts of the spike (spike androgynous), or in separate spikes on the same culm, or rarely the plant diceious. - Perennial grass-like herlss with mostly triangular culms, 3-ranked leaves, usually with rough margins and keel, and spikes in the axils of leafy or scale-like hracts, often aggregated into heads. An exceedingly critical genus, the study of which should be attempted only with conplete and fully mature specimens. (The classical Latin name, of obscure signification; derived by some from $\kappa$ fip $\omega$, to cut, on account of the sharp leaves - as the English name Shear-grass.) (P1.5 and 6.) 


\section{Synopsis of Sections and Groups.}

§1. CAREX proper. Staminate flowers forming one or more terminal linear or club-shaped spikes (often pistillate at base or apex). Pistillate flowers usually in distinct and sim. ple mostly peduncled spikes. Cross-section of perigynium circular, obtusely anglę, or prominently triangular in outline. Style mostly 3 parted and achene triangular or triquetrous.

* 1. Physocarpæe. Perigynium mostly straw-colored at maturity, papery in texture, usually more or less inflated, smooth (sometimes hairy in n.6), nerved, tapering into a beak as long as or longer than the body; spikes few to many, distinct, compactly flowered; stigmas 3 (2 in n. 10).

- 1. Paucifiorce. Perigynium greenish, Jinear-lanceolate or almost needle shaped, not inflated, strongly deflexed at maturity, several times longer than the inconspicuous scale; spike androgynous, the pistillate flowers at base, few. - Sp. 1 .

-2. Lupurint: Perigynimm green or greenish-tawny or sometimes yellow, more or less inflated (except in 11. 2-4), long, usually very turgid at base, mostly ereet or nearly so, very gralually attenuate to a loug sleuderly toothed beak exceeding the scale; spikes 3 or more, the staminate mostly 1 and stalked, the pistillate often sessile, usually short and thick, often becoming dark colored in drying. - Sp. 2 - S.

- 3. Vesicarice. Perigynium smooth and shining, much inflated, at maturity straw-colored or sometimes purple, beaked and conspicuously short-toothed (entire in n. 10), usually prominently few-nerved, much shorter than in +2 ; staminate spikes commonly 2 or more; pistillate spikes as a rule long and densely eylindrical. - Sp. 9-16.

-4. Pseudocyperce. Perigynium less inflated, more conslicuously nerved or even costate, and with more or less setaceous or awned teeth; scale usually awned; spikes mostly nodding or spreading, comose in appearance, greenish, greenish-yellow, or ochroleucous. -Sp. $17-19$.

+5. Squarrosce. Perigynium obconic or obovoid, squarrose in exceedingly dense short spikes. - Sp. 20, 21.

* 2. Trachychlæenze. Perigynium mostly thick and hard in texture, often scabrous or hirsute, straight-heaked; pistillate spikes compactly flowered, mostly large, erect or nearly so; staminatc spikes 1 or more; stigmas 3. Generally large and coarse.

- 1. Shortiance. Terminal spike androgynous, staminate below; perigynium small, scabrous, nearly beakles ', entire. - Sp. 22.

+2. Anomalce. Terminal spike all staminate; pistillate spikes long and cylindrical, mostly dense; perigynium broad and short, short-beaked, the orifice very slightly notched or entire, mostly granulate. - Sp. 23.

+3. Hirte. A heterogeneous group, distinguished from +2 by the longer and inore deeply cut beak (slightly toothed in n. 24), and by the hairy perigyniun (smooth in 12.25 ). Sp. $24-27$.

-4. Paludose. Staminate spikes 2 or more, long-stalked; the pistillate 2 -several, usually all pedurcled, long and heavy, loose-flowered, erect or nodding ; perigynium large, thick in texture, strongly nerved, mostly smooth, usually conspicuously beaked. Coarse species. - Sp. 28, 29.

* 3. Microrhynchæe. Parallel with * 2; distinguished in general by the much smaller and nearly or entirely beakless and mostly entire-monthed perigynium, which is much thinner in texture; stigmas 2 or 3. Paludose and alpine speeięs, of various habit, mostly with colored spikes, often in dense tufts or tussocks

-1. Atratce. Terminal spike clnh-shaped and androgynous with the staminate flowers below (very rarely all staminate in n. 32); pistillate spikes mostly short and dark-colored, erect or drooping; stigmas $3 .-\mathrm{S}_{1}$. $30-32$.

+2. Rigida. Mostly stiff, with short erect closely flowered spikes, an entirely staminate terminal spike, dark colored scales, and bracts with purple or black auricles at base; stigmas 2 or 3. - Sp. 33.

-3. Acutce. Mostly larger and more slender, usually paludose, with green or light-colored large and long spikes; stigmas 2 ( 3 in n. 39$)$. Distinguished from +2 mainly by habit. -Sp. $34-39$. 
-4. Cryptocarpo. Large, with nodding or drooping large spikes, their dark scales very long and couspieuous; stigmas 2. - Sp. 40, 41 .

-5. Penduline. Distinguished from +4 hy the smaller size, sinaller spikes, shenthless brnets, and whitish, more or less granulated, nearly pointless perigyumun ; stigmas $3 .-$ Sp. $42-45$.

* 4. Hymenoch lanen. Perigynium mostly light green or whitish, usually thin and inenbrunous, often somewhat intlated or loosely investing the achene, eommonly smooth and shining (hairy in n. 46, sometimes in n. 47), slender or oblong, attenuate to a distinct or long minutely toothed straight beak (or leskless or nearly so in -1 and n. 55); pistillate spikes several or many, mostly lorsely Howered and on flliform nodding or widely spreading peduncles; brat:ts leaf-like; terminal spike staminate or androgynous ; stigmas 3. Mostly rather tall and sleuder upland species.

- 1. Virescentes. Terminal spike pistillate at top' ; pistillate spikes oblong or cylindrical, deuse, erect; perigynimu ovate or obovate, nearly or quite beakless, often hairy. - Sl. 46,47 .

—2. Sylvaticr. Terminal spike all staninate; pistillate spikes mostly long-exserted, slender; perigynium few-nerved, contracted into a cyliudrical beak which is longer than the body. - sp. 48.

- 3. Flexiles. Terminal spike all staminate; pistillate splikes rather thiek (very small in n. 50), more or less drooping; perigyuiun beaked, few-nerved or nerveless, tawny or whitislı. - Sp. 49, 50 .

4. Debiles. Terminal spike all staninate (oceasionally pistillate above in 11. 53); pistillate spikes very narrow and slender, long-exserted and nodding, mostly very loosely flowered; perigynium rather small, not turgid, prominently beaked. - S1. 51-53.

-5. Gracillime. Terminal spike pistillate at top ; pistillate spikes habitually thicker than in +4 ; perigyuium vvate-oblong, more or less turgid; the beak short or uone. - Sp. $54-57$.

-6. Grisece. Terminal spike staminate; perigynium more or less turgid or plump, often glaucous, seareely beaked, finely striate; spikes erect. - Sp. 5s, 59.

* 5. Spirostachyie. Perigynium smooth or minutely granulated or rarely somewhat serrate on the margins, prominently nerved, mostly yellowish, squarrose, mostly beakerl (entirely beakless in 11.63 ), the orifice entire; staminate spike mostly single; pistillate spikes $2-5$, short (usually 1 ' long or less), yellow or fuscous, compactly flowered; stigmas 3. - Medium-sized species, growing in mearlows and grassy swales.

-1. Granulares. Sfrikes scattered, crlindrical, the lowest long-stalked; bracts erect, long and leafy ; sheatlis short or vearly obsolete. $-\mathrm{S}] .60,61$.

- 2. Extensr. Spikes mostly approximate or aggregaced at the top of the culm (becoming remote in C. extensa), the lowest 1 or 2 subtended by a long and leafy mostly abruptly spreading and nearly or entirely sheatliless bract. Terninal spike sometimes androgynous. - Sp. 62.

-3. Pallescentes. Spikes globular or short-oblong. obtuse, sessile or short-perluneled, approximate at the top of the culm ; bracts short, leaf-like, sheathless ; perigynium entire at the orifice, the beak none or very short and stout. - Sp. 63,64 .

* 6. Dactylostachyae. Perigynium mostly short nud triangular, mostly with a short and straight or eurved beak, green or greenish, scarcely inflated; scales of the pistillate spikes mostly whitish (sometimes dark-eolored in the Digitato), often small; staminate spike mostly one: pistillate spikes short (sellom exceeding l'), commonly rither lonsely flowered and slender (spike single and plant lineesous in n. 53): bracts sheathing, the sheaths of en conspicuous and colored. - Low and lax or slender spreeies inlabiting meadows and copses.

- 1. Oligncarpice. Slender and narrow-leaved, with leafy bracts and inconspieunus green sheaths; perigynium rounded on the angles, finely many-striate, often sonewhat punctulate as in n. 58, to which the group forms a transition. - Sp. $65-67$.

4 2. Laxiforre. Slender and more or less broacl-leaved, with inustly leafy liracts, green or purple sheaths, and lonsely flowered spikes: perigynium mostly conspicuously three angled, with a more or less eurved beak. $-\mathrm{S}$. $.68-74$. 
- 3. Panicece. Mostly stouter and narrow-leaved, with thinner spikes; perigynium often strongly nerved, not conspicuously triangular, often somewhat turgid; bracts and sheaths various. - Sp. $75-78$.

-4. Bicolores. Small species with a beakless, more or less round or pyriform perigynium, which is commonly glaucous; terminal spike androgynous or all staminate; stigmas mostly 2. - Sp. 79 .

- 5. Digitata. Low species : sheaths membranaceous or hyaline and colored, either not prolonged into a bract or the bract very short and not foliaceous; perigynium more or less three-angled, often hairy, the beak straight or nearly so. - Sp. 80-83.

* 7. Spharidiophorae. Perigynium mostly short and rounded, three-angled in the Triquetro, tirm or hard in texture, not inflated, hairy or scabrous, the beak straight and usually bifid; staminate spike one ; pistillate spikes short ( $1^{\prime}$ long or less), usually globular or short-oblong, more or less sessile and approximate or the longer ones radical (spike single in n. 84); bracts sheathless, short, or obsolete ; stigmas rarely two. - Low species of dry ground, with leaves all radical.

- 1. Scirpince. Spike one, unisexual; plant diœcious. - Sp. 84.

+ 2. Montance. Spikes two to several, the lowest occasionally long-peduncled and radical ; perigynium rounded, contracted above and below, mostly bearing two prominent ribs, more or less hairy. - Low species of dry soils. - Sp. \$5-91.

- 3. Triquetroe. Taller; spikes mostly approximate at the top of the culm, oblong or cylindrical ; perigynium conspicuously 3-angled. - Sp. 92.

* 8. Phyllostachyae. Perigynium much as in the Montane; spike one, staminate above : pistillate flowers few, often remote, usually on a more or less zigzag rhachis ; scales prolonged and leaf-like. - Sp. 93-95.

* 9. Leptocephala. Perigynium thin in texture, green, oblong or lanceolate or linear in general outline, beakless ; spike one, staminate above, thin and slender ; stigmas mostly three. - Small, slender and grass-like. - Sp. 96.

* 10. Physocephalae. Spike one, globular or short-oblong, staminate at the apex ; perigynium straw-colored, paper-like, more or less intlated; stigmas three. Leaves remarkably broad in our species. - Sp. 97.

§ 2. VIGNEd. Staminate flowers few and inconspicuous, borne at the base or apex of the pistillate spikes. Pistillate flowers in short sessile spikes (or spike single in some cases), which are commouly more or less aggregated into heads or even panieled. Perigynium plano-convex. Styles two and achene lenticular. - The spikes, especially the uppermost, usually have contracted bases when the staminate flowers are borne below the pistillate ones, and emuty scales at the top when the staminate flowers are borne at the summit.

-11. Acroarrhenze. Staminate flowers borne at the top of the spikes (or, in the Multi. florce and Arenario, spikes often wholly staminate and the plants occasionally diocious).

- 1. Fatida. Spikes tawny or brown, not elongated, very densely aggregated into a continuous globose somewhat chaffy head; perigynium ovate or ovate-lanceolate, nerveless or nearly so, mostly thin in texture. - Sp. 98, 99.

\$2. Vulpince. Spikes mostly yellow or tawny when mature, densely aggregated or sometimes somewhat scattered below or even panicled : perigynium thick in texture, spongy at base, mostly stipitate, bearing very conspieuous nerves, which converge below and are especially prominent on the outer side. - Sp. 100-102.

- 3. Multiflorce. Heads varions, mostly loosely flowered, sometimes a panicle, yellow or tawny; spikes short (rarely longer than broad), staminate flowers sometimes occupying whole spikes in the niddle or at the apex of the head; perigynium mostly small and short and nearly nerveless, or in some species becoming nearly lanceolate and more or less prominently nerved, firn in texture, usually numerous. - Sp. 103-108.

-4. Arenarios. Spikes longer than in the last section, linear or nearly so, aggregated into short, almost globose heads; perigynium lanceolate or ovate-lanceolate, inostly larger and more delicate in texture; stales awn-pointed or very acute. Staninate flowels variously situated. - (C. arenaria.) 
-5. Muhlenbergiance. Spikes green or nearly so when mature, aygregated or seattered, never in compound heads; perigynium nostly short-ovate, stammate flowers always at the top of the spike. $-\$ 1$ ). 109-114.

- 6. Dioicre. Spike conmonly one, sumll : vlants sunall and slender, often diøecious. $-\mathrm{S}$ ). $115-117$.

- 12. Hyparrhenge. Staminate flowers borne at the base of the spikes or in $n$. 124 and 125 variously situated).

-1. Elongate. Spikes silvery green or sometimes tawny when mature, distinct, nostly smull, perigynium not wing-margined nor conspicuously broadened, mostly nearly flat on the inner surface. - Sp. 118- 124.

- 2. Ovales. Spikes tawny or dark, rather large, sometimes crowded; jerigynium with a more or less thin or winged margin, which is mostly incurved at maturity, renderin: the perigynim concave inside. - Sp. $125-132$.

- 3. Cyperoidece. Spikes grecn, oblong, densely erowded into a short liead subtended by two or three leafy bracts which are erect and prolonged from six inches to a foot; perigynium linear-lanceolate, scarcely margined. - Sp. 133.

\section{Artificial Key.}

Spike 1, staminate at top ; scales of pistillate flowers leaf-like . . . . Sp.93-95 spike 1 , seales not leaf-like.

Usually dioecious; stigma 2 . . . . . . . . . . . . . . $115-117$

Stigmas 3. - Perigynium densely hairy . . . . . . . . . . . 84

Spike staminate at base; perigrnia squarrose . . . . . 21

Spike staminate at top. - Globose ; leaves broad _ . . . . 97

Perigynium nearly linear, beakless _. . 96

Perigynium long, spindle-shaped . . . 1

Spikes several or numerous, sessile, spicate or capitate ; stigmas 2.

All in a globose or ovoid minterrupted head.

All staminate above. - Usually green at maturity . . . . . . . 112, 114

Usually yellow or tawny or brown . . . 9 98, 99, 104, 105

All staminate below. - Leafy-bracteate . . . . . . . . . 133

Not leafy-bracteate. - Green . . . . . 118-120

Usually tawny or brown . . 125-132

Some or all of the spikes distinct or the head interrupted.

Staminate and pistillate flowers variously disposed, some of the spikes often unisexual.

Head large and long . . . . . . . . . 108, C. arenaria.

Head short or linear . . . . . . . . . . . . . 124, 125

Spikes staminate ahove . . . . . . . . . . . . 100-114

Spikes staminate below . . . . . . . . . . . 118-193

Spikes usually more or less pedicelled, the wholly or partially staminate suikes uppermost.

Terminal spike (rarely the 2 or 3 uppermost) staminate only at base.

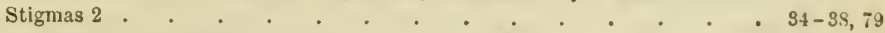

Stigmas 3 ; spikes erect,

Short and squarrose . . . . . . . . . . . 20, 21

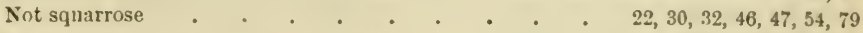

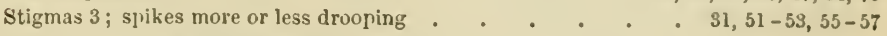

Terminal spike or spikes staminate.

Stigmas 2. - Spikes spreading or pendulons . . . . . . 34, 37, 40,41

Spikes erect or nearly so . . . . . . 9-16, 34-41, 85-91, 79

Stigmas 3 : spikes spreading or drooping.

Perigynium promineutly 3 -angled . . . . . . . . . 6S-74

Perigynium large, thin, much iuflated . . . . . . . . . 9-16

Perigynium firmer, not inflated.

Beakless

Beaked or prominently pointed. - Teeth long, stiff and sharp . 42-45

Teeth short and thin, or none $30,91,39,48-59$ 
Stigmas 3 ; spikes erect or ascending.

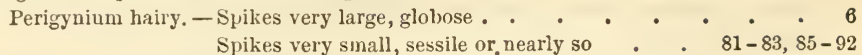

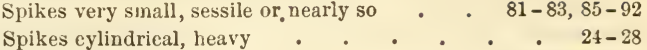

Perigynium granular-roughened .

Perigynium smooth,

Thin and turgid, loosely enclosing the achene. - Beakless _ . . 58, 59

Firm in texture, not inflated, Beaked . . $5-17$

Long-beaked, deeply toothed . . . . . . . 2-4,26,28

Less prominently beaked, short-toothed, sharply 3-angled . . . . 69-74

Wholly beakless and pointless . . . . . . $\quad$. $58,59,63,78,79$

Very small, black and shining; leaves capillary . . . . . . 80

Culnı and leaves thinly pubescent . . . . . . . . . 64

Perigynium more or less pointed or beaked.

Spikes sprearling or drooping . . . . . $51-53,68-70,75$

Spikes erect

$60-62,65-68,71-78$

* 1. Physocárpa. - + 1. Pauciflòco.

1. C. pauciflòra, Lightf. (Pl. 5, fig. 1-16.) Very slender but erect, $6-18^{\prime}$ high ; leaves very narrow, much shorter than the culm; staminate and pistillate flowers $2-5$; perigynium at maturity easily detached. - Cold sphaguum swamps, New Eng. to N. Penn. and Minn.; local. (Eu.)

$$
\text { * 1. - + 2. Lupulince. }
$$

+ Teeth of the perigynium strongly reflexed.

2. C. subulàta, Michx. Green, very slender but erect, $6^{\prime}-2^{\circ}$ high; leaves narrow, somewhat shorter than the culm; bracts leafy, sheathing; pistillate spikes 2-4, scattered, 2-6-flowered; perigynium deflexed.-Deep sphagnum swamps, R. I. to E. Penn., and southward; very local.

++ Teeth erect or spreading.

= Whole plant yellowish; perigynium little or not at all inflated.

3. C. Michauxiàna, Boeckl. Slender but stiff and erect, $1-2^{\circ}$ high ; leaves narrow and firm, shorter than the culm; spikes 2-3, the lowest usually remote and short peduncled, the remainder aggregated and sessile; staminate spike small, wholly sessile; perigynium not inflated, erect or spreading, twice longer than the blunt scale. (C. rostrata, Michx.) - Bogs and lakeborders, mountains of N. H. and N. Y., and westward to I. Superior; local.

4. C. folliculàta, I. Stout, $2-3^{\circ}$ high; leaves very broad and flat. lax; pistillate spikes $3-4$, scattered, all but the uppermost prominently peduncled; staminate spike short-peduncled; perigynium larger, inflated, the scale awned and nearly as long. - Cold swamps, New Eng. to N. J. and Penn., and west to Mich.; rather local.

$$
==\text { Plant green } ; \text { perigynium much inflated } \text {. }
$$

5. C. intuméscens, Rudge. Slender, 18-30' high; leaves narrow; pistillate spikes two, loosely 1 -8-flowered, the perigynium erect-spreading, not prominently many-nerved. - Wet pastures and swamps; common.

6. C. Gràyii, Carey. Larger and stouter; leaves broad and flat, $3-4^{\prime \prime}$ wide; pistillate spikes 1 or 2 , the lowest often peduncled, perfectly globular and compactly 12-30-flowered, the perigynium spreading or deflexed and prominently many-nerved. - Meadows and copses, Vt. to Ill., and south 
to Ga. ; rare eastwarl. - In var. Iuspfoc L, Gray, the perigynium is sparsely hispidulous.

7. C. lupulina, Muhl. Very stout and leafy; leaves rather broad and loose; pistillate spikes 2-6, approximate at the top of the culm, all closely sessile or the lower sometimes short-peduncled, oblong or short-cylindrical, very heary and densely flowered; staminate spike small aml sessile; perigynium large and rather soft, erect or but slightly sprearling, giving the spike a hop-like aspect (whence the name). (C. lurida, Bailey.) - Swamps and wet pastures; frequent.

Var. pedunculàta, Dewey. Spikes more or less scattered, some or all prominently peduncled; staminate spike usually conspicuous, often longpeduncled, very variable in size; perigynium more spreading. (C. gigantea, Rudye.) - With the species, but more common.

Var. polystàchya, schwein. \& Torr. Stonter, the leaves very broad (often $\frac{f^{\prime}}{2}$ ); bracts broad and far exceeding the culm; pistillate spikes 4-6, all long $\left(3-4^{\prime}\right)$ and eyliudrical, more or less short-peduncled, somewhat scattered, becoming yellow; perigyuium very large, ascending. (C. lupuliformis, Sartw.) - N. Y. and N. J.; not common.

C. hepulìsa $\times$ retrórsa, Dudley. Distinguished from C. lupulina by its straw-colored perigynium, which is less inflated and more spreading, standing at nearly right angles to the axis of the spike; scales acute to short-awned, rough. (C. lurida $\times$ retrorsa, Bailey). - Ithaca, N. Y. (Dudley), and Lansing, Mich. (Bailey). Resembles n. 16.

8. C. grándis, Bailey. Distinguished from C. lupulina, var. polystachya, by its much more scattered and mostly shorter slim spikes, which are comparatively loosely flowered; perigynium swolleu below but very abruptly contracted into a slender beak $3-4$ times as long as the body, spreading at riglit augles or nearly so, never becoming yellow; seales narrow, smooth. (C. gigantea of previous editions.) - Swanps, Ky., Del., and southward; local.

\section{* 1.- + 3. Tésicàrice.}

\section{+ Spikes very small, globular or short-oblong.}

9. C. oligospérma, Michx. 'Very slender, but stiff, 18-30' high ; leaves and bracts very narrow, becoming involute; staminate spike single, peduncled; pistillate spikes 1 or 2 , sessile or the lowest very short-peduncled, 3-8-flowered; perigynimm turgid, short-oroid, gralually contracted into a very short and minutely toothed beak, prominently few-nerved, yellow, nearly twice longer than the blunt seale. - Deep swamps and borders of lakes, $\dot{N}$. Eng. to Penn. and Minn.; frequent.

10. C. miliàris, Michx. Culm very slender but erect, 12-18' high, smooth, or slightly rough above on the angles; leaves almost filiform, mostly shorter than the culın; staminate spikes 1-2, exceedingly narrow, elevated an inch or two; pistillate spikes 1-3, the upper ono sessile and the lowest very short-stalked, $9^{\prime \prime}$ long or less, the lower subtended by a short leafy bract ; perigynium very small, broad- or romul-ovate or ovate-oblong, thin but firm, bearing a nerve on each side but otherwise nerveless or very nearly so, rounded into a very short terete entire or somewhat erose beak; seales brown, lanceorate, white tipped, about as long as the perigynium. (C. rotundata? of last ed.) - Outlet of Mooselead Lake, Maine, and northward. 
Tar. màjor, Bailey. Culm much stouter (often over $2^{\circ}$ high), thick and very sharply augled; leaves stout and channelled or involute; staminate spikes short-stalked; the pistillate 1-5, darker, mostly longer and larger; scale varying from wholly obtuse to acutish. - Outlet of Moosehead Lake (Porter), and northward.

Var. (?) aurea, Bailey. Taller and mostly stouter than the type; pistillate spikes one or two, often staminate at top, yellow or stramineous; perigrnium longer, gradually produced into a conspicuous and more or less toothed beak, prominently few-nerved, yellow, broader and usually longer than the blunt scale. (C. pulla, and var. miliaris, last ed.) - Outlet of Moosehead Lake (Smith), and northward.

\section{+ + Spikes much larger, cylindrical. \\ = Scales all, or all but the very lowest, smooth.}

11. C. utriculàta, Boott. Very stout and robust, $3-4^{\circ}$ high; leaves broad $\left(4-6^{\prime \prime}\right)$ and flat, very prominently nodulose, particularly below ; spikes $3-4,3-6^{\prime}$ long, very thick and dense above but usually more or less attenuate below, erect or nearly so, all but the lowest sessile or very short-stalked; perigynium ovate, only moderately inflated, rather abruptly contracted into a short toothed beak, at maturity usually squarrose, rather prominently fewnerved, the upper longer than the sharp scale, the lower shorter than or only equalling the sharper or awned scale. (C. rostrata, Bailey, etc.) - Swamps, everywhere; common. Passes imperceptibly into var. uìon, Boott, which is distinguished by its much smaller size, spikes $2 \frac{1^{\prime}}{2}$ long or less, smaller perigynium, blunt scales, and narrower and little nodulose leares. With the type.

12. C. monile, Tuckerm. Rather slender but erect, $2-3^{\circ}$ high, the culm sharply angled and usually rough above; pistillate spikes $2-3$, the lowest one or two short-stalked, erect or spreading, 1-3' long, narrowly cylindrical; perigynium turgid, prominently beaked, about 10-nerved, ascending, longer than the rery sharp scale. (C. Vaseyi, Dewey.) - Meadows and swales; common. - In var. Moxstròs, Bailey, the plant is very slender throughout, and the terminal spike more or less pistillate, while the remaining spikes are reduced to one or two which are very small and loosely flowered and usually on very long filiform peduncles. E. Mass. (Swan).

13. C. Tuckermani, Dewey. Differs from the last chiefly in the comparatively shorter ( $1-2^{\prime}$ long) spikes, which are much thicker (usually $\frac{1^{\prime}}{2}$ or more); perigynium greatly inflated and very thin and papery, the body broader than long (about $3^{\prime \prime}$ thick); scale thin and narrow, acute, all but the very lowest less than half the length of the perigynium. - Swamps, W. New Eng. to N. J., and west to Minn. ; frequent.

14. C. bullàta, Schkuhr. (Pl.6, fig. 15-20.) Slender, $1-2^{\circ}$ high ; culm very sharply and roughly angled, thin but stiff; leaves narrow, rough-edged, stiff; spikes 1 or 2 , remote, short and thick (rarely $1 \frac{1^{\prime}}{2}$ long), sessile or the lower short-peduncled, more or less spreading; perigrnium turgid but very firm, dull straw colored and shining as if varuished, prominently few-nerved, the long beak usually minutely roughened; scale membranaceous and blunt, about $\frac{1}{3}$ as long as the perigynium. - Swamps from E. Mass. to N. J. and E. Peun., and southward; frequent. 
C. Buthata X utriclidta, Bailey. I'erigynim consilerably smaller and more spreading, less shining; scales longer aud sharper. (C. ULneyi, Boott.) - Providence, R. I. (Ulney).

15. C. retrórsa, Schwein. Stout, 2-3 $3^{\circ}$ high; culm olıtusely angled and smooth or nearly so; leaves broal and soft, roughish, much longer than the culm; spikes $3 \mathbf{- 5}$, approximate near the top of the culm or the lowest remote, all but the lowest 1 or 2 sessile, $1-2$ ' long and very compractly Howered, erect or spreading ; perigynium very thin and papery, much intlated, prominently nerved, strongly retlexed ; scale very short and small. - Swamps, from l'enn. northward, common. - In var. Háktu, Gray, a common monstrous form, the spikes are more or less scattered and peduncled, lousely flowered, and the perigynium less reflexed or sprealing.

$$
==\text { scules all rough-uicued. }
$$

16. C. lùricla, Wahl. Variable in size, mostly ranging from $1 \frac{1}{2}-3^{\circ}$ high, stout; cul n rather obtusely angled and smooth; leaves long and loose, rough; spikes $2-4$, variously disposed, the 1 or 2 upper sessile, nearly erect or ofteu drooping, very densely flowered; perigynimm thin and turgid, often somewhat shining, rather lightly about I0-nerved, very loug and slenderly heaked, ascending; staminate spike single, scales linear, half as long as the perigynium or more. (C. tentaculata, M/ul.) - swamps, N. Eng. to S. Ill., and southward; abunlant eastward. Very variable. - Var. Gı́́cıls, Bailey. Plant more sleuder; spikes $2-3$, very small and narrowly cylindrical ( 1 ' long or less, and $3^{\prime \prime}$ broad or less). Mts. of V't., l'enn, and 'Tenn.

Var. fláccida, Bailey. Lower, scarcely excreding 12-15' in height; spikes 2-4, all sessile and approximate at the top of the culm, small ani straight ( $I^{\prime}$ long or less), dull brown or reddish-brown, loosely flowered and entirely lacking the dense and comose appearance of the type ; perigynium very thin and much inflated, the boly nsually larger than in the type and more gradually contracted into the beak. - N. Y. to N. J.; apparently sarer.

C. utomu Xurutiss, Bailey. Very like C. Inrida, but the spikes usually all approximate or only the lowest separated, erect or spreading, all sessile, green or greenish, often curvel ; perigyniun very long-heaked and aseending; staminate spike one, sessile or very nearly so, strongly resembling that of C. lupulina. (C. tentaculata, var. altior, Bnott.) - Mass., Conn., and X. Y. ; little known. C. lupulina $\times$ retrorsa is distinguished from this by its yellow or straw-colored more seattered spikes which are shorter and always straight, and the loose, larger and more inflated perigynia.

\section{* 1. - + 4. Pseudocypèrre. \\ +. Spikes all erect or ascending.}

17. C. Schweinitzii, Dewey. Suft hut erect, $1-2^{\circ}$ high, stoloniferous, yellowish-green and becoming straw-colored in drỵing; culm flattish and smooth; leaves broad $\left(3-t^{\prime \prime}\right)$, the radical longer thin the 'ulm, the others mostly short; spikes 3-4, the lower one or two short-pecluncled, narrowly long-cylintrical ( $1 \frac{1}{2}-3^{\prime}$ long, $4^{\prime \prime}$ broad); perigynium thin and somewhat inflated, prominently few-nerved, the long beak short-tuothed, ascending; scale awned and commonly rough at the tip, a little shorter than the perigynium. - Swamps, W. New ling. to N. J., and west to Mich.; lucal. 


\section{+ + Spikes widely spreading or drooping.}

18. C. hystricina, Muhl. Slender but erect, $1-2^{\circ}$ high; culm very sharply augled and rough, at least above; leaves rather narrow, roughish; spikes $1-3$, borne near the top of the culm, the upper one often sessile, the remainder on more or less filiform stalks, short (rarely $1 \frac{1}{2}^{\prime}$ long) and compactly flowered; perigynium greenish, very strongly 15-20-nerved, the very slender beak strongly toothed; scale linear and rough-awned, nearly or quite as long as the perigynium. - Swales, throughout; frequent. Often confounded with n. 16.

Var. Dudleyi, Bailey. 'Taller; spikes larger and slimmer ( $1 \frac{1}{2}-2 \frac{1}{2}$ ' long), light straw-colored, all secund and widely divaricate or nodding ; perigynium stronger toothed; scales usually more prominent. - Swales, Conn. (I'right), Ithaca, N. Y. (Dudley), Wisc. (Lapham).

19. C. Pseùdo-Cypèrus, L. Tall and stont, $2-3^{\circ}$ high; culm thick and very sharply triangular, rough throughont; leaves very long, rough-margined; spikes $3-5$, all slenderly peduncled and more or less drooping, all somewhat contiguous, long (mostly $2-3^{\prime}$ ) and narrowly cylindrical, very compactly flowered; perigrnium elliptic-lanceolate, more or less 2-edged, manycostate, the beak shorter than the body, with erect slort teeth, strongly reflexed; scale very rough-awned, about the length of the perigrnium. - Swamps and lake-borders, N. Eng. to Peun., and Mich.; rare. (Eu.)

Var. Americàna, Hochst. Mostly stouter, the leaves broader (about $\frac{1^{\prime}}{4}$ ); spikes thicker and commonly more drooping; perigynium longer, the beak mostly longer than the body and the teeth loug and prominently spreadiug. (C. comosa, Boott.) - Swamps; common.

\section{* 1. - + 5. Squarròsce.}

20. C. stenólepis, Torr. Stout and very leafy, $1-2^{\circ}$ high; culm obtusely angled, very smooth; leaves about $3^{\prime \prime}$ broad, rough on the nerves, the upper and the bracts very much longer than the culm; terminal spike often pistillate at top; other spikes $3-5$, the uppermost sessile on the zigzag rhachis, short ( $1-1 \frac{1^{\prime}}{2}$ or less) and evenly cylindrical, oiten staminate at top ; perigrnium very abruptly contracted into a short but slender toothed beak, shorter than the long-linear and rough scale. - Swamps and meadows, central Penn., to $\mathrm{N}$. Ohio, west and southward; frequent.

21. C. squarròsa, L. Cespitose, $2-3^{\circ}$ high ; culm sharply angled, more or less rough above; leaves broad and weak, roughish, exceeding the culm; bracts much less prominent than in the last; spikes $1-3$, thick, the terminal always two thirds pistillate or more, the remainder more or less stalked, erect or slightly nodling, globular or oblong-cylindric, brown, exceedingly densely flowered; periggnium larger, the beak rough; scale short and usually invisible. - Bogs, throughout; infrequent.

\section{* 2. Trachychl一xe. - + 1. Shortiànce.}

22. C. Shortiàna, Dewey. Tall and slender but strict, in small clumps, $2-3^{\circ}$ high; leaves about $\frac{1^{\prime}}{4}$ broad, flat, rough on the nerves; spikes $3-5$, somewhat approximate near the top of the culm, the lowest 2 or 3 short-peduncled, erect, small ( $l^{\prime}$ long or less, and 2" wide), evenly cylindrical, exceedingly densely flowered; perigynium small, circular or round-ovate, flat, 
sharp-edged, nerveless, the orifice entire, perfectly squarrose; scale thin and blunt, about the length of the perigynium. - Wet meadows, S. Yenn. and Va. to Ill. ; rare eastward.

\section{* 2. -+2 . Anómalce.}

23. C. scabràta, Schwein. 'Tall and rather stont, very leafy, $1-3^{\circ}$ high, culm sharply and very roughly angled; leaves broad and flat, very rough; spikes 3-5, scattered, the upper 1 or 2 sessile, the remainder often long-peduncled and sometimes nodiling, I-2' long, narrowly cylindrical and compactly flowered; periggnium broally ovate, prominently few-nerved, rough, the beak nearly as long as the body and slightly toothed; scale acute and rough-tipped, green-nerved, ahout as long as the body of the perigynium. Wet meadows and glades, as far west as Mich.; common eastward.

$$
\text { * 2. }-+3 \text {. Hirlu. }
$$

24. C. vestita, Willd. Stout and stiff, $2-3^{\circ}$ high; eulm sharply angled, smooth or somewhat rough; leaves narrow and rather short, roughish; staminate spike 1, rarely 2, sessile or nearly so; pistillate spikes 2-5, approximate and sessile, or rarely the lowest sub-radical, often staminate at top, oblong or short-cylindric (rarely l' long), compactly fluwered; perigynium ovate, nerved, stiftly hairy, short-beaked, the beak often purple, and whitehyaline at the orifice, which becomes more or less split with age; scale thin and blunt or acute, shorter than the perigynium. - Tufted in sandy soils, from N. Eng. to N. Y., and southward; frequent.

25. C. striàta, Michx., var. brèvis, Bailey. Stiff, $1 \frac{1}{2}-22^{\circ}$ high ; culm sharply angled, smooth or slightly rough above, mostly exceeding the leaves; leaves narrow and stiff, becoming involute; spikes 1-2, mostly closely sessile, considerably separated when two, short (rarely $1 \frac{1^{\prime}}{2}$ long) and rather thick, erect; perigynium broad-ovate with impressed nerves, smooth, ascending, shortbeaked and very short-toothed; scale thin, obtuse or acutish, mostly alout $\frac{1}{2}$ as long as the perigynium. - Pine-barren swamps, N. J., and sonthward; local.

26. C. Houghtònii, Torr. Stiff, $1-2^{\circ}$ high, extensively ereeping; culm rather sharply angled, rough, exceeding the leaves; leaves flat and very sharp-pointed; spikes $1-3$, sessile or the lowest short-stalked, ereet, varying from nearly globular to cylindric ( $1 \frac{1}{2}^{\prime}$ long), compact; perigynium short-ovate, stiffy pubescent, prominently nerved and toothed; seale thin-margined, acute or awned, shorter than the perigrnium. - Sandy knolls and banks from Maine to Minn. along our northern borders, and northwestward; rather loeal.

27. C. filifórmis, L. 'Tall and very slender but ereet, $2-3^{\circ}$ high ; culm obtuse, smooth; leaves very long, involute-filiform, rough; spikes $1-3$, sessile, somewhat scattered, erect, short and thick (rarely over l' long); perigynium very short-ovate, the teeth very short, the few nerves olscured by the dense stiff hairs; seale thin and blunt, alout as long as the perigynium. Bogs, throughout, north of I'enn. ; frequent. (En.)

Var. latifolia, Boeckl. Culm mostly rough above; leaves flat, 1-2" broad ; spikes usually somewhat slimmer and scales often sharper and longer. (C. lanuginosa, Michx.) - Swales and low meadows, throughout; common.

C. nfRTA, I. Variahle in size $\left(\frac{1}{5}-2^{\circ}\right.$ high), willely creeping; culm rather slender but erect, obtuse and smooth or slightly rough above; leaves soft and 
flat, generally sparsely hairy and the sheaths very hirsute, rarely smooth; spikes $2-3$, distant, more or less shortly-peduncled, erect or nearly so, $1 \frac{1}{2}{ }^{\prime}$ long or less and rather loose; perigynium long-ovate, nerved, soft-hairy, the prominent beak slenderly toothed; scale thin and green-nerved, awned, mostly a little shorter. - E. Mass. to central N. Y. and Penn. (Nat. from Eu.)

$$
\text { * 2. - +4. Puludòsé. }
$$

\section{+ Teeth slender, mostly spreading.}

28. C. trichocárpa, Muhl. Stout and tall, 2-30 high; culm sharply angled, rough above; leaves very numerous, flat and very rough, but not hairy, much exceeding the culm; spikes 2-5, scattered, the lower stalked and more or less spreading, long aud heary $\left(1-4^{\prime}\right)$ but loosely flowered at base; perigynium long-ovate, many-costate, sparsely short-hairy, about twice as long as the membranaceous, acute or acuminate scale. - Marshes ; frequent. - Var. imé́rbis, Gray. Mostly smaller throughout; perigynium smooth; scales usually sharper and longer. Drier places, N. Y. to Mo.; infrequent.

Var. Dewèyi, Bailey. Leares narrower, often becoming somewhat involute, smoother; spikes short (seldom orer $1 \frac{1^{\prime}}{2}$ long), all but the lowest one sessile; perigynium smooth, thick in texture, becoming polished with age, the nerves impressed; scales sharp, mostly a little shorter than the perigynium. - Dakota (Seymour), and northwestward. Resembles small forms of n. 29.

Var. aristàta, Bailey. Mostly stonter; leares more or less hairy on the under surface and sheaths; perigynium usually longer, smooth, the teeth longer and more spreading. (C. aristata, R. Br.) - N. Eng. to Minn.; rare eastward.

$$
\text { + Teeth short, erect or very nearly so. }
$$

29. C. ripària, W. Curtis. Very large and stout, $2-4^{\circ}$ high, stoloniferous; leaves mostly broad, flat, rough, glaucous, much longer than the sharply angled culm; spikes $2-4$, scattered and all more or less peduncled, the lowest often very long-stalked, varying from almost globular in starved plants to $3-$ $4^{\prime}$ long, erect or the lower somewhat drooping, loosely flowered below; perigynium ovate-lanceolate, coriaceous, rather lightly many-nerred, becoming polished, the beak short and thick; scale varying from blunt to awned, shorter or longer than the perigynium. - Swales; common. (Eu.)

C. Acutifóruis, Ehrh. Stout, $2-3^{\circ}$ high; culm thick and sharp, mostly smooth; leaves broad, flat and glaucous, much prolonged; spikes $3-5$, all but the uppermost peduncled, spreading or drooping, narrowly cylindric $(2-3$ ' long), loosely flowered below; perigynium ovate, very strongly many-nerved, the short beak slightly toothed; scale rough-awned and longer than the perigynium. (C. paludosa, Gooden.) - Swales, Dorchester, and New Bedford, IIass (Nat. from Eu.) The former station has been recently destroyed.

\section{* 3. Microrhynche. -+1 . Atràtce.$$
\text { - Alpine; plant small. }
$$

30. C. alpina, Swartz. Small and slender, $\frac{1}{2}-2^{\circ}$ high; culm thin and obtuse, smooth or roughish, naked above; leaves narrow and flat, shorter than the culm; spikes commonly 3 , sometimes 2 or 4 , aggregated, globular and very small, all closely sessile or rarely the lowest exceedingly short-stalked; perigynium orbicular or obovate, nerveless or nearly so, the short beak slightly notched, a little longer than the orate and black mostly obtuse scale. - Isle Royale, L. Superior. (Eu.) 
31. C. atràta, L., var. ovàta, Bontt. Very slender but erect, $1-2^{\circ}$ high ; culın rather sharp, roughish above; leaves narrow but flat, shorter than the culm ; spikes $3-5$, all but the terminal one on slender stalks $\frac{1}{2}-2$ ' long, drooping when nature, 1' long or less, ovate-oblong or short-cylindric, redilishbrown; perigynium broadly ovate, thin and puncticulate, very short-beaked, the orifice sliglitly notched; scale blunt, thin-margiued, about as long as the perigynium. (C. atrata, Man.) - White Mountains, N. H., Sinugglers' Notch, Vt. (Brainerd), and northward.

\section{+ Paludose ; plant larger.}

32. C. fúsca, All. Rather slender but stiff, $1-3^{\circ}$ high; culm sharp, roughish above; leaves very narrow, rougl, mostly slovter than the culm; spikes $2-4$, the terminal rarely all staminate, all sessile and approximate or the lowest sometimes very short-stalked, varying from globular to narrowly cylindric (often becoming $1 \frac{1}{2}^{\prime}$ long), dark brown or variegated; perigrninm elliptic and beakless, whitish and granular, nearly nerveless, the orifice entire; staminate scales very long-lanceolate, the pistillate lance-ovate and very sharp, conspicuously longer than the perigynium. (C. Buxbaumii, Wahl.) - Bogs, throughout; frequent. (Eu.)

$$
\text { * 3.-+2. Rígida. }
$$

33. C. vulgàris, Fries. Low and stiff, about $1^{\circ}$ or sometimes $18^{\prime}$ high ; culm sharp, smooth or rather rough above; leaves narrow and stiff, shorter than the culm, glancous-blue; staminate spike sessile or nearly so; spikes 24 , all sessile or rarely the lowest very short-stalked, short and erect ( $\mathrm{I}^{\prime}$ long or less), very densely flowered or sometimes becoming loose below, the lowest subtended by a bract $1-3^{\prime}$ long; perigynimn appressed, oral or round-ovate, mostly finely striate toward the base, the beak entire or very nearly so, bright green until over-mature; scale ovate and very obtuse, purple with a faint white nerve, conspicuously narrower and shorter than the perigynium, thus causing the spike in the growing plant to assume a characteristic green-and-black appearance. - Swales and low meadows along the sea-board, from Mass. northward; common. (Eu.)

Var. strictifórmis, Bailey. Taller $\left(1 \frac{1}{2}-2 \frac{1}{2}{ }^{\circ} \mathrm{high}\right)$ and looser ; culms slender; leaves long and narrow, lax, scarcely glaucous; stamiuate spike longer peduncled; pistillate spikes looser and often longer, mostly brown or tawnygreen. (C. limula, IIan.) - Swales from E. Penn. northward, near the seaboard; frequent. Often confounded with n. 34 , but easily distinguished by the non-cespitose habit, sheaths not fibrillose, and the short scales very obtuse.

Var. hyperborea, Boott. Somewhat stoloniferous, low, often smaller than the type; spikes shorter and mostly loosely flowered, often beccming very thin; scales generally longer, giving the spikes a darker color; stigmas often 3. (C. rigidla, var. (?) Bigelovii, Tuckerm.) - Alpine summits of N. H., Vt., and N. Y. (Eu.)

$$
\text { * 3. }-+3 \text {. Aritre. }
$$

+Stigmas 2 ; scales not conspicuously acute, or if so, divaricate. $=$ Spikes erect, or rarely spreading in n. 34 .

34. C. strícta, Lam. Tall and sleuder but erect, $2-4^{\circ}$ high, generally in dense clumps when old, or rarely in small tufts; culm sharp, rough above; 
leares long and narrow, rough on the edges, the lowest sheaths usually becom. ing prominently fibrillose; 1 or 2 lowest bracts leafy and equalling the culm; spikes $3-5$, variable in size and shape, scattered, the lowest usually more or less peduncled and clavate and the others sessile, erect or spreading, oblong or cylindric $\left(\frac{1}{2}-2^{\prime}\right.$ long and $2-3^{\prime \prime}$ broad), all compactly flowered above but often attenuate at base (or rarely alternate-flowered throughont), the upper mostly staminate at top, all greenish-purple or pallid; perigynium ovate and small, tawny, mostly lightly few-nerved and somewhat granular, the beak very short and commonly entire; scale obtuse to nearly acute, about equalling the perigynium or a little shorter. - Swales, throughout; abunciant and variable.

Var. angustàta. Stricter; spikes longer and narrower $\left(3-4^{\prime}\right.$ long and about $1 \frac{1}{2}$ " broal), never clavate, more approximate and always erect, the staminate portion usually much longer (often $1-2^{\prime}$ ), rust-colored; scales narrower and sharper, mostly longer than the perigynium. (C. angustata, Boott, in part.) - Same range as the type, but less common.

Var. decòra, Bailey. Usually smaller; basal sheaths rarely fibrillose; spikes shorter (seldom over $\mathrm{I}^{\prime}$ long), sessile or very nearly so, rarely attennate at base, spreading, the terminal staminate flowers few, rust-colored; bracts more spreading; scales very sharp and spreading, longer than the perigynium. (C. aperta, $M($ an. $)-N$. Eng. to Wisc.; rather rare.

C. strícta $\times$ Filifóruis. Leaves and culms very slender; spikes short ( $1^{\prime}$ long or less), sessile and compact, the upper 1 or 2 scarcely bracted, pallid; perigyninm small, smooth. - Keweenaw Co., Nich. (Farwell.) Exactly intermediate between the two species.

35. C. aquátilis, Wahl. Large and stout, glaucous, $2-4^{\circ}$ high ; culm very obtuse and smooth; leaves exceedingly long, broader than in the last, the bracts broad and prolonged far beyond the culm; spikes $3-5,1-2^{\prime}$ long, very compact or the lowest sometimes attenuate below, erect, thick ( $3^{\prime \prime}$ broad or less); perigynium round-ovate or broadly elliptic, nerveless, greenish, imbricated; scale obtuse and much shorter and narrower than the perigynium. - Swamps and lake-margins, N. Eng. to Minu.; not common. (Eu.)

36. C. lenticulàris, Michx. Rather slender but erect, pale throughout, $1-2^{\circ}$ high; culm sharp, usually slightly rough above; leaves very narrow, numerous, much surpassing the culm; spikes $3-6$, more or less aggregated or the lowest remote, the terminal androgynous or staminate, mostly sessile, erect; perigynium ovate, minutely granular, brown-nerved, the tip empty and entire; scale pale and obtuse, about $\frac{1}{2}$ the length of the perigynium. - Gravelly borders of ponds and lakes, northern N. Eng. to Minn.; mostly local.

$$
==\text { Spikes widely spreading or drooping. }
$$

37. C. tórta, Boott. Slender but erect, $1 \frac{1}{2}-2 \frac{1}{2}{ }^{\circ}$ high, in clumps, with exceedingly tough and cord-like roots; culm rather sharp, smooth or roughish above; leaves flat and rather soft, those of the culm very short; spikes 3-5, mostly somewhat approximate or the lower remote, the upper sessile and ascending but the others drooping, long and slender (often $3^{\prime}$ long, $2^{\prime \prime}$ broad or less); perigynium lance-ovate, thin and green, nerveless, the slim upper half empty and more or less tortnous, the beak entire or erose; scale purple-margined and. very ohtnse, shorter than the perigynium. - Cold banks and swamps, Vt. to N. C. ; infrequent. 


\section{++ Stigmas 2 ; scales long-acute and ascending.}

38. C. salina, Wahl., var. cuspidàta, Wahl. Rather stout, $1-2 \frac{1}{2}^{\circ}$ high; culm rather sharp, smooth; leaves narrow but flat; spikes $2-4$, sumewhat approximate, the lowest 1 or 2 very short-stalked, erect, short ( $1 \frac{1^{\prime}}{2}$ or less) and rather thick, the lower subtended by leaf-like bracts $3-4^{\prime}$ long; perigynium elliptic, somewhat granular, marked with 2 or 3 nerves or nerveless, the minute beak entıre; scale brown-margined, produced into a lighter and rough awn much exceeding the perigynium. (C. salina, Mun.) - Salt marshes, Mass., and along the coast northward ; rare in the United States. (Ku.) Anomalous furms, which appear to be hybrids, have been separated as

C. stufcta $\times$ sAlivi, Bailey. Spikes thinner and more scattered, more inclined to be peduncled; scales blunt or short-awned, little exceeding the perigynium. - Near Boston, Mass., W. Boott, Murong.

$$
+++ \text { Stigmas } 3 \text {. }
$$

39. C. prasina, IVahl. Slender, somewhat flexuose, $1 \frac{1}{2}-21^{\circ}$ high; culm rather sharp, smooth; leaves very uarrow, soft and tlat, rough; spikes $2-3$, peduncled and spreading or drooping, somewhat approximate, green, $1-2^{\prime}$ loug, uarrow and loosely flowered; perigynium pale, narrowly triaugular-ovate, thin, nearly nerveless, produced into a short but slender entire or minutely toothed beak; scale very thin and acute, nearly colorless, shorter than the perigynium. (C. miliacea, Muhl.) - Meadows and bogs, Vt. to Mich., and southward; infrequent.

$$
\text { * 3. - + 4. Cryptocárpee. }
$$

40. C. marítima, O. F. Mueller. Mostly stout, $1-2 \frac{1}{2}^{\circ}$ high; eulm sharp, smooth or rough above; spikes $2-6$, scattered, all or all but the upper one on very long weak stalks and pendulous, $1-3^{\prime}$ long and thick and bushy, usually staminate at top; perigynium nearly orbicular, pale, few-nerved or nerveless, the beak very short and entire or nearly so; scale produced into a greenish rough awu 3-8 times as long as the perigynium. - Salt marshes of the coast, Mass., Maine, and northward; not common. Leaves smooth, broad and flat. (Eu.)

41. C. crinita, Lam. Robust and mostly stont, $2-4^{\circ}$ high ; culm sharp and rough or sometimes smooth; leaves about $3^{\prime \prime}$ broad, flat, more or less rough on the nerves and margins ; spikes $3-6$, somewhat scattered, all variously peduncled, mostly secund, curved and drooping (or in small forms rarely nearly erect), 1-4' long, narrowly and evenly cylindric, compact or attenuate below, often staminate at top; perigynium ovate, thin and puncticulate, obscurely nerved, the minute point entire; scale greenish-brown and rough-awned, $2-3$ times as long as the perigynium. (C. gynandra, Schucein.) - Swales; common. - Var. mìor, Boott. Much smaller in all its parts, 10-18' high ; leaves narrow; spikes $3-4,1 \frac{1}{2}$ long or less, less drooping; scales less prominent. Maine to N. Y. ; scarce. Somewhat resembles n. 39.

C. crixìta $X$ tórta, Bailey. More slender than C. crinita, the leaves narrower; spikes nearly as slencler as those of C. torta ; seales blunt or simply acute and little longer than the perigynium, or sometimes very short-awned. - Moist meadows near the flen House, White Mts. (Brainerd). Might be mistaken for drooping-spiked forms of n. 34 . 
* 3. -+5 . Pendutince.

- Spikes narrouly cylindrical.

42. C. littoràlis, Schwein. Somewhat slender but erect, $1-2^{\circ}$ high; leaves narrow and rather stiff, flat, glaucous, shorter than the sharp and nearly smooth culm; staminate spikes $1-3$, dark purple, $1 \frac{1}{2}$ long or less, the scales obtuse; pistillate spikes $2-4$, somewhat approximate, on thread-like peduncles, $1-2^{\prime}$ long, usually staminate at top; perigvnium lance-oval, faintly nerved, the minute beak entire, mostly longer than the obtuse purple scale; bracts prominently purple-auricled. (C. Barrattii, Schwein. \& Torr.) Marshes near the coast, N. J. and southward; rare.

$$
\text { ++ Spikes globular or oblong. }
$$

$=$ Scales very sharp, prominently longer than the perigynium.

43. C. Magellánica, Lam. Slender but erect, $8-18^{\prime}$ high; leaves flat and lax, somewhat shorter than the culm; lowest bract as wide as the leaves or nearly so and exceeding the culm; spikes $2-3$, approximate, all slenderly stalked and drooping; perigynium orbicular or broal-ovate, nerved in the centre, $\frac{1}{2}-\frac{2}{3}$ the length of the scale. (C. irrigua, Simith.) - Deep swamps, throughout, north of Penn.; local. (Eu.)

$$
==\text { Scales blunt, little exceeding the perigynium. }
$$

44. C. rariflora, Smith. Very small but stiff, $4-10^{\prime}$ high, somewhat stoloniferous; culm obtuse and very smooth; leaves rery narrow, becoming involute, shorter than the culm; spikes I-2, only 3-10-flowered, drooping, borne in the axil of a minute awl-like and purple-auricled lract; perigynium ovate, nearly pointless, obscurely nerved, mostly a little shorter than the enveloping scale. - Mt. Katahdin, Maine (Goodale). (Eu.)

45. C. limosa, L. Slender but rather stiff, $1-2^{\mathrm{C}}$ high, stoloniferous; culm sharp, rough above; leaves rery narrow, strongly kecled or involute; spikes 1-2, nodding on short stalks or the upper one erect, oblong, springing from the axil of a very narrow bract which is nearly always shorter than the culm; perigynium very short-pointed, about the length of the broad scale. Deep swamps, throughout, north of Penn.; local. (Eu.)

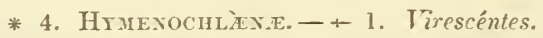

46. C. viréscens, Muhl. Slender, erect or spreading, $1-1 \frac{1}{2} 0$ high; leaves very narrow, more or less hairy; spikes $3-5$, green, short-oblong, all somewhat stalked and often spreading, compact ( $1 \frac{1}{2}$ " thick or less); perigynium ovate and costate, very hairy, longer than the thin and white acute scale. - Var. costàra, Dewey, nsually the commoner form, is taller (often reaching $\left.2 \frac{1}{2}\right)^{\circ}$, with spikes long-cylindric, $\frac{1}{2}-2^{\prime}$ long, and a stronger ribbed perigynium. - Banks and copses, N. Eng. to Mich., and southward; common eastward.

47. C. triceps, Michx., var. hirsùta, Bailey. L'sually stiffer; leaves hairy; spikes 2-4 (usually 3 ), all contiguous or occasionally the lowest somewhat removed, sessile, short-oblong or globular, green or brown (2-3" thick); perigrnium broad-ovate, flattish, very obtuse, often sparsely hirsute when young but smooth at maturity; staminate scales very sharp; pistillate scales acute or short-awned, about the length of or shorter than the perigrnium. Dry copses and fields, N. Eng. to Mo., and southward; rare northward. - Var. 
Sufтиi, Porter. Tall, slender, olive-green, the leaves very long, very nearly

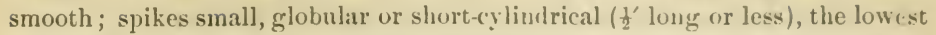
often somewhat remote, all more inclined to be peluucled; perigynium globular and turgid, brown, squarrose, giving the spike a characteristic plump appearance. - Fields and woodlands, southern N. J., L. I'enn., and southward; also in $\Lambda$ rk. ; frequent.

\section{* 4.- - 2. Sylrcática.}

48. C. longiróstris, 'Torr. Very slender but ereet, $1 \frac{1}{2}-3^{\circ}$ highl, growing in stools; leaves narrow, flat, loose; spikes $3-5,1-2$ ' long, loosely flowered, lrooping; perigynium thin, slightly inflated, green, nearly nerveless, spreading, the beak longer than the body, about the length of the awned scale. Shady banks from N. Eng. to Neb., and northward; frequent. - Var. Mìor, Boott. Smaller and slenderer; spikes $9^{\prime \prime}$ long or less, very narrow and very loosely or even alternately few-Howered; perigynium smaller. Neb. and westward.

$$
\text { * 4.- - + 3. Fléxiles. }
$$

49. C. castánea, Wahl. Slender but erect, $1-2 \frac{1}{2}^{\circ}$ high; leares broad and flat, hairy, much shorter than the rough culm ; spikes 2-4, approximate, widely spreading or drooping on filiform stalks, l' long or less, rather dense, tawny ; perigynium broad-lanceolate, gradually narrowed into a beak $\frac{1}{2}$ as long as the body, thin, with a nerve on each side, longer than the light brown or whitish acute thin scale. (C. flexilis, Rudge.) - Banks, Cunn. to Minn.; local.

C. ARctita $\times$ CAstaveA, Bailey. Leaves mostly narrower, less hairy or smooth; spikes very slender aud loosely flowered (scarcely over l" wide), erect or drooping, chestnut color; perigynium thin, long-ovate, shorter-beaked, lightly nerved, mostly surpassing the pointed whitish scale. (C. Knieskernii, Dewey.) - Oneida Co., N. Y.; Keweenaw Co., Mich. (Faruell); N. Minn.

50. C. capillàris, L. Very slender but erect, $2-12^{\prime}$ high; culm smooth, longer than the narrow flat or at length involute leaves; spikes 2-4, either scattered or approximate, all more or less long-peduncled and drooping, borue in the axils of conspicuous sheathing bracts, very small (3-12-flowered); perigynium thin, very small, oblong-ovoid, the beak hyaline-lipped, longer than the very obtuse white scale. - Alpine summits of the White Mts.; Cortland, N. Y., Alcona Co., Mich., and I'oint de Tour, L. Huron. (Eu.)

$$
\text { * 4. - + 4. Débiles. }
$$

- Perigynium thin, rarely with more than two prominent nerves.

51. C. arctàta, Boott. Slender, ereet, $1-2^{\circ}$ high; radical leaves much shorter than the culm and very broad $\left(2 \frac{1}{2}-5^{\prime \prime}\right)$, flat; bracts broad and short, long-sheathing; spikes $3-5$, all widely spreading or drooping on filiform stalks, $1-3^{\prime}$ long and exceedingly slender; perig!nium short ( $2^{\prime \prime}$ long or less), abruptly and conspicuously stipitate and abruptly contracted into a beak, 3-cornered, prominently nerved, green, mostly spreading, searcely longer than the very sharp or cuspidate seale. - Woods and copses, $\mathbf{X}$. Eng. to I'enn. and Minn. ; common.

Var. Faxoni, Bailey. Spikes shorter and usually short-perlunclerl, ereet or nearly so, much more densely flowered, part of them commonly contiguous at the top of the culm, rendering the shorter staminate spike inconspicuous; 
perigynium usually larger. - Lisbon, N. H. (Faxon); Keweenaw Co., Mich. (Furwell); extreme northern Minn. (Builey); also in Canada.

52. C. débilis, Michx., var. Rúdgei, Bailey. Very slender and diffuse, $1-2 \frac{1}{2}{ }^{\circ}$ high (or rarely reduced to $3-4^{\prime} !$ ); leaves narrow and lax, longer than the culm; spikes mostly heavier than in the last; perigynium much longer, very gradually narrowed at each end, scarcely angled and not prominently nerved, rusty when ripe, erect, twice longer than the obtuse or acutish scale. (C. debilis, of last ed.) - Copses, N. Eng. to N. Mich., and southward; frequent east and southward. - Var. strf́ction, Bailey. Usually taller, strict; leares broader (about $2^{\prime \prime}$ wide) and firmer; spikes stiffer, simply spreading or even erect; perigynium mostly shorter and greener, often little exceeding the scale. White Mts. (Faxon). - Var. P'Ùbera, Gray. Perigynium usually more slender, more nerved and minutely pubescent. Center and Lancaster Counties, Penn. (Porter, Lumsden), and Bedford Co., Va. (Curtiss).

C. Débilis $X$ viréscexs, Bailey. Plant slender and very green; leaves flat, rough, mostuy longer that the culm, spikes $2-3,2^{\prime}$ long, thin and slender, erect or nearly so, the terminal one bearing a few pistillate flowers at top; perigynium exactly intermediate between the two species, lance-ovate, nerved and slightly hairy, short-beaked, thin, twice longer than the scale. - Revere, near Boston, Mass. (Fuxon).

\section{++ Perigynium firm, prominently many-nerved.}

53. C. venústa, Dewey, var. minor, Boeckl. Slender but strict, $1 \frac{1}{2}-$ $2^{\circ}$ high; leares narrow and strict, about as long as the culm; spikes $1-2^{\prime}$ long, scattered, the upper usually ascending, the terminal one sometimes staminate at top; perigynium ascending, the rery short and stout beak prominently toothed, thrice longer than the rusty narrow scale. (C. glabra, Boott.) - Sphagnous swamps, Oneida Co., N. Y., N. J., and southward; local.

$$
\text { * 4. - + 5. Gracillime. }
$$

+Perigynium small, scarcely turgid.

54. C. æstivàlis, M. A. Curtis. Slender but erect, $1-1 \frac{1}{2} 0$ high; leaves very narrow, flat, shorter than the culm, the sheaths pubescent; spikes $3-4$, erect or spreading, $1-2^{\prime}$ long and very loosely flowered, all but the lowest short-stalked; perigynium rery small, ovate, scarcely pointed and the orifice entire, few-nerved, about twice longer than the obtuse scale. - Saddle Mountain, W. Mass., and southward in the mountains to N. C.; rare.

55. C. gracillima, Schwein. 'Tall and slender, sometimes diffuse, $1 \frac{1}{2}-$ $3^{\circ}$ high; leaves broad and flat (the radical about $3^{\prime \prime}$ wide), very dark and bright green; spikes $3-4$, scattered, the terminal rarely staminate, densely flowered except at base, peduncled and drooping, green; perigynium ovate, thin and slightly swollen, nerved, obtuse, orifice entire, twice longer than the very obtuse scale. - Woodlands and low meadows, throughout; common. In poorer soil and sunny places, it runs into rar. HƯmuls, Bailey, and is then smaller, has much narrower leaves and very small erect spikes (2-12-flowered), and mostly smaller perigynia.

C. gracfllima $\times$ mirsưta, Bailey. In habit like var. humilis; spikes tawny ; perigynium like that of C. triceps, var. hirsuta ; plant smooth, or very minutely pubescent under a strong lens. - Philipstown, N. Y. (Barratt). 
C. gracfluma $\times$ rembicexs, Bailey. Tall and erect; leaves narrower than in the last, usually slightly hairy ; spikes slenter, erect or slightly spreating, often staminate at top; perigrnium exactly intermediate hetween the two species, ovate, obscurely nervel, sparsely hairy, beaked, about the length of the ovate ciliate rough-awned scale. (('. Sullivantii, Boott.) - C'olumbus, Ohio (Sullicunt); Yonkers, N. Y. (L. C'. Howe); Stanton, Del. ('ommons).

\section{+ Perigynium large, prominently inflated.}

56. C. formósa, Dewey. Sleurler, erect, $1-2 \frac{1}{2} \circ$ high; leaves flat, mostly rather bruad, those of the culm very short; spikes $3-5$, seattered, oblung or short-cylintrical (1'long or less), compact, all flexnose or drooping; perigynium ovate, puncticulate, obscurely nerverl, short-heaked with a slightly notched orifice, all but the lowest one or two twice longer than the blunt or cuspiclate scale. - Woorls and copses, Vt. to Mich. ; local.

57. C. Davísii, Schwein. \& Torr. Always taller; spikes henvier; perigyıium more inflated, strongly nerved and prominently toothed, no longer or shorter than the conspicuously awned and spreading scale. - Wet meadows, W. Mass. to S. Minn., and southward; rare east and northward.

\section{* 4.- - 6. Grisece.}

58. C. grísea, Wahl. Stout, $1-2^{\circ}$ high ; leaves broad $\left(2-3^{\prime \prime}\right)$ and slightly glaucous; bracts broad and leaf-like, diverging, very much exceeding the culm ; staminate spike small and sessile; pistillate spikes $3-4$, short ( $1^{\prime}$ long or less), the highest two usually contiguous to the staminate spike and sessile, the others somewhat remote and peduncled, all erect, compact ; perigynium oblong, pointless, marked with impressed nerves, turgid and cylindric, all but the lowst longer than the narrow, cuspidate or blunt, nerved scale.-Moist grounds, throughont, except along our northern borlers; common. - Var. Axcistr Fólia, Boott. Much more slender; leaves scarcely half so wide, the bracts, especially, much narrower and shorter and more erect; spikes slenter; perigynium scarcely inflated, triangular-ohlong, hearing a sharp beak-like point, 2-ranked; scale nerveless, long-awned and sprealing. N. J. to S. Uhio, and southwarl ; common. - Var. G LoB'ss, Bailey. Low, 3-12' high, often spreading; spikes few-flowered, often with lut 2 or 3 perigynia; perigynium short, inflated, very blunt, nearly globose or obovate; scale short, not promineutly cuspidate or the upper ones wholly blunt. Mo., Kan., and southward.

Var. (?) rígida, Bailey. Rigid; leaves rather narrow, long and erect; staminate spike prominently peduncled; pistillate spikes scattered, all more or less stalked, conspicuously 2-ranked; perigynium triangular-oblong, hard, longer than the cuspiclate ascending scale. - Sollersville, I'enu., and Del.

59. C. glaucodèa, Tuckerm. Lax or somewliat strict $\left(6-1 \mathrm{~s}^{\prime}\right.$ high $)$, densely glaucous; leaves flat, variable in wilth; spikes as in 11.58 ; peringnium firm, not inflated, prominently impressed-nerver, glaucous, longer thau the short-cuspidate or blunt thin and ajpressed scale. (C. flaccosperma, last ed.) - Mealuws and swamps, Mass. to S. Ill., and southward; local.

\section{* 5. Sprrostàcirya. - C Circunulares.}

60. C. granulàris, Muhl. Erect or spreacling, $8^{\prime}-2^{\circ}$ high, somewhat glaucous; leaves flat, varions; bracts broal and long, much exceeling the culm; spikes 3-4, scattered, all but the upper perluncled, erect or ascending, 
compact, short-oblong to cylindric, never exceeding $\mathrm{l}^{\prime}$ in length; staminate spike small and usually sessile; perigynium ovoid, very strongly nerved, the nearly entire short beak usually bent; scale thin and pointed, about $\frac{1}{2}$ the length of the perigynium. - Moist grassy places; common. - Var. HALEAxa, Porter. Habitually lower and more slender; radical leares very broad $\left(3-4^{\prime \prime}\right)$ and more glancous; pistillate spikes $\frac{t^{\prime}}{2}$ long or less, thiuner; perigynium a half smaller, narrower. Wisc. to Va.; infrequent.

61. C. Cràwei, Dewey. Low, strict, stoloniferous (4-12' high); leaves narrow; bracts scarcely exceeding the culm; spikes 2-4, scattered, the lowest radical or nearly so, short-peduncled or the upper sessile, erect, compact, $9^{\prime \prime}$ long or less; staminate spike generally pednncled; perigynium ovate, usually resinous-dotted, obscurely or few-nerved, very short-pointed, longer than the obtuse or short-pointed scale. - Moist places, N. Y. to Ill. and Miun.; local, especially eastward.

\section{* 5. - + 2. Exténsar.}

C. Extéxsı, Gooden. Slender but strict, $1-2^{\circ}$ high; leaves involute; spikes about 3 , the lowest remote and short-peduncled, the remainder approximate and sessile, short (about $\frac{1}{2}$ long) and compact; perigynium ovate, very strongly nerved, ascending, the short stout beak sharply toothed, longer than the blunt brown-edged scale. - Long Island and Coney Island, N. Y.; Norfolk, Va., Mc.Minn. (Nat. from Eu.)

62. C. flàva, L. Very slender but strict and stiff, $1-2^{\circ}$ high, yellowish throughout; leares flat but narrow, mostly shorter than the culm; staminate spike sessile or nearly so, usually oblique; pistillate spikes 2-4, all contiguous or rarely the lowest one remote, all but the lowest sessile, short-oblong or globular, densely flowered, the lowest subtencled by a long divaricate bract; perigrnium ovate, produced into a deflexed beak as long as the body, strongly nerved, thrice longer than the blunt scale. - Swales and wet meadows, N. Eng. to L. Superior; rare westward. (Eu.) - Var. Grímixis, Bailey. Smaller and green, 6-12' high; leaves mostly longer than the culm; bracts erect; perigynium straight or nearly so, the beak often rougl. Grassy places, probably common and generally distributed.

Var. virídula, Bailey. Small and slender, very strict, green or greenishwhite; leaves narrow, equalling or exceeding the culm; hracts long and strictly erect; spikes very small or sometimes becoming cylindric, more closely aggregated; perigrnium conspicuously smaller, the beak rery short and straight. (C. Ederi, last ed.) - Cold bogs, N. Eng. to Penn., and northwestward; local.

$$
\text { * 5. - + 3. Pallescéntes. }
$$

\section{- Perigynium wholly beakless.}

63. C. palléscens, L. Slender, erect, $4^{\prime}-2^{\circ}$ high, tufted; leaves narrow, flat, the lower slightly pubescent, particularly on the sheaths; spikes 2 $4, \frac{1}{2}$ long or less, densely flowered, all but the upper one very shortly peduncled, erect or spreading; perigrnium globular-oblong, thin and very nearly nerveless, about the length of the cuspidate scale. - Glades and meadows, N. Eng. to Peun., Wrisc. and L. Superior; rare westward. (Eu.)

\section{++ Perigynium very stout-beaked.}

64. C. Torrèyi, Tuckerm. Stiff, $1-1 \frac{1}{2} 0$ high; culm and leares thinly pubescent; spikes all sessile, rery short; perigynium obovate, very strongly 
many-nerved, retuse, the beak short and straight, equalling or exceeding the mostly cuspirlate scale. - Supposed to have been collected, a half-century ago, in N. Y. by Torrey, and in Penn. by schweinitz. It vecurs in the Rocky Mountain region, and high northward.

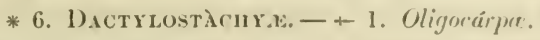 \\ + Sheaths smooth.}

65. C. conoídea, Sclikuhr. Slender liut strict, $1-11^{\circ}$ high; staminate spike long-pedumcled or rarely nearly sessile; spikes 2-3, scattered, shortstalked or the upper one sessile (the lowest frequently very long-stalked), oblong (rarely l' long) and rather loosely flowered, erect; perigyninm oblongconical, impressed-nerved, gratually narrowed to a point, the orifice entire; scale loosely spreading and rough-awned, equalling or exceeding the perigynium. - Moist grassy places, N. Eng. to Ill., and southward; rare westward.

66. C. oligocárpa, Schkulır. 1)iffuse, 10-18' ligh; bracts flat and spreading; staminate spike sessile or stalked; spikes $2-4$, scattered, stalked or the uppermost sessile, loosely 2-8-flowered, erect; perigynium smoll, hard, finely impressel-nerred, abruptly contracted into a conspicnous mostly oblique beak, the orifice entire; scale very loosely sprealing and rough-awned, longer than the perigynium. - Dry woods and copses, IV. New Eng. to Mo., and southward; rare westward. Often confounded with small forms of 11.58 .

++ Sheaths pubescent.

67. C. Hitchcockiàna, Dewey. Erect, $1 \frac{1}{2}-2^{\circ}$ high; spikes $2-4$, all more or less peluneled, very loosely few-flowered, erect; perigynium triangular-ovate, many-striate, the strong beak prominently ollique, shorter than the rough-awned scale. - Rich woods, WV. New Eng. to Ill., and southward to Peun. and Ky. ; frequent.

\section{* 6. - + 2. Lrixifiòrce.}

+ Sheaths grcen.

= Perigynium mostly obscurely triangular, the beak very prominent.

68. C. laxiflora, Lam. Slender but mostly erect, $1-2^{\circ}$ high; leaves rarely over $2^{\prime \prime}$ wide, rather soft; staminate spike peduncled or at least conspicuous; pistillate spikes 2-4, scattered, peduncled or the upper one sessile, loosely flowered, cylindric or sometimes reduced to short-oblong, ereet or the lower loosely spreading; perigynium obovate, conspicuously nerved, the short entire beak much bent or recurved; scale thin and white, blunt or cuspidate, mostly shorter than the perigruium. - Grassy places, throughont; common. Exeeedingly variable. - Var. vinı...s, Bailey. Mostly stouter than the type, the leaves broader; pistillate spikes $\frac{1}{2}-l^{\prime}$ long, the two upper more or less contiguous to the staminate spike and sessile or nearly so; bracts leafy and prolongel. - Copses and grassy places, throughout; common. Counterfeits var. patulifolia. - Var. stıIATILA, Carey. Diffuse; pistillate spikes rarely over $\frac{1}{2}$ long, the upper sessile aud aggregated about the inconspicuons staminate spike, the lowest usually long-exserted. Grassy places, throngliout; very common. - Var. LATIFòiA, Boott. Rather low; leaves $\frac{1}{2}$ broal or more; staminate spike sessile or very nearly so : pistillate spikes cylindric and loose, the upper one or two contiguous; bracts very hroad. Deep rich woods, F. Mass. (Deane) to Penu. and Mich.; common westward. - Var. Patulifólia, 
Carey. Glaucous ; leaves 3 " broad or more ; staminate spike prominent, mostly stalked; pistillate spikes long and alternately flowered, scattered and peduncled; perigynium (as in the following varieties) elliptic, attenuate at both ends, mostly less prominently nerved, and the beak not strongly recurved. Open places, N. Eng. to Mich., and southward; frequent. - Var. Divaricata, Bailey. Tall and stout; leaves narrower ; staminate spike large and stalked; pistillate spikes scattered, all but the upper one prominently peduncled, long; perigynium very large, divaricate, triangular, contracted into a stipe-like base at least half as long as the body. Near Washington, Vasey.-Var. struoFLÉxA, Boott. Very weak and slender; leares 2 " wide or less; staminate spike usually peduncled; pistillate $2-3$, scattered, few-flowered, lowest drooping; perigynium very long-pointed. S. E. Penn., and southward; frequent. $==$ Perigynium sharply triangular, short, and mostly not prominently beaked. a. Spikes drooping or flexuose.

69. C. digitàlis, Willd. Very slender, bright green, tufted, $6-18^{\prime}$ high ; leaves very narrow ( $1-2^{\prime \prime}$ wide); staminate spike short-stalked; pistillate spikes 2-4, all on filiform stalks and all but the upper widely spreading or drooping, linear, alternately flowered; perigynium rery small, impressednerved, longer than the acute whitish scale. - Dryish woods and glades, N. Eng. to Mich., and southward ; frequent. - Var. Copllata, Bailey. Leaves much broader, and the culms weak and reclined; spikes heavier and mostly shorter; perigynium larger, very sharp. Rich woods, central Mich., and probably elsewhere westward.

70. C. laxicúlmis, Schwein. Differs from the variety of n. 69 chiefly in its more cespitose habit, its densely glaucous-blue covering, very slender culm, and very long and filiform peduncles. (C. retrocurva, Dewey.) - Glades, N. Eng. to Mich. and V'a.; rare westward.

\section{b. Spikes erect.}

71. C. ptychocárpa, Steudel. Low, glaucous, $3-10^{\prime}$ high ; leaves flat and rather broal ( $2^{\prime \prime}$ or more), much exceeding the culm; bracts leafy and much prolonged; staminate spike very small and sessile, mustly overtopped by the upper pistillate spike; pistillate spikes $2-3$, sessile or short-stalked or rarely the lowest long-peduncled, erect; perigynium tawny, much as in n. 69, twice longer than the very thin obtuse scale. - Low grounds or swamps, E. Mass., N. J., Del., and sonthward; local.

72. C. platyphýlla, Carey. Low, spreading, glaucous, 6-12' high ; leaves $\frac{1^{\prime}}{2}$ broad or more, mostly shorter than the culms; bracts with thin and sharp-pointed leaf-like tips $1-2^{\prime}$ long; staminate spike stalked; pistillate spikes $2-3$, scattered, all more or less peduncled, alternately $2-10$-flowered; perigynium short, strongly many-striate, about the length of the acute or cuspidate scale. - Rich shady wools and bauks, N. Eng. to Mich., and southward to Va.; mostly local.

73. C. Careyàna, Torr. Tall and slender, mostly erect, $1-2^{\circ}$ high, leaves bright green, firm, $3-4^{\prime \prime}$ wide or more, shorter than the loug culm; bracts leafy, longer than in the last; staminate spike heavy and stalked; pistillate spikes 2-3 (mostly 2), the upper usually near the terminal spike, and nearly sessile, the other remote and long-peduncled, loosely 2-8-flowered; 
perigynium very large and very sharply angled, the beak oblique, finely manynerved, twice longer than the sharp scale. - Rich woods, N. Eng. to Mich., and southward to Washingtou; rare.

\section{+ + Sheaths usually purple.}

74. C. plantagínea, Lam. Slender but erect, $1-2^{\circ}$ high; leaves $\frac{1}{2}-l^{\prime}$ hroal, very firm, appearing after the flowers and persisting over winter, shorter than the culm; staninate spike purple and clavate, stalked; pistillate spikes $3-4$, scattered, loosely few-flowered, erect, the peduncles included in the leafles, sheaths; perigynium smaller than in n. 73, promineutly beaked, about as lung as the sharp scale. - Rich woods, N. Eng. to WVisc., and southward; local.

$$
\text { * 6. - + 3. P'anicece. }
$$

\section{+ Beak cylindrical and prominent; plant not glaucous.}

75. C. Saltuénsis, Bailey. Very slender aud more or less diffuse, strongly stoloniferous, $1-1 \frac{1}{2}^{\circ}$ high; leaves narrow and soft, shorter than the culm; spikes 2-3, scattered, all perluncled and more or less spreading, loosely 3-10flowered; perigynium small, nearly nerveless, thin, the beak straight and sharply toothed; scale loose, acute, shorter than the perigyuium. (C. vaginata, last ed.) - Deep swamps, Vt. to Minn.; local.

76. C. polymórpha, Muhl. Stont, $1-2^{\circ}$ high; leaves rather broad, short; spikes 1-2, short-stalked, erect, compact or rarely louse, usually staminate at the apex, $1 \frac{1}{2}$ long or less; perigynium long-ovate, obscurely nerved; the very long and nearly straight beak oblique or lipped at the orifice; saale reddish-brown, obtuse, shorter thau the perigyuium. - Moist meadows, Mass. to N. C.; local.

\section{+ + Beak short or none; plant often glaucous. = Plants of ordinary hubit.}

77. C. tetánica, Schkuhr. Rather slender, rarely glaucous, somewhat stoloniferous; culm scabrous, at least above; spikes all peduncled, the upper one very shortly so, pale, all more or less attenuate below, the lower borue in the axils of bracts $3^{\prime}$ long or more; perigynium not turgid, greenish, prominently many-nerved, the beak strongly bent; scale obtuse or abruptly mucronate, all except the lowest mostly shorter than the perigyninm. - Meadows and borders of ponds from IW. Mass. westward; common westward. - Var. WoònI, Bailey. Very slender and strongly stoloniferous; leaves narrow, very long and lax; spikes mostly alteruately flowered throughout; scales often sharper. (C. Woodii, Dewey.) Rich woods, N. Y. to Mich., and south to Washington; frequent. - Var. Mìanı, Bailey. Stiffer; leaves mostly broader and stricter; spikes thick and densely flowered, not attenuate at base, the upper one often sessile; perigynium larger. (C. Meadii, Dewey.) R. I. to Neb., and southward; rare eastward. - Var. Cíxisy, Porter. Stout and stiff ; leaves still broader (about $2^{\prime \prime}$ wide) and flat ; spikes thick, often $\frac{1}{4}$ ' wide; perigynium long, straight or very nearly so; scale large, nearly equalling or exceeding the perigyninm. E. P'enn. $(C u n b y)$; Ill. and W' isc.; little known.

C. PAxfeEA, L. Strict, often stiff, glaucous-blue $1-2^{\circ}$ high ; ('ulm smooth; bracts $1-2^{\prime}$ long; spikes $1-3$, scattered, colored, peduncled, erect, rather compact or loose below, seldom l' long; perigrnimm uvid, yellow or purple, somewhat turgid, scarcely nerved, the point nsually curved, mostly longer than the purple-margined scale. - Fields, K. Mass. and l. I. (Nat. from Liu.) 
$==$ Very strict, densely glaucous.

78. C. lívida, Willd. Culms 18' high or less; leaves narrow, often becoming involute; spikes 1 or 2 and aggregated or approximate, or rarely a third nearly radical, sessile or nearly so, erect, narrow; perigynium ovoid-oblong, nerved, granular, beakless, the point straight or nearly so, orifice entire; scale obtuse, mostly a little shorter than the perigynium. - Pine-barrens of N. J., and sphagnum swamps northward to X. Eng. and L. Superior; local.

(Eu.)

$$
\text { * 6. - + 4. Bicolòres. }
$$

79. C. aùrea, Nutt. Low and slender, $1^{\circ}$ high or less; bracts exceeding the culm; spikes 2-4, all but the lowest usually approximate, peduncled or the upper one or two sessile, erect, loosely few-flowered or sumetimes becoming $3^{\prime}$ long, at maturity yellow or brown, the terminal one frequently pistillate above; perigynium fleshy at maturity, nerved, longer than the blunt scale. Wet meadows and springy banks, throughout; rather common.

\section{* 6. - + 5. Digitàtce.}

+ Spikes two or more.

80. C. ebúrnea, Boott. Exceedingly slender and capillary, erect, 4-12' high, stoloniferous; leaves shorter than the culm; staminate spike very small and very short-peduncled, overtopped by the two upper pistillate spikes; pistillate spikes 2-4, approximate or the lowest remote, all stalked, erect, 2-6-flowered ; perigrnium very small, almost nerveless, smooth and becoming black and shining at full maturity ; scale white and thin, obtuse, shorter than the perigynium. - Tufted in sandy or light soils from N. Eng. to Ky. and Neb.; frequent.

81. C. Richardsòni, R. Br. Rather stiff, 4-9' high, stoloniferous; sheaths short, purple or brown; staminate spike stout and mostly short-peduncled; pistillate spikes 1-2, approximate, the very short stalks included, erect, compact, less than $\frac{1}{2}$ in length; perigynium obovoid, firm, hairy, the very short beak entire or erose; scale brown with a conspicuous white-hyaline margin, obtuse or pointless, and longer than the perigynium. - Dry ground, western N. Y. to Ill., and northwestward; rare.

82. C. pedunculàta, Muhl. Low and diffuse, 3-10' high, forming mats; leaves abundant, very green, flat and firm, longer than the weak culms; staminate spike very small, with the uppermost pistillate spike sessile at its base; pistillate spikes $2-4$ on each culm, scattered and long-peduncled from green sheaths, erect or spreading, many other spikes nearly or quite radical and very long-stalked, all 3-8-flowered; perigynium triangular-obovate, smooth or very slightly pubescent above, the short and nearly entire beak somewhat oblique; scale green or purple, truncate and cuspidate, mostly a little longer than the perigynium. - Dry woods and banks, N. Eng. to Va. (Kennedy) and Minn.; frequent northward.

$$
++ \text { Spike one or rarely a rudiment of a second; plant diæcious. }
$$

83. C. pícta, Steudel. Rather weak, $1^{\circ}$ high or less; leaves flat and firm, persisting through the winter, at least twice longer than the culm; a sheathing purple scale at the base of the spike; staminate spike ahout l' long, clavate in anthesis, the purple scales ending in a rery short and blunt whitish tip ; pistillate spike narrower and mostly longer, the scales more abruptly contracted 
into a colored cusp and at length deciduous; perigynium olovate, much contracted below into a stipe-like base, very strongly nerved, entirely pointless, hairy above, covered by the scale. (C. Boottiana, Benth.) - ln a wooded ravine with Hepatica and Ljpiga, near Bloomington, Ind. (Dudley) ; also Ala. and La.

\section{* 7. Sill knidó PHole. - - 1. Scirpince.}

84. C. scirpoídea, Michx. Strict, the pistillate plant mostly stiff, $6-18^{\prime}$ high; leaves flat, shorter than the culm; spike 1' long or less, densely (ylindrieal, very rarely with a rudimentary second spike at its base; perigynium ovate, short-pointed, very hairy, about the length of the ciliate purple scale. Mountains of N. New Eng.; Drummond's lsland, L. Huron. (Norway.)

* 7. - + 2. Montàna.

+ Some or all of the culms longer than the leaves (or in the type of $\mathbf{n} .85$ frequently shorter).

$=$ Staminate spike minute, wholly or parlially concealed in the head; leaves always very narrow; radical spikes often present.

85. C. defléxa Hornem. Diffuse and low, tufted; eulms $1-6^{\prime}$ high, setaceous, more or less curved or spreading, little exceeling or shorter than the leaves; staminate spike exceedingly minute and nearly always entirely invisiblo in the head; pistillate spikes 2-3,2-5-flowered, green, or green and brown, all aggregated into a heal, the lowest one always more or less shortpeduncled and subtended by a leafy bract $\frac{1^{\prime}}{2}$ long or less; radical spikes few ; porigynium very small and much contracted below, sparsely hairy or nearly smooth, the beak flat and very short, mostly longer than the acutish scale. (C. Novæ-Anglix, last ed., mostly.) - lligh mountains of $\mathrm{N}$. H. and Vt.

Var. Dèanei, Bailey. 'Taller and lax, the culıns 6-12' high and some or all prominently longer than the longer and loose leaves; staminate spike much larger ( $2-3^{\prime \prime}$ long), erect or oblique, sessile; pistillate spikes larger ( $4-$ 8-flowered), less aggregated or the lowest usually separated, though rarely more than $1_{4}^{\prime}$ apart; radical spikes usually numerous ; bract mostly longer. - - Swales or dryish places, high or subalpine regions, Mt. lesert, Maine (liand) ; Essex, Mass.; N. H., Vt., and N. Y.; scarce. In aspect like n. 86 .

Var. media, Bailey. Rather stiff, $4-12^{\prime}$ high, in dense tufts; most of the spikes equalling or exceeding the leaves, the staminate prominent, erect (35 "long), sessile or very short-peduncled; pistillate spikes 2-3, all scattered, the uppermost at or near the base of the staminate spike, the lowest usually very prominently peduncled and subtended by a conspicuons brat which surpasses the culm, all rather compactly 3-8-flowered, green, or brown and green ; radical spikes several ; perigynium larger, much like that of short-beaked forms of n. 90. - lieweenaw Co., Mich. (Faruell); also far westward.

86. C. vària, Muhl. Erect, mostly strict, 6-15' high, tufted and somewhat stoloniferous; culms variahle in length, often twice longer than the leaves; staminate spike $3^{\prime \prime}$ long or less; pistillate spikes closely aggregated, or rarely somewhat loosely disposed but never scattered, all strictly sessile, green; radical spikes none; lower bract usually present; perigynium longerpointed than in the last, about the length of the sharp scale. (C. Emmonsii, Dewey.) - Banks and dry woods; frequent. - In var. colordta, Bailey, the scales are purple. Mostly southward. 
$==$ Staminate spike very prominent (or in the variety of $\mathrm{n} .89$ very small, but the leaves broad); radical spikes none.

a. Scales smooth.

87. C. Nòvæ-Ángliæ, Schwein. Very slender and soft, erect, stoloniferous, 6-8' high; culms little longer than the very narrow leaves; staminate spike exceedingly narrow $\left(3-8^{\prime \prime}\right.$ long by about $\frac{1}{2}{ }^{\prime \prime}$ wide), mostly minutely peduncled; pistillate spikes 2 , or rarely 3, the upper one near the base of the staminate spike, the lower very short-peduncled and removed $\frac{1}{2}-1^{\prime}$ and subtended by a leafy bract which nearly or quite equals the culm, both rather loosely 3-6-flowered; perigynium very narrow, often nearly oblanceolate, small, very thinly hairy, the beak sharp and prominent; stigmas often 2. Mountain swamps of W. Mass., and Mt. Desert, Maine (Rand); rare.

88. C. Pennsylvánica, Lam. A foot high or less, erect, strongly stoloniferous, forming large patches ; leaves narrow and more or less involute, dark or dull green, mostly nearly as long as the culm; staminate spike $\frac{1^{\prime}}{2}$ (rarely $\frac{8^{\prime}}{4}$ ) long, usually dull brown or brown-purple, sessile or very nearly so; pistillate spikes $1-3$, contiguous or the two lower rarely $\frac{1}{2}^{\prime}$ apart, all sessile and usually dark-colored, the lowest bract very short or at least rarely prominent; perigynium short- or round-ovate, hairy. - Dry fields; our commonest species.

89. C. commùnis, Bailey. Habitually, taller and stricter, $8-18^{\prime}$ high, in small tufts, never stoloniferous; leaves proportionately shorter, broad (about $2^{\prime \prime}$ ), flat and pale; staminate spike mostly longer, often short-peduncled and usually paler; pistillate spikes $2-4$, scattered on the upper part of the culm, green or tawny, the lowest one or two sometimes peduncled and often with prominent leafy bracts. (C. varia, last ed.) - Dry hill-sides; common.

Var. Wheèleri, Bailey. Mostly greener, 3-14' high; leaves soft and flat and much shorter than the culm; staminate spike $\frac{1}{4}$ long or less, very narrow, sessile and oblique; pistillate spikes mostly closer together. - Knolls in woods, Ionia Co., Mich. (Wheeler), and Alcona Co. (Bailey); Middletown, Conn. (Barratt), and Cheshire Co., N.H. It has much the aspect of n. 86 , but is readily distinguished by the broal leaves and more scattered spikes.

\section{b. Scales rough-cuspidate.}

C. PR.̇cox, Jacq. Rather stiff, the culm sometimes curved, 3-10' high; leaves flat, shorter than the culm ; staminate spike prominently clavate, mostly sessile; pistillate spikes $2-3$, all contiguons, sessile or the lowest very shortpedunclerl and subtended by a bract scarcely as long as itself, all oblong or short-cylindric, the lowest about $6^{\prime \prime}$ long; perigynium triangular-obovoid, the very short beak entire or erose, thinly hispid-hirsute, about the length of the scale. - Fields, E. Mass. (Nat. from Eu. early in the century.)

+o + Part or usually all of the culms much shorter than the leaves.

90. C. umbellàta, Schkuhr. (P1.6, fig. $11-14$.) Low, growing in small and dense mats ( $1-3^{\prime}$ across) ; leares short and often stiff $\left(2-6^{\prime}\right.$ long), flat, the earliest very narrow but the later often ' 2 " broad; spikes all on separate scapes which rarely exceed $1-2^{\prime}$ in length (or rarely one or two short true culms), usually densely aggregated at the surface of the ground and hidden by the leaves, the pistillate spikes green or tawny and rather loosely few-flowered; perigynium slenderly beaked, toothed, very lightly pubescent, about the length of the acute and often rough-tipped scale.-Dry banks and knolls, N. Eng. 
to N. J. and N. Y., and perhaps farther westward ; infrequent. - Var. vfciss, Dewey. 'Tufts looser and larger; leaves longer (often $1^{\circ}$ or more) and laxer, sometimes broader; some pistillate spikes borne near the base of the staminate on a true culm which is $3-8^{\prime}$ high, one or two on each culm. With the species and farther westward; infrequent.

91. C. nigro-marginàta, Schwein. Leaves mostly stiffer than in n. 90, often broader, and some of the culms prolonged; perigynium smooth or nearly so, shorter beaked; scales purple-margined, giving the spikes a very dark or variegated appearance, considerably larger and longer than in the last. - Dry hillsides, N. J., aud southward; local.

\section{* 7. -+3 . Triquétré.}

92. C. pubéscens, Muhl. Strict, $1-2^{\circ}$ high, pubescent throughout; leaves Hat and soft, shorter than the culn; spikes $2-4$, the lower 1 or 2 shortpeduncled, and about $\frac{l^{\prime}}{2}$ long, loosely Howered, ereet; perigynium very hairy, conspicuously beaked and minutely toothed, straight, about the length of the truncate and rough-cuspidate thin scale. - Copses and moist meadows, $N$. Eng. to Ky, and westward; frequent.

\section{* 8. Piyllostáchy.e.}

93. C. Jamèsii, Schwein. (Pl. 5, fig. 17-21.) Diffuse, 6-10' high ; leaves very narrow ( 1 " or less), much surjassing the eulm; spike very small, the staminate portion inconspicuous, the pistillate flowers $1-3$ and loosely disposed; perigrnium globular, produced into a very long and roughened nearly entire beak; scale narrow, the lowest often $1-2^{\prime}$ long, the upper often shorter than the perigynium. (C. Steudelii, Kunth.) - Woods, N. Y. to Ill., and southward; frequent.

94. C. Willdenòvii, Schkuhr. Lower, stiffer, the leaves broaler and pale; spike larger, the pistillate flowers $3-9$, compact; perigynium bearing a prominent two-edged very rough beak; scales chaffy, nerved, as broad as and somewhat longer than the perigynium, or the lowest rarely overtopping the spike. - Copses, Mass. to Mich., and southwarl ; rare.

95. C. Báckii, Boott. Forming deuse mats; leaves still broader (2" or more), very abundant; staminate flowers about 3 ; pistillate $2-5$; perigynium more gradually beaked, smooth throughont; scales very broad and leaf-like, all exceeding the culm and entirely enveloping the spike. - W. Mass. to Ohio, and far westward; local and rare, especially eastward.

\section{* 9. LePtocérilat.E.}

96. C. polytricholdes, Muhl. Capillary, erect or slightly diffuse, 6$18^{\prime}$ high; leaves mostly shorter than the eulm; spike $2-4^{\prime \prime}$ long, linear, the staminate portion very small; perigynimm thin and green, nerved, about twice longer than the obtuse caducous seale. - Bogs; common.

\section{* 10. PiysocérHal.e.}

97. C. Fràseri, Andrews. Cespitose; cnlm 6-15' high, naked or the lower portion included in loosely sheathing abortive leaves, smooth and stiff; leaves $1^{\prime}$ broad or more, destitute of midrib, very thick and persistent, pale, $1-2^{\circ}$ loug; spike whitish; perigynium oroid, faintly nerved, much longer than the scale. - Rich mountain woods, Va. and southward; very local and rare. A most remarkable plant. 


\section{§ 2. VÍGNEA. - * 11. Acroarrhìxe. - + 1. Fátidee}

98. C. chordorhiza, Ehrh. Very extensively stoloniferous; culm mostly erect, $1-1 \frac{1}{2} \circ \mathrm{long}$; leaves involute, shorter than the culm ; perigynium globular, very strongly nerved, short-pointed and entire, about the length of the acute scale. - Cold bogs and soft lake-borders, Vt. to Iowa, and northward; infrequent. (Eu.)

99. C. stenophýlla, Wahl. Stiff, $3-8^{\prime}$ high ; leaves involute and shorter than the culm; perigynium ovate, flat on the inuer face, lightly nerved, gradually contracted into a short and entire rough-edged beak, tightly enclosing the achene, at maturity longer than the hyaliue acutish scale. - Dry grounds, Thayer Co., Neb. (Bessey) ; Emmet Co., Iowa (Cratty), and westward. (Eu.)

$$
\text { * 11. - + 2. Vulpince. }
$$

- Beak shorter than or about as long as the body of the perigynium.

100. C. conjúncta, Boott. Strict but rather weak, $1 \frac{1}{2}-3 \frac{1}{2} \circ$ high; culm soft and sharply triangular or nearly wing-angled, becoming perfectly flat when pressed; leaves soft, about $3^{\prime \prime}$ broad; head $1-3^{\prime}$ long, interrupted, often nearly green, infrequently bearing a few setaceous bracts; perigynium lanceovate, light colored, whitish and thickened below, the beak lightly notched and roughish, about equalling or a little exceeding the cuspidate scale. Swales and glades, N. J., Ky., and westward; usually rare.

$$
+ \text { + Beak twice the length of the body of the perigynium or longer. }
$$

101. C. stipàta, Muhl. Stout, $1-3^{\circ}$ high, in clumps; culm rather soft, very sharp; head $1-3^{\prime}$ long, rarely somewhat compound at base, interrupted, the lowest spikes often $\frac{1^{\prime}}{2}$ long; perigynium lanceolate, brown-nerved, the beak toothed and roughish, about twice the length of the body, and much longer than the scale. - Swales; common and rariable.

102. C. crus-córvi, Shuttlew. Stout, glaucons, 2-30 high; culm rough, at least above; leaves flat and very wide; head much branched and compound, 3-6' long; perigynium long-lanceolate, the short base very thick and disk-like, the roughish and very slender beak thrice the length of the body or more, 3-4 times the length of the inconspicuous scale. - Swamps, S. Minn to Neb. and Ky., and southward; rare northward.

$$
\begin{aligned}
& \text { * 11._- - 3. Multiflòre. } \\
& + \text { Spikes conspicuously panicled. }
\end{aligned}
$$

103. C. decompósita, Muhl. Stout, exceedingly deep green, $1 \frac{1}{2}-3^{\circ}$ high, in stools; culm very obtusely angled, almost terete below; leaves firm, channelled below, longer than the culm; head 2-4' long, the lower branches ascending and $1-2^{\prime}$ long; perigynium very small, round-obovate, few-nerved, hard and at maturity shining, the abrupt short beak entire or very nearly so; scale acute, about the length of the perigynium. - Swamps, N. Y. to Mich., and southward; local.

$$
\text { + Spikes in a simple or nearly simple head. }
$$

$=$ Leaves very narrow ( $1^{\prime \prime}$ broad or less), becoming more or less involute.

104. C. teretiúscula, Gooden. Slender but mostly erect, $1 \frac{1}{2}-2 \frac{1}{2} 0$ high, in loose stools; culm rather obtuse, rough at the top, mostly longer than the leaves; head $1-2^{\prime}$ long, compact or somewhat interrupted, narrow ( $\frac{1}{4}$ ' wide or 
less) ; perigynimm very small, ovate and truncate below, bearing a few inconspicuous short nerves on the onter side, stipitate, firm and at maturity blackish and shining, the short beak lighter colored; scale chaffy and acute, about the length of the perigynium. - Swales, N. Eng. to l'enu., and westward ; common. (Eu.) - Var. R.ıòsı, Boott. More slender; heal mustly longer, the upper portion often somewhat nodding, the spikes scattered and the lowest ones often slightly compound. N. Y., and westward; common.

$==$ Leaves broader and flut (occasionally involute in $\mathrm{n.106)}$.

a. Scales very sharp, mostly rough-tipped.

1. Perigyniun large (2"lony or more), nerveless on the inner fuce.

105. C. alopecoidea, Tuckerm. Stout but rather soft, $2-3^{\circ}$ high; culm rather sharp, thick and soft in texture; leaves $2-3^{\prime \prime}$ wide, about the leugth of the culn, very green; head $1 \frac{1}{2}$ long or less, sometimes green, and occasionally a little compound, the spikes many and compactly or somewhat loosely disposed or the lowest often separate and all mostly short-oblong; perigynium ovate, tapering into a rough beak, very prominently stipitate, with a few brown nerves on the outer face, ascending, about equalling or a little exceeding the scale. - Open swales, N. Y., Penn., and Mich.; local. In aspect like n. 101.

Var. sparsispicata, Dewey. Weak, the leaves much narrower and lax; head I -3 ' long and linear or nearly so, the spikes smaller and separated or scattered. - S. E. Mich. (Cooley, Clark); little known.

106. C. grávida, Bailey. Lower and the culm thinner and more sharply angled, $1-2^{\circ}$ high ; leaves rather narrower and firmer, shorter than the culm; head short, always simple, globular or short-oblong, the lowest spikes rarely distinct; spikes few $(t-i)$, globular, or broader than long ; perigyuium broadly ovate, nearly twice larger, sessile, plump and somewhat polished at maturity, prominently spreading. - N. 111. to Iowa and Yeb. - Var. LAxı́̀ Lı, Baileỵ. Much larger, $2-3 \frac{1}{2}{ }^{\circ}$ high ; leaves broader (about 1') and lax; head large and dense, ovoid or oblong, scarcely interrupted. N. Ill. to Dak.

\section{Perigynium very small, mostly nerved on the inner face.}

107. C. vulpinoídea, Michx. Mostly rather stiff, 1-210 high; culm very rough, at least above; leaves various, mustly flat and longer than the culm; head 1-t' long, usually much interrupted and frequently somewhat compound, varying from dull brown to almost green at maturity, commonly provided with many very setaceous short bracts; spikes very numerous, ascending and densely fluwered; perigynium ovate or lance-ovate, mostly ascending. - Low places, variable; very abundaut, especially northward.

\section{b. Scales blunt, smooth and hyaline-tipped.}

108. C. Sartwéllii, Dewey. Stiff and strict, $1 \frac{1}{2}-21^{\circ}$ high; leaves produced into a long slencler point, mostly shorter than the culm; staminate flowers variously disposed, frequently whole spikes being sterile; head 1-3' long and rather narrow, the individual spikes usually clearly defined, or occasionally the head interrupted below, tawny-brown; perigynium elliptic or lance-elliptic. nerved on both sides, very gradually contracted into a short beak; scale abput the length of the perigynium. (C. disticha, last ed.) Bogs, central N. Y., west and northward; frequent. 
* 11. - + 4. Arenàrice.

C. ARExaria, Linn. Extensively creeping, $1^{\circ}$ high or less; leaves very narrow and very long-pointed, shorter than the culm; head about $\mathrm{I}^{\prime}$ long, clense or sometimes interrupted, oroid or oblong; spikes few to many, those at the apex of the head usually staminate, the intermediate ones staminate at the summit, the lowest entirely pistillate and subtended by a bract about $\mathbf{I}^{\prime}$ long; perigrnium very strongly nerved on both faces, wing-margined above, sharply long-toothed, about the length of the scale. - Sea-beaches near Norfolk, Va. (I/ K.Minn). (Adv. from Eu.)

\section{* 11. - + 5. Muhlenbergiàna.}

+Heads narrow, the spikes scuttered (or often aggregated in C. muricata.)

$$
=\text { Perigynium almost terete. }
$$

109. C. tenélla, Schkuhr. Exceedingly slender, $6^{\prime}-2^{\circ}$ high, in tufts; leaves flat, soft, and weak, mostly shorter than the culm; spikes 1-3-flowered, or the terminal 4-6-flowered, all distinct and scattered on the upper part of the culm, the bracts obsolete or the lowest present and very short; perigynium elliptic-ovate, very plump, finely nerred, the minute beak entire, longer than the white scale, usually at length splitting and exposing the blackish achene. - Cold swanıs, N. Eng. to Penn., and far westward; common. (Eu.)

$$
==\text { Perigynium flattish. }
$$

110. C. ròsea, Schkuhr. Always sleuder and weak, erect, $1-2 \frac{1}{2} 0$ high, exceediug the narrow leares; spikes 5-8, 6-14-flowered, the upper 3-4 aggregated, the others $3-9^{\prime \prime}$ apart, the lowest usually with a setaceous bract; perigynium lance-ovate, thin and shining, nerveless, scarcely margined, rough on the edges above, perfectly squarrose, very green, about twice longer than the trauslucent white scale. - Rich woods, N. Eng. to Minu. and Neb.; frequent. - Var. Radiàta, Dewey. Lower and much more slender, the culms sometimes almost capillary ; spikes 2-5, scattered, 2-4-flowered; perigynium mostly narrower and more ascending. Open places and drier woods; common.

Var. Texénsis, Torr. Very slender but strict, $1^{\circ}$ high or less; spikes $3-4$, all contiguous or the lower ones approximate, $2-6$-flowered ; perigynium lanceolate, the base prominently spongy, smooth or nearly so, conspicuously divaricate. - Dry places, S. Ill. (Schnerk), and southward.

Var. retrofléxa, Torr. Often rather stiff, $1-1 \frac{1}{2}^{\circ}$ high; spikes $4-8$, the upper ones aggregated, the lower 1 or 2 separated and commouly subtended by a conspicuous bract, often brownish; perigynium ovate, smooth throughont, very prominently corky and swollen at the base, which is frequently contracted almost to a stipe, at inaturity usually widely spreading or reflexed; scale brownish and sharp, at length deciduous. (C. retroflexa, M I hhl.) - Copses, throughont; rare northward.

111. C. sparganioides, Muhl. Stouter, stiff; culm $2-3^{\circ}$ high ; leares very broad (usually $\frac{1}{4}$ or more) and flat, their sheaths conspicuously clothing the base of the culm; spikes $6-10$, the 2 or 3 upper ones contiguous, the remainder entirely separate, very green, oblong or short-cylindric, the lowest often compound, all truncate at top; perigynium ovate, wing-margined, rough on the short beak, often obscurely nerved on the outer face, considerably longer than the rough-pointed scale. - Rich woods; frequent.

C. MURICÀtA, L. Culm $1-2^{\circ}$ high, rough, longer than the narrow leaves; spikes $5-10$, variously disposed, but usually some of them scattered, frequently 
all aggregated, rarely tawny; perigynium heavy, ovate, thin and shining, nerveless, the long beak minutely rough, sprealing, a little longer than the sharp green or brownish scale. - 1)ry fields, E. Mass., where it is common, and sparingly south and westward to Va. and (Ohio. (Nat. from Eu.)

++ Heads short-oblong or globular, the spikes all aggregated, or only the lowest one or two separate.

$$
=\text { Plant very stiff throughout. }
$$

112. C. Muhlenbérgii, Schkulır. Pale, growing in small tufts, $1-2 \frac{1}{2}^{\circ}$ high; culns much prolonged beyond the few narrow and at length involute leaves; head $\frac{8}{4}$ long or less, the individual spikes clearly defined; spikes globular, 4-8; perigrnium nearly circular, very strongly nerved on both faces, broader than the rough-cuspidate scale and about as long. - Open sterile soils; frequent. - Var. exímvis, Boott. Perigynium nearly or entirely nerveless. Southeastern N. Y., and southward; rare.

$$
==\text { Plant strict but not stiff. }
$$

113. C. cephaloídea, Dewey. Lax, very green, $2-3^{\circ}$ high; leaves broad $\left(2-3^{\prime \prime}\right)$ and thin, shorter than the long culm; heal rather loose, $\frac{8}{4}$ long or more, all but the very uppermost spikes clearly defined; perigynium ovate, entirely nerveless, long rough-pointed, spreading, twice longer than the very thiu scale or more. - Shady banks, W. Mass. to Mich.; frequent.

114. C. cephalóphora, Muhl. Mostly smaller and stricter, pale; leaves half as wide or less; head small, rarely $\frac{1}{2}$ long, globular or very short-oblong, never interrupted, the lower 1 or 2 spikes usually bearing a very setaceous short bract; perigynium twice smaller than in the last, scarcely longer than the rough-cuspidate scale. - Dry and mostly sterile knolls; common.

Var. angustifolia, Boott. Low, 8' high or less; leaves very narrow; head smaller, usually tawny ; perigynium mostly broader. - West and southward; rare.

$$
\text { * 11. - + 6. Diòica. }
$$

+ Perigynium nerveless or very nearly so.

115. C. capitàta, L. Rigid, $3^{\prime}-1^{\circ}$ high; leaves filiform, shorter than the culm; head globular, uniformly staminate above, brown, very small ; perigynium broadly ovate, very thin, whitish, prominently beaked, erect and appressed, longer than the very thin and obtuse seale. - Alpine summits of the White Mountains. (Eu.)

\section{+ + Perigynium prominently nerved.}

116. C. gynòcrates, Wormsk. Stiff but very slender, $3-6^{\prime}$ high, diøe cious; leaves filiform and setaceous, about the length of the culm; spike ob. long, 2-4" long; perigynium elliptic-ovate, nearly terete, stipitate, widely sprealing or reflexed at maturity, 1 or 2 sometimes borne at the base of the staminate spike. - Cold sphagnum swamps, l'enn., north and westward; local, particularly sonthwarl.

117. C. exilis, Dewey. Very stiff, slender, $1-2^{\circ}$ high ; leaves involntefiliform and very stiff, shorter than the culm; spike varying from almost globular to cylindrical (frequently $l^{\prime}$ long), either unisexual or the sexes variously placed, very rarely a supplementary spike at base; perigynium ellipticovate, flattish, stipitate and somewhat cordate at base, strongly browu-nerved 
on the outer face, rather faintly nerved on the inner, rough-edged above, sharply toothed, spreading, a little longer than the scale.-Cold swamps and lake-borders, N. Eng. and eastern N. Y. to N. J.; rare.

\section{* 12. Hyparrhèva. - + 1. Elongàtoe.}

+ Perigynium very sharp-margined, firm, often thickened at base, spreading in open and at maturity stellate spikes.

118. C. echinàta, Murray, var. cephalántha, Bailey. Rather stiff but slender, $1-2^{\circ}$ high ; leaves very narrow and involute, about the length of the culm; spikes 5-8, approximate or even aggregated into a head, green, compactly 15-30-flowered, short-oblong or nearly globular; perigynium ovatelanceolate, rough on the margins above, nerved on both faces, spreading or reflexed at maturity, the beak long and prominent, longer than the sharp white scale. (C. stellulata, last ed.) - E. Penu. (Porter) to Mass. (Morong), and westward to L. Superior; rare.-Var. Conférta, Bailey. Very stiff ; spikes contiguous or scattered, spreading, short-oblong or globular, dense; perigynium broadly ovate or even nearly round-ovate, very strongly nerved, reflexed or widely spreading. Near the sea-coast; uncommon. The perigynia resemble those of n. 112. - Var. Micnóstachys, Boeckl. Mostly very slender; spikes few, 3-10-flowered, usually tawny; perigynium small, lanceovate, nerved on the outer face but usually nerveless on the inner, erect or spreading, the beak rather long or prominent. (C. scirpoides, Schkuhr. C. sterilis, Willd.) Swales, throughout; very common and variable. - Var. AxGustAta, Bailey. Exceedingly slender; spikes few and very few-flowered, mostly all contignous; perigynium lanceolate or linear-lanceolate, twice the length of the scale or more. N. Y., Vt., and northward; rare.

++ Perigynium scarcely sharp-margined, thin in texture, not thickened at base, mostly in closely flowered and rounded or oblong spikes.

$=$ Perigynium ovate or nearly so, the beak short or none.

a. Bracts not prolonged.

119. C. canéscens, I. Stiff and rather stout, 1-210 high, glaucous and pale throughout, growing in stools; spikes $4-8$, globular or oblong, very densely 20-50-flowered, approximate or somewhat scattered on the upper part of the eulm, usually prominently contracted below with the staminate flowers; perigynium short-ovate, silvery-white and minutely puncticulate, never thickened at base, faintly few-nerved, smooth throughout, ascending, the beak very short and entire; scale obtuse or acutish, about the length of the perigynium. - Cool swamps and bogs, N. Eng. to Penn., west and northward; frequent northward. (Eu.)

Var. vulgàris, Bailey. Very slender, lower, not glaucous, in small and loose tufts; spikes smaller and usually fewer, loosely flowered; perigynium mostly more beaked, prominently spreading. - Mostly in drier places; very common. Perigynium much shorter than in any form of $\mathbf{n} .118$.

Var. alpícola, Wahl. Low and stiff, or at lower altitudes becoming somewhat slender, seldom much over $1^{\circ}$ in height; spikes small, globular or nearly so, dense, well defined and brown or tawny ; perigynium as in the type, ascending. (C. vitilis, Fries.) - Mountains from N. Eng. to Ga., sparingly along our northern boundary, and far westward. (Eu.) 
Var. polystàchya, Boott. Erect and mostly strict, not glancous, $1 \frac{1}{2}-2 \frac{1}{2}$ high, scarcely tufted; leaves very lax and exceediug the culn ; spikes oblung, more or less aggregated in an oblong internpted head, the lowest 1 or 2 subtended by short scale-like bracts; periggnim somewhat spreading. (C areta, Boott.) Low woods, N. New Eng. to N. Minn.; rare. licsembles (. echinatil, var. cephalantha.

120. C. Norvégica, Willd. Low and stiff, but rather slender, $1^{\circ}$ high or less; leaves very narrow, mostly shorter than the culm; spikes $3-5$, somewhat scattered, brown, globular or oblong, compactly many-flowered, the terminal one long-contracted below with the staninate flowers; perigynimm very short-ovate, thick, the beak rough, a little longer thau the very obtuse s ale. - Salt marshes, Maine, and northward, rare. (liu.)

121. C. tenuiflòra, Wahl. Very slender and diffuse, $1-1 \frac{1}{2}^{\circ}$ high, in tufts; leaves very narrow and lax, shorter than the filiform culm; spikes 24, all loosely few-flowered and silvery-green, and aggregated into a small globular head; perigynium elliptic, olssurely nerved, smouth, beakless, sprealing, about the length of the white thin scale. - Bogs, N. New Eng. to N. Minn.; lucal. (Eu.)

\section{b. Bracts much prolonged, the lowest 2-3' long.}

122. C. trispérma, Dewey. (Pl. 6, fig. 1-5.) Exceedingly slender, in small and louse tufts, the weak reclining culms $1-2^{\circ} \mathrm{long}$; leaves soft and narrow, shorter than the cnlm; spikes $2-3,1-3^{\prime}$ apart, silvery-green, $2-3$ flowered; perigyuim very thin, finely nerved, the beak entire or nearly so ; scale acnte, very thin, usually shorter than the periggnium. - Cold bogs, throughout; common northward.

$$
==\text { Perig.ynium ovate-lanceolate to linear-lanceolate. }
$$

123. C. Deweyàna, Sclwein. Weak, $1-1 \frac{1}{2}^{\circ}$ high; leaves flat and soft, shorter than the culm, yellowish-green; spikes $3-6$, mostly oblong or sometimes but 2-3-flowered, loose, the upper ones contiguous but the lower 1 or 2 usually considerably separated on the zigzag rhachis and mostly subtended by a bract, all silvery-green; perigynium ovate-lanceulate or narrower, very thin in texture, nerveless, somewhat thickened helow on the outer face, the long beak rough; seale very thin, acute or cuspidate, about the length of the perigynium. - Dry woods; common.

124. C. bromoides, Schkuhr. Lax, $1-2^{\circ}$ high, in dense stools; leaves very narrow, ahout as long as the culm; staminate flowers variously situated in the head, sometimes a few spikes wholly sterile, rarely the plants dicecious; spikes 3-6, ollung or short-cylindric, erect, silvery-tawny or brown; perigynium linear-lanceolate, firm especially at the basc, prominently nerved, tho long and roughened beak toothed; scale sharp, shorter than the perigynium. -Opeu bogs; common.

$$
\text { * 12. - + 2. Ordales. }
$$

+Perigynum ovate-lanceolate, with uinged margins.

125. C. siccàta, Dewey. Extensively creeping, $1-2^{\circ}$ high, erect; leaves firm, narrow, about the length of the culm; staminate flowers varionsly situated, usually some of the spikes wholly sterile; spikes :3-5, aggregated or separated, ovoid or short-oblung, silvery-brown; perigynium firm, nerved on 
both faces, the long beak rough and toothed, the margins prominent or sometimes very narrow; scale acute, about the length of the perigynium. - Sandy fields and banks, N. Eng. to Ohio, west and northward; frequent.

++ Perigynium ovate-lanceolate or narrower, scale-like, with little distinction between body and margin.

126. C. Muskinguménsis, Schwein. Robust, erect, $2-3^{\circ}$ high; leaves many and lax, loosely sheathing, those on the sterile shoots crowded near the top, all flat and loug-pointed; spikes 6-12, coutiguous, erect, narrowly cylindric (often $\mathrm{l}^{\prime}$ long), becoming light brown and presenting a dried appearance, very densely flowered; perigynium linear-lanceolate ( $3^{\prime \prime}$ long), prominently nerved, ciliate on the white margins above, appressed, twice the length of the scale or more. (C. arida, Schwein. \& Torr.) - Woods and copses, Mich. and Ohio to Ill. and Wisc.; local.

127. C. tribuloides, Wahl. Stout and erect, $2-3^{\circ}$ high; leaves narrower than in the last, loosely sheathing; spikes 6-15, aggregated into an oblong or somewhat interrupted heavy head, short-oblong or sometimes nearly globular, green or tawny-green, compact, not narrowed above; perigynium linear-lanceolate $\left(3^{\prime \prime}\right.$ long), obscurely nerved, erect but the points conspicuous, rough-margined, nearly twice the length of the scale. (C. lagopodioides, Schkuhr.) - Open swales; frequent.-Var. тйвÀтA, Bailey. Culm softer and often lax; the leaves broader; spikes more loosely disposed, forming a head $1-2^{\prime}$ long, which is slender and more or less interrupted but always erect, green, becoming tawny, if at all, only when the perigynia begin to fall, obovateoblong ( $\frac{1}{4}$ to rarely $\frac{1}{2}{ }^{\prime}$ long), contracted below; perigynium ascending and more appressed, the points therefore not conspicuous. Woods, throughont; rare. - Var. Redúcta, Bailey. Very slender, $1-2^{\circ}$ high, the culm projecting beyond the leaves; spikes 2-10, small and nearly globular (usually less than $3^{\prime \prime}$ broad), all usually distinct, the lowest separated, brown, especially at maturity, the head often flexuose; perigynium small, the points spreading and conspicuous. Copses, N. Eng. to Dak.; infrequent.

Var. Bébbii, Bailey. Stiff or rather slender, erect, $1-2 \frac{10}{2}$ high; head dense, ovoid or oblong $\left(\frac{1}{4}-\frac{8}{4}\right.$ or very seldom $l^{\prime}$ long), the lowest spike only rarely distinct, straw-colored; spikes small ( $3^{\prime \prime}$ long or less), their axes ascending; bracts at the base of the head small or none ; points of the small perigynium conspicuous. (C. Bebbii, Olney.) - Dry low grounds, throughout; common.

Var. cristàta, Bailey. Stont and stiff, $1 \frac{1}{2}-3^{\circ}$ high; head more or less open or at least the lower 1 or 2 spikes commonly distinct, $1^{\prime}$ long or more, green; spikes larger than in the last and almost exactly globular, their axes more divergent or fully horizontal; bracts usually conspicuous, sometimes one of them foliaceous; perigynium spreading, the points more conspicuous. (C. cristata, Schwein.) - Noist ground, throughout from Peun. northward; common.

128. C. scopària, Schkuhr. Rather slender but erect, $1-2 \frac{1}{2}{ }^{\circ}$ high ; leaves very narrow, shorter than the culm; head short and comparatively thick, always tawny or brown, bractless or nearly so ; spikes 3-8, all contiguous or bunched, orate-oblong, always prominently narrowed or cone-shaped above, ascending; perigynium as in $\mathbf{n} .127$, but erect or asceuding. - Open swales, throughout; common eastward. 
Var. minor, Boott. Nuch smaller, 6-10' high, the leaves very narrow; head very small and darker brown; spikes very small (2-4" long). - liocky and sterile places, northward; frequent.

+++ Perigynium ovate or broader, thickened in the middle, wing-margined (in 11.129 marginless).

$=$ IIead silvery-Urou'n, silvery-green, or silvery-uhitish.

129. C. adústa, Boott. Very stiff and stout, $1 \frac{1}{2}-2 \frac{1}{2}^{\circ}$ high, in dense tufts; head very lieavy, erect, varying from globular to oblong, silvery-brown; spikes $5-10$, globular and heary, all aggregated or sometimes distinct, the lowest 1 or 2 subtended by a short and very broad-based, nerved and pointed bract; perigynium broadly ovate, wingless or very nearly so, plump, shining, nerved on the outer face but nerveless on the inner, filled by the large achene; scale acute, about the length of the perigynium. ( $\mathrm{C}$. ] inguis, Bailey.) - Dry and mostly hard soils, Mt. Desert, Maine (Greenlenf'), and northward, and Crawford Co., Mich. (Bailey), to N. Minn., and far northwestward; local.

130. C. fœnea, Willd. Slender, erect or the top of the culm flexuose, $1-2^{\circ}$ high; head long and weak, often nodding; spikes $5-8$, small, nearly globular and much contracted below, silvery-green, alternately disposed; perigynium varying from ovate to long-ovate, very thin, much longer than the sinall achene, prominently rough-margined, strongly many-nerved on both faces, especially on the small inner face; bracts entirely wanting or inconspicuous. (C. adusta, last ed.) - Dryish copses, N. Eng. to Penn. and Minn. ; not common. - Var. PERPLÉxA, Bailey. Mostly taller and stouter; spikes larger and less attenuated or even truncate below, approximate or even aggregated, the head erect or nearly so and the lowest bract occasionally prominent; perigynium thicker and firmer in texture. N. Eng. to Minn.; infrequent.

131. C. silícea, Olney. Stiff, $1-2^{\circ}$ high, in clumps; leaves very narrow, becoming involute, not exceeding the culm; head $1-3^{\prime}$ long, usually flexuose or nodding above the middle at maturity ; spikes 5-8, silvery-white or silverytawny at full maturity, all more or less separated, ovate, conspicuously contracted below and cone-shaped above, erect on the culm; perigynium very broad-ovate and very thin, obscurely nerved, appressed, about as long as the acute colorless scale. (C. fœnea, var. sabulonum, last ed.; C. straminea, var. moniliformis, Tuckerm.) - Sands of the sea-shore, Maine to N. J.; frequent.

$==$ Head dull brown or green (usually somewhat silvery in var. fonea of $\mathrm{n}$. 132).

132. C. stramínea, Willd. Very slender, erect, but the top of the culm often flexuose, $1-3^{\circ}$ ligh ; leaves narrow and long-pointed, stiff, shorter than the culm; spikes $3-8$, tawny, very small ( $2-3^{\prime \prime}$ broad), globular or sometimes a little tapering below from the presence of many staminate flowers, usually all entirely distinct on the very slender, often zigzag or flexuose rhachis; bracts none, or only the lowest conspicuous; perigynium small and ovate, nerver on both faces but never unusually prominently nerved on the inner face (as is the perigynium of n. 130), the points spreading and rather conspicuous; scale acute, about the length of the perigynium. (C. straminea, var. tenera, last ed.) - Dryish copses and fields; common. Immensely variahle.

Var. mirábilis, Tuckerm. Culm long and mostly weak, often $4^{\circ}$ high, much longer than the loose leaves; spikes $4-8$, larger, usually all contiguouy 
or occasionally the lowest 1 or 2 separate, spreading, loosely flowered, tawny or frequently greenish; perigynium narrowly orate, thin, longer than the scale, the points much spreading and very conspicuous. (C. mirabilis, Dewey.) - Shady places, throughout; frequent.

Var. brèvior, Dewey. (PI. 6, fig. 6-10.) Culm always stiff, $1 \frac{1}{2}-2 \frac{1}{2}^{\circ}$ high, longer than the stiff long-pointed leaves; spikes 3-8, all distinct, contiguous or more or less separated, large $\left(3-5^{\prime \prime}\right.$ broad), globular, the head always short and erect; perigynium orbicular or ovate-orbicular, often cordate at base, mostly very broadly winged. (C. straminea, and vars. typica, hyalina, and Meadii, last ed.) - Dry soils, throughout; common.

Var. apérta, Boott. Culm slender but strict below the head, $1-2^{\circ}$ high, growing in dense tufts; leaves very narrow, usually much shorter than the culm; spikes 4-6, large, heary, much contracted below, usually all separated, becoming rusty, disposed in a weak or nodding head; perigynium narrowly ovate. - Bogs, throughout; rare westward. Transition to $\mathrm{n} .128$, from which the ovate perigynia distinguish it.

Var. invisa, W. Boott. Culm very slender, weak above; leaves very narrow with exceedingly long thin points, about the leugth of the culm; spikes small ( $3^{\prime \prime}$ broad or less), orate, variously disposed in dense or open heads or sometimes the lowest remote or even subradical, rusty, the lower ones subtended by filiform bracts $2-5^{\prime}$ long. - Swales near the sea-board, Maine to Del.; infrequent. Apt to be confounded with n. 128.

Var. alàta, Bailey. Culm very stiff, $1 \frac{1}{2}-3^{\circ}$ high, longer than the stiff leares; spikes very large, oblong or conical, always pointed, usually all contiguous, green or sometimes becoming tawny; perigynium orbicular or orbicular-obovate, very abruptly contracted into a short beak which is prominent in the spike. (C. alata, Torr.) - Swales, Mass. to Ill., and southward; rare and uncharacteristic far inland.

Var. cumulàta, Bailey. Culm very stiff, $2-3^{\circ}$ high, greatly exceeding the firm leaves; spikes 5-30, all aggregated or densely capitate, green, widely divergent, pointed above, very abruptly contracted or even truncate at base, very densely flowered; perigynium small, broad, very obscurely nerved, the points. inconspicuous.-Dry grounds, Penn. to N. Eng., and northward; rare.

Var. fœ̀nea, Torr. Culm very stiff, longer than the leaves, $1-2^{\circ}$ high ; spikes $4-8$, contiguous or separated, never densely aggregated, prominently contracted both above and below, very densely flowered, green, or often silverygreen. (C. fœnea, last ed., excl. vars.; not Willd.) - Near the sea-coast; frequent.

C. LEPonisa, L. Distinguished from C. straminea, var. brevior, as follows : - Usually lower; spikes rusty-brown, ovoid or oblong, erect or appressed, more or less contracted both above and below, contiguous in an interrupted head 1' long or less; perigynium lance-ovate, thin, very narrowly margined, erect and appressed, obscurely nerved. - About Boston (W. Boott, Morong). (Adv. from Eu.)

\section{* 12. -+3 . Cyperoídece.}

133. C. sychnocéphala, Carey. Erect, $3-18^{\prime}$ high, leafy; head $\frac{1}{2}-1^{\prime}$ long; perigynium very slender, faintly nerved, $5-6$ times longer than the exceedingly small achene, mostly a little longer than the sharp scale. - Glades, central N. Y. to Minn., and far westward; rare. 


\section{Order 1a9. GRAMíneae. (Grass Family.)}

Grasses, with usually hollow stems (culms) closed at the joints, alternate 2-ranked leaves, their sheaths split or open on the side opposite the blarle; the hypogynous flowers solitary in the axils of imbricaled 2-runked glumes, forming a 1-many-flowered spikelet; the lower glumes (1 or usually 2) empty, the succeeding flowering glumes enclosing each a somewhat smaller and usually thinner seale (called the $p a l e l$ ) and 2 or 3 very ninute hyaline seales (lodicules) at the base of the flower. Stamens 1-6, commonly 3 ; anthers versatile, 2-eclled, the cells distinct. Styles mostly 2 or 2-parted; stigmas hairy or feathery. Ovary 1-celled, 1-ovuled, forming a seed-like grain (caryopsis) in fruit. Embryo small, on the outside and at the base of the floury albumen. - Rnots fibrous. Sheath of the leaves usually more or less extended above the base of the blade into a scarious appendage (ligule). Spikelets panicled or spiked. Palet usually 2-nerved or 2-keeled, enclosed or partly covered by the glume. Grain sometimes free from, sometimes permanently allherent to, the palet. - A vast and most important family, as it furnishes the cereal grains, and the principal food of eattle, ete. The terms flowering giume and palet are now adopted in place of the outer and inner palets of previous editions, while for convenience the term flower is often retained for the flower proper together with the enclosing flowering glume. (See Plates 7 - 15.)

Serres A. Spikelets jointed upon the pedicel below the glumes, of one terminal perfect flower (sometimes a lower staminate or neutral flower in n. 5), or some or all of the 1-flowered spikelets unisexual in n. 10-12. Glumes 4 (rarely only 2 or 3 ).

Tribe I. PANICE.E. Spikelets of one perfect flower, in spikes or panicles. Flowering glune awnless, in fruit more rigid than the empty glumes.

* Spikelets in 2-4 ranks on a more or less flattened rhachis. - See also n. 5 (§ Digitaria).

+ Rhachis produced beyond the upper spikelet; glumes 3 .

1. Spartina. Spikelets much flattened laterally in 2 close ranks. ++ Rhachis not produeed above the upper spikelet (rarely in n. 3 ).

2. Berkmannia. Spikelets obovate, in 2 close rows. Glumes 3 (or 4 ), strungly concave, carinate.

3. Paspalum. Spikelets plano-convex, sessile or nearly so. Glumes 3 (rarely 2).

4. Eriochloa. Spikelets flano-tonvex, lanceolate, with a basal eallus, short-pedicelled. * Spikelets irregularly paniculate or spicate.

5. Panicum. Spikelets ovate, not involncrate nor the pedicels bristly. Gilumes 4 , the lowest usually small or minute.

6. Setaria. Spikelets in dense eylindrieal spikes or panieles, the pedieels bristle-bearing.

7. Cenchrus. Spikelets $(1-5)$ enclosed in a globular spiny bur-like involucre.

8. Amphicarpum. Spikelets of 2 kinds, one in a teruinal panicle, the otlier subter ranean on radical peduncles.

Tribe II. ORYZEIE. Spikclets unisexual or perfect, in loose panieles, with only 2 glumes (in our genera) and palet none. Stamens often 6.

9. Leersia. Flowers perfeet. Sipikelets mueh flattened. Glumes carinate.

10. Zizania. Spikclets unisexual. Glumes convex, narrow. 
Tribe III. MAYDEAE. Spikelets of a single perfect or unisexual or rudimentary flower, in jointed spikes, in pairs at each joint, mostly imbedded in the thick rhachis.

11. Tripsaeum. Spikelets monœcious, the stanninate above in the spike.

12. Rottbœllia. One spikelet of each pair sterile and shortly pedicelled, the other fertile, sessile and sunk in the rhachis.

Tribe IV. ANDROPOGONEAE. Spikelets in pairs or threes on the (usually jointed and bearded) rhachis of a spike or branches of a panicle, one sessile and fertile, the lateral pedicelled and often sterile or rudimentary; 2 upper glumes snıaller and hyaline, that of the fertile flower mostly awned.

13. Erianthus. Spikelets in pairs, spieate, all alike fertile, involucrate with a silky tuft.

14. Andropogon. Spikelets spicate, in pairs, the pedicellate sterile or rudimentary; rhachis bearded.

15. Chrysopogon. Spikelets in open panieles, in pairs or threes, only the sessile fertile.

Series B. Rhachis of the spikelet usually jointed above the persistent lower glumes (jointed below the glumes only in n. 19,31, and 36). Spikelets 1 - many-flowered, the uppermost flowers often imperfect or rudimentary.

Tribe V. PHALARIDEA. Glumes 5, only the uppermost fertile, the 2 middle ones rudimentary or empty or staminate; palet 1-nerved. Paniele mostly contracted and spike-like.

16. Phalaris. Middle glumes mere rudiments each side of the shining triandrous flower.

17 Anthoxanthum. Midale glunes empty, awned on the back. Stamens 2.

18. Hierochloe. Mirldle glumes triandrous. Fertile flower diandrous.

Tribe VI. AGROSTIDEA. Glumes 3 ; flower solitary, perfect (rarely a rudimentary or perfect second flower in n. 23 and $32-31$ ); palet 2-nerved.

* Flowering glume with a terminal awn (none ir n. 22), closely embracing the grain in fruit; spikelets in panieles or loose spikes, the rhachis not produced beyond the flower (except in $\mathrm{n} .24$ and a single species of n. 23). - STIPE.E.

- Fruiting glume firn and indurated, with a callus at base (none in n. 22).

19. Aristida. Awn 3-firl, the branches divaricate. Callus acute.

20. Stipa. Awn simple, twisted. Callus mostly acute.

21. Oryzopsis. Awn simple, straight, cleciduous. Flower oblong; callus short, obtuse.

22. Milium. Awn none. Flower small, ovoid, without callus.

+ + Fruiting glume thin and membranous; outer glume smaller or minute.

23. Muhlenbergia. Flower mostly hairy at base, the glume mucronate or awned.

24. Bracliyelytrum. Rhachis produced into a bristle above. Outer glumes very small, the flowering one long-awned. Staniens 2.

* * Flowering glume awnless or short-awned, losely embracing the grain, thin, the lower glumes complicate-carinate; spikelets in dense spike-like panicles, the rhachis not produced. - PhLeOIDles.

25. Heleochloa. Awns none. Spikes short and scarcely exserted.

26. Phleum. Glumes somewhat truncate, mucronate or short-awned. Spike cylindric.

27. Alopecurus. Lower glumes united at base, the flowering awned on the back. Palet none. Spilke eylindric.

* * Glumes membranous, the lower rarely strongly complicate, the flowering with a dor sal awn or awnless; spikelets variously panieled. - AgROSTEE.

- Flowering glume 1- (rarely 3-) nerved, awnless ; grain loosely enclosed or naked.

25. Sporobolus. Culms wiry or rigid. Leaves involute.

+- Flowering glume 3-5-nerved, mostly awned; grain enclosed.

++ Rhachis not rodueed above the single flowcr.

29. Agrostis. Spikeleis in an open paniele.

30. Polypogon. Empty glumes long-awned. Panicle spike-like.

31. Cimna. Spikelets flattened, in a loose panicle. Palct 1-nerved. Stamen 1. 
++ Rhachis bearing a rudimentary second flower or short bristle (except in specles of n. 33).

32. A pera. Flowering glume bifid, awned. Panicle very loose and delicate.

33. Calamagrostis. Flowers hairy-tufted at base. Glumes meubranaceous. Palet thin.

34. Ammophila. Spikelets large. Flowers hairy-tufterl at base. Glumes and palet chartaceous.

Tribe VII. AVENEAE. Spikelets 2-several-flowered, panicled, the rhachis or batse of the flowers often bearded; upper flower imperfect or rudimentary (except in n. 37 ). Flowering glume bearing a twisted, bent or straight awn on its back or below the apex.

* One of the flowers staninate only.

35. A rrhenatherum. Lower flower staminate, loug-awned; middle flower perfect, nearly awnless; the upper rudimentary.

36. Holcus. Flowers '2, the lower perfect, awnless, the upper staminate, awned.

* Flowers all perfect or the uppermost usually rudimentary.

37. Aira. Spikelets very small, in a diffuse panicle. Flowers 2 , perfect, awned towarl the base.

39. Deschampsia. Spikelets 2-flowered, with a hairy rudiment. Glumes thin-scarious, the floweriug one erose-truncate, awned near the mildle.

39. Trisetum. Spikelets 2 -several-flowered. Flowering glume thin, compressed, carinate, 2-tonthed, awned above by the excurrent mid-nerve.

40. Avena. Spikelets 2 -several-flowered. Flowering glume harl and firnı, rounded on the back, 5-9-nerved, the mid-nerve long-excurrent at or below the 2-tnothed apex.

41. Danthonia. As Avena, hut the 3 uiddle nerves of the flowering glume running into a flattish twisted awn from between the teeth.

Tribe VIII. CHLORIDEA. Spikelets 2 -several-flowered with one or more of the upper flowers imperfect (fower $I$ and perfect in n. 45), arranged in 2 rows upon the rhachis of a $\mathbf{l}$-sided spike.

* Spikelets with one perfect flower.

42. Cynodon. Spikes $3-5$, slender, digitate. Flower and the rudinent awnless.

43. Ctenium. Suike solitary, terminal. Flowers $4-6$, the middle one perfect.

44. Gymnopogon. Spikes filiform, racemose. Spikelets remote, of a perfect flower and all awned rudiment.

45. Schedounardus. Spikes $3-9$, slender, scattered, distant. Spikelets small, I-flowerecl, awuless.

46. Bouteloua. Spilies scattered (rarely $\mathrm{I}$ and terminal), dense. Glume of perfect flower 3-tootlied. Rudimentary flowers I-3-awned.

* Spikelets with two or more perfect Howers; awns none.

47. Eleusine. Spikes digitate, dense.

48. Leptochloa. Spikes racemose, slender. Spikelets small, alternate.

** * Spikelets diœcious; spikes small, very dissinuilar.

49. Buchloe. Pistillate spikes capitate, sessile, the spikelets 1-fluwered; staminate spikes (2 or 3 ) on a peduncle, the spikelets $2-3$-flowered.

Tribe IX. FESTUCE.E. Spikelets few-many-flowered, panieled, the uppermost flowers often imperfect or abortive. Glunes pointless or the flowering ones tipped with a straight awn or bristle.

* Flowering glume 1-3-nerved, 2-3-toothed. Rhachis short-bearded or glabrous.

50. Triodia. Rhachis of the sprikelet bearded. Nerves of the flowering glume 3, villous, at least the middle one more or less exeurrent.

51. Diplachne. Rhachis glabrous. Gluue 1-3-nerved, with 2 small teeth, and a short awn in the cleft.

* Glume 3-nerved, entire or 2-toothed and mucronate between the teeth. Rhachis aml flowers long-villous. Tall reeds with ample piuicles.

52. Phragmites. Spikelets 3-7-flowered; lowest flower naked, staninate or neutral. Glume entire.

53. Arundo. As $\mathrm{u}$. 52, but flowers all perfect. Glume bifid. 
*** Glume 3-nerved, the nerves (at least the mid-nerve) excurrent; spikelets few, in the axils of fioral leaves.

54. Munroa. Low or prostrate nuch-branclied annual.

**** Glume 3- (rarely 1-) nerved, obtuse or acute, awnless ; rhachis and flower naked.

55. Koeleria. Panicle contracted. Spikelets 2-4-flowered. Glumes compressed-keeled, acute or inucronate.

56. Eatonia. Panicle slender, more or less dense. Spikelets 2-flowered. Glumes very dissimilar, usually obtuse, the upper empty one enclosing the flowers.

57. Eragrostis. Spikelets flattened, 2-many-flowered. Glumes acute or acutish. Palet persistent.

***** Glume 3-5-1nerved, obtuse or abrupt-cuspidate ; spikelet 3-5-flowered; upper sterile flowers convolute around each other.

58. Melica. Glumes 5-nerved or more, scarious, obtuse. Panicle simple or nearly so.

59. Diarrhena. Glumes 3-ncrved, coriaceous, the flowering one abruptly cuspidate. Panicle loosely few-flowered.

****** Flowering glume 5 -nerved or more (sometimes obscurely so). Only the ter minal flower abortive, or none.

+ Glumes more or less strongly compressed and carinate (ventricose in n. 63).

60. Uniola. Spikelets broad, flat and 2-edged, in usually loose panicles. Glumes coriaceous, acute, the 3-6 lower ones empty.

61. Distichlis. Diøcious. Spikelets large, flattened, in a close panicle. Empty glumes 2 , acuite.

62. Dactylis. Panicle contracted in 1-sided clusters. Glunes herbaceons, awn-jointed, rough-ciliate on the keel.

63. Briza. Spikelets heart-shaped, in lax panicles. Glumes roundish, ventricose, scariousmargined.

64. Poa. Spikelets small, flattened, ovate to lance-ovate, in a loose panicle. Flowering glumes membranous and scarions-marginerl, pointless, usually weblyy or pubescent towarl the base.

65. Graphephorum. Spikelets compressed, in a loose panicle, the lrairy jointed rhachis produced into a hairy jedicel. Glumes thin-membranous, faintly nerved, entire.

++ Glumes convex on the back, not carinate (or somewhat so in 11.70 )

66. Scolochloa. Spikelets subterete, in a lax paniele, the rhachis villous at the base of the flowers, ending in a naked jedicel. Glumes coriaceons, prominently $\boldsymbol{i}$-nerved, tootheri at the apex. In water.

67. Glyceria. Syikelets terete or flattish. Flowering glumes searious at the usually blunt simmit, prominently 5 - 7 -nerved.

68. Puceinellia. Mainly as Glyceria, but the glumes obsoletely 5-nerved.

69. Fest uca. Spikelets terete or flattish. Flowering glume acute, pointed or awned at the tip, few-nerverl. Styles terminal.

70. Bromus. Glume rounded or keeler on the back, mostly awued below the 2-cleft tip, 5-9-ncrved. Styles scarcely terminal.

Tribe X. HORDEX. Spikelets 1 -several-flowered, sessile on oppositc sides of a zigzag jointed channelled rhachis, forming a spike. Empty ghmes sometinucs abortive or wanting. Uppermost flower imperfect or abortive.

* Spikelets single at cach joint of the solitary spike.

71. Lolium. Spikelets many-flowered, placed edgewise on the rhachis of the spike, with one empty glume.

72. Agropyrum. Spikelets 3-several-flowered, placed flatwise on the rlachis. Empty glumes 2, right and left.

73. Lepturus. Spikelets small, 1-2-flowered; empty glumes 1 or 2. Spike very slender.

* * Spikclets 2 or more at each joint of the solitary spike; the empty glumes side by side in front of the spikelets (none or rudimentary in n. 76.)

74. Hordeum. Spikelets 1-flowered, 3 at each joint, the lateral ones usually sterile. 
75. Elymus. Spikelets 1 - several-flowered, all perfeet and similar.

76. Asprella. Spikelets few-flowered, somewhat pedicelled, 1-3 at each joint. Glumes none or small and deciduous.

Tribe XI. BAMBUSEA. Tall woody reeds, the flat leaves with a short petiole jointed upon the sheath. Spikelets few-many-flowercd, flattenerl, in panicles (or racemes.

77. Arundinaria. Flowering glumes rounded on the back, many-nerved, acuminate or bristle-pointed; enuty glumes very small.

\section{SPARTì N A, Schreber. Cord or Marsil Grass. (Pl. 9.)}

Spikelets l-flowered, very much flattened laterally, jointed and sessile in 2 ranks on the outer side of a triangular rhachis. Glumes 3, unequal, lanceolate, strongly compressed-keeled, acute or bristle-pointed, mostly rough-bristly on the keel; palet thin, equalling or longer than the flowering glume. Stamens 3. Styles long, more or less mited. - l'erennials, with simple and rigid often reed-like culms, from extensively creeping scaly rootstocks, racemed spikes, very smooth sheaths, and long tough leaves (whence the name, from $\sigma \pi a \rho \tau i \nu \eta$, a cord, such as was made from the bark of the sjartium or Broom).

* Spilielets compuctly imbricated very rough-hispid on the heels; spikes (2-4' long) more or less peduncled; culm and elongated leures rigid.

1. S. cynosuroides, Willd. (Fresin-waten Conw-Grass.) Culm rather slender $\left(2-6^{\circ}\right.$ high $)$ - leaves narrow $\left(2-4^{\circ}\right.$ long, $\frac{1}{2}^{\prime}$ wide below or less), tajering to a very slender point, keeled, flat, but quickly involute in drving, smooth except the margins; spikes 5-20, scattered, spreading; rhachis rough on the margins ; glumes aun-pointed, especially the middle one (its awn about $\frac{1}{4}$ long), strongly serrulate-hispid on the keel, the lower equalling the upper, whose strong midrib abruptly terminates below the membranous apex. - Banks of rivers and lakes, or in rich soil, especially northward. $\Lambda \mathrm{ug}$.

2. S. polystàchya, Willd. (Silt Reed-Grass.) Culm tall and stout (4 - $9^{\circ}$ ligh. often $1^{\prime}$ in diameter near the base); leaves broad $\left(\frac{1}{2}-1^{\prime}\right)$, ronghish underneuth, as well as the margins; spiles 20-50, forming a dense oblong racene (purplish); glumes barely mucronate, the lower half the length of the flowering one, of which the rough-hispid midrib reaches to the apex. - Salt or brackish marshes, within tide-water, especially southward.

3. S. júncea, Willd. (Rusu SAlt-Grass.) Culms low $\left(1-2^{\circ}\right.$ high) and slender; leaves narrow and rush-like, strongly involute, very smooth; spikes 1 - 5, on very short peduncles, the rhachis smooth; glumes acute, the lower scarcely half the length of the midale one, not half the length of the upper. - Salt marshes and sea-beaches. Aug. (Eu.)

* Spikelets looscly imbricated, or somenhat remote and alternate, the keels only slightly hairy or roughish under a lens; spikes sessile and crect, soft ; leaves, rhachis, etc., very smooth; culm rather succulent.

4. S. strícta, Rotli. (Salt Marsi-Girass.) (l'l. 9, fig. 1-3.) Culm $1-4^{\circ}$ high, leafy to the top; leaves soon convolute, narrow; spikes fow $(2-4)$, the rhachis slightly projecting heyond the crowded or imbricated spikelets; glumes acute, very unequal, the larger 1-nerved, a little longer than the flower. - Salt marshes, l'enu., etc. - Odor strong and rancid. (Eu.)

Var. glàbra, Gray. Culm and leaves longer; spikes 5-12 (2-3' long); sjikelets imbricate-crowded. - Common on the coast. 
Var. alterniflora, Gray. Spikes more slender (3-5' long), and the spikelets remotish, barely overlapping, the rhachis continued into a more conspicuous bract-like appendage; larger glume indistinctly 5-nerved; otherwise as in the preceding form, into which it passes. - Common with the last; also Onondaga Lake, J. A. Paine.

\section{BECKMÁN NIA, Host.}

Spikelets jointed upon the pedicels, 1-2-flowered (only one fervile), oborate and laterally compressed, imbricated in 2 rows upon one side of the angled rhachis of a spike. Glumes 3 or 4 , the 2 lower strongly concare and carinate, obtuse or acutish, the 1 or 2 flowering glumes narrower, lanceolate, acute or acuminate and a little exserted, becoming rather rigid and with the thin palet enclosing the oblong grain. - A stout erect subaquatic perennial, with the short spikes erect and simply spicate or in a strict narrow panicle. (Named for John Beckmann, professor of botany at Goettingen.)

1. B. erucæfórmis, liost, var. uniflòra, Scribn. Glumes 3 and spikelets 1-flowered; spikes ( $6^{\prime \prime}$ long or less) panicled. - N. W. Iowa, W. Minn., and westward. 'The Old World form, which also is found in the far northwest, has 2-flowered spikelets.

\section{PÁ S P A LU M, I. (Pl. 13.)}

Spikelets spiked or somewhat racemed, in 2-4 rows on one side of a flattened or filiform continuous rhachis, jointed upon rery short pedicels, planoconvex, awnless, 1-flowered. Glumes 3 (rarely only 2), the terminal one flowering. Flower coriaceous, mostly orbicular or ovate, flat on the inner sile, convex on the outer. Stamens 3. Spikes one or more, at or toward the

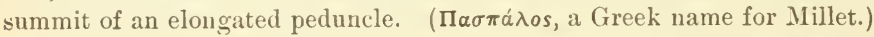

* Spikes with a $\left(1^{\prime \prime}\right)$ broad and thin membranaceous or foliaceous and keeled rhachis, the incurved margins partly enclosing the small two-rowed spikelets. (Smooth, aquatic, or nearly so, decumbent or floating.)

1. P. fluitans, Kunth. Annual; leaves lanceolate, flat $\left(3-8^{\prime \prime}\right)$, broad; spikes numerous in a raceme, the rhachis somewhat projecting beyond the minute and slightly pubescent spikelets into a tapering point, scabrous on the back. - River-swamps, Va. to S. Ill., Mo., and southward. Sept., Oct.

2. P. Walteriànum, Schultes. Perennial; leaves linear, short; spikes $3-7$, the lowest partly included in the sheath of the uppermost leaf, the rhachis blunt; spikelets glabrous. - Low or wet grounds, N. J. (Cape May, Nuttall), Del., and southward.

* * Spikes with a narrow wingless rhachis; perennials, or mostly so. - Spikelets very obtuse, orbicular; spikes one terminal and often $1-5$ lateral.

3. P. setàceum, Michx. Culm ascending or decumbent ( $1-2^{\circ}$ long), slender; leares ( $2^{\prime \prime}$ wide, flat) and sheaths clothed with soft spreading hairs; spikes very slender (2-4' long), smooth, mostly solitary on a long peduncle, and usually one from the sheaths of each of the upper leaves on short peduncles or included; spikelets ( $\frac{1}{2}{ }^{\prime \prime}$ wide) narrouly 2-roued. - Sandy fields; common from E. Mass. to Ill., and southward. Aug.

4. P. læve, Michx. (Pl. 13, fig. 1-3.) Bright green, sparingly villous, rather stout; stems somewhat decumbent; leaves and spikes widely spread. 
ing; spikes $(2-4)$ approximate, $2-4^{\prime}$ long, smooth or nearly so; spikelets about l" wide, 2-rowed. - Moist soil, s. New Eng. to Ky., and soutlwwarl.

5. P. Floridànum, Michx. Stout, erect, $3-6^{\circ}$ high, glaucous; sheaths and leaves more or less villous, the latter and the spikes erect or ascending; spikes $(2-5)$ broader, $2-5^{\prime}$ long, the smooth spikelets nearly $2^{\prime \prime}$ broad, in 2 rows. - Moist soil; Del. to Fla., Ark., and 'Tex.

$$
++ \text { Spikelets acute; spikes several, racemose. }
$$

6. P. dilatàtum, Poir. Stout, erect, $2-5^{\circ}$ high, villous at the top of the sheath; spikes few on a naked peduncle, erect, 2-3' long; spikelets $1^{\prime \prime}$ long or more, the lower glume soft-villous on the margin. - Va. to Tex. +++ Spikelets acute; spikes always a pair at the summit of the naked
peduncle.

7. P. dístichum, L. (Jornt-Grass.) Nearly glabrous, rather glaucous; ctilns ascending (about $1^{\circ}$ high) from a long creeping base; leaves linearlanceolate ( $2-3^{\prime}$ long); pedumcle usually short; spikes short and closely-flowered $\left(9^{\prime \prime}-2^{\prime}\right.$ long), often slightly separated; rhachis flat on the back; spikelets ovate, slightly pointed (barely $1 \frac{1}{2}$ "long), approximate on one side of the rhachis. - Wet fields, Va. and southward. July-Sept.

8. P. Ellióttii, Watson. Culms ascending ( $1-2 \frac{1}{2}^{\circ}$ high) from a creeping hase ; leaves lanceolate $\left(3-6^{\prime}\right.$ long, $4-6^{\prime \prime}$ wide); spilies slender, rather sparsely flowered ( $1-4^{\prime}$ long), both sessile upon the long slender peduncle; spikelets ovate-lanceolate (2" long), on nearly opposite sides of the rhachis. (Milium paspalòdes, Ell. P. Digitaria, Chapm.; not Poir.) - Va. and southward.

\section{ER I ÓCH LOA, HBK. (Pl. 15.)}

Spikelets ovate, subsessile or shortly pedicelled upon one side of the rhachis of a spike, with a callus at base and jointed on the pedicel, 1-flowered. Glumes 3 , the 2 empty ones slightly unequal, membranaceous, acute, the flowering one shorter, indurated, obtuse, enclosing the free grain. - Coarse tufted grasses, with flat leaves, the spikes more or less scattered along a common peduncle, and the pedicels and rhaclis of the spike usually pubescent or hairy (hence

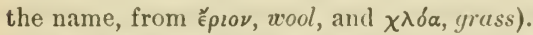

1. E. polystàchya, HBK. Culms erect or decumbent, $2^{\circ}$ high; spikes $6-12$, erect or ascending, $1-2^{\prime}$ long, forming a compound spike $3-6^{\prime}$ long ; spikelets glabrous, very shortly pedicelled, oblong-lanceolate, nearly 2" long. -S. Kan. to Tex. and Mex.

\section{PÁ N I C U M, L. Paxic-Grass. (Pl. 13.)}

Spikelets jointed upon the pedicels, ovate, panicled, racemed, or sometimes spiked, not involuerate, with one perfect and sometimes a second lower rudimentary or staminate flower. Glumes 4, but the lower one usually short or minute (rarely even wanting), and the third empty or sterile, membranaceoherbaceous. I'pper flower perfect, closed, coriaceous or cartilaginous, usually flattish parallel with the glumes, awnless (except in $\$ 3$ ), enclosing the free and grooveless grain. Stamens 3. Stigmas plumose, usually purple. (An ancient Latin name of the Italian Millet, P'. Italicum (now Setaria Italica), of uncertain origin and meaning.) 
$\$ 1$. DIGITÅRIA. Spikelets crowded 2-3 together in simple and mostly 1 sided clustered spikes or spike-like racemes, wholly aunless and pointless, 1-flowered; lower glume minute or obsolete or wanting; annual, often purplish.

* Spikes crect; the rhachis filiform and nearly terete.

1. P. filifórme, L. Culms very slender ( $1-2^{\circ}$ high), upright; lower sheaths hairy ; spikes $2-8$, alternate, approximate, filiform ; spikelets oblong, acute ( $\frac{1}{2}$ " long); lower glume almost wanting. - Dry sandy soil, Mass. to N. J. along the coast, to Iowa, Neb., and southward. Aug.

* * Spikes spreading; the rhachis flat and thin.

P. GlAbru, Gaudin. Culms spreading, prostrate, or sometimes erect (5-12' long), glabrous; spikes $2-6$, widely diverging, nearly digitate; spikelets ovoid (about 1" long); npper empty glume equalling the flower, the lower almost wanting. - Cultivated grounds and waste places; common, especially southward; sometimes appearing indigenous. Aug., Sept. (Nat. from Eu.)

P. saxguinale, L. (Commox Crab- or Finger-Grass.) (Pl. 13, fig. $1-3$.) Culms erect or spreading ( $1-2^{\circ}$ high $)$; leares and sheaths glabrous or hairy ; spikes $4-15$, spreading, digitate; spikelets oblong ( $1 \frac{1}{2}{ }^{\prime \prime}$ long); second glume half the length of the flower, the lower one small. - Cultivated and waste grounds. Aug.-Oet. (Nat. from Eu.)

§ 2. PANICUM proper. Spikelets scattered, in panicles, aunless.

* Panicle elongated and racemose, wand-like or pyramidal; the numerous and usully pointed spilielets short-pedicelled, excepting n. 3 and 4.

- Sterile flower none; lou'er glume short; spikelets $\frac{1}{2}-1 \frac{1}{2}$ "long; annuals except 11. 4 ; leaves flat; sheaths flattened.

+-Glabrous and smooth throughout; spikelets appressed, short-pedicelled.

2. P. prolíferum, Lam. Culms usually thickish and rather succulent, brancherl, geniculate and ascending from a procumbent base; sheaths flattened; ligule ciliate; panicles terminal and lateral, compound, pyramidal, the slender primary branches at length spreading; spikelets pale green, rarely purplish; lower glume loroad, $\frac{1}{3}$ to $\frac{1}{4}$ the length of the upper, which is little longer than the flowering one. - Marshy river-banks and shores, especially if brackish, but also in the interior, from Mass. to Iowa, and southward. Aug.

+ + Hispid or hairy on the sheaths, at least the lower; spikelets mostly scattered on slender pedicels in an ample, lonse, at length very effuse panicle; culms mostly branched from the base, erect or ascending $\left(10-20^{\prime}\right.$ high).

3. P. capillàre, L. (OLd-witch Griss.) (Pl. 13, fig. 4, 5.) All the sheaths and usually the leaves copionsly hairy or hispid; panicle mostly very compound, the branches divaricate when old ; spikelets from ovoid to narrowly oblong, pointed; lower glume half the length of the upper empty one, which is longer than the elliptical obtuse perfect flower. - Sandy soil and cultivated fields everywhere. Aug. - Oct. - Varies extremely in size and appearance, the culms erect and simple, or decumbent, geniculate and branched; in depauperate forms the spikelets only $\frac{8^{\prime \prime}}{4}$, in the larger forms $1 \frac{1}{2}$ " in length.

4. P. autumnàle, Bosc. Root perennial (?), lower sheaths and margins of the small narrow leaves more or less hairy, otherwise glabrous, except some bristly hairs in the main axils of the very effuse capillary panicle, its much elongated divisions sparingly branched, or even simple and terminated with solitary spindle-shaped spikelets; louer glume minute; perfect flower lanceolate. 
oblong and pointed, nearly equalling the lance-oblong ol,tusish empty glumes. - Sand-hills, Mll. to Mim., Mo., and southward.

+ + Sterile floner rudimentary (stuminate in $\mathrm{n} .7)$, its glume fully twice the

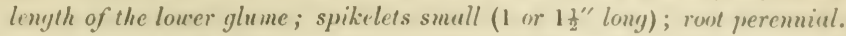

5. P. ánceps, Michx. Culms flut, upright $\left(2-4^{\circ}\right.$ high $)$; leaves rather hroadly linear $\left(1-2^{\circ}\right.$ long, 4-5" wille), sinosth; panicle contractedl-pyranidal; spikelets ovate-lunceolute, puinted, a little curverl; second g/une 5-7nerved; neutral flower one third longer than the perfect one. - Wet sandy soil, N. J. and l'emu. to S. IIl., and sonthward. Aug. - Spikelets larger and luanches of the panicle longer and narrower than in the next.

6. P. agrostoides, Muhl. ('ulms fluttenel, upright (2-4 high) ; leaves long, and with the sheaths smooth; panieles terminal and often lateral, pyramjidal $\left(4-8^{\prime}\right.$ long); spitelets racemose, crowded and one-sided on the sprearling branches, nete-oblong, acute (purplish) ; second glume 5-nerved, longer than the neutral flower; perfect Hower shorter, hearled at the apex. - Wet meadows and shores, L. Mass. to Minu., Neb., and common sonthward. Aug.

7. P. Curtísii, Clajpm. Culms stont, $3-4^{\circ}$ ligh, often rooting helow; mostly glabrous; panicle slenter, simple, spike-like $\left(6-8^{\prime}\right.$ long $)$, the spikes appressed; spikelets lanceolate, acute; lower glume latf the length of the 5-nerved second one. - Ponds, Del. to Fl. and Tex.

+++ Sterile flouer staminute; louer glune more than half the length of the next; spikelets larye ( $2-2 \frac{1}{2}$ "long), otute, pointed, as are the glumes, etc.; peremials, glabrous, with tull or stout and rigid upright culms.

8. P. virgàtum, L. (Pl. 13, fig. 8, 9.) 'Tall $\left(3-5^{\circ}\right.$ high) ; leaves very lon!, flut; lignle silky-bearded; bianches of the compond loose and large panicle $\left(9^{\prime}-2^{\circ} \mathrm{long}\right)$ at length spreading or drooping; spikelets scattered, usually purplish. - Moist sancly soil; conmon. Aug.

9. P. amàrum, Ell. Culms ( $1 \frac{1}{2} 0$ high or more) sheathed to the top; lemes immolute, yluurous, coriuceous, the uppermost exceeding the contracted panirle, the simple racemose hrauches of which are appressed; spikelets pale. Sandy shores, Conn., Va., and southward. Aug., Sept. - The northern form (var. mixts, Vasey \& Scribn.) somewhat smaller thin the southern.

* Panicle short or small, loosely spreading or diffuse; perennials.

+ Sterile fower none; spitielets wurty roughened.

10. P. verrucosum, Mulıl. Smooth; culms branching and spreading, very slender $\left(1-2^{\circ}\right.$ long $)$, naked above; leaves linear-lanceolate ( $2-3^{\prime \prime}$ wile), shining; brancles of the diffuse punicle capillary, few-flowered ; spikelets lark green, oval, acute, $\frac{3^{\prime \prime}}{4}$ long; lower glume $\frac{1}{4}$ as long as the faintly nerved secoul. - Sandy swamps, N. Ling. to Va., near the coast, and southward.

+ + Louer (sterile) flower noutrul, or in 12.12 and sometimes in 11.11 stuminate, the palet scurious and sometimes small and inconspirnons.

+ Culm-leaves broadly lanceolate or wider, with 9-15 principal nerves (obscure or none in $\mathrm{n.17}$ ).

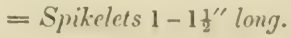

11. P. Xanthophýsum, Gray. Culm simple, or at length branched near the base $\left(9-15^{\prime}\right.$ high) ; sheaths hairy; leares lanceolate, v'cry acule (4-6' 
long by $\frac{1^{\prime}}{2}$ wide), not dilated at the ciliate-bearded clasping base, smooth except the margins, strongly 9-11-nerved; panicle long-peduncled, very simple, the appressed branches bearing a few roundish-obovate spikelets (about 1 ${ }_{2}^{\prime \prime}$ long); lower glume ovate, acutish, $\frac{1}{3}-\frac{1}{2}$ the length of the 9-nerved second. - Dry sandy soil, Maine to Penn., Wisc., Iowa, and northward; rare. June. - Yellowish-green; spikelets minutely downy; sterile flower sometimes staminate.

12. P. latifolium, L. Culm $\left(1-2^{\circ}\right.$ high $)$ smooth; the joints and the throat or margins of the otherwise smooth sheaths often bearded with soft woolly hairs; leaves broadly oblong-lanceolate from a heart-clasping base (often 1' wide), taper-pointed, 11 - 15-nerved, smooth, or sparingly downy-hairy; panicle more or less exserted ( $2-3^{\prime}$ long), usually long-peduncled, the branches spreading; spikelets obovate, $1 \frac{1}{2}$ "lony, downy; lower glume ovate, not half the length of the many-nerved second; sterile flower often (not always) with 3 stamens. Moist thickets; common. June-Aug.

13. P. clandestinum, L. (Pl. 13, fig. 6, 7.) Culm rigid $\left(1-3^{\circ}\right.$ high), very leafy to the top, at length producing appressed branches, the joints naked; sheaths rough with papilloe bearing very stiff and spreading bristly hairs; leaves oblong-lanceolate from a heart-clasping base, very taper-pointed; lateral and usually also the terminal panicle more or less enclosed in the sheaths, or with the terminal one at length long-peduncled; - otherwise resembling n. 12; but the spikelets more ovoid, often smooth; the lower flower (always?) neutral. - Low thickets and river-banks, N. Eng. to Mich., Mo., and southward. June - Sept.

14. P. víscidum, Ell. Culms stout, upright or ascending, at length much branched, leafy to the top, densely velvety-downy all over, as also the sheaths, with reflexed soft and often clammy hairs, except a ring below each joint; leaves likewise relvety, lanceolate $\left(\frac{1^{\prime}}{2}\right.$ wide), 11 -13-nerved; panicle spreading, the lateral ones included; spikelets obovate, 1 or $1 \frac{1}{2}$ "long, downy; the roundish lower glume scarcely one fourth the length of the 7-nerved second sne. - Damp soil, N. J. to Va., and southward. Aug.

15. P. scopàrium, Lam. Culms upright, at length much branched and reclining $\left(1-2^{\circ}\right.$ long), roughish; leaves lanceolate ( $3-5^{\prime}$ long by $\frac{1}{3}-\frac{1}{2}^{\prime}$ wide), rather faintly 9-nerved, hairy or smooth, fringed on the whole margin or next the base with long and stiff spreading hairs, the sheaths bristly throughout with similar hairs; panicle open, nearly simple, bearing few tumid-obovate hairy or smoothish spikelets about $1 \frac{1}{2}$ "long; lower glume roundish, about half or a quarter of the length of the upper one. (P. pauciflorum, Ell.) - Wet meadows and copses, E. Mass. to Minn., west and southward. June, July.

16. P. commutàtum, Schultes. Rather slender, erect, $1-2^{\circ}$ high, nearly glabrous; leaves lanceolate, acuminate $\left(3-6^{\prime}\right.$ long), the margins toward the base and the sheaths sparsely ciliate; panicle spreading, often shortpeduncled; spikelets scattered, glabrous, oblong, acutish, little more than $1^{\prime \prime}$ long; lower glume ovate, often acute. - N. Y. to Fla. - A frequent variety with smaller spikelets (not $1^{\prime \prime}$ long) approaches the next, and has also been conrused with P. dichotomum. - Ont. to Va. and southward.

$$
==\text { Spikelets less than } \mathrm{l}^{\prime \prime} \text { long. }
$$

17. P. nítidum, Michx. (Lam.?) Resembles the last; leaves rather thick and the principal uerves very obscure or none except at the base; pan. 
icle hroad, more slender; spikelets smaller ( $3^{\prime \prime}$ long), broarlly ovate and rery ubtuse; lower glume very ubtuse. (P. spheruearpun, Lll.) - N. Y. to Ga., and westward.

18. P. microcárpon, Muhl. Like the last; the broadly lanceolate leaves nearly similar, but usually longer ( $8^{\prime}$ long or less), distinctly nerved; panicle soon exserted on a slender peduncle, rather narrower, with numerous sleuder branches and very many-flowered (3-7' long); spikelets about $\frac{1}{2}{ }^{\prime \prime}$ long, ovoid, smooth or smoothish; lower glume orbicular and very small. Dry or moist thickets, I'enn. to Mich., Neb., and southward. July-Sept.

+ + Culm-leaves linear or sometimes narrowly lanceolate (basul often lanceolate); primary nerves oflen indistinct or none; spiticlets small.

19. P. depauperàtum, Muhl. Culms simple or branched from the lase, forming close tufts $\left(6-12^{\prime}\right.$ high), terminated by a simple and few-flowered contracted panicle, often much overtopped by the narrowly linear and elungated $\left(4-\tau^{\prime}\right)$ upper leaves; spikelets $\frac{z}{4}-1 t^{\prime \prime}$ long, oval-obovate, commonly pointed when young; lower glume ovate-Varies, with the leaves involute, at least when dry (P. involutum, Torr.), and with the sheaths either beset with long hairs or nearly sinooth; the panicle either partly included, or on a long and slender peduncle.-1)ry woods and hills; rather common. June.

20. P. consanguíneum, Kunth. Culms slender, $1-2^{\circ}$ high, often decumbent and rooting below; nearly glabrous or the sheaths and leares somewhat pubescent or villous; panicle small, with rather few spreading fewflowered branches; spikelets $1-1 \frac{1}{2}$ "long, oblong-obovate, acutish. - Dry woods, Norfolk, Va., and south to Fl. and Tex.

21. P. dichótomum, L.! Culms $\left(8^{\prime}-2^{\circ}\right.$ high) at first mostly simple, bearing a more or less exserted spreading compound panicle $\left(1-3^{\prime}\right.$ long), and linear to linear-lanceolate flat leaves (those tufted at the root usually ovatelanceolate and very short, thickish); but commonly branching later in the season, the branches often clustered, and bearing nearly simple and included small panicles; spikelets $\frac{1}{2}-\frac{2}{3}$ " long, clliptical, obtuse, downy or smooth; lower glume roundish. - Common everywhere. Very variable both in habit and in the amount of villosity (depending upon the soil, exposure, season, etc.), so that it is difticult to specify any well clefined rarieties. The more conspicuous forms are (a) commine, with simple culıns erect or ascending, and leaves suberect, usually pale green-(b) fasciculatum, with clustered leafy branches and short peduncles, a common autumnal state - and (c) grácile, the culms lax, very slender and elongated, with rather distant spreading leaves (usually bright green), and mostly long-pedunculate panicles.

22. P. laxiflorum, Lam.! Closely resembling the last species, in its several forms; distiuguished by the larger acutish spikelets (nearly or quite $\mathbf{l}^{\prime \prime}$ long). - Common.

$\S 3$. ECHINOCHLOA. Spikelets imbricated-spiked on the branches of the simple or compound raceme or panicle, usually rough with appressed stiff hairs; lower palet of the sterile flower au\%-pointed or auned.

P. Crus-gílli, L. (Baryyard-Grass.) Root aumual; culms stout, branching from the base $\left(1-4^{\circ}\right.$ high); leaves lanceulate ( $\frac{1}{2}$ ' wide or inore), rough-margined, otherwise with the sheaths smooth; spikes alternate $\left(1-3^{\prime}\right.$ long), crowled in a denso panicle; glumes ovate, abruptly pointed, glume 
of the neutral flower bearing a rough awn of variable length. - Varies greatly; sometimes awnless or nearly so; sometimes long-aumed, expecially in the var. HísPDL, a very large and coarse form with the sheaths of the leaves very bristly. - Moist, chiefly manured soil ; the variety in ditches, especially of brackish water; possibly indigenous. Aug. - Oct. (Nat. from Eu.)

\section{SETÀ RIA, Beauv. Bristly Foxtall Grass. (Pl. 13.)}

Spikelets altogether as in Panicum proper, and awnless, but with the short peduncles bearing below the joint of the spikelet solitary or clustered bristles resembling awns (but not forming an involucre). Inflorescence a dense spiked panicle, or apparently a cylindrical spike. - Annuals, in cultivated or manured grounds, with linear or lanceolate flat leares. (Name from seta, a bristle.)

$$
\text { * Bristles single or in pairs, roughened or barbed downuard. }
$$

S. verticillita, Beauv. Spike cylindrical (2-3' long, pale green), composed of apparently whorled short clusters; bristles short, adhesive. Near dwellings. (Adv. from Eu.)

$$
\text { * Bristles in clusters, ronghened or barbed upward. }
$$

S. glaúca, Beauv. (Foxtan. Pigeox-Grass.) (Pl.13, fig. 1, 2.) Spike cylindrical, dense, taun! yellow (2-4' long); bristles 6-11 in a cluster, much longer than the spikelets; perfect flower transversely wrinkled. - Very common, in stubble, etc. (Adv. from Eu.)

S. víridis, Beaur. (Greex Foxtall. Bottle-Grass.) Spike nearly cylindrical, more or less compound, grcen; bristles, fen, longer than the spikelets; flower striate lengthwise and dotted. - Cultivated grounds. (Adv. from Eu.)

S. ÍÁlicA, Kunth. Spike compound, interrupted at base, thick, nodding ( $6-9^{\prime}$ long), yellourish or purplish; bristles 2 or 3 in a cluster, either much longer or else shorter than the spikelets. - Cultivated under the name of Millet, or Husgariax or BexGal Grass; rarely spontaneous. (Adv. from Eu.)

\section{CÉNCHRUS, I. Hedgenog- or Bur-Grass. (Pl. 14.)}

Spikelets as in Panicum, awnless, but enclosed 1 to 5 together in a globular and bristly or spiny involucre, which becomes coriaceous and forms a deciduous hard and rigil hur; the involucres sessile in a terminal spike. Styles united below. (An ancient Greek name of Setaria Italica.)

1. C. tribuloides, I. Anmual; culns branched and ascending ( $1^{\circ}$ high or less) ; leaves flat; spike oblong, of 8-20 spherical heads; involucre prickly all over with sprearling and barbed short spines, more or less downy, enclosing 2 or 3 spikelets. - Sandy soil, on river banks, etc. Aug. - A vile weed.

\section{A M PHICÁ R P U M, Kủnth.}

Spikelets jointed upon the pedicels, 1-flowered, oblong or ovoid, of two kinds; one kind in a terminal panicle, decidnous from the joint without fruit, although the flower is perfect; the other kind solitary at the extremity of slender runner-like radical peduncles (more or less sheathed toward the base), much larger than the others, perfect and fertile, subterranean, fertilized in the bud. Glumes 3, nearly equal, 5-nerved in the panicle, many nerved in the fertile spikelets; palet a little shorter; all becoming indurated and enclosing the very large grain. Stamens 3 (small in the radical flowers). Stigmas plumose,

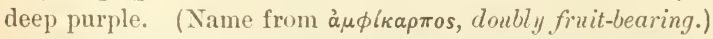

1. A. Púrshii, Kunth. Anuual or biennial (?), erect, $1-4^{\circ}$ high ; leaves lanceolate, copious on the lower part of the culm, hispid, especially on the 
sheaths; panicle strict, naked ; grain ovoid or oblong (2-3" long), terete. Moist sandy pine-barrens, N. J. to Fla. Sicpt.

\section{IEÉRSIA, Swart\%. Wutt: Grass. (l'l. 7.)}

Flowers crowderl in one-sided panicled spikes or racemes, perfect, lut those in the open panicles usmally sterile by the abortion of the ovary, those enclosed in the sheaths of the leares close-fertilized in the bud and prolific. Spikelets 1-flowered, flat, more or less imbrieated over each other, jointed upon the short pedicels. Glumes 2, chartaceous, strongly flattened laterally or conduplicate, awnless, bristly-ciliate on the keels, closed, nearly equal in length, but the lower much broader, enclosing the flat grain. I'alet none. Stamens 1-6. Stigmas feathery, the hairs hranching. - P'erenuial marsh grasses; the flat leaves, sheaths, etc., rough upward, being clothed with very minute hooked prickles. (Named after John Daniel Leers, a German botanist.)

* Spikelets narrowly oblong, rather loosely crowded.

1. L. Virgínica, Willd. (Wnite Grass.) Panicle simple; the spikelets closely appressed on the slender branches, around which they are partly curved ( $1 \frac{1}{2}$ "long); stamens 2 (a third imperfect or wanting); glumes sparingly ciliate (greenish-white). - Wet woods; Maine to Minn., and southward. Aug.

2. L. oryzoides, Swartz. (Rice Cut-gisss.) (Pl. i, fig. 1-3.) Panicle

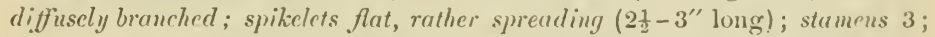
glumes strongly loristly-ciliate (whitislı). - Very wet places; Mass. to Minn., and southward; common. Aug. (Eu.)

* * Spikelets broadly oval, imbricately covering each other $\left(2 \frac{1}{2}-3\right.$ "long).

3. L. lenticulàris, Michx. (CAтch-FLy Grass.) Smoothish; panicle simple; glumes very flat, strongly bristly-ciliate (said to close and catch flies) ; stamens 2; otherwise like the preceding. - I Low grounds, Va., Ill., and soutliward.

\section{ZIZ À NIA, Gronov. Water or Indix Rice. (Pl. 7.)}

Flowers monocious; the staminate and pistillate both in 1 -flowered spikelets in the same panicle. Glumes 2 , subtended by a small cartilaginous ring, herbaceo-membranacenns, eonvex, awnless in the sterile, the lower one tipped with a straight awn in the fertile spikelets. Palet none. Stamens 6. Sitigmas pencil-form. - Large, often reed-like water-grasses. Spikelets jointed upon the club-shaped perlicels, very deciduous. (Adopted from ç〔ávıov, the ancient name of some wild grain.)

1. Z. aquática, L. (INiıin Rič. Water O.ıTs.) (P'l. 7, fig. 1-4.) Annual; culms $3-9^{\circ}$ high; leaves flat, $2-3^{\circ} \mathrm{long}$, linear-lanceolate; lower branches of the ample pyranidal panicle staminate, spreuding; the upper ercet, pistillate; lover glume long-auned, rough; styles distinct; grain linear, slender, 6 " long. - Swampy borders of streams and in shallow water; common, especially northwestward. $\Lambda \mathrm{ng}$.

2. Z. miliàcea, Michx. I'erunial; panicle diffuse, ample, the stuminate and pistillate flowers intermixed; an'ns short; styles united; grain ovate. Penn. (?), Ohio, and southward. Aug. - Leaves involute. 


\section{Trít S A C U M, L. Gama-Grass. Sesame-Grass. (Pl. 14.)}

Spikelets nonœcious, in jointed unilateral spikes, staminate above and fertile below. Staminate spikelets in pairs, sessile at each triangular joint of the narrow rhachis, both alike, 2 -flowered, longer than the joints; glumes 4 , coriaceous, the lower (outer) one nervel, the second boat-shaped, the upper with the palets very thin and membranaceous, awnless; anthers opening by 2 pores at the apex. Pistillate spikelets 2 -fowered (the lower flower neutral), single and deeply imbedded in each oblong joint of the cartilaginous thickened rhachis, occupying a boat-shaped recess which is elosed by the polished and cartilaginous ovate outer glume, the inner glume much thinner and pointed, the upper with the palets very thin and scarious, pointless. Styles united; stigmas very long (purple), hispid. Grain ovoid, free.-Culms stout and tall, solid, from very thick creeping routstocks. Leaves broad and flat. Spikes axillary and terminal, separating spoutaneously into joints at maturity. (Name from $\tau \rho i \beta \omega$, to $r u b$, perhaps in allusion to the polished fertile spike.)

1. T. dactyloides, I. Spikes $\left(4-8^{\prime}\right.$ long) $2-3$ together at the summit (when their contiguous sides are more or less flattened), and also solitary from some of the upper sheaths (when the fertile part is cylindrical); in var. sonostacnyum, the terminal spike also solitary. - Moist soil, from Conn. to Penn. and Fla., near the coast, and from Ill. southward. Aug. - Culm 4-7 high; leaves like those of Indian Corn. This is one of our largest and most remarkable Grasses; sometimes used for fodder at the South.

\section{ROTTBǴ LIIA, I. f.}

Spikelets in pairs at each joint of a terete slender spike, awnless; one imperfect or rudimentary on a short and thick appressed pedicel; the other sessile and imbedded in an excavation of the joint of the rhachis, 1-flowered or rarely with a second staminate flower. Glumes 4, obtuse, the outer hard aud cartilaginous, with a transverse depressiou next the base, the iuner one boatshaped and membranaceous, the 2 upper thin and delicate. Stamens 3. Styles 2. - Tall or coarse peremnials, with rigid stems, and single cartilaginous spikes terminating the stem and axillary branches, chiefly subtropical. (Named for Prof. C.F. Rottboell, an excellent Danish botanist, who wrote much upon Gramineæ, Cyperaceæ, etc.)

1. R. rugòsa, Nutt. Culm flattish, 2-4 ${ }^{\circ}$ high ; leaves linear; spikes 1-2' long, the lateral ones on short clustered branches in the axils, often partly included in the sheaths of the leaves; sterile flower neutral; lower glume transversely rugose. - Low pine-barrens, from S. Del. ( W. M. Canby) southward near the coast. Sept. - Oct.

\section{ERIán THU S, Michx. Woolly Beard-Grass. (Pl. 14.)}

Spikelets spiked, in pairs upon each joint of the slender rhachis, one sessile, the other pedicelled, both 1-flowered, alike. Glumes 4, the 2 lower nearly equal, one 4-5-nerved, the other many-nerved; the 2 upper hyaline, one empty, the upper awned from the tip. Stamens 3. Grain free.-Tall and stout reed-like perennials, with the spikes crowded in a panicle, and clothed with long silky hairs, especially in a tuft around the base of each spikelet

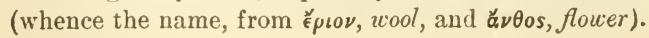


1. E. saccharoides, Michx. (I'l. 14, fig. 1, 2.) Culm (4-6 high) woolly-bearded at the joints; panicle contracted ; the silky hairs long r than the spikelets, shorter than the awn; stamens 2. (K. alopecuroides, I:ll.) - Wet pine-lariens, from $\mathrm{N}$.J. and Ill. sonthward; rare. Sejt., Oct.

2. E. brevibárbis, Michx. Culm (2-5 hignh), sumeshat hearded at the upper joints; panicle rather open; silky hairs shorter than the spikelets. Low grounds, Va., and southward.

\section{A N D R O P Ò ON, Royen. Beard-Grass. (1'l. 14.)}

Spikelets in pairs upon each joint of the slender rhachis, spiked or racemed, one of them pedicelled and sterile (staminate, pistillate or neutral), often a nere vestige, the other sessile, l-flowered and fertile; lower glume the larger, coriaceous and nerved, blunt, the second carinate and acute, the 2 upper hyaline, the flowering glume awned from the tip. Stamens $1-3$. Grain free.Coarse, mostly rigid perennials, mostly in sterile or sandy soil; with lateral or terminal spikes commonly clustered or ligitate; the rhachis hairy or plumose-bearded, and often the sterile or staminate flowers also (whence the name, composed of áví $\rho$, man, and $\pi \dot{\omega} \gamma \omega \nu$, beurd).

* Spikes digitate, thickish, short-bearded, the sterile spikelet staminate; stamens 3.

1. A. furcàtus, Muhl. (I'l. 14, fig. 1-3.) 'Tall, 3-40 high, rigid, the naked summit of the culm (and usually some lateral branches) terminated by $2-5$ rigid spikes; spikelets approximate, appressed; hairs at the base of the fertile spikelet, on the rhachis and on the stout pedicel of the awnless staminate spikelet short and rather sparse; awn of fertile flower long aud bent; leaves flat, roughish, the lower ones long. ("A. provincialis, Lam.") - Common in dry sterile soil. Aug. - Oct.

$$
\text { * * Spikes with slender oficn zigzag rhachis, silky-villous, }
$$

- Single and scattered along the branches, with the silky hairs shorter than the flowers; sterile spikelet conspicuous but mostly neutral; the fertile triandrous.

2. A. scopàrius, Michx. Culms slender ( $1-3^{\circ}$ high $)$, with numerous paniculate branches; lower sheaths and narrow leaves hairy; spikes slender, scattered, mostly peduncled ( $1-2^{\prime}$ long), very loose, often purplish, silky with lax dnll-white hairs; sterile spikelet awn-pointed or awnless; the fertile about half the length of its twisted or bent awu. - I)ry ground. July-Sept.

3. A. marítimus, Clajmm. Sinooth and glancous; culms ascending from creeping rootstocks, $1-1 \frac{1}{2}$ high; leaves rather rigid, divaricate, their compressed sheaths imbricated; panicle slort; perluncles included within the conspicuous bracts; rhachis and pedicels copiously ciliate with spreading hairs; glumes larger, $3-4^{\prime \prime}$ long. - Saudy sea-coast; Cape May, and south to Fla.

+ + In pairs or clustered; the copious soft-silky hairs much longer than the flowers; sterile spikelet a small neutral rudiment (in 11.4 and 5), or altogether wanting on the very plumose-huiry pedicel; fertile fower monandrous, its aun capillary; leaves narrow, the lower or their sheuths often rather hairy.

4. A. argénteus, Ell. Smooth; culms rather slender $\left(1-3^{\circ}\right.$ high $)$; spikes in pairs (rarely in fours) on short mostly exserted and loosely panicu- 
late peduncles, densely flouered (1-2' long), very silky with long bright white hairs. (A. argyræus, Schultes.) - Md. to Va., near the coast, and southward.

5. A. Ellióttii, Chapm. Closely resembling the last; sheaths and leaves villous ; upper nodes of the branches densely bearded. - Md. to Fla. and Tex.

6. A. Virgínicus, L. Culm flattish below, slender $\left(2-3^{\circ}\right.$ high $)$, sparingly short-branched above, sheaths smooth; spikes 2 or 3 together in distant appressed clusters, shorter than their sheathing bracts, weak ( $1^{\prime}$ long), the spikelets loose on the filiform rhachis, the soft hairs dull white. (A. dissitiflorus, Michx. A. vaginàtus, Ell., a form with larger and inflated sheatlıs.) - Sandy soil, E. Mass. to Va., Ill., and southward. Sept., Oct.

7. A. macroùrus, Michx. Culm stont $\left(2-3^{\circ}\right.$ high $)$, bushy-lranched at the summit, loaded with very numerous spikes forming thick leafy clusters; sheaths rough, the uppermost hairy; flowers nearly as in the preceding; the sterile spikelet of each pair wholly wanting, its pedicel slender and very plumose. - Low and sandy grounds, N. Y. to Va., near the coast, and southward.

8. A. laguroides, 1)C. Culms slender, tall, the elongated peduncle bearing numerous sessile spikes in a spike-like panicle $2-4^{\prime}$ long; spikes slender, l' long or more, rery silky; spikelets glabrous, the sterile a narrow convolute empty glume. - Central Kan. to Tex. and Mex.

+ + + Spikes digitute-clustered, very silky; sterile spikelet larger than the fertile one.

9. A. Hàllii, Hackel. Culm stout, 2-3 $3^{\circ}$ high ; lateral peduncles few, scarcely exserted from the sheaths; spikes 2-5, 1-3' long, dense; spikelets $3-4$ " long. - Central Kan. to Dak., and westward.

\section{CHRY S O P Ò G N, Trin.}

Spikelets in pairs on the ramifications of an open panicle (those at the ends of the branches in threes), the lateral ones pedicellate, sterile or often reduced merely to their pedicals; only the sessile middle or terminal one fertile, its glumes coriaceons or indurated, sometimes awnless; otherwise nearly as in Audropogon. Stamens 3. (Name composed of $\chi \rho v \sigma o ́ s$, gold, and $\pi \dot{\omega} \gamma \omega \nu, b \in a r d$.

1. C. nutans, Benth. (Ixmax Grass. Wood-Grass.) Root perennial; 'ulm simple $\left(3-5^{\circ}\right.$ high $)$, terete; leaves linear-lanceolate, glaucous; sheaths smooth; panicle narrowly oblong, crowded or loose $\left(6-12^{\prime}\right.$ long); the perfect spikelets at length drooping (yellowish or russet-brown and shining), clothed especially toward the base with fawn-colored hairs, lanceolate, shorter than the twisted awn; sterile spikelets small and imperfect, deciduons, or reduced to a mere plumose-hairy pedicel. (Andropogon avenaceus, Michx. Sorghum nutans, Gray.) - Dry sil ; common, especially southward.

\section{PHÁLARIS， L. Caxary-Grass. (Pl. 13.)}

Spikelets crowded in a clustered or spiked pas:-?e, 1-flowered. Glumes 5, the third and fourth reduced to mere rudiments (a scale or a pedicel), one on each side, at the base of the flowering glume and palet, which are flattish, awnless and shining, shorter than the equal boat-shaped and keeled persistent empty glumes, finally coriaceous or cartilaginous, and closely enclosing the flattened free and smooth grain. Stamens 3.-Leaves broad, mostly flat.

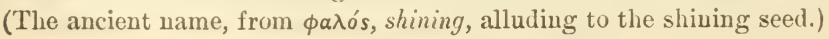


§ 1. PIIALARIS proper. Panicle very dense, spike-like; glumes ving-kecled.

P. Caxanísus, L. (Cavary-Grass.) Anumal, 1-2 high; spike oval; empty glumes white with green veins, the rudimentary ones small lanceolate scales. - Waste places and roulsides; rare. (Awr. from liu.)

\$2. DfGRApIIS. Panicle branched, the rlusters open in unthesis; glumes not winged on the buck.

1. P. arundinàcea, L. (KEEv C.) (1'l. 13, fig. 1, 2.) l'erennial, $2-4^{\circ}$ high; leaves flat (3-5" wide); glumes open at flowering, 3-nerved, thrice the length of the fertile flower; ruclimentary glumes reduced to a minute hairy scale or pedicel. - Wet grounds; common, especially morthwarl. June, July. - Var. Pf'TA, the leaves striped with white, is the familiar RıBBox-Grass of the gardens. (Lu.)

\section{ANThoXÁnthum, I. Swemt Vernal-Grass. (I'l. 13.)}

Spikelets spiked-panicled, I-flowered. Glumes is, the thiril an.l fourth empty, hairy, 2-lobed and awned on the back, the flowering shme and palet smail, hyaline and obtuse; basal glumes persistent, very thin, acnte, keeled, the lower half as long as the upper. Squanule none. Stamens 2. Grain ovate,

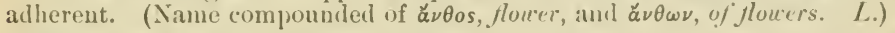

A. onondть u, L. Supikelets (hrownish or tinged with green) spreading at flowering-time; one midlle glume bearing a beut awn from near its base, the other short-awned helow the tip. - Meadows, pastures, etc. Low slender perenuial; very sweet scented in (lrying. May-July. (Nat. from ku.)

\section{H I E RÓ CH LOE, Guclin. Hory Griss. (I’l. 13.)}

Spikelets 3-flowered, open-panicled, the two lower (lateral) flowers staminate only, 3-androus, sessile, the carinate glumes often awned on the middle of the back or near the tip, the uppermost flower perfect, short-pedicelled, scarcely as long as the others, 2-androus, awnless. Basal glumes persistent, carinate, acute, somewhat 3-nerved, equalling or exceerling the spikelet. - Perennials; leaves flat. (Name composed of ifp's, sacred, and $\chi \lambda$ in $\eta$, gruss; these sweetscented grasses being strewn before the church-doors on saints' days, in the North of Europe.)

1. H. boreàlis, Roem. \& Schultes. (Vaxilla or Sexect Grass.) (Pl. 13, fig. 1, 2.) Panicle somewhat one-sided, pyramidal (2 -5 ' long); peduncles smooth; staminate flowers with the glume mucronate or bristle-pointed at or near the tip; rootstock creeping. - Moist meadows, chicfly northward near the coast and along the Great Lakes. May. - Culm $1-2^{\circ}$ high, with short, lanceolate leaves. Spikelets chestnut-color; the staminate flowers strongly hairy-fringed on the margins, and the fertile one at the tip. (Eu.)

2. H. alpina, Roem. \& Schultes. Panicle contracted (1-2'long); one of the staminate flowers with its glume harely pointed or short-awned near the tip, the other long-awned from below the midlle; luwest leaves very narrow. - Alpine mountain-tops, N. Eug., N. Y., and northwarl. July. (Eu.)

\section{ARÍstida, L. Triple-awned Grass. (I'l. 8.)}

Spikelets 1-flowered, not jointed on the pedicels. Outer glumes unequal, often bristle-pointed; the flowering glume tipped with three awns; the palet much smaller. Otherwise much as in Stipa. - Culms branching; leaves nar- 
row, often involute. Spikelets in simple or panicled racemes or spikes. Grain linear. All grow in sterile, dry soil, and all ours have the awns naked and persistent, and flower late. (Name from arista, a beard or awn.)

* Awns separate to the base, not jointed with the glume.

- Awns very unequal; the much shorter or minute lateral ones erect, the elongated middle one horizontal or turned downward; low (5-18' high) and branching, mostly tufted annuals, and the spikelets in nearly simple spikes.

+ Middle awn more or less coiled.

1. A. ramosíssima, Engelm. Culms much branched; spikes loose, usually exserted; lower glumes 6-10" long, exceeding the upper, usually rather strongly 3-5-nerred; middle awn $l^{\prime}$ long, soon abruptly looked-recurved, the lateral ones $1-3^{\prime \prime}$ long. - Dry prairies of Ill., Ky., and Mo. Also var. Uxiaristita, Engelm., with the lateral awns wanting.

2. A. basiràmea, Engelm. Spikes closer, mostly enclosed at base, at all the lower nodes (even to the base of the culm) very short and sessile; lower glumes $4-8^{\prime \prime}$ long, mostly thin and 1-nerved or rather faintly 3 -nerved; middle awn very slender, 6 " long, the lateral $2^{\prime \prime}$ long. - Ill. to Neb. and Minn.

3. A. dichótoma, Michx. (Poverty Grass.) Culms low, very slender, much branched throughout, ascending; spikelets in narrow strict simple or compound spikes; lower glumes nearly equal ( $3-4^{\prime \prime}$ long), longer than the flowering glume and fully equalling its minute lateral awns (or unequal and shorter, in var. Curtíssil, Gray), the soon reflexed middle awn about as long. - Dry, sandy or gravelly fields; common, Maine to Ill., and southward.

++ Middle aun nearly straight (not coiled).

4. A. grácilis, Ell. Culms slender, erect (6-18' high), naked above and terminating in a slender raceme- or spike-like virgate panicle; lower glumes 1-nerved, about the length of the upper, the exserted lateral awns varying from one third to fully half the length of the horizontally bent middle one; or in var. DEPAIPERATA, from one fifth to one third its length. - Sandy soil, coast of Mass., and from Ill. sonthward. - Middle awn 3-9" long in the ordinary forms, but not rarely shorter, and rery variable often on the same plant.

+ + Auns all diverging and alike, or the lateral ones moderately shorter, rarely at all coiled.

* Glumes equal or the middle one longer.

5. A. strícta, Michx. Culms $\left(2-3^{\circ}\right.$ high) densely tufted from a perennial root, bearing a $\left(1^{\circ}\right)$ long spiked panicle; leaves involute-thread-form, long, rigid, sometimes downy; awns about the length of the glumes $\left(6^{\prime \prime}\right)$ or the lateral one third shorter. - Va. and southward.

6. A. oligántha, Michx. Culms $\left(6-20^{\prime}\right.$ high) tufted from an annual root, bearing a loosely few-flowered raceme; leaves short, somewhat involute when dry ; lower glume 3-5-nerved (nearly $\mathrm{l}^{\prime}$ long) ; awns capillary, $1 \frac{1}{2}-3^{\prime}$ long, much exceeding the slender spikelet. - Va. to Ill., and common southwestward.

7. A. purpùrea, Nutt. Perennial; culms ( $1^{\circ}$ high or less) densely tufted, spreading; leaves revolute and filiform, short; panicle loose, of rather few slender-pedicellate spikelets; lower glumes thin, 1-nerved, loose, the outer 
abont half the length of the inner, which is 8-10" long; awns 2-4" long Minn. and 1)ak. to Tex. - Very variable.

+ Hiddle glume shorter than the lower: peremials, simple-stemmed, 2-4 high.

8. A. purpuráscens, I'oir. (Pl. 8.) Glabrous; leaves long, rather involute; spikelets in a $\left(10-18^{\prime}\right)$ long spiked panicle; lower glumes 1-nerved; au'ns much longer than the spitielet, the middle one about $\mathrm{l}^{\prime}$ long. - Mass. to Mich., Minn., and southward; common.

9. A. lanàta, Poir. 'Tall and stout; leaves tarlily involute, rough above, rigid ; sheaths woolly; panicle $\left(1-2^{\circ}\right.$ long) spike-like or more compund and open; glumes 1-nerved, 6-8" long; middle awn 1' loug. - 1)el. to Fla.

* A Ans united below into one, jointed with the apex of the glume; root annual.

10. A. tuberculosa, Nutt. Culm branched below $\left(6-18^{\prime}\right.$ high), tumid at the joints; panicles rigil, loose, the branches in pairs, one of them short and about 2-flowered, the other elongated and several-fluwered; lower glumes $\left(\mathbf{l}^{\prime}\right.$ long, including their slender-awned tips) longer than the upper, which is tipped with the common stalk (about its own length) of the 3 equal diver-

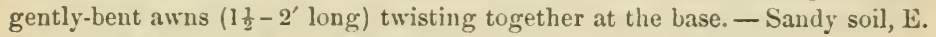
Mass. to N. J.; also Wisc., Minn., and southward.

\section{STİ P A, L. Feather-Grass. (Pl. 8.)}

Spikelets l-flowered, terete; the flower falling away at maturity (with the conspicuous obconical bearded and often sharp-pointed callus) from the membranaceous persistent lower glumes. Fertile glumes coriaceous, cylindricalinvolute and closely embracing the snialler palet and the cylindrical grain, having a long and twisted or tortuous simple awn jointed with its apex. Stamens mostly 3. Stigmas plumose. - Perennials, with narrow involute leares and a loose panicle. (Name from $\sigma \tau v \dot{\pi} \eta$, $t o w$, in allusion to the flaxen appearance of the featlery awns of the original species. In our species the awn is naked.)

* Callus or base of the flower short and blunt; lower glumes pointless.

1. S. Richardsonii, Ijink. Culm $\left(1 \frac{1}{2}-2^{\circ}\right.$ high) and leaves slender; panicle loose ( $4-5^{\prime}$ long), with slender few-flowered branches; lower glumes nearly equal, oblong, acutish $\left(2 \frac{1}{2}-4^{\prime \prime}\right.$ long), about equalling the pubescent linear-oblong fertile one, which bears a tortuous awn 6-9" long. - Pleasant Mountain, near Sebago Lake, Maine, Mt. Marey, N. Y., north shore of L. Superior, Mont., and northward.

* Cullus pungently pointed, at maturity villous-bearded; flowering glume slender and minutely bearded at the tip; empty glumes laper-pointed.

2. S. avenàcea, I. (BцAск Oıт-Grass.) (I'l. 8.) Culm slender (1$2^{\circ}$ ligh); leaves almost bristle-form; panicle open; fertile glume blackish, nearly as long as the louer ones (about 4 " long); the awn bent above, twisted below $\left(2-3^{\prime}\right.$ long). - I)ry woods, S. New Eng. to Wise., and southward.

3. S. spártea, 'Trin. (Ponccpixe Grass.) Culm rather stout $\left(1 \frac{1}{2}-3^{\circ}\right.$ high); panicle contracted; fertile glume linear, \&-1' long (including the long callus), pubescent below, shorter than the lanceolate slender subulate-pointed 


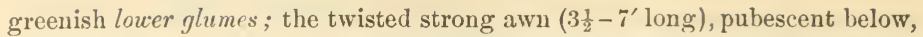
rough above. - Plains and prairies, from Ill. and N. Mich. northwestward.

4. S. virídula, Trin. Culns clustered, $1-3^{\circ}$ high or more; panicle narrow and usually deuse, $6-18^{\prime}$ long; glumes very thin, $3-4^{\prime \prime}$ long; fertile glume usually somewhat silky, with a short callus; awn 1' long, slender, glabrous or a little pubescent below. - W. Minu., Dak., and southwestward.

\section{ORYZÓPSIS, Michx. Mocxtain Rice. (P1. 8.)}

Spikelets 1-flowered, nearly terete. Lower glumes herbaceous or thin-membranaceous, several-nerved, nearly equal, commonly rather longer than the oblong flower, which is deciduous at maturity, and with a very short obtuse callus or scar-like base. Flowering glume coriaceous, at length involute so as closely to enclose the equal palet and the oblong grain ; a simple untwisted and deciduous awn jointed on its apex. Stamens 3. Squamulæ 2 or 3, conspicuous. Stigmas plumose. - Perennials, with rigid leaves and a narrow raceme or panicle. Spikelets greenish, rather large. (Name composed of

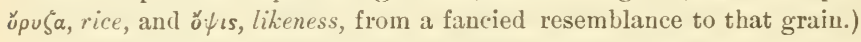

* Styles distinct, short; culm leafy to the summit; leaves broad and fut.

1. O. melanocárpa, Muhl. Leaves lanceolate, taper-pointed; sheaths bearded in the throat; panicle simple or sparingly branched; awn thrice the leugth of the blackish glume (nearly $\mathrm{I}^{\prime}$ long). - Rocky woods, N. Eng. to Penn., Minn., Mo., and westward. Aug. - Culm 2-3 high.

* * Styles united belou, slender; culms tufted, naked; leaves concave or involute.

2. O. asperifolia, Michx. (Pl. 8, fig. 1, 2.) Culms $\left(9-18^{\prime}\right.$ high), with sheaths bearing a mere rudimentary blade, overtopped by the long and rigid linear leaf from the base; very simple panicle or raceme few-flowered; awn 2-3 times the length of the rather hairy whitish glume. - Hillsides, etc., in rich woods; common, N. Eng. to Minu., and northward. May. - Leaves without keels, rough-edged, pale beneath, lasting through the winter. Squamula lanceolate, almost as long as the palet!

3. O. Canadénsis, 'Torr. Culms slender $\left(6-15^{\prime}\right.$ high $)$, the lowest sheaths leaf-bearing; leaves involute-thread-shaped; panicle contracted (1-2' long), the branches usually in pairs; glume pubescent, whitish; awn short and very deciduous, or wanting. - Rocky hills and dry plains, Maine to W. New Eng., the mountains of Penn., Wisc., Minn., and northward; rare. May.Glumes 1-2" long, sometimes purplish.

\section{MÍIIU M, Tourn. Millet-Grass. (Pl. 13.)}

Spikelets 1-flowered, diffusely panicled, not jointed with their pedicels, consisting of 2 equal membranaceous convex and awnless persistent glumes, with a coriaceous awuless flowering glume and narrow palet. Stamens 3. Stigmas branched-plumose. Grain not grooved, enclosed in its glume and palet, all deciduons together. (The ancient Latin name of the Millet, which however belongs to a different genus, of uncertain meaning.)

1. M. effùsum, L. Smooth perenuial, $3-6^{\circ}$ high; leaves broad and flat, thin ; panicle spreading (6-9' long); flower ovoid-oblong. - Culd damp woods and mountain meadows, N. Eng. to Ill., and northward. June. (Eu.) 
Spikelets 1-flowered, in contracted or rarely in open panicles. Einpty glumes mostly acute or bristle-pointed, persistent, usually thiu; the lower rather smaller or minute. Flower very short stalked or sessile, the glume and palet usually minutely bearled at base, herbaceous, decidnous with the enclosil graiu, often equal, the glume 3-nerved, mucronate or awnel at the apex. Stamens 3. (I)edicated to the Kev. L)r. Kenry Muhlenberg, a distinguished $\Lambda$ merican botanist of the early part of this century.)

§ 1. MUHLFXBERGIA proper. Panicles contracted or glomerate, on branching rigid culms from sculy creeping rootstocks; leaves short and narrow.

* Floucring glume barely mucronate or shurp-pointed.

1. M. sobolifera, Trin. Culms ascending (1-2 high), rarely branching; the simple contracted panicle very slender or filiform ; lower glumes barely pointed, almost equal, one third shorter than the flower; flowering glume abruptly short-inueronate, equalling the palet. - Open rocky woods, Mass. to Mich., Minn., and sonthward. Aug. - Spikelets less than l" long.

2. M. glomeràta, Trin. Culms upright ( $1-3^{\circ}$ high), sparingly branched or simple; panicle (2-3' long) oblong-linear, contracted into an interrupted glomerute spike, long-peduncled, the branches sessile; glumes awned, nearly equal, and (with the bristle-like awu) abont twice the length of the unequal very acute flowering glume and palet. - Bugs and wet rocks, common, especially nortbward. Aug. - Var. RA.òss, Vasey. A stout strict much-branched leafy form, the lower glumes but little longer than the flower. Ill. to Dak.

3. M. Mexicàna, Trin. Culms asceuding, much branched $\left(2-3^{\circ}\right.$ high $)$; panicles lateral and terminal, often included at the base, contracted, the branches densely spiked-clustered, linear (green and purplish); lower glumes awnless, sharp-pointed, unequal, the upper about the length of the very acute flowering one. - Low grounds; common. Aug. Varies with more slender panicles.

* * Flowering glume bristle-auned from the tip; flowers short-pedicelled.

\section{- Louer glunes long and bristle-pointed.}

4. M. sylvática, Torr. \& Gray. (Pl. \&, fig. 1, 2.) Culms ascending, much branched and diffusely spreading $\left(2-4^{\circ}\right.$ long) ; contracted panicles densely muny-flowered; lower glumes almost equal, bristle-pointed, nearly as long as the flowering one, which bears an awn twice or thrice the length of the spikelet. - Low or rocky woods; common. Aug., Sept.

5. M. ambígua, Torr. Cnlms ascentling, clustered and branching, 10 high ; panicles contracted, clensely many-flowered; spikelet 2-flucered, the upper flower like the lower and perfect, or more frequently reluced to a mere awn at the base of the lower fluwer; lower glumes nearly equal, long-pointed; flowering glume villous, as long as the lower and equalling the palet, its awn nearly twice longer. - Minn. (shore of Elysian lake, Waseca Co., Geyer). A remarkable species, approaching Brachyelytrum in the structure of the spikelet, but with wholly the habit of Muhlenbergia.

+ + Lower glumes short or minute, not or scarcely pointed.

6. M. Willdenóvii, Trin. Culms upright ( $\left.3^{\circ} \mathrm{high}\right)$, slender, simple or sparingly branched; contracted panicle slender, loosely flowered; lower glumes 
slightly unequal, short-pointed, half the length of the flowering one, which bears an awn 3-4 times the length of the spikelet. - Rocky woods; rather common. Aug.

7. M. diffùsa, Schreber. (1)rop-Seed. Nimble Will.) (Pl. 8, fig. $3-5$.) Culms diffusely much branched (8-18' high); contracted panicles slender, rather loosely many-flowered, terminal and lateral; empty glumes extremely minute, the lower obsolete, the upper truncate; awn once or twice longer than the flowering glume.- Dry hills and woods, from S. New Eng. to Mich., Iowa, and southward. Ang., Sept. - Spikelets only l" long.

§ 2. TRICHÓCHLOA. Panicle very loose and open, the long branches and pedicels capillary; leaves narrow, often convolute-bristle-form.

8. M. capillàris, Kunth. (HaIr-Grass.) Culm simple, upright (2० high) from a fibrous root ; panicle capillary, expanding (6-20' long, purple); empty glumes unequal, the lower mostly pointless, the upper more or less bristle-pointed, one third or half the length of the long-awned flowering glume. - Sandy soil, W. New Eng. to N. J., Ky., Mo., and sonthward. Sept. Pedicels $1-2^{\prime}$ long, scarcely thicker than the awns, which are about $l^{\prime}$ long.

\section{B R A C H Y É Y T R U M, Beauv.}

Spikelets 1-flowered, with a conspicuous filiform pedicel of an abortive second flower about half its length, nearly terete, few, in a simple appressed racemed panicle. Lower glumes unequal, persistent, usually minute, or the lower one almost obsolete. Flowering glume and palet chartaceo-herbaceous, involute, enclosing the linear-oblong grain, somewhat equal, rough with scattered short bristles, the first 5-nerved, extended iuto a long straight awn, the palet 2-pointed; the awn-like sterile pedicel partly lodged in the groove on its back. Stamens 2; anthers and stigmas very long. - Perennial, with simple culms $\left(1-3^{\circ}\right.$ high) from creeping rootstocks, downy sheatls, broad and flat lanceolate pointed leaves, and spikelets $\frac{1^{\prime}}{2}$ long without the awn. (Name com-

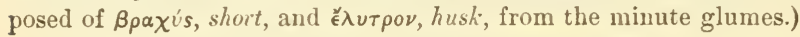

1. B. aristàtum, Beauv. Rocky woods; common. June.-Var. ExGELMÁNin, Gray, is a westeru form, with the second glume awn-pointed, nearly half the length of the flowering one.

\section{HELEÓCHLOA, Host. (P1. 7.)}

Spikelets l-flowered, crowded in a dense spike or spike-like panicle. Lower glumes persistent, membranaceous, acute, ciliate-cariuate, awnless ; flowering glume similar, a little longer, and a little exceeding the palet. Stamens 3.L.w cespitose annuals; spike often scarcely exserted from the upper sheatl.

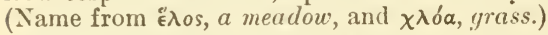

H. schexoldes, Host. Lsually nearly prostrate and tufted; leaves rather rigid, tapering to a sharp point; spike oblong, thick, 7-20" long. (Crypsis schœnoides, Lam.) - Waste places, N. J. to Del. (Nat. from Eu.)

\section{PHLEU U, L. Cat's-tall Grass. (Pl. 7.)}

Spikelets 1-flowered, in a very dense cylindrical spike-like panicle. Lower glumes persistent, membranaceous, folded-carinate, subtruncate, mucronate $\mathrm{nr}$ short-awned; flowering glume hyaline, shorter, truncate. Stamens 3. Styles distinct. - Perennials. (From ф $\lambda$ éws, a Greek name for a kind of reed.) 
P. pratéxse, L. ('Tumotux. IIEnn's-Grass in New Eng. and N. Y.) Tall; spike long-cylindrical; lower glumes ciliate on the back, tipperl with a short bristie. - Mealows, commonly cultivated for hay. (Nat. from Eu.)

1. P. alpinum, I. Low; sprike ovate-oblong; lower glumes strongly ciliate on the back, tipped with a rough aun about their oun length. -1 lpine tops of the White IIountains, N. H., aud high northward. (Eu.)

\section{A L O PEU RUS, L. Foxtal Grass. (Pl. 7.)}

Spikelets 1-fluwered, jointed on the pedicel. Lower glumes boat-shaped, strongly compressed and keeled, nearly equal, mited at base, equalling or exceeding the flowering glume, which is awned on the back below the middle; palet mostly wanting! Stauens 3. Styles mostly united. Stigmas long and feathered. - Clusters contracted into a cylindrical and soft dense spike ; perennial. (Name from $\dot{\alpha} \lambda \omega \pi_{\eta} \xi, f o x$, and oúá, tail, from the shaje of the spike.)

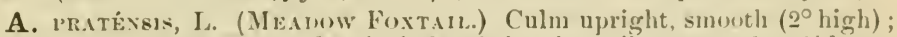
the upper leaf much shorter than its inflated sheath; spike stout, $1 \frac{1}{2}-2 \frac{1}{2}{ }^{\prime}$ long: flowering glume equalling the acute lower glumes; aun exserted more than half its length, tuisted. - Meadows and pastures, eastward. May. (Nat. from Eu.)

A. Gevicitates, L. (Frontrag F.) (I'l. 7, fig. 1-4.) Culm ascending, often bent at the lower joints; upper leaf as long as its sheath; spike slender, 1-2' long; flowering glume rather shorter than the obtuse lower glumes, the awn from near its base and projecting from half to tuice its length beyond it. - Moist meadows, eastward. June-Nug. (Nat. from Eu.)

Var. aristulàtus, Torr. 'The awn very slender and scarcely exserted. (A. aristulatus, Michx.) - In water and wet places; common. Jume-Aug.

\section{S P O Ró BOLUS, R. Br. Drop-send Grass. Resi-Grass. (Pl. . .)}

Spikelets small, 1- (rarely 2-) flowered, in an open or contracted or spiked panicle. Lower glumes persistent, 1-3-nerved, not awned or pointed, the lower smaller; flowering glume of the same texture as the lower ones (membranaceo-chartaceous) and usually longer than they, naked, awnless and mostly pointless, 1-nerved (rarely somewhat 3-nerved); palet similar, 2-nerved. Stamens chiefly 3. Stigmas simply feathery. Grain globular to oblong or cylindrical, deciduous, often very thin, containing the loose seed. - Culms wiry or rigid. Leares involute, the throat usually bearded, and sheaths often enclosing the panicles. (Name from $\sigma \pi o \rho a$, seed, and $\beta a ́ \lambda \lambda \omega$, to cust forth.)

* Panicle contracted, often simple; grain oval or oblong; perennial, except n. 2.

1. S. ásper, Kunth. Culms tufted $\left(2-4^{\circ}\right.$ high); lowest leaves very long, rigid, rough on the edges, tapering to a long involute and threal-like point, the upper short, involute; sheaths partly or at first wholly enclusing the contracted panicle; flower much longer than the unequal lower glumes; grain oral or oblong. (Vilfa aspera, Beauv.) - Sandy fields and dry hills, especially southward. Sept. - Spikelets $2-3^{\prime \prime}$ long. Flowering glume and palet rough above, smooth or hairy below, the palct tapering upward, acnte, and one half to twice longer than the glume, or else obtuse and equalled or even considerably exceeded hy the glume!

2. S. vaginæflorus, Vasey. (Pl. 7, fig. 4, 5.) Culms slenter $(6-12$ ' high), ascending; leaves involute-awl-shaped ( $1-4^{\prime}$ long); panicles simple and spiked, the lateral and often the terminal concealed in the sheaths; flower- 
ing glume and palet somewhat equal, acute, about the length of the nearly equal lower glumes, only $\frac{1}{3}$ longer than the oval grain. (Vilfa vaginæflora, Torr.) - Barren and sandy dry fields; common, especially southward. Sept.

3. S. cuspidàtus, Torr. Erect culms and appressed leares more slender than in the preceding; panicle exserted, very simple and narrow; spikelets smaller, the lower glumes acuminate, little shorter than the cuspidate upper one. (Vilfa cuspidata, Torr.) - Maine (on the St. John's River, G. L. Goodale); also Iowa, Minn., and common westward.

4. S. depauperàtus, Vasey. Resembling n. 3, but the culms decumbent at base and matted, the leares short and usually widely spreading, and the lower glumes barely acute, not half the length of the upper one. - W. Minn. to Kan., and southwestward.

5. S. Virgínicus, liunth. Culms tufted, slender $\left(5-12^{\prime}\right.$ long), often procumbent, brunched; leaves convolute, rigid; palets rather shorter than the nearly equal acute glumes. (Vilfa Virginica, Beanv.) - Sandy seashore, Virginia (Clayton) and southward. - Spikelets much smaller and more numerous than in the others.

6. S. minor, Vasey. Culms tufted, very slender, geniculate and ascending, simple, $1^{\circ}$ high; leaves short and narrow ; peduncles little exserted from the sheaths; spikelets ( $1 \frac{1}{2}-2^{\prime \prime}$ long) in a very narrow simple compressed panicle (1 - 2' long), not crowded; glumes and palet nearly equal, acute or some what acuminate. - Va. to if. C., Tenn. and Tex.

S. frorces, R. Br. Culms stout, erect, $2-3^{\circ}$ high ; leares elongated, attenuate; panicle very narrow, $6-18^{\prime}$ long, the densely crowded spikelets $\frac{1^{\prime \prime}}{2}$ long. - On ballast, and naturalized southward. (From Trop. Am.)

* * Panicle pyramidul, open; glumes very unequal; grain globose, utricular, perennials.

7. S. júnceus, Knnth. Leaves involute, narrow, rigid, the lowest elongated; (nlm (1-20 ligh) naked abore, beariug a narrow loose panicle; empty glumes ovate, ruther obtuse, the lower one half as long as, the upper equalling, the nearly equal. flowering glume and palet. - Dry soil, Penu. to Wisc. and Minn., and (chiefly) south to Fla. Ang. - Spikelets 1-2" long, shining.

8. S. heterólepis, Gray. Leaves involute-thread-form, rigid, the lowest as long as the culm $\left(1-2^{\circ}\right)$ which is naked above; panicle very loose; empty glumes very unequal; the lower awl-shaped (or bristle-pointed from a broad base) and somewhat shorter, the upper ov:ate-oblong and taper-pointed and longer, than the equal flowering glume and palet. - Dry soil, Conn. and N. Y. to Mimn., Neb., and Mo. Aug. - Plant exhaling an unpleasant scent (Sullivant), stouter than the last, the spikelets thrice larger. Utricle $l^{\prime \prime}$ in diameter, shining, thick and coriaceous!

9. S. cryptándrus, Gray. (Pl. 7, fig. 1-3.) Culm 2-3 high; leaves flat, pale (2" wide); the prramidal lead-colored panicle bursting from the upper sheath which usually encloses its base, its spreading branches hairy in the axils; spikelets $1^{\prime \prime}$ long; upper empty glume lanceolate, rather acute, twice the length of the lower one, as long as the nearly equal flowering glume and palet; sheaths strongly bearded at the throat. - Sandy shores, coast of New Eng. and of the Great Lakes, Minn. to Kan., and westward. Aug., Sept. 
10. S. airoldes, Torr. Culm tufted, often stout, erect, $\frac{1}{2}-3^{\circ}$ high ; leaves strongly revolute and attenuate, rather rigid; panicle open and diffuse, broadly pyramiilal, glabrous; spikelets solitary on slender pedicels, 1" long; lower glumes unequal, rather ol,tuse. - Neb. to 'lex., and westward.

S. Asprofòcus, Thurb., a similar but smallur species, with thinner and shorter leaves very rough on the margin, the inflorescence scabrous, and spikelets smaller, with the glumes nearly equal, is very common west ward, and probably occurs within our limits - as also $S$. coxfitsts, Vasey (S. rimulosus of authors, not $K$ unth), a low slender annual, with very short culns and a delicate diffuse panicle, the very small spikelets ( $\frac{1}{2}$ " long) on filiform-clarate pedicels.

* * Empty glumes almost equal; panicle racemose-elongated, open, the pedicels capillary; sheaths naked at the throat; spikelets not unfrequently twoflowered; peremial.

11. S. compréssus, Kunth. Very smooth, leafy to the top ; culms tufled, stout, very flut; sheaths flattened, much longer than the internodes; liaves evert, narrow, conduplicate-channelled; empty glumes acutish, about one third shorter than the obtuse flowering one.- Bogs, on Long Island and in the pine-barrens of X. J. Sept. - Forming strong tussocks, $1-2^{\circ}$ high. Panicle 8-12' long; spikelets I" long, purplish.

12. S. serótinus, Gray. Smootlı; culms very slender, flattish (8-15' high), feu-leaved; leaves very slender, channelled; panicle soon much exserted, the diffuse capillary branches scattered; glumes ovate, obtuse, about half the length of the flower. - Sandy wet places, Maine to N. J. and Mich. Sept. A very delicate grass; the spikelets lialf a line long.

\section{A GRóstis， L. Bent-Grass. (Pl. 7.)}

Spikelets 1-flowered, in an open panicle. Empty glumes somewhat equal, or the lower rather longer, usually longer than the flowering one, pointless. Flowering glume and palet very thin, pointless, naked; the first 3-5-nerved, frequently awnerl on the back; the palet often minute or none. Stamens chicfly 3. Grain (caryopsis) free. - Culms usually tufted, slender; root commonly perennial. (Name from àypós, a field, the place of growtlı.)

$\S 1$. AGROSTIS proper. Palet manifest, but shorter than the glume.

A. Álba, I. (Fiorin or White Bext-Grass.) Rootstocks creeping or stoloniferous; culums $1-2^{\circ}$ high, often decumbent at lase: leaves short, flat, the ligule long and acute; panicle contracted after flowering, greenish, purplish or brownish, the branches slightly rough; flowering glume nearly equalling the empty ones, 3-nerved, rarely short-awned, the pallet alout laalf as long. - Meadows and fields, a valuable grass; naturalized from Eu. and cultirated, and perhajs native north and westwarl.

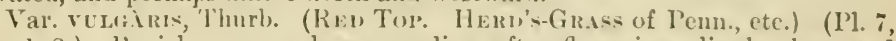
fig. 1, 2.) l'anicle more or less spreading after flowering; ligule short and truncate. (A. vulgaris, With.) - Low mealows and pastures; nat. from Eu. and cultivated, also perhaps indigenous.

1. A. arachnoldes, Ell. Culms $\left(1^{\circ}\right.$ high) and leaves very slender; panicle open, weak and dronping; glumes nearly equal, roughish on the keel and margins, the flowering glume shorter, with 2 minute bristles at the truncate apex and a long exceedingly delicate awn on the back above the middle; palet minute. - Mo. to Ky., Tenn., and s. Car. 
2. A. exaràta, Trin. Culms erect, $1-2^{\circ}$ high; leaves mostly erect; panicle narrow, crowded, greenish, the rays mostly flower-bearing to the base; spikelets $1 \frac{1}{2}-2^{\prime \prime}$ long; glumes nearly equal, acute, the flowering ones shorter, sometimes awned above the middle.- Wisc. (Tasey) to Sask., and far westward.

\section{§2. 'TRICHÒDIUM. Palet abortive, minute, or none.}

3. A. elàta, Trin. Culms firm or stout $\left(2-3^{\circ}\right.$ high $)$; leaves flat $\left(1-2^{\prime \prime}\right.$ wide) ; upper ligules elongated ( $2-3^{\prime \prime}$ long); spikelets crouded on the branches of the spreading panicle above the middle ( $1 \frac{1}{2}{ }^{\prime \prime}$ long); flowering glume awnless, slightly shorter than the rather unequal lower ones; the palet wanting. Swamps, N. J. and southward. Oct.

4. A. perénnans, Tuckerm. ('Tuix-Grass.) C'ulms slender, erect from a decumbent base $\left(1-2^{\circ}\right.$ high) ; leaves flat (the upper $4-6^{\prime}$ long, $1-2^{\prime \prime}$ wide) ; panicle at length diffusely spreading, pale green; the branches short, divided and flower-bearing from or below the middle; flowering glume aunless (rarely short-awned), shorter than the unequal lower ones; the palet minute or obsolete. - Damp shaded places. July, Aug. - spikelets, etc., as in u. 5, into which it seems to vary.

5. A. scàbra, Willd. (Hair-Grass.) (Pl. 7, fig. 3.) Culms rery slender, erect $\left(1-2^{\circ}\right.$ high $)$; leaves short and narrow, the lower soon involute (the upper 1-3' long, less than $\mathrm{I}^{\prime \prime}$ wide); panicle very loose and divergent, purplish, the long capillary branches flower-bearing at and near the apex; flowering glume aunless or occasionally short-awned on the back, shorter than the rather unequal very acute empty ones; the palet minute or obsolete ; root biennial ? - Exsiccated places; common. June-Ang. - Remarkable for the long and divergent capillary brauches of the extremely loose panicle; these are whorled, rough with very minute bristles (under a lens), as also the keel of the glumes Spikelets 1" long. A dwarf mountain form occurs, growing in tufts in hollows of rocks, etc. $-A$ variety (?) from about the White Mountains, etc. (var. montana, Tuckerm.), has a more or less exserted awn.

6. A. canina, L. (Brows Bext-Grass.) Culms $8^{\prime}-2^{\circ}$ high; rootleaves involnte-bristle-form, those of the culm flat and broader; panicle loose; lower glumes slightly unequal, orate-lanceolate, very acute, the flowering one exsertly auned on the back at or below the middle; spikelets brownish or pur. plish, rarely pale or greenish ( $1-1 \frac{1}{2}$ ' long). - Meadows, sparingly naturalized eastward. A monntain form with shorter and more spreading panicle (A. Pickeríngii \& A. conciuna, Tuckerm., A. canina, var. alpina, Oakes, \& Ed. 2, and essentially A. rubra, L. ex Wahl., and A. borealis, Hartm.) is indigenous on mountain-tops, Maine to N. Y.; also an ampler form in the Alleghanies of Penu. aud southward (A. rupéstris, Chapman, etc.). July-Aug. (Eu.)

\section{POLY Pò G O N, Desf. Beard-Grass. (Pl. 8.)}

Spikelets 1-flowered, in a contracted, mostly spike-like panicle. Empty glumes nearly equal, loug-awned, much longer than the membranaceous flowering one which is commonly short-awned below the apex. Stamens 3. Graiu free. (Name composed of $\pi o \lambda \dot{v}$, much, and $\pi \omega \gamma \dot{\omega} \nu$, beard.)

P. Moxspelı́xsis, Desf. Panicle interrupted; lower glumes oblong, the awn from a notch at the summit, the flowering one also awned; root annual. - Isles of Shoals (Lobbins), ballast heaps, and southward. (Nat. from Eu.) 


\section{Cí N N A, L. Wool) Reen-Ghass. (Pl. 8.)}

Spikelets l-flowered, much flattened, crowled in an open flaccil panicle. Empty glumes persistent, lanceolate, acute, strongly keeled, rongh-serrulate on the keel; the lower rather snaller, the upper a little exceeding the flower, which is manifestly stalked, smooth and naked; flowering glume much like the lower, longer than the palet, usually short-awned or mucronate on the back below the poiutless apex. Stamen one, opposite the I-nerved palet! Grain linear-oblong, free. $-\Lambda$ perennial, rather sweet-scented grass, with simple and upright somewhat reed-like culıns $\left(2-7^{\circ}\right.$ high $)$, bearing an ample conıpound terminal panicle, its branches in fours or fives; the liroadly linear-lanceolate flat leaves $\left(4-6^{\prime \prime}\right.$ wille) with conspicuous ligules. Spikelets green, often purplish-tinged. (From $\kappa i \nu \nu a$, a name in Dioscorides for a kind of grass.)

1. C. arundinàcea, I. (Pl. 8, fig. 1, 2.) Panicle 6-15'long, rather dense, the branches and pelicels spreading in flower, afterward erect; spikelets $2 \frac{1}{2}-3^{\prime \prime}$ long; awn of the glume either obsolete or manifest. - Moist woods and shaded swamps; rather common. July, Aug.

2. C. péndula, Trin. Panicle loose and more slender, the branches nearly capillary and drooping in flower; pedicels very rough; glumes thinner, the lower less unequal; spikelets $1 \frac{1}{2}-2^{\prime \prime}$ long; palet obtuse. (C. arundinacea, var. pendula, Gray.) - Deep damp woods, N. New Eng. to Lake Superior aud northward, and on mountains southward. (Eu.)

\section{A P E R A, Adans.}

With the characters of Agrostis; distinguished by the presence of a second rudimentary flower in the form of a short bristle, and by the 2-toothed palet little shorter than the flowering bifid glume, which is dorsally awned. - A rather late annual, with narrow flat leaves, and a contracted or spreading panicle with numerous filiform branches and very numerous small shining spikelets. (Name from ămipos, unmaimed; application obscure.)

A. slìcA-v́́xtr, Beauv. Spikelets $\frac{7}{2}-1$ " long. - Sparingly naturalized. (Nat. from En.)

\section{C A L A M A GRóS T I S, Adans. Reen Bent-G.}

Spikelets 1-flowered, and (in our species) often with a pedicel or rudiment of a second abortive flower (rarely 2-flowered), in an open or spiked panicle. Lower glumes mostly membranaceous, keeled or boat-shaped, often acute, commonly nearly equal, and exceeding the flower, which bears at the base copious white bristly hairs; flowering glume thin, bearing a slender awn on the back or below the tip, or sometimes awnless; the palet mostly shorter. Stamens 3. Grain free. - Perennials, with running rootstocks, and mostly

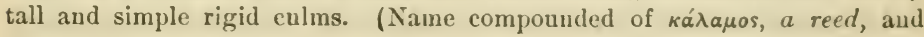

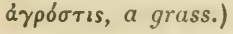

\$1. DEYEUXIA. Rudiment of a second flower present in the form of a plumose or hairy small pedicel behind the palet (very rarely more developed and having a glume or even stamens); glumes membranaceous, or the flowering one thin and delicate, the latter 3-5-nerved and aun-bearing.

* Panicle loose and open, even after flowering: the mostly purple-tinged or leadcolored strigose-scabrous glumes not closing in fruit; copious hairs of the 
rhachis about equaling the flowering glume, not surpassed by those of the rudiment; awn delicate, straight.

1. C. Canadénsis, Beauv. (Blue-Jorvt Grass.) (Pl. 8, fig. 1, 2.) Culm tall $\left(3-5^{\circ}\right.$ high); leaves flat when fresh, glancous; panicle oblong; glumes ovate-lanceolate, acnte, $1 \frac{1}{4}-1 \frac{1}{2}$ "long; aun from near the middle of the upper glume, not exceeding and scarcely stouter than the basal hairs. (Deyeuxia Canadensis, Hook.f.) - Wet grounds; common northward. July.

2. C. Langsdórffii, 'Trin. Spikelets larger, $2 \frac{1}{2}-3^{\prime \prime}$ long; glumes lanceolate or oblong-lanceolate and gradually taper-pointed; awn stonter; otherwise like the preceding. (Deyeuxia Langsdorffi, Kunth.) - Mountains of N. New Eng., L. Superior, and northward. (Eu.)

* * Panicle strict, its short Uranches appressed or erect after flowering, and the glumes mostly closed; flowering glume less delicate, roughish, sometimes of as firm texture as the lower; awn stouter.

+- Leaves narrou, inclined to be involute; awn straight.

3. C. strícta, 'Trin. Panicle glomerate and lobed, strict, $2-4$ ' long; glumes $1 \frac{1}{2}-2^{\prime \prime}$ long, ovate-oblong, not acuminate; hairs scarcely or little shorter than the flower, and as long as those of the rudiment; awn from the middle of the thin flowering glume or lower, and barely exceeding it. (Deyeuxia neglecta, Kunth?) - Mountains of N. New Eng., Lake Superior, and north and westward. (En.)

4. C. Lappónica, Trin. Culm and rootstocks stouter than in C. stricta; the narrow panjclo less dense, and purplish spikelets larger; glumes fully 2" long, tapering to a point; awn from much below the middle of the glume, stout. (Deyeuxia Lapponica, Kunth.) - Isle Royale, Lake Superior, to Lab., north and westward. Ang. (Eu.)

+ + Leaves broader, flat; aun stouter, bent, divergent, or tuisted uhen dry.

5. C. confinis, Nutt. Tall; panicle elongated $\left(4-6^{\prime}\right)$, its rather slender branches spreading at flowering-time, afterward appressed; glumes lanceoblong, very acute, $2^{\prime \prime}$ long, pale; hairs of the flouer copious, equal, slightly or one third shorter than the thin flowering glume and than those of the rudiment; awn borne mucls below the middle of the glume, somewhat surpassing it; grain glahrons. (Deyenxia confinis, Kunth.) - Swamps, N. and W'. New York (especially Penn Yan, Sartwell) and Penn.; Minn., and westward. July.

6. C. Nuttalliàna, Steud. Culm stont $\left(3-5^{\circ}\right.$ high $)$; panicle contracted and spike-like; glumes lanceolate and tapering into slender awl-shaped tips, $3^{\prime \prime}$ long; hairs on the lower side scanty and barely half the length of the firm and keeled flowering glume, on the other side longer and equalling the copious tuft on the summit of the rudiment; awn borne half-way between the middle and the tapering tip of the glume, stout, not twisted; grain bearded at the top. (Deyeuxia Nuttalliana, Vasey.) - Moist grounds, E. New Eng. to Penn., Va., and sonthward. Aug.

7. C. Pórteri, Gray. Culm slender $\left(2-4^{\circ}\right.$ high); a woolly-bearded ring at the junction of the broadly linear leaves with the sheath; panicle long and narrou", with the branches appressed; glumes lanceolate, acute, pale, $2-2 \frac{1}{2}$ " long; hairs of the flower and of the short rudiment scanty, and both reaching about to the middle of the flower behind the palet, but very siturt or none at the 
base of the firm-membrunaceous flowering glume, which bears near its base a twisted aun of its own length. (I)eyeuxia Porteri, I usey.) - I)ry woods, l'ulpit Rocks and vicinity, Iluntingdon Co., Penn., Prof: T. C. Porter.

8. C. Pickeríngii, Gray. Culm 1-1 $\frac{1}{2}{ }^{\circ}$ high ; leares short; panicle pyramidal, purplish; glumes ovate-oblong, hluntish or hluntly pointed $\left(1 \frac{1}{2}-2^{\prime \prime}\right.$ long); hairs both of the flouer and of the rudiment very short and scanty, one fourth or fifth the length of the flower, none behind the obtuse flowering glume, which hears between its midlle and base a short stont (straight or bent, not twisted) awn. (Deyeuxia I'ickeringii, Jasey.) - White Mts., in the alpine region of Mt. Washington, and a more luxuriant form with smaller spikelets at Echo Lake, Franconia; Andorer, Mass. (J. Robinson); Cape Breton.

§ 2. CALAMUVILFA. Rudiment of second flower uanting; glumes and palet rather chartaceous, compressad-kceled; flowering glume 1-nerved, entirely aunless; pulet strongly 2-keeled : panicle at length open und loose.

9. C. brevípilis, Gray. Branches of the diffuse pyramidal panicle capillary (purplish); empty glumes ocute, nucronate; the upper slightly, the lower nearly one half shorter than the flouering glume aud palet, which are more than tuice the length of the hairs and bristly-bearded along the kecls. (Ammophila brevipilis, Benth.) - Sandy swamps, pine-barrens of N. J.; rare. Sept. - Culm 2-4० ligh; leares nearly flat; spikelets $2^{\prime \prime}$ long.

10. C. longifolia, Hook. Cnlm $\left(1-4^{\circ}\right.$ high $)$ stout, from thick running rootstocks; leaves rigid, elongated, imeolute above and tapering into a long thread-like point; panicle at first close, beconing open and pyramidal, the brauches smooth; glumes lanceolute, the upper as long as the flower, the lower $\frac{1}{4}$ shorter; the copious hairs more than half the length of the naked flower. (Ammophila longifolia, Benth.) - Sands, along the upper Great Lakes, from Ill. and Mich. to Dak., Kan., and westward. Aug. - Spikelets $2 \frac{1}{2}-3^{\prime \prime}$ long.

\section{A M M Ó PHILA, Host. (Pl. 15.)}

Spikelets large, in a contracted spike-like panicle, l-floweresl, with a pedicellike rudiment of a second flower (plumose above), the flower hairy-tufted at base. Empty glumes scarious-chartaceous, lanceolate, compressed-keeled, nearly equal; flowering glume and palet similar, a little shorter, the glume 5-nerved, slightly mucronate or obscurely awned near the tip, the pallet 2keeled. $-\Lambda$ coarse perennial maritime species, with rumning rootstocks.

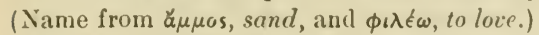

1. A. arundinàcea, Host. (Sed SAxn-Renn.) Culm stout and rigid $\left(2-3^{\circ}\right.$ high) from firm running rootstocks; leaves long, soon involute; panicle contracted into a dense cylindrical spike $\left(5-9^{\prime}\right.$ long) : spikelets $5-6^{\prime \prime}$ long; hairs only one third of the length of the flower. (Calamagrostis arenaria, Roth.) - Sandy beaches, N. J. to Maine and northward, and on the Great Lakes. Aug. (Eu.)

\section{ARRHENATH ERUM, Beauv. OAT-Grass. (Pl. 12.)}

Spikelets open-panicled, 2-flowered, witl the rudiment of a third flower; the middle flower perfect, its glume barely bristle-pointed from near the tip; the lowest flower staminate only, bearing a long bent awn lielow the middle of

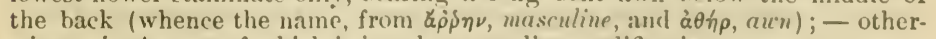
wise as in Avena, of which it is only a peculiar modification. 
A. Avexacecu, Beauv. Root pereunial; culm $2-4^{\circ}$ high; leaves broad, flat; panicle elongated; glumes scarious, very unequal. - Meadows and lots; absurdly called Grass of the Andes. May-July. (Nat from Eu.)

\section{HÓ L C U S, L. (partly). Meadow Soft-Grass. (Pl. 12.)}

Spikelets crowded in an open panicle, 2-flowered; the boat-shaped membranaceous glumes enclosing and much exceeding the remotish flowers. Lower flower perfect, its papery or thin-coriaceous glume awnless and pointless; the upper flower staminate, otherwise similar, but bearing a stout bent awn below the apex. Stamens 3. Styles plumose to the base. Grain free. (A name iri Pliny for a kind of grass, from $\delta \lambda \kappa o ́ s$, attractive, of obscure application.)

H. LAxAtes, L. (Velvet-Grass.) Perennial, soft-downy and pale; panicle oblong; upper empty glume inucronate-awned under the apex; awn of the staminate flower curved. - Moist meadows. June. (Nat. from Eu.)

\section{A İ R A, L. Hair-Grass.}

Spikelets very small, in an open diffuse panicle, of 2 perfect contignous flowers. Glumes thin-membranaceous, the two lower persistent, nearly equal, acute, keeled; the flowering ones obscurely nerved, acutely 2-cleft at the apex, bearing a slender twist awn below the middle. Stamens 3. Styles plumose to the base. Grain oblong, adnate. - Low annuals, with short setaceous leaves (An ancient Greek name for Darnel.)

A. CARYOPHÝlLEA, L. Culms 5-10' high, bearing a very diffuse panicle of purplish and at length silvery scarions spikelets. - Dry fields, Nantucket; also Newcastle, Del., W. $\boldsymbol{V}$. Canby. (Nat. from Eu.)

A. PR.tcox, I. Culms tufted, 3-4' high; branches of the small and dense panicle appressed; awn from below the middle of the glume. - Sandy fields, N. J. to Va.; rare. (Nat. from Eu.)

\section{DESCHÁ M P I A, Beauv.}

(Pl. 12.)

Spikelets small, panicled, of 2 perfect flowers and the hairy pedicel or rudi ment of a third (rarely staminate); rhachis hairy. Empty glumes persistent, membranaceous and shining, carinate, acute, nearly equal; flowering glumes toothed or erose-denticulate at the truncate summit, usually delicately 3-5nerved, with a slender twisted awn near or below the mildle. Grain oblong, free. - Root perenuial. (Named for Loiseleur-Deslongchamps, a French botanist.)

* Empty glumes somewhat shorter than the flowers.

1. D. flexuosa, Trin. (Common Halr-Grass.) (Pl. 12, fig. 1-3.) Culms slender, nearly naked $\left(1-3^{\circ}\right.$ high) above the small tufts of involnte bristle-form root-leaves ( $1-6^{\prime}$ long); branches of the small spreading panicle capillary; aun longer than the palet, at length bent and twisted. (Aira flexuosa, L.) - Dry places; common. Jun॰. (Eu.)

2. D. cæspitòsa, Beaur. Culm tufted $\left(2-4^{\circ}\right.$ high $)$; leaves flat, linear; panicle pyramidal or oblong ( $6^{\prime}$ long); aun straight, barely equalling the glume. (Aira cæspitosa, L.) - Shores of lakes and streams ; N. Eng. to Penn., Mich., and northward. June, July. (Eu.)

$$
\text { * * Empty glumes longer than the flowers, 2-2 } \frac{1}{2} \text { " long. }
$$

3. D. atropurpùrea, Scheele. Culms $8-15^{\prime}$ high, weak; leaves flat, rather wide; panicle of few spreading branches; awn stout, twice longer than the nerveless truncate ciliolate-denticulate glume. (Aira atropurpurea, Wahl.) - Alpine sunmits of N. H. and N. Y., to Lab. and northward. Aug. (Eu.) 


\section{TRISETU M, Persoon.}

Spikelets 2 -several-flowered, often in a contracted panicle; the flowering glume compressed-keeled, of about the same thin-membranaccous texture as the empty glumes, bearing a bent or flexuous (rarely twisted) awn at or below the sharply 2-tuothed or 2-pointed apex (whence the name, from tris, three, and seta, a bristle); otherwise nearly as in Avena. Ours are percmials.

1. T. subspicàtum, Beauv., var. mólle, Gray. (I'l. 12, fig. 1, 2.) Minutely soft-douny; quaicle dense, much contracted, oblong or linear (2-3' forg); glumes about the leugth of the 2-3 smonth flowers; awn dursal, di. verging, much exserted. - Mountains and rocky river-banks, N. New Ling. to L. Superior, and northward. July. - A bout $1^{\circ}$ high; leaves flat, slort. (Liu.)

2. T. palústre, 'Torr. Snooth; panicle rather long and narrow (5' long), loose, the branches capillary; spikelets flat ( $3^{\prime \prime}$ long); lower glumes shorter than the two smooth lanceolate flowers; the upjer flower on a slightly hairy joiut of the rhachis, with a slender spreading or bent awn next the short 2 pointed tip, the lower commonly aunless or only mucronate-pointed. - Low grounds, southern N. Y. to Ill., and southward. June.-Culm slender, $2-3^{\circ}$ high; leaves flat, short; spikelets yellowish-white, tinged with green.

\section{A V E N A, Tourn. OAt. (Pl. 12.)}

Spikelets 2-many-flowered, panicled; the flowers herbaceo-chartaceous, or becoming harder, of firmer texture than the large and mostly unequal empty glumes; the uppermost flower imperfect; rhachis and base of the flower often bearded. Floweriug glume rounded on the back, mostly 5-11-nerved, bearing a long usually bent or twisted awn on the back or between the two acute teeth at the apex, proceeding from the mid-nerve only. Stamens 3. Grain oblong-linear, grooved on one sille, usually hairy at least at the top, free, but invested by the palet. (The classical Latin name.)

* Spikelets large (1'long); annual.

A. FAtCA, I. Resembling the common oat (A. sativa), the few spikelets in a loose paniele, mostly pendulous; flowering glumes covered with long brownish hairs and bearing a bent awn 1-2' long. - Wisc., Minn. (Nat. from liu.)

* Simaller-flowered perennials.

1. A. striàta, Michx. (I'l. 12, fig. 1, 2.) Glabrous and smooth throughout, slender (1-20 high); leaves narrow ; ligule short, truncate; panicle simple, loose; spikelets ( $6^{\prime \prime}$ loug) on capillary pedicels, 3 -6-towered, much exceeding the scarious-margined purple acute empty glumes; lower glume 1-, upper 3-nerved ; rhachis smooth; flowers short-bearded at base; flowering glume 7-nerved, much longer than the ciliate-fringed palet ( $4^{\prime \prime}$ long), mostly shorter than its soon bent or divergent awn, which rises just below the tapering very sharply cuspidate 2-eleft tip. - Rocky, shaded lills, N. New Eng., N. I., and northwestward. June.

2. A. Smíthii, Porter. Taller $\left(2 \frac{1}{2}-4 \frac{1}{2}^{\circ}\right.$ high), rather stout; leaves broadly linear (3-6" wide) and taper-pointed, flat, and with the sheaths and culm retrorsely scabrous; ligule elongated, acute; panicle larger $\left(6-12^{\prime}\right.$ long), the few branches at length spreading; empty glumes slightly purplish, the lower 3-nerved, the upper 5-nerved, seabrous on the nerves ; rhachis miuntely hispid, 
flowers $(3-5)$ naked at base; awn straight, $\frac{1}{3}-\frac{1}{2}$ the length of the 7 -nerved glume. - N. Mich. and Isle Royale, L. Superior. $\Lambda$ pril, May.

\section{DA N TH Ò I A, DC. Wild OAT-Grass. (Pl. 12.)}

Flowering glume (oblong or ovate, rounded-cylindraceous, 7 - 9-nerved) bearing between the sharp-pointed or awn-like teeth of the tip an awn usually composed of the 3 middle nerves, which is flattish and spirally twisting at base; otherwise nearly as in Avena. Empty glumes longer than the imbricated flowers. Ours perennials, $1-2^{\circ}$ high, with narrow and soon involute leaves, hairy sheaths bearded at the throat, and a small simple panicle or raceme of about 7 -flowered spikelets. (Named for Danthoine, a French botanist.)

1. D. spicàta, Beaur. (F1. 12, fig. 1-3.) Culms tufted, low; leares short, very narrow; spikelets few; $3-5^{\prime \prime}$ long, subspicate; flowering glume loosely hairy, its teeth short and pointless. - Dry and sterile or rocky suil.

2. D. serícea, Nutt. Culms taller and not tufted $\left(1-3^{\circ}\right.$ high $)$, terete; leaves larger, at least the sheaths sillyy-villous; spikelets more numerous and panicled, 6-9" long; flowering glume very silky-villous, tipped wiih slender au'n-pointed teeth. - Dry or moist sandy soil, southern Mass., N. J., and southward; rare. June.

3. D. compréssa, Aust. Culms slender, $2^{\circ}$ high, somewhat compressed, paler and subcaniculate on the narrower side; leaves elongated, very narrow, villous only at the summit of the sheath; spikelets $6-12$, loosely panicled, 5 " long; flowering glume loosely hairy or pubescent, the teeth very long-awned. - Dry banks; Vt. (Pringle); E. Mass., N. Y., Penn., and mountains of N. C.

\section{CÝ NODON, Richard. Bermeda or Scutch-Grass. (Pl. 9.)}

Spikelets 1-flowered, with a mere naked short-pedicelled rudiment of a second flower, imbricate-spiked on one side of a flattish rhachis ; the spikes usually digitate at the naked summit of the flowering culms. Empty glumes keeled, pointless, rather unequal; flowering glume and palet pointless and awnless, the glume larger, boat-shaped. Stamens 3.- Low diffusely branched and extensively creeping perennials, with short flattish leaves. (Xame composed

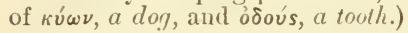

C. Díctrion, Pers. Spikes 3-5; flowering glume smooth, longer than the blunt rudiment. - Penn., and southward, where it is cultivated for pasturage. (Nat. from Eu.)

\section{C TÉ N I U M, Panzer. 'Тоотнасhe-Grass. (Pl. 9.)}

Spikelets densely imbricated in two rows on one side of the flat curred rha chis of the sulitary terminal spike. Glumes persistent; the lower (interior) much smaller; the other concave below, bearing a stout recurved awn, like a horn, on the middle of the back. Flowers 4-6, all but one neutral; the one or two lower consisting of empty awned glumes, and the one or two uppermost of empty awnless glumes; the perfect flower intermediate, its glume membranaceous, awned or mucronate below the apex and densely ciliate toward the

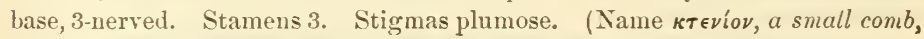
from the pectinate appearance of the spike.)

1. C. Americànum, Spreng. Culm (3-40 high from a perennial root) simple, pubescent or roughish; larger glume warty-glandular outside, conspicuously awued. - Wet pine-barrens, S. Va. and southward. - Taste very jungent. 


\section{G Y M N O P O G O N, Beauv.}

Spikelets of one perfect flower, and the rudiment of a second (consisting of an awn-like pedicel mostly bearing a naked bristle), sessile and remotely alternate on long filiform rays or spikes, which form a crowded naked raceme. Glumes lance-awlshaped, keeled, almost equal, rather longer than the membranaceous flowering glnme, which is eylindrical-involute, with the midrib produced from just below the 2-cleft apex into a straight and slender bristlelike awn; palet nearly as long, with the abortive rudiment at its base. Stamens 3. Stigmas pencil-form, purple. - Root peremial. Leaves short and

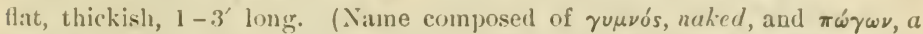
beard, alluding to the reduction of the abortive flower to a bare awn.)

1. G. racemósus, Beauv. (I'l. 9, fig. 1, 2.) Culms clustered from a short rootstock $\left(1^{\circ}\right.$ high), wiry, leafy; leaves oblong-lancolate; spikes flouerbearing to the base $\left(5-8^{\prime}\right.$ long), soon divergent; awn of the abortive flower shorter than its stalk, equalling the pointed glumes, not more than half the length of the awn of the fertile flower. - Sandy pine-barrens, N. J. to Va., and southward. Ang., Sept.

2. G. brevifolius, Trin. Filiform spikes long-peduncled, i. e. flowerbearing only above the middle; flowering glume ciliate near the base, shortawned; ann of the abortive flower obsolete or minute; glumes acute. - Sussex Co., Del., and southward.

\section{SCHEDONNÁRDUS, Steud.}

Spikelets small, acuminate, l-flowered, appressed-sessile and scattered along one side of the slender rhachis of the distant sessile and divaricately spreading spikes. Empty glumes persistent, narrow, acuminate, more or less unequal, the longer usually a little shorter than the rather rigid acuminate flowering one. Stamens 3. Styles distinct. Grain linear. $-\Lambda$ low slender annual, branching from the base, with short narrow leares. (Name from $\sigma \chi \in \delta o ́ v$, near, and Vardus, from its resem!lauce to that genus.)

1. S. Texánus, Stend. Stem $\left(6-20^{\prime}\right.$ long) naked and curved above, bearing $3-9$ racemosely disposed thread-like and triangular spikes $1-3^{\prime}$ long; spikelets $1 \frac{1}{2}$ "long. (Lepturus paniculatus, Nutt.) - Open grounds and saltlicks, Ill. to Mont., Col., and Tex. Aug.

\section{BOUTELOÙ A, Lagasca. Miskít-Grass. (l’l.9.)}

Spikelets crowded and closely sessile in 2 rows on one sile of a flattenexl rhachis, comprising one perfect flower below and one or more sterile (mostly neutral) or rudimentary flowers. Glumes convex-keeled, the lower one shorter. Perfect flower with the 3-nerved glume 3-toothed or cleft at the apex, the 2uerved palet 2-toothed; the teeth, at least of the former, pointed or subulateawned. Stamens 3 ; anthers orange-eolored or red. - Rudimentary flowers mostly 1-3-awued. Spikes solitary, racemed or spiked; the rhachis somewhat extended beyond the spikelets. (Named for Clandins Boutelon, a Span. ish writer upon floriculture and agrienlture.)

§1. CHONIDRÒSIUMI. Spikes pectinate, of very many spikelets, oblong or linear, very dense, solitary and terminal or few in a raceme; sterile flowers $1-3$ on a short pedicel, neutral, consisting of $\mathrm{I}-3$ scales and auns. 
1. B. oligostàchya, Torr. Glabrous, perennial $\left(6-12^{\prime}\right.$ high); leaves very narrow; spikes I -5 , the rhachis glabrous; glumes all sparingly soft-hairy, the lobes awl-pointed; sterile flower copiously villous-tufted at the summit of the naked pedicel, its 3 awns equalling the larger glume. $-\mathrm{N}$. W. Wisc. to Dak., and south to Tex. and Mex. - Glumes obscurely if at all papillose along the keel, the middle lobe of the flowering one 2-cleft at the tip. Sterile flowers often 2 , the second mostly a large awnless scale, becoming hood-like and coriaceous.

2. B. hirsùta, Lag. Tufted $\left(8-20^{\prime}\right.$ high $)$, perennial; leaves flat, lancelineur, papillose-hairy or glabrous; spikes $1-4$; upper empty glume hispid with strong bristles from dark warty glands; flowering glume pubescent, 3-cleft into awl-pointed lobes; sterile flower and its pedicel glabrous, the 3 anns longer than the g/umes and fertile flower. - Sandy plains, Mll., Wisc., Minn., and southwestward to Mex.

§ 2. ATHEROPȮGON. Spikes short, numerous in a long and virgate onesided spike or raceme, spreading or reflexed, each of few (4-12) spikelets; sterile flowers neutral, rudimentary.

3. B. racemòsa, Lag. (Pl. 9, fig. 1, 2.) Culms tufted from perennial rootstocks $\left(1-3^{\circ}\right.$ high) ; sheaths often hairy; leaves narrow; spikes $\frac{1^{\prime}}{2}$ or less in length, nearly sessile, $20-60$ in number in a loose general spike $\left(8-15^{\prime}\right.$ long); flowers scabrous; glume of the fertile with 3 short awl-pointed teeth; sterile flower reduced to a single sinall awn, or mostly to 3 awns shorter than the fertile flower, and 1 or 2 small or minute scales. (B. curtipendula, Gray.) - Dry hills and plains, southern N. Y. to Minn., and south to Tex. and Mex. July - Sept. - Passes by transitions into var. ARISTòsA, with spikes shorter; sterile flower of a large saccate glume, awned at the 2-cleft tip and from the luteral nerres, the middle awn exserted, and with a rudiment of a palet. - Ill. (Gejer), and southward.

\section{ELEUSìn E, Gaertn. Crab-Grass. Yard-Grass. (Pl. 9.)}

Spikelets 2-6-flowered, with a terminal imperfect flower or naked rudiment, closely imbricate-spiked on one side of a flattish rhachis; the spikes digitate. Glumes membranaceous, shorter than the flowers; flowering glume and palet awnless, the glume ovate, keeled, larger than the palet. Stamens 3. I'ericarp (utricle) containing a loose wrinkled seed. - Low annuals, with flat leaves, and flowers much as in Poa. (Name from 'E $\lambda \epsilon v \sigma l \nu$, the town where Ceres, the goddess of harvests, was worshipped.)

E. Ixdica, Gaertn. (Dog's-tall or Wire Grass.) (Pl. 9, fig. 1-6.) Culms ascending, flattened; spikes 2-5 (about 2' long, greenish); glumes pointless; terminal flower a mere rudiment. - Yards, etc., chiefly southward. (Nat. from Ind. ?)

E. EgrptìcA, Pers. (Pl. 9, fig. 1-4, as Dactyloctenium.) Culms often creeping at base; leaves ciliate at base; spikes $4-5$; the flowering one pointed. (Dactyloctenium Egyptiacum, Willd.) - Cultivated fields and yards, Va., Ill., and southward. (Adv. from Afr.?)

\section{LEPTÓCHLOA, Beauv. (Pl. 15.)}

Spikelets 3 - many-flowered (the uppermost flower imperfect), loosely spiked on one side of a long filiform rhachis; the spikes racemed. Glumes membranaceous, keeled, rarely awned, nearly equal; flowering glume 3-nerved. 
sometimes simply awned, larger than the palet. Stamens 2 or 3 . Seed closely enclosed. - Ours anumals. Leaves flat. (Name composed of $\lambda \epsilon \pi \tau$ ós, slender, and $\chi \lambda \delta$, grass, from the long atteunated spikes.)

1. L. mucronàta, Kunth. Slieaths hairy; spikes numerous $(20-40$, $2-4^{\prime}$ in leugth), in a loug panicle-like raceme ; spikelets small; glumes more or less mucronate, nearly equalling or exceeling the $3-4$ awnless flowers. Fields, Va. to Ill., Mo., and southward. Aug.

\section{B Ù C H L O Ė, Engelm. Berrano Grass. (l'l. 15.)}

Spikelets diocious (rarely monocious), very unlike; the staminate 2-3flowered, sessile in 2 rows in short l-sided spikes, the empty glumes blunt, 1-nerved, very unequal, the flowering larger, 3-nerved, a little exceeding the 2-nerved palet; fertile spikelets 1-flowered, in a contracted, capitate, 1-sided spike, the large outer glumes indurated, 3 -firl at the apex, united at base and resembling an involucre, the inner (lower) much smaller and membranaceous, or in the lowest spikelet resembling the outer; flwering glume narrow, hyaline, bifid or nearly entire, enclosing the 2-nerved palet. Sityles distinct. Grain ovate, free. - A perennial, creeping or stoloniferous, with narrow flat leaves; staminate spikes $(2-3)$ in a pedunculate spike, the pistillate pair sessile in the broal sheaths of the upper leaves. (Nane a contraction of Buba-

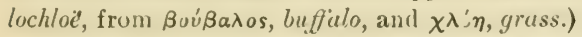

1. B. dactyloides, Engelm. Low $\left(3-8^{\prime}\right.$ high) and broadly tufted; sterile spikes $3-6^{\prime \prime}$ long, the fertile heads $3^{\prime \prime}$ long. - Plains of the Sask. to Minn., Kan., and 'Tex. One of the most valuable grasses of the plains.

\section{TRIÒ D I A, R. Br. (P'l 10.)}

Spikelets 3-12-flowered, somewhat terete, the rhachis with bearded joints; terminal flower abortive. Empty glumes unequal; flowering glumes membranaceous or somewhat chartaceous, much larger than the 2-toothed palet, convex, 2-3-toothed or cleft at the apex, conspicuonsly hairy-bearded or villous on the 3 strong nerves, of which the lateral are marginal or nearly so and usually excurrent, as is the mid-nerve especially, into a short cusp or awu. Stamens 3. Stigmas dark purple, plumose. Grain olılong, nearly gibbous. Leaves taper-pointerl; sheaths bearded at the throat. Panicle simple or compound; the spikelets often racemose, purplish. (Name from $\tau \rho \iota$, three, and ósois, a tooth, alluding to the flowering glume.)

$\S 1$. TRIODIA proper. Glumes shorter than the rrouded flowers, the flowering one 3-cuspidate by the projertion of the nerres, and usually with intermediate membranaceous teeth: palet naked.

1. T. cùprea, Jacq. ('TAL. Rin-tor.) Perennial; culm upright $\left(3-5^{\circ}\right.$ high), very smooth, as are the flat leaves; panicle large and compound, the rigicl capillary hranches spreading, naked below; spikelets very numerous, 5 - 7 -flowered, shining, purple ( $4^{\prime \prime}$ long); the flowering glumes hairy toward the base, their points almost equal, scarcely exceeding the intermediate teeth, thus appearing 5-toothed. ('Tricuspis seslerioides, Torr.) - 1)ry or sandy fields, southern N. Y. to Mo., and sonthward. Aug. - A showy grass, with the spreading panicle sometimes $1^{\circ}$ wide. 
§ 2. TRIPLASIS. Glumes much shorter than the somewhat remote flowers; flowering glume and palet strongly fringe-bearded, the glume 2-cleft at the summit, its mid-nerve produced into an awn between the truncate or awnpointed divisions.

2. T. purpùrea, Hack. (SAxd-Grass.) Culms many in a tuft from the same anmul root, ascending $\left(6-12^{\prime}\right.$ high), with numerous bearded joints ; leaves involute-awl shaped, mostly short; panicles very simple, bearing few 2-5-flowered spikelets, the terminal one usually exserted, the axillary ones included in the commonly hairy sheaths; axn much shorter than the glume, seldom exceeding its eroded-truncate or obtuse lateral. lobes. (Tricuspis purpurea, Gray.) - In sand, Mass. to Va. along the coast, and southward; also L. Erie, near Buffalo, and Ill. Aug., Sept. - Plant acill to the taste.

\section{D I P LÁ C H N E, Beauv.}

Spikelets sereral-flowered, narrow, erect and scattered along the slender rhachis of the long spicate spikes; flowers all perfect or the uppermost staminate. Empty glumes membranaceous, carinate, acute, unequal; flowering glume slightly longer, 1-3-nerred, 2-toothed, and mucronate or shortly awned between the teeth. Stamens 3. Styles distiuct. Graiu free-Coarse grasses, with narrow flat leaves, and several or many slender spikes sessile upon an elongated peduncle. (Name from $\delta\left\llcorner\pi \lambda j_{\text {os }}\right.$, double, and ă $\chi \nu \eta$, in the sense of chaff, with reference to the 2-lobed glume.)

1. D. fasciculàris, Beauv. Smooth; leares longer than the geniculatedecumbent and brauching culms, the upper sheathing the base of the paniclelike spike, which is composed of many strict spikes $\left(3-5^{\prime}\right.$ long); spikelets slightly pedicelled, 7 -11-flowered, much longer than the lanceolate glumes; flowers hairy-margined toward the base, the glume with 2 small lateral teeth and a short awn in the cleft of the apex. (Leptochloa fascicularis, Gray.) Brackish meadows, from R. I. southward along the coast, and from Ill. southward on the Mississippi. Aug. - Sept.

\section{PHRA G M I T $\mathrm{PS}$, Trin. REED. (Pl. 11.)}

Spikelets 3-7-flowered; the flowers rather distant, silky-villons at base, and with a conspicuous silky-bearded rhachis, all perfect and 3-androus, except the lowest, which is either neutral or with 1-3 stamens, and naked. Glumes membranaceous, shorter than the flowers, lanceolate, keeled, sharp-pointed, very unequal; flowering glume and palet membranaceous, slender, the glume narrowly awl-shaped, thrice the length of the palet. Squamulæ 2, large. Styles long. Grain free. - Tall and stout perennials, with long running root-

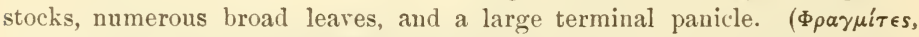
jrowing in hedges, which this aquatic grass does not.)

1. P. commùnis, Trin. Panicle loose, nodding; spikelets 3-5-flowered; flowers equalling the beard. - Edges of ponds. Sept. - Looks like BroomCorn at a distance, $5-12^{\circ}$ high ; leaves $2^{\prime}$ wide. (Eu.)

\section{A R Ú N D O, L.}

Flowers all perfect; flowering glume bifid, short-awned netween the teeth. Otherwise as Phragmites. (The Latin name of the species.) 
A. Dowax, L. Very tall $\left(10-18^{\circ}\right)$; spikelets 3-4-flowered. - Closely resembling Phragmites communis. Cultivated for ornament, and naturalized in Bedford Co., Va. (1. I1. Curtiss.) (Nat. from liu.)

\section{MÚ N ROA, 'Torr. (I'l. 15.)}

Spikelets usually 3-flowered, few (2-4) and nearly sessile in the axils of floral leaves; flowers perfect, or the uppermost abortive. Empty glumes lanceolate, acute, hyaline and 1-nerved; flowering glumes larger, 3-nerved, rather rigid, the mid-nerve stout, excurrent, the lateral ones scarcely so.Low or prostrate many-stemmed amuals, fasciculately branched, with crowded short flat rigid or pungent leaves, the short sheaths strongly striate. (Named for the English agrostologist, Maj.-Gen. I'illian Munro.)

1. M. squarrosa, Torr. Glaucous, ssmewhat pubescent and villous at the nodes or glabrons; leaves 3-12" long. - Dry plains, central Kan. to Dak., west to Mont., Utah, and New Mex.

\section{K CEL E I A, Pers. (Pl. 10.)}

Spikelets 3-7-flowered, crowded in a dense and narrow spike-like panicle. Glunes membranaceous, compressed-keeled, obscurely 3-nerved, barely acute, or the flowering glume often mucronate or bristle-pointed; the empty ones moderately unequal, nearly as long as the spikelet. Stamens 3. Grain free. - Tufted with simple upright culms, the sheaths often downy; allied to Dactylis and Poa. (Named for Prof. G. L. Koeler, an early writer on Grasses.)

1. K. cristàta, Pers. Culms $1-2^{\circ}$ high; leaves flat, the lower sparingly hairy or ciliate; panicle narrowly spiked, interrupted or lobed at base; spikelets 2-4-flowered; flowering glume acute or mucronate. - Var. GRÁcilis, Gray, with a long and narrow spike, the flowers usually barely acute. - Dry hills, Penu. to Ill. and lian., thence north and westwarl. (Eu.)

\section{EATÒNIA, Raf.}

Spikelets usually 2-flowered, with an abortive rudiment or pedicel, numerous, in a contracted or slender panicle, very smooth. Empty glumes somewhat equal in length, but very dissinilar, a little shorter than the flowers; the lower narrowly linear, keeled, l-nerved; the upper broadly obovate, folded round the flowers, 3-nerved on the back, not keeled, scarions-margined. Flowering glume oblong, olstuse, compressed-boat-shaped, naked, chartaceous; the palet very thin and hyaline. Stamens 3. Grain linear-oblong, not grooved. - Perennial, tall and slender grasses, with simple tufted culıns, and often sparsely downy sheaths, flat lower leaves, and small greenish (rarely purplish) spikelets. (Named for Prof. Amos Eaton, author of a popular Manual of the Botany of the United States, which was for a long time the only general work available for students in this country, and of other popular treatises.)

* Upper empty glume rounded-obovate and very obtuse: panicle usually dense.

1. E. obtusàta, Gray. (Pl. 10.) Panicle dense and contracted, somewhat interrupted, rarely slender; the spikelets crowded on the short erect branches; upper glume rough on the hack; flowers lance-oblong. - Dry soil, N. l'enn. te Fla., Mich., and far westward. Juwe, July. 
* Glume narrower, sometimes acutish; panicle more loose and slender.

2. E. Pennsylvánica, Gray. Leaves mostly 3-6’ long; panicle long and slender, loose, the racemose branches lax and somewhat elongated; glumes thin and broadly scarions, the lowest half the length of the flower, very narrow, the upper obtuse or bluntly somewhat pointed; the 2 (rarely 3 ) flowers lanceolate, with pointed glumes. - Varies, with a fuller panicle, $6-8^{\prime}$ long, with the aspect of Cinna (var. vìor, Torr.) ; and, rarely, with the lower palet minutely mucronate-pointed! - Moist woods and meadows; common.

3. E. Dudlèyi, Vasey. Culms very slender; leaves shorter, $1-2^{\prime}$ long ; panicle very slender, the branches few, short and mostly appressed; empty glumes nearly equal, the lower oblong, the upper broadly elliptical, apiculate; flowering glumes shorter than in n. 2, acutish. - Long Island to central N. Y., south to S. C.

\section{ERAGRÓs TIS, Beauv.}

Spikelets 2-70-flowered, nearly as in Poa, except that the flowering glume is but 3- (rarely 1-) nerved, not webby-haired at the base, and is deciduous; palet persistent on the rhachis after the rest of the flower has fallen. - Culms often branching. Leaves linear, frequently involute, and the ligule or throat of the sheath bearded with long villous hairs. Panicle various. (Name from भु $\rho$, spring, and ă $\gamma \rho \circ \sigma \tau \iota s$, a grass.)

* Prostrate and creeping, much branched; root annual; spikelets flat, imperfectly diccious, clustered, almost sessile, in the more fertile plant almost capitate.

1. E. réptans, Nees. Spikelets linear-lanceolate, 10-30-flowered; flow. ers lance-ovate, acute; leaves short, almost awl-shaped. - Gravelly riverborders; common. Aug. - Flowering branches 2-5' high.

* * Diffusely spreading, or the flouering culms ascending, low (6-15' high), ammal; spilielets often large, flat, forming a narrow crouded panicle.

E. ù̀xor, Host. Sheaths often hairy; leaves flat. smooth; spikelets shortpedicelled, lance- or oblong-linear, $8-20$-flowered, lead-colored $\left(2-5^{\prime \prime}\right.$ long); flowers ovate, obtuse, the lateral nerves becoming evident, and keel smooth. (E. poxoides, Beauv.) - Sandy waste places, eastward; rare. (Nat. from Eu.)

E. мגјJor, Host. Sheaths mostly glabrous; spikelets larger (3-10"long), becoming linear, whitish when old, $10-50$-flowered; flowers more spreading, their glumes larger, with very strong lateral nerves and rough on the keel. (E. poxoides, var. megastachya, Gray.) - Similar situations, and more common. Aug. - Emits a sharp, unpleasant odor. (Nat. from Eu.)

* * Erect, or in group + diffusely spreading and ascending; panicle open, its branches capillary; spikelets proportionally small, sometimes minute. (Number of flowers in the spikelet very variable, according to age, etc.)

- Annual; culms slender, branching and decumbent or spreading at base; leaves narrow, flat, soft; branches of the narrow panicle rather short and thicklyflowered, not bearded in the axils, or sometimes the lowest sparingly.

E. PILòsA, Beauv. (Pl. 10, fig. 1-4.) Panicle elongated-oblong, with rather erect branches (except at flowering-time) ; spikelets 5-12-flowered (24" long, purplish-lead-color), becoming linear, about equalling their pedicels; empty glumes (small) and flowering ones obtuse, the latter broadly ovate, 1-neried (lateral nerves obsolete). - Sandy or gravelly waste places, S. New Eng. to Ill., and southward. Aug. - Plant 6-12' high." (Nat. from Eu.) 
2. E. Fránkii, Meyer. Much branched and diffuse $\left(3-8^{\prime}\right.$ high $)$; panicle ovate-oblong, rather dense, spreading ; spikelets $2-5$-flouered (1-1 $\frac{1}{2}$ "long), on slender pedicels; glumes veriy acute; the flowering one orate, acute, rather obscurely 3-nerved. - Low or sandy ground, S. P'enn. to Kan., and southwestward. Aug.

3. E. Púrshii, Schrader. Sparingly branched at the decumbent base, then erect $\left(\frac{1}{2}-2^{\circ}\right.$ ligh); panicle elongated, the branches willely spreading, very loose ; spikelets 5-18-flowered, oblong-lanceolate, at length linear (2-4 $\frac{1}{2}$ " long), mostly much shorter than their capillary pedicels; glumes all ovate and acute, or the flowering ones acutish, 3-nerved. - Sandy or sterile open grounds, Penn. to Mo., and southwestward; also introduced northward.

+- + Culms simple, or branching only at the very base, firm, erect, mostly forming thick tufts; leaves very long; panicle very large, compound, often longer than the culm, with elongated loosely-flowered branches, their axils often bearded. (Doubtfiul perennials, or 11. 5 annual.)

4. E. ténuis, Gray. Panicle virgately elongated ( $1-2 \frac{1}{2}$ long), very loose, the spreading branches bearded in some of the lower axils, their remote divisions and long diverging pedicels eapillary; spikelets 2-6- (sometimes 7-12-) flowered, pale or greenish; louer glumes lanceolate or aul-shaped, very acute $\left(1 \frac{1}{2}-\right.$ $2^{\prime \prime}$ long), membrauaceous, as are the oblong-lanceolate acute flowers; flowering glume distinctly 3-nerved; the upper ciliate-scabrous. - Sandy soil, Olio to 11l., Kan., and southward. Aug.-Oct. - Leaves rather rigid, $1 \frac{1}{2}-2^{\circ}$ long, glabrous or sparingly hairy; the sheaths hairy or glabrous; the throat strongly bearded; flowers much larger than in the next, fully $1 \frac{1}{2}$ " long.

5. E. capillàris, Nees. Panicle widely expanding, usually much longer than the culm, its spreading branches (mostly naked in the axils) and long diverging pedicels capillary; spikelets rather terete, very small, 2-4-flowered, greenish or jurplish; glumes and flovers ovate, acute (less than 1" long); flowering glume obscurely 3-nerved, scarcely keeled : the palet rough-ciliate. - Sandy dry soil and fields; common, especially sonthward. Ang., Siept. - Leaves and sheaths very hairy, or nearly glabrous; the former about $1^{\circ}$ long, not rigid; panicle $1-2^{\circ}$ long, soon diffuse.

6. E. pectinàcea, Gray. P'unicle widely diffuse, its rigicl divergent main branches bearded in the axils; the capillary pedicels more or less approssed on the secondary branches; spikelets flut, 5-15-flowered, becoming linear, purple or purplish; glumes and flowers ovate or oblong-ovate, acutish ; flowering glume strongly 3-nerved ; palet hirsute-ciliate. - Leaves long, rigid, mostly hairy, the sheaths especially so; plant $1-3^{\circ}$ high; spikelets $2-3^{\prime \prime}$ long, $1^{\prime \prime}$ wide, closely flowered. - Var. splectíbuns, Gray. Leaves and sheaths mostly glabrous; branches of the panicle (the lower reflexerl with age) and pedicels shorter; spikelets rather larger. - Sandy lry ground, from E. Mass. near the coast, and from Ohio and Ill., southwarl. Ang. - Oet.

7. E. campéstris, Trin. Glabrous or the sheaths villous at the throat; culm short, bearing an elongated and very open panicle with divaricate branches bearded at base; sprikelets linear, flat, 8-12-flowered, sessile or nearly so along the branchlets; glumes very acute or acuminate, 3-nerved, roughish on the keel; palet minutely ciliate. (E. pectinacea, var. refracta, Chapm. I'oa refracta, E!ll.) - 1)el. and Md. to Fla. and Ala. 


\section{M Él I C A, L. Melic-Grass. (Pl. 10.)}

Spikelets 2-8-flowered; the 1-3 upper flowers imperfect and dissimilar, convolute around each other, and enwrapped by the upper fertile flower. Empty glumes usually large, scarious-margined, convex, obtise; the upper 7-9nerved. Flowering glume papery-membranaceous, dry and sometimes indurating with age, rounded or flattish on the back, 5-many-nerved, scarious at the entire blunt summit. Stamens 3. - Perennials with soft flat leaves. Panicle simple or sparingly branched; the rather large spikelets racemose-onesided. (An old Italian name for Sorghum, from mel, honey.)

1. M. mùtica, Walt. (Pl. 10.) Slender, with usually narrow leaves, the panicle often reduced to a simple raceme; lower glumes nearly equal and almost equalling the spikelet; fertile flowers usually 2 ; flowering glumes broad, smooth, obtuse. - Rich soil, Penn. to Fla., west to Wisc., Iowa, and Tex.

2. M. diffúsa, Pursh. 'Taller, $2 \frac{1}{2}-4^{\circ}$ high, with mostly broader leaves and a more usually compound and many-flowered panicle; lower glumes more unequal, the outer very broad; fertile flowers usually 3 ; flowering glumes somewhat scabrous and more acute. (M. mutica, var. diffusa, Gray.) - Penn. to Ill., and southward.

\section{DIARRHENA, Raf. (Pl. 10.)}

Spikelets several-flowered, smooth and shining, one or two of the uppermost flowers sterile. Empty glumes ovate, much shorter than the flowers, coriaceous; the lower much smaller; flowering glume ovate, convex on the back, rigidly coriaceous, its 3 nerres terminating in a strong and abrupt cuspidate or awl-shaped tip. Squamulæ ovate, ciliate. Stamens 2. Grain very large, obliquely oroid, obtusely pointed, rather longer than the glume, the cartilaginous shining pericarp not adherent to the seed. - A nearly smooth perenuial, with running rootstucks, producing simple culms $\left(2-3^{\circ}\right.$ high) with long linearlanceolate flat leaves toward the base, naked above, bearing a few short-pedicelled spikelets $\left(2-3^{\prime \prime}\right.$ long) in a very simple panicle. (Name composed of

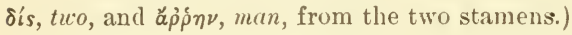

1. D. Americàna, Beauv. Shaded river-banks and woods, Ohio to Ill., and southward. Aug.

\section{U N İ O L A, L. Spike-Grass. (Pl. 11.)}

Spikelets closely many-flowered, very flat and 2-edged; $3-6$ of the lowest glumes empty, lanceolate, compressed-keeled ; flowering glume coriaceo membranaceous, strongly laterally compressed and keeled, striate-nerved, usually acute or pointed, entire, enclosing the much smaller compressed 2-keeled palet and the free laterally flattened smooth grain. Stamen $\mathbf{l}$ (or in U. paniculata 3). - Upright smooth perenuials, growing in tufts from strong creeping rootstocks, with broad leaves and large spikelets in an open or spiked panicle. (Ancient name of some plant, a diminutive of unio, unity.)

* Spikelets large ( $\frac{1}{2}-2^{\prime}$ long), ovate or oblong, 9-30-flowered; panicle open.

1. U. paniculàta, L. (SEA OATs.) Culm and panicle elongated (4$8^{\circ}$ high); leaves narrow, when dry convolute; spikelets ovate, short-pedicelled; glumes glabrous, bluntish, several of the lower sterile; stamens 3. — Sand-hills on the sea shore, S. Va. and southward. 
2. U. latifolia, Michx. (Pl. 11, fig. 1-3) ('ulm 2-4 high; panicle loose; leaves broud and flat (nearly I' wide); spikelets at length oblong, hanging on long pedicels: glumes acute, riliate on the keel, all lut the lowest with perfect monandrous flowers. - Shaded slopes,, . l'enn. to lll., and southward.

* * Spikelets small; panicle contracted, wand-like: perfect jlowers long-pointed.

3. U. grácilis, Michx. Culm $3^{\circ}$ high, slender; spikelets short-pedirelled $\left(2-3^{\prime \prime}\right.$ long $)$, broally werlge-shaped, acute at base, 4 - s-fouered ; glumes ovate and divergently beaked, long, the 3 lowest empty. - Sandy suil, from Long Island to Va., near the coast, and sonthward. Aug.

\section{D ISTÍCHLIS, Raf. SPike-Grass. (Pl. 10.)}

Spikelets and numerous flowers compressed, crowded in a densely spiked or capitate panicle. Gilumes herbaceous or membranaceous, the luwer faiutly many-nerved; fluwering glumes rather coriaceous, laterally much fattened, faintly many-nerved, acute. () vary stalked. - Fluwers dicecious, rather large.

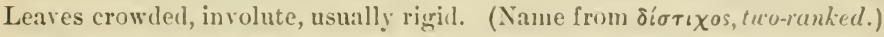

1. D. marítima, Raf. Culns tufted from creeping rootstucks $\left(9-18^{\prime}\right.$ high); spike oblong, flattened ( $l^{\prime}$ long); spikelets ovate or oblong, 5-10-flowered; glumes smooth and naked; grain pointed. (Brizopyrum spicatum, Hook.) - Salt marshes and shores. Aug. - Glumes of the pistillate flowers more rigid and alnust keeled; stigmas very long, plumose; the stamiuate glumes smaller and somewhat rounded on the back.

\section{DÁ C T Y I S, L. Orchard Grass. (Pl. 10.)}

Spikelets several fluwered, erowded in one-sided clusters, forming a branching dense panicle. Glumes all herbaceous, keelerl, awn-pointed, rougl-ciliate on the keel; the flowering one 5-nerved, the upper nost commonly smaller and thinner. Stamens 3. Grain lance-ohlong, arnte, free.-- Stout tufted perennial; leares keeled. (Dactylos, a name in 1 liny for a grass with digitate spikes, from $\delta a ́ k \tau v \lambda o s, a$ finger.)

D. GrouerdtA, L. Rough, rather glaucous ( $3^{\circ}$ high); leaves broadly linear; branches of the panicle naked at base; spikelets $3-4$-Howered. - Fields and yards, especially in shade. June. (Nat. from liu.)

\section{BRİZ A, L. Quaking Grass. (Pl. 10.)}

Spikelets many-flowered, orate or heart-shaped, flattish-tumid; the flowers elosely imliricated. Glumes roundish, unequal, purplish, very concave or ventricose, $3-5$-nervel ; the fluwering ventricose on the lack, heart-shaped at the base, papery-membranaceous and becoming dry, scarious-margined, obscurely many-nerved; the palet much smaller, ovate, flat. Stamens 3. Stigmas branched-plumose. Grain flattened paralled with the glumes, adhering to the palet. - Leaves flat; panicle loose, diffuse, with large showy spikelets often drooping on delieate pedicels. (B $\rho$ i $\zeta a$, the Greek name of a kind of grain.)

B. мìnı, I. Panicle erect, the branches sprealing; spikelets 5-9-flowered (3" long); lower glumes shorter than the first flowering one; root pereunial. - Pastures; sparingly eastward. June. (Adr. from Eu.)

\section{PÒ A, I. Mkanow-Gmass. Splin-Grass. (l'l. 10.)}

Spikelets ovate or lance-ovate, laterally compressed, several- (2-10-) flowered, in an open panicle. Empty glumes mostly shorter than the flowers, the 
lower smaller; flowering glume membranaceo-herbaceous, with a delicate scarious margin, compressed-keeled, pointless, 5-nerved (the intermediate nerves more obscure or obsolete), the principal nerves commonly clothed with soft hairs at and toward the often cobwebby base; palet membranaceous, 2-toothed. Stamens 2 or 3. Stigmas simply plumose. Grain oblong, free. - Culms tufted, from perennial roots, except n. 1. Leaves smooth, usually flat and soft. (חó $\alpha$, an ancient Greek name for grass or fodder.)

* Low and spreading (3-6' high) from an annual or biennial root, flaccid; branches of the short panicle single or in pairs.

P. ÁxvuA, I. (Low Spear-Grass.) Culms flattened; panicle often 1sided, usually short and pyramidal, sometimes more slender (P. cristata, Chapm.); spikelets crowded, very short-pedicelled, 3-7-flowered. - Cultivated and waste grounds, everywhere. April-Oct. (Nat. from Eu.)

* Low ; the culms $\left(6-20^{\prime}\right.$ long) geniculate-ascending from a running rootstock, rigid, very much flattened; panicle simple and contracted.

P. compréssa, L. (Wire-Grass. Exglisi Blue-Grass.) (Pl. 10, fig. $1-4$.) Pale, as if glaucous; leaves short; panicle dense and narrow, somewhat one-sided ( $1-3^{\prime}$ long), the short branches mostly in pairs; spikelets almost sessile, 3-10-flowered, flat. - Dry, mostly sterile soil, in waste places; rarely in woods. (Nat. from Eu.)

* * Low alpine or alpestrine species, erect, in perennial tufts.

- Soft and flaccid, smooth or nearly so, even to the branches of the panicle; leaves short and flat, short-pointed; ligule elongated.

1. P. alpina, L. Culms rather stout ( $8-14^{\prime}$ high); leaves broadly linear, especially those of the culm (1 $\frac{1}{2}-2^{\prime}$ long, $1 \frac{1}{2}-3^{\prime \prime}$ wide) ; panicle short and broud ; spikelets broadly ovate, 3 -9-flowered (about $3^{\prime \prime}$ long); flowering glume villous on the midrib and margius. - N. Maine (?), Isle Royale and north shore of Lake Superior, and northward. (Eu.)

2. P. láxa, Haenke. Culms slender (4-9’ high); leaves narrow; panicle somewhat raceme-like, narrou, often one-sided and nodding; spikelets 2-4-flowered, one half smaller. - Alpine mountain-tops of Maine, N. H., and N. New York, and high northward. (Eu.)

++ More strict and rigid, roughish, especially the panicle; ligule short.

3. P. nemoràlis, L. Culms $6-20^{\prime}$ high; leaves narrow, short, soon in volute; branches of the panicle $2-5$ together, very scabrous; spikelets purplish (or sometimes pale), 2-5-flowered; lower glumes ovate-lanceolate and taperpointed, the flowering lanceolate, somewhat webby at base, villous on the keel and margins below the middle, its nerves obscure. (P. cæsia, Smith.) - The more common form has a usually narrow somewhat nodding panicle, with short ascending branches, the small pale or purplish spikelets 2 -flowered. Lab. to N. Maine and N. Vt.; Lake Champlain (Pringle); N. shore of L. Superior to $\mathrm{N}$. Iowa, and westward. - A form with somewhat stouter aud stricter habit, the darker or often pale spikelets 3-5-flowered (P. cæsia, var. strictior, ( corresponds nearly to the European P. cæsia. High mountains of N. H. and Vt., and Garlner's Island, L. Champlain (C.E. Faxon), Isle Royale and N. shore of L. Superior, and westward. - Also a form with the branches of the short panicle broadly divaricate; N. Wisc. (Lapham). (Eu.) 
**** Taller $\left(1-3^{\circ}\right)$ meadow or woodland grasses; panicle open.

- Spikelets mostly very numerous and crowded on the rather short rough branches (usually in fives) of the oblong or pyrumidal panicle, yreen, or sometimes violet-tinged; flowers acute, crowded, more or less webbed at base.

4. P. serótina, Ehrhart. (False Reidop. Fowl Meanow-Grass.) Culms tufted without running rootstocks; leaves narrowly linear, soft and smooth; ligules elonguted ; spikelets $2-4$ - (rarely 5-) flowered ( $1-2^{\prime \prime}$ long), all short-pedicelled in an elongated panicle, often tingerl with dull purple; flowers and glumes narrow; flowering glume very obscurely nervel. - Wet meadows and low banks of streams; common, especially northward. July, Aug. $-\Lambda$ good grass for moist meadows. (Eu.)

5. P. praténsis, I. (Jink Grass. Spear Grass. Kextecky BuelGrass.) Culms sending off copious running rootstocks from the base, and the sheaths smooth; ligule short and blunt; panicle short-pyramidal; spikelets $3-5$ flowered, crowded, and mostly almost sessile on the branches, ovate-lanceolate or ovate; flowering glume 5-nerved, hairy on the margins as well as keel. - Common in dry soil ; imported for pastures and moalows. Indigenous in mountaiu regions from N. Y'enn. to New Ling., and northward. May-July. (Eu.)

P. trividis, L. (liovginsu Meadow-Grass.) Culmserect from a somewhat decumbent base, but no distinct running rootstocks; sheaths and leares more or less rough; ligule oblong, acute; panicle longer or with the branclies more distant; spikelets mostly 3 -flowered, broader upward; flocering glume prominently 5-nerved, naked at the maryins: otherwise nearly as in the preceding. - Moist meadows, ete. July. (Nat. from Eu.)

+- Spikelets feuer and more scattered, on slender pedicels; plants soft and smooth, flowering early. (No running rootstocks, except in n. 10.)

+ Spikelets small (1-2"long), pale green, rather loosely 2-4-flowered; flourers oblong, obtuse; flowering glume scarcely scarious-tipped; culm-leaves luncelinear, acute, $1-3^{\prime}$ long.

6. P. sylvéstris, Gray. Culm flattish, erect; branches of the oblongpyramidal panicle short, numerous, in fives or more; flou'ering glumes villous on the keel its whole length, and on the margins below the middle, sparingly webbed at base. - Rocky woods and meadows, western N. Y. to Wisc., Kan., and southward. June.

7. P. débilis, Torr. Culms terete, weak; branches of the small panicle few and slender (the lower $1 \frac{1}{2}-2^{\prime}$ long to the few spikelets), in pairs and threes; flowers very obtuse, smooth and ylabrous, except a sparing web at base. - Rocky woodlands, R. I. to Penn. and Wise. May.

+. Spikelets 2" long, light green; oblongtanceolate flourers and glumes acute.

8. P. alsodes, Gray. Leaves rather narrowly linear, acute, the uppermost $\left(2 \frac{1}{2}-4^{\prime}\right.$ long) often sheathing the hase of the narrow and loose panicle, the capillary branches appressed when young, mostly in threes or fours; flowering glume very obscurely nerved, villuus on the keel below, and with a narrow cobwebby tuft at base, otherwise glahrous. - Wools, on hillsides, N. Eng. to Penn. and Va., west to Wisc. May, June.

++ Spikelets larger (3-4" long). pale green, rarely purple-tinged, few and scattered at the ends of the long capillary branches (mostly in pairs or threes) of the very diffuse panicle; flowers 3-6, loose, oblong and obtuse, as 
is the larger glume; flowering glume conspicuously scarious at the apex, villous below the middle on the keel and margins; culms flattish, smooth.

9. P. flexuòsa, Muhl. (not of Wahl.) Culms $1-3^{\circ}$ high, tufted, its leaves all linear $\left(2-5^{\prime}\right.$ long), gradually taper-pointed; panicle very effuse (its branches 2-4' long to the 4-6-fiowered spikelets or first ramification); flowering glume prominently nerved, no web at the base. - Dry woods, Penn. and Del. to Ky., and southward. Feb. - May. - Near the last.

10. P. brevifolia, Muhl. Culms $1-1 \frac{1}{2}^{\circ}$ high from running rootstocks, 2-3-leaved, the upper leaves very short $\left(\frac{1}{2}-2^{\prime}\right.$ long), lanceolate, all abruptly cuspidate-tıpped; branches of the short panicle mostly in pairs; spikelets 3-4flowered; flowering glume rather obscurely nerved, cobwebby at base. - Rocky or hilly woodlands, Penn., Va., and sparingly westward to Ky. and Ill. April, May. - Culm scarcely surpassing the long root-leaves.

\section{GRAPH É PHORUM, Desv.}

Spikelets 2-4-flowered, compressed, the rhachis pilose on one side, jointed, produced above the flowers into a hairy pedicel. Einpty glumes thin-membranaceous, acute, carinate, mostly nearly equalling the remote flowers; flowering glume thin and membranaceous or scarious, convex, scarcely keeled, faintly nerved, entire, pointless and awnless. Stamens 3. Stigmas plumose. Ovary glabrous. - Perennial, with linear flat leaves, their sheaths closed at base, the

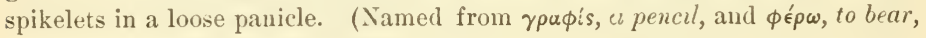
from the terminal hairy pedicel.)

1. G. melicoídeum, Desv. Culm $1-2^{\circ}$ high; leaves roughish; panicle open; glumes unequal, lanceolate, their midrib and the pedicels rough. N. Maine, N. Vt., Upper Mich., and northward; rare. - Var. vàus, Gray, is a luxuriant form, $2-3^{\circ}$ high, with ampler panicle; borders of a swamp, Macomb Co., Mich. Aug.

\section{SCOLÓCHLOA, Link. (Pl. 15.)}

Spikelets 2-4-flowered, subterete. Rhachis hairy at the base of the flowers, ending in a naked pedicel. Empty glumes concave, membranaceons, unequal, the outer 3-nerved, acute, the inver 5-nerved, toothed at the apex, nearly equalling the flowers; flowering glume more rigid, prominently 7 -nerved, toothed at the apex; nerves all parallel. Stamens 3. Stigmas plumose. Ovary hairy. - Tall perennials, growing in water, with loosely sheathing leaves, and spikelets in a lax panicle. (Name probably from $\sigma \kappa \hat{\omega} \lambda o s$, a prickle, and $\chi \lambda$ óa, grass.)

1. S. festucàcea, Link. Stout, $3-4^{\circ}$ high, smooth; leaves rough on the margins; panicle suberect; spikelets 3-4" long. (Festuca borealis, Hook.) - Emmet Co., Iowa (C'ratty), and northward.

\section{GLYCERIA, R. Br. Maxya-Grass. (Pl. 10.)}

Spikelets terete or flattish, several - many-flowered; the flowers mostly early deciduous by the breaking up of the rhachis into joints, leaving the short and unequal 1-3-nerved membranaceous lower glumes behind. Flowering glume and palet naked, of a rather firm texture, nearly equal; the glume rounded on the back, scarious (and sometimes obscurely toothed) at the blunt or rarely 
acute summit, glabrous, prominently $5-7$-nerved, the nerves parallel and separate. Squamulix fleshy and truncate, or none. Stamens commonly 2. Styles present; stigmas compoundly plumiose. ()vary smooth. Grain oblong, free, the furrow very narrow or none. - l'erennial snuoth marsh grasses, mostly with creeping bases or rootstocks; spikelets panicled. (Name from y $\lambda u \kappa \in \rho l s$, swcet, in allusion to the taste of the grain.)

* Spikelcts ovate, oblong, or linear-oblong, 1-3" in length,

+ At length nodding in an open panicle, flattish laterally but turgid.

1. G. Canadénsis, 'Trin. (Rattlesnake-(irass.) Culm stout, 2-3으. high; leaves long, runghish; panicle oblong-pyramidal, at length drooping; spikelets ovate, at length very broad and tumid, Briza-like, $2^{\prime \prime}$ long, pale, with purplish glumes; flowering glume acute or blunt-pointed, firm, with not very prominent uerves, longer than the rounded palet. - IBogs and wet places; common from Peun. to E. Kan., and northward. July.

+- +- Erect in a narrow contracted panicle, somewhat flattened and turgid.

2. G. obtùsa, Trin. Culm stout, $1-2^{\circ}$ ligh, very leafy; leaves long, smooth; panicle narrowly oblong, dense $\left(3-5^{\prime} \mathrm{long}\right)$; spikelets $3-7$-flowered, 2-3" long; flowering glume obtuse. - Bogs, E. New Eng. to Penn. and southward, near the coast.

3. G. elongàta, Trin. Leaves very long $\left(1^{\circ}\right.$ or more $)$, rough; panicle narrowly racemose, elongated $\left(1^{\circ}\right.$ long), recurving; the branches and $3-4$-flowered spikelets appressed ; flowering glume ubtuse. - Wet woods, N. Eng. to Mich., Minn., and northward; Roan Mt., N. C. (sicribner). July-Aug.

+ + + Diffuse; flower-glume truncate-obtuse, strongly 7-nerved; palet 2-toothed.

4. G. nervàta, Trin. (Fowl Meanow-Grass.) (Pl. 10, fig. 1-3.) Culm erect, I $-3^{\circ}$ high; leaves rather long; branches of the loose panicle capillary, at length drooping, the numerous smull spikelets (1-2" long, commonly purplish) ovate-oblong, 3-7-flowered. - Moist meadows; common. June.

5. G. pállida, Trin. Culms slender, $1-3^{\circ} \mathrm{long}$, ascending from a creeping base; leaves short, sharp-pointed, pale; branches of the rather simple panicle slender, erect-spreading, rough; the spikelets usually few, someuthat apressed, oblong-linear, 5-9-flowered (pale, 2-3" long); flowering glume minutely 5toothed; the palet lanceolate, couspicuously 2-toothed. - Shallow water; Maine to Va., west to Ky., Ind., and Mich.; common, especially northward. July.

6. G. grándis, Watson. (REen MEanow-Grass.) Culm stout, upright, $3-5^{\circ}$ high ; leaves large $\left(1-2^{\circ}\right.$ long, $\frac{1}{3}-\frac{1}{2}{ }^{\prime}$ wide $)$; punicle much branclied, ample (8-15' long), the numerous branches a scending, sprealling with age; spitielets oblong or linear-oblong, 3-6-flowered (usually purplish, 2-3" long); flowering glume entire. (G. aquatica of A ner. authors.) - Wet grounds; N. Eng. to western N. Y., Mich., Minu., and westward.

* * Spitielets linear ( $\frac{1}{2}-1^{\prime}$ long), pale, appressed on the branches of the long narrow racemose panicle, terete except during anthesis; palets minutely roughish, the upper 2-toothed; squamule unilateral or united ; ligule long; culm flattened ( $1-5^{\circ}$ high), ascending from a rooting base. (Glyceria, R. Br.)

7. G. fluitans, R. Br. Panicle $1^{\circ}$ long; the simple branches appressed, finally spreading below ; leaves short and rather broal, very smooth ; spikelets 
7 - 13-flowered; flowering glume oblong, obtuse, or the scarious tip acutish, entire or obscurely 3-lobed, usually rather longer than the blunt palet. - Shallow water; common. June-Aug.

8. G. acutiflora, Torr. Spikelets 5-12-flowered, few and scattered; flouering glume oblong-lanceolate, acute, shorter thun the long tapering point of the palet. - Wet places, Penn. to Maine; rather rare. June. - Resembles the last; but the erect leaves smaller, the separate flowers twice the length (4" long), and less nerved.

\section{PUCCINÉLIIA, Parl.}

Characters as in Glyceria, but the flowering glumes inconspicuously or obsoletely 5-nerved; squamula thin and distinct ; stigmas sessile and simply plumose; grain compressed, often broadly furrowed. - Mostly saline species; perennial. (Named for Prof. Benedetto Puccinelli, an Italian botanist.)

1. P. marítima, Parl. (Goose-Grass. Sea Spear-Grass.) Root stoloniferous; culns erect, $1-1 \frac{1}{2} 0$ high; leaves involute, acute or pungent; lower branches of the narrow panicle often solitury or in pairs, appressed or more or less spreading; spikelets 3-6" long, oblong or linear, 4-9-flowered; flowering glumes rounded at the summit, $1 \frac{1}{2}{ }^{\prime \prime}$ long. (Glyceria maritima, Wahl. Atropis maritima, Girseb.) - Marshes along the coast; not rare, and somewhat variable in the form of the panicle and size of the glumes. (Eu.)

Var. (?) minor, Watson. Culms low and slender, from very slender creeping rootstocks; leaves very narrow and involute; ligule long; panicle short and very narrow ; spikelets 2-4-flowered, the flowers $1^{\prime \prime}$ long or less. Shore of Mt. Desert Island (E. L. Rund); Labrador (J. A. Allen).-Probably rather a form of the western P. airoides (Poa airoides, Nutt.).

2. P. dístans, Parl. Not stoloniferous; culms rather stont, geniculate below; leaves mostly flat, short; ligule short; lower branches of the panicle in fours or fives, usually more or less nakerl at base, soon spreading and at length deflexed; spikelets 2-3" long, 3-6-flowered; flowering glume truncate-obtuse, $\frac{1}{2}-1$ " long. (Glyceria distans, Wall. Atropis distans, Griseb.) - Salt marshes along the coast and on ballast; apparently much rarer than the last, and perhaps not native. (Eu.)

\section{FESTÙ C A, L. Fescue-Grass. (Pl. 10.)}

Spikelets 3-many-flowered, panicled or racemose; the flowers not webby at base. Lower glumes unequal, mostly keeled. Flowering glumes chartaceous or almost coriaceous, roundish (not keeled) on the back, more or less 3-5-nerved, acute, pointed, or often bristle-awned from the tip, rarely blunt; the palet mostly adhering at maturity to the enclosed grain. Stamens 1-3. - Flowers, and often the leaves, rather dry and harsh. (An ancient Latin name of some kind of grass, of uncertain meaning.)

* Flowers awl-shaped, bristle-pointed or awned from the tip; panicle contracted. + Annuals or biennials, slender, 5-18' high; leaves convolute-bristle-form.

F. Mrưus, L. Panicle spike-like, one sided; spikelets about 5-flowered; lower glumes very unequal; aun nuch longer than the flowering glume, fully $6^{\prime \prime}$ in length; stamen 1.- Dry fields, Nautucket, Mass., to Del., and southward. July. (Nat. from Eu.) 
1. F. tenélla, Willd. Panicle spike-like, one-sided, or more compound and open; spikelets 7-13-flowered; aun 1-3"long or more, usually shorter than or about equalling the glume; stamens 2.- I)ry sterile soil, especially southward. June, July.

$$
\text { + + Perennial, tufted, 6-24' high; stamens } 3 \text {. }
$$

2. F. ovina, L. (SHeEr's Fescrw.) Glaucous, $\frac{1}{2}-2^{\circ}$ high ; leaves mostly radical, very narrow and convolute; panicle somewhat one-sided, short, usually more or less compound, open in flowering; spikelets 3-8-flowered; awn not more than half the leugth of the flower, often much shorter or almost wanting. - Indigenous in northern New Eng., about Lake Superior, and northward; naturalized farther south as a pasture grass. June. - Varies greatly. - Var. vivfPARA, L. (which with us has runuing rootstocks), a state with the spikelets partially converted into leaf shoots, is found on the alpine summits of the White Mts., and high northwart. - Var. Nerıćsceld, Kuch, is a tall form, with spikelets rather larger, usually in a more compound pauicle; culm-leaves often flat or less convolute, and the lower with their sheaths either sinooth or hairy. New Eng. to Va., and westward, as a naturalized plant, and indigenous northward. A native form of this variety with a lax panicle, 2-4-flowered spikelets, and slender awns nearly as long as the glume (var. rubra, of last ed.), is found on Keweenaw P'euiusula (Robbins) and Isle Royale, L. Superior (Gilman). (Eu.)

* * Flowers oblong or lanceolate, aunless or nearly so $\left(1 \frac{1}{2}-4^{\prime \prime}\right.$ long $)$; grain often fiee! (Root perennial; culms mostly tall; leaves flat.)

3. F. nùtans, Willd. Culm $2-4^{\circ}$ high, naked above; leaves broadly linear, taper-pointed, dark green, often rather hairy; panicle of severul long and slender spreading branches, mostly in pairs, drooping wheu old, rough, naked below, bearing near their extremity a few ovate $3-5$-flowered spikelets ( $3^{\prime \prime}$ long) on pretty long pedicels; flowers ovate-oblong, rather obtuse, close together, coriaceous, smooth, very obscurely 5-nerved. - Rocky woods and copses. July. - A common form with the panicle more or less contracted and somewhat erect has been distinguished as F. Shortii.

F. elatior, L. (Tallek or Meanow Fescue.) (Pl. 10, fig. 1-3.) Panicle narrow, contracted before and after flowering, erect, with short branches; spikelets crowded, 5-10-flowered; flowers rather remote, oblong-lanceolate; flowering glume 5-nerved, scarious-margined, blunt, acute, or rarely with a distinct but very short awn. - The type is large, $3-4^{\circ}$ high ; spikelets about 6" long, in an ample and compound panicle. Rich grass-lancl. - Var. PRATÉxsis, Gray (F. pratensis, Huds.), is lower ( $1-3^{\circ}$ high), with a simpler or close panicle of smaller or narrower spikelets, and abounds in grass-lands. June-Aug. (Nat. from Eu.)

F. Gigaxtèa, Vill. Frect, glabrons, $3-4^{\circ}$ high ; leaves bright green, 3-6" broad; panicle very loose, nodlling; spikelets $3-6$-flowered; flowering glumes 3 " long, with a slender awn of twice the length. - Of rare occurrence near the coast. (Nat. from Eu.)

\section{B R Ò M S, I. Brome-Grass. (Pl. 10.)}

Spikelets 5-many-flowered, panicled. Glumes unequal, membranaceous ; the lower 1-5-, the upper 3-9-nerved. Flowering glume either convex on 
the back or compressed-keeled, 5-9-nerved, awned or bristle-pointed from below the mostly 2-cleft tip; palet at length adhering to the groove of the oblong or linear grain. Stamens 3. Styles attached below the apex of the ovary. - Coarse grasses, with large spikelets, at length drooping, on pedicels thickened at the apex. (An ancient name for the Oat, from $\beta$ óp $\mu$ s, food.)

$\S 1$. Flowering glume oblong, turgid, and convex on the back; the flowers imbricated over one another before expansion; lower empty glume distinctly 3-5nerved, the upper 5-9-nerved.

* Perennial; indigenous. Lower glume strongly 3-nerved, the upper 5-nerved.

1. B. Kálmii, Gray. (Wild Chess.) Culm slender $\left(1 \frac{1}{2}-3^{\circ}\right.$ high); leaves and sheaths conspicuously or sparingly hairy; panicle simple, small (3-4' long); spikelets drooping on capillary peduncles, closely $7-12$-flowered, densely silky all over; awn only one third the length of the lance-oblong flower; flowering glume 7-9-nerved, much longer and larger than the palet. - Dry ground, N. Eng. to Penn., Mo., Minn., and northward. June, July.

* Annuals or biennials, introduced into grain-fields, or rarely in waste grounds.

B. secálinus, L. (Cheat or Ciness.) (Pl. 10, fig. 1, 2.) Panicle spreading, even in fruit, the drooping peduncles little branched; spikelets oblongovate, turgid, smooth, of 8-10 rather distant flowers; glume rather longer than the palet, short-awned or awnless; sheaths nearly glabrous. - Too common in wheat-fields. June, July. (Ady, from Eu.)

B. Móllis, L. (Soft Chess.) Whole plant downy; panicle more erect, contracted in fruit; spikelets coniral-ovate, somewhat flattened ; flowers closely imbricated; glume acute, equalling the awn. - Wheat-fields, N. Y. to Va.; scarce. June. (Adv. from Eu.)

B. Racenóscs, L. (Uprigit Ciness.) Very similar to the last, but nearly glabrous or the sheaths sometimes hairy; glumes glabrous and shining. (Adv. from Eu.)

§ 2. Flowering glume somewhat convex, but keeled and laterally more or less compressed, at least above; flowers soon separating from each other; lower empty glume 1-nerved, the upper 3-nerved, or with an obscure additional pair.

* Perennial, tall $\left(3-5^{\circ}\right.$ ligh $)$; flowers oblong or lanceolate.

2. B. ciliatus, L. Panicle compound, very loose, the elongated branches at length divergent, drooping; spikelets 7-12-flowered; flowering glume tipped with an awn $\frac{1}{2}-\frac{8}{4}$ its length, silky with appressed hairs near the margins, at least below (or rarely naked), smooth or smoothish on the back; or, in var. PÚRGANs, Gray, clothed all over with short and fine appressed hairs. - River-banks and moist woodlands; common. July, Aug. - Culm and large leaves $\left(3-6^{\prime \prime}\right.$ wide) smooth or somewhat hairy; the sheaths in the larger forms often hairy or densely downy near the top. Variable, comprising several forms.

B. Ásper, L. Culm sleuder and panicle smaller; spikelets 5-9-flowered; glume linear-lanceolate, scarcely keeled, hairy near the margins, rather longer than the awn; sheaths and lower leaves hairy or downy. - N. Brunswick to Mich. and Ky. (Nat. from Eu.)

* * Annual or biennial; flowers slender; palet pectinate-ciliate on the nerves.

B. stérilis, L. Culm glabrous; leaves rather downy; panicle open : spikelets on elongated nearly straight simple peduncles, of $5-9$ rather distant 7-nerved roughish linear-awl-shaped long-awned flowers (awn l' long). Waste places and river-banks, E. X. Iass. to I'enn.; rare. June. (Nat. from Eu.) 
B. TECtórci, L. I Leaves short; panicle lax, somewhat 1 -sicled, the moro numerous pubescent spikelets on very slender curving pelicels. - Nore cummon, N. King. to Penn. and N. Y. (Adv. from Eu.)

\section{L Ò I U M, L. Daraet. (I'l. 11.)}

Spikelets many-flowered, solitary on each joint of the continuous rlaschis, placed edgewise; empty glumes, except in the terminal spikelet, only one (the upper) and exterual. Otherwise nearly as in Agropyrum. (Aicient Latin vame.)

L. PEnéxe, L. (Common Darsel, Ray-or RYy-Grass.) Root perennial; glume shorter than the spikelet; flowers 8-15, awnless or sometimes shortawned. - Fields and lots; eastward. June. (Nat. from Eu.)

L. temléntur, L. (Bearded DarNel.) Root annual; culm taller; outer glume fully equalling the 5-7-flowered spikelet; aun longer than the flower ( $\frac{t^{\prime}}{2}$ long). - Grain-fields; rare. (Adv. from Eu.)

\section{A G RO P Ỳ R U M, Gaertn. (Pl. 11.)}

Spikelets 3-many-flowered, compressed, 2-ranked, alternate on opposite sides of a solitary terminal spike, single at each joint (the lowermost, or all, rarely in pairs) and sessile with the side against the axis. Glumes transverse (i. e. right and left), nearly equal and opposite, lanceolate, herbaceous, nerved. Flowering glumes rigid, convex on the back, 5-7-nerved, pointed or awned from the tip; palet flattened, bristly-ciliate on the nerves, adherent to the groove of the grain. Stamens 3. - Our species rather coarse pereunials,

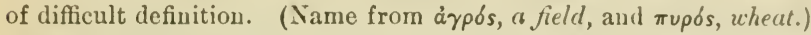

* Multiplying by long running rootstocks; aun shorter than the flower or none.

1. A. rèpens, Beauv. (Coucr-, Quiтch-, or Quick-Grıss.) spikelets 4-8-flowered, glabrous or nearly so; glumes 3-7-nerved; rhachis glabrous, but rough on the edges; awns when present straight; leaves flat and often roughish or pubescent above. (Tríticum repeus, L.) - Nat. from Europe in cultivated grounds, fields, etc., and very troublesome; indigenous in some of its forms northwestward and on the coast. - Varies greatly. The ordinary form has a narrow spike, with 3-5-flowered spikelets, the glumes merely acute and rigicl-cuspidate, or acuminate, or short-awned. A tall form, rather bright green, bears awns nearly as long as the glumes. Other forms abound, especially on or near the coast. A maritime variety, much resembling var. glaucum, Boiss. (A. glaucum, $R . \S . S$.), with large crowiled 5-10-flowered spikelets and glumes very blunt or mucronate, glaucuus and the leares rather rigid and pungent, occurs on the coast of Maine (Cape Elizabeth, Tuckerman). In the more usual form of this variety, with the large spikes often elongated $\left(3-9^{\prime}\right)$ and the leaves less rigid, the glumes are acuminate or rarely short-awned. 'The rhachis or the whole inflorescence and the lower sheaths are sometimes very pubescent. The glabrous state, or a very similar glabrous variety, is also abundant in the western region, from Kan. and Neb. to Dak., and westward, where it is known as Blue-joint or Blue-stem. (En.)

2. A. dasystàchyum, Vasey. Resembling the last; glaucous; leaves narrow and often involute; the 5-9-flowered spikelets densely douny-hairy all over; glumes thinner with scarious margins, mostly long-acuminate. ('Triticum dasystachyum, Giray.) - Sandy shores of Lake Hurou and Superior, and northward. Aug. 
* No obvious running rootstochs, glabrous, or the flat and roughish leaves sometimes hairy above; glumes as well as flowers mosll!y awned or awn-pointed.

3. A. violàceum, Lange. Spike short, dense, strict and rigid, usually tinged with violet or purple; spikelets 3-5-flowered; glumes conspicuously 5nerved, rather abruptly narrowed into a cusp or short awn. (Triticum violaceum, Hornem.) - Alpine region of the White Mts., L. Superior, north and westward. (Eu.) - Passing into a rauety with longer usually pale narrow spikes and attenuate often long-awned glumes, which sometimes approaches A. caninum. N. Brunswick, White Mts., N. H., Peun. (Porter), L. Superior, and westward.

4. A. caninum, R.\& S. (Awxed Wheat-Grass.) Spike usually more or less nodding, at least in fruit, rather dense (3-6' long); spikelets 3-5flowered; glumes 3-5-nerved; awns straight or somewhat bent or spreading, fully twice the length of the palet. (Triticuin caninum, L.) - Sparingly naturalized in cultivated ground and meadows. Indigenous along our northern borders, and westward. (Eu.)

5. A. ténerum, Vasey. Culms $1-3^{\circ}$ high; leaves narrow; spike very narrow, 2-7' long; spikelets 3-5-flowered; glumes short-acuminate. - Minn. to Kan., and very common westward.

\section{LEPTÙ RUS, R. Br.}

Spikelets 1-2-flowered, solitary and alternate upon the opposite sides of a narrow spike, sessile and appressed in the concave joints. Empty glumes transverse, narrow, rigid, 5-nerved, the flowering much shorter, thin and hyaline. - Low annuals, branching at the base, with narrow leaves and rigid often curved spikes. (Name from $\lambda \epsilon \pi \tau o ́ s, n a r r o w$, and oủpá, tail, or spike.)

L. Incenvatus, Trin. Much branched, decumbent, 6 ' high or less; spikes terminal and lateral, 1-4' long, the base included in the broad sheath. Borders of brackish marshes, Md. to S. Va., and on ballast northward. (Nat. from Eu.)

\section{HÓ R D U M, Tourn. Barley. (Pl. 11.)}

Spikelets 1-flowered, with an awl-shaped rudiment on the inner side, three at each joint of the rhachis of a terminal spike, but the lateral ones usually imperfect or abortive, and short-stalked. Empty glumes side by side in front of the spikelets, 6 in number, forming a kind of involucre, slender and awnpointed or bristle-form. Flowering glume and palet herbaceous, the former (anterior) convex, long-awned from the apex. Stamens 3. Grain oblong, commonly arlherent. - Spike often separating into joints. Ours annuals or biennials, or scarcely perenuial. (The ancient Latin name.)

1. H. jubàtum, L. (Squrrel-Tail Grass.) (Pl. 11, fig. 1, 2.) Low; lateral flowers abortive, on a short pedicel, short-awned; the perfect flower bearing a capillary awn ( $2^{\prime}$ long) about equalling the similar capillary glumes, all spreading. - Sandy sea-shore, upper Great Lakes, and westward. June.

2. H. praténse, Huds. Low (6-18' high); lateral flowers imperfect or neutral, awnless or merely pointed; perfect flower with awu as long as those of the glumes $\left(3-6^{\prime \prime}\right)$; spike linear, $1-2^{\prime}$ long. - Plains, especially in saline soil, Ohio to Ill. and westward; also sparingly introduced, Va., and southward along the coast. May, June. (Eu.) 


\section{5. ÉLY MUS, I. IYME-Grass. WrLI) RY̌. (I'l. 11.)}

Spikclets 2-4 at each joint of the rhachis of a terminal spike, all fertile and alike, sessile, each I -7-Howered. Glumes conspicuous, uearly side hy side in front of the spikelets, 2 for each spikelet, forming an involuere to the cluster. Fluwer coriaceons; the glume rounded on the back, acute or awner! at the apex. Grain alherent to the involving glume (whence the namo, an ancient one for some grain, from $\epsilon^{\lambda} \boldsymbol{u} \omega$, to roll up).

* Glumes and flowers firm or rigid, all or only the latter awned; spikelets 1 -5flouered; slender perennials, with rather harsh and broad flat leaves.

$$
\text { - Spile lurge and stout. }
$$

1. E. Virgínicus, I. (Pl. I1, fig. I-3.) Culm stout, $2-3^{\circ}$ high; spike rigirlly upright, dense (2-3' long, $6^{\prime \prime}$ thick), the short peduncle usually included in the sheath; spikelets 2-3 together, 2-3-flowered, smooth, rather shortawned, about the length of the thiekened strongly-nerved and bristle-pointed lanceolate glumes. - River-bauks ; common. Aug.

2. E. Canadénsis, L. Spile som nodding (5-9' long), on an exserted peduncle; spikelets mostly in pairs, of 3-5 loug-awned rough or rough-hairy Howers; the awl-shaped glumes tipped with shorter awns. - Var. GLAUCiFò LIUS, Gray, is pale or glaucous throughout, the flowers with more spreadiug awus (1 $\frac{1}{2}$ long). - Var. INTERMìnes, Vasey, has the awns scarcely longer than the glumes. - River-banks; common.

$$
\text { + + Spike and culm more slender. }
$$

3. E. striàtus, Willd. More or less pubescent; spike dense and thickish (2-4' long), upright or slightly nodding; spikelets mostly in pairs, 1-2- (or rarely 3-) flowered, minutely bristly-hairy; glumes awl-shaped, bristle-auned, 1-3-nerved, about thrice the length of the flowers, which are only $3^{\prime \prime}$ long exclusive of the capillary awn (I'long). - Var. vilcosus, Gray, has very hairy flowers and glumes, and villous sheaths. - Rocky woods and banks. July, Ang.

4. E. Sibíricus, L., var. Americànus. Glabrous; spike wand-like (2-6' long, 2-3" thick), often somewhat nodding; spikelets in pairs, 3-6flowered; glumes linear-lanceolate, 3-5-nerved, acuminate and smooth or often scabrous on the nerves, short-awnel, shorter than the flowers, which hear an erect awn of once or twice their length. - Marquette, Mich. (Porter), N. Minn., and westward.

* * Glumes and palet aunless and soft in texture; reed-like perennials.

5. E. móllis, 'Trin. Culm ( $3^{\circ}$ high) velvety at top; spike thick, erect ( $8^{\prime}$ long) ; spikelets 2 or 3 at each joint, 5-8-flowered ; the lanceolate pointed 5 -7-nerved glumes ( $I^{\prime}$ long) and the pointed flowers soft-villous; rlachis of the spikelets separating into joints. - Shore of the (ireat Lakes, Maine, and northward. (Near E. arenarius.)

*** Empty glumes very narmor, and all rery long-awned; spike disarticulating at maturity.

6. E. Sitànion, Schultes. Iow $\left(\frac{1}{2}-2^{\circ}\right.$ high $)$, stont; spike $1-4^{\prime}$ long, the peduncie slightly exserterl ; the spreading scabrous awns $2-3^{\prime}$ long. - Central Minn. to Kan., and westward. 


\section{A S PRELA, Willd. Bottle-Brush Grass. (Pl. 11.)}

Spikelets 2-3 or sometimes solitary on each joint of the rhachis of a terminal spike, raised on a very short callous pedicel, loosely $2-4$-flowered (when solitary flatwise on the rhachis). Glumes none! or small, awn-like, and deciduous. Otherwise nearly as in Elymus. (Name a diminutive of asper, rough or prickly.)

1. A. Hýstrix, Willd. Perennial; culms $3-4^{\circ}$ high; leaves and sheaths smoothish; spike loose (3-6' long); the spreading spikelets $2-3$ together, early deciduous; flowers smoothish or often rough-hairy, tipped with an awn thrice their length (1' long). (Gymnostichum Hystrix, Schreb.) - Moist woodlands. July, Aug.

\section{A RUIDINÀRIA, Michx. CAxe. (Pl. 11.)}

Spikelets flattened, 5-14-flowered; the flowers somewhat separated on the jointed rhachis. Empty glumes very small, membranaceous, the upper one larger. Flowering glumes and palet herbaceous or somewhat membranaceous, the glume convex on the back, many-nerved, tapering into a mucronate point or bristle. Squamule 3, longer than the ovary. Stamens 3. Graiu oblong, free. - Arborescent or slirubby grasses, simple or with fascicled branches, and with large spikelets in panicles or racemes; blade of the leaf jointed upon the sheath; flowers polygamous. (Name from arundo, a reed.)

1. A. macrospérma, Michx. (LARge CANe.) (Pl. 11, fig. 1, 2.) Culms arborescent, $10-40^{\circ}$ high and $\frac{1}{2}-3^{\prime}$ thick at base, rigid, simple the first year, branching the second, afterwards at indefinite periols fruiting, and soon after decaying; leaves lauceolate ( $1-2^{\prime}$ wide), smoothish or pubescent, the sheath ciliate on one margin, stoutly fimbriate each side of the base of the leaf; panicle lateral, composed of few simple racemes; spikelets $1-3^{\prime}$ long, purplish or pale, erect; flowering glume lanceolate, acute or acuminate, glabrous or pubescent, fringed (5-12" long). - Rirer-banks, S. Va. (?), Ky., and southward, forming cane-brakes. April.

Var. suffruticosa, Munro. (Switch Caxe. Small Cane.) Iower and more slender $\left(2-10^{\circ}\right.$ high), often growing in water; leaves $4^{\prime \prime}-1^{\prime}$ broad; spikelets solitary or in a simple raceme at the summit of the branches, or frequently on leafless radical culms. (A.tecta, $M u h l$.) - Swamps and moist soil, Md., S. Ind. to S. E. Mo., and southward. Sometimes fruiting several years in succession. 


\section{SERIES II.}

\section{CRYPTOGAMOUS OR FLOWERLESS PLANTS.}

Vegetables destitute of proper flowers (i. e. haring no stamens nor pistils), and producing instead of seeds minute one-celled germinating bodies called spores, in which there is no embryo or rudimentary plantlet.

\section{Class III. ACROGENS.}

Cryptogamous plants with a distinct axis or stem, growing from the apex, and commonly not with later increase in diameter, usually furnished with distinet leaves; reproduction by antheridia and archegonia, sometimes also by gemmation.

\section{Surclass I. VASCULAR ACROGENS, or PTERI- DOPHY'TES. ${ }^{1}$}

Stems containing woody fibre and ressels (especially scalariform or spiral ducts). Antheridia or archegonia, or both, formed on a minute prothallus which is developed from the spore on germination, the archegonium containing a nucleus, which after fertilization becomes an oöspore and at length grows into the conspicuous spore-bearing plant.

\section{Order 130. EQUISETACEAE. (IIorsetall Family.)}

Rush-like, oflen branching plants, with jointed and mostly hollow stems from running rootstocks, having sheaths at the joints, and, when fortile, terminated by the conical or spike-lite fructification composed of shieldshaped stalked scales bearing the spore-cases beneath. $-\mathrm{A}$ single genus.

1 The orders of this Subclass have been elaborated anew for this edition by Prof. Daniel C. Eaton of Yale University. 


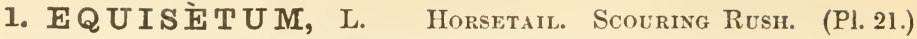

Spore-cases (sporangia, thecce) 6 or 7 , adhering to the under side of the angled shield-shaped scales of the spike, 1-celled, opening down the inner side and discharging the numerous loose spores. To the base of each spore are attached 4 thread-like and club-shaped elastic filaments, which roll up closely around the spore when moist, and uncoil when dry. - Rootstocks perennial, wide-creeping, hard and blackish, jointed, often branched and sometimes bearing small tubers. Stems erect, cylindrical, hollow, jointed; the surface striated or grooved with alternate ridges and furrows, the cuticle in most species con. taining silica in the form of minute granules, rosettes, or tubercles; the joints containing besides the central air-cavity a circle of smaller hollows beneath the furrows and a set of still smaller ones beneath the ridges; the nodes closed and solid, each bearing instead of leaves a sheath which is divided into teeth corresponding in number and position to the principal ridges of the stem; stomata in the furrows, each with two pairs of guard-cells, of which the outer pair is marked with raliating lines of silica. Branches, when present, in whorls from the hase of the sheath, like the stem, but without the central aircavity. Prothallus green, formed upon the ground, often variously lobed, usually diœcious. (The ancient name, from equus, horse, and seta, bristle.)

$\S 1$. Annual-stemmed, not surviving the winter.

* Fruiting in spring from soft and rather succulent pale or brounish fertile stems, the sterile stems or branches appenring later, herbaceous and very different.

- Fertile stems unbranched, destitute of chlorophyll and soon perishing; the sterile branching copiously.

1. E. arvénse, L. (Common H.) Fertile stems $\left(4-10^{\prime}\right.$ high) with loose and usually distant about 8-12-toothed sheaths; the sterile slender (at length $1-2^{\circ}$ high), $10-14$-furrowed, producing long and simple or sparingly branched 4-angular brauches, their teeth 4, herbaceous, lanceolate- - Moist, especially gravelly soil; very common. March-May. Rootstocks often bearing little tubers. - Var. CAMpéstre, Milde, is a not uncommon state, in which the sterile stem bears a small fruitiug spike at the summit. (Eu.)

+ + Fertile sterns when older produciny herbaceous 3 -sided branches, and lasting through the summer, except the naked top which perishes after fructification.

2. E. praténse, Ehrh. Sterile and finally also the fertile stems producing simple straight branches; sheaths of the stem with ovate-lanceolate short teeth, those of the branches 3-toothed; stems more slender and the branches shorter than in the last. - Mich. to Minn., and northward. April, May. (Eu.)

3. E. sylváticum, L. Sterile and fertile stems (about 12-furrowed) producing compound racemed branches; sheaths loose, with 8-14 rather blunt teeth, those of the branches bearing 4 or 5 , of the branchlets 3 , lance-pointed divergent teeth. - Wet shady places; common northward. May. (Eu.)

* Fruiting in summer; stems all of one kind, or the fertile contemporaneous with and like the sterile, equally herbaceous, producing mostly simple branches, or sometimes nearly naked.

4. E. palústre, L. Stems $\left(10-18^{\prime}\right.$ high) slender, very deeply 5-9. grooved, the ridges narrow and acute, roughish, the lance-awl shaped teeth 
whitish-margined; branches always loollow, 4-7-angled, rather few in a whorl. - Wet places, Niagara River (Clinton), Wise. (A ustin), and northward. June. (Eu.)

5. E. littoràle, Kühlewein. Stems $\left(8-18^{\prime}\right.$ high) slender, leeply 6-16grooved, the ridyes rounded, the teeth shorter than in the last, narrowly u.litemargined; branches often solid, 3-4-angled, 2-6 in a whorl. - Wet sandy shores, Vt. and N. Y., and northward. - Spores always abortive, whenee the plant has been considered a hybrid, perhaps of E. arvense and E. limosum. July. (Eu.)

6. E. limósum, I. (Pl.21, fig. 1-5.) Stems $\left(2-5^{\circ}\right.$ high $)$ slightly manyfurroued, smooth, sometimes continuing unbranched, but usually producing ascending branches after fructification; sheatlis appressed, with 10-22 (com. monly about 18) dark-brown and acute rigid short teeth. - In shallow water; rather common. - Air-cavities none under the grooves, but small ones under the ridges. A form in which the branches bear numerous small spikes is var. Polystacirum, Brückner. June, July. (Eu.)

§2. Stems all alike, evergreen, unbrunched, or producing a few slender ercet branches; fruiting in summer. Central air-cavity of the stem very large.

* Stems tall and stout $\left(1 \frac{1}{2}-4^{\circ}\right.$ or even $6^{\circ}$ high), simple, or casually luanched, evenly many-grooved; sheaths appressed.

7. E. hyemàle, L. (Scouring-Rusir. Sinve-Grass.) Stems $1 \frac{1}{2}-4^{\circ}$ high, 8-34 grooved, the ridges roughened by two more or less distinct lines of tubercles; sheaths elongated, with a black girdle above the base and a black limb; ridges of the sheaths obscurely 4 -carinate, the teeth blackish, membranaceous, soon falling off. - Wet banks; common northward. Formerly in common use for polishing wood and metal. (Eu.)

8. E. robústum, Braun. Stems tall and stout (sometimes $8-10^{\circ}$ high and nearly an inch thick), 20-48-grooved, the ridges roughened with one line of transversely oblong tubercles; sheaths rather short, with a black girdle at base and a black limb; rilges of the sheaths tricarinate, the blackish teeth soon falling off. - River-banks, Ohio and westward.

9. E. lævigàtum, Braun. Stems $1-4^{\circ}$ high, rather slouder, pale green, 14-30-grooved, the ridges almost smooth; sheath slightly enlarged upward, with a black girdle at the base of the mostly deciduous white-margined teeth, and rarely also at the hase of the sheath; rilges of the sheath with one keel, or sometimes obseurely tricarinate. - By streams and in clayey ylaces. Ohio to Minn., and westward.

* * Stems slender, in tufts, 5-10-grooved; slicaths looser.

10. E. variegàtum, Schleicher. Stems ascending $\left(6-18^{\prime}\right.$ long), usually simple from a branched base, 5-10-groored; sheaths green variegated with black ahove, the $5-10$ teeth tipped with a deciluous bristle. - Shoref or riverbanks, N. H. (Bellows Falls, Carey) and Niagara to Minn, and northward ; rare. (Eu.)

11. E. scirpoides, Michx. Stems very munerous in a tuf filiform $\left(3-6^{\prime}\right.$ high), flexuons and curving, mostly 6-grooved, with acuto ridges; sheaths 3 . toothed, the bristle-pointed teeth more persistent; central air-cavity wanting. - Wooded hillsides, N. Eng. to Penn., Minn., and northward. (En.) 


\section{Order 131. Fíllices. (Ferns,}

Leafy plants, with the leaves (fronds) usually raised on a stalk or petiole (stipe), rising from a (sometimes greatly elongated) rootstock, separately rolled up (circinate) in the bud, and bearing on the under surface or along the margin small reticulated sporangia, which at length split open and discharge the numerous minute spores. Prothallus green, above ground, normally moncecious.

Suborder I. Polypodiàcex. Sporangia collected in dots, lines, or variously shaped clusters (sori or fruit-dots) on the back or margins of the frond or its divisions, cellular-reticulated, stalked, the stalk running into a vertical incomplete many-jointed ring, which by straightening at maturity ruptures the sporangium transversely on the inner side, discharging the spores. Fruit-dots often covered (at least when young) by a membrane called the indusium (or less properly the involucre), growing either from the back or the margin of the frond. (Plates 16-19.)

Tribe I. POLYPODIEA. Fructification on the back of the frond, in round or roundish fruit-dots (sori) placed on the veins or at the ends of the veins, without indusium of any kind. Stipes articulated to the rootstock, leaving a distinct scar when separated. Veins free (not reticulated) in our species.

1. Polypodium. Sori round, in one or more rows, on each side of the midrib or of the seginents of the frond.

Tribe II. GRAMMITIDEA. Sori more or less elongated, without indusium, placed on the back of the frond, usually along the veins or near their extremities. Veins free in our species.

2. Notholæna. Sori short, of few rather large sporangia, placed near the tips of the veins ; nnder surface of the frond usually either chaffy, woolly, or powdery.

Tribe III. PTERIDEAE. Fructifieation marginal or intramarginal, provided with a general indusium formed of the (either altered or unchanged) margin of tlie frond. Stipes not articulated to the rootstock. Veins free in all our species.

* Sporangia at the ends of the veins, on a reflexed portion of the margin of the frond.

3. Adiantum. Midrib of the pinnules marginal or none. Stipe black and polished.

* * Sporangia borne on a continuous marginal vein-like receptacle, connecting the apices of the veins, and covered by a delicate whitish indusium formed of the reflexed margin.

4. Pteris. Midrib of the pinnules central. Stipe light-colored.

* * Sporangia at or near the ends of the unconnected veins, borne on the under surface of the frond; indusium various.

5. Cheilanthes. Sori ninute, at the ends of the veins; indusium continuous or interrupted. Fronds mostly chaffy, woolly, or pulverulent, rarely smooth.

6. Pellaea. Sori on the upper part of the veins, distinct, or mostly forming a confluent submarginal band of sporangia. Indusium membranaceous, continuous, rarely wanting. Sterile and fertile fronds not very unlike; stipes dark-colored; fronds smooth.

7. Cryptogramme. Sori roundish or elongated and extending far down the free veins, at first covered by the very broad continuous indusium, at length exposed and confluent. Sterile and fertile fronds very different; stipes light-colored; fronds smooth.

Tribe IV. BLECHNEAE. Sori oblong or linear, borne on a veinlet parallel to the midrib, and covered with a special usually concave or arched indusium attached to the fruiting veinlet, and opening along the inner side.

8. Woodwardia. Sori forming a chain-like row each side of the midrib or central vein. Veins reticulated. 
Tribe V. ASPLENIEA. Sori more or less elongated, occupying one or buth sides of oblique veins, envered by a special indusium which is attached by one side to the furtile vein, and is free on the other. Stipes not articulated.

9. Asplenium. Sori on the upper side or rarely on both sides of a veinlet. Veins free in all our sjecies.

10. Scolopendriun. Sori linear, confluent in pairs, each pair appearing like a single sorus with a donble indusium opening lown the midale. Veins free.

11. Camptosorus. Sori oblong, variously curved, or sowe of them in opposite pairs. Veins reticulated.

Tribe VI. AsPIDIEA. Sori round or roundish, on the back or rarely at the apex of the vein, with a special indusium, rarely naked. Stipes not artieulated to the rontstork.

* Indusium obsolete or none.

12. Phegopteris. Sori round, rather small. Veins free in our species.

* Indusiun evident, round or roundish, covering the sporangia, at least when young. Sterile and fertile fronds not very unlike. Veins free in our species.

13. Aspidium. Indusıum flat or slightly convex, orbicular or round-reniform, fixed by the centre, opening all round the margin.

14. Cystopteris. Indusium convex, fixed by a broad base partly under the sorus, coulnonly reflexed as the sporangia ripen.

* * Indusium obscure, irregularly senicireular. Fertile fronds much contracted and very unlike the sterile ones.

15. Onoclea. Sporangia on an elevated receptacle; divisions of the fertile frond pod-like or berry-like.

Tribe VII. WOODSIEA. Sori round, borne on the veins; indusium fixed under the sorus, divided into segments or into sleuder filanents.

16. Woolsia. Small ferns with free veins. Indusium very delicate.

Tribe VII. DICKSONIEA. Sori roundish, marginal or subinarginal. Indusium cup-shaped or two-valved, the outer portion composed of a reflexed lobule of the frond, or more or less united to it.

17. Dicksonia. Indusium in our species small, membranaccous, nearly globular. Frond elougated, decomipound.

Suborder II. Hymenophyllinceae. Sporangia sessile on a bristle-like receptacle within a cup-shaped or bivalvular involucre, the ring transverse and complete. Fronds delicately membranaceous.

18. Trichomanes. Involucres funnel-form or cup-slıajed.

Suborder III. Schizaracea. Sporangia ovate, sessile, having a complete transverse articulated ring at the apex, and opening by a longitudinal slit. (Pl. 19.)

19. Schizzea. Sporangia naked, fixed in a double now to the midrib of the narrow fertile segments, sterile fronds rigid, simple or dichntomously brauched.

20. Lygodium. Sporangia borne in a donble row on narrow fertile segments, each sporangium seated on a separate veinlet, and provided with a special scale-like indusium. Fronds leafy, elimbing.

Suborder IV. Osmundàcea. Sporangia naked, globose, mostly pedicelled, reticulated, with no ring or mere traces of one near the apex, opening into two valves by a longitudinal slit. Stipes winged at base and almost stipulate! (Pl. 19.)

21. Osmunda. Fertile pinnæ or fronds very much contracted, bearing the abundant and large sporangia upon the margins of the very narrow segments. Veins free. 


\section{POLYPÒ DIUM, L. Polypudy. (Pl. 16.)}

Fruit-dots round, naked, arranged on the back of the frond in one or more rows each side of the midrib or central vein, or irregularly scattered, each borne in our species on the end of a free veinlet. Rootstocks creeping, branched, often covered with chaffy scales, bearing scattered roundish knobs, to which the stipes are attached by a distinct articulation. (Name from $\pi 0 \lambda u ́ s$, many, and $\pi$ ovs, foot, alluding to the branching rootstock.)

1. P. vulgàre, L. (Pl. 16, fig. I -3.) Fronds evergreen, oblong, smooth both sides, 4-10' high, simple and deeply pinnatifid; the divisions linear-oblong, obtuse or somewhat acute, remotely and obscurely toothed; reins once or twice forked; fruit-dots large, midway between the midrib and the margin.Rocks; common. July. (Eu.)

2. P. incànum, Swartz. Fronds evergreen and coriaceous, oblong, 2-6' high, grayish and very scurfy underneath with peltate scales, simply piunatifid; the divisions oblong-linear, obtuse; fruit-dots rather small, near the margin; veins forking, free in the N. American plant! - Rocks and trunks of trees, Va. and Ohio to Ill., and southward. Aug.

\section{NOTHOL ì N A, R. Brown. Cloak-Fern.}

Fruit-dots roundish or oblong, placed near the ends of the veins, soon more or less confluent into an irregular margiual band, with no proper involucre. Veins alwars free. Eronds of small size, 1 -4-pinnate, the lower surface almost always either hairy, tomentose, chaffy, or covered with a fine waxy white or

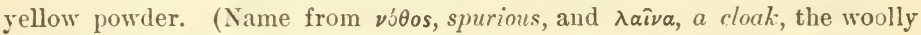
coating of the original species forming a spurious covering to the sporangia.)

1. N. dealbàta, Kunze. Fronds triangular-ovate, 1-3' long, 3-4-pinnate; rhachis and branches straight, black and shining; ultimate pinnules scarcely a line long, white and powdery on the lower surface. - Clefts of calcareous rocks, Mo., Kan., and southwestward. July-Aug.

\section{A D I Á N T U M, I. Maidenhair. (Pl. 17.)}

Fruit-dots marginal, short, borne on the under side of a transversely oblong, crescent-shaped or roundish, more or less altered margin or summit of a lobe or tooth of the frond reflexed to form an indusium; the sporangia attached to the approximated tips of the free forking veins. - Main rib (costa) of the pinnules none (in our species), or at the lower margin. Stipes black and polished.

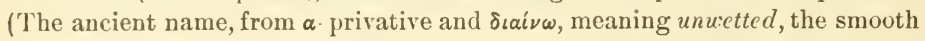
foliage repelling rain-drops.)

1. A. pedàtum, L. (Pl. 17, fig. 1-3.) Frond forked at the summit of the upright slender stalk $\left(9-15^{\prime}\right.$ high), the recurved branches bearing on one side several slender spreading pinnate divisions; pinnules numerous, shortstalked and obliquely triangular-oblong, entire on the lower margin, from which the veins all proceed, and cleft and fruit-bearing on the other. - Rich, moist woods. July. - A delicate and most graceful Fern.

2. A. Capíllus-Véneris, L. Fronds with a continuous main rhachis, ovate-lanceolate, $9-18^{\prime}$ long, often pendent, 2-3-pinnate at the base, the upper third or half simply piunate; pinnules wedge-obovate or rhomboid, 6-12" long, deeply and irregularly incised; veinlets flabellately forking from the 
lase; involucres lunulate or trausversely oblong. - Moist rocky places, Va. to Mo., and southward. (Ku.)

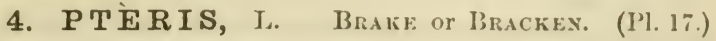

Sporangia in a continuous slender line of fructification, occupying the entiro margin of the fertile frond, and covered ly its reflexed narrow edge which forms a continuous membranaceous indusium, attached to an uniuterrupted transverse vein-like receptacle connecting the tips of the forked free veius. Fronds 1-3-pinnate or decompound. (The ancient Greek name of Ferns, from $\pi \tau \epsilon \rho^{\prime} \nu$, a wing, on account of the prevalent pinnate or feathery fronds.)

1. P. aquilina, L. (Comuon Braкょ.) Frond lull green $\left(2-3^{\circ}\right.$ wide), ternate at the summit of an erect stont stalk $\left(1-2^{\circ}\right.$ high $)$, the widely spreading branches twice pinnate; pinnules oblong-lanceolate; the upper undivided; the lower more or less pinnatifid, with oblong obtuse lohes, margined all round with the indusium, which is really double in this species. - Var. caundra, with the lobes very narrow and revolute, the terminal ones much elongated, is a southern form, which extends in a modified condition as far north as New Jersey. - Thickets and hillsides, common. Aug. (Eu.)

\section{C H E I L Á N TH E, Swartz. Lip-Fers. (Pl. 17.)}

Sporangia borne on the thickened ends of free veinlets, forming small and roundish distinct or nearly contiguous marginal fruit-dots, covered by a mostly whitish and membranaceous, sometimes herbaceous, common indusium, formed of the reflexed margin of separate lohes or of the whole pinnule. - Low, nnostly with 2-3-pinnate and hairy or chaffy, rarely sinooth fronds, the sterile and fertile nearly alike, the divisions with the principal vein central. Some species with continuous indusium connect this genus very closely with the next. (Name composed of $\chi \epsilon \hat{i} \lambda o s$, a lip, and äblos, flower, from the shape of the indusium.)

$$
\text { * Fronds smooth, or at most hairy. }
$$

1. C. Alabaménsis, Kunze. Fronds smooth, chartaceous (2-8' long), ovate-lanceolate, bipinnate; pinnæ numerous, oblong-lanceolate; pinnules triangular-oblong, rather acute, often auriculate or loberl; indusium continuous, rather brond, pale, and of firm consistence. - On rocks, mountains of Va. to $\mathrm{Ky}$., and sonthward.

2. C. vestita, Swartz. (Pl. 17, fig. 1, 2.) Fronds $\left(6-15^{\prime}\right.$ high), lanceolate-oblong, hirsute, as are the brown and shining stipes, with straightish promirently articulated rusty hairs, twice pinnate; pinns rather distant, triangularovate; pinnules oblong, crowded (2-4" long), more or less incised, the ends of the roundish or oblong lohes reflexed and forming separate herbaccous involucres, which are pushed back by the ripened sporangia. - Clefts of rocks, Mauhattan Island ( W. W. Denslow) and N. J. to Ill., and southward.

\section{* * Fronds uoolly or tomentose.}

3. C. tomentósa, Iink. Fronds (12-20' high) lanceolate-oblong, densely tomentose with slender and entangled whitish nhscurely articulated hairs, thrice pinnate; primary and secondary pimse oblong or ovate-oblong; pinnules distinct, minnte ( $\frac{1}{2}-1^{\prime \prime}$ long), roundish-obovate, sessile or adnate-decurrent, the upper surface less woolly, the reflexed narrow margin forming a continuous some- 
uhat membranaceous indusium. - Mountains of Va. and Ky.; thence west and southward. - Stipe and rhachis rather stout, brown, covered with narrow chaffy scales and whitish hairs.

4. C. lanuginòsa, Nutt. Stipes slender, at first hairy, black or brown, shining; fronds ( $3-6^{\prime}$ high) ovate-lanceolate, woolly with soft whitish distinctly articulated flattened hairs, becoming smoother above, twice or thrice pinnate; pinnæ (5-6"long) ovate, the lowest distant, the others contiguous; pinnules crenately pinnatifid, or mostly divided into minute and roundish densely crowded segments ( $\frac{1}{2}-1^{\prime \prime}$ long), the herbaceous margin recurved forming an al. most continuous indusium. - In dense tufts, on dry rocks and cliffs, Ill. to Minn., thence west and sonthward.

\section{PELL苮 A, Link. Cliff-Brake. (Pl. 16.)}

Sporangia in roundish or elongated clusters on the upper part of the free veins, distinct, or confluent laterally so as to imitate the marginal continuous line of fructification of Iteris, commonly covered by a broad membranaceons and continuous (rarely interrupted) general indusium, which consists of the reflexed and altered margin of the fertile pinnule or division. Small ferns, with 1-3-pinnate fronds, the fertile ones with narrower divisions than the sterile, but otherwise similar. Stipes generally dark-colored, smooth and shining. (Name from $\pi \in \lambda \lambda{ }^{\prime} s$, dusky, alluding to the stipe.)

1. P. grácilis, Hook. (Pl. 16.) Fronds smooth $\left(3-6^{\prime}\right.$ high $)$, delicately membranaceous and slender, of few pinnæ, the lower ones once or twice pinnately parted into $3-5$ decurrent divisions, those of the fertile frond oblong or linear-oblong, entire or sparingly incised; of the sterile ovate or obovate, crenate or incised; veins of the fertile fronds mostly only once forked.Shaded calcareous rocks, Mass. to Minn., and northward; rare. July.Rootstock very slender, creeping; stipes polished, brownish, darker and sparingly chaffy at base.

2. P. atropurpùrea, Link. Sinooth, except some bristly-chaffy hairs on the midribs and especially on the dark purple and polished stalk and rhachis, $6-15^{\prime}$ high ; frond coriaceons, pale, once or below twice pinnate; the divisions broadly linear or oblong, or the sterile sometimes oval, chiefly entire, somewhat heart-shaped or else truncate at the stalked base; veins about twice forked. - Dry calcareons rocks; not common, but of wide range. July. Rootstock short and stout; stipes clustered.

\section{CRYPTOGRÁ M ME, R. Brown. Rоск-Вrake.}

Fruit-dots roundish or elongated and extending far down on the free forking veins. True involucre or indusium none, the herbaceous margins of the fertile segments at first reflexed and meeting at the midrib, at length opening out flat and exposing the confluent sporangia. - Low ferns, with smooth, 2-3-pinnate fronds, the fertile ones taller than the sterile, and with much narrower divis-

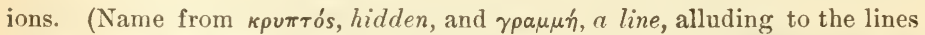
of sporangia at first concealed by the reflexed margin.)

1. C. acrostichoides, R. Brown. Stipes densely tufted, straw-colored; fronds 2-3-pinnate $\left(6-10^{\prime}\right.$ high $)$; fertile segments stalked, linear or linearoblong $\left(3-5^{\prime \prime}\right.$ long), the sporangia in lines extending down the veins almost 
to the midrib, confluent when ripe and covering the under surface of the now fully opened segments; sterile fronds on much shorter stipes, with ovate or obovate decurrent and erenately toothed or incised segments. (Allosorus acrostichoides, Sprengel.) - ()n rucks, from L. Superior westward and northwarl. - Very near C. erispa of lu.

\section{WOODW ÁRDIA, Smitl. Cnus-Frnx. (Pl. 17.)}

Fruit-dots oblong or linear, arranged in one or more chain-like rows on transverse anastomosing veinlets parallel and near to the midrih. Indusium fixed by its outer margin to the fruitful veinlet, free and opening on the side next the midrib. Veins more or less reticulated, free toward the margin of the frond. - Iarge ferns, with pinnatifid or pinnate fronds. (Named for Thomos. $J$. Woodward, an English botanist.)

\$1. ANCHISTE $\Lambda$. Sterile and fertile fronds alike; veins forming only one row of meshes (areoles).

1. W. Virgínica, Smith. (Pl. 17, fig. 4, 5.) Fronds $\left(2-3^{\circ}\right.$ high) pinnate, with numerous lanceolate pinnatifid pinna; segments oblong; reins forming a row of narrow areules along the midrib both of the pinua and of the lobes, the outer veinlets free; fruit-dots oblong, one to each areole, confluent when ripe. - Wet swamps, Maine to Ark., and southward. Rootstocks creeping, often $6-8^{\circ}$ long! July.

§2. LORINSERIA. Sterile and fertile fronds unlike; veins of the sterile fronds forming many rows of meshes.

2. W. angustifòlia, Smith. (Pl. 17, fig. 1-3.) Fronds pinnatifid; sterile ones $\left(12-18^{\prime}\right.$ high) with lanceolate serrulate divisions united by a broal wing; fertile fronds taller, with narrowly linear almost disconnected divisions, the areoles and fruit-dots $\left(4-5^{\prime \prime}\right.$ long) in a single row each side of the secondary midribs; rootstocks creeping. - Wet woods, New ling., near the cuast, to Ark., and southward; rare. $\Lambda$ ng., Sept.

\section{A S P L E N I M, L. Srleenwort. (Pl. 18.)}

Fruit-dots oblong or linear, oblique, separate; the straight, or rarely curved, indasium fixed lengthwise by one edge to the upper (inner) side of the fertile vein ; - in some species a part of the fruit-dots are double, the fertile vein bearing two indusia placed back to back. Veins free in all our species. (Name from $a$-privative and $\sigma \pi \lambda \eta \nu$, the spleen, for supposed remedial properties.)

§ 1. ASPIENIUM proper. Indusium straight or slightly currerl, attached to the upper side of the vein, rarely double.

* Small evergreen ferns; fronds pinnatifid, or pimate mly near the base.

1. A. pinnatífidum, Nutt. Fronds $\left(3-6^{\prime}\right.$ long) lanceolate, pinnatifid, or pinnate below, tapering above into a slender prolongation, " the apex sometimes rooting"; lobes roundish-orate, obtusp, or the louest pair long-ncuminate; fruitdots irregular, those next the millib often double, even the sleuler prolongation fertile. - On cliffs and rocks, l'enn. to Mu., and sonthward; very rare. July. - Resembles the Walking-Ieaf (Camptosorus), hut the veins aro free. Stipes brownish, becoming green above, and so passing into the broad pale green midrib. 
2. A. ebenotdes, R. R. Scott. Fronds $\left(4-9^{\prime}\right.$ long) broadly lanceolate pinnatifid, below pinnate, the apex prolonged and slender; divisions lanceolate from a broad base, the lower ones shorter, often proliferous, as is the apex of the frond; fruit-dots much as in the last; stipes black and polished, as is the lower part of the midrit, especially beneath. - Limestone cliffs, Conn. and Penn., and southward; very rare, usually growing with Camptosorus and Asplenium ebeneum, of which Rev. M. G. Berkeley considered it a probable hybrid.

* * Small evergrcen ferns; the narrow fronds simply pinnate with numerous pinne.

+ Pinne not auricled.

3. A. víride, Hudson. Fronds $\left(2-5^{\prime} \mathrm{long}\right)$ tufted, linear in outline, pale green, softly herbaceous; pinnce roundish-orate or orate-rhomboid, short-stalked, crenately toothed $\left(2-4^{\prime \prime}\right.$ long), the midvein indistinct and forking; the slender stipe brownish and passing into a green herbaceous rhachis. - Shaded cliffs; northern New Eng., west and northward; rare. (Eu.)

4. A. Trichómanes, L. Fronds $\left(3-8^{\prime}\right.$ long) in dense spreading tufts, linear in outline, dark green and more rigid; pinnce roundish-oblong or oval $\left(3-4^{\prime \prime}\right.$ long), entire or crenulate, rarely incised, unequal-sided, obliquely wedge-truncate at base, attached by a narrow point, the midvein forking and evanescent; the thread-like stipe and rhachis purple-brown and shining. - Shaded cliffs; common. July. (Eu.)

+ + Pinnce more or less auricled.

5. A. párvulum, Mart. \& Gal. Fronds upright $\left(4-10^{\prime}\right.$ high), narrowly linear-oblanceolate; pinnce (2-6" long) rigid and thickish, mostly opposite, nearly sessile, somewhat deflexed, oblong, obtuse, entire or crenulate, auricled on the upper or both sides; sori rather few, as near the margin as the continuous midvein; stipe and rhachis black and shining. - Mountains of Va. to Mo., and sonthward. - Nearly intermediate between the last and the next.

6. A. ebèneum, Ait. Fronds upright $\left(9-18^{\prime}\right.$ high $)$, linear-oblanceolate in outline, fertile ones much the taller; pinnce $\left(6-18^{\prime \prime} \mathrm{long}\right)$ firnly membranaceous, mostly alternate, sessile, spreading, oblong or oblong-linear, finely serrate or even incised, the base auricled on the upper or both sides; sori many, nearer the elongated midvein than the margin; stipe and rhachis blackishpurple and shining. - Rocky, open woods; rather common.

*** Small evergreen ferns; the broader fionds 1-3-pinnate; pinnoe incised.

7. A. Bradlèyi, D. C. Eaton. Fronds oblong-lanceolate, $4-\tau^{\prime}$ long, besides the blackish and somewhat shining stipe, membranaceous, piniate; pinnæ rather numerous, the lower ones no larger than the middle ones, all short-stalked, oblong-ovate, obtuse, incised or pinnatifid into oblong toothed lobes. - On rocks, Ky. and sonthward; rare. $\Lambda$ single plant has been gathered near Newburg, N. Y. - Intermediate between A. ebeneum and A. montanum.

8. A. montànum, Willd. Fronds orate-lanceolate firm a broad base (2$5^{\prime}$ long), subcoriaceous, pinnate; pinnæ ovate-oblong, the lowest pinnately cleft into oblong or ovate cut-toothed lobes, the upper gradually simpler; rhachis green, broad and flat; stipe brown at base. - Cliffs and rocks, from Conn. and Penn. to Ky., and southward. July.

9. A. Rùta-murària, L. Fronds deltoid-ovate $\left(1-2 \frac{1^{\prime}}{2}\right.$ long), subcoriaceous, laxly 2-3-pinnate at base, the pinnæ alternate; ultimate segments few, 
stalked (2-5" long), from narrouly cuneate to roundish-obvate, toothed or incised at the apex; veins forking; sori 2-4 on a segment. - Limestone cliffs, V't. to Mich., and southward; scarce. July. (Eu.)

****Tall ferns $\left(2-4^{\circ}\right.$ high $)$, not evergreen; fronds pinnate or sub-bipinnate.

10. A. angustifolium, Michx. Fronds thin, simply pirnate; pinnte numerous, short-stalked, lineur-lanceolate, acuminute, cntire or crenulate (3-4' long), those of the fertile frond narrower; fruit-dots linear, 20-40 each side of the midvein; indusia slightly convex. - Rich woods, W. New Eng. to Wisc,, and southward along the mountains. Sept.

11. A. thelypteroides, Michx. (l'l. 18, fig. 1, 2.) Fronds $\left(2-3^{\circ}\right.$ high) pimnate; pinne deeply pinnatifid, linear-lanceolate $\left(3-5^{\prime}\right.$ long $)$; the lobes oblong, obtuse, minutely toothed, crowder, each bearing 3-6 pairs of oblong finit-dots, some of them double. - Rich woods; not rare. July-Sept.

§2. ATHÝRIUM. Indusium delicute, curved, often crossing the vein, and attached to both sides of it, thus becoming reniform, or shaped like a horseshoe.

12. A. Filix-fœémina, Bernh. Fronds $\left(1-3^{\circ}\right.$ high $)$ ovate-oblong or broadly lanceolate, twice pinnate; pinnæ lanceolate, numeruus; pinnules confluent on the secondary rhachis by a narrow margin, oblong and doubly serrate, or elongated and pinnately incised with cut-toothed segments ; fruit-dots short, variously curved, at length conflnent. - Moist woods ; common and presenting many varying forms. July. (Eu.)

\section{SCOLOPÉ N D R I M, Smith. Hart's-Toxgue. (Pl. 18.)}

Fruit-dots linear, elongated, almost at right angles to the midrib, contiguous by twos, one on the upper side of one veinlet, and the next on the lower side of the next superior veinlet, thus appearing to have a double indusium opening along the middle. (The ancient Greek name, so called because the numerous parallel lines of fruit resemble the feet of the centipede, or Scolopendra.)

1. S. vulgàre, Smith. Frond oblong-lanceolate from an auricled-lieartshaped base, entire or wavy-margined ( $7-18^{\prime}$ long, 1-2' wide), bright green. - Shaded ravines and under limestone cliffs; central N. Y.; also in Canada and Tenn.; very rare. $\Lambda$ ug. (Eu.)

\section{C A M PTós Ò U S, Link. Walking-Leaf. (Pl. 18.)}

Fruit-dots oblong or linear, as in Asplenium, but irregularly scattered on either side of the reticulated veins of the simple frond, those next the midrib single, the outer ones inclined to approximate in pairs (so that their two indusia open face to face), or to become confluent at their ends, thus forming crooked lines (whence the name, from $\kappa a \mu \pi \tau o ́ s, ~ b e n t$, and $\sigma \omega \rho o ́ s$, for fruit-dot.)

1. C. rhizophýllus, Link. Fronds evergreen, sub-coriaceous, growing in tufts, spreading or procumbent $\left(4-12^{\prime}\right.$ long), gradually narrowed from a cordate or auricled base to a long and slender acnmination, which often roots at the end and forms a new plant. - Shaded rocks, especially calcareous rocks, N. Eng. to Minn., and southwarl to Kan. and Ala. - The auricles are sometimes greatly elongated, and even rooting; in another form they are lacking, as in the thinner leaved C. Sibiricus. July. 


\section{PHeGó Pteris, Fée. Веech Fern.}

Fruit-dots small, round, naked (no indusium), borne on the back of the veins below the apex. Stipe continuous with the rootstock. - Our species have free veins and bright green membranaceous fronds, decaying in early autumn. (Name composed of $\phi \eta \gamma \delta s$, an oak or beech, and $\pi \tau \epsilon \rho$ is, fern.)

* Fronds twice pinnatifid; pinnce all sessile, adnate to the winged rhachis.

1. P. polypodioides, Fée. Fronds triangular, longer than broad (4-9' iong), hairy on the veins, especially beneath; pinnæ linear-lanceolate, the lowest pair deflexed and standing forward; their divisions oblong, obtuse, entire, the basal decurrent upon the main rhachis ; fruit-dots all near the margin. Damp woods; common northward. July. - Rootstock slender, creeping, bearing a few distant slender stalks, rather longer than the fronds. (Eu.)

2. P. hexagonóptera, Fée. Fronds triangular, usually broader than long (7-12' broad), slightly pubescent and often finely glandular beneath; pinnæ lanceolate; upper segments oblong, obtuse, toothed or entire, those of the very large lowest pinnce elongated and pinnately lobed, basal ones very much decurrent and forming a continuous many-angled wing along the main rhachis; fruit-dots near the margin; some also between the sinus and the midrib. - Rather open woods, New Eng. to Minn., and southward; common. July. - Larger and broader than the last, which it often closely resembles.

* Fronds ternate, the three divisions petioled; rhachis wingless.

3. P. Dryópteris, Fée. Fronds smooth, broadly triangular (4-6' wide); the three triangular primary divisions all widely spreading, 1-2-pinnate; segments oblong, obtuse, entire or toothed; fruit-dots near the margin. - Rocky woods; common northwarl. July. (Eu.)

4. P. calcàrea, Fée. Fronds minutely glandular and somewhat rigid, the lateral divisions ascending: lowest inferior pinnæ of the lateral divisions smaller in proportion than in the last species, which it otherwise closely resembles. - Iowa and Minn.; rare. July. (Eu.)

\section{A S PÍd I M, Swartz. Simeld Fern. Wood Ferx. (Pl. 19.)}

Fruit-dots round, borne on the back or rarely at the apex of the veins. Indusium covering the sporangia, flat or flattish, scarious, orbicular and peltate at the centre, or round-kidney-shaped and fixed either centrally or by the sinus, opening all round the margin. Stipe continuous (not articulated) with the rootstock. - Our species have free veins and 1-3-pinnate fronds. (Name,

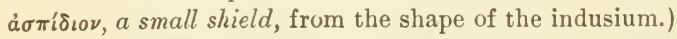

§ 1. DRYÓPTERIS. Indusium reniform, or orbicular with a narrow sinus.

* Veins simple or simply forked and straight; fronds annual, decaying in autumn, the stalks and slender creeping rootstocks nearly naked.

1. A. Thelýpteris, Swartz. Fronds pinnate, lanceolate in outline; pin$\mathrm{n} \circledast$ horizontal or slightly recurved, linear-lanceolate, deeply pinuatifid, the lowest pairs scarcely smaller; lobes oblong, entire, obtuse or appearing acute when in fruit from the strongly revolute margins; veins mostly forked, bearing the (soon confluent) fruit-dots near their middle; indusium minute, smooth and naked. - Marshes; common. Aug. - Stalk $1^{\circ}$ long or more, usually longer than the frond, which is of thicker texture than the next, and slightly downy. (Eu.) 
2. A. Noveboracénse, Swartz. Fronds pinnate, lanceolate in outline, rapering both ways fiom the middle; pinua lanceolate, the louest 2 or more jairs gradually shorter and deflexed; lubes flat, oblong, basal ones often enlarged and incised; reins simple, or forked in the basal lobes; fruit-duts distinct, near the margin ; indusium minute, the margin glanduliferous._- Swamps and moist thickets; common. July. - Frond pale green, delicate and membranaceous, hairy beneath along the midribs and veins.

* Veins, at least the lowest, more than once forked or somewhat pinnately branching; fruit-bearing veinlets often obscure or vanishing above the fruitdot; fronds, at least the sterile ones, often evergreen; stalks and apex of the thickened rootstock scaly or chaffy, and often the main rhachis also.

- Fronds small, pinnate; pinnce pinnatifid; indusia very large, persistent.

3. A. fràgrans, Swartz. Fronds (4-12' high) glandular and aromatic, narrowly lanceolate, with linear-oblong pinnately-jarted pinnæ; their crowded divisions (2" long) oblong, obtuse, toothed or nearly entire, nearly covered beneath with the very large thin imbricated indusia, which are orbicular with a narrow sinus, the margin sparingly glanduliferous and often ragged. - On rocks, especially near waterfalls, mountains of northern New Eng., west and northward. - Rootstock stout, nearly erect, densely chaffy, as are the crowded stipes and rhachis. (Asia, and barely reaching S. E. Eu.)

+ + Large (1 - 2! 0 high), the fronds mostly twice pinnate with variously toothed and incised pinnules; indusia rather small, shrivelled in age, or deciduous.

4. A. spinulosum, Swartz. Stipes with a few pale-brown deciduous scales; frond ovate-lanceolate, twice pinnate; pinnce oblique to the rhachis, elongated-triangular, the lower pairs broadly triangular; pinnules set obliquely on the midribs, connected by a very narrow wing, oblong, acute, incisely serrate or pinnatifid with spinulosely-toothed lobes; indusium smooth and without marginal glands. - In damp woods, New Eng. to Ky., and northward. July. - The common European type, rare in North America. (Eu.)

Var. intermedium, 1). C. Eaton. Scales of the stipe few, broun with a darker centre; frond broadly oblong-ovate, twice or often thrice pinnate; pinnce spreading, oblong-lanceolate, the lower unequally triangular-ovate; pinnules crowded, ovate-oblong, spreading, pinnately divided; the oblong lobes spinulose-toothed at the apex; margin of the indusium denticulate and beset with minute stalked glands. - Woods, everywhere.

Var. dilatàtum, Hook. Scales of the stipe large, brown with a dark centre; frond broader, ovate or triangular-ovate in outline, oftenest thrice pinnate; pinuules lance-oblong, the lowest often much elongated; indusium (in tho North American plant) smooth and naked. $-\Lambda$ (iwarf state, fruiting when only $5-8^{\prime}$ high, answers to var. dunnetorum. $-N$. New Eng. to Minn., chiefly in mountain woods, aud northward. (Eu.)

5. A. Boottii, Tuckerman. Scales of the stipe pale-broun: fronds $\left(1-2 \frac{1}{2}^{\circ}\right.$ long) elongated-lanceolate in outline, somewhat narrowed at hase ; lowest pinиæ triangular-ovate, the upper longer and narrower; pinnules oblong-ovate, sharply spinulose-serrate or the lower pinuatifil; indusium minutely glandular. (A. spinulosum, var. Boottii, of last ed. A. cristatum, var. uliginusum, Milde.) - Wet thickets and about ponds, New Eng. to Del. and Xíinn. July. - Sterile fronds much smaller and simpler than the fertile. (Lu.) 
+++ Large $\left(2-4^{\circ}\right.$ high $)$; fronds once pinnate and the pinnce deeply pinnatifid, or nearly twice pinnate; fruit-dots not very near the margin; the indusium large, thinnish and flat, persistent.

6. A. cristàtum, Swartz. Frond linear-oblong or lanceolate in outline $\left(1-2^{\circ}\right.$ long) ; pinnce short $\left(2-3^{\prime}\right.$ long), triangular-oblong, or the lowest nearly triangular-ovate, from a somewhat heart-shaped base, acute, deeply pinnatifid; the divisions ( $6-10$ pairs) oblong, very obtuse, finely serrate or cut-toothed, the lowest pinnatifid-lobed; fruit-dots as near the midvein as the margin; indusium round-reniform, the sinus mostly shallow, smooth and naked. - Swamps, etc.; common. July. - Stipes and the stout creeping rootstock bearing broad and deciduous chaffy scales. (Eu.)

Var. Clintoniànum. Frond in every way much larger $\left(2 \frac{1}{2}-4^{\circ} \mathrm{long}\right)$, pinnee oblong-lanceolate, broadest at base $\left(4-6^{\prime}\right.$ long, $1-2^{\prime}$ broad), deeply pinnatifid; the divisions ( $8-16$ pairs) crowded or distant, linear-oblong, obtuse, obscurely serrate or cut-toothed, the basal sometimes pinnately lobed; reins pinnately forking, the lowest anterior veinlets bearing the fruit-dots near the midvein; indusium orbicular with a shallow sinus, smooth and naked. Swampy woods, New Eng. to N. J., N. Y. (G.W. Clinton, etc.), and westward. July. - Rootstock stout, creeping, chaffy (like the stipes) with large bright-brown scales. A showy fern, unlike any European form of A. cristatum, and often mistaken for A. Goldianum.

7. A. Goldiànum, Hook. Frond broadly ovate, or the fertile orateoblong in outline $\left(2-3^{\circ} \mathrm{long}\right)$; pinnce $\left(6-9^{\prime}\right.$ long $)$, oblong-lanceolate, broadest in the middle, pinnately parted; the divisions (about 20 pairs) oblong-linear, slightly scythe-shaped $\left(9-15^{\prime \prime}\right.$ long), serrate with appressed teeth; veins pinnatcly forking and bearing the fruit-dots very near the midvein; indusium very large, orbicular with a deep narrow sinus, smooth and without marginal glands. - Rich and moist woods, from Conn. to Ky., and northward. July. - A stately fern, often $4^{\circ}$ high, the fronds growing in a circle from a stout ascending chaffy rootstock, and decaying in autumn. Indusium with the sides of the sinus often overlapping, thus appearing to be round and entire as in § Polystichum.

++++ Large $\left(1-3^{\circ}\right.$ high $)$; stipes very chaffy at base; fronds twice pinnate, but the upper pinnules confluent, some of the lower pinnatifid-toothed; fruitdots rather large; indusium convex, without marginal glands, persistent.

8. A. Fílix-mas, Swartz. Frond lanceolate in outline $\left(1-3^{\circ}\right.$ high $)$; pinnæ linear-lanceolate, tapering from base to apex; pinnules oblong, very obtuse, serrate at the apex and obscurely so at the sides, the basal incisely lobed, distinct, the upper confluent; fruit-dots nearer the midvein than the margin, and usually confined to the lower half of each fertile pinnule. Rocky woods, N. Mich. to Dak. and Col. - Frond thickish but not surviving the winter. (Eu.)

9. A. marginàle, Swartz. (Pl. 19, fig. 1, 2.) Frond evergreen, smooth, thickish and almost coriaceous, ovate-oblong in outline $\left(1-2^{\circ} \mathrm{long}\right)$; pinnæ lanceolate, acuminate, slightly broadest above the base; pinnules oblong or oblong-scythe-shaped, crowded, obtuse or pointed, entire or crenately-toothed; fruit-dots close to the margin. - Rocky hillsides in rich woods; common, especially northward. Aug. 
§2. POIXYSTICHUM. Indusinm orbicular and entire, peltute, fixed by the depressed centre; fronds rigid and coriaccous, evergreen, very chaffy on the rhachis, etc.; pinne or pinnules anricled at base on the upper side, crowded, the teeth or loles bristle-tipped.

* Fronds simply pinnate.

10. A. acrostichoides, swartz. (Cunistuas Ferx.) (P1.19, fig. 3, 4.) Frond lanceolate $\left(1-2 \frac{1}{2}^{\circ}\right.$ ligh), stalked; pinnce linear-lanceolate, somewhat scythe-shaped, half-halberi-shaped at the slightly stalked base, serrulate with appressed bristly teeth; the fertile (upper) contracted and smaller, bearing contiguous fruit-dots near the nidrib, which are confluent with age, covering the surface. - Var. ıncisum is a state with cut-lobed pinnæ, a not unfrequent case in the sterile fronds; sometimes with all the tips fertile.-Common in rocky woods, especially northwari. July.

11. A. Lonchitis, Swartz. Frond linear-lanceolate $\left(9-20^{\prime}\right.$ high $)$, scarcely stalked, very rigid; pinna broadly lanceolate-scythe-shaped, or the louest triangular, strongly auricled on the upper side, and wedge-truncate on the lower, densely spinulose-toothed ( $l^{\prime}$ or less in length), copiously fruit-bearing; fruitdots contiguous and near the margins. - Woods, southern shore of Lake Superior, and northward. (Eu.)

\section{* Fronds bipinnate.}

12. A. aculeàtum, Swartz, var. Braùnii, Koch. Fronds spreading ( $1 \frac{1}{2}-2^{\mathrm{C}}$ long), oblong-lanceolate in outline, with a tapering base, the lower of the many pairs of oblong-lanceolate pinnæ gradually reduced in size and obtuse; pinnules ovate or oblong, obtuse, truncate and alınost rectangular at base, short-stalked, or the upper confluent, sharply toothed, beset with long and soft as well as chaffy hairs. - Deep woods, mountains of New Eng., N. Y., and Penn., and northward. (Eu.)

\section{CySTÓ PTERIS, Bernhardi. Bladder Fern. (P1. 19.)}

Frnit-dots roundish, borne on the back of a straight fork of the free veins; the delicate indusium hood-like or arched, attached by a broad base on the inner side (toward the midrib) partly uuder the fruit-dot, early opening free at the other side, which looks toward the apex of the lobe, and is somewhat jagged, soon thrown back or withering away. - Tufted ferns with slender and delicate 2-3-pinnate fronds; the lobes cut-toothed. (Name composed of $\kappa \dot{\sigma} \sigma \tau \iota$, a bladder, and $\pi \tau \epsilon \rho i s$, fern, from the inflated indusium.)

1. C. bulbífera, Beruh. (Pl. 19, fig. 1-3.) Frond lanceolate, elongated ( $1-2^{\circ}$ long), 2 -pinnate; the pinnæ lanceolate-oblong, pointed, horizontal (1 2 ' long); the rhachis and pinnce often bearing bulblets underneath, wingless; pinnules crowded, oblong, obtuse, toothed or pinnatifid; indusium short, truncate on the free side. - Shaded ravines, not rare from N. Fing. to Ark., commoner on calcareons rocks. July. - Specimens from 'Tenn. and Ark. havo sometimes shorter frouds and few or no bulblets, indicating an approach to the next species.

2. C. frágilis, Bernh. Frond oblong-lanceolate (4-8' long, besides the brittle stalk which is fully as long), 2-3-pinuate; the pinna and pinnules ovato or lanceolate in outline, irregularly pinnatifid or cut-toothed, mostly acute, 
decurren. on the nargined or winged rhachis; indusium tapering or acute at the free end. - Shaded cliffs and rocky woods; common and greatly varying in the shape and cutting of the pinnules. July. (Eu.)

\section{ONOCLitA, L. (H1. 16 and 19.)}

Sporangia borne on elevated receptacles, forming roundish sori imperfectly covered by very delicate hood-shaped indusia attached to the base of the receptacles. Fertile fronds erect, rigid, with contracted pod-like or berry-like divisions at first completely concealing the sporangia, and at last, when dry and indurated, cracking open and allowing the spores to escape. Sterile fronds foliaceous. Rootstocks creeping and constantly forming new plants. (Name apparently from óvos, a vessel, and $\kappa \lambda \epsilon i \omega$, to close, from the singularly rolled up fructification.)

§1. ONOCLEA proper. Sterile frond with anastomosing veins.

1. O. sensíbilis, L. (Sensitive Fern.) (Pl. 19, fig. 1, 2.) Fronds scattered; the sterile ones long-stalked $\left(2-15^{\prime}\right.$ long), triangular-ovate, pinnatifid into a few oblong-lanceolate sinuately lobed or nearly entire segments; veins reticulated with fine meshes; fertile fronds contracted, closely bipinnate, the pinnules rolled up into berry-like bodies. - Moist meadows and thickets, very common and variable. July. - Imperfectly fertile fronds sometimes occur, with the still foliaceous pimn cut into obovate segments with free veins and abortive sori; the so-called var. овтеsilobita.

\section{§2. STRUTHIÓPTERIS. Sterile frond with free reins.}

2. O. Struthiópteris, Hoffmann. (Pl. 16, fig. $1-5$.) Fronds growing in a crown ; sterile ones short-stalked $\left(2-10^{\mathrm{\rho}}\right.$ high $)$, broadly lanceolate, narrowed toward the base, pinnate with many linear-lanceolate, pinnatifid pinna; veins free, the veinlets simple; fertile frond shorter, pinnate with pod-like or somewhat necklace-shaped pinnæ. (Struthiopteris Germanica, Willd.) Alluvial soil, common northward. July. - The rootstock sends out slender uuderground stolons, which bear fronds the next year. (Eu.)

\section{WO Ó DSIA, R. Brown. (Pl. 19.)}

Fruit-dots round, borne on the back of simply-forked free reins; the rery thin and often evanescent indusium attached by its base all around the receptacle, under the sporangia, either small and open, or else early bursting at the top into irregular pieces or lobes. - Small and tufted pinnately-divided ferns. (1)edicated to Joseph Woods, an English botanist.)

* Stalks obscurely articulated some distance from the base; fronds chaffy or smooth, never glandular; indusium divided nearly to the centre into slender hairs which are curled over the sporangia.

1. W. Ilvénsis, R. Brown. Frond oblong-lanceolate $\left(2-6^{\prime}\right.$ long by $12-$ $18^{\prime \prime}$ wide), smoothish and green above, thackly clothed underneath as well as the stalk with rusty bristle-like chaff, pinnate; the pinnæ crowded, oblong, obtuse, sessile, piunately parted, the numerous crowded segments oblong, obtuse, obscurely crenate; the fruit-dots near the margin, somewhat confluent when old. - Exposed rocks; common, especially northward, and southward in the Alleghanies. June. (Eu.) 
2. W. hyperborea, R. Brown. Frond narrowly oblong-lanceolate (2$6^{\prime}$ long by $8-12^{\prime \prime}$ wide), smooth above, sparingly palcaceous-hirsute beneath, pinnate; the pinna triangular-ovate, obtuse, pinnately lobed, the lobes fow and nearly entire; fruit-dots rarely confluent. - Mountain ravines, northern Vt. and N. Y., and northward ; rare. (Eu.)

3. W. glabélla, R. Brown. (1'1. 19, fig. 1-3.) Simooth and naked throughout; firond linear and very delieate (2 - 5' high), pinnate; pinne roundish-ocate, the lower ones rather remote $(2-4$ "long $)$, obtuse, crenately lobed; fruit-dots scanty; the hairs of the indusium fewer than in the last two species. - On moist mossy rocks, mountains of northern New Eng., north and westward. First found at Little Falls, N. Y., by Dr. Vasey. (Eu.)

* * Stalks not articulated; fionds never chaffy, often glandular-pubescent.

- Indusium of a few broad seyments, at first covering the sorus completely.

4. W. obtùsa, Torr. (I'l. 19, fig. 4, 5.) Frond broally lanceolate, minutely glandular-hairy $\left(6-12^{\prime}\right.$ high $)$, pinnate, or nearly twice pinnate; piunx rather remote, triangular-ovate or oblong $\left(1-2^{\prime}\right.$ long), hluntish, pinnately parted ; segments oblong, obtuse, crenately toothed, the lower pinnatifi.l with toothed lobes; reins forked, and bearing the fruit-dots on or below the minutely toothed lobes; indusium at length splitting into several spreading jagged lobes. - Rocky bauks and cliffs; not rare.

+- Indusium entirely concealed beneath the sorus, divided into very narrow segments or reduced to minute hairs.

5. W. Oregàna, D. C. Eaton. Smooth, with fronds $\left(2-8^{\prime}\right.$ high, $8-12^{\prime \prime}$ wille) elliptical-lanceolate, pinnate, the fertile ones tallest; pinnx triangularoblong, obtuse, pinnatifid; segments oblong or ovate, obtuse, finely toothed, and in larger fronds incised; fruit-dots near the margin; indusium very small, divided almost to the centre into a few necklace-like-jointed cilia. - Crevices of rocks, south shore of Lake Superior (Rublins), and westward.

6. W. scopulina, D. C. Eaton. Much like the last, hut the rather larger fronds puberulent beneath with minute jointed hairs and stalked glands; indusium deeply cleft into narrow segments ending in jointed hairs. - Rocky places, Minn., southward and westward.

\section{DI C K S Ò N I A, L'Her. (Pl. 18.)}

Fruit-dots small, globular, marginal, each placed on the apex of a free vein or fork; the sporangia borne on an elevated globular receptacle, enclused in a membranaceous cup-shaped indusium which is open at the top, and on the outer side partly adherent to a reflexed toothlet of the frond. (Named for James Dickson, an English Cryptogamic botanist.)

1. D. pilosiúscula, Willd. Fronis minntely glanlular and hairy $\left(2-3^{2}\right.$ high), ovate-lunceolate and acuminate in ontline, pale green, very thin, with strong chafiless stalks rising from slender extensively crecping naked rootstoeks, mostly bipinuate; primary pinna lanceolate, pointod, the secondary pinnatifid into oblong and olsuse cut-toothed lobes; fruit-1ots minute, each on a recurved toothlet, usually one at the upper margin of each lobe. (D. punctilobula, Kunze.) - Common in moist and shady places, from New Eng. to Minn. - Frond sweet-scented in drying. 


\section{TRICHÓMANES, L. FilMY FERN.}

Sporangia with a transverse entire ring, sessile on a cylindrical receptacle which is produced from the end of a rein and enclosed in a funnel-form or cup-shaped involucre of the same substance with the frond. Fronds very thin and pellucid, often consisting of a single layer of cells. (An ancient Greek name for some fern.)

1. T. radicans, Swartz. Fronds very delicate, oblong-lanceolate in outline ( $4-8^{\prime}$ long, $6-18^{\prime \prime}$ wide), bipinnatifid; rhachis narrowly winged; pinnæ triangular-ovate, the divisions toothed or again lobed; involucres tubularfunnel-shaped, margined, the mouth truncate; receptacle often much exserted. - On moist and dripping sandstone cliffs, Ky., and sonthward; rare. - Though the fronds are so very delicate, yet they survive for several years; they begin to fruit the second or third year, and thereafter the receptacle continues to grow and to produce new sporangia at its base. (Eu.)

\section{SCHIZ度 A, Smith.}

Sporangia large, ovoid, striate-rayed at the apex, opening by a longitudinal cleft, naked, vertically sessile in a double row along the single vein of the narrow divisions of the pinnate (or radiate) fertile appendages to the slender and simply linear, or (in foreign species) fan-shaped or dichotomously many-cleft fronds (whence the name, from $\sigma \chi i \zeta \omega$, to split).

I. S. pusílla, Pursh. Sterile fronds linear, very slender, flattened and tortuous; the fertile ones equally slender ( $x^{\prime \prime}$ wide), but taller $\left(3-4^{\prime}\right.$ high), and bearing at the top the fertile appendage, consisting of about 5 pairs of crowded pinnæ (each 1-1 $\frac{1}{2}$ " long). - Low grounds, pine barreus of N.J.; very local. Sept. (Also in Nova Scotia and Newf.)

\section{LY Y Ò D U M, Swartz. Climbixg Ferx. (Pl. 20.)}

Fronds twining or climbing, bearing stalked and variously lobed (or compound) divisions in pairs, with mostly free veins; the fructification on separate contracted divisions or spike-like lobes, one side of which is corered with a double row of imbricated hooded scale-like indusia, fixed by a broad base to short oblique veinlets. Sporangia much as in Schizæa, but oblique, fixed to the reinlet by the inner side next the base, one or rarely two covered by each indusium. (Name from $\lambda v \gamma \omega \dot{\delta} \eta s$, flexible.)

1. L. palmàtum, Swartz. Very smooth; stalks slender, flexile and twining ( $1-3^{\circ}$ long), from slender running rootsticks; the short alternate branches or petioles 2 -forked; each fork bearing a round-heart-shaped palmately 4-7-lobed frondlet; fertile frondlets above, contracted and several times forked, forming a terminal panicle. - Low moist thickets and open woods, Mass. to Va., Ky., and sparingly southward; rare. Sept.

\section{OSMÚNDA, L. Flowering Fers. (Pl. 20.)}

Fertile fronds or fertile portions of the frond destitute of chlorophyll, very much contracted, and bearing on the margins of the narrow rhachis-like divis ions short-pedicelled and naked sporangia; these are globular, thin and reticulated, large, opening by a longitudinal cleft into two valves, and bearing near 
the apex a sinall patch of thickened oblong cells, the rudiment of a transverse ring. - Fronds tall and upright, growing in large crowus from thickened rootstocks, once or twice pinnate; veins forking and free. Spores green. (Osmunder, a Saxon uame of the Celtic divinity, Thor.)

\section{* Sterile fronds truly bipinnate.}

1. O. regàlis, L. (Flowenixg Fewx.) Very smooth, pale green (2 $5^{\circ}$ high); sterile pinnules $13-25$, varying from oblong-oval to lance-oblong, finely serrulate, especially toward the apex, otherwise entire, or crenatcly lobed toward the rounded, oblique and truncate, or even cordate and semi-anriculate base, sessile or short-stalked ( $1-2^{\prime}$ long); the fertile racemose-panicled at tho summit of the frond. - Swanps and wet woods; common. The cordate pinnules sometimes found here are commoner in Europe. May, June. (Eu.)

* * Sterile fronds once pinnate; pinnce deeply pinnatifid; the lobes entire.

2. O. Claytoniàna, L. (1'1. 20, fig. 1-3.) Clothed with loose wool when young, soon sinooth; fertile fronds taller than the sterile $\left(2-4^{\circ}\right.$ high); pinuæ oblong-lanceolate, with oblong obtuse divisions; some $(2-5$ pairs $)$ of the middle pinnce fertile, these entirely pinuate; sporangia greenish, turuiug brown. - Low grounds, common. May. - Fruiting as it unfolds.

3. O. cinnamomea, L. (Crxsumox Fesix.) Clothed with rusty wool when young; sterile fronds tallest (at length $3-5^{\circ}$ high), smooth when full grown, the lanceolate pinnæ pinnatifid into broadly oblong obtuse divisions; fertile fronds separate, appearing earlier from the same rootstock and soon withering $\left(1-2^{\circ}\right.$ high), contracted, twice pinnate, covered with the cinnamoncolored sporangia. - Var. FroxdòsA is a rare oecasional state, in which sume of the fronds are sterile below and more sparsely fertile at their summit, or rarely in the middle. - Swamps and low copses, everywhere. May.

\section{Order 132. OPHIOGLOSS I CEAE. (AdDer's-Tongue FA.MLY.)}

Leafy and often somewhat fleshy plants; the leaves (froncls) simple or branched, often fern-like in appearance, erect in vernation, developed from underground buds formed either insile the base of the old stalk or by the side of it, and bearing in special spikes or panicles rather large subcoriaceous bivalvular sporangia formed from the main tissue of the fruiting branches. Prothallus underground, not green, monecious. $-A$ sinall order, separated from Ferns on account of the different nature of the sporangia, the erect vernation, etc.

1. Botrychium. Sporangia in pinnate or componnd spikes, distinct. Veins free.

2. Ophioglossum. Sporangia cohering in a simple spike. Veins reticulated.

\section{BOTRÝ CHIUM, Swartz. Mooxwort. (Pl. 20.)}

Rootstock very short, erect, with elustered fleshy roots (which are full of starch, in very minute, irregular granules!); the base of the naked stalk containing the bud for the next year's frond; frond with an anterior fertile and a posterior sterile segment; the former mostly 1-3-pinnate, the contracted divisions bearing a double row of sessile naked sporangia; these are distinct, rather coriaceous, not reticulated, globular, without a ring, and upen traus- 
versely into two valves. Sterile segment of the frond ternately or pinnately divided or compound; veins all free. Spores copious, sulphur-color. (Name a diminutive of Bótpus, a cluster of grapes, from the appearance of the fructification.)

$\S 1$. BOTRYCHIUM proper. Base of the stalk containing the bud completely closed; sterile segment more or less fleshy; the cells of the epidermis straight.

* Sterile portion of the frond sessile or nearly so at or above the middle of the plant. Plants small.

1. B. Lunària, Swartz. Sterile segment nearly sessile, borne near the middle of the plant, oblong, simply pinnate with 5-15 lunate or fan-shaped very obtuse crenate, incised or nearly entire, fleshy divisions, more or less excised at the base on the lower or on both sides, the veins radiating from the base and repeatedly forking; fertile segment panicled, 2-3-pinnate. - N. Eng. to Lake Superior, and northward; rare.- Very fleshy, 4-10' high. (Eu.)

2. B. simplex, Hitcheock. Fronds small $\left(2-4^{\prime}\right.$, rarely $5-6^{\prime}$ high), the sterile segment short-petioled from near the middle of the plant, thickish and fleshy, simple and roundish, or pinnately 3 -7-lobed; the lobes roundish-obovate, nearly entire, decurrent on the broad and flat indeterminate rhachis; the veins all forking from the base; fertile segment simple or 1-2-pinnate. - Maine to N. Y., Minn., and northward; rare. (Eu.)

3. B. lanceolàtum, Angstroem. Fronds small (3-10' high); the sterile segment closely sessile at the top of the long and slender common stalk, scarcely fleshy, triangular, ternately twice pinnatifid; the acute lobes lanceolate, incised or toothed; veinlets forking from a continuous midvein; fertile part 2-3-pinnate. - N. Eng. and N. J. to Ohio and Lake Superior. July - Aug. (Eu.)

4. B. matricarizfollium, Braun. Fronds small $\left(3-10^{\prime}\right.$ high); the sterile segment nearly sessile at the top of the long and slender common stalk, moderately fleshy, ovate or triangular, varying from pinnate to bipinnatifil; the lobes oblong-ovate and obtuse; midvein dissipated into forking veinlets; fertile part 2-3.pinnate. - Same range as the last. June, July. (Eu.)

* * Sterile portion of the frond long-stalked; the common stalk short in proportion to the size of the plant. Plants usually larger.

5. B. ternàtum, Swartz. (Pl. 20.) Plant very fleshy $\left(4-16^{\prime}\right.$ high), sparsely hairy; sterile segment long-petioled from near the base of the plant, broadly triangular, ternate and variously decompound with stalked divisions; nltimate segments varying from roundish-reniform and sub-entire to ovatelanceolate and doubly incised; fertile segment erect, 2-4-pinnate. - The following varieties pass into each other : - Var. A LSTRA LE ; frond ample; ultimate segments rhomboid-ovate with a denticulate margin. - Var. INTERMìnium; frond of moderate size; ultimate segments as in var. australe. (B. lunarioides, of last ed.) - Var. RUT.єFòlum ; frond sinall; ultimate segments few, ovate and semicordate. - Var. LUNARIOÌDEs ; frond small ; ultimate segments roundish-reniform. - Var. oBLìQU UM f frond moderate ; ultimate segments obliquely lanceolate, denticulate or toothed. - Var. Disséctur ; segments dissected into innumerable narrow lobes or teeth. - Pastures and hillsides, sometimes in dry woods, rather common, especially vars. intermedium and obliquum. - Var. rutæfolium occurs in Europe. 
§ 2. OSMUNDÓP'TERIS. Base of the stulk containing the bud open along one side; sterile segment membranaceous; the cells of the epidermis flexuous.

6. B. Virginianum, Swartz. Fronds tall and ample; sterile segment sessile above the middle of the plant, broally triangular, thin and membranaceous, ternate; the short-stalked primary divisions once or twice pinnate, and then once or twice pinnatifid; the oblong lobes cut-toothed towarl the apex; reins forking from a midvein; fertile part 2-3-pinnate. - Rich wools; common. - I'lant $1-2^{\circ}$ high, or often reduced to a few inches, in which case it is B. gracile, Pursh. June, July. (Eu.)

\section{OPHIOGLÓSS U M, L. ADner's-Tongue. (Pl. 20.)}

Rootstock erect, fleshy and sometimes tuberous, with slencler fleshy roots which are sometimes proliferous; bud placed by the side of the base of the stalk; fronds with anterior and posterior segments as in Botrychinm, but the coriaceous sporangia connate and coherent in two ranks on the eilges of a simple spike. Sterile segment fleshy, simple in our sjecies; the veins reticulated. Fipores copfous, sulpliur-yellow. (Name from ö $\phi$ ss, a serpent, and $\gamma \lambda \hat{\omega} \sigma \sigma \alpha$, tongue.)

1. O. vulgàtum, L. Fronds from a slender rootstock (2-12' high), mostly solitary ; sterile segmeut sessile near the midllle of the plant, ovate or elliptical ( $1-3^{\prime}$ long); midvein indistinct or none; veins forming small meshes enclosed in larger omes. - Bogs and pastures; not common. July. (Eu.)

\section{Order 133. I YCOPODIÀCEA. (Club-Moss Family.)}

Low plants, usually of moss-like aspect, with elongated and often much branched stems covered with small lanceolate or subulate, rarely oblong or rounded, persistent entire leaves; the sporangia 1-3-celled, solitary in the axils of the leaves, or on their upper surface, when ripe opening into two or three valves, and shedding the numerous yellow spores, which are all of one kind. - The Order, as here defined, consists mainly of the large genus

\section{L Y C O P Ò D I U M, L. Chem-Moss. (Pl. 21.)}

Spore-cases coriaceous, flattened, usually kidney-shaped, 1-celled, 2-valved, mostly by a transverse line round the margin, discharging the subtile spores in the form of a copions sulphur-colored inflammable powder. - Perennials, with evergreen one-nerved leaves, imbricated or crowded in 4-16 ranks. (Name compounded of $\lambda u$ vos, $a \mathrm{wolf} f$, and $\pi$ ous, foot, from no obvious resemblance.)

$\S 1$. Spore-cases in the axils of the ordinary (dark green and shining, rigid, lanceolate, about 8-ranked) leares.

1. L. Selàgo, L. Stems erect and rigid, lichotomous, forming a leveltopped cluster (3-6' high) ; leares uniform, crowded, ascending, glossy, pointed, entire or denticulate sporangia in the axils of unaltered leaves. - Mountaintops, Maine to Lake Superior, and northward. - The leaves of this and the next species often bear little gemme, with the lower bracts pointed, and the 2-3 uppermost broally obovate and fleshy, as figured in 1768 by I)illenins. These gemma fall to the ground and their axis grows into the stem of a new plant, 
as specimens collected in 1854 show very plainly. (For their true nature see Sachs' Lehrbuch, Engl. trans., p. 411.)

3. L. lucídulum, Michx. Stems assurgent, less rigid, dichotomous (6 $12^{\prime}$ long); leaves pointed, toothed, at first spreading, then deflexed, arranged in alternate zones of shorter and longer leaves, the shorter leaves more frequently bearing sporangia in their axils; proliferous gemmæ usually abundant. - Cold, damp woods; common northward. Aug.

§ 2. Spore-cases only in the axils of the upper (bracteal) leaves, thus forming a spike.

* Leaves of the creeping sterile and of the upright fertile stems or branches and those of the simple spike nearly alke, many-ranked.

3. L. inundàtum, L. Dwarf; creeping sterile stems forking, flaccid; the fertile solitary $\left(1-4^{\prime}\right.$ high), bearing a short thick spike; leaves lanceolate or lance-awl-shaped, acute, soft, spreading, mostly entire, those of the prostrate stems curving upward. - Var. Bigelòviı, Tuckerm., has fertile stems 5 - $\boldsymbol{7}^{\prime}$ high, its leaves more awl-shaped and pointed, sparse-and more upright, often somewhat teeth-bearing. - Sandy bogs, northward, not common; the var., eastern New Eng. to N. J., and southward. Aug. (Eu.)

4. L. alopecuroides, L. Stems stout, very densely leafy throughout; the sterile branches recurved-procumbent and creeping; the fertile of the same thickness, 6-20' high; leaves narrouly linear-awl-shaped, spinulose-pointed, spreading, conspicuously bristle-toothed below the middle; those of the cylindrical spike with long setaceous tips. - Pine-barren swamps, N. J. to Va., and southward. Aug., Sept. - Stems, including the dense leaves, $\frac{1^{\prime}}{2}$ thick; the comose spike, with its longer spreading leaves, $\frac{8}{4}-1^{\prime}$ thick.

* * Leaves (bracts) of the catkin-like spike scale-like, imbricated, yellowish, ovate or heart-shaped, very different from those of the sterile stems and branches.

+ Spikes sessile (i.e. branches equally leafy to the top), single.

5. L. annótinum, L. Much branched; stems prostrate and creeping (1 $4^{\circ}$ long); the ascending branches similar $\left(5-8^{\prime}\right.$ high), sparingly forked; the sterile ones making yearly growths from the summit; leaves equal, spreading, in about 5 ranks, rigid, lanceolate, pointed, minutely serrulate (pale green); spike solitary, oblong-cylindrical, thick. - Var. PÉxGENs, Spring, is a reduced sub-alpine or mountain form, with shorter and more rigid-pointed erectish leares. - Woods; common northward; the var. on the White Mountains, with intermediate forms around the base. July. (Eu.)

6. L. obscùrum, L. Rootstock cord-like, subterranean, bearing scattered, erect, tree-like stems dividing at the summit into several densely dichotomous spreading branches; leaves linear-lanceolate, decurrent, entire, acute, 6-ranked, those of the two upper and two lower ranks smaller and appressed, the lateral ones incurved-spreading; spikes $1-10$, erect, mostly sessile; bracts scarious-margined, broadly ovate, abruptly apiculate. - Var. DENDRofDEcM (L. dendroideum, Michx.) has all the leaves alike and incurved spreading. Moist woods. Aug. - Remarkable for its tree-like appearance.

L. ALPINUM, L., or its var. SABINAFòlivM, occurs from Labrador to Washington Territory, and is to be expected in northern Maine and Minn. It has slender branches with rigid nearly appressed leaves. 
+ - Spikes peduncled, $i$. e. the leaves minute on the fertile branches.

+ Leares homogeneous and equal, many-ranked; stems terete.

7. L. clavàtum, L. (Commox Cucu-Moss.) Stems creeping extensively, with similar ascending short and very leafy branches; the fertile terminated by a slender peduncle $\left(4-6^{\prime} \mathrm{long}\right)$, bearing about $2-3$ (rarely 1 or 4 ) linear-cylindrical spikes; leaves linear-awl shaped, incurved spreading (light green), tipped, as also the bracts, with a fine bristle. - I)ry woods; common, especially northwarl. July. (Eu.)

$\rightarrow+$ Leaves of two forms, few-ranked; stems or branches flattened.

8. L. Caroliniànum, I. (l'l. 21.) Sterile stems and their few short branches entirely creeping (leafless and rooting on the under side), thickly cluthed with broadly lanceolate acute and somewhat oblique 1-nerved lateral leaves widely spreading in 2 ranks, and a shorter intermediate row appressed on the upper side; also sending up a slender simple peduncle $\left(2-4^{\prime}\right.$ high, clothed merely with small bract-like and appressed awl-shaped leaves), bearing a single cylindrical spike. - Wet pine-barrens, N. J. to Va., and sonthward.

9. L. complanàtum, L. (Ground-Pixe.) Stems extensively creeping (often subterranean), the erect or ascending branches several times forked above; bushy branchlets crovded, flattened, fan-like and spreading, all cluthed with minute imbricated-appressed awl-shaped leaves in 4 ranks, with decurrentunited bases, the lateral rows with somewhat spreading tooth-like tips, those of the upper and under rows smaller, narrower, wholly appresserl; peduncle slender, bearing 2-4 cylindrical spikes. - Var. Chayxcrparíssus has narrower, more ereet and bushy branches, and the leaves less distinetly dimorphous. - Woods and thickets; common, especially northward. (Eu.)

\section{Order 134. SELAGINELLACEAE.}

Leafy plants, terrestrial or rooted in mud, never very large; the stems branching or sliort and corm-like; the leaves small and 4-6-rowed, or subulate and elongated; sporangia one-cellerl, solitary; axillary or borne on the upper surface of the leaf at its base and enwrapped in its margins, some containing large spores (macrospores) and others small spores (microspores). The macrospores are in the shape of a low triangular pyramid with a hemispherical base, and marked with elevated ribs along the angles. In germination they develop a minute prothallus which bears arehegonia to be fertilized by antherozoids developed from the microspores.

1. Selaginella. Terrestrial; stems slender; leaves small; sporangia minute and axillary.

2. Isoetes. Aquatic or growing in mud ; stems corm-like ; leaves elnngated and rush-like ; sporangia very large, euwrapped by the dilated bases of the leaves.

\section{SELA GI N ÉLIA, Beauv.}

Fructification of two kinds, namely, of minute and oblong or globular sporecases, containing reddish or orange-colored powdery microspores; and of mostly 2-valved tumid larger ones, filled by 3 or 4 (rarely 1 -6) much larger globoseangular macrospores; the former usually in the upper and the latter in the lower axils of the leafy 4-ranked sessile spike, but sometines the two kinls 
are on opposite sides all along the spike. (Name a diminutive of Selago, an ancient name of a Lycopodium, from which this genus is separated, and which the plants greatly resemble in habit and foliage.)

\section{* Leaves all alike and uniformly imbricated; those of the spike similar.}

1. S. spinòsa, Beauv. Sterile stems prostrate or creeping, small and slender; the fertile thicker, ascending, simple (1-3' high); leaves lanceolate, acute, spreading, sparsely spinulose-ciliate. (S. selaginoides, Link.) - Wet places, N. H. (Pursh), Mich., Lake Superior, Colorado, and northward; rare. - Leaves larger on the fertile stems, yellowish-green. (Eu.)

2. S. rupéstris, Spring. (P1. 21, fig. 1-4.) Much branched in close tufts (1-3' high); leaves densely appressed-imbricated, linear-lanccolate, convex and with a grooved keel, minutely ciliate, bristle-tipped; those of the strongly quadrangular spike rather broader. - Dry and exposed rocks; very common. - Grayish-green in aspect, resembling a rigid Moss. Very variable farther west and south. (Eu.)

* Leaves shorter above and below, stipule-like; the lateral larger, 2-ranked.

3. S. àpus, Spring. Stems tufted and prostrate, creeping, much branched, flaccid; leaves pellncid-membranaceous, the larger spreading horizontally, orate, oblique, mostly obtuse, the smaller appressed, taper-pointed; those of the short spikes nearly similar; larger spore-cases copious at the lower part of the spike. - Low, shady places; not rare, especially southward. - A delicate little plant, resembling a Moss or Jungermannia.

\section{IS ÒETES, L. Quillwort. (Pl. 21.)}

Stem or trunk a fleshy more or less depressed corm, rooting just above its 2lobed (or in many foreigu species 3-lohed) base, above covered with the dilated and imbricated bases of the awl-shaped or linear somewhat quadrangular leaves, which include four air-tubes, intercepted by cross partitions. Sporangia pretty large, orbicular or ovoid, plano-convex, very thin, sessile in the axils of the leares, and united at the back with their excavated bases (the thin edges of the excavation folding round partly cover them, forming the velum), traversed internally by transverse threals; those of the outer leaves filled with large spherical macrospores, their whitish crustaceous integument marked by one circular, and on the upper surface by three radiating elevated lines (circumscribing a lower hemisphere, and three upper segments which open valve-like in germination); those of the inner leaves filled with very minute and powdery grayish microspores; these are always obliquely oblong and triangular. - Mostly small aquatics, grass-like or rush-like in aspect, some always submerged, others amphibious, a few living in merely moist soil, maturing their fruit in late summer and early autumn, except n. 7 and some forms of $n$. 6 .

This genus is left essentially as it was elaborated for the 5th edition by the late Dr. George Exgelmaxis. The present editor has added to the range of a few species, and given var. robusta of n. 3 .

* Growing under water, only accidentally or in very dry seasons out of water; leaves without stomata (except in forms of n.3) and peripherical bast-bundles.

1. I. lacústris, L. (P'l. 21, fig. 1-5.) Leaves (10-25 in number, 2-6* long) dark green, rigid; sporangium oroid or circular, the upper third, or less, 
covered by the velum, the free part pale and unspotted; botl kinds of spores the largest of our species; macrospores $\left(0.32-0.38^{\prime \prime}\right.$ wide) cuvered with short and twisted crested rilges, which often anastomose ; microspores $\left(0.017-0.020^{\prime \prime}\right.$ long) smooth. - Mountain lakes, Penn., N. Y., and New Eng. to Lake Superior, and northward, often with n. 3. (Eu.)

2. I. Tuckermàni, Braun. Leaves $\left(10-30,2-3^{\prime}\right.$ long) very slender, awl-shaped, olive-green, the vuter reeurved; sporangium ovoid or circular, the upper third covered by the velum, the free part sometimes lirownish-spottel ; macrospores $\left(0.22-0.28^{\prime \prime}\right.$ wide) on the upper segments covered with parallel and anastomosing ridges, the lower half reticulated; microspores (0.013$0.015^{\prime \prime}$ long) smooth or very delicately papillose. - Mystic and other ponds near Boston, together with the next (Tuckerman, $W$. Boott).

3. I. echinóspora, I)urieu. Leaves sleuder, awl-shaped; sporangium ovoid or circular; macrospores $\left(0.20-0.25^{\prime \prime}\right.$ wide) beset all over with small entire and obtuse or slightly forked spinules. (Eu.) - In this European form, the leaves are very slenderly attenuated (3-4' long), the upper margin of the sporangium only is covered with the narrow velum, the free part is unspotted, and the slightly papillose microspores are larger $\left(0.015-0.016^{\prime \prime}\right.$ long).

Var. Braunii, Engelm. Leaves (15-30 in number, 3-6' long) dark and often olive-green, straight or commonly recurved, half or two thirds of the sporaugium covered by the velum, the free part often with light brown spots; macrospores as in the type; microspores smaller $\left(0.013-0.014^{\prime \prime}\right.$ long), smootl. (I. Braunii, Durieu.) - I'onds and lakes, New Eng. to N. Y., Penn., Mich., and northward, often with the two preceding. - Frequently with a few stomata, especially in Niagara specimens.

Var. robústa, Engelm. Stouter; leaves (25-70,5-8' long) with abundant stomata all over their surface ; velum covering about one half of the large spotted sporangium ; macrospores $0.18-0.27^{\prime \prime}$ wide. - Lake Champlain, north end of Isle La Motte (Pringle).

Var. muricàta, Engelm. Leaves (15-30,6-10' long) straight or flaccid, bright green ; about oue half of the almost circular sporangium covered by the velum, unspotted ; macrospores $\left(0.22-0.27^{\prime \prime}\right.$ wide) with shorter and blunter spinules; microspores as in the last variety, or rarely spinuluse. (I. muricata, Durieu.) - In some ponds north of Boston ( $W$. Boott).

Var. Boóttii, Engelm. Leaves $\left(12-20,4-5^{\prime}\right.$ high) awl-shaped, stiflly erect, bright green, with stomata; sporangium as in the last; macrospores as in the type, but a little smaller and with very slender spiuules. (I. Boottii, Braun, in litt.) - Pond in Woburn, near Boston, partly out of water ( $\mathrm{W}$. Boott).

* * Growing partly out of water, ether by the pond drying up or by the receding of the ebb tide; lenves with stomata, and in $\mathrm{n} .6$ and 7 with four or more peripherical bast-bundles.

4. I. saccharàta, Engelm. I.eaves $\left(10-15,2-3^{\prime}\right.$ long $)$ slender, olivegreen, curved; sporangium small, ovoid, only the upper edge covered by the velum, nearly unspotted ; marrospores (0.20-0.2.2" wide) minutely tubereulate; microspores ( $0.912^{\prime \prime}$ long) papillose. - On Wicomico and Nanticoko Rivers, eastern shore of Maryland, between high and low tide (Canby).

5. I. ripària, Engelm. Leaves $\left(15-30,4-8^{\prime}\right.$ long) slender, deep green, erect; sporangium mostly oblong, upper margin to one third covered by the 
velum, the free part spotted; macrospores very variable in size $\left(0.22-0.30^{\prime \prime}\right.$ wide), the upper segments covered by short crested ridges, which on the lower hemisphere run together forming a network; microspores larger than in any other species except $n .1$ (0.013-0.016" long), mostly somewhat tuberculated. - Gravelly banks of the Delaware, from above Philadelphia to Wilmington, between flood and ebb tide; margins of ponds, Lake Saltonstall, Conn.(Setchell), and northward. - Distinguished from the nearly allied I. lacustris by the stomata of the leaves, the spotted sporangium, the smaller size of the macrospores and their reticulation on the lower half.

6. I. Engelmánni, Braun. Leaves long (25-100, 9-20' long), light green, erect or at last prostrate, flat on the upper side; sporangium mostly oblong, unspotted, the velum very narrow; macrospores $\left(0.19-0.24^{\prime \prime}\right.$ wide) covered all over with a coarse honeycomb-like network; microspores (0.012$0.014^{\prime \prime}$ long) mostly smooth. - Shallow ponds and ditches, from Mass. (near Boston, W. Boott, H. Mann) and Meriden, Conn. (F. W. Hall), to Penn. and Del. and (probably through the Middle States) to Mo. - By far the largest of our species, often mature in July.

Var. grácilis, Engelm. Leaves few (8-12 only, 9-12' long) and very slender; both kinds of spores nearly as in the type. - Southern New Eng. (Westrille, Conn., Setchell) and N. J. (Ennis); entirely submersed!

Var. válida, Engelm. 'Trunk large and stont (often 1-2' wide); leares (50-100, even $\left.200,18-25^{\prime} \mathrm{long}\right)$ with an elerated ridge on the upper side; sporangium obloug or linear-oblong $\left(4-9^{\prime \prime}\right.$ loug $), \frac{1}{3}-\frac{1}{2}$ or more covered by the velum; spores very small; macrospores $0.16-0.22^{\prime \prime}$ wide; microspores $0.011-0.013^{\prime \prime}$ long, spinuluse. - Del. (C'anby) and Penn. (Porter). Sept.

7. I. melanópoda, J. Cay. Leaves $\left(15-50,6-10^{\prime}\right.$ long) very slender, keeled on the back, straight, bright green, usually with dark brown or black shining bases; sporangium mostly oblong, with a very narrow velum, brown or spotted; macrospores very small $\left(0.14-0.18^{\prime \prime}\right.$ wide), smoothish, or with faint tubercles or ridges; microspores (0.010-0.012" long) spinulose. - Shallow ponds, and wet prairies and fields, central and northern Ill. (E. Hall, I'asey), and westward. June, and sometimes again in Nov. - Trunk more spherical and more deeply 2-lobed, and both kinds of spores smaller than in any other of our species; leaves disappearing during the summer heat. Closely approaching the completely terrestrial species of the Mediterranean region.

\section{Order 135. MARSILIÀCEAE.}

Perennial plants rooted in mud, having a slender creeping rhizome and either filiform or 4-parted long-petioled leaves; the somewhat crustaceous several-celled sporocarps borne on peduncles which rise from the rhizome near the leaf-stalks, or are more or less consolidated with the latter, and contain both macrospores and microspores.

\section{MARSİLIA, L. (Pl. 25.)}

Submersed or emersed aquatic plants, with slender creeping rootstocks, sending up elongated petioles, which bear at the apex a whorl of four nervoseveined leaflets, and at or near their base, or sometimes on the rootstock, one 
or more ovoid sporocarps. These sporocarps or fruit usually have two teeth near the hase, and are 2-celled vertically, with many transserse partitions, and split or burst into 2 valves at maturity. The sporocarps have a ring along the edges of the valies, which at length swells up and bears the sausageshaped compartments from their places. The compartments cont:in macrosporangia and microsporangia intermixed. (Named for Aloysius Marsili, an early Italian naturalist.)

1. M. quadrifolia, L. Leaflets broadly obovate-cuneate, glabrous; sporocarpss usually 2 or 3 on a short peduncle from near the hase of the petioles, pedicelled, glabrous or somewhat hairy, the basal teeth small, obtuse, or the upper one acute. - In water, the leaflets commonly floating on the surface; Bantam Lake, Litchfield, Conn., and now introduced in many places. (Eu.)

2. M. vestita, Hook. \& Grev. Leaflets broadly cuneate, usually hairy, entire ( $2-7^{\prime \prime}$ long and broad); petioles $1-4^{\prime}$ long; peduncles free from the petiole; sporocarps solitary, short-peduncled (abont $2^{\prime \prime}$ long), very hairy when young ; upper basal tooth of sporocarp lougest, acute, straight or curved, lower tooth acute, the sinus between them rounded. (M. mucronata, Braun.) - In swainps which become dry in summer; Iowa and southwestward.

\section{Order 136. SALVINIÀCEAE.}

Floating plants of small size, having a more or less elongated and sometimes branching axis, bearing apparently distichous leaves; sporocarps or conceptacles very soft and thin-walled, two or more on a common stalk, one-celled and having a central, often branched receptacle which bears either macrosporangia containing solitary macrospores, or microsporangia with numerous microspores.

\section{A ZÓ L L A, Lam. (Pl. 21.)}

Small moss-like plants, the stems pinnately branched, covered with minute 2-lobed imbricated leares, and emitting rootlets on the under side. Conceptacles in pairs beneath the stem; the sulaller ones acorn-shaped, containing at the base a single macrospore with a few corpuscles of unknown character above it; the larger ones globose, and having a basal placenta which bears many pedicellate microsporangia which coutain masses of microspores.

1. A. Caroliniàna, Willd. Plants somewhat deltoid in outline $\left(4-12^{\prime \prime}\right.$ broad), much branched; leaves with ovate lobes, the lower lobe reddish, the upper one green with a reddish border; macrospores with three attendant corpuscles, its surface minutely granulate ; masses of microspores glochidiate. Floating on quict waters, from Lake Ontario westward and southward, - appearing like a reddish hepatic moss.

Salrfina ndtaxs, L., was said by Pursh to grow floating on the surface of small lakes in Western New York, and has more recently been said to occur in Missouri. It has oblong-oval floating leaves $4-6$ " long, closely pinuatelyreined, which bear conceptacles and branching plumose fibres on their under surface. 


\section{Subclass II. CELLULAR ACROGENS, or BRYOPHY'TES.}

Plants composed of cellular tissue only. Antheridia or archegonia, or both, formed upon the stem or branches of the plant itself, which is developed from the germinating spore usually with the intervention of a filiform or conferva-like prothallus. - Divided into the Musci, or Mosses, and the $\mathrm{He}$ paticoe.

\section{Division I. HEPÁTIC. E. $^{1}$ (Liverworts.)}

Plants usually procumbent, consisting of a simple thallus, a thalloid stem, or a leafy axis; leaves when present 2-ranked, with uniform leaf-cells and no midvein; thalloid forms with or without a midvein, smooth or scurfy or scaly beneath and usually with numerous rootlets. Sexual reproduction by antheridia and archegonia, which are immersed in the thallus, or sessile or pedicelled upon it, or borne on a peduncled receptacle. The fertilized archegonium develops into a capsule (sporogonium) closely invested by a calyptra, which ruptures above as the ripened capsule (containing numerous spores and usually elaters) pushes upward. It is also commonly surrounded by a usually double involucre, the inner (often ealled periunth) more or less tubular, the outer tubular or more often foliaceous, sometimes wholly wanting. Propagation is also effected by offshoots (innovations), runners (flagella), or by gemmo, which appear at the margin of the leaves or on the surface of the thallus, often in special receptacles.

\section{Order 13\%. JUNGERMANNiÀCEA. Scale-Mosses.}

Plant-body a leafy axis or rarely thallose. Capsule borne on a slender often elongated pedicel, splitting at maturity into 4 valves. Elaters mixed with the spores, mostly bispiral (unispiral in n. 1-3, 32, and 33, 1-3-spiral in n. 5 and 28). Antheridia and archegonia diœcious or monœcious, in the latter case either mingled in the same inflorescence, or separated upon the same branch, with the antheridia naked in the axils of the lower leaves, or on separate parts of the same plant. Leaves

1 Elaborated for this edition by Prof. L. M. Underwood, of Syracuse, N. Y. 
2-ranked, incubous (i. e. the apex of each leaf lying on the base of the next above), or succubous (i. e. the apex of each leaf lying under the base of the next above), or sometimes transverse, with frequently a third row of rudimentary leaves beneath the stem.

\section{Artlficial Key to the Genera.}

$\S 1$. Plant-body a leafy axis.

* Leaves complicate-bilobed (i. e. folded together) or with a small basal lotie.

- Lower lobe smaller than the upper.

++ Root-liairs borne on the stems or underleaves.

1. Frullania. Lower lobe mostly saceate, more or less remote from the stem. Branches intra-axillary, the leaves on either side free.

2. Jubula. Lower lobe saceate ; branches lateral, a basal leaf borne partly on the stem, partly on the braneh.

3. Lejeunea. Lower lobe incurred, more or less inflated.

5. Porella. Lower lobe ligulate. Perianth triangular, the third or odd angle ventral.

+++ Root-hairs rising from the lower lobes.

4. Radula. Perianth compressed. Underleaves none.

++ Upper lobe smaller than the lower, or the two somewhat equal.

+ Leaves succubous as to their lower lobes.

15. Scapania. Involucral leaves 2 ; perianth dorsally compressed, the mouth truncate, bilabiate, decurved.

16. Diplophyllum. Involucral leaves few; perianth erect, round, the mouth denticulate. ++ Leaves transverse.

25. Marsupella. Perianth tubular or somewhat compressed. (Compare also Jungermannia $\$$ Sphenolobus.)

* * Leares palmately 3-4- (or many-) cleft.

- Divisions numerous, eapillary. Plants large, usually in conspicuous mats.

6. Ptilidium. Leaves palmatifid with ciliate margins.

7. Trichocolea. Leaves setaceonsly inultificl.

++ Leaves $3-4$-cleft or parted; plants small, mostly inconspicuous.

10. Lepidozia. Leaf-divisions two cells wide or more.

11. Blepharostoma. Leaf-divisions only one cell wide.

*** Leaves entire, emarginate, or 2-3-toothed or -lobed.

- Leaves closely imbricate on short julaccous stems.

27. Gymnomitrium. Involucre double, the inner shorter.

++ Leaves deeply bilobed.

8. Herherta. Underleaves large. Perianth fusiform on an elongated liranch.

12. Cephalozia. Underleaves unostly wanting; perianth mostly triangular on a short branch. +++ Leaves incubous, mostly plane or depressed.

9. Bazzania. Leaves mostly 2 -3-toothed. Perianth fusiform on a short branch.

14. Kantia. Leaves mostly entire. Perianth fleshy, pendulous, subterranean.

\section{++++ Leaves succubous or transverse.}

+ Underleaves entire or nearly so.

13. Odontoschisma. Involucral leaves numerous, small, incised, those of the stem rounded or retuse.

21. Mylia. Involucral leaves 2, connate at lase. Large.

22. Harpanthus. Involucral leaves few, smaller than the semi-vertical cmarginate stemleaves. Small. 
24. Jungermannia. Involucral leaves few, mostly larger than the entire or bidentate stem-leaves. Medium-sized or large.

++ ++ Underleaves 2-4-cleft, -parted, or -divided.

17. Geocalyx. Involuere fleshy, saccate, pendent. Leaves bidentate; underleaves 2-cleft.

18. Lophocolea. Fruit terminal on the inain stem or a primary branch. Involueral leaves distinct.

19. Chiloscyphus. Fruit on a short lateral branch. Involucral leaves distinct. (See also Jungermannia.)

++++ Underleaves mostly wanting.

a. Leaves entire or barely retuse.

23. Liochlana. Involucral leaves distinct, like those of the stem; perianth truncatedepressed at the apex.

26. Nardia. Involucral leaves connate at base and adnate to the perianth.

b. Leaves bidentate or bilobed, rarely 3 -lobed.

12. Cephalozia. Branches all from beneath. Perianth on a short branch, mostly trigunal witl the odd angle beneath.

24. Jungermannia. Simple or branehing laterally. Perianth terminal, mostly laterally compressed.

c. Leares mostly spinuluse or dentate.

20. Plagiochila. Involucral leaves large ; perianth laterally compressed.

§2. Plant-body pseudo-foliaceous with succubous leaf-like lobes.

2S. Fossombronia. Perianth large, campanulate.

§ 3. Plant-body a thallus.

* Thallus with a distinct costa.

29. Pallavicinia. Thallus $3-6^{\prime \prime}$ wide, mostly simple, the margins sinuate or undulate. Perianth tubular, at length dorsal.

30. Blasia. Thallus $3-6^{\prime \prime}$ wide, lobed, dichotomous, or radiate, the margins pinnatifidsinuate.

32. Metzgeria. Thallus narrow $\left(1-2^{\prime \prime}\right)$, ciliate at the margins or on one or both sides.

* Thallus with an inconspicuous costa or none.

33. Aneura. Thallus rather narrow, mostly palmately or pinnately lobed. Sporogonium risıng from the under sicle near the margin.

31. Pellia. Thallus wider, mostly simple or forked. Sporogonium rising from the upper surface.

\section{F R U L L À N I A, Raddi. (Pl. 24.)}

Leaves incubous, complicate-bilobed, the lower lobe usually inflated, helmetor club-shaped; underleaves bifid, rarely entire, with basal rootlets. Diœcious or monceious. Fruit terminal on the branches. Involucral leares 2 or 4, larger than the stem-leaves; perianth 3-4-angled, mucronate. Calyptra pyriform, fleshy. Capsule globose, the lower third solid. Elaters truncate at each end, unispiral, adherent to the valves. Spores large, reddish, minutely muricate. Antheridia most often on a short branch, globose-oblong or cylindric. Archegonia 2-4, long-styled. (Named for Leonardo Frullani, an Italian Minister of State.)

§ 1. TRACHYCÓLEA. Perianth triangular in section, rough with tubercles or scales, or villous; lower leaf-lobe helmet-shaped, truncate at base.

* Lover leaf-lobe about three fourths the size of the upper.

1. F. Oakesiàna, Aust. Stems widely branching; fertile branches short; leaves obliquely orbicular, loosely imbricate, the lower lobe rotund, contiguous to the stem; underleares ovate-rotund or subobovate, little wider than the 
stem, bifid; involucral leaves more or less connate, equally bilobed, the lobes entire, obtuse; perianth small, subobovate-pyriform, smooth or 1-7-nerved or alate both sides. - White Mts., on stunted spruce and birch trees.

* * Louer leaf-lobe much smaller than the upper.

- Underleaves scarcely wider than the stem, ovate, bifid, the divisions entire, acute; perianth 1-carinate or smooth, except in n. 2; stems creeping.

2. F. Virgínica, Lehm. Stems short, irregularly branching; leaves crowded, ovate, entire, somewhat concave, the lower lobes sometimes expanded into a lanceolate lamina; underleaves round-ovate, bifid, twice the width of the stem; perianth compressed-pyriform, tuberculate, 2 -4-carinate dorsally, 4-carinate ventrally. - On bark of trees, rarely on rocks; common.

3. F. Eboracénsis, Lehm. Branches clustered; leaves loose, imbricate on the branches, round-ovate, entire; perianth pyriform, slightly compressed and repand, smooth, obscurely carinate beneath and gibbous toward the apex. (F. saxatilis, Lindeuh.) - (In trees aud rocks; common northward.

4. F. Pennsylvánica, Steph. Stems dichotomous; leaves imbricate, flat, ovate, mucronate or rarely obtuse, entire; lower lobe marginal, large, round-cucullate; underleaves broadly ovate, deeply parted, the divisions longacuminate; diocious; antheridial spikes on short lateral branches, elongated; lobes of the iuvolucral leaves acuminate, much narrowed at base, and the large underleaves carinate-concave, deeply parted, their apiculate divisions entire or toothed. - Shaded rocks, Stony Creek, Carbon Co., Penn. (Riuu). Known only from the original description.

5. F. saxícola, Aust. Stems numerous, widely branching; leaves orbicular, scarcely oblique, flat; lower lobe near the stem, small, or rarely larger and round-galeate; underleaves scarcely wider than the stem, suborate, bifid; perianth broadly oblong, bowl-shaped with very short mouth, papillose, abruptly broad-carinate beneath, 1-many-nerved each side of the keel, 2-angled. Sloping dry trap rocks, Closter, N. J. (Austin).

++ Underleaves 2-3 times wider than the stem, round or subquadrate, bifid, the divisions blunt or truncate.

- Leaves lax, rather distant; lower lobe mostly expanded, ovate-lanceolate.

6. F. æolòtis, Nees. P'rocumbent, irregularly branched or subpinnate; leaves semi-vertical, subsquarrose, obliquely cordate, the lower lobe expanded; underleaves ovate, acutely bifid, the upper margin angular-dentate or entire; sporogonium unknown. - On trees and rocks, chiefly in mountain regions.

++ Leaves close-imbricate; lower lobe galeate, seldom expanded except on terminal leaves.

7. F. squarrosa, Nees. Decumbent, pinnately branching, the short fertile branch lateral; leaves subvertical, suborbicular, obtuse, entire; lower lobe obovate-cucullate or galeate, subappressed; underleaves cordate or rounded, sinuate-subdentate, slightly bifil; perianth oblong, tri juetrous, convex dorsally, strongly keeled ventrally. - On rocks and trees, N. Y. to Ohio, and southward; rather common.

8. F. plàna, Sulliv. Procumbent, widely hranching or subpinnate; leaves orbicular, subimbricate; lower lobe very small, as broad as long, close to the stem; underleaves rather large, flat, rounded, slightly bifid; mono- 
cious ; perianth oblong-oval or subobovate, triquetrous, dorsally sulcate, acutely keeled ventrally; antheridial spikes globose. - Shaded rocks, N. Y. and N. J. to E. Tenu.

9. F. dilatàta, Nees. Loosely and widely pinnate; leaves round, entire, opaque; lower lobe subrounded, cucullate, close to the stem; underleaves subquadrate, toothed at the anterior angles; involucral leaves with 2 or 3 entire lobes; perianth tuberculate, retuse. - Rocks and trunks of trees; rather common. (Eu.)

§ 2. THYOPSIELLA. Perianth smooth; leaves semicordate at base (marked by a central moniliform row of cells, or sometimes in $\mathrm{n} .12$ by a few scattered large cells); lower lobe near the stem (except in n. 11), cylindric-saccate, mostly erect; underleaves round-oval, the margin entire, recurved; dicecious.

* Leaves orbicular.

10. F. Asagrayàna, Mont. (Pl. 24.) Creeping, simply pinnate; leaves concave, obtuse, decurved; lower lobe oblong-clavate, emarginate at base; underleaves oblong, flat, 2-cleft, the sinus obtuse; involucral leaves unequally 2-cleft, the dorsal segment oblong, pointed, nearly entire, the rentral subulate; perianth pyriform, 3-sided, obtusely keeled beneath. (F. Grayana of authors.) - Rocks and bark of coniferous trees; frequent.

11. F. Tamarísci, Nees. Bipinuately brauching, somewhat rigid; leaves ubtuse, mucronately acute or subacuminate, decurved, entire; lower lobe distant from the stem, oval or oblong; underleaves quadrate-ovate or obovate, emarginate, the margin revolute; involucral leaves bifid, serrulate; perianth oblong, sulcate dorsally, obtusely keeled reutrally. - N. Eng. and southward; rare. (Eu.)

* Leaves oblong from a narrowed base.

12. F. fragilifolia, Tayl. Procumbent, subpinnate, the alternate flattened branches subremote; leaves subimbricate, ascending, recurved, entire; lower lobe oblong-galeate; underleaves round-obovate, flat, appressed, bifid, the margins entire or angled; perianth obovate-cordate, concave dorsally, keeled rentrally; involncral leaves subequally lobed, obtusely few-toothed. (F. polysticta, Mont. F. Sullivantiæ, Aust.) - On trees in a cedar swamp, Urbaua, Ohio (Sullivant). (Eu.)

\section{J Ù B U L A, Dumort. (Pl. 25.)}

Characters nearly as in Frullania. Leaves large and flat, an axillary one at the base of each branch without a lower lobe. Calyptra turnip-shaped, abruptly globose above. Monœcious, with 2 antheridia in each leaf of a spikelike branch, and the archegonia mostly solitary. (Name from juba, a mane, alluding to the persistent elaters.)

1. J. Hutchínsiæ, Dumort., var. Sullivántii, Sprnce. Subdichotomously branching; leares dark olive-green, subimbricate, obliquely ovate, acnte, entire or subrepand; lower lobe saccate, rather remote from the stem, not spurred as in the European form; underleaves roundish, serrate or entire; involucral leaves bificl, serrate; perianth triangular-obpyriform. (Frullania Hutchinsiæ, Nees, in part.) - Wet rocks, N. Eng. to S. C. ; more common in the mountains. 


\section{LE J E Ù N E A, Libert. (1) 24.)}

Leaves decurrent at the folds, the lower lobe incurverl and ventricose ; underleaves usually present, entire or bifid. Archegonium with a slender persistent style, solitary on a usually very short branch ; the perianth free from the involucral leaves, oval or oblong, terete or angular, variously carinate, cristate, or ciliate. Capsule globose, 4 -cleft to the middle, the valyes recurved. Spores large $(40-50 \mu$ broad), globose or oblong, tuberculate. Antheridia at the base of ordinary leaves or in the axils of the leaves of a spike-like branch. (Utherwise as Frullania. (Named for A.-L.-S. Lejeune, a French botanist.)

* Underleaves entire.

1. L. clypeàta, Sulliv. (Pl. 24.) Stems procumbent, somewhat pinnately branched, $\frac{8}{4}-1^{\prime}$ long; leaves whitish-green, round-ovate, cellular-crenulate, deflexed; lower lobe flat, oblong-quallrate; underleaves round-quadrate; monocious; involucral leaves larger than those of the stem, the perianth round-obovate, 2-3-carinate dorsally, 1-carinate ventrally, the keels rongh. (L. calyculata, Tayl.) - On rocks and trees; common south and westward.

\section{* Enderlaves bifid; leaves entire.}

2. L. serpyllifòlia, Libert, var. Americàna, Lindb. Stems long, somewhat branching, pale, pellucid and fragile; leaves rather remote, flat, opening from a basilar sac, searcely decurved, obliquely roundish-orate, obtuse, often slightly repand; underleaves about half as large, round-oval with a broad obtuse sinus and acute lobes; monœcious ; the obovate-clavate perianth on a lateral branch. (I. cavifolia, Aust.) - On cedars, etc., Catskill Mts. (Cleve), Belleville, Ont. (Macoun), and southward; rather common.

3. L. lùcens, Tayl. Whitish, filiform, pinnately branched; leares remote, rarely subimbricate, obliquely ovate-triaugular, rounded or obtuse, semi-cordate at base; lower lobe ovoid, acute or apiculate; underleaves $\frac{1}{2}$ as large as the lateral, round-oval, decply bifid, the lobes broad-subulate; diœcious ; involucral leaves rather longer, witl lanceolate lobes; perianth scarcely emersed, broadly pyriform, 5-carinate. (L. cucullata, Sulliv.; not Nees.) - Near Cincinnati; moist rocks, Alleghany Mts. and southward (Sullivant). Minute and flaceid.

***Underleares obsolete; leaves muriculate-denticulate.

4. I. calcàrea, Libert. Very minute; stems slender, loosely brauching; leares ovate, falcate-lecurved, sinuate-complicate at base; monœcious ; involucral leaves bific, the divisions entire; perianth on a very short lateral branch, pyriform-clavate, acutely 5-angled, the margin echinate-muriculate. (1. echinata, Tayl.) - On rocks and roots of trees; rather common. (Eu.)

\section{RÁ DULA, Dumort.}

Leares large, complieate-bilobed, incubous; lower lobe small, bearing roothairs; underleares none. Dicecions, rarely moncecions. Fruit usually terminal. Involucral leaves 2, slightly smaller than the cauline, 2-lobed ; perianth tubular, compresserl or nearly terete, truncate, entire or crenate. Calyptra pyriform, persistent. Capsule oval-eylindric. Elaters slender, free. Spores large, globose, minutely tuberculate. Antheridia in the ventricose bases of 
spicate leaves. (Radula, a scraper or spatula, in allusion to the form of the perianth.)

* Lower lobe subquadrate, barely incumbent on the stem.

1. R. complanàta, Dumort. Creeping, widely subpinnately branching; leaves imbricate, spreading, rounded, the lower lobe obtuse or acute; monœcions; perianth obconic, compressed, the mouth entire, truncate; antheridia in the bases of $2-3$ pairs of strongly imbricate tumid leaves. - On rocks and roots of trees; common. (Eu.)

2. R. obcónica, Sulliv. (Pl. 24.) Smaller, indeterminately branched; leaves somewhat remote, round-obovate, convex; moncecious; perianth clavate-obconic, obliquely truncate; antheridia axillary on short lateral branches rising near the terminal involucre. - On trees in cedar swamps, N. J. to Olio.

* Louer lobe small, rounded, nore or less transversely adnate.

3. R. tènax, Lindb. Stems brownish-green, rigid, tenacious; leaves remote, scarcely decurrent, obliquely elliptic-ovate, opaque, the cells round and strongly chlorophyllose; diœcious; the antheridial spike lateral below the keel of a leaf, long, linear, somewhat obtuse. (R. pallens, Sulliv.; not Gottsche.) - On rotten trunks, in the Catskill Mts., and southward, especially in the mountains.

\section{PORÉLIA, Dill. (Pl. 24.)}

Leaves large, incubous, complicate-bilobed; lower lobe ligulate, suberect; underleaves similar, decurrent at base, the apex entire. Diœcious. Fruit on a short lateral branch. Involucral leaves nsually 4, 2-lobed, the margin ciliate or denticulate; perianth somewhat oval, compressed, bilabiate, incised or entire. Calyptra globose, persistent. Capsule globose, reddish, short-stalked. Elaters very numėrous, 2-3-spiral, free. Spores large, rough. Antheridia solitary in the saccate bases of leaves, crowled in short spikes. (Name a diminutive of porus, an opening.)

\section{* Leaves more or less remote; stems bipinnate.}

1. P. pinnàta, L. Stems irregularly pinnate, fastigiate at the ends; leaves scarcely incubous, ovate-oblong, the rounded apex sometimes slightly decurved; lower lobe minute, flat, oblong, obtuse, as long but not half as wide as the flat, entire, orate-rectangular, scarcely decurrent underleaves. (Madotheca Porella, Nees.) - On rocks and trees subject to inundation; common. (Eu.)

* Leaves mostly closely imbricate; stems mostly simply pinnate (or bipinnate in $\mathrm{n.} 2$ ).

2. P. platyphýlla, Lindb. (Pl. 24.) Yellowish or fuscous-green; stems irregularly pinnate, often fastigiate at the ends; leaves obliquely ovate, more or less concave at base and the rounded upper margin curved upward and undulate, mostly entire; lower lobe obliquely ovate, the margin strongly recurved, with an acute tooth at base; underleares semicircular, with strongly reflexed margins. (Madotheca platyphylla, Dumort.) - On rocks and trees; common eastward. (Fu.)

3. P. Thùja, Lindb. Fuscous-green or blackish, somewhat regularly pinnate; leaves convex, closely appressed, obliquely round-ovate, the rounded 
apex decurved, more or less denticulate; lower lobe oblong, obtuse, with an acnte tooth at base, longer but narrower than the quadrate unlerleaves, both with strongly recurved sparsely deuticulate margins. (Madotheca 'Thuja, Du. mort.) - (In rocks and trees; more common westward. (Lin.)

4. P. dentàta, Lindb. Mostly fuscons-green, irregularly pinnate or subdichotomous; leaves more remote on the branches, obliquely round-ovate, the rounded summit slightly decurved, more or less denticulate; lower lobe decurrent, twisted, olliquely ovate, acute, with recurved undnlate denticulate margin and a large acute tooth at base; underleaves twice as wide as the lower lobes, quadrate-oval, the undulate reflexed margin dentate, especially near the base. (Madotheca rivularis, Nees.) - Shaded rocks, Yellow Springs, Ohio (Sullivant). (Eu.)

5. P. Sullivántii, Lnderw. Stems strongly decurved at the ends in drying; leaves suberect, the straight ventral margin strongly involnte toward the apex; cells large, punctate-stelliform; perianth broadly keeled beueath, the keel 2-angled. (Madotheca Sullivantii, Aust.) - Alleghany Mts. (Sullivant) ; rare.

\section{PTILÍDIUM, Nees. (Pl. 24.)}

Leaves incubous, complicate-bilobed, each lobe divided and lacerately ciliate; underleaves 4-5-lobed, ciliate. Diœcious. Fruit terminating short branches. Involucral leaves 2-4, 4-cleft; perianth terete, obovate, the mouth connivent, plicate, denticulate. Calyptra pyriform, coriaceous. Capsule ovate. Spores globose. Antheridia in the base of closely imbricated leares. (Name a diminutive of $\pi \tau i$ i $o \nu, a$ feather, from the fringed foliage.)

1. P. ciliàre, Nees. Stems erowded, subpinnate; fringes of the foliage long-setaceous. (Blepharozia eiliaris, Dumort.) - On rotten logs and stumps ; common. (Eu.)

\section{TRICHOCÓLEA, Dumort.}

Leaves succubous, 4-5-divided, and with the underleaves setaceously fringed. Diøcions. Fruit terminal, or axillary from the growth of inno. vations. Involucral leaves coalescent into an oblong truncate hairy tube, blended in our species with the calyptra; perianth none. Capsule oblong, its pedicel bulbous at base. Elaters free. Antheridia large, in the axils of leaves on terminal branches. (Name from $\theta \rho i \xi$, hair, and кoגєós, a sheath, from the hairy involucre.)

1. T. tomentélla, Dumort. Stems pinnately decompound, densely tufted, glaucous, 2-6' long; leaves nearly uniform; underleaves subquadrate, as wide as the stem. $-\Lambda$ mong mosses in swamps; commou. (Eu.)

T. Bunfeconiz, $\Lambda$ ust., very imperfectly described from specimens collected in Urbana, Ohio, is said to be simply and rather distantly pinnate.

\section{HER BÉRTA, S. F. Gray.}

Leaves large, incubous or nearly transverse, narrow, 3-ranked, the underleaves heing scarcely smaller, cleft to or below the midlle, the lobes acute. Dicecious. Fruit terminal on a long hranch. Involucral leaves numerous, equitant ; perianth ovate-subulate or narrowly fusiform, 3-angled, deeply 6-8- 
lobed. Calyptra small, obovate, deeply trifid. Capsule large, globose. Elaters free. Spores large, muriculate. Antheridia in the bases of leaves of a short terminal spike. (Named for William Herbert, an English botanist.)

1. H. adúnca, S.F. Gray. Stems long and slender, erect, brownish, nearly simple; leaves and underleaves almost alike, curved and one-sided, the lobes lanceolate. (Sendtnera juniperina, Sulliv.; not Nees.) - On rocks, Greenwood Mts., N. J., Catskill Mts., N. Y., and probably northward. (Eu.)

\section{B $\triangle$ ZZ Z $\mathbf{N} I$ A, S. F. Gray. (Pl. 24.)}

Leaves incubous, oblique, decurved, mostly truncate-tridentate; underleaves wider than the stem, mostly 3-4-toothed or crenate. Diøcious. Fruit on a short branch from the axil of an underleaf. Involucral leares much imbricate, concave, orbicular or ovate, incised at the apex; perianth orate-subulate or fusiform, somewhat 3-keeled. Calyptra pyriform or cylindric-oblong. Capsule oblong. Antheridial spikes from the axils of underleaves. (Named for 11. Bazzani, an Italian Professor of Anatomy.)

1. B. trilobàta, S. F. Gray. (Pl. 24.) Creeping, dichotomous, proliferous; leaves ovate, the broad apex acutely 3 -toothed; underleaves roundishquadrangular, spreading, 4-6-toothed above; perianth curved, cylindric, plicate at the narrow apex and 3-toothed. (Mastigobryum trilobatum, Nees. M. tridenticulatum, Lindenb.) - Ravines, wet woods and swamps; common and variable. (Eu.)

2. B. defléxa, Underw. Stems forked or alternately branched; leaves strongly deflexed, cordate-ovate or ovate-oblong, falcate, the upper margin arcnate, the narrow apex 2-3-toothed or entire; underleares roundish-quadrate, the upper margin lifid, crenate, or entire; perianth cylindric, arcuate, plicate abore and deníiculate. (Mastigobryum deflexum, Nees.) - On rocks in the higher mountains eastward. (Eu.)

\section{LEPIDÒZIA, Dumort. (Pl. 24.)}

Leares small, incubous, palmately 2-4-cleft or -parted; underleares similar, often smaller. Diœcious or rarely monœcious. Fruit terminal on short branches from the under side of the stem. Involncral leaves small, appressed, concare, 2-4-cleft; perianth elongated, orate-subulate or narrowly fusiform, obtusely triangular above, entire or denticulate. Calyptra included, pyriform or oblong. Capsule oblong-cylindric. Spores minute, smooth or roughish. Antheridia large, pedicelled, solitary in the axils of 2-cleft spicate leaves. (Name from $\lambda \in \pi i s, a$ scale, and ósos, a shoot, for the scale-like foliage.)

1. L. réptans, Dumort. (Pl. 24.) Creeping, pinnately compound, the branches often flagellate; leaves decurved, subquadrate, 3-4-cleft ; involucral leaves ovate, truncate, unequally 4-toothed; perianth incurved, dentate. - On the ground and rotter wood, N. J., and common northward. (Eu.)

2. L. setàcea, Mitt. Leaves deeply 2-3-cleft or -parted, incurred, the lobes subulate, formed of a somewhat donble series of cells; underleaves similar; perianth ciliate. (Jungermanuia setacea, $\left.W^{\top} e b.\right)-O n$ the ground and rotten wood; common. Resembling the next in its leaves, but smaller and browrish. (Eu.) 


\section{BLEPHA RÓS TO M A, Dumort. (Pl. 25.)}

Leaves transverse or slightiy incubous, 3-4-parted, the divisions capillary ; underleaves smaller, mostly 2-3-parted. Diceious or monceious. Fruit terminal. Involucral leaves numerous, verticillate, deeply 4-cleft; perianth exserterl, pyriform-cylindric, laciniate. Calyptra short, oblong, bilali ite. Capsule eylindric-oblong. Elaters large, very obtuse. Spores large, smooth. Antheridia solitary in the axils of leaf-like bracts. (Name from $\beta \lambda \epsilon ́ p a \rho o \nu, a n$ eyelid, and $\sigma \tau o \dot{\mu} \alpha$, month, in allusion to the fringed orifice of the perianth.)

1. B. trichophýllum, Dumort. Flaccid, branched, creeping; leafdivisions straight, sprealing, each composed of a single row of cells; perianth orate-cylindric. (Jungermannia trichoplylla, L.) - On the ground and rotten wood. Minute, light green. (Eu.)

\section{CEPHALÒZIA, Dumort. (Pl. 23.)}

Leaves mostly succubous, chiefly 2-lobed, the margins uniformly plane or subincurved; underleaves smaller, often wanting except on fruiting branches. Branches from the under side of the stem. Monocious or dicecious. Involucral leaves numerous, capitate, 3-ranked, usually 2-lobed; perianth long, triangular-prismatic, the constricted mouth varionsly dentate. Calyptra small. Capsule somewhat oblong. Elaters free. Spores minute. Antheridia in the base of inflated spicate leares. (Name from $\kappa \in \phi a \lambda \eta ́$, head, and ǒ $\zeta o s, b u d$, for the capitate involucre.)

§ 1. CEPHALOZIA proper. Perianth more or less 3-angled or 3-carinate; leaf-cells large (mostly $25-50 \mu$ broad); plants mostly medium-sized.

* Underleaves rarely present except or fruiting branches.

1. C. Virginiàna, Spruce. Without runners, usually pale; leaves small, obliquely round-ovate, acutely 2-lobed nearly to the middle; cells quadratehexagonal, opaque; diœcious, rarely monœcious; involucral leaves roundquadrate, with slender acuminate lobes; perianth large, widest above the middle, unequally ciliolate; eapsule large, long-exserted; antheridial spike long. (C. catenulata of authors; not $I$ uebn.) - On rotten wool or swampy ground, N. Eng. to Va., and southward.

2. C. multiflòra, Spruce. (Pl. 23.) Often subpinnate, withont runners, pale green; leaves small, round-rhombic, decurrent, hifid $\frac{1}{3}$ their length; cells qualrate-hexagonal, pellucid; diøecious; inner involucral leaves $3-4$ times as long as the outer; perianth linear-fusiform, 3-plaited when young, triangular only abore when mature, ciliate or toothed, fleshy; calyptra fleshy, oral-globose ; cajsule rather short-pedicelled ; spores cimimon-color. - On the ground and rotten wood; common. (Eu.)

3. C. pléniceps, Underw. Stems very short, lranching, densely cespitose, pale green or whitish; leares thick, orbicular, strongly concave, subclasping but not decurrent, lifid $\frac{1}{8}$ their length, the acute lobes incurved and strongly conuivent; involucral leaves oblong, palmately $2-4$-cleft, the rentral like the underleaves; perianth large, oblong-cylindric, obtusely angled, the plicate mouth denticulate. (Jungermannia pleniceps, A ust.) - Among Splragnum in the White Mts. (Oakes). 
4. C. bicuspidàta, Dumort. Prostrate or assurgent, cespitose, usually greenish or reddish, with runners; lower leaves small and distant, the upper larger, round-ovate, cleft nearly to the middle, the lobes ovate-lanceolate and acute, the lower lobe narrower and acuminate; cells large, pellucid; monœcious; involucral leaves about 3 pairs, the innermost nearly three times as long as the outer, cleft $\frac{1}{2}$ their length ; perianth four times as long as the leaves, linear-prismatic or fusiform, thin, denticulate or ciliate; capsule cylindricoblong; spores purple. (Jungermannia bicuspidata, L.) - On the ground, mountains of N. Eug., N. Y., and N. J. (Eu.)

5. C. curvifolia, Dumort. Slender, rarely forked, without runners, greenish, reddish, or often purple; leaves imbricate, ascending, obovate, concare, semicordate at base, lunately bifid below the middle, the lobes incurved or hooked; cells small, quadrate; inonœcious or diœcious; involucral leaves complicate, the lobes suborate, spinulose-denticulate; perianth large, rosepurple, triquetrous, the wide mouth ciliate; calyptra thin; capsule oblongglobose. (Jungermannia curvifolia, Dicks.) - On rotten logs in swamps, etc.; common. (Eu.)

* * Underleaves usually present ; leaves rarely subimbricate.

6. C. flùitans, Spruce. Stems 2-3' long, loosely creeping, with short thick rumers; leaves large, ovate-oblong, lobed to near the middle, the lower lobe larger, lanceolate, obtuse; cells large, mostly hexagonal; underleaves linear, appressed; diøcious; involucral leaves cleft to the middle; perianth oval-cylindric, nearly entire; calyptra short, pyriform ; capsule oblong; spores small, minutely tuberculate; antheridia globose, pedicelled, solitary in the axils. - In bogs, on mosses or partly floating; rare. (Eu.)

§ 2. Cepialozí́lda. Perianth 3-6-angled; leaf-eells small $(14-20 \mu$ broad); plants small, often minute; underleaves present in $\mathbf{n} .9$.

7. C. divaricàta, Dumort. Sparingly branched, without runners; leaves very small, cuneate or round-quadrate, the orate-triangular lobes acute; cells pellucid or subopaque; involucral leaves larger, the lobes acute, denticulate; perianth linear or narrowly fusiform, prismatic, denticulate or subentire; capsule oblong-globose, long-exserted. (Jungermannia divaricata, Smith.) Dry rocks and sand, pine barrens of N. J., and northward. (Eu.)

8. C. Macoùnii, Aust. Slender, much branched, dark green; leares scarcely bruader than the stem, wide-spreading, bifid with a broad or lunate sinus, the broad-subulate lobes mostly acute; cells subquadrate, somewhat pellucid ; diøcious ; involucral leaves appressed, 2 - 3-lobed, irregularly spinulose ; perianth small, whitish, obovate or ovate-fusiform, obtusely 3-angled, setulose or ciliate. - Rotten logs, mountains of N. Eng., and northward (Austin, Macoun).

9. C. Sullivántii, Aust. Stems 3-6" long, fleshy, rootlets numerous; fertile branches suberect, clavate; leaves imbricate, often narrower than the stem, subquadrate-ovate, more or less serrate, the sinus and lobes subacute; diœcious; involucral leaves 3 , erect, free; perianth broadly oral or subobovate, obtusely and sparingly angled, the apex slightly plicate, the mouth connirent, dentate, sometimes narrowly scarious; capsule oval. - On rotten wood, N. J., Ohio, and Ill.; rare. Our smallest species. 


\section{ODONTOSCHÍSMA, Iumort.}

Leaves succubons, ovate or roundish, cutire or retuse, rarely bidentate; underleaves minute, sometimes obscure or wanting. Diccious or sometimes moncecious. Fruit terminal on a short branch from the luwer side of the stem. Involucral leaves few, 3-rauked, bitid or rarely 3-4-cleft; perianth large, triangular-fusiform, ciliate or dentate. Calyptra membrauous. Capsule cylindric-oblong. Antheridia in small whitish spikes on the under side of the stem. (Name from ósoús, a tooth, and $\sigma \chi i \sigma \mu a, a$ cleft, alluding to the jerianth.)

1. O. Sphágni, Dumort. (1'l. 24.) Leaves spreading or ascending, ovate, rounded or oblong, entire or retuse, subconcave; underleaves inostly wanting; perianth $3-6$ times longer than the leaves, subulate-fusiform, laciniate or ciliate. (Sphagnecetis communis, Nees.) - Among mosses, N. J. to Ill., and southward. (Eu.)

2. O. denudata, Lindb. Stems densely rooting, somewhat leafless at bise, flagellate, branching above; leaves spreadiug, broadly ovate, entire; underleaves broadly oval, entire or subdenticulate; perianth close-comivent above, at length bursting irregularly. - On rotten wood, Canada to Uhio, and south along the mountains. (Eu.)

\section{K Á N T I A, S. F. Gray.}

Leaves large, incubous, flat or convex, entire or retuse; underleaves small, roundish, the apex entire, retuse or bificl. I)iocious or monocious. Involucre pendulous, subterranean, clavate or subcylindric, fleshy, liairy, attached to the stem by one side of its mouth. Calyptra membranous, partly aduate to the involucre. Capsule cylindric, the valves spirally twisted. Sipores minute, roughish. Antherillia solitary in the rednced leaves of short lateral branches. (Naine from $J$. Kant, a physician at The Hague.)

1. K. Trichómanis, S. F. Gray. (Pl. 24.) Creeping, without ventral runners; leaves pale green, imbricate, spreading, roundish-ovate, obtuse. (Calypogeia Trichomanis, Cordu.) - On the ground and rotten logs; very common. (Eu.) - Var. RIVulàis, Aust. Leaves dnsky green or blackish, more scattered, flaccid; cells large. N. J. (Austin.) - Var. TÉxcis, Aust. Very slender, innovate-branching; leaves smaller, especially above, dimidiateovate or subfaleate, subdecurrent. Southern N. J. (Austin).

2. K. Sullivántii, Underw. Prostrate, with ventral runners; leaves flat, subcontiguous or imbricate, obliquely round-ovate, minutely 2-toothel with a lunulate sinus, abruptly decurrent; cells large, uniform; underleaves minute, the upper orbicular, bifid, the lower twice 2-lohed, the primary lobes round-quadrate, divaricate, the secondary ovate or subulate. (Calypogeia Sullivantii, Aust.) - Delaware Water Gap, N. J. (Austin).

\section{S C A P À N I A, I)umort.}

Leaves complicate-bilobed, the upper lobe smaller, the lower succubous; margins entire or dentate or ciliate; underleaves none. Diacions. Fruit terminal. Involucral leaves like the canline but more equally lobed; periauth obovate, dorsally compressed, bilabiate, the mouth truncate, entire or toothed, decurved. Capsule ovate. Elaters long, attached to the middle of 
the valves. Antheridia 3-20, in the axils of small saccate leaves, which are scarcely imbricate or crowded into termiual heads. (Name from $\sigma \kappa \alpha \pi \alpha$ c shovel, from the form of the perianth.)

\section{* Leaf-lobes somewhat equal.}

1. S. subalpina, Dumort. Leaves equidistant, imbricate, cleft nearly to the middle, the roundish obtuse lobes denticulate on the outer margin; perianth much exceeding the involucral leaves, obovate from a narrow base, denticulate. - Mountains of N. Eng. (Oakes, Austin); L. Superior (Gillman, Macoun). (Eu.)

2. S. glaucocéphala, Aust. Stems short, cespitose, creeping or ascending, subsimple, with numerous offshoots; leaf-lobes broadly ovate, entire, mostly obtuse and apiculate; involucral leaves sometimes denticulate; perianth small, subcuneate, entire. (Jungermannia glaucocephala, Tayl.; S. Peckii, Aust.) - On rotten wood, N. Eng. to N. Y. and Canada.

* Lower lobe about twice the size of the upper, except near the summit.

- Leaves broader than long; upper lobes rounded or blunt.

3. S. undulàta, Inmort. (Pl. 24.) Ascending or erect, slightly branched; leaves lax, spreading, entire or ciliate-denticulate, the lobes round-trapezoidal, equal at the summit of the stem; perianth oblong-incurved, nearly entire, twice as long as the outer involucre. - In woods, damp meadows, and rills; common, especially in mountain districts. - Var. PURPùreA, Nees; a form with long lax stems and rose-colored or purplish leaves. (Eu.)

4. S. irrígua, Dumort. Creeping; leaves somewhat rigid, repand, deeply lohed; lobes rounded, submucronate, the lower appressed, the upper convex with incurved apex; perianth ovate, denticulate. (S. compacta, var. irrigua, Aust.) - Wet places, N. J., Catskill Mts., mountains of N. Eng., and northward. (Eu.)

\section{+ + Leaves longer than broad; upper lobes more or less acute.}

5. S. nemoròsa, Dumort. Rather stout, flexuose, creeping at base, leaves rather distant, decurrent on both sides, ciliate-dentate, the lower lobe obovate, obtuse, slightly convex, the upper cordate, acute, concave; perianth densely ciliate; capsule large, roundish-ovate, reddish-brown. (S. breviflora, Tayl.) - On rochs, etc., in swamps and rills; common and variable. (Eu.)

6. S. Oakèsii, Aust. Leaves oborate, somewhat spreading, often deflexed, closely complicate, convex, the lower lobe coarsely dentate, and with deep purple spur-like teeth on the keel, the upper roundish and less dentate; perianth usually dentate. - White Mts. (Oakes, Austin).

\section{*** Lower lobes $3-4$ times the size of the upper.}

7. S. exsécta, Aust. Ascending; leaves subcomplicate, entire, the lower lobe ovate, acute or bidentate, concare, the upper small and tooth-like; involucral leaves 3-5-cleft; perianth oblong, obtuse, plicate. (Jungermannia exsecta, Schnidel.) - High mountains, far northward; rare.-Perhaps better retained in Jungermannia. (Eu.)

8. S. umbròsa, Dumort. Stems short, decumbent, slightly branched; leaf-lobes ovate, acute, serrate; perianth incurved, naked at the mouth. White Mts.; rare. - The tips of the shoots are frequently corered witl a dark mass of gemmæ. (Eu.) 


\section{DIPLOPH Ý LL U M, 1)umort.}

Leaves rather narrow, complicate-bilubed, the lobes subecual or the upper smaller, the lower succubous; moderleares none. Fruit terminal. Involucral leaves few. Perianth cylindrical, scarcely or not at all compressed, pluriplicate, denticulate. (Name from $\delta\left\llcorner\pi \lambda o_{s}\right.$, double, and $\phi u ́ \lambda \lambda o v, l e u f$, on account of the folded 2-loled leaves.)

1. D. álbicans, I)umort., var. taxifolium, Nees. Stems asccuding, almost rootless; leaves clusely folded, subdenticnlate, with a rudimentar: pellucid line near the base or noue, the lubes obtuse or acutish, the lower oblong-scymitar-shaped, the upper smaller, subovate; perianth orate, plicate. (Jungermannia albicans and J. obtusifolia of Sulliv.; not of $L$. aud //ook.) Lnder rocks in mountain ravines and on the ground. (Eu.) - The typical form occurs in N. Scotia, distinguished by a broad pellucid median line in both lobes.

\section{GEÓCALYX, Nees.}

Leaves snecubous, bidentate; underleaves 2-cleft, with linear divisions. Fruit lateral, pendent. Involucre simple, fleslyy, saccate, oblung, truncate, attached to the stem by one side of the moutl. Calyptra membranous, partly adnate to the involucre. Capsule ollong. Elaters free. Antheridia in the axils of small leaves on spike-like lateral branches. (Name from réa, the earth, and $\kappa a ́ \lambda \nu \xi, a c u p$, from the sulterranean involucres.)

1. G. gravèolens, Nees. Leaves ovate-quadrate, 2-toothed, liglit green ; underleares oral-lanceolate, cleft to the middle. - On the ground, and rotten logs ; not rare. (Eu.)

\section{LOPHOCÓLEA, Dumort.}

Leaves succubous, dorsally decurrent, obliquely ovate-oblong, broadly truncate or bidentate; underleaves smaller, more or less quadrate, bifid or with 4-8 eapillary lobes. Diucions or monecions. Fruit terminal on the main stem or primary branches. Involueral leaves 2-4, large, often spinulose; perianth triangular-prismatic, 3-lobed, ciliate or laciniate. Calyptra short, obovate, at length lacerate ahove. Cajsule ollong-globose. Antheridia mostly solitary in or near the hase of ordinary leaves. (Name from $\lambda 6 \phi o s$, a crest, and $\kappa o \lambda \epsilon \delta$ s, a sheath, from the crested periantl.)

* Underleaves mostly bifid (or 3-4-cleft in n. 1); divisions mostly cntire.

1. L. bidentàta, Dumort. Stems 1-2' loug, procumbent, sparsely branching; leaves pale green, ovate-triangular, acutely 2-toothed, the teeth oblique with a lunulate sinus; monceious; perianth oblong-triangular, laciniate; anthericlia $2-3$ in a cluster, axillary. - On rocks in shady rills; not common. (Eu.)

2. L. Austini, Iindb. Creeping; leaves uniformly deeply lobed, the lobes and usually the sinus acnte; underleaves comparatively small, the lobes subulate; cells small; monocious; antheridia solitary in the upper axils. (I. minor, 1 ust.; not $\left.N_{\text {ees. }}\right)$ - On roots of trees in woods (.1ustin). Imperfectly known.

3. L. Macoùni, Aust. Stems very short, prostrate, ascending at the apex, densely radiculose; leaves suberect, orate-subquadrate, 2 -lubed with ob- 
tuse lobes and sinus, or retuse or often entire; underleaves light pink, deeply bifid, the setaceous lobes spreading-incurved; monœcious; involucral leaves somewhat oblong, repandly 2-4-toothed at the apex; perianth subobovate, slightly angled. - On logs, Little Falls, N. I. (Lustin); Ont. (Macoun).

4. L. minor, Nees. Diffusely branching; leares pale green, oral-subquadrate, expanded, convex, slightly rigid, equally and acutely bifid with a lunate sinus; underleaves $\frac{1}{3}$ as large, deeply bifid, the lanceolate lobes acuminate; diœcious; involucral leaves like the cauline; perianth obtusely triangular-plicate at the apex. (I. crocata, Aust.; not Nees.) - On the ground rad dry rocks in limestone regions (Austin). (Eu.)

* Divisions of the underleaves more or less dentate.

5. L. heterophýlla, Nees. (Pl. 23.) Stems short, creeping or ascending, much brauched; leaves ovate-subquadrate, entire, retuse and bidentate on the same stem; underleaves large, 2-3-cleft ; involucral leaves lobed and dentate; perianth terminal, the mouth crested.-On the ground and rotten logs in woods and swamps; very common. (Eu.)

6. I. Hàllii, Aust. Creeping, very slightly rooting; leares subvertical, oblong, cleft nearly to the middle with obtuse sinus and erect mostly obtuse lobes; lower underleaves small, subequally 2-parted witl an obtuse sinus, the upper ones larger, with a single tooth on each side or palmately 3-4-parted, the apical sublanceolate and narrowly bifid. - On the ground, Ill. (Hall).

\section{CHILOSCỲPHUS, Corda. (Pl. 23.)}

Leaves succubous, dorsally decurrent, mostly rounded and entire; under. leaves rooting at the base, usually deeply 2-cleft. Fruit terminal on a very short lateral branch. Involucral leaves $2-6$, the outer smaller, the inner variously cut; periauth small, obconic or campanulate, 3-angled and 3-lobed only at the apex, the lobes usually spinose. Calyptra fleshy, subglobose or clavate Capsule oblong-globose. Antheridia in the saccate bases of stem-leaves. (Name from $\chi \in \hat{i} \lambda o s, a$ lip, and $\sigma \kappa v \dot{\phi} o s$, a boul, from the form of the periauth.) * Underleaves 4-parted.

1. C. ascéndens, Hook. \& Wils. (Pl. 23.) Prostrate; leaves large, pale-green, ascending, roundish-oblong, slightly emarginate; involucral leaves two, 2-cleft; perianth 2-3-lobed, the lobes long and irregularly laceratetoothed. - On rotten logs; rather common.

\section{* * Underleaves bifid.}

2. C. palléscens, Dumort. Procumbent, creeping; leaves flattened, ovate-subquadrate, obtuse or retuse ; underleares ovate, distant, free ; involucral leaves two, 2-toothed; perianth deeply trifid, the lobes spinose-dentate, mostly shorter than the conspicuous calyptra. - Mountains of N. Eng. (Oakes).

3. C. polyánthos, Corda. Procumbent, creeping; leares subascending, ovate-subquadrate, truncate or subretuse; underleares orate-oblong, distant, free; involucral leaves 2, slightly 2-toothed; periauth 3-lobed, the short lobes nearly entire, shorter than the calyptra. - Var. Rrvulàris, Nees. Larger, more branching, succulent; leaves mostly rounded above; underleaves often divided in halves or wanting. - On the ground among mosses or on rotten logs, common; the variety in shaded rills or still ponds. (Eu.) 


\section{PLAGIOCHìl Aumort.}

Leaves large, succubous, rounded or truncate above, dentate or spinose or rarely entire, the dorsal margin reflexed; underleaves usually none. Diucious or monceious. Fruit terminal, or axillary by the growth of offshonts. Involucral leaves larger than the cauline; perianth laterally compressed, erect or decurved, obliquely truncate and bilabiate, the lobes entire or ciliate-ilentate. Capsule thick, oval. Elater's attached to the midule of the valves. Anthoridia oval, $2-3$ in the axils of spicate leaves. (Name from $\pi \lambda \alpha$ ' $\gamma$ os, oblique, and $\chi \in \hat{\epsilon} \lambda$ os, lip, from the form of the perianth.)

* Underleaves 2-3-cleft, fugucious.

1. P. porelloides, Lindenb. Branches ascending; leaves subimbricate, convex-gibbuus, round-obovate, the uppermost repand-denticulate, the rest entire, the clorsal margin reflexed; perianth terminal, oblong-ovate, the mouth compressed, denticulate. - Among mosses in swanjs and river-bottoms; common.

2. P. interrúpta, Inmort. (Pl. 24.) Prostrate, horizontally luranched, copionsly rooting; leaves imbricate, horizontal, oval, entire or sliglitly repaud; underleaves lanceolate; perianth terminal, broadly obconic, the mouth compressed, repand-crenulate. (P'. macrostoma, Sulliv.) - Moist banks and docayed $\operatorname{logs}$, N. Eng., Ohio, and northward. (Eu.)

\section{* * Underleuves wanting.}

3. P. spinulosa, Dumort. Creeping, branches ascending; leaves remote, obliquely spreading, obovate-cuneate, the dorsal margin reflexed, entire, the ventral and apex spinnlose-toothed; periantlı rounded, at length oblong, the mouth spiuulose. - Shaded rocks in mountain regions; rare. (Fu.)

4. P. asplenoides, 1)umort. Branched, creeping or ascending; leaves subimbricate, obliquely spreading, round-obovate, entire or denticulate, the dorsal margin reflexed; perianth much exceeding the involucral leaves, oblong, dilated at the truncate or ciliate apex. - In rocky rivulets; common. (Eu.)

\section{M Ý L I A, S. F. Grav. (I'l. 25.)}

Leaves succubous, semi-vertical, circular, or ovate and pointed ; underleaves subulate. Diœecious. Fruit terminal or pseudaxillary. Involucral leaves 2, clasping; perianth ovate-oblong, laterally compressed above a subterete base, the apex at length bilabiate, denticulate. Capsule ovate, coriaceous. Elaters free. Antheridia 2 in the axils of bracts clustered near the apex of distinct branches. (Name from Mylius, an early botanist.)

1. M. Taylori, S. F. Gray. Stems erect, nearly simple, raliculuse; leaves large, convex, orlicular, entire, purplish ; cells large; underleaves lance-subulate, entire or subdentate; perianth terminal, oval; ealyptra finally longexserted. (Jungermannia Taylori, Hook.) - Wet rocks, high mountains of N. Eng. and N. Y. (Fu.)

\section{HARPÁNTHUS, Nees.}

Ieaves succubous, semi-vertical, ovate, emarginate; underleaves connato with the leaves, orate or lanceolate, 1-toothed at hase. 1)iacious. Fruit on short shoots from the axils of the uuderleares, fiually sublateral. Involucral 
leaves 2 or 4 . Perianth terete, the lower half thickened. Calyptra fleshy, confluent with the perianth for $\frac{2}{3}$ its length. Capsule oval. Antheridia 1 or 2 in the axils of bracts terminal on sleuder branches. (Name from å $\rho \pi \eta, a$ sickle, and ă $\nu$ Oos, flower.)

1. H. scutàtus, Spruce. Stems filiform, decumbent, usually simple; leaves smaller at the base and apex of the stems, roundish-ovate, concave, sharply bidentate, the apex lunate or acute; underleaves large, acuminate involucral leaves two, 2-3-cleft, the upper adnate to the perianth; perianth ovate, becoming obovate, obscurely 3-4-plicate, splitting above on one side; capsule deep brown. (Jungermannia scutata, Weber.) - On rotten logs in dainp places; common. (Eu.)

H. Flotoviaxus, Nees. (Pl. 23.) Stems flexuous, procumbent, mostly unbranched; leaves ovate-orbicular, horizontal, the apex contracted and emarginate with a shallow sinus; underleaves large, ovate or lanceolate, obliquely inserted, entire or more often toothed on one or both sides near the middle; diceious; perianth subcylindric, slightly sickle-shaped, the mouth pointed at first, notched on one side and finally crenulate; antheridia elliptic, single in the base of swollen leaves. (Pleuranthe olivacea, Tayl.) — "North America" (Drummond), but not collected recently; certainly extralimital.

\section{LIOCHL㐫 NA, Nees.}

Leaves succubous, ovate-oblong, entire or slightly retuse; underleaves none. Diocious or moncecious. Involucral leares 2 or 4 , like the cauline; perianth Fyriform, becoming cylindric, incurved, abluptly rounded at the summit, the minute orifice prominently ciliolate. Capsule oblong, long-exserted. Elaters attached to the middle of the valves. Spores minute, globose. Antheridia in the axils of ordinary leaves. Archegonia 5-12. (Name from $\lambda \epsilon \hat{i}$ s, smooth, and $\chi \lambda \alpha \hat{\imath} \nu \alpha, a$ cloak, referring to the perianth.)

1. L. lanceolàta, Nees. Closely creeping, branched; leaves sometimes decurrent; involueral leaves vertical; perianth at right augles with the stem; monocious. - On banks and rotten logs; not rare. (ku.)

\section{JU NGERMÁ N N I A, Micheli.}

Leaves succubous, rarely subtransverse, entire, lobed or dentate, the margins never recurved; underleaves present or none. Diœcious or monnecious. Fruit terminal. Involucral leaves 4 or fewer, like the cauline or more incised, free ; perianth laterally compressed or terete, usually 3-10-carinate, the usually small mouth entire or toothed. Calyptra oval-pyriform. Capsule globose or oblong, rarely cylindric. Spores minute, smooth or roughish. Archegonia 8-70. (Named for L. Jungermann, a German botanist of the 17th century.)

§ 1. JUNGERMANNIA proper. Leaves orbicular or ovate, entire or barely retuse; underleaves none (very small in $\mathrm{n} .1$ ).

1. J. Schràderi, Martins. (P1. 25.) Creeping, flexuous; leaves roundolliptic, entire, ascending; underleares broadly subulate, not apparent on old stems; involucral leaves large, elongated, the inner smaller and more or less laciniate; perianth oval-obovate, ascending. - On the ground and rotten logs; common. (Eu.)

2. J. sphærocárpa, Hook. Stems creeping, the tips ascending, subsimple, greenish; leares semi-vertical, rather rigid, orbicular, obliquely spread- 
ing, decurrent dorsally, pale green; involucral leaves separate; perianth exserted, obovate-oblong, the mouth 4-cleft; capsule globose. - Mountains of N. Eng. (Austin) ; rare. (Eu.)

3. J. pumila, With. Stems creeping, the tips somewhat ascending, subsimple, rooting, pale; leaves ascending, ovate, ohtuse, concave, entire; involucral leaves like the cauline, erect; jerianth terminal, fusiform, plicate above and denticulate; capsule oval. - On shaded rocks along rivulets, Clogter, N. J. (Austin). (Eu.)

§ 2. LOPHÖZIA. Leaves roundish or subquadrate, bidentate, bifid, or sometimes 3-5-cleft; underleaves none, or small and mostly 2-parted; perianth usually strongly plicate.

\section{* Underleaves present. \\ - Leaves bifid or 2-lobed.}

4. J. Gillmàni, Aust. Stems short, densely cespitose, prostrate, strongly radiculose; leaves vertical, round-ovate, subconcave, bifid, the lower leaves with usually acute sinus and lobes, the upper nuch larger with rounded lobes and obtuse sinus; underleaves entire or the broader bifid; perianth without involucral leaves, dorsal, sessile, obovate, subgibbous, ciliate, at length much incised. - In a sandstone cave, Traiue Island, I. Superior (Gillman).

5. J. Wattiàna, Aust. Stems rather thick, 2-4" long, fragile, subflexuose, strongly radiculose; leaves subvertical or spreading, subovate, concave, emarginately 2-lobed, the lobes acute or the upper obtuse; underleaves somewhat obsolete, hair-like or subulate, incurved; involncral leaves little larger, less deeply lobed; perianth terminal, small, ovate-gourd-shaped, whitish, ciliate. - On the ground, northern shore of L. Superior (.1/acoun).

\section{+ - Leaves 3-5-cleft.}

6. J. barbàta, Schreb. (Pl. 25.) Procumbent, sparingly branched; leaves roundish-quadrate, with obtuse, acute, or mucronulate lohes and obtuse undulate sinuses; underleaves broad, entire or 2-toothed, sometines obsolete; perianth ovate, plicate-angled toward the apex, denticulate.-On rocks in mountain regions; common. (Fu.)

Var. attenuàta, Martius. Ascending, with numerous offshoots; stemleaves semi-vertical, obliquely spreading, roundish, acutely $2-4$-trothed, those of the shoots closely imbricate, premorsely 2-4-denticulate; involucral leaves two, 3-toothed; perianth oblong. - In similar localities. (Eu.)

7. J. setifórmis, Whrh. Erect or ascending, dichotonous; leaves toothed at base, 3-4-cleft, the lohes ovate-ohlong, acute, chanuelled; underleaves ciliate-rlentate at base, deeply hifil, the livisions lanceolate, acuminate; involucral leaves more toother than the cauline; perianth terminal, oral, plicate. - Alpiue summits of N. H. (Oukes). (Eu.)

\section{* Underleaves uanting.}

\section{+ Lraves 2-toothed; incolucral leaves 2-4-clen.}

8. J. alpéstris, Schleich. Stems creeping, crowled, lifu-branching, the ends ascenling; leaves semi-vertical, orate-sulquadrate, obliquely toothed, the teeth unequal, acute or mucronulate, distant ; involucral leaves wider, 2-3-cleft ; perianth twice as long, oblong, sinooth, the mouth complicate; capsule oval. Alpine region of $\mathrm{N}$. H. (Oukes). (Eu.) 
9. J. ventricòsa, Dicks. Stems dense, close-creeping, branching from beneath; leares semi-rertical, subquadrate, mostly flat, broadly and acutely emarginate-bidentate, often bearing globules; involucral leaves larger, round, erect-spreading, 3-4-cleft, subdentate ; perianth ovate, inflated, narrowly complicate above; capsule oval. - On the ground and rotten wood in the mountains, and far northward; common. (Eu.)

10. J. Wallrothiana, Nees. Minute, blackish; stems creeping, strongly rooting, subsimple; leaves clasping, semi-vertical, closely imbricate, ovatequadrate, concave, obtusely bidentate with an obtuse sinus, or acute in the upper leaves; involucral leaves larger, erect, connate at base, 3-toothed, wavyplicate; perianth oval-cylindric, plicate and subdentate, pellucid, reddish below. - On coarse sand in the White Mts. (Oakes). (Eu.)

+- Leaves bifid or 2-lobed, the ventral lobe often inflexed or subcomplicate; involucral leaves merely toothed, except in $\mathrm{n} .11$.

11. J. láxa, Lindb. Widely creeping, mostly simple, usually purplishblack; leaves imbricate, or distant on the erect fertile stems, 2-3-lobed, the lobes obtuse, wary; cells very large, lax; involucral leaves 2, wide, short, cristate-undulate, obtusely many-lobed; perianth exserted, long-clavate, subplicate above, minutely ciliate. (J. polita, Aust.; not Nees.) - Among Sphagnum near Closter, N. J. (Austin).

12. J. excisa, Dicks. Stems closely creeping, short, subsimple, rather rigid; leaves semi-vertical, erect-spreading, pellucid, roundish, with straight acute lobes and deep obtuse sinus; involucral leaves erect, quadrate, usually 4-5-toothed; perianth erect, oblong, pale, banded and spotted with pink, plicate above, irregularly denticulate. - Sterile grounds in open woods; common. (Eu.)

Var. críspa, Hook. Leaves round-quadrate, closely imbricate, deeply and obtusely 2-3-cleft; involucral leaves 3-4-cleft, connate at base, subserrate. (J.intermedia, Lindenb.) - In crerices of rocks, N. Y. and N.J. (Austin). (Eu.)

13. J. incisa, Schrad. Stems thick, rooting, closely creeping or ascending; leaves crowded, semi-rertical, complicate, subquadrate, 2-6-cleft, the acute lobes unequal, more or less spinulose-dentate; involucral leaves similar, more plicate and dentate, free; perianth short, oral or obovate, plicate above, denticulate. - On rotten wood in the mountains, and northward. (Eu.)

§3. SPHFNÓLOBUS. Leaves 2-lobed, subtransverse, complicate-concave; underieaves none; involucral leaves 2-3-cleft. (Verging toward Marsupella on one side and Diplophyllum on the other.)

14. J. Michaùxii, Weber. Stems ascending, flexuous by repeated innovations below the summit; leaves crowded, subvertical, erect-spreading, subsaccate at base, subquadrate, bifid with straight acute lobes and a narrow sinus; involucral leaves similar, the outer serrulate, the inner smaller; perianth ovate-subclarate, obtuse, plicate above, fringed. - Fallen trunks, mountains of N. Y. and N. Eng.; common. (Eu.)

15. J. minùta, Crantz. Rootless; leaves cleft $\frac{1}{4}-\frac{1}{2}$ their length, the lobes ovate, subequal, acute or obtuse, entire, or gemmiparous ones subdentate; involucral leaves trifid; perianth oval-oblong or subcylindric. - On rocks in high mountain regions, and northward. (Eu.) 
16. J. Helleriàna, Nees. (P1.25.) Creeping, entangled; leaves spreading, subascending, cleft $\frac{1}{-1}-\frac{1}{2}$ their length, the lobes equal, acute, entire or serrate; involucral leaves $2-3$-cleft, spinuluse-serrate; perianth ovate, the mouth contracted. - On rotten wood, N. Y., N. Ling., and northward. (Liu.)

§4. GYMNOCÓLEA. Leaves 2-lobed; underleaves none; involucral leaves like the cauline; perianth pedunculate, denticulute.

17. J. inflàta, Huils. (Pl. 25.) l'rocumbent or ascending, loosely radiculose, branching; leaves semi-vertical, rounclish-elliptic, inequilateral, the sinus and unequal loles obtuse; perianth terminal or at length dorsal, oval or pyriform, smooth, the mouth connivent; capsule oblong. - On sterile ground and rocks, N. J. (Austin), and northward in the mountains. (Eu.)

\section{MARS UPÉLLA, Dumort.}

Stems dorsally compressed, with rootlets at the base and often producing somewhat leafless runners. Leaves transverse, complicate-bilobed; involucral leaves 2 or 4 , connate with the perianth. I'erianth tubular or oval, subcompressed parallel to the base of the leaves. Elaters free. Spores round, rufous (in our species). Antheridia mostly terminal. (Name a diminutive of marsupium, a pouch, from the form of the periauth.)

1. M. sphacelàta, Dumort. Stems erect, subflexuous, pale brown; leaves rather distant, concave, obovate to obcordate, somewhat clasping, the sinus narrow; diøcious; involucral leaves larger than the cauline, cordate; periauth free at the apex, with 4-5 broad acute teeth; antheridia $1-3$, in short terminal spikes. - Wet rocks, mountains of N. Eng. to N. J., and southwarl. (Eu.)

2. M. emarginàta, Dumort. (Pl. 23.) Stems simple or innovating at the summit, rigid, somewhat thickened upward; leaves usually broader than long, round-cordate or subquadrate, lobes obtuse or mucronate, sinus acute; dicecious; involucral leaves 4-8, usually larger, more deeply and acutely emarginate; periauth urceolate, the closed apex splitting into $4-5$ triangular lobes; antheridia 2-3, oval, axillary in terminal spikes. (Sarcoscyphus Ehrharti, Corda.) - On wet rocks, chiefly in mountain rivulets, $\mathrm{N}$. Y. and $\mathrm{N}$. Eng. Fluating forms are longer with distant leaves. (Eu.)

3. M. adústa, Spruce. Stems minute, clavate; leaves $(5-8$ pairs) imbricate, round or broadly ovate from a sheathing base, acutely lobed with angular sinus; monocious; perianth included, campanulate, create becoming irregularly lobed; spores punctate; antheridia 1 or 2 , oval, in the axils of the lower involucral leaves. (Gymnomitrinm adustum, Nees.) - Alpine region of the White Mts. (Oakes, Austin). (Eu.)

\section{N Á R D A, S. F. Gray.}

Stems laterally compressed, usually without runners. Ieaves succubous, subconeave or flat, the apex roundel, rarely retuse or bidentate; underleaves none (in our species). Monocions or dimeious. Involucral leaves $2-4$ pairs, comnate at base. Perianth subcompressed laterally, connate with the involucral leaves. Antheridia terninal on somewhat spike-like stems. (Named for S. Nardi, an Italian abbot.) 
\$1. EÜCALYX. Perianth connate at lase with the inner involucral leaves, someuhat surpussing them, 3-8-carinate, the mouth constricted.

1. N. hyalina, Carring. Creeping, with ascending tips, the branches dichotomous-fastigiate, with claret-colored rootlets; leaves loosely imbricate, decurrent, roundish, repand-undulate; moncecious or dicecious; involucral leares broader, appressed, one connate with the lower third of the perianth, which is somewhat exserted, obovate, plicate with acute rough angles, rostellate, at length 4-cleft; (apsule round-ovate. (Jungermanuia hyalina, Lyell.) - On banks in woods, Closter, N. J. (Austin), Ohio (Lesquereux). (Eu.)

2. N. crenulàta, Lindb. (Pl. 25.) Prostrate, branching; leares orbicular, entire, larger toward the involucre and with large marginal cells; riœcious; involucral leaves 2 , rarely 3 , adnate to the base of the perianth, which is flattened or terete, more or less regularly 4-5-plicate, the angles smooth; mouth much contracted, toothed. (Jungermannia crenulata, Smith.) - On the ground in old fields, N. Y. and southward. (Eu.)

3. N. crenulifórmis, Liudb. Iensely cespitose ; fertile stems creeping, thickened upward, with numerous purple rootlets, the sterile subascending, attenuate upward ; leaves subdecurrent, obliquely spreading, orbicular, concave, entire or nearly so; perianth small, subobovate, more or less connate with the involucral leaves, not exserted or slightly so, rooting at base, triquetrous above, becoming 4-7-plicate; calyptra often violet-purple; capsule oral-globose. (Jungermannia crenulifornis, Aust.) - On rocks in rivulets, Closter, N. J. (Austin), Coshocton Co., Ohio (Sullivant).

4. N. bilórmis, Lindb. Densely cespitose, much branched, innovating from beneatls; rootlets numerous; leaves scarcely imbricate, alternate, spreading, obliquely semicircular or broadly ovate, retuse or entire, decurrent dorsally ; cells large, hyaline; branch-leaves half as large, ovate or obovate, scarcely decurrent; diœcious; antheridia solitary; fruit unknown. (Jungermannia biformis, Aust.) - On steep wet rocks, Delaware Water Gap, N. J. (Austin).

§ 2. CHASCÓS'TOMA. Perianth exserted, subcampanulate and open, deeply laciniate, connate with the involucral leaves.

5. N. fossombronioides, Lindb. Stems densely cespitose, ascending; rootlets numerous, purple; leaves 2-ranked, subvertical, spreading-subrecurved, rooting, closely imbricate, orbicular, clasping by a slightly cordate base, subventricose, undulate-repand, the apex uniplicate and slightly emarginate; monocious; perianth very large, 6-10-plicate, the lobes entire; calyptra violet; capsule short-oval. (Jungermannia fossombronioides, Aust.) - On rocks in a rivulet, Closter, N. J. (Austin), and southward.

\section{GYM NOMÍtRIUM, Corda.}

Leaves closely imbricated, 2-ranked on fascicled ascending julaceous stems, emarginate-bidentate; underleaves none. Diøcious. Iuvolucre double, the inner shorter, of 2 or more dentate and deeply cleft leaves. Calyptra short, campanulate. Capsule globose, the valves at length reflexed. Elaters cadu. cous. Antherillia in the axils of leaves, oval, stipitate. (Name from rupuós, naked, and $\mu \iota \tau$ píov, a little cap.)

1. G. concinnàtum, Corda. Stems simple or imbricately branching, thickened at the apex; leaves ovate, bifid, with a narrow scarious margin. 
(Cesia concinnata, S. F. Gray.) - Alpine regions of the White Mts. (Oakes). - Grayish or silvery-olive. (Eu.)

\section{FOS SOMBRÒ NIA, Radli.}

Stems thalloid, with large subquadrate succulous leaves; underleaves none. 1)iœcious or monecious. Fruit terminal or by innovation dorsil on the main stem. Involncral leaves 5-6 (in our species), small, subulate, adnate. I'erianth open-campanulate or ohyyramilal, crenate-lohed. Calyjtra free, subglobose. Capsule short-pedicelled, globose, irregularly valved. Elaters very short, 1-3- (mostly 2-) spiral, free. Spores large, very rough. Antheridia 2-3, short-pedicelled, naked. Perfect archegonia 2-3. (Named for V. Fossombroni, an Italian Minister of State.)

\section{* Plant large or of medium size; stems mostly simple.}

1. F. pusílla, Dumort. (I'l. 23.) Stems 6-10" long; leaves retuse, entire or irregularly indented; perianth obconic, dentate; elaters short and thick; spores brown, depressed-globose-tetrahedral, $40 \mu$ bruad, crested, the sleuder crests pellucid, rarely becoming confluent. - On damp ground. Its occurrence in America is doubtful. (Eu.)

2. F. Dumortièri, Lindb. Cespitose, greenish or brownish-yellow; stems $3-6^{\prime \prime}$ long, $1^{\prime \prime}$ wide, shortly bifurcate; rootlets copious, purple; leaves numerous, smaller toward each end of the stem; monœcious; perianth large, broadly obpyramidal ; calyptra nearly as long; elaters seanty; spores globosetetrahedral yellowish-brown, regularly pitted. - White Mits. (Farlow), N. J. (Austin), and perhaps elsewhere; confused with n. 1 .

3. F. angulòsa, Raddi. Stems narrowly furkel at the apex; leaves horizontal, subquadrate, the upper undulate-lobed ; dicecious ; perianth dilatedconic, crenate; spores brownish-yellow, globose-tetrahedral, not depressed, $30 \mu$ broad, deeply reticulated, the reticnlations large, 5-6-augled. - Brackish meadows, common; fruiting in early spring. (Eu.)

* *lant minute; stems forked or fustigiately divided.

4. F. crístula, Aust. Stems 1-2" long; leaves whitish, quadrate or round-obovate, subentire, strongly crisped-undulate; capsule immersed on a short pedicel ; elaters short, nore or less diverse, with a single narrow annular and spiral fibre; spores pale fuscous, more or less tuberculate. - On moist sand in unfrequented paths, Batsto, N. J. (Austin).

\section{PALIA VICÍ N I A, S. F. Gray.}

Thallus with a distinct costa. Fruit arising from the costa, at first terminal, becoming dorsal. Diøcious. Involucre cup-shaped, short-lacerate. I'erianth long-tubular, denticulate. Calyptra irregularly lacerate. Capsule slendercylindric. Elaters slender, free. Spores minute. Antheridia dorsal, eovered with minute fimbriate scales. (Named for L. Pullavicini, Archlishop of Genoa.)

1. P. Lyéllii, S. F. Gray. Thallus thin, $1-4^{\prime}$ long, $3-5^{\prime \prime}$ wide, simple or bifid, the margin entire, slightly crenate or serrate; cells large, oblong-hexagonal; perianth erect, fleshy ( 5 cells thick below), the somewhat constricted mouth lobate-ciliolate; pedicel long, exceeding the thallus; capsule cylindric, 
five times as long as broad. (Steetzia Lyellii, Lehm.)-Among mosses in swamps and on dripping rocks; common, especially southward. (Eu.)

\section{BLÀ S I A, Micheli. (Pl. 23.)}

Thallus simple or forked or stellate, with sinuous margins. Diœcious. Fruit from an oval cavity in the costa. Involucre mostly none. Calyptra obovate. Capsule oval-globose. Antheridia immersed in the thallus, covered with dentate scales. Gemmæ globose, issuing by a slender ascending tube from large flask-shaped receptacles which are immersed in the thallus. (Named for Blasius Biagi, a monk of Valombrosa and companion of Micheli.)

1. B. pusílla, L. Thallus $\frac{3}{4}-1 \frac{1}{2}$ long, $2-3^{\prime \prime}$ wide, narrowly obovate, the margins pinuatifid-sinuous. - Wet banks; common. (Eu.)

\section{PÉLLIA, Raddi. (Pl. 23.)}

Thallus with a broad indeterminate costa. Monœcious or diœcious. Fructification dorsal near the end of the thallus. Involucre short, cup-shaped, lacerate-dentate. Calyptra membranous, oval, longer or shorter than the involucre. Capsule globose. Elaters long, free. Antheridia globose, immersed in the costa. (Named for A. L. Pelli, an Italian botanist.)

\section{* Monocious.}

1. P. epiphýlla, Raddi. (P1. 23.) Thallus oblong, lobed ard sinuate, somewhat fleshy, much thickened in the middle; capsule exserted. - On the ground in wet places; not uncommon eastward. (Eu.)

* * Dicecious.

2. P. endiviæfolia, Dumort. Thallus flat, green or purplish, broadly linear, dichotomous, the inargin mostly undulate or crisped. - On the ground and in ditches; common, but often confused with n. 1. (Eu.)

3. P. calycina, Nees. Thallus dichotomous, proliferous, the early divisions linear-oblong, the margins ascending and remotely sinuate, the later divisions linear-palınatifid, coarsely nerved; cells large, hexagonal; involucre ciliate-friuged or lacerate: calyptra smooth, included. - Wet limestones and shales. (Eu.)

\section{METZGERIA, Raddi. (Pl. 23.)}

Thallus linear, dichotomous, with well defined costa. Diœeious. Frnctification arising from the under side of the costa. Involucre 1-leaved, scale-like, at length ventricose. Calyptra clavate or pyriform, fleshy. Capsule shortpedicelled. Elaters unispiral, some remaining attached to the tips of the valres. Spores minute, mostly smooth. Antheridia globose, enclosed in a scale on the under surface of the costa. (Named for J. Metzger, a German botanist.)

* Densely villous throughout.

1. M. pubéscens, Raddi. Thallus $1-2^{\prime}$ long, $1^{\prime \prime}$ wide, alternately pinnate or somewhat decompound, the short linear branches of uniform width, flat, the margin undulate; hairs longer beneath, single or in twos and threes near the margin, irregularly curved; midrib nearly without cortical layer, with 6-10 (mostly 8) rows of very uniform peripheral cells; diœcious. - In mountain regions, eastward. (Eu.) 
* Hairy on the margins and midrib beneath, smooth above; diacious (u. I monacious).

2. M. myriópoda, Linlb. 'Thallus elougated ( 2 ' long, $\frac{1}{2}$ " widc), dichotomous, the long linear branches of uniform width, convex above, the reflexed margins not undulate; midrib densely pilose beneath; hairs rather long, straight or nodling, the marginal mostly in clusters of $3-6$, some with diseoid tips; midrib covered above with 2 rows of enlarged cells, and beneath with $3-7$ (usually $4-6$ ) rows of smaller cells, lax and often indistinct. ( $M$. furcata, sullic., in part; not . Necs.) - Shaded rocks and trees in tho Alleglanies (Sullivant), and southward.

3. M. hamàta, Liudb. Like the last; thallus much elongated ( $4^{\prime}$ long, $1-1 \frac{1}{2}$ " wide); hairs very long, divaricate and hooked-deflexed, the marginal in twos, rarely with discoid tips; midril, covered ahove and below with two rows of enlarged lax cells. (M. furcata, Sulliv, in part.) - Alleghany Mts. (Sullivant).

4. M. conjugàta, Lindb. 'Thallus $1 \frac{1}{2}$ ' long, $\frac{1}{2}-1$ " wide, usually dichotomous, the short branches irregular in wilth, convex above, the margins moro or less undulate; hairs rather long, straiglit, divaricate, the marginal usually in twos, very often disk-bearing; midribs coverel alove with 2, helow with 3-6 rows of enlarged lax cells. - On shaded rocks and trunks of trees, central N. Y., and southward. (Eu.)

\section{A NE Ù A, Dumort.}

Thallus fleshy, prostrate or assurgent from a creeping base; costa obscure. Diœcious or monœcious. Fructification arising from the under side near the margin. Involucre cup-shaped, short and lacerate, or none. Calyptra large, fleshy, more or less clavate. Capsule large, oblung-cylindric. Elaters unispiral, in part adherent to the tips of the ralves. Spores minute, smocth or minutely roughened. Antheridia inmersed in the surface of receptacles proceeding from the margin of the thallus. (Name from $\alpha$-privative, and $\nu \in \hat{v}$ pov, a nerve.)

* Thallus narrow (ahout 1" wide), palmatcly dirided.

1. A. látifrons, Lindl. Thallus cespitose, ascending or erect, usually dark green, 6-9" long, mostly pellucid; branches linear, olituse aud emarginate, plano-convex; cells large, oblong-rhombic ; monocions; archegonia 3 10, short, conic; calyptra white, verrucose, pyriform-clavate; capsule oval, brown; spores $12 \frac{1}{3}-14 \frac{1}{2} \mu$ broad, globose, minutely and densely papilluse; antheridia globose. ( 1 . palmata of authors; not Dumort.) - On rotten logs ; common.

* * Thallus narrow (about 1" wide), pinnate or bipinnate.

2. A. multífida, Dumort. 'Thallus prostrate, brownish-green, pinnately divided, the primary portion biconvex, somew lat rigid, the branches horizontal, pectinately pinnate with narrow linear divisions; monceious; fructification rising from the primary part or from the branches; involucre fleshy; calyptra tuberculate. - Var. mAson, Nees. Primary portion and branches thick, tho branches interruptedly pinnate with short obtuse divisions. - On decayed wood and moss in swamps, N. J. (Austin), and south in the mountains. (Eu.) 
3. A. pinnatifida, Nees. Thallus pinnately divided or subsimple, flat or somewhat channelled; branches horizontal, the broader pinnatifid or dentate, obtuse; calyptra somewhat smooth.-On dripjing rocks, Hokokus, N. J. (Austin), N. Haveu, Conn. (Eaton). (Eu.)

* * Thallus wider ( 2 " or more), simple or irregularly lobed.

4. A. séssilis, Spreng. Thallus decumbent, irregularly lobed, $1-2$ ' long, $3-5^{\prime \prime}$ wide; involucre none; pedicel $\frac{8}{4}-1^{\prime}$ long, sometimes folded upon itself and remaining within the calyptra, the capsule thus appearing sessile ; antherilia on elongated receptacles. - Wooded swamps. Elongated floating forms, $5-6^{\prime}$ lorg, have been found in the White Mts. (Farlow, Fuxon).

5. A. pínguis, Dumort. Thallus $1-2$ ' long, decumbent or ascending, fleshy, linear-oblong, simple or slightly lobed, the margin sinuate; dicecious; involuce short, lacerate; calyptra cylindric, smooth; capsule brownish, furrowed; antheridia in 2-lobed receptacles. - Wet banks, N. J. to Ohio, and southward. (Eu.)

\section{Crder 138. ANTHOCEROTA CE A. (Horned Liverworts.)}

Plant-body a thallus, irregularly branching, flaceid, without epidermis or pores, and more or less vesiculose. Involucre single, tubular. Calyptra rupturing early near the base, and borne on the apex of the capsule. Capsule dorsal, poll-like, erect or eurved outward, more or less perfectly 2-valved, usually stomatose, tapering into a pedicel or often sessile with a bulbous base. Columella filiform. Elaters with or without spiral fibres. Spores flattish, more or less convex-prismatie, papillose or smooth.

1. Anthoceros. Capsule narrowly linear, exsertly pedicelled, 2-valved. Elaters present.

2. Notothylas. Capsule very short, sessile, not valved below the middle. Elaters not obviuus.

\section{A NTHÓCEROS, Micheli.}

Thallus dark green or blackish, usually depressed, variously lobed, with large chlorophyll-grains, frequently glandular-thickened at the apex or in lines along the middle so as to appear nerved. Monœcious or diøecions. Capsule linear, 2-valved, exsertly pedicelled. Elaters simple or brauched, often geniculate, more or less heteromorphous, the fibres wanting or indistinct.

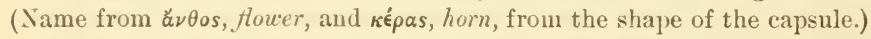

1. A. lævis, L. (Pl. 22.) 'Thallus smooth, nearly flat above; diøcious; involucre 1-2" long, trumpet-shaped when dry, repand-toothed; capsule pale brown or yellowish, $1-1 \frac{1}{2}$ long; elaters rather short, yellowish; spores yellow, nearly smooth, angular. - Wet clay banks, from Canada south and westward. (Eu.)

2. A. punctàtus, I. Thallus small, depressed, or often cespitose and erect, more or less glandular; moncecious; involucre rather short, oblouglinear, slightly repand, sometimes scarious at the mouth; capsule l' high, black; elaters fuscous, flattish, geniculate; spores black, strongly muriculate, sharply angled. - Wet banks, Canada to Mo., and southward.

(Eu.) 
2. NOTOTH XLA S, sulliv.

(P1. 22.)

Thallus orbicular, tender, laciniate and undulate or erispeel, papillose-reticulate. Moncelous. Involucre sessile, continnous with the thallns, oprening irregularly above. Capsule very short, oblong-glolose or os ate-eylimlric, poelicelled from a thickened lulb, 2-valved to the midhlle or rupuring irregrularly.

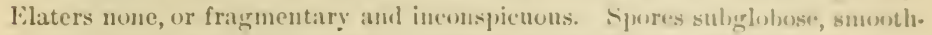
ish. Antherilia elliptic-glolose, immersed in the thallus. (Xame from vôtos, the back, and $\theta 0 \lambda a$ s, a bay, from the shape and position of the involucre.)

1. N. orbiculàris, Sulliv. (1'1.22.) 'Thallus $3-8$ " wide; calsules 1 $2^{\prime \prime}$ long, erect or decurved, wholly included or slightly exserted, of thin and loose texture, with a suture on each side; spores light yellowish-brown. (Includiug N. valvata, sullir.) - Wet places, Canada to tlw Gulf.

2. N. melanóspora, sulliv. Thallus small, depressed or sometimes cespituse, of lax texture; capsule often without sutures; spores dark brown, a half larger. - Moist ground, (Hhio (Sullivenl).

\section{Order 139. MARCHANTIACEAs. Liverworts.}

Plant-body a thallus, dichotomous or subpaluately lonanching, usually innovating from the apex or bencath it, more or less thickened in the middle, and bearing numerous rovtlets leneath and usually colored or imbricatiug scales. Epidermis usually more or less distinct and strongly porose above. Capsules globose, rarely oval, opening irregularly, pendent from the under side of a peduncled disk-like receptacle (carpocephalum). Elaters present, mostly 2-spiral.

* Thallus plainly costate, distiuetly porose except in n. 6 .

- Gemma present on sterile stems.

1. Marchantia. Gemnx in eup-shaped recepticles. Fertile receptacle $\gamma-11$-rayed.

8. Lunularia. Gemma in ereseent-shaped recpptacles. Fertile receptacle crucifurm. ++ Gemmic wanting.

+ Receptacle conie-hemispherieal, 2-4-hohel; periantls luhell or fringed.

2. Preissia. Receptarle $2-4$-lobed, with as many alternate rib-like rays. Perianth $4-5$ lubel.

3. Fimbriaria. Receptaele 4-lobed. Perianth eonspicuous, split into 8-16 fringe-like sergments.

++ ++ Receptacle more or less conical; jerianth nono.

4. Conocephalus. Thallus very large, strungly arenlate. Recejtacle ponieal, membranous.

5. Grimaldia. Thallus small. l'eluncle chaffy at base and ajex. Recejtacle conichemispluerie, trimeately $3-4$-lohed.

6. Asterella. Thallus epwrose. Receptacle conic-hemispheric, hecoming fattened, acitely 4- (1-6-) lobed.

* Thallus thin, ecostate or barely costate.

7. Dumortiera. Reepplacle convex,2-S-lobel. I'erianth none.

\section{MARCHÁ NTIA, Marchant f.}

Thallus large, forking, areolate, porose, with broul diffused midrib; gemma in a cup-shaped receptacle. Diocions. Fertile recoptacle peduncled from an apieal sinus of the thallus, raliately lohed. Involueres alturuate with the rays, membranous, lacerate, enclosing 3-6 l-fruited cleft perianths. Calyptra per- 
sistent. Capsule globose, exserted, pendulous, dehiscing by several revolute segments. Elaters long, attenuate to each end. Spores smooth. Antheridia immersed in a peduncled disk-like radiate or lobed receptacle. (Named for Nicholas Marchant, a French botanist.)

1. M. polymórpha, L. Thallus $2-5^{\prime}$ long, $\frac{1}{2}-1 \frac{1^{\prime}}{2}$ wide, numerously porose, venulose; receptacle divided into usually 9 terete rays; peduncles 1 3 ' high; autheridial disk crenately or palmately 2-8-lobed, on a peduncle 1' high or less. - Everywhere common. (Eu.)

\section{PREİSSIA, Nees.}

Thallus obcordate, sparingly forked, increasing by joints; pores conspicuous; gemmæ none. Diœcious or monœcious. Fertile receptacle hemispheric, 1-4-lobed, with as many alternating shorter rib-like rays. Outer involucres attached beneath the lobes, 1-3-fruited, opening outward by an irregular line; perianth obconic-campanulate, angular, unequally 4-5-lobed. Calyptra persistent. Capsule large, distinctly pedicelled, dehiscing by $4-8$ revolute segments. Elaters short. Spores coarsely tuberculate. (Named for L.Preiss, a German botanist.)

1. P. commutàta, Nees. Thallus 1-2' long, with conspicuous white pores above, and dark purple scales beneath; usually monœcious; peduncle $\frac{1}{2}-1^{\prime}$ high ; capsules conspicuous, dark purple; antheridia in a peduncled disklike receptacle. (P. hemisphærica, Cogn.) - On slaty and limestone rocks, from N. J. north and westward. (Eu.)

\section{FIMBRI ÀRIA, Nees. (Pl. 22.)}

Thallus thickened in the middle by a keeled costa, usually conspicuously porose, with dark purple scales beneath; gemmæ none. Monœcious. Receptacle rising from the apex, conic or hemispheric, concave beneath and expanded into usually 4 large campanulate 1 -fruited involucres. Perianth oblong-oral or subconic, exserted half its length and cleft into 8-16 fringe-like segments. Calyptra with a long style, fugacious. Capsule nearly sessile, irregularly circumscissile. Elaters rather short, 1-4-spiral. Spores angular, subreticulated. Antheridia immersed in the thallus. (Name from fimbria, a fringe, alluding to the perianth.)

1. F. tenélla, Nees. Thallus of one or more long-wedge-shaped emarginate divisions about $6-9^{\prime \prime}$ long, grayish-green and porose above, purple on the margins; peduncle $1^{\prime}$ high or more, usually purple; receptacle obtusely conic; periantl white, 8-cleft. - On damp ground in sandy fields or on rocks, central N. Y. to Mo., and southward.

\section{CONOCÉPHALUS, Neck. (Pl. 22.)}

Thallus dichotomous, copiously reticulate and porose, with a narrow costa ; gemmæ none. Receptacle conic-mitriform, membranous. Involucres 5-8, tubular, 1-fruited, suspended from the apex of the peduncle; perianth none. Calyptra persistent, campanulate, 2-4-lobed at the apex. Capsule pedicelled, oblong-pyriform, dehiscing by $5-8$ revolute segments. Elaters short, thick. Spores muriculate. Antheridia inibedded in an oval disk sessile near the apex of the thallus. (Name from $\kappa \hat{\omega} \nu o s, a$ cone, and $\kappa \epsilon \phi a \lambda \hat{\eta}, a$ head.) 
1. C. cónicus, 1)umort. 'Thallus $2-6$ ' long, $\frac{1}{2}-g^{\prime}$ wide; receptacle conic, striate, crenate. (Fegatella conica, Corda.) - Shady banks; commun. (Eu.)

\section{GRI M Á L D I A, Radili. (I'l. 23.)}

Thallus thick, more or less channclled, dichotomous, innovating from the apex, with thick epidermis, clusely areolate and prose-scabrus above, purple and more or less scaly beneath; gemmax none. Monucious or limeinus. Roceptacle peduncled, hemispherical or conodial, $3-4$-holerl. Involucres as many, l-fruited, each a distention of the lobe. Capsnle filling the involucre, circum scissile in the middle, the ealyptra persistent at its base. Anthericlia in an oval or obeordate disk immersed in the apex of the thallus. (Named for I). Grimaldi, an Italian botanist.)

1. G. bárbifrons, Bisch. (Pl. 23.) Thallus linear-oheuneate, $3-6$ "long, $1-2$ " wile, 2 -lobed at the apex, pale green with usually distinct whitish pores, the scales beneath often extending far beyoud the margin and becoming whitish; pertuncle profusely chaffy at hase and apex, sumctimes much reduced; antheridiạl disks obeorelate. (Including (i. sessilis, Sullic.) - Thin soul on rocks, Conn. and N. J. to Iowa ; rare or lucal. (Eu.)

2. G. rupéstris, Lindenb. 'Thallus $3-6^{\prime \prime}$ lonğ, $1-3$ " wide, with membranous margins; receptacle small, hemispherical, 1 -4-fruited, the pecluncle about $l^{\prime}$ ligh, sparingly scaly at base, harbulate at the apex; iusoluce short, crenulate; spores tuberculate. (Duvalia rupestris, Nees.) - On calcarcous or shaly rocks, N. Y. and Ohio. (Eu.)

\section{A S TERÉLLA, Beauv.}

Thallus rigid, very indistinctly porose, the midrib broad, strong and distinct. Receptacle conic-hemispheric, becoming flattened, 1-6- (usually 4-) loted. Monœecious. Involucres coherent with the lobes, l-fruited, 2-valved. Calyptra minute, lacerate, persistent at the base of the capsule. Capsule greenish, rupturing by irregular narrow teeth or hy a fragnentary operculum. Elaters moderately long, mostly 2-spiral. Spores tuherculate. Autheridia in sessile lunate disks. (Dimimutive of aster, a star, from the form of the receptacle.)

1. A. hemisphærica, leauv. 'Thallus forking and increasing by joints, pale green, purple beneath ; receptacle papillose on the summit (less so at maturity) ; peduncle bearded at base and apex, 年 - l' long, often $2-3$ times longor after maturity. (Reboulia hemisphurica, liuddi.) - Shaded banks, chietly along streams; more common southwart. $-\Lambda$ smaller form or perhaps variety (Reboulia microcephala, Nees; R. Sullivantii, Lchm.) occurs in I'enn., Ohio, and southward. (Eu.)

\section{DUMORTIERA, Nees.}

Thallus large, thin, soft, with a slight costa, dichotomous, usually with scattered hais-like rootlets beneath ; gemme none. Receptacle convex, 2-8-lobed. Involucres 1-fruited, connate with the lobes beneath, horizontal, opening by a vertical terminal slit. Capsule distinctly pedicelled, oblong-globose, dehiscing by 4-6 irregular valves. Elaters 2-3-spiral, parietal, very long, straight, attenuate both ways. Spores muriculate. Antheridia in a short peduncled disk paleaceous beneath. (Named for B. C'. Dumortier, a Belgian botanist.) 
1. D. hirsùta, Nees. Thallus $2-5^{\prime}$ long, $6-9^{\prime \prime}$ wide, deep green, becoming blackish, entire on the margins, naked above or with a delicate appressed pubescence; diœcious; receptacle many-fruited, the margin closely hairy; peduncle rather long, chaffy at the apex. - On moist calcareous rocks, Easton, Penn. (Porter), and southward.

\section{I U N U I À R I A, Micheli.}

Thallus oblong with rounded lobes, distinctly areolate and porose, with imbricate sublunate scales beneath; gemmæ in crescent-shaped receptacles. I)icecious. Fertile receptacle usually cruciately divided into 4 horizontal segments or involucres, which are tubular, vertically bilabiate and 1-fruited. Calyptra included, persistent. Capsule exserted, 4-8-valved. Elaters short, very slender, mostly free. Spores nearly smooth. Antheridia borne in the apical siuus of the thallus. (Name from lunula, a little moon.)

L. velgiris, Raddi. Thallus 1-2' long, forked, innovating from the apex, with a somewhat diffuse costa; peduncle very hairy, $1-1 \frac{1}{2}{ }^{\prime}$ long. Introduced into greenhouses; always sterile, but easily recognized by the characteristic receptacles. (L. cruciata, Dumort.) (Int. from Eu.)

\section{Order 140. RICCIACEJE.}

Plant-body a dichotomously branching thallus, terrestrial or aquatic. Capsules short-pedicelled, or sessile on the thallus, or immersed in its substance, free or connate with the calyptra, globose, at length rupturing irregularly. Calyptra erowned with a more or less de: iduous point. Elaters none. Spores usually angular, reticulate or muriculate. Antheridia ovate, immersed in the thallus in flask-shaped cavities with protruding orifices (ostivles).

1. Riceia. Capsule immersed in the thallus. Involuere none.

2. Sphærocarpus. Capsule sessile on the thallus. Involucre inflated-pyriform.

\section{RÍCCIA, Micheli.}

Thallus at first radiately divided, the centre often soon decaying; the divisions bifid or di-tri-chotomous, flat or depressed or channelled above, usually consex and naked or squamulose beneath; margins naked or spinulose-ciliate; epidermis usually distinct, eporose; air-carities evident or wanting. Capsule immersed, sessile. Calyptra with a persistent style. Spores alveolate or muriculate, usually flattened and angular. (Named for P.F. Ricci, an Italian nobleman, patron of Micheli.)

\$1. LICHENÒDES. Fruit mostly protuberant above; spores about $84 \mu \mathrm{broad}$, issuing through openings in the upper surface of the thallus; terrestrial species (on damp, usually trodden or cultivated ground), without air-cavities.

* Thallus naked, without cilia or scales.

1. R. Fróstii, Aust. Thallus orbicular, 6-12" broad, thinnish, grayishgreen, the apex and narrowly membranous margins sometimes purplish, minutely pitted; divisions linear or subspatulate, snbtruncate and slightly emarginate; rootlets smooth or obsoletely papillose within; capsules very prominent beneath; spores barely $50 \mu$ broad, nearly round, somewhat margined, with depressed sides when dry, fuscous. - Ohio, Ill., and westward. 
* * Thallus with white scales beneath (dark purple in n. 4), the margin naked.

2. R. sorocárpa, Bisch. 'Ihallus 3-8" in himeter, jale gren liecoming whitish, finely reticulate, subraliatuly or dichotomously divilenl, the oflong-linear segments subacute, deeply sulcate, with a few inconspicuons sales toward the apex not extending beyond the margin; margins crect when dry; spores issuing through chinks early appearing along the groove aluwe. Thin rocky soil and cultivated fielels, Cluster, N. J. (4ustin), western N. Y. (Clivton), and Ill. (Hall). (Eu.)

3. R. lamellosa, lialli. 'Thallus pale green, elegantly reticulateil, sul,radiately divided, the divisions obovate or obcordate, hifid or 2-lobed, 2-5" long, channelled at the apex, with membranous ascending margins, and furnished heneath with transverse scales which extend consilkrably heyond tho margin; spores much as in n. 2. - Thin rocky soil, ('loster, N. J. (Austiu).

4. R. nigrélla, DC. 'Thallus dichotomously divided, the divisions linear, chamnelled, with entire nurrowly membranous nargins, green above, dark purple beneath and furuished with transverse semicircular scals's not excading the margin. - liocky grouud, N. Y. (Torrey), aud Chester, I'enn. (Porter). (Eu.)

* * Thullus more or less ciliate, natied beneath or obsoletely squumons along the extreme edlye.

5. R. arvénsis, Anst. 'Thallus much diviled, 3-9" loroal, papillosereticulate, dull green both siles, becoming fuscous ahove, the flat marcrius at length purple; divisions sulcate, dichotomous, the linear-elliptic or subspatulate lobes acutish and obsoletely emarginate; cilia whitish, very short and inconspicuous or nearly wanting; capsules aggregated toward the apex; spores $71-8+\mu$ broad, dark fuscous, reticulate, with pellucid margin. - Var. Ifrta, Aust., deciledly ciliate and with spine-like hairs s'attered over the upper surface; divisions broader, more obtuse; spores nearly lilack, larger $(84-101 \mu)$ and smoother. - Cultivated fields and (the var.) rocky places, Closter, N. J. (Austin).

6. R. Lescuriana, Aust. Stellatcly or suberuciately divided, the oleordate or cuneate-linear divisions $2-6^{\prime \prime}$ long, punctate-reticulate, subglaucons or ashy-green both silles or hecoming purple beneath, the slightly coucave lobes emarginate, elosely ciliate with short oltuse spine-like white hairs; capsules scattered, chiefly near the hase of the divisions; spores $71-83 \mu$ broul, dark brown, reticulate, not margined. - Cultivated ficlds and rocky grounds, N. J. to Ill., and southwarl.

§ 2. SPONGODES. Thallus with large air-ravities usually opening by pits through the upper surface, and with slight depressions over the capsules which are prominent beneath; spores $41-51 \mu$ broad, olitusely angular or globose; terrestrial.

7. R. crystállina, L. Orbieular, 6-9" broall, the obeorlate or cumeate divisions buful or "-lohel, flat above and the surface much broken up into jits, the margins suberenate; eapsules scattered ; spores issuing through the upper surface. - ()n mui flats, 111. (I/cll), west and sonthward. (Eiu.)

8. R. lutésceus, schwein. Orbicular, $1-1 \frac{f^{\prime}}{2}$ in diameter, light green ; divisions $6-8$, linea,, $2-3$ times forked, narrowly channelled, obcordate and 
thickened at the apex, with delicate whitish obliquely ovate appressed scales; rootlets wanting beneath above the middle; fruiting plant unknown. - Dried up pools and ditches, Canada to Mo., and southward. An analogous form has been developed by Lindberg from R. natans.

9. R. ténuis, Aust. Thallus thin, olive or yellowish-green, shining, the $2-4$ divisions roundish-obovate, $2-4^{\prime \prime}$ long, flat, with sinuate margins, green beneath with a slender costa and few rootlets; capsule very delicate, closely adherent to the substance of the thallus, minutely apiculate; spores round or short-oval, conspicuously depressed at one end when dry. - Wet ground in open woods, Closter and Lawrence, N. J. (Austin), and Mo. (Hall).

§3. RICCIÉLLA. Thallus linear, dichotomous, floating or rarely terrestrial; capsule protuberant from the lower surface.

10. R. flùitans, L. Thallus often in extended patches, tlin, green, radiately expanding, the often imbricate divisions $\frac{1}{2}-1 \frac{1}{2}$ " wide, parallel-nerved, flat, without rootlets, cavernous only toward the slightly dilated very obtuse or subtruncate apex; capsules present only in some terrestrial forms, very prominent below, rupturing beneath the apex. - Very variable. The most notable form is var. Scllivixtr, A ust., with divisions about $\frac{1}{2}$ " wide, channelled, carernous throughout, the margins crisped-crenulate, and rootlets numerous on the costa tumid with abundant capsules, which are tipped with a long funnel-mouthed point; spores obscurely angled, reticulate and margined. (R. Sullivanti, Aust.) - In ponds or ditches or growing in wet places upon the ground; the variety often in cultivated fields. (Eu.)

§4. RICCIOCÁRPUS. Thallus obcordate, floating or ravely terrestrial; capsules not protruding, at length exposed by a cleft in the central groove.

11. R. nàtans, I. (P1. 22.) Divisions obcorclate or cuneate, broadly emarginate, $3-6^{\prime \prime}$ long, purplish, very narrowly channelled, with numerous uniform air-cavities beneath the epidermis, rooting toward the base and at lengtlı with dark purple scales beneath the apex; capsules in 1 or 2 rows beneath the groove; spores black, angular, strongly papillose. - Canada to the Gulf. (Eu.)

\section{SPH}

Thallus lobed, without costa or epidermis. Involucres sessile, obconic or pyriform, perforated at the apex, continuous with the thallus at base. Calyptra closely investing the single globose indehiscent capsule, crowned with a deciduous point. Spores globose, muriculate, remaining united in a coccus. Antheridia borne in follicular bodies on the surface of a separate thallus. An anomalous genus, perhaps more closely related to the Jungermanniaceæ.

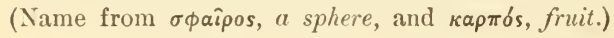

1. S. terréstris, Smith. Thallus orbicular, $3-6^{\prime \prime}$ broad, covered by the clustered inflated involucres, which are nearly $I^{\prime \prime}$ long. $3-4$ times the İength of the capsule; coccus $102-127 \mu$ wide, indistinctly lob Bellardi.) - In cultivated fields, mostly southern. (Eu.) 


\section{ADDITIONS AND CORRECTIONS.}

Page 59.- Argemoxe Mexicaxa. Collected at Merodosia, Ill, with white flowers, by A. B. Seymour.

Page 75. - Insert after Cleome integrifolia -

C. sprooss, I. Viscid-pubescent, 3-40 high; a pair of short stipular spines under the petiole of each leaf; leaflets $5-7$, ublong-liuceolate; flowers large, rose-purple to white; stamens 2-3' long; stipe of the linear poil about 2'long. (C. pungens, Willd.) - In escape from (ultivation, wear Mt. ('armel, Ill. (Schnech), and in waste grounds southward; also ou ballast. (Int. from Trop. Amer.)

Page 86. - Arenaria Grœenlandica. Found on Mt. Desert Island, Maine (Rund).

Page 87. - Stellaria borealis. In the mountains of northern N. J.

S. humifusa. 'This species has also been found on Crauberry Island, near Mt. Desert, Maine, by J. II. Riedfield.

Page 91.- Under Talinum teretifolium add the character - style equalling the stamens. - Insert

2. T. calycinum, Engelm. Leaves somewhat broarler; flowers and capsules larger; stamens 30 or more; style twice longer than the stamens, declined. - Central Kan. to W. Tex.

\section{Under Claytonia insert -}

3. C. Chamissonis, Esch. Weak, procumbent or ascending, rooting below and perennial by lateral and terminal filiform rumers; leaves several pairs, oblong-spatulate, 1-2' long; inflorescence racemoscly 1-9-flowered; petals pale rose-color; capsule small, 1 -3-seeded. - In a cold ravine, W"inona Co., Minn.; in the mountains from Colorado north and westward.

Page 211. - Hydrocotyle Americana. Add - propagating by filiform tuberiferons stolons.

l'age 230. - Insert after the genns Dipsacus-

\section{SCA B I OSA, Tonru. Scaniots.}

Characters of J)ipsacus, but the green leaves of the iuvolucre and inrolncels not rigil nor spinescent. (Name from scabies, the itch, from its use as a remerly.)

S. Acstrdis, Wulf. Peremial, sparsely lianched, nearly glabrous, $1 \frac{1}{2}-$ $3^{\circ}$ high; leaves narrowly laneolate to linear, the lower oblanceolate, slightly toothel or entire; healls short-oblong; ealyx olitusely short-lobed; corolla pale blue. - Central N. Y. and Penn.; rare. ( $\Lambda$ dv. from Eu.) 


\section{Page 395. - After Orobaxche misor insert-}

O. RAMÒA, L. Often branched, $6^{\prime}$ high or less, of a pale straw-color; flowers 3-bracteate, the lateral bracts small; calyx 4-toothed, split at the back; corolla pale blue, $6-8^{\prime \prime}$ long. - On the roots of hemp and tobacco; Ky. (Int. from Eu.)

\section{Page 421. - After Lamidm PURpurev insert -}

L. ixteruk̀dur, Fries. Resembling L. purpureum, but the calyx-teeth longer than the tube, the rather narrower corolla without a hairy ring within near the base, and the nutlet longer ( 3 times as long as broad). - Cultivated fields near Hingham, Mass. ( $(. \mathcal{J}$. Sprague). (Adv. from Eu.)

Page 427. - Insert in the generic key -

5 Cladothrix. Flowers jerfect, minute, axillary. Densely white-tomentose.

l'age 430. - Insert after the genus Frolichia-

\section{CLADÓTHRIX, Nutt.}

Flowers perfect, 3-bracterl. Sepals 5, erect, rigid-scarious, somewhat pilose. Stamens 5, the filameuts united at base; anthers large, 1-celled. Stigma large, capitate, 2-lobed. Utricle globose, indehiscent. - Densely stellatetomentose low herbs or wooly at base, with opposite petiolate leares and rery small flowers solitary or few in the axils. (Name from $\kappa \lambda \alpha$ dos, $a$ branch, and

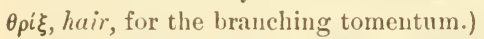

1. C. lanuginòsa, Nutt. Prostrate or ascending, much branched; leaves round-obovate to rhomboidal, 3-10" long. - Central Kan. (Mechan) and southwestward.

Page 435. - Salsola Kali. This species has been found in Emmet Co., Iowa (Crutty), at Yankton, Dak. (Bruhin), and in river-bottoms in N. W. Neb. and central Dak.

\section{Page 437. - After Eriogonum annuum insert-}

2. E. Allèni, Watson. Perenuial, white-tomentose throughout, the tall scape-like stem repeatedly dichotomous above; radical leaves lanceolate, longpetiolate, the upper in whorls of 4 or 5 , ovate to oblong-ovate, very shortly petiolate, much reduced above; involucres mostly sessile; flowers glabrous, yellow, the segments elliptical. - Near White Sulphur Springs, IV. Va. (T. F. Allen).

Page 445. - Asarum Canadense. In this species there are rudimentary subulate petals, alternate with the calyx-lobes.

Page 463. - Celtis Mississippiensis. Common in low river-bottoms of W. Mo. (F. Bush); described as haring a very smooth trunk, like a sycamore, and soft yellowish brittle wood, not coarse-grained as in C occidentalis.

Page 491. - Cnder Pinus add -

10. P. ponderòsa, Dougl., var. scopulòrum, Engelm. Leaves in twos or usually threes from long sheaths, $3-6^{\prime}$ long, rather rigid; staminate flowers $\mathrm{l}^{\prime}$ long; cones subterminal, 2-3' long, oval, often $3-5$ together, the prominent summit of the thick scales bearing a stout straight or incurved prickle. - Central Neb. and westward in the Rocky Mountains. - A large tree with very thick bark. 
Page 514. - After Iris Carolixiaxi insert-

$2^{a}$. I. hexágona, Walt. Stems flexuous, often low and slender $\left(1-3^{\circ}\right.$ high), leafy, leaves much exceetling the stem, 6-12" broul; flowers solitary and sessile in the axils, large, deep hlue, varingaten with yellow, jurple, and white; tube $\frac{1}{2}$ long; segments abont 3 ' long, the inner narrow; (ansule oblong-cylindric, 6-angled, 2' long. - I'rairies, Ky. (short) to W. Mo. (Bush), and on the coast from S. Car. suthward.

l'age $515 .-\mathrm{S}$. angustifolium. What appears to be a form of this species with pale yellow flowers is found near Independence, Mo. (IBush).

Page 516. - Under Zephyranthes Atamasco insert the synonym (A maryllis Atamaseo, L.).

Page 555. - S. teres has been collected also at Brewster, Mass. (Farlou). Page 575. - After E. Torreyana insert -

13a. E. álbida, 'Torr. like n. 12 and 13 in habit, somewhat stouter; spikelet dense, ellipsoitlal or ohlong, 1-4" long, acutish, with pale obtuse scales; achene very small, triangular-obovate, very smooth, with a broally triangular tubercle upon a narrow hase, shorter than or exceeding the reddish bristles. - Salt marshes, Northamptou Co., Va. (C (anby), and south to Fla. and Tex.

Page 653. - T. subspicatum, var molle, is reported from lioan Mt., N. C. (Scribner), and probahly occurs on the higher Alleghanies northward. Page 662. - After M. diffusa insert -

3. M. Pórteri, Scribn. Tall and slender; panicle very narrow, the slender branches erect or the lower slightly divergent; pedicels flexuous or recurred, pubescent; glumes very unequal and shorter than the spikelet; fertile flowers $3-5$, the glumes scabrous. - Mountains of Col. and sonthwarl; reported from Cass Co., Neb. (J. G. Smith).

Page 663. - D. maritima. On alkaline soil in Neb., and very common in similar localities west and southwestward; chiefly the var. sтrferA, 'Thurb, with setaceously convolute leares, the many- $(10-20-)$ flowered spikelets in a loose pauicle.

Page 5. - Under *1 read - (sometimes opposite or whorled, stipulate $i_{1}$ : Magnoliace:e and rarely in Ranunculace $x)$.

Page 8. - Under Ilicineæ real - and usually deciduous stipules.

Page 38.-A. Pennsylvanica. Reported from Aroostook Co., Maine (J. C. Parlin).

Page 40. - M. minimus. Reported from Accomac Co., Va., (E. Mears). Page 41.- R. ambigens. An earlier name is $R$. luxicuulis, 1)arby.

Page 44.-Add-2. C. nàtans, Pall. Stem prostrate or floating; leaves crenulate or entire; sepals oval, 2-3" long, white or pinkish. - Tower, Minn (E.J. Hill), and northward. 
Page 73. - L. Ruderale. Reported at Buckfield and Orono, Maine (Parlin). Page 75. - P. graveolens. Said to range to the Chesapeake (Porter).

Add at bottom - R. ÁLBA, L. Leaves pinnate, undulate, glaucous ; flowers white; sepals and petals 5 or 6 , the latter all 3 -fid. - Buffalo, N. Y. (Clinton); Youngstown, Ohio (Ingraham). (Adv. from Eu.)

Page 83. - D. Deltoines. Read - glabrous or roughish. - On the downs, Martha's Vineyard (Edith W' atson).

Page 84. - S. antirrhina. A very slender form with much smaller apetalous flowers, and capsules only $2^{\prime \prime}$ long, occurs at Rockford, Ill.

Page 85. - L. DIURNA. Flowers sometimes white.

l'age 87. - Under S. uliginosa read - veiny, often ciliate at base.

Page 89. - S. procumbens. Leaves linear-lanceolate to narrowly linear. - Champion Mine, Marquette Co., Mich. (E. J. Hill).

Page 95. - Under genus 3 read - with small usually rather close clusters.

Page 99. - M. angustum. Also found in W. Ill. along the Mississippi. Under S. Napæa read - along and near the Alleghanies.

Page 107. - Under ORDE1 25 insert - Stipules small or minute, usually soon deciduous. - Add - The Aquifolracece of previous editions.

Page 108. - I. mollis. Common on the l'ocono plateau, Penn. (Porter).

Page 127.-C. scoparits. At Usterville, Mass. (Miss S. Minns).

Page 140.-D. sessilifolium. Also at Norweh, Conn. (Graves), and in Plymouth Co., Mass. (Boott).

Page 152. - P. spixosa. The garden Plum, a thornless derivative from var. Ixsititia, rarely occurs as an escape. - Add-P. Avicm, L., the Bird Cherrv, with drooping pubescent acutely serrate leaves on long petioles, lax spreading petals, and sweet fruit-and P. CÉrasos, L., the garden Cherry, with spreading glabrous crenate-serrate leaves on short petioles, firm suberect petals, and acid fruit - are found by roadsirles, etc., in N. Y. and Yenn.

Page 155. - To R. Canadensis add - Var. roribáccus, Bailey. Leaflets triangular-ovate, unequally and sharply doubly serrate, often nearly lobed; peduncles longer and straighter, overtopping the leaves; flowers very large, 1-2' broad, the sepals foliaceous and incised; fruit large. W. Va., and probably southward. Cultivated as the Lucretia Dewberry.

Page 159. - After P. Pennsylvanica insert-P. RÉctA, L. A tall herbaceous perennial, sparsely villous and glandular-puberulent, with digitate 5-7-foliolate leaves, incisely pinnatifid leaflets, and large yellow flowers in a broad cyme. - Central N. Y. (Introd. from Eu.)

Page 164. - Add - R. cisvanònea, L. (Cixsauox Rose.) With brownish-red bark, some straightish prickles, pale leares downy beneath, and small double pale red flowers. - An escape about old gardens and by roadsides. N. Eng, N. Y., etc.

Insert - $\mathbf{P}$. MALrs, L., the Apple, and much more rarely the Pear, $\mathbf{P}$. commùxis, I., occur self-sown in pastures, etc.

Page 176. - R. rubrum. The garden form sometimes occurs as an escape. Page 177. - In the last line read - from western N. Y. to Ga. and S. Ind. Page 181. - M. scabratum. Keweenaw Co., Mich. (O. A. Farwell).

Page 185. - Under A. coccinea read - west to S. Ind., N. Ill., Kan., etc. Add - 2. A. auriculàta, Willd. Flowers smaller, in loose peduncled axillary cymes; capsule $\mathbf{1}^{\prime \prime}$ in diameter. (A. Wrightii, Gray.) - Fillmore Co., Neb. (Rev. J. H. Wibbe). A Texan species, perhaps introduced. Under L. SAlicaria add - and central N. Y. 
Page 201. - D. Canota. Flowers occasionally purple or reddish.

Page 207. - Under B. angustifolia read - Mass. (?), Mich., N. Ill., and westward.

Page 214.-C. circinata. Calyx-teeth minute; stone globular, not furrowed.-C. sericea. Stone large, more or less acute at hase, oblique and irregularly sharp-ridged. - C. asperifolia. Stone nearly glolular or somewhat oblique, smooth or slightly furrowed. - C. stolonifera. Stone very variable, oblique, flattened or scarcely so, more or less furrowerl. - C. stricta. Stone small, nearly globular, smooth. 'This speries appears to include $C$. paniculata. C. candidissima, Marsh., is a little earlicr name, but the identification is somew hat doulitful. $-\Lambda \mathrm{dd}-$

5a. C. Bàileyi, Conlt. \& Erans. Intermediate between nos. 5 and 6 in foliage and pubescence; branches reddish-brown: fruit white; stone compressed, truncate, furrowed on the prominent edges, broader than high. About the Great Lakes (Erie to Superior) and westward. Perhaps a lỵbril.

Page 215. - Add $1^{\text {a }}$. N. biflò, Walt. Leaves smaller than is usual in n. 1 ( $1-3^{\prime}$ long); fertile flowers $1-3$; stone decidedly flattened and more strongly furrowed. - N. J. to Fla., Tenn. and southward.

Page 226. - G. Mollugo. Occurs in eastern N. Eng. - Flowers in this species loosely pauicled, in G. VEruM densely so.

Page 233. - Finter-43a. Franseria. As Ambrosia, but fruit 1-4-celled, 1-4-beaked.

Page 250.-S. neglecta, var. linoides. At Turner, Maine (J. A. Allen). Page 252. - S. Ohioensis. Read - central N. Y., and from Ohio to Wisc. Page 269. - G. purpureum. At Youngstown, (Ohio (R. II. Ingraham).

Page 273. - Adl-43․ F R A N ER I A, Cav.

Resembling $\Lambda$ mbrosia, but the fertile involucre enclosing $1-4$ flowers, the fruit 1-4-celled and 1-4-heaked, more or less bur-like with seattered prickles. (Named for A. Franser, a Spanish botanist)

1. F. tomentosa, Gray. Low, erect and rather stout, densely silkytomentose; leaves very white beneath, more or less pinnately cleft or nearly entire. - Macpherson, Kan. (Kellerman), and southwestward.

Page 275. - H. scabra. Repurted from Oxford Cu., Maine (Parlin).

Page 284. - B. connata, var. comosA. lieported from central X. Y. (Dudley).

Page 297. - Under C. Nigna read-black or brown pectiuately-ciliate fringe; rays usually unting.

Page 302. - P. altissima. Glabrous or somewhat hispidulous.

Page 320. - Under R. nudiflorum read - swamps and open woods.

Page 329. - Lnder D. Meadia add-Var. Frénchii, Vasey. Often dwarf, glabrous or pubescent alove; leaves ovate or ovate-elliptical, sometimes cordate at base. - l'enn. to s. Ill. and Ark.

Page 354. - 1. trachyspermum. Reported from southern N. J. (Britton). Page 361. - Aspert'go rliocrmmiss. At New Belford, Mass. (Ilerey).

Page 378. - Enter - 7a. Paulownia. Corolla tubular with spreading limb. Sterile stamen none. Seeds winged. A Catalja-like tree.

Page 382. - P. albidus. Reported from S. Wr. Miun. (.Mc.Millan). 


\section{Add - $\quad$ 7ª PAULÒWNIA, Sieb. \& Zucc.}

Calyx deeply 5-cleft, woolly. Corolla declined, funnelform, with 5 rounded obliquely spreading lobes. Stamens 4, included. Pod turgid, thick, loculicidal. Seeds small, winged. - A tree with large opposite cordate entire or 3-lobed pubescent leaves, and large terminal panicles of showy violet flowers. (Named for Anna Paulouna, daughter of Czar Paul I.)

P. Imperiàlis, Sieb. \& Zucc. A handsome tree resembling the Catalpa; cult. from Japan. - Growing wild in N. J. and Del.

Page 388. - B. Americana. Also found in S. E. Penn. and southward.

Page 391. - Add-1 ${ }^{\text {a }}$. C. indivisa, Engelm. Winter-annual; leaves linear-lanceolate, entire or with 2 or 3 slender lateral lobes; bracts and calyxlobes obovate, bright red. - Shannon Co., Mo. (S. M. Tracy). May-June. Page 396. - U. clandestina. Reported from mountain bogs, central Penn. (Porter).

Page 397. - U. resupinata. Reported from Lake Co., Ind. (Hill), and Ionia Co., Mich.

Page 401.-Add-3. R. pedunculàta, Torr. Slightly puberulent; leares ovate-oblong, short-petioled; peduncles axillary, about as long as the leaf, 1 -3-flowered, bracteate; calyx-lobes about equalling the narrow corolla tube. - Jefferson Co., Mo. (Hasse), and south to La.

Page 405. - T. dichotomum. Western Maine (Parlin).

Page 419. - P. Virginiana. At Hanover, Maine (Parlin).

Page 426 - P. argyrocoma. Whitecap Mt., Oxford Co., Maine (Parlin).

Page 48\%. - P. heterophylla. 'This has 3-valved capsules and large seeds, and probably dilated styles - and should therefore be placed in $\S 2$.

Page 502. - S. Romanzoffiana. Reported from N. W. Penn. (Porter).

Page 505. - P. affinis. Also reportel from E. Penn. (Porter).

Page 525. - Lnder genus 13 read - ; cells 1-2-seeded.

Page 529. - Under L. Canadense read - flowers 1-16, usually few.

Page 543. - J. pelocarpus, var. stbTilss. Lake Ilopatcong, N. J.

Page 544. - J. acuminatus, var. debilis. At Rumford, Maine (Parlin). Page 545. - Under J. scirpoides read - Mich., Ind., Mo., and Tex.

Page 563. - Under P. Hillii read - Mich., northern ()hio, and western

N. Y. - P. obtusifolius. Reported from 'Tower, Minn. (Hill).

Page 564. - P. Tuckermani. Reported from eastern and central Penn. (Porter). P. confervoides, Reichenb., appears to be an earlier name. P. Robbinsii. Reported from Lake Co., Ind., Marquette Co., Mich., and Chesago Lake, E. Minn. (Hill).

Page 574. - Úurler E. Engelmanni, for E. obtusa, read E. Engelmanni.

Page 577. - F. spadicea. Also in Kankakee, Henderson and St. Clair Cos., Ill. (Hill).

Page 589. - Under + 4. Cryptocarpce read - stigmas 2 or 3.

Page 590. - Under $* 7$ add $-+1^{\text {a }}$. Filifolice. Spike one, androgynous.

Page 599. - For C. vulgaris, Fries, read-C. rígida, Gooden., var. Goodenòvii, Bailey - and at end insert - (C. vulgaris, Fries.). - For Var. hyperborea, loott, read - Var. Bigelòvii, Tuckerm., - and at end substitute the synonym - (C. vulgaris, var. hyperborea, Boott.).

Page 601.-Add - 41 a. C. verrucosa, Muhl. Glaucous, stout and stiff, $2-4^{\circ}$ high; leaves long, rough-angled, becoming revolute; spikes $3-10$, 
stout, seattered to loosely aggregated, then erect or ascending, usually somewhat staninate above, variously peduncled; scales thin, brown, cmarginate, shorter than the broally ovate or obovate strungly f('w-ncrved gl:ulcous perigynium, but the hispid awn from 2-3 times longer to nearly obsulete; beak short, entire; stigmas 3. (C. glaucescens, I:ll.) — Swampis and pouds; extreme southern Va., Mo., and southward.

Page 606. - C. Torreyi. Found in Hennepin Co., Minn. (Sundlerg).

Page 611.- $\mathrm{Add}-\quad * 7 .-+1^{\text {a }}$. Filifolice.

$84^{\mathrm{a}}$. C. filifolia, Nutt. Culm slender, obtusely angled, smooth, 3-12' high; leaves filiform, rigid; perigynium broadly triangnlar-obovoil, thin, with a short white-hyaline entire beak, ustally about equalling the broad hyalinemargined clisping seale. - Ft. Lincoln, N. Dak. (Havard), and westwarl. Page 626. - Lnder 69. Festuca read - tip (rarely blunt), few-nerved.

Page 635. - L. oryzoides. Reported as common in Oxford Co., Maine (Parlin). - Z. miliacea. Reported at Poconoke City, Md. (E. Meurs). Page 646. - S. heterolepis. Reported from S. E. Penn. (Porter).

Page 650. - C. Porteri. Reported from Tompkins Co., N. Y. (Inudley).

Page 651. - A. arundinacea. Reported at Ocean City, Md (.Mears).

Page 652. - Under genus 37 read - in a contracted or open. - A. caryophyllea. Lower flowers sometimes awnless. Accomac Co., Va. (\$eurs).

Page 653. - A. striata. Reported from N. 1'eun. (I'orter). - T. palustre. Occurs in southern Conn.

Page 657. - T. cuprea. Occurs in southern Conn.

Page 658.-D. fascicularis. In saline localities in central N. Y. (Dudley).

Page 659. - E. obtusata. Read-central N. Y. to Fla., etc.

Page 677. - E. littorale. Banks of the Susquehanna, Penn.

Page 682. - P. gracilis. Found in Lycoming and Sullivan Cos., Penn., and in Iowa.

Page 683. - W. angustifolia. Reported from S. Haven, Mich. (Bailey).

Page 694. - B. simplex. Reported from I'ocono Mt., P'eun. (Porter), and Ellicott's Mills, Md. (J. B. Egerton).

Page 695. - L. Selago. Adl - and south in the mountains to Ga.

Page 698. - Substitute - * * Leares in 4 ranks, two lateral and spreading, and two above, which are smuller and ascending.

Page 700. - Var. valida. On Salt P'ond Mt., Va., in wet gronnd ( $C a n b y)$. Page 734. - Salsola Kali. At Madison, Wise.; introduced (L. S. Cheney). In the Index add - A QUIFOLIACE.E, $107-A$ simina, 50 - Franseria, 735 Pastinaca, 202 - I'aulownia, $735^{\circ}$ - Prunus, 151.

Note. - "Western New York," as used throughout the Manual, is to be understood as including the lake-region of central New Yurk.

Several additional species are reported as rarely escilped or as growing wild in cemeteries, about old gardens or deserted homesteals, ete., - as Lunaria biennis, Moench, Honesty or Satin-flower - Lychnis Coronaria, I., Mulein Pink - Levisticum officinale, Koch, Lovage - Lonicera Nylosteum, I., and L. Tatarica, L., Honeysuckles - Valeriana officinalis, L., Valerian - Artemisia Abrotanum, L., Southeruwood - Vinca minor, L., Periwiukle, ete. 


\section{LIST OF ORDERS,}

\section{WITH THE NUMBER OF GENERA AND SPECIES, NATIVE AND INTRODUCED.}

\begin{tabular}{|c|c|c|c|c|c|c|c|c|c|c|c|}
\hline \multirow{2}{*}{\multicolumn{2}{|c|}{$\begin{array}{c}\text { ANGIOSPERMOUS } \\
\text { EXOGENS. }\end{array}$}} & \multicolumn{2}{|c|}{ Genera. } & \multicolumn{2}{|c|}{ Species. } & \multirow{2}{*}{\multicolumn{2}{|c|}{$\begin{array}{l}\text { ANGIONPERMOUS } \\
\text { EXOGENS. }\end{array}$}} & \multicolumn{2}{|c|}{ Genera. } & \multicolumn{2}{|c|}{ Species. } \\
\hline & & & ஓ் & 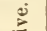 & $\check{g}$ & & & ऐं & : & 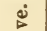 & ஜ் \\
\hline 1. POLYPET & ots. & $\bar{z}$ & $\Xi$ & 学 & $\Xi$ & Div. 2. Gamopetalo & ous. & 4 & $=$ & z & $\Xi$ \\
\hline Ranunculacæ & & 19 & 5 & 62 & 14 & 51. Caprifoliaceæ & & 8 & & 31 & - \\
\hline сеж & & 2 & - & 6 & - & 52. Rubiacea. . & & 7 & 1 & 25 & b \\
\hline 3. Anonaceæ & & 1 & - & 1 & - & 53. Valerianaceæ & & 2 & - & 7 & 1 \\
\hline 4. Menispermaceæ & & 3 & - & 3 & - & 54 Dipsaceæ . . & & - & 2 & & \\
\hline 5. Berberidacex & & 5 & 一 & 5 & 1 & 55. Compositæ & & 78 & 20 & 356 & 51 \\
\hline 6. Nymp & & 5 & - & 8 & - & 56. Lobeliaceæ . • & & 1 & - & 13 & - \\
\hline 7. Sarraceniaceæ & • & ก & - & 2 & - & 57. Campanulaceæ. & & 2 & - & 6 & 2 \\
\hline 8. Рарагеraceæ. & - & 3 & 3 & 3 & 6 & . & & 26 & - & 69 & - \\
\hline 9. Fu & - & 3 & 1 & 9 & 1 & 59. Diapensiacer & . & 3 & - & 3 & - \\
\hline $0 . \mathrm{Cr}$ & 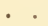 & 15 & 8 & 46 & 25 & 60. Plumbaginareæ. & • & 1 & $\rightarrow$ & 2 & - \\
\hline aceæ & 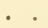 & 3 & - & 4 & 1 & leege. & & 10 & 1 & 16 & 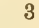 \\
\hline$æ$. & - & - & 1 & - & 2 & 2. Supo & & 1 & - & 2 & - \\
\hline . Cistaceæ . & & 3 & - & 9 & - & 63. Ebenaceæ. & & 1 & - & 1 & - \\
\hline 14. Violaceæ . & - & 3 & 一 & 19 & 1 & 64. Styracer . . & & 3 & $\cdots$ & 5 & - \\
\hline 15. Caryop & & 6 & 6 & 31 & 22 & 65. Olea & 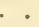 & 3 & 1 & 8 & 1 \\
\hline 16. Por & 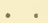 & 3 & - & 7 & 1 & aceie. & & 3 & - & 4 & - \\
\hline - Elat & & 1 & - & 3 & - & aceæ & & 5 & 1 & 29 & 1 \\
\hline 18. Hyper & - & 3 & - & 20 & 1 & $\mathfrak{x}$ & - & 4 & - & 4 & \\
\hline 19. Teri & & 2 & 一 & 3 & $\overline{10}$ & 69. G & & 9 & 1 & 31 & 3 \\
\hline e. . & - & 7 & 4 & 15 & 10 & 70. Pol & & 3 & 一 & 14 & - \\
\hline 21. Tilia & - & 1 & 一 & 3 & - & 71. $1 \mathrm{yc}$ & - & 5 & - & 13 & -. \\
\hline 22. Linaceæ . . & . & 1 & - & 5 & 1 & 72. Bo & • & 8 & 3 & 22 & 11 \\
\hline 23. Ger & . & 4 & 1 & 10 & 7 & 73. Co & & 6 & - & 20 & 7 \\
\hline 24. Rut & . & 2 & - & 3 & - & it. So & 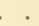 & 3 & . & 14 & \\
\hline 25. Iliciı & • & 2 & 一 & 11) & - & 75. Ser & & 24 & 3 & 603 & 15 \\
\hline 26 Celas & . & 3 & - & 4 & - & 76. Orc & - & 3 & 1 & 5 & 2 \\
\hline 27. Kh & . & 3 & - & 6 & 1 & 77. Le & 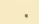 & 2 & 一 & 13 & - \\
\hline 28. Vit & - & 3 & 一 & 11 & - & is. $\mathrm{Bi}$ & & 3 & - & 3 & 一 \\
\hline 29. Sapi & . & 5 & - & 11 & - & liareæ . & : & 1 & 一 & 1 & - \\
\hline 30. An & - & 1 & - & 7 & - & haceæ. & & 3 & - & 4 & - \\
\hline Pol & . & 1 & - & 15 & $\overline{-}$ & aceæ . & & 4 & - & 11 & 1 \\
\hline 32. Leg & . & 41 & 5 & 137 & 19 & 82. Labiatx & & 20 & 14 & 65 & 33 \\
\hline 33. Rosa & . & 17 & 1 & $8 \pi$ & 8 & 83. Plantaginaceæ & & 2 & 一 & 11 & 1 \\
\hline 34. Caly & - & & - & 3 & - & & & & & $8-4$ & 48 \\
\hline 35. Saxi & - & 14 & - & 43 & 1 & & & & & 8.4 & 48 \\
\hline сеæ . & 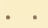 & 3 & 一 & 8 & 3 & Dit. 3. APETaLOU & Us & & & & \\
\hline - Dros & - & 1 & 一 & 4 & - & & & & & & \\
\hline 38. Ha1 & - & 3 & - & 3 & - & - N & & 2 & 1 & & \\
\hline Halc & - & 4 & - & 13 & - & e. & & & & $\begin{array}{l}5 \\
9\end{array}$ & $\frac{1}{7}$ \\
\hline 40. Melas & . & 1 & - & 4 & 一 & - A & & 4 & 2 & 17 & 11 \\
\hline Lythraceæ & - & 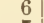 & 一 & 8 & 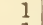 & $8 \pi . \mathrm{Cl}$ & & 8 & & & 11 \\
\hline Ona & - & & - & 43 & 1 & 88. $\mathrm{P}$ & & 1 & & $\begin{array}{l}1 \\
33\end{array}$ & $\overline{13}$ \\
\hline x. & 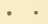 & 1 & - & 3 & - & . $\mathrm{Po}$ & & 6 & & 1 & \\
\hline oraceæ & & 1 & - & 2 & - & - $\mathrm{P}$ & & 1 & & & \\
\hline 45. Cuct & 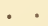 & & - & 5 & - & iaceæ. & & 2 & - & 7 & \\
\hline Cact & . & 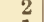 & - & 6 & - & 2. . & & 1 & & $\overline{5}$ & 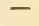 \\
\hline Fico & & 1 & 1 & 1 & 1 & e. & & 4 & & 5 & \\
\hline lliferæ . & - & 26 & 10 & 49 & 13 & aceæ & & 1 & 1 & 1 & 1 \\
\hline cex. . & $\bullet$ & 1 & 一 & 6 & - & Ela & & 2 & - & 3 & - \\
\hline eæ . • & - $\cdot$ & 2 & & 11 & - & . Loranthaceæ & & 2 & & 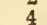 & - \\
\hline & & 251 & 46 & 777 & 141 & 98. Euphorbiacea & & 10 & 1 & 34 & \\
\hline
\end{tabular}




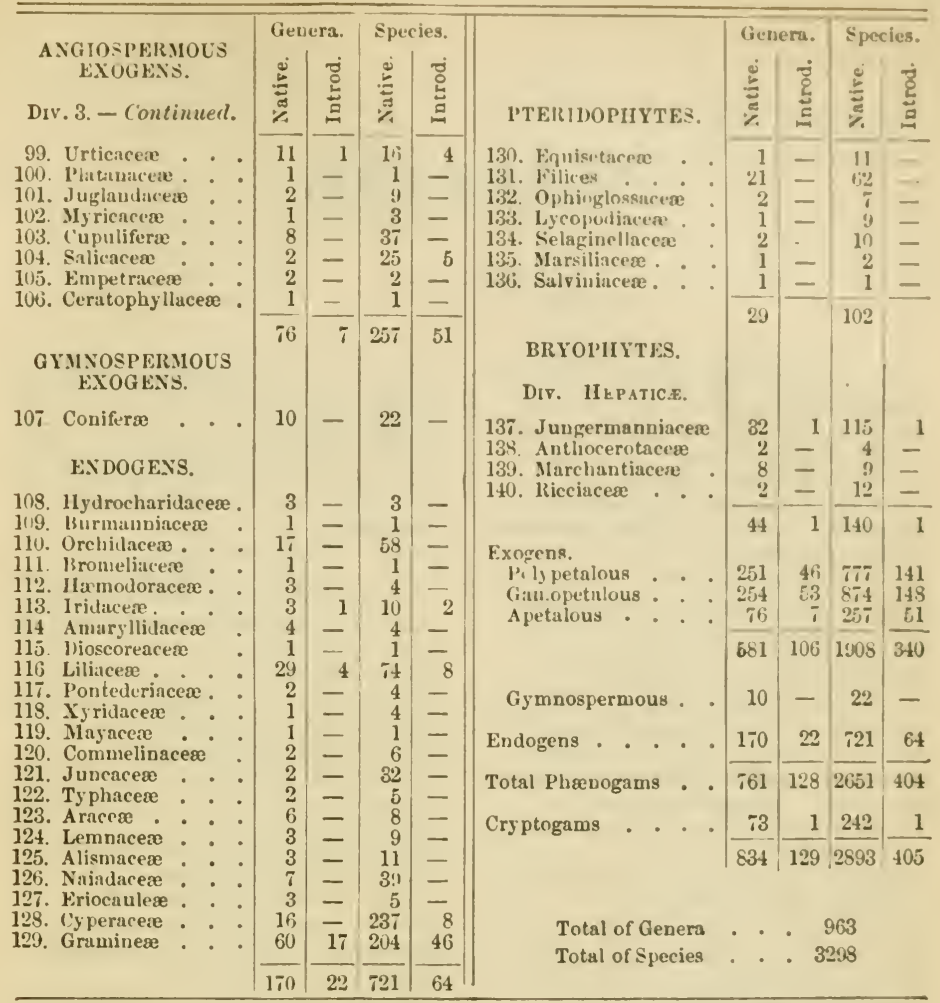




\section{GLOS SAR Y.}

Abnormal. Differing from the normal or usual structure.

Abortion. Imperfect development or nondevelopment of an organ.

Alortive. Defective or barren.

Acaulescent. Stemless or apparently so.

Accumbent (cotyledon). Having the edges against the radicle.

Acerb. Sour and astringent.

Achene. A small, dry and hard, 1-celled, 1seeded, indehiscent fruit.

Achlamydeous. Without calyx or corolla.

Acicular. Slender needle-shaped.

Acrogenous. Growing from the apex by a terminal bud or by the apical cell only.

Aculeate. Prickly; beset with prickles.

Aculeolate. Beset with diminutive prickles.

Acuminate. Tapering at the end.

Acute. Terminating with a sharp or welldefined angle.

Estivation. The arrangement of the parts of the perianth in the bud.

Adnate. United, as the inferior ovary with the calyx-tube. Adnate anther, one attached for its whole length to the inner or outer face of the filament.

Alventive. liecently or imperfectly naturalized.

Alate. Winged.

Albumen. Any deposit of nutritive material accompanying the embryo.

Albuminous. Haring albumen.

Alliaceous. Having the smell or taste of garlic.

Alternate. Not opposite to each other, as sepals and petals, or as leaves upon a stem.

Alveolate. Honeycombed; having angular depressions separated by thin partitions.

Ament. A catkin, or peculiar scaly unisexual spike.

Amphitropous (ovule or seed). Half-inverted and straight, with the hilum lateral.

Amplexicrul. Clasping the stem.

Anastomosing. Connecting by cross-veins and forming a network.

Anatropous (ovule). Inverted and straight, with the micropyle next the hilum and the radicle consequently inferior

Androgynous (inflorescence). Composed of both staminate and pistillate flowers. -androus. In composition, having stamens. Angiospermous. Having the seeds borne within a pericarp.

Annual. Of only one year's duration. Win. ter annual, a plant from autumn-sown seed which blooms and fruits in the following spring.

Ammlar. In the form of a ring.

Anterior. On the front side of a flower and next the bract, remute from the axis of iuflorescence; equivalent to inferior and (less properly) exterior.

Anther. The polliniferous part of a stamen. Autherielium. In Cryptogams, the organ corresponding to an auther.

Antherifious. Anther-bearing.

Antherizoid. One of the minute organs developed in an antheridium, corresponding to polleu-grains.

Anthesis. The time of expansion of a flower. Apetalous. Having no petals.

Apical. Situated at the apex or tip.

Apiculate. Ending in a short pointed tip.

Appressed. Lying close anil flat agaiust.

Aquatic. Growing in water.

Arachnoid. Cobwebby; of slender entangled hairs.

Archegonium. The organ corresponding to a pistil in the higher Cryptogams.

Arcuate. Moderately curved.

Areolate. Ilarked out into small spaces; reticulate.

Aril. An appendage growing at or about the hilum of a seed.

Arillate. Having an aril.

Articulate. Jointed; having a node or joint. Ascentling. Rising somewhat obliquely, or curving upward. Ascending ovule, one that is attached above the base of the orary and is directed upward.

Assurgent, Ascending.

Attemuate. Slenderly tapering; becoming very narrow.

Auricle. An ear-shaped appendage.

Auriculate. Furnished with auricles.

Aul-shaped. Narrowed upward from the base to a slender or rigid point.

$A w^{\prime} n$. A bristle-shaped appendage.

Axil. The angle formed by a leaf or branch with the stem. 
Axile. Situated in the axis.

Axil'ary. Situnted in an axil.

Axis. The central line of any organ or support of a group of organs; a stem, etc.

Baccate. Berry-like; pulpy throughout.

Burbed. Furnished with rigid points or short bristles, usually retlexed like the barb of a fish-houk.

Barbellate. Finely barbed.

Barbulate. Finely bearded.

Busul, Busilar. At or pertaining to the bave.

Basifixed. Attached by the base.

Beaked. Evding in a beak or prolonged tip.

Beurled. Bearing a long $a w n$, or furnished with loug or stiff hairs.

Berry. A fruit the whole pericarp of which is theshy or pulpy.

Bi- or Bis-. A Latin prefix signifying two, twice, or doubly.

Bidentute. Having two teeth.

Bicnnial. Of two years' duration.

Bifid. Two-cleft.

Bilabiate. 'Two-lipped.

Bilocellate. Having two secondary cells.

Bilocular. Two-celled.

Bisexual. Having both stamens and pistils.

Blacldery. Thin and intlated.

Blade. The limb or expanded portion of a leaf, etc.

Bruct. A niore or less modified leaf subtending a flowe: or belonging to an intloresceuce, or sometimes cauline.

Bracleate. Having bract8.

Bracteolate. Having bractlets.

Bructeose. With numerous or conspicuous bracts.

Bractlet. A secondary bract, as one upon the pedicel of a flower.

Bristle. A stiff hair or any similar outgrowth.

13ul. The rudimentary state of a stem or branch; an unexpanded flower.

Bulb. A subterranean leaf-bud with fieshy seales or conts.

Bulbiferous. Bearing bulbs.

Bullilet. A small bulb, especially one borne upon the stem.

Bulbous. Ilaving the character of a bulb.

Carlucous. Falling off very early.

Calcarale. Producesl into or having a spur.

Callus. A hard protuberance or callosity.

Calyculate. II aving bracts around the caly $x$. imitating an outer calyx.

Calyplrre. The membranous hood or envering of the capsule in Hepaticse and Mosser.

Calyx. The outer perianth of the thwer.

Campanulate. Bell-shaped; cup-shaped with a broad base.

Cany gitudinally involute nurgins, แล in some Umbellifere.

Campylotropous (ovule or seed). So curved as to bring the apex and base nearly to gether.

C'cualieulate. Longituillually channelled.

Citnescent. Hoary with gray pubereence.

Cipitale. Shaped like a betad; collected into a head or desise eluster

Ciapitellute. Collectud into a small heas.

C'ipsular. Belonging to or of the naturo of a capsule.

('ipsule. A dry dehiserent fruit composed of more than one carpel; the sporo-case of Ilepatica, etc.

Cipsulifirous. Capsule-bearing.

Cirinate. Ilaving a keel or a projecting lon. gitudinal medial liue on the lower surfice.

Cierpel. A simple pistil, or one member of a compound piscil.

Curtiluginous. Of the texture of cartilage ; firm and tough.

Curuncle. An excrescence or appendage at or about the hilum of a seed.

Carunculate. IIaring a caruncle.

Curyopsis. A graiu, as of grasses; a seerllike fruit with a thin pericarp adnate to the contuined seed.

Castuneous. Of a chestaut color; brown.

Cutkin. An ament.

Cunclute. Having a slender tail-like appendage.

Caulex. The persistent base of an otherwise annual herbaceous stem.

Cuulescent. Llaving a manifest stem.

Cauline. Belonging to the stem.

Cucernous Hollow; full of air-cavities.

Cell. Uue of the minute vesicies, of very various formis, of which plants are foruted. Any structure containing a cavity, as the cells of an anther, ovary, etc.

Cellulur (tissue). Composed of short trans. parent thin-walled cells, in distinction from fibrous or vascular.

C'espitose. Growing in tufts; furming mats or turf.

Chaff. A sinall thin seale or bract, vecoming dry and meutiranous.

Chaffy. Having or resembling chaff.

Chrinnelled. Deeply groovel longitudinally, like a gutter.

Chartaceous. IIaving the texture of writingpaper.

Chlorophyll. The green grains within tho cells of plants.

Chlorophyllose. Containing rhlorophyll.

(ilinte. Marginally fringed with bairs.

Ciliolute. Minutely ciliate.

Cinereous Ash-color.

Circinate. Colled from the top downward, as the young frond of a firn.

Cirmumarissile. Debisclug by a regular transverse circular line of division.

Clarate. Club-shaped; gradually thickened upwarl.

Cleistogramous. Fertilized in the bud, without the opening of the flower. 
Cleft. Cut about to the middle.

Climbing. Ascending by laying hold of surrounding objects for support.

Cluster. Any assemblage of flowers on a plant.

Clustered. Collected in a bunch of any sort.

Coalescence. The uuion of parts or organs of the same kind.

Coccus (pl. Cocci). One of the parts into which a lobed fruit with 1-seeded cells splits.

Cochleate. Spiral, like a snail-shell.

Cohesion. The union of one organ with another.

Columella. The persistent axis of some capsules, spore-cases, etc.

Columnar. Like a eolumn.

Commissure. 'The surface by which one carpel joins another, as in the Umbelliferæ.

Comose. Furnished with a coma or tuft of hairs.

Complicate. Folded upon itself.

Compound. Composed of 2 or more similar parts united into one whole. Compound leaf, one divided into separate leaflets.

Compressed. Flatteued laterally.

Conceptacle. In some Cryptogams a case or receptacle containing the organs of fructification.

Concluplicate. Folded together lengthwise.

confluent. Running into each other; blended into one.

Coniferous. Cone-bearing.

Connate. United congenitally.

Connective. The portion of a stamen which connects the two cells of the anther.

Connivent. Coming into contact; converging.

Conoidal. Nearly conical.

Convergent. Approaching each otber.

Convolute. Rolled up longitudinally.

Cordate. Heart-shaped with the point upward.

Coriaceous. Leathery in texture.

Corm. The enlarged fleshy base of a stem, bulb-like but solid.

Corolla. The inner perianth, of distinct or counate petals.

Coroniform. Shaped like a crown.

Corrngate. Wrinkled or in folds.

Corymb. A flat-topped or convex open flowercluster, in the stricter use of the word equivalent to a contracted raceme and progressing in its flowering from the margin inward.

Corymbose. In corymbs, or corymb-like.

Cosmopolite. Found in most parts of the globe (of plants).

Costa. A rib; a midrib or mid-nerve.

Costate. Ribbed; having one or more longitudinal ribs or nerves.

Cotyledlous. The foliar portion or first leaves (one, two, or more) of the embryo as found in the seed.

Crateriform. In the shape of a saucer or cup, hemispherical or more shallow.
Creeping. Running along or under the ground and rooting.

Crenate. Dentate with the teeth much rounded.

Crenulate. Finely crenate.

Crested, C'ristate. Bearing an elevated appendage resembling a crest.

Crown. An inner appendage to a petal, or to the throat of a corolla.

Cruciate. Cross-shaped.

Crustaceous. Of hard and brittle texture.

Cucullate. Hooded or hood-shaped; cowled.

Culm. The peculiar stem of sedges and grasses.

C'uneate. Wedge-shaped; triangular with the acute angle downward.

Cuspidate. Tipped with a cusp, or sharp and rigid point.

Cylindraceous. Somewhat or nearly cylindrical.

Cyme. A usually broad and flattish determinate inflorescence, i. e. with its central or terminal flowers blooming earliest.

Cymose. Bearing cymes or cyme-like.

Deciduous. Not persistent; not evergreen.

Decompound. Nore than once compound or divided.

Decumbent. Reclining, but with the summit ascending.

Decurrent (leaf). Extending down the stem below the insertion.

Decurved. Curved downward.

Decussate. Alternating in pairs at right angles, or in threes.

Definite. Of a constant number, not exceeding twenty.

Deflexed. Bent or turned abruptly downward.

Dehiscent. Opening regularly by valves, slits, etc, as a capsule or anther.

Deltoid. Shaped like the Greek letter $\Delta$.

Dentate. Toothed, usually with the teeth directed outward.

Denticulate. Minutely dentate.

Depressed. Somewhat flatteneil from above.

Di-, Nis-. A Greek prefix signifying two or twice.

Diadelphous (stamens). Combined in two sets.

Diandrous. Having two stamens.

Dicarpellary. Composed of two carpels.

Diclıotomous. Forking regularly by pairs.

Dicotyledonous. Ilaving two cotyledons.

Didymous. 'Twin ; found in pairs.

Didynamous (stanens). In two pairs of unequal length.

Diffuse. Widely or loosely spreading.

Digitate. Conspound, with the members borne in a whorl at the apex of the support.

Dimerous (flower). Having all the parts in twos.

Dimidiate. In halves, as if one half wert wanting. 
Dimorphous. Occurring in two forms.

Diaecious. Unisexual, with the two kinds of flowers on separate plunts.

Discoid. Resembling a disk. Discoid head, in Compositie, one without ray-flowers.

Disk. A development of the receptacle at or around the base of the pistil. In Compositie, the tubular flowers of tho head as distiuct from the ray.

Dissected. Cut or divided into numerous segments.

Dissepiment. A partition in an ovary or fruit.

Distichous. In two vertical ranks.

Distinct. Separate; not united; evident.

Jivaricate. Widely divergent.

Dicergent. Inclined away from each other.

Diviled. Lobed to the base.

Dorsal. Upon or relating to the back or outer surface of an organ.

Drupaceous. Resembling or of the nature of a drupe.

Jrupe. A theshy or pulpy fruit with the in. ner portion of the pericarp (1-celled and 1 seeded, or sometimes several-celled) hard or stony.

Drupelet. A diminutive drupe.

$E$ - or $E x$-. A Latin prefix having often a privative siguification, as ebracteate, without bracts.

Echinate. Beset with prickles.

Effuse. Very loosely spreading.

Elater. A usually spirally marked thread found in the capsules of most Hepaticr.

Ellipsoidal. Nearly elliptical ; of 8oljds, elliptical in outline.

Elliptical. In the form of an ellipse; oval.

Emarginate. Ilaving a shallow noteh at the extremity.

Embryo. The rudimentary plantlet within the seed.

Endocarp. The inner layer of a pericarp.

Endogenous. Growing throughout the substance of the stem, instead of by superficial layers.

Entire. Without toothing or division.

Ephemeral. Lasting only for one day.

Epidermis. The cuticle or thin membrane covering the outer surface.

Epigynous. Growing on the summit of the ovary, or apparently so.

Epiphyte. $\Lambda$ plant growing attached to another plant, but not parasitic; an air-plant.

lipornse. Without pores.

Equitant. Astride, used of conduplicate leaves which enfold each other in two ranks, as in Iris.

Erect. Vertical; upright as respects the plane of tive base.

Erose. As if goawed.

E.xalbuminous. Without albumen.

Excurrent. Running out, as a nerve of a leaf projecting beyoud the margin.
Exfoliating. Cleaving off in thin layers.

Exogenous. Growlng by auuular layers nenr the surfuce; belonging to the Exogens.

Exsertel. Projerting beyond an euvelope, as staneus from a corolla

Extrorse. Fucing outward.

Falcate. Seythe-shaped; curred and flat, tapering gradually.

Farineceous, Coutaining starch; starchlike.

Furinose. Covered with a meal-like powder.

Fiscicle. A close bundle or cluster.

Fistigiate (branches). Erect and near together.

Ferruginous. Rust-color.

Fertile. Capable of producing fruit, or productise, as a flower having a pistil, or an auther with pollen.

Fibrillose. Furnished or sbounding with fine fibres.

Filrous. Composed of or resembling fibres. Fibrous tissue, a tissue formed of eiongated thick-walled cells.

Fibro-rascular. Composed of woody fibres and ducts.

Filcment. The part of a stamen which supports the auther; any threal-like body.

Filcmentous. Composed of threads.

Filifermus. Thread-bearing.

Filiform. Thread-shaped; long, slender, and tercte.

Fimbriate. Fringed.

Fimbrillate. IIaving a minute fringe.

Fingered. Digitate.

Fistular. IIollow and cyllndrical.

Flaccid. Without rigility; lax and weak.

Fleshy. Sueculent; juicy; of the consistence of flesh.

Flexuous. Zigzag : bending alternately in opposite directions.

Floccose. Clothed with locks of son hair or wool.

Foliaceous. Leaf-like in texture or appearance.

-folinte. Having leares.

-folinlate. Having leaflets.

Follicle. A fruit consisting of a single carpel, dehiscing by the rentral suture.

Follinutar. Like a follicle.

Forked. Dividerl into nearly equal branches.

Fornicute. Archel over, as the corona of some Borraginacere, closing the throat.

Free. Not adnate to other organs.

Friable. Fasily crumbled.

Frmud. The leaf of Ferns and some other Cryptognms; also in some Phanogama, as In Leminaces, where it serves for stem as well as foliage.

Fruit. The sced hearing product of a plant, simple, compound, or aggruguted, of whatever form.

Fingacious. Falling or fading very early.

Funicle. The free stalk of an orule or seed 
Fuscous. Grayish-brown.

Fusiform. Spindle-sliaped; swollen in the middle and narrowing toward each end.

Galea. A hooded or helmet-shaped portion of a perianth, as the upper sepal of Aconitum, and the upper lip of some bilabiate corollas.

Galeate. Helmet-shaped; having a galea.

Gamopetalous. Having the petals of the corolla more or less united.

Gamophyllous. Couposed of coalescent leaves, sepals, or petals.

Gemmec. A bud cr body analogous to a bud by which a plant propagates itself.

Gemmiparous. Producing gemmæ.

Geniculate. Bent abruptly, like a knee.

Gibbous. Protuberant or swollen on one side.

Glabrate. Somewhat glabrous, or becoming glabrous.

Glabrous. Smooth; not rough, pubescent, or hairy.

Gland. A secreting surface or structure; any protuberance or appendage having the appearance of such an organ.

Glandular. Bearing glands or of the nature of a gland.

Glaucous. Covered or whitened with a bloom.

Glolose, Globular. Spherical or nearly so.

Glochidiate. Barbed at the tip.

Glomerate. Compactly clustered.

Glumaceous. Furnished with or resembling glumes.

Glume. One of the chaffy bracts of the inflorescence of Grasses.

Granular. Composed of small grains.

Gregarious. Growing in groups or clusters.

Gymmospermous. Bearing naked seeds, withont an ovary.

Gynandrous. Having the stamens horne upon the pistil, as in Orchidaceæ.

Gymobase. An enlargement or prolongation of the receptacle bearing the ovary.

Habit. The general appearance of a plant.

Halberd-shaped. The same as IIastate.

Hastate. Like an arrow-head, but with the basal lobes pointing outward nearly at right angles.

Head. A dense cluster of sessile or nearly sessile flowers on a very short axis or re. ceptacle.

Heart-shriped. Ovate with a sinus at base.

Herb. A plant with no persistent woody stem above ground.

Herbaceous. IIaving the characters of an herb: leaf-like in color and texture.

Heterocurpous. Producing more than one kind of fruit.

Heterogamous, Bearing two kinds of flowers.
Hilum. The scar or point of attach ment of the seed.

Hirsute. Pubescent with rather coarse or stiff hairs.

Hispid. Beset with rigid or bristly hairs or with bristles.

Hispidulous. Minutely hispid.

Hoary. Grayish-white with a fine close pubescence.

Homogamous. Bearing but one kind of flowers.

Hooded. Shaped like a hood or cowl.

Hyaline. Transparent or translucent.

Hybrid. A cross-breed of two species.

Hypogynous. Situated on the receptacle beneath the ovary and free from it and from the calyx ; haviug the petals and stamens so situated.

Imbricate. Overlapping, either vertically or spirally, where the lower piece covers the base of the next higler, or laterally, as in the æstivation of a caly $x$ or ccrolla, where at least one piece must be wholly external and one internal.

Immersed. Growing wholly under water; wholly covered by the involucral leaves, as sometimes the capsule in Ilepaticæ.

Incised. Cut sharply and irregularly, more or less deeply.

Included. Not at all protruded from the surrounding envelope.

Incubous (leaf). Having the tip or upper margin overlapping the lower margin of the leaf a bove.

Incumbent (cotyledons). Lying with the back of one against the radicle.

Indefinite (stamens). Inconstant in number or very numerous.

Indehiscent. Not opening by valves, etc.; remaining persistently closed.

Indigenous. Native and original to the country.

Indurated. Hardened.

Indusium. The proper (often shield-shaped) covering of the sorus or fruit-dot in Ferns.

Inequilateral. Unequal-sided.

Inferior. Lower or below ; outer or anterior. Inferior ozary, one that is adnate to the calyx.

Inflated. Bladdery.

Inflorescence. The flowering part of a plant, and especially the mode of its arrangement.

Infra-. In composition, below; as infraaxillary, below the axil.

Innoration. An offshoot from the stem.

Inserted. Attached to or growing out of.

Inter-or intra-. In composition, between.

Interfoliaceous. Between the leaves of a pair, as the stipules of many Rubiacere.

Internole. The portion of a stem between two nodes.

Intramarginal. Within and near the margin. 
Introrse. Turned iuward or toward the axis. Ineolucel. A secondary invuluere, as that of an umbellet in Uubellifera.

Involucellete. Having an involucel.

Ineolucrul. Belouging to an involucre.

Involucrute. Ilaving an involuere.

Involucre. A circle or collection of bracty surrounding a tlower cluster or hesd, or a single tlower.

Ineolute, Rolled inward.

Irregular (tlower). showing inequality in the size, form, or union of its similar parts.

Julaceous. Resembling a eatkin in appearance.

Keel. A central dorsal ridge, like the keel of a boat; the two anterior united petals of a papilionaceous tlower.

Kidney-shaped. Cruscentic with the ends broad and rounded; reniforn.

Labiate. Lipped; belonging to the Labiatæ.

Lacerate. Irregularly cleft us if torn.

Laciniate. Slashed; cut into narrow pointed lobes.

Lamella. A thin flat plate or laterally flattened ridge.

Lanceolate. Shaped like a lance-bead, broadest above the base and narrowed to the apex.

Lateral. Belonging to or borne on the side.

Lax. Loose and slender.

Leaflet. A single division of a compound leaf.

Legume. The fruit of the Leguminosx, formed of a simple pistil and usually deliscent by botlı sutures.

Legruminous. Pertaining to a legume or to the Ieguminosie.

Lenticular. Ientil-shaped; of the shape of a double-convex lens.

Lepilnte. Beset with small scurfy scales.

Ligulate. Furnished witl a ligule.

Ligule. A strap-shaped corolla, as in the ray-flowers of Composita; a thin scarions projection from the sumnit of the sheath in Grasses.

Lilincunus. Lily-like; belonging to the Lilincer.

Liml. The expanded portion of a gamopetalous corolla, ulove the thront; the expandel portion of any petal, or of a leaf.

Linear. Ising and narrow, with parullel markins.

Lip. Fich of the upper and lower divisions of a bilubiate corolln or caly $\mathrm{x}$; the peculiar upper petal in Orchlds.

Lobe. Any segusent of an organ, especially if rounded.

Lobed. Divided into or bearing lobes.

-locular. In composition, having cells.

Ioculicislal. Dehiscent into the cavity of a cell through the lorsal suture
Lunate. Of the shape of a half-moon or crescent.

Lunulute. Dinsinutive of Lunate.

Lyrate. P'inatifid with a large nud rounded terminal lobe, and the lower lobes swall.

Mucrospore. The larger kind of epore in Selaginellaces, etc.

Murcesent. Withering but persistent.

Merginal. Aloug or near tlas edpe.

Maryinate. Furnished nith a border peculiar in texture or apucarance.

Mealy. Fariumeous.

Membranaceous, Me merranous. Thin and ruther suft and nore or leves trauslucent.

Meniscoil. Conenvo-couvex.

Mericrep. One of the achene-like carpels of Unbellifera.

-merous. In composition, having parts, as 2-merous, having two parts of carb kind.

Micrnpyle. The point upon the seed at which was the orifice of the orule.

Microspore. The smaller hiud of spore in Celaginellatex, etc.

Mirlrib. Tlie central or main rib of a leaf.

Mitriform. Shaped like a mitre or cap.

Momulelphous (stamens). United by their filaments into a tube or column.

Moniliform. Resembling a string of beads cylindu iral with contractions at iutervals.

Monocotyledonous. IIaving but one cotyledon.

Monocious. With stamens and pistils in separate tlowers on the sauie plant.

Mucilaginous. Sliny; eontaining nucllage.

Nucro. A short and snial] abrupt tip.

Mucronate. Tipjed with a uucro.

Multifid. Cleft into muny lobes or segments. Iuricule. Rough with slort hard points.

Muriculate. Very finely muricate.

Naked. Bare; withont the usual corering or appenduges.

Nectary. Any place or organ where vectar is secreted.

Nectarifirous. Proulucing nectar.

Nerie. $\Lambda$ siniple or unbranched vein or slemeler rib.

Sole. The place upon a stem which uormally biars a leaf or whorl of lenves.

Vinclose. litotty or knobby.

Nucleus. Tlu gurni-cell of the osule, which by fertilization becomes the seel ; the hernel of a seed.

Numerous. Indefinite in number.

Vut. A hard indehiscent 1-celled and 1 revilei fruit, though usually resulting from a compound ovary.

Sutlet. A diminutive nut.

(1)- A Iatin prefix, usually carrying the idea of inversion.

Oirompressirl. Compressed dorso ventrally iusteal of laterally 
Obconically. Inversely conical, having the attachment at the apcx.

Obcordate. Inverted heart-shaped.

Oblanceolate. Lanceolate with the broadest part toward the apex.

Oblique. Unequal-sided or slanting.

Oblong. Considerably longer than broad and with nearly parallel sides.

Obovate. Inverted ovate.

Obovoid. Having the form of an inverted egg.

Obsolete. Not evident; rudimentary.

Obtuse. Blunt or rounded at the end.

Ocrea. A leggin-shaped or tubular stipule.

Ocreate. Having sheathing stipules.

Ochroleucous, Yellowish-white.

Officinal. Of the shops; used in medicine or the arts.

Oöspore. The fertilized nucleus or germ-cell of the archegonium in Cryptogams, from which the new plant is directly developed.

Opaque. Dull; not smooth and shining.

Operculate. Furuished with a lid.

Operculum. A lid; the upper portion of a circumscissile capsule.

Orbicular. Circular.

Orthotropous (ovule or seed). Erect, with the orifice or micropyle at the apex.

Oval. Broadly elliptical.

Ovary. The part of the pistil that contains the ovules.

Ovate. Egg-shaped; having an outline like that of an egg, with the broader end downward.

Ovoid. A solid with an oval outline.

Ovule. The body which after fertilization becomes the seed.

Ovuliferous. Bearing ovules.

Palate. A rounded projection of the lower lip of a personate corolla, closing the throat. Paleaceous. Chaffy.

Palet. The upper thin chaffy or hyaline bract which with the glume encloses the flower in Grasses.

Palmate (leaf). Radiately lobed or divided.

Palniately. In a palmate manner.

Panicle. A loose irregularly compound inflorescence with pedicellate flowers.

Panicled, Paniculate. Borne in a panicle; resembling a panicle.

Papilionaceous (corolla). Having a standard, wings, and keel, as in the peculiar corolla of many Leguminosæ.

Papillose. Bearing minute nipple-shaped projections.

Pappus. The modified calyx-limb in Compositæ, forming a crown of very various character at the summit of the achene.

Parasitic. Growing on and deriving nourishment from another plant.

Parietal. Borne on or pertaining to the wall or inner surface of a capsule.

Parted. Cleft nearly but not quite to the base.
Partial. Of secondary rank.

Pectinate. Pinnatifid with narrow closely set segments ; comb-like.

Pedate. Palmately divided or parted, with the lateral segments 2-cleft.

Pedicel. The support of a single flower.

Pedicellate. Borne on a pedicel.

Peduncle. A primary flower-stalk, supporting either a cluster or a solitary flower.

Pedunculate. Borne upon a peduncle.

Peltate. Shield-formed and attached to the support by the lower surface.

Pendulous. More or less hanging or declined. Pendulous ovule, one that hangs from the side of the cell.

Perennial. Lasting year after year.

Perfect (flower). Having both pistil and stamens.

Perfoliate (leaf). Having the stem apparently passing through it.

Perianth. The floral envelope, consisting of the calyx and corolla (when present), whatever their form ; in Hepaticæ, the inner usually sac-like involucre of the archegonium.

Pericarp. The matured ovary.

Perigynium. The inflated sac which encloses the ovary in Carex.

Perigynous. Adnate to the perianth, and therefore around the ovary and not at its base.

Persistent. Long-continuous, as a calyx upon the fruit, leares through winter, etc.

Personate (corolla). Bilabiate, and the throat closed by a prominent palate.

Petal. A division of the corolla.

Petaloir. Colored and resembling a petal.

Petiolate. Having a petiole.

Petiole. The footstalk of a leaf.

Phrenogamous. Having flowers with stamens and pistils and producing seeds.

Phyllodium. A somewhat dilated petiole haring the form of and serving as a leafblade.

Pilose. IIairy, especially with soft hairs.

Pinna (pl. Pinna). One of the primary divisions of a pinnate or compoundly pinnate frond or leaf.

Pinnate (leaf). Compound, with the leaflets arranged on each side of a common petiole.

Pinnatifid. Pinnately cleft.

I'innule. A secondary pinna; one of the pinnately disposed divisions of a pinna.

Pistil. The seed-bearing organ of the flower, consisting of the ovary, stigma, and style when present.

Pistillate. Provided with pistils, and, in its more proper sense, without stamens.

Pitted. Marked with small depressions or pits.

Placenta. Any part of the interior of the ovary which bears ovules.

Plane. Flat; with a flat surface or surfaces.

Plicate. Folded into plaits, usually lengthwise. 
Plumose. Having fine hairs on each alde, like the plume of a feather, as the pappusbristles of Thistles.

Plumule. The bud or growing point of the embryo.

I'od. Any dry and dehiscent fruit.

l'ointed. Acuminate.

Pollen. The fecuudating grains contained in the anther.

Polliniferous. Bearing pollen.

Pollinium (pl. P'ollinia). A mass of waxy pollen or of coherent pollen-grains, as in Aselepias and Orchids.

Polypetalous. Llaving separate petals.

Pome. A kind of tleshy fruit of which the apple is the type.

Porose. l'ierced with small holes or pores.

Posterior. In an axillary flower, on the side nearest to the axis of inflorescence.

I'osticous. On the posterior side; extrorse.

Promorse. Appearing as if bitten off

Prickle. A small spine or more or less slen. der sharp outgrowth from the bark or rind.

Prismatic. Of the shape of a prisin, angular, with flat sides, and of nearly uniform size throughout.

Procumbent. Lying on the ground.

Proliferous. Producing oftshoots.

Prostrate. Lying flat upon the ground.

Proterogynous. Having the stigma ripe for the pollen before the maturity of the anthers of the same flower.

Prothallus. A cellular usually flat and thallus-like growth, resulting from the germinatlon of a spore, upon which are developed sexual organs or new plants.

Pseuclaxillary. Terminal but becoming apparently axillary by the growth of a lateral branch.

Pseudo-costate. Falp-ribbed, as where a marginal vein or rib is formed by the confluence of the true veins.

Pteridophytes. Fern-plants; Ferns and their allies.

Puberulent. Minutely pubescent.

Pubescent. Covered with hairs, especially if short, soft and downy.

Punctate. Dotted with depressions or with translucent internal glands or colored dots.

Puncticulate. Minutely punctate.

Pungent. Terminating in a rigid sharp point; acrid.

Putamen. The shell of a nut; the bony part of a stone-fruit.

Quadrate. Nearly square in form.

Raceme. A simple inflorescence of pedicelled flowers upon a common more or less elongated axis.

Racemose. In racemes; or resembling a raceme.
Radiate. Spreading from or arranged around a common centre; bearing ray-flowers.

lialical. Belonging to or procueding from the root or base of the stem near the ground.

lialicle. The portion of the embryo below the cotyledons, more properly called the caulicle.

liculiculose. Bearing rootlets.

liameal. Belonging to a branch.

lícumification. Branchlag.

liay. The branch of an umbel; the manginal flowers of un intlorescence when distinct from the disk.

lieceptacle. The more or lesa expanded or produced portion of an axis whlch hears the organs of a flower (the torus) or the collected flowers of a head; any similar Btructure in Cryptogams.

Recurved. Curved downward or backward.

lieflexed. Abruptly bent or turned downward.

liegular. U'niform in shape or structure.

Reniform. Kilney-shaped.

Repand. With a slightly uneren and somewhat sinuate margin.

Resiniferous. Prolucing resin.

Reticulate. In the form of network; netveined.

Retrorse. Directed back or downward.

lietuse. With a shallow notch at a rounded apex.

Rerolute. Rolled backward from the mar. gins or apex.

Rhachis. The axis of a spike or of a com. pound leaf.

Rhaphe. The rilge or adnate funicle which in an anatropous ovule connects the two ends.

Rhizmme. Any prostrate or subterranesn stem, usually rooting at the nodes and becoming erect at the apex. Very rariable in character, and including morphologically the tuber, corm, bulh, etc.

Rhombic, lihominidal. Somewhat lozengeshaped; obliquely four aided.

liib. A primary or prominent vein of a leaf.

Ringent. Gaping, as the mouth of an open bilabiate corolla.

Ront. The underground part of a plant which supplies It with nourishnent.

Rootstock. Same as Rhiznue.

Rostrate. Ilaving a beak or spur

liosulate. In the form of a rnsette.

Rotate (corolla). Wheel-shaped; flat and circular in outline.

Rotund. Rounded in outline.

liudiment. A very partially developed organ; a restige.

Kudimentary. But slightly dereloped.

Rufous. Redilish browu.

liugose. Wrinkled.

Iiuncinate. Sharply incled, with the segments directed backward.

Runner. A tiliform or very slender stolon. 
Saccate. Sac-shaped.

Sagittate. Shaped like an arrow-head, the basal lobes directed down ward.

Salver-shaped (corolla). Having a slender tube abruptly expanded in to a flat limb.

Samara. An indehiscent winged fruit.

Scabrous. Rough to the touch.

Scalariform (vessels). Having transverse markings like the rounds of a ladder.

Scape. A peduncle rising from the ground, naked or without proper foliage.

Scapose. Bearing or resembling a scape.

Scarions. Thin, dry, and menbranaceous, not green.

Scorpioirl (inflorescence). Circinately coiled while in bud.

Scurf. Snall bran-like scales on the epiderınis.

Scymitar-shaperl (leaf). Curved with a flattriangular section, the straighter edge the thickest.

Sced. The ripened ovule, consisting of the embryo and its proper coats.

Segment. Oue of the parts of a leaf or other like organ that is cleft or divided.

Sepal. A division of a calyx.

Septiciclal (capsule). Dehiscing through the partitions and between the cells.

Septum. Any kind of partition.

Serrate. Having teeth pointing forward.

Serrulate. Finely serrate.

Sessile. Withont footstalk of any kind.

Setacenus. Bristle like.

Setose. Beset with bristles.

Setulose. Ilaving ninute bristles.

Sherth. A tubular envelope, as the lower part of the leaf in Grasses.

Sheathing. Enclosing as by a sheath.

Shrub. A woody perennial, smaller than a tree.

Silicle. A short silique.

Silique. The peculiar pod of Cruciferæ.

Silky. Covered with close-pressed soft and straight pubescence.

Simple. Of nne piece; not compound.

Simuate. With the outline of the margin strongly wavy.

Sinus. The cleft or recess between two lohes.

Smonth. Without roughness or pubescence.

Sorus (pl. Sori). A heap or cluster, applied to the fruit-dots of Ferns.

Sparlix. A spike with a fleshy axis.

Spathe. A larce bract or pair of bracts enclosing an inflorescence.

Spatulate. Gradually narrowed downward from a rounded summit.

Spicate. Arranged in or resembling a spike. Spiciform. Spike-like.

Spike. A form of simple inflorescence with the flowers sessile or nearly so upon a more or less elongated common axis.

Spikelet. A small or secondary spike.

Spindle-shaped. Same as Fusiform.
Spine. A sharp woody or rigid outgrowth from the stem.

Spinose. Spine-like, or having spines.

Sporangium. A spore-case.

Spore. The reproductive organ in Cryptogams which corresponds to a seed.

Sporocarp. The fruit-cases of certain Cryptogams containing sporangia or spores.

Spur. A hollow sac-like or tubular extension of some part of a blossom, usually nectariferous.

Squamulı. A reduced scale, as the hypogynous scales in Grasses.

Squarrose. Having spreading and projecting processes, such as the tips of involucral scales.

Squarrulose. Diminutively squarrose.

Stamen. One of the pollen-bearing or fertilizing organs of the flcwer.

Staminodium. A sterile stamen, or any structure without anther corresponding to a stamen.

Standirl. The upper dilated petal of a papilionaceous corolla.

Stellate, Stelliform. Star-shaped.

Stem. The main ascending axis of a plant.

Sterile. Unproductive, as a flower without pistil, or stamen without an anther.

Stigma. That part of a pistil through which fertilization by the pollen is effected.

Stigmatic. Belonging to or characteristic of the stigma.

Stipe. The stalk-like support of a pistil ; the leaf-stalk of a Fern.

Stipitate. IIraving a stipe.

Stipulur. Belonging to stipules.

Stipulate. IIaring stipules.

Stipule. An appendage at the base of a petiole or on each side of its insertion.

Stolon. A runner, or any basal branch that is disposed to root.

Stoloniferous. Producing stolons.

Stoma (pl. Stomnta). An orifice in the epidernis of a leaf communicating with internal air-cavities.

Striate. Marked with fine longitudinal lines or rilges.

Strict. Very straight and upright.

Strigose. Beset with appressed sharp straight and stiff hairs.

Strobile. An intlorescence marked by imbricated bracts or scales, as in the Hop and Pine-cone.

Strophiole. An appendage at the hilum of certain seeds.

Style. The usually attenuated portion of the pistil connecting the stigma and ovary.

Stylopolium. A disk-like expansion at the base of a style, as in Umbelliferæ.

Sub-. A Latin prefix, usually signifying somewhat or slightly.

Subulate. Awl-shaped.

Succubous (leaves). Having the upper mar- 
gin of a leaf covered by the base of the one above.

Succulent. Juicy ; fleshy.

Suffrutescent. Slightly or obscurely shrubby.

Sufruticose. Very low and woody; diminutively shrubby.

Sulcute. Grooved or furrowed.

Superior (ovary). Free from the calyx.

Suspenderl (ovule). Hanging from the apex of the cell.

Suture. A line of dehiscence.

Symmetrical (Hower). Regular as to the number of its parts; haring the same number of parts in each circle.

Synonym. A supersedel or unused nanie.

Trail. Any slender terminal prolongation.

Terete. Having a circular transverse section.

Terminul. At or belonging to the apex.

Ternary. Consisting of three.

Ternate. In threes.

Tetralynamous. II aving four long and two shorter stamens.

Tetragonu'. Four-angled.

Thalamiflorous. Having the parts of the flower hypogynous.

Thalloil, Thullose. Resembling a thallus.

Thallus. In Cryptogams. a rellular expansion taking clie plare of stem and foliage.

Throat. The orifice of a gamopetalous corolla or calyx; the part between the proper tube and the linb.

Thyrse. A contracted or ovate and usually compact pauicle.

Thyrsoid. Resembling a thyrse.

Tomentose. Densely pubescent with matted wool.

Tooth. Any small marginal lobe.

Torose. Cylindrical with contrections at intervals.

Thrulose. Diminutive of Torose.

Torus. The receptacle of a flower.

Transierse. Across; in a right and left direction.

Trim. In composition, three or thrice.

Triandrous. Having three stamells.

Trifoliolate. Having three leaflets.

Trigonous. Three-angled.

Trimorphous. Ocenrring uniler three forms.

Triquetrous. IIaving three salient angles, the sides concave or channelled.

Truncate. Ending abruptly, as if eut of transversely.

Tuber. A thickened and short subterranean branch, having numerous buds or eyes.

Tubercle. A small tuber or tuber-like body.

Tuberiferous. Bearing tubers.

Tuberous. II aving the character of a tuber : tuber-like in appearance.

Trumirl. Swollen

Tunicated. Uaving concentric coats, as an onion
Turbinale. Top-shaped; inversely confeal. I'xining. Whuling epirally about a support.

Umbel. An inflorescence in whlch a cluster of peiluncles or pedicels spring from the same point.

Umbellute. In or like an unbel.

L'mbellet. A seeondiry umbel.

Umbonate. Braring a stout projection in the centre; bosied.

Underlouces. The small accessory learis or stipules on the under side of the stem in Ilepatica.

I'mlulate. With a wavy surface; repan I.

Engriculute. Contracted at base into a claw.

Uni-. In romposition. oue.

Uniserual. Of one sex, either staminate or pistillate only.

Urceolate Hollow and rylindrical or orold, and contracted it or below the nouth, like an urn.

Utricle. A small bladdery 1-seeded fruit; any suall bladder-like body.

Taleate. Opening by valves, as a capsule; in restivarion, meeting by the edges without overlappin $r$

Valre. One of the pieces isto which a eapsule spli's

Vascular Furnished with ressels or ducts. Veins. Threads of fibro-vascular tissue in a leaf or other organ, especially those which brapch (as distinguished from nerves).

I'entral. Belonging to the anterior or inner fuce of an organ; the opposite of dorsal.

Ventricose. Swelliug unequally, or iuflated on one side.

Vermution. The arrangement of leaves in the buil.

Verrucose, Covered with wart-like elevations.

I'ersatile (anther). Attached near the nuhldle and turning freely on its support.

Vertical. Perpendicular to the horizon; longitudinal.

Verticillate. Disposed in a whorl.

resicle. A small bladder or air-cavity.

resiculur, resiculose. Composed of or covered with resicles.

rillous. Bearing long and soft hairs.

Virgate. Wiund-shaped; slender, straigh: and erect

riscirl. Glutinous; sticky.

Whorl. An armngenent of leaves, etc, in a circle mund the stem.

Wing. Any membranous or thin expansinn borileriug or surrounding an organ; the laterul petal of a papilionareous corolla.

II mlly. Clnthed with long and tortuous or matted hairs. 



\section{N D E X.}

[SYNoxyms in Italics.]

\begin{tabular}{|c|c|c|c|c|c|}
\hline Abele & 496 & Alopecurus & 645 & Apple, Мвy & 53 \\
\hline Abies & 492,492 & Althaen & 97 & Thora & $3 \pi$ \\
\hline Abronia & 425 & Alum-root & $1 \div 1$ & A pple-of-Peru & 876 \\
\hline Abutilon & 99 & Alyssum & 68 & Aquilegir & 45 \\
\hline Acacia, Rose & 134 & AMARANTACEA & $42 \pi$ & Arubis & $35,71,72$ \\
\hline Acalypha & 459 & Amarintus (Amara & ath) & ABACE.E & 543 \\
\hline ACANTHACE.E & 393 & AMARYLLIDACLE & 515 & Aralia & 212 \\
\hline Acer & 117 & Amaryllis & 735 & ARALLACEE & 212 \\
\hline Acerates & 339,343 & Aubrosia & 273 & Arbor-vitae & 493 \\
\hline Acbillea & 259 & Amelanchier & 166 & Arbutus, 'Trailing & 315 \\
\hline Acnida & 429 & Amianthium & 535 & Arceuthobium & 450 \\
\hline Aconitum (Aconite) & 46 & Ammannia & $t, 185,185$ & dichangelica 201, & , 202, 205 \\
\hline Winter & 45 & Ammopliila & 651,651 & Archemora & 202 \\
\hline Acorus & 551 & Amorpha & 131 & Arctium & 295 \\
\hline Actæa & 47 & A mpelopsis & 115 & Arctostaphylos & 315 \\
\hline Actinella & $28 \pi$ & Amphiachyris & 243 & Arenaria & 85,733 \\
\hline Actinomeris & 281,281 & Amphicarpæea & 146 & Arethusa & 504 \\
\hline Adam-and-Eve & 499 & Amphicarpum & 631 & Argenione & 59,733 \\
\hline Adam's Needle & 524 & Amsonia & 337 & Argy thamnia & 453 \\
\hline Alder's-mouth & 498 & ANACARDIACEXE & 118 & Arisama & 549 \\
\hline Adder's-tongue & 695 & Anacharis & 496 & Aristidu & 633 \\
\hline Yellow & 528 & Anagallis & 331 & Aristolochia & 445 \\
\hline Adenocaulon & 269 & Anaphalis & $2 t ; 8$ & ARISTOLOCHIACES & 444 \\
\hline Adiantum & 650 & Andromeda & 316 & Arnica & $2 y 2$ \\
\hline Adlumia & 60 & Andropogon & $63 i, 638$ & Arrhenatberum & 601 \\
\hline Adonis & 40 & Androsice & 329 & Arrow-grass & 557 \\
\hline Adoxa & 216 & Androstephium & $5: 2$ & Arrowbead & 654 \\
\hline Egopodium & 208 & Anemone & $3 i$ & Arrow-wood & 217 \\
\hline Aicaynomene & 137 & Rue & 39 & Artemisia & 290 \\
\hline Esculus & 115 & Anemonella & 39 & Articlıoke, Jerusalem & -277 \\
\hline Athusa & 205 & Aneura & $72 ;$ & Arum & 650 \\
\hline Agat ve & 516 & Angelica & 201 & A rrow & $54 ?$ \\
\hline Agrimonia (Agrimon & 161 & Angelica-tree & 210 & I) rngon & 549 \\
\hline Agropyrum & 671 & ANONIC & 50 & Water & 650 \\
\hline Agrostemma & 85 & Anteunaria & 267,268 & Arundinaria & $6 i 4$ \\
\hline Agrostis & 647 & Antheuris & 288 & Arundo & 659 \\
\hline Ailanthus & \pm 07 & Anthoceros & 726 & Asarabacea & 444 \\
\hline Aira & 652,652 & ANTISOCEROTACE.E & 726 & Asarum & 444,734 \\
\hline Ajuga & 406 & Anthoxanthum & 639 & ASCLEPIADACEE & 338 \\
\hline Alchemilla & 161 & Anthriscus & 206 & Ascleplas & 339 \\
\hline Alder & 472 & Antirrhiuuns & 350 & Asclepiodora & 339 \\
\hline Black & 109 & Anychia & 426 & Aseyrum & 92 \\
\hline White & 322 & A per: & 649 & A*h & 335 \\
\hline Aletris & 512 & A phanostephus & 253 & Mountuin & lits \\
\hline Alfalfa & 129 & Aplyylon & 394 & Prickly & 106 \\
\hline Alisma & $5 i 24$ & dpiastrum & 209 & Asparngus & $62 j$ \\
\hline A LISMACEA & 553 & Apios & 144 & Aspen & 456 \\
\hline Alligator Pear & 446 & Apium & 209 & Asperupo & 361 \\
\hline Allium & 521,522 & $\begin{array}{l}\text { Aplectrum } \\
\text { A plopappus }\end{array}$ & $\begin{array}{l}4 ! 9 \\
245\end{array}$ & Asphodel, Bog & 539 \\
\hline Allosorus & $\begin{array}{l}683 \\
167\end{array}$ & $\begin{array}{l}\text { A plopappus } \\
\text { APOCrNACE. }\end{array}$ & $\begin{array}{l}245 \\
337\end{array}$ & $\begin{array}{r}\text { False } \\
\text { Aspillium }\end{array}$ & $\begin{array}{l}532 \\
6.46\end{array}$ \\
\hline $\begin{array}{l}\text { Allspice, Carolina } \\
\text { Wild }\end{array}$ & $\begin{array}{l}167 \\
447\end{array}$ & $\begin{array}{l}\text { APOCYNACE. } \\
\text { Apocynum }\end{array}$ & 33.4 & $\begin{array}{l}\text { Aspilium } \\
\text { Aspuleninm }\end{array}$ & 643 \\
\hline Alnus & 472 & Apple & 164 & Asprella & 674 \\
\hline Aloe, American & 516 & Balkam & 195 & Aster & 255 \\
\hline False & 516 & Crab & 164 & acuminatus & 254 \\
\hline
\end{tabular}




\begin{tabular}{|c|c|c|c|c|c|}
\hline Aster astivus & 262 & Ballota & 420 & Blite, Sea, & 435 \\
\hline amethystinus & 260 & Balm & 412 & Strawberry & 432 \\
\hline angustus & 264 & Bee & 411 & Blitum & 432,433 \\
\hline anomalus & 258 & Horse & 406 & Bloodroot & 58 \\
\hline azureus & 258 & Balm-of-Gilead & $48 \pi$ & Bloodwort Family & 512 \\
\hline carneus & 261 & Balsam & 105 & Bluebell & 64 \\
\hline coueinnus & 250 & Balsam Poplar & 487 & Blueberry & 16 \\
\hline coneolor & 258 & Baneberry & 47 & Bluebottle & 6 \\
\hline cordifolius & 259 & Baptisia & 125 & Blue-eurls & 5 \\
\hline cory mbosus & 255 & Burbarea & 70 & Blue-hearts & \\
\hline diffusus & 261 & barberry & 52 & Blue-joint & 650 \\
\hline Drummondii & 259 & Barley & 672 & Blue-stem & \\
\hline dumosus & 2 & Bartouia & 352 & Blue-tangle & \\
\hline ericoides & 260 & Bartsia & 392 & Bluets & \\
\hline Fendleri & $25 \vec{i}$ & Basil & 409,412 & Blue-weed & \\
\hline flexuosus & 264 & Bass-wood & 101 & Boehmeria & 36 \\
\hline gracilis & 256 & Bay, Loblolly & 96 & Bois d'Are & \\
\hline grauditlorus & 257 & Fed & 447 & Boltonia & \\
\hline Herveyi & 256 & Kose & 320 & Bonamia & \\
\hline infirmus & 263 & Bay berry & 469 & Boneset & \\
\hline junceus & 262 & Bazzauia & 710 & Borage Family & \\
\hline lævis & 259 & Bean. Indian & 399 & BORRAGINAC & \\
\hline Jinariifolius & 263 & Kiduey & 144 & Borrichia & \\
\hline Lindleyanus & 259 & Sacred & ¿5 & Botryehium & 3 \\
\hline linifolins & 264 & Wild & 144 & Bouneing Bet & \\
\hline longrifulius & 262,262 & Bearberry & 315 & Bouteloui & D? \\
\hline macrophyllus & 256 & Beard-tongue & 381 & Bowman's-root & 34 \\
\hline miser & 261 & Beekmaunia & 628 & Boxberry & \\
\hline modestus & 257 & Bedstraw & 225 & Box-eluer & \\
\hline multiflorus & 260 & Beech & 479 & Boykinia & U. \\
\hline nenoralis & 64 & Blue & 474 & Brachyehreta & \\
\hline Anglixe & 57 & Water & $47 t$ & Brachyely trum & \\
\hline Novi-Belgii & 262 & Beech-drops & 394 & Bracken & \\
\hline oblongifolius & 57 & False & 3265 & Brake & \\
\hline paludusus & 55 & Beggar-lice & $36^{2}$ & Cliff & \\
\hline datus & 61 & Begrar-ticks & 284 & Rock & \\
\hline piat & 58 & Belaucanda & 515 & Bramble & 4 \\
\hline peitulus & $j 2$ & Bellthower & 308 & Braseuia & 5 \\
\hline hyllus & i0 & Bellis & 253 & Brassiea & \\
\hline ithoides & 63 & Bellwort & $52 i$ & Breweria & 0 \\
\hline ptarmicoides & 64 & Benjamin-bush & 447 & Brickellia & \\
\hline puniceus & 3 & BERBERIDACEA & 52 & Briza & 3 \\
\hline radula & 66 & Berberis & 52 & Brizopyrum & 3 \\
\hline ifolius & 9 & Berehemia & 111 & BRoMLLLACEA & 1 \\
\hline salicifolius & 31 & Berganot, Wild & 414 & Bromus & 69 \\
\hline sericeus & 57 & Berlındiera & $2 \pi 1$ & Brooklime, American & \\
\hline Slıortii & 58 & Berula & $20 \vec{i}$ & Brockweed & 32 \\
\hline simplex & 61 & Betony, Wood & $3: 2$ & Broom & \\
\hline spectabilis & 56 & Betula & 471 & Broom-rape & \\
\hline subulatus & 64 & Bidens & 84 & Naked & \\
\hline surculosus & 56 & Bigelovia & 45 & Brunella & \\
\hline rus & 2 & Birnonia & 8 & Brunniehia & \\
\hline olius & 1,264 & BIGXONILEE & 3 & thus & \\
\hline Tradescauti & 261 & Bilberry & 312 & Buchloë & \\
\hline turbinelius & 259 & Bilsted & 180 & Buchnera & \\
\hline unibellatus & & Bindweed & 369 & Buckbean & \\
\hline undu & 1 & Black & 412 & Buckeye & \\
\hline viıni & 0 & Birch & 471 & Buckthorn & 111, \\
\hline virgatus & & Birthroot & 530 & Buck wheat & \\
\hline ster, Golden & & Birthwort & & Climbing Falso & \\
\hline White-topped & & Bishop's-cap & & Buda & 0 \\
\hline Asterella & & Bishop-weed, Mock & 209 & Buffalo-berry & 49 \\
\hline Astilbe & & Bitter-nut & & Buffalo-nut & 51 \\
\hline Astrigalus & & Bittersweet & 373 & Bugbane & \\
\hline o Lily & & Climbing or Shrubb & by 110 & False & \\
\hline Atriplex & 433 & Bitter-weed & 273 & Bugleweed & 08 \\
\hline Atropis & 68 & Blackberry & 155 & Bugloss & \\
\hline Avena & & Bladder Ketmia & 100 & Bugseed & \\
\hline & 156 & Blad & 118 & Bulrush & 578 \\
\hline A wlwort & 69 & Bladderwort & 395 & Bumelia & \\
\hline Azalea & 320 & Blasia & 724 & Bunchberry & \\
\hline \multirow{3}{*}{ Azolla } & 322 & Blazing-star & 242,532 & Bunch-flower & \\
\hline & 701 & Blepharostoma & $\pi 11$ & Bupleurum & \\
\hline & & Blepharozia & 709 & Burdock & \\
\hline & & Blephilia & & Burmannia & \\
\hline ple Berry & 15 & Bletire & 501 & BURMANNIACEX & \\
\hline Baidwinia & 285 & Blite, Coast & 432 & Burnet & \\
\hline
\end{tabular}




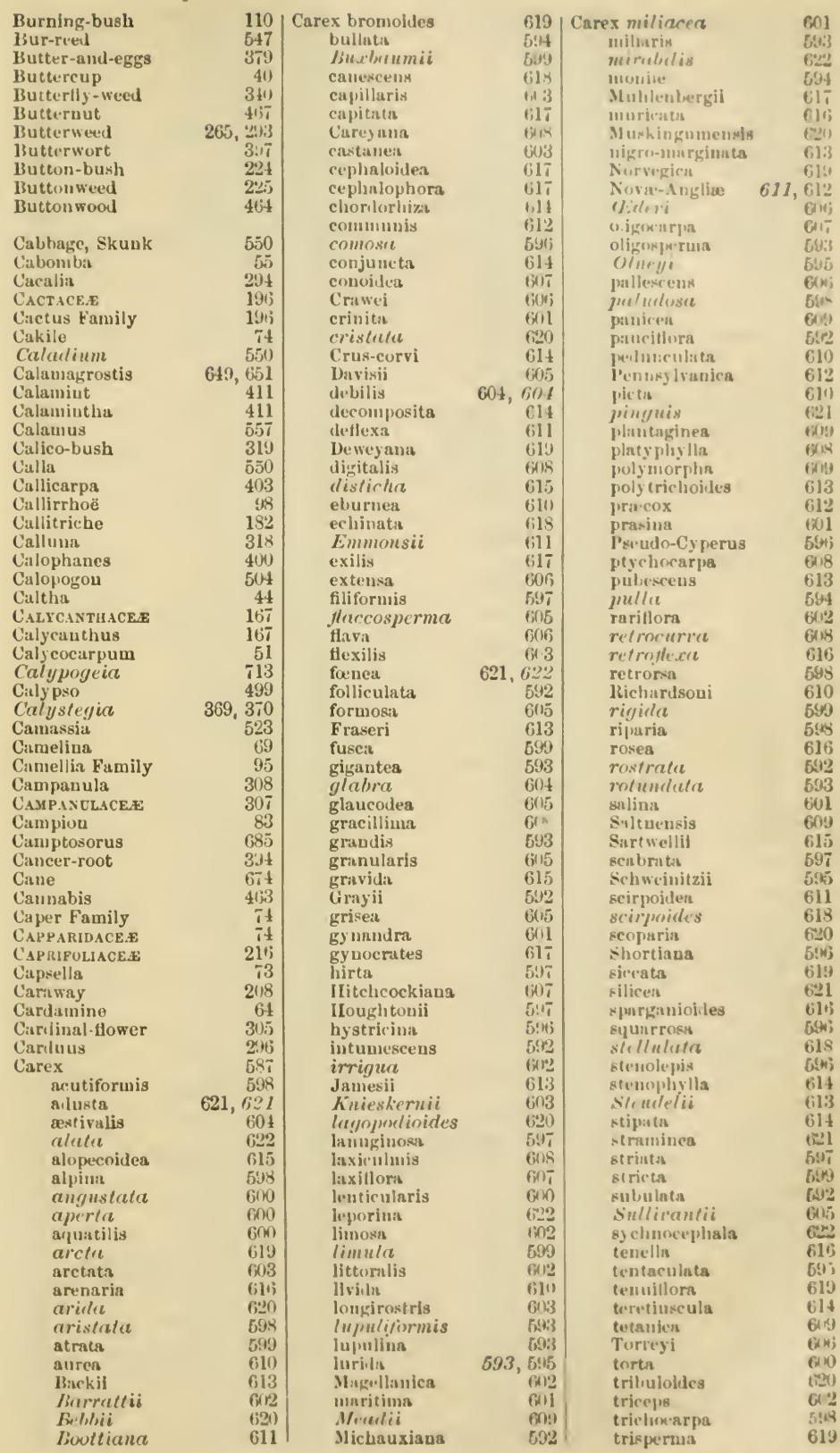


Carex Tuckermani umbellata utriculata vaginata varia

Vaseyi venusta vestita virescens vitilis vulgaris vulpinoidea villdenorii Woodii

Carnation

Carpetweed

Carpinus

Carrion-flower

Carrot

Carum

Carya

C.aryophyllaces

Cashew Family

Cassandra

Cassena

Cassia

Cassiope

Castanea

Castilleia

Castor-oil Plant

Catalpa

Cat-brier

Catchfly

Catgut

Catmint

Catrip

Cat-tail Flag

Caucalis

Caulophyllum

Ceanothus

Cedar, Red White

Cedronella

Celandine

Czlastracex

Celastrus

Celtis

Cenchrus

Centaurea

Centaury

Centrosema

Centunculus

Cephalanthus

Cephalozia

Cerastium

Ceratophyllaces

Ceratophyllum

Cercis

Cesia

Chærophyllum

Chæ topappa

Chafficed

Chaffweed

Chamæcyparis

Chamælirium

Chamæsaracha

Cbamomile IVild

Charlock

Cheat

Checkerberry

Cheilanthes

Chelidonium

Chelone

Cheyopodiace.e

Chenopodium

Cherry

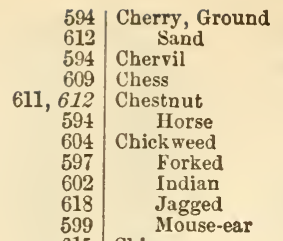

615 Chicory

613 Chiloseyphus

609 Chimaphila

83 Chinquapin

198 Water

474 Chiogenes

520 Chionanthus

201 Chives

208 Chokeberry

468 Choudrilla

82 Chrysanthemum

118 Chrysogonum

317 Chrysopogon

108 Chrysopsis

147 Chrysosplenium

318 Cichorium

479 Cicuta

390 Cimicifuga

460 Cinna

399 Cinquefoil

519 Circæa

83 Cirsium

133 Cissus

416 Cist ice.e

416 Cladium

547 Cladothrix

201 Cladrastis

52 Clary

11. Claytonia

494 Clear-weed

493, 494 Cleavers

416 Clematis

58 Cleome

109 Cleomella

110 Clethra

463, i3t Clintonia

634 Clitoria

297 Clotbur

347 Cloudberry

145 Clover

332 Bush

234 Prairie

711 Sweet

88 Club-moss

488 Cnicus

488 Cocculus

147 Cochlearia

723 Cockle

206, 209 Cocklebur

253 Colopleurum

391 Coffee, Wild

332 Coffee-tree, Kentuck

493 Cohosh

531 Colic-root

374 Collinsia

258 Collinsonia

289 Collomia

72, it Coltsfoot

$670 \quad$ Srreet

316 Columbine

681 Columbo, American

58 Comandra

391 Comfrey

430 Wild

431 Commelina

151 Commelisacea

375 Compass-plant

152 Composita

206 C'omptonia

670 Cone-flower

479 Purple

115 CONIFER $\mathbb{R}$

86 Conioselinum

426 Conium

198 Conobea

87 Conocephalus

88 Conopholis

298 Convallaria

716 Convolvelaces

322 Convolvulus

479 Coptis

55 Coral-berry

314 Coral-root

337 Corallorhiza

522 Corema

164 Coreopsis

303 Corispermum

289 CORNACEE

271 Cornel

638 Corn-salad

244 Cornus

172 Coronilla

298 Corpse-plant

208 Corydalis

47 Corylus

649 Cottonwood

158 Cowberry

193 Cowslip

295, 2

11

586 Crab-apple

734 Crauberry

1:6 Cranberry-tree

413 Cranesbil

91, 733 Crantzia

465 Crassulace

225 Cratmgus

35

75,73

Cress, Bitter

73 Mouse-ear

322 lRock

527

145

274

154

128

141

132

129

695,697

295,297

51 Crowberry

70 Crowfoot

85 Crown-beard

274 Cruciffres

205 C'rypsis

219 Cryptogramme

148 Cryptotænia

47, 52 Ctenium

512 Cuckoo-flower

350 Cucumber

406 Bur

356 Cucumber-root Indian

291 Cucumber-tree

292 Cucurbita

45 Cucurbitace

352 Cudweed

450 Culver's-physic

367 Culver's-root

362 Cunila

538 Cuphea

5-38 Cup-plant

230

470

270

275

489

202

209

383

728

394

524

367

369

45

220

500

500

488

281

434

213

214

228

214

138

325

61

473

487

314

321

328

364

398

161

312,314

217

103

205

176

165

64

73

65

65

74

69

70

300

398

127

457

458

487

488

40

280

61

640

682

207

654

65

194

195 
INI)EX.

\begin{tabular}{|c|c|c|c|c|c|c|}
\hline Cupressus & 493 & Disporum & $52 j$ & Krsocatleas & & 566 \\
\hline Cupseed & 51 & Vistichlis &, 735 & Kricecaulon & & 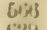 \\
\hline CUPLLAFEBA & 470 & Dittuny & 409 & Eriochloa & & 628 \\
\hline Currant & 174 & Dock & 437 & Eriogonum & 436, & 73 \\
\hline Indiau & 220 & I'rulrie & 270 & Kriophorum & & \\
\hline Cuscutas & 369 & Spatter & $50^{\circ}$ & Erodiun & & 4 \\
\hline Custard-apple Famil & 50 & Dockmackie & 213 & Eryngium & & \\
\hline Cyelinthers & 196 & 1)odder & 370 & Eryugo & & $\prod_{-1}^{11}$ \\
\hline Cycloloma & 431 & Dodecatheon & 325 & Erysimum & & \\
\hline cjmopterus & 203 & Dogbario & 333 & Erythras & & \\
\hline Cynodon & 654 & Dogwood & 211 & Erythronlum & & \\
\hline Cynoglossum & 362,363 & Draba & 67 & Eulophus & & \\
\hline Cynthia & 293 & Dracocephalum & 416 & Euonymuz & & \\
\hline CYPERACE. & 567 & Dragon-head & 416 & Eupatorium & & \\
\hline Cyperus & 569 & False & 419 & Euphorbia & & \\
\hline Cypress & 493 & Dragon-root & 543 & ECPIIORBIACE.B & & \\
\hline Cypress-rine & 368 & Drosera & 173 & Euplirasia & & \\
\hline Cypripedium & 510 & DROSERACEE & 178 & Eustoma & & 19 \\
\hline Cystopteris & 689 & Dryas & $15 i$ & Evax & & \\
\hline Cytisus & 127 & Duck's-meat & 552 & Eveniug Primrose & Family & 36 \\
\hline & & Duckweed & 50 & Everlasting & 267 & \\
\hline Dactylis & 663 & Dulichium & $5 \div 3$ & Evolvulus & & \\
\hline Dactyloctenium & $\mathrm{C} 56$ & Dumortiera & 729 & Eyebright & & \\
\hline Dahoon Ilolly & 108 & Dutchman's-brecches & 60 & & & \\
\hline Daisy & 253 & Dutchman's-pipe & $44 j$ & Fagopyrum & & 43 \\
\hline Ox-eye & 289 & Duralia & 729 & Fagus & & \\
\hline White & 259 & Dyer's-weed & 75 & False-nermaid & & \\
\hline Dalea & 132 & Dysodia & 285 & Farkleberry & & \\
\hline Dalibarda & 156 & & & Featherfoil & & \\
\hline Dame's-violet & 71 & Fatonia & 659 & Fedia & & 29 \\
\hline Dandelion & 303 & Ebexace.T & 333 & Fegatella & & \\
\hline Dwarf & 297 & Ebony Family & 333 & Fennel & & \\
\hline Fall & 299 & Echinacea & 275 & Dog & & 33 \\
\hline False & 303 & Echinocystis & $19 j$ & Fennel-Hower & & \\
\hline Dangleberry & 311 & Echinodorus & 556 & Fern, Beech & & 656 \\
\hline Danthonia & 654 & Echinospermum & $3 i j 2$ & Bladder & & \\
\hline Daplune & .148 & Echium & $36 \pi$ & Chain & & \\
\hline Darnel & \pm 1 & Eclipta & 274 & Christmas & & \\
\hline Datura & 377 & Eel-grass &, 565 & Cinuamon & & \\
\hline Daucus & 201 & Eglantine & 164 & Climbing & & \\
\hline Day-flower & 538 & ELEAGNACEX & 445 & Cloak & & \\
\hline Dead-nettle & 420 & Elæagnus & 443 & Filmy & & \\
\hline Decodon & 186 & ELATINACEAB & 91 & Flowering & & \\
\hline Decumaria & 173 & Elatine & 91 & Lip & & \\
\hline Deerberry & 312 & Ëlder & 217 & Sensitive & & 90 \\
\hline Delphinium & 46 & Box & 118 & Shield & & \\
\hline Dentaria & 64 & Marsh & $2 \pi 2$ & Wood & & 86 \\
\hline Deschaupsia & 652 & Wild & 213 & Ferns & & \\
\hline Desmanthus & 149 & Elecampane & 269 & Fescue & & \\
\hline Desmodium & 138 & Eleocharis & 735 & Sheep's & & \\
\hline Devil's-bit & 531 & Elephantopus & 237 & Festuca & 666 & \\
\hline Dewberry & 155 & Eleplant's-foot & $23 i$ & Fever-bush & & \\
\hline Deyeuxia & 650 & Eleusine & 656 & Feverfew & & \\
\hline Dianthera & 401 & Ellisia & 358 & Feverwort & & \\
\hline Dianthus & 83 & Elm & 462 & FICOIDE.E & & \\
\hline Diapensia & 326 & Elodea & $4 ! 5$ & rig, Indian & & \\
\hline DHAPENSIACEE & 326 & Eloules & 95 & Figwort & & \\
\hline Diarrhena & 662 & Elymus & 673 & Filago & & i \\
\hline Dicentra & 60 & EMPETRACEE & 457 & Filbert & & \\
\hline Dichondra & 368 & Empetrum & $48 \%$ & Filices & & \\
\hline Dichromena & $5 \%$ & Enchanter's Nightshade & $1 ! 3$ & Fimbriaria & & \\
\hline Dieksonia & 691 & Engelmannia & 272 & Finbristylls & & \\
\hline Didliplis & 184 & Enslenia & 343 & Fiorin & & \\
\hline Diervilla & 222 & Epigrea & 315 & Fir & & \\
\hline Diodia & 225 & Epilobium & 188 & Fire-weed & 158 & \\
\hline Dionæa & 179 & Epipactis & $511 \%$ & Five-finger & & \\
\hline Dioscorea & 517 & Hpiphegus & 8.4 & Flag & & \\
\hline Dioscorvaces & 517 & FeUTSTACEA & 675 & Cat-tail & & \\
\hline Diospy ros & 3.33 & Equisetum & 676 & Sweet & & \\
\hline Diphylleia & 53 & Eragrostis & 660 & Flax & & \\
\hline Diplachne & 658 & Eranthis & 45 & Flenbane & & \\
\hline Diplopappus & 273 & Erechtites & $2 ! 4$ & Marsh & & \\
\hline Diplophyllum & 715 & Frianthus & $630 \mathrm{i}$ & Floating-heart & & \\
\hline DIPSACR.X & 224 & Krica & 318 & Flaerkea & & 104 \\
\hline Diряасия & $202 !$ & ERICACE B & 3!9 & Flower-de-luce & & \\
\hline Diren & 448 & Erigenis & 210 & Fly-poison & & \\
\hline Discopleura & 209 & Erigeron & 264 & Faeviculum & & \\
\hline
\end{tabular}




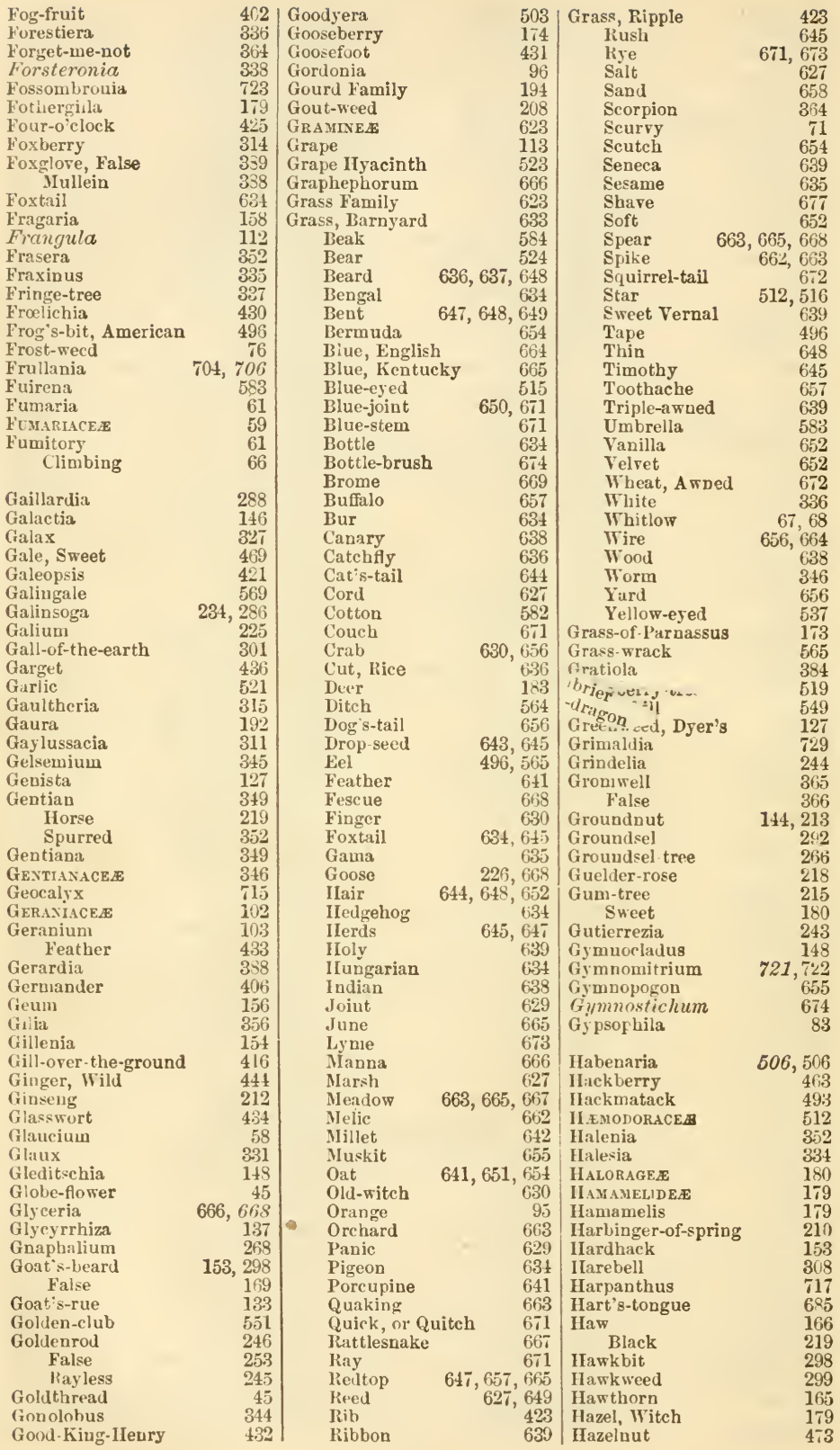


IIeal-all

Heart's-ease

IIeather

IIeath Family

IIedeoma

IIedysarum

Helenium

IIeleochlon

Ieliantheunum

IIelianthus

Heliophytum

Heliopsis

IIeliotropium (Heliotrope)

Hellebore False

IIelleborus

llelonias

Ilemerocallis

Ileinicarpha

IIemlock Ground

Water

Hevodoracez

Hemp Indian Water

IIeubane

Hepatica

Hepatic.玉

Heracleum

Herb-Robert

Herba-impia

Herberta

Hercules' Clu's

Herpestis

IIesperis

Heteranthera

Heterotheca

IIeuchera

IIexalectris

Ilibiscus

IIickory

Hieracium

Hierochloë

High-water Shrub

Hippuris

Hobble-bush

Hoffunansegria

Ilogweud

Holcus

Holly Dahoon Mountaín

IIolosteum

Honewort

Honey suckle Bush

Ionkenya

Hop

Hop tree

Hordeum

Horehound Blrek Fetial Water

IIorntieam IIop

IIornwurt

Horse-brier

Horse-chestnut

IIorseradion

Horse-sugar

Horsetail

Horse-weed

IIosackia

Hottonia

Hound's-tongue
419 IIoustonia

75, 81 IIuckleberry

318 siquaw

309 Iludsondis

412 IIumulus

139 II untsman's-cup

$2 \varsigma$ IIyuciuth, Grape

cott Wild

i6 Ilydrangea

27 llydrastis

362 HYDROCHARH)ACR.B

275 Ilydrorotyle

361 IIydrolen

45 II YDropH YLLACE.

IIydrophyllum

45 Ilyurenocallis

531 IIy uicnopappus

523 IIyoseyamus

583 IITPERIC.ACE.A

209,492 llypericum

494 Hypoxis

208 IIyssopus (IIyssop)

512

463

338

429

$3 \pm, 3$

Ilex

Giant

ILICLNE.

- Illecebraces

202 Ilysanthes

103 Impatiens

267 I udian-physic

267 Indiau-pipe

709 Indian-poke

Indigo

38

$530^{\circ}$

244

1i1

501

100

468

299

639

272

182

217

148

273

652

107

108

109

87

201

220

86
454
107

672

419

$4: 20$

420

408

$4 i 4$

474

485

i2 30

115

33

67

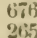

1.30

32

362

Jеssumine, Yellow
False

Wild

Indigofera

Inkberry

Innoceuce

Inula

Ionidium

I pecas, American

Ipomuea

Iresine

IRIDACE E

Iris

Ironweed

Iron-wood

Isanthus

Isoetes

Isopyrum

Itea

Ivy, American

Grouna

P'oison

Jacob's-laduer

Jamestowu-Wieed

Jatropha

Jeffersonin

Jewel-weed

Joe-P're Weed

Jubula

Jud.LS-tree

Juglandaces

Juglans

JUNCACEA

Juncus

Juneberry

Jungermannia $\approx 10-712, \tau 11$ $\pi 15, \pi 17, \pi 15,718, \pi$.

Jexgervanincr.s:

Juniperus (Juniper)

Jessial

133

$2 * 3$

269

81

154

$3 ; 8$
429

357
202 Kalmis

311 Kisntia

$\$ 12$ Ketmia, Hadler

76 King-nut

464 Klunikiunlk

$5 i$ Knapwerd

523 Knawel

523 linotweed

173 Knotwort Eamily

$4 y$ Koclala

495 Kuleria

210,733 Kontuletzkja

$3 \%$ Krigis

357 Kry nitzkis

357 Kuhnja

616 Kyllinga

256

92 Labiat.F

y2 Laclinanthes

516 Lnclinocaulon

403 Lactuca

415

Lady's-mantle

Lady'g-8lipper

Lady's-thumb

Lavly's-tresses

Lausbkill

Lamb's-quarters

Lamium

Lampsana

Laportea

wirch

Larix

larkspur

Lathyrus

L.ACRACE.E

Laurel

513
, 735

American

Ground

Mountain

Laurestiuus

Lavender, Sea

Lead-plant

wadwort Family

Leaf-cup

Leather-llower

Leatluer-leaf

Leat berwoud

Leavenworthia

Lechea

Ledum

Leek, Wild

Leer:ia

LEGLMINOS.E

Leiophyllum

Lejeunea

Leuna

LEMNACE.E

LENTHULLARIACE.

Lenntodon

Leonurus

Lapachys

Iepillum

Jeplinzia

Le jigonum

Leptixnulls

Jepinchiona

lepenporar

Lepturus

Lasperleza

lesquerella

Letturs:

$$
\text { I } 24 \text { mb }
$$

$$
\text { White }
$$

Leueranthe mum

494 Lencuthoe

137 Leter-wood

310,319

713

Ix)

40 id 
Liatris

Ligusticum

Ligustrum

LIIIACE.A

Lilium

Lily

Atamasco
Blackberry
Day
Pond
Water

Lily-of-the-valley

Limnanthemum

Limnobium

Limosella

LINACEE

Linaria

Linden

Lindera

Ling

Linnæa

Linum

Liochlæna

Lion's-foot

Liparis

Lipocarpha

Lippia

Liquidambar

Liquorice

Wild

Liriodendron

Listera

Lithospermum

Litsea

Littorella

Live-forever

Liver-leaf

Liverworts

Lizard's-tail

LOASACEA

Lobelia

LOBELIACE

Loblolly-bay

Locust

Honey

Water

LOGANIACE.P

Loiseleuria

Lolium

Lonicera

Loosestrife

False

Swamp

Lophanthus

Lophiola

Lophocolea

Lopseed

LORANTHACEAB

Lousewort

Lovage

Lucerne

Ludwigia

Lungwort

Lunularia

Lupinus (Lupine)

Luzula

Lychnis

Lycium

Lycopsis

LrCOPODIACEA

Lycopodium

Lycopus

Lygodesmia

Lygodium

Lysimachia

LYTHRACEA

Lythrum

\begin{tabular}{r|l}
242,243 & Maclura \\
214 & Madder Family \\
337 & Madotheca \\
517 & Magnolia \\
529 & MAGNoLLAcE $E$ \\
529 & Maianthemum \\
516 & Maidenhair \\
515 & MaIlow \\
523 & False \\
56 & Glade \\
55 & Indian \\
524 & Marsh \\
353 & Rose \\
496 & Malva \\
384 & MALVACE. \\
101 & Malvastrum \\
379 & Mamillaria \\
101 & Mandrake \\
447 & Man-of-the-earth
\end{tabular}

318 Maple

219 Ash-leaved

101 Marchantia

718 Marchantiaces

301 Mare'tail

499 Marigold, Bur

581 Fetid

402 Marsh

179, 180 Water 137 Marjoram, Wild

226 Marrubium

50 Marshallia

501 Marsilia

365 Marsiliaces

447 Marsupella

424 Martynia

178 Marvel-of-Peru

33 Mastigobryum

702 Matricaria

446 Matrimony-vine

193 Mayaca

305 M IY ACE.

305 May-apple

96 Mayflower

134 May-weed

148 Meadow-beauty

149 Meadow-sweet

315 Medeola

3 .2 Iledicıgo

671 Medick

$22 \mathrm{v}$ Melampyrum

185, 330 Jelanthium

187 Melastomace

186 Melica

415 Melilotus (Melilot)

512 Melissa

715 Melothria

403 Mexispermace.s

449 Menispermum

392 Mentha

205 Mentzelia

1:29 Menyanthes

187 Menziesia

363 Mercury, Three-seeded

730 Mermaid-weed

128 Mertensia

546 Metzgeria

85 Mezereum

376 Nicranthemum

367 Mierostylis

695 Mignonette

695 Mikania

408 Milfoil

302 Water

692 Milium

330, 330 Milkweed

184 Green

185 Milkwort

\begin{tabular}{|c|c|c|}
\hline 464 & Milkwort, Sea & 831 \\
\hline 222 & Millet & 642 \\
\hline 08,709 & Mimulus & 382 \\
\hline 49 & Mint & 407 \\
\hline 49 & Cat & 416 \\
\hline 526 & Horse & 413 \\
\hline 680 & Mountain & 409 \\
\hline 97 & Pepper & 407 \\
\hline 93 & Spear & 407 \\
\hline 98 & Mirabilis & 425 \\
\hline 99 & Mist-flower & 241 \\
\hline 97 & Mistletoe & 450 \\
\hline 100 & False & 449 \\
\hline 97 & Mitchella & 224 \\
\hline 96 & Mitella & 171 \\
\hline 98 & Mitreola & 346 \\
\hline 197 & Mitrewort & 171,346 \\
\hline 53 & False & 171 \\
\hline 369 & Moccason-flower & 510 \\
\hline 117 & Jlocker-nut & 468 \\
\hline 118 & Modiola & 100 \\
\hline $72 \pi$ & Mollugo & 1 \\
\hline 727 & Monarda & 413 \\
\hline 182 & Moneses & 828 \\
\hline 291 & Moneywort & 331 \\
\hline 288 & Monkey-flower & 382 \\
\hline 44 & Monkshood & 46 \\
\hline 285 & Monotropa & 325 \\
\hline 411 & Montelia & 429 \\
\hline 419 & Moonseed & 51 \\
\hline 256 & Moonwort & 693 \\
\hline 700 & Moosewood & 443 \\
\hline 700 & Moruing-glory & 368 \\
\hline 721 & Morus & 464 \\
\hline 399 & Moschatel & 216 \\
\hline 425 & Moss, Black, or Long & 511 \\
\hline 710 & Club & 695,697 \\
\hline 283 & Flowering & 326 \\
\hline $3 \pi 6$ & Motlierwort & 420 \\
\hline 538 & Mouse-tail & 0 \\
\hline 537 & Mudwort & 384 \\
\hline 53 & Mugwort & 291 \\
\hline 315 & Muhlenbergia & 643 \\
\hline $2 \times 3$ & IIulberry & 464 \\
\hline 183 & French & 403 \\
\hline 153 & Mulgedium & 304,305 \\
\hline 529 & Mullein & 379 \\
\hline 129 & Munroa & 659 \\
\hline 129 & Muscari & 523 \\
\hline 393 & Mustard & 72 \\
\hline 533 & Hedge & 71,72 \\
\hline 183 & Tansy & 72 \\
\hline 2,735 & Tower & 66 \\
\hline 129 & Treacle & 1 \\
\hline 412 & Wormseed & 71 \\
\hline 196 & Mylia & 717 \\
\hline 51 & Myosotis & 364 \\
\hline 51 & Myosurus & 40 \\
\hline 407 & Myrica & 469 \\
\hline 193 & Myricacee & 4 \\
\hline 353 & Myriophyllum & \\
\hline 319 & Myrtle, Sand & 322 \\
\hline 459 & Wax & \\
\hline 151 & Nabalus & 301,302 \\
\hline 72 & Naiad & \\
\hline 44 & NAIADACE $\mathbb{B}$ & \\
\hline & Naias & \\
\hline 49 & Napæa & \\
\hline & Nardia & 721 \\
\hline 2 & Nardosmia & 2 \\
\hline & Narthecium & 532 \\
\hline 18 & Nasturtium & 69 \\
\hline 6 & Neckweed & 387 \\
\hline & Negundo & 118 \\
\hline 3 & Nelumbium & \\
\hline & Selumbo & \\
\hline
\end{tabular}

642

407

413

409

407

41

24

346

346

171

468

100

328

331

382

325

429

51
693

443

368

464

511

697

326

40

384

643

464

403

379

659

523

72

62

I1

71

364

469

469

181

469

557

98

21

532

69

387

55 
Nemastylis

Nensopanthes

Nemophila

Nepeta

Nesca

Nettlo

Dead

Falso

IIedgo

Ilemp

Horse

Spurge

Wood

Nettl-treu

Nicandra

Nicotiana

Nigella

Nightshade

Enchanter's

Niınble-Will

Ninebark

Nipplewort

Nonesuch

Notholena

Nothoscordum

Notothylas

Nuphar

Nyctaginace $x$

Nymphra

NYMPAEACE

Nyssa

Oak Jerusalem Poison

Oakesia

Oat

Sea

Water

Wild

Obolaria

Odontoschisma

Eusothera

Oil-nut

Oldenlandia

OLEACE.E

Oleaster Family

Olive Fanily

ONagraceAs

Onion

Onotlea

Onopordon

Onosmodium

OpHaglossace E

Ophioglossum

Opuntia

Orisehe

Orange, Mock Osage

Orange-root

ORCHID ACE $A$

Orchis

Crane-fly

Rein

Showy

Orignnum

Ornithogalum

OROBANCHACEA

Orobanche

Orontium

Orpine

Orthocarpus

Oryzopsis

Osier

Osmorrhiza

Osmunda
614 Ostrya

109 Oxalis

3i: Ox-ye

416 Sea

186 Oxybuphus

464 Oxydendrum

420 Oxyria

466 Oxytropis

421 Oyster-plant

421

$3 \pi 4$

457 Pachyaandra

4 Pachystiua

463 Papalanthus

376 Painted-cup

377 Pallavicinia

48 P'ancratium

373 Panicum

193 Pausy

641 Papaver

153 Papaveraces

297 Papaw

130 Pappoose-root

680 Purclanthus

522 Parietaria

727 Parnassia

56 Paronychia

425 Parsley Family

55 Parsley, Fool's

54 Hemlock

215 Parsley-piert

Parsnip

475

433

119

Paspalum

662 Pasque-flower

635 Passiflora

654 PAsSIFLoRACEE

353 Passion-flower

713 Pea, Beach

190 Butterfly

451 Everlasting

224 IIoary

335 Milk

448 Partridge

335 Peanut, IIog

186 Pear

521

690

297

$366^{\circ}$

693 PEDar

695 Pedicularis

197 Pellica

433 Pellia

174 Pellitory

464 Peltandra

49 P'ennycress

497 Pennyroyal, American

498, 506 Hasturd

499 False

506 Mock

506 Pennywort, Water

411 Pentliorum

523 Pentslemon

393 Pepper Family

395, 734 Pepper, Water

551 Pepper-bush

177 Peppergrass

391 Pepperidge

642 Peppermint

430 Pepper-root

210 Pepperwort

692 Perilla

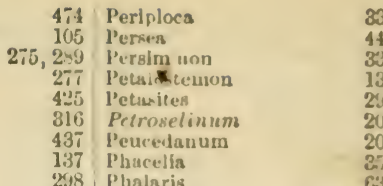

$14,11.5$

thaseol

Pheasant's-eye

456 I'hegopteris

110 Phelijuer

667 Philactelpus

723 phlowis

616 I'hlox 35

629 Phoradendron 44 !

81 Phragmites Ger

69 Phryma 403

57 Phyllanthus 457

50 Phyllorlice 318

53 Physalis 375

515 Physocarpus Jis

466 Physostegia 419

173 Phytolacea 430

426 Pirtolaccacese 435

198 Picea 491

205 Pickerel-weed

202 Picris 293

161 Pigeon-berry 43

¿02 lig nut 469

202 Pigweed 428, 431

204 II inged 431

207 Pilea 465

272 Pimpernel 331

224 Falke 345

628 Water $83^{\circ}$

37 Pinspiuella 206

194 Pine

$194 \quad$ Ground 697

194 Pine-apple tramily 511

143 Pine-drops 325

145 P'ine-sap 325

143 Pine-weed

133 Pinguicula $39 \%$

146 Pink 83, 8

143 Fire $\quad 84$

164 Pinus 490, 734

446 Pinweed

197 Pinxter-Hower

85 PIPERACE.s $440^{\circ}$

469 Pipe-vine 445

399 Pipewort 560

392 Huiry bit

$68^{\circ}$ Pipsissewa 8042

i24 Pitcher-plant $5 \%$

466 Plagiochily

649 Plane-tree Family 466

73 Planer-troo 4 (3)

412 Plantaginacee 422

405 P'lantago 42

406 Plantain 420

412 Indian 244

210 Iud

176 Rattlesnake

$\therefore 81$ Roblu's $2 t 6$

446 Water 554

441 Platanaces $466^{\circ}$

32) Platanus $46 t^{\circ}$

i3 Pleurunthe $\quad$ is

215 Pleurlsy-root 340

407 Pleurogyne $35 \% 2$

64 Pluchea 268

$\begin{array}{rrr}73 & \text { Plum } & 151 \\ 407 & \text { Date } & 398\end{array}$ 
Plum, Ground Red

Plumbaginace.e

Poa

Podophyllum

Podostemaces

Podostemon

Pogonia

Pokeweed

Polanisia

Polemoniacez

Polemonium

Polygala

Polygalacese

Polyg onace e

Polygonatum

Polygonella

Polygonum

Polymui:

Poly podium

Poly pody

Poly pogon

Puly premum

Poly tæuia

Pomme-blanche

Poud-spice

Ponilweed Horned

Pontederia

Pontederiace.

Poplar

Poppy White

Celandine

Corn

Horn

Mexican Prickly

Populus

Porella

Portulaca

Portulacaces

Potanogeton

Potato vine, Wild

Potentilla

Poterium

Preissia

Prenanthes

Prim

Primrose Evening

Primula

Primulace B

Prince's-feather

Prince's-pine

I'rosartes

Psilocarya

Psoralea

Ptelea

Pteris

Pterospora

Ptilidium

Puccinellia

Puccoon Yellow

Pulse Family

Pursline

Sea

Water

Putty-root

Pycnanthemum

Pyrola

Pyrrhopieppus

P'yrularia

Pyrus

Pyxidanthera

Pyxie
135 Quamoclit

151 Queen-of-the-prairie

327 Quercus

663 Quillwort

414 Radish

444 liadula

505 Ragged-Robin

433 Ragweed

it Ragwort

351 Ramsted

356 R.ANCNCULACE

120 Ranunculus

120 Rape, Broom

436 Raphanus

524 Raspberry

443 Rattlebox

439, 413 Rattlesnake-master

269 Rattlesnake-root

680 Rattlesnake-weed

680 Reboulia

648 Redbud

$3 \pm 5$ Red-root

203 Redtop

131 False

447 Tall

558 Reed

565 Bur

536 Reseda

535̃ liEsEDACEE

486 RHAMхасеE

50 lihamnus

59 Rheumatism-root

58 Rhexia

59 Rhinantlus

58 Rhododeudron

59 lihorlora

59 Rhus

486 Rhyuchosia

708 Rhynchospora

50 lijues

90 Ribgrass

558 Ribwort

369 Riccia

159 RiCCIACL2E

161 Rice, Indian

728 Water

300 Richweed

337 licinus

329 Riverweed

190 Robinia

329 Rocket

328 Iyer's

411 Sea

2ะ3 Yellow

¿27 Rock-rose

577 Rosa

130 ROSACEE

107 Rose

681 Cotton

325 Guelder

70.9 Rock

668 Rosebay

3.35 Rosemary, Marsh

48 Rosin-weed

122 Rotala

(0) Rottuoellia

133 Roubieva

1S4, 188 RubIACEE

499 Rubus

409 Rudbeckia

323 Rue Fanily

303 Rue, Neadow

451 Ruellia

164 Rumex

326 Ruppia

326 Rush
368

153

475

698

74

707

$2 \frac{85}{27}$

379

34

40 Sabbatia

3.5 Sage

it

154

127

Sagina

211 Sagittaria

300 St. Andrew's-cross

299 st. John's-wort

729 Marsh

147 St. Peter's-wort

112, 512 SALICACEA

647 Salicornia

665 Salix

667 Salmon-berry

658 Salsify

$5 \pm 7$ Salsola

75 Saltwort

75 Salvia

111 Salvinia

11 SALTINIACEA

53 Sambucus

183 Samolus

392 Samphire

320 Sundul-wood Family

321 Saudweed, sea

118 Saudwort

1+7 Sanguinaria

577,584 Sanicula (Sanicle)

174 SiNTalace

423 SAPINDACEA

422 Sapiudus

730 Sapodilla Family

730 Saponaria

635 SAPOTACEE

635 Sarcoscyphus

407,465 Sarracenia

460 SarRaCeNiace.

444 Sarsaparilla

134 Sassafras

71 Satureia

75 Saururus

74 Sarin

70 Savory

76 Sixifraga

162 SAxifrag.iCE

150 Saxifrage

162 Golden

2 i 7 Scabiosa (Scabious)

218 Scale-mosses

76 Scapania

3:20 Schedonnardus

327 Scheuchzeria

270 Schizaa

184 Schollera

636 Schrankia

433 Schwalbea

222 Schweinitzia

154 Scilla

276 Scirpus

106 Scleranthus

39 Scleria

400 Sclerolepis

437 Scolochloa

564 Scolopendrium

540 Scrophularia

577

540

578

586

586

676

573

586

546

$1 \cup 6$

673

347

412

420

406

554,735

92

9

95

92

480

431

480

154

298

435,734

43.5

412

701

701

217

332

434

450

651

83

55

212

450

115

116

332

83

332

721 
INIFE.

SCrophelariacea

Scutellaria

Sedige

Sedye Family

Sedum

Seed-box

Selaginella

Selugivelaces

Selenia

Self-heal

Sendlinera

Senebiera

Senecio

Senna

Sensitive-brier

Sensitive-plant, Wild

Sericocarpus

Service-berry

Sesuvium

Setaria

Seymeria

Slad-bush

sheep-berry

Shepherdia

Shepherd'8-purse

Sherardia

Shiu-leaf

Shooting-star

Sibbaldia

Sickle-pod

Eicjus

Sida

Sile-saddle Flower

Silene

Silkweed

Silphium

Silver-bell Tree

Silver-berry

Silver-weed

Sinapis

Sisyubrium

Sisyrinchium

Sium

Skullcap

Skunk-cabbage

Sloe

Smartweed

Smilacina

Smilax

Snake-head

Snake-root

Black

Button

Seneca

Virginia

White

Snapdragon

Sneezeweed

Sneezewort

Snowball-treo

Snowberry Creeping

Snowdmp

Soapberry

Soapwort

Solanacees

Solanum

Solea

Solidago

altissima

arguta

bicolor

Bigelovii

Boottii

cresia

Canadensis

Curtisii
377 Solidago Drummondis

416 Elliot tii

587 elliptica

567 giganter

177 Houghtonii

187 humilis

697 juncer

697

418

710

74

292

147

143

118

254

166

198

634

358

166

219

419

73

227

323

3
161

66

195

99

57
83

83
339

270

334

449

160)

72

515,735

207,207

416

อั50

152

525, 526

lanceolata

latifolia

Lindheimeriana

linoides

macrophylla

Missouriensis

monticola

Muhlenbergii

neglecta

neuıralis

odoris

Ohioensis

patula

petiolaris

pilosa

puberula

radula

Riddellii

rigida

rugosa

rupestris

sempervirens

serotina

Shortii

speciosa

squarrosa

stricta

tenuifolis

thyrsoidea

tortifolia

uliginosa

ulmifolia

virgata

Virgaurea

Solomon's-seal False

Sonchus

Sophora

Sorrel

\section{Mountain}

Wood

519 Sorrel-tree

381 Sour-gum

47

212

Sour-wood

Spanish-bayonet

211,242

120

445

241

380

257

218

200

314

334

116

83

373
873

246

246

250

247 Spindle-treo

247 Spiras

250 Spiranthes

247 Spirodela

251 spleenwort

247 Spoouwood
252 Sporobolus

25) Spring-beaty

250 spruce

251 spurge

25i. Spurrey

243 siand

250 Syuaw root

$2: 2$ Squaw. weed

24 Squitrel-corn

217 Stacliys

250 Staff-tree

247 Stagger-bush

251 Stapliylea

247 Star-llower

250 Star-graws

250 star-of-liethlebem

251 Starwurt

249 Water

252 Statice

249 Steeple-bush

246 Steetiun

249 Steirouema

248 Sitellaria

$2 ; 1$ Stenatuthium

252 Stenosiphon

252 Stickreed

249 Sticktight

251 Stillingia

248 stipa

251, 251 Stitchwort

251 Stonecrop

249 Ditch

$24{ }^{\circ}$ Stone-root

248,249 Storax

252 Storksbill

248 Strauouium

24y Strawberry

249 Barren

250 Strawberry-bush

248 Streptopus

248 Strophostyles

524 Struthiopteris

525 Stuartia

305 Stylophorum

127 stylosanthes

437 STrRACACEA

437 sty rax

105 Suxda

316 Subularia

215 succory

316 Sukar-berry

524 Sullivantia

285 Sumach

547 Sundew

6:7 Sunflower

56

407

41
308
346

09

732

713

447

5.3!)

346

213
525

525

11

Supple-Jack

Sweetbrier

Sweet-cicely

Sweet-flag

Swet-gale

Sweet-gum

Swert-leaf

Sweet-scented shrub

Sweet. William

Wild

Syeamore

Symplioriearpos

symphytum

Symplocarpus

Symplneos

Synandra

synthyris

501

$5: 2$ Tacamahac

GeS Talinum

319 Tamarack

C45

ข1

451

452 
Tanacetum

Tansy

Taraxacum

Tare

Taxodium

Taxus

Tea-berry

Tea Family

Tea, Labrador

Mexican

New Jersey

Oswego

Tear-thumb

Teasel

'Tecoma

Tephrosia

Ternstremiacede

Tet ragonotheea

Tetranthera

Teucrium

Thalictrum

Thaspium

Thelesperma

Thely podium

Thermopsis

Thimbleberry

Thistle

Canada.

Cotton

Plumeless

Scotch

Sow

Star

Thlaspi

Thorn

Black

W'lite

Thoroughwax

Thoroughwort

Thuya

'Thy we

Basil

Creeping

THYMELEACE.

Thymus

Tiarella

Tickseed

T'iedemannia

Tilia

Tillaces

Tillrea

Tillandsia

'Timothy

'Tinker's-weed

Tipularia

Tissa

Toadflax Bastard

Tobaceo Indian

Tofieldia

Toothache-tree

Tootliwort

Touch-me-not

Townsendia

Trachelospermum

Tradescantia

Tragia

Tragopogon

Trautvetteria

Tread-softly

Tree-of-hearen

Trefoil

Shrubby

Tick

Trichocoles

Trichomanes
¿90 Tricuspis

303 Trientalis

142 Trifolium

4.3 Triglochin

494 Trilisa

316 Trillium

95 Triodia

321 Triosteum

433 Tripsacum

112 Trisetum

414 Triticum

412 'Trollius

229 Troximon

398 Trumpet-creeper

133 'Trumpet-flower

95 Trumpets

274 Trumpet-weed

447 Tsuga

406 'Tulip-tree

39, 39 Tumbleweed

204, 208 Tupelo

285 Turnip, Indian

72 Turnsole

126 Turtlehead

155 Tussilago

295 Twayblade

296 Twin-flower

297 Twin-leaf

296 Twisted-stalk

297 Typha

305 TYPHACEBS

297

73 Ulmus

165 UMBELLIFFR E

15. Umbrella-leaf

165 Unibrelli-tree

206 Unicorn-plant

23:9 Uniola

493 Urtica

411 URTicace.s

411 Utricularia

411 Uvularia

448

411 Vaccaria

171 Vacciniuus

281 Valeriana (Valerian)

202 Greek

101 VALERIANACE

101 Valerianella

177 Vallisneria

511 Vanilla-plant

645 Velvet-leaf

219 Venus's Fly-trap

439 Looking-glass

89 Veratrum

379 Verbascum

450 Verbena

$3 T$ VERBEXACEA

307 Verbesina

532 Vernonia

106 Veronica

64 Vervain

106 I'esicaria

254 Vetch

338 Joint, Sensitive

539 Milk

460 Vetchling

298 Viburnum

39 Vicia

457 Iilfa

107 Vincetoxicum

128 Tine Family

107 Viola

139 VIOLACEES

709 Violet

692
405 Tiolet, Dame's

$329 \quad$ Green

128 Water 323

557 Tirginian-creeper $\quad 115$

243 Virgin's-bower

530 VITACE. 112

657 Vitis 113, 114

219

636

671,672 Waldsteinia 157

45 Walking-leaf 685

302 Wallflower, Western 71

398 Waluut 467

398 Watercress 69

57 Waterleat 857

239 Water-nympl 55

492 Water-shield 55

50 Waterweed 495

428 Waterwort 91

215 Wax-work 110

549 Wayfaring-tree 217

361 Weigela 2:2

381 Weld 75

291 Wheat, Cow 393

499, 501 India 443

219 Whin

53 Whitewced 289

526 Whitlow-wort 426

547 Wicky 319

5ti Willow 480

Willow-herb 188

46? Wind-flower 36, 38

1.19 Winterberry 109

53 Wintergreen 315, 3ะ3

49,50 Aromatic

394 Chickweed 329

662 Creeping 315

$464 \quad$ Spotted 313

461 Wistaria 134

345 Witch-hazel

527,528 Wolf-berry 220

46

83 Woodbine 115,220

312 Woodsia $r 69$

225 Woodwardia 683

356 Wood-waxen $12 \pi$

225 Wormseed 434

.28 Wormwood 289

496 Roman 273

243
99
$179 n t h i u m$

179 Xanthorrhiza

308 Xanthosoma $\quad 550$

533, 533 Xanthoxylum $\quad 106$

$3 \vec{\imath}$. Xerophyllum 532

401 XYRIDACE.8B 536

401 Xyris 537

280

238 Yam $\quad 517$

386 Yarrow 289

401 Vaupon 108

69 Yellow-eyed Grass

142 Yellow-rattlo 392

137 Yellow-root 48

134 Yellow-wood 126

143 Yew 494

217 Yucea 524

142

645, 646 Zannichellia 565

341 Zephyranthes 516, 735

112 Zizania 635

78 Zizia 206, 207

$\begin{array}{lll}78 & \text { Zostera } & \mathbf{5 6 5} \\ 78 & \text { Zygadenus } & \mathbf{5 3 4}\end{array}$ 
I'LA TES

WTII EXPLANATIONS. 


\section{EXPLANATION OF PLATE I.}

CYPERLS. - (1) Small plant of ('. diandrus; (2) a spikelet magnifien ; (3) a piece of the rhachis with one sale enclosing its flower; (4) a separate Hower more magnified. - (5) (c. erythrorlizos, a sprikelet magnifierl the lower scales and flowers have fallen, showing the small internal scalcs of the section Paprorus, formed of the winged margins of the joints of the rhachis letached; (6) a separate one, more enlargerl; (i) a Hower; ( 8 ) an achene, cut in two.-(9) C. clentatus, a piece of the rhachis of a sjike with the lower part of one suale, showing how it is decurrent on the joint leneath (cut acruss) to form scale-like wings.

DLI.ICHILA. - (1) Cpper part of a plant of I). spathaceum ; (2) part of a spikelet somewhat enlarged; (3) piece of rhachis, and one scale decurrent on the juint beneath; (t) magnified Hower.

KILLINGA. - (1) I'lant of K. pumila; (2) one-flowered spikelet on a piece of the rhachis, enlarged; (3) the same, more enlarged and open; $(4)$ achene; and (5) section of same magnified. 


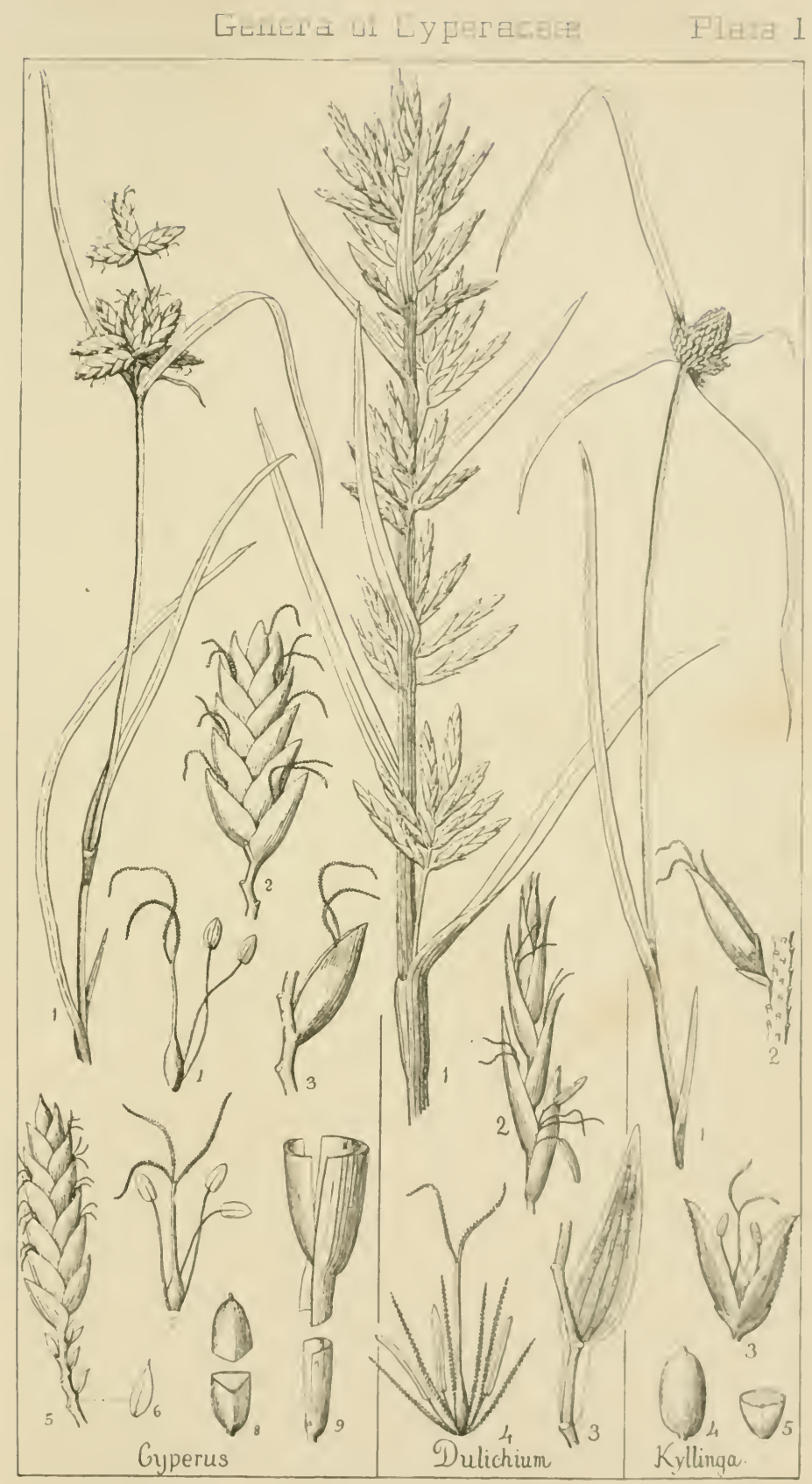




\section{EXPLANATION OF PLATE II}

IIEAICARPIIA. - (1) 1'lant of 11. subsquarrosil, natural size; (2) a spikelet enlarged, with its lmact ; (3) magnified scale of the sime ; (5) a flower, with its single stamen and minute internal scale, magnified; (6) achene, magnified.

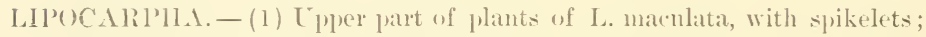
(2) diagram of a flower, representing the ovary botween the two internal suales, a single stamen, the suale of the spikelet on one sile, and the axis of the spikelet on the other; (3) suale of spikelet detached; (-1) a flower with its two immer scales; (5) achene, magnified.

FLIREXA. - (1) Lpper portion of plant of F. spuarrosa, var. pumila; (2) scale of spike enclosing a flower; (3) open scale of same; (4) flower; (5) one of the scales and one of the bristles of the perianth ; 6 ) achene, and ( 7 ) section of same. 


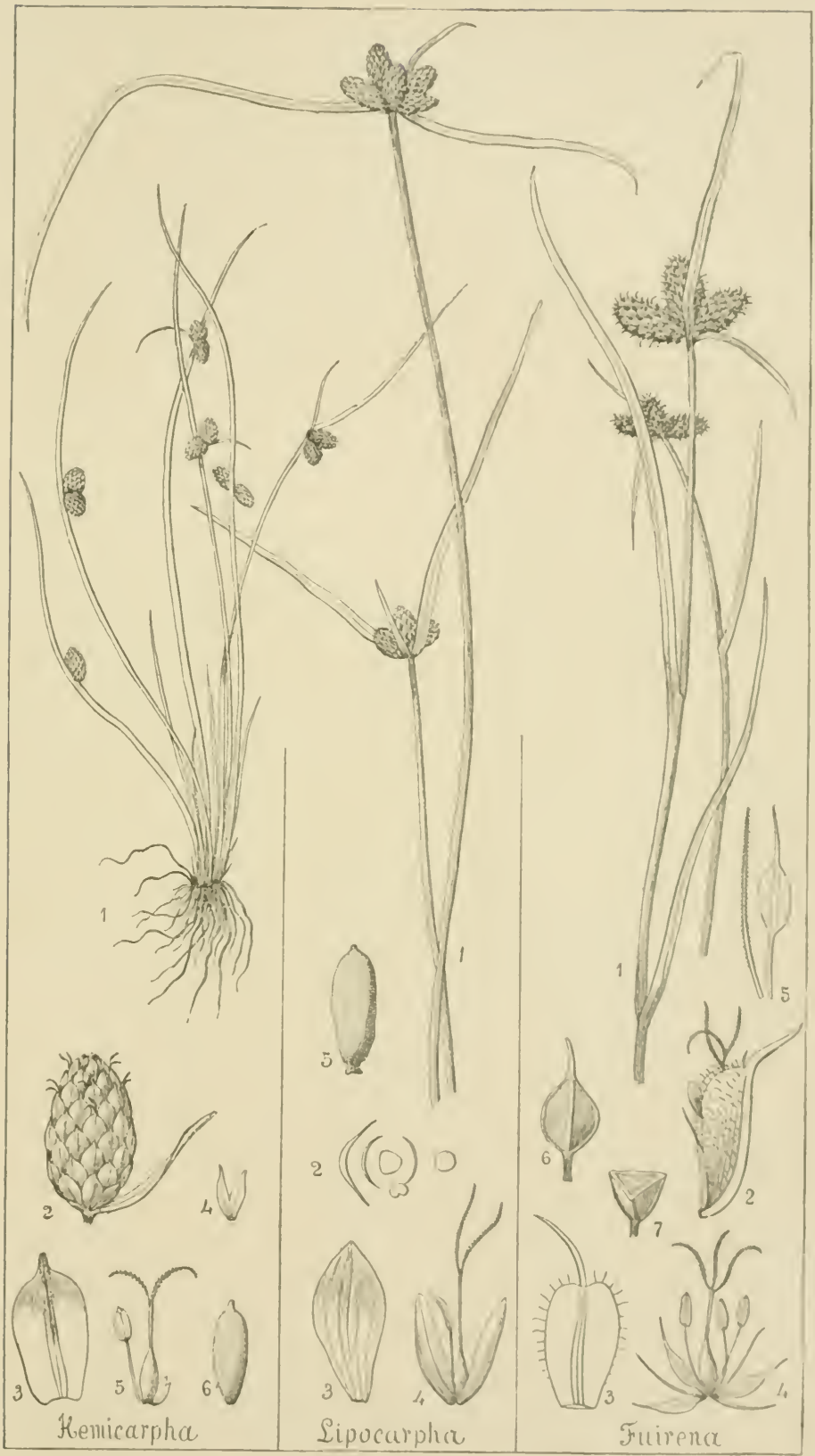




\section{EXPLANATION OF PLATE III.}

ELEOCIIARIS. - (1) Small plant of E. olivacea ; (2) the spikelet enlarged ; (3) detached scale; (4) flower; (5) achene and bristles. - (6) 1.. ymalrangulata, spikelet; ( 7 ) a scale; ( 8 ) flower; (9) achene and bristles. (10) E. tubereulosia the achene with its grat tulerele, and hristles.

SCIRPLS - (1) Summit of plant of small s. debilis; (2) a spikelet; (3) a scale of the same, and (4) flower; (5) achene with its bristles.

ERIOI'HOlit'M. - (1) Snall plant of E. alpinum, in flower; (2) spikelet; (3) a scale, aid (4) a flower from the same; (5) the spikelet, in fruit, the hristles forming a cottony tuft; (6) achene and its lristles. - (6, mnder scopus) a small portion of the inflorescence of E. cyperinum; ( $\bar{c}$ ) a flower; (\&) a spikelet in fruit; (9) achene from the same, with the tortuons bristles; (10) section of the achene.

FIMBRISTYLIS. - (1) - nummit of a small flowering stem of F. laxa: (2) a spikelet of the same; (3) a detached scale, aurl (4) a Hower of the sime; (5) achene. - F. antmmialis ; (6), a spikelet, enlarged ; ( 7 ) flower; (8) achene, and (9) section of the same. 

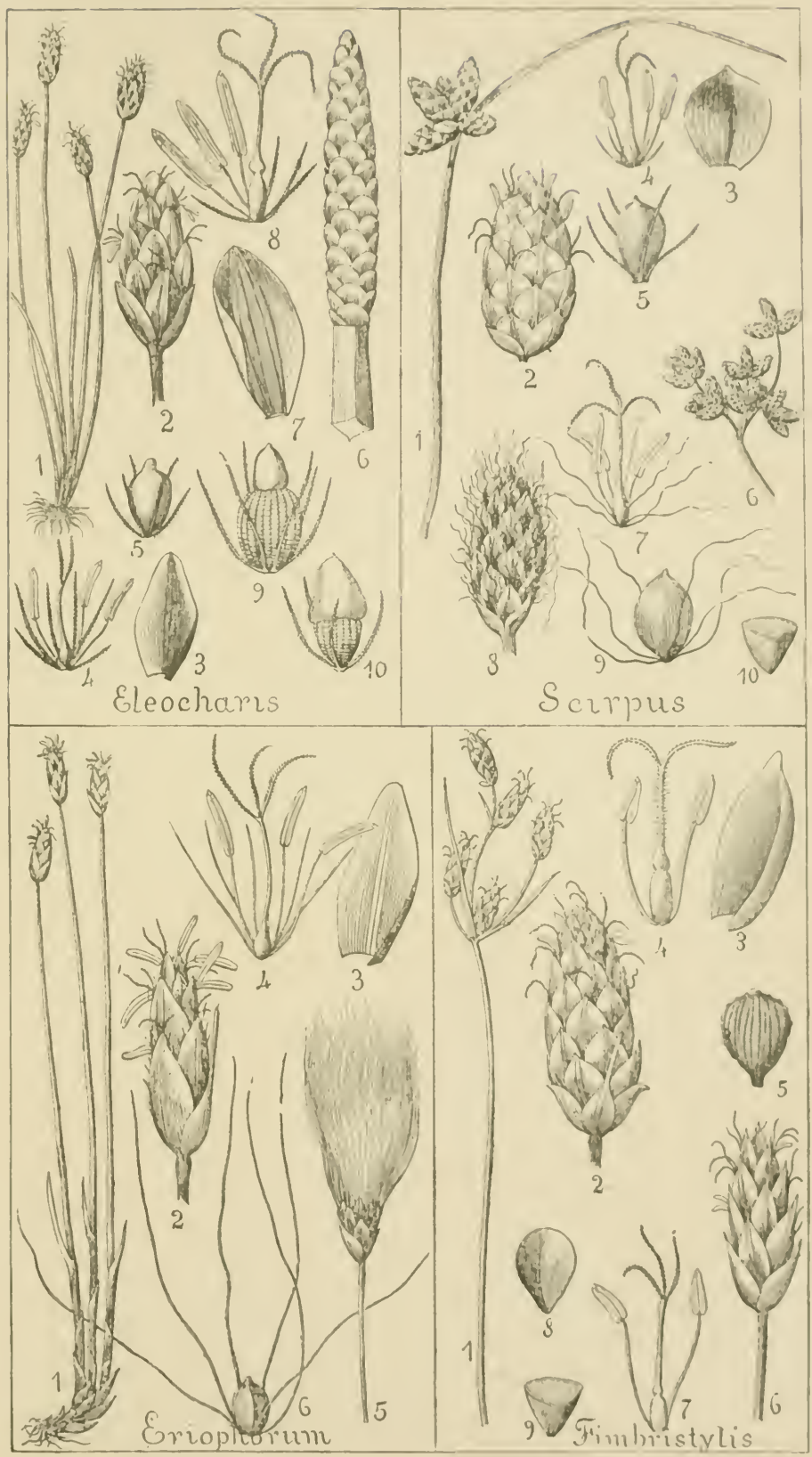


\section{EXPLANATION OF PLATE IV.}

DICHROMENA. - (1) Head and involucre of I). latifolia; (2) a seale from one of the spikelets, and (3) the same cut acruss; (4) a flower; (5) achene with its tubercle.

PSILOCARYA. - (1) Part of plant, (2) enlarged spikelet, (3) detached scale, (4) flower, and (5) achene with its beak, of P'. scirpoides.

RHYNCHOSPORA. - (1) Lpper part of flowering stem of R. Torreyana; (2) a spikelet; (3) detached flower; (4) achene, with short bristles at its base; (5) one of these bristles more magnified.

R. (\$ CERATOSCII(ENLS). - (1) Lpree part of fruiting plant, (2) detached spikelet, (3) flower, and (4) beaked achene, with its lristles, of $\mathrm{R}$. macrostachya. 
Беnета of Гурегесев

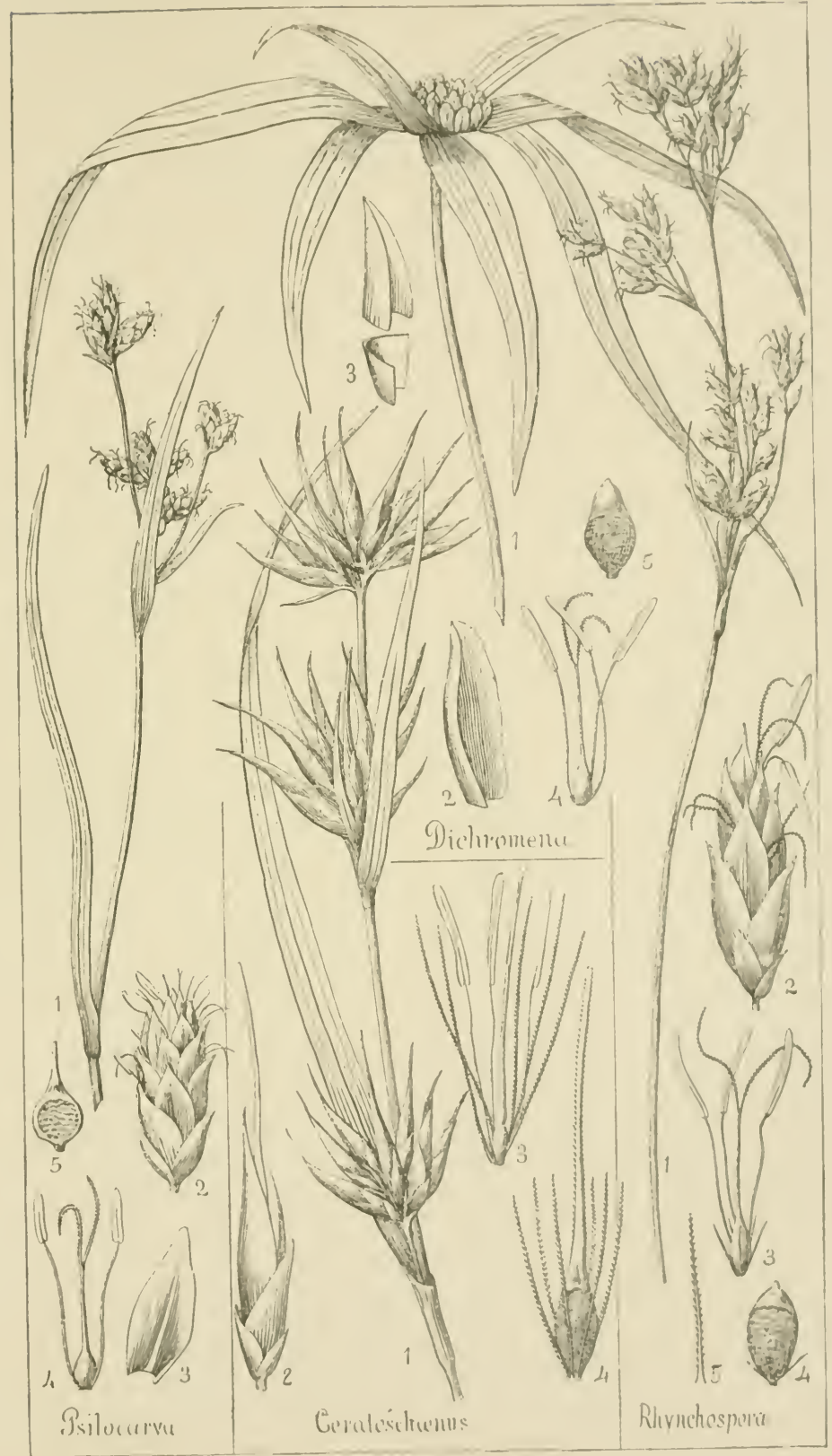




\section{EXPLANATION OF PLATE V.}

CLADILM. - (1) Summit of a plant of C. mariscoides; (2) detached spikelet; (3) same, open, showing a staminate and a perfect flower; (4) the nut-like achene, and (5) the longitudinal section of the same.

SCLERIA. - (6) Summit of a flowering stem of $\mathcal{S}$. reticularis; (7) three spikelets from a cluster, the middle one pistillate, the lateral ones staminate; (8) staminate spikelet displaying four male flower's, the filaments of two of them having lost their anthers; (9) pistillate spikelet displaying a single pistillate flower; (10) achene with the 3-lobed double cup underneatli.

CAREX. - (11) l'lant of C. pauciflora; (12) a staminate flower with its scale; (13) scale, and (14) mature pistillate Hower, in its perigynium; (15) cross-section of perigynium and of the contained achene; (16) achene on its stalk, style and stigmas. - (17) ('. Jaimesii, upper part of flowering plant; (18) the spike enlarged; (19) a staninate flower and its scale; (20) pistillate flower in its perigrnium; (21) the same with half the perigynium cut away to show the contained achene and style. 


\section{Gunera of Cyprotateg \\ Flate I}

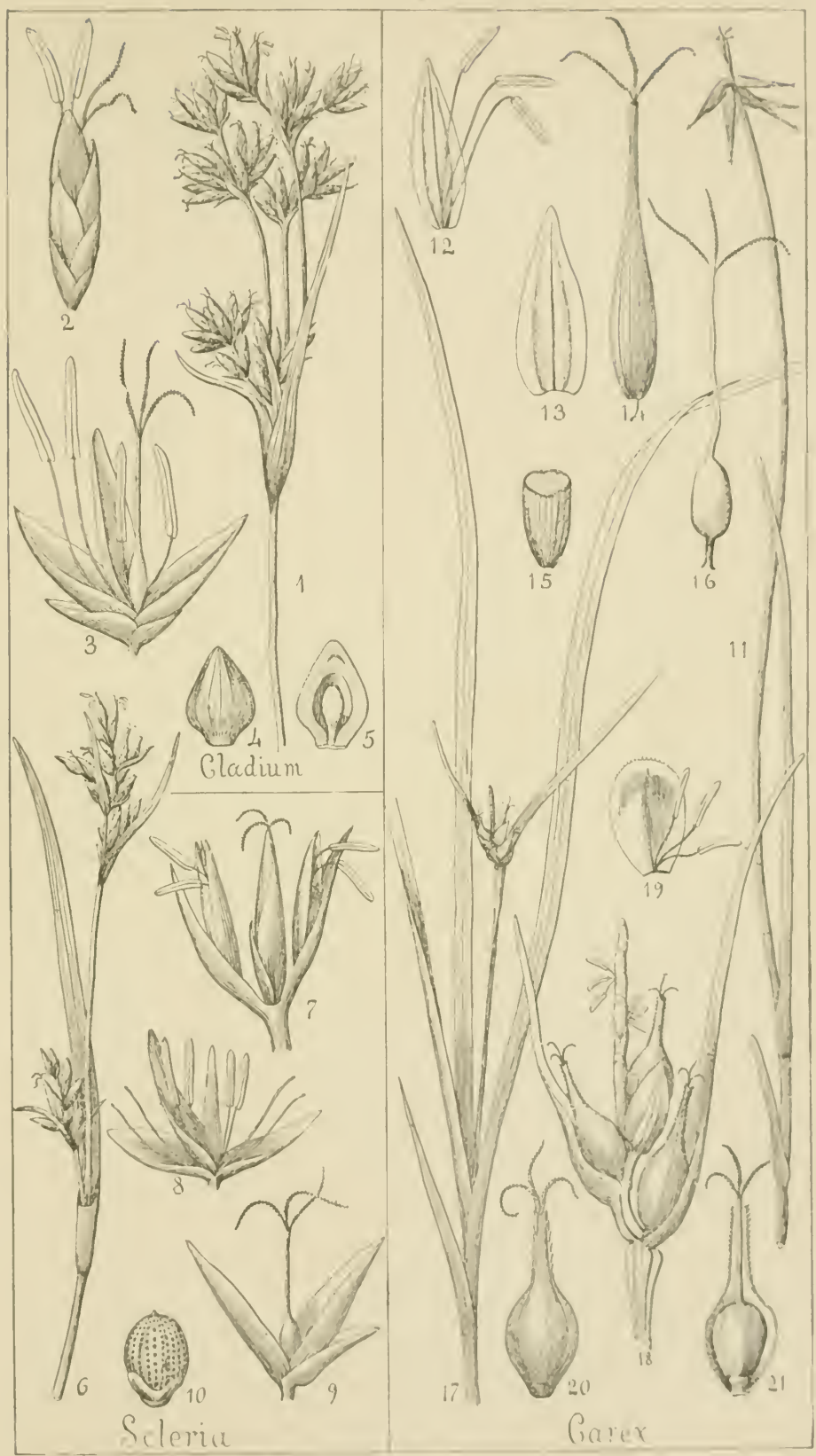




\section{EXPLAN.TTION OF PLATE VI.}

CAREX. - (1) C. trisperma, upper part of a stem in fruit; (2) enlarged spike displayed, with three staminate and two pistillate flowers; (3) a scale, and (4) a ripe perigrnium, of the latter ; with (5) a section of the perigynium near the base, and of the contained achene. - (6) C. straminea, var. brevior, summit of a fruiting plant; ( 7 ) a spike enlarged; (8) scale of a pistillate flower; (9) the winged perigynimm ant the contained achene cut acruss; (10) detacherl achene with persistent style and stigmas. - (11) C. umbellata, whole plant; (12) a perigrnium and its scale; (13) cross-section toward the hase of perigrnium and its contained achene; (14) detached achene with its persistent style and stigmas. - C. bullata; (15) upper part of plant in fruit, with one pistillate and two staminate spikes; (16) one of its staminate flowers with the scale; (17) a pistillate scale, and (18) mature perigrninm; (19) longitulinal section of the latter, showing the achene and its style, and (20) cross section of the same. 


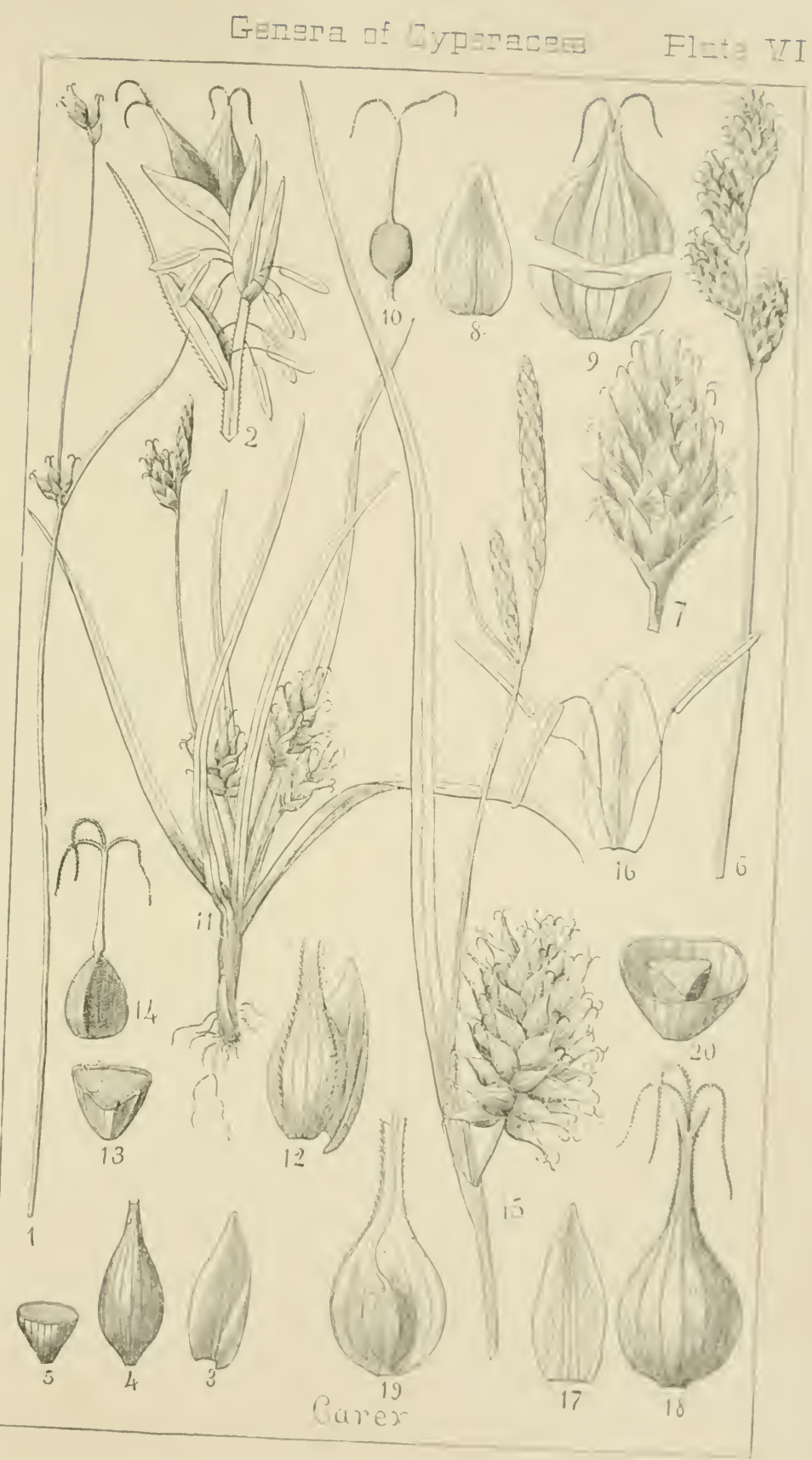




\section{EXPLANATION OF PIATE VII.}

LEERSIA. - (1) Panicle of I. oryzoiles, reduced in size; (2) a branchlet of the same, with its spikelets, of the natural size; and (3) an open spikelet in flower, enlarged.

ZIZANIA. - (1) A staminate, and (2) a pistillate flower or spikelet of $Z$. aquatica; (3) a magnified pistil with a pair of squamulie or hypogrnous scales; (4) a grain, and a magnified longitudinal section of the luwer part of the same, showing the embryo at the outside of the base of the albumen.

ALOPECLRLS. - (1) Part of a plant of A. geniculatus, in flower ; (2) a few spikelets from the spike-like inflorescence, moderately magnified; (3) an open spikelet in flower, more magnifierl, and (4) the single flowering glume detacherl.

PIILELI. - A detached spikelet of $\mathrm{P}$. pratense, having the flower with its glnme and palet raised above the empty glumes, magnified.

HELEOCIL(). 1. - (1) Inflorescence of II. schoenoides; (2) a separate enlarged spikelet; and (3) the same open, in flower.

SPOR(JBOLC: - (1) A spikelet of S. (ryptaudrus, magnified ; (2) the same, with the flower open, rased above the empty glumes; and (3) the fruit, more magnified, showing the seed louse in the periearp (utricle). - (t) In enlarged spikelet of E. raginaflora; and (5) the same displayed.

AGROSTTS. - (1) Panicle of 1 . alba, var. vulgaris, with (2) an enlarged open spikelet of the sime; alsi) (3) the rough perlicel and glumes of A. scalora, with the flower separated, the latter having no palet. 


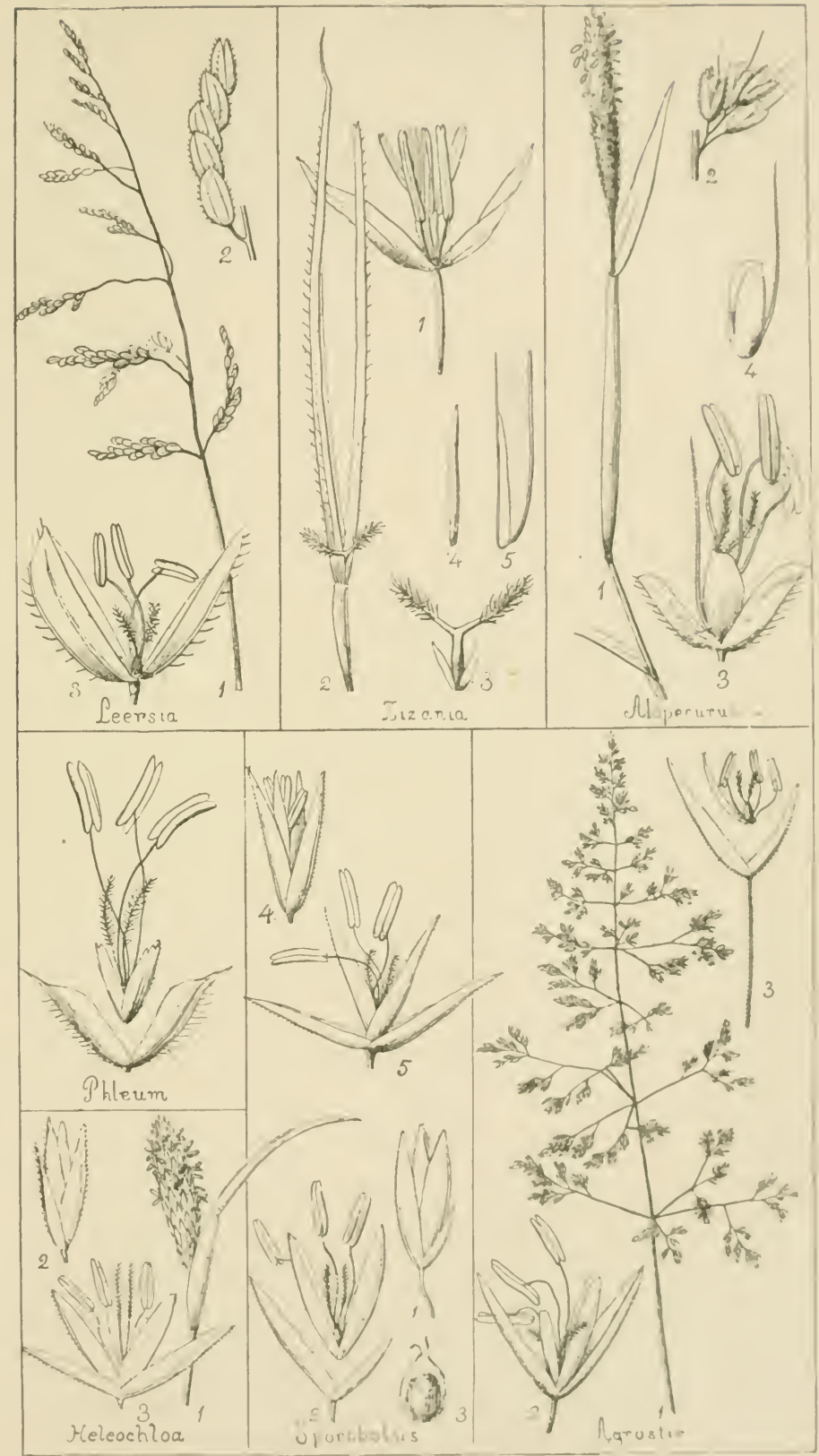




\section{EXPLANATION OF PLATE VIII.}

POLYPOGON. - (1) Spike-like contracted paniele of P'. Monspeliensis; (2) an enlarged detached spikelet, showing the long awns to the empty glumes; (3) the same open in flower; and (4) a separate flower without the empty glumes.

CINNA. - (1) I magnified spikelet of C. armelinacea; and (2) the same open, displaying the flowering glume and palet, the single stamen, and the pistil.

MUHLExBERGLA. - (1) A magnified roserl spikelet of M. syluatica; (2) the same with the open flower aniseal out of the empty glumes. - (3) A magnified spikelet of $\mathrm{M}$. diffusa ; $(4)$ its minnte and merpal empty glumes more magnified; and (5) an open spikelet of the sime.

BRACIIYELYTRLY. - (1) A spikelet of B. aristatum enlarged; (2) the same displayed.

CALAMAGROSTIS. - (1) An open spiketet of C. Canarlensis, enlarged, displaying all the parts; (2) the same with the flower raised ont of the empty glumes, showing the hairy moliment behind the palet:

ORYZOIPIS. - (1) Anopen magnified spikelet of (). asperifolia ; and (2) the flower of the same remorenl from the empty glumes. Notice the remarkahly long squamule or hypogynous scales, which here nearly equal the glume in length.

STIl'A. - Empty glumes and flower (a little separated) of S. avenacen, enlarged.

ARISTID. A. - A spikelet of A. purpurascens, enlarged. 


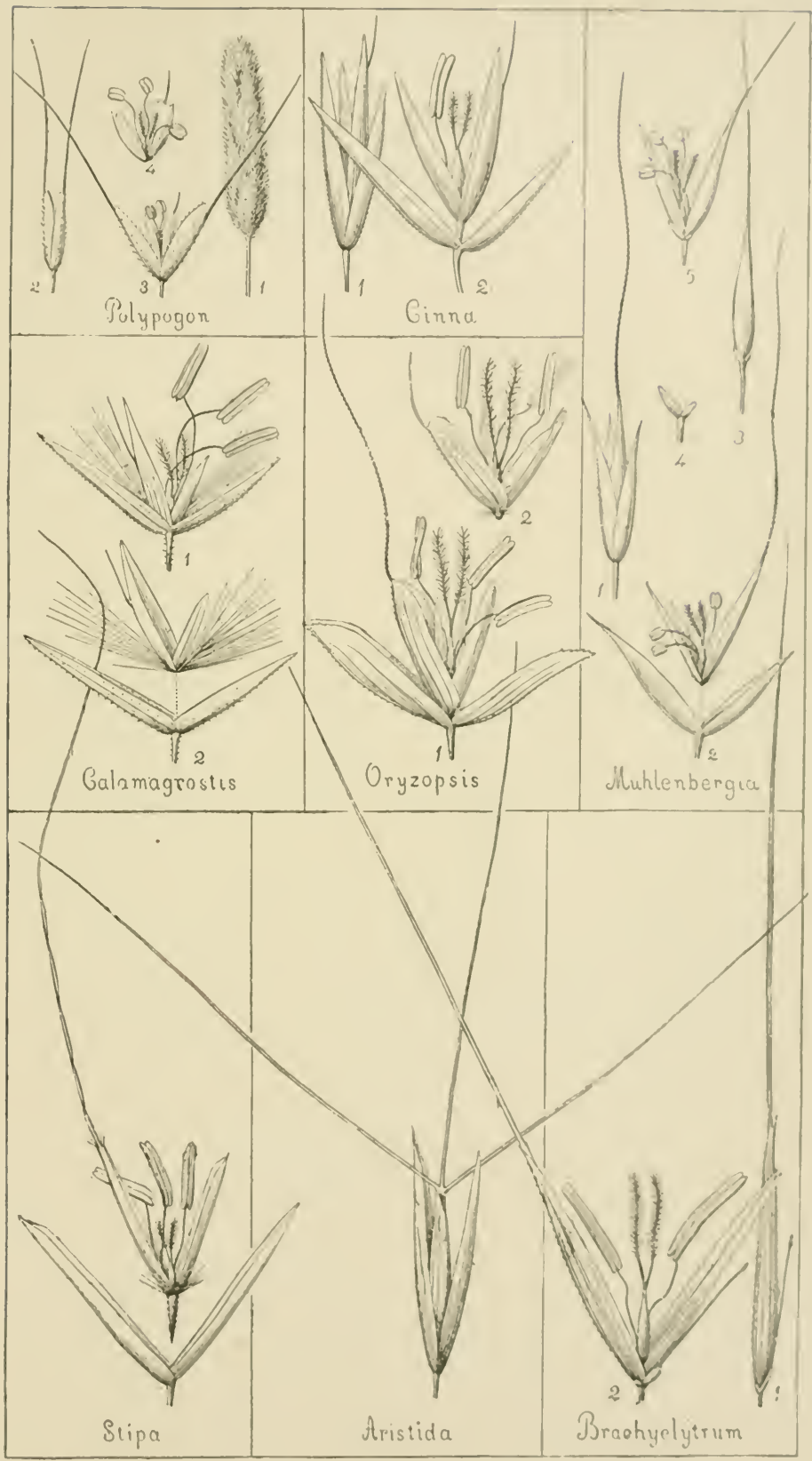




\section{EXPLANATION OF PLATE IX.}

SIARTINA. - (1) Portion of the inflorescence of $\mathbf{S}$. stricta, of the natural size; (2) a spikelet enlarged; and (3) the same displayed, the flower raised above the empty glumes.

CIEXILM. - (1) spike of ('. Americanum; (2) a single spikelet magnified; and (3) the same displayed, the empty glumes sepruated.

BOLTELOLA. - (1) A portion of the compound spike of B. racemosa, of the natural size; and (2) a spikelet displayed and magnified, the flowers raised out of the empty ghumes.

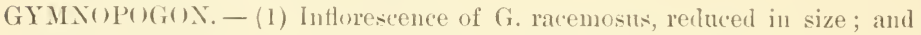
(2) a magnified spikelet with the parts displayed.

CYN(1)(1) - (1) Inflorescence of ('. 1)actylon, of digitate spikes; (2) a spikelet magnified and displayed, showing a perfert flower and a rudinent.

ELELSINE. - (1) ()ne of the spikes from the digitate inflorescence of $\mathrm{E}$. Indica; (2) a magnified spikelet; (3) the same with the fowers more displayed; (4) a flower from the last, showing its parts; (5) the fruit magnified, showing the seed lose in the ntricle; and (6) the wrinkled seed detached. - $(1$, under Inotylocteninm) Influrescence of E. Egrptiaca, of ligitate spikes: (2) one of the spikelets magnified; (3) the fruit magnified, showing the seed loose in the thin pericarp (utricle); and (4) the wrinkled seed more magnified.

DIlLACIIXE. - (1) Small portion of the inflorescence of D). fascicularis; (2) one of its spikelets displayed and magnified; (3) an open flower of the same. 


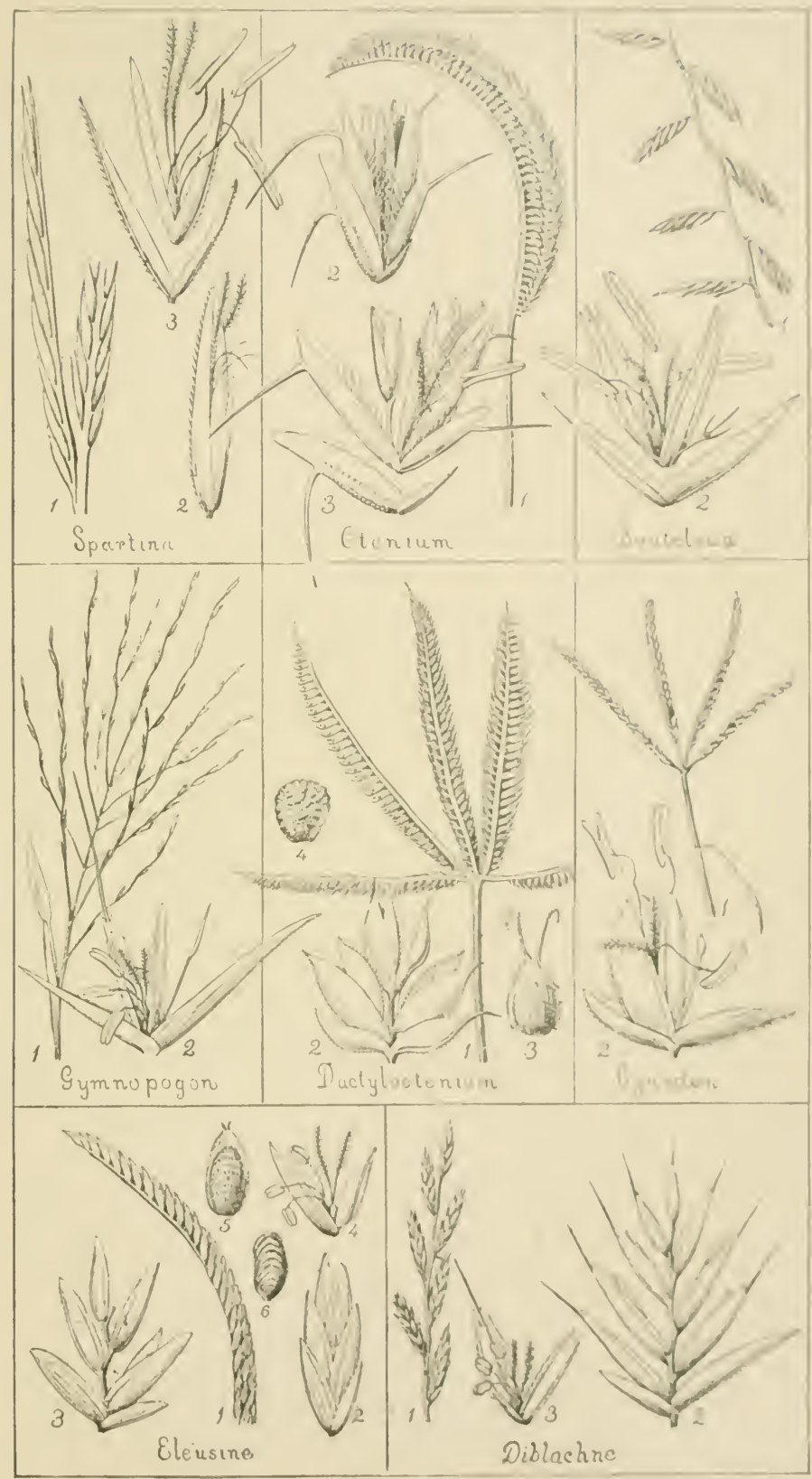




\section{EXPLANATION OF PLATE X.}

TR [()I)]A. - (1) Magnified spikolet of T. seslerioides; (2) the same displayed and the lowest flower open; (3) hack view of the flowering glmme spreat ont.

GRAPHEPHORLM. - (1) A magnified spikelet of (i. melicoides, displayed; (2) a part of the hairy rhachis and one flower of the same.

DIARlilENA. - (1) A spikelet of I). Americana, enlarged; (-2) the grain in its glmme and palet.

D.ACTYLIS. - 1 spikelet of I), glomerata magnified and displayed.

KiELERLA. - (1) A magnified spikelet of K. cristata, expanderl, slowing the empty glumes, the three flowers, and a ruliment; (2) Jower half of a flowering glume, partly spread open; it is much more folderl and keeled in its natural comdition.

EAT(NIA. - I magnifiel spikelet of E. olutnsata, expanded, showing the empty glumes, the two flewers, and a rulinesit.

MEICA. - I magnifie l spikelet of M. mutiea, expanded, showing the empty glumes, two perfect flowers, and an alontive one.

GLYCLIRL.— (1) I magnitiel spikelet of G. nervata: (2) a separate flower with one joint of the rhachis: and (3) the lower half of a flowering glume, showing its form (romuled on the lark, not keeled).

I)INTI('lL1s. - (1) I pistillate spikelet of 1). maritima, enlarged; (2) a flower from the same; and (3) a finwer from a staminate spikelet.

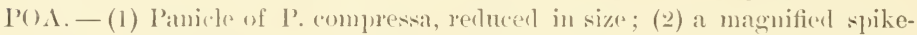
let; (3) a scratate flower more magnifies; (4) a flowering glume cut across and somewhat omtspread.

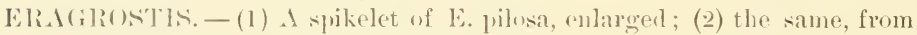
which the glumes and all of six lower flowers except the palets have fallen away; ; (3) a matgnified flower, ofen; (4) the flowering glume of the same ontsprearl.

BIIZA. - (1) A spikelet of B. media, enlarged; (2) a separate flower.

FESTLCA. - (1) I spikelet of I. elatior, (nularged; (2) a separate flower; (3) lower part of a Howering glume, ontspread.

BRo.lIS- (1) A spikelet of B. secalinns, or ('hess; and (2) a scparate flower, enlarged. 


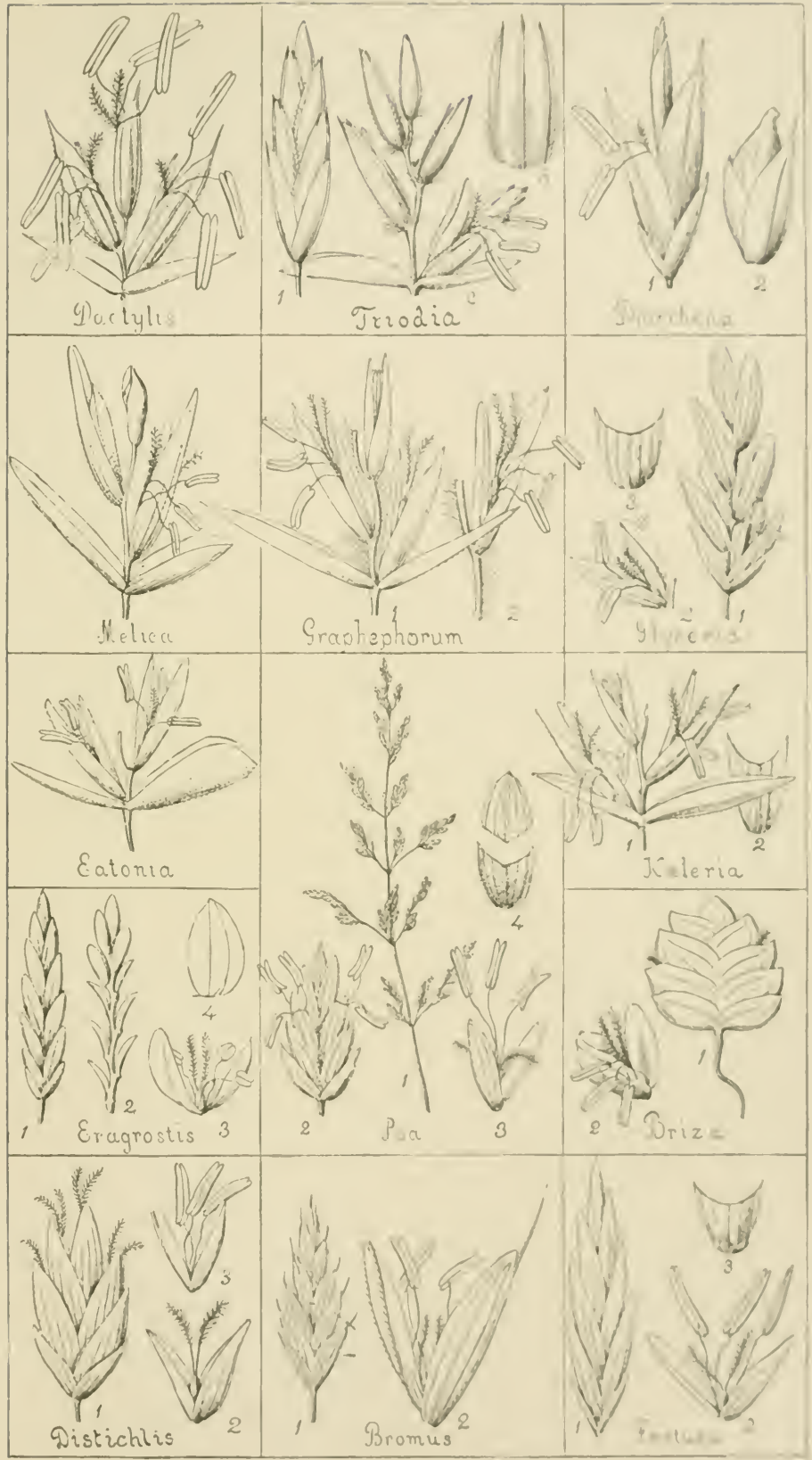




\section{EXPLANATION OF PLATE XI.}

[NIOLA. - (1) A spikelet of 1 . latifolia, of alout the natura] size; (2) a flower, enlatred; (3) empty flowering glime of the lowest (sterile) flower.

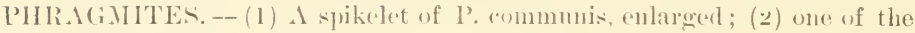
perfect flowers, enlarged; and (3) the lowest flower, which has stamens only.

ARI'TISAARIA. - (1) A spikelet of A. maerosperma; and (2) a separate flower, magnifiel.

S(IIEI)(NXARI)LS. - (1) Portion of the spike of S. Texamu, enlarged; and (2) a flower, mannified.

L()LiEM. - (1) Portion of the spike of L. temulentum; and (2) a separate Hower, magnifiert.

AGRoPYRTM. - (1) Portion of the spike of A. repens, or Conch-(irass, of about the natural size; (2) a flower, magnified.

HORISELM. - (1) The three one-flowered spikelets from one joint of the spike of H. jubatum, with their awn-like empty glumes, the lateral flowers abortive and nentral, the middle one alone perfect; (2) this perfeet flower (with an awn-like rudiment) open and enlargerl.

ELYMIS. - (I) The two spikelets of one joint of the spike of E. Virginicus, about the natural size ; $(2)$ the empty glumes and the flowers of one spikelet, enlarged and displayed; and (3) an open flower, more magnified.

GYMNOSTICHCM. - (1) A spikelet of G. IIystrix; and (2) an expanded flower, magnified.

ASPRELLA. - (1) A spikelet of A. Hỵstrix; and (2) an expanded flower, magnified. 


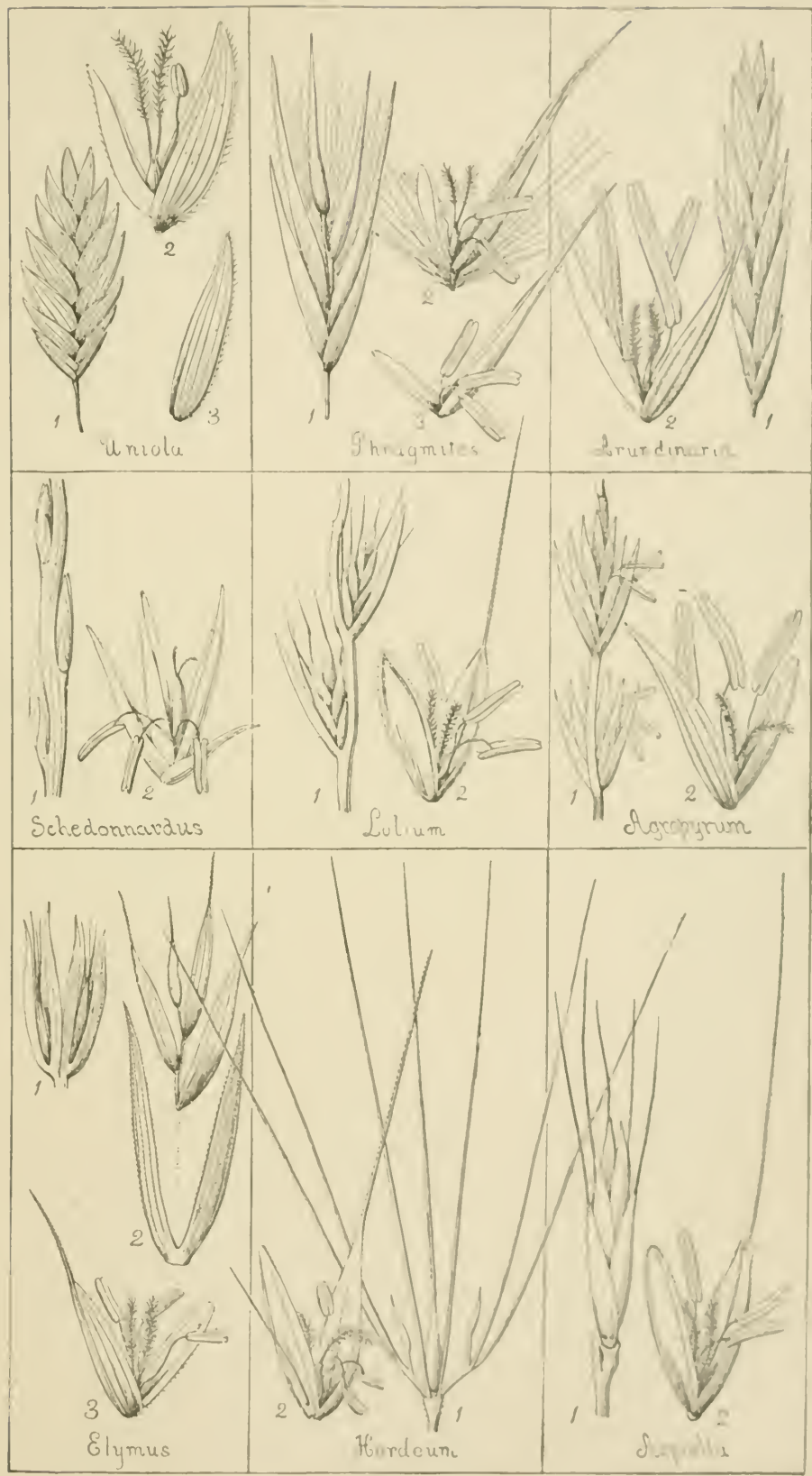




\section{EXPLANATION OF PLATE XII.}

DESCH.LIPSIA. - (1) Panicle of I). flexuosa ; (2) a spikelet, meguified, the parts displayed; and (3) one of the flowers detached and open.

DANTII)NLA. - (1) P'micle of 1). spicata; (2) a spikelet enlarged; and (3) a separate flower from the sime.

TRISETL II. - (1) A spikelet of T. subspicatum, var. molle, expauded and magnified; and (2) a separate open flower.

AVENA. - (1) A spikelet of A. striata, displayed and magnified; and () a separate flower.

ARRHENATIERTM. - $A$ spikelet of $\Lambda$. avenaceum, displayed and magnified; (1) the empty glumes; (2) the flowers, the lower one staninate only, the next perfect, and the third a rudiment.

HOLCLS. - (1) A spikelet of H. lanatus, magnified; (2) the same displayed to show the two flowers, the lower perfect and awuless, the upjer staminate aud awned. 
Ganenta of Grazses Flat Y.TI

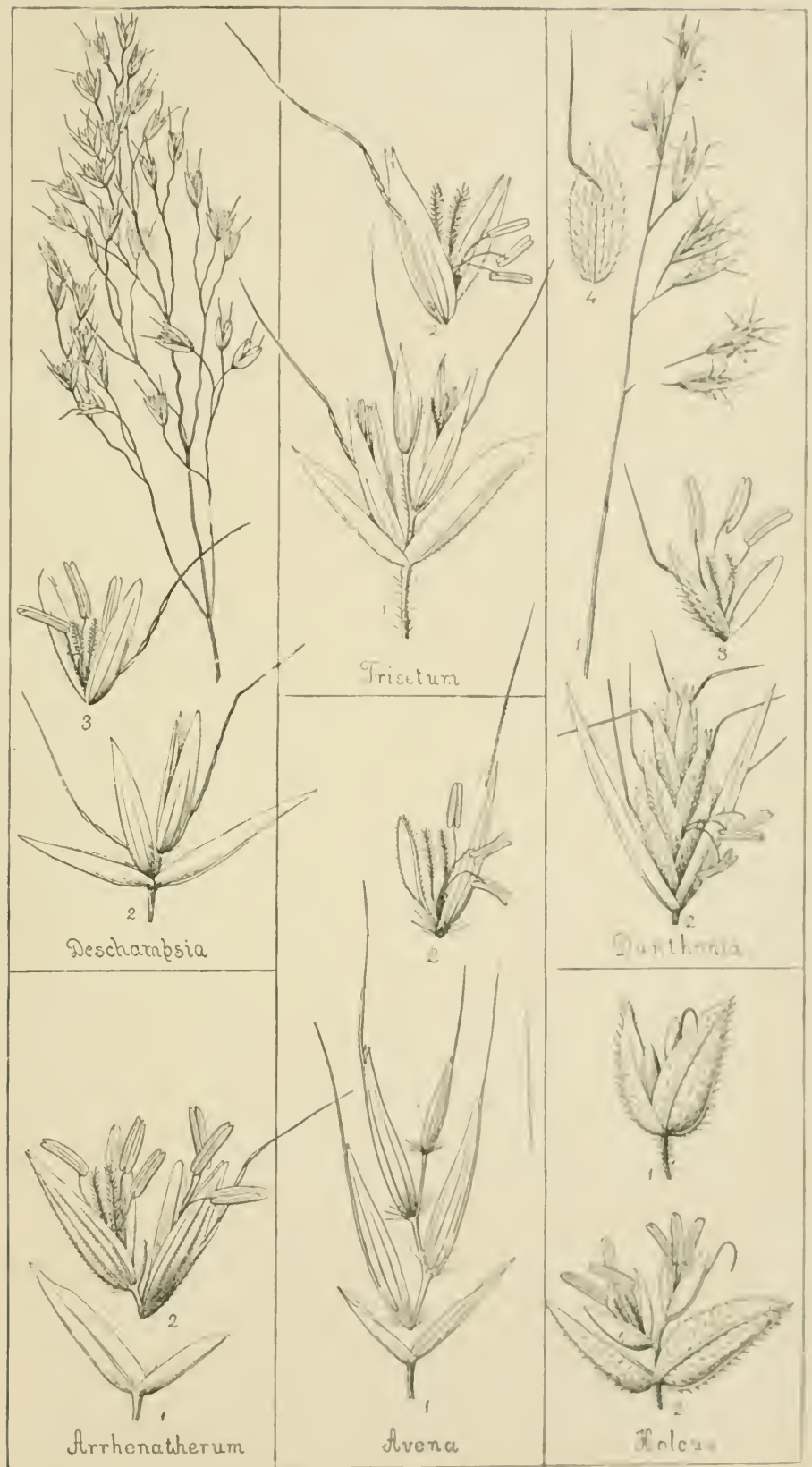




\section{EXPLANATION OF PLATE XII.}

HIER()CHL()A. - (1) A spikelet of II. lorealis, enlarged; (2) the same displayed, the flowers separated from the empty glumes, the two lateral ones with 3 stamens and no pistil, the midlle or terminal one with a pistil and ouly 2 stamens.

ANTHOXANTHLM.-(1) The spike-like infloresence of $\mathrm{A}$. orloratum; (2) a sprikelet magnified; (3) another with the parts displayed, the flowers raised from the lower empty glmues. the lateral glumes empty and awned, the terminal flower jerfect aus diandrons.

PIALARIs. - (1) A spikelet of l'. armulinacea, enlarged, (2) the emuty glumes, and a perfect flower with a hairy ruliment on each sile of it.

MILILII. - (1) l'ortion of the panjele of II. effusmm; (-2) a closecl spikelet, magnified; and (3) the same displayerl.

AMPIICARPLM. - (1) A spikelet from the panicle of A. Purshii, magnified; (2) the same, with the parts displayed; and (3) a radical (fertile) spikelet, enlargerl.

I'ASPALLYI. - (1) Infleresence of P'. live; (2) a clused spikelet, enlarged ; (3) the same with the parts displaty

PANICIII. - (1) I'art of a spike of I'. samguinale; (2) one of its spikelets, magnified; (3) the same with its parts displayed, the thres lower ghunes empty - (4) A s prikelet of l'. eapillatre, magnified; (5) the sime displayed, the three lower glumes empty. - (6) A spikelet of l'. clandestinum, masnified; (7) the same displayed, the lower flower represented by a glume and palet only. - ( 8 ) A sprikelet of l'. virgatnm, magnified; (9) the same displayed, the lower Hower staminate.

SETAlilA. - (1) A magnified spikelet of \&. glanca, with the acempanying chuster of bristles; (2) the spikelet displayed, showing the nentral lower flower, of a glume and palet only, and the perfect flower. 


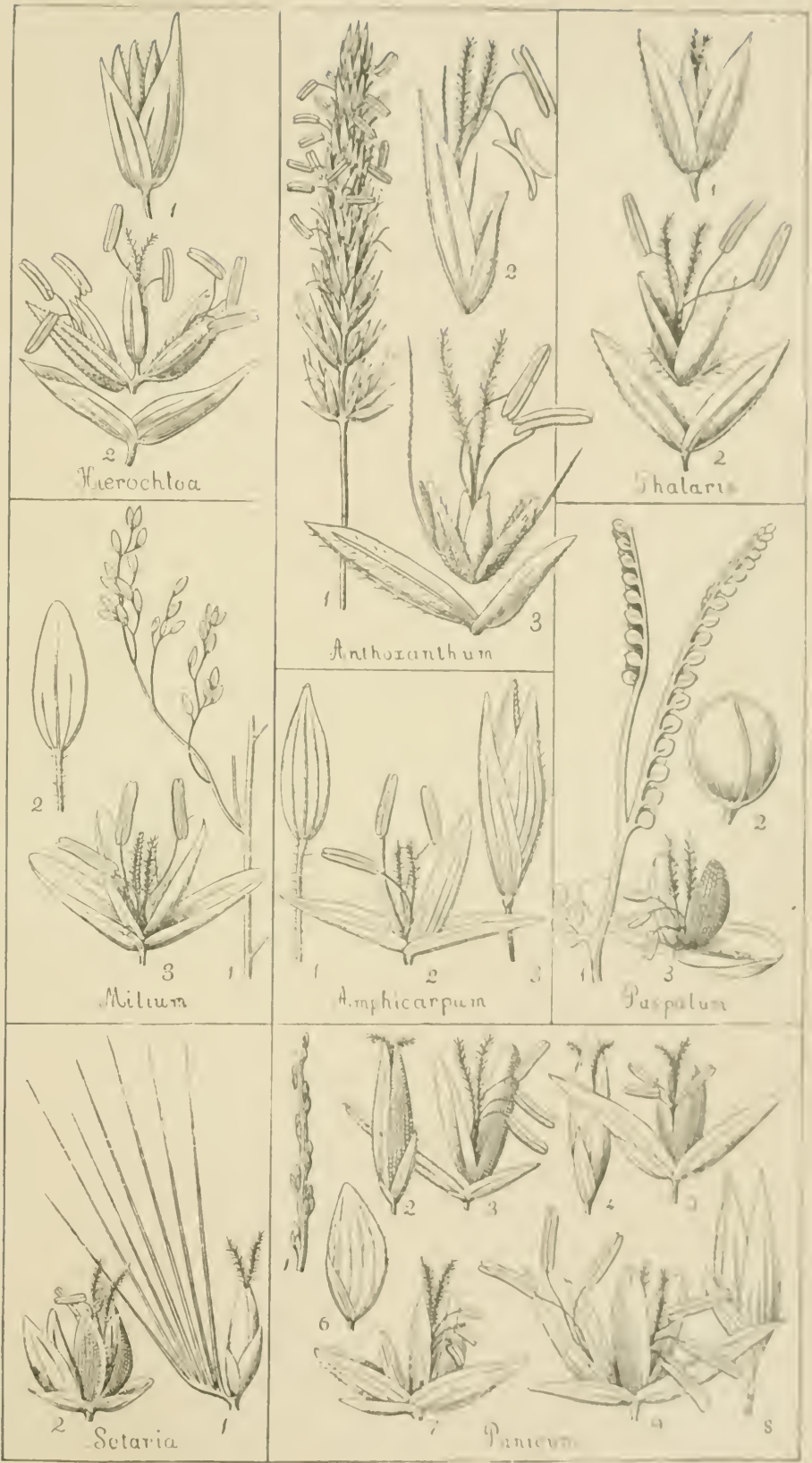




\section{EXPLAN ITION OF PLATE XIV.}

CExCHRTs. - (1) Involuere of ('. tribuloides, in flower, erilurged; (2) longitmlinal section of the sime; $(3 ;$ a spilselet displayed (the stignats should helong to the right-hanel flower ; the left-hand or lower thower is only staninate).

Thil SAC'T M. - (1) I'iece of the spike (of the natural size), pistillate below, staninate above; (2) a longitudinal section of one of the pistillate spikelets; (3) a pistillate spikelet with its parts lisplayed; $(t)$ a staminate (two-flowered) spikelet, with its parts displancel.

ERIANPHI:- (1) l'art of the hairy infloresecence with two spikelets of $\mathrm{E}$. salchlatroides, emlargeal; (2) one of the spiliclets displing (4.t.

ANI)R()P()(i()X. - (1) Sunall portion of the spike of $\mathrm{A}$. fureatus, enlarged, with one fertile and awned spikelet, ambl one staminate and aws less spikelet; (2) the fertile spikelet, and (3) the staminate spikelet, displayed.

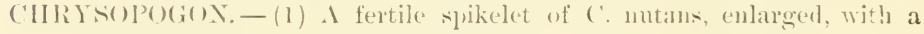
sterile pelicel on each side; (2) the spikelet displayed. 


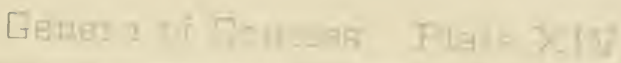

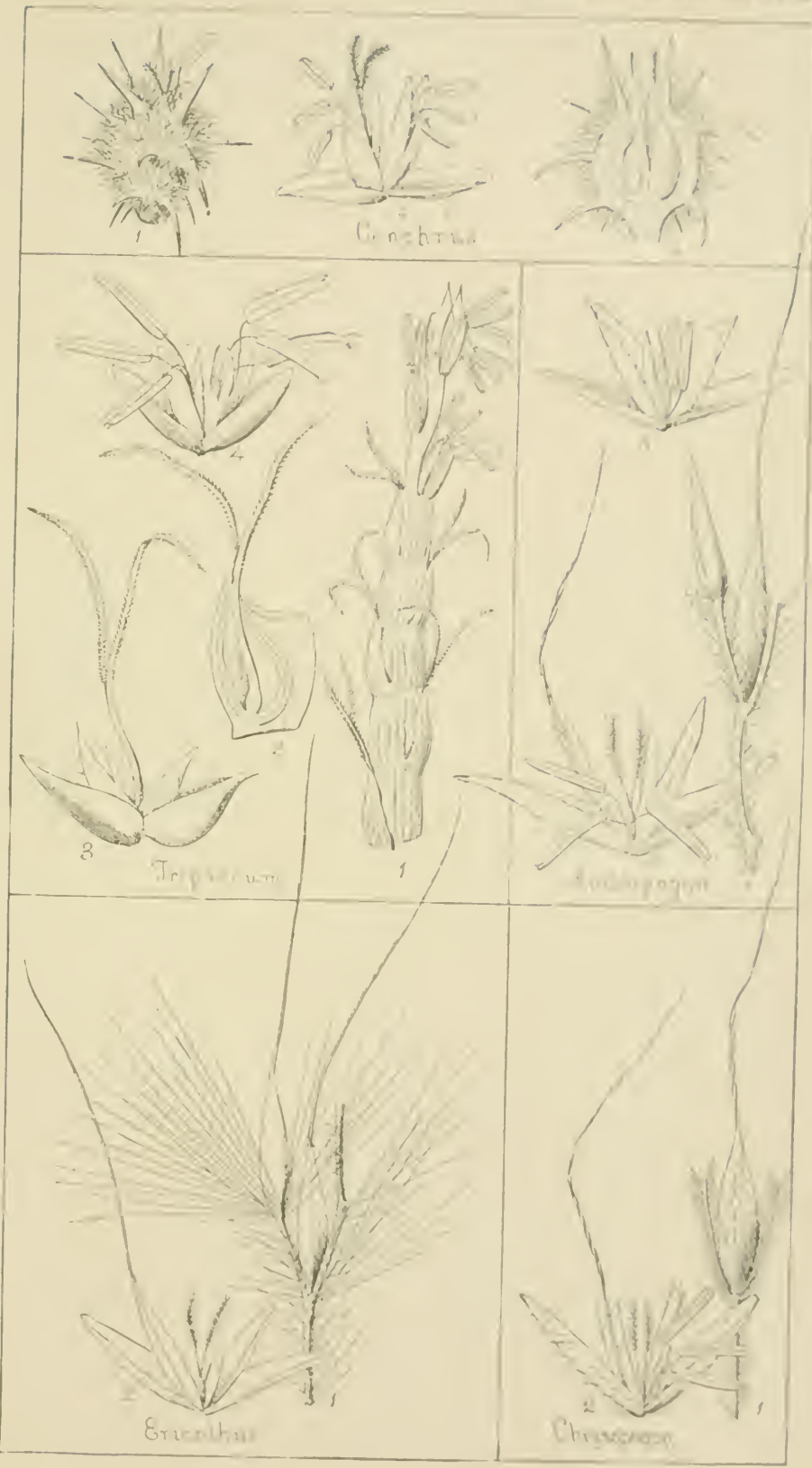




\section{EXPLANATION OF PLATY XT.}

BECKMLANIA. - (1) Inflorescence of B. erncaformis, var., retucel in size; (2) a spike, enlarged; (3) à spikelet, and (t) the sime opened; (5) the flower.

EliIo(HI, (3.1. - (1) Inthoresence of E. polystalcha, reduced; (2) a spikelet, emlarged, and (3) the sane opened; $(+)$ the flower opened.

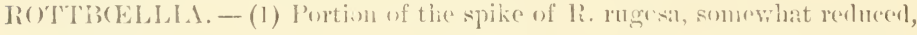
and (2) a prition conlaresenl, with (:3) the fortile spikelet and (4) the perlicolled sterile spikelet of tire midnle joint displaced; (5j the fertile spikelet opened; (i) the thiril (mupty glume, aind (i) the flower.

A.MII)I'IIL.L. - (1) Infloresenee of 1 . armelinarea, reduced; (2) a spikelet, enlirged, and (3) the Hower, with a hairy ruliment at the hase of the palet.

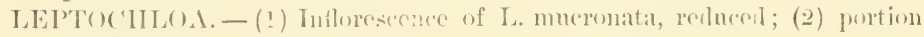
of rhachis of a spike, hearing [wo sprikedets; (3) a :3-flowered spikelet; and (4) a flower removed.

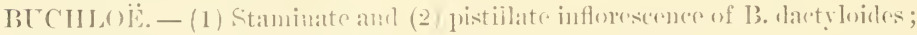
(3) a staminate spikelet, and (4) one of its flowers removel ; (5) a jistil late spikelet, enlarged; (6) vertical section of same; and (7) the outer compty glume remorerl.

MINROA.- (1) Infloresence of N. squarrosa; (2) a spikelet, enlargerl; and (3) a flower, openerl.

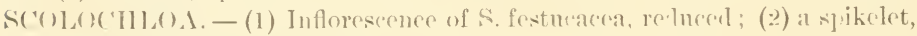
enlarged ; and (3) a flower.

PICCINELILI. - (1) Infloresenee of P'. maritima, reeluces ; (2) a spikelet, erlinered; and (3) a f́lower. 


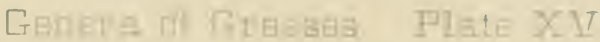

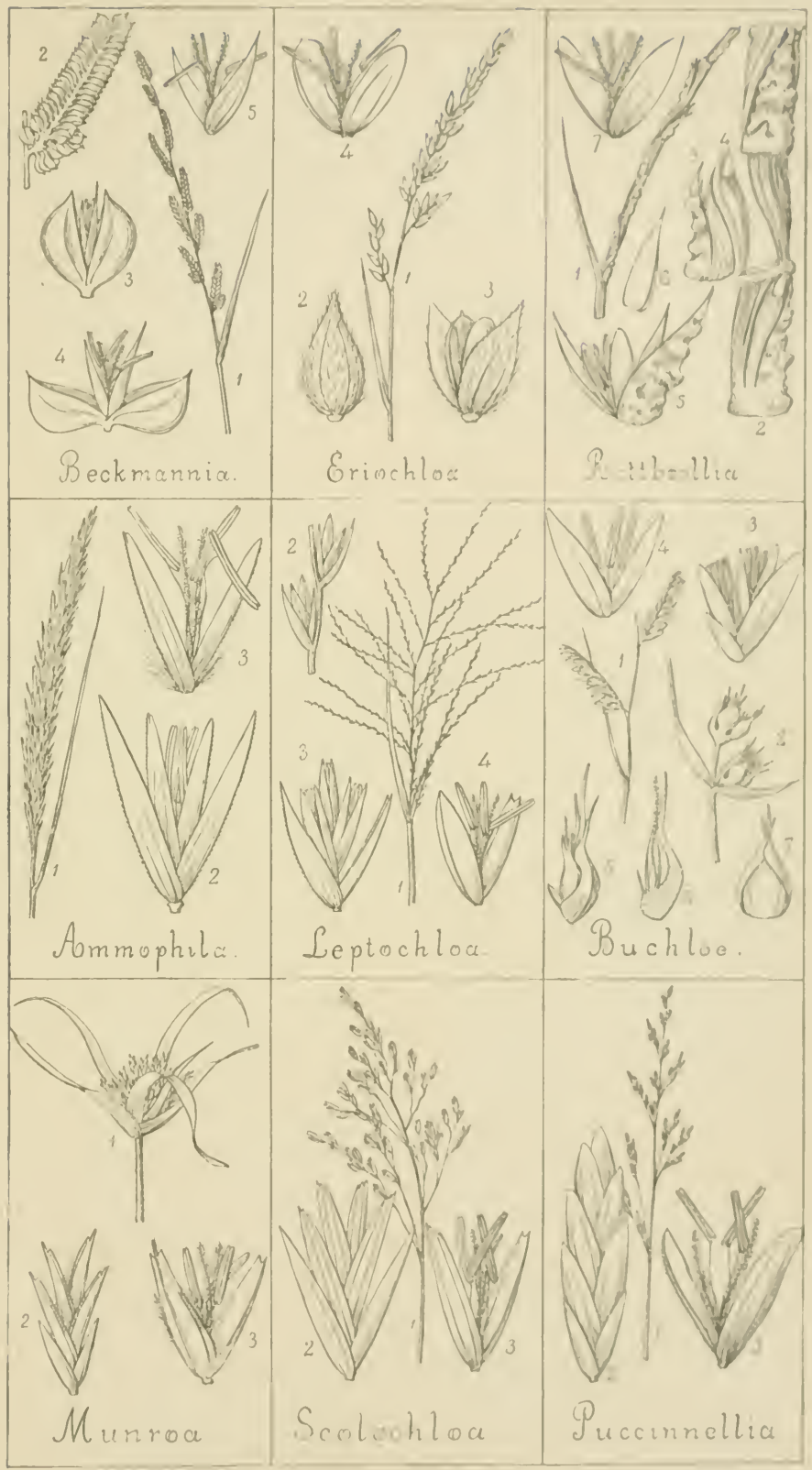




\section{EXPLANATION OF PLATE XVI.}

POLYP(ODIUM. - P'lant of P'. vulgare; piece of the frond; a magnified sporangium with its stalk, and anoth $\mathrm{r}$ bursting and discharging spores.

ONO('LEA. - (1) Pinna of the sterile fromd of (1. Struthiopteris; (2) portion of a fertile frond; (3) a piece of one pinma cut off to show the manner in which it is rolled nl'; and (4) a portion of the last, magnified, with one side nurolled; toward the hase the spromgia all removed, to show how the fruit-dots are borne each on the middle of a rein.

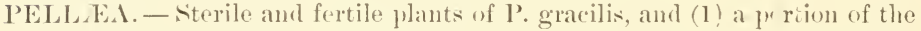
fertile frond enlarged, with a piece of the marginal indusinm turned back to display the fruit; the sporangia are all removed from the fruit-hearing tips of the two forks of the lower rein. 


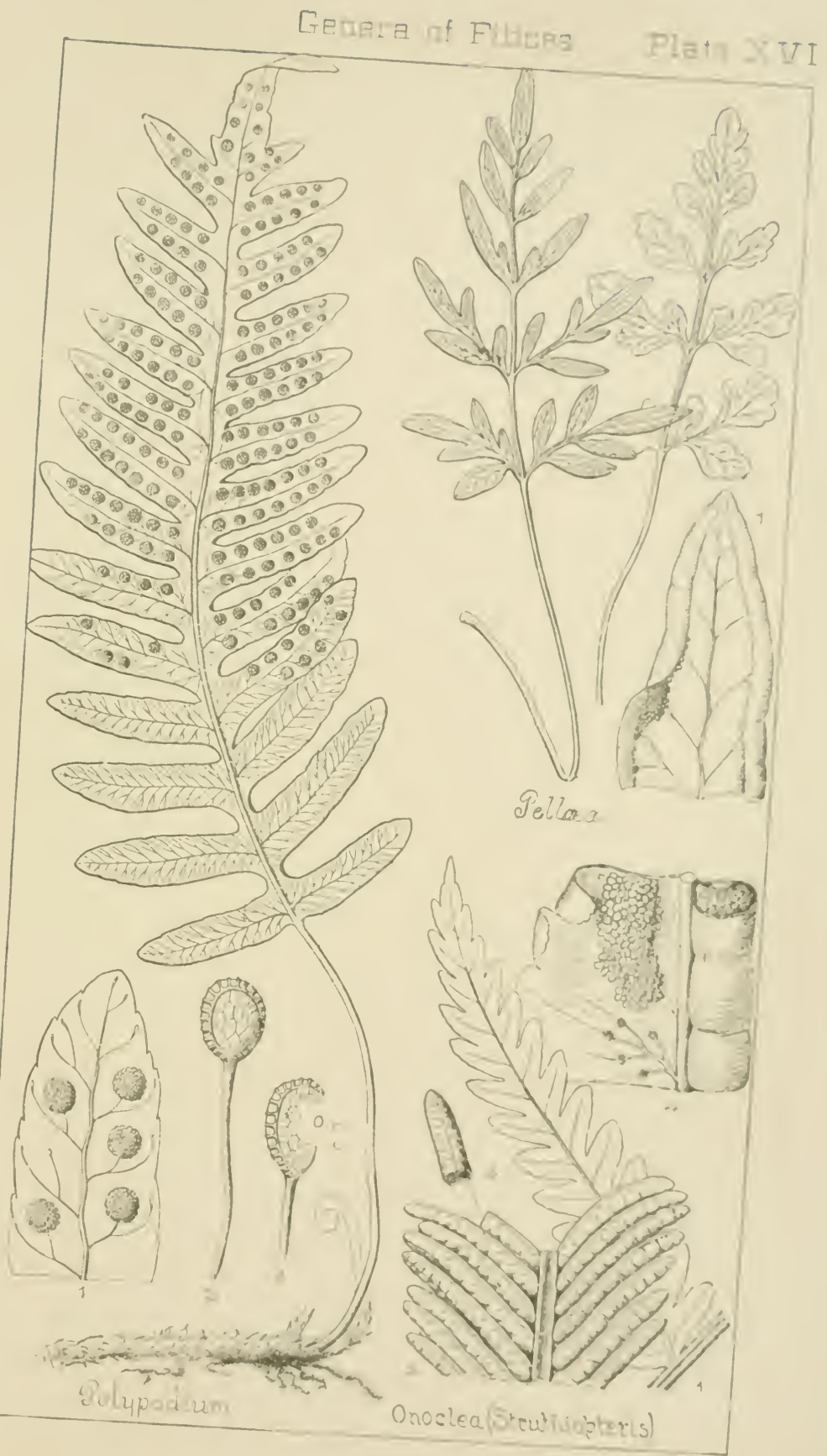




\section{EXPLANATION OF PLATE XVII.}

P'TERIS. - A pinnule of $\mathrm{I}^{\prime}$. aquilina, and (2) a piece of one of the lobes, enlargerl, the marginal indusium rolled back on one side, displaying the fruit; the sporangia all remored from the lower part to show the receptacle that bears them, viz. a cross-line connecting the tips of the reins.

ADIANTIM. - (1) I'iece of the frond of $A$. pedatum; (2) a pinnule somewhat enlarged; and (3) a piece of one more enlargerl, with the indnsium of one fruit-dot turned back to show the attachment of the fruit.

CIIEILANTHES. - (1) sinall plant of C. vestita ; and (2) a fruit-hearing pinnule, enlarged.

WO(1)WARDIA. - (1) Portion of the sterile and (2) of the fertile frond of IV. angustifolia; (3) a piece of the latter, enlarged; (4) piece of the frond of IV. Virginica; aurl (5) part of a fruiting lobe, enlarged. 
Ganeme of Fllnes Plate XVII

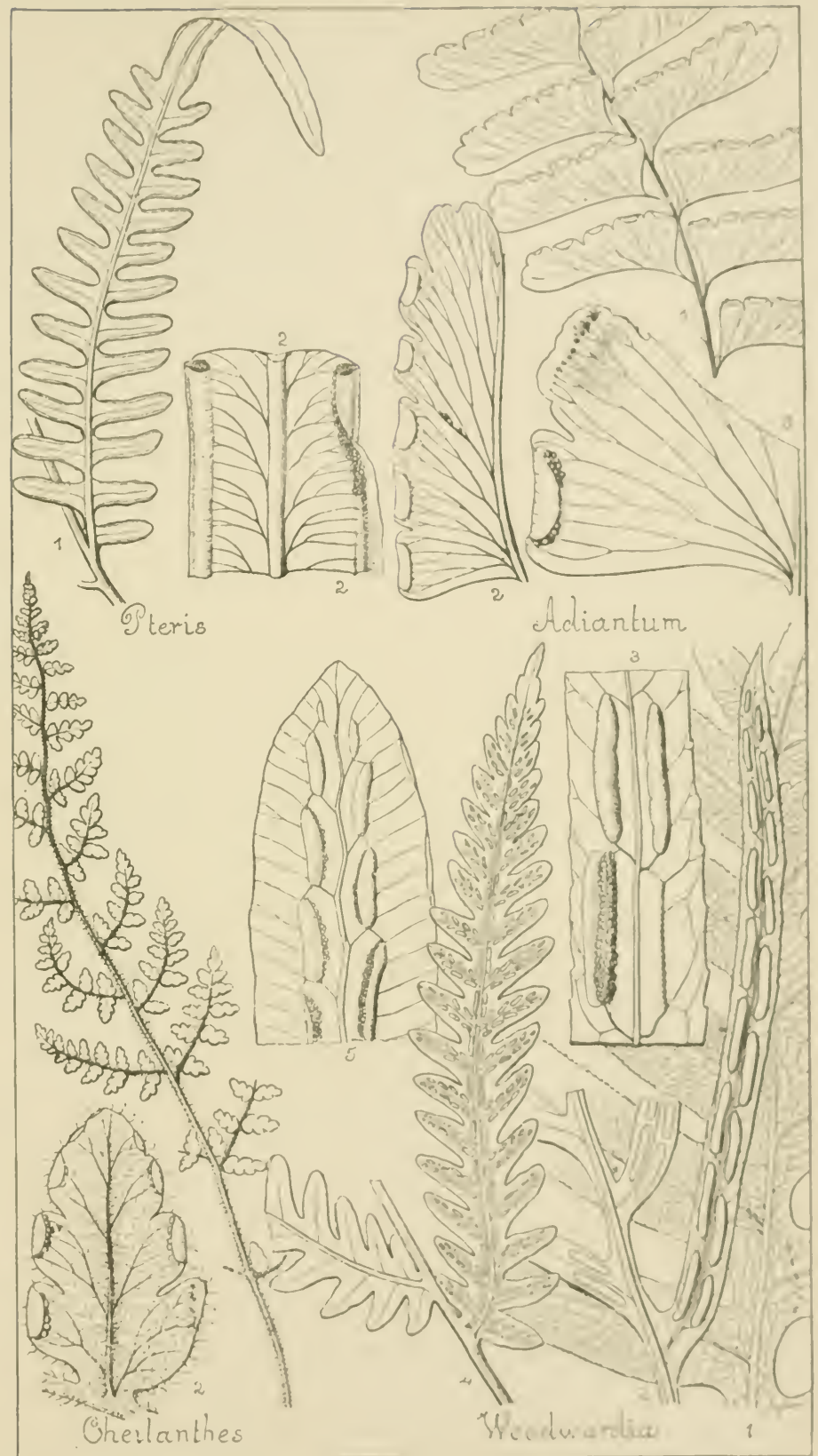




\section{EXPLANATION OF PLATE XVIII.}

CAMPTOSORLS. - Plant of C. rhizophyllus, and (1) a portion of a frond, with fruit-dots, enlarged.

SCOLOPENDRILM. - Tip of a fertile frond of S. vulgare; and (2) a piece enlarged, with two fruit-rlots.

ASPLENIL M. - (1) A pima of $\Lambda$. thelypteroides; and (2) part of a lobe in fruit, enlarged.

DICKSONLA. - (1) I'imma of I). pilosinscula ; (2) portion of a pinnte, enlarged; and (3) a fruit dot in its ('mp-shaped indusinm. 
Gamera of Fliges Flate XVItI

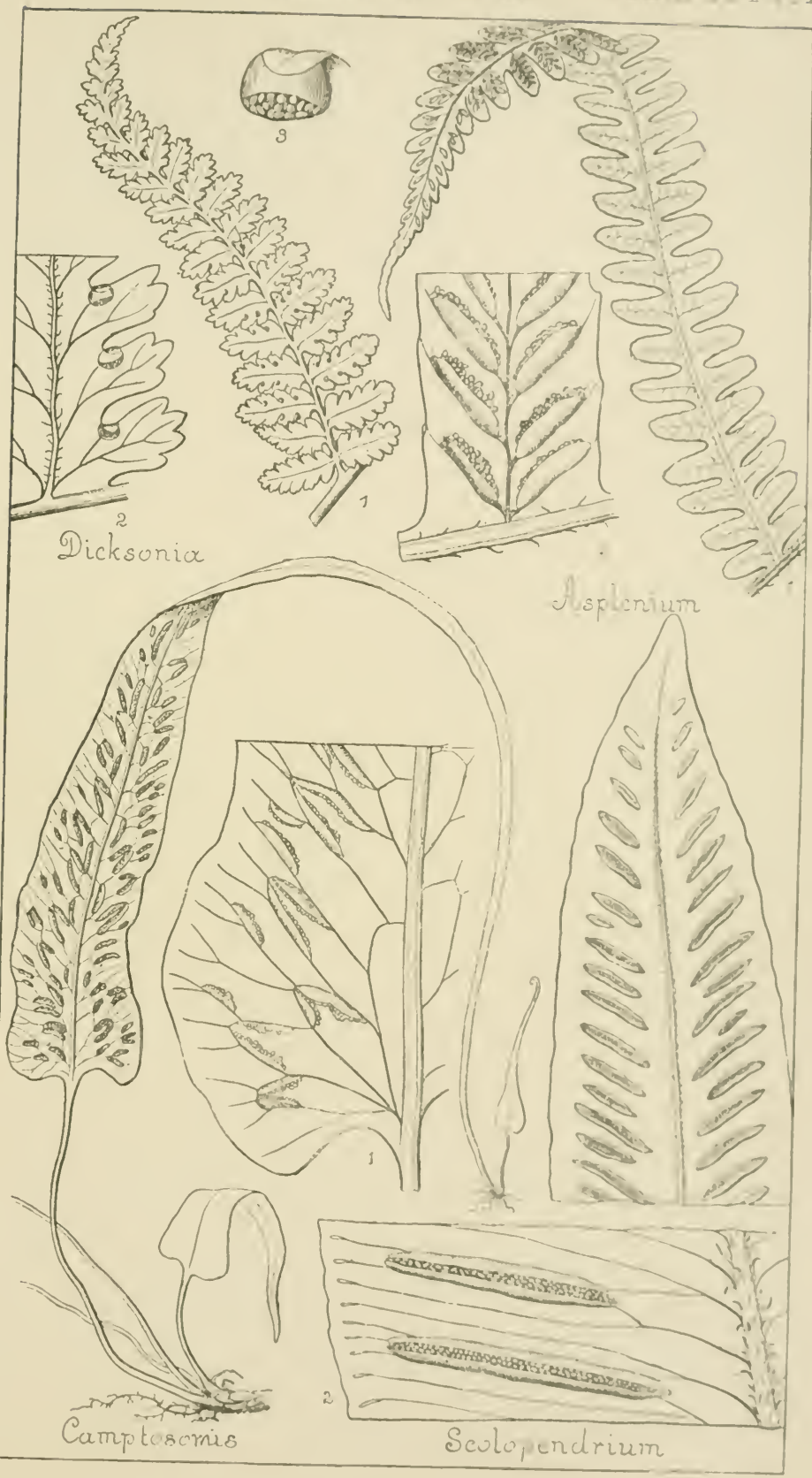




\section{EXPLANATION OF PLATE XIX.}

CYSTOPTERIs. - (1) I'iece of the fromd of C. bulbifera ; (2) a loble in fruit, enlarged; and (3) a small portion more magnified, bearing a fruit-dot with its iurlusium thrown back.

W()()ISIA. - (1) Small frond of IV. glabella ; (2) a part of a fruiting pinna of the same, magnified; and (3) a separate indusimm, more magnified; (4) a piere of a fruitful pimule of $\mathrm{W}$. obtusa, enlarged; and (5) a fruit with the opened indusimm beneath, more magnifierl.

ASIPIIILM. - (1) I'imal of A. (1) ropteris) marginale; aud (2) a magnified fruiting portion; (3) piece of $\Lambda$. (Polystichum) acrostichoides; and (t) a small fruiting portion, magnifierl.

ONo(IEA - Sterile anl fertile frond of O. sensibilis; (1) front view of a fruiting eontracterl pinute, enlarged; and (2) the same lais open and viewed from the other side; on one lohe the sporangia are removed from the veins. 


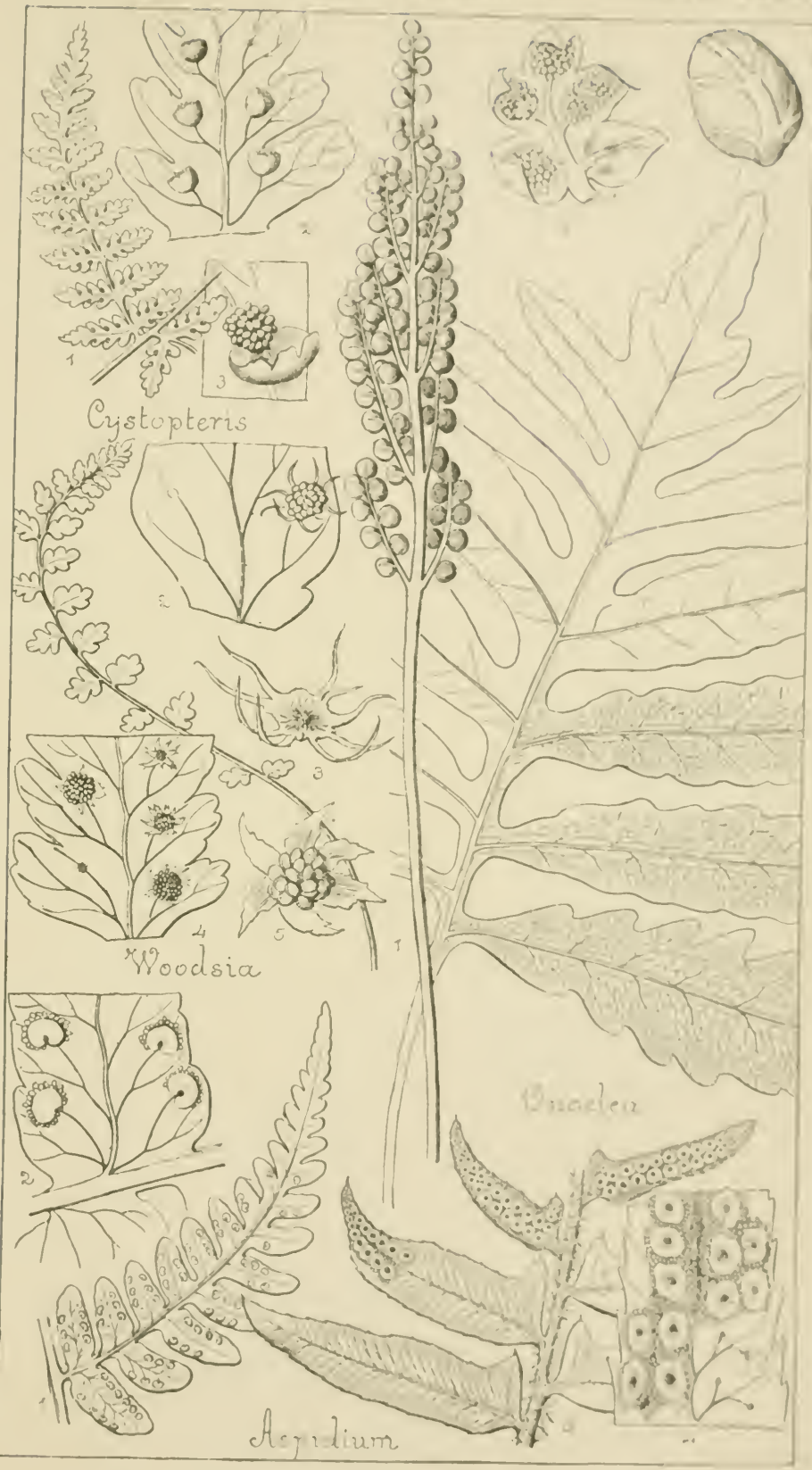




\section{EXPLANATION OF PLATE XX.}

SCIIIZ.E.L. - Plant of S. pusilla, of the natural size; (1) a fertile pinna with eleven sporangia, magnified; and (2) a separate sporangium, nore magnified.

LYGODII I. - (1) Summit of frond of L. palmatum, with fertile and strile divisions; (2) a fruiting lobe enlarged, with two of the lower suales, or indusia, removed, displaying a sporangium under each; and (3) a sporaugium more magnified.

OSMIXIDA. - (1) small piece of the frond of (). Claytoniama, with a fertile and a sterile pinna; (2) a portion of the fruit magnifiel; and (3) one sporangium more magnifierl.

BOTRYCIIILM. - I'lant of B. ternatum, and (1) a portion of the fruit, with six sporangia, magnified.

OPIIUGL(ISAI M. - Fromd of O. rulgatum, and ( 1 ) a portion of the fruiting spiko enlarged. 


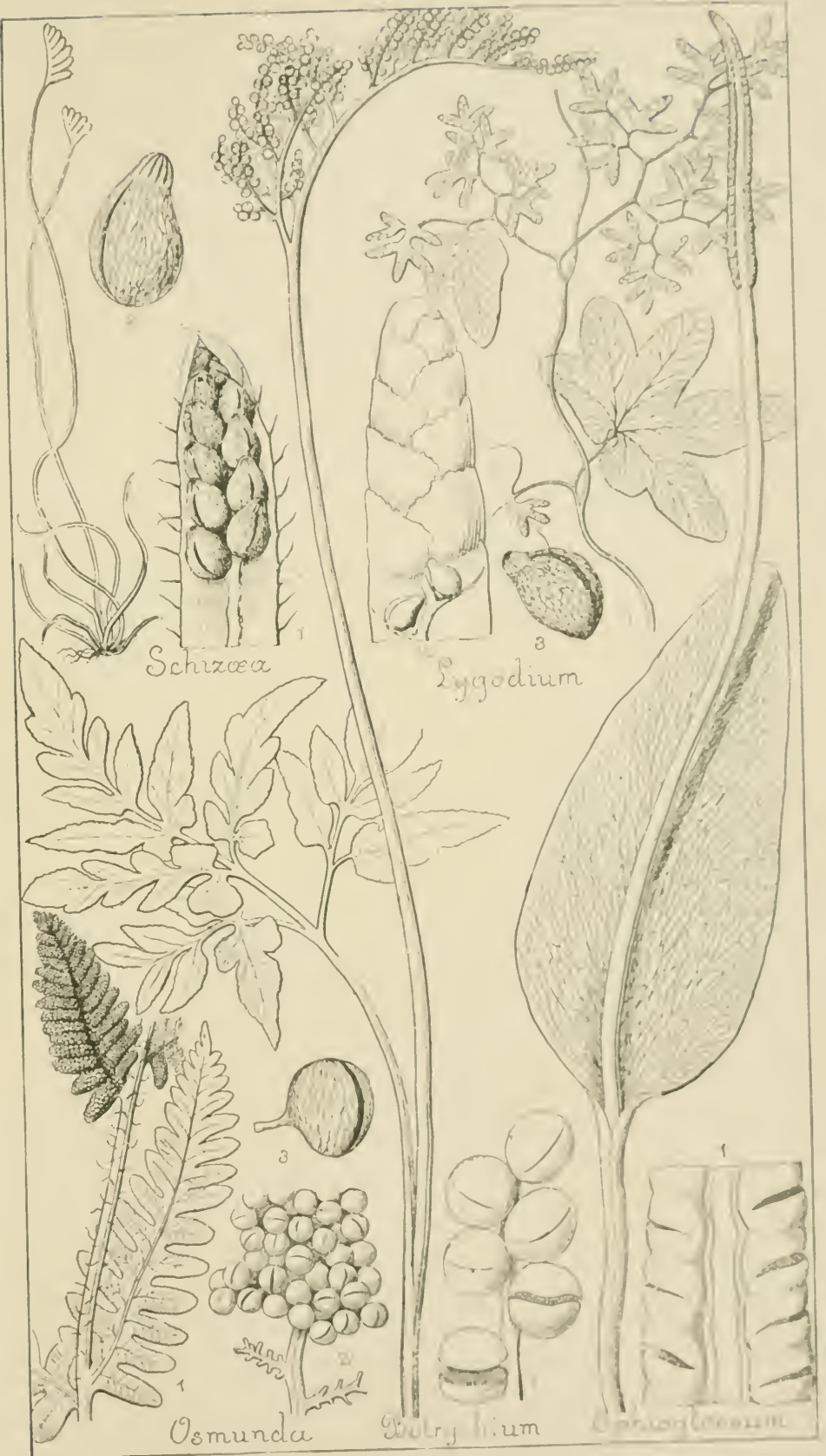




\section{EXPLANATION OF I'LTE XXI.}

EQTISETLYI. - (1) I liper part of fertile plant of E. limosum; (2) one of the shicld shaped seales or receptacles of the spike, with the six sporangia molerneath, enlargerl; (3) same seen from helow, discharging the spores; (4) a magnified spore with the chul-shaped filaments spreading; and (5) the sime with the filaments coiled $1 p$.

LYC()P()IDUM. - Plunt of L. Carolinianmm, and (1) a magnifiel scale of the spike removerl, with the sporangm in its axil, discharging powdery spores.

SELICINELLA. - Plant of S.rupestris; (1) part of a fertile spike, enlarged; (2) scale from the npper part of it, with its sproangimm, containing imumerahle powilery spowes; (3) scale from the base, with its sporangium eontaining few large spores; and (t) three large sjores.

ISOE'TES. - (1) Ilunt of I. lacustris; (2) sporourp contaning the minute speres, cut across, enlargorl: (5) same divided lengtlwise; (3) sporecarp with the large spores, divirled longthwise; and (4) three large spores more magnifiert.

AZ()LLA. - (1) I'lant; (2) a portion magnifiel, with conceptacles of hoth kinds; (3) the macrosporic one, more magnified; (4) the microsporic one, more magnified ; (5) the same lourst open, slowing the stalked microsporangia; (6) one of the latter more magnified; ( 7 ) another lursting; and (s) three masses of microspores leset with glochicliate or harbed bristles. 
[emint Dy

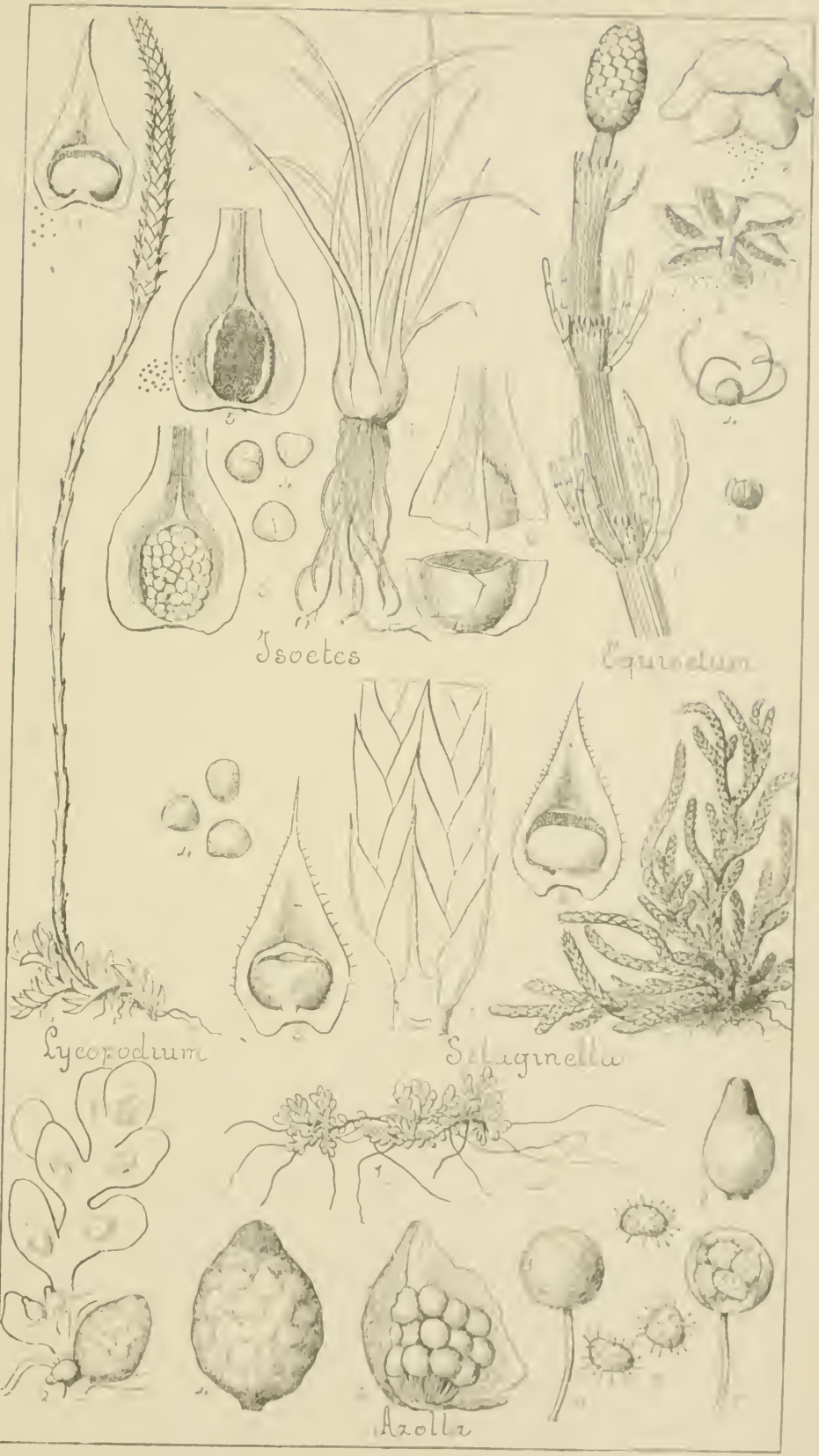




\section{EXPLANATION (YF PLATE XXII.}

R:CCIL. - I lant of R. natans; section of thallns, slowing two imherlded cajsules aml numeroms air cavities; spores encloserl in a mother-cell; three free spores; and (allyptra with st!le.

ANTII ;(EROS. - I lant of $\mathrm{A}$. laevis; portion of the eolumella and valves of the eapsule, with spores and elater's; two spores and two elaters.

NoT('TIYLAS. - P'lants of X. orbicularis; section of the thallus through the involncre; apex of protruliug capsule ; lower half of capsule slowing the colnmella; mper lualf of capsule ; a gemma ; an antheriolimm; twelve free spores, and two clusters of spores $(+$ in each $)$.

ASTERELLA. - I'lant of $\mathrm{A}$. hemisphariea; ? receptacle viewerl from alowe; the sume from helow; capsule dehiscing. with remains of calyptra at lase ; section of $J$ disk; an clater, a portion wl same, and slores.

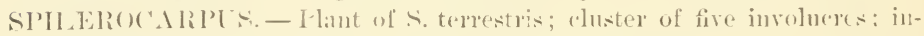
volncere entelusing a capsule; calpsule filled with spores; and three s]ores.

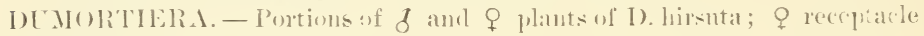
showing three involueres, two with apsules; (al sule with calyptral sectim of 8 disk; elater anel portion of same; speres.

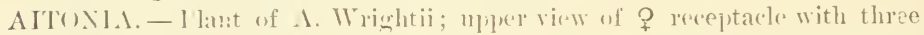
involneres; sile view of same; involncere partly cut away sluwing atpsule and remains of calyptrat; a capsule clused, and delosecent ; an elater, a piefe of sime, and spores.

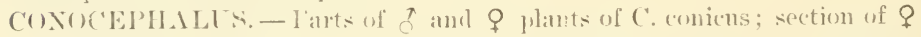
receptacle. sluwing two inwolneres and (apsules; (ap sule with ruptured ealypitra; section of $\delta$ disk; claters, a purtion ol one, and slures.

PRELSil. - l'arts of $\mathcal{f}$ ancl ? plants of l'. commutata : section of $q$ re(eptace; perianth opened showing calyptra and (a) sule; section of part of $\mathcal{Z}$ clisk; elaters, a part of one, amol sporess.

MARCIIANTIA. - Parts of $\delta$ and $q$ plants of M. polymorpha ; section of receptacle; perianth, ealy ptra, and caljsule ; section of $p$ art of $\delta$ disk; an clater, part of same, and spores.

FIMBRIARIA. - Plant of F. tenella; O receptacle, and section of same; capsule dehiscing; elaters aud spores.

PALLAYICIXI.L. - Plant of l'. Lyellii; part of thallus with involnere. perianth, anc calyptra ; perianth cut away slowing young calyptra ; capsulo cluserl, and dehiscent; antheridinin enclosed in a leaf; elater and spores. 


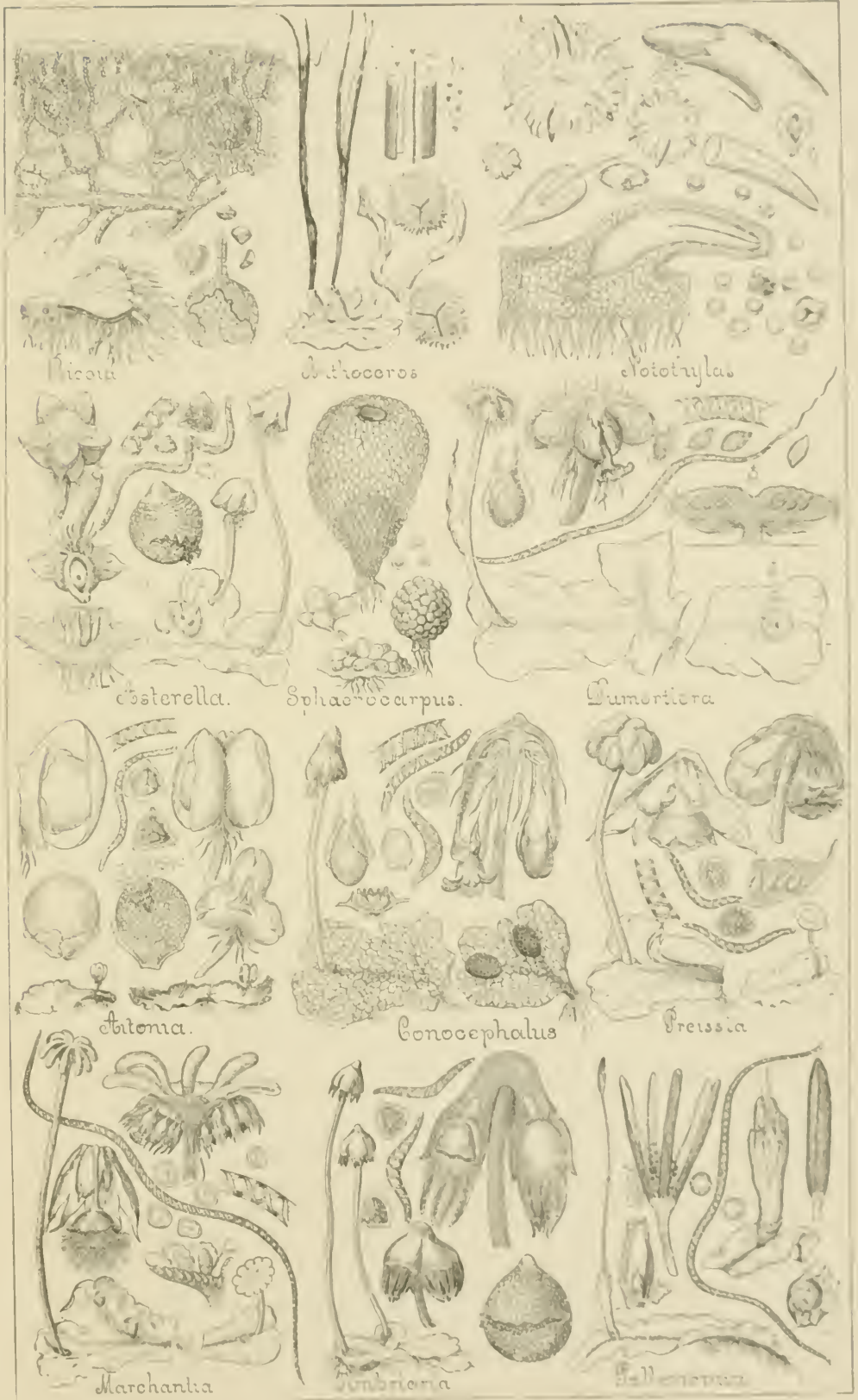




\section{EXPLANATION OF PLATE XXIII.}

PELLIA. - l'lant of P. epiphylla ; calyptra with base of pedicel ; capsule; an elater, part of same, two sprores, and two antheridia.

BLASLA. - Hants of B. pusilla; section of earity at the end of the midrib showing young perianth and calyptra; end of thallus with calyptra and protruling capsule; capsule dehiscing; elaters and spores ; part of elater and two spores; of thallus with two antleridia; gemmiparous thallus with two receptacles; section of a receptacle showing enclosed gemmit and the protruded orifice.

METZGERIA. - l'lants ( $\delta$, $q$, and gemmiparous) of M. furcata, and parts of same enlarged; hispid perianth with 2-lobed involucral leaf and hase of pedicel; a genmma ; an antheridium; claters and spores.

A.NEURA. - plants ( $\delta$ and $q$ ) of .1 . sessilis; section of fleshy calyptra with base of pedicel; dehiscing capsile hearded hy persistent elaters; clater, part of same, and spores; part of thallus with long deflexed $\delta$ receptacles, and one cut transersely showing antheridia.

FossombroNIA. - Plant of F. pusilla, and a part enlarged ; capsule dehiscing, with perianth aul involucral leaves; part of stem with two leaves and dorsil antheridia; an antheridim, elater's, and spores.

GE()( ILYX. - P'lant of ( $\mathrm{x}$. graveolens; two pairs of leaves with underleaves; part of stem with an mulcrleaf; section of involucre showing ealyptra and base of perlicel; dehiscent capsule; elaters and spores.

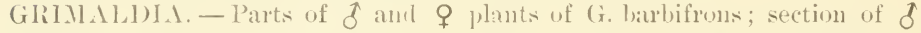
disk: O receptacle and section of same; dehiscent capsule; elaters and spores

CIILUSCYPHLS. - I'lant of ( : ascentens: a leaf with underleaf; a pair of leaves with antherilia; a part of stem with inrolucral leaves, perianth, and calyptra; dehiscent (alpsule; elater's and spores.

IlARPANTIILS. - Plant of II. Flotorianus, and same enlarged; a pair of leaves with underleaf: perianth with involucral leaves, and section showing calyptra ; elaters, a part of one, and spores.

L' I'IIOC'OLEA. - I'lant of L. heterophylla ; a part enlarged with involucral leaves and perianth; cross-section of perianth; three pairs of leaves with underleaves; a leaf and antheridium : an underleaf; an clater and spores.

('EPIIAL()ZILA. - Plant of C'. multiflora; two pairs of leares; periantl with involucral leaves; an involucral leaf; calyptra ; cajsule chosed, ancl clehiscent; an elater and spores.

GTMN(MITRILM. - Plants of G. concinnatum; three pairs of leaves; apex of stem with involucral leaves and dehiscent caysule; two involucral leaves; calyptra.

MLASLPRILA. - Plant of M. emarginata; part of same with involucral leaves; involuce and perianth opened showing calyptra and base of perli(r) ; (a)sule; clater and sporrs. 
Ganka ti Hobatlean Rlalg X-XIT

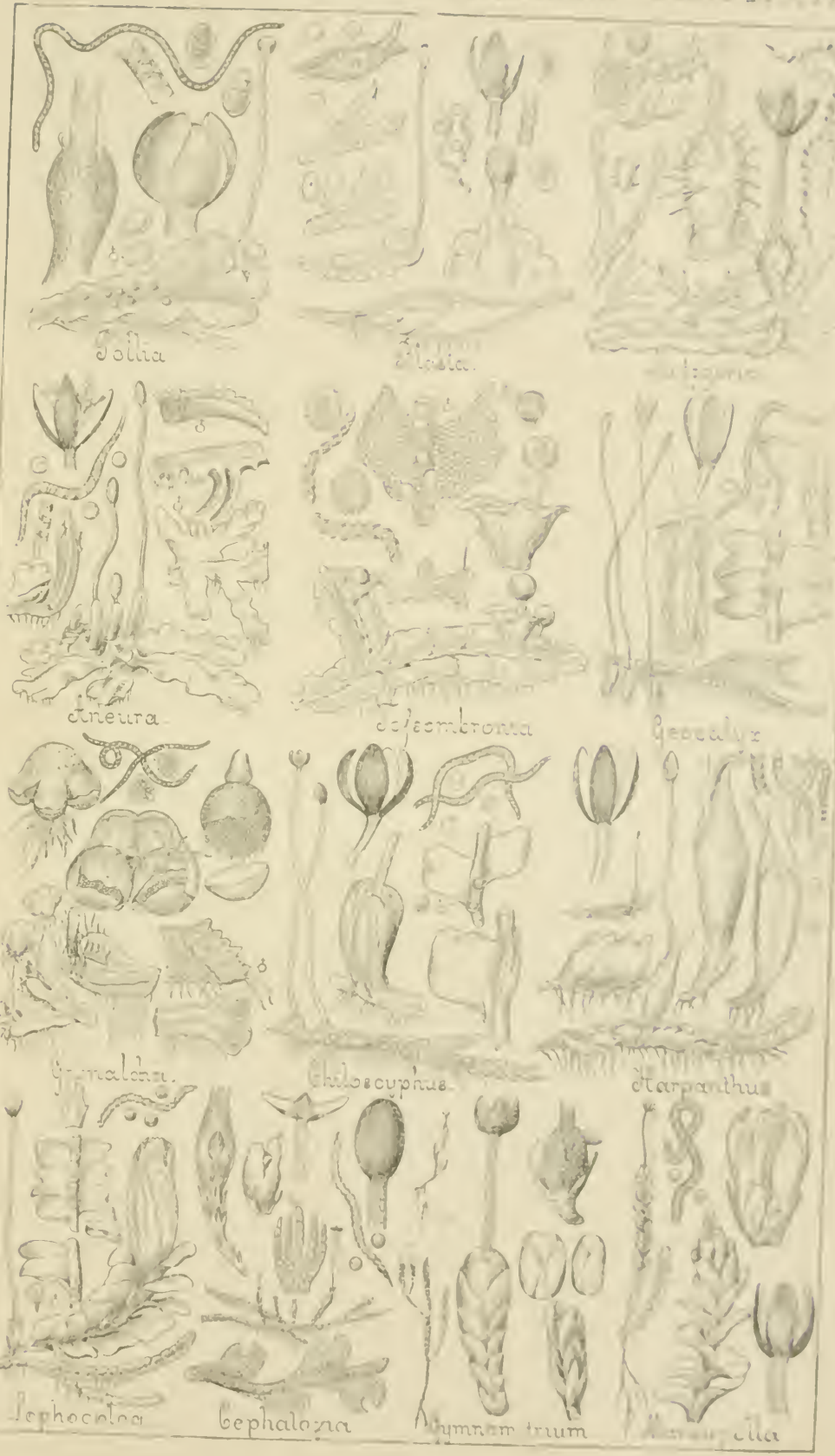




\section{EXILANATION OF PLATE XXIV.}

SCAI'ANIA. - Plant of S.. undulata; apex of stem with involncral leaves and perianth elichosing calypira; three pairs of leaves, a capsule, elater, amel s]ores.

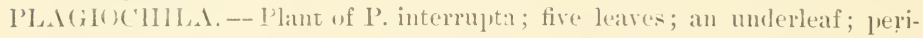
anth enclusing ealyptra; antheridia, capsule, chater's, and spores.

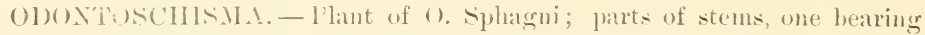
genmer, the other a perianth with involucral leares; an involucral leaf; at cilpsule, claters, and spores.

LEJELYEA. - l'lant of L. clypeata; perianth with capsule aud involucral leaves; cressection of perianth; part of stem with $\delta$ branch; leaves with underleaves; alateris and spores.

FRLLLANIA. - D'lant of F. Asagrayana; two pairs of leaves seen from ahove, amb from below with mulerleares and ventral lobes; perianth with involucral leases; crosssection of perianth; involucral leat; capsule, (elaters, and - prores.

l'() RELLA. - Plant of l'. platyphylla; a pair of leaves with umlerleares; part of stem with $\delta$ spiks's; an antheridium in its leaf; periantl with involucral leaves and (ap)sule; an elater, and spores.

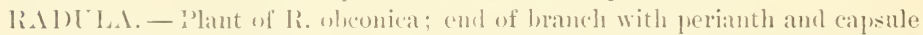
and lateral of hranclus: a $\delta$ lnamch ; an antheridium; leaves seen from above an 1 below; a capsule, elater, and spores.

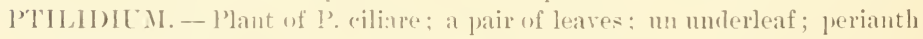
with involneral leaves: (ansinle, elater, and speres.

B.\\%\%. XI.1. - Plant of 13. triloluata; two pairs of leaves with underleaves and $\delta$ spike; portion of $\delta$ spike and antleridium; (ap)sule, elaters, and simeris.

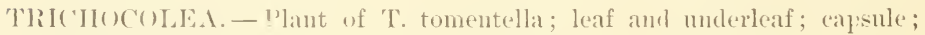
alater and spores.

IIEIBRERT. - I’lant of II. alunca: portion with leaves and mulerleaves; periantlı; (alpsules; elater aunl sprores.

LEI'Il)YZL. - Plant of I. reptans: portion with leaves and unlerleaves; antherilimm in its leaf and free; perianth with involucre; capsule, clater, amil spores.

LiNTld. - l'lant of K. Triclomanis; leaves and underleases; hairy involnere, and section showing calyptra; capsule with spiral valves; elater anil spores. 


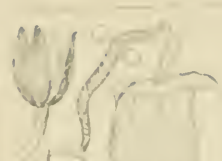

$\sqrt{1}(3)+\sqrt{0}$

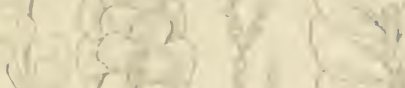

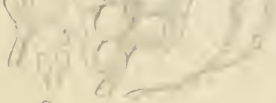

Sezuroma

$(1+(-2,1)$

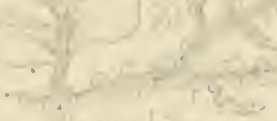

ileguodion.

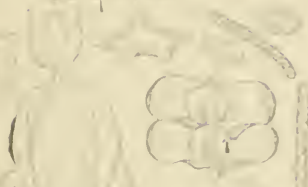

atis 8

in

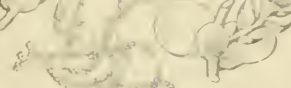

Lejeunia

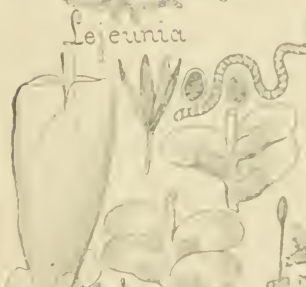

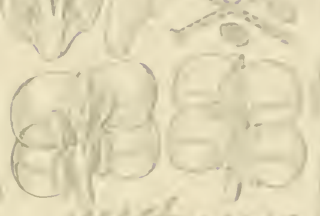

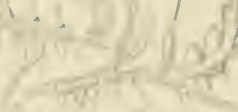

Qomtagchumin

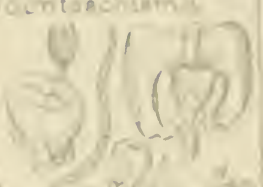

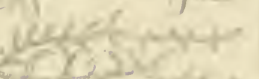

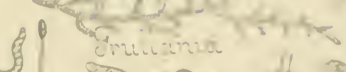

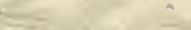

En

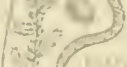

$(1, y)$

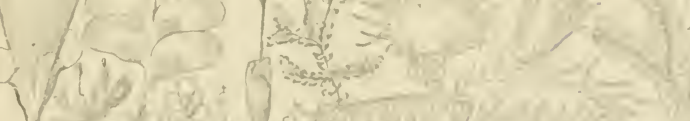

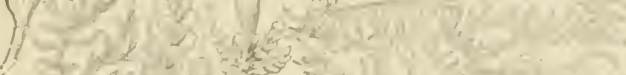

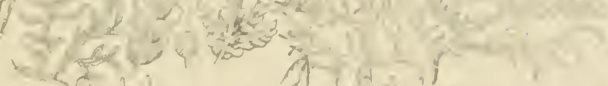

तो 140,0

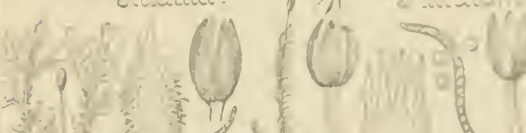

C. (15) 


\section{EXPLANATION OF PIATE XXY}

JUBLLA. - I'lant of typical J. Hutchinsix, enlarged; two pairs of leares seen from helow; a lower lohe separate and divided; a perianth with its outer involucre and the dehiscent (apsule; an elater.

BLEPIA ROSTOMA. - Ilant of B. trichophylla, and same cularged; perianth with the onter involucre, ventral sille; two cross sections of perianth; jortion of the margin of its orifice, expancied.

LIO(11L.ENA. - l'lant of I. lanceslata; end of fertile hranch, with two leares, two inwolncral leares, and young perianth; summit of porianth; perianth and involucre, the capsule protruding; (apsule (1n its pedicel. with remains of (alyptra; cajsule dehiseent.

MYLIA. - I'lants of M. Taylori, enlargerl portion of stem, seen from beneath; a cauline leaf (helow); an underleaf; an involucral leaf (above); perianth partly cut away, showing the calyptra and exscrted dehiscent capsule.

DYPL()PHYLLL MI. - Plant of typieal I). albicans, enlarged; a folded leaf; a leaf with the upper lobe expanded to show the newe; an involucral leaf seen from withont, and from within; periantl, ctit longitudinally; calyptra.

NARI)LA. - Plant of X. crenulata (a slender small-leaved form), enlarged; portion of upper stem with leaves; perianth; calyptra ; clater and spores.

JUNGERAINNIA. - § 1. Plants of J. Schraderi, natural size and enlarged; two leares; two underleares; involucre; summit of perianth. - $\$ 2$. I'lant of j. harbata, enlarged; portion of stem with leares and underleaves; perianth with involucre; involucre.-\$3. Ilant of J. Ielleriana, enlarged; summit of stem with leaves, involucre, and perianth; involucral leaves; margin of perianth unfolded. $-\$ 4$. I lants of $J$. inflata, natural size and enlarged; canline leaves; involncral leaf.

LCXLLARIA. - Sterile and fruiting plants of L. vulgaris, enlarged ; section of involucre, showing calyptra and capsule; lunate receptacle of sterile plant, with gemma.

MARSILIA. - Portion of plant of MI. quadrifolia ; sporocarp; sporocarp hurst in water and extruding the gelatinous ring with compartments attached.

\section{FROPERTY LIBRART N. C. State College}




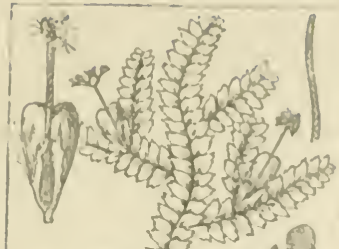

का

\& 3 कर

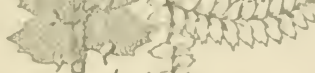
Qubula

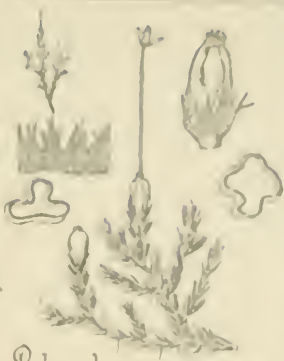

Blepharostome
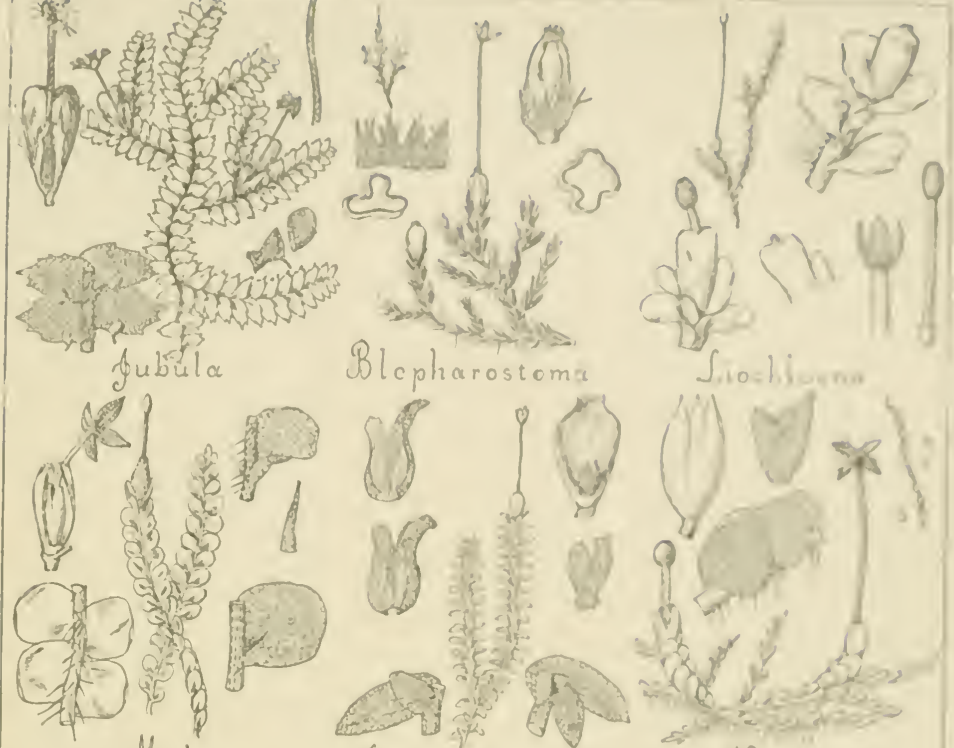
Diplophyllum

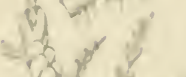
Mylia

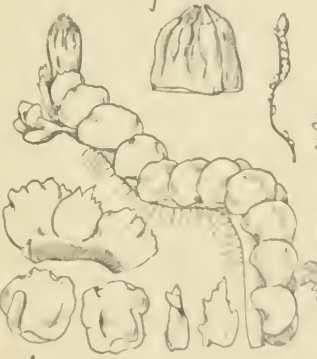

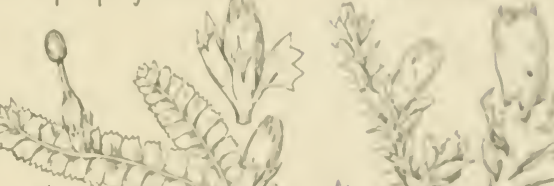

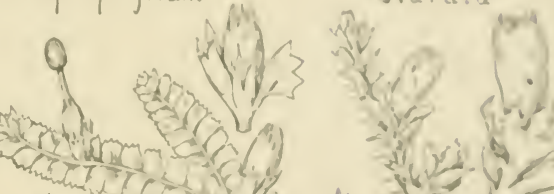

$$
\text { difadia }
$$

(c) 8 , sos

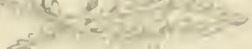

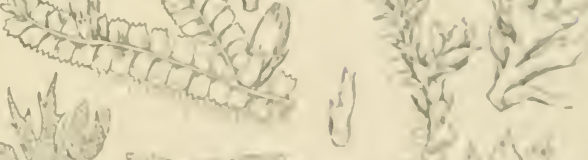

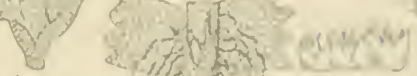
Sungermannias fungermunia

\& 3 a 9 a

काe

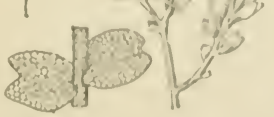

Gungermennix s/t

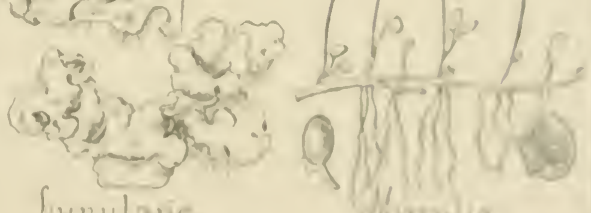

Sunularie

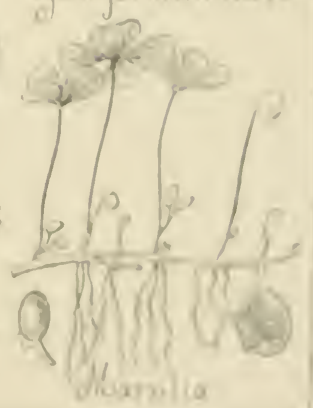






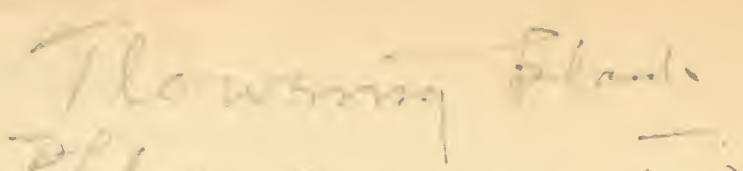

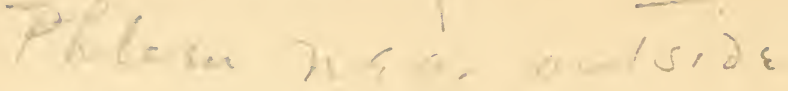

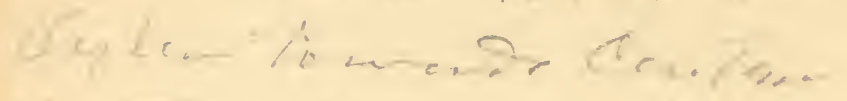

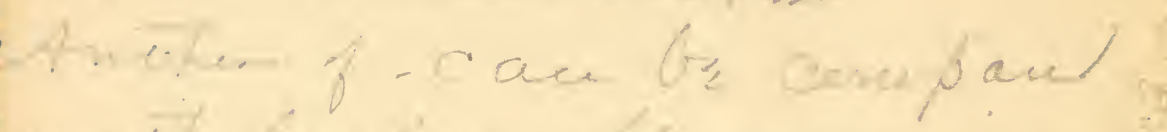

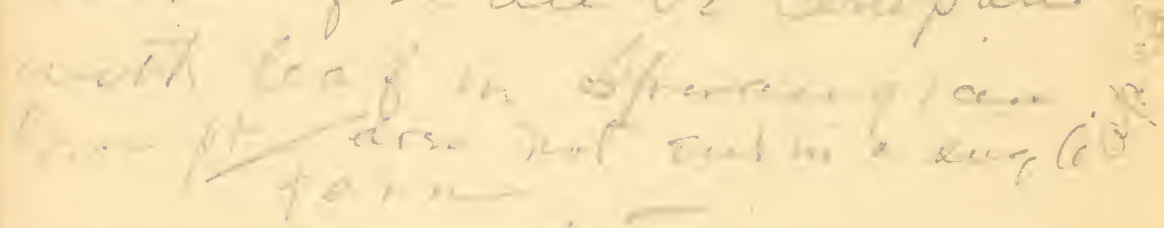

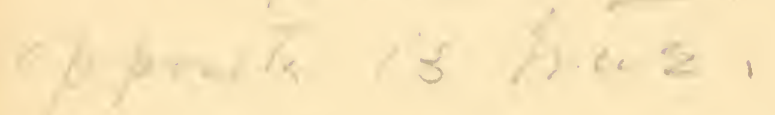

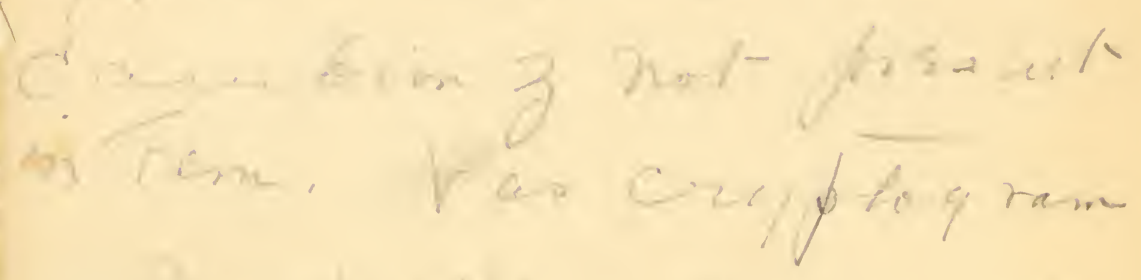



W.
r

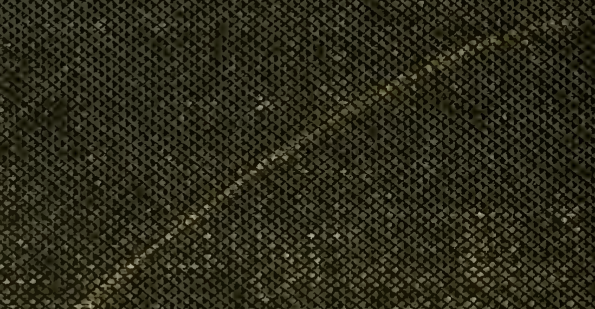

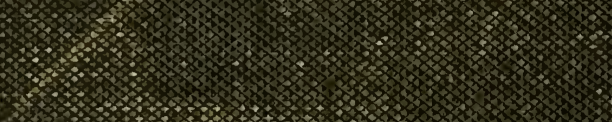

$8 \%$

$8 \% 8$

$8 \% \%$

\%

Y.

H.

H,

Fins

3. 